5

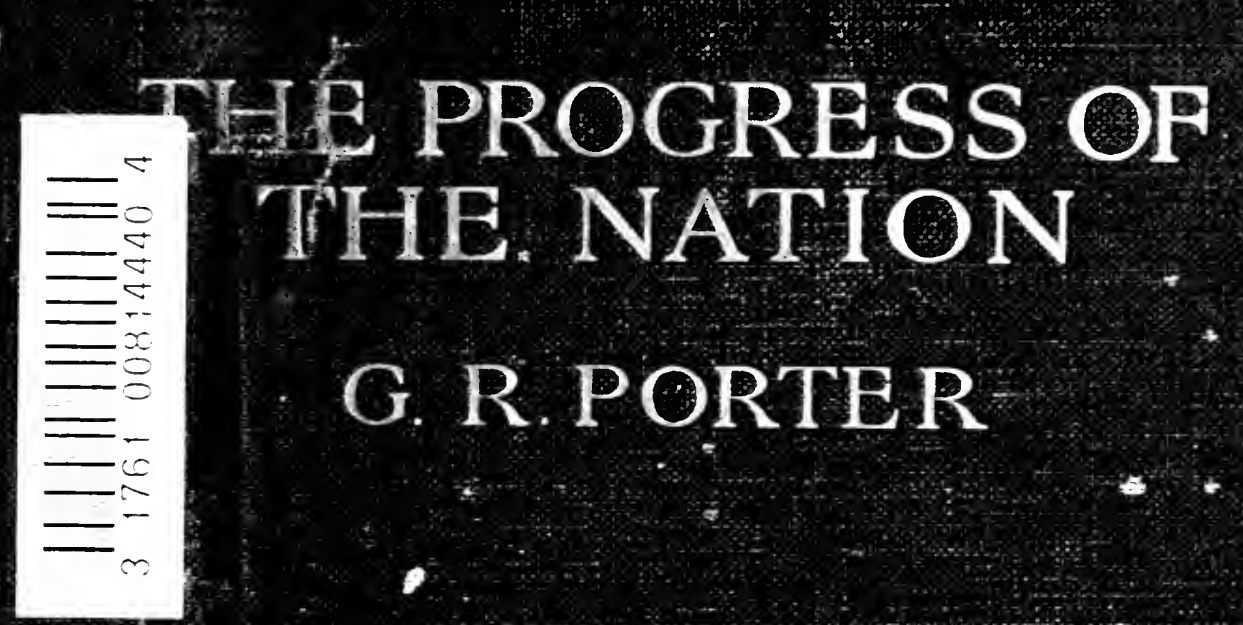

A NEW EDITION
EDTTED BY F.W. HIRST ?.

7 


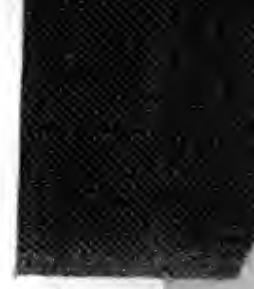





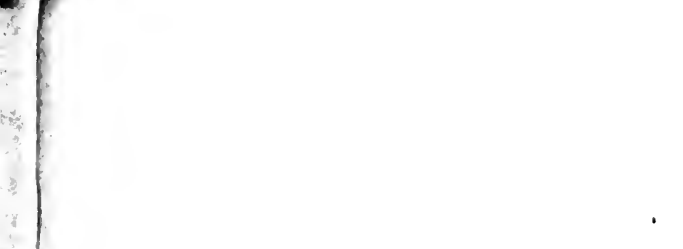

$\therefore$

$$
\text { - }
$$
. 
F

HE PROGRESS OF THE NATION

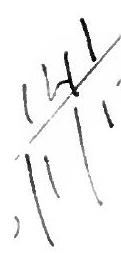


清 


\title{
THE PROGRESS OF THE NATION
}

IN ITS VARIOUS SOCIAL AND ECONOMIC RELATIONS FROM THE BEGINNING OF THE NINETEENTH CENTIRY

\author{
BY \\ G. R. PORTER
}

A COMPLETEly NeW Edition

REVISED AND BROUGHT UP TO DATE

BY

F. W. H I R S T

EDITOR OF "THE ECONOMIST"

METHUEN \& CO. LTD.

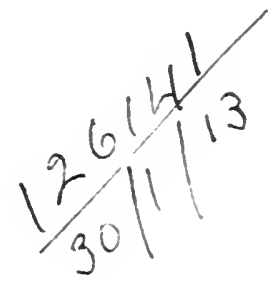

36 ESSEX STREET W.C. 
This Edition was first Published in 1912 


\section{PREFACE}

DORTER'S Progress of the Nation was a statistical and descriptive study of the social, economic, commercial, and fiscal changes which took place in the United Kingdom during the first half of the nineteenth century. The two first sections of the first edition were published in 1836 and the remainder in 1838, the full title being The Progress of the Nation in its social and commercial relations, from the beginning of the Nineteenth Century to the Present Day. A second edition appeared in one thick volume in 1846, and a third in 1851. As the first edition was full of arguments for those fiscal changes in the direction of Free Trade which were being rapidly accomplished when the second and third appeared, these two later editions suffer; for the author naturally endeavoured to preserve as much of the original as possible. The rents in the old garment and the new patches are quite visible to the reader. The book, however, is a storehouse of information, highly valued by all who take a serious interest in the economic history of our country. It was commenced before the modern passion for government statistics had been developed or catered for. But Porter had excellent sources of information so far as information was then available. He was one of the founders of the Statistical Society, and in 1834, when the Board of Trade was reorganized, he was placed at the head of the Statistical Department. In 1840 he became senior member of the Railway Department, and in 1841 was appointed Joint Secretary to the Board of Trade (his colleague being MacGregor), a post which he retained until his death in 1852. It may be gravely doubted whether "the Progress of the Nation" is not a misnomer, if the condition of the working classes from, say, 1794 to 1844 be impartially surveyed. Certainly in many parts of England and Scotland and probably in all parts of Ireland the poor in town and country were poorer at the end than at the beginning 
of the period. The "progress" of debt, the increased burden of taxation upon food and commodities, and the effects of enclosures (graphically depicted in a recent book ${ }^{1}$ ) more than counterbalanced the enriching and fertilizing march of science and invention. That at least is my judgment, though it would be out of place here to produce the mass of contemporary evidence by which it could be supported. Porter, however, was happily for himself an optimist, and he was more impressed by the improvements than by the shortcomings of his time. And in the last years of his life he was privileged to see an outburst of prosperity following directly upon the adoption of those drastic measures which he had so urgently pressed both as an author and as an official. That the work is valuable has never been doubted. It had no rival among the compilations of that time. Porter was a thoroughly painstaking statistician with ready means of access to much information which was not procurable, or not easily procurable, by ordinary people.

Professor Hewins, now secretary of the Tariff Reform League, has described Porter's Progress in the National Dictionary of Biography as "an invaluable record of the first half of the nineteenth century." It is, he adds, "remarkable for the accuracy and variety of its information, and for the skill with which the results of statistical inquiry are presented." Testimony so strong from such a witness relieves me from the need for making any elaborate justification of the present work, which aims at retaining what is still valuable in Porter and carrying his survey up to the present day. In a necessarily close perusal of the work I became aware of a vast amount of "padding" and of frequent lapses into intolerable diffuseness and verbosity. These faults may probably be attributed to less competent assistants; for in a few of the best chapters (which are here reprinted with trifling changes) Porter's obvious mastery of the subject does not suffer much from prolixity of style. I have in my library his translation of Bastiat's Sophismes Economiques (1846), and the sentences would hardly be called ungainly except by comparison with the original.

My original intention was to go through Porter's wood, cut away all the dead branches, and then plant out new sections. But I found eventually that this easy method could only be justified in

1 The Village Labourer, 1760-1832, by Mr. and Mrs. Hammond. 
the case of three or four chapters. The work therefore is substantially new. Porter has been handled freely, and some of his deficiencies have been made good, though of course most pains have been bestowed on the later history, which carries us over the last sixty years of our economic and commercial development.

Porter split the main part of his book into seven sections, adding an eighth for Colonies and Dependencies. The last section, which would have required another volume for adequate treatment, has been omitted. The seven sections have been abolished, as the divisions were not logical, and led to nothing better than overlapping and confusion. The result is a book of thirty-eight chapters. The first nine deal with the growth of population in the nineteenth century, with the trades and occupations of the people, with wages and employment, pauperism, housing, crime, intemperance and lunacy, education, local government, and the standard of comfort. This preliminary survey was contributed mainly by Mrs. Hamilton, Mr. C. M. Atkinson, and Mr. W. T. Layton, on whose competence to deal with questions of local government, criminology, wages and prices, there will be no dispute.

Then follows the principal part of the book. Here also the additions made to Porter have necessarily been enormous. I find that he omitted some important trades, such as the potteries, that existed in his day, and barely touched on others. Many more, such as jute and the electrical industries, have grown up since his time, and most of those that existed have expanded and changed out of all recognition. This part of the work has been executed by members of the staff of The Economist under my supervision, and as. nothing on this scale has been attempted before we can fairly claim the indulgence of the reading public. The figures-taken from official sources-have been so carefully tested and revised that errors must have been reduced to a minimum. But we cannot hope that every expert will be satisfied with the space or treatment of his particular trade. I console myself with the reflection that a general and particular survey, in more or less logical sequence, of all the leading trades of Great Britain and Ireland from Agriculture (Chapter X) to Beer, Spirits, and Tobacco (Chapter XXV) is unique ; and even those who find most imperfections will probably welcome this bird's-eye view (accompanied by official statistics) of the growth 
and present state of our industries. Chapter XXVI is Porter's most informing chapter on our foreign commerce and navigation in the first half of last century. I have followed it up with a chapter on our foreign trade in the last sixty years and another on the progress of British shipping. Then comes a brief treatment of internal transit-roads, canals and railways-followed by postal developments. Next we have chapters on coinage, banking, and insurance. Chapter XXXV is Porter's valuable treatise on the public revenue and expenditure from 1800 to 1850 , which I have endeavoured to carry forward to our own days in two further chapters-the one treating of the national expenditure and debt, the other of taxation and commercial policy. A concluding chapter, in the preparation of which I have had valuable assistance from my friend Mr. W. T. Layton, deals with the difficult problem of the growth of national wealth and capital. The excellence of the index will, I feel sure, be acknowledged by all who have occasion to consult the book; it was prepared by Mr. G. G. Whiskard.

F. W. H.

May, 1912 


\title{
CONTENTS
}

\author{
CHAPTER I \\ POPULATION
}

Historical summary-I. Growth of population; (a) Emigration; (b) Natural increase - The death-rate-Infant mortality rate-Birth-rate-II. Constitution of population; (a) Sex; (b) Age; (c) Narriage; (d) Birthplace-III. Morement of population-IV. Physical infirmity.

CHAPTER II

\section{TRADES AND OCCUPATIONS}

Historical-I. Children-II. Women : home work; Married women wage-earnersIII. Men : proportions in different occupations-Occupational mortality

\section{CHAPTER III}

WAGES (NOMINAL AND REAL), PRICES, AND EMPLOYMENT

Real wages the test of improrement-History of wages to 1815 and after-Agricultural wages-Industrial wages-Index numbers of money wages-History of prices-

Unemployment-Morement of wages aud prices since 1900 .

\section{CHAPTER IV}

\section{PACPERISII}

Historical-The Poor Law before 1\$34-The new Poor Law of 1834-Methods of reliefClassification-Morement of pauperism-The Unemployed Workmen Act-Cost of relief-Medical relief-The aged-Crban and rural pauperism-ChildrenVagrancy-Scotlaud-Ireland .

CHAPTEP $\mathrm{V}$

HOLSING AND RENT

Inhabited houses-Rents-Urban and rural couditions-Overcrowding

\section{CHAPTER VI \\ CRIME-DRINK-INSANITY}

Drvisrox I. Crime.-\$ 1. Historical-The Criminal Code prior to 1850-ExecutionTransportation-\$2. Prison Reforri- $-\$ 3$. Criminal Statistics- $\$$ 4. Prison Adminis. tration-\$5. Causes of Crime. Divisiox II.-Drink. Drrision III.-Insanity . 105

\section{CHAPTER TII}

\section{THE PROGRESS OF EDLCATION}

Primary education-Voluntary schools-The Act of 1870-State aid and rate aidGrowth of secondary education-Endowed schools-The education of girls-Continnation and technical schools-The Board of Education-The Act of 1902Provided and unprorided schools-Erening schools-School feeding-UniversitiesScotland and Ireland 


\section{CHAP'TER VIII}

\section{LOCAL GOVERNMENT IN GENERAL}

Historical--The development of the organs of English local government-Education

and public health-Functions of local authorities-Municipal trading-Municipal finance-The Local Government Board

\section{CHAPTER IX}

\section{THE RISING STANDARD OF COMFORT}

Reality of progress-Increase in wealth-General diffusion of wealth-Working-class savings-Rise in real wages-Improvement in conditions of life-ExpenditureAmusements of rich and por-Hölidays-Religion .

\section{CHAPTER $\mathrm{X}$}

\section{BRITISH AGRICULTURE, 1800-1850}

Importations of wheat, 1801-1819-Comparative smallness of its amount-Numbers fed with wheat of home and of foreign growth-Increased productive power of Great Britain-Means whereby this increase was brought about-Deficiency of statistical information connected with agriculture in England-Improvements in ScotlandInclosure Bills and average prices of wheat since 1760-Corn Law of 1815-Conflicting testimony as to agricultural distress given to the Committee in 1833Increased rents since 1790-Adaptation of the steam-engine to the draining of fens - Land brought under cultivation since 1760-Proportion of cultivated land to the poptlation at different periods during the nineteenth century-Probability of population outstripping the productive powers of the soil-Supposed influence upon this question of the extensive construction of railroads-Estimate of the number of horses, the employment of which may by that means be rendered unnecessary

\section{CHAPTER XI}

\section{BRITISH AGRICULTURE FROM 1850}

Food supply-Growth of imports-Prosperity from 1850 to 1875 -Heavy fall of prices and agricultural depression-Gralual recovery after 1895-Agricultural statistics .

\section{CHAPTER XII}

\section{BRITISH MINES AND MINING}

Coal-Mining.-Great Britain's mineral treasures-History of coal-mining in first half of nineteenth century-Shipments of coal from Tyne, Tees, and Wear, 1801-1849Coal prices in Newcastle, Sunderland, and London-Total shipments of coal, 18191849-Approximate amount of coal carried on canals and railways in 1816Estimated amount of coal used in smelting iron in 1850 - "The limitation of the vend"-Coal-Mining from 1850 onvards: Census of Production figures-Labour value in coal-England's proportion of the world's production-Production, export, home consumption of coal, with total value of all exports, and value of coal exports from 1850-1909-Cause of export trade in coal-Coal as raw material-Coal as cargo-Destination of our coal exports-Importance of coal exports to our foreign trade-Freights-Price of coal since 1850-Jevons on price of coal-Declining freights. Tin-Mining.-Production of the Cornish tin mines, 1750-1834-Imports and re-exports of Banca tin-Exports of British tin, 1820-1849.-Tin-Mining from 1850 onwards: Production of white tin from British ores, 1850-1908-Imports and re-exports of tin ore and crude tin, 1850-1909-Price of tin (English bars), 18701910-Census of Production figures. Copper-Mining.-Production of copper in Cornwall, 1771-1848-Production of copper from British ores, 1820-1908-Imports 
of copper ore and regulus-English copper-mining in eighteenth and nineteenth centuries-Census of Production figures-Prices of tin and copper, 1501-1534Price of copper, 15s0-1910. Leal-Mining.-Proluction of leal from British ores, 1854-1908-Imports and exports of lead ore, red and white lead, and lithargeCensus of Production figures-Price of lead (English pig) from I771-1909. Zinc.Production from 15601-1908-Imports and exports, 1595-1909-Census of Prorluction figures-Price of zinc, 18\%0-1909. Salt.-Different sorts of salt-Quantities of white and rock salt sent down river Weaver, 1503-18 14 - Various duties on salt during first half of nineteeuth century-Consumption of salt. 1801-1817-Exports of rock salt, 182 $i-1844-D e s t i n a t i o n s$ of salt exports, $1844-$ Exports of salt, 18501909. Output of Miscellaneous Minerals in 195\%.-Ironstone-Iron pyrites-Oil shale-Fireclay clay and shale other than fireclay-Limestoue-Sandstone, including Ganiston-Ali other products-Silver and gold production

\section{CHAPTER XIII}

\section{IHON AND STEEL MANLFACTLRES}

Up to 1850.-Quantity of iron made in England and Wales in 17:0-Quantities made from 1523-1830-Sir John Guest's estinates in 1840-Mr. Jessop's estimates of iron made in 1840-Exports of bar iron, pig iron, and castings, 1501-1910-steel trade of Sheffield during first half of nineteenth century-Increasing use of iron, according to Sir John Guest-Home consumption of iron, 1506-1844. From 1850 onvoards.-Great changes in iron and steel trades during last half of nineteenth century-The overlapping of various branches of iron and steel trades-Increasing imports of foreign ores-British iron fields and their outputs-Manufacture of pig iron: (1) Forge and foundry, (2) Bessemer-Great Britain's share in the world's production of pig iron-Hærnatite iron-Pig iron production from 1850-1908Finished iron trades-Decrease in importance as more steel produced-Steel industry - Cruciule steel - The Bessemer process - Open-hearth process - Basic process-Iron and steel output of leading British districts in 1901-Output of steel since 1875 -Prices of pig iron, steel and irou bars since 1835-Census of Production figures for 1907 .

\section{CHAPTER AIV}

\section{MACHINERY, ENGINEERING, SHIPBUILDING, AND ELECTPICAL TRADES}

1800-1850.-Importance of perfect tools and implements-Progress of maunfacturing skill in their production-Foreign mechanical inventions perfected and adopted in England-Policy of allowing the exportation of machinery-Larys for restraining artisans from going abroad-Their repeal-Value of machinery exported. 185' 1909. - The Engineering trades-Census of Production figures-Exports of machinery and mill-work, 1845-1910. The Shipbuilling Industry.-The first iron-built ressels-Growth of industry, 1850-1910-Causes of growth-Steel-brilt vessels-Introduction of steam-The compound engine-Early steam-vesselsTurbines-Changes in design and structure-Shipbuilling centres in the United Kingdom. The Electrical Industry.-Age of industry-Early experiments-The discovery of the dynamo- - 'ses of electrisity-Electric lighting and the are lampThe Edi-Swan lamp-Brush boom-Parliamentary lewislation-Electric tractionThe electric motor-Electric power-Effect on industry and manufacturcs-Towns -Some problems of the electrical industry-Foreign trade in electrical goods. Locomative and Wagon Building.-Our export trade in railway material, etc. The Explosive Engine.-Early types of gas-engine-oil-engines-The motor trade-Our foreign trade in motors--Our foreign trade in cycles-Possibilities of the explosive engines-aeroplanes 


\section{CHAPTER XV}

\section{THE MINOR METAL TRADES-HARDWARE, GLASS, AND POTTERY}

Populations of Sheffield and Birmingham, 1801-1851-Historical accounts of Birmingham industries - Metal trades no longer confined to Birmingham-Census of Production figures for 1907-Prices of hardware, 1812-1832-Imports and exports of hardware and cutlery, 1805-1910-History of the cutlery trade-History of the tin-plate trade-Exports of tin plates, 1860-1910-Exports of galvanized plates, 1890-1910-Exports of wire, 1880-1910-Brass aud copper manufactures exports, 1805-1910-Plated goods and jewellery trades-Exports of plated goods and jewellery, 1830-1910-The glass trades in the first half of the nineteeuth centaryExports and imports of glass since 1860-The modern glass industry-History of the pottery trades-Ceusus of Production figures-Our foreigu trade in pottery .

\section{CHAPTER XYI $(A)$}

\section{- INTRODUCTION TO THE TEXTILE INDUSTRIES}

Early history of textile trades-Number of power-looms in use in 1835- -Persons of different ages employed in textile trades, 1835-1839-Size of our textile trades in 1907-Census of Production figures

\section{CHAPTER XVI $(B)$}

\section{COTTON}

Early history of cotton trade. The Cotton Industry, 1800-1850.-Imports of cotton in eighteenth century-Early textile machinery-Consumption of cotton and exports of cotton goods, 1801-1849-The cotton trade early in the nineteenth century-

A. - Foreign trade in cotton goods in first half of nineteenth century-The advantages of the power-loom-Effect of power manufactare on price of cloth-Prices in Stockport in 1812-The history of the power-loom-Labour conditions in textile trade early in the nineteenth century-Quantity of raw cotton consumed in first half of nineteenth century, and quantities of yarn manufactured-Persons employed in the early days of the textile trades-Wages in cotton trade, 1804-1833-Cottonprinting-Restrictions on cotton printing-Value of cotton manufacture in first half of nineteenth century. The Cotton Industry, 1850-1910.- Size and importance of modern cotton industry-American production and exports of cotton, 1790-1903 -Lancashire's supplies and consumption of cotton-Our consumption of cotton, 1781-1908-The world's consumption of cotton in 1910-The Manchester cotton market-Wages in the cotton trade---The Scottish cotton trade-Textile machinery in last half of nineteenth century-Machinery in use, 1874-1903-Numbers employed, 1881-1901-Our foreign trade in cotton goods

\section{CHAPTER XVII}

\section{WOOL}

Early history-Exports from 1815 to 1845 -Number of mills-Growth of imports in first half of century-Changes in manufacture-Later history-Colonial production 1 -Manufacturing centres-Effects of Free Trade-Number of factories and persons $>$ employed since 1870-Foreign trade siuce 1850-Minor industries . . .

\section{CHAPTER XVIII}

\section{OTHER TEXTILE TRADES-SILK, LINEN, JUTE, AND HEMP}

Progress of silk manufacture during prohibition-Effect of repeal of duties-Exports of silk goods from 1820 to $1849-$ Number of mills-Introduction of machineryEffects of the Cobden Treaty - Foreign trade since 1850-Total output-Early linen production and trade-Imports of flax-Exports of linen from 1850 to 1910-Flax production in Ireland-Numbers employed in jute industry-Exports and imports of jute-History of hemp industry-Number of factories-Imports of raw hemp . 


\section{CHAPTER XIX}

\section{LEATHER, BOOTS AND SHOES}

Leather.-Antiquity of leather-Tsnning industry early in nineteenth centuryGrowth of tanning industry-Imports of raw hides, 1876-1910-Countries that send us hides-Policy of American Beef Trust-Our foreign trade in leather. Boot and Shoe Trades. - Present size-Census of Prodnction figures-Difficulties of estimating the size of the boot and shoe trades-Crowth of boot and shoe trades during the nineteenth century-Boot-making machinery-American competition-

Modern boots and shoes-Our foreign trade in boots and shoes

\section{CHAPTER XX}

\section{+ HOSIERY, LACE, HATS AND GLOVES}

The Hosiery Trade, 1300-1550.-Early seats of hosiery manufacture-Early estimates of stocking frames-Lee's stocking frame-Production of hosiery, numbers employed, wages, etc., in 1833-Bobbin-net trade-Improvements in machineryFancy prodnctions-Warp lace. 1850-1910.- Irr. Thomas Henderson on derelopment of hosiery trade-Amount of persons employed in hosiery trade in LeicesterHosiery a female industry-"Twist ferer"-Effect of American Civil War-Lace trade - Numbers employed, and rages - Stocking making-Census figures of employraent in hosiery trades-Census of Production figtures-Our foreign trade in hosiery and lace. Hats and Gloves. - On foreign trade in hats and glores, 18561910-Census of Production figures

\section{CHAPTER XXI}

\section{PAPER AND PRINTING TRADES}

Paper.-Introduction of machinery into paper-making-Excise duties on paper early in the nineteenth century-Progress of the trade since 1860-Esparto grass-Wood pulp-Our foreign trade in paper. Printing. - The size of our printing tradeCensus of Production figures-The introduction of machinery into the printing trades early in the nineteenth century-The evolntion of the porrer press and of the linotype machine-The development of photogrsphy and the cheapening of illustrations-Oer foreign trade in books and printed matter.

\section{CHAPTER XXII}

\section{THE CHEMICAL AND SOAP TRADES}

The Chemical Trades.-Some founders of the chemical trades-The alkali industry and the manufacture of bleaching powder-Census of Prodnction figures-Oar foreign trade in chemicals-Situation of the chemical industries-Difficulties of early chemical manufacturers - The Alkali Act-Chemical manures-Combinations among chemical manufacturers-The United Alkali Co. - Various other combines. The Soap Trades. - The soap trades early in the nineteenth century and their modern growth-Exports of sosp, 1853-1910-Consumption of soap-Imports of sosp-Quantity manufactured in the United Kingdom

\section{CHAPTER XXIIl}

\section{TIMBER, AND THE BUILDING TRADE}

Inported timber-Amounts in diferent rears-Sources of supply-Census of Production figures-The building trade-Its importance-Peculiar conditions determining itUnemployment in-The supply of labour-Ferro-concrete-By-laws 


\section{CHAPTER XXIV}

\section{FOOD SUPPLIES AND CONSUMPTION}

Statistics of consunption-Changes in 50 years: $(a)$ Conditions governing our food supply; (b) Variety; (c) Standard of consumption - Working-class budgetsCertain staple foorls-Wheat-Other cereals-Meat-Fish-Poultry-Dairy Produce-Groceries - Tea - Coffee-Sugar - Cocoa-Confectionery, etc.-Fruit and regetables

\section{CHAPTER XXV}

\section{BEER, WINE, SPIRITS, AND TOBACCO}

Beer-Origin of beer-Early London beers-The beginning of the brewery-Duties on beer-Quantities of beer consumed in England and Wales, and duties thereon, 1801-1829-Quantity of beer made, exported, and retained for home consumption, 1881-1909-Changes in public taste dnring the last fifty years-Licensing dutiesYields fromrarious beer taxes, 1882-1910 - Number of licences taken out, 1899-1903 -The brewing trade during the past thirty years-Our exports of beer. Malt.Consumption of malt in the United Kingdom, 1801-1841-Rates of duty and average consumption per lead of population, 1740-1790-Quantity of malt, sugar, and other important ingredients used in brewing, 1880-1910. Wine, 1800-1850. - Qnantity and descriptions of wine used in Great Britain and Ireland-Average consumption and amount of duty contributed, 1801-1841-Rates of duty, 18011841-Consumption during the eighteenth century-Quantity of wine made in France in first half of nineteenth century-Quantities of French wine sold for consumption in the United Kingdom, 1815-1845. 1850-1910.-Our imports of wine, 1850-1910-Decrease in consumption during second half of nineteenth centuryOnr re-export tracle in wine, 1860-1910-Countries that send us wines-Sorts of wine imported in 1909-Yield from customs duties on wine, 1850-1910. Spirits, 1800 - 1850. - Consumption of spirits during first half of nineteenth century-Spirit drinking in Ireland-Spirit drinking in Scotland-Revenue derived from foreign spirits, 1811-Imports of rum and foreign spirits into the United Kingdom, 18021841. 1850-1910. -Quantities of spirits made, exported, retained for home consumption and retained in bond, 1880-1910-Imports of rum, brandy and other spirits, 1860-1910-Exports and re-exports of British spirits, 1860-1910-Yields from spirit duties, 1860-1910. Tobacco.-The introduction of tobacco in England -Tobacco dnties in first half of nineteenth century-Consumption of tobacco per head in modern nations-Tobacco prices, 1842-1908

\section{CHAPTER XXVI}

\section{A VIEW OF OUR FOREIGN COMMERCE AND NAVIGATION IN} THE FIRST HALF OF THE NINETEENTH CENTURY

Dependence of various countries upon each other for comforts and conveniencesPeculiar advantages of England for prosecuting foreign commerce-Effect of wars and commercial systems upon foreign trade-Growing importance of its commerce to England-Influence of extended markets in preventing ruinous fluctuationsThe corn laws-Progress of foreign and colonial trade, from 1801 to 1849-Course of trade with various countries-Opening of East India and China trades-Discriminating duties on sngar-on coffee-on timber-Continental system-Return of peace-Free Trade petition of London merchants--Relaxation of Navigation Acts-Reciprocity treaties-Registered tonnage-Ships built-Ships entered and cleared, 1801-1849

\section{CHAPTER XXVII}

BRITISH FOREIGN TRADE (IMPORTS AND EXPORTS), 1850-1910

Imports and exports, 1850-1870-Second period, 1870-1890-Third period, 1890-1910Mr. Chamberlain's Protectionist campaign with its statistical basis-Exports of coal and machinery-The excess of imports-Food and raw material-Our chief foreign and colonial customers-Our chief imports and exports, 1860-1910 . 


\section{$X$ CHapter XxviII}

PAGE

1800-1850.-Farly days of steam navigation-Steam-ressels built and registered in the United Kingdom and British colonies, 1811-184-Steam-ressels belonging to British Empire, 1S14-1S41-Early days of steam narigation on the ThamesSteam-ressels entered and cleared in coasting and foreigu trade, 1\$20-184:. 1850-1910. - Tonnage of vessels registered as belonging to United Kingrom, 1850-1910-Tonnage of British vessels entered and cleared in foreign trade, 18511910 - Where British tonnage is employed-Development of Far Eastern and Indian trade-The Suez Canal-Australian trade-The Atlantic traffic-European and Mediterranean trade-South African trale-South American trade-The development of our cossting trade-Numbers employed on British ships, dis. tinguishing British subjects and foreigners . . . . . . .

\section{CHAPTER XXIX}

\section{INTERNAL COMMUNICATION}

Introductory-Roads-Canals-Railways : railway statistics-The gauge-SpeedCompetition-Receipts-Expenditure .

\section{CHAPTER XXX}

\section{THE POST OFFICE}

Historical-The penny post-Post-office rerenue and expenditure-Post-office sarings bank-Telegraphs and telephones

\section{CHAPTER XXXI}

\section{THE COINAGE SYSTEM OF GREAT RRITAIN AND THE EMPIRE}

Bad state of the coinage at the beginning of the nineteenth century-Disappearance of coin-Bauk tokens-Moneys coined, 1801 to 1910-Diminished weight of silver coins-Proposal of donble standard-Copper coinage, 1821 to 1910 -History of coinage after $1850-$ Indis and the Colonies

\section{CHAPTER XXXII}

\section{PAPER CURRENCY AND BANKING, 1800-1850}

Ballion Committee of 1810-The controversy on the currency-High prices of gold, 1809-1815-Issues of paper money-Peel's Act-Panic of 1825-Formation of branches by Bank of England - Establishment of joint-stock banks-Number established, 1826-1836-Advantages of having only one bank of issue-National Bank-Intluence of currency on prices-Plan for estimating rise and fall of pricesEffects of abundant or deficient harrests upon currency and prices-Table of notes in circulation and bullion held by the Bank

\section{CHAPTER XXXIII}

\section{PROGRESS OF BANKING, 1850-1900}

Working of the Bank Charter Act and of the bank rate during crises-Development of joint-stock banks-Amalgamations and combinations-The crises of 1847,1857 , 1866,1890 , and 1907-Paid-up capital and deposits .

\section{CHAPTER XXXIT}

\section{INSURA TCE}

Growth of insurance business-Marine insurance-Lloyd's-Fire insurance-Employers' liability-Life insurance-Scientific exactitude-The enormons rolume of business 


\section{CHAPTER XXXV \\ PUBLIC REVENUE AND EXPENDITURE, 1800-1850}

Financial condition at the close of the eighteenth century-Triple assessment-Inconetax imposed-Repealed-Enormous Government expenditure-Fallacious show '?f prosperity-Misery of the working classes-Their diminished command of the. necessaries of life-Effect of mechanical inventions in supporting the country under difficulties-Gigantic expenditure during the French War-Consequent exhaustion -Gloomy forebclings of political writers in former times-Amount of debt, 17931816-Yearly income and expenditure, 1792-1849-Debts contracted, 180I-1821Sinking fund-Dead-weight annuity-Conversion of perpetual into terminable annuities-Expenditure beyond income during the war-Income beyond expenditure since-Plans of finance budgets-Civil List from 1701-1849-Crown revenues Pensions - Miscellaneous services - Salaries in Public Departments - Reductions between 1815 and 1835 .

\section{CHAPTER XXXVI}

\section{NATIONAL EXPENDITURE AND DEBT, 1850-1910}

1 National expenditure in 1851-Movements of revenue and debt from 1867-General survey of expenditure-The national debt-The army expenditure-Naval expenditure-Civil services

\section{CHAPTER XXXVII}

TAXATION AND COMHERCIAL POLICY, 1840-1910

Gradual removal of our old Protective and Preferential Tariff-Mr. Gladstone's budgets -South African War finance-Mr. Lloyd George's budget of 1909 . . . .

\section{CHAPTER XXXVIII}

\section{THE GROWTH OF WEALTH AND CAPITAL}

The increase of capital and its measurement-Estimated growth of British capital from 1600 to 1800 , from 1800 to 1885 , and from 1885 to 1910 
THE PROGRESS OF THE NATION 



\title{
THE PROGRESS OF THE NATION
}

\author{
CHAPTER I \\ POPULATION
}

Historical summary-1. Growth of population; (a) Emigration; (b) Natural increase-The death-rate-Infant mortality rate-Birth-rate-II. Constitution of population; (a) Sex; (b) Age; (c) IIarriage; (d) Birthplace-III. Movement of population-IV. Physical infirmity

\section{Historical INTRODUCTION}

" inhabitants of this country was exceedingly vague and imperfect up to the end of the eighteenth century. In the course of the seventeenth century the value of such knowledge began to be felt, and in the following century attempts were made to deduce the increase, or otherwise, from the difference between the births and burials in each decennary period commencing with 1700." There was, however, at that time a general fear that the population was decreasing; and this apprehension caused a proposal, made in the House of Commons in 1753 , for an official enumeration of the people, to meet with violent opposition. Members declared that such a project was "subversive of the last remains of English liberty," found in it " an "engine of rapacity and oppression," thought it likely to be productive of "some public misfortune or epidemical distemper," and though the scheme passed through the Commons it was thrown out by the Lords. The main objection was that a census would show the increasing inability of the country to support an adequate army.

By 1800 , however, the fear of a decline in population had been replaced by a dread, stimulated by Malthus' Essay on Population, that it was increasing faster than the means of subsistence. The need of accurate information was strongly felt, and in 1800 a Bill for the first census passed without opposition. 
First Census, 1801.-Previous to 1801 there existed no official returns for either England or Scotland: those for Ireland were first made in 1821. The scope and machinery of this first inquiry remained practically unaltered at the next three censuses, 1811, 1821, and 1831. There was no central authority. The enumeration was undertaken by the Overseers of the Poor, with the aid of the parish ministers and the co-operation of the Justices of the Peace.

The scope of the inquiry was limited to an enumeration of the numbers of persons and houses in each parish, uninhabited dwellings being distinguished; and a simple classification of occupation as those employed in $(a)$ agriculture; (b) trade, manufactures, or handicraft; $(c)$ other occupations than $(a)$ or $(b)$; and though in 1831 a further attempt at occupational classification was made, great difficulty arose at all early enumerations through want of uniformity in the interpretation of census questions-a difficulty that renders exact comparisons with later year's impossible.

In 1821, the first year of a complete census of the United Kingdom, an age classification was for the first time introduced, and in 1831 an inquiry as to place of birth was included. But it was not till 1841 that the machinery and organization of the census received what has proved to be its final form as the result of two Acts of Parliament-the Poor Law Act of 1834, which made the Poor Law Union the unit of administration over the whole country; and the Registration Act of 1836, which instituted the District Superintendent Registrars as official recorders of births and deaths, and thus controlling census agents in England and Wales. Thus, after 1838, the natural growth of population can be traced by a comparison of the birth- and death-rates.

That in spite of inevitable imperfections the four earliest censuses can be used as the basis for calculation and comparison, is no doubt largely due to the acute intellect of John Rickman, under whose superintendence they were undertaken. Rickman, whom his friend Charles Lamb describes as "a perfect man: up to anything, down to anything," was himself fully aware of the elements of inaccuracy due in part to defective machinery, in part to misunderstandinginaccuracy that has decreased at each subsequent census with the advance in statistical method associated with the names especially of Dr. Farr and Dr. Ogle.

Allowing, however, for this margin of error, it is possible to view the century as a whole, and consider the growth of population from 1801 to 1901 , and, with the aid of the latest figures so far as issued in the Preliminary Report of the Registrar-General, to 1911. 


\section{Growth of Population}

Looking first to the figures for England and Wales, it is seen that during the century the population has nearly quadrupled: it has risen by $265 \cdot 8$ per cent. in the period-from $S, 892,536$ to $32,527,843$.

TABLE I.-Gronth of Population (England and Wales)

\begin{tabular}{|c|c|c|c|}
\hline Year. & Persons. & Males. & Females. \\
\hline 1801 & - & & \\
1811 & $8,892,536$ & $4,254,735$ & $4,637,801$ \\
1821 & $10,164,256$ & $4,873,605$ & $5,290,651$ \\
1831 & $12,000,236$ & $5,850,319$ & $6,149,917$ \\
1841 & $13,896,797$ & $6,771,196$ & $7,125,601$ \\
1851 & $15,914,148$ & $7,777,586$ & $8,136,562$ \\
1861 & $17,927,609$ & $8,781,225$ & $9,116,384$ \\
1871 & $20,066,224$ & $9,776,259$ & $10,289,965$ \\
1881 & $22,712,266$ & $11,058,934$ & $11,653,332$ \\
1891 & $25,974,439$ & $12,639,902$ & $13,334,537$ \\
1901 & $29,002,525$ & $14,052,901$ & $14,919,624$ \\
1911 & $32,527,843$ & $15,728,613$ & $16,799,230$ \\
& $36,075,269$ & $17,448,476$ & $18,626,793$ \\
\hline
\end{tabular}

The periods in which the rate of growth has been most rapid were 1811-1821, when it was as high as 18.06 per cent.; and, in the last half-century, 1871-1881, when it was 14.36 per cent. This decade includes a period of record prosperity, 1871-1875, as testified by a rising birth-rate and average wage-rate and a falling rate of pauperism and unemployment.

Ireland.-But while the population of England and Wales, and that of Scotland, has steadily increased since 1821, that of Ireland, which also rose up to 1841 , has since 1841 steadily declined; it has fallen from eight millions in 1841 to not quite four and a half millions in 1901, and though the rate of decline was checked in 1911, the total failed to reach four and a half millions.

It is to this decline in the population of Ireland that the variation in the rate of increase for the United Kingdom is largely due.

In 1821, of an aggregate population of nearly twenty-one millions,

57.44 per cent. were living in England
10.01 "
$32.55 \quad "$

But in 1901 , of $41,458,721$ persons living in the United Kingdom, 78.46 per cent. were living in England and Wales, $10.79 \quad " \quad$ " Scotland, and only $10.75 \quad, \quad$ Ireland. 
In 1821,1831 , and 1841 the population of Ireland was more than thrice that of Scotland; in 1901 it was rather smaller than that of Scotland.

\section{TABLE II.-United Kingdom}

\section{$A$. Population}

\begin{tabular}{|c|c|c|c|c|c|c|}
\hline Year. & $\begin{array}{c}\text { England } \\
\text { and Wales. }\end{array}$ & Scotland. & Ireland. & $\begin{array}{l}\text { United } \\
\text { Kingdom. }\end{array}$ & $\begin{array}{c}\text { Isle } \\
\text { of Man. }\end{array}$ & $\begin{array}{l}\text { Channel } \\
\text { Islands. }\end{array}$ \\
\hline $\begin{array}{l}1821 \\
1831 \\
1841 \\
1851 \\
1861 \\
1871 \\
1881 \\
1891 \\
1901 \\
1911\end{array}$ & $\begin{array}{l}12,000,236 \\
13,896,797 \\
15,914,148 \\
17,927,609 \\
20,066,224 \\
22,712,266 \\
25,974,439 \\
29,002,525 \\
32,527,843 \\
36,075,269\end{array}$ & $\begin{array}{l}2,091,521 \\
2,364,386 \\
2,620,184 \\
2,888,742 \\
3,062,294 \\
3,360,018 \\
3,735,573 \\
4,025,647 \\
4,472,103 \\
4,759,445\end{array}$ & $\begin{array}{l}6,801,827 \\
7,767,401 \\
8,196,597 \\
6,574,278 \\
5,798,967 \\
5,412,377 \\
5,174,836 \\
4,704,750 \\
4,458,775 \\
4,381,951\end{array}$ & $\begin{array}{l}20,893,584 \\
24,028,584 \\
26,709,456 \\
27,368,736 \\
28,927,485 \\
31,484,661 \\
34,884,848 \\
37,732,922 \\
41,458,721 \\
45,216,665\end{array}$ & $\begin{array}{l}40,081 \\
41,000 \\
47,975 \\
52,387 \\
52,469 \\
54,042 \\
53,558 \\
55,608 \\
54,752 \\
52,034\end{array}$ & $\begin{array}{l}49,427 \\
62,710 \\
76,065 \\
90,739 \\
90,978 \\
90,596 \\
87,702 \\
92,234 \\
95,618 \\
96,900\end{array}$ \\
\hline \multicolumn{7}{|c|}{$B$. InCREASE $(+)$ OR DeCREASE $(-)$ PER CENT. } \\
\hline $\begin{array}{l}1821-1831 \\
1831-1841 \\
1841-1851 \\
1851-1861 \\
1861-1871 \\
1871-1881 \\
1881-1891 \\
1891-1901 \\
1901-1911\end{array}$ & $\begin{array}{l}+15 \cdot 8 \\
+14 \cdot 5 \\
+12 \cdot 7 \\
+11 \cdot 9 \\
+13 \cdot 2 \\
+14 \cdot 4 \\
+11 \cdot 7 \\
+12 \cdot 2 \\
+10.9\end{array}$ & $\begin{array}{l}+13 \cdot 0 \\
+10 \cdot 8 \\
+10 \cdot 2 \\
+6 \cdot 0 \\
+9 \cdot 7 \\
+11 \cdot 2 \\
+7 \cdot 8 \\
+11 \cdot 1 \\
+6 \cdot 4\end{array}$ & $\begin{array}{l}+14 \cdot 2 \\
+5 \cdot 5 \\
-19 \cdot 8 \\
-11 \cdot 8 \\
-6 \cdot 7 \\
-4 \cdot 4 \\
-9 \cdot 1 \\
-5 \cdot 2 \\
-1 \cdot 7\end{array}$ & $\begin{array}{l}+15 \cdot 0 \\
+11.2 \\
+2.5 \\
+5 \cdot 7 \\
+8 \cdot 8 \\
+10 \cdot 8 \\
+8 \cdot 2 \\
+9 \cdot 9 \\
+9 \cdot 1\end{array}$ & $\begin{array}{l}+2.3 \\
+17.0 \\
+9.2 \\
+0.2 \\
+3.0 \\
+0.9 \\
+3.8 \\
-1.5 \\
-5.0\end{array}$ & $\begin{array}{l}+26.9 \\
+21.3 \\
+19.3 \\
+0.3 \\
-0.4 \\
-3.2 \\
+5.2 \\
+3.7 \\
+\quad 0.13\end{array}$ \\
\hline
\end{tabular}

(Census 1901 and 1911.)

The rate of increase for the United Kingdom fell from 11.2 per cent. in 1831-1841, to 2.5 per cent. in 1841-1851-a fall due to a decrease of 19.8 per cent. in the population of Ireland, representing a loss of a million and a half of Irish people, as a result of the failure of the potato harvest in 1846 and the famine that followed upon it in 1847. Ireland shared in the general prosperity of the decade $1871-1881$, and the rate of decrease fell to 4.4 per cent.; but in 1881-1891, when the rate of increase for England and Wales fell to $11 \cdot 7$ per cent., the rate of decrease for Ireland more than doubled itself, rising again to $9 \cdot 1$ per cent. In 1901-1911, however, the Irish rate of decrease fell again to 1.7 per cent.; and the general rate of increase for the United Kingdom was $9 \cdot 1$ per cent. 
Causes of Increase.-The growth of population depends upon two factors; i.e.,

(a) The balance between emigration and immigration, and

(b) "Natural increase," or the difference between the number of births and the number of deaths.

Where the actual increase is lower than the natural increase, as has been the case in every year since 1831, the explanation must be looked for in an excess of emigration over immigration.

(a) Emigration and Immigration.-That the movement of population is not dictated solely by economic causes is obvious. Advantages of elimate and natural resources attract immigrants; social and political disabilities impel men to leave their native land. But the main cause of emigration as it has affected the United Kingdom has been the state of the labour market at different periods and the difficulty of acquiring land. As Porter points out: "In any country which is making any considerable progress in the arts of life, changes will from time to time occur in the sources of employment for particular classes of the people, which must be felt as hardships by individuals, although to the country at large they are productive of great and permanent good." At such times it is natural for those suffering from a distress that, though transitory from the point of view of the historian of progress, is to them long enough to be destructive, to seek better fortune elsewhere. Again :

"In the early part of the present century, although the cry of distress was occasionally loud and urgent on the part of the labouring classes, that distress was occasioned more by the dearness of provisions than by any deficiency of employment, as a remedr for which, if it had occurred, the ranks of the army were at all times open. 'The return of peace threw back in considerable numbers upon the community the surplus labourers who had been thus absorbed, two deficient harvests occurred successively in aggravation of this inconvenience, and in the year 1820 the evil had grown to so great a height that the Government undertook the task of conveying settlers and locating them in South Africa."

\section{8,984 persons emigrated in that year.}

It is natural that the emigration figures should have risen to their highest point in the years 1845-1861, for within that period there began the drain from Ireland which las since been stealily going on, though latterly in much decreased numbers.

The early figures are far from complete: before 1851 nationality is not differentiated. Between 1831-1841 the total emigration, to all parts, from the United Kingdom was 499,871. In the five years $1846-1850$ it rose to $1,216,507$, of which total 855,154 went to the United States (in 1849 , for example, out of 
299,498 emigrants, 219,450 went to the U.S.A.). In 1871-1881 emigration fell to $1,697,719$, of which total 530,924 were Irish; rising again to $2,593,226$ in 1881-1891, it fell again to $1,762,734$ in 1891-1901, 465,273 being Irish. And whereas in 1860 British immigrants to the U.S.A. formed 51 per cent. of the total immigration thither, in 1903 only 8 per cent. were British (including Irish). Irish emigration to U.S.A. was 741,883 in 1881-1891, only 465,273 in 1891-1901. The number of Irish born in U.S.A. was $1,871,509$ in 1890 , and $1,618,567$ in 1900 (U.S.A. census).

TABLE III.-Emigration

\begin{tabular}{|c|c|c|c|c|}
\hline Years. & Total. & English. & Scottish. & Irish. \\
\hline $1821-1831$ & 196,658 & $\ldots$ & $\ldots$ & $\ldots$ \\
$1831-1841$ & 499,871 & $\ldots$ & $\ldots$ & $\ldots$ \\
$1841-1850$ & $1,216,507$ & $\ldots$ & $\ldots$ & $\ldots$ \\
$1851-1861$ & $2,054,578$ & 640,316 & 182,954 & $1,231,308$ \\
$1861-1871$ & $1,674,594$ & 649,742 & 158,226 & 866,626 \\
$1871-1881$ & $1,697,719$ & 996,038 & 170,757 & 530,924 \\
$1881-1891$ & $2,593,226$ & $1,572,717$ & 278,626 & 741,883 \\
$1891-1901$ & $1,762,734$ & $1,109,556$ & 187,905 & 465,273 \\
& & & & \\
\hline
\end{tabular}

Since 1851 emigration has always exceeded immigration by an appreciable amount, but this excess has steadily declined since 1881 . In 1891-1901 the number of emigrants showed a decline, as compared with 1881-1891, of 830,492 ; whereas the number of European foreigners immigrating increased from 198,113 in 1891 to 247,758 in 1901 . Thus, while the loss of population by excess of emigration over immigration was 73 per cent. in 1881 , and 2.31 per cent. in 1891 , it was only $\cdot 23$ per cent. in 1901 . Though emigration still exceeds immigration, emigration is decreasing while immigration is increasing.

The increase of the foreign population has been much more rapid during the century than the increase of the general population. Its proportion to the whole in 1901 was twice what it was in 1861 .

The recent remarkable increase in immigration from Russia and Italy is worthy of note. In 1861 the number of Russian immigrants was 1633 , in 1891 it was 23,626, and in 190161,789 -an increase of 161.5 per cent. on the high total of the previous census. In 1861 the number of Italian immigrants was 4489 , in 1891 it was 9909 ; in 1901 it showed a further increase of $105 \cdot 2$ per cent., the numbers rising to 20,332 . These foreign arrivals are 
found almost exclusively in industrial centres and at seaports, 85 per cent. being found in London and eighty-four other large towns.

TABLE IV.-Aliens Enumerated in England and Wales

\begin{tabular}{|c|c|c|c|c|c|c|c|c|}
\hline \multirow[b]{2}{*}{$\begin{array}{l}\text { Census } \\
\text { Years. }\end{array}$} & \multicolumn{2}{|c|}{$\begin{array}{l}\text { Persons in England } \\
\text { and Wales. }\end{array}$} & \multicolumn{3}{|c|}{$\begin{array}{c}\text { Aliens, irrespective of } \\
\text { Nationality (British } \\
\text { Subjects and Foreign } \\
\text { Subjects). }\end{array}$} & \multicolumn{3}{|c|}{$\begin{array}{l}\text { Aliens, classified as } \\
\text { Foreign Snbjects. }\end{array}$} \\
\hline & Persons. & 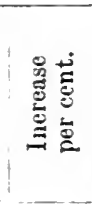 & 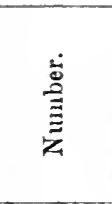 & 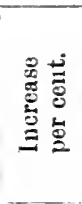 & 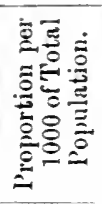 & 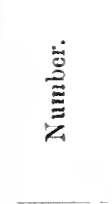 & 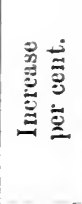 & 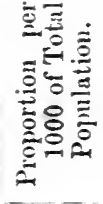 \\
\hline $\begin{array}{c}1841 \\
\text { (Porter) } \\
1851 \\
1861 \\
1871 \\
1881 \\
1891 \\
1901\end{array}$ & $\begin{array}{l}20,066,224 \\
22,712,266 \\
25,974,439 \\
29,002,525 \\
32,527,843\end{array}$ & $\begin{array}{c}\cdots \\
\cdots \\
13 \cdot 2 \\
14 \cdot 4 \\
11 \cdot 7 \\
12 \cdot 2\end{array}$ & $\begin{array}{c}101,832 \\
139,445 \\
174,372 \\
233,008 \\
339,436\end{array}$ & $\begin{array}{c}\cdots \\
\ldots \\
36 \cdot 9 \\
25 \cdot 0 \\
33 \cdot 6 \\
45 \cdot 7\end{array}$ & $\begin{array}{r}5 \cdot 1 \\
6 \cdot 1 \\
6 \cdot 7 \\
8 \cdot 0 \\
10 \cdot 4\end{array}$ & $\begin{array}{r}84,090 \\
100,638 \\
117,999 \\
198,113 \\
247,758\end{array}$ & $\begin{array}{l}\ldots \\
\ldots \\
19 \cdot 7 \\
17 \cdot 3 \\
67 \cdot 9 \\
25 \cdot 1\end{array}$ & $\begin{array}{l}\dddot{4} \cdot 2 \\
4 \cdot 4 \\
4 \cdot 5 \\
6 \cdot 8 \\
7 \cdot 6\end{array}$ \\
\hline
\end{tabular}

TABLE V.-Distribution of Aliens

\begin{tabular}{|c|c|c|c|c|c|}
\hline & & & 1881. & 1891. & 1901. \\
\hline London County & . & . & 60,252 & 95,053 & 135,377 \\
\hline Manchester. & . & . & 2,805 & 2,941 & 11,737 \\
\hline Liverpool . & . & • & 6,858 & 7,402 & 8,974 \\
\hline Leeds . & . & . & 2,134 & $5,92 \pi$ & $\tau, 426$ \\
\hline
\end{tabular}

In London itself they are very unequally distributed. In 1901 there were in-

\begin{tabular}{|c|c|c|c|c|c|c|}
\hline Stepney . & . & - & . & - & - & - 54,310 \\
\hline Westminster & . & . & . & . & . & . $\quad 11,831$ \\
\hline St. Pancras & . & . & . & . & - & - 8,156 \\
\hline Marylebone & . & . & . & . & . & 5,560 \\
\hline Bethnal Green & . & . & - & . & . & 4,634 \\
\hline Woolwich & . & . & . & . & . & 441 \\
\hline
\end{tabular}

The Commission on Alien Immigration (1902) declared "the greatest evils produced by alien immigration" to be "the overcrowding caused by them in certain districts of London, and the consequent displacement of the native population." C'ensus figures, however, do not at all bear out the assertion commonly made that 
alien immigrants largely fill workhouses, infirmaries, and lunatic asylums in England. In the East London areas constituting the Boroughs of Bethnal Green, Poplar, Shoreditch, and Stepney, 62,843 European foreigners, living under the poorest conditions, were enumerated in a population of 715,739 ; but among the 10,820 pauper inmates of the workhouses of this area, only 109 were European foreigners. In 1891 there were 13.5 per cent. indoor paupers per thousand of population, 1.7 among the European foreigners; in 1901 the figures were $15 \cdot 1$ and $1 \cdot 7$ per thousand respectively.

(b) Natural Increase.-Considerable space has been devoted to the balance of emigration and immigration as a factor in the actual increase of population; but the figures recording the progress of natural increase are far more interesting and important.

Since the institution of the Registration of Births and Deaths in 1837 , the birth-rate has always exceeded the death-rate; there has always been an increase in the population. But since 1880 the rate of this increase, which had risen steadily from 1838 , began to decline. The number of births per thousand has declined since 1880 , and though the death-rate has also declined, its decrease does not quite counterbalance the fall in the death-rate.

A table will make this clear.

TAble VI.-Natural Increase of Population

(by Excess of Births over Deaths)

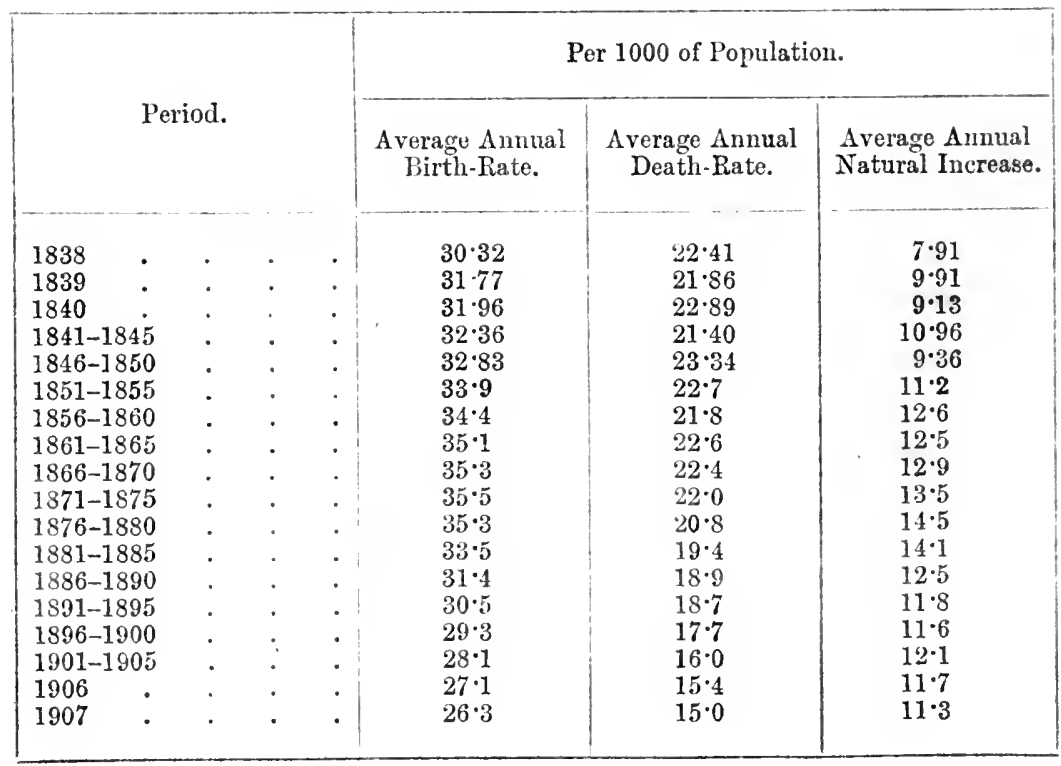


The Death-Rate- - The increase of population which results from a diminishing proportion of deaths is an unerring sign of advancing prosperity and improved sanitary conditions." The steady decline in the death-rate from 1801 to 1851 may be assigned, among other causes, to the less crowded state of dwellings, the command of better kinds of food, the superiority and cheapness of clothing, more temperate habits, and greater personal cleanliness. One influential cause of diminished mortality among children was the introduction of vaccination. The decline in the deaths from smallpox was certainly remarkable:-

\section{TABLE VII}

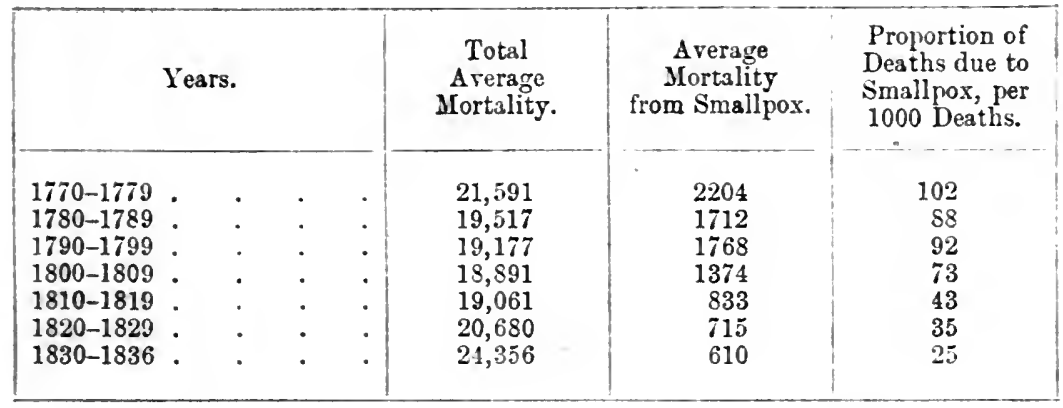

In 1869 the proportion of deaths from smallpox was only 2.62 per thousand, and in 1908 there were no deaths from smallpox.

If in 1851 a proportion of 25 deaths per thousand from smallpox seemed to offer food for congratulation, it must be remembered that at that period sanitary science hardly existed and disinfection was practically unknown.

It was the outbreak of a huge and destructive cholera epidemic which scourged London in 1866 that led to the appointment of the Royal Sanitary Commission, and enabled John Simon, then medical adviser to the Government, and "the creator of sanitary science in all its modern aspects," to effect some co-ordination of the confused machinery of local administration of public health under the general direction of the new Local Government Board. London still draincl into the Thames, which was one gigantic sewer, washed back and forward by the tide. Many large towns had no sewage system, and epidemics were frequent. Smallpox ravager London and the provinces in 1871; and when the Prince of Wales was laid low with typhoid, public interest awoke. In 1875 the Public Health Act consolidated all that Simon had done in the appointment 
of local health authorities, medical officers, and inspectors of nuisances, etc.

Since 1869 enteric fever has greatly declined. The deaths from that cause have fallen from 390 per million in 1870 to 67 in 1907 , and typhus and smallpox have practically died out (the deaths from these two diseases having declined from 193 and 262 per million respectively in 1869, to 1 and 0 in 1909), the improvement being due to improved sanitary administration. The same decline is shown in the death-rate from scarlet fever, diarrhoa, dysentery and cholera, phthisis and bronchitis, and all forms of tuberculosis. The latter disease accounted for 3566 deaths per million in 1869 , for 1605 in 1907 .

The mortality of rural districts is about 23 per cent. lower than that of urban districts. Taking an average of the years 1902-1906-

\section{Corrected Death-Rate}

England and Wales

London and ten urban counties

Sixteen rural counties .

$15 \cdot 69$

$17 \cdot 21$

$13 \cdot 26$

While the general mortality of rural districts is 23 per cent. lower than that of urban, the infant mortality rate is 33 per cent. lower in rural districts.

Infant Mortality. - The importance of the rate of infantile mortality was hardly realized in the first half of the century, and exact figures, therefore, cannot be given.

TABLE VIII.-Infant Mortality in England and Wales, and London.

Deaths of Infants under One Year of Age per Thousand Births

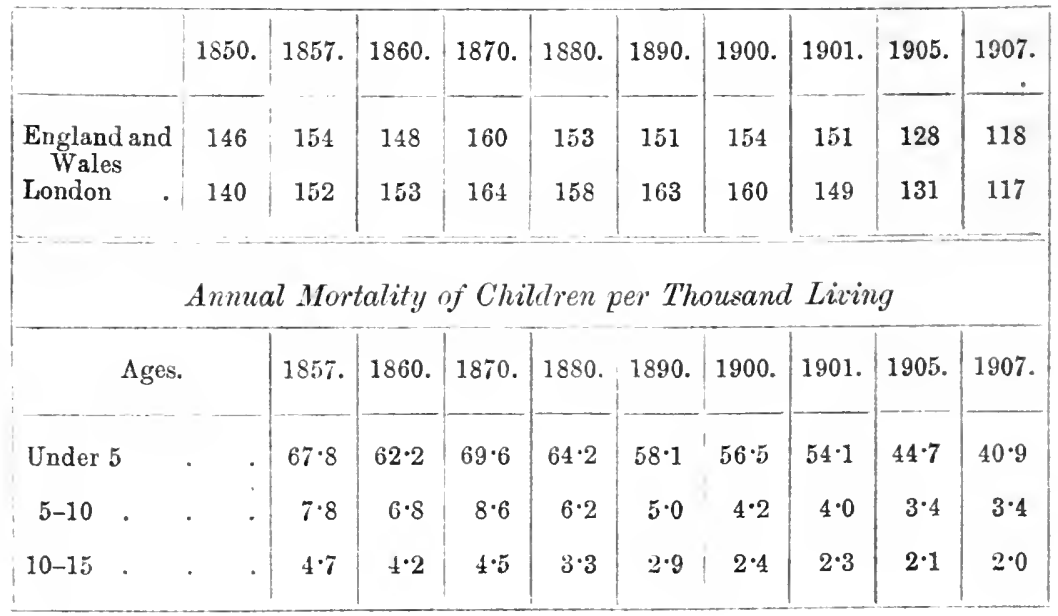


From these two tables it can be seen that since 1870 , when the mortality of infants under one year, and of children, reached its highest point in the century, it has declined, and that since 1900 in particular the decline has been not only steady but rapid. Whether we take the number of deaths per thousand births or per thousand living, the decline is marked.

The death-rate of infants under one year was 146 per thousand births in 1850,118 in 1907 . In the decade $1891-1900$ it was 181.2 per thousand living under the age of one year.

There is thus a marked improvement, and in no European country save Holland is the infant mortality rate so low as in England. In France for 1896-1905 it was 149 per thousand births, in Prussia 196, in Russia 268, in England 147, in Holland 144.

The reduction in the rate effected in the last decade is so great that it is to be hoped that increased recognition of the gravity of the evil as it still remains may produce greater improvements. Children under five years of age form one-ninth of the population: their death-rate is responsible for one-fifth of the total number of deaths. It has been shown, too, that the rate rises directly with urban conditions: that it is high in mining and industrial districts and where women go out to work; lower in purely agricultural ones.

The extreme importance of safeguarding infant life is clearly seen when the decline in the birth-rate is taken into account.

The Birth-Rate.-The 70th Report of the Registrar-General observes that it may be stated that during the past thirty years 14 per cent. of the decline of the birth-rate is due to the decrease in the proportion of married women in the population of conceptive ages; over 7 per cent. to the decrease in illegitimacy. The remaining 79 per cent. is considered to be largely due to deliberate restriction.

Whether the decline in the birth-rate, when accompanied by such progressive decline in the death-rate as maintains an anmual rate of increase in population, is to be regarded as an evil or not, depends on qualitative considerations for which exact data are lacking. "It has been usual with writers on political economy to point to the diminished proportion of marriages and births as evidence of increasing prudence on the part of the peoplc, who, as they become more intelligent, are supposed to be less willing to undertake the charge of a family, until they shall, in some measurc, have secured the means of supporting one. It is true that in years of scarcity some temporary check may be put on the 
contracting of marriages; but if we consider how small the proportion of individuals in a community can be, who, even in the most prosperous times, have any certain assurance that their means of supporting a family will be continued to them in future years, we must perceive that this preventive check can never have any very extensive operation" (Porter).

\section{Constitution of the Population}

(a) Sex.-The first table given showed that the female population has, since 1801, exceeded the male; but the excess of females is really greater than there appears, for there is always a large number of men temporarily absent as sailors, soldiers, or on business. There were 1057 females to every thousand males in the enumerated population of 1801 , in 1821 the ratio fell to 1036 , rising to 1046 in 1831 , falling in 1841 to 1042 , since when it has risen continuously. The ratio for 1901,1068 per thousand, is the highest on record; but it needs to be corrected by the addition to the male population of 277,197 persons returned as absent on service; which reduces the proportion to 1050 females to every thousand males. More males are born than females, but some are always absent at the census, more men than women are lost by emigration; and the rate of mortality is higher for men: it is also true that, though more males are born, this excess has been steadily declining. Between 1841-1851, 954 females were born to every 1000 males; between 1891 and 1901, 968 females. Moreover, every decline in the birth-rate tends to increase the proportion of females living.

The sex proportion in various parts of the country varies according to industrial and social conditions.

The mining counties have the lowest proportion of females. For example, at every census since 1841 males have been in excess in Glamorgan and Moumouthshire, and at nearly every one in Durham and Staffordshire.

The residential counties, with large numbers of domestic servants (e.g. London, Devon, Sussex), have a high ratio of females.

(b) Agc.-The earliest attempt to ascertain the ages of the population was made at the census of 1821 , when eight-ninths of persons complied with the suggestion that they should voluntarily make a return of their ages. In 1831 no attempt to ascertain age was made; but since 1841 a statement of age has been made compulsory. "The age of persons living in any community forms 
a very important element towards the profitable examination of all tables of population."

It is important to observe the proportion that the productive part of the population bears to the number of children and aged persons dependent upon it; and it is noticeable that the decline in the death- and birth-rate has tended to increase this, and to raise the average age of population.

TABLE IX.-Numbers at Different Age Group (England and Wales)

\begin{tabular}{|c|c|c|c|c|c|c|}
\hline & \multirow{2}{*}{ Age. } & & \multicolumn{4}{|c|}{ Per 100.} \\
\hline & & & 1821. & 1841. & 1551. & 1901. \\
\hline Under 15 & • & • & $39 \cdot 24$ & $36 \cdot 13$ & $35 \cdot 44$ & $32 \cdot 42$ \\
\hline $15-50$ & . & - & $46 \cdot 13$ & $49 \cdot 14$ & $50 \cdot 35$ & $53 \cdot \$ 4$ \\
\hline \multirow[t]{2}{*}{ Over 50} & - & $\cdot$ & $14 \cdot 63$ & $14 \cdot 43$ & $14 \cdot 21$ & $13 \cdot 74$ \\
\hline & & & 100.00 & $100 \cdot 00$ & $100 \cdot 00$ & $100 \cdot 00$ \\
\hline
\end{tabular}

"By far the larger proportion of the increased duration of human life in England is lived at useful ages, and not at the dependent ages of either childhood or old age" (cf. Mr. Humphreys in the Statistical Journal, vol. xlvi. p. 195).

Another table, showing the numbers of the population living at all ages in the different census years since 1841, will make this rise in the average age still more clear (Table XI); while Table XII shows the age and sex distribution in urban and rural districts.

(c) Marriage.-The marriage-rate, which rose up to 1850 , has since then gradually declined. Since 1891 there has at the same time been a steady rise in the marriage age of both men and women, and a decline in particular of the number of women married below the age of twenty-one.

Looking at the proportion of married persons at different ages in 1901, at ages 20-25 one-sixth of men and one-fourth of women were married; at ages $35-45$ more than four-fifths of men and three-fifths of women; at $45-55$ a slightly higher proportion of men and a slightly lower proportion of women were found to be Inarried, while one-sixth of the women were widows. 
Table X.-Changes in Age Grouping of the Population (England and Wales)

\begin{tabular}{|c|c|c|c|c|c|c|c|c|c|}
\hline \multirow{2}{*}{\multicolumn{3}{|c|}{ Age Group. }} & & \multirow{2}{*}{$\begin{array}{c}1821 \\
\text { (Porter). } \\
\text { Number } \\
\text { per 1000 } \\
\text { of Total } \\
\text { Popula- } \\
\text { tion all } \\
\text { Ages. }\end{array}$} & \multirow{2}{*}{$\begin{array}{c}1841 \\
\text { (Porter). } \\
\\
\text { Number } \\
\text { per } 1000 \\
\text { of Total } \\
\text { Popula- } \\
\text { tion all } \\
\text { Ages. }\end{array}$} & \multicolumn{2}{|c|}{$\begin{array}{c}1851 \\
\text { Census. }\end{array}$} & \multicolumn{2}{|c|}{$\begin{array}{c}1901 \\
\text { Census. }\end{array}$} \\
\hline & & & & & & $\begin{array}{l}\text { Number of } \\
\text { Persons. }\end{array}$ & $\begin{array}{c}\text { Number } \\
\text { per } 1000 \\
\text { of Total } \\
\text { Popula- } \\
\text { tion all } \\
\text { Ages. }\end{array}$ & $\begin{array}{l}\text { Number of } \\
\text { Persons. }\end{array}$ & $\begin{array}{l}\text { Number } \\
\text { per } 1000 \\
\text { of Total } \\
\text { Popula- } \\
\text { tion all } \\
\text { Ages. }\end{array}$ \\
\hline \multicolumn{3}{|c|}{ 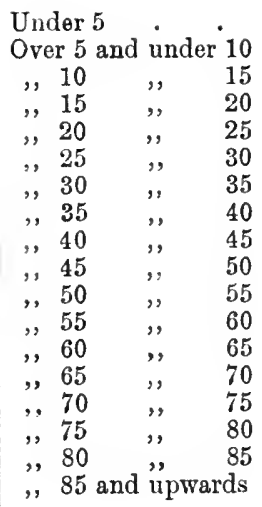 } & . & $\begin{array}{c}149 \cdot 2 \\
130 \cdot 4 \\
111 \cdot 2 \\
99 \cdot 2 \\
\ldots \\
\ldots \\
\ldots \\
\ldots \\
\ldots \\
\ldots \\
\ldots \\
\ldots \\
\ldots \\
\ldots \\
\ldots \\
\ldots \\
\ldots\end{array}$ & $\begin{array}{c}133 \cdot 3 \\
119 \cdot 5 \\
108 \cdot 7 \\
99 \cdot 6 \\
\ldots \\
\ldots \\
\ldots \\
\ldots \\
\ldots \\
\ldots \\
\ldots \\
\ldots \\
\ldots \\
\ldots \\
\ldots \\
\ldots \\
\ldots\end{array}$ & $\begin{array}{r}2,348,107 \\
2,092,359 \\
1,913,357 \\
1,757,189 \\
1,666,607 \\
1,470,475 \\
1,276,126 \\
1,088,559 \\
968,619 \\
798,989 \\
708,801 \\
526,287 \\
481,310 \\
327,519 \\
250,162 \\
146,102 \\
73,840 \\
33,201\end{array}$ & $\begin{array}{r}131 \cdot 0 \\
116 \cdot 7 \\
106 \cdot 7 \\
98 \cdot 0 \\
93 \cdot 0 \\
82 \cdot 0 \\
71 \cdot 2 \\
60 \cdot 7 \\
54 \cdot 0 \\
44 \cdot 6 \\
39 \cdot 5 \\
29 \cdot 4 \\
26 \cdot 8 \\
18 \cdot 3 \\
14 \cdot 0 \\
8 \cdot 1 \\
4 \cdot 1 \\
1 \cdot 9\end{array}$ & $\begin{array}{r}3,716,708 \\
3,487,291 \\
3,341,740 \\
3,246,143 \\
3,120,922 \\
2,824,509 \\
2,431,331 \\
2,145,383 \\
1,850,622 \\
1,573,188 \\
1,329,003 \\
1,052,577 \\
890,673 \\
629,673 \\
446,333 \\
264,480 \\
128,768 \\
48,499\end{array}$ & $\begin{array}{r}114 \cdot 3 \\
107 \cdot 2 \\
102 \cdot 7 \\
99 \cdot 8 \\
95 \cdot 9 \\
86 \cdot 8 \\
74 \cdot 7 \\
65 \cdot 9 \\
56 \cdot 9 \\
48 \cdot 4 \\
40 \cdot 9 \\
32 \cdot 4 \\
27 \cdot 4 \\
19 \cdot 4 \\
13 \cdot 7 \\
8 \cdot 1 \\
4 \cdot 0 \\
1 \cdot 5\end{array}$ \\
\hline To & & . & & $\ldots$ & $\ldots$ & $17,927,609$ & 1000.0 & $32,527,843$ & $1000 \cdot 0$ \\
\hline
\end{tabular}

TABLE XI.-Enumerated Population (England and Wales)

\begin{tabular}{|c|c|c|c|c|c|c|c|}
\hline & 1841. & 1851. & 1861. & 1871. & 1881. & 1891. & 1901. \\
\hline & 4,148 & $17,927,609$ & $20,066,224$ & $22,712,266$ & $25,974,439$ & $29,002,525$ & $32,527,843$ \\
\hline & & & & & & & \\
\hline & & $2,0 \mathrm{~s}$ & 2,3 & & 3,147 & & \\
\hline $10-15$ & 1, & 1,91 & 2,1 & 2,424 & 2,800 & $3,222,567$ & 1,740 \\
\hline-20 & 1,586 & & 1,93 & 2,18 & $\mathbf{2 , 5 4 7}$ & 2,950 & $3,246,143$ \\
\hline $\begin{array}{l}-25 \\
-25\end{array}$ & 1,55 & 1,66 & 1,829 & 2,004 & 2,328 & $2,646,412$ & $3,120,922$ \\
\hline $25-35$ & 2,44 & $2,746,6$ & 2,95 & 3,340 & $3,793,461$ & $4,377,728$ & $5,255,840$ \\
\hline 35-45 & & & & 2,57 & $2,940,7$ & $3,328,809$ & $\begin{array}{l}3,996,005 \\
3,200\end{array}$ \\
\hline & $1,2 \pi$ & & & & & & \\
\hline $55-65$ & 831 , & $1,007,5$ & 1,17 & 1,340 & 1,534 & 1,65 & $1,943,250$ \\
\hline $65-75$ & 483 & & & & & & $1,076,006$ \\
\hline $75-85 \div$ & 190,3 & & & & & & \\
\hline 85 upwards & 32,192 & 33,201 & 33,591 & 37,707 & 38,148 & 43,726 & 48,499 \\
\hline
\end{tabular}

Comparing 1871 and 1901, a decided tendency to a rise in the marriage age is plain, accompanied by a decreasing disparity between the ages of husband and wife. There is a substantial increase in the number of husbands whose wives are within five years of their own age; a decided decrease in the number of those 
whose wives are either much older or much younger; such cases being largely bachelor-widow, or widower-spinster marriages.

Table XII.-Age Distribution in Urban and Rural Districts per Million Living

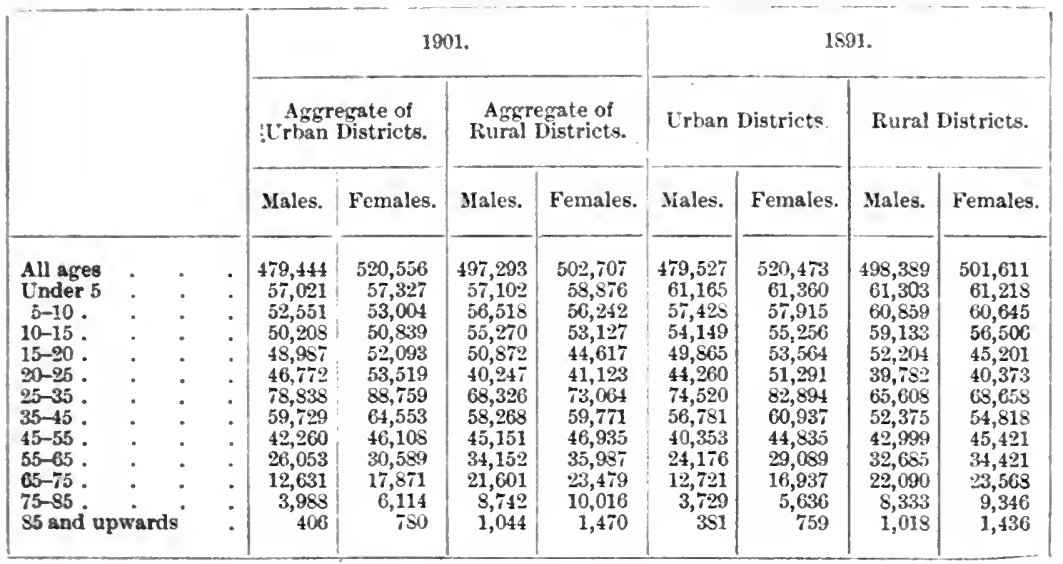

(Census, Table XXII. p. 214.)

TABLE XIII.-Marriage-Rate

\begin{tabular}{|c|c|c|c|c|}
\hline \multirow{2}{*}{ Year. } & \multicolumn{2}{|c|}{ Marriage-Rate per 1000} & \multicolumn{2}{|c|}{$\begin{array}{l}\text { Women under 21: } \\
\text { percentage of Persons Married. }\end{array}$} \\
\hline & $\begin{array}{l}\text { England } \\
\text { and Wales. }\end{array}$ & London. & $\begin{array}{l}\text { England } \\
\text { and Wales. }\end{array}$ & London. \\
\hline $\begin{array}{l}1838 \\
1840 \\
1850 \\
1860 \\
1870 \\
1880 \\
1890 \\
1900 \\
1907\end{array}$ & $\begin{array}{l}15 \cdot 44 \\
15 \cdot 62 \\
17 \cdot 20 \\
17 \cdot 1 \\
16 \cdot 1 \\
14 \cdot 9 \\
15 \cdot 5 \\
16 \cdot 0 \\
15 \cdot 8\end{array}$ & $\begin{array}{c}\cdots \\
\cdots \\
\cdots \\
20 \cdot 2 \\
18 \cdot 9 \\
18 \cdot 1 \\
17 \cdot 6 \\
18 \cdot 0 \\
17 \cdot 0\end{array}$ & $\begin{array}{c}\ldots \\
\ldots \cdot \\
15 \cdot 1 \\
19 \cdot 4 \\
21 \cdot 6 \\
21 \cdot 5 \\
19 \cdot 5 \\
16 \cdot 3 \\
14 \cdot 2\end{array}$ & $\begin{array}{c}\ldots \\
\ldots \\
\ldots \\
\ldots \\
15 \cdot 0 \\
18 \cdot 1 \\
18 \cdot 3 \\
15 \cdot 5 \\
11 \cdot 8\end{array}$ \\
\hline
\end{tabular}

(d) Birthplace.-In the course of the century 1801-1901 the proportion of the inhabitants of England born in that country or in Scotland has varied very little; on the other hand, the proportion of Irish living in England has steadily declined. 29 per thousand in 1851 , it was 24.9 per thousand in $1871,21.65$ in $1881,15.8$ in 1891 , and only $13 \cdot 11$ in 1901 . 
While the proportion of Irish has declined, that of persons born in the Colonies and India has risen from 1.8 per thousand in 1851 to 4.18 in 1901 ; and that of persons born in foreign parts has risen from 3.4 per thousand in $1851,5.07$ in 1861 , 6.14 in 1871 , to 8.03 in 1891 and 10.44 in 1901 , of which number $2: 39$ per thousand were classified as British subjects.

Within Fngland itself there is naturally migration from county to county, and especially from the agricultural districts to the large towns. A comparison of Porter's figures for 1841 and those of the 1901 census show how this tendency has increased.

TABLE XIV.-Birthplaces of Population of England and Wales

\begin{tabular}{|c|c|c|c|c|c|c|c|}
\hline & $\begin{array}{c}1841 \\
\text { (Porter). }\end{array}$ & $\begin{array}{c}1851 \\
\text { Census. }\end{array}$ & $\begin{array}{c}1861 \\
\text { Census. }\end{array}$ & $\begin{array}{c}1871 \\
\text { Census. }\end{array}$ & $\begin{array}{c}1881 \\
\text { Census. }\end{array}$ & $\begin{array}{c}1891 \\
\text { Census. }\end{array}$ & $\begin{array}{c}1901 \\
\text { Census. }\end{array}$ \\
\hline Total population & $15,914,148$ & $17,927,609$ & $20,066,224$ & $22,712,266$ & $25,974,439$ & $29,002,525$ & $32,527,813$ \\
\hline Wales. & $15,362,671$ & $17,165,656$ & $19,120,052$ & $21,692,165$ & $24,855,822$ & $27,882,629$ & $31,269,203$ \\
\hline Born in other parts. & 551,477 & 761,953 & 946,172 & $1,020,101$ & $1,118,617$ & $1,119,896$ & $1,258,640$ \\
\hline Born in Scotland. & 121,507 & 130,087 & 169,202 & 213,254 & 253,528 & 282,271 & 316,838 \\
\hline Born in Ireland . & 292,935 & 519,959 & 601,634 & 566,540 & 562,374 & 458,315 & 426,565 \\
\hline Born in islands in & & & & & & & \\
\hline British seas & $\cdots$ & 13,753 & 18,423 & 25,655 & 29,316 & 30,370 & 35,763 \\
\hline $\begin{array}{l}\text { Born in British } \\
\text { Colonies and India }\end{array}$ & & 33,688 & 51,572 & 70,812 & 94,399 & 111,627 & 136,092 \\
\hline Born in foreign parts & $\ldots$ & 61,708 & 101,832 & 139,445 & 174,372 & 233,008 & 339,430 \\
\hline Born at sea & $\ldots$ & 2,758 & 3,509 & 4,395 & 4,628 & 4,305 & 3,946 \\
\hline
\end{tabular}

Proportion of Persons in England residing in the County of their Birth.-For the year 1841 Porter gives the following:-

\begin{tabular}{|c|c|c|c|c|}
\hline & Males. & Females. & Total. & Per Cent. \\
\hline $\begin{array}{l}\text { In lngland- } \\
\text { English born- } \\
\text { Residing in county of } \\
\text { birth } \\
\text { Out of native county } \\
\text { In Wales- } \\
\text { Bornin Wales or England- } \\
\text { Residing in county of } \\
\text { birth } \\
\text { Out of native county }\end{array}$ & $\begin{array}{l}5,900,950 \\
1,223,172\end{array}$ & $\begin{array}{l}6,190,434 \\
1,247,384\end{array}$ & $\begin{array}{r}12,091,394 \\
2,370,556\end{array}$ & $\begin{array}{l}80 \cdot 7 \\
15 \cdot 9\end{array}$ \\
\hline
\end{tabular}

The census for 1901 finds that in 1000 males enumerated in each county, the number born therein was 712 , in 1000 females the number born therein was 704 ; and in 1000 native males of each county enumerated 743 resided therein, in 1000 native females 729 resided therein. 


\section{Movenent of Population}

The history of the movement of the population during the century is the record of a process increasing agglomeration in towns.

The population of these urban areas had risen from $9,000,000$, or 50 per cent. of the population of England and Wales, in 1851, to $17,600,000$, or 68 per cent., and to $25,000,000$, or 75 per cent., in 1901. Rural districts meantime are being depopulated, as can be seen by comparing the natural increase over the whole area of registration districts containing no urban district with more than 70,000 inhabitants, and comparing it with the actual increase. In 1891-1901 the natural increase was 565,253, whereas the actual increase was 64,599 ; the loss by migration thus being 500,654 , or $91 \cdot 1$ per cent. of the population. The country districts are thus depleted by the influx of their best health and strength to the towns.

Thus, although in every county in the ten years 1891-1901 the births outnumbered the deaths, the population absolutely declined in ten agricultural counties (Oxford, Huntingdon, Hereford, Rutland, and Westmoreland in England, and Cardigan, Brecknock, Montgomery, Flint, and Merioneth in Wales), while in twenty-seven others, including London, the actual increment was less than the natural increment due to the excess of births over deaths. That is, these twenty-seven counties lost by migration.

On the other hand, eighteen counties predominantly industrial, but including all those immediately surrounding London, gained by migration in excess of their natural growth.

Between 1891-1901 Essex gained 170,693. Of the persons born in London 261,533 were enumerated in the county of Essex, nearly 200,000 being resident in West Ham, East Ham, Walthamstow, and Leyton.

Middlesex gained 156,824. Of the persons born in Loudon 241,384 were enumerated in the county of Middlesex, half of them residing in Willesden, Tottenham, and Horusey.

Surrey gained 7 T,089 (114,041 of the persons born in London residiug there).

Of the eight millions of people residing in the area constituted by London, Essex, Surrey, Middlesex, and Kent, about six millions, nearly three-quarters, were born within the area.

Glamorganshire gained 41,093.

Lancashire gained 40,957. 
Table XV.-Rate of Increase of Population per cent. (English Counties)

\begin{tabular}{|c|c|c|c|c|c|c|c|c|c|c|c|c|c|c|}
\hline & & & & & 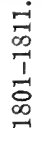 & 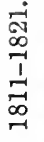 & 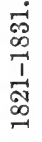 & 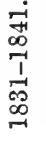 & 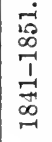 & 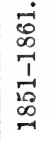 & $\begin{array}{l}-i \\
0 \\
-1 \\
1 \\
-1 \\
0 \\
\infty \\
-1\end{array}$ & 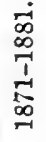 & 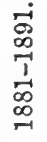 & 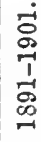 \\
\hline \multicolumn{15}{|c|}{ Agricultural Counties- } \\
\hline Bucks . & . & . & . & . & 9 & 14 & 9 & 6 & 5 & 3 & 5 & 0 & 5 & 6 \\
\hline Cambs & . & . & . & • & 13 & 21 & 18 & 14 & 13 & -5 & 6 & -1 & 2 & 1 \\
\hline Devon & . & . & . & . & 12 & 15 & 13 & 7 & 6 & 3 & 3 & 0 & 5 & 5 \\
\hline Dorset . & - & - & - & . & 9 & 16 & 10 & 10 & 5 & 2 & 4 & -2 & 2 & 4 \\
\hline Hereford . & . & . & . & . & 6 & 10 & 8 & 2 & 2 & 7 & 1 & -3 & -4 & -1 \\
\hline Norfolk . & - & - & & . & 7 & 18 & 13 & 6 & 7 & -2 & 1 & 1 & 2 & 1 \\
\hline Somerset . & . & • & . & . & 10 & 17 & 13 & 8 & 2 & 0 & 4 & 1 & 3 & 5 \\
\hline Suffolk · & . & $\bullet^{\circ}$ & . & • & 9 & 16 & 9 & 6 & 7 & 0 & 3 & 2 & 4 & 4 \\
\hline Westmoreland & . & . & . & & 12 & 12 & 7 & 3 & 3 & 4 & 7 & -1 & 3 & -3 \\
\hline Wilts $\quad \cdot$ & . & . & . & & 4 & 14 & 8 & 8 & -1 & -2 & 3 & 1 & 2 & 3 \\
\hline \multicolumn{15}{|c|}{ MaNufaCturing Counties- } \\
\hline Durham & . & . & . & • & 10 & 17 & 24 & 29 & 27 & 30 & 35 & 27 & 17 & 17 \\
\hline Lancs . & . & . & . & & 22 & 27 & 27 & 24 & 22 & 20 & 16 & 23 & 14 & 12 \\
\hline Monmouth & & • & . & & 35 & 22 & 29 & 36 & 17 & 11 & 12 & 8 & 20 & 16 \\
\hline Northumberlan & & • & . & & 9 & 15 & 11 & 12 & 14 & 13 & 13 & 12 & 17 & 19 \\
\hline Stafford . & . & . & . & $\bullet$ & 21 & 17 & 18 & 24 & 20 & 23 & 15 & 14 & 10 & 14 \\
\hline Glamorgan & - & . & . & & 19 & 20 & 24 & 35 & 35 & 37 & 25 & 29 & 34 & 25 \\
\hline
\end{tabular}

(From Jevons, The Coal Question.)

TABLE XVI.-Rate of Increase of Population per cent. (Scotland)

\begin{tabular}{|c|c|c|c|c|c|c|c|c|c|c|c|c|c|}
\hline & & & 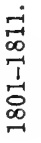 & 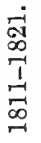 & 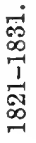 & 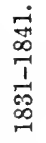 & 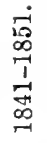 & $\begin{array}{l}\dot{0} \\
\infty \\
\stackrel{1}{1} \\
\frac{1}{19} \\
\infty \\
-1\end{array}$ & 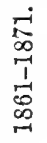 & 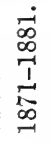 & 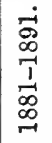 & 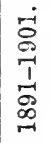 & \\
\hline Argyll & & & 6 & 12 & 4 & -4 & -9 & -11 & -5 & 1 & -2 & -1 & \\
\hline Ross. & . & & 8 & 13 & 9 & 5 & 5 & $\begin{array}{r}1 \\
-2\end{array}$ & -1 & -3 & -1 & $\begin{array}{l}1 \\
-3\end{array}$ & Decrease in \\
\hline Inverness & . & . & 7 & 16 & 5 & 3 & -1 & $-\overline{9}$ & -1 & 3 & -1 & 0 & Highland \\
\hline Sutherland & & . & 2 & 1 & 7 & -3 & 4 & -2 & -4 & -4 & -6 & -2 & counties. \\
\hline Ayr & . & • & 23 & 23 & 14 & 13 & 15 & 5 & 1 & 8 & 4 & 12 & Increase in \\
\hline Lanark & . & • & 29 & 28 & 30 & 34 & 24 & 19 & 21 & 18 & 16 & 21 & manufacturing \\
\hline Renfrew & . & . & 18 & 20 & 19 & 16 & 13 & 10 & 22 & 21 & 10 & 17 & counties. \\
\hline
\end{tabular}

(From Jevons, The Coal Question.)

The most rapid rate of growth is seen in the case of urban centres up to a population of 100,000 . In a higher degree of density, the overflow is apt to be pressed into suburban districts, as has been the case with London.

London.--In the period 1801-1811 London's rate of increase was 18.8 per cent. as compared with 14.3 per cent. for England and Wales. Until 1881-1891 it continued to be higher; in 1891-1901 the rate of increase for London was only $7 \cdot 3$ per cent., 
while that for England and Wales was 12.2 ; in 1911 there was actually a decrease of 03 per cent. in London.

TABLE XVII.-Rate of Increase

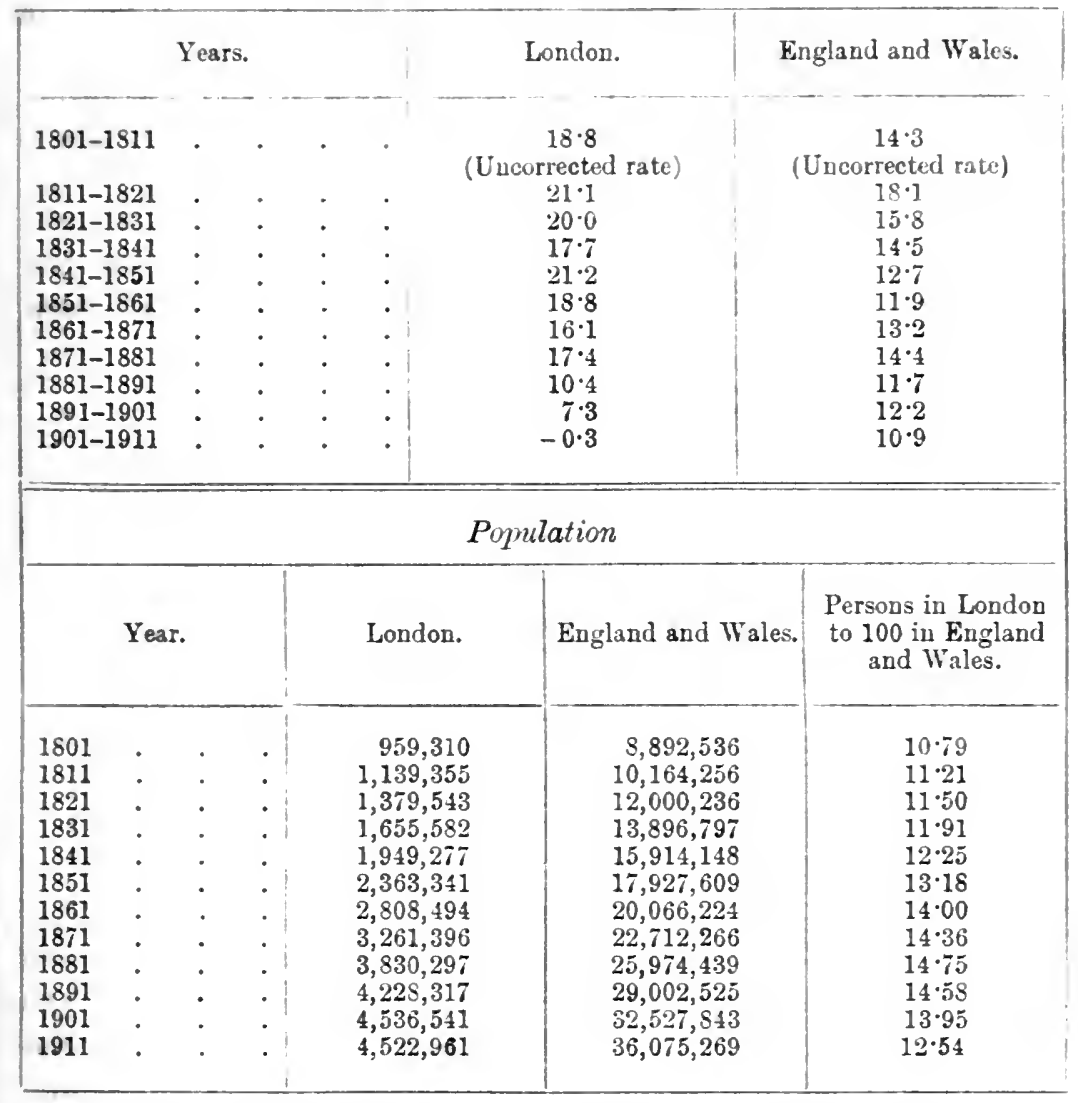

Though the proportion of the whole population living in London has declined since 1881 , when it was 14.75 per cent.the highest proportion in the century-it is still greater than in any period before 1861 .

In the population in London a gradual decentralization has been taking place: since 1861 that of the central area has been steadily declining. The City of London itself declined 33.2 per cent. in 1861-71, 32.4 per cent. in 1871-81, 25.6 per cent. in 1881-91, 28.6 per cent. in 1891-1901, and 27.0 per cent. in 1901-1911; whereas in the Outer Ring the population inereased 50.7 per cent. in 1861-71, 50.0 in $1871-81,50.1$ in 1881-91, 45.5 per cent. in 1891-1901, and 33.5 in 1901-1911. And taking Greater 
London (City of London and Metropolitan Police Districts) as a whole, its population, which was $3,222,720$ in 1861 , rose to $6,581,402$, more than double, in 1901 , and $7,252,963$ in 1911; while in 1891-1901 its rate of increase was 16.8 per cent., in 1901-1911, 10.2.

Density of Population.-The aggregate area of England and Wales, including land and inland water, but not tidal water nor foreshore, is $37,327,479$ statute acres, or 58,324 square miles. Had the population at the 1901 census been evenly distributed, each square mile would have been occupied by 558 persons; each would have had 1.15 acres, and the distance from person to person would have been 80 yards.

TABLE XVIII.-Increase of Density during the Century

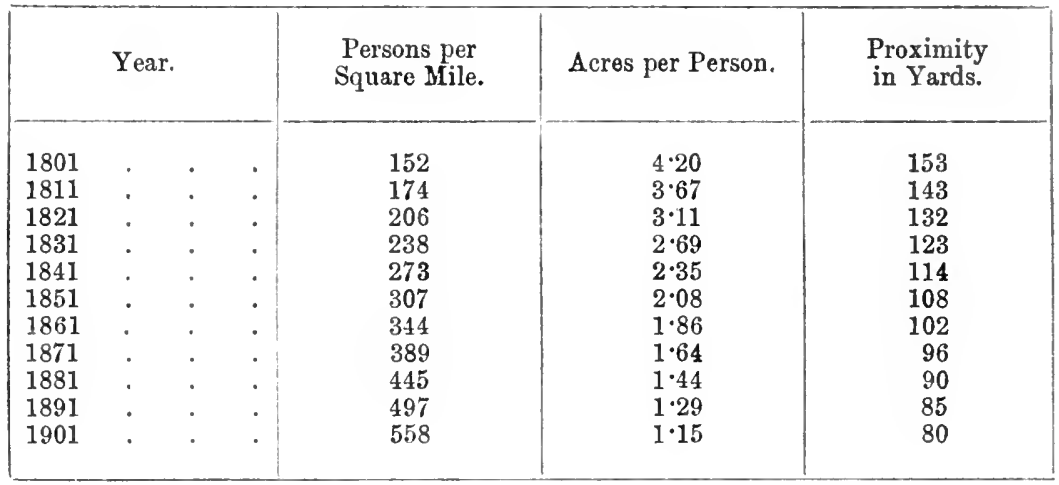

But the density varies very greatly in different parts of the country. In Westmoreland there were only 82 persons to the square mile, Herefordshire 136, Shropshire 178; while in London there were 38,795 , in Middlesex 3410 , in Lancashire 2346, and in Durham 1171 persons to a square mile.

\section{Physical Infirmity}

The first attempt to ascertain the number of blind, deaf, and dumb was made in 1851 .

(a) Blind.-There has been a decided decrease in the number of blind children, probably due to more efficient treatment of infantile disease. Bliudness increases rapidly after the age of thirty-five; and then, except among the very old, it is more prevalent among males; though even among the very old there has been a decline in the proportion since 1851. For the United Kingdom it fell from 1158 per million in 1851 to 954 in 1901. 
TABLE XIX.-Blind

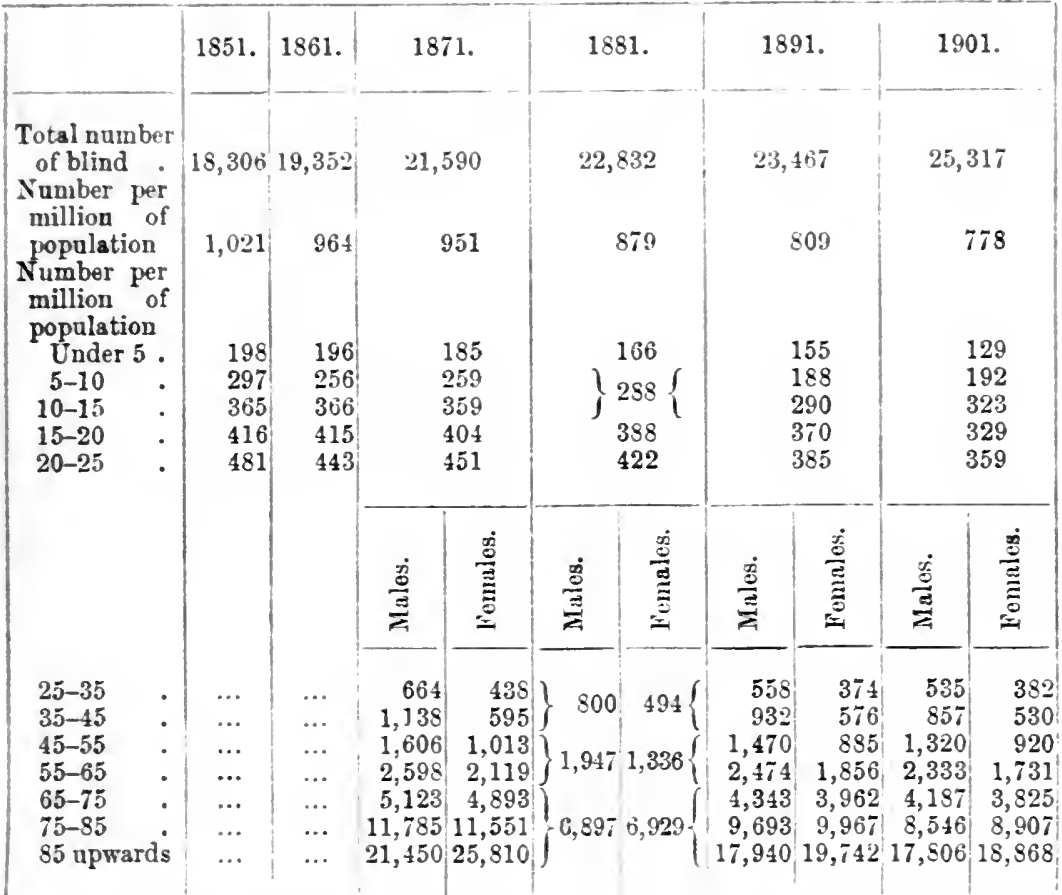

(b) Deaf and Dumb.-In 1901, 524 males and 417 females per million of population were deaf and dumb; 489 males and 643 females deaf only: the total thus being 1013 deaf males and 1060 deaf females per million of population.

For the United Kingdom the number of deaf and dumb per million fell from 791 in 1851 to 291 in 1901.

(c) Insane (first counted in 1871)!

\section{TABLE XX}

\begin{tabular}{|c|c|c|c|c|c|c|c|c|}
\hline \multirow[b]{2}{*}{ Year. } & \multicolumn{4}{|c|}{ Number of Mentally Deranged. } & \multicolumn{4}{|c|}{$\begin{array}{l}\text { Number of Mentally Deranged } \\
\text { per Million of Population. }\end{array}$} \\
\hline & 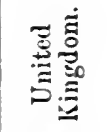 & 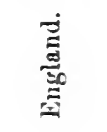 & 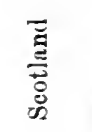 & $\underset{\Xi}{\stackrel{\Xi}{\Xi}}$ & 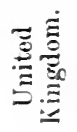 & 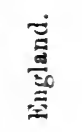 & 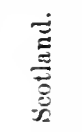 & 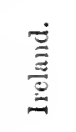 \\
\hline $\begin{array}{l}1871 \\
1881 \\
1891 \\
1901\end{array}$ & $\begin{array}{r}96,937 \\
117.313 \\
134,033 \\
177,995\end{array}$ & $\begin{array}{r}69,019 \\
84,503 \\
97,383 \\
132,654\end{array}$ & $\begin{array}{l}11,413 \\
14,397 \\
15,462 \\
20,291\end{array}$ & $\begin{array}{l}16,505 \\
18,113 \\
21,188 \\
25,050\end{array}$ & $\begin{array}{l}3,079 \\
3,363 \\
3,552 \\
4,293\end{array}$ & $\begin{array}{l}3,039 \\
3,253 \\
3,358 \\
4,078\end{array}$ & $\begin{array}{l}3,397 \\
3,854 \\
3,841 \\
4,537\end{array}$ & $\begin{array}{l}3,049 \\
3,558 \\
4,504 \\
5,618\end{array}$ \\
\hline
\end{tabular}


It will be seen that mental derangement has steadily increased since 1871, and that its increase has been speeially great in the last decennium, though partly this increase is doubtless due to the substitution on the schedule of the word "feeble minded" for idiot. The proportion of derangement to population is higher in both Scotland and Ireland than in England.

(d) Inmates of Institutions.

TABLE XXI.-Hospitals (England and Wales)

\begin{tabular}{|c|c|c|c|c|c|c|c|}
\hline & 1851. & 1861. & 1871. & 1881. & \multicolumn{2}{|c|}{1891.} & 1901. \\
\hline Numbers . .. . . & 7,619 & 10,414 & 19,585 & 24,087 & \multicolumn{2}{|c|}{27,579} & $39,184^{*}$ \\
\hline Per 100,000 of population. & 42 & & 86 & 93 & & 95 & 120 \\
\hline \multicolumn{8}{|c|}{ * Insane and blind hospitals not included. } \\
\hline \multicolumn{8}{|c|}{ Workhouses, Prisons, and Lunatic Asylums, 1901} \\
\hline & \multicolumn{2}{|c|}{$\begin{array}{l}\text { United } \\
\text { Kingdom. }\end{array}$} & England. & \multicolumn{2}{|c|}{ Scotland. } & \multicolumn{2}{|c|}{ Ireland. } \\
\hline \\
\hline $\begin{array}{l}\text { honse infirmarics and } \\
\text { schools). }\end{array}$ & \multicolumn{2}{|c|}{264,922} & 208,650 & \multicolumn{2}{|c|}{13,229} & \multicolumn{2}{|r|}{43,043} \\
\hline \multirow{2}{*}{$\begin{array}{l}\text { Hospitals (including insane } \\
\text { and blind hospitals) }\end{array}$} & \multirow{2}{*}{\multicolumn{2}{|c|}{54,246}} & \multirow{2}{*}{42,026} & \multirow{2}{*}{\multicolumn{2}{|c|}{7,940}} & \\
\hline & & & & & & & $\begin{array}{r}4,280 \\
17\end{array}$ \\
\hline Prisons : : : & \multirow{2}{*}{\multicolumn{2}{|c|}{22,357}} & & \multirow{2}{*}{\multicolumn{2}{|c|}{2,510}} & & 2,367 \\
\hline $\begin{array}{l}\text { Prisons } \\
\text { Reformatories and industrial }\end{array}$ & & & & & & & \\
\hline schools. . . . & \multicolumn{2}{|c|}{33,656} & 19,245 & \multicolumn{2}{|c|}{5,217} & & 9,194 \\
\hline
\end{tabular}

(See Chapter on "Pauperism.") 


\section{CHAPTER II}

\section{TRADES AND OCCUPATIONS}

Historical-I. Children-II. Women: home work; Married women wage-earners -III. Men : proportions in different occupations-Occupational mortality

\section{HISTORICAL}

$\mathrm{L}^{\mathrm{o}}$

OOKING at the century between 1801 and 1901 as a whole, a few general observations may be made as to the movement of occupation within the period. Porter noted in 1847 that "a change has for some time been going forward in regard to the relative proportions of the inhabitants of this country who are employed in agricultural pursuits, or in trade, manufacturing, etc." As a matter of fact the nineteenth century saw the full development of the Industrial Revolution, the accomplishment of the mighty change that transformed England from a predominantly agricultural to a predominantly manufacturing community, and in the statistics of occupation can be read much of the history of the country. From them can be traced the slow progress of factory legislation, the evolution of new educational ideas in the treatment of children, the rise of new economic conceptions as to the necessary protection of adult women and men. Side by side with the decline of agriculture there proceeded a vast expansion of the textile and other manufactures and the multiplication of transport service of every kind, to solve the problem of the food supply of a population removed from the soil. Then the gradual decrease of the number of hands employed in manufacture suggests "the enormous and ever-increasing development of labour-saving machinery."

Occupatiox of CHILDREN.- It is round the occupation of children that the battle of the century has raged; and the great change that marks it is the gradual transference of children under fourteen from wage-earning to education. The transference is not yet complete. In $1901,16.9$ per cent. of children from ten to fifteen were still returned as occupied (200,534 girls and 365,205 boys), and there were still 
84,695 half-timers on the school registers in 1907 ; nevertheless, the theory is now accepted that it is socially wrong and economically unsound to treat a child as an instrument of production. In all the great industries there has been a steady decline in the use of child labour. Yet in the first quarter of this century, of all those employed in cotton factories a half were under sixteen years of age, one in every six was under nine ycars of age; and there werc many hundreds employed much younger in factories and under the more terrible conditions of domestic workshops. In many cases "the children supported the father, contrary to the law of nature." Workmen who lived on the labour of their children opposed any interference with " free contract," and Robert Owen's Factory Act of 1829 , which regulated the hours of work in cotton mills by imposing a twelve-hours' day for those between the ages of nine and sixteen, was vehemently opposed as "establishing idleness by Act of Parliament." In 1839 there were 32,524 children in the textile factories between the ages of mine and thirteen (cf. Table I); and in 1856 children under thirteen still formed 6.6 per cent. of the whole number there employed. The conditions of their work in the earlier decades were indescribably bad even in the textile factories, which, as the earliest regulated, were the best. In the mines they were so terrible that in 1840 the first Commission on Employment forbade children and women to work underground; but in calico print works (where there were 5646 young children in 1843), in the bookbinding, brick-and tile-making, straw-plaiting, silk-weaving, hosiery, lace, and wearing apparel trades the hours were longer and the conditions more awful than in the big factories; while those who worked at home often suffered more. The health and strength of thousands of helpless children were ruined by excessive labour and cruel treatment, and they grew up, stunted in body and mind, without any education whatever.

Factory Acts 1802, 1829, 1833, 1844, 1847, 1850, 1867.Gradually, by a long series of Factory Acts, legal restrictions on hours were imposed; a ten-hours' day established for women and young persons under 18; and children under 9 excluded from factory labour. When it was found that, contrary to all the gloomy prognostications of the manufacturers, those textile factories in which restrictions had been imposed showed a continuous increase in production, the protection of the factory inspector was extended to all premises in which fifty or more persons were engaged in the manufacturing process, and established on a firm basis the half-time system of education for children of $9-14$, who were only to work 
Table I.-Textile Trade

1839-a (a) Numbers of ChILdrex EMployed

\begin{tabular}{|c|c|c|c|c|c|}
\hline Age. & Cotton. & Wool. & Worsted. & Silk. & Flax. \\
\hline $\begin{array}{l}\text { Children under } 9 \\
\text { Children } 9-13 \\
\text { Young persons } 13-18 \\
\text { Adults } 18 \text { and upwards }\end{array}$ & $\begin{array}{r}12,330 \\
97,308 \\
149,747\end{array}$ & $\begin{array}{r}6,021 \\
20,194 \\
28,603\end{array}$ & $\begin{array}{r}4,657 \\
14,028 \\
12,943\end{array}$ & $\begin{array}{r}962 \\
2,757 \\
11,731 \\
13,868\end{array}$ & $\begin{array}{r}1,759 \\
19,135 \\
22,593\end{array}$ \\
\hline Total, 1839 . & 259,385 & 54,818 & 31,628 & 34,318 & 43,487 \\
\hline \multicolumn{6}{|l|}{$1839-(b)$} \\
\hline \multicolumn{2}{|l|}{ Age. } & 1838. & \multicolumn{2}{|c|}{1850.} & 1856. \\
\hline \multirow[t]{2}{*}{$\begin{array}{l}\text { Children under } 13 . \\
\text { Youths } 13-18 \text {. } \\
\text { Women } 13 \text { and upwards } \\
\text { Men } 18 \text { and upwards }\end{array}$} & $\begin{array}{l}\cdot: \\
: \\
\cdot\end{array}$ & $\begin{array}{r}5 \cdot 9 \\
16 \cdot 1 \\
55 \cdot 2 \\
22 \cdot 8\end{array}$ & \multicolumn{2}{|c|}{$\begin{array}{r}6 \cdot 1 \\
11 \cdot 5 \\
55 \cdot 9 \\
26 \cdot 5\end{array}$} & $\begin{array}{r}6 \cdot 6 \\
10 \cdot 6 \\
57 \cdot 0 \\
25 \cdot 8\end{array}$ \\
\hline & & $100 \cdot 0$ & \multicolumn{2}{|c|}{$100 \cdot 0$} & $100 \cdot 0$ \\
\hline
\end{tabular}

1904-(a) Numbers Employed (Exgland axd Wales)

\begin{tabular}{|c|c|c|c|c|}
\hline \multirow{2}{*}{ Age. } & \multicolumn{2}{|c|}{ Total Employed. } & \multicolumn{2}{|c|}{$\begin{array}{l}\text { Percentage of Whole } \\
\text { Number Employed. }\end{array}$} \\
\hline & Male. & Female. & Male. & Female. \\
\hline $\begin{array}{l}\text { Half-timers (under 14) } \\
\text { Full-timers (under 18) } \\
\text { Adults . }\end{array}$ & $\begin{array}{r}14,568 \\
70,965 \\
297,302\end{array}$ & $\begin{array}{r}17,176 \\
137,038 \\
4 \$ 9,329\end{array}$ & $\begin{array}{r}1 \cdot 4 \\
6 \cdot 9 \\
29 \cdot 0\end{array}$ & $\begin{array}{r}1 \cdot 7 \\
13 \cdot 3 \\
47 \cdot 7\end{array}$ \\
\hline Total, 1904 & 382,835 & 643,543 & $37 \cdot 3$ & $62 \cdot 7$ \\
\hline
\end{tabular}

1904-(b) Nombers Eytoloyed (United Kisgdom)

\begin{tabular}{cc|c|c|c|c|}
\hline Year. & $\begin{array}{c}\text { England } \\
\text { and Wales. }\end{array}$ & Scotlaud. & Ireland. & $\begin{array}{c}\text { United } \\
\text { Kingdom. }\end{array}$ \\
\hline 1901 & & & & & \\
\hline 1904 & $\vdots$ & $821,26 \pi$ & 137,948 & 70,138 & $1,029,353$ \\
\hline
\end{tabular}


six and a half hours a day. Soon, children became "unprofitable servants," even at low wages, when their hours were thus restricted. At the same time local authorities were to inspect and regulate workshops. In 1878 and 1891 these Acts were further consolidated and amended, and now, taken in conjunction with the Education Acts of 1870 and 1902 and the School Attendance Acts of 1893 and 1899 , they have more or less fixed the position of children's labour as it at present stands.

A table will show the decline in occupation of children between 1851 and 1901.

\section{TABLE II.-Proportion per cent. of Children aged 10-15 Occupied}

\begin{tabular}{|c|c|c|c|}
\hline Year. & & Males. & Females. \\
\hline $\begin{array}{l}1851^{\circ} \\
1861^{\circ} \\
1871^{\circ} \\
1881 . \\
1891^{\circ} \\
1901 .\end{array}$ & $\begin{array}{l}\dot{.} \\
\dot{.} \\
\dot{.}\end{array}$ & $\begin{array}{l}36 \cdot 6 \\
36 \cdot 9 \\
32 \cdot 1 \\
22 \cdot 9 \\
26 \cdot 0 \\
21 \cdot 9\end{array}$ & $\begin{array}{l}19 \cdot 9 \\
20 \cdot 2 \\
20 \cdot 4 \\
15 \cdot 1 \\
15 \cdot 3 \\
12 \cdot 0\end{array}$ \\
\hline
\end{tabular}

In 1851-1861 the proportion of boys aged 5-10 who were occupied was 2 per cent.; after the Education Act of 1870 it fell to below 1 per cent.; and between 1871 and 1881 the employment of children below 10 was definitely prohibited.

At present the employment of children between the ages of 10-15 depends on a variety of local conditions, industrial and educational. All children must attend school between the ages of 5 and 14 ; but the local education authority has power by its by-laws (i) to exempt children of 11 for agriculture; (ii) to grant half-time or full-time exemption between the ages of 12 and 14. Fifty-nine per cent. of areas do thus grant balf-time.

Exemption. - The number of half-timers from 1875 is as follows :-

\begin{tabular}{|c|c|c|c|c|c|c|c|}
\hline $1875-1876$ & . & . & . & . & . & . & 201,284 \\
\hline $1880-1881$ & . & . & . & . & . & . & 185,980 \\
\hline $1890-1891$ & . & . & . & . & . & . & 173,040 \\
\hline $1900-1901$ & . & . & . & . & . & . & 74,468 \\
\hline $1905-1906$ & . & . & . & . & . & . & 82,328 \\
\hline $1907-1908$ & . & . & . & , & . & . & 84,695 \\
\hline
\end{tabular}

Forty-one per cent. refuse all half-time exemption; and 21 per cent. refuse full-time exemption except to those who have passed Standard VII. ' In 1907, 211,000 children under 14 thus left 


\section{TABLE III.-Occupation of Children}

Boys

\begin{tabular}{|c|c|c|c|c|c|c|c|}
\hline \multirow{3}{*}{ Occupations. } & \multicolumn{4}{|c|}{ Boys 10-15. } & \multirow{2}{*}{\multicolumn{3}{|c|}{$\begin{array}{l}\text { Proportion per } \\
10,000 \text { Living at } \\
\text { following Ages } \\
\text { in } 1901 \text {. }\end{array}$}} \\
\hline & \multicolumn{2}{|c|}{ Numbers. } & \multicolumn{2}{|c|}{$\begin{array}{l}\text { Per } 10,000 \\
\text { Living. }\end{array}$} & & & \\
\hline & 1891. & 1901. & 1891. & 1901. & $10-13$. & $13-14$ & $14-15$. \\
\hline \multirow{2}{*}{\multicolumn{8}{|c|}{ Messengers, etc. (not }} \\
\hline & $\$ 2,581$ & 81,879 & 513 & 490 & 47 & 919 & 1,390 \\
\hline Road conveyance & 8,279 & 10,928 & 52 & 65 & 2 & 84 & 235 \\
\hline Commercial-clerks & 9,456 & 11,249 & 59 & 67 & 1 & 66 & 266 \\
\hline Agriculture . . & 71,169 & 50,545 & 442 & 303 & 34 & 519 & 893 \\
\hline Cosl and shale mines & \multicolumn{7}{|c|}{$\begin{array}{l}\text { Coal and shale mines } \\
\text { Workers in metals, ma- }\end{array}$} \\
\hline $\begin{array}{l}\text { chines, etc. } \\
\text { Building and construc. }\end{array}$ & 27,442 & $2 \pi, i 30$ & 170 & 166 & 3 & 191 & 627 \\
\hline tion. & 12,397 & 13,133 & $\pi$ & 79 & 2 & so & 306 \\
\hline & 62,843 & 41,404 & 390 & 248 & 90 & 461 & 508 \\
\hline $\begin{array}{l}\text { Workers and dealers in } \\
\text { dress goods }\end{array}$ & 17,599 & 14,647 & 109 & 88 & 10 & 132 & 276 \\
\hline $\begin{array}{l}\text { Workers and dealers in } \\
\text { food, drink, tobacco, } \\
\text { and lodging }\end{array}$ & 20,087 & 20,250 & 125 & 121 & 8 & 159 & 420 \\
\hline $\begin{array}{c}\text { General and factory } \\
\text { labour }\end{array}$ & 15,061 & 5,908 & 93 & 35 & 1 & 43 & 129 \\
\hline Other occupations. & 60,959 & 55,845 & 378 & 335 & 26 & 447 & 1,151 \\
\hline \multirow{2}{*}{$\begin{array}{l}\text { Total occupied } \\
\text { Total unoccupied. }\end{array}$} & $\$ 19,209$ & 365,205 & 2,602 & 2,156 & 231 & $3, \pm 73$ & 6,753 \\
\hline & $1,191,649$ & $1,305,765$ & $7,3 \cap s$ & 7,814 & $\varrho, 769$ & 6,527 & 3,247 \\
\hline Total & $1,610,858$ & $1,670,970$ & 10,000 & 10,000 & 10,000 & 10,000 & 10,000 \\
\hline \multicolumn{8}{|c|}{ Girls } \\
\hline \multirow{6}{*}{$\begin{array}{l}\text { Domestic indoor service. } \\
\text { Laundry, washing, etc. } \\
\text { Teaching - } \\
\text { Messengers : } \\
\text { Workers in metals, ma- } \\
\text { chines, etc. } \\
\text { Paper, books, etc. }\end{array}$} & 107,167 & 64,802 & 6005 & 388 & 25 & 527 & 1,351 \\
\hline & 2,158 & 3,265 & 13 & 20 & 1 & 20 & 76 \\
\hline & 5,932 & 4,006 & 37 & 24 & & 22 & 97 \\
\hline & 2,304 & 3,094 & 14 & 19 & 1 & 41 & 49 \\
\hline & & & & & & & \\
\hline & $\begin{array}{l}2,906 \\
5,232\end{array}$ & $\begin{array}{l}4,280 \\
7,646\end{array}$ & $\begin{array}{l}18 \\
32\end{array}$ & 26 & 1 & $\begin{array}{l}37 \\
67\end{array}$ & 90 \\
\hline \multirow{2}{*}{$\begin{array}{l}\text { Textiles. } \\
\text { Workers and dealers in } \\
\text { dress goods }\end{array}$} & 82,661 & 59,863 & 873 & 358 & $\begin{array}{r}1 \\
93\end{array}$ & $\begin{array}{r}61 \\
62:\end{array}$ & 167 \\
\hline & 54,412 & $22=-$ & & & & & \\
\hline & 34,412 & 32,63 & 213 & 296 & 5 & $220^{\circ}$ & 746 \\
\hline and lodging & 5,865 & 6,971 & 36 & 42 & 1 & 51 & 155 \\
\hline Other occupations . & 13,556 & 13,832 & 85 & 81 & 4 & 102 & 307 \\
\hline Total occupied . & 262,194 & 200,534 & 1,626 & 1,200 & 132 & 1,710 & 3,938 \\
\hline Total unoccupied . & $1,350,515$ & $1,470,236$ & 8,374 & 8,800 & 9,868 & 8,290 & 6,062 \\
\hline Total & $1,612,709$ & $1,670,770$ & 10,000 & 10,000 & 10,000 & 10,000 & 10,000 \\
\hline
\end{tabular}


school to enter industry. The distribution of these half-timers and exempted scholars and of children altogether throughout the country varies greatly according to the local character of prevailing industries. The highest proportion of occupied children is found in the textile trades. No less than seven-tenths of girls occupied at ages under 13 are found there. In 1901, Lancashire, Cheshire, and the West Riding of Yorkshire contained 90 per cent. of all the halftime scholars in the country (i.e. 67,393).

Among the towns showing the highest proportion of boy labour the following come first:-

\begin{tabular}{|c|c|c|c|c|c|c|c|}
\hline & & & & & \multicolumn{3}{|c|}{ Ages (1901). } \\
\hline & & & & & $10-13$. & $13-14$. & $14-15$. \\
\hline Rochdale & . & . & . & . & $12 \cdot 6$ & $66 \cdot 1$ & $86 \cdot 2$ \\
\hline Halifax. & . & . & . & . & $17 \cdot 8$ & $71 \cdot 5$ & $84 \cdot 0$ \\
\hline Bradford & . & . & . & . & $12 \cdot 0$ & $68 \cdot 7$ & $84 \cdot 4$ \\
\hline Bolton. & . & . & . & . & $12 \cdot 2$ & $72 \cdot 4$ & $87 \cdot 4$ \\
\hline Burnley & : & . & : & ; & $15 \cdot 6$ & $76 \cdot 4$ & 89.8 \\
\hline Blackburn & . & . & . & . & $15 \cdot 2$ & $74 \cdot 3$ & $88 \cdot 5$ \\
\hline Bury . & . & . & . & . & $9 \cdot \overline{1}$ & $60 \cdot 5$ & $85 \cdot 9$ \\
\hline
\end{tabular}

(In the case of Burnley, Oldham, Blackburn, and Bury it may be noted that the proportion of men over 55 employed is exceptionally low.)

It is in the thirteen textile centres also that the highest proportion of occupied women and of girls under 15 is found. Whereas in England and Wales the average proportion of girls employed at ages $10-15$ was 12 per cent., it was in

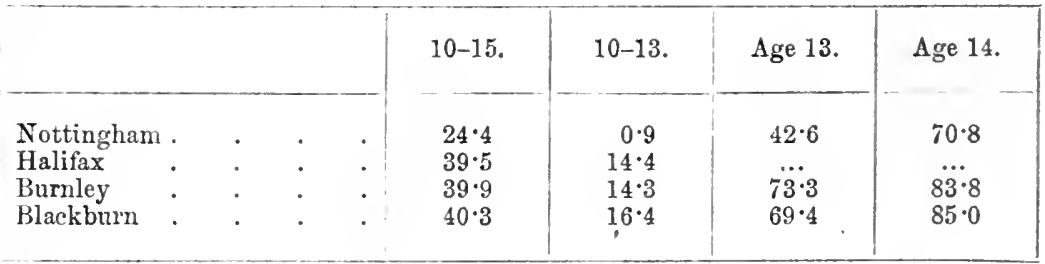

But in the case of all these towns the proportions for 1901, which have been given, show a decline as compared with that of 1891 .

Women.-Historically, closely connected with the labour of children is that of women. In the agitation that preceded the passing of the Factory Acts, the labour of women was coupled with that of young persons under 18 as needing restriction and 
protection. Some of the workmen who supported a ten hours' day for women and children undoubtedly did so because they thought that under the conditions of factory labour, any restriction would be extended to the hours of adult males. As a matter of fact, in textile factories at any rate, the proportion of women has always exceeded that of men. In 1838 women were 55.2 per cent. of textile operatives, in $1856,57 \cdot 0$ per cent., in $1901,63 \cdot 2$ per cent., representing 14 per cent. of the total number of women in industry.

\section{TABLE IV.-Occupied Females}

\begin{tabular}{|c|c|c|c|c|}
\hline & 1891. & \multicolumn{3}{|c|}{1901.} \\
\hline & Total. & Total. & Unmarried. & $\begin{array}{l}\text { Married or } \\
\text { Widows. }\end{array}$ \\
\hline $\begin{array}{l}\text { In occupations other than } \\
\text { domestic indoor service } \\
\text { In domestic indoor service } \\
\text { Without specific occupation. }\end{array}$ & $\begin{array}{l}22 \cdot 3 \\
12 \cdot 1 \\
65 \cdot 6\end{array}$ & $\begin{array}{l}21 \cdot 5 \\
10 \cdot 1 \\
68 \cdot 4\end{array}$ & $\begin{array}{l}32 \cdot 5 \\
19 \cdot 8 \\
47 \cdot 7\end{array}$ & $\begin{array}{r}11 \cdot 8 \\
1.4 \\
86.8\end{array}$ \\
\hline & 100.0 & $100 \cdot 0$ & $100 \cdot 0$ & $100 \cdot 0$ \\
\hline
\end{tabular}

The statistics of women's work have always been surrounded by extreme difficulty, owing to the fact that it is very largely subsidiary and highly casual in its nature. On this ground the Registrar-General omits women in his analysis of mortality rates and occupation; and any comparison as to the real increase of female employment during the century is rendered almost impossible. Porter estimated the number of occupied females in 1841 as $1,920,432$. It was in $1891,3,945,580$ ( 34.4 per cent.), and in $1901,4,171,751$ ( 31.6 per cent.)

The apparent decline in the percentage of occupied females in the last ten years illustrates one of the difficulties in the way of any exact enumeration. In 1891 , daughters and female relatives of the head of a family, when described as assisting in household duties, were classed as domestic servants; in 1901 they were classed as unoccupied. Thus between 1891-1901 there is an absolute decline of 2 per cent., and a decline relative to population of $4 \cdot 6$ in the numbers returned as employed in domestic service. In the same way, many females engaged in work for which they receive no definite wage, are classed as unoccupied. On the question of how far women's work competes with that of men, 
the following quotation from a special report prepared by the Board of Trade for the Poor Law Commission is instructive:-

"Women are obtaining a smaller, not a larger proportion of the aggregate employment.... While women and juveniles are now engaged in many industries in which the specialization of machinery enables them to take part, they are not, in any considerable trade or process, displacing adult males in the sense that they are being more largely employed to do work identical with that formerly done by men. . . The great expansion of women's labour seems to have been in new fields of employment, or in fields which men never occupied. It shonld also be borne in mind that, even where women are employed where men used to be employed, this is largely due to the men going into more highly paid industries, e.g. mining, machine-making, and building."

Only one-fifth of males are engaged in trades where women enter to the extent of 1 per cent. of the whole number of occupied females.

TABLE V.-Showing Occupations in which Females exceed Males (1901)

\begin{tabular}{|c|c|c|c|}
\hline \multicolumn{2}{|l|}{ Group. } & Males. & Females. \\
\hline $\begin{array}{l}\text { Nursing (sick nurses, midwives, an } \\
\text { Teaching . } \\
\text { Domestic service (not outdoor) } \\
\text { Bookbinding, paper, stationery } \\
\text { Textiles (sale of and manufacturin } \\
\text { Manufacturing of dress }\end{array}$ & 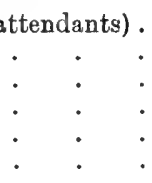 & $\begin{array}{r}1,092 \\
61,899 \\
124,263 \\
42,644 \\
492,175 \\
336,186\end{array}$ & $\begin{array}{r}67,269 \\
172,873 \\
1,690,586 \\
64,210 \\
663,222 \\
689,956\end{array}$ \\
\hline $\begin{array}{l}\text { Total } \\
\text { All other occupations }\end{array}$ & $: \quad:$ & $\begin{array}{l}1,058,259 \\
9,098,717\end{array}$ & $\begin{array}{r}3,348,216 \\
823,535\end{array}$ \\
\hline All occupations . & . & $10,156,976$ & $4,171,751$ \\
\hline
\end{tabular}

The relative proportions of women to men in certain occupations is illustrated in Tables V, VI, and VII, showing certain occupations in which the number of women employed exceeds that of males; and other occupations in which females are in a minority. In the latter the changed proportions between 1861 and 1901 are in most cases due to the introduction of machinery, manipulated by one sex, ousting the hand labour of the other. Thus in the boot and tailoring trades machinery worked by wornen has replaced the manual work of men, whereas in the lace trade and in laundry work the process has been reversed. Domestic indoor service remains the main occupation of females, employing 40.5 per cent. of all occupied women in 1901. 
TABLE VI.-Proportions of Females occupied to every Thousand Males engaged in certain Occupations in which Males exceed F'emales

\begin{tabular}{|c|c|c|c|c|c|c|c|c|c|c|}
\hline \multicolumn{5}{|c|}{ Occupations. } & & 1861. & $18 i 1$. & 1881. & 1891. & 1901. \\
\hline Teaching . & . & . & . & . & . & 725 & $\tau 41$ & $i 2 i$ & 740 & 745 \\
\hline Photography & . & & . & . & . & 66 & 147 & 197 & 234 & 257 \\
\hline Laundry. &.$\quad$. & & . & . & & 990 & 987 & 981 & 961 & 957 \\
\hline Commercial or & business cl & lerks & . & . & & 5 & 16 & 33 & 72 & 153 \\
\hline Telegraph and & telephone & . & & . & . & $\$ 2$ & 76 & 236 & 291 & 406 \\
\hline China-earthel & uware manu & ufact & uring & . & . & 311 & 354 & 384 & 385 & 392 \\
\hline Indiarubber & . &. &. & . & & 206 & 200 & 275 & 391 & 398 \\
\hline Brushes and bre & rooms. & $\dot{.}$ & $\dot{.}$ & i & 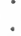 & 321 & $3 \div 6$ & 382 & 389 & $\$ 31$ \\
\hline Stationery-pa & per boxes & . & . & . & . & 345 & 350 & 531 & 600 & 643 \\
\hline Bookbinding & . . & . & . & . & & 450 & 488 & 527 & 554 & 603 \\
\hline Cotton manufac & cturing & . & . & . & & 567 & 598 & 620 & 609 & 628 \\
\hline Woollen. & . & . & . & . & & 461 & 513 & 561 & 557 & 582 \\
\hline Silk. & . & . & . & . & & 642 & 676 & 691 & 667 & 702 \\
\hline Hemp, jute, etc & c. & . & $\dot{.}$ & . & & 265 & 304 & 374 & 393 & 492 \\
\hline Hosiery. & . & . & . & . & & 468 & 468 & 533 & 629 & 713 \\
\hline Lace & . & . & . & . & & $\$ 29$ & 826 & 743 & 625 & 653 \\
\hline Carpets, etc. & . & . & . & . & & 183 & 312 & 362 & 440 & 517 \\
\hline Drapery. & : & i & $\dot{.}$ & i. & & 208 & 257 & 349 & 433 & 504 \\
\hline Hats and caps & (not stran) & & . & . & & 223 & 378 & 400 & 435 & 466 \\
\hline Straw hats & . & . & . & . & & 921 & 926 & 903 & 814 & 737 \\
\hline Tsilors . & . & . & . & . & & 208 & 254 & 330 & 427 & 471 \\
\hline Glove makers & . & . & . & . & . & 861 & 882 & 854 & 769 & 761 \\
\hline Boots and shoes & . & . & $\dot{0}$ & . & & 154 & 115 & 160 & 185 & 210 \\
\hline Tobacco. & - & . & . & . & . & 221 & 296 & 435 & 548 & 610 \\
\hline
\end{tabular}

TABLE VII.-England and Wales. Domestic Indoor Service since 1831

\begin{tabular}{|c|c|c|c|c|c|c|c|c|}
\hline & \multirow{2}{*}{\multicolumn{2}{|c|}{ Year. }} & \multirow{2}{*}{ Persons. } & \multirow{2}{*}{ Male. } & \multirow{2}{*}{ Female. } & \multicolumn{3}{|c|}{$\begin{array}{c}\text { Increase }(+) \text { or } \\
\text { Decrease }(-) \text { per cent. }\end{array}$} \\
\hline & & & & & & Persons. & Male. & Female. \\
\hline $\begin{array}{l}\text { Indoor and } \\
\text { outdoor } \\
\text { Including } \\
\text { "retired" } \\
\text { servants }\end{array}$ & $\begin{array}{l}\{831\} \\
1811 \\
1851 \\
1861 \\
1871 \\
1881 \\
1831 \\
1901\end{array}$ & 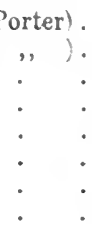 & $\begin{array}{r}665,709 \\
976,863 \\
825,964 \\
1,024,862 \\
1,275,747 \\
1,286,668 \\
1,444,694 \\
1,394,929\end{array}$ & $\begin{array}{r}104,730 \\
211,698 \\
74,323 \\
62,076 \\
63,369 \\
56,262 \\
58,527 \\
64,146\end{array}$ & $\begin{array}{r}560,079 \\
765,165 \\
751,641 \\
962,786 \\
1,207,378 \\
1,230,406 \\
1,386,167 \\
1,330,783\end{array}$ & $\begin{array}{r}\ldots \\
\ldots \\
+24 \cdot 1 \\
+24.5 \\
+\quad 0.9 \\
+12.3 \\
-\quad 3.4\end{array}$ & $\begin{array}{r}\cdots \\
\cdots \\
-16 \cdot 5 \\
+10 \cdot 1 \\
-17 \cdot 7 \\
+\quad 4 \cdot 0 \\
+9 \cdot 6\end{array}$ & $\begin{array}{r}\ldots \\
\ldots \\
+28 \cdot 1 \\
+25 \cdot 4 \\
+1 \cdot 9 \\
+12 \cdot 7 \\
-4.0\end{array}$ \\
\hline
\end{tabular}

The decline in domestic indoor service in the last decade is, as has been explained, more apparent than real; but some of it is real. The decrease since 1881 of 34.0 per cent. in the number of domestic servants under 15 , and the decrease of $7 \because$ per cent. within the same period in the number of domestic servants between 15 and 20, when the general fermale population has increased 28.1 per cent. within the period, suggests that young 
women prefer to enter other employments. Between 1881-1901, while the female population increased 25.2 per cent. domestic service only increased 8.2 per cent.

In so far as the number of domestic indoor servants may be regarded as a fair indication of the prevailing standard of comfort, it is interesting to compare figures for various localities in England. For the whole country the average was 18 per 100 separate occupiers-

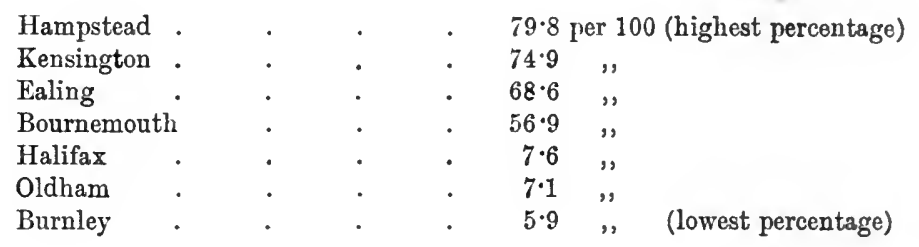

Home Work.-One branch of industry in which women have an unfortunate predominance is what is known as home work, the conditions of which still too closely recall those more generally prevailing at the beginning of the century. In this trade a Committee of inquiry reported in 1908 that "there is_sufficient evidence to show that sweating still exists in such a degree as to call urgently for the interference of Parliament," - sweating_being understood to mean that "work is paid at a rate which, in the conditions under which many of the workers do it, yields to them an income which is quite insufficient to enable an adult person to obtain anything like proper food, clothing, and house accommodation." The reasons for this lowness of wage are various. The work is extremely irregular and for the most part unskilled. It is largely undertaken by the quite destitute, who undercut one another; also for pocket money. The piece rate enables it to be done by those too old, slow, or ill for factory employment. Large proportions of the workers are engaged in the production of articles in competition with machinery, for which the rate of pay is fixed by the machine rate. Moreover, competition between the employers who use home work to evade factory legislation is often extremely keen, and so rates are cut down to the minimum. igain, the middleman makes an extra profit. The workers, helples. and unorganized, cannot protect themselves.

if the total of 289,237 women shown in the table as employed in donstic factories and workshops as home workers or working on theirown account, 253,440 are engaged in the making of

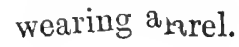


TABLE VIII.-Home Work (i.e. persons employed in domestic factories and tcorkshops, out-zcorkers, and persons vorking on their onon account), 1901

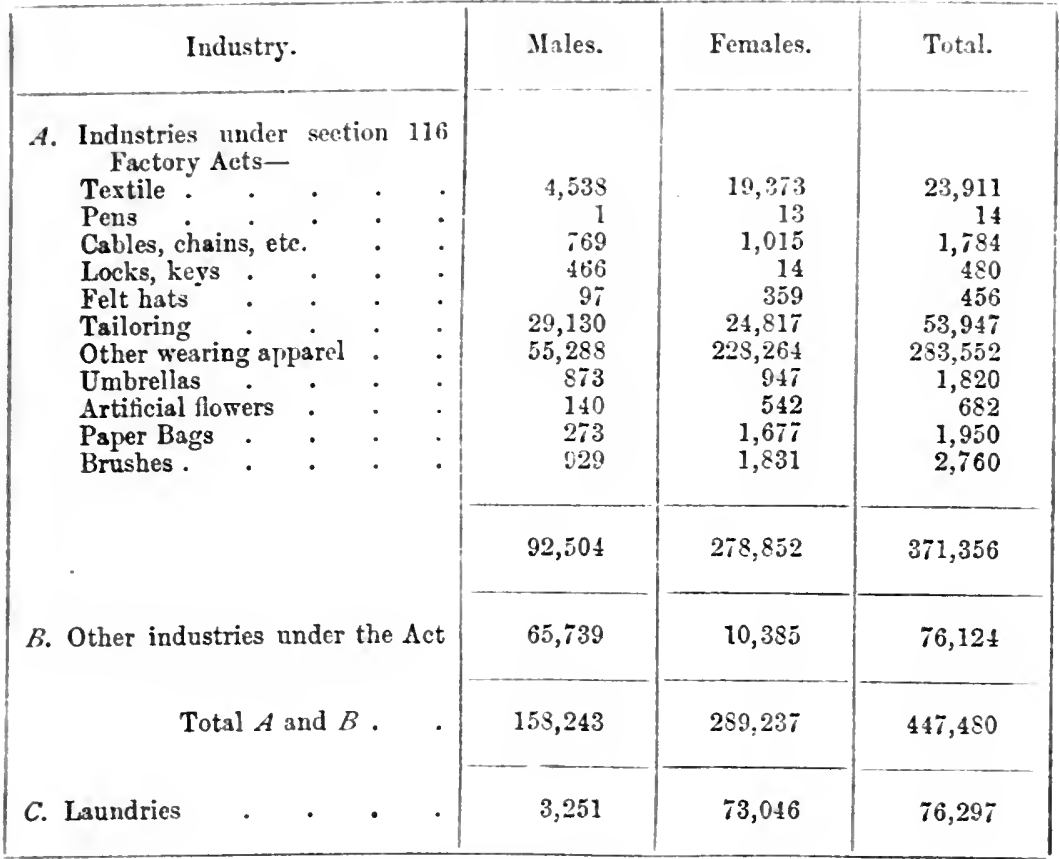

(Factory Iispector's Peport, 1906.)

TABLE IX.-Occupied Females-Home Worti (1901)

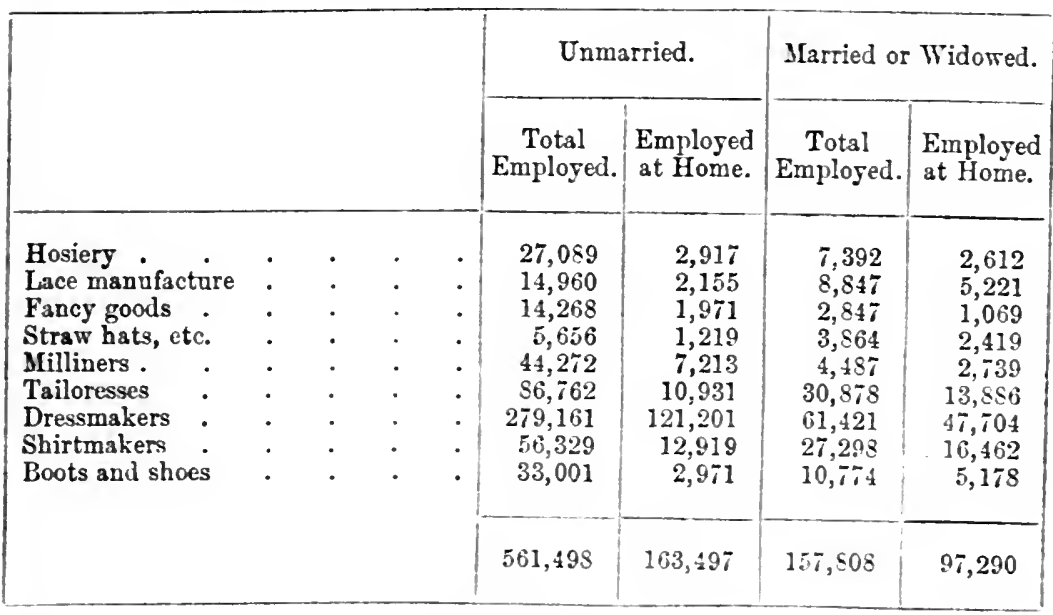


TABLE X.-Employment of Women-Proportion of Married Women in Factory and Home Work

\begin{tabular}{|c|c|c|c|c|c|c|}
\hline \multirow{2}{*}{ Occupations. } & \multicolumn{3}{|c|}{$\begin{array}{l}\text { Proportions per } 10,000 \\
\text { Women Occupied. }\end{array}$} & \multicolumn{3}{|c|}{$\begin{array}{l}\text { Of } 10,000 \text { Occupied the Pro- } \\
\text { portion Working at Home. }\end{array}$} \\
\hline & Total. & $\begin{array}{l}\text { Un- } \\
\text { married. }\end{array}$ & $\begin{array}{l}\text { Married or } \\
\text { Widowed. }\end{array}$ & Total. & $\begin{array}{l}\text { Un- } \\
\text { married. }\end{array}$ & $\begin{array}{l}\text { Married or } \\
\text { Widowed. }\end{array}$ \\
\hline $\begin{array}{l}\text { 1. Domestic services- } \\
\text { Domestic indoor } \\
\text { service : } \\
\text { Charwomen. } \\
\text { Laundry and wash- } \\
\text { ing . } \\
\text { Others in service } \\
\text { 2. Dealers and others } \\
\text { in commercial } \\
\text { pursuits- } \\
\text { Commercial and } \\
\text { other clerks } \\
\text { Shopkeepers, etc. } \\
\text { 3. Industrial occupa- } \\
\text { tions-- } \\
\text { Textile fabrics } \\
\text { Dress } \\
\text { Paper, books, etc. } \\
\text { Other workers } \\
\text { 4. Attendance on the } \\
\text { sick . } \\
\text { 5. Teaching . } \\
\text { 6. Board, lodging, food, } \\
\text { and drink. } \\
\text { 7. All other occupations }\end{array}$ & $\begin{array}{r}137 \\
700 \\
\\
1,421 \\
1,658 \\
180 \\
598 \\
\\
161 \\
414 \\
300 \\
378\end{array}$ & $\begin{array}{r}1,400 \\
1,659 \\
198 \\
612\end{array}$ & $\begin{array}{r}1,496 \\
1,655 \\
113 \\
551 \\
\\
328 \\
147 \\
\\
621 \\
488\end{array}$ & $\begin{array}{r}47 \\
613 \\
6 \\
30 \\
\\
\ldots \\
\ldots \\
\ldots \\
\ldots\end{array}$ & $\begin{array}{r}26 \\
495 \\
3 \\
14 \\
\\
\ldots \\
\ldots \\
\ldots \\
\ldots\end{array}$ & $\begin{array}{r}121 \\
1,031 \\
16 \\
88\end{array}$ \\
\hline Total occupied & 10,000 & 10,000 & 10,000 & & & \\
\hline
\end{tabular}

Married Women's Employment.-In the employment of women there are great local variations, and these variations are also marked in the case of the employment of married women, a question of considerable importance as to which accurate statistics are almost impossible to obtain. In the census of 1901 there is recorded a general belief that it declined between 1891-1901. The general rate of employment for married women (including widows) in 1901 was $13 \cdot 2$, as compared with 52.3 for unmarried women; but in the textile towns the rate is very much higher, e.g.-

Married Women.

Blackburn $37 \cdot 9$ per cent. 
and in certain other districts where female employment is concentrated, higher still, e.g.-

\section{Redditch}

Nantwich Luton
Per cent.

$43 \cdot 3$

$40 \cdot 1$ (tailoring trade)

40.0 (home work, straw hats)

A return dealing with 658,788 women occupied in trades where both home and factory labour is used, showed that among the home workers 59.5 per cent. were married, while of the total number of married workers in these occupations 61.6 per cent. were engaged in home work (the proportion of single women in home work being only 29.8). The high proportion of married women in laundry work is well known,-they are nearly four and a half times as numerous as the single,-and in connexion with this industry it is noted by the special inquirers under the Poor Law Report that "where industrial employment of women is plentiful, the men tend to become parasitic": men are said to "move to North Kensington for the purpose of being kept by their wives."

Occupation of Men.-While a few broad generalizations as to movement of occupation can be made, it is impossible, owing to the changed methods of occupational classification that have prevailed at different censuses, to institute any comparisons covering the whole period as to the numbers in any group.

At the first four enumerations occupations were divided into three groups (subdivided at the 1841 census) as those engaged in agriculture, those engaged in trade and manufacture, and those otherwise employed. But whereas at the first census "persons" were enumerated, at the next three "families" were taken as the unit. The figures for 1801 cannot be regarded as reliable at ail. It was admitted in the Report on the census of 1811 "that the question regarding occupations (in 1801) may be said to have produced no result, if indeed an incorrect result be not worse than none."

For $1811,1821,1831$, Porter gives the following percentage of families employed in Great Britain :-

\begin{tabular}{|c|c|c|c|c|}
\hline & & & 1811. & 1821. \\
\hline Agriculture & - & & $35 \cdot 2$ & $33 \cdot 2$ \\
\hline Trade and manufacture & . & • & $44 \cdot 4$ & $45 \cdot 9$ \\
\hline Other occupations & • & . & 20.4 & $20 \cdot 9$ \\
\hline
\end{tabular}

In 1841 the figures of occupation were again taken by persons: the period cau, however, be compared with the pre- 
ceding decennium by selecting occupied males aged 20 and upwards.

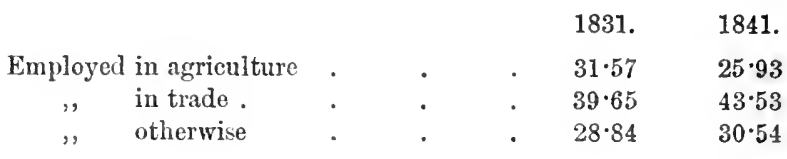

"The circumstance which most requires to be noticed is the decrease in the relative numbers of families einployed in agricultural pursuits. In the course of the thirty years, the proportion of such families has fallen from $35 \cdot 2$ per cent. to 25.9 per cent., showing that the quantity of food for the production of which the labour of seven families was formerly employed, is now produced by the labour of five families; a fact of considerable importance in reference to the capability of this country to continue its present onward course with respect to manufactures, notwithstanding the impossibility of adding to the extent of soil whence the greater quantity of food then needed must be derived."

In 1841, returns were made in accordance with an unclassified list of 877 occupations arranged alphabetically. At the next census these were arranged in 17 classes with 91 sub-classes; a plan modified in 1861 and 1871 , and subjected to so many changes in 1881 , that it is difficult to make any detailed comparisons on a consistent plan.

TABLE XI.-Occupation. Proportions per cent. returned as engaged in occupations at several age-groups in 1891 and 1901

\begin{tabular}{|c|c|c|c|c|c|c|c|c|c|c|}
\hline \multirow{4}{*}{ Ages. } & \multirow{2}{*}{\multicolumn{2}{|c|}{ Males. }} & \multicolumn{8}{|c|}{ Females. } \\
\hline & & & \multicolumn{4}{|c|}{$\begin{array}{l}\text { Including Domestic } \\
\text { Indoor Service. }\end{array}$} & \multicolumn{4}{|c|}{$\begin{array}{l}\text { Excluding Domestic } \\
\text { Indoor Service. }\end{array}$} \\
\hline & \multirow[b]{2}{*}{1891.} & \multirow[b]{2}{*}{1901.} & 1891. & \multicolumn{3}{|c|}{1901.} & 1891. & \multicolumn{3}{|c|}{1901.} \\
\hline & & & $\begin{array}{l}\text { 吾 } \\
\text { है }\end{array}$ & $\begin{array}{l}\text { 苛 } \\
\text { है }\end{array}$ & 点总 & 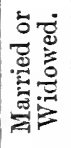 & 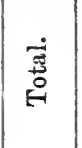 & 艿 & 它 & 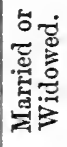 \\
\hline $\begin{array}{l}10-15 \\
15-20 \\
20-25 \\
25-35 \\
35-45 \\
45-55 \\
55-65 \\
65-75 \\
75 \text { and } \\
\text { upwards }\end{array}$ & $\begin{array}{l}26 \cdot 0 \\
91 \cdot 2 \\
96 \cdot 9 \\
97 \cdot 9 \\
97 \cdot 5 \\
95 \cdot 8 \\
89 \cdot 7 \\
64 \cdot 8\end{array}$ & $\begin{array}{l}21 \cdot 9 \\
91 \cdot 8 \\
97 \cdot 4 \\
98 \cdot 3 \\
97 \cdot 8 \\
96 \cdot 1 \\
89 \cdot 0 \\
60 \cdot 6\left\{\begin{array}{l}68 \cdot 9 \\
39 \cdot 0\end{array}\right.\end{array}$ & $\begin{array}{c}16 \cdot 3 \\
68 \cdot 6 \\
57 \cdot 8 \\
33 \cdot 0 \\
25 \cdot 1 \\
25 \cdot 4 \\
24 \cdot 4 \\
16 \cdot 0\end{array}$ & $\begin{array}{l}\cdot 0 \\
\cdot 9 \\
\cdot 3 \\
\cdot 5 \\
\cdot 5 \\
\cdot 7 \\
\cdot 7 \\
3 \cdot 2\left\{\begin{array}{r}15 \cdot 7 \\
7 \cdot 5\end{array}\right.\end{array}$ & $\begin{array}{l}12 \cdot 0 \\
66 \cdot 7 \\
73 \cdot 5 \\
70 \cdot 2 \\
64 \cdot 1 \\
57 \cdot 2 \\
44 \cdot 6 \\
26 \cdot 1 \\
10 \cdot 3\end{array}$ & $\begin{array}{r}11 \cdot 9 \\
10 \cdot 9 \\
10 \cdot 0 \\
13 \cdot 1 \\
16 \cdot 0 \\
17 \cdot 5 \\
14 \cdot 4 \\
7 \cdot 2\end{array}$ & $\begin{array}{r}9 \cdot 7 \\
38 \cdot 3 \\
33 \cdot 3 \\
21 \cdot 7 \\
19 \cdot 1 \\
20 \cdot 3 \\
20 \cdot 0 \\
13 \cdot 2\end{array}$ & $\begin{array}{l}8 \cdot 2 \\
41 \cdot 5 \\
35 \cdot 0 \\
20 \cdot 4 \\
17 \cdot 1 \\
17 \cdot 2 \\
16 \cdot 9 \\
11 \cdot 3\left\{\begin{array}{r}13 \cdot 3 \\
6 \cdot 5\end{array}\right.\end{array}$ & $\begin{array}{r}8 \cdot 2 \\
42 \cdot 0 \\
44 \cdot 4 \\
42 \cdot 1 \\
40 \cdot 3 \\
36 \cdot 3 \\
28 \cdot 9 \\
17 \cdot 8 \\
7 \cdot 2\end{array}$ & $\begin{array}{r}11 \cdot 4 \\
10 \cdot 3 \\
9 \cdot 2 \\
11 \cdot 8 \\
14 \cdot 1 \\
15 \cdot 3 \\
12 \cdot 7 \\
6 \cdot 4\end{array}$ \\
\hline
\end{tabular}


TABLE XII.-Occupation. Proportions occupied in Urban and Rural Districts

\begin{tabular}{|c|c|c|c|c|c|c|c|c|c|}
\hline \multirow{3}{*}{ Ages. } & & \multicolumn{4}{|c|}{$\begin{array}{c}\text { Aggregate of Urban } \\
\text { Districts. }\end{array}$} & \multicolumn{4}{|c|}{$\begin{array}{l}\text { Aggregate of Rural } \\
\text { Districts. }\end{array}$} \\
\hline & & \multirow[b]{2}{*}{ Males. } & \multicolumn{3}{|c|}{ Fenales. } & \multirow[b]{2}{*}{ Males. } & \multicolumn{3}{|c|}{ Females. } \\
\hline & & & 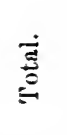 & 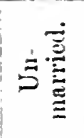 & 离荧 & & 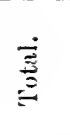 & 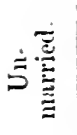 & 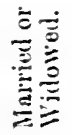 \\
\hline All ages above 10 & . & $84 \cdot 1$ & $33 \cdot 6$ & $55 \cdot 0$ & $14 \cdot 1$ & $82 \cdot 5$ & $24 \cdot 8$ & $42 \cdot 3$ & $9 \cdot 9$ \\
\hline $10-15$. . & . & $21 \cdot 5$ & $12 \cdot 9$ & $12 \cdot 9$ & & $22 \cdot 9$ & $9 \cdot 3$ & $9 \cdot 3$ & $\ldots$ \\
\hline $15-20$ & . & $91 \cdot 8$ & $68 \cdot 5$ & $69 \cdot 4$ & $13 \cdot 6$ & $91 \cdot 9$ & $55 \cdot 8$ & $56 \cdot 5$ & $4 \cdot 0$ \\
\hline $20-25$ & . & $97 \cdot 5$ & $58 \cdot 3$ & $76 \cdot 2$ & $12 \cdot 2$ & $96 \cdot 9$ & $47 \cdot 6$ & $62 \cdot 1$ & $4 \cdot 6$ \\
\hline $25-35$ & . & $98 \cdot 5$ & $31 \cdot 9$ & $73 \cdot 1$ & $11 \cdot 1$ & $97 \cdot 5$ & $24 \cdot 4$ & $58 \cdot 7$ & $5 \cdot 6$ \\
\hline $35-45$ & . & $98 \cdot 1$ & $24 \cdot 0$ & $67 \cdot 1$ & $14 \cdot 3$ & $96 \cdot 8$ & $17 \cdot 2$ & $53 \cdot 5$ & $8 \cdot 6$ \\
\hline $45-55$ & . & $\$ 6.3$ & $23 \cdot 0$ & $59 \cdot 6$ & $17 \cdot 3$ & $95 \cdot 3$ & $17 \cdot 2$ & $49 \cdot 5$ & $12 \cdot 0$ \\
\hline $55-65$ & . & $88 \cdot 3$ & $21 \cdot \bar{t}$ & 46.0 & $18 \cdot 4$ & $90 \cdot 7$ & $17 \cdot 7$ & 40.4 & $14 \cdot 8$ \\
\hline $65-75$. & . & $65 \cdot 0$ & $15 \cdot 9$ & $26 \cdot 2$ & $14^{\circ}$ & 76.8 & $15 \cdot 2$ & $25 \cdot 8$ & $14 \cdot 0$ \\
\hline 75 and upwards & . & $33 \cdot 9$ & $7 \cdot 0$ & $9 \cdot \overline{6}$ & 6. & $46 \cdot 5$ & $8 \cdot 6$ & $21 \cdot 1$ & $8 \cdot 2$ \\
\hline
\end{tabular}

Comparisons that are at all complete can only be made as regards the last three censuses, and even there caution is needed. In 1901 the 347 occupational headings were further increased to 352 ; and more accurate subdivision has had the effect of apparently reducing some numbers: e.\% of general labourers, there were 594,128 in $1891,409,773$ in 1901 ; while the real decline, if any, has not been nearly so marked.

Nevertheless, for some of the main groups of industries the goneral movement can be fairly accuiately traced.

Agriculture. - In considering the comparative proportions of population at different decades employed in any occupation, the growth of population, and of occupied population in particular, must always be borne in mind. The proportion of males engaged in any industry might apparently decline, owing to the growth of some other industry attracting a larger proportion of workers, but so long as its own numbers continued to grow the industry could not be said to be declining alsolutely. But in the case of agriculture the decline already marked in 18.7 has steadily proceeded, relatively and absolntely. From the landlord's point of view agricultural land is a less profitable investment than it was; and though agriculture still oecupies 30 per cent. of those living in rural districts, there is a steady drain of young men to 
the towns. One cause for a decline of agricultural profits since the 'seventies is no doubt the immense development of steam transport, which has rendered available the corn supplies of countries more favoured by climate and soil, against whose competition the home producer has not been able to maintain his

\section{TABLE XIII.-Occupation of the People, 1841 Census}

\begin{tabular}{|c|c|c|c|c|c|}
\hline & \multicolumn{4}{|c|}{ England and Wales. } & \multirow{3}{*}{ Total. } \\
\hline & \multicolumn{2}{|c|}{ Males. } & \multicolumn{2}{|c|}{ Females. } & \\
\hline & $\begin{array}{l}20 \text { Years } \\
\text { and over. }\end{array}$ & $\begin{array}{l}\text { Under } \\
20 .\end{array}$ & $\begin{array}{l}20 \text { Years } \\
\text { and over. }\end{array}$ & $\begin{array}{l}\text { Under } \\
20 .\end{array}$ & \\
\hline Persons engaged in commerce, & & & & & \\
\hline $\begin{array}{l}\text { trade, and manufacture } \\
\text { Agriculture. }\end{array}$ & $1,750,128$ & 318,434 & 391,261 & 159,383 & $2,619,206$ \\
\hline Labour-not agricultural & $1,041,980$ & $\begin{array}{r}161,697 \\
85\end{array}$ & 48,450 & 9,321 & $1,261,448$ \\
\hline $\begin{array}{l}\text { Army at home and abroad, } \\
\text { including half-pay and East } \\
\text { India Company- }\end{array}$ & 482,683 & 85,182 & 98,828 & 7,229 & 673,922 \\
\hline At home & 30,460 & 6,303 & $\ldots$ & $\cdots$ & 36,763 \\
\hline Abroad and in Ireland. & 89,215 & 15 & $\ldots$ & $\ldots$ & 89,230 \\
\hline $\begin{array}{l}\text { Navy and merchant service, } \\
\text { fishermen, etc. - }\end{array}$ & & & & & \\
\hline At home . . & 87,843 & 7,350 & $\ldots$ & ... & 95,193 \\
\hline fufloat & 79,619 & 17,180 & $\ldots$ & $\ldots$ & 96,799 \\
\hline (clerical & 20,450 & $\ldots$ & $\ldots$ & $\ldots$ & 20,450 \\
\hline Professions legal. . & 14,155 & $\ldots$ & & $\ldots$ & 14,155 \\
\hline (medical. & 17,666 & $\ldots$ & 770 & $\ldots$ & 18,436 \\
\hline $\begin{array}{l}\text { Other pursuits requiring edu- } \\
\text { cation }\end{array}$ & 81,372 & 10,637 & 30,060 & 1,809 & 123,878 \\
\hline Government and civil service & 13,340 & 219 & 515 & 14 & 14,088 \\
\hline Municipal and parochial & & & & & \\
\hline officers . $\quad . \quad$. & 19,955 & 321 & 1,896 & 13 & 22,125 \\
\hline Domestic servants & 150,005 & 83,524 & 476,081 & 289,438 & 999,048 \\
\hline Living on means & 118,688 & 5,092 & 308,061 & 14,132 & 445,973 \\
\hline In institutions . & 64,924 & 28,051 & 60,019 & 23,212 & 176,206 \\
\hline Total occupied . . & $4,062,483$ & 724,005 & $1,415,881$ & 504,551 & $6,706,920$ \\
\hline $\begin{array}{l}\text { Unoccupied (including } \\
\text { women and children). }\end{array}$ & 239,013 & $2,935,752$ & $3,059,350$ & $3,156,751$ & $9,390,866$ \\
\hline Total population . & $4,301,496$ & $3,659,757$ & $4,475,231$ & $3,661,302$ & $16,097,786$ \\
\hline
\end{tabular}

higher prices. The low supply of efficient labourers has steadily raised agricultural wages in some districts, but in many the absence of good cottages and the general tedium and lack of prospect of the life drive men to seek brighter chances in the towns. Recently, endeavours have been made to retain men on the soil by the 
granting of small holdings and allotments; but so far the efforts of the Legislature have not met with any very lively response on the part of local authorities. In Ireland the decline has been

\section{TABLE XIV.-Occupation of the People}

I. SHowiNg INCREASE, 1881-1901

\begin{tabular}{|c|c|c|c|c|c|c|c|c|c|}
\hline \multirow{2}{*}{$\begin{array}{l}\text { Occupations or Groups } \\
\text { of Oocupations. }\end{array}$} & \multicolumn{3}{|c|}{$\begin{array}{l}\text { Proportion per } \\
\text { Million Persons. }\end{array}$} & \multicolumn{3}{|c|}{$\begin{array}{l}\text { Proportion per } \\
\text { Million Males. }\end{array}$} & \multicolumn{3}{|c|}{$\begin{array}{l}\text { Proportion per } \\
\text { slillion Females. }\end{array}$} \\
\hline & $18 S 1$. & 1591. & 1901. & 1851. & 1891. & 1901. & 1581. & 1891. & 1901. \\
\hline General or local government . & 5,386 & 6,543 & 7,826 & 10,373 & 12,204 & 14,149 & 738 & 1,312 & 2,009 \\
\hline Defence of the country. & 5,545 & 5,735 & 6,643 & 11,494 & 11,940 & 13,865 & .. & $\cdots$ & $\therefore$ \\
\hline $\begin{array}{l}\text { Froressional occupation and } \\
\text { subordinate services }\end{array}$ & 21,674 & 23,029 & 23,940 & $24,7 \$ 1$ & 25,035 & 25,681 & 18,778 & 21,175 & 23,339 \\
\hline $\begin{array}{l}\text { Commercial (excluding mer- } \\
\text { chants, salesmen, buyers) }\end{array}$ & 15,638 & 18,277 & 23,022 & 31,666 & 36,190 & 43,154 & 699 & 1,725 & 4,542 \\
\hline $\begin{array}{l}\text { Converance of men, goods, and } \\
\text { messages (excluding plate- } \\
\text { layers, railway labourers, } \\
\text { etc.) }\end{array}$ & 41,088 & 45.498 & 50,022 & 83.985 & 93,209 & 102.814 & 1.105 & $19-9$ & $49-$ \\
\hline Cosl and sbale mine : & $\begin{array}{l}41,008 \\
19,774\end{array}$ & $\begin{array}{l}45,4 \\
23,4\end{array}$ & $\begin{array}{l}50,022 \\
25,418\end{array}$ & $\begin{array}{l}83,985 \\
40,657\end{array}$ & $\begin{array}{l}93,209 \\
48,513\end{array}$ & $\begin{array}{r}102, \\
52,\end{array}$ & $\begin{array}{r}1,105 \\
310\end{array}$ & $\begin{array}{r}1,272 \\
286\end{array}$ & $\begin{array}{r}1,426 \\
203\end{array}$ \\
\hline Metals, machines, implements & 35,190 & 35,367 & 39,051 & 69,043 & 69,659 & 77,003 & 3,639 & $3,6 \pi$ & 4,136 \\
\hline Ships and boats & 2,801 & 3,162 & 3,421 & 5,794 & 6,505 & 7,131 & 11 & 15 & \\
\hline Vehicles . : : & 8,280 & 3,694 & 4,679 & 6,750 & 7,5 & 9,484 & 44 & 105 & 257 \\
\hline $\begin{array}{l}\text { Precious metals (electricity } \\
\text { included) }\end{array}$ & 4,005 & 4,317 & 6,016 & 7,261 & 7,864 & 11,012 & 970 & 1,039 & 1,420 \\
\hline Building and construction : & 39,620 & $36,2 \div 9$ & $44,5,0$ & $\$ 1,925$ & 75,307 & $92, \$ 11$ & 169 & 213 & 185 \\
\hline Wood, fur & 9,326 & 9,152 & 10,172 & 17,368 & 17,089 & 19,202 & $1, \$ 29$ & $1, \mathrm{S18}$ & 1,865 \\
\hline Brick, cement, glass & 6,638 & 6,309 & 6,331 & 11,154 & 10,391 & 11,732 & 2,429 & 2,530 & 2,513 \\
\hline Chemicals & 3,629 & 4,139 & 5,050 & 6,696 & 7,268 & 8,401 & 760 & 1,248 & 2,024 \\
\hline Paper, prints, books & 8,194 & 9,908 & 11,016 & 12,649 & 14,778 & 15,498 & 4,181 & 5,524 & $6,89=$ \\
\hline Drapers . . & 4,266 & 4,853 & 5,357 & 5,753 & 5,728 & 5,540 & 2,800 & 4,044 & 5,189 \\
\hline Food, tobacco, drink & 36,849 & 41,609 & 42,403 & 59,088 & 62,178 & 63,810 & 16,121 & 22,601 & 22,709 \\
\hline Gss, water, and sanitary service & 1,310 & 1,855 & 2,705 & 2,696 & 3,853 & $5,63 \%$ & 1,118 & & \\
\hline \multirow[t]{2}{*}{ Engine-drivers } & 3,426 & 3,721 & 4,198 & 7,101 & 7,747 & s, 762 & .. & $\ldots$ & $\cdots$ \\
\hline & 267,639 & 256,888 & $322,4 \div 0$ & 496,084 & 523,098 & $5 \leqslant 8,540$ & 54,711 & $6 s, 604$ & $7 \pi, 691$ \\
\hline
\end{tabular}

II. Showixg Decrease, 1881-1901

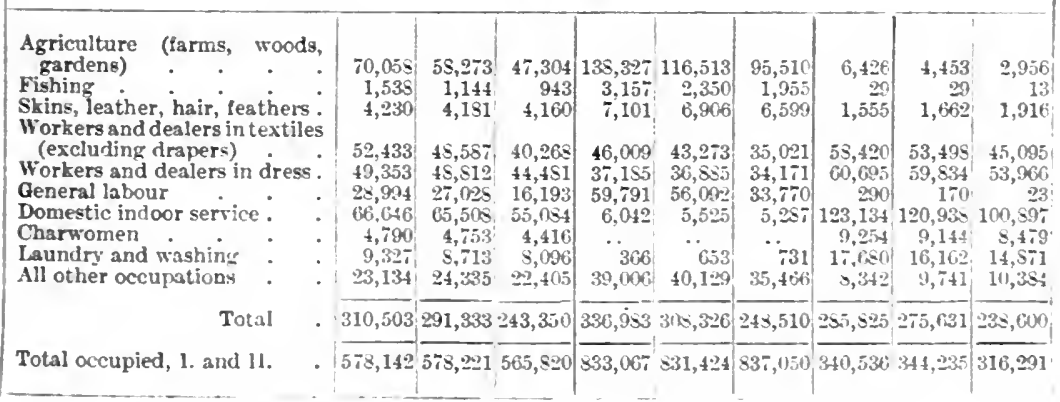

less rapid, as Table XVI shows; but the falling off in the numbers for the United Kingdom as a whole, which amounted to over half a million of men in the years 1881-1901, indicates, as far as numbers employed are concerned, continuous agricultural depression. 
At the same time the total amount of arable land fell between 1891-1901 by $6 \cdot 1$ per cent., declining from $12,903,585$ to $12,118,289$ acres: while the area of mountain and heath used for grazing rose $26 \cdot 3$ per cent., from $2,815,063$ to $3,556,636$ acres.

\section{TABLE XV.-Agriculture (England and Wales)}

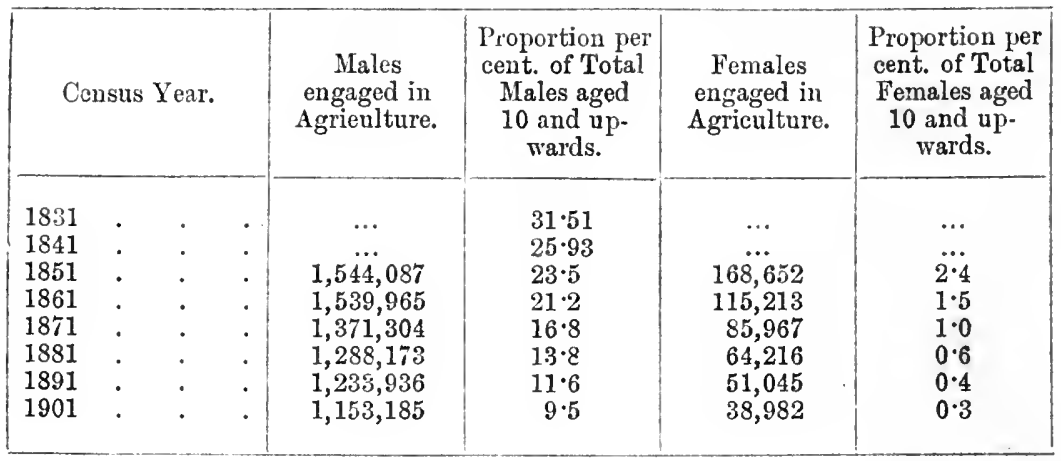

TABLE XVI.-Proportion horn by Males engaged in Agriculture to total Male population of 10 and upwards

\begin{tabular}{|c|c|c|c|c|c|c|}
\hline & Year. & & $\begin{array}{l}\text { United } \\
\text { Kingdon. }\end{array}$ & $\begin{array}{l}\text { England } \\
\text { and Wales. }\end{array}$ & Scotland. & Ireland. \\
\hline $\begin{array}{l}1881 \\
1891 \\
1901\end{array}$ & $\begin{array}{ll}. & . \\
. & \\
. & \end{array}$ & . & $\begin{array}{l}18 \cdot 8 \\
16 \cdot 2 \\
13 \cdot 6\end{array}$ & $\begin{array}{r}13 \cdot 8 \\
11 \cdot 6 \\
9.5\end{array}$ & $\begin{array}{l}14 \cdot 4 \\
12 \cdot 7 \\
10 \cdot 7\end{array}$ & $\begin{array}{l}46 \cdot 0 \\
45 \cdot 7 \\
44 \cdot 3\end{array}$ \\
\hline
\end{tabular}

Mining.--In all branches of the mining industry, except coal-mining, there has since 1881 been a decline. The number employed in coal-mining has on the other hand steadily increased.

In 1901 the number employed in mining was 6.0 per cent. of males aged 10 (U.K.). In 1891 it was 5.4 per cent., in 1881 4.9 per cent. The total number of miners was 937,482 in 1901 .

The increase in the number of coal-miners in the last twenty year's has been more rapid than the increase in output.

\section{Finglanil and Wales}

1881-1891.

Miners increased Output increased
$24 \cdot 7$ per cent. . $16 \cdot 4$,
$1891-1901$.

$35 \cdot 7$ Irer cent. $20 \cdot 0$, 


\section{TABLE XVII._Mines (England and Wales)}

\begin{tabular}{|c|c|c|c|c|c|c|c|c|c|c|}
\hline & \multicolumn{2}{|c|}{$\begin{array}{c}1841 \\
\text { (Porter). } \\
\text { (Gt. Eritain). }\end{array}$} & \multicolumn{6}{|c|}{ Jales (Census). } & \multicolumn{2}{|c|}{$\begin{array}{c}\text { Increase }(+ \text { )or } \\
\text { Decrease }(-) \\
\text { per cent. }\end{array}$} \\
\hline & 总 & 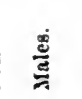 & $1 \$ 51$. & 1861. & 153. & 1891. & 1891. & 1901. & $\begin{array}{l}1 \mathrm{SS} 1- \\
1 \mathrm{~s} 91 .\end{array}$ & $\begin{array}{l}1891- \\
1201 .\end{array}$ \\
\hline Coal. & 2,350 & 115,883 & 183,359 & 246,613 & $26 \$, 091$ & 378,664 & 513,843 & 640,959 & $1+357$ & $+24 \cdot 7$ \\
\hline Iron . & 497 & 10,452 & 19,380 & 20,626 & 20,931 & 25,879 & 18,158 & $17,00 \mathrm{~s}$ & $-29 \cdot 8$ & $-6 \cdot 3$ \\
\hline Tin . & 150 & 5,951 & 12,911 & 14,314 & 10,617 & 10,499 & 9,670 & $6,57 \pi$ & $-7 \cdot 9$ & $-32 \cdot 0$ \\
\hline Lead. & 60 & 11,359 & 20,030 & 18,552 & 14,563 & 11,022 & 5,723 & 4,375 & $-48 \cdot 1$ & $-23 \cdot 6$ \\
\hline Copper & 2,113 & 13,114 & 18,449 & $17, i 2 \pi$ & 3,063 & 3,800 & 1,130 & 759 & $-70 \cdot 3$ & $-30-2$ \\
\hline Other minerals. & 963 & 30,753 & .. & 8,039 & 39,130 & 2,061 & 2,401 & 2,457 & .. & .. \\
\hline Total & 6,133 & $15 \pi, 512$ & 254,159 & $325,8 \mathrm{il}$ & 356,395 & 431,925 & 550,925 & 672,195 & +276 & $+22 \cdot 0$ \\
\hline
\end{tabular}

Textiles. - In 1901 all branches of the textile industry except jute, hemp, and coarse lace showed a falling off as compared with the very high figures of the previous decade. This steady decrease, which had been going on since 1895 (especially marked in the great cotton industry), is no doubt due in part to the restricted employment of children. To some extent also, as far as the decline in the ages of males up to twenty-five goes, it is true that "many young persons who formerly would have joined the cotton trade now enter, amongst others, the metal, machine and engineering industries, which offer prospects of higher wages and better conditions of employment." In these industries in Lancashire the numbers have greatly increased, especially at ages between 15 and 25.

Some reduction is no doubt due to the great development of labour-saving machinery; but the reality of the decline between 1895-1901 was reflected in the reduced importation of raw cotton; it was 1.9 per cent. lower in 1895-1901 than it had been in 1885-1891. This decline continued to progress in 1902 and 1903 , but in 1904 there was a marked recovery; in 1905 imports of raw cotton rose by over 2 million ewt., and in 1907 reached the record total of $21,311,617 \mathrm{cwt}$. In that year the numbers employed in textiles was $1,087,223$; in cotton alone to 576,820. Taking this in comnexion with the rising wages of the cotton industry, its recovery seems established.

Examination of the tables shows that from 1861 , on the whole, textile industry has been subject to considerable fluctuations; but only two branches, the silk industry and the flax and linen, show 


\section{TABLE XVIII.-Textiles}

(a) Makers of and Dealers in all Textile Fabrics (excluding Drapers)

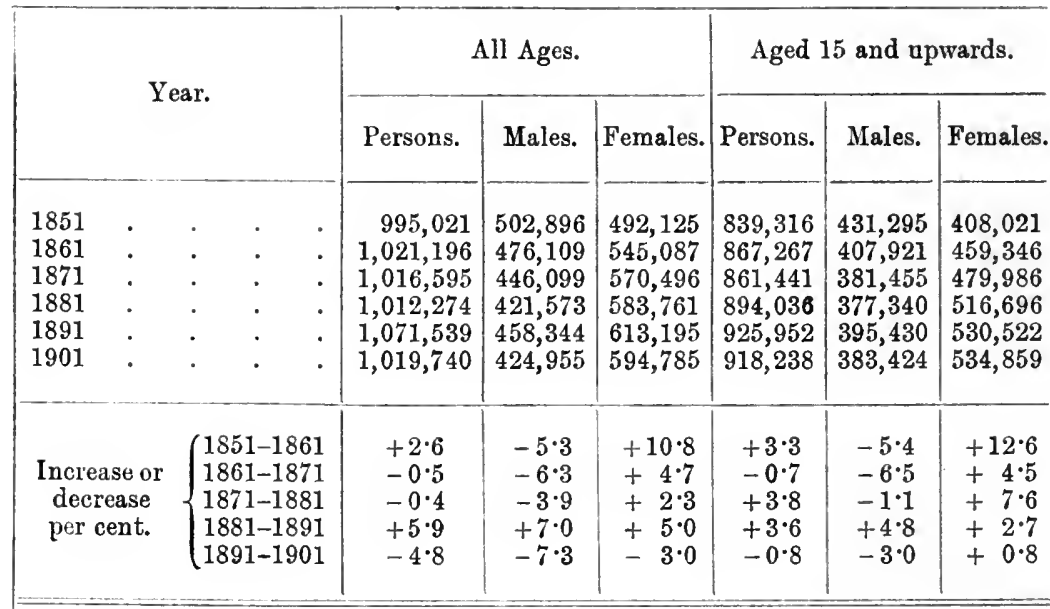

(b) Cotton

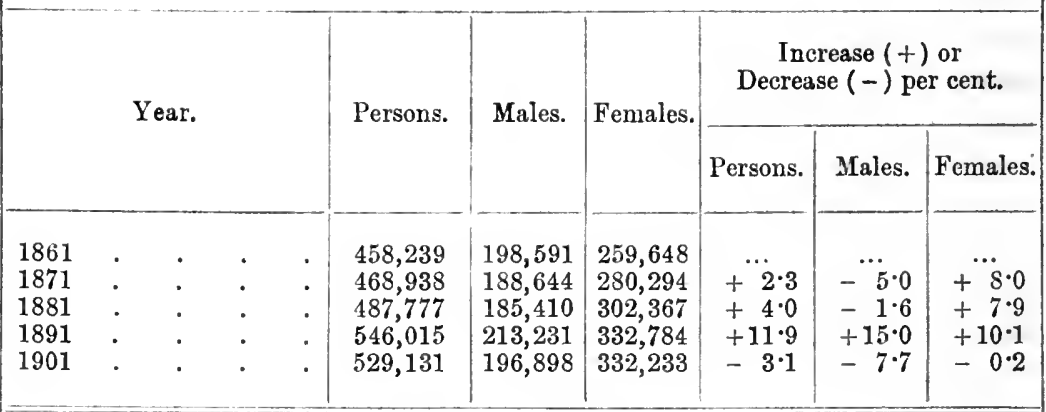

(c) Wool and Worsted

\begin{tabular}{rlllll|r|r|r|r|r|}
\hline 1861 & $\cdot$ & $\cdot$ & $\cdot$ & $\cdot$ & 220,892 & 119,502 & 101,390 & $\ldots$ & $\ldots$ & $\ldots$ \\
1871 & $\cdot$ & $\cdot$ & $\cdot$ & $\cdot$ & 235,235 & 114,485 & 120,750 & $+6 \cdot 5$ & $-4 \cdot 2$ & $+19 \cdot 1$ \\
1881 & $\cdot$ & $\cdot$ & $\cdot$ & $\cdot$ & 222,371 & 97,638 & 124,733 & $-5 \cdot 5$ & $-14 \cdot 7$ & $+3 \cdot 3$ \\
1891 & $\cdot$ & $\cdot$ & $\cdot$ & $\cdot$ & 242,334 & 107,237 & 135,097 & $+9 \cdot 0$ & $+9 \cdot 8$ & $+8 \cdot 3$ \\
1901 & $\cdot$ & $\cdot$ & $\cdot$ & $\cdot$ & 209,740 & 87,671 & 122,069 & $-13 \cdot 5$ & $-18 \cdot 2$ & $-9 \cdot 6$ \\
\hline
\end{tabular}

real decline. In 1851 , silk manufacture occupied 120,000 persons, in 1891 only 48,797 , and in 1901 only 34,847 .

Conveyance.-This heading, including those engaged on or in railways, roads, seas, rivers and canals, lochs and harbours, and in storage, porterage and conveyance of messages, contains the largent number of adult males of any single group, all over the coun 
workers in metals and machines coming second, and agriculture third. In 1901 it employed $1,267,825$ persons, of whom only 18,825 were females; and employed 10.29 per cent. of males in the country as a whole, $11 \cdot 16$ in the aggregate urban districts. The numbers employed on railways (excluding platelayers, packers, gaugers, and railway labourers) have increased as follows:-

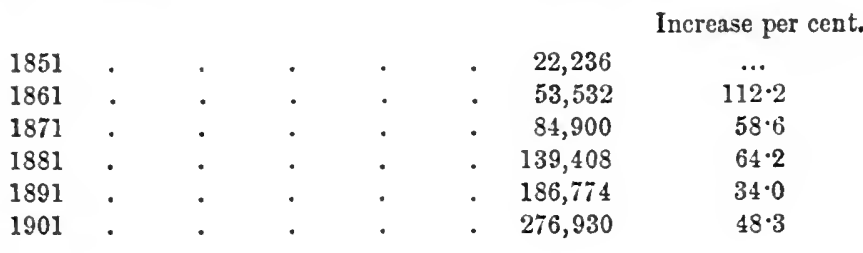

but the most striking development has been that of the Tramway Service.

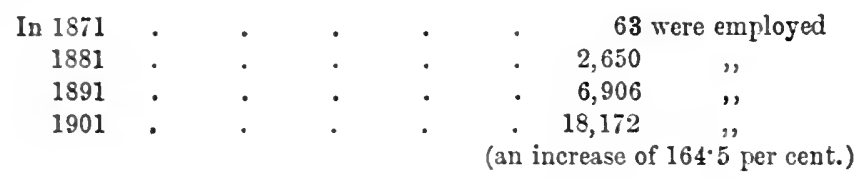

and between 1891-1901 the length of line increased by 35 per cent. and the number of passengers conveyed 108 per cent.

Metals, Machincs, etc.-This great branch of industry, including the departments of shipbuilding and engineering, employed in 1901 $1,237,196$ persons of whom only 63,016 were females, or $9 \cdot 42$ per cent. of occupied males (England and Wales). The engineering trade proper employed in $1891,208,508$ males and $2 \pm 66$ females, in $1901,353,166$ males and 1522 females, an increase of 68.6 in the employment of males, and a decline of 38.3 per cent. in that of females. Shipbuilding increased $24 \cdot 2$ per cent. in the country as a whole; but in Newcastle it increased 50.3 per cent., in Durham $43 \cdot 7$, in the North Riding of Yorkshire $39 \cdot 1$, while in the East Riding it declined 23.4 per cent., in Norfolk 19 per cent., and in London 18 per cent.

The general increase for all metal trades was $26 \cdot 6$ per cent. for England and Wales, 28.4 per cent. for Scotland; while in the iron and steel trades the increase was $9 \cdot S$ per cent. for England and Wales, 20.5 per cent. in Scotland (1901).

Occupational Mortality. - The mortality rate of different occupaons varies very greatly: comparing the census of 1901 with the revious one, however, a decline in the mortality rate of almost 
all occupations can be observed, keeping step with the decline in the death-rate for the population as a whole.

If the death-rate of all males between 25 and 65 be taken as 1000 in 1901 , that of all males in 1891 . was 1155 ; that of occupied males 925 in 1901, 1102 in 1891 for England and Wales as a whole.

The following table gives the comparative figures for: occupied and unoccupied males, and for those occupations having the highest and lowest mortality rates respectively. General labour had the highest death-rate in 1891, and in 1901 it was still highest, and at an increased figure. Lace and hosiery, tin and copper mining, shopkeeping and general labour alone show an increased rate.

\section{TABLE XIX.-Occupational Mortality}

Rate of Mortality of all Males 25-65 in 1900-1-2=1000

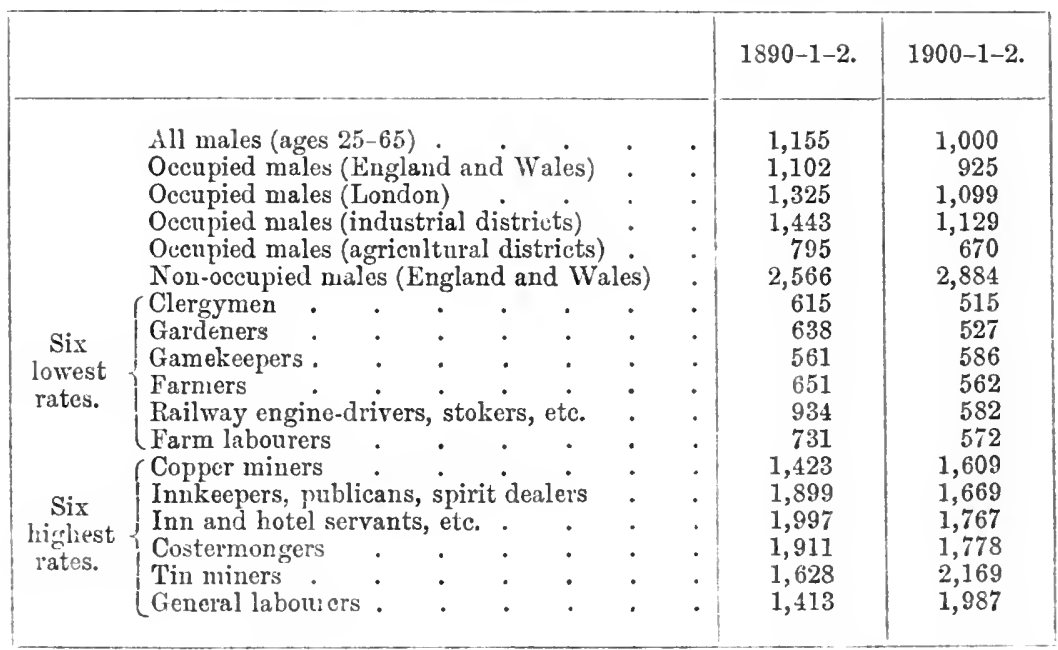

There is a heavy yearly toll of victims of occupational disease and accident.

In 1900 there were 1058 cases of lead poisoning in the potteries, 38 of which ended fatally; 37 cases of anthrax, of which 7 ended fatally (in 190139 , with 10 deaths); 22 cases of arsenic poisoning, of which 3 died; and 38 deaths from lead poisoning among plumbers.

With regard to industrial accidents, in 1897 there were, in factories, mines, quarries, shipping and railroads, 58,061 tit, of injury-3785 deaths; in $190194,45 \pm$ cases of in $p$ : 
4061 deaths. The total number of accidents reported under the Factory and Workshops Act was in 1897,63,856; in 1901, 107,290 : the number of deaths being 4262 in 1897,4627 in 1901. Thus per 1000 of those employed in these industries, which, as we have seen from the preceding table, are not among those with the highest mortality rate, the rate of deaths from accident is $5 \cdot 25$, of injuries $17 \cdot 29$. 


\section{WAGES (NOMINAL AND REAL), PRICES, AND EMPI.OYMENT}

Real wages the test of improvement-History of wages to 1815 and after-Agricultural wages-Industrial wages-Index numbers of money wages-History of prices -Unemployment-Movement of wages and prices since 1900

FTER ascertaining the population of the country and the rough
division of it into ages, sexes, classes, trades, and occupations
- a task which has been made possible in the United Kingdom by a long series of census returns-we come to the allimportant question of wages and prices. For the progress of a civilized nation is to be judged more by the improvement in the condition of the working classes than by any other test. And this improvement depends on the growth of real wages. Hence this chapter is devoted first to a brief survey of the movements of money wages in so far as they can be ascertained, and secondly, to a survey of prices, which will enable us to see how the real value of wages has varied. A fall in rents and in the price of food and clothing may be just as beneficial to the working classes as a rise in wages, whereas the latter may, and in fact often has been accompanied by so rapid a rise of prices that the labourer is left worse off than before. Thus there can be little doubt that as a result of almost continuous war and rapidly increased taxation upon the necessaries of life the diet of the poor in town and country both in Great Britain and Ireland was worse from 1815 to 1845 than it had been from 1745 to 1775 .

The only continuous figures that Porter was able to collect relate to wages paid in Greenwich Hospital and in certain miscellaneous occupations in other parts of the country. The modern statistician on the other hand suffers from a plethora rather than from a dearth of statistical material relating to wages. Trade Union standard rates of wages have become well-nigh universal in many industries. Official investigations bave been made in many particular cases; records have been hunted up and data collected which together give a fairly complete account of the wages history of the century. 
So far as the first half of the century is concerned, Professor Thorold Rogers' investigation gives us all that is needed in a general review. "I have shown," he says, "that from the earliest recorded annals, through nearly three centuries, the condition of the English labourer was that of plenty and hope, that from perfectly intelligible causes it sunk within a century to so low a level as to make the workmen practically helpless, and that the lowest point was reacher just about the outbreak of the great war between King and Parliament. From this time it gradually improved, till in the first half of the eighteenth century, though still far below the level of the fifteenth, it achieved comparative plenty. Then it began to sink again, and the workmen experienced the direst misery during the great continental war. Latterly, almost within our own memory and knowledge, it has experienced a slow and partial improvement, the causes of which are to be found in the liberation of industry from protective laws, in the adoption of certain principles which restrained employment in some directions, and most of all in the concession to labourers of the right so long denied, and forming labour partnerships."

Thus at the beginning of the century with which we are concerned, the working classes were in a condition of the utmost degradation as a result of the great continental war following hard upon the Industrial and Agricultural Rerolutions in this country.

The pernicious system of grants-in-aid of wages, though no doubt it served its immediate purpose of keeping alive the workers in agricultural districts during the worst years of famine, played complete havoc with the labour market, at the same time that it encouraged a rapid increase of the population. Incidentally it makes it difficult to quote agricultural wages at the beginning of the nineteenth century, as the wages paid in so many cases do not represent the income received by the family.

But the following figures given by Thorold Rogers show the general tendency of events. According to Arthur Young's calculations, the average had been $7 \mathrm{~s}$. $6 \mathrm{~d}$. a week from 1767 to 1789 , $10 \mathrm{~s}$. a week from 1799 to 1803 ; then under the influence of the famine prices of the great war, they rose to $12 \mathrm{~s}$. in 1804 and 1810 . In 1811 they rose still further to $12 \mathrm{~s} .9 \mathrm{~d}$, and continued at this rate for three years. But with the coming of peace and with better harvests, the utmost efforts of a stringent Corn Law was unable to keep prices so abnormally high, and wages fell with prices. As labour was very plentiful during the succeeding period, wages sunk about 17 per cent. between 1814 and 1818 , some 
20 per cent. in 1819 and 1820,12 per cent. more in 1821, and 5 per cent. in 1822. As is always the case, economic distress goes liand in hand with internal political disturbance, and students of English History will remember that this period of falling wages coincided with the Peterloo Massacre, the Manchester Riots, and the repressive legislation embodicd in the Six Acts. From 1822 onwards agricultural wages under the influence of increasing manufacturing activity began to rise slowly. A Parliamentary Return gives $9 \mathrm{~s} .4 \mathrm{~d}$. in $1834,10 \mathrm{~s}$. $4 \mathrm{~d}$. in 1837 , and $11 \mathrm{~s} .7 \mathrm{~d}$. in 1860. As this was also a period of falling prices these figures indicate a very considerable improvement in the lot of the labourer. The subsequent history of agricultural labour has been almost entirely determined by the growing demand for, and the increasing productivity of, labour in manufacturing industries and in town occupations. The farmer has been caught between the upper and nether grindstone of falling prices, caused by the opening up of vast producing areas in distant parts of the world on the one hand, and of rising wages on the other. There has therefore been a steady falling off in the agrieultural population, for labour could be more productively employed elsewhere. The first series of wages in the following table are from various sources, and are therefore not strictly comparable with one another. But the second column, which is taken from Mr. Wilson Fox's report on agricultural wages, relate to sixty-nine English farms in which books have been continuously kept. As these figures confirm the first series, there can be little

\begin{tabular}{|c|c|c|c|c|c|}
\hline Year. & Authority. & $\begin{array}{l}\text { Average } \\
\text { Weekly } \\
\text { Rate of } \\
\text { Wages. }\end{array}$ & $\begin{array}{l}\text { Average } \\
\text { on } 69 \\
\text { Farms. }\end{array}$ & $\begin{array}{l}\text { Average } \\
\text { on } 128 \\
\text { Farms. }\end{array}$ & Year. \\
\hline & & s. d. & s. d. & s. d. & \\
\hline $1850-1851$. & $\begin{array}{c}\text { Caurd, Englash Agrichuture } 2 \text {. } 1530- \\
1851 .\end{array}$ & & $93 \frac{1}{2}$ & & 1850 \\
\hline 1860. & $\begin{array}{l}\text { Purdy, " Earnings of Agricultural } \\
\text { Lahourers," Journal of Statistical } \\
\text { Society, } 1861 .\end{array}$ & & 1011 & & 1860 \\
\hline $1867-1870$. & $\begin{array}{l}\text { Little, "Royal Commission on } \\
\text { Latour," The Agricultural La. } \\
\text { bourer, vol. v. part i. }\end{array}$ & 12 & 120 & $\therefore$ & 1868 \\
\hline 1870-1871) & Druce, Journal of Royal Agri- & 12 & $1110 \frac{1}{2}$ & & 1870 \\
\hline $1880-1881\}$ & cultural Society of England, 1885 & 14 & $132 \frac{1}{2}$ & $137 \frac{1}{2}$ & 1880 \\
\hline 1892-1893. & Little, as above $\cdot$. & 13 & 135 & $1310^{-}$ & 1892 \\
\hline 1898 . . & $\begin{array}{l}\text { First Report of W. Fox on Wages } \\
\text { and Earnings of Agricnltural }\end{array}$ & & & & \\
\hline & Labourers (C). 346). . . & 14 & 13 & $14 \quad 1 \frac{1}{2}$ & 1898 \\
\hline 1902 . & Second ditto. $\cdot$. $\cdot$. & 14 & 14 & $1411 \frac{1}{2}$ & 1900 \\
\hline
\end{tabular}


doubt that there occurred something like a 50 per cent. rise between 1850 and 1902.

The figures given are exclusive of allowances in kiud, such as cottage, garden, etc. If these are taken into account, the Board of Trade estimate on the basis of Mr. Wilson Fox's inquiry that wages would amount to $18 \mathrm{~s} .4 \mathrm{~d}$. in England, 18s. in Wales, 19s. 7 d. in Scotland, and 11s. 3d. in Ireland.

Industrial wages in the first half of the century show in the main a slight improvement in the condition of the working classes, but the tendency was not uniform. The methods of production were changing so rapidly that many were left in great distress, while others improved their position enormously. In no case is this more clearly to be seen than in that of the cotton trade, where the hand-loom weavers suffered great privations through the loss of a market for their skill; whereas the machine workers, though at first drawn to an excessive extent from the ranks of women and children, secured from the beginning of the century onwards a steady improvement in their material position.

The first of these tendencies is illustrated by the following list of wages quoted by Porter :-

Hand-Loom Weavers

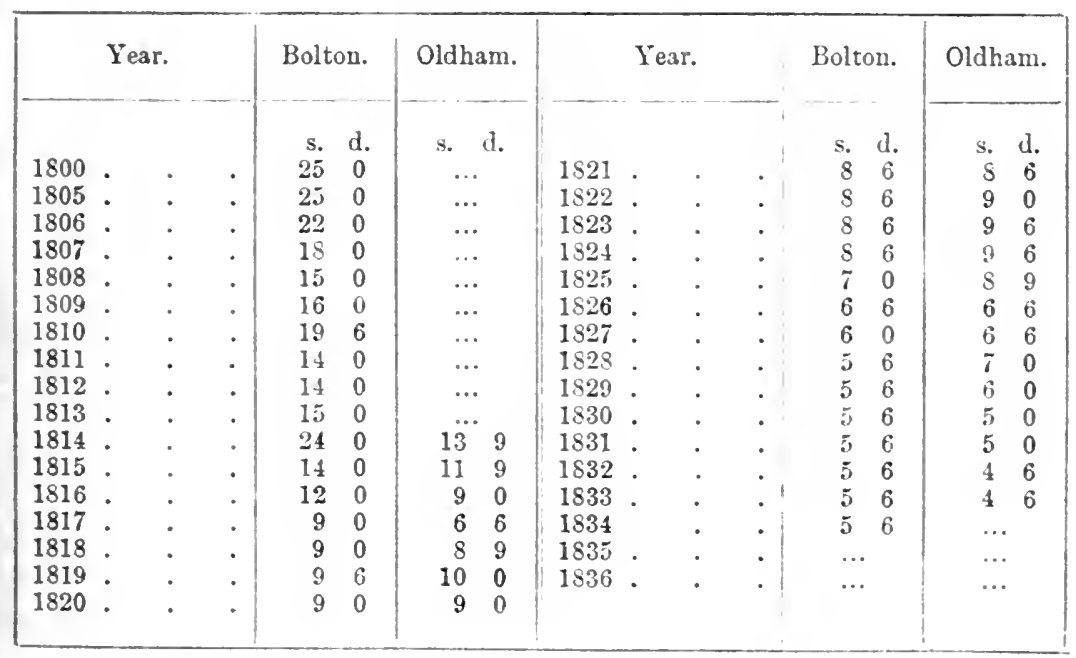

The progress of the industry as a whole on the other hand is clearly brought out in the following table collected by Messrs. Ellison and Merthens-a table which not only shows that wages soon began to rise, but also explains that these higher wages are 
possible because of the increased productivity of labour which has permitted the labour cost of both spinning and weaving to be enormonsly reduced in spite of higher weekly wages. This is clearly brought out by comparing columns 6,9 , and 11 in the spinning table, and 5,8 , and 10 in the weaving table.

\section{Spinning}

\begin{tabular}{|c|c|c|c|c|c|c|c|c|c|c|c|}
\hline \multirow{3}{*}{ Years. } & \multirow{3}{*}{ 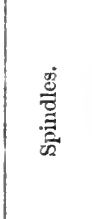 } & \multirow{3}{*}{ 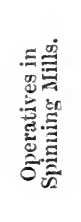 } & \multirow{3}{*}{ 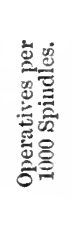 } & \multirow{3}{*}{ 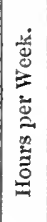 } & \multirow{3}{*}{ 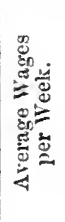 } & \multicolumn{3}{|c|}{ Production } & \multirow{3}{*}{ 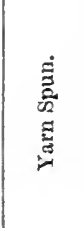 } & \multirow{3}{*}{ 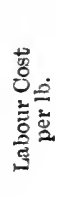 } & \multirow{4}{*}{ 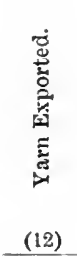 } \\
\hline & & & & & & $\begin{array}{c}\text { Per } \\
\text { Spindle. }\end{array}$ & $\begin{array}{r}\mathrm{P} \\
\text { Oper }\end{array}$ & & & & \\
\hline & & & & & & $\begin{array}{l}\text { Per } \\
\text { Year. }\end{array}$ & $\begin{array}{l}\text { Per } \\
\text { Year. }\end{array}$ & $\begin{array}{l}\text { Per } \\
\text { Day. }\end{array}$ & & & \\
\hline (1) & (2) & (3) & (4) & (5) & (6) & (7) & (8) & (9) & (10) & (11) & \\
\hline $\begin{array}{l}1829-1831 \\
1844-1846 \\
1859-1861 \\
1880-1882 \\
1891-1893\end{array}$ & $\begin{array}{l}\text { million. } \\
10 \cdot 0 \\
19 \cdot 5 \\
30 \cdot 4 \\
42 \cdot 0 \\
45 \cdot 27\end{array}$ & $\begin{array}{l}140,000 \\
190,000 \\
248,000 \\
240,000 \\
220,000\end{array}$ & $\begin{array}{c}14 \cdot 0 \\
9 \cdot 74 \\
8 \cdot 16 \\
5 \cdot 71 \\
4 \cdot 86\end{array}$ & $\begin{array}{l}69 \\
60 \\
60 \\
56 \frac{1}{2} \\
56 \frac{1}{2}\end{array}$ & $\begin{array}{ll}\text { s. } & \text { d. } \\
10 & 6 \\
11 & 0 \\
12 & 6 \\
17 & 0 \\
19 & 0\end{array}$ & $\begin{array}{l}1 \mathrm{~b} . \\
21 \cdot 6 \\
26 \cdot 8 \\
30.0 \\
31 \cdot 5 \\
32 \cdot 4\end{array}$ & $\begin{array}{c}\text { lb. } \\
1,546 \\
2,754 \\
3,671 \\
5,520 \\
6,662\end{array}$ & $\begin{array}{l}\text { lb. } \\
.431 \\
.883 \\
1.176 \\
1.879 \\
2 \cdot 267\end{array}$ & $\begin{array}{c}\text { million } \\
\text { lb. } \\
216 \cdot 5 \\
523 \cdot 3 \\
910 \cdot 0 \\
1324 \cdot 9 \\
1465 \cdot 6\end{array}$ & $\begin{array}{l}d . \\
4 \cdot 2 \\
2 \cdot 3 \\
2 \cdot 1 \\
1 \cdot 9 \\
1 \cdot 6\end{array}$ & $\begin{array}{l}\text { million } \\
\text { lb. } \\
63 \cdot 300 \\
145 \cdot 190\end{array}$ \\
\hline
\end{tabular}

\section{Weaving}

\begin{tabular}{|c|c|c|c|c|c|c|c|c|c|c|}
\hline \multirow{3}{*}{$\begin{array}{l}\text { Years. } \\
\text { (1) } \\
\end{array}$} & \multirow{3}{*}{$\begin{array}{l}\text { Looms. } \\
\text { (2) }\end{array}$} & \multirow{3}{*}{ 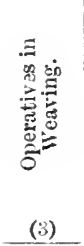 } & \multirow{3}{*}{ 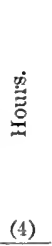 } & \multirow{3}{*}{ 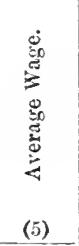 } & \multicolumn{3}{|c|}{ Production } & \multirow{3}{*}{ 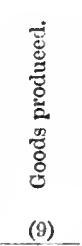 } & \multirow{3}{*}{ 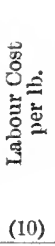 } & \multirow{3}{*}{ 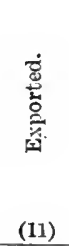 } \\
\hline & & & & & \multirow{2}{*}{$\begin{array}{c}\begin{array}{c}\text { Per } \\
\text { Loom. }\end{array} \\
\begin{array}{c}\text { Per } \\
\text { Year. } \\
(6)\end{array}\end{array}$} & \multicolumn{2}{|c|}{$\begin{array}{c}\text { Per } \\
\text { Operative. }\end{array}$} & & & \\
\hline & & & & & & $\begin{array}{c}\text { Per } \\
\text { Year. } \\
(7)\end{array}$ & $\begin{array}{c}\text { Per } \\
\text { Hour. } \\
(8) \\
\end{array}$ & & & \\
\hline $\begin{array}{l}\text { 1844-1846. } \\
1959-1861 . \\
1880-1882 \\
1891-1893\end{array}$ & $\left\{\begin{array}{r}\text { Power, } 80,000 \\
\text { lland, } 225,000 \\
\text { Power, } 225,000 \\
\text { lland, } 60,000 \\
400,000 \\
550,000 \\
660,000\end{array}\right.$ & $\begin{array}{r}50,000 \\
225,010 \\
150,000 \\
60,000 \\
203,000 \\
246,000 \\
310,000\end{array}$ & $\begin{array}{l}69 \\
69 \\
60 \\
60 \\
60 \\
56 \frac{1}{1} \\
56 \frac{1}{2}\end{array}$ & $\begin{array}{rr}\text { s. } & \text { d. } \\
\vdots & 6 \\
7 & 0 \\
10 & 0 \\
8 & 0 \\
11 & 10 \\
15 & 0 \\
16 & 6\end{array}$ & $\begin{array}{l}1,231 \\
1,627 \\
1,806 \\
1,866\end{array}$ & $\begin{array}{l}1,681 \\
3,206 \\
4,039 \\
3,972\end{array}$ & \begin{tabular}{r|}
$\cdot 539$ \\
$1 \cdot 027$ \\
1.374 \\
$1 \cdot 352$
\end{tabular} & $\begin{array}{r}318 \cdot 11 \\
650 \cdot 57 \\
993 \cdot 54 \\
1,231 \cdot 3\end{array}$ & $\begin{array}{l}3 \cdot 5 \\
2 \cdot 9 \\
2 \cdot 3 \\
2 \cdot 59\end{array}$ & $\begin{array}{l}298 \cdot 5 \\
536 \cdot 0 \\
888 \cdot 0 \\
303 \cdot 64\end{array}$ \\
\hline
\end{tabular}

(Wages calculated by Merthens for Ellison by dividing by 52.)

When we come to consider the latter half of the century, we find that there are so many different grades in modern industry, and so many local variations in wages, that it is far simpler to show wage changes by means of percentage figures, than by means of actual weekly wages. We therefore give a table below based on this principle, wages in the various inclustries in the five years from 1898 to 1902 being taken as standard, and the average for other quinquennial periods calculated as a proportion of that wage. 
Index Numbers of Money Wages in various Occupations 1

\begin{tabular}{|c|c|c|c|c|c|c|c|c|c|c|}
\hline $\begin{array}{l}\text { Quinquennial } \\
\text { Period. }\end{array}$ & 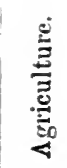 & 缡 & 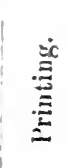 & 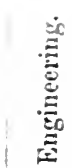 & 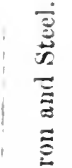 & $\stackrel{\Xi}{\Xi}$ & $\frac{\dot{0}}{3}$ & 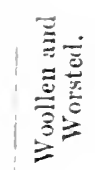 & $\stackrel{\stackrel{D}{\vec{J}}}{\vec{U}}$ & 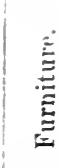 \\
\hline $1848-1852$. & 65 & 59 & \$1 & 69 & 93 & 10 & 55 & 71 & 67 & 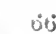 \\
\hline $1853-185 \%^{\circ}$ & 75 & 63 & 81 & 75 & 61 & 64 & 59 & 74 & 68 & 68 \\
\hline $1858-1862$. & 77 & 68 & 81 & 74 & 65 & 67 & 67 & 82 & 70 & 71 \\
\hline $1868-1867$ & 80 & 71 & 81 & 77 & 70 & 72 & 73 & 90 & 73 & 77 \\
\hline $1868-1872$ & 85 & 77 & 84 & 9 & 7. & 72 & 79 & 98 & 79 & 81 \\
\hline $1873-1877$ & 95 & 87 & 91 & 87 & 82 & 90 & 85 & 113 & s7 & 91 \\
\hline $1878-188 \%$ & 94 & 88 & 94 & 86 & 78 & 70 & 84 & 101 & 87 & 92 \\
\hline $1883-1887$ & 92 & SS & 94 & 86 & so & 72 & Ss & 95 & 87 & 91 \\
\hline $1888-1892$ & 92 & 90 & 96 & 91 & $\$ 2$ & 88 & 90 & 95 & 94 & 93 \\
\hline $1893-1897$. & 94 & 95 & 99 & 93 & 90 & 84 & 95 & 97 & 97 & 95 \\
\hline 1898-1902. & 100 & 100 & 100 & 100 & 100 & 100 & 100 & 100 & 100 & 100 \\
\hline $1903-1907$. & 103 & 101 & 102 & 100 & 103 & 95 & 105 & 106 & 102 & 100 \\
\hline
\end{tabular}

If we allow for each of these groups an importance in proportion to the numbers engaged in them, and take a weighted average, we find that wages have risen in aecordance with the following general index number:-

\begin{tabular}{|c|c|c|c|c|c|c|c|}
\hline $1818-1552$ & . & . & & 67 & $1878-1882$ & . & . \\
\hline $1853-1857$ & . & . & . & 69 & $18 \$ 3-1 \$ 87$ & . & • \\
\hline $185 S-1862$ & . & • & & 72 & $18 s 8-1892$ & . & . \\
\hline $1863-1867$ & . & & . & 76 & $1893-1897$ & . & . \\
\hline $1868-1872$ & . & • & . & 81 & $1898-1302$ & • & • \\
\hline $1873-1877$ & . & • & . & 21 & $1903-1907$ & . & . \\
\hline
\end{tabular}

Now, if we compare this general figure with each of the preceding groups, we can at once see which trades have offered a greater and which a less attraction to labour. On the whole wages have risen less rapidly than the average in agriculture, in the woollen and worsted industries, and in printing. Iron and steel workers' and miners' wages on the other hand have risen, especially during the latter quarter of the century, at at considerably more rapid rate than the average. These industries have had difficulty in securing adequate labour, and as both of them are highly capitalized, the threat of a strike is a more potent weapon than in some other cases. The general conditions of these trades have in fact thrown

'The Index Numbers for agricnlture are taken from Mr. Wilson Fox's report; those for the bulluing trades, printing, engineering, iron and steel and mining are based on statistics collected by Mr. Bowley. and sapplemented where uecessary by Boand of Trade figures. The Index Number for cottwin, woollen, gas and furniture trades are mainly based on Mr. Wood's investigntion published in the statistical Journal for 1909 . 
the advantage in bargaining on to the side of the workmen. It is often quite impossible to replace the staff of a blast furnace, for example, at a moment's notice from the surplus labour in an iron manufacturing town; and as the closing down of a furnace means that a great deal of capital lies idle, that considerable expense must be incurred before the furnace can be set to work again, and that even at the moment vigorous steps must be taken to damp down the furnace before irreparable damage is done, ironmasters are always very anxious to avoid a sudden strike. At the end of 1897 the men demanded that the two twelve-hour shift system should be abolished, and a three eight-hour system introduced. To this the masters consented on condition that the rate of wages was not increased. Statistics of earnings on the north-east coast hence show a sudden drop of two-thirds in 1898 compared with 1897 ; but within less than ten years the men, at all events in the upper grades, recovered the lost ground, so that their earnings were as great for eight hours' work as they had formerly been for twelve. Wages in the cotton trade have also risen much faster than the average.

It has sometimes been objected that such figures as those given above only apply to staple industries, and cases can undoubtedly be found where the rise of wages has been considerably less rapid than that here indicated. An investigation, however, by Mr. Wood ${ }^{1}$ shows that in the case of women engaged in industry, at all events, the rise has been almost as great, and in some cases greater than that in the case of men. Nearly two millions of the remaining occupied women are in domestic service, and in their case it is notorious that wages have risen rapidly. ${ }^{2}$ An inspection

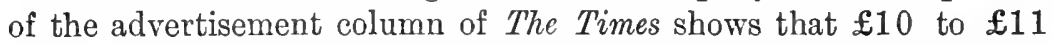
was a common wage for general servants and housemaids in the 'fifties in London. $\mathfrak{E 2 0}$ a year is the modern equivalent for the corresponding type of household to-day.

The great class of commercial clerks and railway servants are excluded from the above table, as no statistics for either of these groups are yet available.

We may complete this review of money wages by quoting such results of the recent Board of Trade Wages Inquiry as have been published up to the present time in comparison with similar figures collected in 1886 .

'See Mr. Wood's appendix on Women's Wages in Hutchins and Harrison's History of Factory Legislation.

"See also article on "Wages of Domestic Servants in the last Fifty Years" by Mr. Layton in the Statistical Jourial, 1908. 
Average Earnings of Adult Men in a Full Week

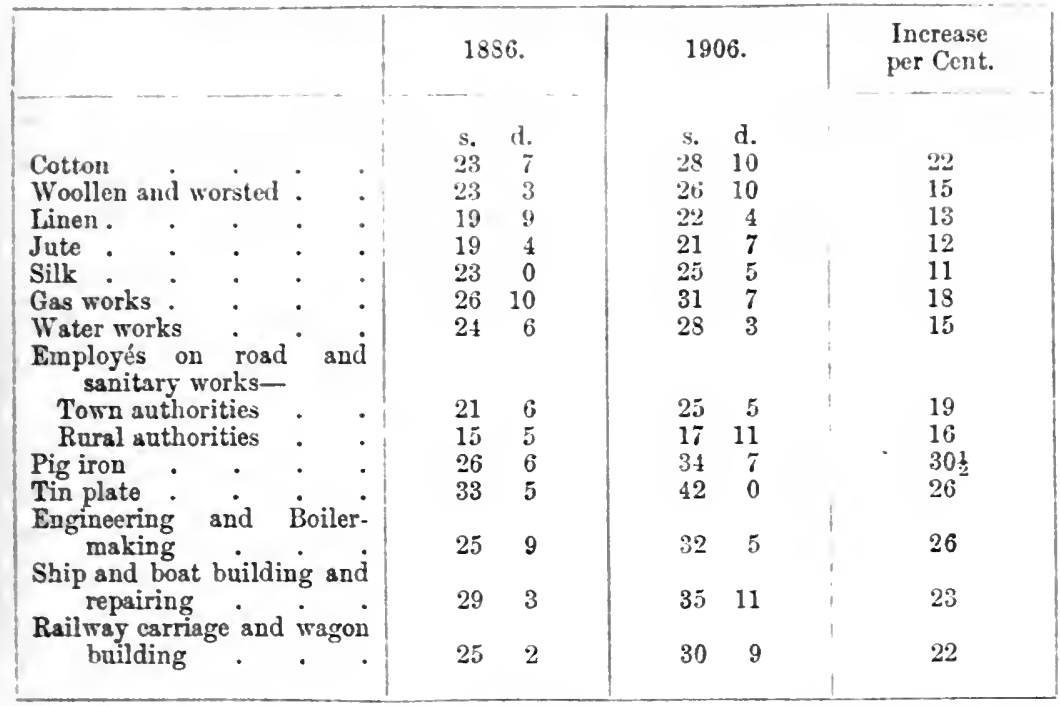

In the same period it is estimated by the Board that rates of wages in the building trade have increased 18 per cent.

Average Earnings of Adult Women in a Full Week

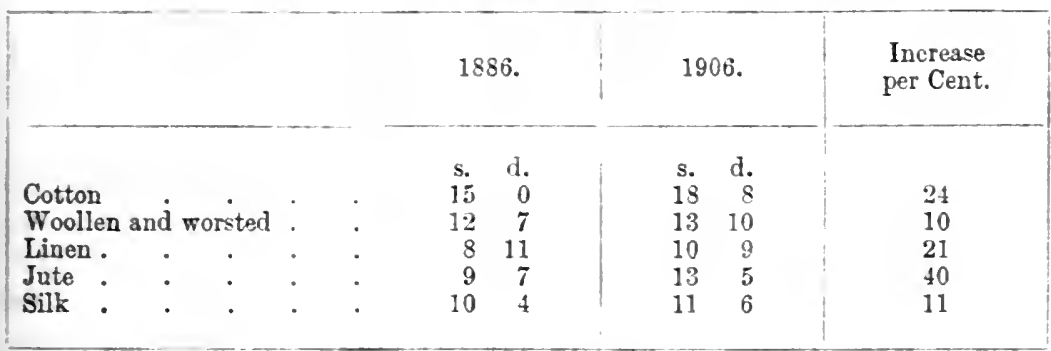

There are many points of contrast in these various groups, but they all show that the advance of wages has been maintained right up to the present time.

Turning to the second part of our inquiry, it remains to see how changes in prices have affected the material position of the working classes. Porter was chiefly concerned to show that their prosperity depended upon the cheapness of wheat, which even then was the principal article of food. He shows that in the bad years of 1795,1800 , and 1801 , there was a very marked falling off in the number of marriages registered, which he also regarded as a sign of bad times. The harvest of 1801 was moderately abundant, and as, in addition to the home produce, imports of wheat under 
the stimulus of a bounty had been very large, the price fell in the latter part of the year to less than half what it had been before the harvest. In 1802, the crops, though not very abundant, yielded enough with a small import for our wants, and prices again became moderate. The number of marriages in the years following these two good harvests, according to the registers, was 90,396 and 94,379 respectively, compared with 67,288 in 1801. A similar correlation is shown to have occurred in France and in Germany. It would, however, be unprofitable to pursue this point further into the nineteenth century, for the fluctuations in the price of wheat, at all events since the repeal of the Corn Laws, have been far too small to cause anything like the disturbance which is represented by the above figures. Moreover, wheat is now so cheap that it absorbs a much smaller proportion of the wages of the working classes than at the beginning of the century.

The history of prices in the nineteenth century since the Napoleonic wars falls easily into four periods, which are in the main related to changes in the production and consumption of gold throughout the world. Taking wholesale prices as the measure of purchasing power, we find that up to the middle of the century the general level of prices fell at the rate of a little over 1 per cent. a year, the world's production of gold being $£ 5,140,000$ a year. In the period from 1850 to 1873 (i.e. the period following the great gold discoveries in California and Australia), prices rose at the rate of about $: 35$ per cent. a year, gold production rising to $£ 25,000,000$ a year. In the twenty years or so following 1873, gold production fell off, while the demand for it increased owing to the adoption of the gold standard by many leading commercial countries. The annual production of the precious metal fell to $£ 24,500,000$, while prices fell away by about 1.61 per cent. a year. From 1896 to 1905 the average annual output was about $£ 58,100,000$ a year, and prices rose about 1.85 per cent. each year. This division into periods may be shown tabularly thus:-

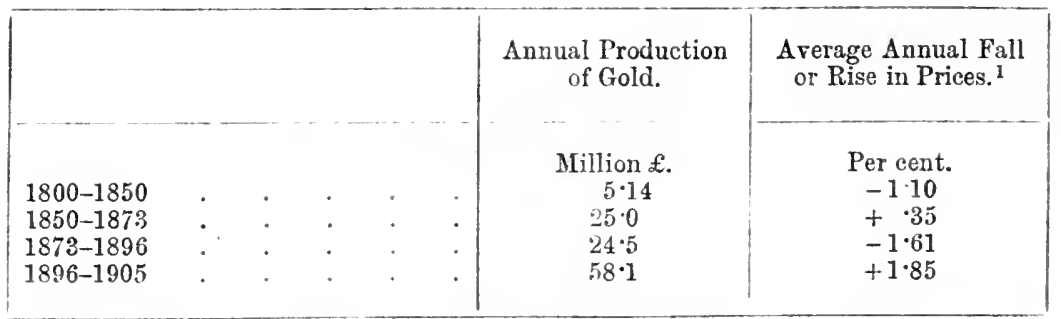

1 This column is based on the price index numbers of Jevons and of The Economist. 
These figures are put in this way in order to show how great an interest consumers have in the world's output of gold. But price changes are, of course, by no means so uniform as the table implies. The actual index numbers, based on wholesale prices, show violent fluctuations between boom years and depression, the percentage figures being arrived at by comparing the level at the beginning and end of each period-averaging the change over the intervening years.

In the first of the periods to which we have referred, the worker secured a very slight advantage by reascn of the fall in prices, for the stringent Corn Law prevented the price of bread from falling with other commodities. In the second period the gold discoveries affected prejudicially the position of the receiver of a fixed income, but the stimulus to trade and the improvements in the methods of production which were then being made caused wages to increase far more rapidly. In the third period the wage-earner benefited from falling prices as well as from rising wages, while in the last decade or so there has been a halt in conditions, owing to the upward tendency of prices at a time when wages are not rising as fast as hitherto.

Two comments must, however, be made on this generalisation. In the first place rent is not taken into account. As is well known, the increase in house rent for many years tended to offset the fall in commodity prices; but the extraordinary development of transport in the last two decades has reliered the congestion of our large towns, and rents have, therefore, tended downwards rather than upward. The accommodation bas incomparably improved, and though rates are hirh on account of the many activities of municipal bodies, there is every reason to believe that the artisan of to-day not only gets the benefit of more healthy surroundings, but also that in respect of the actual housing he gets better value for his money. The other point is that, so long as prices steadily fell, the margin available after the necessaries of life had been paid for tended steadily to increase. The expenditure of this surplus is nainly on manufactured articles, which have chempened during the ceutury far more rapidly than food prices. The working classes have thus to an increasing extent shared in the benefits of industrial advance.

The combined result of money wage and price changes is summarised by Mr. Bowley in the following table, which gives at a glance the bistory of working class prosperity:- 


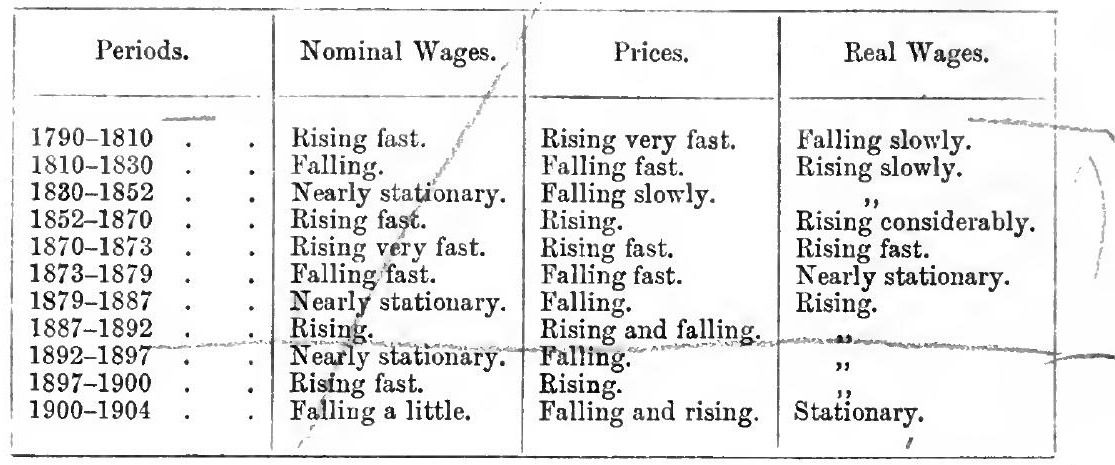

We cannot leave this question of real wages without referring to the shortening of the average working day - a fact which has given the worker leisure to enjoy the advantages which higher wages have brought within his reach.

So far we have-been considering money wages and their purchasing power. But a high rate of wages is of little use if employment is discontinuous. The phenomenon of unemployment is specially noticeable in the nineteenth century, for it naturally arises where conditions of industry are rapidly changing, where labour is mobile and where the term of employment is only for short periods. All these conditions are fulfilled in the economic organization which has arisen in England since the Industrial Revolution. The discontinuity of employment is a feature which drew Porter's attention, and he devotes some pages to pointing out the advantages of constant and regular work. It may be taken from the writings of contemporary observers that during the early nineteenth century this evil reached its maximum. The causes of fluctuations of trade and industry were but little understood, while female and boy labour completely disorganized a labour market which was already overstocked by the increase in the population. But industry began to settle down in the middle of the century, and since then the amount of labour unemployed seems to have been reduced to a fairly constant factor.

This conclusion, which is based on the returns of Trade Unions paying unemployment benefit, is, however, founded on a comparatively slender basis, for the Trade Union figures in the earlier years are based on only one or two Union records (see Second Fiscal Blue Book). Even in later years they give undue prominence to certain industries from which records are readily obtainable-the Unions represented being determined by the more or less accidental condition of paying 
or not paying out-of-work benefit. In any case, the figures have no bearing whatsoever on agricultural employment and all the unorganized trades of the country. The figures are, however, capable of showing a general conclusion-limited, of course, in its application to the particular industries or branches of industry included. Within these limits the returns show that no permanent change has taken place in the stability of employment. The figures are arranged in quinquennial periods in the following table :-

\section{Percentage of Unionists Unemployed}

\begin{tabular}{|c|c|c|c|c|c|c|}
\hline 1850-1852. & . & . & . & \multicolumn{2}{|c|}{$4^{\cdot} 6$ per cent. } & \multirow{5}{*}{$\begin{array}{l}\text { Average } \\
5 \text { per cent. }\end{array}$} \\
\hline $1853-1857$. & - & . & . & $4 \cdot 2$ & , & \\
\hline 1858-1862. & . & - & - & $7 \cdot 8$ & , & \\
\hline 1863-1867. & . & . & . & $4 \cdot 4$ & ," & \\
\hline 1868-1872. & . & . & . & $4 \cdot 2$ & , & \\
\hline $1873-1877$. & . & . & . & $2 \cdot 7$ & , & \\
\hline 1878-1892. & . & . & . & $5 \cdot 9$ & ," & \\
\hline 1883-1887. & . & . & - & $7 \cdot 6$ & ", & \\
\hline 1888-1892. & . & . & . & $3 \cdot 8$ & ; & Average \\
\hline $1893-1897$. & . & . & . & $5 \cdot 4$ & & \\
\hline 1S98-1902. & . & . & . & $3 \cdot 3$ & ,: & \\
\hline $903-1907$. & . & . & & $6 \cdot 3$ &, & \\
\hline
\end{tabular}

The conclusion which emerges from this table is borne out by an inspection of the detailed figures. It is thus evident, if these figures may be trusted, that the popular opinion that unemployment is on the increase, is, at any rate, not true of the organized trades. It is also certainly not a factor of importance in the case of government, municipal, railway, or domestic service, all of which are occupations that absorb an increasing number of the population; and although in the case of commercial occupations we are on quite speculative ground, it is very questionable whether commercial clerks, retail shop-keepers, and other small income earners, are receiving less regular incomes than was the case fifty years ago. But there is an important exception to this view in the case of the unskilled labourer and the casual. Here it must be admitted that our data are so imperfect as to be practically useless, and the assertion that unemployment among casuals has increased cannot be met by statistical arguments. The unemployed of the lowest grade have certainly become very articulate of recent years, but the amount of public attention attracted may be a sign rather of an increasing sense of social responsibility than of increasing unemployment. The only figures which touch the question in the least are just sufficient to show that for two or three years, in London at all events, the amount of unemployment among this class as represented by the 
number of applications to Distress Committees varies in very much the same way and to much the same extent as the Trade Union unemployment figures. The two sets of figures are as follows, being taken from Mr. Johm Burns's recent blue book of social statistics: ${ }^{1}$

\begin{tabular}{|c|c|c|c|c|}
\hline & $1905-1906$. & $1906-1907$. & $1907-1908$. & $\begin{array}{c}1908-1909 \\
\text { (to 6th March). }\end{array}$ \\
\hline $\begin{array}{c}\text { Applications to Distress } \\
\text { Committees in London }\end{array}$ & 39,728 & 28,181 & 32,624 & 48,532 \\
\hline \hline $\begin{array}{c}\text { Percentage of trade unionists } \\
\text { in London returned as } \\
\text { unemployed }\end{array}$ & 1905. & 1906. & 1907. & 1908. \\
\hline
\end{tabular}

The table indicates that the state of employment among organized workers influences much more than is popularly supposed the demand for labour among casual and unskilled workers. They show, in fact, that the curves of unemployment in the two grades move up and down together.

The Socialist writer, Frederick Engels, whose book on the condition of the English working classes in 1844 is one of the most scathing denunciations of social injustice that has ever been penned, was constrained to admit in 1880 that the liberation of industry and commerce had brought with it a great amelioration in the lot of the working classes. His theory, that the degradation would deepen until, in despair, the working classes would rise up and overthrow the capitalist state, was not altogether unwarranted at a time when the severity of the new Poor Law was driving men in thousands into the Chartist movement, and when the utmost efforts of a great national movement were required to secure the abolition of the hated Corn Law. His thesis was for the time disproved by the rapid growth of national wealth during the 'fifties, 'sixties, and early 'seventies. But the depression of the later 'seventies seemed to Engels the beginning of the end. Agriculture was in a bad way; England was for the first time beginning to feel the effect of foreign competition, and several strikes for an advance in wages ended disastrously for Trade Unionists. Crisis after crisis, he said,

${ }^{1}$ Publie Health and Social Conditions in the last Half.Century. 
will lead to one long drawn out depression, from which the only way of escape will be by the nationalization of the means of production. But Engels has been falsified by events. The means of production have continued to improve, and with that advance the material welfare of the working classes has been continuously strengthened right to the very end of the nineteenth century. Some of the ways in which this advance has revealed itself are discussed in the following chapter.

But in the first decade of the twentieth century there has arisen a widespread feeling of discontent both at home and abroad among the members of the working classes, the causes of which are partly social and political and partly economic. To discuss all aspects of this "labour unrest" would carry us very far afield, but the economic factors which have contributed to this result may here be briefly referred to.

The crux of the situation is in the word "stationary" which appears at the bottom of Mr. Bowley's summary of "Real Wages" given on page 56 . This remark represents the condition of the working classes between 1900 and 1904, and if Mr. Bowley had carried his table to 1911 he would probably have written "slightly falling"-at all events for the perion between 1907 and 1911 . The enormous additions to the world's stock of gold which have been made since 189 o, together with the corresponding increases which have been made to the credit currencies of many nations, has added greatly to the money power of bankers and speculators in the industrial and commercial communities in England, America, Germany, and elsewhere. As this currency expansion has coincided with a wider diffusion of manufacturing enterprise in various parts of the world, the effective demand for raw materials has increased much faster than the world's available supply and therefore driven up prices, while the increasing demand of the industrial population for food products has produced a smaller but quite substantial advance in the price of food. Hence the European drought of 1911, coming at a time when the world's resources were being taxed to meet the demand, sent up the prices of certain conmodities 50 to 100 yer cent. This last movement is a temporary phenomenon, which will, of course, be rectified by a few good harvests; but the underlying tendency has produced and will continue to produce discontent so long as wages do not respond quickly and promptly to the rise in the cost of living.

In a certain number of industries where the workers are organized, or where wages are promptly readjusted whenever prices, 
output, or profits increase, wages have risen quickly. In the cotton trade, for example, average earnings have risen very largely on account of the steady improvement in the quantity and quality of the output per head, while adjustments of wages have been made with comparatively few stoppages of work, thanks to the effective organization of both employés and employed. But in many scattered or unorganized trades and in employments paid on a time wage basis (very often a round sum, such as $£ 1$ or $£ 110$ s. a week) wages do not readily rise with either wholesale or retail prices, and therefore real wages fall. Practically all workers in transport industries - in which the unrest has been most marked-come under this category. The difficulty of organization or effective bargaining in such scattered occupations produces a feeling of impotence, which causes a reaction either in favour of strong political measures or of a combined movement on the part of the whole working class. The general feeling of dissatisfaction is undoubtedly increased by the fact that this halt in real wages has occurred when signs of great wealth are extravagantly displayed on every hand. It is true that there is to-day a movement from the lower to the artisan and middle classes, while the educational ladder enables many of the rising generation to enter upon life at a higher stage than their parents. But for the mass of the working classes whose place in life is settled, a rise of prices means that they cease to share in the growing wealth of the community as a whole.

The remedy for this grievance is in the establishment of machinery for the more prompt adjustment of wages to changes in the level of prices and in the more general recognition of the slaim to higher wages. In both these respects students of labour troubles in Great Britain during the year 1911 may find grounds for hope and satisfaction. 


\section{CHAPTER IV}

\section{PAUPERISM}

Historical-The Poor Law before 1834-The now Poor Law of 1834-Methods of relief-Classificstion-Movement of pauperism-The Unemployed Workmen ActCost of relief-Medical relief-The aged-Urban and rural pauperism-ChildrenVagrancy-Scotland-Ireland

Yo early as 1388, an Act was passed, providing "that a con$D$ venient sum shall be paid and distributed yearly out of the fruits and profits of the several churches, by those who shall have the said churches in proper use, and by their successors, to the poor parishioners in aid of their living and sustenance for ever." Until the era of the Reformation, when so many richly endowed religious establishments were seized by the Crown and appropriated to secular uses, the poor had generally found in them a source of relief for their distresses. Nevertheless, by the Act of Henry vil, the officers of the towns are directed to collect alms for the purpose of keeping "sturdy vagabonds and valiant beggars" to continual labour. This Act further directs "every preacher, parson, vicar and curate, to exhort, move, stir and provoke people to be liberal for the relief of the impotent, and for keeping and setting to work the said sturdy vagabonds." By another clause it was provided that "a sturdy beggar is to be whipped for the first offence, his right ear cropped for the second; and, if he again offend, to be sent to the next jail until quarter sessions, there to be indicted for wandering, loitering, and idleness; and, if convicted, shall suffer execution as a felon and enemy of the commonwealth."

The inundation of mendicancy which appears at this time to have overspread the country had in all probability chiefly originated out of the first great breaking-up of the feudal system, by the permission given in the preceding reign to the great landed proprietors to dispose of their estates-a change which speedily occasioned the dispersion of all those numerous bands of retainers which used to be fed by every lord of the soil. This state of things could 
not but be aggravated by the subversion of the great religious establishments in 1539, from which time, until the close of the reign of Elizabeth, many statutes were passed relative to vagrancy and mendicity.

It is to the Act 43rd of Elizabeth that we owe the system which until the last century provided in England and Wales for the compulsory maintenance of the poor. That the system then introduced has since been greatly abused and applied to purposes which did not enter into the contemplation of the Legislature of that day, caunot be doubted. The chief provisions of the Act of Elizabeth gave to the Overseers of the Poor power to levy upon the inhabitants of their respective parishes "such sums as should be necessary to support the aged and infirm parishioners, and for setting to work all persons using no ordinary and daily trade of life to get their living by."

Unhappily, as the 1834 Commissioners stated, "the fund which Elizabeth 43 directed to be employed in setting to work children and persons capable of labour, but using no daily trade, and in the necessary relief of the impotent, is applied to purposes opposed to the letter and still more to the spirit of that law, and destructive to the morals of the most numerous class and to the welfare of all." It was not, however, until a long time after the passing of the Act that these disastrous effects arose, themselves largely due to the infamous Act of Settlement of 1662 and the Allowance system that was developed under the Georges. In 1775 the amount raised for Poor Rate and County rose to $£ 1,700,000$ from the average of the preceding quarter of a century which had been $£ 730,000$; and of this sum rather more than a million and a half was expended for the relief of the poor. The war of American Independence, followed by the Napoleonic wars, aggravated the distresses of the poor, and the rates were in a state of continued progression. Even after the peace they did not decline. In 1807 the sum expended

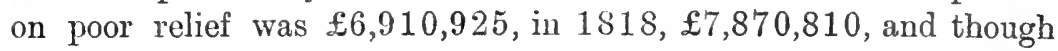
the actual amount expended declined to $£ 5,786,989$ in 1825 , it was again $£ 7,036,968$ in 1832 . Moreover, whereas the first period was one of exceptional distress, marked by high prices (wheat was $94 \mathrm{~s}$. a quarter in $1817,83 \mathrm{~s}$. 8d. in 1818) and low wages, by 1831-1832 the price of corn had fallen by a third (it was $58 \mathrm{~s}$. a quarter in 1832) and that of clothes and other necessities in still greater proportion. Population meantime had increased by a fifth. The real amount of relief given in 1832 was greater, in proportion to population, than that given in 1818 , and much greater than any 
year since 1818. Over and above this vast recorded expenditure, which showed no symptoms of deeline, but was rapidly ruining the landlords and erushing the ratepayers under intolerable burdens, was the vast unrecorded loss involved in the wholesale deterioration of the labouring classes.

It was this state of things that led to the appointment of the Royal Commission in 1832, whose Report, published in 1834, was speedily passed into law. In the view of the Commissioners the great souree of the abuses that they noted as "steadily and rapidly progressive" was the system of out-relief of the able-bodied.

One of the greatest evils was the practice of paying the wages of labour partly out of rates levied for the relief of the indigent poor. "Under such a system a labourer in an agrieultural district was inevitably rendered a pauper; he was deprived of all means of exereising the virtue of prudenee, and became almost necessarily improvident while he was brought to look upon the parish allowance as his freehold. Payment for labour, awarded not according to the value of serviees performed but with referenee to the numbers of a family to be maintained, was kept down to the lowest level at which nature could be sustained, and at seasons when it no longer suited the farmer to give employment the whole labouring part of the rural population might be, and often was, thrown for subsistence upon the parish rates. Wages and efficiency were thus reduced to a minimum, labour was progressively casualized, and the labourer, removed alike from moral restraint and moral stimulus, was a slave in all but name. Those who harl, by virtue and prudence, saved anything, found employment refused them until they were redueed to the level of pauperism."

\section{Table I.-Cost of Poor Lau Reliej}

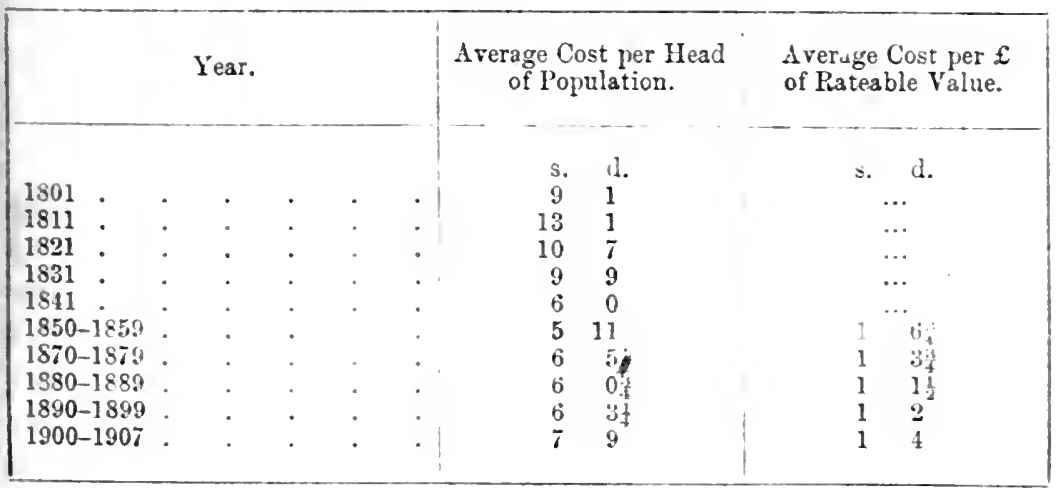


To this deterioration of the labouring class by subsidized employment the attention of the Commissioners was principally directed in their Report, which was in the main the work of two among them, Nassau William Senior, an orthodox economist, and Edwin Chadwick, a pupil of Bentham. It is dominated by two main ideas : (1) That relief should not be offered to able-bodied persons and their families otherwise than in a well-regulated workhouse; (2) that

TABLE II.-Grouth of Poor Law Expenditure, relative to growth of (a) Rateable Value, (b) Population

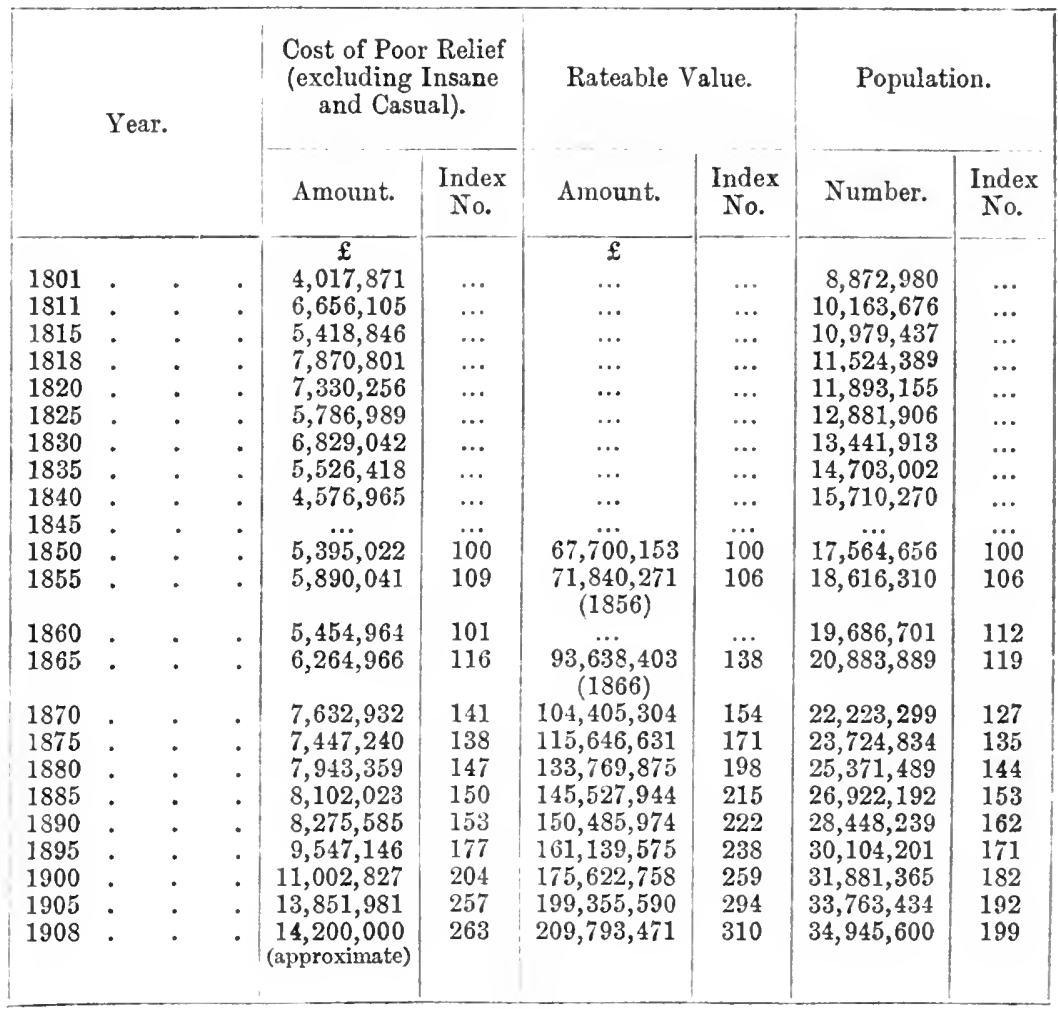

the lot of the pauper should be made less eligible than that of the independent labourer. By the application of these principles an immense reform was almost immediately effected. At the time there was a great outcry in the country and especially in the Press. The great authority of The Times appealed against the "Pinch-Pauper Triumvirate," as the three Commissioners were called. But the Government was supported by the middle classes, who were being 
ruined by excessive rates, and by the more intelligent and better organized workmen. Men like Francis Place saw clearly enough that labour as a whole could only suffer from the progressive pauperization going on. There seems reason to believe that after the immediate effects had passed away, little real hardship resulted from the application of the new policy of strictness. Writing in 1847, Porter says: "The power steadily enforced upon all occasions of refusing relief to the able-bodied, except within the workhouses, has had an effect for the extent of which it is difficult fully to account in converting the idle to habits of industry, and by that means increasing the demand for labour, since employers can now rely upon obtaining its value for the money which they so disburse." And he goes on to quote a certain Mr. Woolley, formerly a land-agent, afterwards an assistant commissioner for the commutation of tithes, as saying: "I am fully convinced that the measure has doubled the value of property in-many parts of the kingdom. .. . This is important; but pounds, shillings and pence will not measure the value of the change in character which is already visible, and which, I am well convinced, will develop itself more and more."

The decline in the amount and cost of poor relief was striking evidence of the success of the new policy. Expenditure, which had been $£ 7,330,256$ in 1820 , $66,829,042$ in 1830 , fell to

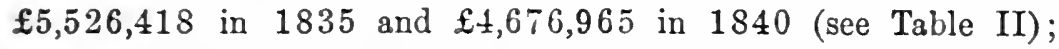
and per head of population from $13 \mathrm{~s} .1 \mathrm{~d}$. in $1811,10 \mathrm{~s} .7 \mathrm{~d}$. in 1821 , and $9 \mathrm{~s} .9 \mathrm{~d}$. in 1831 , it fell to $6 \mathrm{~s}$. in 1841 and $5 \mathrm{~s} .11 \mathrm{~d}$. in 1850-1859 (see Table II).

Constitution of Relieving Authorities.-The Act of 1834 effected a complete change, not only in the actual constitution of the local relieving authorities but by the introduction of the principle of a strong central control. In the first instance the Commissioners constituted themselves the central authority for carrying their recommendations into effect. For this purpose the whole field of inquiry was divided into districts, and a special Commissioner assigned to each to investigate its conditions and submit a report upon them. The Commissioners were at first appointed for five years only, but their term was subsequently extended in 1847. Within the framework of the existing law they were empowered to lay down general rules of administration. In 1847 their functions of control and supervision were (with little change of personnel) assigned to a Central Poor Law Board, with a president entitled to sit in Parliament. This connexion 
with Parliament became more definite still in 1871, when the new Local Government Board took over the supervision of the local relieving authorities through its Poor Law Department. This power is exercised positively by the issue of orders and circulars regulating general policy; negatively through its inspectors, the audit of local expenditure by its officers, and the holding of inquiries in case of any sort of abuse. But the actual administration of relief belongs to the local authorities. The Board may guide and restrain them and lay down general rules for them to follow: it cannot compel them to act or govern the spirit in which the letter of its instructions may be carried out. The extreme variation of size and composition of the local authorities militates against uniformity, in the absence of any code of orders and rules. The constitution of the local authority was revolutionized by the Act of 1834. A new Poor Law district, the union, was created, according to geographical and administrative convenience, to take the place of the parish. These unions vary in size (1908), from Colwyn (population 2265) and West Ham $(580,386)$. The average size in England is about 55,000. Vestries and overseers were swept away, and their place taken in each union by a Board of Guardians elected every three years by the ratepayers of the district. The J.P.'s were ex-officio members of the Boards, but they, with certain other nominated members, disappeared after the Local Government Act of 1894 made the franchise completely democratic. The guardians decide all applications for relief, administer and manage the workhouse and any other institutions within their area, out of the rates levied for the purpose. They have under their control a certain number of paid officials (relieving officers), who distribute relief and to whom application for it is, in the first instance, made; their clerk is paid (usually a solicitor), and a paid medical officer is associated with them. But the main work of administration is in the hands of the unpaid elected guardians. Popular interest in the elections is, as a rule, very small. In 1907 only 28.1 per cent. of the electorate voted, as compared with 78.3 per cent. in the parliamentary election of the previous year. There is often a dearth of really qualified persons as candidates. The absence of qualification in those who elect and are elected often prevents really efficient administration, and the danger of interested administration has, since 1894, not always been absent.

Method of Relief.-It was the avowed intention of the Commissioners, so soon as each union was provided with a workhouse, to 
abolish outdoor relief altogether in the case of the able-bodied, and establish in the workhouse a self-acting test of destitution. Had they succeeded in thus "standardizing" relief, the importance of securing trained and capable local administrators would have been much less than it is. In 1844 the Outdoor Relief Prohibitory Order was issued, representing the new policy as applied to rural unions. The absorption of surplus labour was assisted by the rapid development of industry, and especially by railway expansion. Nevertheless, the order prohibiting outdoor relief to the able-bodied was not extended to the urban unions until 1852 , and then only in a modified form, as its title, the "Outdoor Relief Regulation Order," sufficiently indicates. Edwin Chadwick himself had to

\section{TABLE III.-Comparative Grouth of Indoor and Outdoor Relief}

\begin{tabular}{|c|c|c|c|c|c|c|c|c|c|}
\hline & \multirow{2}{*}{ Year. } & & \multicolumn{2}{|c|}{$\begin{array}{c}\text { Arerage (Daily) Number } \\
\text { of Paupers (excluding } \\
\text { Casual and Insane). }\end{array}$} & \multicolumn{2}{|c|}{$\begin{array}{c}\text { Percentage of } \\
\text { Total. }\end{array}$} & \multicolumn{3}{|c|}{$\begin{array}{l}\text { Proportion per } 1000 \\
\text { of Population. }\end{array}$} \\
\hline & & & Indoor. & Outdoor. & Indoor. & Outdoor. & Indoor. & Outdoor. & Total. \\
\hline \multicolumn{10}{|c|}{ England and Wales- } \\
\hline 1850 & . & . & 114,000 & 878,000 & $11 \cdot 5$ & $88 \cdot 5$ & 6.5 & 50.0 & $56 \cdot 5$ \\
\hline 1870 & . & . & 140,778 & 838,295 & $14 \cdot 4$ & $85 \cdot 6$ & 6.4 & $37 \cdot 7$ & $44 \cdot 1$ \\
\hline 1890 & . & . & 165,603 & 530,050 & $23 \cdot 8$ & $76 \cdot 2$ & $5 \cdot 8$ & $18 \cdot 7$ & $24 \cdot 5$ \\
\hline 1908 & - & - & - 237,549 & 534,797 & $30 \cdot 8$ & $69 \cdot 2$ & $6 \cdot 8$ & $15 \cdot 3$ & $22 \cdot 1$ \\
\hline \multicolumn{10}{|c|}{ London- } \\
\hline 1850 & . & . & 24,000 & 81,000 & $22 \cdot 8$ & $77 \cdot 2$ & 10.5 & $35 \cdot 4$ & $45 \cdot 9$ \\
\hline 1870 & . & . & 33,289 & 108,184 & $23 \cdot 5$ & 76.5 & $10 \%$ & $34 \cdot 0$ & $44 \cdot 5$ \\
\hline 1890 & . & . & 51,808 & 35,554 & $57 \cdot 3$ & $42 \cdot 7$ & $12 \cdot 5$ & $9 \cdot 3$ & $21 \cdot 8$ \\
\hline 1908 & . & . & 69,853 & 46,185 & $60 \cdot 2$ & $39 \cdot 8$ & $14 \cdot 7$ & $9 \cdot 7$ & $24 \cdot 4$ \\
\hline
\end{tabular}

(From Public Health and Social Conditions.)

admit that "in a manufacturing district emergencies may arise in which the workhouse test cannot be applied." The Prohibitory Order has itself been modified by Outdoor Labour Test Orders, permitting relief to the able-bodied on the lines of the Regulation Order, i.e. provided they are kept at work. The objects of the reformers were to make independence more desirable than dependence, and to abolish subsidized employment. They held that relief in a workhouse provided the element of less eligibility in so far as it involved a form of constraint, and that out-relief should only be given where it could be used without the danger to independence inherent in the subsidized employment of the past, i.e. to the impotent. Out-relief did steadily decline in the years between 1834 and 1860 . In 1843 the proportion of adult paupers receiving 
indoor and outdoor relief was 201,927 to $1,105,972$; in 1844, 195,220 to $1,249,682$. But in $1862-1863$ it rose from $35 \cdot 3$ per thousand of population (in 1860) to $42 \cdot 8$; in $1869-1870$ it was 37.7 per thousand. In 1870 there was a vigorous crusade against it, which, assisted by the economic prosperity of the period, did reduce the numbers receiving out-relief from 881,000 to 531,000 within twenty years, without a corresponding increase in the numbers of indoor paupers. In 1901 it reached its lowest point, 15.3 per thousand. Nevertheless, at the present day outdoor relief outnumbers indoor by 2 to 1 , except in London. There are still about balf a million persons receiving it on any given day, and while in urban unions (London excluded) there were $2 \cdot 45$ outdoor to every 1 indoor pauper, in rural or mainly rural unions the proportion was 4.46 outdoor to 1 indoor in 1908 . Thus we have, even in the case of the able-bodied, to consider indoor and outdoor relief side by side.

This is due partly to the changing economic circumstances which Chadwick had to some extent realized in 1852, partly to a failure in the method established by the Commission with regard to institutional treatment itself, and partly to the fact that some of their recommendations have not yet been fully carried out. The increased complexity of industrial arrangements and the higher pressure of modern work and life have undoubtedly rendered the position of the ordinary workman less secure. Lack of physical and industrial mobility may expose even the skilled man to unemployment in the rapidly changing circumstances of the labour market of to-day. This is a "new problem." The Commissioners were not faced by it. They had to save men, by deterrence, from pauperization which was almost being forced upon them. Thus it came about that they did not make sufficient provision against the deterioration which results from unemployment, and often is, at the present day, rather aggravated than averted by the acceptance of workhouse relief. The Commissioners failed, in a word, to make provision for discriminative treatment with reference to the various causes that brought people into the workhouse. They did intend that there should be some discrimination once they were received there. Their original scheme included classification by institutions; a separate type being provided for each class of destitute person.

But the small area of the union and the practical unwillingness of the unions to combine led to the substitution of classification in institutions for classification by institutions, and in a great number of cases, to very little classification at all. In 1834 all 
workhouses corresponded to the "general mixed" type, in which old and young, unfortunate and degraded, sane and insane, sick and sound, were herded together. To this day nearly 62 per cent. of workhouses are general workhouses, and in spite of great improvements the average workhouse is a place where the ablebodied man is treated in a manner very little likely to restore him to independence, to cure or reform him. And the ineligibility which consists in undesirable company punishes only the best of those who are relieved. The workhouse is a deterrent to the decent, not to the hardened loafer or the work-shy. This in itself accounts for the preference felt for out-relief by many Boards. It is, moreover, less expensive. The cost of in-maintenance has

TABle IV.-Average Annual Cost of Indoor and Outdoor Relief

\begin{tabular}{|c|c|c|c|c|}
\hline & \multicolumn{2}{|c|}{$1856-1857}$. & \multicolumn{2}{|c|}{$1906-1907$} \\
\hline & $\begin{array}{l}\text { Cost } \\
\text { (Approxi- } \\
\text { mate). }\end{array}$ & $\begin{array}{l}\text { Cost per } \\
\text { Head of } \\
\text { Paupers. }\end{array}$ & $\begin{array}{l}\text { Cost } \\
\text { (Approxi- } \\
\text { mate). }\end{array}$ & $\begin{array}{l}\text { Cost per } \\
\text { Head of } \\
\text { Panpers. }\end{array}$ \\
\hline $\begin{array}{l}\text { Cost of relief }{ }^{2}- \\
\text { i. To psupers in institu. } \\
\text { tions } \\
\text { ii. Outdoor relief . }\end{array}$ & $\begin{array}{c}£ \\
2,039,000 \\
3,482,000\end{array}$ & $\begin{array}{rr}£ & \text { s. } \\
16 & 12 \\
4 & 13\end{array}$ & $\begin{array}{c}£ \\
7,731,000 \\
3,828,000\end{array}$ & $\begin{array}{rr}\mathfrak{f} & \text { s. } \\
29 & 5 \\
7 & 1\end{array}$ \\
\hline Total & $5,521,000$ & 67 & $11,5559,000$ & 14 \\
\hline
\end{tabular}

(From Public Health and Social Conditions, Cd. 4671.)

progressively advanced with the improvement in institutions (see Table IV). But whereas out-relief, in very skilful hands, may be a useful method of discrimination, it is too often given without that intimate knowledge of the individual case which alone ean enable it to be used restoratively. Out-relief is still often given where it is neither needed nor deserved, and, as a result, "few," according to Mr. Preston-Ihomas, "are relieved adequately." "Bad administration of outdoor relief is still," according to the 1909 Commission, "largely instrumental in creating pauperism." Nevertheless, the difficulty of applying the workhouse test, as things are, would be much greater but for the possibility of giving out-relief.

It was of course with regard to the able-bodied only that the

\footnotetext{
${ }^{1}$ Lunatic asylums not included.
} 
1834 Commissioners wished to prohibit out-relief. The outdoor labour test order permitted Boards to open stone-yards, as temporary expedients, in order to relieve men at their homes in return for a daily task. This method, and the plan of work for wages, were intended to meet periods of exceptional distress. The danger is that they tend to become permanent. Under the "sudden and urgent necessity order" relief may be given at the home; by the "modified workhouse test" relief is given to dependents in the home while the man comes into the house. The failure of all these methods is measured by the fact that in both England and Scotland able-bodied pauperism, instead of declining, is increasing in the last few years, in the urban centres.

To look for a moment at the movement of pauperism.

\section{TABLE V.-Pauperism in United Kingdom, including Insane (England, Wales, and Scotland) and Casual}

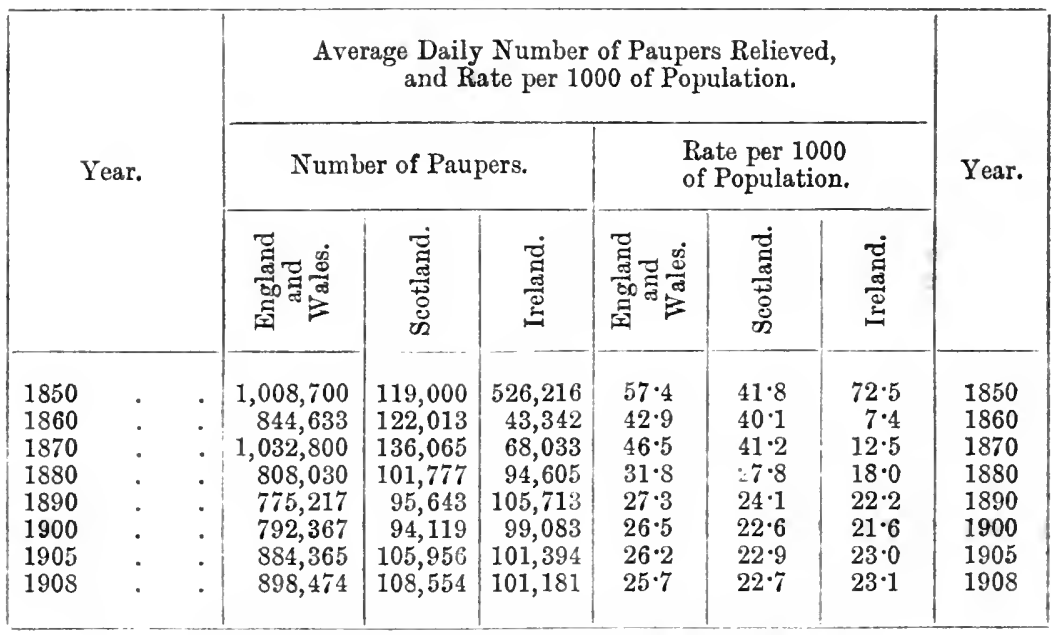

(From Public Health and Sucial Conditions, Cd. 4671.)

Movement of Pauperism. - There has been for all parts of the United Kingdom a steady decline in average daily pauperism between 1850 and 1900 : but in the last decade the rate has been rising again, as can be seen from the tables (V, VI, VII). Thus for England and Wales the rate (excluding insane and casual), which declined from 56.5 per thousand of population in 1850 to 21.7 in 1900 , rose again to 22.1 in 1908 ; while for London the rate which was 31.5 in 1860 , and 21.6 in 1900 , was 24.4 in 1908. If insane and casual be included, the rate for England 
and Wales has been slowly declining throughout the period from $57 \cdot 4$ in 1850 to $25 \cdot 7$ in 1908 .

In 1906-1907 the rate of average daily pauperism was $22 \cdot 7$ per thousand or 798,898 persons; but the whole number of persons receiving relief in the course of the year 1906-1907 was, for England and Wales, $1,709,436$ persons or 48.9 per thousand. In other words, the average rate of daily pauperism was 1 in 47 , the number relieved during the year 1 in 24 . Of the year's pauperism for $1906-1907,44.2$ per cent. are chargeable for periods amounting

TABLE VI.-Pauperism of a Year (Insane and Casual excluded)

\begin{tabular}{|c|c|c|c|c|c|}
\hline \multirow[b]{2}{*}{ Classes. } & \multicolumn{5}{|c|}{ Paupers received in the Course of a Year. } \\
\hline & $\begin{array}{l}\text { England } \\
\text { and Wales. } \\
1906-1907 .\end{array}$ & $\begin{array}{l}\text { Scotland. } \\
1906-1907 .\end{array}$ & $\begin{array}{l}\text { Ireland. } \\
1907-1908 .\end{array}$ & $\begin{array}{l}\text { United } \\
\text { Kingdom. }\end{array}$ & $\begin{array}{l}\text { Per Cent. } \\
\text { of Total } \\
\text { Pauperism. }\end{array}$ \\
\hline $\begin{array}{l}\text { (i) Permanent paupers } \\
\text { (i.e. } 6 \text { months or } \\
\text { over). } \\
\text { (ii) Occasional or tem- } \\
\text { porary paupers, } \\
\text { Total. }\end{array}$ & $\begin{array}{l}743,131 \\
966,305\end{array}$ & $\begin{array}{l}87,249 \\
60,411\end{array}$ & $\begin{array}{r}87,630 \\
131,590\end{array}$ & 918,010 & $\begin{array}{l}44 \cdot 2 \\
55 \cdot 8\end{array}$ \\
\hline $\begin{array}{l}\text { (a) Chargeable once } \\
\text { only } \\
\text { (b) Twice or oftener }\end{array}$ & $\begin{array}{l}760,935 \\
205,370\end{array}$ & $\begin{array}{r}51,14 i \\
9,264\end{array}$ & $\begin{array}{r}110,246 \\
21,314\end{array}$ & $\begin{array}{l}922,328 \\
235,978\end{array}$ & $\begin{array}{l}41 \cdot 4 \\
11 \cdot 4\end{array}$ \\
\hline Total number relieved & $1,709,436$ & 147,660 & 219,220 & $2,076,316$ & $\ldots$ \\
\hline $\begin{array}{c}\text { Rate per } 1000 \text { of } \\
\text { population }\end{array}$ & $48 \cdot 9$ & $31 \cdot 1$ & $50 \cdot 1$ & $47 \cdot 1$ & $\ldots$ \\
\hline
\end{tabular}

(From Public Health and Social Conditions, Cd. 4671. )

in the year to six months or orer, that is to say, 20.8 per thousand of the population of the United Kingdom are practically permanent paupers; $26 \%$ ler thousand apply only once for relief, and for a period of less than six months in all; 5.4 per thousand have relief more than once, though for less than six months in all. (Cf. Tables V, VI, and VII for comparative figures, over the last fifty years of English, Scoteh, and Irish pauperism.)

Thus, although pauperism steadily declined, in proportion to population, between 1850 and 1900 , there is an increase in the last decade (1897-1907). And this increase is an increase in 
able-bodied male pauperism. In 1842,38 per cent. of the population of the workhouses were able-bodied; in 1860,15 per cent.; in 1890,13 per cent.; in 1905 it rose again to 18 per cent. And these figures do not show the real gravity of the evil, for they represent England as a whole, whereas the increase has occurred wholly in London and other urban centres. This tendency cannot be wholly unconnected with administration. "It is in regard to the able-bodied," according to the 1909 Commission, "that least progress has been made. . . . Either the urban population is becoming less fitted for maintaining its independence,

\section{Table VII.-Average Daily Pauperism (excluding Casuals and Insane)}

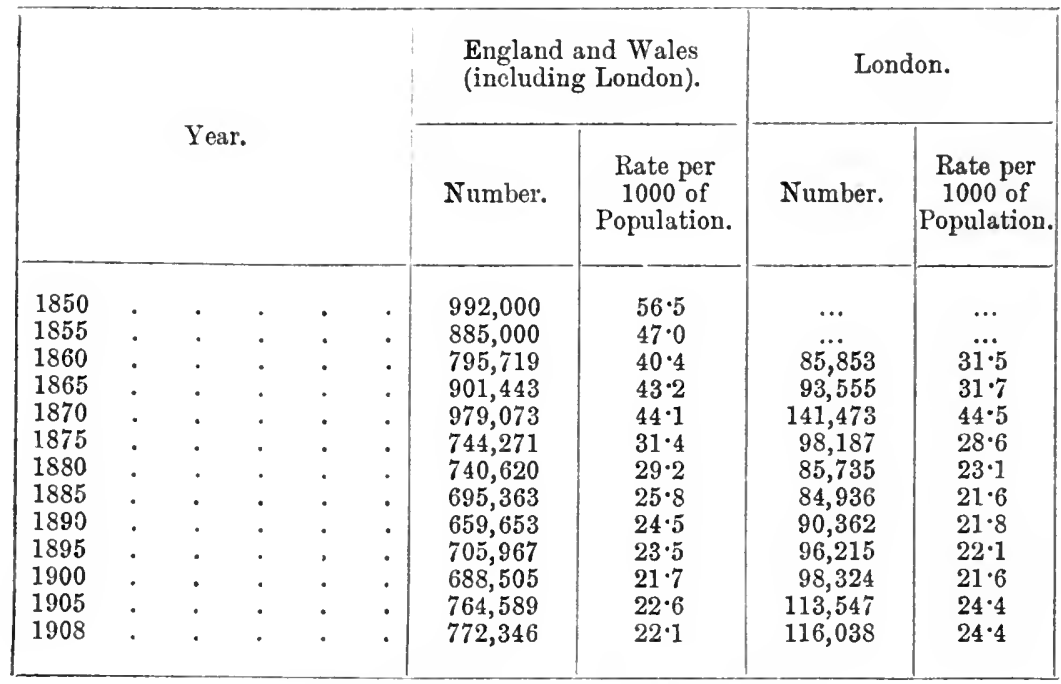

(From Public Health and Social Condition, Cd. 4671.)

or the facility with which relief may be obtained and the immunity from labour which it confers, are enticing a larger number of persons to avail themselves of Poor Law relief." The difficulty appears whether the able-bodied are compelled to go into the workhouse, to deteriorate there through idleness and bad company; whether they come in and out recurrently for short periods at a time (" it is not too much to say that this class has been created by our administration of the Poor Law, while the law itself affords no means of checking it, now that it has come into existence"), or whether they are assisted by means of the various expedients (labour yards, work for wages, etc.) devised to meet exceptional distress, but all tending to attract a class of men quite different 
from that for which they were intended. None of the expedients have proved successful in assisting the genuine workman during temporary distress. Accordingly, whereas in 1842 or in 1860 all the able-bodied relieved were relieved by the Poor Iaw, to-day the number assisted by agencies outside the Poor Law, which have arisen in consequence of the inadequacy of the Poor Law, is far greater than that applying to the Poor Law. Some of these agencies are unofficial and charitable, others have been set up by the State, e.g. The Unemployed Workmen Act of 1908 (cf. Table VIII). Thus on March 31, 1906, for example, the number of able-bodied men in health in receipt of Poor Law relief was

TABLE VIII. - The Unemployed Workmen Act. Returns for 1908-1909 (38th Annual Report, Local Government Board, Cd. 4786)

\begin{tabular}{|c|c|c|c|c|}
\hline & $\begin{array}{c}\text { London } \\
\text { (29 Distress } \\
\text { Committees). }\end{array}$ & $\begin{array}{c}\text { Outside } \\
\text { London } \\
\text { (102 Distress } \\
\text { Committees). }\end{array}$ & Total. & $\begin{array}{l}\text { Difference } \\
\text { as com- } \\
\text { pared with } \\
1907-1908 \text {. }\end{array}$ \\
\hline $\begin{array}{l}\text { Total number of applicants } \\
\text { (1908-1909) } \\
\text { Number of applicants found } \\
\text { qualified for assistance } \\
\text { under the Act- }\end{array}$ & 49,239 & 147,518 & 196,757 & $+106,700$ \\
\hline (i) Applicants & $\begin{array}{l}22,414 \\
71,276\end{array}$ & $\begin{array}{l}114,175 \\
304,767\end{array}$ & $\begin{array}{l}136,589 \\
376,043\end{array}$ & $\begin{array}{r}+81,976 \\
+225,072\end{array}$ \\
\hline $\begin{array}{l}\text { Number of applicants provided } \\
\text { with work } \\
\text { Number of persous assisted to }\end{array}$ & 16,632 & 71,558 & 88,190 & $+51,098$ \\
\hline $\begin{array}{l}\text { emigrate or migrate. } \\
\text { Expenditure }\end{array}$ & $\begin{array}{r}486 \\
£ 155,586\end{array}$ & $\begin{array}{r}1,061 \\
£ 171,893\end{array}$ & $\begin{array}{r}1,547 \\
£ 327,479\end{array}$ & $-5,295$ \\
\hline
\end{tabular}

between 13,000 and 14,000 ; while during the winter months of 1905-1906 the number of applicants to Distress Committees was 111,000 (of which only 1400 were women). Of these 52 per cent. belonged to general or casual labour, $20 \cdot 1$ per cent. to the building trade. Experience has proved that treatment under the Unemployed Workmen Act caunot be regarded as a form of discrimination: the conditions of work offered by the Distress Committees are little, if at all, superior to those provided by the Poor Law.

The social movements of the last quarter of a century, the development in all directions of humanitarian and philanthropic feeling, and the increased recognition of a more than merely individual responsibility for the existence of distress, have led to an 
immense expansion of charitable and voluntary effort in the assistance of the poor, and to an improvement in the provision made for the pauper by the Poor Law. Complete co-ordination between the different lines of effort, even a realization of Mr. Groschen's Cireular of 1868 , is yet to come; but that the administration of relief has already been affected by the movement of opinion outside is beyond doubt.

Cost of Poor Law Relief.-The expenditure on relief has in the last thirty years increased out of all proportion to numbers. In 1844 the total yearly pauperism was $1,249,682$; in 1906 it was $1,709,436$. The cost of relief in 1840 was $4 \frac{1}{2}$ millions, in 1908 (excluding insane and casual), over 14 millions, and including

TABLE IX.-Cost of London Poor

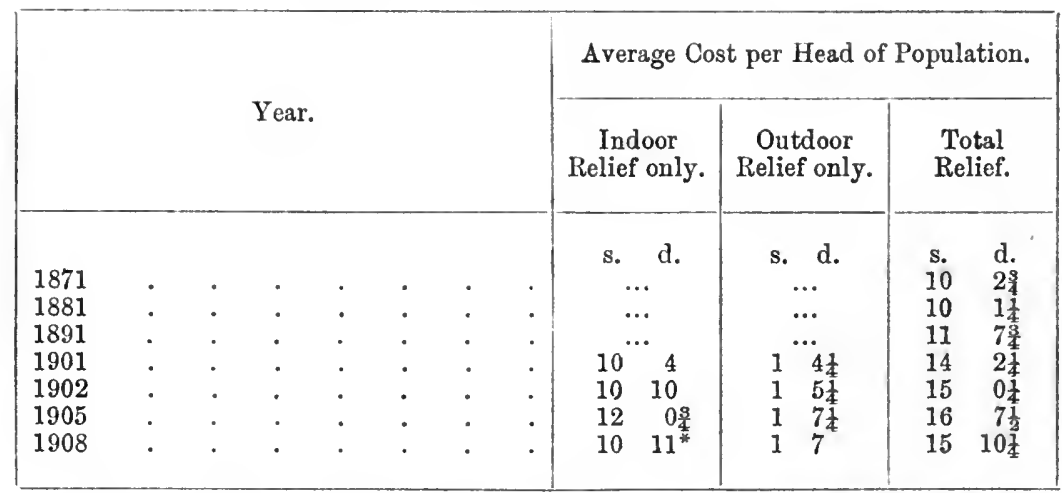

* Not including expenditure on paupers in non-Poor-Law institutions (included in previous years).

insane and casual over 17 millions-four times what it was in 1840 (see Tables II and IX). Between 1894 and 1906 the rise has been rather more rapid than the increase of rateable value and a good deal more rapid than that of population. Over the period the rate of increase of population was 15 per cent., of rateable value 28 per cent., and of poor relief 51 per cent. The rise is also seen when we consider the average at per head of population (sce Table I). This heavy burden of expenditure is no negligible maiter, especially in London, where the poorest parts are often most heavily rated.

The tendency throughout the past century has been, on the whole, to improve institutional treatment more and more, and to make the workhouse more comfortable, that is, more suitable as an asylum for the aged and infirm inmates. In so far as it is so, of 
course, and one workhouse receives all who are having relief, it ceases to be deterrent to other classes. This dilemma can only be avoided by proper classification. It is not avoided at present. Many rural workhouses offer an undeservedly harsh form of treatment to the impotent. Many urban workhouses are in no sense deterrent to the able-bodied.

Medical Relief-Thirty-one per cent. of those under the care of the guardians are so on account of some form or degree of ill-health. In no department of administration is progress more striking than in the accommodation and treatment provided for this class. Before 1834 medical relief was given out of the rates to practically the whole mass of the labouring population. After 1834 medical relief in the home was at first, and until the Act of 1867 , left almost

Table X.-Poor Law Medical Service

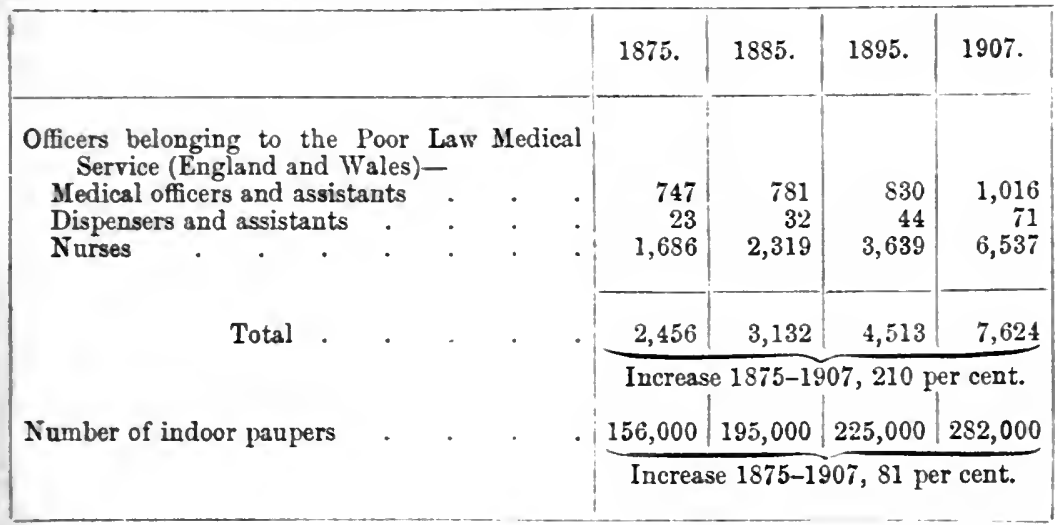

solely to voluntary agencies. In 1885 the disqualification attendant on the receipt of relief was removed in the case of medical relief, and since then the system, based almost entirely upon orders from the central authority, is one in which destitution means no more than the inability to provide whatever medical treatment is necessary. Between 1834 and 1864 little attention was paid to sick treatment indoors, although select committees inquired from time to time and reported the absence of any adequate provision. The Report issued in 1866 showed the prevalence of a state of things so unsatisfactory that action was forced upon the Legislature. Paupers did the nursing and cooking: they attended upon one another. Proper medical arrangements were wholly lacking in the smaller unions and most imperfect eren in large towns. The Metropolitan Poor Act of 1867 provided for separate 
infirmaries, apart from the workhouses, in London, and the precedent was gradually followed in most parts of the country. To-day many Poor Law infirmaries in the large towns compare favourably as to attendance and treatment with the best hospitals. The cost of medical provision has steadily risen. By 1878 it averaged $£ 37$ per bed; in $1906, £ 50$ (exclusive of loan charges). By 1880 the infirmary accommodation in London (apart from that for the infectious sick and insane poor managed by the Metropolitan Asylums Board) amounted to 9046 beds, and by 190 \% to 16,465 beds (cf. Table X).

The Aged.-The 1832 Commissioners regarded the aged, the sick and the infirm together, under the one heading as the "impotent." The practice of viewing the aged as a separate class is modern: statistics afford no indication as to the proportion of aged paupers in the earlier decades. On March 31,1906 , a census was taken which showed that the number of persons over 60 (omitting insane in asylums, etc., and vagrants) was over 379,902 , or 46.5 per cent. of the total number of persons relieved.

TABLE XI.-Age Distribution

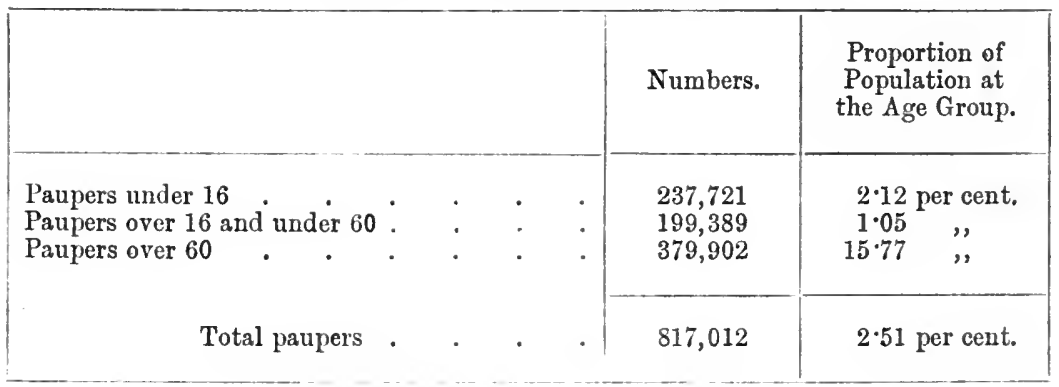

The number of nale paupers over 60 was 13.02 per cent. of the male population at those ages; that of female paupers 16.30 per cent.

The necessity and possibility of favourable discrimination in treatment as regards the aged has always been admitted and practised by most unions. The Commission of .1832 held that for the old the workhouse should be a place "where they might enjoy their indulgences without torment from the boisterous," and expressly sanctioned the giving of out-relief in their case.

With regard to old men the proportions receiving indoor and outdoor relief are about equal; but more than four aged women are relieved at home for every one relieved in an institution. Certain Boards have attempted to provide for the aged in a really humane 
manner; but much remains to be done in the way of differential treatment.

The most recent departure in this direction is the establishment by the Act of $190 \mathrm{~S}$ ( $8 \mathrm{Ed}$. III, c. 40 ) of a general system of Old Age Pensions, which confers the right to a pension up to 5 s. a week on every man and woman over 70 who satisfies the authorities that he fulfils the statutory conditions imposed by the Act. The working of the Act has already effected considerable reduction in the pauperism of the aged, especially outdoors.

Urban and Rural Pauperism.- At present the proportion of paupers over 60 is relatively higher in rural than urban districts, and there the largest class of paupers consists of old people who are practically permanent inhabitants of the workhouses, only a small proportion of whom could maintain themselves outside even on a pension. There is thus less variation between the average of daily and of yearly pauperism in rural than in urban districts.

Pauperism per Cent. of Population

\begin{tabular}{|r|c|c|c|c|c|}
\hline & London. & $\begin{array}{c}\text { Other wholly } \\
\text { Urban Unions. }\end{array}$ & $\begin{array}{c}\text { Unions 75 per } \\
\text { Cent. Urban. }\end{array}$ & $\begin{array}{c}\text { Other } \\
\text { Unions. }\end{array}$ & $\begin{array}{c}\text { Whoily } \\
\text { Rural Unions. }\end{array}$ \\
\hline $\begin{array}{r}\text { Year 1906-1907. } \\
\text { Average daily pan. } \\
\text { pers 1906-1907. }\end{array}$ & $2 \cdot 1$ & $5 \cdot 07$ & $4 \cdot 1$ & $4 \cdot 5$ & $5 \cdot 0$ \\
\hline
\end{tabular}

Thus the rate of pamperism is seen to vary for different parts of the country. Generally speaking it is lowest in urban, highest in the rural unions, "where the movement of the working sections in the towns leaves behind a mass of pauperism that bears a large proportion to the remaining population." The following are some of the lowest and highest rates per thousaud of population :-

\begin{tabular}{|c|c|c|c|c|c|c|c|c|c|c|}
\hline & & & & & & & & $190 \pi$ & 1908. & 1209. \\
\hline Lowest rates- & & & & & & & & & & \\
\hline Yorks (West & Riding & & . & . & . & . & . & $15 \cdot \tau$ & $17 \cdot 0$ & $18 \cdot \frac{1}{4}-1$ \\
\hline Lancashire & & . & . & . & . & . & . & $17 \cdot 6$ & $19 \cdot 1$ & $21 \cdot 5$ \\
\hline Westmoreland & & . & . & . & . & . & . & $19 \cdot 4$ & $19 \cdot 8$ & $20 \cdot 8$ \\
\hline Northumberla & and & . & . & . & . & . & . & $19 \cdot 5$ & $20 \cdot 6$ & $21 \cdot 0$ \\
\hline Highest rates- & & & & & & & & & & \\
\hline Oxfordshire & . & . & . & . & . & . & . & $33 \cdot 3$ & $34 \cdot 1$ & $34 \cdot 8$ \\
\hline Herefordshire & & . & & . & . & . & & $34 \cdot \pi$ & $36 \cdot 9$ & $37 \cdot 3$ \\
\hline Snffolk . & . & . & . & . & . & . & . & $36 \cdot 4$ & $35 \cdot 8$ & $37 \cdot 7$ \\
\hline Dorsetshire & . & . & . & . & . & . & & $37 \cdot 3$ & $37 \cdot 7$ & $39 \cdot 0$ \\
\hline Norfolk . & . & . & . & . & & . & & $38 \cdot 5$ & $39 \cdot 1$ & 40.0 \\
\hline
\end{tabular}


Until 1900 London's rate was below that of the rest of England and Wales: it is now above it. In London itself the rate varies from 73.1 per thousand in the Strand Union to 8.7 in Hampstead. Though the general rate of pauperism is lower in urban areas, the rate of adult male and casual pauperism is highest there. The recent increase in adult male pauperism is in fact confined to London and the urball areas; while the decrease in child pauperism has been confined almost wholly to rural areas, where enormous reductions have taken place.

Female Pauperism. - The rate of pauperism is higher among women. Taking the average daily rates, 19.8 per thousand men are paupers, 27.8 per thousand women, and 20.6 per thousand children-an average rate of 22.9 per thousand of population. In $1907,12.4$ per cent. of women in receipt of out-relief were widows.

Children under the Poor Law.-Children under 16 formed in $1908,29.4$ of the average daily pauperism. Their numbers have, however, declined considerably since 1870 .

\section{TABLE XII}

\begin{tabular}{|c|c|c|c|c|}
\hline & & Indoor. & Outdoor. & Total. \\
\hline $\begin{array}{l}1871-72 \text { to } 1879-80 \\
1880-81 \text { to } 1887-88 \\
1888-89 \text { to } 1895-96 \\
1896-97 \text { to } 1905-06\end{array}$ & 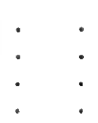 & $\begin{array}{l}47,814 \\
54,863 \\
51,002 \\
52,661\end{array}$ & $\begin{array}{l}220,765 \\
205,330 \\
184,439 \\
166,475\end{array}$ & $\begin{array}{l}268,579 \\
260,193 \\
235,441 \\
219,136\end{array}$ \\
\hline
\end{tabular}

The great decline in the number receiving outdoor relief more than counterbalances the small increase in the number in institutions.

"The History of the Poor Law in its dealings with pauper children has been one of continual improvement, and the success or failure of any system which may be adopted must depend almost entirely upon administration" (Sir William Chance).

One of the first and most urgent matters that claimed the attention of the Commissioners of 1834 was the care of the children. A Report prepared by Dr. Ray in 1836 declared "that the education provided for the children sent to the workhouses was valueless". . . they were "seminaries for the preparation of victims of the Penal Code."

After the formation of the new unions there were such improvements as was possible under the conditions of a general mixed workhouse; but elucation at the time was everywhere 
in a deplorable state. The shocking system of compulsory apprenticeship, by which pauper children were handed over to factory owners, who were compelled to take them, practically as slaves, though declining since 1802 was not abolished until the Factory Act of 1844, which also gave the unions power to establish district schools. These give an excellent education and those trained therein do well in after life. 3712 pauper children are at present being educated in them. They have, however, the defects of large institutions in which children of all ages are grouped together; and in 1896 they were strongly condemned by the Committee on the Care of Poor-Law Children.

\section{TABLE XIII.-Education of Pauper Children}

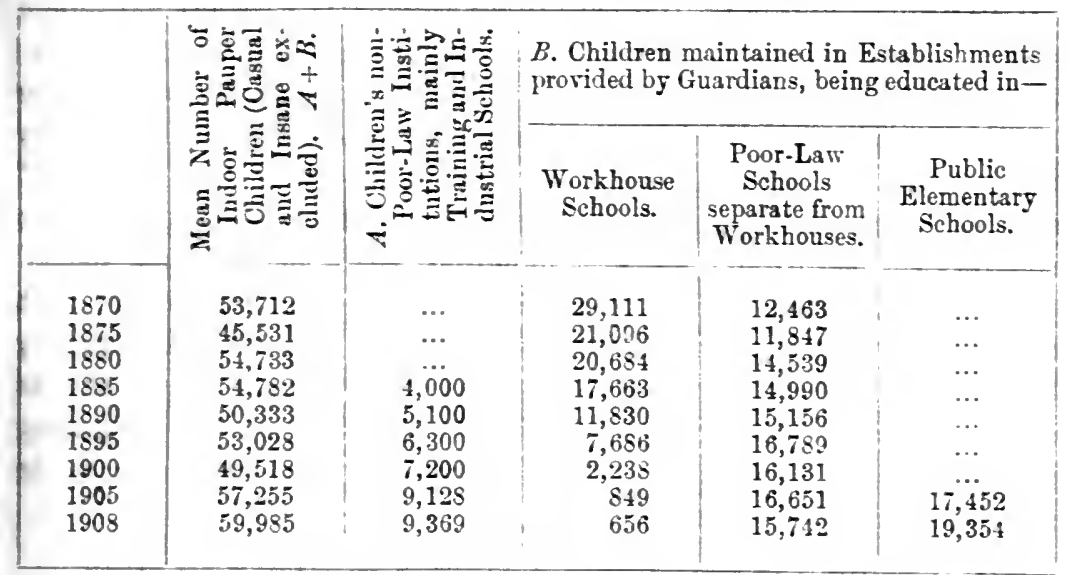

(From Public Health and Social Conditions.)

In 1861 the Royal Commission on Education reported very unfavourably on the workhouse schools; and in the next year guardians were empowered to send children to approved institutions for industrial training, or to schools for blind, deaf and dumb, etc., where suitable: shortly afterwards (1871) the first training ship for Poor-Law boys was established. In 1908, 916 boys were thus maintained on various ships. Public opiuion is now fairly unanimous that it is nothing but a misfortune for any child to grow up within the workhouse. It is highly improbable that a child thus reared will feel as an adult any disgrace in returning thither. In the case of orphans and deserted children, a Local Government Board Order in 1890 permitted the guardians to board them out with suitable foster-parents in the district, subject to 
periodical inspection; in 1889 this method was extended to children whose parents are in prison or unfit to have charge of them, and urban unions were permitted to board-out in the country. Boarding-out has, as a matter of fact, been found far more satisfactory in this case than when children are within their own union. In 1908, 8565 children were thus being brought up under the normal conditions of home life, without any stigma. In Scotland the system is universal: it must always depend for its success on efficient inspection. The grouped Cottage Homes established in 1867 have given very good results; but they are very expensive to equip and maintain.

The normal type of education for pauper children nevertheless still remains one in close connexion with the workhouse. Of the 70,991 children under the care of guardians (i.e. receiving indoor relief) 22,483 were in workhouses, infirmaries, and sick asylums; and 53,057 altogether in Poor-Law establishments of one sort or another. Of these 48 per cent. were being sent to Public Elementary Schools and 35 per cent. being educated in "separate" or "district" schools. Practically no children now receive their education within the workhouse except infants under 3 years of age and special classes of children who from infirmity, etc., cannot be dealt with elsewhere. But the 19,354 children educated in Public Elementary Schools still have the workhouse as their home, with all its disadvantages. On the other hand, difficulty is found in separating children from their parents, as is necessary if they are to be removed from the workhouse.

TABLE XIV.-Children under the care of Boards of Guardians, March 31, 1906 (England and Wales)

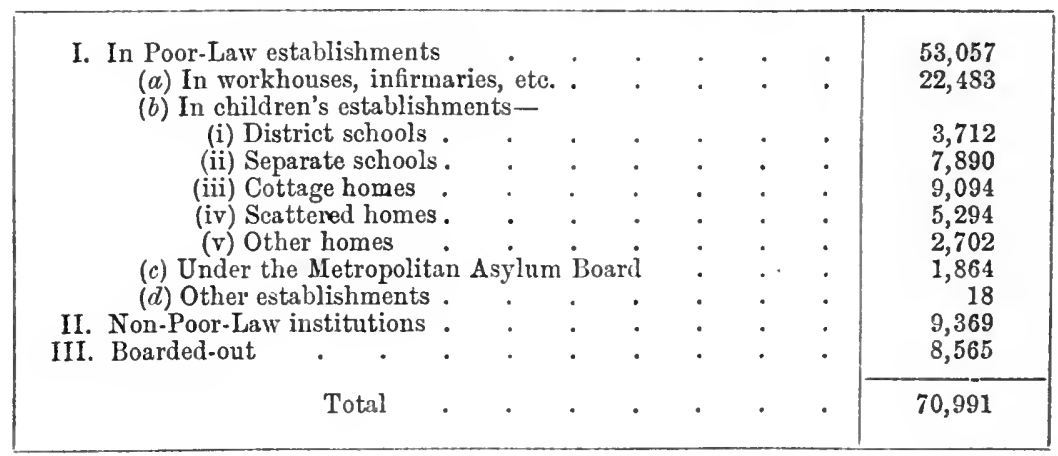

In the course of the century, then, no final system of dealing with the children has been evolved. Nevertheless, while in 1834 
not one-third of pauper children found any respectable employment, in 1908 the Commissioners declare "the evidence was almost unanimous as to the good results obtained under the various systems of training and education in force. . . Few children in after life fall back into pauperism."

If, however, the condition of these children treated by the guardians in various types of institution, though still far from perfect whether in theory or practice, does yet afford food for satisfaction, the same cannot be said of those receiving outdoor relief. Out-relief is frequently inadequate, and given where housing conditions are unsatisfactory, the children dirty, in improper surroundings and insuffieiently fed. Many of the 172,366 outrelief children are growing up under conditions too likely to lead them to pauperism in the future.

TABLE XV

\begin{tabular}{|c|c|c|c|c|}
\hline & \multicolumn{2}{|c|}{1849.} & \multicolumn{2}{|c|}{1908.} \\
\hline & $\begin{array}{l}\text { Per } 1000 \text { of } \\
\text { Population. }\end{array}$ & $\begin{array}{l}\text { Per Cent. } \\
\text { of Total } \\
\text { Paupers. }\end{array}$ & $\begin{array}{l}\text { Per } 1000 \text { of } \\
\text { Population. }\end{array}$ & $\begin{array}{l}\text { Per Cent. } \\
\text { of Total } \\
\text { Paupers. }\end{array}$ \\
\hline (a) Inssne and idiots . & $0 \cdot 9$ & $1 \cdot 1$ & $3 \cdot 2$ & $12 \cdot 1$ \\
\hline $\begin{array}{l}\text { adults. } \\
\text { (ii) Able-bodied adults } \\
\text { (ii) Children }\end{array}$ & $\begin{array}{l}22 \cdot 7 \\
13 \cdot 5 \\
25 \cdot 7\end{array}$ & $\begin{array}{l}35 \cdot 9 \\
21 \cdot 3 \\
40 \cdot 6\end{array}$ & $\begin{array}{r}12 \cdot 7 \\
3 \cdot 5 \\
6 \cdot 7\end{array}$ & $\begin{array}{l}47 \cdot 9 \\
12 \cdot 9 \\
25 \cdot 3\end{array}$ \\
\hline poor. & 0.5 & 0.8 & 0.5 & $1 \cdot 8$ \\
\hline Total & $63 \cdot 3$ & $100 \cdot 0$ & $26 \cdot 6$ & $100 \cdot 0$ \\
\hline
\end{tabular}

It must be remembered that from most of the calculations referring to the decline of average pauperism, and the tables upon which they are based, the insane and the casual pauper have been excluded. While every other class of pauperism has steadily declined since 1880 , these two have formed a striking exception. Insane and idiot poor formed in 18491.4 per cent. of total pauperism; in 1908 they accounted for 12.1 per cent. In 1849 the number of insane paupers per thousand of population was $\cdot 9$, in 1904 it was $3 \cdot 2$. Expenditure on their maintenance rose from $4 \frac{3}{4} \mathrm{~d}$. to $1 \mathrm{~s} .4 \frac{1}{2} \mathrm{~d}$. per head of population in the period 1857-1907. No doubt part of this great increase in the numbers 
of the mentally defective among the poor is due to better classifieation and the more humane treatment in segregating them from the sane which now prevails : this part of the subject, however, will be found more fully treated in the chapter dealing with feeble-mindedness in general.

Vagrancy.-The genuine vagrant is the lineal descendant of the sturdy beggar of Elizabeth's day: but not all who come under the operation of the Poor Law eonform to this type. Some part of the increase in the population of the casual wards must be set down to distress due to want of employment. Nevertheless, it is the opinion of the Poor Law Commissioners that less than 3 per cent.

TABLE XVI.-Vagrants: Day Count of January 1st and July 1st

\begin{tabular}{|c|c|c|c|c|c|c|c|}
\hline 1848. & 1860. & 1869. & 1875. & 1881. & 1889. & 1900. & 1908 (Jan.) \\
\hline 13,714 & 1,542 & 7,020 & 2,235 & 6,215 & 7,058 & 9,841 & 17,083 \\
\hline
\end{tabular}

Table XVII._Casual Paupers Relieved in England and Wales at any time during the day

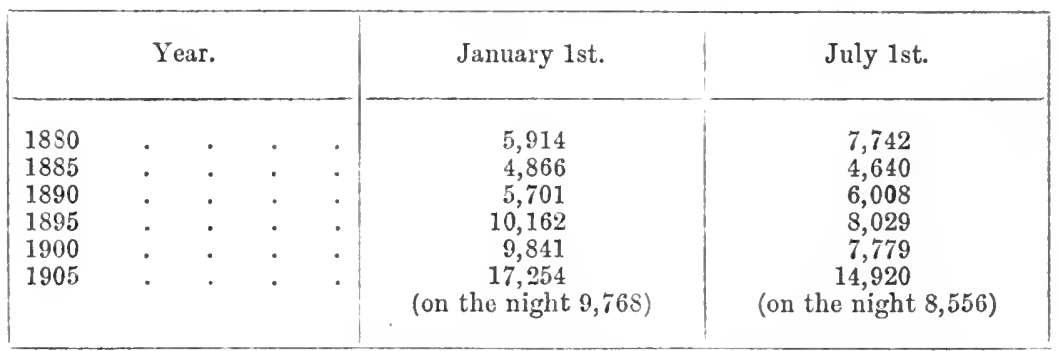

(Departmental Committee on Vagraney Report, vol. iii, Cd. 2892.)

of the total are working men, travelling in search of employment. The vast majority consists of those who do not want steady work. Some of them are willing to undertake easual labour for a short time, but incapable of continued work-the first to be dismissed when trade is slack, the last to be taken on again. Others do not want work at all. "The army of vagrants has increased of late years and there is reason to fear that it will continue to increase if things are left as they are. It is mainly composed of those who avoid any work and depend for their living on almshouses and casual wards, and for their benefit the industrious portion of the community is heavily taxed." Such is the opinion of the reeent Committee on Vagrancy, whose Report, issued in 1906, declared that the system of 
casual wards (instituted in 1865 ) as managed by the guardians was a failure mainly through want of uniformity in administration.

That there has been a steady increase in the numbers of this elass is certain : but exact figures are not easy to obtain. On the night of January 31,1858 , the number sleeping in casual wards was 2416 ; on January 31,1905 , it was 9768 . Of this latter number no less than 6143 or 70 per cent. were males between 35 and 65 .

Only about 5 per cent. of vagrants in casual wards are really discharged soldiers.

\section{TABLE XVIII.-Discharged Soldiers}

\begin{tabular}{|c|c|c|c|}
\hline Date. & $\begin{array}{c}\text { Total Number of } \\
\text { Inmates of Casual } \\
\text { Wards. }\end{array}$ & $\begin{array}{c}\text { Army Reservists, Discharged Soldiers } \\
\text { and Militiamen. }\end{array}$ \\
\cline { 3 - 5 } & $\begin{array}{c}\text { Men Substantiating } \\
\text { Claim. }\end{array}$ & $\begin{array}{c}\text { Men unable to sub- } \\
\text { stantiate Claim. }\end{array}$ \\
\hline May 8, 1896. & 8,209 & 444 & 1,540 \\
\hline
\end{tabular}

In February 1901 a return made by the authorities showed that more than one-fourth of the inmates of local prisons were of the vagrant class.

A census of persons without a settled home or visible means of subsistence made in July 1905 gave the following figures for vagrants :-

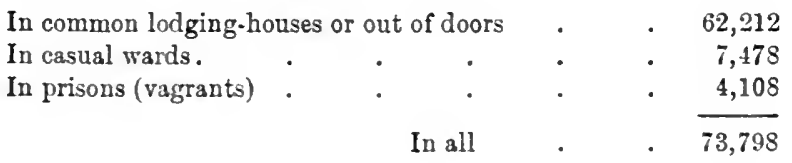

or 2 per thousand of the population. All those in common lodginghouses cannot be taken as vagrants: a rough estimate by a competent authority gave 20,000 to 30,000 as the probable number of habitual vagrants on any one night; in bad times the number may swell to 70,000 or 80,000 .

Vagrancy clings to the metropolis and its neighbourhood and to the manufacturing and coal-mining districts.

Scotland.-The Poor Law of Scotland as at present administered is based upon the Poor Law Act of $18 \pm 5$, which resulted from the 
Report of the Poor Law Inquiry Commission appointed in January 1843. "It cannot perhaps in strictness be said that Scotland was, until 1845, without a law for providing means of relief to the indigent; but inasmuch as it depended upon the will of the parties who should have furnished the needful funds to put the law into force, and as, with only two exceptions, the heritors in the different Scottish counties refused or omitted to tax themselves for the benefit of their less fortunate fellow-creatures, it may be said that until the passing of the Act 8 and 9 Victoria, c. 83, there was no legal provision made for the poor of Scotland. Voluntary offerings, to a small amount, were indeed always made for that purpose, and entrusted for distribution to the kirk-session of each parish, but the degree of relief which that body was thus empowered to afford was, in every case, so limited as to be a perfect mockery of charity. . . . It requires indeed no small degree of forbearance to limit all comment (on the evidence presented to Parliament in 1844) to an expression of astonishment that any country calling itself Christian, and especially in one where so much stress is laid on the outward observances of religion, a degree of heartless neglect as regards the calls of humanity, such as is recorded by the Commissioners, could have been allowed to exist." The problem presented by Scotland was the opposite of that found in England. There the need was to prevent the pauperization of the able-bodied. In Scotland the able-bodied were not relieved by the Poor Law at all. The need in Scotland was to secure that relief should be adequately given where it was required.

\section{TABLE XIX.-Numbers Relieved (Scotland)}

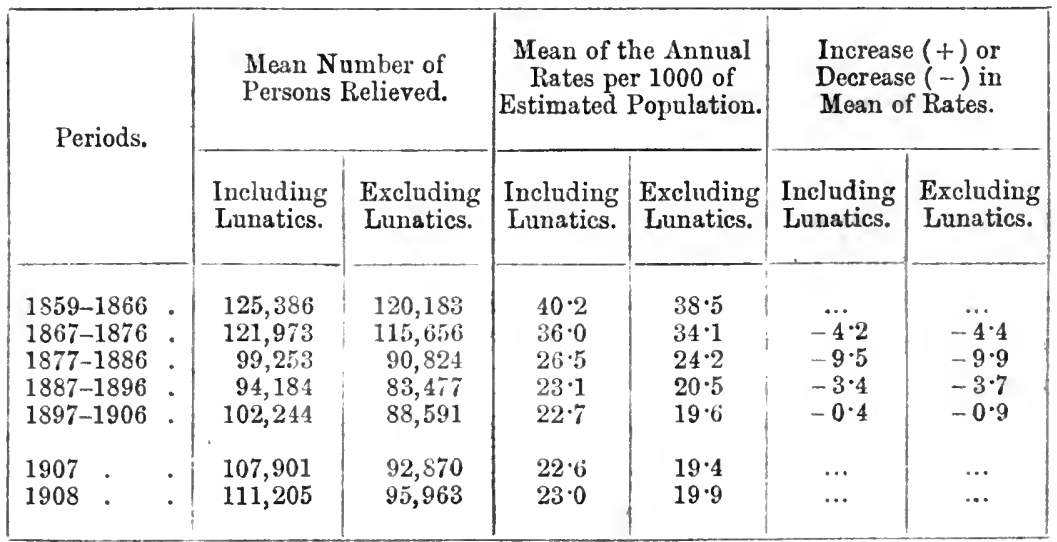

(From Report by Poor Law Commissioners, 1909 (Scotland).) 
Theoretically the Scotch law still gives no relief to the ablebodied so long as they are "able to earn a livelihood." The Scotch poorhouse was intended as an asylum for the aged and impotent. The Act of 1845 did not make its establishment compulsory in every parish. The growth of poorhouses was slow, and only in response to constant admonishment from the Scottish Iocal Government Board. Even now there are sixty-seven parishes with no poorhouse accommodation available; and the accommodation that does exist is very unequally distributed. In many landward parishes the houses remain almost empty. The Scotch system was, and is, primarily an out-relief system. The Commissioners found no need to suggest the universal application of the "workhouse test." Thus in theory there remains a wide divergence between the Scotch and English systems.

TABLE XX.-Male and Female Pauperism (Scotland)

\begin{tabular}{|c|c|c|c|}
\hline & & \multicolumn{2}{c|}{ Mean Number of Persons Relieved, excluding Lunatics } \\
and Dependents.
\end{tabular}

But the divergence is more apparent than real. Disability as a qualification for relief is by no means universally maintained. It has been found to lead to malingering, desertion, hardship, and physical deterioration. In many parishes the medical test is formal, and the real test, as in England, is a test not of disability but of destitution. The able-bodied man is offered relief, in most parts of Scotland, and in all the large towns, on condition of his going into the poorhouse. Thus Scutch conditious, as a matter of fact, present the English dilemma in an exaggerated form. The poorhouse, intended as an asylum for the impotent, affords no real test to the able-bodied unless it is made so disagreeable that residence in it forms an undeservedly harsh form of punishment for the aged and infirm.

The extension of the system of indoor relief was between 
1864-1896 accompanied by a diminution in pauperism. But since that time there has been an actual increase in the numbers in receipt of relief. Morcover, while throughout the period the movement in adult malc pauperism has "never been so satisfactory as that in female pauperism, it has recently been growing more unsatisfactory"; and the greater comparative increase in those receiving indoor relief shows that "the poorhouse has lost much of its power as an agency for controlling pauperism." This must to some extent be connected with administration: the absence of classification and the increasing attractiveness of institutional relief to that class which it is most desirable to repel (cf. Tables XIX, $\mathrm{XX}$, and $\mathrm{XXI}$ ).

\section{TABLE XXI.-Indoor and Outdoor Relief (Scotland)}

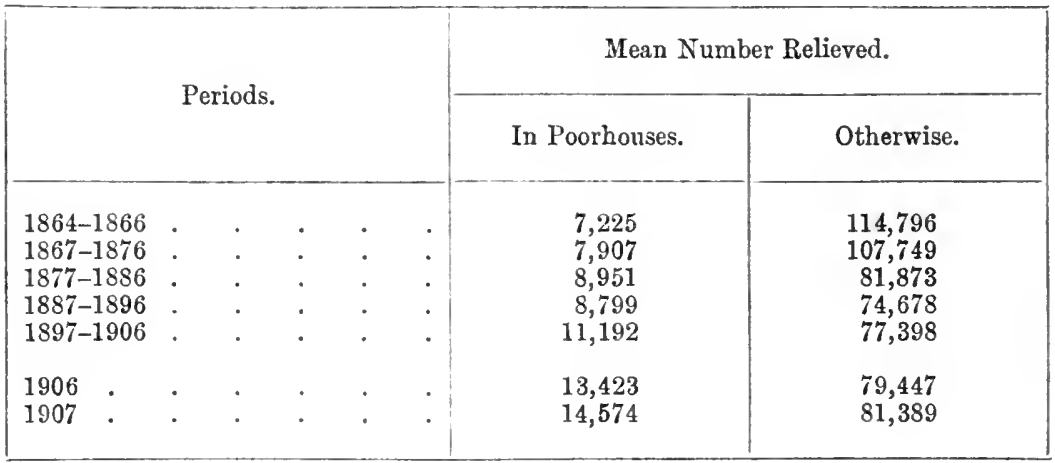

Rate of Pauperism.-Compared with the estimated population living in the middle of $1906(4,726,070)$ the number of sane persons relieved in Scotland on March 31, 1906, was 20.0 per thousand. The English rate (also omitting lunatics elsewhere than in workhouses) was $24^{\circ} 0$ per thousand, or entirely omitting the insane, $23 \cdot 0$.

Age.-Comparing the age rates for the two countries, we find

TABLE XXII.-Age Distribution

\begin{tabular}{|c|c|c|c|c|}
\hline Age Groups. & & $\begin{array}{l}\text { English } \\
\text { Rate. }\end{array}$ & $\begin{array}{l}\text { Scottish } \\
\text { Rate. }\end{array}$ & $\begin{array}{c}\text { Excess }(+) \text { or Deficit }(-) \\
\text { of Scottish Rate. }\end{array}$ \\
\hline $\begin{array}{l}\text { Under } 14 \text { years. } \\
14 \text { and under } 60 \\
60 \text { and upwards. }\end{array}$ & $\begin{array}{l}. \\
\dot{5} \\
\dot{5}\end{array}$ & $\begin{array}{r}2 \cdot 20 \\
0 \cdot 95 \\
14 \cdot 71\end{array}$ & $\begin{array}{l}2 \cdot 69 \\
0 \cdot 87 \\
8 \cdot 64\end{array}$ & $\begin{array}{l}+0.49 \\
-0.08 \\
-6.07\end{array}$ \\
\hline Total & . & $2 \cdot 33$ & $2 \cdot 00$ & -0.33 \\
\hline
\end{tabular}


that the difference is wholly accounted for by the smaller proportion of aged persons, both male and female, coming upon the Scottish Poor Law.

Cost.-In Scotland, as in England, there has been a development in indoor relief, and in the more expensive forms of such relief (hospitals, etc.), and the same improvement in general comfort. As the standard improves, reluctance to accept the conditions must "in the absence of balancing deterrents" diminish.

\section{TABLE XXIII.-Expenditure}

\begin{tabular}{|c|c|c|}
\hline Years. & Expenditure. & Per Head of Population. \\
\hline 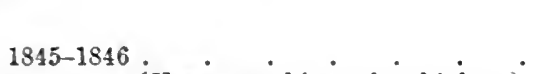 & $\underset{295,232}{£}$ & $\begin{array}{ll}\text { s. } & \text { d. } \\
2 & 1\end{array}$ \\
\hline $\begin{array}{l}1868-1869 \text { Years marking the highest } \\
1850-1881 \text { points of upward movement } \\
\text { in expenditure. }\end{array}$ & $\begin{array}{l}821,184 \\
853,345\end{array}$ & $\begin{array}{rr}4 & 11 \frac{1}{4} \\
4 & 6\end{array}$ \\
\hline $1890-1891\left\{\begin{array}{c}\text { Year before commencement of } \\
\text { recent rise in expenditure. }\end{array}\right\}$ & 841,645 & 21 \\
\hline 1904-1905. . . . . . . & $1,285,721$ & 5 \\
\hline
\end{tabular}

Administration of Scotch Poor Law.-As a result of the recommendations of the 1845 Commission, an unpaid Board of Supervision was established in Edinburgh to exercise, in a modified form, the functions of central control assigned to the Poor Law Board in England; and this Board remained in possession until 1894, when its place was taken by the Local Government Board for Scotland, with the Secretary for Scotland for its president. The power of the Board over local administration is mainly exercised through their yearly inquiry and report "as to the condition and management of the poor throughout Scotland," the inquiries being mainly carried out by officers of the Board known as "General Superintendents of Poor," to each of whom a district is allotted. They have, moreover, to scrutinize the roll of poor in each parish and see that those who need relief get it, while those not in need do not. The main difference in the functions of the Board is its power to interfere in individual cases, on appeal, for the purpose of ordering adequate relief. Although mandatory orders are not issued, regulations, minutes and circulars serve for the guidance of Parish Councils, over whom there is further the check of the central audit. The weakness of the Board is the lack of any initiatory powers.

The unit of Scottish administration is the parish. There are 
874 parishes in Seotland, of extraordinarily various size and population. Kilmonivaig in Inverness-shire covers 267,047 acres; Anstruther Easter, in Fife, only 28. Glasgow has 571,615 inhabitants; Lyne, in Peeblesshire, only 98.

The Poor Law in Ireland.- The first Irish Poor Law was enacted in 1838. The condition then existing in Ireland was totally different from that found in England. As the Irish Royal Commissioners said: "The difficulty in Ireland is not to make the able-bodied look for employment, but to find it profitably for the many who seek it. . . We see that the labouring classes are eager for work: that work is not there for them, and that they are therefore, and not from any fault of their own, in permanent want. ... Our conviction is that the able-bodied in general and their families would endure any misery rather than make a workhouse their domicile." They therefore recommended, first, the direct provision, compulsorily, for the sick, aged, infirm, lunatics and others incapable of work; secondly, indireet measures for the development of the resources of the country and the improvement of the condition of the poor. The second set of recommendations were, however, put aside by the Government and only very gradually and partially realized in the course of the century: all their attention was devoted not to the prevention of destitution but to direct measures for alleviating it after it had arisen.

Unfortunately, however, the Bill of 1838 was only to a very small extent based on the findings of the Irish Commission, rather, in spite of the vast differences in the condition of the two countries, upon the opinion of Mr. George Nicholls, "that the Poor Law of Ireland should assimilate in all respects as nearly as possible to the Poor-Law system now established in England." The weight of opinion from Ireland in both Houses was against the Bill. Daniel O'Connell observed that "what was now suggested was that a country unable to give employment to its labourers should be made to feed them in idleness within the walls of a poorhouse."

The machinery for the carrying out of the new Poor Law, the establishment of the central office, of unions with their officers and workhouses, was entrusted to the English Commissioners.

In 1841, when a few of the first workhouses were opened, the population of Ireland was 8,175,000. In 1901 it had fallen to $4,458,000$. Absolute destitution used to prevail largely in Ireland for about thirty weeks of the year. The Commission of 1833 estimated that over two million and a half men, women and children were in great need of food. As the result of the great 
Since 1855 the tendency has been for out-relief to increase on the whole. "It is well known that in Ireland . . . outdoor relief is often, and we think we may say generally, given to persons who, though poor, are by no means destitute of resources and means of livelihood. The boundary line has in practice been extended from destitntion to poverty, with the result that the number of possible applicants is much increased. Instead of outdoor relief being the sole support of the destitute, it has become merely an item in the receipts of the poor person." (Report of the Viceregal Commission, 1906.) (See Table XXIV.)

TABLE XXV.-Out-relief (Ireland)

\begin{tabular}{|c|c|c|c|c|c|c|c|}
\hline & Year. & & & $\begin{array}{l}\text { Daily Average } \\
\text { Number of } \\
\text { Persons on Out- } \\
\text { door Relief List. }\end{array}$ & $\begin{array}{c}\text { Annual } \\
\text { Amount } \\
\text { Paid. }\end{array}$ & $\begin{array}{c}\text { Average } \\
\text { Amount } \\
\text { Paid } \\
\text { per Week. }\end{array}$ & $\begin{array}{l}\text { Average } \\
\text { Weekly } \\
\text { Amount Paid } \\
\text { per Person. }\end{array}$ \\
\hline $\begin{array}{l}1896 \\
1900 \\
1903 \\
1905\end{array}$ & $\dot{\dot{.}}$ & $\begin{array}{l}\dot{5} \\
\dot{5}\end{array}$ & $\begin{array}{l}\dot{ } \\
\dot{ } \\
\dot{ }\end{array}$ & $\begin{array}{l}56,619 \\
58,012 \\
57,875 \\
57,665\end{array}$ & $\begin{array}{c}£ \\
185,936 \\
200,053 \\
201,746 \\
203,212\end{array}$ & $\begin{array}{crc}£ & \text { s. } & \text { d. } \\
3,565 & 18 & 0 \\
3,836 & 13 & 0 \\
3,869 & 2 & 0 \\
3,886 & 11 & 0\end{array}$ & $\begin{array}{ll}\text { s. } & \text { d. } \\
1 & 3 \\
1 & 4 \\
1 & 4 \\
1 & 4\end{array}$ \\
\hline
\end{tabular}

(Report of the Viceregal Commission, 1906.)

It should be added that in Ireland, owing to the enormous emigration of young people between the 'forties and 'eighties of last century, the number of the old is far greater proportionately than in England or Scotland. Hence Ireland has received a much larger share of old-age pensions than Great Britain. 


\section{CHAP'TER V \\ HOUSING AND RENT}

Inhabited houses-Rents-Urban and rural conditions-Overcrowding

TO account of social and economic conditions would be at all complete which left out the housing of the people in town and country. Much has been done for public health rural districts of England, Wales, and Scotland the need of good cottages and good gardens is great. In Ireland it has been solved by the Lahourers Acts.

The census of 1901 showed 6,260,852 inhabited houses in England and Wales -an increase of 14.87 per cent. on the number in 1891, and higher than that at any intercensal period since 1831-1841. The number of uninhabited houses (448,932) also showed an increase $(20.6$ per cent.), but of these only 259,795 or 57.9 per cent. were really empty; the remaining 189,137 had no inmates on the census night, but were really occupied during the day as offices, shops, etc. : 60,909 houses were returned as "building," an increase of 60 per cent. on the number so returned in 1891 . The proportion of houses "building" in urban districts was 10.8 to every 1000 inhabited houses, and $7 \cdot 1$ in rural districts.

Since population increased $12 \cdot 17$ per cent. in the period, and houses 14.87 , the average number of persons to a house declined between 1891 and 1901 from $5 \cdot 32$ to $5 \cdot 20$; and throughout the century there has been a steady decline.

The proportion of persons to a house was-

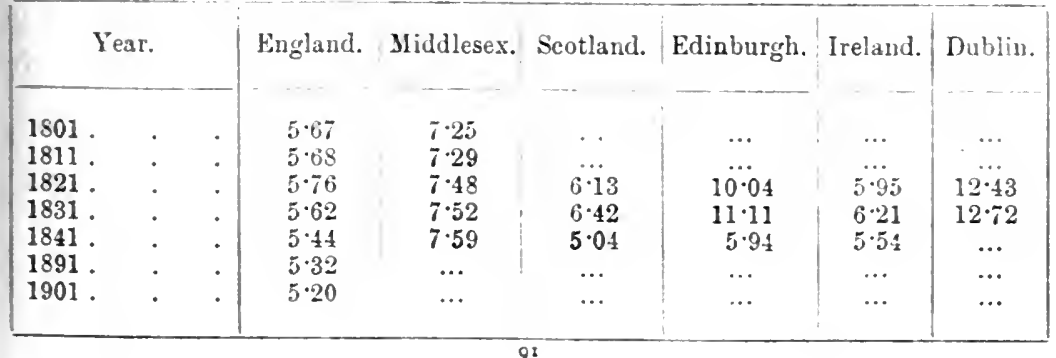


(The great discrepancy in the Scotch figures between 1831 and 1841 is due to the fact that in the latter year separate flats or apartments (tenements) were returned as "houses".)

Figures merely showing the average number of persons to a house are not, however, of much value, since houses vary enormously in accommodation and cubic capacity. Housing figures that are of use for measuring the progress of the standard of comfort must be given relative to the number of persons per room, or per so much cubic space. For instance, the fact that the average number of persons to a house was 4.12 in Rochdale and 8.55 in Devonport in 1901 may indicate smaller houses in Rochdale or overcrowding in Devonport. In all large towns the average number of persons to a house declined between 1891 and 1901 , with the exception of London (with the neighbouring urban districts of Tottenham, Walthamstow, West Ham), Southampton, Newcastle-on-Tyne, Tynemouth, Gateshead, and Merthyr Tydvil. It is certain that in the last ten years the building of large block dwellings has been rapidly proceeding: but to see how far such causes as this, and the building over the country in general of large houses, has affected housing statistics, it is necessary to look not at houses, but at tenements. A tenement is a separate occupation. It may be a house, one or more rooms, a flat, or even a cellar. Since 1890 , occupiers of less than five rooms have been required to state the number of rooms occupied by them. "Room," like house, has been found to be a term impossible of rigid definition: it may be "stretched, by those who please, to cover a landing, a lobby, a closet, or any other more or less distinct space within a dwelling." In 1901 there were in England and Wales 7,036,868 tenements, or 112 tenements to every 100 separate houses (this ratio was the same in 1891 ); and the average occupation is thus 4.62 persons per tenement.

In $1891,47 \cdot 7$ per cent. of these temements in England and Wales consisted of five or more rooms; in $1901,53.2$ per cent. Moreover, between 1891 and 1901 the number of one-roomed tenements declined by more than 35,000 ; they represented 1.6 per cent. of the whole in $1901,2 \cdot 2$ por cent. in 1891 . In 1901 the proportion of the population living

London.

in 1-room tenements

, 2 , . .

", 3 ",

, 4,

, 5 ,
$6 \cdot 7$ per cent. $15 \cdot 5$

$16 \cdot 6$

$15 \cdot 2$ $46 \cdot 0$
England and Wales.

$1 \cdot 6$ per cent.

$6 \cdot 6$,

$9 \cdot 8$ "

21.9 ,

$60 \cdot 1$, 
The problem of the housing of the poorer classes is an exceedingly complicated one: and in spite of considerable improvement, as the result of much expenditure on the part of public and private bodies, housing continues to be responsible for a great deal of suffering and deterioration.

Overerowding is the most serions evil: but it is not the only one. Many existing houses are old, badly arranged, and thoroughly insanitary: strects have been built too close together, so that there is neither light nor breathing space: houses have been neglected by their owners and ill-used by their occupiers. New houses are jerry-built and will not stand wear and tear: old ones, intended for quite a different class of tenant, are cut up into tenements without proper sanitary or kitchen conveniences. The better-off move farther and farther from the centre of growing towns, leaving one ring after another of unsuitable houses to be converted into dwellings for the working classes. As the town expands, accommodation at or near the centre becomes more and more expensive for those who cannot afford to move far away from their work, and the tendency to overcrowding keeps pace with the rise in rents. Excessive ground rents cause great blocks to be built up to an enormous height, more like rabbit warrens than homes.

\section{TABLE I.-Housing and Overcrouding}

\begin{tabular}{|c|c|c|c|c|c|c|c|c|}
\hline Bngland and Wales. & \multicolumn{4}{|c|}{$\begin{array}{l}\text { Total Number of Occupants of } \\
\text { each Class of Tenement. }\end{array}$} & \multicolumn{4}{|c|}{$\begin{array}{l}\text { Occupants of Overcrowded } \\
\text { Tenements. }\end{array}$} \\
\hline \multirow[t]{2}{*}{ Class of Tenements. } & \multicolumn{2}{|c|}{ Number. } & \multicolumn{2}{|c|}{$\begin{array}{l}\text { Percentage of } \\
\text { total Popula- } \\
\text { tion of each } \\
\text { Class of } \\
\text { Tenement. }\end{array}$} & \multicolumn{2}{|c|}{ Ninmber. } & \multicolumn{2}{|c|}{$\begin{array}{l}\text { Percentage of } \\
\text { total Popula- } \\
\text { tion of each } \\
\text { Class of } \\
\text { Tenement. }\end{array}$} \\
\hline & 1891. & 1901. & 1891. & 1901. & $1 s 91$ & 1901. & 1891. & 1901. \\
\hline 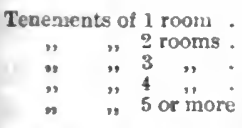 & $\begin{array}{r}640,410 \\
2,416,617 \\
3,237,464 \\
6,514,009 \\
15,903,305\end{array}$ & $\begin{array}{r}507,763 \\
2,158,644 \\
3,156,640 \\
-, 130,062 \\
19,544,734\end{array}$ & $\begin{array}{l}2 \cdot 2 \\
8 * 3 \\
11 \cdot 1 \\
23 \cdot 5 \\
54 \cdot 9\end{array}$ & $\begin{array}{r}1 \cdot 6 \\
6 \cdot 6 \\
9 \cdot 8 \\
21 \cdot 9 \\
60 \cdot 1\end{array}$ & $\begin{array}{l}357,707 \\
1,124,056 \\
951,877 \\
824,404 \\
\cdots\end{array}$ & $\begin{array}{c}245,546 \\
854,6 i 2 \\
397,596 \\
729,652 \\
\ldots\end{array}$ & $\begin{array}{l}55 \cdot 9 \\
46 \cdot 5 \\
29 \cdot 5 \\
12 \cdot 1 \\
\ldots\end{array}$ & $\begin{array}{l}48 \cdot 4 \\
41 \cdot 0 \\
25 \cdot 3 \\
10-2 \\
\ldots\end{array}$ \\
\hline . Total . & $29,002,525$ & $32,527,343$ & $100 * 0$ & $100 \cdot 0$ & $3,255,044$ & $2, \mathrm{C} 67,506$ & 112 & $8 \cdot 2$ \\
\hline 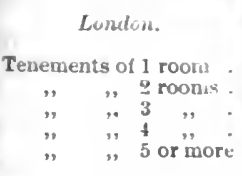 & $\begin{array}{r}357,150 \\
630,544 \\
600,1 \% 0 \\
594,716 \\
1,859,475\end{array}$ & $\begin{array}{r}304,571 \\
701,203 \\
752,221 \\
691,491 \\
2,066,752 \\
\end{array}$ & $\begin{array}{l}9 \cdot 2 \\
16 \cdot 3 \\
15 \cdot 8 \\
14 \cdot 1 \\
44 \cdot 6\end{array}$ & $\begin{array}{l}6 \cdot \% \\
15 \cdot 5 \\
16 \cdot 6 \\
15 * 2 \\
46 \cdot 0\end{array}$ & $\begin{array}{c}215,332 \\
331,1 \geq 2 \\
193,1 \geq 9 \\
92,155 \\
\cdots\end{array}$ & $\begin{array}{l}145,7,11 \\
0 \times 1,659 \\
157,619 \\
44,04 \\
\ldots\end{array}$ & $\begin{array}{l}5.5 \cdot 6 \\
47-9 \\
271 \cdot 0 \\
15 \cdot 5 \\
\cdots\end{array}$ & $\begin{array}{l}45 \cdot 5 \\
42 \cdot 3 \\
24 \cdot 9 \\
13 \cdot 6 \\
\cdots\end{array}$ \\
\hline Total & $4,220,317$ & $4,536,541$ & $100 \cdot 0$ & $100 \cdot 0$ & 831,648 & 726,030 & $19 \cdot 7$ & 160 \\
\hline
\end{tabular}


By an evil paradox the most insanitary and unsuitable dwellings are found to be most overcrowded, since better tenants, more able to pay, occupy the more desirable tenements; therefore it is possible to regard overcrowding as the chief symptom of the disease of bad housing, and feel that were it removed cure would be in sight.

The relation between bad housing and every sort of social evil is of the closest. It is " the main cause of drink and vice," according to Mr. Charles Booth (Life and Labour, vol. x. p. 122); it is "of all causes the most potent in the creation of morally and physically degenerate types," according to the Committee on Physical Deterioration. It has a direct connexion with a high rate of infant mortality. By comparing various districts with approximately the

TABLE II.-Tenements (England and Wales) in 1891 and 1901

\begin{tabular}{|c|c|c|c|c|c|c|c|c|}
\hline \multirow[t]{2}{*}{$\begin{array}{l}\text { Rooms in } \\
\text { Tenements. }\end{array}$} & \multirow{2}{*}{ Tenements. } & \multirow{2}{*}{$\begin{array}{c}\begin{array}{c}\text { Occupants } \\
\text { of } \\
\text { Tenements. }\end{array} \\
1901 .\end{array}$} & \multicolumn{2}{|c|}{$\begin{array}{l}\text { Percentage } \\
\text { of Total } \\
\text { Tenements. }\end{array}$} & \multicolumn{2}{|c|}{$\begin{array}{c}\text { Percentage } \\
\text { of Total } \\
\text { Population in } \\
\text { each Group } \\
\text { of Tenements. }\end{array}$} & \multicolumn{2}{|c|}{$\begin{array}{l}\text { Average } \\
\text { Occupants } \\
\text { per Room. }\end{array}$} \\
\hline & & & 1891. & 1901. & 1891. & 1901. & 1891. & 1901. \\
\hline $\begin{array}{l}1 \text { room }: \\
2 \text { rooms }: \\
3 \quad " \\
4 \stackrel{ }{4} \text { or more rooms }\end{array}$ & $\begin{array}{r}251,667 \\
658,203 \\
779,992 \\
1,596,664 \\
3,750,312\end{array}$ & $\begin{array}{r}507,763 \\
2,158,644 \\
3,186,640 \\
7,130,062 \\
19,544,734\end{array}$ & $\begin{array}{r}4 \cdot 7 \\
11 \cdot 4 \\
12 \cdot 3 \\
23 \cdot 9 \\
47 \cdot 7\end{array}$ & $\begin{array}{r}3 \cdot 6 \\
9 \cdot 4 \\
11 \cdot 1 \\
22 \cdot 7 \\
53 \cdot 2\end{array}$ & $\begin{array}{r}2 \cdot 2 \\
8 \cdot 3 \\
11 \cdot 1 \\
23 \cdot 5 \\
54 \cdot 9\end{array}$ & $\begin{array}{r}1 \cdot 6 \\
6 \cdot 6 \\
9 \cdot 8 \\
21 \cdot 9 \\
60 \cdot 1\end{array}$ & $\begin{array}{l}2 \cdot 23 \\
1 \cdot 73 \\
1 \cdot 42 \\
1 \cdot 16 \\
\ldots\end{array}$ & $\begin{array}{l}2 \cdot 02 \\
1 \cdot 64 \\
1 \cdot 36 \\
1 \cdot 12 \\
\ldots\end{array}$ \\
\hline Total & $7,036,868$ & $35,527,843$ & $100^{\circ} 0$ & $100 \cdot 0$ & $100 \cdot 0$ & $100 \cdot 0$ & & \\
\hline
\end{tabular}

(Census, 1901.)

same population we find, for instance, that in Durham county with a population of $1,194,442$ the percentage of overcrowding is 28.4 and the rate of infant mortality 156 per thousand, or 41 per thousand in excess of the infant mortality rate for Essex, where, in a population of $1,062,452$, the overcrowding was only $2 \cdot 7$ per cent. The death-rate for England and Wales was 15.8, but in Shoreditch, with 29.9 per cent. of the population living under overcrowded conditions, it was 21.5 in 1907 ; in Finsbury, where there were in 1903 14,516 people living in one-roomed tenements, the death-rate of those in one room was 38.9 per thousand, for the whole borough $19 \cdot 6$, and for those in four rooms and over only 5.6. In Glasgow the death-rate of those living in one-roomed tenements is nearly 
twice that of the whole city; while the death-rate there from pulmonary tuberculosis was 2.4 per thousand in one-room tenements, 1.8 in two-roomed tenements, and 0.7 in other houses. In London, with $5 S$ persons per acre, the lunacy rate was 1.9 per thousand, in Bethnal Green with 171 it was $6 \%$, in the Strand with $143,11.0$.

A Scotch Education Blue Book for 1907, dealing with school children in Glasgow, shows that boys from one-roomed houses are on an average $11.7 \mathrm{lb}$. lighter and 4.7 inches smaller than boys from four-roomed houses; while girls from one-roomed houses are $14 \mathrm{lb}$. lighter and 3.3 inches smaller than girls from four-roomed houses. Great efforts have been made to reduce bad housing and overcrowding by public and private effort, and a comparison of

TABLE III.-Overcrouded Tenements (England and Wales), 1891 and 1901

\begin{tabular}{|c|c|c|c|c|c|c|c|}
\hline \multirow{2}{*}{\multicolumn{2}{|c|}{ Rooms in Tenements. }} & \multicolumn{2}{|c|}{$\begin{array}{l}\text { 1-4 Room Tene- } \\
\text { ments with more } \\
\text { than } 2 \text { Occupants } \\
\text { per Room. }\end{array}$} & \multicolumn{2}{|c|}{$\begin{array}{l}\text { Occupants of such } \\
\text { Tenements. }\end{array}$} & \multicolumn{2}{|c|}{$\begin{array}{l}\text { Percentage of } \\
\text { Occupants of such } \\
\text { Tenements to } \\
\text { Total Population. }\end{array}$} \\
\hline & & 1891. & 1901. & 1591. & 1901 & 1891. & 1901. \\
\hline $\begin{array}{l}1 \text { room } \\
2 \text { rooms } \\
3 \quad, \\
4 \quad,\end{array}$ & 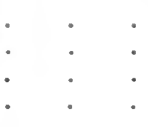 & $\begin{array}{r}92,259 \\
184,231 \\
120,031 \\
85,132\end{array}$ & $\begin{array}{r}66,669 \\
147,257 \\
102,556 \\
75,662\end{array}$ & $\begin{array}{r}357,707 \\
1,124,056 \\
951,877 \\
824,404\end{array}$ & $\begin{array}{l}245,586 \\
884,672 \\
807,596 \\
729,652\end{array}$ & $\begin{array}{l}1 \cdot 23 \\
3 \cdot 88 \\
3 \cdot 28 \\
2 \cdot 54\end{array}$ & $\begin{array}{l}0 \cdot 76 \\
2 \cdot 72 \\
2 \cdot 18 \\
2 \cdot 24\end{array}$ \\
\hline \multicolumn{2}{|c|}{ Tutal under 5 rooms } & 481,653 & 392,414 & $3,258,044$ & $2,66 \tau, 506$ & $11 \cdot 23$ & $8 \cdot 20$ \\
\hline
\end{tabular}

(Census, 1901.)

the figures for 1901 with those of 1891 show that it is, all over the country, declining. The proportion of one-roomed tenements has declined (Table II).

In 1891 it was assumed that tenements containing more than two occupants per room might be considered as overcrowded. On this basis there were found to be 481,653 overcrowded tenements of fewer than five rooms in 1891 , in which 11.2 of the total population were living. In 1901 this number declined to $392, \pm 14$, and the proportion of population living in then to $S \cdot 2$ (Table III).

In London ('Table IV), where rents are highest, overerowding remains nearly twice as bad as in the rest of England and Wales as a whole: though in certain coal-mining districts the conditions 
are even worse. The proportion of overcrowding was in typical districts (1901) —

\begin{tabular}{|c|c|c|c|c|c|c|}
\hline Isle of Wight (lowest) & - & - & . & . & \multicolumn{2}{|c|}{0.91 per cent. } \\
\hline West Sussex & . & • & . & & 1.05 &, \\
\hline Cumberland $\quad$. & . & - & - & . & $8 \cdot 53$ & ", \\
\hline Yorks (W. Riding) & . & - & - & - & $10 \cdot 32$ & , , \\
\hline London & . & - & . & . & $16 \cdot 01$ & ", \\
\hline Durham . & . & . & . & & $28 \cdot 48$ & 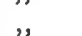 \\
\hline Northumberland & . & . & . & . & $32 \cdot 09$ & $"$ \\
\hline
\end{tabular}

TABLE IV.-Overcrowding in London

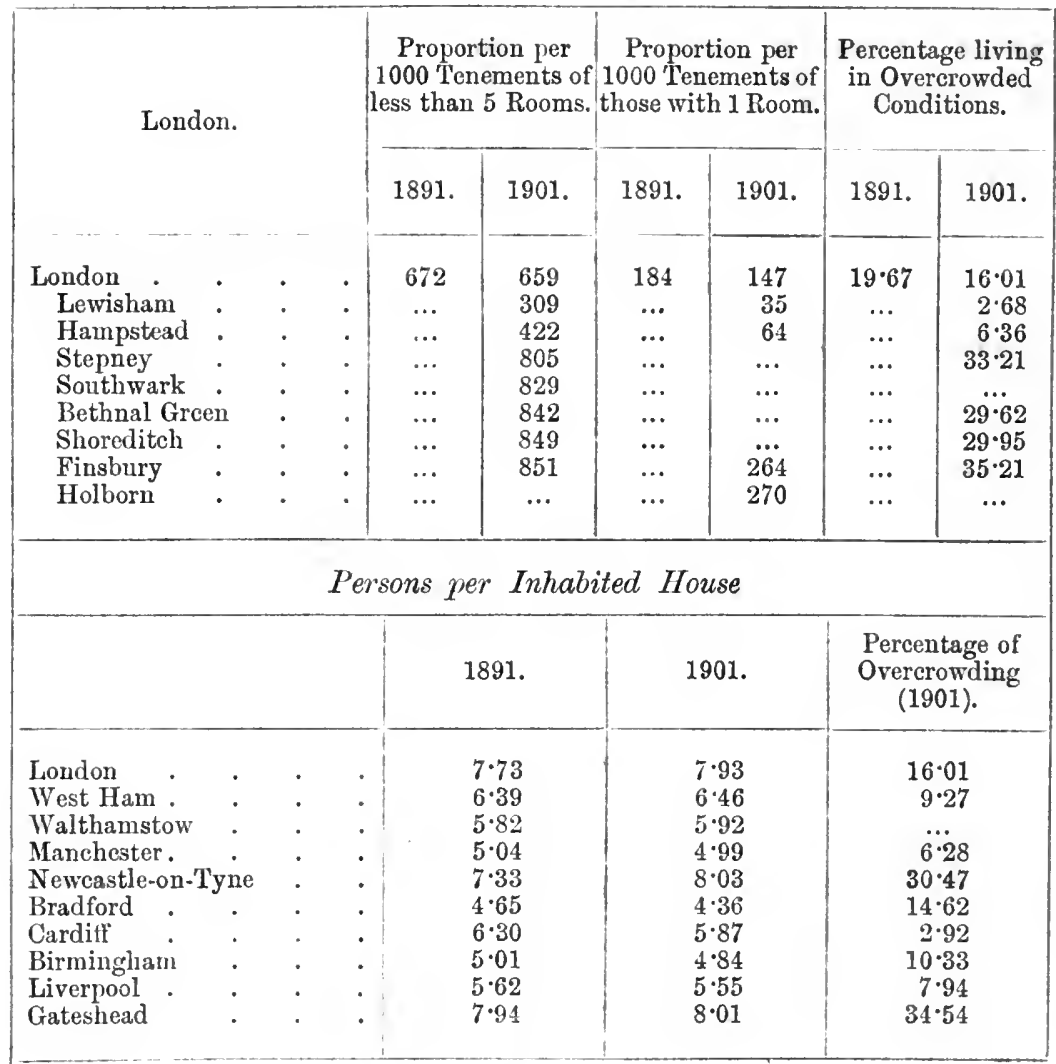

(Census, 1901.)

While in certain rural districts of Durham it was even higher-

Chester-le-Street .

Lanchester .

Easington
37 per cent.

38 ,

39 ,

Rents.-The connexion between overcrowding and bigh rents is unfortunately of the closest. Rents are decidedly higher in 
of one self-contained floor of a two-storied house, with its own separate entrance from street and backyard.

In Scotland the typical residence of the working man is a flat of one, two, or three rooms. These flats are built in blocks of two, three, four and more stories: the rooms generally being larger than in the English cottage, additional accommodation being provided by the extremely insanitary contrivance of a "bedcloset" let into the wall. The predominant range of weekly rents is 2 s. to $2 \mathrm{~s}$. $6 \mathrm{~d}$. for one room, $3 \mathrm{~s}$. $6 \mathrm{~d}$. to $4 \mathrm{~s}$. $3 \mathrm{~d}$. for two, and $5 \mathrm{~s} .2 \mathrm{~d}$. to $6 \mathrm{~s}$. 5 d. for three.

In Ireland, except in Dublin, the cottage type prevails. In Dublin the working class dwell in tenement houses, consisting for the most part of large houses once occupied by the wealthier classes: the rents there are 30 per cent. above the average for the rest of Ireland. The predominant range of weekly rents (including rate) is for one room 1s. 6 d. to $2 \mathrm{~s}$. 6 d. ; for two 2 s. 6 d. to $3 \mathrm{~s} .6 \mathrm{~d}$.; for three $4 \mathrm{~s}$. to $5 \mathrm{~s}$; f for four $5 \mathrm{~s} .6 \mathrm{~d}$. to $6 \mathrm{~s}$. $9 \mathrm{~d}$.

Outside the towns of Ireland under the Labourers Acts almost enough new cottages with half an acre or an acre of land attached to each had already been built by the Rural District Councils in 1911 to supply the demand. Probably about two-thirds of the population (apart from the new peasant proprietors) have been housed in this way, the rents varying from a minimum of ninepence per week in the south of Ireland to a maximum of two shillings per week in parts of Ulster, where the Councils object to any contribution from the rates.

Apart from any improvement in accommodation, rents have risen in the course of the century with the increased aggregation of population. While between 1880 and 1900 the urban population has increased by 47 per cent., the rural population has decreased by 10 per cent., and the proportion of urban to total population has increased by 11 per cent. "This movement has of necessity resulted in a raising of the general average rent of all houses-the value of houses being greater in urban than in rural districts." The increase is perhaps least marked in London, where the pressure has to some extent been relieved by the expansion of the suburbs. According to Board of Trade figures (British and Foreign Trade and Industry II, Cd. 2337), there was in the years 1880-1900 an increase in the rents of all houses in London under $£ 50$ rental of 13.7 per cent., and an increase of 8.2 per cent. in the rents of all houses in London. In the same period the course of rents for all houses in Great Britain (including London) 
under $£ 20$ gross annual rental shows an increase of 25.3 per cent., when rates are included, and of 17.9 per cent. in rent exclusive of rates.

In London the increase was much greater in certain districts, where, moreover, it is possible to select for comparison streets identical in the two periods.

Thus rents have, since 1880 , risen-

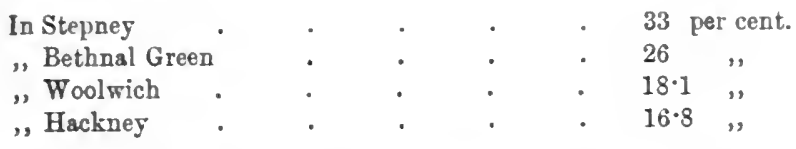

There is a close connexion between high rents and overcrowding. London rents are 40 to 50 per cent. higher than the average for the rest of the kingdom, and London is twice as overcrowded. In those areas where rents are highest, overcrowding is highest (Table VI). The impossibility of finding houses in many crowded parts of London and in the mining districts compels people to pay high rents for insufficient accommodation. Crowded conditions weaken those who live in them, morally and physically; and dirt and insanitary arrangements are added to the already existing discomforts which drive the inhabitants to seek comfort in the public-house.

\section{TaBLE VI.-Overcrouding and Rent}

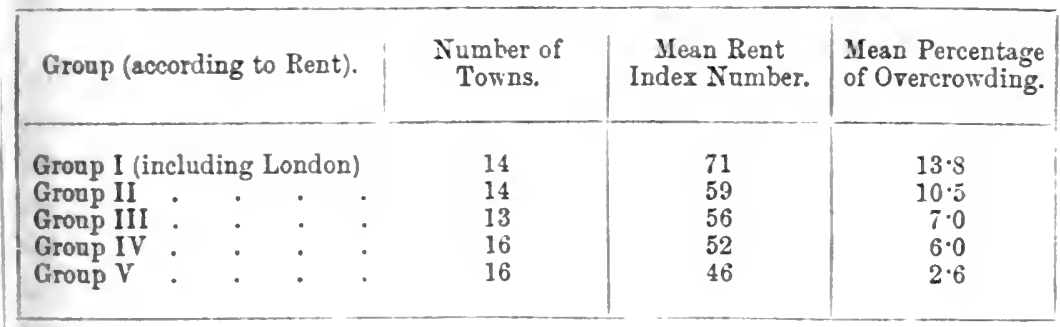

In London various agencies attempted to provide accommodation of a better sort for the working classes before the municipality stepped in. The Peabody Trust built model blocks which are always full, but owing to high ground rents the cost of rooms is too high for the poorest class; the Guinness Trust, founded later, erected dwellings of the same kind-the income in each case being invested in extension of the undertaking. The Artisans' Dwelling Company builds blocks of somewhat the same kind, but for profit. 
Block dwellings, even the best of them, have their drawbacks; and much depends on the character of the caretaker. Some are desperately gloomy. "The condition of the stairs at night (used for sleeping) is often a scandal." In some the bousing accommodation is exceedingly bad.

Table VII.-Population and Rent

\begin{tabular}{|c|c|c|c|}
\hline Population Group. & & $\begin{array}{l}\text { Number of } \\
\text { Towns. }\end{array}$ & $\begin{array}{c}\text { Mean Rent } \\
\text { Index Number. }\end{array}$ \\
\hline $\begin{array}{r}\text { Population exceeding } 250,000 \\
, " \quad \text { from } 150,000 \text { to } 250,000 \text {. } \\
", \quad, \quad 100,000 \text { to } 150,000 . \\
", \quad \text { less than } 50,000 .\end{array}$ & $\dot{:}$ & $\begin{array}{r}8 \\
8 \\
11 \\
24 \\
22\end{array}$ & $\begin{array}{l}64 \\
60 \\
59 \\
54 \\
53\end{array}$ \\
\hline
\end{tabular}

Very good results have been attained by the method of personal service initiated over forty years ago by Miss Octavia Hill in her management of the collection of rents for the Ecclesiastical Commissioners. Some of their property was among the worst in London when she took it in hand; and she has succeeded not only in making the best of existing houses by sanitary teaching and improvement, and the enforcement of a high standard in the mutual relations between landlord and tenant, but in building model dwellings of a modified cottage type from the proceeds of admirable management. From the first she laid the greatest stress on the character of the tenants.

The Acts for the housing of the working classes in 1890 , 1900 and 1903 consolidated and extended the provisions previously made in the Labouring Classes' Lodging-Houses Acts, the Artisans' and Labourers' Dwellings Act, and the Labourers' Dwellings Improvement Acts. By them provision is made for the "clearing of insanitary areas, the removal of unhealthy or obstructive buildings, the rehousing of persons displaced, and the erection of dwellings for the persons of the working classes." The current expenditure of local authorities, which was $£ 14,528$ in $1889-1890$, rose to $£ 179,932$ in $1905-1906$; while their outstanding debt was $£ 3,835,490$ in $1889-1890$ and $£ 9,345,491$ in $1905-1906$. In 1895 the London County Council built 358 model tenements containing 871 rooms, and 1 model lodging-house with 324 cubicles, accommodation used by 1470 persons and bringing in $£ 4904$ in rent; in 1907 they had 7474 tenements with 19,879 rooms, 3 model lodging-houses with 1845 cubicles, accommodating in all 
26,408 persons who paid $\mathfrak{£} 141,205$ in rents. The activities in this field of London and six provincial boroughs is shown in the accompanying table, from which it is seen that sanitary authorities in Londou and the six provincial towns were in 1907 housing

\section{Table VIII.-Dicellings Provided and Persons Housed by Local Authorities}

\begin{tabular}{|c|c|c|c|c|c|c|}
\hline \multirow{2}{*}{ Authority. } & \multicolumn{2}{|c|}{ Number of Tenements. } & \multicolumn{2}{|c|}{$\begin{array}{l}\text { Number of } \\
\text { Occupants. }\end{array}$} & \multicolumn{2}{|c|}{$\begin{array}{l}\text { Total Ainount le- } \\
\text { ceived in Rerits. }\end{array}$} \\
\hline & 1595. & $190 \pi$. & is95. & $190 \pi$. & 1535. & $120 \%$ \\
\hline $\begin{array}{l}\text { London County } \\
\text { Council- } \\
\text { (a) Tenements } \\
\text { (b) Lodging.houses }\end{array}$ & $\begin{array}{c}358 \\
(\mathrm{~s} 71 \text { rooms }) \\
1 \\
\text { (324 cubicles) }\end{array}$ & $\begin{array}{c}7,494 \\
(19,879 \text { rooms }) \\
3 \\
\text { (1,845 cubicles) }\end{array}$ & $\begin{array}{r}1,150 \\
320\end{array}$ & $\begin{array}{r}24,969 \\
1,419\end{array}$ & j.204 & $\begin{array}{c}£ \\
141,025\end{array}$ \\
\hline $\begin{array}{l}\text { City of London } \\
\text { and } 14 \text { metro- } \\
\text { politan bor- } \\
\text { oughs- } \\
\text { (a) Tenements . } \\
\text { (b) Shops - }\end{array}$ & $\begin{array}{r}290 \\
36\end{array}$ & $\begin{array}{r}2,831 \\
36\end{array}$ & $1,155\{$ & 11,471 & $\begin{array}{l}4,781 \\
1,463\end{array}$ & $\begin{array}{r}51,033 \\
1,792\end{array}$ \\
\hline Liverpool . & 373 & 2,046 & $\begin{array}{c}1,164 \\
\text { (approx.) }\end{array}$ & 7,580 & $3, \$ 13$ & 17,215 \\
\hline $\begin{array}{l}\text { Mancbester- } \\
\text { (a) Tenements } \\
\text { (b) Shops }\end{array}$ & $\begin{array}{r}119 \\
16\end{array}$ & $\begin{array}{r}1,3500 \\
33\end{array}$ & $\begin{array}{r}702 \\
98\end{array}$ & 3,404 & $\begin{array}{l}\operatorname{sis} \\
\ldots\end{array}$ & $\begin{array}{l}14,956 \\
\ldots\end{array}$ \\
\hline Salford & $\begin{array}{l}\text { Not fully in } \\
\text { operation, } \\
6 \text { tenentents }\end{array}$ & $\begin{array}{l}553 \text { houses with } 4 \\
\text { or more rooms, } \\
69 \text { tenements with } \\
3 \text { rooms }\end{array}$ & $\cdots$ & 3,078 & $5: 9$ & 11,027 \\
\hline Sheffield . & . & $\$ 36$ & .. & $1,6 ? 0$ & .. & 6,940 \\
\hline Plymouth . & $\cdots$ & $3 i \overline{7}$ & .. & 1,401 & . & 3,458 \\
\hline Southampton & . & $\begin{array}{l}\text { (a) Lodging - houses } \\
\text { acoonmodating } \\
181 \text { males } \\
\text { (b) } 26 \text { Artisans } \\
\text { dwellings } \\
\text { (c) } 69 \text { cottage tene- } \\
\text { ments }\end{array}$ & .. & $\left\{\begin{array}{l}(a) 176 \\
(b, c) 280\end{array}\right.$ & .. & $\begin{array}{c}\cdots \\
(b, c) 1,5 \& 6\end{array}$ \\
\hline $\begin{array}{l}\text { Total London } \\
\text { and six provin- } \\
\text { cial boroughs }\end{array}$ & $\begin{array}{l}\text { Lodging-houses, } 1 \\
\text { shops, } 62 \\
\text { Cottsges and } \\
\text { other tenements, } \\
1,4.9\end{array}$ & $\begin{array}{r}4 \\
69 \\
13,255\end{array}$ & 4,520 & 55,615 & 10,408 & 350,652 \\
\hline
\end{tabular}

12 times the number of people they housed twelve years earlier, and receivug 15 tines the rents.

Pulling down bad houses is not enough. Where clearances are made, things become worse in the surrounding streets. The people who go into the new buildings are not those who have 
been turned out of the old. It is now thoroughly realized that constructive as well as destructive reform is urgently needed. The Housing and Town Planning Act of 1909 aims at so regulating the growth of large towns as to secure provision of breathing spaces in the shape of gardens, parks, and playgrounds, and proper distances between blocks of buildings and streets.

TABLE IX.-Expenditure on Housing Schemes

\begin{tabular}{|c|c|c|c|c|c|c|}
\hline \multirow{3}{*}{ Authority. } & \multicolumn{3}{|c|}{ 1889-1890. } & \multicolumn{3}{|c|}{$1905-1906$} \\
\hline & \multicolumn{2}{|c|}{$\begin{array}{l}\text { Current Expendi- } \\
\text { ture (not includ- } \\
\text { ing Expenditure } \\
\text { out of Loans). }\end{array}$} & \multirow{2}{*}{$\begin{array}{l}\text { Out. } \\
\text { standing } \\
\text { Debt. }\end{array}$} & \multicolumn{2}{|c|}{$\begin{array}{l}\text { Current Expendi- } \\
\text { ture (not includ- } \\
\text { ing Expenditure } \\
\text { out of Loans). }\end{array}$} & \multirow{2}{*}{$\begin{array}{l}\text { Out- } \\
\text { standing } \\
\text { Debt. }\end{array}$} \\
\hline & 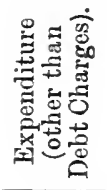 & 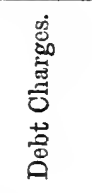 & & 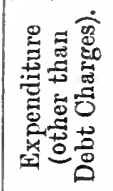 & 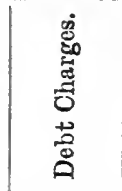 & \\
\hline $\begin{array}{l}\text { London County Council. } \\
\text { Metropolitan Borough } \\
\text { Councils (and prede- } \\
\text { cessors) } \\
\text { Corporation of London . } \\
\text { Town Councils } \\
\text { Urban District Councils. } \\
\text { Rural District Councils . }\end{array}$ & $\begin{array}{r}15 \\
3,957 \\
10,344 \\
\ldots \\
\ldots\end{array}$ & 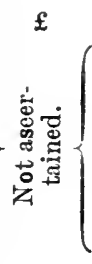 & $\begin{array}{c}247,000 \\
2,254,024 \\
\cdots \\
\cdots\end{array}$ & $\begin{array}{r}18,511 \\
2,378 \\
88,313 \\
7,452 \\
202\end{array}$ & $\begin{array}{c}31,214 \\
14,260 \\
235,000 \\
11,939 \\
403\end{array}$ & $\begin{array}{r}671,559 \\
80,500 \\
5,155,347 \\
256,422 \\
6,682\end{array}$ \\
\hline Total & 14,528 & $\ldots$ & $3,835,490$ & 179,932 & $431,000 *$ & $9,345,491$ \\
\hline
\end{tabular}

(From Public Health and Social Conditions, Cd. 4671.)

Sanitary notions are very slowly making their way. Open windows are not now regarded with such horror as they used to be, though still very uncommon in the poorer parts. Baths are provided in most modern houses, even of the smaller type, and they are not always used for keeping coal or rubbish in. At Garden City, Letchworth, and the Garden City suburb, Hampstead, new experiments in town planning are being tried. At Bournville and Port Sunlight great firms have already provided for the accommodation of their workpeople under good conditions. But the evil is still very grave: and it is not confined to the towns.

The Select Committee on Housing (1906) found that "the want of proper housing in rural districts finds its counterpart in the congestion of towns; and the evils arising out of over- 
crowding will never be successfully grappled with until it is fully realized that the root of the problem lies in the diminution or stagnation of population that has for years characterized rural districts."

\section{TABLE X.-Urban and Rural Tenement Statistics}

\begin{tabular}{|c|c|c|c|c|c|c|c|c|c|}
\hline \multirow{2}{*}{$\begin{array}{l}\text { Rooms in } \\
\text { Tenements. }\end{array}$} & \multicolumn{3}{|c|}{$\begin{array}{l}\text { Percentage of Total } \\
\text { Tenements. }\end{array}$} & \multicolumn{3}{|c|}{$\begin{array}{l}\text { Percentage of Total } \\
\text { Population in each } \\
\text { Group of Tenenients. }\end{array}$} & \multicolumn{3}{|c|}{$\begin{array}{l}\text { Average Occupants } \\
\text { per Room. }\end{array}$} \\
\hline & 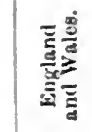 & 竞恋 & 焉惫 & 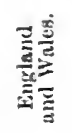 & 衰蒡 & 焉 & 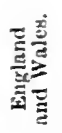 & 总竞 & 总竞 \\
\hline $\begin{array}{l}1 \text { room } \\
2 \text { rooms }: \\
3 \\
4 \text { or more roonis }\end{array}$ & $\begin{array}{r}3 \cdot 6 \\
9 \cdot 4 \\
11 \cdot 1 \\
9 \cdot 7 \\
53 \cdot 2\end{array}$ & $\begin{array}{r}\$ .5 \\
10.4 \\
11.5 \\
21.7 \\
51.9\end{array}$ & $\begin{array}{r}0 \cdot 6 \\
6 \cdot 0 \\
9 \cdot 7 \\
2 \cdot 8 \\
57 \cdot 9\end{array}$ & $\begin{array}{r}1 \cdot 6 \\
6 \cdot 6 \\
9 \cdot 8 \\
21.9 \\
60 \cdot 1\end{array}$ & $\begin{array}{r}2 \cdot 0 \\
7 \cdot 4 \\
10 \cdot 3 \\
21 \cdot 2 \\
59 \cdot 1\end{array}$ & $\begin{array}{r}0 \cdot 2 \\
3 \cdot 9 \\
8 \cdot 1 \\
21 \cdot 0 \\
63 \cdot 5\end{array}$ & $\begin{array}{l}2 \cdot 02 \\
1 \cdot 64 \\
1 \cdot 36 \\
1 \cdot 12 \\
\cdots\end{array}$ & $\begin{array}{l}2.03 \\
1.67 \\
1.39 \\
1.14 \\
. .\end{array}$ & $\begin{array}{l}1 \cdot 77 \\
1 \cdot 47 \\
1 \cdot 96 \\
1.05 \\
\cdots\end{array}$ \\
\hline Total & 100.0 & $100 \cdot 0$ & 100.0 & 100.0 & 1000 & $100 \cdot 0$ & .. & .. & .. \\
\hline
\end{tabular}

Even in the rural districts 5.84 per cent. of population, 436,507 persons, are living under overcrowded eonditions (Tables $\mathrm{X}$ and $\mathrm{XI}$ ), and a potent cause of immigration of the towns is the difficulty, in many villages, of getting decent cottages, and the impossibility of getting land. The Committee admit that "in rural districts

\section{TABLE XI.-Overcrouding in Urban and Rural Districts}

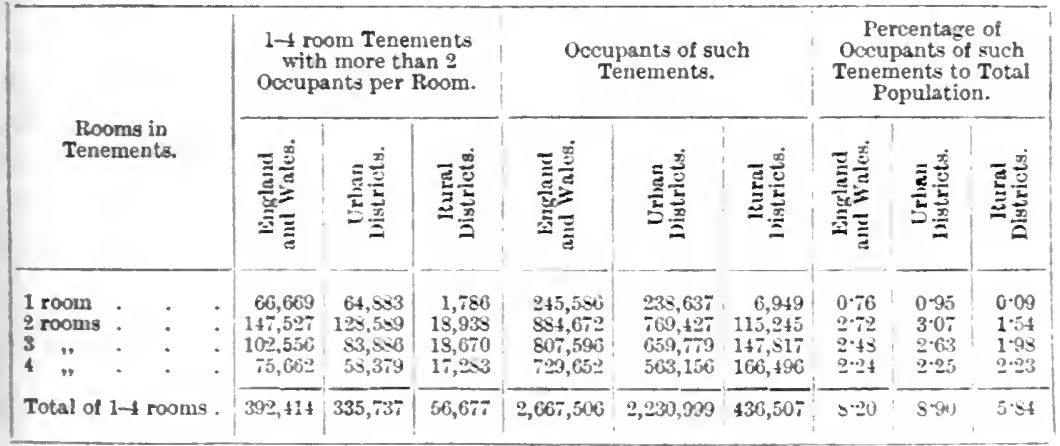

(Census, 1901.)

the Housing Aet of 1890 is practically a dead letter;" they found "abundant evidence as to the insufficiency of cottages in rural districts. . . People have had to leave a village because of the lack of house accomnodation, while others have been prevented from coming to live in a district because no house or cottage was 
to be found fit to live in, and there was no one financially interested in meeting the demand by building. The house famine in town and country which often exists in regard to the working classes is incontestable."

Figures give no adequate picture of the state of the case, because while there is great overcrowding and lack of accommodation in some villages, in others, owing to migration to the towns, there is an over-supply of cottages.

Out of 199 returns from different rural districts in England in July 1906, there were 56 cases of insufficient accommodation, 111 cases where the accommodation was adequate, and 32 where it was more than sufficient. In 44 villages in 17 different counties investigated 464 cottages had only one bedroom, 1852 cottages had two (in many cases one and a landing), and 759 had three or more.

Cardinal Manning, the Bishop of Bedford, Lord Carrington, Mr. Broadhurst and Mr. S. Morley endorsed the following powerful summary by Mr. Jesse Collings of the evidence submitted to the Housing Commission of 1885 :-

"On many estates, for various reasons, cottages have been pulled down and allowed to go into decay, and labourer's, while their services have been required and retained on the land, have been deprived of the necessary dwelling accommodation, and been forced into neighbouring towns and villages, often at long distances from their work. Private owners of large estates, estates extending miles in area, including often villages and hamlets, besides outlying dwellings, have absolute power to determine arrangements with respect to dwellings and buildings on their lands." The Committee in 1906 believed that this state of things was not materially altered.

The difficulty, from the landlord's point of view, of obtaining an adequate return for outlay in the shape of rent would be largely diminished by the addition of land to the cottage, but in many parts of rural England gardenless cottages are quite common. 


\section{CHAPTER VI}

\section{CRIME-DRINK-INSANITY}

Drvistox I. Crime. $-\$ 1$. Historical-The Criminal Code prior to 1850-ExecutionTransportation-- $\$ 2$. Prison Reform- $\$ 3$. Criminal Statistics-\$ 4. Prison Administration-\$5. Causes of Crime. Divisiox II. -Drink. Drvisiox III.-Insanity

\section{Division I.-Crime}

§ 1. TISTORICAL. -The progress of the century steadily tended towards increased security of life. In the period of disorder that followed the Napoleonic wars, further complicated by the Industrial Revolution, the proportion of legal criminals was cnormously high, in spite of an incredibly savage code. In the years 1857-1861 the annual average of persons tried for indictable offences was 265.87 per 100,000 , in the years 1903-1907 it was $175 \cdot 87$ per 100,000 .

There are reasons, to be dealt with later on (see $\S$ Criminal Statistics), why no exact comparison can be made between the number of commitments prior to and subsequent to 1850 . Nevertheless, it is certain that while the graver forms of crime have declined since that period, during the first half of the century they were found, in spite of the appalling list of offences punishable by death, to be steadily and rapidly on the inerease.

In 1841 the number of committals had greatly outstripped the increase of population in every county in England. In Rutland, which showed the lowest increase of population between $1805-1841$, i.e. only 30 per cent., crime had increased 250 per cent.; in Monmonth, where population had increased most rapilly, i.e. $12 S$ per cent., crime har increased 1720 per cent. Anl the increase was as great in the agricultural as in the manufacturing counties. For the whole of England, while population increased 79 per cent. between 1805 and 1841 , committals increased 482 per cent. Porter wrote in 1847: "The amount of guilt and wretchedness which might fairly be imputed to the carelessness and 
ignorance of the British Parliament, would, if any estimate could be formed on the subject, prove an emphatic warning to legislators. The course pursued for the purpose by Parliament was for a long period only a series of wretched expedients. When, by the greater frequency of its occurrence, or by some notorious instance, any particular offence forced itself upon public attention, it was not the rule, as reason could have dictated, to examine and remove the causes of the increase, but to multiply the terrors of the law to a degree out of all proportion with the guilt of the offenders."

In the period of unrest and disorder when economic distress was driving men to larceny and assault, men like Romilly and Macintosh pled in vain for more humanitarian treatment of criminals.

The Criminal Code prior to 1850.-The condition of the prisons was known to be appalling, for the reforming movement initiated by Howard had died with him; such legislation as existed as to the administration of jails was a dead letter. In spite of statistics proving the connexion of illiteracy and brutal crime, men dreaded lest education should cause the masses to be more dissatisfied than they were already with the station to which Providence had pleased to call them; and in the general fear of revolution the punishment of crimes was regarded as a necessary retribution that ought to be made as severe as possible in order to instil terror sufficient to deter all likely to commit them.

The extreme and brutal severity of the criminal code led to constant refusals to convict on the part of juries. Between 1805-1810 only 59 per cent. of those committed were condemned. Yet in 1817,1302 ; in 1820,1236 ; in 1831,1601 ; and in 1832,1449 persons were sentenced to death. Death was the penalty for over forty offences when in 1810 Sanuel Romilly in vain proposed that it should be abolished in the case of theft from a shop where the article stolen did not exceed $5 \mathrm{~s}$. in value, or from a dwelling or bleaching-ground where it did not exceed $40 \mathrm{~s}$. In the House of Lords, Eldon and Ellenborough strongly opposed any such change. The latter said, he trusted "that the laws which a century had proved to be beneficial would not be changed for the illusory opinions of speculatists." In 1812 capital punishment was removed in the case of soldiers and sailors found begging in the streets. In 1813 and 1816 Romilly carried through the Commons a Bill for the abolition of death as the peaalty for shoplifting, but it was until 1818 thrown out by the Lords. In 1832 the death penalty was abolished for forgery and coining, for horse, sheep, or cattle stealing, for stealing a post-office letter, and for sacrilege, and in 
1837 (when 438 persons were condemned to death) Lord John Russell further limited the application of the death penalty.

Excoutions.-Until 1868 executions always took place in public, and large crowds used to assemble at Tyburn for the purpose of enjoying the spectacle.

Transportation.-While death was the penalty for a very large number of offences, the punishment of those guilty of so-called minor crimes was not much less terrible. In 1783 the first shipload of convicts was dispatched to Botany Bay. Between 1825 and 184148,712 convicts, male and female, were transported to New South Wales, an average of 2865 per annum: and the main criticism passed by an enlightened critic at the time is the unsuitability of Australia (which will "probably never become an agricultural country") as a place to receive them, when compared with Canada. Porter says: "Although their absence has undoubtedly been a blessing to society in this country, and in some degree also a benefit to the colony which has received them, it might easily be shown that, by pursuing a different plan, the system of transporting convicts might have been made to yield advantages much greater than it has ever realized." These "pestilent members" were largely political offenders, persons guilty of perjury, forgery, petty larceny, and offences against the currency. The punishment for a person sentenced to transportation who returned home was

\section{Punishment of Political Offenders, 1840}

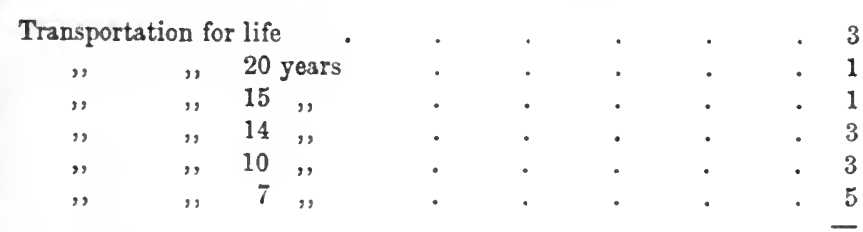

Imprisonment for 3 ,$$
18 \text { months }
$$

15

12

less than 12 months

Fined $£ 100$.

,, £10

Lesser fines. 
death. He goes on to say: "Among the 61 instructed persons convicted in 1840 were 14 for political offences, and 1 of offering a bribe at an election for a member of Parliament; 1 for manslaughter, a lad of nineteen, whose punishment was the payment of a fine of $£ 100$. Eight were convicted of forgery and offences against the currency; 3 were cases of larceny by servants, 15 of simple larceny; the other 17 were minor offences." That the offences were altogether not of a very dark character will appear from a description of the punishments awarded (cf. Table, p. 107).

The horrors of transportation to Norfolk Island were beyond description. In 1849, Cape Colony refused to receive transported convicts; and although Lord Grey continued (in spite of the indignation of the Colonists everywhere, save in West Australia where labour was scarce) to send convicts to Van Diemen's Land, in 1853 public opinion in Parliament pronounced definitely against the system, which was at last abolished. Penal servitude took its place.

$\S 2$. Prison Reform.-Meantime, with the growth of public order a movement had grown for the reform of the prisons, as the final outcome of which we have the modern view as to the function of incarceration not solely as a mode of keeping dangerous characters from exercising their evil propensities, but for bringing, where possible, influences to bear which may reform those capable of reformation and prevent their committing further crime, and deter those who are incorrigible. As a matter of fact, the incompatibility of these two aims accounts for much of the dissatisfaction felt at the failure of our prison system. There are no signs of the disappearance of the criminal.

In the early years of the century the condition of prisons was appalling from every point of view, and a disgrace to the country that maintained them. The great reform movement associated with John Howard died with him, and prisons in general relapsed to their old insanitary and inhuman condition. In some of the eastern counties things were not so bad, but elsewhere the overcrowding was terrible (hence the popularity of transportation). In some prisons the wretched inmates slept sideways for want of room to lie flat. There was no protection against disease in the unhealthy, ill-constructed buildings, which were so insecure that prisoners had to be shackled and fettered to keep them from escape, weakened though they were by a diet of bread and water. There was practically no separation between the sexes. Few prisons had chaplains or doctors. Acts for the reformation of jails were passed from time to time, but they remained a dead letter. 
After the peace a Society for the Improvement of Prison Discipline was formed, mainly by a body of Quakers, among whom Wilberforce, Mr. Buxton, the Gurneys and Frys were prominent, assisted in Parliament by Macintosh. As a result of their efforts a series of jail Acts were passed in 1823-1824, which continued, however, to be largely evaded and ignored. Many people sneerer at humanitarianism exercised on behalf of criminals. Sydney Smith declared if the society had its way prisons would cease to be a salutary terror to evil-doers. But the principle enunciated by Romilly, "that extreme severity was calculated to produce immunity for crimes," held here also; and the reformers continued in their heroic task. The big prisons were often the worst: Newgate, where hapless debtors were shut up with no chance of ever regaining their liberty, was pre-eminently bad. A Conmittee of the House of Lords denounced the existing conditions.

\section{TABLE I.-Penal Serritude}

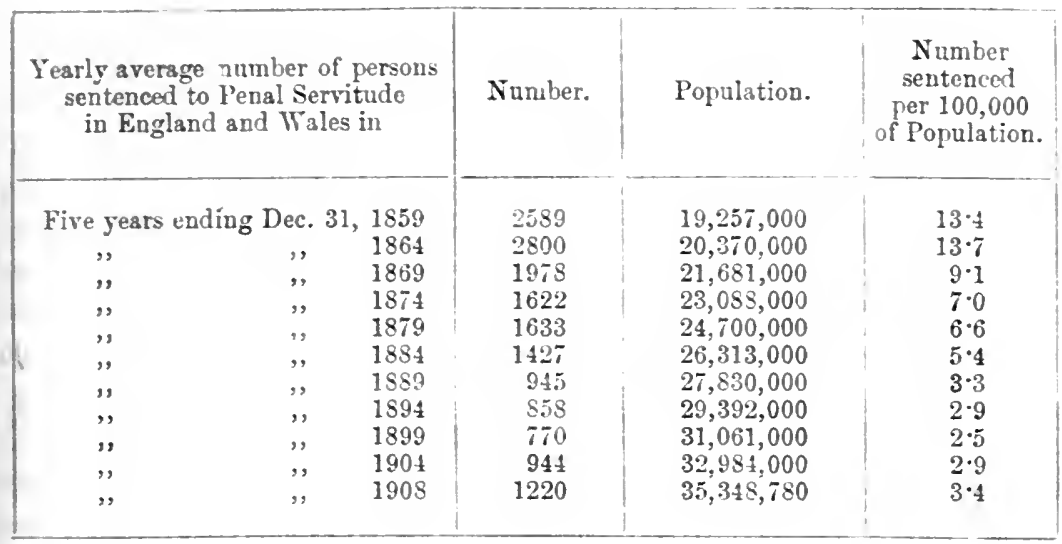

In 1908 , out of 25 sentences of death, 11 were commuted to penal servitude for life; '2 free pardons were granted. Remission of the term of penal servitude or imprisomment was granted to 236 persons. Forty convicts were released on licence, in special cases, at earlier dates than those allowed by the ordinary prison regulations (cf. Table I).

\$. Criminal Statistics. - During the latter half of the nineteenth century students of criminology in this country were abundantly supplied with material for their investigations, and it is natural that the attempt should be made to institute a comparison with early data, to show the movement of crime. This 
can, however, only be undertaken with great caution. The table most often used as the basis for speculation and generalization was as follows:-

TABLE II

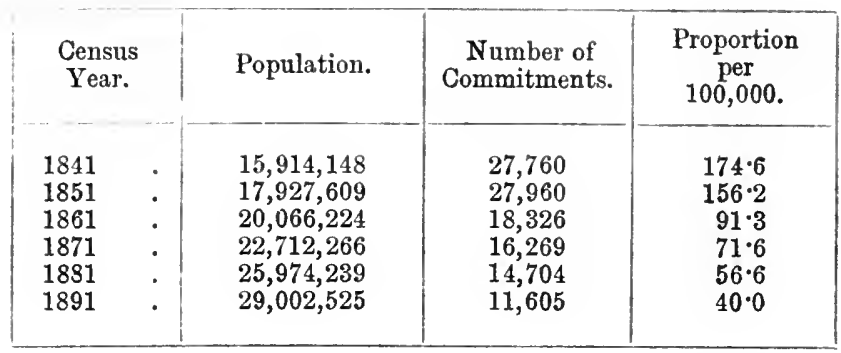

It is manifestly not unreasonable to ask the reader to accept, as criteria of the state of crime, figures showing the aggregate number of indictable offences; yet this table as it stands proves little or nothing, and any conclusions drawn from it are wholly unwarranted. The table does not, in point of fact, show the number of indictable offences prosecuted in the various years cited as illustrations. It shows merely the number of cases committed for trial by jury. During the second half of the nineteenth century there sprang up a system under which vastly more than half the number of indictable offences tried by the courts were not committed for trial at all either to the Assizes or Quarter Sessions. They were disposed of by magistrates sitting in courts of summary jurisdiction. Statutes passed in 1847 and 1850 were followed by the Criminal Justice Act, 1855, and later by the Summary Jurisdiction Act, 1879, which has since been extended by the Summary Jurisdiction Act, 1899. It was under these statutes that the summary jurisdiction to try indictable offences was exercised; but it is not to the present purpose to inquire precisely as to the scope or particular provisions of these enactments. Suffice it to say, although it is true that the total number of indictable offences tried in 1841 was 27,760 , the aggregate for 1861 was not 18,326 but 60,056 ; while, for 1881 , the total was 60,620 , not 14,704 ; and in 1891 the figure was 54,087 , not 11,605 . It will thus be seen that the proportion of charges for every 100,000 of population so far from having decreased from 174.6 in 1841 to 40 in 1891, had actually increased from 174.6 in 1841 to more than 180 in 1891 .

In truth, all that can be safely predicated of the course of serious crime during the period $1850-1900$ is that during the 
last twenty years a steady and somewhat marked diminution was observable. The position from 1856 to the end of the century is seen from the following table, showing the proportions of persons tried for indictable offenees-i.e. the proportions of annual averages to 100,000 of population:-

\begin{tabular}{|c|c|c|c|c|c|c|c|c|}
\hline $1857-60$. & $1861-65$. & $1866-70$. & $1871-75$ & $1876-80$ & $1881-85$. & $1880^{\circ}-90$ & $1891-95$ & $1896-$ \\
\hline $262 \cdot 69$ & $287 \cdot 96$ & $270 \cdot 55$ & $223 \cdot 76$ & $221 \cdot 69$ & $225 \cdot 87$ & $201 \cdot 53$ & 1860.05 & $163 \cdot 76$ \\
\hline
\end{tabular}

This diminution was the more encouraging as (a) the increased strength of the police forces would be calculated to promote the detection and prosecution of serious crime; (b) the diminished harshness of the sentences, due to the more enlightened condition of the judiciary, would tend to make humane prosecutors less unwilling to prefer charges; and (c), the average duration of imprisonment being shorter, the professional and the habitual criminal would have more frequent opportunity of committing the offences of dishonesty to which they are prone. It should, too, be added that a number of new indictable offences were created during the period under consideration, as, e.g., by the Criminal Law Amendment Act, 1885-a circumstance which would, of course, tend to increase the aggregate number of charges. The creation of new offences will probably exert further effect on the statistics in the near future, seeing that the promotion of legislation in criminal matters now rests largely with laymen who ignore or differ from the view of Jeremy Bentham: "La legislation, en un mot, a bien le même centre que la morale mais elle n'a pas la méme circonférence." It may be that the great jurisprudents were right in holding that penal laws can only be effectively applied within certain limits. If so, much of our more modern legislation will prove a dead letter, and the statistics accordingly remain practically unaffected. But it is almost as idle to speculate on the causes of any diminution of crime, as it is to attempt a forecast of the future. Felix qui potuit rerum cognoscere causas. Charging a Grand Jury early in November, 1900, one of Her Majesty's judges congratulated them on the lightness of the calendar, observing that "there had been a remarkable diminution of crime during the last twelve months, not merely in particular localities, but generally throughout the country." This remarkable diminution was attributed by the learned judge to "the spirit of patriotism which the war (i.e. the 
Boer War) has evoked." As a matter of fact, there had been an appreciable increase in serious crime during that year as compared with the year preceding; the prisoners tried for indictable offences in 1900 numbering 53,628 as against 50,494 for 1899 , while in 1901 the figure was swelled to 55,453 , and again rose in each of three following ycars, thus:-1902, 57,068; 1903, 58,444; and $1904,59,960$. In 1908 the figure had risen to $68,116 !$ The numbers for 1904 represented 177.59 per 100,000 , the highest figure for ten years. In 1908 it had reached $192 \cdot 70$ per 100,000 .

In the Introduction to the Criminal Statistics for 1908 it is asserted that "a comparison of crime with the total population is somewhat misleading. Obviously there is no relation between the amount of crime and the number of children, women, and aged persons, who together make up the three-fourths of the total population. The bulk of crime is committed by a section of the male population within certain limits of age." But if the numbers included in this "section" bear to the aggregate population a ratio which is approximately constant, there would seem to be nothing misleading in the use of these figures for purposes of comparison.

Statistics which disclose the number of persons tried for indictable offences are now generally accepted as the surest index to the fluctuations of crime, temporary disturbances being, of course, explicable by variations in the conditions of trade and employment. It is, therefore, apparent, in view of the conspicuous recrudescence of crime after 1900 , that no deduction can safely be made from the favourable figures which marked the last two decades of the nineteenth century; and it may be taken that even if the returns for a whole generation continued satisfactory, ever tending towards a diminution in the number of serious charges, the causes of the pheuomenon would be so numerous, and many of them so obscure, that any attempt to arrange these causes in order of relative importance would prove vain.

So far as nou-indictable offences are concerned, the statistics for the first half of the century are very vague and incomplete. No proper records were kept of the cases disposed of by justices at their own houses or elsewhere out of Quarter Sessions; but it is probable that the number of offenders received in prison on summary conviction increased by more than 150 per cent. between 1836 and 1896 . It is, however, futile to advance figures relating to summary proceedings as affording any evidence of the number of breaches of the law that have been committed. "They will, in fact," writes Mr. H. B. Simpson, "scarcely help us to go beyond the 
of a Board of Prison Commissioners to act as the contral authority, under the Home Office. By this means uniformity of treatment, diet, labour, etc., and inspection is secured, and publicity afforded for the redress of abuses.

One great problem in prison administration is to discover a rational occupation for prisoners such as shall prevent their deteriorating while in confinement. In theory all prisoners condemned to serve sentences of a certain length are subject to "hard labour." The treadmill and the crank, which were the means used for attaining this object in the earlier part of the period, were abolished in 1895 as being quite useless and so demoralizing. Prisoners are now employed on coal-sack making, oakum-picking; stone-breaking, wood-chopping, mat-making, and ship-fender making. According to the medical officer at Pentonville, "There is no such thing now as hard labour: hard labour is a term used at the present day, but the thing itself is absolutely obsolete." The difficulty of finding suitable employment for prisoners is partly economic, partly caused by the fact that a great proportion are serving exceedingly short sentences. This applies forcibly to women (the average length of sentence of female prisoners in local prisons is only twenty-six days) and to the vagrant class, which, for one reason or other (begging, sleeping-out, or poor-law offences), now forms one-fifth of all males received into local prisons, and is continually on the increase. By this class, moreover, a short time in prison is regarded as preferable to the casual ward, owing to the better food and lighter task prevailing there. It was with regard mainly to this class that $\mathrm{Mr}$. Preston Thomas estimated that a prisoner's work was worth $6 \mathrm{~d}$. per head while his maintenance cost the country $£ 50$ a year. To this class prison is in no sense a deterrent, nor can the short period of detention exercise any reformative effect.

Discrimination.-Recent endeavour in the direction of prison reform has been mainly directed to discrimination between the different classes of those who are condemned to some form of punishment and the effort to prevent one conviction from leading to habitual criminality. The Prisons Act of 1898 was intended as a step in this direction. It gave magistrates the power to place offenders in three divisions, having regard to the nature of the offence and the antecedents of the offender. As a matter of fact, a diminishing number of offenders are placed in the second division, and the Prison Commissioners state that the "main obstacle to proper classification lies in the use by the courts of 
the antiquated, and quite meaningless, distinction 'with or without hard labour.'" Nominal hard labour is the universal rule; yet 50,000 to 60,000 prisoners every year are sentenced to imprisonment without hard labour, and all, with few exceptions, placed in the third division. The real utility of the divisions is lost.

Since 1897-1898 first offenders have been segregated from habitual criminals by the establishment of the star class system in all local prisons. Since $1897,68,430$ males and 12,154 females have been placed in this class. Of these, $9 \cdot 1$ per cent. of males and $14 \cdot 2$ per cent. of females have been recommitted to local prisons.

Since 1879,3828 convicts have been placed in the star class. Of these only 1.76 per cent. have returned under fresh sentences, and only 1.57 per cent. have had their licences revoked or forfeited.

Probation of Offenders Act, 1907.-A further step in the same direction-that of the preventive treatment of crime-is found in the Probation of Offenders Act (1907), which provides a method by which a person who has offended against the law, instead of being punished by imprisonment, or, in the case of a child, sent for a prolonged period to a reformatory or an industrial school, may be brought under the influence of a man or woman chosen for excellence of character and for strength of personal influence. The penalties of the law are, meantime, held suspended over the head of the person under influence.

In 1908,8023 persons were placed under the care of probation officers (i.e. one-ninth of all the persons tried before courts of summary jurisdiction for indictable offences). Of these only 367 , or less than 5 per cent., had to be recalled before the court and penalties imposed.

A committee appointed to inquire into the working of the Act found that the courts have availed themselves of the Act to a very unequal extent. They agreed that it has already proved to be of great value in a large number of cases, and that if actively used, it may become in future a most useful factor in penal law.

The most disquieting feature of any detailed statement of the numbers of criminals in the earlier half of the century is the number of juvenile criminals, "who may be considered the victims of the evil influeuces to which they have been exposed." In 1835 , 2002 boys and 354 girls under 16 were committed to prison; in 1841 the numbers had risen to 2656 and 556 respectively. The prisons to which these juvenile offenders were sent were then 
"schools wherein the child who may have been led into some petty delinquency is made to perfect his education in crime, and whence he is sent back into the world an accomplished villain." The first measures which had for their object the prevention and not merely the repression of crime lay then in providing reformatory treatment for this class. The first reformatory was that established at Parkhurst. Tables IV and V show the marked and steady decline in the number of youthful offenders. Their treatment has progressively tended to be more and more of an educational character. Preliminary imprisonment in the case of juveniles was abolished by the Act of 1901 ; they go straight to reformatories and industrial schools; the industrial schools being managed by county or county borough councils, or their education committees.

\section{Table IV.-Age Distribution of Criminals}

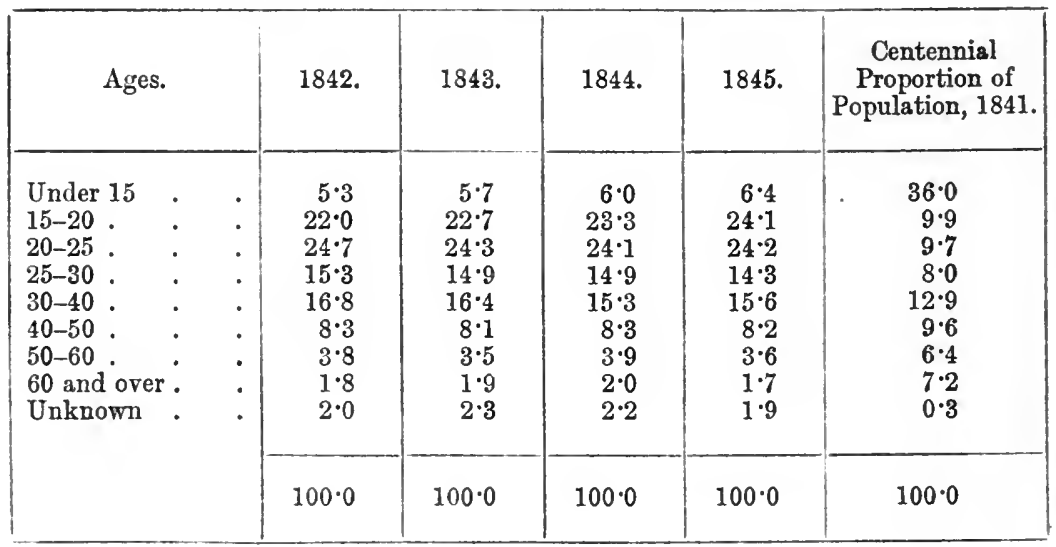

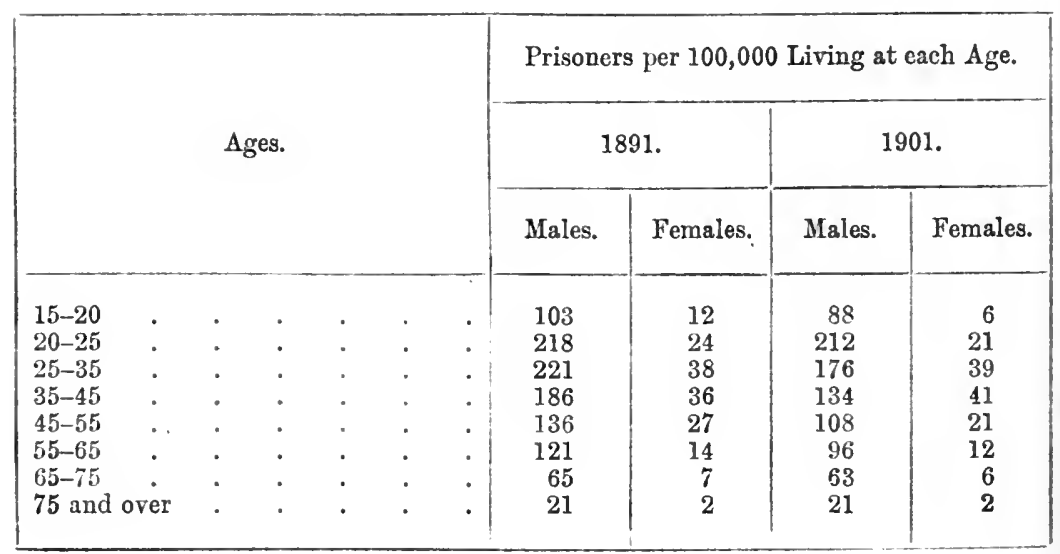


While the number of adult commitments has steadily increased since 1861 , as is shown by the judicial statistics, the number of juveniles (under 16) committed has steadily declined.

\section{TABIE $\mathrm{V}$}

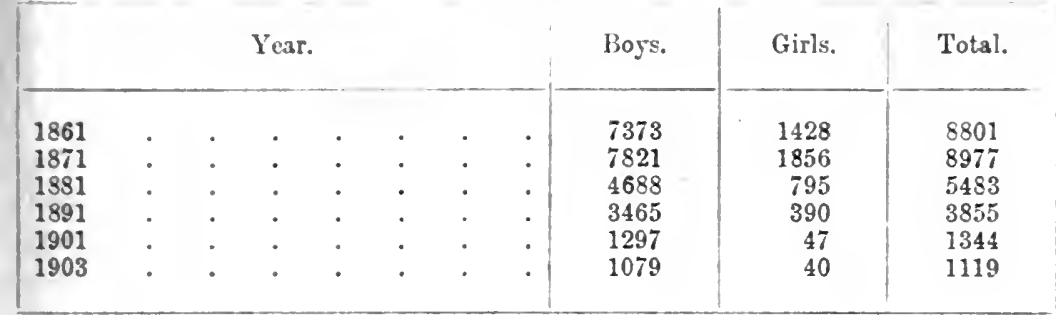

In 1904 there were, in the various reformatory and industrial schools in England and Scotland, 4013 boys and 581 girls. "Juveniles" are, by definition, (a) children under 14 years of age, or (b) young persons under 16 years of age. Legislation as it affects them was consolidated in the Children Act of 1908 .

In 1908 was introduced the Prevention of Crime Bill by which for the reformation of young offenders-i.e. adolescents between 15 and $21-a$ new form of sentence and a new type of institution have been established. "The sentence passed by the court will be detention under penal discipline in a Borstal institution for a term of not less than one year and no more than three years, and the persons liable to such detention will be between the ages of 16 and 21 who, by reason of criminal habit or tendency, it is expedient to detain for lengthened periods under such instruction and discipline as appear most conducive to reformation and repression of crime" (Report of the Prison Commissioners for 1909).

TABLE VI

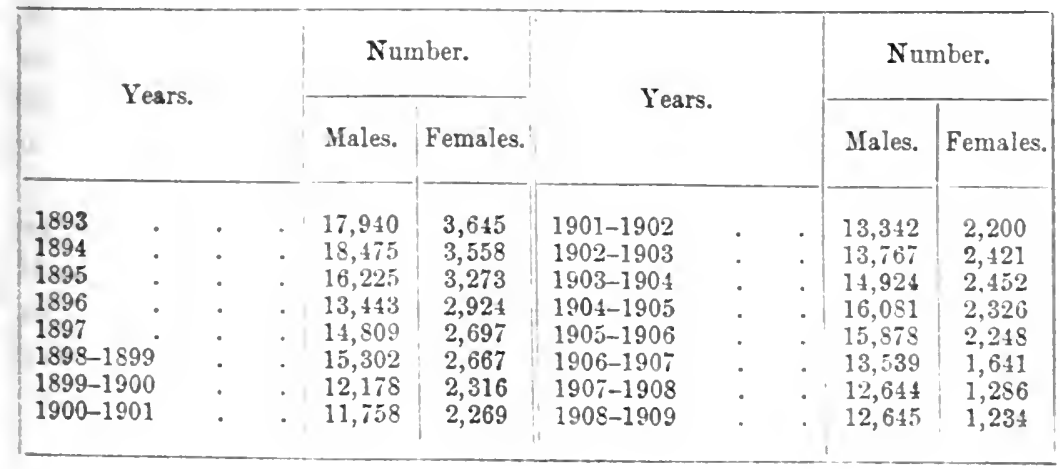


Borstal treatment may be applied to young women between 16 and 21 in a special wing of Aylesbury prison, while Borstal itself and part of Lincoln is reserved for males. In the ten years of its existence the Borstal Association has shown such excellent results, in spite of the very unpromising material on which it has to work, that much more may be hoped from the larger scope given to it by this Act. 60 to 70 per cent. of those hitherto discharged are doing well. Already the numbers of juvenile-adults show a decline.

The experience upon which the Act is based has established that ordinary detention in prison does not allow the specialization eminently necessary in the case of young criminals; that a succession of short sentences tends to accentuate rather than arrest the habit of crime; that the element of time is essential and that after-care is of crucial importance.

Discharged Prisoners.-In comnexion with almost every prison there is a Discharged Prisoners' Aid Society, in the great majority of cases duly certified by the Secretary of State; but the ordinary Prisoners' Aid Society "is not able, from the numerous demands made upon it by all classes of prisuners, to give that particular attention to the case at the time of discharge, and that kindly supervision afterwards, which is one of the principal conditions of successful reclamation."

Habitual Crime.-. "There is a large class of offenders whom the criminal law cannot either reform or deter from crime. If one took as a very rough test of the numbers of the criminal classes those who have been convicted five times or oftener, there would be in prison at any one time about 5000 belonging to these classes" (Judicial Statistics, 1908, p. 60). Thus, in 1908 it was estimated that over 4000 such habitual offenders were at large on any given day.

For these habitual offenders the second part of the Act of 1908 provides a new from of treatment, i.e. a term of "preventive detention" over and above their sentence of penal servitude, and amounting together with it to not more than ten years in ali, at a special place, under discipline.

It was found in 1908 that of 1102 males and 48 females sentenced to penal servitude only 163 and 17 had not been previously convicted. It was found at a census of convicts taken in 1894 that 56 per cent. had previously been convicted five times or oftener (see Table VII). 


\section{TABLE VII.-Previmus Convictions}

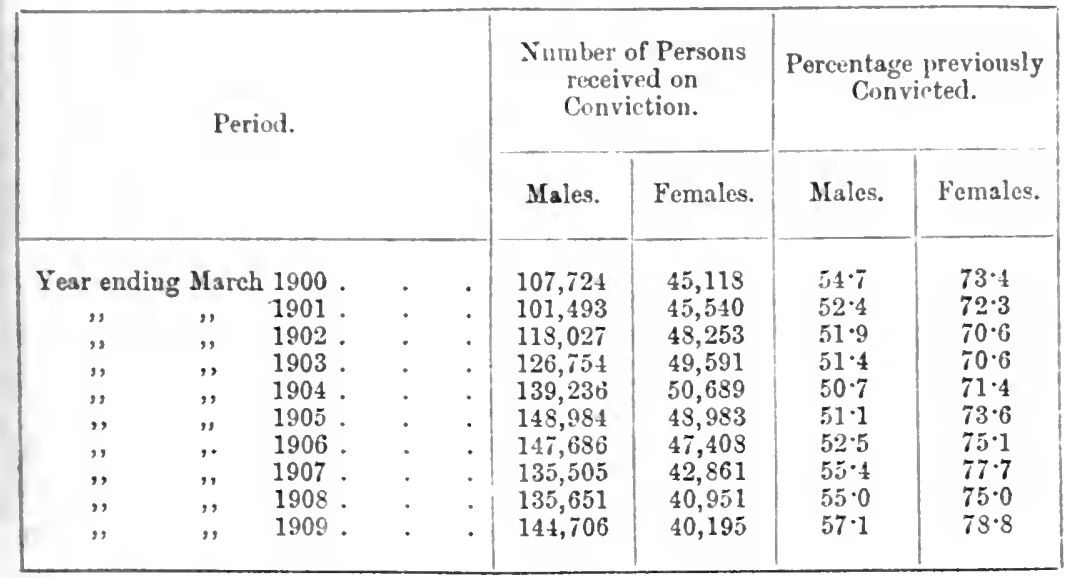

The new treatment of recidivism is in the nature of an experiment. A minimum period of three years' penal servitude will be followed by a term of detention which will "adnit of certain indulgences and privileges, earned by industry and good conduct, which will render the conditions of detention less onerous in some respects than those of ordinary penal servitude; and the system will generally be directed to fostering the habit of industry and self-control, so that, after a lapse of sufficient time, the prisoner may be considered eligible for conditional licence and may revert to liberty without danger to the community.

Tables VIII and IX afford interesting evidence as to the connexion of ignolance and crime. Porter declares "these figures must carry conviction to every mind that instruction has power to restrain men from the commission of crimes-of such a nature at least as will bring them before the bar of justice."

\section{TABLE VIII.-Education and Crime}

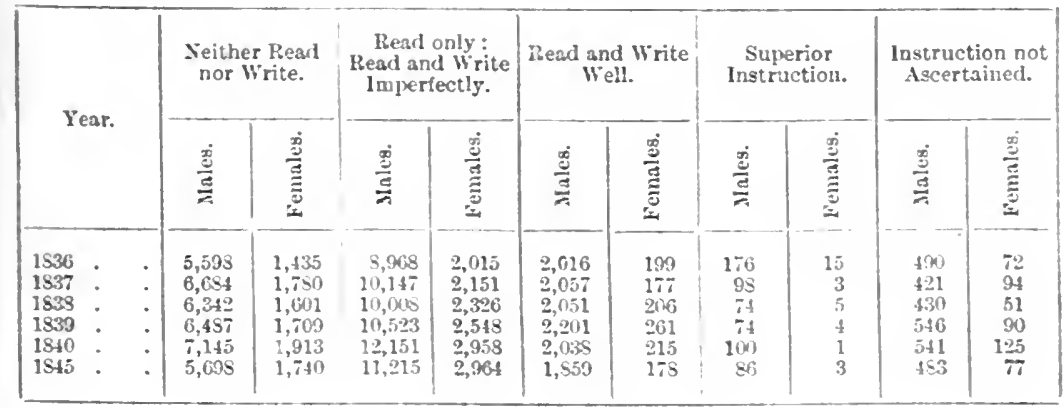


TABLE IX (1909)

\begin{tabular}{|c|c|c|c|c|c|c|c|}
\hline Prisons. & 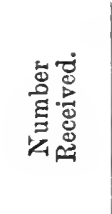 & 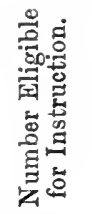 & 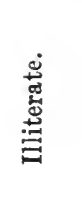 & 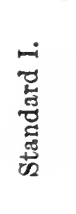 & 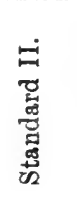 & 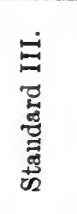 & 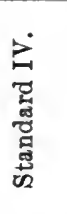 \\
\hline $\begin{array}{l}\text { Local } \\
\text { Convict } \\
\text { State Inebriate } \\
\text { Reformatories . }\end{array}$ & $\begin{array}{r}185,350 \\
1,331\end{array}$ & $\begin{array}{r}10,756 \\
111\end{array}$ & $\begin{array}{r}1,503 \\
5\end{array}$ & $\begin{array}{r}2,783 \\
21\end{array}$ & $\begin{array}{r}3,684 \\
52\end{array}$ & $\begin{array}{r}2,230 \\
26\end{array}$ & $\begin{array}{r}556 \\
7\end{array}$ \\
\hline
\end{tabular}

$\S 5$. Causes of Crime.-In spite of moral, material, and educational progress, however, and the expenditure on the improvement of reformative agencies in particular, the proportion of criminality to population still remains unduly high. In 1909 the proportion committed to prison was 5.23 per thousand of population; in Scotland, 12.8 per thousand.

The reasons for this high rate are variously estimated. The Report of the Prison Commissioners indicate as a cause for the exceptional increase of crime in 1908, marked depression of trade and an unusual amount of unemployment. This is borne out by the fact that nearly five-sixths of the increase (which is noted as causing great congestion in many local prisons) took place in the principal mining and manufacturing counties.

The increase was even more marked in Scotland, the average number in custody there in 1908 exceeding any recorded in the last fifty-five years. In England there was an increase of 4178 in the number of vagrants committed, and an increase of 1078 in the commitments for debt; a marked increase in offences against property. The causes for this may very well be looked for "in the social and economic conditions of the period"; but while in England there was a decline in the cases of imprisonment for drunkenness, in Scotland there is no doubt that the main cause of the increase in crime is drink.

Moreover, while in Scotland the committals for drunkenness amounted to one-third of the total, and in many more cases drink was the cause of the offence for which the prisomer was charged, in England, in spite of a decline in the figures, it is perfectly true, to quote the words of the medical inspector, that "over one-half of the women and nearly a third of the men who are sent to prison in this country are committed for drunkenness." That "a great weight of evidence indicates drink as the most potent and universal factor in bringing about pauperism," is the opinion of the Poor- 
Law Commissioners; and the same is true of crime; alcohol is the most powerful agent.

\section{Division II.-DRINK}

A writer in the British Medical Journal in March 1816 says: "The one degrading vice to which the lower classes of London are so miserably and universally addicted, i.e. drunkenness, has alone deprived the city of more inhabitants anuually than all the devastating wars of Bonaparte hare in Paris. To the consequences of this disgusting habit may justly be imputed the larger proportion of infantile lives sacrificed in this metropolis." Porter goes on to say: "Nor were those habits of drunkenness confined to the labouring classes. What would now be called drinking to excess was then so much the custom in every circle, that it was as uncommon for any party to separate while any member of it remained sober as it is now for anyone in such a party to degrade himself through intoxication."

Nevertheless, while actual drunkenness is no longer so prevalent as it was in the upper ranks of society, the average expenditure upon drink per head of population, which was $£ 32$ s. $8 \frac{1}{2} \mathrm{~d}$. in 1837 , was nearly $\mathfrak{f 4}$ in 1899; and when we considel the proportion of the national expenditure on alcohol that belongs to the working classes, these figures become more serious still.

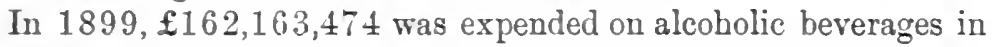
the United Kingdom, a sum equal to nearly one and a half times the national revenue. The Royal Commission on the Licensing Lars in 1897 accepted the estimate of Professor Leone Levi that twothirds of this expenditure belongs to the working classes, who constitute roughly 75 per cent. of the population. Thus $£ 108,000,000$ in round figures was spent by $30,400,000$ persons, and taking five as the average number per family, each working-class family spent in $1899 £ 17$ 15s. 3d. or 6s. 10d. per week on drink.

TABle X.-The National Drink Bill. Expenditure per Head

\begin{tabular}{|c|c|c|c|c|c|c|}
\hline Year. & & $\begin{array}{l}\text { Expenditure } \\
\text { per Head. }\end{array}$ & Year. & $\begin{array}{c}\text { Expenditure } \\
\text { per Head. }\end{array}$ & Year. & $\begin{array}{l}\text { Expenditure } \\
\text { per Head. }\end{array}$ \\
\hline $\begin{array}{l}18377^{\circ} \\
18400^{\circ} \\
18460^{\circ} \\
1850^{\circ} \\
1856 \\
1860^{\circ}\end{array}$ & - & $\begin{array}{lcl}\mathfrak{E} & \text { s. } & \text { d. } \\
3 & 2 & s \underline{2} \\
3 & 0 & 4 \\
2 & 18 & 7 \\
2 & 19 & 6 \frac{1}{2} \\
2 & 18 & 5 \frac{1}{2} \\
2 & 18 & 0+\frac{1}{4}\end{array}$ & $\begin{array}{l}1867 \\
1870 \\
1876 \\
1880 \\
1886 \\
1890\end{array}$ & \begin{tabular}{r|rrr} 
& $£$ & $\mathrm{~s}$. & $\mathrm{d}$. \\
$\cdot$ & 3 & 12 & $i$ \\
$\cdot$ & 3 & 16 & 1 \\
$\cdot$ & 4 & 9 & 0 \\
$\cdot$ & 3 & 10 & 11 \\
$\cdot$ & 3 & 6 & 10 \\
. & 3 & 13 & 0
\end{tabular} & $\begin{array}{r}1896 . \\
1899 . \\
1908 . \\
1909 . \\
\ldots \\
\ldots\end{array}$ & $\begin{array}{ccc}£ & s . & d . \\
3 & 15 & 6 \\
3 & 19 & 11 \frac{1}{2} \\
3 & 12 & 3 \frac{1}{4} \\
3 & 8 & 11 \frac{1}{2} \\
& \ldots & \\
& & \ldots\end{array}$ \\
\hline
\end{tabular}


TABLE XI.-The National Drink Bill. Consumption in 1909

ENGLAND and Wales (Population, $35,756,615$ )

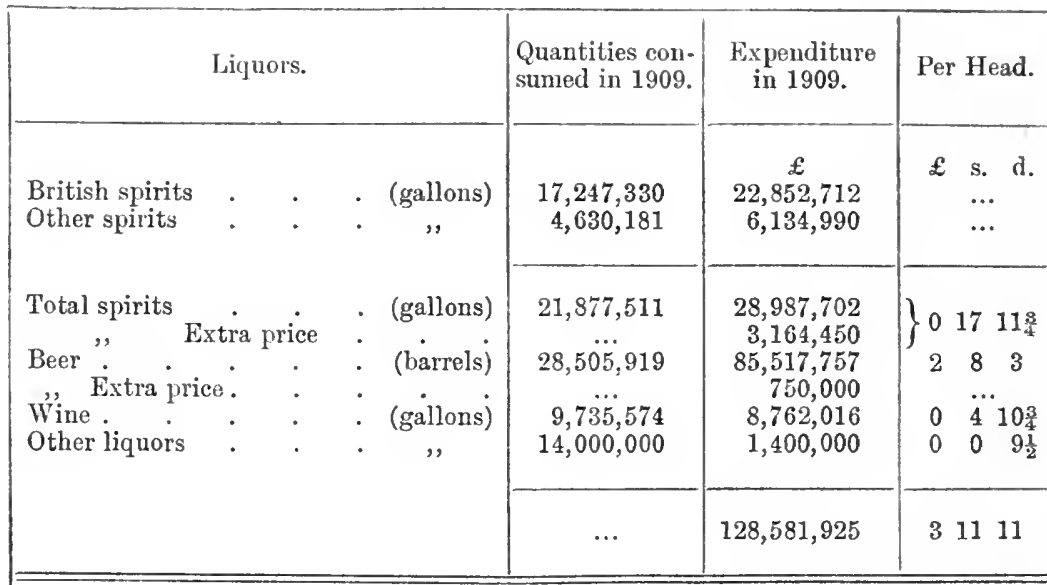

Scotlaxd (Population, 4,877,648)

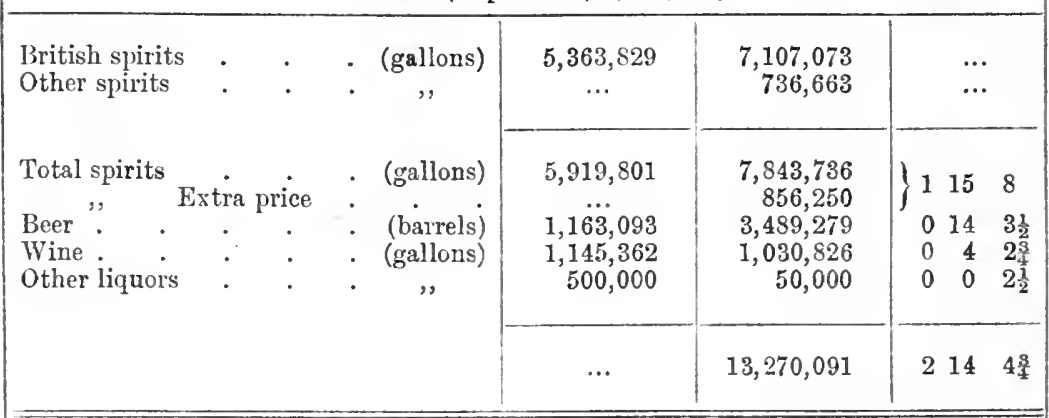

IreLAND (Population, 4,370,121)

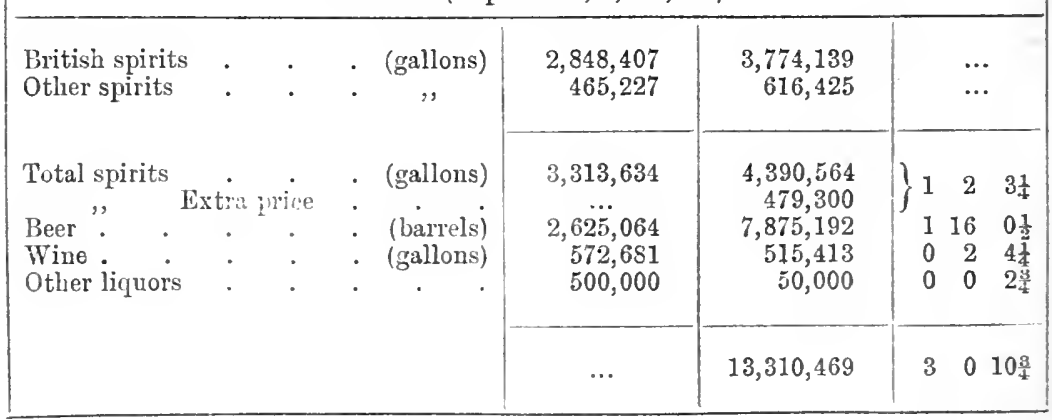

Since 1899 a decline in the expenditure on alcoholic beverages per head, and in the revenue obtained from the licensing and excise 
duties, is marked. This decline is due to various causes. According to a parliamentary paper, "The diminishing consumption of alcoholic liquors, though to some extent attributable to the recent depression of trade, is principally the result of a continuous change in the habits of the people, which has been in progress for some time, and seems likely to be permanent." A third cause, operative in the last year, is the rise in the price of spirits effected by the Budget of 1909-1910.

The annual average of cases of drunkenness was in 1857-1861, 84,358 ; in 1903-1907, 219,675; while in 1907 in London alone 11,841 males and 6660 females were proceeded against for simple drunkenness, 22,565 males and 9439 females for drunkenness with aggravation.

The rate per thousand of persons tried annually for drunkenness has risen from 3.94 in 1857 to 6.01 in 1907 .

TABLE XII

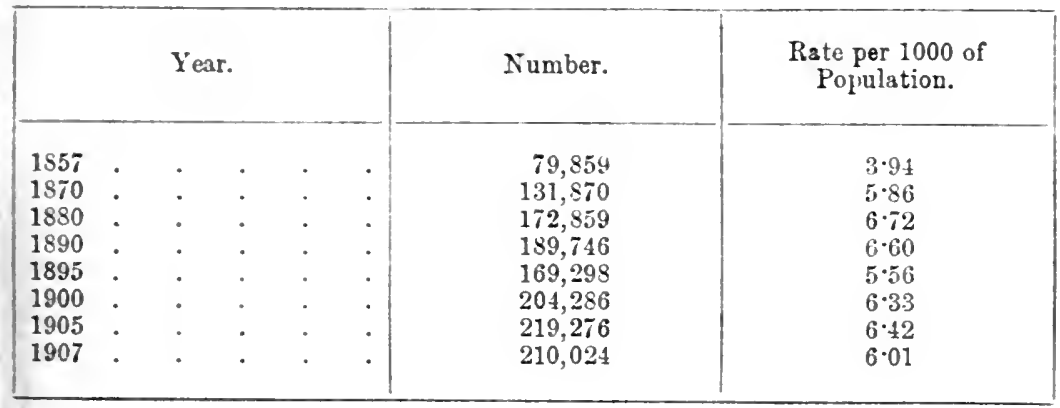

The effect of intemperance in shortening life can be measured by the number of deaths from aleohol, though, as shown in Table XIII, the death-rate so caused has risen alarmingly, more especially in the case of women.

Figures given by the Insurance Companies (Appendix XV1, Physical Deterioration Committee) show that of 6215 men between 25 and 65,1000 die in one year; but of 6125 abstainers only 560 die in one year. The report sums up the subject in unequivocal language:- " As the result of evidence laid before them the Committee was convineed that alcohol is the most potent and deadly agent of physical deterioration."

The increase of driuking habits among women is noted by $\mathrm{Mr}$. Charles Booth in his Life and Labour of the People: and he says it is an increase of both drink and drunkemness among them, although 
he finds on the whole that "while there is more drinking among men there is less drunkenness." The Physical Deterioration Committee remark the same thing. "The tendency of the evidence was to show that drinking habits among women of the working classes are certainly growing, with consequences extremely prejudicial to the care of offspring, not to speak of the possibility of children being born permanently disabled."

TABLE XIII.-Annual Death-rates from Alcoholism in England and Wales per million living, 1875-1904 (Registrar-General's Reports)

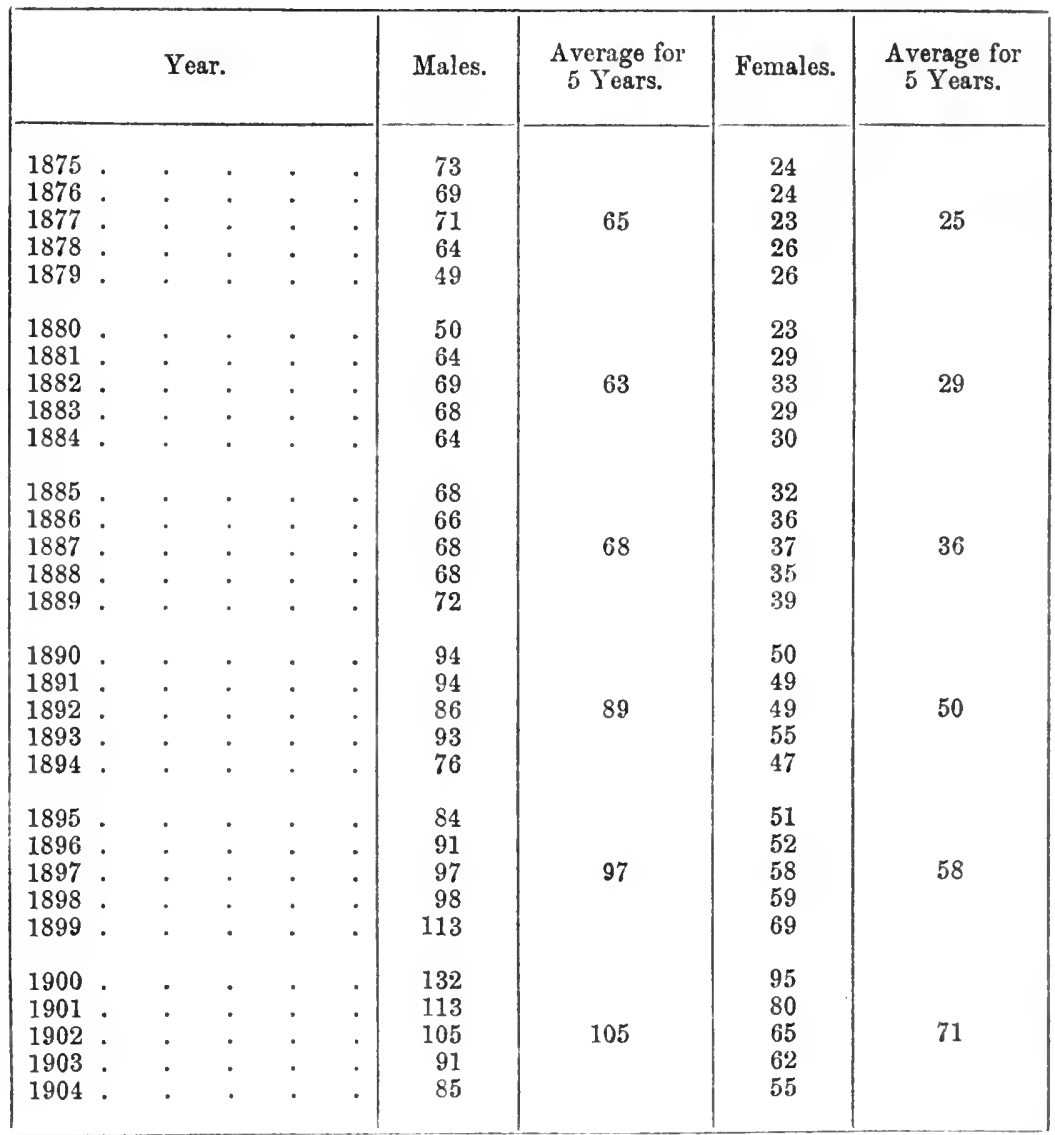

The connexion of drink, and especially of habitual drunkenness, with crime, is obvious. The Habitual Drunkards Act of 1879 was the first systematic effort to deal with this class. It provided short terms of imprisonment for disorderly or criminal drunkards, 
who might, voluntarily, submit themselves to detention in a retreat.

This voluntary method proved a complete failure. The Act of 1898 established a court with power to commit the habitual drunkard to an inebriate reformatory for a term not exceeding three years-this applies to habitual drunkards committing penal offences, or three times convicted, or disorderliness, etc. For the corrigible cases, there are Certified, and for the incorrigible, State Inebriate Reformatories.

Unfortunately the practice of the Law Courts maintains the short-sentence system, which is useless as a means of dealing with persons of this class. Out of 1012 cases only 510 have been committed for three years, although in such cases reversion to drinking habits is almost invariably followed by a recurrence of the tendency to commit the offence; since, as the Medical Inspector of Prisons declares in his Report, " a large number of drunken recidivists are persons of congenitally weak mind."

\section{Division III.-Insanity}

Lunacy.-The earliest statute dealing with lunacy is 17 Edward II, which asserts the royal prerogatives in the case of the property of a person who is either "fatuus naturalis," i.e. an idiot, or "non compos mentis sicut quidam sunt per lucida intervalla," i.e. subject to recurring intervals of madness; in either case incapable of managing his own affairs. But for the poor lunatic no provision was made until the 17 George II ordered him to be "apprehended and kept safely locked up in some secure place ... and if the justices of the peace find it necessary, then to be chained." His goods were to be seized for his maintenance. He was looked upon merely as a danger to others; and from this point of view arose the extraordinarily inbuman mode of treatment that prevailed far into the nineteenth century. "Many and dangerous abuses" known to exist in the "present state of madhouses" led to a permissive Act for the creation of asylums in 1808. But the state of things in them continued to be appalling.

Public opinion on the subject was quite barbarous. It was the recognized amusement of respectable Londoners on Sunday to visit Bedlam, and view the wretched maniacs who were chained naked to pillars with no bed but straw. Wilder patients were in solitary confinement in cells where walls had no glazing, their windows no glass, and where the cold and darkness of the winter were in 
themselves sufficient to have unhinged their minds. No one saw them but the keeper, the medical officer's visits were infrequent and irregular. Many patients were kept confined in chains for years although there was no real proof of their insanity, but the desire of relatives to get them out of the way.

In 1814 the old Bethlehem Hospital in Moorfields was pulled down and a new building erected in St. George's Fields, but the old abuses continued with little improvement till fifteen Commissioners were appointed to visit the asylums all over the country. In 1844 the Report of the Metropolitan Commissioners led to further inquiry, and in 1859 the Lunacy Commission was constituted in its present form-consisting of six paid visiting members, three being men of medical and three of legal experience, five unpaid members and an unpaid chairman to form a committee-to which all plans for buildings, etc., must be submitted, and by whom all persons admitted to asylums must previously be examined. The work of the Commission-on January 1, 1906 there were 116,361 lunatics to be visited-is admittedly beyond its present powers. In Scotland the Lunacy Board consists of two paid doctors who visit, and two unpaid lawyers and an unpaid chairman, who are members of committee but do not visit.

Insanity.--Since the formation of the Lunacy Commission in 1859 enabled a more or less accurate estimate of the numbers of the mentally affected to be made, there has been a constant increase in the number of the registered insane in England and Wales; and the rate of that increase has considerably exceeded the rate of increase of population.

The figures for 1844 , based upon a Report of the Metropolitan Commissioners in Lunacy to the Lord Chancellor, are admittedly incomplete. They give an estimate of 21,427 insane (see Table XIV), or 1.3 per thousand of population. For 1906 the number of the insane under the control of the Lunacy Commissioners was 121,979 , or 3.5 per thousand of population. Certainly, as years passed, the figures of the Commissioners have grown more complete; there is a decreasing amount of feeble-mindedness which remains outside their ken, an increasing reserve of it under their control.

In the census of 1901 the word "feeble-minded" was substituted for lunatic, imbecile or idiot, with the result that a return was obtained more accurate as to numbers but not really comparable with the preceding years. According to these returns there has been an increase in the number of the mentally deranged 
amounting to 770 between 1871 and $1881 ; 3.2$ per cent. between 1881 and 1891 ; and 21.4 per cent. between 1891 and 1901, when the new terminology was introduced. In 1871 the rate was $3 \cdot 0$ per thousand, in $18813 \cdot 25$, in $18913 \cdot 35$, and in $19014 \cdot 07$ per thousand.

TABLE XIV.-Lunacy (1844)

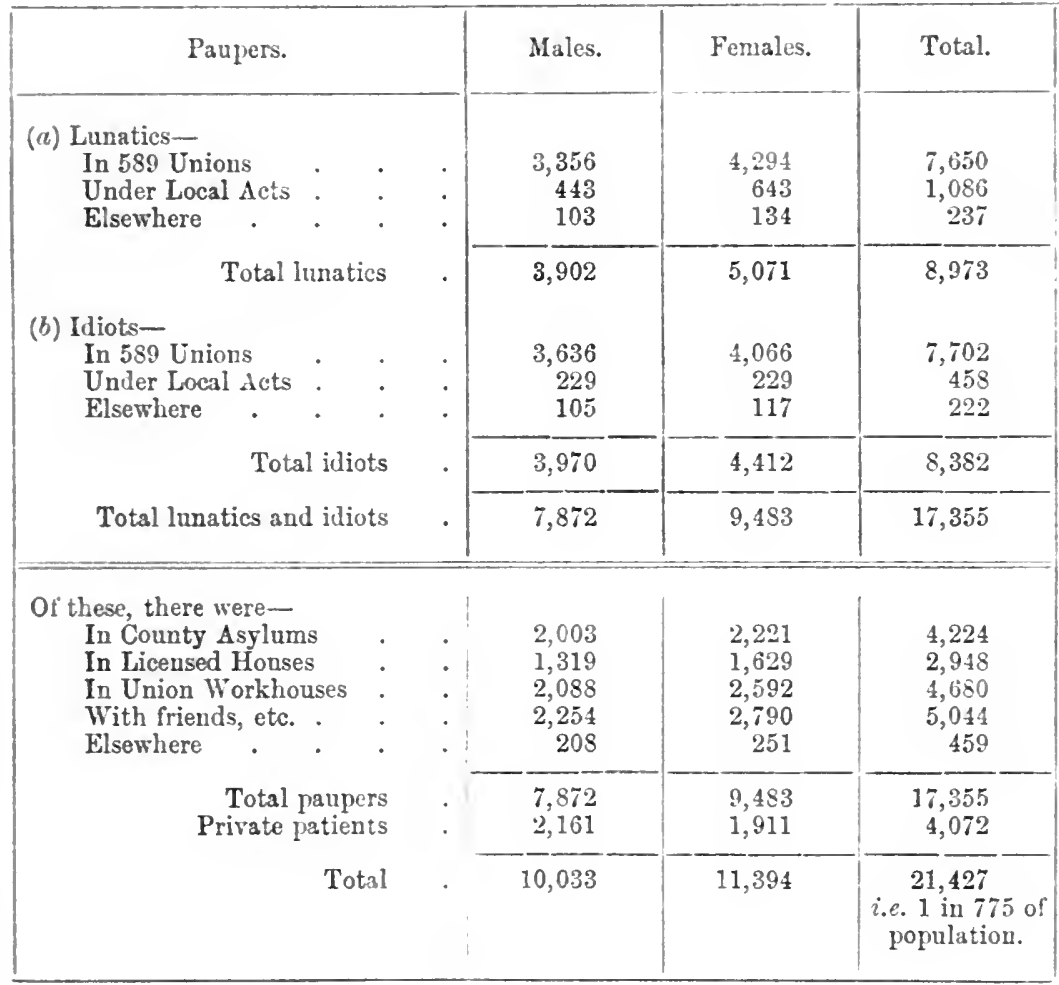

But, on the one hand, this constant increase in the number and proportion of the insane is partly due to other causes than an actual increase in the proportion of the insane.

It is due (1) to the growing tendency to treat an increasing proportion of cases of mental unsoundness in asylums.

The improvement in asylum treatment has led to a wider appreciation of the fact that there is no real humanity in keeping a mentally unsound person in the home; it is kind neither to him nor to the relatives who have to look after him. In the early decades of the century cruelty only could induce the friends of a mentally afflicted person to commit them to Bedlam. 
Since 1888 the establishment of a grant of $4 \mathrm{~s}$. a week, paid by the exchequer towards the maintenance of pauper lunatics in County Borough Asylums, added to the pressure on accomodation in many unions due to the increase in the number of aged paupers, has caused this tendency to apply to the case of insane or feeble-minded inmates of workhouses. The apparent increase in the number of insane paupers, especially among the aged, is greater than the real increase, for this reason.

(2) It is due to the reduction of the rate of mortality, and of the rate of discharge of the insane under treatment in asylums, which has caused and is still causing a very considerable accumulation of cases there (Table XV). As Dr. Farr declared in 1841: "There may be ten times as many lunatics in civilized as in barbarous times and countries; not because the tendency to insanity is greater, but because the lunatics live ten times as many months or years."

TABLE XV.-Mortality of the Insane (1904)

\begin{tabular}{|c|c|c|c|c|c|c|}
\hline \multirow{2}{*}{ Ages. } & \multicolumn{2}{|c|}{$\begin{array}{l}\text { Annual Rate of } \\
\text { Mortality per } 1000 \\
\text { Males. }\end{array}$} & \multicolumn{2}{|c|}{$\begin{array}{l}\text { Annual Rate of } \\
\text { Mortality per } 1000 \\
\text { Females. }\end{array}$} & \multicolumn{2}{|c|}{$\begin{array}{l}\text { Annual Rate of } \\
\text { Mortality per } 1000 \\
\text { Persons. }\end{array}$} \\
\hline & $\begin{array}{l}\text { England } \\
\text { and Wales. }\end{array}$ & $\begin{array}{l}\text { In } \\
\text { Asylums, } \\
\text { etc. }\end{array}$ & $\begin{array}{c}\text { England } \\
\text { and Wales. }\end{array}$ & $\begin{array}{l}\text { In } \\
\text { Asylums, } \\
\text { etc. }\end{array}$ & $\begin{array}{c}\text { England } \\
\text { and Wales. }\end{array}$ & $\begin{array}{l}\text { In } \\
\text { Asylums, } \\
\text { etc. }\end{array}$ \\
\hline $\begin{array}{l}\text { Above } 15 . \\
15-25: \\
25-45 \\
45-65 \\
65 \text { and upwards }\end{array}$ & $\begin{array}{r}15 \cdot 2 \\
3 \cdot 7 \\
7 \cdot 5 \\
23 \cdot 4 \\
92 \cdot 7\end{array}$ & $\begin{array}{r}111 \cdot 9 \\
71 \cdot 7 \\
86 \cdot 5 \\
108 \cdot 7 \\
252 \cdot 6\end{array}$ & $\begin{array}{r}13 \cdot 8 \\
3 \cdot 1 \\
6 \cdot 2 \\
18 \cdot 4 \\
83 \cdot 6\end{array}$ & $\begin{array}{r}85 \cdot 9 \\
65 \cdot 7 \\
59 \cdot 8 \\
76 \cdot 0 \\
190 \cdot 4\end{array}$ & $\begin{array}{r}14 \cdot 5 \\
3 \cdot 4 \\
6 \cdot 8 \\
20 \cdot 8 \\
87 \cdot 5\end{array}$ & $\begin{array}{r}97 \cdot 9 \\
69 \cdot 0 \\
73 \cdot 1 \\
90 \cdot 8 \\
214 \cdot 5\end{array}$ \\
\hline
\end{tabular}

But, on the other hand, between the figures of the insane as returned in the census, and those coming under the cognisance of the Lunacy Commissioners, there has always been a discrepancy. Since 1871 this difference steadily declined. In 1871 it was 17.8 per cent.; in $1881,13.5$; in $1891,10.9$. But in 1901 , when the new census nomenclature was introduced, the percentage of deficiency in the Commissioners' figures rose again to 18.69 per cent.

This state of things gravely impressed the Royal Commission on the Feeble-minded, 1908. They say in their Report: "There are numbers of mentally defective persons whose training is neglected, over whom no sufficient control is exercised, and whose wayward and irresponsible lives are productive of crime and misery, of much injury and mischief to themselves and to others, and of much 
continuous expenditure wasteful to themselves and to individual families." The number of mental defectives not in or connected with any institution, but living at home, is probably greater, certainly not less, than the census figure. Of 149,628 mentally defective persons estimated to exist in England and Wales by the Royal Commission, as many as 66,509 or 44.45 per cent. are, at the present time, urgently in need of provision. It is necessary that the special legal protection, at present granted to lunatics, imbeciles, and idiots, should be extended to all mentally defective persons.

TABLE XVI.-Estimated Number of Mentally Defective Persons (excluling Certified Lunatics) in England and Wales (Commission Report)

\begin{tabular}{|c|c|c|c|c|c|}
\hline (1) & 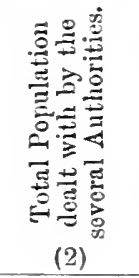 & 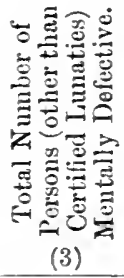 & 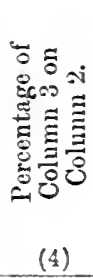 & 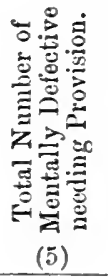 & 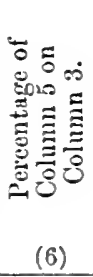 \\
\hline \multicolumn{6}{|l|}{$\begin{array}{l}\text { Registers } \\
\text { II. Poor Law- } \\
\text { 1. Indoor Paupers }\end{array}$} \\
\hline \multirow{3}{*}{$\begin{array}{l}\text { (casual included) } \\
\text { 2. Outdoor Panpers. } \\
\text { III. Lunacy- } \\
\text { 1. Certified Lunatics } \\
\text { 2. Uncertified. } \\
\text { IV. Prison Authorities- } \\
\text { 1. Local Prisons } \\
\text { 2. Convict Prisons. } \\
\text { Parkhurst Convict }\end{array}$} & $\begin{array}{l}229,80 \\
532,778\end{array}$ & $\begin{array}{l}41,793 \\
12,308\end{array}$ & $\begin{array}{r}18 \cdot 19 \\
2 \cdot 31\end{array}$ & $\begin{array}{l}6,990 \\
4,790\end{array}$ & $\begin{array}{l}16 \cdot 72 \\
39 \cdot 92\end{array}$ \\
\hline & & {$[19,517]$} & $\begin{array}{l}\ldots \\
\ldots\end{array}$ & {$\left[1,{ }_{145}\right]$} & {$[\ddot{9 \cdot 97}]$} \\
\hline & $\begin{array}{r}18,217 \\
3,004\end{array}$ & $\begin{array}{l}1,831 \\
\cdots\end{array}$ & $\begin{array}{c}10 \cdot 05 \\
\ldots\end{array}$ & $\begin{array}{c}1,608 \\
\ldots\end{array}$ & $\begin{array}{c}87 \cdot 82 \\
\cdots\end{array}$ \\
\hline \multirow{5}{*}{$\begin{array}{l}\text { Prison } \\
\text { V. State Criminal Linatic } \\
\text { Asylum, Broadmoor } \\
\text { VI. Inebriates in Certified } \\
\text { Reformatories } \\
\text { VII. Persons mostly under } \\
\text { no Public Authority }\end{array}$} & ... & 111 & $\ldots$ & $\ldots$ & $\ldots$ \\
\hline & & {$[800]$} & & & $\ldots$ \\
\hline & 970 & 582 & 60.00 & $\cdots$ & $\cdots$ \\
\hline & $25,576,697$ & 45,488 & 0.18 & 17,317 & $38 \cdot 07$ \\
\hline & $32,527,843$ & 149,628 & 0.46 & 66,503 & 44.45 \\
\hline
\end{tabular}

Mental Defect and Criminal Responsibility.-There is often a close connexion between mental defect and crime. No less than 10-28 per cent. of the inhabitants of prisons inspected by the Royal Commission are feeble-minded. This is brought out also by the medical officer's report in the Prison Commissioners' state- 
ment for 1909 (see Table XVII). In this percentage the State Criminal Asylum at Broadmoor is not included. There is a very large class of persons who cannot be certified as positive lunatics, but are yet from weakness of mind not really responsible. They are potential and very often actual criminals. When brought before the courts "the state of their mind is such that they ought not to be set at liberty and allowed to commit further crimes of the same sort."

TABle XVII.-Proportion of Mental Defect in Prisons, etc.

\begin{tabular}{|c|c|c|c|c|c|c|c|c|c|}
\hline \multirow{2}{*}{$\begin{array}{l}\text { Areas. } \\
\text { (Unions). }\end{array}$} & \multicolumn{3}{|c|}{$\begin{array}{l}\text { Number of } \\
\text { Prisoners seen. }\end{array}$} & \multicolumn{3}{|c|}{$\begin{array}{l}\text { Number } \\
\text { found Mentally } \\
\text { Defective. }\end{array}$} & \multicolumn{3}{|c|}{$\begin{array}{l}\text { Percentage of } \\
\text { Mental Defect. }\end{array}$} \\
\hline & 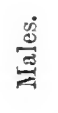 & 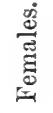 & 苞 & 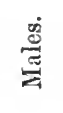 & 苞 & कृ & 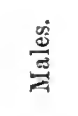 & 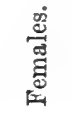 & 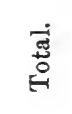 \\
\hline Stoke-upon-Trent & 138 & 31 & 169 & 27 & 6 & 33 & $19 \cdot 5$ & $16 \cdot 1$ & $18 \cdot 9$ \\
\hline Birmingham $\cdot$ & 334 & 69 & 403 & 28 & 16 & 44 & $8 \cdot 4$ & $23 \cdot 2$ & $10 \cdot 9$ \\
\hline and Prestwich. & & & 1,048 & 60 & 79 & 139 & & $\ldots$ & $13 \cdot 26$ \\
\hline Hull and Sculcoates. & 326 & 110 & 436 & 4 & ... & 4 & $1 \cdot 23$ & $\cdots$ & 0.92 \\
\hline Durham . & 61 & 18 & 79 & 2 & 1 & 3 & $3 \cdot 28$ & $5 \cdot 56$ & $3 \cdot 80$ \\
\hline Somerset . & $\ldots$ & $\ldots$ & 40 & 5 & $\ldots$ & 5 & & $\ldots$ & $12 \cdot 5$ \\
\hline Wilts. . . & 32 & 5 & 37 & 3 & $\ldots$ & 3 & $9 \cdot 38$ & $\ldots$ & $8 \cdot 11$ \\
\hline Nottinghamshire & $\ldots$ & $\ldots$ & 73 & 6 & 1 & 7 & & $\ldots$ & $9 \cdot 59$ \\
\hline \multirow[t]{2}{*}{ Lincolnshire . } & 68 & $\ldots$ & 68 & 4 & $\ldots$ & 4 & $5 \cdot 88$ & $\ldots$ & $5 \cdot 88$ \\
\hline & $\cdots$ & $\ldots$ & 2,353 & 139 & $\ldots$ & 242 & $\ldots$ & $\ldots$ & $10 \cdot 28$ \\
\hline
\end{tabular}

1.25 per cent. of the inmates of industrial schools and reformatories are feeble-minded. In general, feeble-minded children are excluded from industrial schools, but they are there too often, e.g.-

In Manchester, they are

,, Glasgow

, Belfast

, Dublin

,"
,,

$4 \cdot 6$ per cent.

$1.5 \quad$,

1.5,

2.48 ,

of the school population.

In the Manchester, Chorlton and Prestwich joint casual ward, 4 per cent. of the inhabitants were feeble-minded (1908); and 10 per cent. of the tramps in the casual wards in the country districts of Somerset.

Mental Defect and Inebriety.-There is a very close connexion between mental defect and the excessive use of alcohol. Alcoholic 
parents tend to have mentally defective children. In 150 defective children examined, 46.5 per cent. had alcoholism in their parental records. On persons of feeble mind the action of alcohol is positively poisonous. Experience under the Habitual Drunkards Act led the Royal Commissioners to the conclusion that habitual drunkenness often indicates mental defect. $62 \cdot 7$ per cent. of those in inebriate reformatories are mentally defective, 17 per cent. very defective, being imbecile, degenerate, or epileptic.

The condition of the mentally defective is substantially the same in England and Scotland. In Scotland there is no adequate provision for mentally defective children. In Glasgow the rate of mental defect was ' 26 of the population examined.

In Ireland, of 1527 cases dealt with by investigators to the Commission,

983 were returned as "needing provision."

Of these $\begin{cases}115 & \text { are idiots. } \\ 451 & , \text { imbeciles. } \\ 417, & \text { feeble-minded. }\end{cases}$

87 of them are in public elementary schools.

352 in poor-law institutions.

14 in receipt of outdoor relief.

and the rest at large. The accommodation existing in the workhouses is absolutely unsuitable. The provision in asylums is by no means ideal, and very expensive, while the majority of them at home are even worse off than those in the workhouse.

Judging from four typical areas selected, the rate of insanity in Ireland is .57 per thousand; the numbers, according to the census, have declined since 1861 . 


\section{CHAP'TER VII}

\section{THE PROGRESS OF EDUCATION}

Primary cducation-Voluntary schools-The Act of 1870-State aid and rate aid-Growth of secondary education-Endowed schools-The education of girlsContinuation and technical schools-The Board of Education-The Act of 1902Provided and unprovided schools-Evening schools-School feeding-UniversitiesScotland and Ireland

REVIEW of public education in England during the early
decades of the nineteenth century was little more than
a lament on the want of any general provision for it. "It would be difficult to conceive, if we had not the facts before us, that any nation calling itself civilized could have so totally neglected this all-important subject." Public instruction simply did not exist.

Primary Education.-In 1807 a Bill presented to Parliament by Whitbread for the purpose of establishing parochial schools on the plan in vogue in Scotland and abroad, was thrown out by the Lords, on the ground that instruction would tend to make the poor discontented with their lot in life. Sunday schools had been founded in 1784 by Robert Raikes of Gloucester; they, with the parochial charity schools, "in which the little that was taught had nothing in it that was useful," provided such poor children as were being educated at all with all the instruction they received. Many endowments were mismanaged and wasted: but the State did not interfere. The sects at last took up the neglected work. In 1798, Joseph Lancaster, a Quaker, opened what was practically a free school in St. George's Fields. The rapid increase of numbers soon induced him to found a second in the Borough Road. Owing to the pupil-teacher system which he introduced the expenses were not great, but as the numbers grew, as they did very quickly after the King in 1805 expressed the wish that "every poor child in his dominions should be taught to read the Bible," the necessary outlay on buildings increased so much faster than subscriptions 
towards them that Lancaster was in danger of being erushed by debt. At this point, Joseph Fox, William Allen, Joseph Foster and two other friends came to his assistance, and converted his private venture into the British and Foreign Schools Society.

Rise of Voluntary Schools. - The success of Lancaster's schools, where the religious teaching was undenominational and confined to the Scriptures, alarmed the Church. Very soon afterwards a second great association for the voluntary provision of education arose in the National Society for Promoting the Education of the Poor in the Principles of the Established Church, founded by Dr. Andrew Bell and Mrs. Trimmer. In these schools "the pupils were all obliged to receive instruction in the Liturgy and Catechism of the Established Church of Fngland, and were required to attend its prayers and services."

In 1816, Brougham's committee began its inquiry into education in London and the management of charitable endowments there, which subsequently extended its reference to cover the whole country; but the Bill he formulated in 1829 for the establishment of rate-aided schools was rejected owing to the irreconciliable claims of Churchmen and Dissenters, although the evidence showed that only 605,704 children were receiving instruction in England out of two millions requiring it.

State Aid.-In 1833 a government grant was made to the voluntary schools; and in 1839 the control of this subsidy was vested in a Committee of the Privy Council, which made inspection a condition of receiving a grant, and proposed the foundation of normal schools for the training of teachers. In 1839 the sum voted was $£ 30,000$; but in the next year a majority of 229 to 118 in the House of Lords prayed the Queen, happily in vain, to revoke the order creating the committee. The normal scheme failed owing to the opposition of the Church party.

One of the Poor-Law Commissioners reported in 1840: "It is impossible to overlook the fact that a certain portion of the upper and middle classes harbour a rooted distrust of any plan for the education of the poor."

In 1833 there were still only $1,2 \nmid 6,947$ daily scholars, including infant and Sunday schools, ont of a population of $:, 4,2,2,023$ between the ages of 5 and 15 . The standard of such education as was received was pitiably low; the schools frequented by children of the working classes being too often kept by persons "whose only qualification for this employment seemed to be their unfitness for every other." While nearly all the primary schools belonged to 
one of the two great voluntary societies, the connexion was often merely formal. There was no sort of uniform management, no code, no standard of teaching. Moreover, the distribution of schools was quite irregular. In many of the large manufacturing towns that were rapidly growing up there were no schools at all, while in some parts of the country charity had been too generous. Perbaps the greatest want was that of qualified teachers.

Between 1839 and 1870 a gradual change took place in the attitude of the Government and of the public generally towards the question of state interference. At first this was energetically opposed by all the sects; but the efforts of educational enthusiasts, among whom Sir J. Kay Shuttleworth was prominent, led to steadily increasing grants from the exchequer which in 1861 amounted to

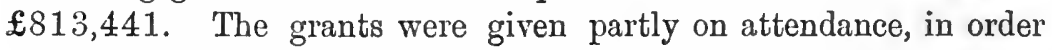
to encourage local managers to attract children to their schools; in 1861 the system of payment by results was formulated, and two-thirds of the grant was subsequently given on the principle that where the teaching was not efficient there should be no grant from the taxes.

\section{TABLE I.-Treasury Grants for Elementary Education (Great Britain)}

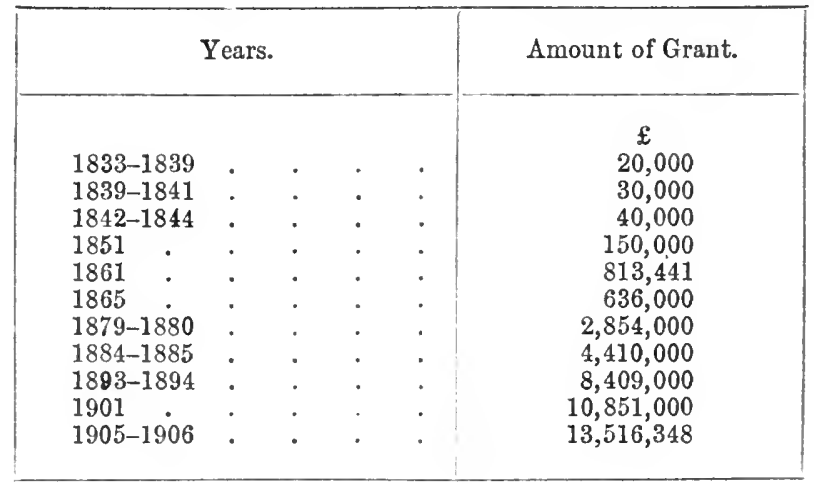

Meantime, although the attendance was still voluntary the numbers educated at schools subject to government inspection had been rapidly growing. In 1860 there were 962,732 children on the registers and 7249 certificated teachers; in 1870 the number of children had risen to $1,949,026$ and that of certificated teachers to 14,966 . But the proportion attending school was still small. In 1870 only two-fifths of children between 6 and 10 and onefifth of those between 10 and 12 were on the registers. There 
was still a great deficiency in proper accommodation. "No child need receive any instruction unless it happened to be a pauper, a criminal, the child of a soldier, or at work in a factory." 1

Education Act, 18ro.- In 1870, under Mr. Gladstone's ministry, Mr. Forster's Elementary Education Act was passed to remedy this deficiency in the supply of efficient elementary schools. The country was mapped out into school districts in which wherever accommodation was deficient school boards might be formed, elected for the purpose (ad hoc) by all ratepayers, and empowered to levy rates for the maintenance of public elementary schools.

Rate Aid.-In these rate-aided schools the teaching was to be purely undenominational (Cowper-Temple Clause). The Boards could make bylaws enforcing the attendance of children between 5 and 13. The exchequer grant continued, as before, to give state aid to all schools certified by inspection as providing education up to a certain minimum standard, and these schools were subject to inspection at any time except in the teaching of religious knowledge. Pates, on the other hand, were not to go to the maintenance of any denominational religious teaching. The conscience clause provided that in the voluntary schools (which remained practically untouched by the Act), parents were free to withdraw their children from religious teaching or observance, and such teaching or observance must be held always at the beginning or end of school hours.

In 1872 there were 82 board schools, 9772 voluntary ones: in 1903, 5965 "provided," 14,20S "non-provided" or voluntary schools. The average attendance, which had been 855,077 in $1860,1,152,000$ in 1870 (19 per cent. of population between 3 and 15), had risen to above 5,037,000 in 1903 (see Table II).

In 1876 elementary education up to a certain standard was made compulsory, the local authorities being empowered by their bylaws to fix the standard of exemption within certain prescribed limits. At the present day, all children must attend school between the ages of 5 and 14 , but the local authority may specially (a) exempt children under 11 for agriculture, $(b)$ grant half-time or full-time exemption to those between 11 and 14 who have attained a certain standard; they must at least have passed Standard IV (see Table III).

In 1907, in 41 per cent. of educational areas the bylaws allow no half-time exemption, and in 21 per cent. of thesc areas Standard VII is demanded for full-time exemption. In 1907,

${ }^{1}$ Redlich and Hirst, English Local Government, ii. p. 226. 


\section{Table II.-Pullic Elementary Education}

\begin{tabular}{|c|c|c|c|c|c|c|c|}
\hline & & \multicolumn{6}{|c|}{$\begin{array}{c}\text { Number of Scholars on Registers and Population } \\
\text { at corresponding ages. }\end{array}$} \\
\hline & & $\begin{array}{c}3 \text { and } \\
\text { under } \\
5 .\end{array}$ & $\begin{array}{l}5 \text { and } \\
\text { under } \\
7 .\end{array}$ & $\begin{array}{l}7 \text { and } \\
\text { under } \\
12 .\end{array}$ & $\begin{array}{c}12 \text { and } \\
\text { under } \\
15 .\end{array}$ & Total. & $\begin{array}{l}\text { Increase } \\
\text { per cent. } \\
\text { in } \\
10 \text { Years. }\end{array}$ \\
\hline $1870-18$ & & & & & & & \\
\hline $\begin{array}{l}\text { Scholars. } \\
\text { Population at } \\
\text { ponding ages }\end{array}$ & corres- & $\begin{array}{r}275,608 \\
1,619,228\end{array}$ & $\begin{array}{r}404,929 \\
1,222,613\end{array}$ & $\begin{array}{r}945,376 \\
2,596,224\end{array}$ & $\begin{array}{c}169,819 \\
1,427,863\end{array}$ & $\begin{array}{l}1,795,732 \\
6,315,928\end{array}$ & \\
\hline $1880-188$ & & & & & & & \\
\hline $\begin{array}{l}\text { Scholars. } \\
\text { Population at } \\
\text { ponding ages }\end{array}$ & $\begin{array}{l}. \\
\text { corres- } \\
.\end{array}$ & $\begin{array}{r}393,056 \\
1,339,826\end{array}$ & $\begin{array}{r}871,724 \\
1,309,599\end{array}$ & $\begin{array}{l}2,270,063 \\
3,008,196\end{array}$ & $\left|\begin{array}{c}523,826 \\
1,649,921\end{array}\right|$ & $\begin{array}{l}4,058,669 \\
7,307,542\end{array}$ & $\begin{array}{c}+126 \cdot 02 \\
+15 \cdot 7\end{array}$ \\
\hline $\begin{array}{l}\text { 1890-189 } \\
\text { Scholars. } \\
\text { Population at } \\
\text { ponding ages }\end{array}$ & $\begin{array}{l}\text { corres- } \\
. \quad \text {. }\end{array}$ & $\begin{array}{r}458,267 \\
1,377,515\end{array}$ & $\begin{array}{l}1,062,608 \\
1,374,495\end{array}$ & $\left\{\begin{array}{l}2,745,678 \\
3,350,518\end{array}\right.$ & $\begin{array}{r}566,033 \\
1,912,008\end{array}$ & $\begin{array}{l}4,832,586 \\
8,014,536\end{array}$ & $\begin{array}{r}+19.07 \\
+9.67\end{array}$ \\
\hline $\begin{array}{l}\text { 1900-190 } \\
\text { Scholars, } \\
\text { Population at } \\
\text { ponding ages }\end{array}$ & corres- & $\begin{array}{r}615,007 \\
1,428,597\end{array}$ & $\begin{array}{l}1,215,674 \\
1,399,882\end{array}$ & $\left\{\begin{array}{l}3,100,371 \\
3,433,546\end{array}\right.$ & $\begin{array}{r}835,707 \\
2,015,205\end{array}$ & $\mid \begin{array}{l}5,767,359 \\
8,277,230\end{array}$ & $\begin{array}{r}+19 \cdot 34 \\
+3.28\end{array}$ \\
\hline
\end{tabular}

TABle III.-T'able showing Average Duration of School Life and Age at leaving School, in Schools receiving Education Grants (England, 1907-1908)

$$
\text { A. Boys }
$$

\begin{tabular}{|c|c|c|c|c|c|c|c|c|c|c|c|c|}
\hline & \multicolumn{6}{|c|}{$\begin{array}{l}\text { Number of Schools in } \\
\text { which the Average Length of } \\
\text { School Life after } 12 \text { was- }\end{array}$} & \multicolumn{6}{|c|}{$\begin{array}{l}\text { Number of Schools at which the } \\
\text { Average Age of Leaving was- }\end{array}$} \\
\hline & 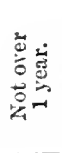 & 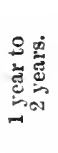 & 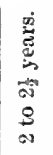 & 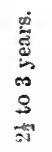 & 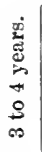 & 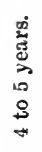 & 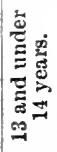 & 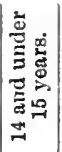 & 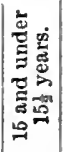 & 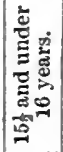 & 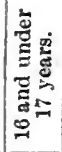 & 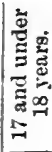 \\
\hline \multirow{3}{*}{$\begin{array}{l}\text { (a) Council Schools. } \\
\text { (b) Roman Catholic Schools } \\
\text { (c) Foundation and other } \\
\text { Schools . } \\
\text { Total }\end{array}$} &.$^{1}$ & $\begin{array}{r}40 \\
2\end{array}$ & $\begin{array}{r}44 \\
6\end{array}$ & $\begin{array}{r}45 \\
1\end{array}$ & $\begin{array}{l}3 \\
2\end{array}$ & .. & $\ddot{. .}$ & $\begin{array}{r}25 \\
4\end{array}$ & $\begin{array}{r}50 \\
3\end{array}$ & $\begin{array}{r}45 \\
4\end{array}$ & $\begin{array}{l}14 \\
. .\end{array}$ & .. \\
\hline & & 34 & 115 & 121 & 54 & 1 & .. & 27 & 112 & 124 & 62 & 2 \\
\hline & 1 & 76 & 165 & $16 ?$ & 59 & 1 & .. & 56 & 165 & 173 & 70 & 2 \\
\hline \multicolumn{13}{|c|}{ 13. Girls } \\
\hline \multirow{5}{*}{$\begin{array}{l}\text { (a) Council Schools. } \\
\text { (b) Girls' Public Day Schools: } \\
\text { (c) Roman Catholic Schools : } \\
\text { (d) Foundation and other } \\
\text { Schools . } \cdot \text {. } \\
\end{array}$} & 6 & 56 & 55 & 40 & & & .. & 9 & 30 & 51 & 73 & 5 \\
\hline & $\cdot$ & $\ddot{i r}_{r}$ & 2 & 7 & 20 & 2 & .. &.$_{3}$ & $\begin{array}{l}3 \\
6\end{array}$ & $\begin{array}{r}4 \\
13\end{array}$ & $\begin{array}{l}24 \\
15\end{array}$ & 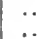 \\
\hline & 1 & 16 & & & & & & & & & & \\
\hline & 1 & 14 & 61 & 36 & 26 & .. & .. & 10 & 21 & 45 & 61 & 2 \\
\hline & 8 & 87 & 130 & 88 & 59 & 2 & .. & 22 & 60 & 113 & 173 & 7 \\
\hline
\end{tabular}


211,000 children between 11 and 14 obtained full-time exemption and 48,000 half-time exemption. But the Consultative Committee of the Board record their conviction of the social evils of the half-time system, which are also acknowledged by workingclass leaders, and there is a strong feeling among reformers generally that the limit of age for primary education should be raised at least to 15 .

In 1891 elementary education was made free as well as compulsory, at a cost to the nation of two millions per annum. Uniformity of administration was partially secured by the Act of 1890 ; and the code formulated as the result of the Commission of 1858 has gradually been improved by an extension in the field of choice of optional subjects. In 1897 , payment by results was abolished and the grant determined by attendance. A uniform standard of primary education once established depends for efficiency on teachers and inspectors. In England there are under the senior chief inspectors appointed by the Board, 11 chief inspectors, 87 inspectors, 23 juniors, 52 first-class sub-inspectors and 11 subinspectors in manual instruction and drawing.

As regards the training of teachers the nation has preferred voluntary instruction to the state normal school. In 1901 there were 17 day and 45 residential training colleges, with $418 \mathrm{~s}$ resident and 1426 day students, attached to universities and university colleges, trained on a two years' course that has from time to time to be submitted to the Board for approval. An efficient supply of teachers is largely a question of salary; and the salaries are still low- $£ 129$ for men and $£ 90$ ior women being about the average.

Before considering the administrative machinery established by the Act of 1902 for co-ordinating primary and secondary education, a brief sketch of the growth of education other than elementary may be given, bearing in mind, however, that there never has been devised any satisfactory distinction between the two.

Secondary Education. - Though in 1833 the State began to feel its responsibility for primary education, it was not until 1861 that secondary instruction received serious attention. Broughan's Commission in 1816 had shown the existence of great abuses in the management of charitable endowments, and the nuethols of the great public schools had been long known to be very imperfect. At Eton, for instance, the number of school hours was said to be only eleven a week. The education given was wholly classical, and bad at that. Sidney Smith paid from $£ 150$ to $£ \geq 00$ a year to 
have his son educated at Westminster, and said that the system of tyranny exercised by the elder boys there was intolerable. "The English are very fond of this, and think that it fits a boy for the world; but the world, bad as it is, has nothing half so bad." The idolatry of games was detrimental to learning. The curriculum of these grammar schools was narrow in the extreme, and they were of course confined to the upper classes. Technical education did not exist.

In 1861 a Commission was appointed to inquire into the management of the nine great public endowed schools-i.e. Eton, Harrow, Westminster, Winchester, Rugby, Charterhouse, Shrewsbury, St. Paul's, and Merchant Taylors (which were then educating 2696 boys, in 1901 well over 5000). The Public Schools Act of 1868 led to substantial and much needed reforms in the seven boarding-schools. It was for this Commission, which extended the scope of its inquiry to cover all the endowed schools in the country, that Matthew Arnold investigated the systems of Germany and Switzerland and returned with the message, "organize your secondary and superior instruction." The epoch-making report finally issued caused the formation of a committee, merged in 1874 in the Charities Commission, and the passing of the Endowed Schools Act in 1869 , with the reform of over 900 endowments.

Endowed Schools.-The condition of things found by the Commission had certainly been lamentable enough. In two-thirds of the towns of England there was no school at all above the primary school. In those that did exist the education was often miserable. "The schools, either public or private, which are thoroughly satisfactory are few," the Commission declared, "in proportion to the need." The improved administration introduced caused nearly every endowed school in the country to enter upon a new lease of life. New public schools sprang up, many quite without endowments; and in London and the provinces great day schools were founded or revived.

Girls' Education.-In their Report the Charity Commissioners declare- "as to one particular branch of national endowments, namely, that of the advancement of the secondary and superior education of girls and women, it may be anticipated that future generations will look back to the period immediately following upon the Schools Inquiry Commission, and the consequent passing of the Endowed Schools Act, as marking an epoch in the creation and endowment of that branch of education similar to that which is marked by the education of boys and men by the Reformation." In the earlier 
half of the century, deportment and accomplishments were considered all that was necessary for the life-equipment of an "elegant female." In 1848 a higher school or college was opened for women in Harley Street, with F. D. Maurice as its parent and founder. In 1847 Mrs. Reid, a Unitarian, established classes for women in her house in Bedford Square, which ultimately developed into Bedford College, now a constituent college of the University of London. Two pupils of Queen's College were Miss Beale, who in 1858 became prineipal of Cheltenham, which before her death had 1000 pupils; and Miss Buss, under whose able direction the Girls' Public Day School Company was founded on a commercial basis in 1873 , to provide for girls' instruetion of the same standard as the public schools give to boys. In 1897 the company owned 36 schools with over 7150 pupils. Already, too, women were knocking at the doors of the universities. In 1856 Miss White, and in 1872 Miss Garrett, applied to be admitted to a medical diploma at London University. In 1869 a group of women established at Hitchin the nucleus of Girton College; in 1871 Newnham was founded. Ten years later women were formally admitted to university examinations in Cambridge: while London placed them on that footing of complete equality with men which they now enjoy at all the universities of the kingdom except Oxford and Cambridge, where the privilege of a degree is still denied them.

Higher education, however, was for long confined to those who could afford to pay for it. Dr. Anderson, a professor at Glasgow University, gave lectures on experimental physics to working men in the evenings; and on his death he left his fortune for the foundation of a college where this work might be carried on. The leetures of his successor, Dr. Birkbeek, at Anderson's College were attended by 500 artisans. When he removed to London in 1804, Dr. Birkbeck founded the institute there which bears his name.

Technical Schools.-Mechanics' institutes existed in various parts of the country. In $18: 36$ the first Trade Designing School was established in London and similar schools in the provinces were subsidized by govermment grants, becoming in 1853 the nucleus of the Science and Art Department now located at South Kensington. Within the next decade the Working Men's College had been founded by F. D. Maurice on the same plan as the People's College at Sheffield, based upon the notion that teacher and taught must educate one another; and he found able helpers in Ruskin, Kingsley, Frederic Harrison, and many other notable 
men of the time. Polytechnics, too, began to spring up, organized by Quintin Hogg. Much effort, energy, and money was being expended: but far more was needed, and, above all, co-ordination and unity of administration was urgently required. In 1888 the government was stirred to do something. County Councils were set up and authorized to levy a penny rate for technical instruction. In the next year the Local Taxation (Excise) Act, by granting what is known as the "whisky moncy" to technical schools, suddenly gave them an annual sum equal to the income of all the endowed schools in England. All over the country there was a rapid multiplication of so-called technical schools, which were really in most cases very little different from the so-called secondary ones, since it was frequently found that the pupils had too little general groundwork to profit by specialized instruction. Meantime, the secondary schools proper were being starved. A very lax interpretation of "technical instruction" enabled the Science and Art Department to give grants to any instruction other than classical; and in this way crumbs fell to secondary education. But in 1894 , out of $£ 316,969$ administered by technical education committees, only $£ 17,169$ went to secondary schools.

Board of Education. - The general state of things was so unsatisfactory that in 1897 a Commission, with Mr. Bryce at its head, was appointed to inquire into the whole question; and they recommended the formation of one central authority to co-ordinate education throughout the country, regulate examinations, and raise the standard of the teaching profession. This authority is the new Board of Education.

The starvation of secondary education had led the school boards to endeavour to supply it. Many boards, created "principally to administer primary education," had added upper classes to their schools, and were thus giving what was really secondary education at the expense of the rates. At the same time they were organizing Evening Continuation Schools, also out of the rates. In 1900 there were 5263 such evening schools with 206,335 scholars. The Cockerton case brought up the whole question of the legrality of such expenditure. Mr. Cockerton, District Auditor of the Local Govermment Board, refused to pass an estimate containing such expenditure, and his refusal was confirmed by the Court of Appeal. It was thereby decided that the rates levied by the school boards could only be applied to the provision of primary education. In this state of confusion, when no definition existed as to what was and what was not primary education, it was 
evidently necessary for the Government to step in and complete the policy outlined by the Bryce Commission and initiated by the creation of the Board of Education, by a system of uniform provision and control. At the same time the Church was pressing for relief for the voluntary schools, in which more than half of the children in Englaud and Wales were still being educated (cf. Tables IV and V).

Education Act, 1902 (Mr. Balfour). - The Act passed in 1902 was therefore something of a compromise between educational and religious difficulties. By it school boards were abolished, and committees of the County, County Borough, and (for primary education) Borough and Urban District Councils made the local authorities for education with full control over all education within their area, save for the important reservation that the managers of the voluntary (or, as they are now called, non-provided) schools retain control over religious teaching in these schools and the appointment of teachers there. The local authorities may levy rates for the upkeep of all schools alike, and they administer the "whisky money" for secondary and technical education. Secondary instruction is simply defined as any given after 4 p.m. Higher education includes the training of teachers for elementary schools. In 1907 there were 328 such local education authorities, managing 19,207 schools -6579 being provided, 12,628 non-provided. In all provided schools denominational teaching is disallowed, except under special conditions which give all denominations equal facilities at their own cost. In many country districts, however, the only school is a non-provided one, where Church of England teaching alone is given. This is a real grievance to Nonconformists and others who have to pay rates for the support of teaching of which they do not approve for their children. Moreover, the fact that in these schools teachers are appointed by managers, whereas their salaries are paid by the education committee, means that from the greater number of schools and training colleges Nonconformists are as a matter of fact excluded.

TABLE VI.-Denominations of Voluntary Schools (England and Wales), 1908 (Number, 13,336 ; accommodation, 3,336,023)

\begin{tabular}{|l|r|r|r|r|r|}
\hline & $\begin{array}{r}\text { Church of } \\
\text { England. }\end{array}$ & Wesleyan. & $\begin{array}{r}\text { Roman } \\
\text { Catholic. }\end{array}$ & Jewish. & $\begin{array}{c}\text { Undenomina- } \\
\text { tional and } \\
\text { others. }\end{array}$ \\
\hline Number of Schools & - & 11,180 & 294 & 1,064 & 12 \\
Accommodation. & $2,624,789$ & 105,664 & 401,595 & 10,735 & 161,391 \\
\hline
\end{tabular}


It remains to be seen whether the smaller authorities for elementary education prove more efficient and more zealous than the school boards whose place they fill. At any rate, in the coordination of primary and secondary education a position is gained from which progressive improvement is possible.

Much remains to be done in an increase of efficiency among teachers. The organization of the teaching profession has, so far, been entirely the work of voluntary effort. In 1868 it was practically unorganized. 1870 saw the establishment of the Headmasters' Conference, and of the National Union of Teachers, which had 28,000 members in 1893. In 1874 the Association of Headmistresses was formed, and ten years later that of Assistants. Many others followed. But the great need is an improvement in salaries. "The headmasters were quite in agreement with the assistants as regards the inadequacy of the salary fund in many schools" (Bryce Commission III, 210). "There are clear indications from the evidence that the best work of efficient men is prevented by inadequate salaries from flowing into the schools."

TABLE VII.-Estimate of the Number of Boys and Girls at each Year from 11-21 attending and not attending School during 1906-1907

\begin{tabular}{|c|c|c|c|c|c|c|c|c|c|c|c|}
\hline \multicolumn{3}{|c|}{ Age. } & 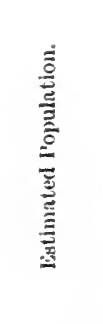 & 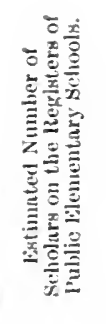 & 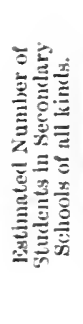 & 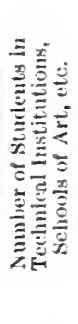 & 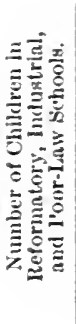 & 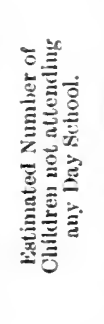 & 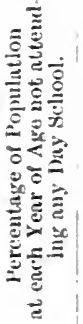 & 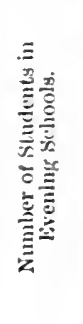 & 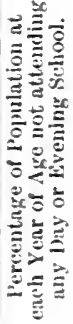 \\
\hline \multicolumn{3}{|c|}{11 and under 12} & 683,700 & 623,100 & 52,000 & .. & $3,35 i$ & 5,243 & & .. & 0.7 \\
\hline $\begin{array}{l}12 \\
13\end{array}$ & $"$ & $\begin{array}{l}13 \\
14\end{array}$ & $\begin{array}{l}657,300 \\
690,300\end{array}$ & $\begin{array}{r}596,759 \\
400,341\end{array}$ & $\begin{array}{l}66,000 \\
88,000\end{array}$ & $\begin{array}{l}1,639 \\
2,524\end{array}$ & $\begin{array}{l}4,652 \\
4,860\end{array}$ & $\begin{array}{r}18,250 \\
192,575\end{array}$ & $\begin{array}{r}2 \cdot 66 \\
27 \cdot 09\end{array}$ & $\begin{array}{r}3,526 \\
36,704\end{array}$ & $\begin{array}{r}2 \cdot 10 \\
22.53\end{array}$ \\
\hline 12 & ", & 14 & $1,37 \pi, 600$ & $1,005,100$ & 143,000 & 4,163 & 9,512 & 210,525 & $15 * 30$ & 40,530 & $12 \cdot 36$ \\
\hline $\begin{array}{l}14 \\
15 \\
16\end{array}$ & ", & $\begin{array}{l}15 \\
16 \\
16\end{array}$ & $\begin{array}{l}691,000 \\
689,100 \\
649,2(x)\end{array}$ & $\begin{array}{r}67,811 \\
6,932 \\
507\end{array}$ & $\begin{array}{l}80,000 \\
55,000 \\
34,000\end{array}$ & $\begin{array}{l}4,520 \\
4,158 \\
4,600\end{array}$ & $\begin{array}{l}3,351 \\
2,801 \\
1,042\end{array}$ & $\begin{array}{l}535,318 \\
610,179 \\
609,051\end{array}$ & $\begin{array}{l}77 \cdot 47 \\
89 \cdot 46 \\
93 \cdot 82\end{array}$ & $\begin{array}{r}92,368 \\
86,796 \\
77,035\end{array}$ & $\begin{array}{l}64 \cdot 10 \\
86 \cdot 3 \\
51 \cdot 95\end{array}$ \\
\hline 14 & , & 17 & $2,022,300$ & 75,950 & 172,000 & 13,303 & 7,194 & $1,754,540$ & $50 \% 76$ & 256,199 & $74 \cdot 09$ \\
\hline $\begin{array}{l}17 \\
15 \\
19 \\
90\end{array}$ & "" & $\begin{array}{l}18 \\
19 \\
90 \\
91 \\
\end{array}$ & & $\begin{array}{l}. . \\
. \\
. .\end{array}$ & $\begin{array}{r}18,000 \\
s, 000 \\
z, 000 \\
1,000 \\
\end{array}$ & & $\begin{array}{l}695 \\
257 \\
\because . \\
\therefore\end{array}$ & & & $\begin{array}{l}64,133 \\
53,7,0 \\
43,86 \\
36,992\end{array}$ & $\begin{array}{l}86 \cdot 57 \\
89 \cdot 83 \\
9 \cdot 45 \\
93 \cdot 58\end{array}$ \\
\hline 17 & ", & 21 & $2,639,900$ & .. & 29,000 & 17,335 & 952 & $2,592,613$ & $95-21$ & 198,796 & $90^{\circ} \mathrm{CS}$ \\
\hline
\end{tabular}

(From Report of Consultative Committee of Board of Education, Cd. 4557.) 
The State in 1898 passed the Teachers' Superannuation Act; and by the establishment of the register of trained teachers assists the maintain status; but no reform can be permanent short of an improvement in salaries.

Continuation Schools. - The proportion of those whose education is closed when they leave the elementary school is unfortunately still very large indeed. Even in the case of the middle classes the tendency is to cut the school period unduly short.

Of the total number of boys and girls coming under the control of the education authorities, 74.09 per cent. of those between the ages of 14 and 17 are receiving no schooling at all, and 86.76 per cent. are not attending any day school; while only 9 per cent. of those above 17 are attending any sort of school or college. Yet more than a third of the total expenditure incurred by local authorities under Part II of the Education Act in 1905-1906 went to the maintenance of schools and institutions for evening teaching, i.e. $£ 1,165,278$ out of $£ 3,141,248$. The total number of students attending evening or other continuation classes was in 1907-1908 701,538: of these only 126,435 received free instruction (cf. Table VIII).

TABLE VIII.-Evening and all Similar Schools and Classes (England), 1907-1908

I. Number of teachers-

Men

Women

II. Students-

12 and under 15

$15,2,18$

$18 \quad, \quad 21$

21 and over

132,100

212,762

123,705

232,971

Number on account of whom grants were paid .

547,228

" being $\left\{\begin{array}{l}\text { male } \\ \text { female }\end{array}\right.$

Total receiving free instruction .

Total paying for instruction

Total attending schools

701,538

III. Number of schools, classes, or centres recognized

6,234

356 out of the 676 secondary schools on the grant list of the Board of Education in 1906-1907 were centres for the instruction of pupil teachers, and educated 2265 boys and 6541 girls (roughly a half and a third respectively of the whole number) who were destined for elementary teaching. 
TABLE IX.-Secondary Schools (England), 1907-1908

\begin{tabular}{|c|c|c|c|c|c|c|}
\hline \multicolumn{6}{|c|}{ Number of Pupils. } & \multirow{2}{*}{$\begin{array}{l}\text { Number of } \\
\text { Schools on } \\
\text { Grant List. }\end{array}$} \\
\hline & & Under 12. & $\begin{array}{c}\text { Over } 12 \text { and } \\
\text { under } 16 .\end{array}$ & 16 and over. & Total. & \\
\hline Boys & . & 15,365 & 47,919 & 4,820 & 68,104 & 320 \\
\hline Girls & . & 11,540 & $3 \pi, 213$ & $\tau, 606$ & 56,359 & 239 \\
\hline Total & . & 26,905 & 85,132 & 12,426 & 124,463 & $\begin{array}{c}1 \pi \tau \text { (boys and } \\
\text { girls) }\end{array}$ \\
\hline Totsl & . & & & & & 736 \\
\hline
\end{tabular}

The latest developments with regard to elementary education have to do mainly with the health and physical condition of the children attending school. The first movement in that direction originated in the work of Hermann Cohn, and the results of his investigation, at Breslau, into the eyesight of 10,000 scholars there. In 1890 the first medical officer was appointed by the London School Board. A great stimulus to general interest in the question was given by the Report of the Committee on Physical Deterioration in 1904 , which drew attention to the need for improvement in the lighting, heating, and seating arrangements in schools, and stated that, over and above the desirability of more directly physical training, "there is need of a much more complete system of medical inspection than has yet been attempted." Certain local authorities had by this time already made the medical officer of health of their area medical officer to the education authority also: and in some localities arrangements had been made for feeding necessitous school children on a voluntary basis.

The Education (Provision of Meals) Act of 1906 gave power to local education authorities to take steps for providing school children with meals. The Education (Administrative Provisions) Act of 1907 further imposed on all local education authorities the duty of medically inspecting children attending public elementary schools, and empowered them, with the sanction of the Board, to make arrangements for attending to the health and physical condition of such children.

Table $\mathrm{X}$ shows the extent to which local authorities availed 
themselves of the Act of 1906, in the year 1908-1909. It will be seen that the proportion of expense borne by voluntary contributions is not considerable, and that the amount recovered from parents is negligible. For such recovery the education authority has of course no adequate machinery, and the whole working of the Act indeed imposes upon it a responsibility which is really outside of its proper sphere. "A large proportion of the badly nourished children suffer from unsuitable food rather than from lack of food. It is probably no exaggeration to say that the improvement which

Table X.-Education (Provision of Meals) Act. Expenditure and Receipts for 1908-1909

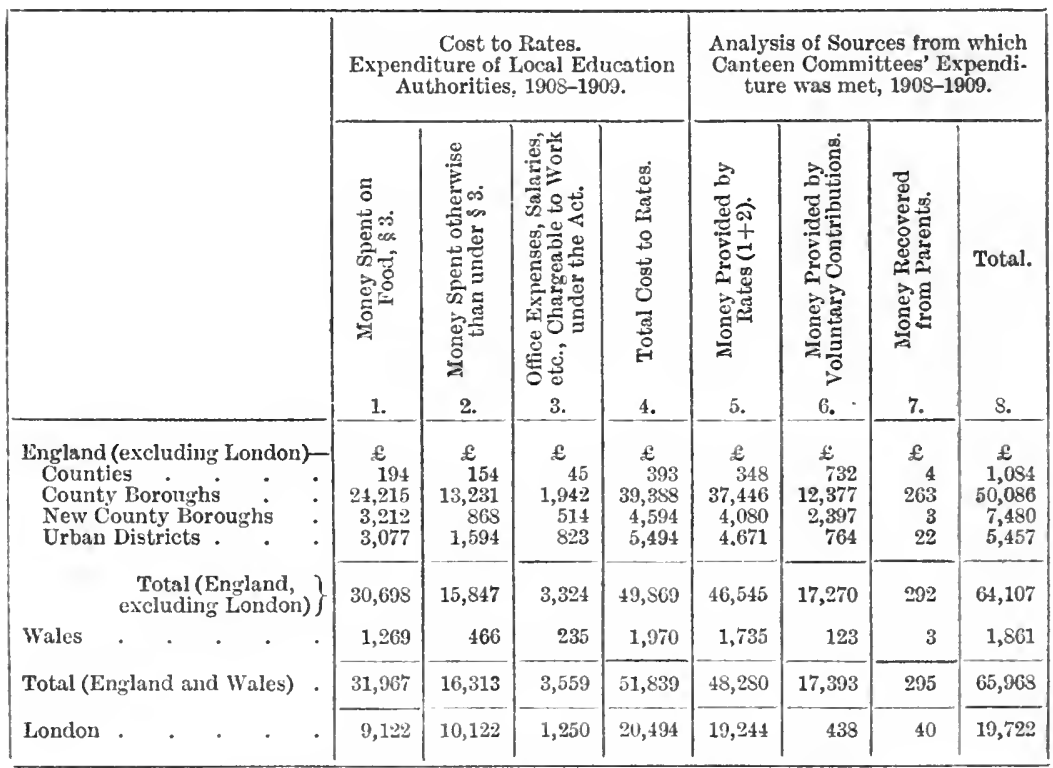

(From Report issued by the Board of Education, 1910, Cd. 5131.)

could be effected in the physique of elementary school children in the poor parts of our large towns, if their parents could be taught or persuaded to spend the same amount of money as they now spend on their children's food in a more enlightened and sensible manner, is greater than any improvement which could be effected by feeding them intermittently at the cost of the rates" (Report of the Board on the Working of the Act).

The Act of 1907 was followed up by three eireulars issued by the Board, suggesting the methods by which it could be carried out. "Whereas only a small minority of local education authorities 
had, before 1907 , made any arrangements for medical work in the public elementary schools, all the 328 authorities in England and Wales are now endeavouring, generally speaking with considerable enthusiasm and success, to make adequate provision for the medical inspection of children, and for meeting more or less effectually the collateral questions of school hygiene raised thereby" (Report of the Chief Medical Officer for 1908).

TABLE XI.-Illiteracy

\begin{tabular}{|c|c|c|c|c|c|c|c|c|}
\hline \multicolumn{2}{|r|}{ Year. } & & \multicolumn{2}{|c|}{ England and Wales. } & \multicolumn{2}{|c|}{ Ireland. } & \multicolumn{2}{|c|}{ Scotland. } \\
\hline $\begin{array}{l}1839 \\
1841 \\
1851 \\
1861 \\
1871 \\
1881 \\
1891 \\
1900 \\
1907\end{array}$ & $\begin{array}{ll}: & \cdot \\
\cdot & \cdot \\
\cdot & \cdot \\
: & \cdot \\
\cdot & \cdot \\
\cdot & \cdot \\
\cdot & \cdot \\
\cdot & \cdot\end{array}$ & $\begin{array}{l}: \\
: \\
: \\
:\end{array}$ & \begin{tabular}{|c} 
Males. \\
Per Cent. \\
33.7 \\
32.7 \\
30.7 \\
24.6 \\
19.4 \\
13.5 \\
6.4 \\
2.8 \\
1.4
\end{tabular} & $\begin{array}{c}\text { Females. } \\
\text { Per Cent. } \\
49 \cdot 5 \\
48 \cdot 9 \\
45 \cdot 2 \\
34 \cdot 7 \\
26 \cdot 8 \\
17 \cdot 7 \\
7 \cdot 3 \\
3 \cdot 2 \\
1 \cdot 7\end{array}$ & $\begin{array}{c}\text { Males. } \\
\text { Per Cent. } \\
\ldots \\
\ldots \\
\ldots \\
\ldots \\
37 \cdot 5 \\
26 \cdot 1 \\
19 \cdot 4 \\
13 \cdot 2 \\
\ldots\end{array}$ & $\begin{array}{c}\text { Females. } \\
\text { Per Cent. } \\
\ldots \\
\ldots \\
\ldots \\
\ldots \\
45 \cdot 2 \\
30 \cdot 7 \\
19 \cdot 4 \\
10 \cdot 7 \\
\ldots\end{array}$ & $\begin{array}{c}\text { Males. } \\
\text { Per Cent. } \\
\ldots \\
\ldots \\
\ldots \\
10 \cdot 6 \\
10 \cdot 0 \\
7 \cdot 1 \\
3 \cdot 4 \\
\ldots \\
\ldots\end{array}$ & $\begin{array}{c}\text { Females. } \\
\text { Per Cent. } \\
\ldots \\
\ldots \\
\ldots \\
21 \cdot 3 \\
19 \cdot 6 \\
13 \cdot 9 \\
5 \cdot 3 \\
\ldots \\
\ldots\end{array}$ \\
\hline \multicolumn{9}{|c|}{ IRELAND } \\
\hline - & Year. & & & $\begin{array}{l}\text { Persons ore } \\
\text { Read but } n\end{array}$ & $\begin{array}{l}\text { r } 5 \text { able to } \\
\text { ot Write. }\end{array}$ & & $\begin{array}{l}\text { lo neither } t \\
\text { nor Read }\end{array}$ & $\begin{array}{l}\text { o Write } \\
\text { d. }\end{array}$ \\
\hline $\begin{array}{l}1841 \\
1851 \\
1861 \\
1871 \\
1881 \\
1891 \\
1901\end{array}$ & $\begin{array}{l}\cdot \\
:\end{array}$ & : & $\dot{.}$ & $\begin{array}{l}19 \cdot 0 \text { per } \\
20.0 \\
20.0 \\
17 \cdot 0 \\
16 \cdot 0 \\
11 \cdot 0 \\
6.9\end{array}$ & $\begin{array}{l}\text { r cent. } \\
,, \\
, \\
", \\
", \\
",\end{array}$ & & $\begin{array}{l}53.0 \text { per ce } \\
47.0 \quad \text { ", } \\
39.0 \quad \text { ", } \\
33.0 \quad \text { ", } \\
25.0 \quad \text { ", } \\
18.0 \quad \text { ", } \\
13.7 \quad \text { ", }\end{array}$ & \\
\hline
\end{tabular}

(From the Registrar-General's Returns.)

For the great majority of the people school life still ends far too early, and in spite of all the progress slowly attained in the course of a century which has devoted much of the best energy of its best citizens to the cause of education, the instruction which is received, especially by the workers of the country, is still defective in many ways and capable of great inprovement. To the domestic ignorance of women and the industrial ignorance and want of adaptability of men, many of our greatest social difficulties are due.

Nevertheless, faith in the possibilities of education continues 
to be the surest foundation for a rational optimism, and some assurance of the possibility of accomplishment of the immense work still to be done can be drawn from a comparison of the present condition with that prevailing half or even a quarter of a century ago.

A bare enumeration of the number of schools existing and a record of the scholars attending them, does not measure the real educational opportunities open to everyone. Except in Ireland the proportion of persons without any education is fast disappearing (Table XI). There is now hardly any town-in Scotland, no village - that does not possess an excellent free library. There are disadvantages in the phenomenal development of the cheap sensational Press, but at the same time good literature has now been brought within the reach of all. In numberless ways the influence of the universities is extending so as to reach a much wider circle.

Universities. - At the beginning of the nineteenth century, Oxford and Cambridge, with a thousand students between them, were the only universities in England. University College, London, was founded on undenominational lines in 1826, and King's College followed on a Church basis five years later. In 1832 the grant of funds by the Dean and Chapter created the University of Durham. In $1846 \mathrm{John}$ Owens, a Manchester merchant, left his fortune for the foundation there of a college to be called after him, "free from the religious tests that then limited the extension of university education." The movement once started soon gathered strength. The Acts of 1852,1854 and 1871 abolished religious tests at the old universities. In the 'seventies and early 'eighties colleges sprang up at Aberystwyth (1872), Leeds (1874), Bristol (1876), Sheffield (1879), Birmingham (1880), Nottingham (1881), Liverpool (1882), Cardiff (1883), Bangor (1884). In 1893 the three Welsh colleges were incorporated in the University of Wales, and in the course of the next decade Manchester, Birmingham, Liverpool, Leeds, Sheffield, and Bristol received charters as independent universities with power to grant degrees of their own.

The new universities in many respects resemble those of Scotland more closely than they do Oxford and Cambridge. The comparatively lower seale of fees, made possible by a non-residential system, enabled them to reach a poorer class of students, though the diffusion of university education in Scotland has as yet no parallel in the South.

Something of that sort was the aim of the University Extension Movement that originated in lectures given by Mr. James Stuart, 
a Fellow of Trinity College, Cambridge, first to an association of women in the North of England, of which Mrs. Josephine Butler was president and Miss Clough secretary, and then to railway men at Crewe and co-operators at Rochdale. In 1873 this system was sanetioned by the University of Cambridge; and it was introduced in connexion with every university college. The Workers' Educational Association, started in 1903, is a later development of the same movement.

TABLE XII

\begin{tabular}{|c|c|c|c|c|c|c|c|}
\hline \multirow{2}{*}{\multicolumn{2}{|c|}{ Year. }} & & \multicolumn{4}{|c|}{$\begin{array}{c}\text { Cost of Public Education (Unirersities and Colleges } \\
\text { excluded). }\end{array}$} & \multirow{2}{*}{$\begin{array}{l}\text { Science and } \\
\text { Art Depart- } \\
\text { ment and } \\
\text { Iuseums. }\end{array}$} \\
\hline & & & $\begin{array}{c}\text { Great } \\
\text { Britain. }\end{array}$ & $\begin{array}{l}\text { England and } \\
\text { Wales. }\end{array}$ & Scotland. & Ireland. & \\
\hline $\begin{array}{l}1833 \\
1840 \\
1850 \\
1860 \\
1870 \\
1880 \\
1890 \\
1901\end{array}$ & 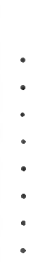 & : & $\begin{array}{c}£ \\
20,000 \\
30,000 \\
125,000 \\
798,167 \\
914,721 \\
\ldots \\
\ldots \\
\ldots\end{array}$ & $\begin{array}{c}£ \\
\cdots \\
\cdots \\
\cdots \\
\cdots \\
2,536,077 \\
3,782,221 \\
9,747,716\end{array}$ & $\begin{array}{c}£ \\
\ldots \\
\ldots \\
\ldots \\
\ldots \\
\ldots \\
464,203 \\
611,581 \\
1,363,881\end{array}$ & $\begin{array}{c}£ \\
25,000 \\
50,000 \\
125,000 \\
270.000 \\
381,172 \\
722,366 \\
918,316 \\
1,305,771\end{array}$ & $\begin{array}{c}£ \\
\ldots . \\
1,300 \\
14,755 \\
94,951 \\
218,336 \\
336,002 \\
474,896 \\
\ldots\end{array}$ \\
\hline \multicolumn{8}{|c|}{ Local Rates. } \\
\hline $\begin{array}{l}1880 \\
1890 \\
1901\end{array}$ & : & . & $\begin{array}{l}\cdots \\
\cdots \\
\cdots\end{array}$ & $\begin{array}{l}1,579,752 \\
2,968,096 \\
6,229,064\end{array}$ & $\begin{array}{r}205,011 \\
559,273 \\
1,012,360\end{array}$ & $\begin{array}{l}8,324 \\
8,192 \\
\ldots\end{array}$ & $\begin{array}{l}\ldots \\
\cdots \\
\cdots\end{array}$ \\
\hline
\end{tabular}

(From Graham Balfour, Educational Systems of Great Britain and Ireland.)

Scotland.-Even in 1850 every parish in Scotland contained at least one parish school, and "there were but few parishes in which further provision had not been made for the instruction of the people." In 1825 there were 56,232 scholars in parochial schools, 101,495 in non-parochial schools: in all 157,727 or $29 \cdot 84$ per cent. of the population between the ages of 5 and 15 . In 1837 there were 61,921 scholars in parochial schools, 128,318 in non-parochial schools: in all 190,239 or 3141 per cent. of the population between 5 and 15 . The academies and the burgh schools were thoroughly democratic in character: rich and poor learned their Latin and mathematics side by side there, and proceeded side by side to the universities, often when still children. 


\section{Table XIII.-Public Education (Scotland)}

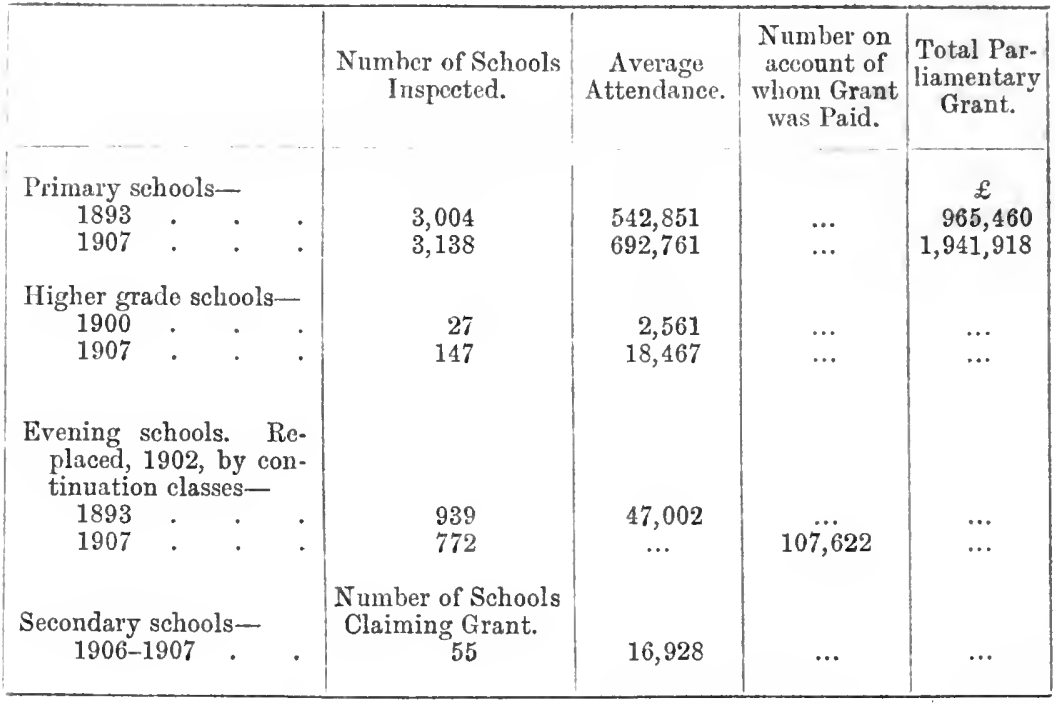

(From the Statistical Abstract, 1908, Cd. 4258.)

TABLE XIV.-Public Education (Scotland)

Teachers

\begin{tabular}{|c|c|c|c|c|c|c|c|c|c|c|c|c|}
\hline \multirow{3}{*}{\multicolumn{2}{|c|}{ Year. }} & & \multicolumn{4}{|c|}{ Certified Teachers. } & \multirow{2}{*}{\multicolumn{2}{|c|}{$\begin{array}{l}\text { Assistant } \\
\text { Teachers. }\end{array}$}} & \multirow{2}{*}{\multicolumn{2}{|c|}{$\begin{array}{c}\text { Pupil } \\
\text { Teachers. }\end{array}$}} & \multirow{3}{*}{\multicolumn{2}{|c|}{$\begin{array}{c}\text { Female } \\
\text { Assistants }\end{array}$}} \\
\hline & & & \multicolumn{2}{|c|}{ Traiued. } & \multicolumn{2}{|c|}{ Untrained. } & & & & & & \\
\hline & & & 惢 & 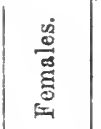 & $\frac{\dot{g}}{\stackrel{\Xi}{\rightleftarrows}}$ & 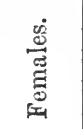 & $\stackrel{\dot{\Xi}}{\stackrel{\Xi}{\leftrightarrows}}$ & \multirow{2}{*}{ 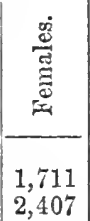 } & 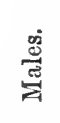 & 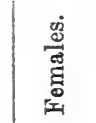 & & \\
\hline $\begin{array}{l}1893 \\
1907\end{array}$ & . & . & $\begin{array}{l}2,987 \\
3,882\end{array}$ & $\begin{array}{l}2,833 \\
5,829\end{array}$ & $\begin{array}{l}877 \\
940\end{array}$ & $\begin{array}{l}1,628 \\
4,370\end{array}$ & $\begin{array}{l}163 \\
207\end{array}$ & & $\begin{array}{l}75 \\
64\end{array}$ & $\begin{array}{l}3, \\
2,\end{array}$ & $\begin{array}{l}17 \\
40\end{array}$ & $\begin{array}{r}129 \\
69\end{array}$ \\
\hline \multicolumn{13}{|c|}{ Training } \\
\hline \multirow{2}{*}{\multicolumn{2}{|c|}{ Year. }} & \multirow{2}{*}{\multicolumn{2}{|c|}{ 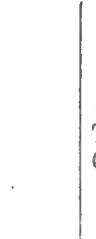 }} & \multirow{2}{*}{$\begin{array}{l}\text { Number } \\
\text { of } \\
\text { Training } \\
\text { Colleges. }\end{array}$} & \multicolumn{3}{|c|}{$\begin{array}{c}\text { Number of Students } \\
\text { in Training } \\
\text { Colleges. }\end{array}$} & \multirow{2}{*}{\multicolumn{2}{|c|}{$\begin{array}{l}\text { Number } \\
\text { of } \\
\text { Training } \\
\text { Centres. }\end{array}$}} & \multicolumn{3}{|c|}{$\begin{array}{l}\text { Number of Students } \\
\text { at other Training } \\
\text { Centres. }\end{array}$} \\
\hline & & & & & 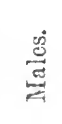 & 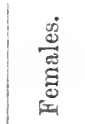 & 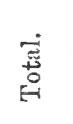 & & & 递 & 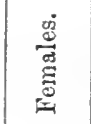 & हुं \\
\hline $\begin{array}{l}1893 \\
1907\end{array}$ & $\dot{.}$ & . & . & $\begin{array}{l}7 \\
2\end{array}$ & $\begin{array}{c}281 \\
\ldots\end{array}$ & $\begin{array}{l}658 \\
261\end{array}$ & $\begin{array}{c}939 \\
\ldots\end{array}$ & $\dddot{4}$ & & 606 & 2,138 & $2,7 \ddot{74}$ \\
\hline
\end{tabular}


In spite of the pronouncedly religious bent of the Scotch character, the denominations readily transferred their schools to the school boards created under the Act of 1872 to manage both primary and secondary education. These school boards still renain the local anthority for education in Scotland. In 1855 the Scotch Education Department was created to inspect public and endowed higher schools, and a government examination constituted to grant a leaving certificate on a uniform standard. In 190218,212 candidates sat for this certificate, coming from 441 schools of which 353 were under state control.

\section{TABLE XV.-National Education (Ireland) \\ Primiry Schools}

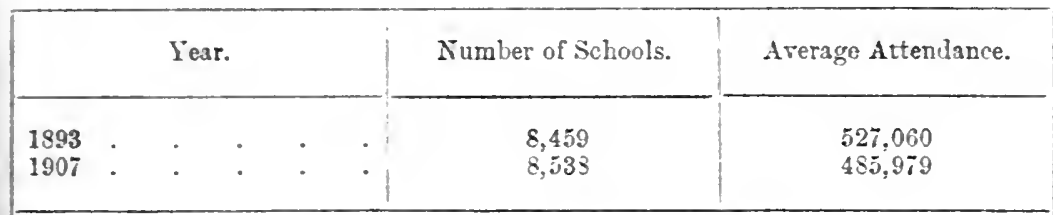

Teachers under the Dational Edusation Commissioners

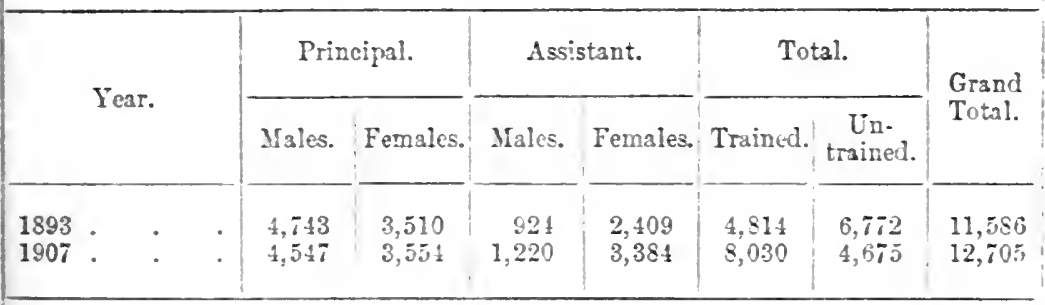

Espeiditure (Parliainentary Granls and Pates)

1893

$£ 1.193 .629$

1907

$£ 1,470,347$

Ireland.-The opposition offered to government control of education in England was of a moderate character when compared with the opposition shown to the Board of National Education organized in Ireland in 1831 by Lord Stanley. Great sums of money had previously been misspent on education in Ireland. To the Society for I'romoting English Protestant Schools upwards of $£ 1,100,000$ was roted at different times since its foundation in 1731 , and great sums were also granted to the Charter schools. But the object of these schools was not education, but the making 
of proselytes; and the result of their management precisely what might have been foretold. In the Charter schools pupils were entirely cut off from their parents.

In 1858 the Kildare Commission reported that there were only fifty-two endowed Grammar Schools, with an annual income of $£ 14,954$, while ninety-one towns had no endowed schools at all. Only three out of the six Diocesan Free Schools survived in 1880. In 1878 the Rosse Commission found the secondary schools to be quite antiquated, and the numbers attending endowed intermediate schools was for Protestants 199 per 100,000, for Catholics only 2 per 100,000 . At the disestablishment of the Irish Church $£ 32,000$ was set apart for intermediate education, granted on the system of payment by results.

Even now, although in 1891 a Board of Educational Commissioners was set up, there is no real co-ordination, and the system of payment by result remains. A new influence, however, has been brought to bear upon Irish Education by the Celtic movement, which seeks to preserve the Gaelic language and to revive interest in the old national literature. A genuine Irish school of literature and art has sprung up, and a new national university has been established in Dublin, which may prove a formidable competitor to Trinity College. 


\section{CHA PTER VIII}

\section{LOCAL GOVERNMENT IN GENERAL}

Historical-The development of the organs of English local gorernment-Edneation and public health - Functions of local suthorities - Municipal trading Innicipal finance-The Local Government Board

ATHOUGH it is necessary in estimating the progress of the nation to examine some of the different fields of activity of local authorities in considerable detail (cf. Chapters III and VI), it will be well to give some general outline of the development during the century and present form of local government in England. That development has been throughout conditioned by historical precedent. Proceeding within the forms existing, for the most part from the remote past, it has issued in a complex system that is in some ways unlike that of any other country.

Local government in England is, in the first place, subject throughout to the rule of ordinary law. It is legal in all its aspects, and governed not by any special law but by the ordinary law of the land. No local body, no local official, can act without definite legal authority. Official actions are judged in the same way and in the same courts as private actions. Administrative law, the droit administratif of the French code, does not exist. English local government is not bureaucratic or centralized. It is unofficial and autonomous. It is carried out locally and there controlled, not by salaried officials but by bodies of unpaid persons elected by the inhabitants of the locality concerned.

Its development has proceeded within these conditions on morc or less empiric lines. In the course of the century two main tendencies may be marked, neither of which has proceeded unimpeded or as yet attained its full development. There is first the gradual and as yet far from complete realization of the principle laid down by Mill in his Representative Government. "The authority," he says, "which is most conversant with principles should be supreme orer principles, while that which is most 
competent in details should have the details left to it. The prineipal business of the central authority should be to give instruetions, of the local authority to apply them. Power may be localized, but kuowledge to be most useful must be centralized." Central control in the positive sense even now hardly exists, but there is a real if negative eontrol in the powers of inspection, of audit, and of withholding a grant, that have been gradually developed by the eentral departments of state over the boards that earry out similar functions loeally. At the beginning of the century even the most rudimentary form of interdependence was absent, while the powers of municipal corporations and select vestries were regarded by those who exercised them as privileges carrying little responsibility. The second noticeable feature is the gradual democratization of loeal government by a movement parallel to that which gradually widened the parliamentary franchise. The three landmarks of constitutional reform throughout the eentury - 1832,1867, and 1884 - serve to mark the periods of internal and administrative reform that followed after each of them. Politieal change reacted almost at once in each case upon loeal government.

The Reform Bill of 1832 was followed immediately by the Poor Law Amendment Aet of 1834, in which the recommendations of the Royal Commission were transferred to the statute book, the whole method of administering relief reformed, and a Central Poor Law Board eonstituted, at first only for five years. A new poorlaw district (the Union) was erected to take the place of the parish and enlarge the area so that there might be "aggregation for the purposes of segregation"; and a new organ of poor-law administration created to take the place of the justices of the peace, in the board of guardians elected by the ratepapers, the larger ratepayers having additional votes. The Central Board had powers of audit and sureharge, and could dismiss though not appoint officials. There was to be inspection. The whole was a triumph of Benthamite ideas.

Almost immediately on this great reform there followed the reorganization of the municipal boroughs, again as the outeome of the findings of a Royal Commission. The Report issued in 1835 displayed a. state of things hardly less chaotic and injurious than that of the old poor laws. The greatest diversity prevailed. It was hardly possible to find two munieipal corporations conforming to the same species. "Existing municipal corporations," the Commissioners state, "neither possess nor deserve the confidence and 
respect of your Majesty's subjects." They found a "complete breakdown of administrative efficiency, joined with a decay of the elementary rules of local self-government." Municipal elections were a nere farce. Affairs were managed in secret, and much corruption prevailed. The magistrates, besides often being venal, were ignorant and inefficient. Instances were adduced where they were unable to read or write; so incompetent were they that in most boroughs of any size municipal interests were managed, not by the proper municipal authority, but by special ad hoc bodies. Even the police was often managed in this way. Sometimes private subscriptions had to be raised to carry out the work of the corporation, left undone by it. The ratepayers had no control over the finance of the council. The members of corporations regarded the funds as existing for the advantage of themselves, not for the community as a whole; they were expended on salaries, feasts, etc., while public objects were wholly neglected. Educational endowments were found subject to gross abuse. "From various causes . . . the schools have become in great measure useless to the inhabitants, and much valuable property given for the purpose of education, wasted." In the rapidly-growing towns where industry was expanding by leaps and bounds, railways springing up and population becoming more and more congested, the housing and sanitary conditions were appalling; the highways were ill-lit and neglected; the water supply a frequent cause of disease. The provision of such things was wholly overlooked by the corporations. To reform this state of affairs Lord John Russell's Municipal Corporations Act was passed: all old charters were annulled, the municipal corporation was restored to its original meaning as the legal personification of the local community, represented by a council to be elected by the equal and direct vote of local ratepayers for a limited period; its meetings to be open and its accounts audited yearly. The sanction of the Treasury was made necessary for the raising of loans and selling of property. Judicial and ministerial functions were separated.

The larger boroughs are the seat of Quarter Sessions: the smaller ones may possess a separate Commission of the Peace or be subject merely to the petty sessional jurisdiction of the county. In any case the Act of $18: 35$, as completed and extended in 1882 , finally severed magisterial from corporate office, and withdrew administrative work from the magistrates to hand it over to the town councils.

In each borough, whether a county borough (i.e. one which as 
having more than 50,000 inhabitants is exempt from the authority of the county council in whose area it is situate) or a noncounty borough, the authority is the town council, which is at once a representative body charged with the exercise of municipal affairs and the urban sanitary authority. It consists of councillors, clected for three years, one-third retiring annually, and aldermen, to the number of one-third of the councillors, elected by the councillors for six years. Ratepayers occupying premises of an annual value of $\mathfrak{f 1 0}$, who have resided for twelve months in the borough, are eligible to vote. The chairman is the mayor. Most of the business of the council is carried out by committees-some statutory, others optional; but decisions are subject to the approval of the council as a whole. The Act, which set up machinery that remains little altered to this day, was followed by an immense extension of municipal activity in response to the growing needs of the inhabitants of the towns. As compared with the Poor Law Amendment Act, the Municipal Corporations Act represented a great deal of autonomy and a minimum of centralization. But although no general control was established over municipal bodies, and by no means all the functions of government within their own locality were concentrated in their hands, gradually central control was established with regard to certain new functions, namely, those of Public Health.

The Statistical Department, whose establishment Edwin Chadwick had secured in connexion with the administration of the poor law, afforded absolute proof of preventable disease as a cause of pauperism. With the help of this knowledge Chadwick began his campaign against insanitary conditions, and in 1848, shortly after the great cholera epidemic, a general Board of Health was established, empowered to create a local health district and local board: in the municipal boroughs which adopted the Act (which was permissive) the town council was ipso facto the sanitary authority; elsewhere a new local health authority could be created for sanitation, the supply of water, management of the streets, making of burial-grounds, management of offensive trades, etc.

Those who disliked centralization made a determined attack upon the Board of Health; and in 1858 it was dissolved by the Local Government Act, which enlarged the powers of the local authorities and enabled them to adopt portions of certain Acts (the Model or Clauses Act connected with the name of Joseph Hume, 1845) without the necessity of private bill legislation. Sanitary legislation remained permissive. 
In the year after the passage of the Second Reform Bill (1867) a Commission was appointed to examine into the sanitary condition of the country. Their Report, issued in 1871, was a masterly document which convinced parliament that sanitary administration, still very backward in urban distriets, was practically non-existent in the country: a complete chaos of jurisdictions and areas. The entire absence of any strong central authority, the parcelling out of such controlling functions as existed between the Poor Law Board, the Home Office, the Medical Office, the Privy Council and the Board of Trade, was regarded by the Commission as the gravest defect of Euglish local government. The recommendations of the Commission, most of which became law in the Act of 1875 , was to actualize the sanitary laws. For this purpose the fragments of the old Board of Health were united with the Poor Law Board into a new central department, the Local Goverument Board, with power to compel a local authority to do its duty, to inspect, to issue orders and regulations, and control expenditure. The Public Health Acts ceased to be permissive. The local authorities whose business it was to carry out the Act, the function of the central authority being to give them information and guidance, were, in the towns, in the municipal boroughs, the town couneil, and in places of more than 3000 inbabitants a local board; in rural distriets the area was at first the poor-law union, afterwards the rural sanitary district, a subdivision of the county.

By the Public Health Aet of 1875 central control over principles was definitely established. The democratization of local government proceeded much more slowly; and the first great step towards it came from the centre, not from the localities. This was the Education Aet of 1870 , which provided for the formation, in districts where no voluntary school existed, of a school board for the provision of education. For election on to this sehool board all ratepayers, male or female, were eligible; and all had votes, as many as there were candidates, of which they could, if they chose, give all to one candidate. The Education Act thus created one more independent loeal authority with a new area oi its own. In 1885, Mr. Rathbone described the English system of local government as a "chaos of areas, a chaos of franchises, a chaos of authorities, and a chaos of rates." The Publie Health Act had included every parish in either an urban or a rural sanitary district. But the boundaries of the poor law and sanitary areas are seldom coterminous. A puor-law union was often composed partly of urban, partly of rural parishes, and eomprised part or the whole of 
a municipality. For five centuries there had been three kinds of parishes, formed without reference to county boundaries. A borough, too, was often in more than one county. The relations of municipal and county administration showed the greatest possible diversity. The county system had not been touched by the Act of 1835 ; the counties were still administered by Quarter Sessions ; the vastly increased business they had to do was still governed by the ancient forms and machinery. In size there was the most extraordinary variation between borough and borough, county and county, parish and parish. Meantime the activities of every department of local government had been rapidly increasing, both in urban and rural districts. The reform of the municipalities had enabled them to grapple with the task with success, but the rural authorities stood in grave need of reorganization. That reorganization must lie to some extent in an increase of popular control was made inevitable by the trend of general political movement.

The County Councils Act of 1888 extended to the counties the separation of magisterial and judicial functions that had been accomplished for the towns by the Act of 1835. Administrative powers were transferred from the justices of the peace to county councils-local parliaments composed of representatives directly elected by the ratepayers. The administrative county was divided into equal electoral districts in which every ratepayer had a singie vote. Towns of more than 50,000 inhabitants were made county boroughs, analogous to the municipal boroughs, with councils of their own. Burgesses had no votes for the county council. London, i.e. the metropolitan area, was made a single administrative county. Below the county council urban and rural district councils were erected, responsible for the management of subordinate areas. The county was also divided into licensing divisions, controlled by committees of the county council. A comprehensive financial scheme was bound up with this reform.

Magisterial administration, the "exemplary administration" of the justices of the peace, was at an end. This was a step in the democratic direction. But the area of a county or even of a rural district was too wide to permit of working men being elected to the council or board of guardians. Government "by horse and trap" continued. Local authorities had still to be simplified. To do this was the object of the Parish Councils Bill of 1894, "the last of the great constructive measures which built up a democratic 
system of local government in England," an attempt to fill up the "outline map" to which Mr. Gladstone compared the Act of 1888 . The principle established by the Act of 1894 is that " the district of a local authority must fall entirely within the district of the local authority next above it in the hierarchy." The county councils were empowered to rectify boundaries, local self-government was carried into the smallest units by giving the larger parishes parish councils (elected by universal suffrage of ratepaying inhabitants) and the smaller ones parish meetings (composed of all ratepaying inhabitants). The old urban and rural sanitary authorities were reconstituted as urban and rural district councils, elected likewise on universal suffrage. Class voting was abolished for boards of guardians and nominated and ex-officio members swept away. At the same time the rural sanitary authority (now the rural district council) was made the board of guardians in its area (whereas before the board of guardians had been the sanitary authority). The democratization of local government was thus complete.

In 1902 another step in the direction of simplification of area was attempted by the substitution for the school boards of the county and county borough councils as the education authority, and, so far as elementary education is concerned, the council of a borough of more than 10,000, and an urban district of more than 20,000 inhabitants. (See Chapter VI.)

The functions of the local authorities are thus extraordinarily varied and complicated, and likely to grow more so. Councils may and do manage and acquire property ; they carry out the functions of public health authorities, regulating drainage, sewerages, offensive trades, water supply, lighting, markets and street improvements; they may provide cemeteries and hospitals for infectious diseases: they can carry out housing and improvement schemes; they apply adoptive Acts with regard to libraries, baths and washhouses, depots, parks and open spaces, museums, art galleries, gymnasiums; they may carry on reproductive undertakings of various kinds, such as tramways or steamboats, the provision of electricity or gas.

The most recent development of the activity of local authorities is the undertaking of public services which, requiring large and special plant and expert management, can be carried on so as to yield a financial profit and would be so carried on by private companies. Such are waterworks, gasworks, electric light and power works, tramways, etc. The procedure of municipal councils 
is various. Some councils do not undertake such services themselves but impose regulations and restrictions upon the private companies rendering them, their scale of charges, and the quality of the goods they supply; others own the plant but leave the working

Services carried out by Local Authorities, 1905-1906

\begin{tabular}{|c|c|c|c|c|}
\hline \multirow[b]{2}{*}{ Services. } & \multicolumn{3}{|c|}{$\begin{array}{l}\text { Expenditure Defrayed otherwise } \\
\text { than out of Loans. }\end{array}$} & \multirow[b]{2}{*}{$\begin{array}{l}\text { Expenditure } \\
\text { Defrayed } \\
\text { out of } \\
\text { Loans. }\end{array}$} \\
\hline & $\begin{array}{l}\text { i. } \\
\text { Maintenance } \\
\text { and other } \\
\text { Expenses (not } \\
\text { being Loan } \\
\text { Charges). }\end{array}$ & $\begin{array}{c}\text { ii. } \\
\text { Loan } \\
\text { Charges. }\end{array}$ & $\begin{array}{l}\text { Total } \\
\text { (i. and ii.). }\end{array}$ & \\
\hline & $£$ & $\mathfrak{f}$ & $£$ & $£$ \\
\hline Education $\{$ i. Elementary & $18,049,053$ & $2,271,999$ & $20,321,052$ & $2,094,045$ \\
\hline Education $\{$ ii. Higher & $2,988,766$ & 146,998 & $3,125,254$ & 275,805 \\
\hline Electric lighting . & 990,886 & $1,713,415$ & $2,704,301$ & $2,391,809$ \\
\hline Gasworks. & $5,082,726$ & $1,456,743$ & $6,539,469$ & 523,394 \\
\hline Harbours, docks, etc. & $1,942,373$ & $1,728,050$ & $3,670,423$ & $1,781,679$ \\
\hline Highways, bridges, etc. & $10,795,539$ & $2,840,658$ & $13,636,197$ & $3,114,367$ \\
\hline $\begin{array}{l}\text { Hospitals (not poor-law } \\
\text { infirmaries). }\end{array}$ & $1,359,409$ & 341,724 & $1,701,133$ & 462,855 \\
\hline Libraries. & 709,449 & 14,245 & 723,694 & 37,812 \\
\hline Lighting . & $2,126,130$ & 15,659 & $2,141,789$ & 10,849 \\
\hline Lunatics and lunatic & & & & \\
\hline asylums . & $2,909,269$ & 592,469 & $3,501,738$ & 355,222 \\
\hline Markets . . . & 466,339 & 366,593 & 832,932 & 126,763 \\
\hline Parks and open spaces & 733,661 & 430,845 & $1,164,506$ & 273,002 \\
\hline Police and police stations. & $6,055,156$ & 124,440 & $6,179,596$ & 90,697 \\
\hline Poor relief $\quad$. & $10,486,349$ & $1,189,610$ & $11,675,959$ & 998,106 \\
\hline Private strect works. & $1,249,186$ & 430,471 & $1,679,657$ & 323,207 \\
\hline Sewerage . . . & $2,089,223$ & $2,306,286$ & $4,395,509$ & $2,781,252$ \\
\hline Tramways & $3,800,070$ & $1,567,183$ & $5,367,253$ & $3,129,402$ \\
\hline Waterworks (excluding & & & & \\
\hline Metropolitan Water & & & & \\
\hline Board) ${ }^{2}$. . . & $1,774,933$ & $3,280,917$ & $5,055,850$ & $2,940,638$ \\
\hline Other works . . . & $12,719,110$ & $1,178,586$ & $13,897,696$ & $2,825,923$ \\
\hline Unappropriated loan charges & $\ldots$ & $3,015,730$ & $3,015,730$ & $73,118^{1}$ \\
\hline $\begin{array}{l}\text { Total (expenditure not } \\
\text { out of loan) }\end{array}$ & $86,327,627$ & $25,012,121$ & $111,339,748$ & $25,139,950$ \\
\hline & Total expen & iture & $f 138$ & 79,698 \\
\hline
\end{tabular}

(Statistical Abstract, vol. Iv., Cd. 4258.)

of the service to the company. There is, however, an increasing tendency for municipalities themselves to supply the services needed. To what a large extent this is being done can be seen from the table, which gives no account, moreover, of the large expenditure

${ }^{1}$ Unappropriated loans. 
incurred in the provision of working-class dwellings. In 1906 the capital value of certain undertakings of the Iondon County Comncil was estimated as follows:-

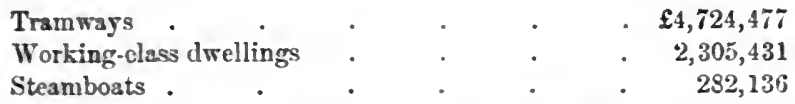

On the London County Council tramways alone 6365 men were employed in 1905-1906 (as compared with 2784 in 1902-1903). The lines covered $102 \frac{2}{3}$ miles, and in the year 1905-1906 183 million passengers were carried. Most of the London Borough Councils, as well as all the larger towns in the kingdom, are engaged in municipal industries of some kind. In 1900, 173 municipal boroughs in England and Wales and 53 in Scotland supplied water; in 1899,222 local authorities were authorized to provide gas, and 300 to provide electric lighting. "Outside of these staples many local authorities construct, own, hire, or manage telephones, markets, slaughterhouses, cemeteries and crematoria, recreation grounds, quays, docks, harbours, piers, as well as concert rooms, lavatories, refreshment rooms, etc., baths and washhouses, ferries, golf links, houses, warehouses, shops, building ground, allotments, milkshops, refrigerators and cold storage, supply of paving stones, etc., and there exists a strong tendency to extend their operations to more questionable undertakings, such as banking, insurance, pawnbroking, mining, etc." (Poor-Law Commission Report). In 1902, 299 out of 317 municipal corporations in England and Wales were carrying on reproductive undertakings of some kind, and over one-half of the municipal debt, which stood at over $£ 370,000,000$ in 1903 , was computed to be capital invested in undertakings producing profit.

In $1908,14,651$ persons were in the service of the corporation (excluding police) out of a population of 800,000 .

For all these purposes revenue is required, and this is derived from two main sources-loans and rates. All loans are subject to the sanction of the Local Government Board, and must be repayed by instalments over a period not longer than thirty years, or by means of a sinking fund. In the case of a county council a certain revenue is derived from sums that, though actually raised within its area, are collected there by officials of the central yovernment. Such are the proceeds of local taxation licences, i.e. icences for the sale of intoxicants, game dealing, dogs, horses, arms, ptc.; the proceeds of the estate duty, and certain specified customs ind excise duties. Sums derived in this way from contributions 
are as a rule devoted to certain prescribed purposes, such as official salaries or technical instruction. For general purposes the councils rely ultimately on the levying of rates. The amount of the rate required being determined, its payment is divided among the ratepayers "in respect only of certain kinds of property, and levied from the occupiers, not the owners of that property," on a scale which is, roughly, proportionate to benefit received. The Poor Rate, established by Elizabeth's Act of 1601, is the basis of all English local taxation; and for long the largest item in the expenditure of local authorities was that of poor relief. The tables show how greatly the expenditure of local authorities has increased even within the last decade, how enormously it has increased in the course of the century, and the change in the relative proportion to total expenditure of expenditure on poor relief. Though the cost of poor relief has steadily risen, it has been vastly exceeded by the increasing expenditure on the public health and other sanitary services, to say nothing of the outlay on education. This increasing expenditure has involved a steady rise in the rates.

Rates in general are based upon the assessment and valuation made by the overseers for the purpose of the poor rate, and presented by them to the board of guardians of the union of which the parish forms a part. Appeal against their decision can be made, within a certain period, to Quarter Sessions. In London the functions of the overseers in making the valuation are carried out by the metropolitan borough councils, who levy a general rate. The Act of 1894 directed that in the administrative county of London a uniform rate of $6 \mathrm{~d}$. in the $£$ on rateable value should be levied and the proceeds distributed among the boroughs according to population-a first step in the direction of equalization of rates that needs to be carried further.

\section{Local Finance}

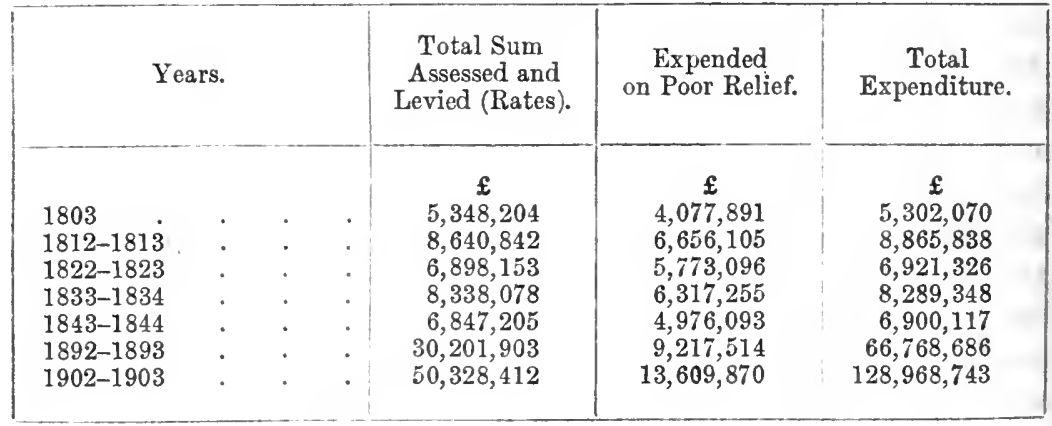


Local Finance

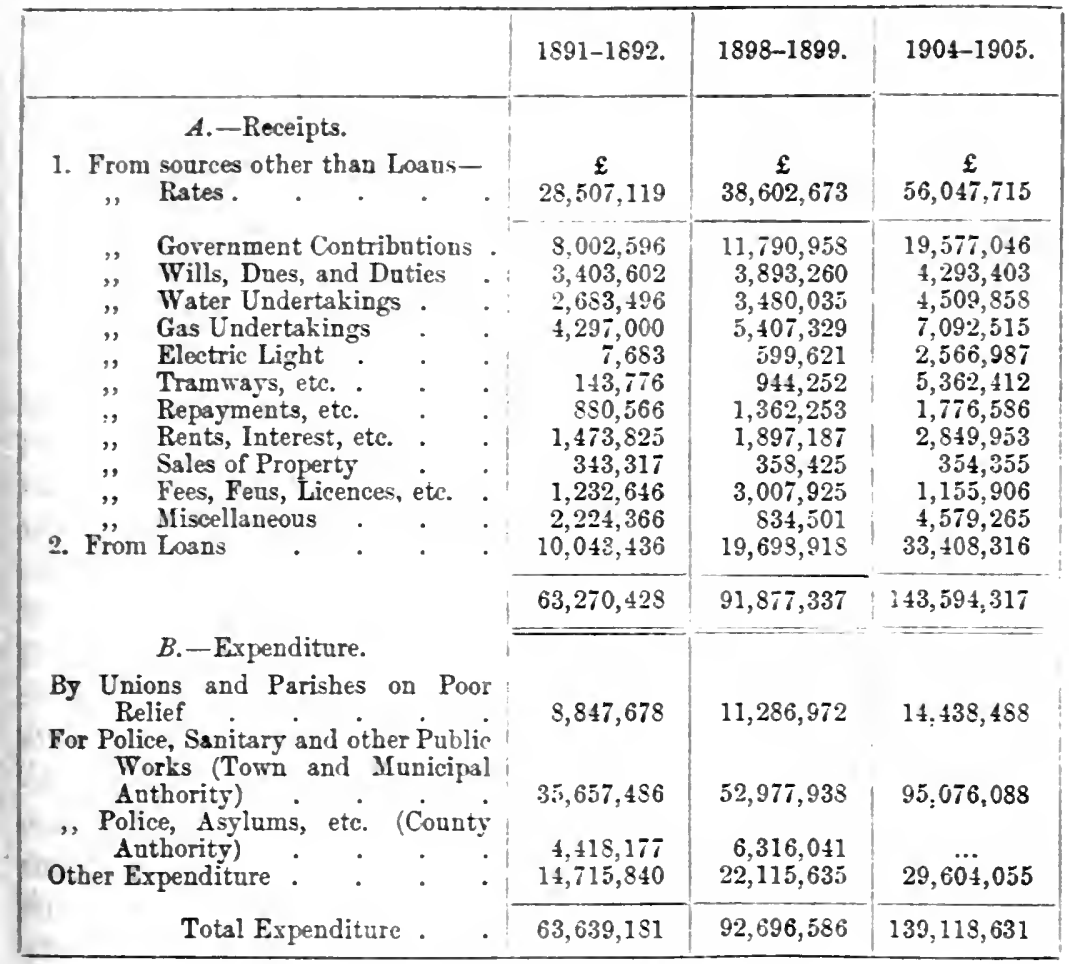

(Statistical Abstract, 1906.)

Average Ayotet per $£$ of Valeatios

\begin{tabular}{|c|c|c|c|c|c|c|c|}
\hline \multirow{2}{*}{ Years. } & & \multicolumn{2}{|c|}{$\begin{array}{l}\text { Administrative } \\
\text { County of London. }\end{array}$} & \multicolumn{2}{|c|}{$\begin{array}{l}\text { Rest of England } \\
\text { and Wales. }\end{array}$} & \multicolumn{2}{|c|}{$\begin{array}{l}\text { England and } \\
\text { Wales. }\end{array}$} \\
\hline & & Rates. & $\begin{array}{l}\text { Exchequer } \\
\text { Grants. }\end{array}$ & Rates. & $\begin{array}{l}\text { Exchequer } \\
\text { Grants. }\end{array}$ & Rates. & $\begin{array}{l}\text { Exchequer } \\
\text { Grants. }\end{array}$ \\
\hline $\begin{array}{l}1879-1880 \\
1904-1905 \\
1906-1908\end{array}$ & $\dot{.}$ & $\begin{array}{ll}\text { s. } & \text { d. } \\
4 & 3 \cdot 0 \\
7 & 0 \cdot 8 \\
7 & 0.3\end{array}$ & $\begin{array}{ll}\text { s. } & \text { d. } \\
0 & 7 \cdot 1 \\
1 & 3 \cdot 0 \\
1 & 3 \cdot 3\end{array}$ & $\begin{array}{lr}\text { s. } & \text { d. } \\
3 & 0 \cdot 9 \\
5 & 8 \cdot 0 \\
5 & 10 \cdot 0\end{array}$ & $\begin{array}{ll}\text { s. } & \text { d. } \\
0 & 4 \cdot 5 \\
2 & 1 \cdot 4 \\
2 & 2 \cdot 4\end{array}$ & $\begin{array}{lr}\text { s. } & \text { d. } \\
3 & 3 \cdot 5 \\
5 & 11 \cdot 8 \\
6 & 1 \cdot 2\end{array}$ & $\begin{array}{lr}\text { s. } & \text { d. } \\
0 & 4 \cdot 9 \\
1 & 11 \cdot 2 \\
2 & 0 \cdot 2\end{array}$ \\
\hline
\end{tabular}

Average Ayocst per head of Estimated Poptlation

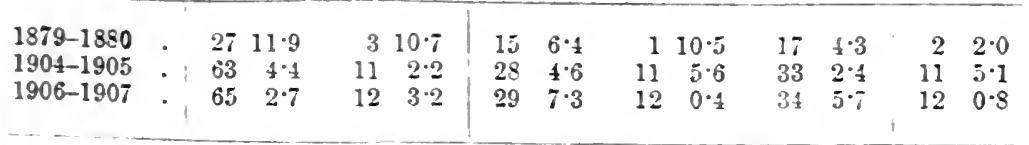

(From 38th Annual Peport of Local Government Board, Cd. 4928.) 
A certain control over expenditure is exercised by the Local Government Board in so far as all loans require its sanction, the year's financial statements of all local authorities are subject to its audit, and exchequer contributions can theoretically be withheld on its disapproval. But the actual machinery by which, in this last case, the withholding of the grant is effected is not such as to make it a real test of efficiency except in the case of the grant through the Home Office for the maintenance of police, and to some extent in the payment to medical officers and sanitary inspectors.

In so far as they are the local authorities for education, the councils are subject to the codes and orders of the Board of Education. Concessions or licences authorizing local authorities to undertake the supply of gas, water, tramways, or electric light in their districts are granted by the Board of Trade. Procedure under the Diseases of Animals Act and the superintendence of fisheries is controlled by the Board of Agriculture. Since 1856 counties and municipal boroughs have been the sole police authorities outside the metropolis. The statutory watch committee appoints and dismisses constables, organizes the service and controls expenditure in county boroughs. In the counties a committee composed half of justices and half of county councillors supervises expenditure and buildings: the direction and disposition of the force belonging to the chief constable. Here the central authority is the Home Office; and the service is subject to inspection from the Home Office. But with these exceptions the Local Government Board has a general, if loose, control over local authorities and a more direct control over their activities with regard to the poor law and public health. By its orders and circulars it does exercise a sub-legislative power over them. But the huge area which it is supposed to supervise and the vast congestion of business with which it has, through its various departments, to deal, has made it, in Redlich's phrase, "a Board of Controls, not a Board of Control."

The developments of local government, public health, and education in Scotland and Ireland have been on the whole similar and parallel but have been carried through by separate and district legislation. Political disaffection and agrarian discontent held back social improvement in Ireland from the Union onwards. The great famine of 1848 led to the clearances, and four millions of people had emigrated, mainly to the United States, before the end of the nineteenth century. The disestablishment of the Irish 
Church in 1869, the Land Acts of 1878 and 1881, the Land Purchase Acts 1885 to 1909 , and the Labourers Acts have gradually converted Ireland from a miserably poor to a thriving and progressive agricultural country. Local self-government in the Irish counties dates from 1898 , when county and rural districts were created to take the place of the old grand juries. The new bodies, especially the county councils, have proved on the whole efficient and economical. The Local Government Board of Ireland is an efficient body, with its headquarters in Dublin.

Local Government (Scotland).-Scottish local government, in its present shape, dates from the Local Government (Scotland) Act of 1894 . In 1833 popularly elected bodies were constituted for burghs; and in 1845 parochial boards, representative in the main of property, were formed for poor-law administration, the unit being the parish. School boards were set up throughout the country in 1872 , elected ad hoc in each parish, by cumulative vote. The Act of 1889 gave to the counties an organization of local self-government similar to that which the burghs had enjoyed for the last half-century, and divided them into districts for highway and public health purposes. By the Act of 1894 the permanent Local Government Board for Scotland was set up in place of the Board of Supervision which had continued from year to year since the Poor Law Commission. It reformed the bodies set up for poor-law administration and reconstituted them as parish councils, and effected a considerable readjustment and simplification of areas.

The recommendations of the Poor Law Commission, in Scotland as in England, are in favour of carrying further the process then begun. The need for co-ordination in education and the lack of popular interest in school board elections also indicate a movement in the same direction. 


\section{CHAPTER IX}

\section{THE RISING STANDARD OF COMFORT}

Reality of progress-Increase in wealth-General diffusion of wealth-Workingclass savings-Rise in real wages-Improvement in conditions of life-ExpenditureAmusements of rich and poor-Holidays-Religion

NY attempt to estimate the progress of the nation in the
course of a century must, in the last resort, resolve itself
into an examination of the changes undergone by the ordinary daily life of the average person, an evaluation of the conditions of existence of the normal household. To do this comparatively, over so long a series of years, is very difficult. Estimates of prosperity and progress are relative to a certain standard, and that standard varies from generation to generation. It has its effect upon what purport to be quite impartial descriptions of the facts of any given period.

That there has been remarkable and steady progress since 1850 is hardly open to doubt. Many features of normal life as lived by the great majority of the people of England at the present day, and the condition of large masses of the population, whether from a moral or material point of view, afford ground for grave and legitimate dissatisfaction, and cause many to question the reality of the advance. At the same time, that dissatisfaction is connected with an awakening of the sense of social responsibility on the one hand, and, in part as its consequence, with an increased knowledge of the way of life of all classes upon the other, that may entitle it to be regarded to some extent as itself a symbol of progress. It represents the demand for a standard as applied to all that is, relatively, a high one. Conditions that might have been esteemed as admirable, even as improbable of realization, at the opening of the century, are now taken as matter of course. Evils that would not be tolerated now were regarded as inevitable then, or not noticed at all. Whether the net sum of happiness be greater or less in consequence is of course beyond the province 
of this review to estimate; nor is it necessary here to pause and consider whether some of the tendencies at work in our own day, directed no doubt to the elevation of the standard, are likely really to achieve that end. The standard, it need hardly be remarked, depends upon moral and personal as well as physical and social requirements.

Here it is germane merely to examine, so far as may be, what changes have actually taken place in the standard of comfort of the nation as a whole.

Increase in Wealth.-National wealth has, during the century, increased enormously. No exact or even approximate estimate can be given of the income of the country at the beginning of the century, but that it has been rapidly increasing is established. Porter, writing in 1847 , says: " abundant proof is afforded that . . . the substantial wealth, the capital of the country, has kept pace with our modern progress in other respects." In 1867, Dudley Baxter estimated the national income at 814 millions. For 1875 it was calculated by Sir Robert Giffen at 1200 millions and for 1885 at 1350 millions. In $1904, \mathrm{Mr}$. Bowley considered it very probable that the national income in the preceding year fell very little short of 2000 millions, and he further declared (National Progress in Wealth and Trade, 1906) "our information, so far as it goes, suggests that very remarkable and stable progress has been made in those aspects of national well-being which are generally considered in measuring prosperity." In 1909 the Poor Law Commissioners said: "Wealth in this country seems to be increasing so fast, as compared with population, that we might have expected to find that by this time industrial porerty at least was disappearing."

General Diffusion of Wealth.-The increase, moreover, has not been confined to any one class or section of the population. All classes have benefited, though not all to an equal degree. There has, no doubt, been an increase, on the part of the very rich, of luxurious and visible expenditure, noticeable especially in London, which is, however, the centre for the extravagance of the extravagant of all nationalities. But it is still true, as Sir Robert Giffen said in 1883: "The rich have become more numerous but not richer" individually; the poor are, to some smaller extent, fewer; and those who remain 'poor' are, individually, twice as well off on the average as they were fifty sears ago. The poor have thus had almost all the benefit of the great material advance of the last fifty years." The growth of small incomes, noted by Lord Goschen, is an important mark of prosperity. The gross incomc- 
tax assessment, which was over 600 millions in 1882 , rose to over 1000 millions in 1906. Measured by the produce of a penny tax, national income has increased 68 per cent. since 1870-1871 (in 1870-1871 a penny tax produced $£ 1,592,000$; in 1906-1907

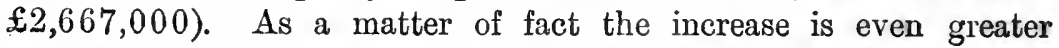
than these figures testify, owing to the changes in the scale of abatement and exemption. The growth, not merely in income, but in the number of those who come within the purview of the income-tax collector, is testified by the increased number of claims for abatement in respect of incomes between $£ 160$ and $£ 700$; the increased number of assessments under Schedules D and $\mathrm{E}$ (profits from businesses, professions, employments, etc., and șalaries of government, corporation and public officials), and the increase in Great Britain in the number of private dwelling-houses

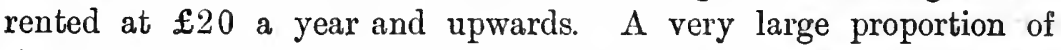
the total dividend remains in the hands of a comparatively small number of very large owners- “ one and a quarter million persons take $£ 585,000,000$ " (Chiozza Money, Riches and Poverty)—but "the preponderating factor in the total increase has been the growth of small incomes" (Times, May 23, 1910).

Working-class Savings. - The increase in the prosperity of the working classes, not included under income-tax schedules, can partly be estimated from their savings. Between 1850 and 1907 the deposits in post offices and saving banks rose from 29 millions to $209 \frac{1}{2}$ millions, or from $£ 11$ s. per head of population to $£ 415 \mathrm{~s} .1 \mathrm{~d}$. If government stock be included they lave risen to $£ 55 \mathrm{~s} .6$ d. a head. The same remarkable advance may be measured by the growth of the co-operative movement, or trade unions and friendly societies (cf. Tables I, II, and III).

TABLe I.-Post-Office Savings Bank

\begin{tabular}{|c|c|c|c|c|c|c|c|}
\hline & $18 \check{0} 0$. & 1860 & 1870. & 1880. & 1890. & 1900. & 1907. \\
\hline $\begin{array}{l}\text { Amount of deposits at } \\
\text { end of year- } \\
\text { In Post-Office Savings } \\
\text { Banks } \\
\text { In Trustee Savings } \\
\text { Banks . }\end{array}$ & $\begin{array}{c}\text { Thousand } \\
\text { \&. } \\
\\
\ldots \\
29,301\end{array}$ & $\begin{array}{c}\text { Thousand } \\
\text { L. }\end{array}$ & $\begin{array}{c}\text { Thousand } \\
£ .\end{array}$ & $\begin{array}{c}\text { Thousand } \\
£ .\end{array}$ & $\begin{array}{c}\text { Thousand } \\
£ .\end{array}$ & $\begin{array}{c}\text { Thousand } \\
£ .\end{array}$ & $\begin{array}{c}\text { Thousand } \\
£ .\end{array}$ \\
\hline $\begin{array}{l}\text { Total . } \\
\text { Total per head of Popu- } \\
\text { lation } \\
\text { Percentage of rate in } \\
1850\end{array}$ & $\mid \begin{array}{ccc}£ 1 & 1 & 0 \\
& 100 & \end{array}$ & $\begin{array}{ccc}21 & 8 & 8 \\
137 & \end{array}$ & $\begin{array}{c}£ 11311 \\
162\end{array}$ & $\begin{array}{c}22411 \\
214\end{array}$ & $\mid \begin{array}{c}111,285 \\
2219 \quad 5 \\
283\end{array}$ & $\begin{array}{c}£ 41011 \\
433\end{array}$ & $\begin{array}{c}209,654 \\
\text { S4 } 15 \quad 1 \\
453\end{array}$ \\
\hline
\end{tabular}


TabLe II.-Friendly Societies

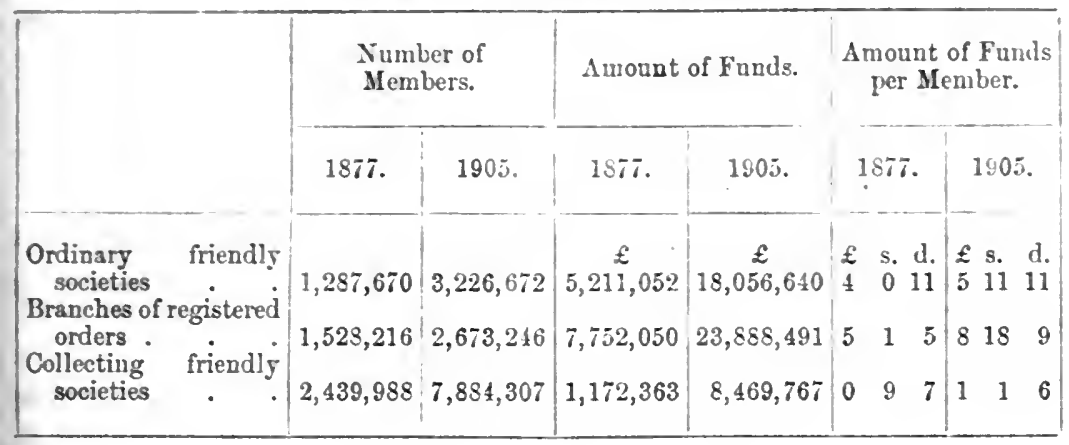

\section{Table III.-Trade Unions}

\begin{tabular}{|c|c|c|c|c|c|c|c|}
\hline & & & & $\begin{array}{l}\text { Number } \\
\text { of Unions. }\end{array}$ & $\begin{array}{l}\text { Number of } \\
\text { Nembers. }\end{array}$ & $\begin{array}{l}\text { Annual } \\
\text { Ineome. }\end{array}$ & $\begin{array}{l}\text { Balanee of Funds } \\
\text { at end of Year. }\end{array}$ \\
\hline $\begin{array}{l}1872 \\
1890 \\
1906\end{array}$ & : & . & : & $\begin{array}{r}83 \\
490 \\
674\end{array}$ & $\begin{array}{r}203,732 \\
645,451 \\
1,719,031\end{array}$ & $\begin{array}{r}120,977 \\
990,872 \\
2,709,665\end{array}$ & $\begin{array}{r}107,290 \\
1,102,147 \\
5,864,342\end{array}$ \\
\hline
\end{tabular}

(From Public Health and Suciul Conditions.)

Rise in Real Wayes.-Sir liobert Giffen made a comparison in 1883 with the wage-rates arrived at by Porter from which he deduced an enormous apparent rise in money wages, with a mean percentage of increase of over 70 per cent. This rise was accompanied by a reduction in the hours of labour, which he put at 20 per cent., and a fall in the price of wheat (accompanied by a steadying of that price) and other commodities. Rents had risen, but not in proportion, and though meat was dearer it hardly entered into the working-man's budget in 1880. And according to a Memorandum prepared for the Poor-Law Commissioners by the Board of Trade (1909), "The general results of records in several trades, covering some thirty years, and of comparative statistics based upon the census of wages in $1886^{\circ}$, are that, in all these groups of industries, allowing for trate cycles, a general tendency of wages to rise is perceptible through the last thirty years. . . The rise of nominal wages has been accompanied by such a fall in wholesale and retail prices as implies a rise of 'real' wages, or wages as measured in commodities, considerably greater than the rise of money wages."

Labour has, moreover, tended to flow into the better-paid 
industries. There has, for example, been a great diminution in the number of agricultural labourers, and a great increase in coal-miners.

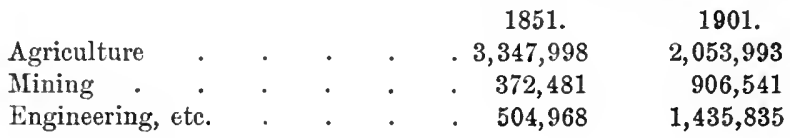

Prices have fallen, and at the same time the amount consumed per head of various articles of diet has increased enormously (Table IV).

TABLE IV.-Quantities of the Principal Imported and Exciseable Articles retained for Home Consumption, per head of the Total Population of the United Kingdom

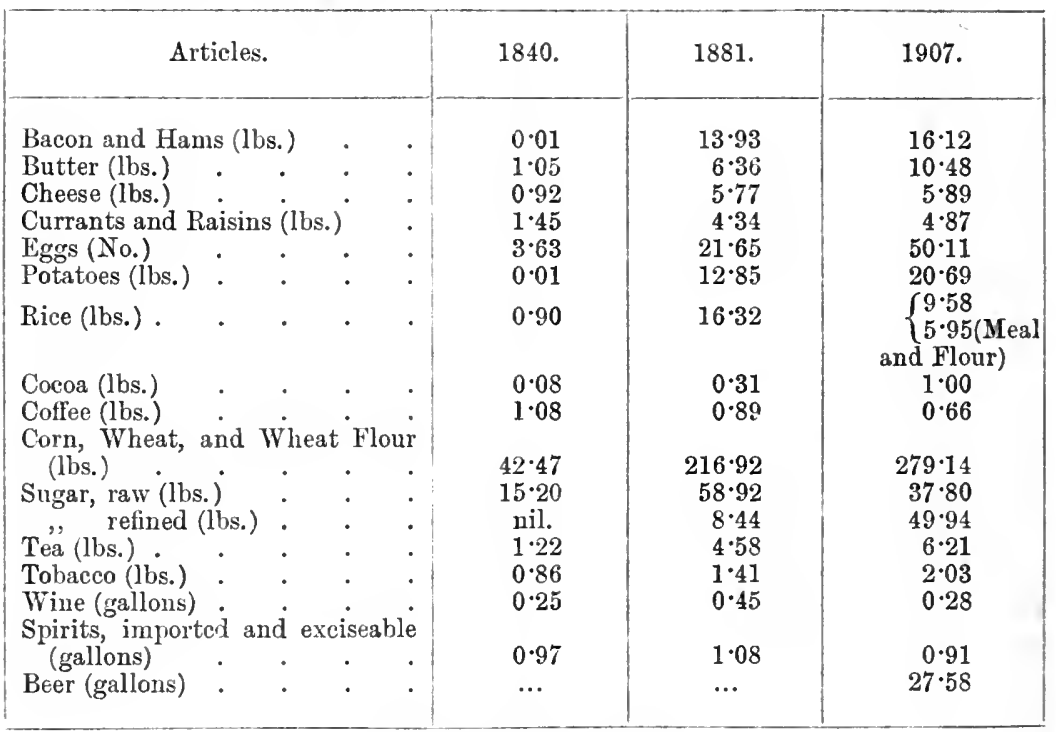

(Statistical Abstract, 1908.)

It must, however, be recollected, to quote once more from the Memorandum, that "the fall of prices does not benefit the various grades of wage-earners in direct ratio to their wages. Rent and certain other necessary elements of expenditure, which have risen in amount for the large majority of workers, play a relatively larger part in the budget of the lower grades of workers, reducing to that extent the gain from the general fall of prices. The poorest classes, whose retail purchases are made in very small quantities, also gain least from the lower prices of other commodities than housing and fuel." 
The rise in the standard of comfort is sufficiently evidenced from the table, which shows the great increase in the consumption of many articles that would have been esteemed luxuries at the beginning of the era. There are now, too, many new commodities in existence, and at low prices, that could not then have been bought at all. The range of variety has been indefinitely extended. Meat has become an article of general consumption. Fruits are exposed for sale at cheap rates, in the barrows that line the street sides in many of the poorest quarters, that would in earlier decades have been the luxury of the few. While rents have risen, housing accommodation is vastly improved, though capable still of vast improvement.

Improved Conditions of Life.-The increasing expenditure of government and of the local authorities (reflected in the rise of the rates) has raised the standard of comfort in countless ways that have benefited all classes, but particularly those within whose reach it has brought many utilities and amenities that they could not have provided for themselves. Better paving, drainage and lighting of the streets, the provision of public parks, libraries, recreation grounds, baths and washhouses may be mentioned as making accessible even to the rery poor comforts that only the comparatively well-to-do could provide for themselves at the beginning of the century.

Increased facilities for cheap travel, both for long and short distances, have immensely affected the standard of the middle and lower middle classes. Knowledge of all kinds has, moreover, been brought within their reach by the indirect effect of this upon the Press. Communication is now possible with any part of the world: the rich man can speak to America now and obtain a answer more rapidly (by means of the cablegram and the wireless telegraph) than he could do to a place a few miles away in 1800 . The telephone has done something similar for the poor man, and the imperial penny post for the very poorest.

Sir Robert Giffen observes in the essay from which quotation has already more than once been made, that "it is conceivable . . . that while earning more money, and being able to spend it to more advantage, the workiug classes might be no better off than formerly. There may be masses, as there are individuals, who do not know how to spend."

Expenditure.-This question as to wise expenditure nay very well be asked with regard not only to the working class.

There seems some reason to think that wasteful expenditure 
on the part of the rich, expenditure mainly directed to display, is as great as it ever was, perhaps greater since modern life affords facilities for display on a more extensive scale than formerly. The evils attendant on the rapid change of fashion, with the irregularity of employment that they bring in their train, certainly show no sign of lessening. On the other hand, those who live viciously, in this sense, and spend vast sums on exotic banquets, entertainments, etc., are comparatively the very few. There is an increasing class of wealthy people who spend their money in a rational and not excessively luxurious way, who get a great deal of enjoyment out of the motor-car, the country house (often on quite a moderate scale), and foreign travel, and invest heavily in the education of their children.

Amusements.-At the same time there is both at the top and bottom of the scale a decided increase in the proportion spent on amusement, and it is estimated that more than five millions annually will not cover the losses incurred by those who bet. Betting and gambling indeed are no doubt on the increase, especially among the poor. "The more money there is to spend, the more betting is done" (Life and Labour of the People, final vol., p. 57). Thousands bet on horse races who have never seen a horse, on football wlro never see a match. "Betting," said a police inspector, "is increasing out of all proportion to other forms of vice."

Drink, too, is responsible for a vast amount of wasted and often positively harmful expenditure. "Gambling, though it wastes the resources of its victims, does not lead to such physical and moral degeneration as drink" (Poor Law Commission, p. 221). Though drunkenness is less frequent, there is more drinking, at any rate among the poor. In the upper classes opinion has in this respect undergone a complete transformation: At the beginning of the century "what would now be called drinking to excess was . . . so much the custom in every circle, that it was as uncommon for any party to separate while any member of it remained sober as it is now for any one in such a party to degrade himself through intoxication. ... In those days it rarely happened that men holding the rank and otherwise bearing the character of gentlemen, rose from the dinner-table in a condition to enter the society of females" (Porter). At the universities and elsewhere drunkenness was looked upon as a venial offence, and all that was demanded was "to carry your drink like a gentleman." The increase of drinking among the working classes is, says Mr. Charles Booth, "to be laid 
mainly to the account of the female sex." Women feel no shame in entering a public-house, even quite respectably-dressed women. The people drink enough to keep them poor. The fact that they do so is no doubt largely connected with the monotony of their work, the ugliness and want of interest of their lives, and the absence of other resources. But the fact remains.

"The improvement visible in the habits of the working people of England as respects intoxication is accompanied, as might be expected, by an abatement of coarseness in their general deportment and by a weaning from some of the pursuits which, having been part of the favourite pastimes of their own immediate predecessors, are now looked upon as evidences of a brutal temper" (Porter). Prize-fighting has disappeared. Cock-fighting and rat-hunting are no longer the sports of gentlemen. The coarse language common even in good society at the end of the eighteenth century was much ameliorated in 1849 when Porter wrote. Conversation has become further refined, though it has doubtless at the same time lost much of its elegance by the growing use of slang expressions and phrases, often adopted from the lower classes. In the same way the direct grossness of the eighteenth-century comedy has disappeared from the stage, where its place has, however, to some extent been taken by the double entendre of the adapted French comedy. The decreasing vulgarity of the places of amusement frequented by the working classes was ascribed by Francis Place, in his evidence before a Select Committee in 1835 , to information. "You will find," he said, "as the working people get more information they will get better habits. . . Manners descend from class to class." This applies forcibly to the music hall of to-day; it is less vulgar than even twenty years ago.

Holidays. - The rise of the standard of comfort is seen in nothing more clearly than in the increased demand for holidays and amusements common to all classes. Every class takes more holidays now than it did fifty or a hundred years ago. Every class demands more amusement. The discomfort of home life in cramped surroundings, which is said to account for early and improvident marriages among the poor, makes it necessary that their hours of freedom should, if they are not to be spent in the public-house, be provided with rational entertainment. The opening of picture galleries and museums, and the provision of cheap concerts on Sunday afternoons, is a step in this direction.

Sunday is increasingly a day of recreation. There can be little question that the sway of religion over the people as a whole 
has decreased since the beginning of the century. Mr. Booth says of London, "the great masses of the people remain apart from all forms of religious communion." The rich go out in their motors, the poor on their bicycles.

Religion.-Religion has lost some of its hold. What is taking its place? It is difficult to say. In the standard of comfort thus comprised ideal factors seem to play a very small part. The increased diffusion of education must have some effect; reading is much more widespread, and the cheap editions of the classics command enormous sales-the best is accessible to those who want it. Manners have softened; morals have no doubt in many ways improved. There is a decline in the more brutal forms of crime and vice. The broadening of the franchise has brought social questions more and more into politics, and has given the working classes not only power, but also an increasing sense of responsibility. Even the idlest of the idle rich are more conscious than they used to be of the claims of the poor. There is more humanity, more kindness to children and animals, more sympathy with poverty. 


\section{CHAPTER X}

\section{BRITISH AGRICULTURE, 1800-1850 ${ }^{1}$}

Inportations of wheat, 1801-1S49-Comparative smallness of its amountNumbers fed with wheat of home and of foreign growth - Increased productive power of Great Britain-Means whereby this increase was brought abont-Deficiency of statistical information connected with agriculture in England-Improvements in Scotland-Inclosure Bills and average prices of wheat since 1760-Corn Law of 1815 - Conflicting testimony as to agricultural distress given to the Committee in 1833-Increased rents since 1790-Adaptation of the steam-engine to the draining of fens-Land brought under cultivation since 1760-Proportion of cultivated land to the population at different periods during the nineteenth century-Probability of population outstripping the productive powers of the soil-Supposed influence upon this question of the extensive construction of railroads-Estimate of the number of horses, the employment of which may by that means be rendered unnecessary

TT has been shown in a previous chapter how rapidly the population of the United Kingdom has increased after the beginning of the nineteenth century. During the forty years that intervened between the census of 1801 and that of 1841 , that increase amounted to $10,700,000$ souls, and in 1850 must have reached $13,000,000$, a number probably equal to the entire population of Great Britain in 1811.

This increase of inhabitants would be sufficient, as already remarked, to contradict the idea of any great inadequacy in the quantity of food, if the observation and experience of every one did not enable him otherwise to disprove such a position; and as it is equally impossible to believe that the increasing wants of the people have been in any material degree met by supplies from without, the conviction is irresistibly forced upon us, that a most important increase in the amount of agricultural products must have taken place within the kingdom. The following short statement of the quantity of wheat and wheat flour that was imported for consumption on an average in the first half of the nineteenth century will suffice to show how insignificant, when

${ }^{1}$ This chapter is condensed from Porter's Prayress of the Vition. 
compared with the wants of the community, have been the supplies which we drew from foreign countries:-

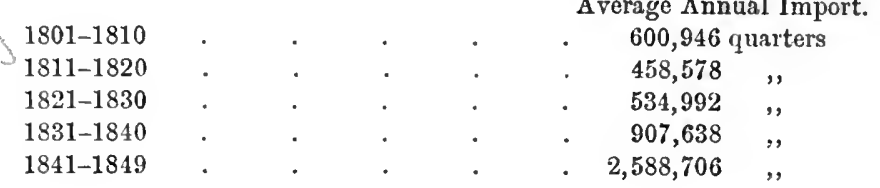

It appears from this statement, that in the ten years from 1801 to 1810 the average annual import of wheat into the kingdom amounted to 600,946 quarters; and as the mean number of the population during that period was $17,442,911$ souls, this quantity would afford a very small fraction above a peck for the annual consumption of each person. The average importation in the ten years between 1811 and 1820 was 458,578 quarters; and as the mean number of the population had in that period advanced to $19,870,589$, that number of quarters would afford each person one gallon and a half towards the year's consumption. In the third period, between 1821 and 1830, the average annual importation advanced to 534,992 quarters; but the population had advanced in an equal proportion, so that the annual share of each person in the foreigu supply remained the same (one gallon and a half) as last stated. The average amount of importation in the ten years from 1831 to 1840 rose to 907,638 quarters; and the mean number of consumers in this period having been $25,601,119$, the importations, if fairly divided among them, would have given annually to each about $2 \frac{1}{4}$ gallons.

In each of the three periods of ten years into which the foregoing statement has been divided, up to 1830 , there were two years of large importation arising from deficient harvests, and in the last decennary period there occurred four years of this character. If those years were excluded from the calculation, the average importations would of course be materially lessened.

During the last nine years of the series, namely, from 1841 to 1849 , the average quantity of foreign and colonial wheat and wheat flour taken for home use advanced to 2,588,706 quarters per annum, which quantity, divided equally among the increased number of consumers, would afford nearly 6 gallons per annum for each person.

It will be remembered that, in addition to several years of somewhat deficient grain harvests, we were, during the period included in these nine years, visited by one of the severest calamities 
arising from the influence of the seasons which it has been our misfortune ever to encounter. The famine caused in Ireland by the destruction of the potato crop in 1847 will ever remain as a dark page in our history. During its continuance food of various kinds was bought in every market open to us, the laws regulating its importation were suspended, and our navigation law was placed in partial abeyance. It must be clear that under such circumstances it would be idle to attempt to draw a fair comparison between this and other periods.

The foregoing calculations show in how little we were dependent upon foreigners, in ordinary seasons, for our staple food. It is not, however, with this view that those calculations are brought forward, but rather to prove how exceedingly great the increase of agricultural production must have been to have thus effectively kept in a state of independence a population which has increased with so great a degree of rapidity. To show this fact, the one article of wheat has been selected, because it is that which is the most generally consumed in England; but the position advanced would be found to hold equally good were we to go through the whole list of the consumable products of the earth. The supply of meat, during the years comprised in the inquiry, certainly kept pace with the growth of population; and, as regards this food, our bome agriculturists, during almost the whole period, enjoyed a strict monopoly.

The consumption of wheat in this country has been variously estimated by different writers. Some have supposed the average quantity used by each inhabitant to be 8 bushels in the year, while others have assumed it to be only 6 bushels. Using the foregoing figures, and applying them to each of these quantities, we may find in what degree the soil has been rendered increasingly productive. In the closing years of the last century there occurred a succession of deficient harvests, which caused a considerable importation of corn into this country; but previous to that time the production of wheat had been about adequate, taking one year with another, for the feeding of the inhabitants.

The mean number of the population in Great Britain between 1801 and 1810 was $11,769,725$, and the average yearly importaFions of wheat and wheat flour during those years having been 300,946 quarters, the home-grown supply sufficed for the food of $11,168,779$ persons, at the rate of 8 bushels per annum, or of $10,968,464$, at 6 bushels per annum. During the next ten ears the mean population was $13,494,217$, and the importations 
averaged 458,478 quarters yearly. The home supply, consequently, sufficed for $13,035,639$ persons at the rate of 8 bushels, or of $12,882,780$ at the rate of 6 bushels per head. There was, consequently, a greater home produce, equal to the food of $1,866,860$, or of $1,914,316$ persons, according as the average consumption is estimated at 8 or at 6 bushels yearly. Between 1821 and 1830 the mean number living in Great Britain was $15,465,474$, and the average yearly importation of wheat and flour were 534,992 quarters. The home-grown corn sufficed, therefore, for $14,930,482$ persons, at 8 bushels, or for $14,752,151$ persons, at 6 bushels, and the productive power of the land was increased, so as to feed $1,894,843$ more persons, at 8 bushels, or $1,869,371$ persons, at 6 bushels. During the next period of ten years, ending with 1840 , the mean population was $17,535,826$, and the average yearly importations were equal to the consumption of 907,638 , or of $1,210,184$ persons, calculated at 8 or at 6 bushels each. Our home produce, therefore, sufficed for either $16,628,188$, or for $16,325,642$ persons; and the increased number fed from our own soil was $1,697,706$ or $1,573,491$ persons. Between 1841 and 1849 the mean number living was probably about $19,592,824$, and the average importations increased to $2,588,706$ quarters. Our home-grown corn, therefore, fed $17,004,118$ persons, at 8 bushels, or $16,141,216$, at 6 bushels per head; and the additional numbers so fed were 375,930 at 8 bushels, but 184,426 fewer if the consumption be 6 bushels.

Great as we have szen the increase to have been, since the beginning of the nineteenth century, in the production of agricultural products in Great Britain, there is reason to believe that a far more profitable result would have followed from the amount of skill and enterprise, and the application of capital to which that increase must be ascribed, but for the restrictions that have been placed, in the supposed interests of our agriculturists, upon the importation of articles of food from other countries. By means of those restrictions, and the consequent enhancement of the cost of living, not only has a limit been placed to the employment of labour in other branches of industry, through the lessening of the fund out of which that labour would have been rewarded, but the land itself has been injuriously restricted in its application; so that while the energies that have been bestowed upon its cultivation have been chiefly directed towards extending the growth of certain descriptions of food, our farmers have neglected the production of other articles for which a demand would then have 
arisen, which would in a greater degree have given employment to labour, have enabled the cultivators to pay a higher rent for the use of the land, and in various ways would bave added to the sum of the nation's prosperity.

It would lead to a digression which might be considered out of place in these pages, if any attempt were made to examine the question of agricultural distress, as to which so much bas been said year after year, during a very large portion of the time in which the extension of tillage and the increase of production, here described, have been going forward; but we may be allowed to remark, that the parties who, during all that time, embarked their capitals in this branch of industry, must have been actuated by motives altogether different from those which influence the rest of mankind, if they were, year after year, content to accelerate their own ruin by increasing the extent of their operations. While the total number of families in Great Britain increased, between 1811 and 1831, from 2,544,215 to $3,414,175$, or at the rate of 34 per cent., the number of families employed in agriculture increased only from 895,998 to 961,134 , or at the rate of $7 \frac{1}{4}$ per cent. The increased production which is thus seen to have been brought about by a comparatively small addition of labour, has in a great degree resulted from the employment of capital in improving the soil, in draining and manuring, ${ }^{1}$ in throwing down a great part of the fences with which our forefathers were accustomed to divide their farms into small patches; through the use of improved implements of husbandry, and, above all, through the employment of a better

1 The use of crushed bones as a manure was first introduced in 1800, and the result has been to raise the value of such lands most materially. The increasing demand causes large quantities of boues to be imported from foreign, and sometimes distant, countries. The numerous herds of eattle that roam in a state of nature orer the plains of Sonth America, used formerly to be slanghtered for the sake of their hides, tallow; and horns, which were brought to Europe. Their bones were left to whiten on the plains, but they are now carefully collected together, and ships are rerularly dispatched to be lasded with thern for the use of our farmers. Since 1810 an extensive trade has been carried on in an article called Guano-the deposits of birds on certain islands in the Pacific and off the coast of Africu; which substance has been fouml to possess most important fertilizing properties. The number of tons of this fertilizer imported between 1841-1849 were:-

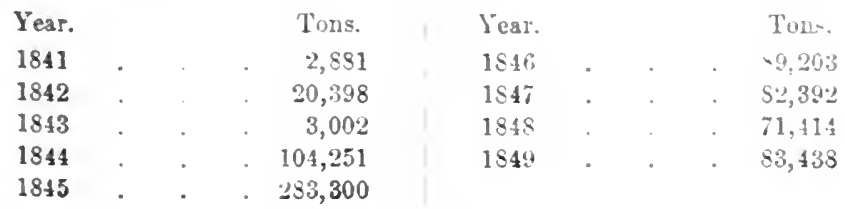


system of cropping by rotation. Nor should we omit to notice, among the most effective causes of this improved condition of agriculture, the help that has been borrowed from men of science. In particular the researches of Davy, undertaken at the instance of the Board of Agriculture, about the beginning of the nineteenth century, and the more recent investigations of Liebeg, may be mentioned as having produced the happiest results, by showing the various resources we can command, through the application of chemical knowledge, for remedying the defects and improving the natural capabilities of different soils. It may be added, that the great agricultural improvements since the peace, while they negative the notion of an uninterrupted series of losses to cultivators, are, in a great degree, the consequence of the stimulus to exertion supplied by low prices.

It is much to be regretted that in this country, rich as we are in the possession of facts connected with many branches of social economy, we are almost wholly uninformed with regard to the statistics of agriculture. The knowledge we have upon that most important subject, the quantity of land in cultivation within the kingdom, is entirely due to the industry of an individual whose estimates have never been either confirmed or questioned. What proportion of the cultivated land is applied to the production of any one article of food, it has never been attempted to ascertain. We know every rood of ground that is employed for the cultivation of hops, because of the direct financial interest which the government has in ascertaining the fact; but it does not appear to be sufficiently understood how the national interest can be concerned in any kind of knowledge that does not yield money to the exchequer.

An endeavour to obtain a part of this knowledge was made about the year 1810 in Scotland, by a spirited individual, the late Sir John Sinclair, by whom the clergy of that part of the island were induced to prepare those accounts of their respective parishes, the collection of which is well known under the name of the Statistical Account of Scotland. The property of this work was generously made over by Sir John to the society established in Scotland for the benefit of the sons and daughters of the clergy; and the managers of that society have since produced a new Statistical Account of Scotland, which interesting work brings to light many of the improvements which have been so generally made throughout the country. These improvements resulted in a general bettering of the condition of the 
farmers and labourers, an increase in the amount of land under cultivation, and an even greater increase in the yield per acre. The size of the farms has tended to increase, more capital has been put into them, and they have been cultivated with greater intelligence. A few extracts have been taken at random from the work, and are here inserted to illustrate the various forms, as well as the degree, in which those improvements have shown themselves.

Jedburgh, Roxburghshire.- "Since the period when the last statistical account was written, the state of the parish has been much improved; farms, which were entirely pastoral, now bear luxuriant crops, the fields have been neatly inclosed with hedges, waste ground has been planted, the style of dwellinghouses is now vastly superior, the means of communication have been greatly enlarged, the population has been nearly doubled, and all classes seem to enjoy a large share of the comforts of civilized society."

Melrose, Roxburghshire.- "The chief circumstance in which the present differs from the past state of the parish, is the general enlargement of the farms. Except in the case of a carrier or miller, who rents a few acres to furnish fodder for his horses, a small farm is nearly unknown. The displacing of the old small tenants was at first viewed with deep regret; but the introduction of a better and more spirited style of agriculture which immediately followed, the rapid improrement of the country, which in a limited period has raised the rental of this parish from $£ 4000$ nearly to $£ 20,000$ a year, besides the improved condition of the agricultural labourers, seem to show that it was a change for the better. The land is divided into a limited number of great farms, and the tenants, men of capital and intelligence, are enabled to gire the best effect to the rirtues of the soil, and the great body of the people live quietly under them as farm serrants and hired labourers, having no care but to do their work and receive their wages."

A consideration of the Inclosure Bills passed by Parliament, and of the average prices of wheat in England, will give a tolerably correct idea of the progress of agriculture in that part of the kingdom, between 1760 and 1849 .

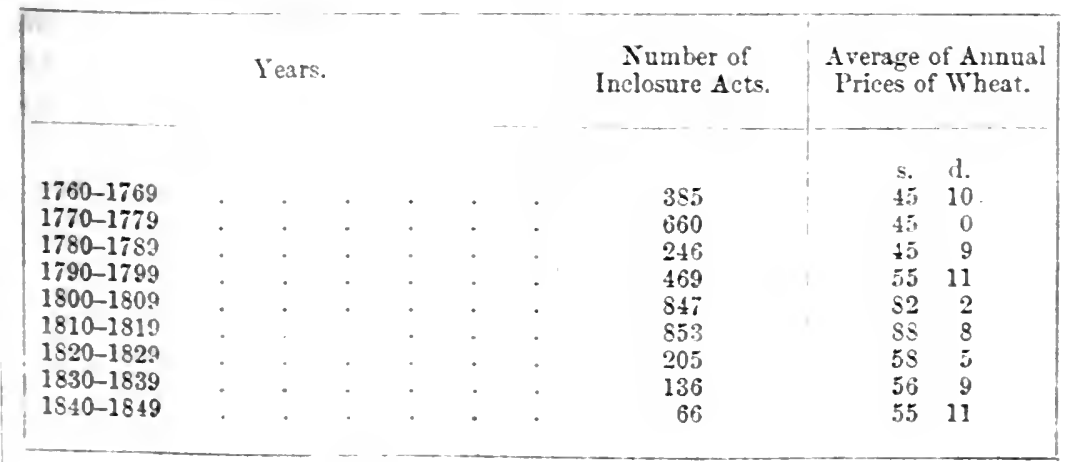


In the ten years from 1760 to 1769 , when the average number of inhabitants of England and Wales was 6,850,000 souls, the quantity of wheat produced was more than sufficient for home use by $1,384,561$ quarters-an inconsiderable quantity, and so near to the then wants of the people, that the deficient harvests of 1767 and 1768 occasioned the importation of the comparatively large quantity of 834,669 quarters. There were no means employed during that period for ascertaining the prices of grain with the correctness that has since been attained, and those given in the table cannot be received with confidence. If the Eton price then bore the same proportion it has since borne to the average price as computed for advertisement in the London Gazette, which is about 10 s. per quarter below that given in the Eton records, the average price of wheat must have been then about $37 \mathrm{~s}$. per quarter. At this price agriculture appears to have been considerably stimulated, the number of Inclosure Bills passed by the Legislature having been $385 .^{1}$ This stimulus was continued through the next decennary period, when the the number of Inclosure Bills was increased to 660 . This second period comprised five years of export and five years of import, the imports preponderating in quantity, but not considerably. The mean number of the population had in the meantime advanced to $7,520,000$ souls, and the average price of wheat, as ascertained for insertion in the London Gazette, was $45 \mathrm{~s}$. per quarter. In the next period, namely, from 1780 to 1789 , the mean number of the inhabitants had reached $8,170,000$ souls, but the supply of wheat was brought more nearly to a level with the demand. Owing to the fluctuations of seasons, six of the ten years were years of export, and four were years of importation, but the excess of the quantity brought in over that sent out was no more than 233,502 quarters. The average price for the whole number of ten years was $45 \mathrm{~s}$. 9 d., having once been as high as $52 \mathrm{~s}$. $8 \mathrm{~d}$. In two of the exporting years, namely, 1785 and 1789 , the average prices for the year were above 50s. per quarter. The number of Inclosure Bills fell off during this period to 246 .

In the next period of ten years, from 1790 to 1799 , England

${ }^{1}$ In the year 1689 an Act was passed allowing a bounty of fire shillings per quarter upon all British-grown wheat exportcd when the home price did not exceed 48s. per quarter. This Act was modified in 1773 , so that the bounty was not payable after the average price exceeded 44s. per quarter, and in 1815 the bounty was repealed. In point of fact, no bounty could have been claimed in any year after 1792 , when the average price for the whole year was only $41 \mathrm{~s}$. $9 \mathrm{~d}$. 
ceased to be an exporting country for wheat. In 1792 the price fell to $41 \mathrm{~s}$. 9d., and a considerable quantity was shipped abroad; but this was the last occasion on which our farmers found relief in foreign markets for an over-abundant stock of grain. The war of the French Revolution immediately followed; and in 1795 a series of deficient harvests began, which forced up the prices of agricultural prodnce, and caused a great additional number of Inclosure Bills to be passed.

The deficiency was aggravated to a dearth in 1800 and 1801 ; the price of wheat was driven up to the then unprecedented height of $115 \mathrm{~s} .11 \mathrm{~d}$. per quarter; and a considerable breadth of land was additionally brought inder the plough, the number of Inclosure Bills passed during the ten years from 1800 to 1809 reaching to 847 . A trifling export of wheat in 1808 , during which year the average price of that grain was $78 \mathrm{~s}$. 11d. per quarter, was not the consequence of any commercial demand from other countries, but was occasioned by military operations in the Peninsula. In 1810 , the first year of the next decennary period, we experienced the effects of another deficient harvest, and imported a million and a half quarters of wheat. The average price of wheat in 1810 was $103 \mathrm{~s}$. 3d. per quarter; but this rate, owing to the then depreciated state of our currency, was not equal to more than about $90 \mathrm{~s}$. if paid in gold. In 1812 the price advanced to $122 \mathrm{~s}$., but the deprecintion of the currency was then still greater; and the real price was not beyond $\mathfrak{£}$ j per quarter-a price sufliciently high, howerer, to cause the application of much additional capital to agricultural pursuits, so that in this year 133 Inclosure Bills were passed, being the largest number on record in any one year. The impulse thus given continued to operate for some time. It will be seen by inspection of the table, that 853 Inclosure Bills receired the royal assent in the ten years between 1810 and 1820 ; but the increased production thus brought about, together with the much diminished cost of transport from foreign countries, caused so great a reaction in the markets for grain, that the average price of wheat for the year 1814 fell to a rate which, measured by the standard price of gold, was not more than 54s. per quarter.

In this state of things the cry of distress among the orners and occupiers of land becnme exceedingly urgent, and the Houses of Parliament so far symrathized with them as to pass an Act in 1815 by which the monopoly of the home market was secured to the British grower of corn until the average price of wheat should 
reach $80 \mathrm{~s}$. per quarter, and that of other grain should attain a proportionate elevation.

For some time but little opportunity was given for judging of the efficacy of this law. A deficient harvest in 1816 caused prices to rise so high as to render the Act inoperative. In 1817 the harvest was again bad; during that year and 1818 more than $2,500,000$ quarters of wheat were imported, and the prices, although not nominally so high as they had been in previous years, were extremely burdensome to the people, owing to the operation of the restoration of the currency, which was then in progress.

The previous occasions of deficient harvests which have been noticed were always followed by the application of additional capital for bringing waste or common-field lands into arable cultivation; and it may in some measure be owing to the circumstance of those previous inclosures having greatly reduced the quantity of waste land applicable to this purpose, that the number of Inclosure Bills has since been materially diminished.

The number of Inclosure Bills passed in the ten years between 1820 and 1830 was only 205 , not one-fourth part of the number passed in the preceding period of the like duration-a disproportion which is the more remarkable from these circumstances:- - that the increase of population, which between 1811 and 1821 amounted to $2,645,738$, was $3,113,261$ between 1821 and 1831 ; and that the foreign supply during the first of these intervals was nearly double that obtained in the latter period. The disproportion between the average prices experienced in the two divisions of time was not so great in reality as in appearance, owing to the depreciation of the currency already noticed; but still when full allowance has been made for this consideration, it will be found that the fall of price was nearly 25 per cent. The periods of ten years chosen for

- making the comparison are sufficiently long for avoiding the objection that the seasons were less genial in the one case than in the other; and it would be impossible even without other evidence of the fact, to arrive at any other conclusion than that a larger amount of produce has been continually drawn from a given portion of ground than was obtained in general at the beginning of the century.

Between 1830 and 1844, a period of fifteen years, only 202 Inclosure Bills were passed, being on the average nearly 30 per cent. fewer than in the preceding ten years, and only about one-sixth of the yearly number passed between 1810 and $1820 \circ^{\circ}$ In the 
meanwhile, the population has advanced with accelerated rapidity, while the importatious of foreign wheat have kept pace with that advance.

The Select Committee of the House of Commons, which sat in 1813 to inquire into the state of the corn trade, stated in their Report, that through the extension of, aud improvements in, cultivation, the agricultural produce of the kingdom had been increased one-fourth during the ten years preceding the time of their inquiry. Earl Fitzwilliam, whose acquaintance with the subject of agriculture few persons will question, has expressed unequivocally his belief that the land has of late years been made, by means of better farming, to yield an increased quantity of produce. The following passage, in which this opinion is given, occurs in his Second Address to the Landovners of England on the Corn Lrews, published in April, 1835 :-

"It is somewhere about twenty years since we began to hear prophetic annunciations of this approaching abandonment of the soil. That, in the years which intervened between 1810 and the peace, wheat was extracted by a sort of hot-bed cultivation from soils whose natural sterility has, under the diminished pressure of necessity, and the influence of more genial seasons, rescued them from the plough, I entertain not a loubt; but I must confess that I have watched in rain for any extensive fulfilment of the prophesy. On the contrars, I am satisfied that the breadth of land under the plough (taking that as the criterion, though it is none, and I only take it in deference to those witl whom I am arguing) is greater than it was in 1814, and that the produce of equal surfuces of ploughed land has increased in a still greater ratio."

This opinion was decidedly contradicted by the witnesses examined before a Committee of the House of Commons in 1833, many of whom averred that owing to a deficient application of capital the productivity of land had diminished. Such a statement could, at most, only be true of certain "cold clay lands" and was certainly not true of land in general. On the contrary, during the last half-century a great revolution has taken place in the management of land. By proper attention to the rotation of crops, and by the application of capital to lighter descriptions of soil, those soils have been brought to a state which enables the farmer to draw from them a better return than would follow the application of the same amount of labour to the old wheat lands. According to the evidence given before the Committee of the House of Commons, almost the only grain produced in the fens of Camuridgeshire consisted of oats. Since then, by draining and manuring, the capability of the soil has been so changed that these fens now 
produce some of the finest wheat that is grown in England; and this more costly grain now eonstitutes the main dependence of the farmers in a district where, fourteen years ago, its production was searcely attempted.

In spite of the fact that the Committee of the House of Commons was appointed in 1833 as a concession to the agriculturalists and those interested in maintaining a protective system, the Report abounds with evidence of increased prosperity. Everywhere, the condition of agricultural labourers is stated to be visibly amended; while towns in agricultural districts, which are dependent upon the farming interests, had uniformly improved in extent, and in every other circumstance which indieates prosperity. Nor had the situation of the landowner been less materially improved, so far at least as his condition depended upon the rent he received for his land. With searcely any exception, the revenue drawn in the form of rent, from the ownership of the soil, has been at least doubled in every part of Great Britain since 1790. In the county of Essex, farms could be pointed out which were let just before the war of the French Revolution at less than $10 \mathrm{~s}$. per acre, and which rose rapidly during the progress of that contest, until, in 1812 , the rent paid for them was from $45 \mathrm{~s}$. to $50 \mathrm{~s}$. per acre. This advance has not, it is true, been maintained sinee the return of peace: in 1818 the rent was reduced to $35 \mathrm{~s}$, and at the present time is only 20 s. per acre, which, however, is still more than double that which was paid in 1790. In Berkshire and Wiltshire there are farms which in 1790 were let at $14 \mathrm{~s}$. per acre, and which in 1810 produced to the landlord a rent of 70 s., being a five-fold advance. These farms were let in 1820 at 50 s., and now (1850) pay $30 \mathrm{~s}$. per acre, being 114 per cent. advance upon the rent paid in 1790 . In Staffordshire there are several farms on one estate which were let in 1790 at $8 \mathrm{~s}$. per acre, and which having in the dearest time advanced to $35 \mathrm{~s}$, have since been lowered to $20 \mathrm{~s}$, , an advance, after all, of 150 per cent. within the half-century. The rents here mentioned as being those for which the farms are now let, are not nominal rates from which abatements are periodically made by the landlord, but are regularly paid, notwithstanding the depressed prices at which some kinds of agrieultural produce have been sold.

In Norfolk, Suffolk, and Warwickshire, the same, or nearly the same, rise has been experienced; and it is more than probable that it has been general throughout the kingdom. During the same period the prices of most of the articles which constitute the landlord's expenditure have fallen materially; and if his condition 
be not improved in a corresponding degree, that circumstance must arise from improvidence or miscalculation, or habits of expensive living beyond what would be warranted by the doubling of income which he has experienced and is still enjoying.

Among the agents employed for the improvement of agriculture we have now to mention the steam-engine. The fens in Cambridgeshire, Lincolnshire, and other eastern counties in which the low lands known as the Bedford Level occur, were formerly very imperfectly relieved from their surplus water by means of windmills, and to a considerable extent they are so still. Where this is the case, the farmer has sometimes to witness the frustration of all his hopes for the year, almost at the very period of their expected acconplishment. It frequently happens, that when rain falls in large quantities near the time of harrest, there is not a breath of wind to move the sails of his mill, and the field in which the yellow grain was waving is speedily converted into a lake. Some of the land thus circumstanced is among the most fertile in the kingdom, consisting of a bed of decomposed vegetable matter 30 feet in depth, and yielding crops of from four to five quarters of wheat per acre. By the substitution of steam-power for the uncertain agency of wind, the crop is now secured from the disaster we have mentioned. The expenditure of a few bushels of coals places it at all times in the farmer's porrer to drain his fields of all superfluous moisture, at a comparatively inconsiderable cost. It has been found that an engine of the power of ten horses is sufficient for draining 1000 acres of land, and that on the average of years this work may be performed by setting the engine in motion for periods amounting, in the aggregate, to 20 days of 12 hours each, or 240 hours in all. Several engines have been erected for this purpose within the last three or four years, some of them having the power of 60 or 70 horses; each of these large engines is employed in draining from 6000 to 7000 acres of land. The cost of the first establishment of these engines is stated to be $\mathfrak{f} 1$ per acre, and the amnual expense of keeping them at work 2s. $6 \mathrm{~d}$. per acre. This plan is found to bring with it the further advantage, that, in the event of longcontinued drought, the farmer can, without apprehension, admit the water required for his cattle and for the purpose of irrigation, secure in the means he possesses of regulating the degree of moisture, if the drought, as is frequently the case, should be followed by an excess of rain.

It is not possible to state the amount of land which has been brought into cultivation under the Inclosure Acts of which mention 
has been made. In a Report drawn up by a Committee of the House of Commons, which sat in 1797 to inquire into the state of the waste lands, an estimate is given of the number of acies which had been comprised in the Inclosure Bills carried into execution between 1710, when the first Inclosure Bill was passed in England, and the time of the inquiry. If the estimate of this Committee be taken as the basis of a further calculation, it will be found that the whole number of acres brought into cultivation from the beginning of the reign of George III to the end of the year 1849 has been $7,350,577:-$

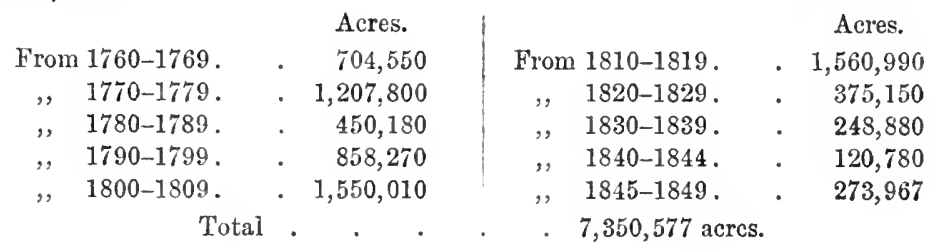

The proportion brought into use since the commencement of the nineteenth century has, according to this estimate, been $4,129,777$ acres, nearly four-fifths of which were so appropriated in the first twenty years.

No accurate statement can be made as to the amount of uncultivated land which may be expected to yield crops in the future. Evidence, however, was given by Mr. William Couling before the Select Committee of the House of Commons in 1827, as to the amount of land in the United Kingdom, classified in three divisions as cultivated, uncultivated but improvable, and unprofitable wastes. Mr. Couling, who was a civil engineer and surveyor, made careful inquiries, as a result of which he made the following estimate :--

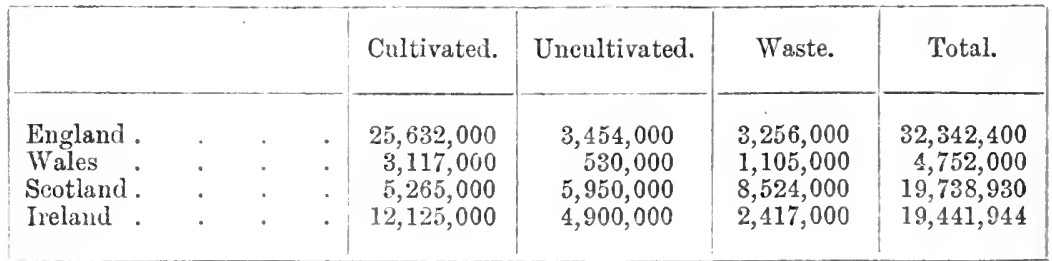

Mr. Couling made a further division of the cultivated land into arable and pasture, according to which there were in the United Kingdom 19,135,990 acres of arable and gardens and 27,386,980 acres of meadows, pastures, and marshes. How far the improvable land which has not yet been brought under cultivation will 
ultimately be able to provide for the needs of an increasing population will to a large extent depend on future improvements in methods of production. It has been affirmed, that in Wales the land does not produce half of what it is capable of producing; and that if all England were as well cnltivated as Northumberland and Lincoln, it would produce more than double the quantity that is now obtained. We have seen that out of 236,343 males, 20 years of age, who were occupiers of land in England in 1831, the large proportion of 94,883 employed no labourers, while the remaining number of occupiers $(141,460)$ employed among them only 744,407 , being in proportion of $5 \frac{1}{4}$ labourers to each farmer.

The distinction drawn in 1831 between the occupiers of land who do and those who do not employ labourers was not made at either previous census, so that we have no means of judging by such an indication of the progress of agricultural improvement; but it is well known that the tendency of late years-at least in England and Scotland - has been to enlarge the size of farms, and to place them under the charge of men possessed of capital, who have enjoyed a degree of instruction beyond that which fell to the lot of farmers in those days, the departure of which is deplored by the poet,

"When every rood of ground maintain'd its man."

By the employment of means such as have been indicated, there can be no doubt that for a much longer period than twenty years, the soil of these islands will continue to yield the largest proportion of the food of the inhabitants; and when at length the increase of population shall have passed the utmost limit of production, there can be no reason to doubt that we shall still obtain, in full sufficiency, the food that we shall require.

It has been seen that the meadows and pastures of the United Kingdom amount to $27,000,000$ of acres, or about three-fifths of the land hitherto brought under cultivation. The whole of this meadow and pasture land, with the exception of that part required for the production of fodder and pasturage for horses used for pleasure or for trading purposes, is used equally with arable land for the production of human food.

A very gencral opinion now prevails, that by means of the extension of railroads throughout the country, a large proportion of the pasture land here spoken of, as well as that important portion of the arable land which at present is employed in raising grain for horses, will be rendered more directly available than at present for 
the service of man. It is said that the successful establishment of the railroad between Liverpool and Manchester, a distance of little more than 30 miles, has had the effect of dismissing from that particular employment 1000 horses. The great extent and peculiar nature of the traffic between the two towns here mentioned will not justify the expectation of a similar saving through the establishment, in other quarters, of railroads of the like extent; but the saving from this source might certainly be productive of some effect, in placing at a somewhat greater distance, than would otherwise be the case, the time when the United Kingdom will cease to produce the principal part of the food of its inhabitants. In a Report presented by a Committee appointed to inquire into the subject of railroads, it is gravely stated that the effect of constructing railroads between the principal towns of the kingdom would be to render unnecessary no fewer than a million of horses.1 A very slight examination of the documents bearing upon this question, within their reach, would have sufficed to preserve the Committee from hazarding so extravagant an assertion. The extent of turnpike-roads in Great Britain, as they existed in 1829, amounted to 24,541 miles; and if the whole of these roads were converted into railroads, and the traffic upon every part of them were fully equal to that already mentioned as the estimate for the Liverpool and Manchester line, the number of horses that would by such means be rendered superfluous would amount to only 785,312. It would be greatly beyond the mark to estimate the saving at one-fourth of this number, or less than one-fifth of the million stated in the Committee's Report. But much more direct means of testing the accuracy of the Committee's estimate were at hand, furnished by detailed returns made from the Tax Office of the number of horses in respect of which assessed duties were charged in 1832, and which, including horses used in trade and that description of farm horses not wholly used in husbandry, upon which the duty is still retained $(124,076)$, amounted to no more than 340,678 . However much the railroad system may be extended, it is certain that a very large proportion of these animals must still be kept. Nearly all those employed for pleasure, and for the internal trade of towns, as well as the whole of those used on farms, would be continued.

${ }^{1}$ In many cases where railroads have been opened, it has been found that, although the use of horses has been discontinued upon the direct line, the increased traffic has made it necessary to employ, for bringing travellers to the railroad, at least as great a number of horses as had been displaced. 
A further examination of the returns made by the Tax Office proves that the anticipation of the Committee of the House of Commons has not hitherto been realized in any serious degree. In 1823 , the first year following the repeal of the duty on horses used in husbandry, and when the railway system had no existence, the number of all kinds of horses chargeable with duty was 305,275 , whereas in the latest year to which the statements reach (1848-49) the number chargeable was 317,319 , a result which completely refutes the notion of any serious diminution in the number of horses employed by reason of the opening of railroads.

There are not any documents from which the number of horses kept in this country can be ascertained. The elements for such a computation, which never were very complete, have of late years been rendered much less so, through the repeal of the taxes levied upon horses used for rarious employments. These taxes having existed up to 1822 , a statement is here given of the number of each description of horses charged to the duty in 1821, with the numbers for some recent years of borses in respect of which the tax is continued:-

\begin{tabular}{|c|c|c|}
\hline & \multicolumn{2}{|c|}{ Year ending 5 th April, } \\
\hline & 1821. & 1849. \\
\hline $\begin{array}{l}\text { Horses used for riding or drawing carriages } \\
\text { Horses let to hire } \\
\text { Race horses } \\
\text { Horses not exceeding } 13 \text { hands high } \\
\text { Horses ridden by farming baililfs } \\
\text { Horses ridden by butchers } \\
\text { Horses not wholly used in husbandry } \\
\text { Horses nsed in trade }\end{array}$ & $\begin{array}{r}\text { No. } \\
174,790 \\
1,616 \\
579 \\
11,536 \\
1,010 \\
3,631 \\
135,542 \\
\ldots\end{array}$ & $\begin{array}{r}\text { No. } \\
145,846 \\
1,859 \\
1,099 \\
21,736 \\
40 \\
3,281 \\
\ldots .709\end{array}$ \\
\hline $\left.\begin{array}{l}\text { Horses used in husbandry, charged at varions } \\
\text { rates of duty, according to the rent of } \\
\text { the farm, etc., and which have been re- } \\
\text { pealed in and since } 1822\end{array}\right\}$ & $\begin{array}{l}328,704 \\
832,726\end{array}$ & $\begin{array}{l}303,569 \\
\text { exempt }\end{array}$ \\
\hline Total number upon which duties werc charged & $1,161,430$ & 303,569 \\
\hline
\end{tabular}

It appears from this table, that of the horses liable to duty there are not more than 180,000 , out of which the saving contemplated by the Colmmittee can be made. But the returns from the Tax Office do not include horses used in posting, in stage- 
coaches, mail-coaches, or hackney-coaches. In Middleton's Survey of Middlesex, the number of such horses was estimated at 100,000 for the whole of England and Wales; Mr. M'Culloch states, as the result of more recent inquiries, that "if the number of such horses in Great Britain is now estimated at 125,000 , we shall be decidedly beyond the mark." 


\section{CHAPTER XI}

\section{BRITISH AGRICULTURE FROM 1850}

Food supply-Growth of imports-Prosperity from 1850 to 1875 -Heavy fall of prices and agricultural depression-Gradual recovery after 1895-Agricultural statistics

THE rapid increase in population which bas taken place during the last sixty years has already been shown in a previous chapter. This increase has been entirely due to the great expansion of the industrial and cistributing centres of the country, and to the success of British manufacturers in the world's markets. A necessary condition of such a development has been a large and expanding supply of food for the artisan and labouring classes, a supply which our agriculturalists have found themselves, at least as regards the staple products, progressively less able to produce. The result has been that the agricultural history of the period is mainly a history of the development of and readjustment to these altered conditions of demand and supply. In the economic life of a nation it is a commonplace to say that every sudden and extensive change, however beneficial in its ultimate effects, must cause a dislocation in the established relations of different classes, and that the process of readjustment to the new conditions generally entails some suffering and distress. This has certainly been true of agriculture. British farmers have had to accustom themselves within a comparatively short period to conditions utterly unlike those which confronted their forefathers. The old routine which with slow assimilation of modifications and improvements had been successfully followed by generations of farmers was, within the space of a few years, thrown out of gear and shown to be at many points inadequate to their needs. Since 1850 , therefore, we have to watch first of all the altered conditions which British agriculture was called upon to meet, and how they arose, and also to see in what.ways and how far the readjustment has in the end been accomplished. 
The most striking feature of the present position of agriculture, as compared with the position sixty years ago, lies in the very much smaller proportion of home-grown to forcign produce. The figures showing the average annual imports into the United Kingdom of wheat, barley, oats, butter and beef in short groups of years supply ample evidence on this point.

\section{Million Cuts.}

\begin{tabular}{|c|c|c|c|c|c|c|c|c|c|c|c|c|}
\hline & 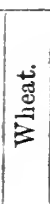 & 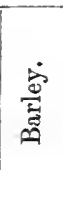 & $\frac{\dot{p g}}{\tilde{E}}$ & 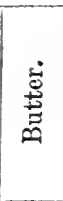 & 芯 & & 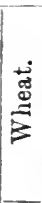 & $\frac{\dot{g}}{\ddot{\Xi}}$ & 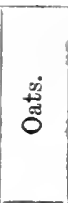 & 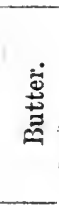 & 㤫 & 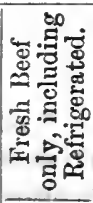 \\
\hline $\begin{array}{l}1851-1855 \\
1856-1860 \\
1861-1865 \\
1866-1870 \\
1871-1875 \\
1876-1880\end{array}$ & $\begin{array}{l}14 \\
18 \\
28 \\
32 \\
44 \\
53\end{array}$ & $\begin{array}{r}2 \cdot 3 \\
5 \cdot 7 \\
6 \cdot 3 \\
7 \cdot 4 \\
11 \cdot 0 \\
12 \cdot 0\end{array}$ & $\begin{array}{r}2 \cdot 9 \\
4 \cdot 8 \\
5 \cdot 9 \\
9 \cdot 0 \\
11 \cdot 6 \\
13 \cdot 0\end{array}$ & $\begin{array}{l}0.4 \\
0.5 \\
1.05 \\
1 \cdot 2 \\
1 \cdot 4 \\
1 \cdot 9\end{array}$ & $\begin{array}{l}0.17 \\
0.2 \\
0.24 \\
0.24 \\
0.25 \\
0.73\end{array}$ & $\begin{array}{l}1881-1885 \\
1886-1890 \\
1891-1895 \\
1896-1900 \\
1901-1905 \\
1906-1908\end{array}$ & $\begin{array}{l}58 \\
56 \\
69 \\
67 \\
87 \\
94\end{array}$ & $\begin{array}{l}12 \cdot 0 \\
16 \cdot 6 \\
21 \cdot 8 \\
20 \cdot 1 \\
24 \cdot 8 \\
19 \cdot 2\end{array}$ & $\begin{array}{l}16 \cdot 3 \\
15 \cdot 1 \\
15 \cdot 4 \\
17 \cdot 0 \\
17 \cdot 2 \\
13 \cdot 3\end{array}$ & $\begin{array}{l}2 \cdot 4 \\
1 \cdot 8 \\
2 \cdot 4 \\
3 \cdot 2 \\
4 \cdot 0 \\
4 \cdot 2\end{array}$ & $\begin{array}{c}1 \cdot 02 \\
1 \cdot 14 \\
\ldots \\
\ldots \\
\ldots \\
\ldots\end{array}$ & $\begin{array}{l}1 \cdot 11 \\
2 \cdot 02 \\
3 \cdot 3 \\
4 \cdot 3 \\
5 \cdot 6\end{array}$ \\
\hline
\end{tabular}

It is quite clear from this table that the increased demand for food required by the growing numbers and wealth of the population has been met by a corresponding growth of imports. The remarkable increase in the importation of corn and meat, as shown above, if not directly caused, has at any rate only been rendered possible by the development of steam transport, which has enabled farmers in distant countries to raise large crops in the certainty that, if not required at home, they can be shipped and delivered to any port of the world where there may be a demand for them. In 1849 there were 4,835,280 qrs. of wheat and wheat flour imported into Great Britain. Of this France supplied more than any other country, namely, 742,023 qrs.; then came Prussia with 618,690 qrs., then the United States of America with 617,131 qrs., and then the Black Sea Provinces with 551,378 qrs. $^{1} \quad$ No less than 78 per cent. of the total import came from European countries. So long as ships were dependent on the wind and weather for making port, England must have looked primarily to Europe to satisfy her needs for all such perishable articles as corn, nor, under such circumstances, would it ever have been possible to meet the growing demand for all kinds of food from very distant markets. But with the development of steam navigation England began to draw upon all the 
world for her supplies. In the period 1S71-75 the average import of wheat had grown, as shown above, to 44,000,000 cwt., and of this no less than 58.7 per cent. was on the average imported from countries outside Europe, the United States of America and Canada being responsible for $47 \cdot 2$ per cent. In the period 1896-1900, while the total import, as shown above, had grown to $67,000,000$ cwt., the proportion coming from countries outside Europe had increased to no less than 87 per cent.

Following on this increased importation of foreign food-stuffs there has taken place a general lowering of prices. Taking again the annual average in groups of years, the price of wheat per imperial quarter has been :-

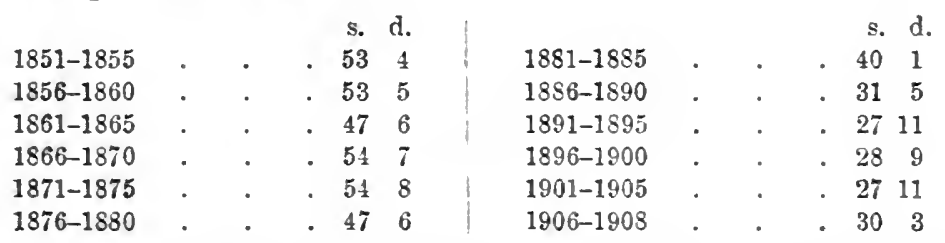

The period between 1850 and 1875 shows the price of wheat to have remained fairly stable between $54 \mathrm{~s}$. 8 d. and $47 \mathrm{~s}$. 6 d., but it should be remembered that even this level was considerably lower than that prevailing during the first twenty years of the century, and somewhat lower than the average of prices between 1820 and 1840. So long, however, as the price of wheat remained in the neighbourhood of $50 \mathrm{~s}$. a quarter, it was even then possible for British farmers by progressive improvements in their methods of cultivation to continue their production under satisfactory conditions. But after 1875 the question of prices became much more serious. It was found impossible by technical improvements so to increase the yield on ordinary corn-growing land as to give the farmer any hope of profit at prevailing rents.

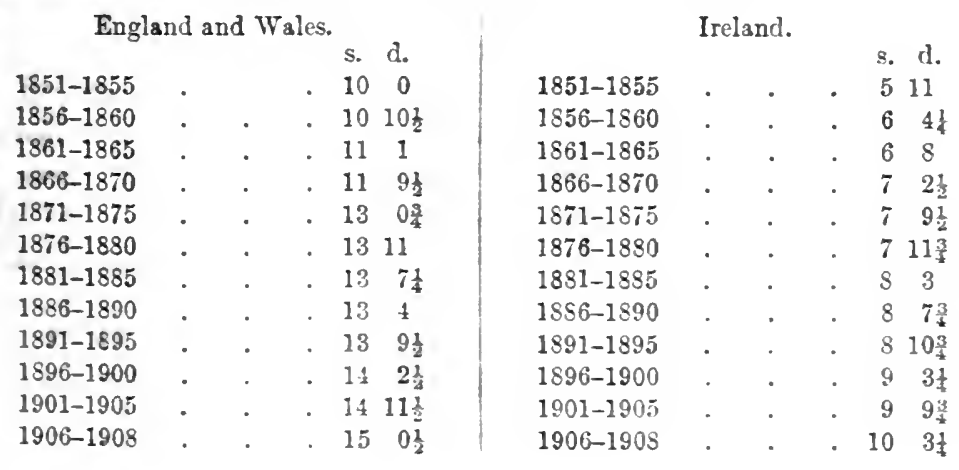


Not only were prices beginning to fall, but wages had been steadily rising for some time. The table at the foot of p. 195 gives the average rate of agricultural wages in England and Wales and also in Ireland in groups of years.

It should be observed that the periods 1871-75 and 1876-80 are not strictly comparable, as the latter figures and those following them are based on a larger number of returns, which make the average rate for England and Wales about 5d. higher and that for Ireland about $5 \mathrm{~d}$. lower for the second period than they would have been on the older basis of returns. Allowing for this, however, it will be seen that the rate of wages in Ireland has risen continuously, nearly doubling in the period, and wages in England and Wales, except for a slight fall which took place between 1880 and 1890 , have also risen fast.

The increase of wages, however, has not been sufficient to countervail the ever-increasing attractions of town life and the development of labour-saving machinery. The number of agricultural labourers has diminished very rapidly, as appears from the following census returns for England and Wales: ${ }^{1}$

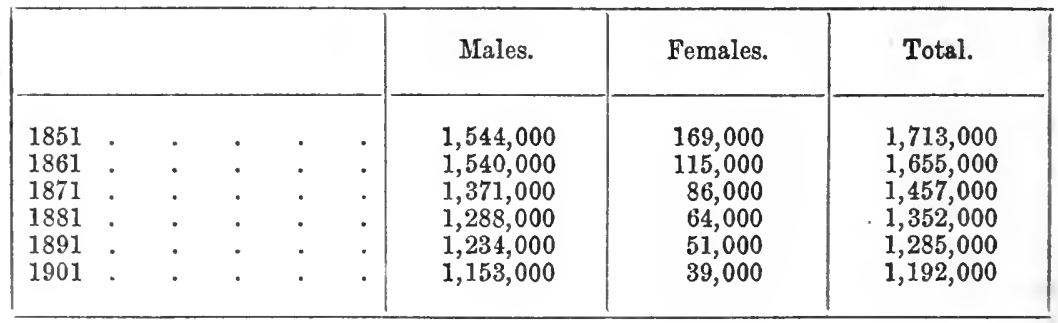

It is impossible to make many generalizations as to the course of British agriculture which shall be true, or equally true, for all parts of the United Kingdom at the same time. The figures and tables which have already been given are based upon returns made by Government Departments, and may be taken as giving in a summarized form the average or mean of what has occurred in the country considered as a whole. But the changes so indicated have been by no means equally apparent in different parts of the United Kingdom. What is true of one part, or of the country as a whole, may be quite untrue of other parts, or only true of them at a later date.

The period between the repeal of the Corn Laws in 1848 and the beginning of the agricultural depression, which first became 
generally felt nearly thirty years later, was one of an almost unparalleled prosperity for farmers. Although wheat did not rise to the famine prices which so constantly recurred in the first half of the century, yet it maintained a consistently high and remunerative level, and tended, if anything, to rise rather than to fall. The average price of barley had risen from $29 \mathrm{~s}$. $2 \mathrm{~d}$. per $q \mathrm{r}$. in $1850-54$ to $38 \mathrm{~s}$. $8 \mathrm{~d}$. in $1870-74$, and the average price of oats per quarter had risen in the same periods from $20 \mathrm{~s}$. 7 d. to $25 \mathrm{~s} .1 \mathrm{~d}$., without serious annual fluctuations in either case. Comparing the year 1879 with the average for the years $1845-50$, we find that the price of butcher's meat had risen 27 per cent. and raw wool had risen 9 per cent. Salt beef, mutton and pork all showed a marked rise. These good prices were maintained in spite of increased supplies from abroad, and were very largely due to the better standard of living in the towns. In 1850 the mass of the people scarcely ever tasted butcher's meat, but rapidly rising wages in the towns led to a great increase in its consumption by the working classes. In 1851 only 86,520 head of cattle were imported. In 1879 the number had risen to 247,768 . The most remarkable increase, however, is shown in the imports of bacon and ham which during the same period rose from 192,118 cwt. to $4,917,631$ cwt., the price in the meantime falling about $10 \mathrm{~s}$. per ert.

Meanwhile farming methods underwent considerable improvements. The most noticeable of these was the general introduction of reaping machines, one of which was reckoned to have an efficiency equal to that of ten men. Their greatest merit, however, lay in an economy of time at the critical period of harvesting, when the farmer so often requires to get in his crop with the greatest possible speed. A similar machine for cutting hay was also introduced. Another but less popular invention was the steam plough. The expense of this machine, however, put it out of reach of small farmers, and it was found not to be equally advantageous on all kinds of soil. But on large farms with heavy soil the steam plough has proved its value. With regard to cultivation itself several improved systems of manuring were introduced. Chemical research discovered what were the valuable properties in the old forms of manure, and experiments were made with nitrate of soda and various other ammoniacal and phosphatic manures which, together with largely increased supplies of guano and natural manures, combined still further to raise the average fertility per acre. While all estimates as to average yield must 
be used with care, those given by Mr. Caird for this period are probably the most reliable. ${ }^{1}$ He estimated the average fertility of England in 1850 to be $26 \frac{1}{2}$ bushels of wheat per acre. In 1868 he fixed it at 28 bushels, the average produce in Ireland over the same period being 24 bushels per acre, and even this was reckoned by him to be 50 per cent. better than the average yield in France. Intensive cultivation, in fact, made great progress, and the old system of crop rotation, wheat, turnips, barley and clover, itself a great step forward, could be dispensed with for long periods, so great was the increased fertility due to these artificial manures. Their chief advantage lay in the fact that; weight for weight, they yielded a far greater return than the old farmyard manure, and could be distributed over the ground more evenly and with much less labour. Further, in many parts of the country great additions to the natural resources of the country were made by extensive drainage and reclamation, assisted both by loans from the Government and, later, by Land Improvement Companies. ${ }^{2}$ These loans during thirty years (1848-77) amounted to about $£ 15,000,000$, a great part of which was taken up in Scotland. Further progress was also made in the construction of buildings and in other applications of steam power, while the Royal Agricultural Societies in England and Ireland and the Highland Agricultural Society of Scotland did much to stimulate enterprise and good breeding by their experiments, their exhibits of live stock, and by the general dissemination of knowledge.

With regard to the permanent improvement of farm capital, the Agricultural Holdings Act of 1875, from which, however, exemption could until 1883 be secured by contracting out, gave the English farmer a legal right, on expiry of the lease, to compensation for all unexhausted improvements of which he had borne the cost. In Scotland a similar incentive to progress had been achieved long before in the custom of granting nineteen-year leases. In Ireland, where the landlords had been chiefly absentees and the more human relations between landlord and tenant had therefore been lacking, a change was brought about largely as a result of political agitation and intense economic discontent. The Irish tenant had for a long time tenaciously held the view, repugnant to English law and custom, that so long as he paid the stipulated rent he could do as he liked with the farm, sell it to whomsoever he wished and recover the full value of all the unexhausted improve-

${ }^{1}$ Caird, Statistical Jowrinal, p. 130, 1868.

2 Jour. of Roy. Agric. Soc. Caird, 1879. 
ments. He regarded himself, in fact, as part owner of the soil. In prosperous times the system worked well enough and the landlord was satisfied to receive his rent. After the potato famine, however, landlords in their endeavours to collect arrears of rent, and in violation of past custom, resorted to evictions and other measures which exasperated the tenants, filled them with a sense of injustice, and led to agrarian risings. This period marked an epoch in the agricultural history of Ireland and gave a forcible impetus to that stream of emigration which has continued ever since to flow from the country. In some parts of Ireland, however, especially in Ulster, the law courts upheld the Irish tenants in their view of what constituted customary "tenant right," and enforced it where it could be proved. At length, after the failure of many other measures, the Land Act of 1870 was passed which made "tenant right" universal throughout Ireland. Later, under various Acts, the land of Ireland began to be transferred from landlords to tenants. And this plan was gradually extended in succeeding years, until by the Wyndham Act of 1903 a vast financial scheme was carried by which the Irish landlords were induced to sell land to their tenants at the rate of about $£ 5,000,000$ a year. The Act imposes a serious strain upon British credit, but has on the whole given great satisfaction in Ireland.

During the whole of this period, from 1850 to the middle of the 'seventies, every class engaged in agriculture benefited to some extent in the general prosperity. Rents, wages and profits all showed a tendency to rise. Mr. R. J. Thompson gives the following figures in the Statistical Journal for the average rent per acre in England and Wales between 1850 and 1877 , based on returns from 132,000 acres up to 1871 and on 400,000 acres after that date. These latter figures show a somewhat higher average than would be given on the earlier basis:-

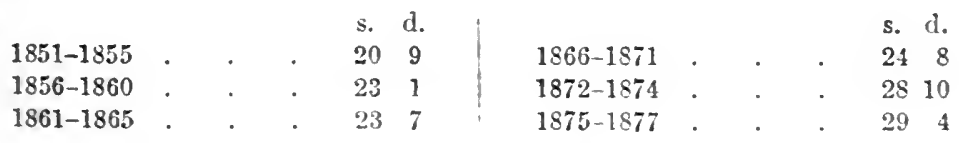

These figures, of course, do not pretend to show the average rent of land over the whole country, nor on any particular kind of soil, but they may fairly be taken as an indication that the rent of agricultural land rose steadily.

Wages, as has been shown in a previous table, rose on the average from $10 \mathrm{~s}$. in $1851-55$ to $13 \mathrm{~s}$. $11 \mathrm{~d}$. in $1876-80$ in 
England and Wales, and from 5s. 11d. to $7 \mathrm{~s} .11 \frac{3}{4} \mathrm{~d}$. in Ireland.

In spite of having to pay more wages and rent there is no doubt that farmers also shared in the general prosperity. They suffered, however, from a diminishing number of labourers. Women, especially, tended to be withdrawn from field-work, but the census figures on this point are not altogether to be relied upon, owing to changes in the method of enumeration. Children, too, largely as a result of the Education Act of 1870 , show a marked falling off. At the same time the attractions of town life, and especially the higher wages to be obtained in industry, also curtailed the agricultural labour market. According to the census returns, the chief falling off in males occurred between 1861 and 1871 , as is shown by the following figures:-

\begin{tabular}{|c|c|c|c|c|c|c|c|}
\hline & & & & \multicolumn{2}{|c|}{$\begin{array}{l}\text { Total Workers on Farms (ex- } \\
\text { cluding Farmers' Sons under } \\
15 \text { and Female Relatives). }\end{array}$} & \multicolumn{2}{|c|}{ Decline on Previous Census. } \\
\hline & & & & Males. & Females. & Males. & Females. \\
\hline $\begin{array}{l}1851 \\
1861 \\
1871 \\
1881 \\
1891 \\
1901\end{array}$ & : & $\begin{array}{l}\cdot \\
\text { : } \\
\text { : } \\
\text { : }\end{array}$ & $\begin{array}{l}\dot{ } \\
\dot{5} \\
\text {. }\end{array}$ & $\begin{array}{r}1,233,000 \\
1,206,000 \\
1,014,000 \\
925,000 \\
842,000 \\
715,000\end{array}$ & $\begin{array}{r}143,000 \\
91,000 \\
59,000 \\
40,000 \\
24,000 \\
12,000\end{array}$ & $\begin{array}{r}27,000 \\
192,000 \\
89,000\end{array}$ & $\begin{array}{l}52,000 \\
32,000 \\
19,000\end{array}$ \\
\hline
\end{tabular}

To some extent the farmer overcame the labour difficulty by the consolidation of holdings which proceeded rapidly at this time, but more by a general use of labour'saving machinery and by the conversion of arable into pasture land.

The agricultural depression beginning at the end of the 'seventies has been the subject of much inquiry and discussion. Certain features, however, admit of no dispute. Distress was no mere local or national phenomenon. It was felt, in greater or less degree, in every country of Europe. During the early stages great stress was laid upon temporary or accidental circumstances, which were held to be chiefly accountable, and it is true that in the United Kingdom the harvests of $1875,1876,1877$ and 1879 were very deficient, probably to the extent of about one-quarter of the normal, while the stocks of cattle and sheep both declined about 7 per cent. during the same years. Indeed, 1879 is said to have been the 
worst season of the century. The figures of the estimated home produce of wheat for the years 1874-1879 are:-

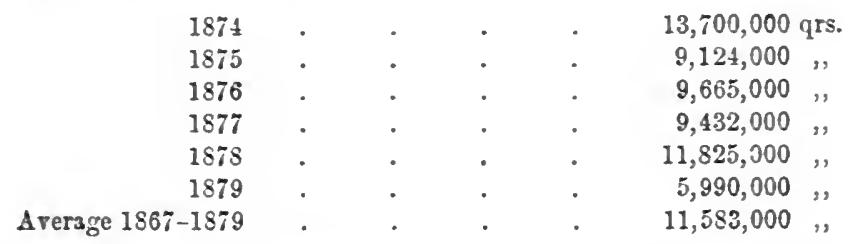

The bad seasons, however, did not affect the whole country equally, Cheshire, the north and south-west of England suffering less than the southern counties, whilst the hilly regions of Wales and Scotland, dependent more on stock raising than on cultivation of the soil, suffered much less. Various estimates have been made of the loss of farm capital sustained during these few years. Assuming a constant rate of consumption per head, not an absolutely reliable assumption, and allowing for the increase of population, the loss to British farmers as represented by the increased imports of agricultural produce was estimated by Mr. Caird before the Royal Commission of 1882 to amount to $£ 138,828,000$ in six years. As this was a period of growing industrial depression, it is unlikely that any large proportion of these increased imports was due to any gradual increase in the demand for food per head, which would, of course, invalidate any such method of estimating the loss. It is legitimate, therefore, to assume that most, if not all, of these foreign importations represented an actual displacement of British produce.

The Royal Commission which reported in 1882 found that in the rest of Europe agricultural depression existed in most countries of the Continent except Denmark. They none the less were of opinion that circumstances peculiar to the United Kingdom were mainly accountable for the existing distress. But so far as bad seasons and short crops were concerned, they had been experienced before without any serious disaster to agriculturalists. Generally, indeed, higher prices following a diminished supply, had gone far towards recouping the farmer. The peculiarity of the present case lay in the fact that short crops at home, being so much smaller a proportion of the total consumption, had very much leas effect upon prices. Besides the poor seasons, farmers had to contend with a rise of wages, a rise which was in no degree the result of increased efficiency, but represented merely the balancing of supply and demand. In fact, the general testimony was that the efficiency of agricultural labour had fallen anything up to 25 per cent. 
within the preceding twenty years. However this may be, it is quite probable that the continual drain of labourers to the towns tended to deprive the country of the most enterprising and efficient class of men. The agricultural labourer, indeed, appears to have suffered far less from the depression than either the farmer or landowner. The very causes which reduced the rents of the landlord and the profits of the farmer and sometimes practically ruined both or either of these classes, was beneficial to the agricultural labourer. For in the old periods of scarcity he was hardly able to live in consequence of the high prices of food; whereas now his cheaper food, clothing and rent compensated him for the slight fall in wages which occurred between 1877 and 1887. About this time agricultural labourers began to imitate the action of trade unionists in the towns. The National Agricultural Labourers Union, founded by Joseph Arch in 1872, was created primarily for the purpose of raising the social and economic condition of the labourers. The society grew rapidly and in 1881 had a membership of about 25,000 agricultural labourers, united under the Trades Unions Act, and paying about $£ 3000$ per annum in sickness and death benefits. The society also assisted to emigrate about 700,000 persons in eight or nine years.

While in Great Britain the acreage under 'wheat had fallen between 1874 and 1881 from 3,630,000 acres to 2,806,000 acres, that under oats had actually increased from 2,596,000 acres to 2,901,000 acres, 1881 being the first year in which the oats acreage in England exceeded the wheat. The net fall in the total corn crop acreage during the same years was from $9,431,000$ acres to $8,848,000$ acres, while permanent pasture increased from $13,178,000$ acres to $14,643,000$ acres. At the same time there was an increase in the acreage under fruit, nursery and market gardens, an increase which has since continued. According to the census returns the number of seedsmen, florists and gardeners (including domestic gardeners) in England and Wales has been:-

$\begin{array}{cccccc}1851 . & 1861 . & 1871 . & 1881 . & 1891 . & 1901 . \\ 76,5000 & 94,100 & 119,600 & 145,200 & 174,000 & 211,000\end{array}$

Between 1874 and 1881 the number of cattle, sheep and pigs declined considerably, but the number of horses used in agriculture increased from $1,312,000$ to $1,425,000$.

For ten years after 1882 the seasons showed a marked improvement on the average, but the period between 1893 and 1895 , with alternate drought and excess of rain, brought further heavy 
losses on the farmer, especially in the east and south of England. Harvest conditions, however, were not, generally speaking, such as by themselves to account for the continued depression which in 1893 called for the appointment of another Royal Commission. The callapse was most noticeable in such purely agricultural counties as Essex and Suffolk which relied mainly upon cereals. Rents were not infrequently found to have fallen 50 per cent. in twenty years, bankruptcies were frequent, capital was being drained away, many landlords were embarrassed and many farmers were ruined. Norfolk, South Cambridgeshire and North Lincolnshire suffered hardly less. These are the typical corn-growing counties, but nearly the same conditions prevailed in all the arable districts of the country. The grazing sections and such counties as Wiltshire and Gloucestershire suffered less than the arable districts. Those parts which showed least signs of distress were either in close proximity to large manufacturing towns or else chiefly devoted to dairying. Some evidence of the magnitude of the depression is afforded by the reduction in the land valuations which appear in the reports of the Commissioners of Inland Revenue. Under Schedule $\mathrm{A}$ of the Income Tax returns, the annual value of land in Great Britain fell between 1875 and 1894 from $\mathfrak{£} 66,911,000$ to $£ 56,212,734$, a decrease of $£ 10,698,266$. In the same period the capital value of land is stated to have fallen from thirty to about eighteen years' purchase of annual value. On this basis, which is probably an extreme one, the capital value of land fell between 1875 and 1894 from $£ 2,007,330,000$ to $£ 1,011,829,212$, a decrease of $£ 995,500,788$, or about 50 per cent.

Whereas in 1882 it was still possible to regard the fall in prices as only a secondary factor in the agricultural depression, it had become evident by 1895 that it was of paramount importance. The following table of triennial average prices of British wheat, barley and oats shows the extent of the collapse :-

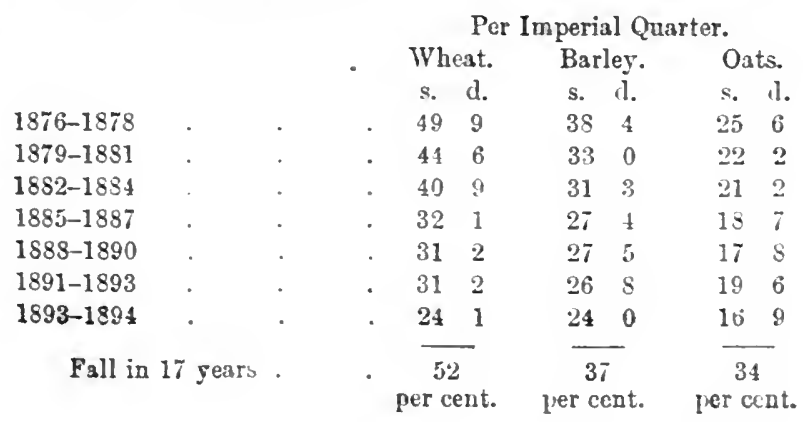


The price of pork in the same period fell 10 per cent. The price of the different varieties of wool fell between 40 and 50 per cent. As regards dairy produce, the fall between 1874 and 1891 is estimated to have been from 25 to 33 per cent. Potatoes fell about 20 per cent. in the twenty years. The price of hops fluctuated widely but exhibited a falling tendency after 1883 :-

\begin{tabular}{|c|c|c|c|c|c|c|c|c|c|}
\hline 1801 & & s. & d. & & & & & d. & \\
\hline 1881 & . & 5 & 9 per cwt. & 1889 & - & & & & $\mathrm{c}$ cwt. \\
\hline 1882 & . & . 10 & ", & 1890 & . & & 8 & 0 & ," \\
\hline 1883 & . & . 10 & , & 1891 & . & & 8 & 0 & , \\
\hline 1884 & . & 6 & 2 & 1892 & . & & 7 & 2 & , \\
\hline 1885 & . & 5 & , & 1893 & . & . & 3 & 9 & , \\
\hline 1886 & . & 3 & , & 1894 & . & . & 4 & 9 & , \\
\hline 1887 & . & 4 &, & 1895 & . & . & 3 & 7 & , \\
\hline 1888 & . & 5 & 8 & & & & & & \\
\hline
\end{tabular}

There is no need to go behind these figures to understand why the situation was regarded as so serious. A general fall in price of from 20 to 50 per cent. in the staple articles of agricultural production could have nothing but a disastrous effect upon both farmers and landlords. Mr. Thompson's figures for rent, based on returns from 400,000 acres, are as follow:-

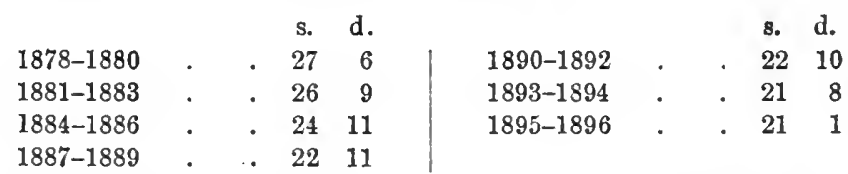

It is, however, somewhat surprising to find that the number of male agriculturalists declined during this period rather more slowly than they had done in the times of prosperity. Whereas between 1861 and 1871 there was a reduction of 192,000 or 13 per cent.; the fall between 1871 and 1881 was only 89,000 or 9 per cent., and between 1881 and 1891 only 83,000 or $7 \cdot 7$ per cent. Here again, however, the figures cannot be pressed too closely owing to changes in the method of enumeration. Between 1879 and 1895 the acreage under wheat in the United Kingdom declined from $3,056,000$ acres to $1,456,000$ acres or 52 per cent., barley or beer from $2,932,000$ to $2,346,000$ acres or 20 per cent., whilst oats increased from $3,998,000$ to $4,528,000$ acres or 13 per cent. The total corn crop area was reduced from $10,777,000$ to $8,865,000$ acres or 18 per cent.

By 1895 the average price of agricultural produce bad fallen to its lowest point. The difficulty of meeting foreign competition had fallen heavily on both tenants and owners of land. The small 
owner suffered most of all, because, while possessed of very little, if any, liquid capital, he had no hope of meeting his losses either by a saving in rent or out of his private means. In such cases the land was often allowed to relapse into pasture, or devoted to some other kind of cultivation, or converted wholly to sport.

But in cases where the owner was not the cultivator the farmer was to some extent assisted by securing a reduction in rent. It is quite clear, however, that reductions in rent, although general throughout the country, did not nearly keep pace with the fall in the price of agricultural produce. So much was implied by the Royal Commission which reported in 1897. Nevertheless the fall in rents has been a most important factor in enabling British farmers to adjust themselves to the altered conditions with which they were then faced. The natural tendency has been more and more to shift the burden from the occupier back on to the owner of the soil. But the Commissioners reporting in 1897 were not satisfied with the natural working of economic laws in this respect, and considered that, in order more equally to distribute the burden, the owners of agricultural land should be relieved of some of their rates. The Agricultural Rates Act of 1896 accomplished this by enacting that agricultural land should be assessed for rating purposes at half its real value. How far this monetary relief resulted in a more profitable cultivation of the soil is doubtful, but it may have had some effect in hastening the reduction of rents to a level economically more justifiable. Another and totally different method of dealing with the situation had been adopted in 1892 by the Small Holdings Act of that year, following on the Report of a Select Committee. That Act enabled county councils to acquire land which they could subsequently sell as small holdings to purchasers on deposit of one-fifth of the purchase money, receiving the remaining capital and interest over a period not exceeding fifty years. Lots not exceeding ten acres could, however, be let instead of sold on certain conditions, and there were certain limited facilities for advancing money to purchasers when the county council was satisfied that the purchaser could not find the money himself. A return of the Board of Agriculture in 1895 showed that only eight county councils had put the Act into operation to the extent of purchasing 483 acres in the whole of Great Britain. The Report of 1897 calls attention to the practical failure of the Act, but does not suggest the causes or the remedy. The chief hindrances to its effective working lay in the inability of the county council to lease holdings over ten acres in size, in 
the absence of powers of compulsory purchase, and in the necessity for energetic and sympathetic administration of the Act by county councillors who had had extensive agricultural experience. But it is no doubt also true that small holders in the United Kingdom have to a great extent been lacking in that spirit of co-operation which is essential to their success, and to which the strength of the small holder in France, Germany and Denmark is largely due. The backwardness of England in this respect has been partly caused by the relatively great number of large estates which renders cooperation between the smaller a more difficult matter. The Small Holdings Act of 1907, of which much was expected, proved equally futile. So far back as changes in statistical methods allow of strict comparison, it would seem that there has been only a trifling increase in the total number of small holdings.

In Ireland the period following the potato famine was responsible for a great amount of farm consolidation. But since 1885 , at least, the co-operative movement in Ireland has made some headway. In 1907 there were 249 co-operative credit associations in the United Kingdom, of which 32 were in England and Wales, 1 in Scotland, and 216 in Ireland. The total membership of all these societies amounted to nearly 21,000. There were also in 1907 in the United Kingdom 296 co-operative societies engaged in distribution and 350 engaged in agricultural production, of which latter 286 were special dairying and farming societies.

A third important way in which methods of agriculture have been adapted to meet modern conditions can be seen by reference to crop statistics. Of all cereals wheat had during the depression fallen most in price and consequently, as has been shown, it was the wheat land which, most of all, tended either to fall out of cultivation or be used for another kind of crop. For this reason all deductions based on an examination of figures relating to wheat only are very apt to be misleading. Since 1881 wheat has ceased to be the chief cereal crop of England, and in Scotland the oat crop has always been of far greater importance than that of wheat. Whereas between 1879 and 1895 the average price of wheat had fallen 47 per cent., oats had only fallen 34 per cent. This relative advantage in the price of oats over wheat is the chief reason for its substitution. But wheat land has also gone into other forms of cultivation. One of the most interesting of these is fruit. The acreage under small fruit had risen between 1897 (the first year for which reliable figures are available) and 1907 from 70,000 acres to 81,000 acres, and that under orchards from 
148,000 acres in 1873 to 250,000 acres in 1907 . Although this acreage is a small proportion of the total under cultivation, fruit farming bears every sign of being a successful and progressive industry, the development of which has in many cases come most opportunely to the assistance of the farmer.

The most general and far-reaching influence which has come to the support of the British farmer is, however, the recent firming up of prices for most agricultural products. It appears that first corn and then meat became articles with what is known as a world market. The sudden development of this process was accompanied by the great fall in prices which has been described. So soon, however, as the new countries which were opened up under this stimulus began to find their costs of production rise, while the food demands of the older countries went on expanding, the fall in prices was checked. Since 1895, in fact, the general tendency has been distinctly upwards.

The following table shows the average prices for the most important agricultural products since 1895 :-

\begin{tabular}{|c|c|c|c|c|c|c|c|c|c|}
\hline Year. & & 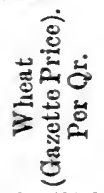 & 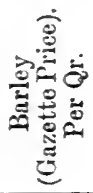 & 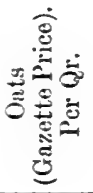 & 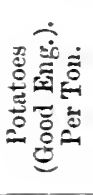 & 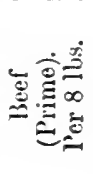 & 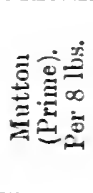 & 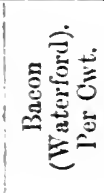 & 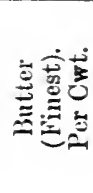 \\
\hline & & $\mathrm{d}$ & s. d. & s. d. & $\mathrm{s}$. & d. & d. & s. & s. \\
\hline 1895 & . & 231 & 2111 & 146 & 80 & 47 & 58 & 51 & $\ddot{93}$ \\
\hline 1896 & . & $26 \quad 2$ & 2211 & 149 & 55 & 45 & 53 & 50 & 98 \\
\hline 1897 & . & 302 & 236 & 1611 & 70 & 47 & 55 & 59 & 94 \\
\hline 1898 & . & 340 & 272 & 185 & 82 & 46 & 52 & 58 & 95 \\
\hline 1899 & . & 258 & 257 & 170 & 70 & 49 & 54 & 51 & 103 \\
\hline 1900 & . & 2611 & 2411 & $17 \pi$ & 78 & 51 & 59 & 60 & 102 \\
\hline 1901 & . & 269 & 252 & 185 & 78 & 49 & 54 & 63 & 105 \\
\hline 1802 & . & 281 & 258 & $20 \quad 2$ & 69 & 54 & 55 & 63 & 102 \\
\hline 1903 & . & 269 & 228 & 172 & 84 & 48 & 58 & 60 & 100 \\
\hline 1904 & . & 28 & 224 & 164 & 90 & 48 & 59 & 57 & 102 \\
\hline 1905 & . & 298 & 244 & 174 & 65 & 47 & 59 & 65 & 107 \\
\hline 1906 & . & 28 & 24 & 184 & 67 & 47 & 60 & 65 & 110 \\
\hline 1907 & . & 30 & 251 & $18 \quad 10$ & 88 & 49 & 60 & 63 & 108 \\
\hline 1908 & . & 320 & $25 \quad 10$ & 1710 & 81 & 52 & 58 & 62 & 114 \\
\hline
\end{tabular}

Further, there is little doubt that until lately rents have continued to fall slightly. Mr. Thompson's figures unfortunately do not go beyond the century, but show an average fall of about 18. per acre during the period between 1895 and 1900 . The gross income from lands returned under Schedule $\mathrm{A}$ of the Income Tax show for Great Britain a fall from $£ 42,885,610$ in 1900 to $£ 42,326,989$ in 1906 . These figures, however, do not exhibit 
with great certainty changes in the annual value of agricultural land, as they include incomes derived from gardens and many other non-agricultural lands. They are, moreover, liable to fluctuations which are the result of administrative changes.

In these different ways, partly by their own efforts and initiative and partly by the working of economic laws, farmers have gone some way already to meet the new circumstances which have arisen. It is impossible to make any definite statistical statement as to the course of farming profits. It is never easy to define the meaning of profits and, in the case of farming, where production is for use and personal consumption as well as for sale, it is impossible. Indeed it would be very unusual for a farmer to keep a strict profit and loss account, and, if it were attempted, on no two farms would the methods of book-keeping tally or offer any basis for reliable comparison. Without going into such detail, however, it will be generally admitted that the present position, if not one of such prosperity as prevailed during the 'fifties and 'sixties, is a substantial improvement on the subsequent period of difficulty and hardship through which the agricultural community passed in the 'eighties and 'nineties. So far, indeed, as the labourer is concerned, his social and economic status is better now than it had ever been in the preceding century. His wages are higher, the cost of his clothing and food has, until the last decade, continuously declined; he has a higher standard of health and comfort, while in his old age he is relieved from fear of the workhouse. Moreover, for the more enterprising and industrious there is a better chance of acquiring some measure of the economic independence which the introduction of capitalistic farming and the conversion of the yeoman into a wage earner, had almost entirely destroyed.

Agricultural Statistics for 1909.-Perhaps the most interesting feature of the latest Agricultural Statistics of Great Britain is the fact that, although the "farmed area"-that is, the acreage returned as under crops or grass-was reduced by 28,313 acres, the number of separate occupations increased by 542 . As by the reduction of the cultivated area-attributable, no doubt, in the main to the ceaseless encroachment of the towns on the countrya certain, though unknown, number of individual farms must have disappeared, it is evident that the subdivision of farms indicated by the returns must have been even greater than the actual figures show. The totals in 1909 in Great Britain for each of the four groups of holdings in which the returns are classed were as follow:-1-5 acres, 108,$458 ; 5-50$ acres, 232,$096 ; 50-300$ 
acres, 150,911; and above 300 acres, 17,706. The first two classes show increases, as compared with 1908, of 364 and 277 respectively; the last two classes show decreases of 91 and 8 respectively.

While the tendency to divide the larger farms is very marked in Great Britain as a whole, it is not apparent in all parts of the kingdom, for, while small holdings-that is, farms of 50 acres or less-have increased by 754 in England and by 81 in Wales, there is a decrease of 194 in Scotland, making the present total of small holdings in Great Britain 340,554. Since 1905 there has been a reduction of 2533 in the total number of farms in Great Britain, chiefly among the smallest and the largest classes of holdings. During the same period, $1905-9$, the cultivated area was reduced by 103,759 acres, which obviously involves the disappearance of a considerable number of holdings. But, allowing for this, the statisties suggest that there has been a general tendency towards holdings of medium size since 1905 , though it was somewhat modified from 1908 to 1909 by a bias towards the smaller class of holdings, which was not previously apparent. But the fact remains that up to June 1909 the number of small holdings both in England and Scotland had diminished during the previous four years, in the one case by nearly 2000, and in the other by over 800 , Wales alone showing a slight increase; while medium farms increased in England and Scotland. Although urban expansion appears inevitably to result in the continued absorption of the smaller holdings, the preponderance of that class of farm in the agricultural system of the country has not been appreciably affected during the past twenty-five years. In 1885 the returns showed that about 66 per cent. of the farms in Great Britain were not more than 50 acres in size, and the latest returns show that the proportion is now about 67 per cent.

The total acreage under crops and grass, including bare fallow, was returned in 1909 at $32,183,073$ acres. A reduction of 64,849 acres of arable land was partly set off by an addition of 36,536 acres to permanent grass, the net decrease being thus 28,313 acres, or 0.1 per cent. of the 1908 area. The total area of wheat, barley, and oats in 1909 was $6,469,761$ acres, an increase of 66,673 acres, or 1 per cent. from the minimum recorded for these crops in 1908. The recovery of the acreage was due to the large extension of the wheat area, which was only in part set off by a diminution in the area of the oat crop. There was practically no change in the area nnder barley. The area (1,823,498 acres) 
returned as under wheat was nearly 200,000 acres (12 per cent.) larger than in 1908, and the greatest recorded since 1900. The increase was largely caused by the favourable autumn of 1908 for sowing, while the comparatively high prices for wheat current at that time had no doubt some influence. Additions to the wheat acreage were made in each county of England and Wales and in all but four counties of Scotland, generally at the expense of the oat crop or of clover and rotation grasses. As might be expected, the gains are largest in the eastern and north-eastern divisions of England, nearly 15,000 acres being added in Lincoln, nearly 12,000 acres in Essex, over 9000 acres in Suffolk, and nearly 8000 acres in Norfolk. Large additions were also reported from the West Riding (11,000 acres, or 30 per cent.), the North Riding (7900 acres, 41 per cent.), Lancashire (nearly 7000 acres, 43 per cent.), and Devonshire (over 7000 acres, 17 per cent.). In twentyone other counties increases of over 3000 acres occurred. The area under barley, as already mentioned, showed practically no variation from the previous year, but the area under oats $(2,981,877$ acres) was 127,041 acres less than in 1908 , and the lowest since 1899. The shrinkage occurred almost entirely in England. The areas in Scotland and Wales were 5076 acres and 3067 acres respectively less than in the previous year, and were in each case the lowest yet reported. The area under beans in 1909 was 313,864 acres, the largest recorded since 1891 , and 18,840 acres larger than in 1908 , while the area under peas $(183,910$ acres) also increased by 20,000 acres since the previous year, and was the largest since 1897. A further extension of the area devoted to potatoes is recorded for 1909 , the increase of 13,356 acres bringing the total to 575,461 acres. This is the largest area since 1905 , when 608,473 acres were cropped. The total area $(1,555,548$ acres) of turnips and swedes in 1909 was only 4651 acres above the total for 1908 . In England reductions of area were mainly confined to the south-eastern, west-midland, and south-western counties, and included 2250 acres in Devonshire. Among the additions may be noted nearly 2000 acres in Suffolk and over 1200 acres in Norfolk. The mangold crop, however, showed the substantial increase on the year of 28,718 acres, thus more than recovering the reduction in 1908. The total for 1909 $(456,490$ acres) constitutes a record. The total acreage under hops in 1909 was 32,539 acres, as compared with 38,921 acres in 1908 and 44,938 acres in 1907. An area of 6382 acres (16 per cent.) has, therefore, been withdrawn from hops since June 1908, 
and 12,399 acres since June 1907. The area of 1909 is the lowest ever returned for the crop, and the decrease is the largest recorded, except that of 6421 acres between the years 1886 and 1887 .

Very striking is the extension of the area devoted to fruit culture. In 1909 there were 87,116 acres of small fruit, compared with 84,880 acres in 1908 and 82,175 acres in 1907 ; and 251,336 acres of orchards, as against 250,297 acres in 1908 and 250,176 acres in 1907 . The counties mainly contributing to the increase of 2236 acres in the small fruit crops were: Kent, which added 1361 acres; Norfolk, 423 acres; Cambridge, 344 acres; and Suffolk, 127 acres. In Worcester the area was reduced by 120 acres. Strawberries show an extension of nearly 1250 acres, nearly 500 acres being added in Kent, over 300 acres in Cambridge, over 250 acres in Norfolk, and over 100 acres in Hampshire. The more noticeable changes in the area under orchards were additions of 1178 acres in Kent, 530 acres in Cambridge, and 439 acres in Worcester. Allowing for the acreage of small fruit grown in orchards, the total acreage devoted to fruit crops in Great Britain in 1909 appears to be about 310,000 acres, the increase since 1908 being 2200 acres. The area under clover, sainfoin, and rotation grasses in 1909 was $4,214,575$ acres, being 207,012 acres less than in 1908. Nearly seven-eighths of the reduction took place in the English counties, and among the largest individual losses were 15,000 acres in Lincoln, over 12,000 acres in Suffolk, and over 11,000 acres in both Essex and Norfolk. A further addition of 36,536 acres to the land laid down to permanent grass has to be noted in 1909 , bringing the total for Great Britain to $17,452,405$ acres. 11,000 acres were added in England, 12,600 acres in Wales, and nearly 13,000 acres in Scotland. In England, however, some reversals of the usual tendency took place. Nearly 7000 acres, previously returned as permanent grass, disappeared in the eastern counties, including over 3000 acres in Essex and over 1500 acres in Cambridge. In the southwestern counties the permanent grass area was reduced by over 4800 acres, of which about 3000 acres would appear to have returned to the plough. In Lancashire nearly 6500 acres of grass were removed from the category of permanent grass, but much of this was accounted for under the heading of mountain and heath land used for grazing. The breadth of permanent grass mown for hay was 172,403 acres less than in 1908 , the whole of the decrease occurring in England. Adding clovers and rotation grasses 
and permanent grass together, the total area mown for hay amounted in 1909 to $6,813,161$ acres, as compared with $7,182,144$ acres in $1908,7,186,970$ acres in 1907 , and $6,976,482$ acres in 1906 .

The total number of horses returned in 1909 was $1,552,993$, being 7322 , or $0.5 \mathrm{per}$ cent., more than in 1908. An increase was recorded in each division of England, excepting the northeastern, but in Wales and Scotland the number returned was practically the same as the previous year. The increase occurred. among the class returned as horses used for agricultural purposes; which includes also mares kept for breeding. The number of these was the highest recorded, the total reaching $1,132,014$, or 12,690 . more than in 1908. In 1906 the total number of cattle in Great Britain first exceeded $7,000,000$, but this level was not maintained during the two succeeding seasons. In 1909 an increase of 115,848 over 1908 raised the total to $7,020,982$, being the highest on record. The number of sheep has also increased greatly, and last year there were $27,618,419$, being the highest recorded since 1892, and nearly half a million more than in 1908. During the last five years the flocks of the country have increased by about. two and a half millions, an addition nearly as great and as rapid as that which occurred at the beginning of the 'nineties. The number of pigs returned in 1909 was $2,380,887$, as compared with $2,823,482$ in 1908 , showing a decline of 442,595 , or $15 \cdot 7$ per cent. The decrease was generally attributed by the collecting officers to the enhanced prices of corn, offals, and other feeding stuffs, although, on the other hand, it was stated by some that the increased home demand for pig products: tempted pigowners to slaughter more rapidly, and thus to reduce the number at the time of the enumeration. 


\section{CHAPTER XII}

\section{BRITISH MINES AND MINING}

Coal-Mining. - Great Britain's mineral treasures-History of coal-mining in first half of nineteenth century-Shipments of coal from Tyne, Tees, and Wear, 1801-1849-Cosl prices in Newcastle, Sunderland, and London-Total shipments of coal, 1819-1849Approximate amount of coal carried on canals and railways in 1816-Estimated amount of coal used in smelting irou in 1850-" The limitation of the vend"-Coal-Mining from 1850 onvards: Census of Production figures-Labour value in coal-England's proportion of the world's production-Production, cxport, home consumption of coal, with total value of all exports, and value of coal exports from 1850-1909-Cause of export trade in coal-Coal as raw material-Coal as cargo-Destination of our coal exports-Importance of coal exports to our foreign trade-Freights--Price of coal since 1850-Jevons on price of coal-Declining freights.

Tin-Mining. - Production of the Cornish tin mines, 1750-1834-Imports and reexports of Banca tin-Exports of British tin, 1820-1849.-Tin-Wining from 1850 omvards: Production of white tin from British ores, 1850-1908-Imports and reexports of tin ore and crude tin, 1850-1909-Price of tin (English bars), 1870-1910 -Census of Production figures.

Copper-Mining.-Production of copper in Cornwall, 1771-1848-Production of copper from British ores, 1820-1908-Imports of copper ore and regulus-English copper-mining in eighteenth and nineteenth centuries-Census of Production figuresPrices of tin and copper, 1801-1834-Price of copper, 1880-1910.

Lead-Mining.-Production of leal from British ores, 1854-1908-Imports and exports of lead ore, red and white lead, and litharge-Census of Production figures-Price of lead (Evglish pig) from 1771-1909.

Zinc.-Production from 1860-1908-Imports and exports, 1895-1909-Census of Production figures-Price of zinc, 1870-1909.

Salt.-Different sorts of salt-Quantities of white and rock salt sent down river Weaver, 1803-1844-Various duties on salt during first half of nineteenth century-Consumption of salt, 1801-1817-Exports of rock salt, 1827-1844-Destinations of salt exports, 1844-Exports of salt, 1880-1909.

Output of Miscellancous Winerals in 190\%.-Ironstone-Iron pyrites-Oil shale -Fireclay clay and shale other than fireclay - Limestone-Sandstone, including Ganiston-All other products-Silver and gold production.

" GROM the very earliest period," writes Porter, "to which record or even tradition can reach, this country has been celcbrated for its mineral treasures." It is not intended to carry back our inquiries to the time when the Phonicians traded with " the tin island of Britain," described by Herodotus under the name of Cassiterides, or to discuss whether the rings and money of iron which Cæsar states to have been in the possession of the Britons, at the time of the Roman invasion, were really the produce of this conntry, 
or whether, as some persons have supposed, they were acquired in barter for tin. Our inquiry into the progress of mining as a source of national wealth must necessarily be limited to a period comparatively recent, and to statement of results.

\section{CoAl-Mining, $1800-1850$}

To begin with coal - the great mainspring of modern industry - without which we should still be using the primitive manufacturing contrivances of our ancestors. In Porter's words, "the value of the mineral products of England would be greatly inferior to what it actually is, were it not for the abundant supply of good coal found in various districts of the kingdom. It cannot here be necessary to point out the many advantages which we derive from the possession of our coal mines, the sources of greater riches than ever issued from the mines of Peru, or from the diamond grounds at the base of the Neela Mulla mountains. But for our command of fuel, the inventions of Watt and Arkwright would have been of small account, our iron mines must long since have ceased to be worked, and nearly every important branch of manufacture which we now possess must have been rendered impracticable, or at best have been conducted upon a comparatively insignificant scale."

"But for the invention of the steam-engine, a large proportion of the coal mines now profitably worked could not have been opened or must have been abandoned."

Porter adds an interesting account of the system of coalmining that prevailed during the early decades of the nineteenth century :-

"The science of mining in all its branches has made great advances within the present century. It was stated by the Rev. Adam Sedgwick, Woodwardian Professor of Geology in the University of Cambridge, in his examination in 1830 before a Cornmittee of the House of Commons, that 'a great deal of coal appears formerly to have been left under ground, in consequence of a want of general plans or maps of the underground workings; a number of excavations have taken place, independently of each other, and the consequence is, there is a great number of piers or large barriers between the old coal-works, some of which it may be almost impossible to remove.' It was likewise the custom in working the mines, to leave large piliars of coal, in order to support the roof; so that at the depth of 100 fathoms, little more than 40 per cent. of the coal was abstracted, and the remainder was given up as lost. In 1795 an attempt was made to substitute wooden pillars for a part of the coal previously left, and this, to a certain extent, was successful. At that time it was not attempted to remove more than one-half of each alternate pillar of coal, still leaving between 40 and 
50 per cent. of the coal in the mine. In 1810 an improvement in this system was introduced, by means of which every intermediate pillar was wholly removed, and a part of the adjoining pillars was likewise taken away; and by working thus, about 80 or 90 parts out of every 100 were brought to market. It was in the year 1815 that Sir Humphry Davy brought the safety lamp to use, and in the opinion of Mr. Buddle, an intelligent and experienced coalengineer, who was examined in 1830 before the Committees of Lords and Commons concerning the coal trade, 'this operated as a complete renovation to many of the collieries which were then in a state of exhaustion. By its means, combined with the system of artificial propping, every particle of coal can now be got out of the mine before it is abandoned."

The following tables show the amount of shipments of coals made from the Tyne, Tees, and the Wear at various years from 1801 to $1849:-$

Quantity of Coals shipped from Newcastle-on-Tyne.

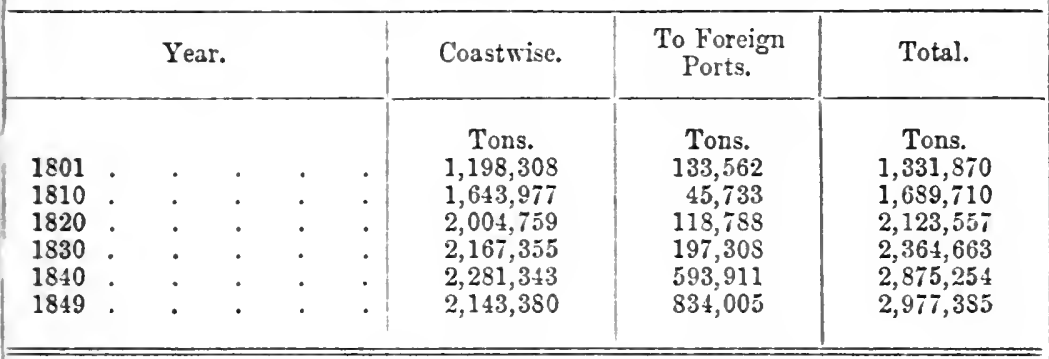

Quantity of Coals shipped from the Port of Sunderland.

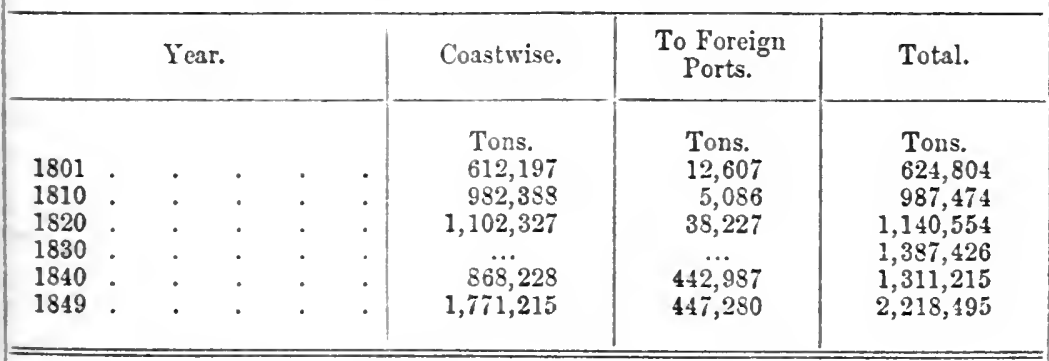

Quantity of Coals shipred from the Port of Stockton.

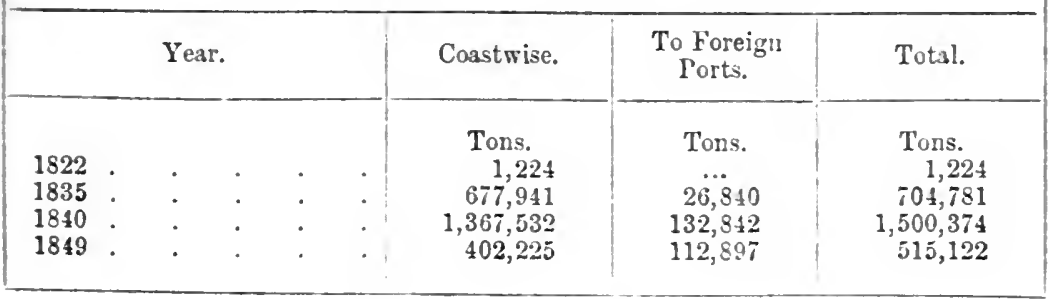


The progressive increase in the shipments from the Newcastle coal district, as shown by the foregoing tables, was not the result of any stimulus given by advancing prices. The rates at which coals were sold in London do not afford any correct view of the prices paid to the coal-owners, becanse freights and charges incurred in conveying them to the metropolis varied constantly; and this will be found especially the case, if a comparison is made between years of war and peace. The anxiety of the Legislature to shield the consumers of coals in London from unfair practices on the part of dealers, led to the compulsory registration of prices. So long ago as the reign of Queen Anne, an Act was passed, requiring the shipper of coals to give a certificate with each cargo, setting forth the quantity, quality and price paid for the same; and this certificate, on the arrival of the ship in London, was delivered to an officer at the Mansion House, for the inspection of the public. The prices in these certificates are stated, up to 1825 , for Newcastle chaldrons of 53 cwt. each; from that time until 1832 the imperial chaldron, equal to $25 \frac{1}{2}$ ewt., was the standard; after 1832 the rates were given per ton weight. To simplify the matter, the prices given below are reduced to those paid per ton. The best quality of coals is given in all cases; and the period chosen for the quotation is the beginning of June in each year, at which time there is less probability of accidental fluctuations than during the winter season.

Prices paid at Newcastle and Sunderland for Coals of the first quality shipped to London

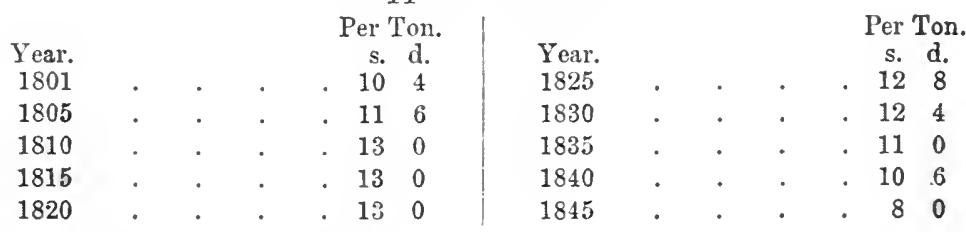

The following statement of prices paid in London, in July of each year, from 1815 to 1850 , will show how materially the inhabitants of the capital benefited through the reduction, and subsequent repeal, of the duty on sea-borne coals. It also exhibits the rates of freight and charges between Newcastle and the river Thames:-

Prices of the best Nencastle Coals at the Coal Exchange, London, in July

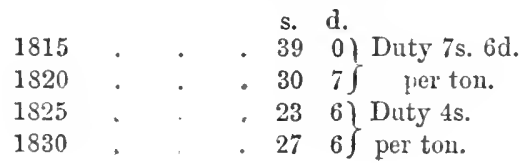

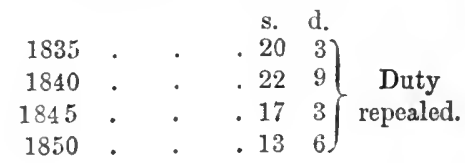


The next table shows that the quantity of sea-borne coals, the produce of our mines, rose from $4,365,040$ in 1819 to $11,380,745$ tons in 1849 , or at the rate of 160 per cent.

Quntity of Crals shipped Coastwise from Ports of Great Brituin to other Ports in Great Britain, Ireland, Colonies, and Foreign Conntries

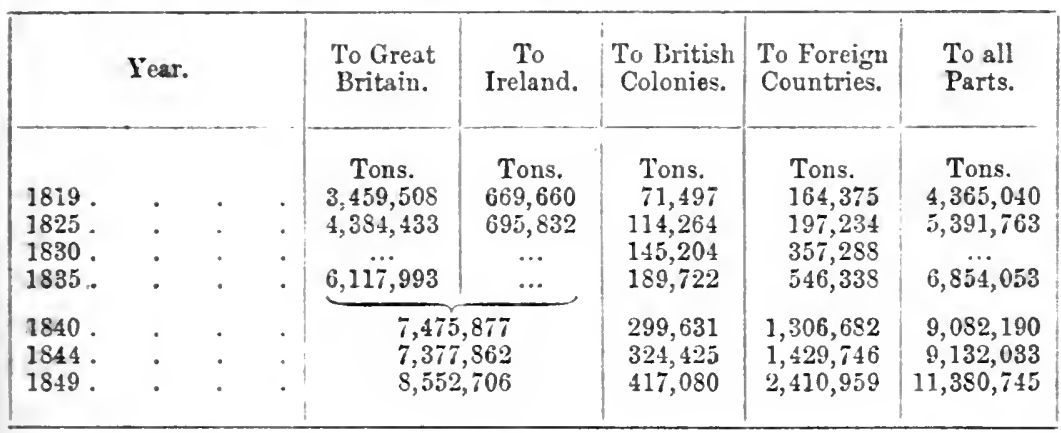

The quantity of coals, whose transmission is recorded by the Customs, affords, however, but a very imperfect indication of the progress of coal-mining. The construction first of canals, and then of railroads, had the effect of bringing many places within reach of inland collieries, which were formerly in this respect dependent altogether upon wood for fuel or upon coal supplies brought by sea. So long ago as 1816 , it was a matter of complaint on the part of the coal-owners of Northumberland and Durham that they were thus subjected to great and increasing competition, and a deputation from that borly was then sent throughout the kingdom to inquire into the quantity of coals passing by inland navigation and by railroads in different parts of the country. In a report made by the members of this deputation it was stated that the quantity thus distributed amounted to 4,078,508 Newcastle chaldrons, or 10,808,046 tons, namely-

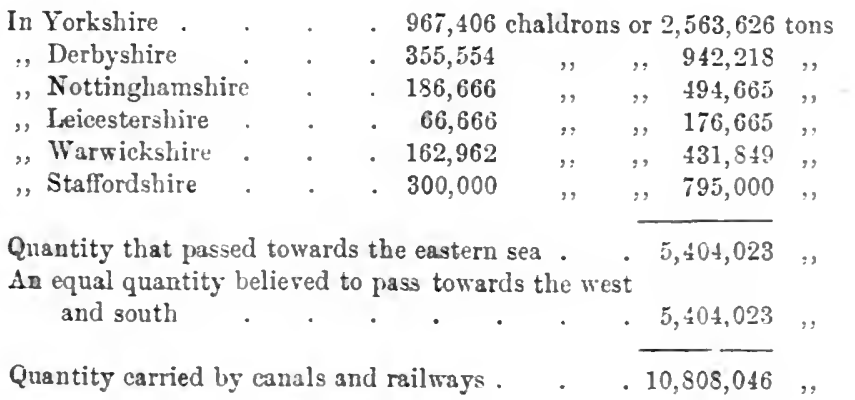


On the assumption that four tons of coals were required to melt one ton of ore, and that the quantity of iron produced in this country in 1850 amounted to $2,000,000$ tons, it followed that $8,000,000$ tons of coals were consumed in the single process of producing pig or cast iron. To convert this quantity into bar iron and the further manufactures of iron a further consumption of coal, bringing the total up to $10,000,000$ tons per annum, would be required.

Porter discussed the proposal of an excise duty on coal, but dismissed it as impossible owing to "the most determined and general opposition it would meet, as being oppressive to the poor and injurious in various ways to the prosperity of nearly every branch of national industry." Nevertheless the English people did submit for three-quarters of a century to a regulation which had the effect of a very severe tax upon coal. This regulation was called the "limitation of the vend," and existed, with some partial interruptions, from the year 1771. This arrangement was no less than a systematic combination among the owners of collieries having their outlets by the Tyne, the Wear, and the Tees, to raise the price of coal to consumers by a self-imposed restriction as to the quantity supplied. A committee appointed from among the owners held its meetings regularly in the town of Newcastle, where a very costly establishment of clerks and agents was maintained. By this committee, not only was the price fixed at which coals of various qualities might be sold, when sea borne, for consumption within the kingdom, but the quantity was assigned which, during the space of the fortnight following each order or "issue," the individual collieries might ship. The manner in which this combination was conducted, and the effect which it could not but have upon the interests of the consumers, will best be understood by describing the course pursued upon the opening of a new colliery. The first thing to be determined in that case was the rank or "basis" to be assigned to the colliery. For this purpose, one referee was appointed by the owners of the colliery, and another by the coal-trade committee, who, taking into view the extent of the royalty or coal-field secured, the size of the pits, the number and power of steam-engines erected, the number of cottages built for workmen, and the general scale of the establishment, fixed therefrom the proportionate quantity the colliery would be permitted to furnish towards the general supply, which the directing committee from time to time authorized to be issued. The point to be attained by the owners of the colliery, was to secure for their establishment the largest basis possible; and with this view it was 
common for them to secure a royalty extending over from five to ten times the surface which it was intended to work, thus burthening themselves with the payment of possibly $£ 5000$ per annum, or more, of "dead rent" to the owner of the soil, who, of course, exacted such payment in return for his concession, although his tenants might have no intention of using it. Instead of sinking one or two pits, which would afford ample facility for working the quantity which the mine was destined to yield, a third, and, possibly, a fourth pit were sunk, at an enormous expense, and without the smallest intention of their being used. A like wasteful expenditure was made for the erection of useless steam power, and to complete and give an appearance of consistency to the arrangements, instead of building 200 cottages for the workmen, double

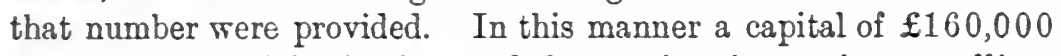
to $£ 200,000$ might be invested for setting in motion a colliery allowed to raise and sell only such a quantity of coal as might be produced by means of an outlay of one-fourth or one-fifth of that amount. By this wasteful course the end of the colliery owners was attained; they got their basis fixed-if a large concern, as is here supposed-say at 50,000 , and this basis probably secured for them a sale of 25,000 chaldrons during the year, instead of 100,000 chaldrons, which their extended arrangements would have enabled them to raise. The Nercastle committee met once a fortnight, or twenty-six times in the year, and, according to the price in the Iondon market, determined the quantity that might be issued during the following fortnight. If the London price was what is considered high, the issue was increased, and if low diminished. If the "issue" were twenty on the 1000 , the colliery here described would have been allowed to sell $(20 \times 50) 1000$ chaldrons during the ensuing fortnight. The pit and establishment might be equal to the supply of 3000 or 4000 chaldrons; orders might be on the books to that extent or more; ships might be waiting to receive the largest quantity, but, under "the regulation of the vend," not one bushel beyond the 1000 chaldrons could be shipped until a new issue should be made. By this system the price was kept up; and as regards the colliery owners, they thought it more for their advantage to sell 25,000 chaldrons at 30 s. per chaldron, than to sell 100,000 chaldrons at the price which a free competition would have brought. If, under this system of restriction, any undue profit was obtained, nothing can be more certain than that competition for a portion of this undue profit would cause the opening of new collieries until the advantage should be neutralized; and 
this result of the system at length became apparent. Every new colliery admitted into the "vend" took its share in the "issues," and to some extent limited the sales of all the rest. The disadvantage during all this time to the public at large is incontestible. The great staple manufactures of the country, being located in inland coal districts, happily did not suffer from this combination; but in other innumerable processes which require the aid of heat, and which are carried on in cities and places where coal is not found, the addition to the cost of fuel thus occasioned placed the manufacturers at a great disadvantage, while the other inhabitants of those cities, and especially the poor, were very greatly injured by it. The loss to the community at large, through the unprofitable investment of unnecessary capital, no one can dispute.

There was another consequence resulting from this limitation of the home coal trade which it is necessary to state, as it is productive of great national evil :-

"The owners of collieries being restricted in their fortnightly issues to quantities which their establishments enabled them to raise in three or four days, were naturally desirous of finding for their men during the remainder of the time some employment which should lessen the expense of maintaining them in idleness, and spread over a larger quantity of product the fixed expenses of their establishments and their dead rents. To this end coals were raised which must find a sale in foreign countries; and it practically resulted that the same quality of coals which, if shipped to London, were charged at 30s. 6d. per Newcastle chaldron, were sold to foreigners at 18s. for that quantity, giving a preference to the foreign buyer of 40 per cent. in the cost of English coal. By this means the finest kinds of coal used in London, at a cost to the consumer of abont 30s. per ton, might be had in the distant market of St. Petersburg for 15s. to 16s., or little more than half the London price. Nor was this the worst effect of the system. In working a colliery, a great proportion of small coal is raised. The cost to the home consumer, under the system of limitation, being exaggerated, and the freight and charges being equally great upon this article as upon round coal, very little small coal would find a market within the kingdom, except on the spot where it was raised; and as the expense of raising it must be incurred, the coal-owners were forced to seek elsewhere for a market at any price beyond the mere cost of putting it on board ship. By this means, "nut coal," which consists of small pieces, free from dust, which have passed through a screen, the bars of which are five-eighths of an inch apart, was sold for shipment to foreign countries at the low price of 3s. per ton. The intrinsic quality of this coal is quite as good as that of the round coal from the same pits; it is equally suitable for generating stean, and for general manufacturing purposes; and thus the manufacturers of Denmark, Germany, Russia, etc., obtained the fuel they required, and without which they could not carry on their operations, at a price not only below that paid by English manufacturers, but for much less than the cost at which it was raised. The coal-owner might, it is true, have sold this small coal at home at a better price than he obtained from his foreign customer, but every ton so sold would have taken the place of an equal quantity of large 
coal, upon which his profit was made, and by such home sale he would by no means have lessened his sacrifice, but the reverse."

In this way during three-quarters of a century every person using sea-borne coal in Great Britain was exorbitantly taxed for the benefit of rival manufacturers in other countries.

\section{Coal-Mining, 1850-1910}

If anything, coal is even more important to modern industry than to the industries of Porter's time, as the value of windmills and watermills has declined. And not only does it supply the motive power to almost all our manufacturing trades, but it also plays an immense and increasing part of our foreign exports, as will be seen later when we examine our export trade in coal. Our production of coal has reached a magnitude which our ancestors would have thought impossible. According to Part I of the Preliminary Tables issued by the Census of Production, the size of our coal industry in 1907 was as follows:-

\begin{tabular}{|c|c|c|c|c|}
\hline & $\begin{array}{c}1 . \\
\text { Gross Ontput. } \\
\text { Selling Value. }\end{array}$ & $\begin{array}{c}2 . \\
\text { Materials } \\
\text { used. } \\
\text { Cost. }\end{array}$ & $\begin{array}{l}3 . \\
\text { Net Output. } \\
\text { (Excess of } \\
\text { Col. } 1 \text { over } \\
\text { Col. 2). }\end{array}$ & $\begin{array}{c}4 . \\
\text { Persons } \\
\text { Employed. }\end{array}$ \\
\hline $\begin{array}{l}\text { Mines under the Coal Mines } \\
\text { Regulations Act } \\
\text { Coke works }\end{array}$ & $\begin{array}{r}\mathfrak{f} \\
123,245,000 \\
10,141,000\end{array}$ & $\begin{array}{r}\stackrel{£}{£} \\
16,881,000 \\
7,148,000\end{array}$ & $\begin{array}{r}\mathfrak{E} \\
106,364,000 \\
2,993,000\end{array}$ & $\begin{array}{r}840,280 \\
10,944\end{array}$ \\
\hline & $133,386,000$ & $24,029,000$ & $109,35 \pi, 000$ & 851,224 \\
\hline
\end{tabular}

Nor can the value of our coal trade from the standpoint of wages and employment be easily overrated. Mr. D. A. Thomas in an excellent monograph on "Coal Exports," read before the Royal Statistical Society in 1903, estimated the average cost of the items forming the expense of the production of a ton of large coal at the pit's mouth in the case of the output of three steamcoal collieries in South Wales for the under-mentioned years (the first a year of low, and the second of high wages) as follows:-

Labour.

Stores and inaterials

Royalties

Rents, rates, etc.

Incidentals

\begin{tabular}{rr}
1897. & 1900. \\
77.98 & 81.72 \\
12.67 & 11.87 \\
6.64 & 4.38 \\
2.57 & 1.84 \\
0.14 & 0.19 \\
\hline 100.00 & 100.00
\end{tabular}


In 1900 the world's production of coal exceeded 225 million tons; but notwithstanding the great increase in the quantity of coal produced in the United Kingdom, we were no longer the premier coal-producing nation of the world; for the United States held that position. Yet our output then amounted to one-third of the total coal production of the world. In oversea trade in coal both for bunkers and other purposes, Great Britain is still easily first, our trade of this description amounting to four or five times that of the rest of the world together.

The next table, which with the exception of the figures for 1909 is extracted from Mr. Thomas's paper, exhibits our production and export of coal since 1850 :

\begin{tabular}{|c|c|c|c|c|c|c|c|c|}
\hline Year. & 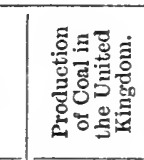 & 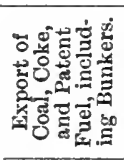 & 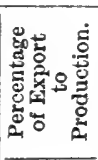 & 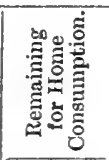 & 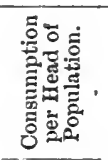 & 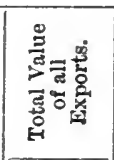 & 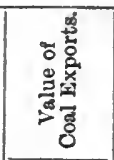 & 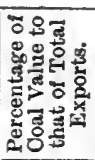 \\
\hline $\begin{array}{l}1850 . \\
1860 \\
1870 \\
1880 \\
1890 \\
1900 \\
1909\end{array}$ & $\begin{array}{c}\text { In Million } \\
\text { Tons. } \\
56^{\circ} 0^{*} \\
80^{\circ} 0 \\
110^{\circ} \cdot 4 \\
147 \cdot 0 \\
181 \cdot 6 \\
225 \cdot 2 \\
263 \cdot 8\end{array}$ & $\begin{array}{c}\text { In Million } \\
\text { Tons. } \\
3 \cdot 8 \dagger \\
8 \cdot 4 \dagger \\
14 \cdot 1 \dagger \\
93 \cdot 9 \\
38 \cdot 7 \\
58 \cdot 4 \\
83 \cdot 3\end{array}$ & $\begin{array}{r}6 \cdot 8 \\
10 \cdot 5 \\
12 \cdot 8 \\
16 \cdot 3 \\
21 \cdot 3 \\
25 \cdot 9 \\
31 \cdot 9\end{array}$ & $\begin{array}{c}\text { In Million } \\
\text { Tons. } \\
52 \cdot 2 \\
71 \cdot 6 \\
96 \cdot 3 \\
123 \cdot 1 \\
142 \cdot 9 \\
166 \cdot 8 \\
180 \cdot 5\end{array}$ & $\begin{array}{c}\text { In Tons. } \\
1 \cdot 91 \\
2 \cdot 49 \\
3 \cdot 11 \\
3.56 \\
3.81 \\
4.08 \\
4.01\end{array}$ & \begin{tabular}{|c|} 
In Million \\
f's. \\
$71 \cdot 4$ \\
$135 \cdot 8$ \\
$199 \cdot 6$ \\
$223 \cdot 0$ \\
$263 \cdot 5$ \\
$291 \cdot 2$ \\
$378 \cdot 2$
\end{tabular} & 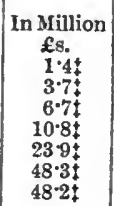 & $\begin{array}{r}2 \cdot 0 \\
2 \cdot 7 \\
3 \cdot 4 \\
4 \cdot 8 \\
9 \cdot 0 \\
16 \cdot 6 \\
18 \cdot 1\end{array}$ \\
\hline
\end{tabular}

* Estimated.

† Including estimated quantity of bunker coal.

¥ Bunker coal not added to total values, but included here and estimated to be of the same average value per ton as exported coal.

These figures very clearly indicate the enormous value of our export trade in coal. True, there was a considerable export of coal early in the nineteenth century. In fact there has been such a trade since the reign of Edward II. But until a comparatively recent period the export trade was almost entirely confined to Northumberland and Durham. Between 1850-1909, while the quantity of British coal retained for home consumption rather more than trebled (or estimated per capita rather more than doubled), the export, including coal shipped for the use of steamers engaged in foreign trade, has grown twentyfold, and has increased from a proportion of 6.8 per cent. to one of 31 per cent. of the total output.

Mr. D. A. Thomas in elucidating this branch of our coal trade writes: "The great stimulating cause which has led to this continuity in the growth of our export of coal, and enabled it to go on steadily increasing, notwithstanding the many adverse circumstances of a temporary nature, and in the face of the more permanent 
causes in the way of increasing severity of foreign competition in certain minor markets, has been the great expansion in the use of steam, more particularly for navigation purposes."

He adds-to expose the groundless fears of those who complain that in exporting coal we are assisting our rivals- " it is only necessary to point to the fact that of those who may be considered our industrial rivals, the United States in 1900 took from us less than 1 per cent. ( 03 ) of the quantity of coal she consumed, Germany 6.14 per cent., France 16.42 per cent., Russia 12.90 per cent., Belgium 6.04 per cent., Japan 1.99 per cent., and Austria-Hungary 1.08 per cent. True,. Spain took from us 41.57 and Italy 93.56 of the coal they consumed, but by no stretch of the imagination can either country be regarded as a serious industrial rival to Great Britain. The great bulk of our export is for the use of steamships, and it is within the mark to say that over half of our exports are for navigation purposes, and, further, that more than half the coal exported is for British consumption abroad." Besides, it is conceivable that if at some future date the tides were harnessed the value of coal would fall heavily, and in view of the practical inexhaustibility of our supplies it behoves us to sell as much as possible to foreign customers.

In 1908 we exported $62,547,175$ tons of coal, which were worth $£ 39,546,169$. Of this no less than $60,636,032$ tons, worth $£ 38,117,578$, was sent to foreign countries, while only $1,911,143$ tons, worth $£ 1,428,591$, were sent to British Possessions. The principal foreign countries to which we exported coal are as under:-

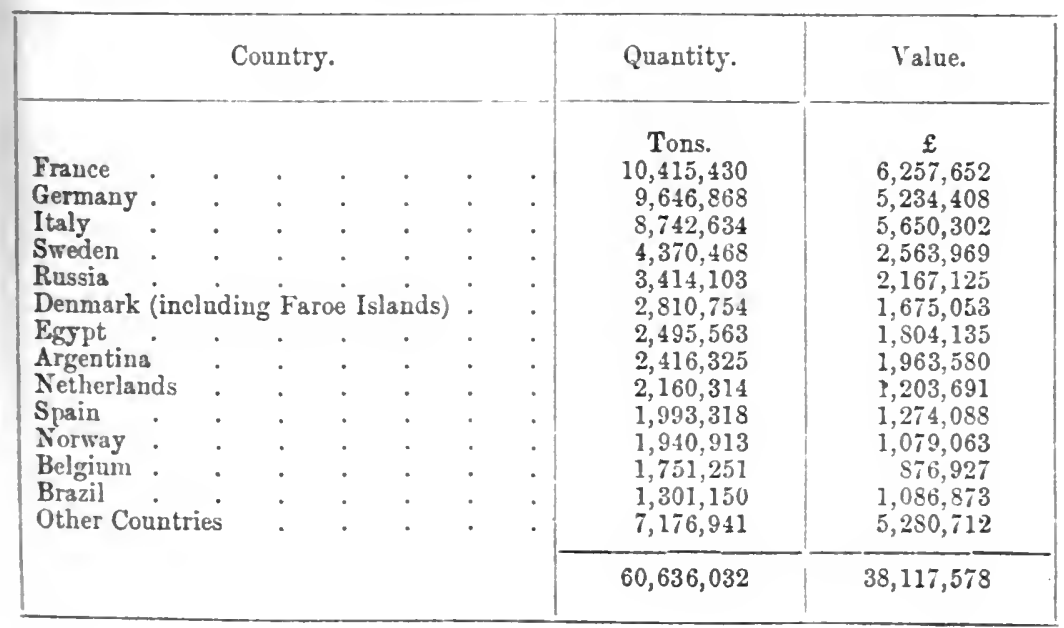


Of the exports of coal that went to British Possessions 445,011 tons went to Malta and Gozo, 252,525 tons to Ceylon and Dependencies, 220,991 tons to Gibraltar, 168,736 tons to Bombay, and 145,714 tons to Aden and Dependencies.

We mentioned earlier in this chapter that coal plays an important part in our foreign trade. This is owing to its weight and bulk. Mr. D. A. Thomas puts the case as follows: "There is another aspect in which it (i.e. coal) bulks even more largely, that is as cargo for outward-bound vessels. Its importance, in this: respect, to the shipping industry would be difficult to exaggerate. More than four-fifths of the weight of our exports consists of coal; without it the great bulk of the shipping bringing corn, cotton, wood, wool, sugar, etc., to our shores would be compelled perforce to clear without cargo and in ballast. No outward freights: would be earned in the majority of instances, and consequently, in order to earn a profit, or, for the matter of that, to make both ends meet, a very much heavier freight would have to be charged on articles of import, which would thereby be heavily increased in price to the consumer." Mr. Thomas goes on to explain that "the freight. earned by vessels in conveying the $44,000,000$ tons of coal exported abroad in 1900 was probably not far, if anything, short of $£ 20,000,000$ sterling. Including the cost of bunkers, and if we assume that two-thirds of the coal was exported in British bottoms, then something like $£ 60,000,000$ of our imports were paid for by coal and its carriage."

The price of coal is subject to wide variations, as increased difficulties of transport and labour troubles are instantly reflected in the price. The index numbers given below are taken from

\begin{tabular}{|c|c|c|c|c|c|c|c|c|c|c|}
\hline & 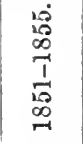 & $\begin{array}{l}8 \\
8 \\
\infty \\
11 \\
0 \\
0 \\
0 \\
0 \\
7\end{array}$ & $\begin{array}{l}10 \\
0 \\
0 \\
7 \\
1 \\
0 \\
0 \\
0 \\
-1\end{array}$ & 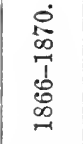 & 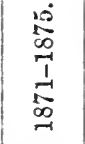 & $\begin{array}{l}\dot{0} \\
\infty \\
\infty \\
\infty \\
0 \\
0 \\
\infty \\
\infty \\
r\end{array}$ & $\begin{array}{l}0 \\
0 \\
\infty \\
\infty \\
1 \\
1 \\
\infty \\
\infty \\
\cdots\end{array}$ & $\begin{array}{l}\dot{8} \\
\infty \\
-1 \\
0 \\
0 \\
\infty \\
-1\end{array}$ & 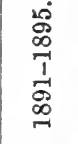 & $\begin{array}{l}\dot{8} \\
\stackrel{5}{1} \\
1 \\
0 \\
\infty \\
\infty \\
-1\end{array}$ \\
\hline Coal $\dot{1}$ & $88 \cdot 7$ & $97 \cdot 1$ & $96 \cdot 6$ & $103 \cdot 3$ & $181 \cdot 5$ & $100 \cdot 6$ & $95 \cdot 3$ & 100 & $110^{\circ} 6$ & $115 \cdot 2$ \\
\hline $\begin{array}{l}\text { Sauerbeck } \\
\text { articles) }\end{array}$ & $128 \cdot 5$ & $139 \cdot 6$ & $144 \cdot 7$ & $141^{\circ} 0$ & $147 \cdot 6$ & $120 \cdot 7$ & $113 \cdot 7$ & 100 & $94 \cdot 9$ & $94 \cdot 0$ \\
\hline $\begin{array}{c}\mathbf{E x p o r t s} \\
\text { articles) }\end{array}$ & $132 \cdot 5$ & $145^{\circ} 0$ & $145 \cdot 5$ & $136^{\circ} 3$ & $145 \cdot 0$ & $125 \cdot 4$ & 111.3 & 100 & $95 \cdot 9$ & $97 \cdot 0$ \\
\hline $\begin{array}{l}\text { Imports } \\
\text { articles) } \dagger\end{array}$ & $\ldots$ & $136 \cdot 1$ & $138 \cdot 1$ & $134 \cdot 3$ & $134 \cdot 1$ & $120 \cdot 6$ & $112 \cdot 8$ & 100 & $91 \cdot 7$ & $87 \cdot 9$ \\
\hline
\end{tabular}

* 1851-1855, the average is of 36 articles; $1856-1860$, of 39 articles; and from 1861-1875, of 44 articles.

$+1856-1860$, the average is 83 articles. 
Mr. Thomas's monograph and show the relative trend of the price of coal in comparison with the prices of other commodities during the last half of the nineteenth century. The basic number of 100 is taken from an average of the prices during the period 1886-1890.

From these figures it will be seen that the price of coal rose considerably during the last twenty years of the nineteenth century, while the prices of other commodities fell.

This tendency towards an abnormal rise in the price of coal was noticed by Jevons as early as 1865 , who estimated that the rise in the price of coal from $7 \mathrm{~s}$. 6d. in 1794 to $9 \mathrm{~s}$. in 1860 meant that comparatively to the other general mass of commodities the price of coal had almost doubled during that time. From this and other inquiries he was led to predict the early exhaustion of our coal supplies; but these predictions have been happily falsified, and a Government Commission has recently proved conclusively that our coal supplies are practically inexhaustible.

Although prices of coal have risen freight has diminished, and it is no exaggeration to say that outward coal freights to what may be recorded normal times, are now not half what they were thirty years ago, and that the price delivered to the buyer abroad, is, on an average, a third less than it was thirty-five years ago. The explanation of this fall in freights is found in the fact that the improvement in the economy of the marine engine measured in coal would be at least 50 per cent. during the last quarter of a century, that is to say, not more than half the quantity is now required to perform the same work as formerly.

The history of iron ore mining will be found in the next chapter on Iron and Steel Manufactures.

\section{The Miror Metals}

We now come to the minor metals, namely, tin, copper, lead, zinc. Records of the produce of the tin and copper mines of Cornwall were kept with considerable regularity from early times. The following table shows the produce of the Cornish tin mines in five-yearly averages according to the records, from 1750 to the most recent period recorded :-

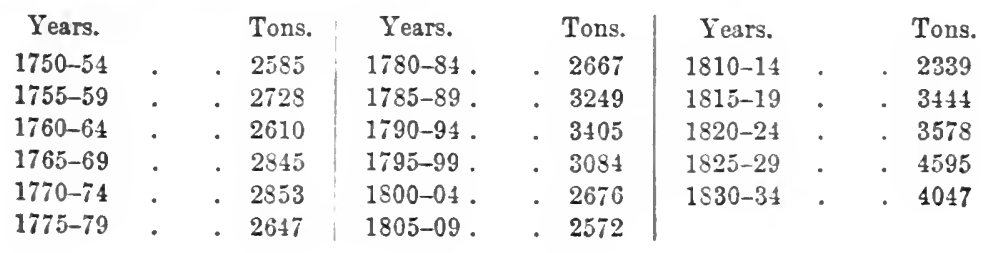


The fluctuation shown by these figures is very small, but the increase observable in the produce of the last twenty years is the more remarkable, because, within that time, the produce of the tin mines of Banca was greatly augmented. Until 1817 the mines of Cornwall afforded a considerable supply of this metal to China, the shipments amounting in some years to 800 tons; but after the restoration of the island to the Dutch, its mines became so productive as to supply the markets of China and India, and to furnish in addition a large quantity of tin for the continent of Europe. The imports and re-exports of foreign (Banca) tin from 1820 to 1849 were as follow:-

\begin{tabular}{|c|c|c|c|c|c|}
\hline Year. & $\begin{array}{c}\text { Imported. } \\
\text { Cwt. }\end{array}$ & $\begin{array}{l}\text { Re-exported. } \\
\text { Cwt. }\end{array}$ & Year. & $\begin{array}{c}\text { Imported. } \\
\text { Cwt. }\end{array}$ & $\begin{array}{c}\text { Re-exported. } \\
\text { Cwt. }\end{array}$ \\
\hline 1820 & 1,309 & 3,047 & 1840 & 9,391 & 6,594 \\
\hline 1825 & 4,213 & 4,709 & 1844 & 12,085 & 19,153 \\
\hline 1830 & 15,539 & 10,426 & 1849 & 35,826 & 8,940 \\
\hline 1835 & 19,704 & 23,795 & & & \\
\hline
\end{tabular}

Notwithstanding the foreign competition, the exports of English tin remained considerable. The exports of British tin were :-

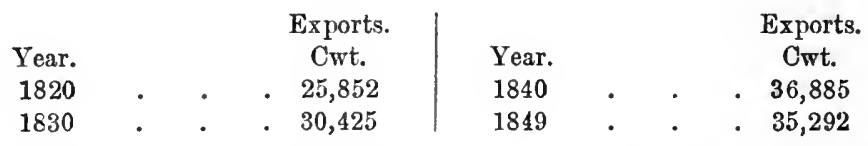

"The English tin mines had long a fancied protection against the foreign producer by an import duty of $50 \mathrm{~s}$. per ewt. This duty was reduced in 1842 to $6 \mathrm{~s}$. per cwt. : both rates being equally inoperative, since our production of this metal was uniformly greater than our consumption, under which state of things it would be absurd to suppose that any foreign producer could enter into competition with that of our own mines."

The progress of the production of tin in England during the latter half of the nineteenth and the beginning of the twentieth centuries is shown by the following figures, which give the productions of white tin from British ores :-

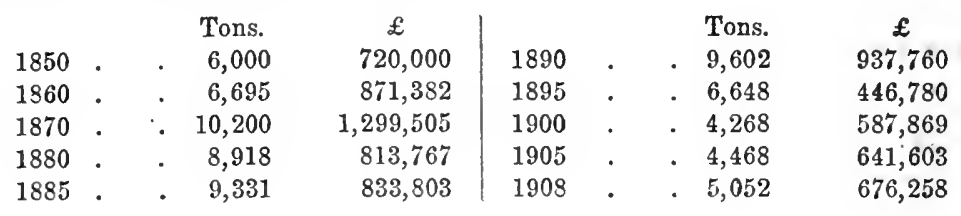

There has been of later years a considerable increase in the amount of foreign tin ore imported, although the quantity of crude 
tin in blocks, slabs, etc., imported has remained fairly stationary. The following table shows the details:-

\begin{tabular}{|c|c|c|c|c|c|c|c|c|}
\hline \multirow[b]{3}{*}{1850} & \multicolumn{2}{|c|}{$\begin{array}{c}\text { Imports of Tin } \\
\text { Ore. }\end{array}$} & \multicolumn{2}{|c|}{$\begin{array}{c}\text { Imports of Crude } \\
\text { Tin. }\end{array}$} & \multicolumn{2}{|c|}{$\begin{array}{l}\text { Re-exports of } \\
\text { Tin Ore. }\end{array}$} & \multicolumn{2}{|c|}{$\begin{array}{c}\text { Re-exports of Crude } \\
\text { Tin. }\end{array}$} \\
\hline & Tons. & $£$ & Cwt. & $£$ & Tons. & $£$ & Cwt. & $£$ \\
\hline & ... & $\ldots$ & 33,711 & $\ldots$ & ... & $\ldots$ & 3,800 & $\ldots$ \\
\hline 1860 & $\ldots$ & $\ldots$ & 58,220 & & $\ldots$ & $\ldots$ & 10,160 & $\cdots$ \\
\hline 1870 & $\ldots$ & $\ldots$ & 94,787 & 603,979 & $\ldots$ & $\ldots$ & 21,946 & 139,906 \\
\hline 1880 & ... & $\ldots$ & 389,967 & $1,736,096$ & $\ldots$ & $\ldots$ & 174,431 & 770,633 \\
\hline 1890 & ... & & 540,769 & $2,547,416$ & $\ldots$ & & 296,355 & $1,408,659$ \\
\hline 1895 & 4,705 & 149,221 & 832,028 & $2,631,038$ & 993 & 30,483 & 414,209 & $1,318,711$ \\
\hline 1900 & 7,329 & 375,910 & 662,359 & $4,359,133$ & 921 & 32,164 & 395,063 & $2,620,252$ \\
\hline 1905 & 17,806 & $1,173,232$ & 795,300 & $5,632,776$ & 2,578 & 153,71 & $5 \$ 3,100$ & $4,120,385$ \\
\hline 1909 & 24,086 & $1,621,175$ & 834,500 & $5,603,844$ & 2,811 & 171,855 & 604,720 & $4,059,984$ \\
\hline
\end{tabular}

The most noteworthy features about these figures are the rise in value of tin during the last few years of the series, and the growth of the re-export trade. The rise in values is still further shown by the following figures of the price of tin in London, which have been extracted from a German Annual Report published in Frankfort on the production of the minor metals :-

\begin{tabular}{|c|c|c|c|c|c|c|c|c|c|}
\hline & \multicolumn{3}{|c|}{$\begin{array}{c}\text { Average } \\
\text { Yearly Price. }\end{array}$} & & & & \multicolumn{3}{|c|}{ Average } \\
\hline & & $£$ & s. d. & & & & $\mathfrak{f}$ & s. & d. \\
\hline 1880 & . & . 87 & 76 & 1900 . & . & . & 133 & 11 & 6 \\
\hline 1885 & . & 86 & 12 & 1905 . & . & . & 143 & 1 & 8 \\
\hline 1890 & . & 94 & 36 & 1909 . & . & . & 134 & 15 & 6 \\
\hline 1895 & . & . 63 & $\begin{array}{ll}7 & 1\end{array}$ & & & & & & \\
\hline
\end{tabular}

In the fourth series of Preliminary Tables issued by the Census of Production we get the following (the figures apply to 1907$)$ :-

TrY ORE (including tin recovered from tin streams).

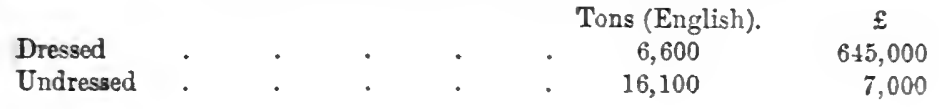

The figures for manufactures of tin are as follow :-

Tons.

Unwronght (including ingots, blocks, bars, etc.) 13,000

Manufactures.
$£$

$2,184,000$

36,000

$2,220,000$

Our exports of unwrought tin in 1907 amounted to 8700 tons, or 67 per cent. of the quantity produced in the United Kingdom, 
while the net imports were 17,000 tons, or about one-third more than the quantity produced in the United Kingdom.

Copper is a very important metal in modern industry, owing to its facility for being combined with other metals and thus forming alloys, such as brass and bronze, and also owing to its increasing use in the electrical industries where in many cases it is practically indispensable.

In the first balf of the nineteenth century the produce of the copper mines of Cornwall increased in a much greater proportion than that of the tin mines, as appears by the following statement of the produce of the former, from 1771 to 1786 , and from 1796 to 1848 :-

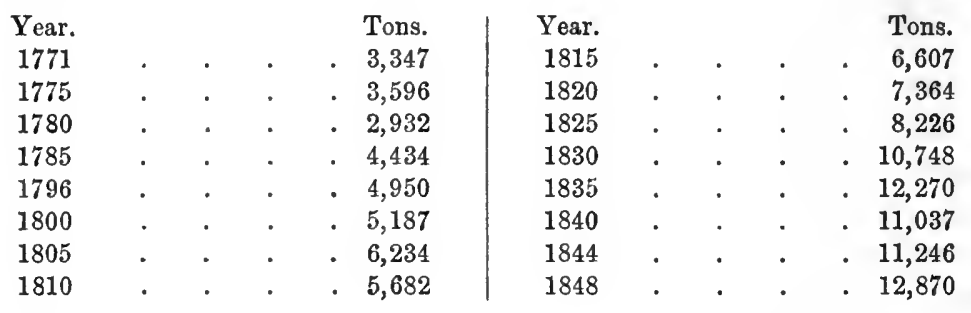

The productive power of the Cornish mines thus increased more than threefold in the last sixty years of the period. No statement can be given of the total quantity of copper raised in the United Kingdom before 1820; from that year onwards the produce was as under (we have carried Porter's figures up to date):-

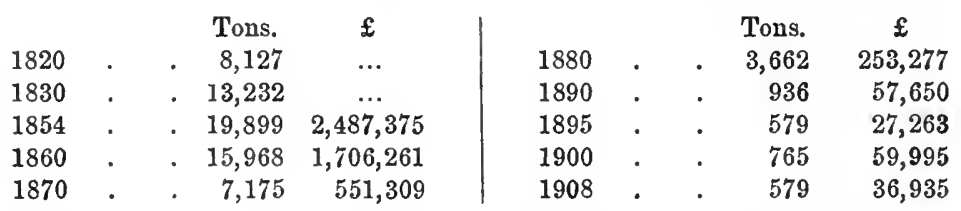

There has been, it will be seen, a rapid decrease in the quantity produced during the last fifty years. Our imports of the copper ore and regulus over the same series of years were as follow:-

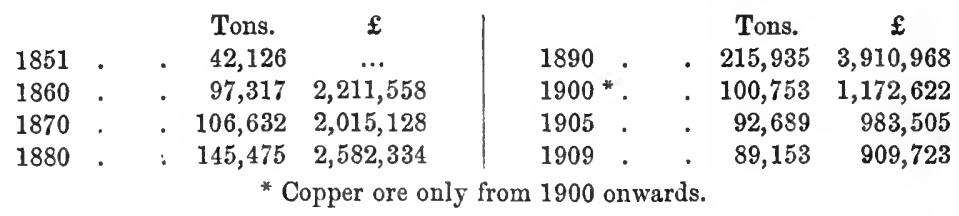

The Copper Handbook (vol. ix.), by Horace J. Stevens, of Houghton, U.S.A., contains the following interesting account of the English copper mines:- 
"At the beginning of the eighteenth century the English mines, in Cornwall, were inaking much the largest part of the world's copper output, and even at that date were of such considerable depth, and with such extensive underground openings, that the problem of disposing of the water was of vital inportance. Many good mines were allowed to remain idle, solely because of the expense of keeping them free of water was greater than the profits of operation. The first steam-engine was built for a Cornish mine, the Wheal Por, by a Captain Savery, very early in the eighteenth century. It was but a partial success, and the plan was improved on by Newcomen, who erected a pumping engine at the Wheal Fortune mine, Cornwall, 1720. The first Watt engine, erected at Chacewater, Cornwall, in 1777 , proved a great success, and came none too soon, as the larger mines, deepened by reason of the aid given from Newcomen's pumps, were at a depth where the first crude engines no longer could give satisfactory results.

"Although steam power was first applied to copper-mining two centuries ago, it was used only for handling water until after the beginning of the ninereenth century. The first application of steam power to other mining uses was in the first or second decade of the nineteenth century, when a hoisting drum was first actuated by steam.

"For the first half of the nineteenth century, Great Britain maintained its position at the head of the world's copper producers, but for British copper mines the latter half of the century was a period of ever-increasing depression, relieved by only occasional years of prosperity. The invention of the Watt engine and its application to pumping machinery enabled the mine operators of Cornwall and Anglesea to penetrate to depths theretofore undreamed of. In 1790 the Dolcoath mine in Cornwall was 600 feet deep; in 1816 it was down 1368 feet, and in 1830 the Tresarean mine, also of Cornwall, reached the great depth of 1920 feet. As the mines increased in depth rapidly, various improvements became necessary. The old method of raising ore in baskets, carried up ladders on the backs of men and women, was replaced by whims, operated first by hand, then by horse power, later by water-wheels, and eventually by steam, the ropes that hoisted ore in wicker baskets being coiled around these whims. A little later the hempen ropes were replaced by wire cables, and the baskets gave way to iron skips and cages. In $18+2$ the first man-engine was built, for taking miners to and from their work in the deep shaft. Mine surveying was introduced, and machinery employed in the mills, where hand work had been the rule for centuries. The Anglesea mines enjoyed great prosperity for the first quarter of the century, but gave unmistakable signs of exhaustion a few years later, and in the fourth decade ceased to be important factors in the world's copper industry. The smelters of Wales had attained such growth, however, that Swansea still remains the seat of one of the greatest and most diversified smelting industries of the world."

Turning again to the Census of Production Report, we find that in 1907 the production (exports and imports) of copper ore, regulus, and precipitate were as follows:-

$\begin{array}{ccc}\text { Production. } & \text { Exports. } & \text { Net Imports. } \\ \text { Tons. } & \text { Tons. } & \text { Tons. } \\ 10,500 & \ldots & 170,400\end{array}$


As regards the manufacture of pure copper goods the Rcport states the production to be as under:-

$$
\begin{aligned}
& \text { Copper-Wrought or inanufactured (including plates, } \mathfrak{E} \\
& \text { rods, tubes, wire, etc.) . . . . } 4,963,000 \\
& \text { Copper-Sulphate . } \quad . \quad \text {. } \frac{897,000}{5,860,000}
\end{aligned}
$$

The total production is probably rather greater than this, as some pure copper goods are classified with brass goods. The exports of copper sulphate in 1907 amounted to 45,000 tons (English), or a little over 71 per cent. of the quantity manufactured in the United Kingdom.

As regards the price of both tin and copper raised in Cornwall

\begin{tabular}{|c|c|c|c|c|c|c|c|}
\hline \multirow{2}{*}{ Year. } & & & & \multicolumn{4}{|c|}{ Price per Ton. } \\
\hline & & & & \multicolumn{3}{|c|}{ Tin. } & $\begin{array}{l}\text { Standard of } \\
\text { Copper. }\end{array}$ \\
\hline & & $£$ & $£$ & $\mathfrak{£}$ & s. & d. & $£$ \\
\hline 1801 & Topper $_{\text {Cin }}$ & $\left.\begin{array}{l}254,722 \\
. \quad 476,313\end{array}\right\}$ & 731,035 & 101 & 0 & 0 & 117 \\
\hline 1806 & $\begin{array}{l}\text { Tin } \\
\text { Copper }\end{array}$ & $\left.\begin{array}{r}344,027 \\
. \quad 730,845\end{array}\right\}$ & $1,074,872$ & 120 & 10 & 0 & 138 \\
\hline 1811 & Tin & $\left.\begin{array}{l}\text { - } \quad 337,336 \\
\text { - } 563,748\end{array}\right\}$ & 901,078 & 141 & 10 & 0 & 126 \\
\hline 1816 & Tin & $\begin{array}{r}383,346 \\
-541737\end{array}$ & 925,083 & 114 & 10 & 0 & 109 \\
\hline 1821 & $\begin{array}{l}\text { Tin } \\
\text { Copper }\end{array}$ & $\left.\begin{array}{r}242,730 \\
-\quad 628,832\end{array}\right\}$ & 871,562 & 77 & 10 & 0 & 111. \\
\hline 1826 & Tin & $\left.\begin{array}{l}348,074 \\
. \quad 788,971\end{array}\right\}$ & $1,137,045$ & 79 & 0 & 0 & 123 \\
\hline 1831 & $\begin{array}{l}\text { Tin } \\
\text { Copper }\end{array}$ & $\left.\begin{array}{l}300,845 \\
. \quad 806,090\end{array}\right\}$ & $1,106,935$ & 73 & 10 & 0 & 100 \\
\hline 1834 & $\begin{array}{l}\text { Tin } \\
\text { Copper }\end{array}$ & $\left.\begin{array}{l}\cdot 321,860 \\
\cdot \quad 887,902\end{array}\right\}$ & $1,209,762$ & 77 & 0 & 0 & 114 \\
\hline
\end{tabular}
during the first half of the nineteenth century, Porter gives the following details :-

Commenting on these prices, he says :-

"The increase thus shown in the value since the peace (1815), which apparently amounts to more than 30 per cent., is really much beyond that rate. In 1813 , the last year of the war with France, the price of tin was $£ 134$, and of copper $£ 113$ per ton, estimated in a currency depreciated to the extent of 29 per cent."

The price of standard copper during the latter part of the 
nineteenth century, according to the German Report previously quoted, has been-

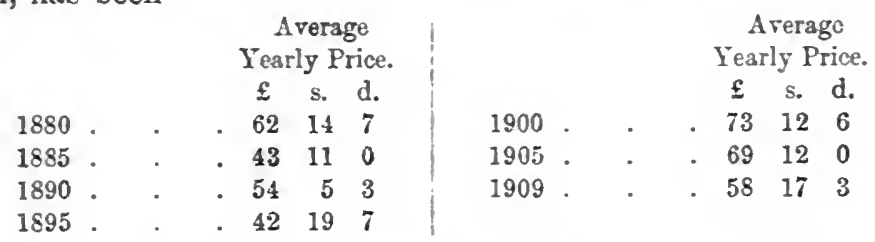

As regards lead, another very important metal, Porter is unable to give any information. He states: "There are no means by which to ascertain the progress made at any time in the productiveness of the lead mines of this kingdom. To answer private purposes, he continues, "the individuals by whom some of the most productive of those mines were worked, studiously concealed the amount of metal which they raised. Various conjectural estimates were made as to that amount, but little dependence can be placed upon their accuracy; and even if we could determine which of those estimates was nearest to the truth, this would afford no help towards forming a comparison between different periods. Neither is any light thrown upon the subject by our custom-house records, since the amount of our exports of lead was, in a great degree, governed by the comparative productiveness of the mines of other countries, and particularly by those of Adra in Spain. The extent to which these were wrought appeared to fluctuate considerably from one year to another."

Of course since Porter's day information has been available. Our production of lead since 1854 has been as follows:-

\begin{tabular}{rrr|rcc} 
& Tons. & $£$ & & Tons. & $£$ \\
1854. & 64,005 & $1,497,717$ & 1890. & $.33,590$ & 449,826 \\
1860. & $.63,317$ & $1,412,760$ & 1900. & $.24,364$ & 418,960 \\
1870. & $.73,420$ & $1,452,715$ & 1905. & $.20,646$ & $286,37 \%$ \\
1880. & $.56,949$ & 953,895 & 1908. & $.20,999$ & 288,124
\end{tabular}

Our imports, exports, and re-export of lead ore (red and white lead and litharge) have been-

\begin{tabular}{|c|c|c|c|c|c|c|c|c|}
\hline & \multicolumn{2}{|c|}{ Injюrts. } & \multicolumn{2}{|c|}{ Exports. } & \multicolumn{2}{|c|}{ Re-exports. } \\
\hline & & & Tons. & $\mathfrak{E}$ & Tons. & $\mathfrak{E}$ & Tons. & $£$ \\
\hline $\begin{array}{l}1900 \\
1905 \\
1909\end{array}$ & : & . & $\begin{array}{r}21,219 \\
9,397 \\
15,542\end{array}$ & $\begin{array}{r}219,082 \\
78,423 \\
120,543\end{array}$ & $\begin{array}{l}1,482 \\
3,535 \\
3,263\end{array}$ & $\begin{array}{l}14,046 \\
32,365 \\
31,383\end{array}$ & $\begin{array}{l}6,491 \\
2,945 \\
5,631\end{array}$ & $\begin{array}{l}63,794 \\
21,432 \\
44,337\end{array}$ \\
\hline
\end{tabular}


More information as regards the production of lead in the United Kingdom is provided by the Report of the Census of Production. In 1907 our production of lead was 29,000 tons (English), our export 7300 tons, and our import 10,500 tons. The imports of lead in that year amounted to 36 per cent. of the quantity raised in the United Kingdom, and about 25 pec cent. of the lead ore raised here was exported. Over 200,000 tons of lead, pig and sheet ore are now imported annually. As to home manufactures, the Census Report gives the following details :-

\begin{tabular}{|c|c|c|c|c|c|}
\hline Pig lead. & . & & . & $\begin{array}{l}\text { Tons. } \\
111,000\end{array}$ & 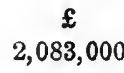 \\
\hline \multicolumn{6}{|c|}{ Manufactures- } \\
\hline \multirow{2}{*}{\multicolumn{2}{|c|}{$\begin{array}{l}\text { Returned by weight } \\
\text { Returned by value only }\end{array}$}} & . & . & 128,000 & $2,630,000$ \\
\hline & & . & . & $\ldots$ & 142,000 \\
\hline White lead & . $\quad$. & . & . & 39,000 & 856,000 \\
\hline
\end{tabular}

The Report adds that it is impossible to state precisely the value of the lead manufacturing industry of the United Kingdom taken as a whole, as it is not known what proportion of the lead manufactures made in the United Kingdom was produced from imported pig-lead. But the above figure of $£ 5,711,000$ may be taken as a close estimate.

It should be observed that the figures showing the quantity of pig-lead produced applies only to that sold or warehoused as such, but on the basis of a voluntary inquiry it was estimated that the total quantity of pig-lead in the United Kingdom during the censal year amounted to between 133,000 and 141,000 tons.

The price of lead every ten years since 1771 has been as follows (we again quote from the German Report):-

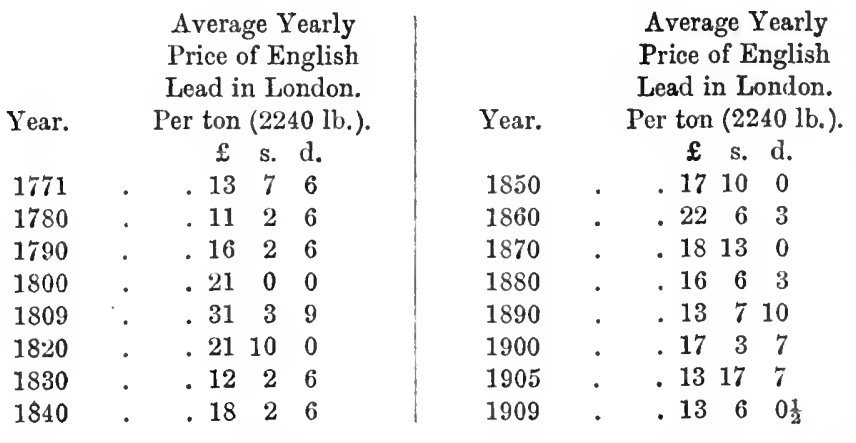

There is another important metal of which Porter makes no 
from which English salt is produced in the fossil or solid form are situated in Cheshire, near the town of Northwich. Brine springs are also found in the same neighbourhood, as well as in other counties, more especially in Staffordshire and Worcestershire. Nearly the whole of the fossil or rock salt that is raised is exported, some to Ireland but the principal part to North Europe. A small quantity is used to strengthen the brine yielded by salt springs, from which the salt used for domestic purposes, and also a large part of what is exported, is produced by evaporation."

"The following table exhibits the quantities of white and rock salt sent down the river Weaver in certain years from 1803 to 1844. If to the quantity here stated 100,000 tons of white salt are added to each year of the series for the produce of springs in other counties, and for that part of the Cheshire salt which is not sent to Liverpool, it is probable that the total produce of this mineral in England will be very nearly ascertained":-

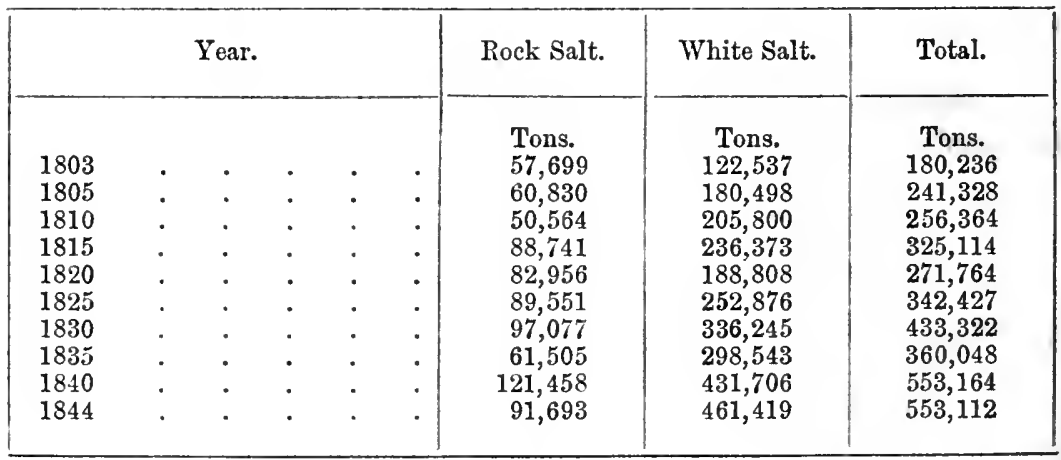

Up to the year 1823 salt was subject to an excise duty of $15 \mathrm{~s}$. per bushel, which was reduced in that year to $2 \mathrm{~s}$; and from the 5 th of January 1825 the duty was wholly repealed. The following figures show the total quantity of salt made, and the proportion taken for consumption every alternate year from 1801 to 1817 , the latest period to which the account was called for by Parliament previous to the repeal of the duty. Subsequent to that event there are, of course, no means for obtaining such information. We may, however, make an approximation towards the truth for the eighteen years from 1827 to 1849 by means of the preceding table, and of the statements which will be found below of the quantities exported during those years, the difference between the quantities produced and exported representing the internal consumption of the country. 


\begin{tabular}{|c|c|c|c|c|c|}
\hline Year. & & & & $\begin{array}{l}\text { Bushels } \\
\text { made. }\end{array}$ & $\begin{array}{l}\text { Bushels taken } \\
\text { for Consumption. }\end{array}$ \\
\hline 1801 & - & • & - & $9,469,491$ & $1,822,683$ \\
\hline 1803 & . & • & . & $8,741,808$ & $1,996,261$ \\
\hline 1805 & . & . & . & $10,210,004$ & $1,951,602$ \\
\hline 1807 & . & . & . & $10,872,672$ & $1,912,462$ \\
\hline 1809 & - & . & - & $9,849,499$ & $1,965,161$ \\
\hline 1811 & . & . & - & $10,387,932$ & $2,038,252$ \\
\hline 1813 & . & . & . & $11,067,603$ & $2,037,931$ \\
\hline 1815 & . & . & . & $15,084,644$ & $2,136,912$ \\
\hline 1817 & & . & . & $9,357,482$ & $1,939,674$ \\
\hline
\end{tabular}

Exports of Rock Salt

\begin{tabular}{|c|c|c|c|c|c|c|c|}
\hline 1827 & - & - & . & . & . & $7,475,025$ & ushels \\
\hline 1830 & - & • & . & . & . & $10,499,778$ & , \\
\hline 1835 & - & . & . & . & . & $8,317,029$ & ," \\
\hline 1840 & . & . & . & . & . & $12,847,663$ & , \\
\hline 1844 & . & . & . & . & . & $13,476,884$ &, \\
\hline 1849 & . & . & . & . & . & $18,604,907$ & \\
\hline
\end{tabular}

Of the quantity exported in 1844

\begin{tabular}{|c|c|c|c|c|c|c|}
\hline Russia & took & . & . & . & \multicolumn{2}{|c|}{$1,823,726$ bushels. } \\
\hline Denmark & $"$ & . & - & . & 462,576 &, \\
\hline Prussia & ", & . & . & . & $1,686,520$ &, \\
\hline Holland &, & . & - & • & 799,802 & , \\
\hline Belgium &, & . & . & • & $1,041,028$ & , \\
\hline Sweden and Norway &, & . & . & . & 237,594 & , \\
\hline Germany &, & . & . & . & 301,426 & 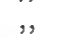 \\
\hline British North America & a, & . & . & . & $1,772,799$ & , \\
\hline United States & $\eta$ & . & . & . & $4,664,430$ & , \\
\hline West Coast of Africa & 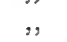 & . & . & 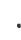 & 374,452 & , \\
\hline New South Wales & , & . & - & . & 125,801 & , \\
\hline Guernsey, Jersey, etc. &, & . & . & . & 41,032 &, \\
\hline
\end{tabular}

The remaining quantity was sent in small shipments to the West Indies, ports in the Mediterranean, and Brazil.

Porter estimates that the average consumption of salt in the United Kingdom between 1827 and 1844 was $11,051,555$ bushels, which compares with an average consumption of $1,928,739$ bushels for the eight years 1801-1808 -an increase of more than 470 per cent.

With the increase of population and wealth the home consumption of salt has enormously increased; nevertheless we have been able to continue the exportation of salt although in diminishing quantities. The figures are as follow:-

Salt Eayorts 
Porter makes no mention of quarries, but the following figures extracted from Part I of the Preliminary Tables issued by the Census of Production are of interest:-

\section{Output}

\begin{tabular}{|c|c|c|c|c|c|c|}
\hline \multirow{10}{*}{$\begin{array}{l}\text { Ironstone } \\
\text { Iron Pyrites } \\
\text { Oil Shale } \\
\text { Fireclay } \\
\text { Clay and Shale } \\
\text { (otherthan Fire- } \\
\text { clay) } \\
\text { Limestone: } \\
\text { Sandstone(includ. } \\
\text { ing Ganiston). } \\
\text { All other Products }\end{array}$} & \multicolumn{2}{|c|}{ England and Wales. } & \multicolumn{2}{|c|}{ Scotland. } & \multicolumn{2}{|c|}{ United Kingdom. } \\
\hline & Tons. & $\mathfrak{£}$ & Tons. & & Tons. & \\
\hline & $\tau, 379,000$ & $1,946,000$ & 805,000 & 382,000 & $8,184,000$ & $2,328,000$ \\
\hline & 11,000 & 5,000 & & & 11,000 & 5,000 \\
\hline & $\ldots$ & $\ldots$ & $2,715,000$ & 650,000 & $2,715,000$ & 650,000 \\
\hline & $\cdots$ & $\ldots$ & $\ldots$ & ... & $2,542,000$ & 519,000 \\
\hline & & & & & 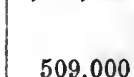 & 58.000 \\
\hline & 343,000 & 49,000 & 48,000 & 14,000 & 391,000 & 63,000 \\
\hline & 157,0 & & 37,000 & 10 & 194,000 & \\
\hline & $\ldots$ & 17,000 & $\ldots$ & 2,000 & $\ldots$ & 19,000 \\
\hline
\end{tabular}

Although in Roman times Britain was celebrated for its gold mines, the production of the precious metals in this country is insignificant. A certain amount of silver is, however, obtained from lead mines.

In $1854,558,659$ ounces valued at $£ 140,664$ were produced, and the production rose to 835,542 ounces in 1868 , valued at $£ 229,773$. This was the highest point reached, and in 1880 the production of silver only amounted to 295,518 ounces, valued at $£ 63,015$. In 1870,191 ounces of gold were obtained in Great Britain, and the amount rose to 702 ounces in 1878 , dropping to 10 ounces in 1880 , but rising again to 8745 ounces in 1888 . 


\section{CHAPTER XIII}

\section{IRON AND STEEL MANUFACTURES}

Up to 1850.-Quantity of iron made in England and Wales in 1740-Quantities made from 1823-1830 - Sir John Guest's estimates in 1840-Mr. Jessop's estimates of iron made in 1840-Exports of bar iron, pig iron, and castings, 1801-1910 - Steel trade of Sheffield during first half of nineteenth century-Increasing use of iron, according to Sir John Guest-Home consumption of iron, 1806-1844.

From 1850 onwards.-Great changes in iron and steel trades during last half of nineteenth century-The overlapping of various branches of iron and steel tradesIncreasing imports of foreign ores-British iron fields and their outputs-Mannfacture of pig iron : (1) Forge and fonndry, (2) Bessemer-Great Britain's share in the world's production of pig iron-Hæmatite iron-Pig-iron production from 1850-1908Finished iron trades-Decrease in importance as more steel produced-Steel industryCrucible steel-The Bessemer process-Open-hearth process-Basic process-Iron and steel output of leading British districts in 1904-Output of steel since 1875-Prices of pig iron, steel and iron bars since 1835-Census of Production figures for 1907 .

T $N$ the first half of the nineteenth century our iron and steel industries made rapid progress; but since that time, in consequence of inventions, the output has been enormously enlarged. In his Progress of the Nation, Porter treated of iron and steel partly under the heading of "Mining," partly under the heading of "Manufactures," and partly in a section dealing with consumption. It will be more convenient to collect this scattered information and embody it in the present chapter.

\section{Iroy ANd SteEL, 1800-1850}

The quantity of iron made in England and Wales in 1740 was estimated at 17,350 tons, the produce of fifty-nine furnaces, in which only charcoal was used. Between that time and 1788 the plan of smelting iron ore by means of coke was introduced, and in the latter year there were in England, Wales, and Scotland, eightyfive furnaces, producing annually 68,300 tons of iron, of which quantity 55,200 tons were smelted with coke. In 1796, in consequence of a tax projected by Mr. Pitt, upon coals at the pit, but which was not imposed, a careful inquiry was made as to the 
condition and extent of the iron-works that would have been affected by such a measure. On this occasion it appeared that there were-

In England and Walcs 104 furnaces, producing 108,793 tons of iron.

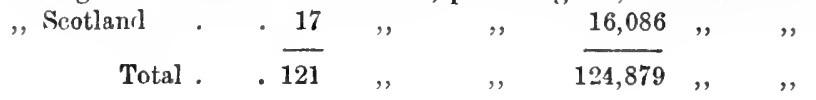

In 1802 it was further estimated that forty additional furnaces were in use in England and Wales, and seven in Scotland-the total annual production of iron amounting to 170,000 tons in the year. In 1806 a Bill was introduced into the House of Commons by the Minister for imposing a duty of $£ 2$ per ton upon all pig iron made in the kingdom. This Bill was afterwards withdrawn, but the attempt occasioned inquiries to be set on foot respecting the quantity of metal produced, and it was stated then to amount to 250,000 tons annually.

The following estimate, beginning with 1823 , is said to have been made with great care by the manager of one of our largest iron smelting establishments:-

\begin{tabular}{|c|c|c|c|c|c|c|}
\hline & & & 1823. & 1825. & 1828. & 1830. \\
\hline $\begin{array}{l}\text { South Wales } \\
\text { Staffordshire } \\
\text { Shropshire. } \\
\text { Yorkshire . } \\
\text { Scotland . } \\
\text { Derbyshire. } \\
\text { North Wales } \\
\text { Other places }\end{array}$ & $\begin{array}{ll}. & . \\
. & . \\
. & . \\
. & . \\
. & . \\
. & . \\
. & .\end{array}$ & $\begin{array}{l}\dot{.} \\
\dot{.} \\
\dot{.} \\
\dot{.}\end{array}$ & $\begin{array}{r}\text { Tons. } \\
182,325 \\
133,590 \\
57,923 \\
27,311 \\
24,500 \\
14,038 \\
\ldots \\
2,379\end{array}$ & $\begin{array}{r}\text { Tons. } \\
223,520 \\
171,735 \\
86,320 \\
35,308 \\
29,200 \\
19,184 \\
13,100 \\
3,000\end{array}$ & $\begin{array}{r}\text { Tons. } \\
279,512 \\
219,492 \\
81,224 \\
32,968 \\
37,700 \\
22,360 \\
25,168 \\
4,160\end{array}$ & $\begin{array}{r}\text { Tons. } \\
277,643 \\
212,604 \\
73,418 \\
28,926 \\
37,500 \\
17,999 \\
\ldots \\
\ldots, 327\end{array}$ \\
\hline & Total. & & 442,066 & 581,367 & 702,584 & 653,417 \\
\hline
\end{tabular}

The quantities contained in this table agree with the evidence given before the Committee on Import Duties in 1840, by Sir John Guest, the proprietor of the Dowlais iron-works in Glamorganshire. According to Sir John Guest, the manufacture remained stationary between 1823 and 1831, when it again began to advance, and in 1835 there were good grounds for estimating the quantity made at a million of tons. In the following year the estimate was $1,200,000$ tons, and in 1840 it reached $1,500,000$ tons. A statement was prepared in October of that year by one 
of our most intelligent iron-masters, ${ }^{1}$ giving the number of furnaces in blast and out of blast, and the number of tons of iron made at each work in Great Britain. It was there shown that the annual product, exclusive of Ireland, amounted to 1,396,400 tons; the number of furnaces in blast was 402 , of which number 162 employed the process of blasting with hot air. The manufacture was in this statement distributed as follows among the various divisions of the kingdom, and an estimate was offered of the quantity of coal used in the manufacture, namely-

\begin{tabular}{|c|c|c|c|c|c|}
\hline & & & & $\begin{array}{l}\text { Tons of Iron } \\
\text { IIade. }\end{array}$ & $\begin{array}{c}\text { Tons of Coal } \\
\text { Used. }\end{array}$ \\
\hline Forest of Dean & . & . & . & 15,500 & 60,000 \\
\hline South Wales & . & . & . & 505,000 & $1,436,000$ \\
\hline North ," & . & . & . & 26,500 & 110,000 \\
\hline Northumberland & . & . & . & 11,000 & 38,500 \\
\hline Yorkshire & . & . & . & 56,000 & 306,500 \\
\hline Derbyshire & - & . & . & 31,000 & 129,000 \\
\hline North Staffordshi & & . & . & 20,500 & 83,000 \\
\hline South , & & . & . & 407,150 & $1,582,000$ \\
\hline Shropshire & . & . & . & 82,750 & 409,000 \\
\hline Scotland . & . & . & - & 241,000 & 723,000 \\
\hline & & & & $1,396,400$ & $4,8 \pi \tau, 000$ \\
\hline Coals used in con & rer & 10 & ught iron. & . $\quad$. & $2,000,000$ \\
\hline
\end{tabular}

The commercial depression, which continued for about four years after Mr. Jessop's statement was compiled, led our iron-masters to diminish the scale of their operations in order thereby to lessen their losses. A statement was drawn up in 1842, under the direction of an association of the Yorkshire and Derbyshire iron-masters, showing the quantity of iron made during the first six months of that year, in Yorkshire, Derbyshire, Staffordshire, Shropshire, South Wales, and Scotland, as under :-

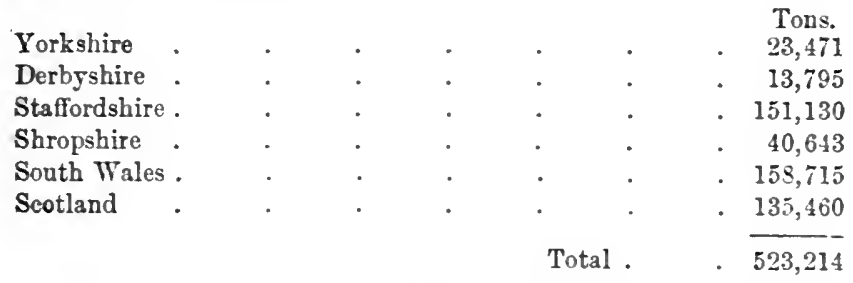

equal to $1,046,428$ tons per annum. The quantity made in the above divisions of the kingdom, in 1840 , according to Mr. Jessop, was $1,343,400$ tons,- - showing a diminished production at the rate of 296,972 tons, or more than 22 per cent.

\footnotetext{
${ }^{1}$ Mr. Jessop, of Butterley, in Derbyshire.
} 
The number of furnaces in and out of blast, and the quantity of iron made in different parts of Great Britain, in each of the years 1847 and 1848 , is here given upon what was considered good authority :-

\begin{tabular}{|c|c|c|c|c|c|c|c|}
\hline & \multicolumn{4}{|c|}{ Furnaces. } & \multirow{2}{*}{\multicolumn{2}{|c|}{ Iron Made. }} \\
\hline & & \multicolumn{2}{|c|}{ In Blast. } & \multicolumn{2}{|c|}{ Out of Blast. } & & \\
\hline & & 1847. & 1848. & 1847. & 1848. & 1847. & 1848. \\
\hline $\begin{array}{l}\text { North Staffordshire } \\
\text { South ", } \\
\text { Shropshire } \\
\text { Derbyshire } \\
\text { Yorkshire. } \\
\text { Newcastle-on-Tyne } \\
\text { North Wales : } \\
\text { South ". : } \\
\text { Scotland . : }\end{array}$ & $\begin{array}{l}\dot{\dot{ }} \\
\dot{\dot{ }} \\
\dot{\dot{ }} \\
\dot{\dot{ }}\end{array}$ & $\begin{array}{r}\text { No. } \\
16 \\
77 \\
28 \\
20 \\
23 \\
24 \\
5 \\
151 \\
89\end{array}$ & $\begin{array}{r}\text { No. } \\
14 \\
112 \\
31 \\
20 \\
20 \\
17 \\
5 \\
139 \\
94\end{array}$ & $\begin{array}{r}\text { No. } \\
3 \\
62 \\
6 \\
10 \\
5 \\
12 \\
6 \\
45 \\
41\end{array}$ & $\begin{array}{r}\text { No. } \\
7 \\
25 \\
4 \\
10 \\
11 \\
15 \\
9 \\
57 \\
36\end{array}$ & $\begin{array}{r}\text { Tons. } \\
65,520 \\
320,320 \\
88,400 \\
95,160 \\
67,600 \\
99,840 \\
16,120 \\
706,680 \\
539,968\end{array}$ & $\begin{array}{r}\text { Tons. } \\
67,080 \\
465,920 \\
111,020 \\
78,000 \\
59,800 \\
94,380 \\
22,256 \\
631,280 \\
564,000\end{array}$ \\
\hline & & 433 & 452 & 190 & 174 & $1,999,608$ & $2,093,736$ \\
\hline
\end{tabular}

A striking progress was made during the nineteenth century in the exportation of British iron in an unmanufactured state. The quantities supplied to other countries by Great Dritain have increased since 1801 as follows:-

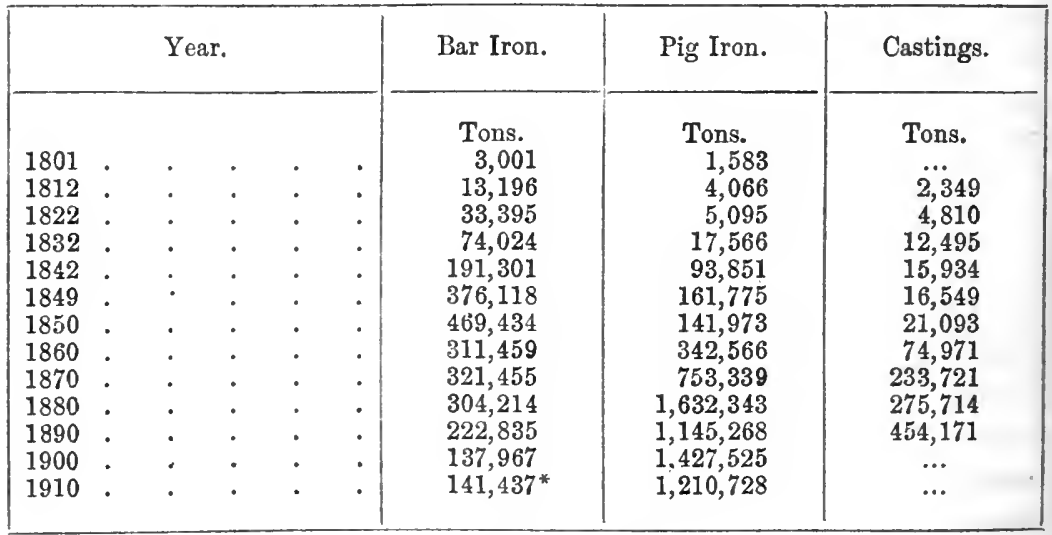

* Of wronght iron only.

One branch of manufacture carried on in Sheffield, the conversion of iron into steel, was very greatly extended during the first 
half of the last century, and a considerable part of the output was exported in an unwrought form. The town of Sheffield, in 1835, contained fifty-six furnaces for converting iron into steel; beside which, there were sixty-two establishments, containing 554 furnaces, for moulting steel. The original conversion of the metal into blistered steel occasioned the use of about 12,000 tons of coal in the form of coke, and the subsequent processes required about 81,000 tons in addition. Five-sixths of the iron then used for manufacturing purposes in Sheffield was of foreign production; only 2000 out of the 12,000 tons consumed annually being of British origin. The cost of the fuel formed just one-third part of the expense of converting and casting steel.

The progress of this particular branch of trade may be understood from the following statement of the quantity of unwrought steel exported at various periods, from 1814 to 1849 :-

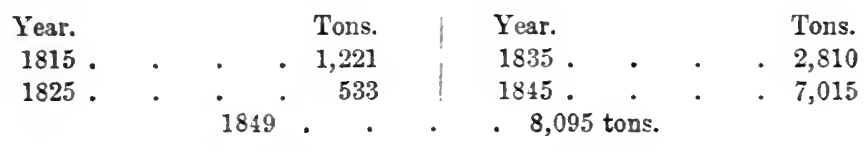

Our principal market for unwrought steel in the first half of the nineteenth century was the United States of America. The quantities sent there at various periods during the thirty-five years from 1815 to 1849 were as follow:-

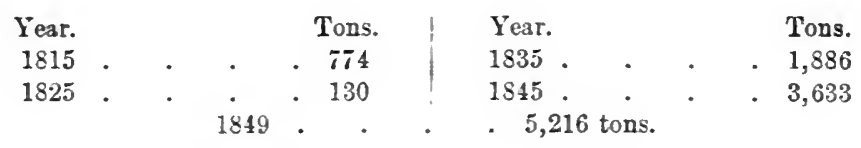

The increased use of iron in this country during the first half of the nineteenth century was truly extraordinary. The imports of this metal at the beginning of the century amounted to about 40,000 tons yearly, and the quantity made at home was under 150,000 tons. It was given in evidence, by Sir John Guest, before the Committee of 1840 on Import Duties, that in the year 1806 the quantity of iron made in the kingdom was 258,000 tons; that in 1823 the quantity produced was 452,000 ; in 1825 it had reached 581,000 tons: and in 1828 the quantity was 703,000 tons.

Another tremendous impulse was given to the trade by the invention and rapid extension of railways and steam locomotion. It is probable that by the year 1845 in Scotland alone the quantity 
of iron made had risen to not less than half a million tons annually.

Accepting Sir John Guest's data and the figures of the parliamentary returns for the quantities imported and exported during the period 1806-1844, we arrive (after a further small deduction for exported hardware) at the following results for home consumption :-

\begin{tabular}{|c|c|c|c|c|c|c|}
\hline & Year. & & $\begin{array}{l}\text { British Iron } \\
\text { Made. }\end{array}$ & $\begin{array}{l}\text { Foreign Iron } \\
\text { Used. }\end{array}$ & $\begin{array}{c}\text { British Iron } \\
\text { Exported. }\end{array}$ & $\begin{array}{l}\text { Remained for } \\
\text { Home Use. }\end{array}$ \\
\hline $\begin{array}{l}1806 \\
1825 \\
1835 \\
1844\end{array}$ & $\begin{array}{l}\dot{5} \\
\dot{ } \\
\dot{ }\end{array}$ & . & $\begin{array}{l}\text { Tons. } \\
258,000 \\
581,000 \\
1,000,000 \\
1,400,000\end{array}$ & $\begin{array}{l}\text { Tons. } \\
27,411 \\
14,977 \\
17,571 \\
21,599\end{array}$ & $\begin{array}{r}\text { Tons. } \\
36,925 \\
34,372 \\
199,007 \\
458,745\end{array}$ & $\begin{array}{c}\text { Tons. } \\
243,857 \\
550,625 \\
798,367 \\
940,302\end{array}$ \\
\hline
\end{tabular}

This rapid and great increase during the last period shown by these figures was in some part caused by the economy introduced through the use of the hot blast in smelting, a process which materially lowered the cost of iron, and therefore led to its employment for many purposes in which its use was previously unknown. An account of many branches of iron and steel manufactures will be found in a later chapter.

\section{IroN AND STEEL, 1850-1910}

So great has been the progress, and so revolutionary the changes introduced into the iron and steel trades since 1850 , that it is impossible to give more than a brief sketch of their development. The modern steel trade is practically a new industry since Porter's day; for no less than three new distinct processes for making steel have been discovered during the last fifty years. In the following pages our account of the iron and steel trades will include the production of iron ore, pig iron, finished iron, and steel, but certain special engineering trades and the cutlery trade will be dealt with in later chapters.

To begin with iron ore. In Porter's time most of the iron and steel produced in this country was made from ores that were obtained from the home supply. During the latter half of the nineteenth century the demand for iron and steel manufactures expanded so rapidly that more and more foreign ores had to be imported. The growth of this import trade is shown in the following table:--- 


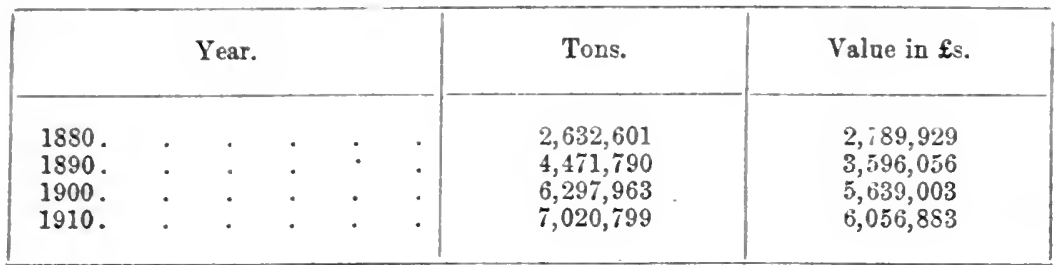

The country that sends us the most iron ore is Spain, her contribution amounting to $4,714,744$ tons in 1910 . Other countries of supply are Sweden, Greece, Italy, and Algeria.

The British iron fields and their outputs in 1904 are shown in the following table, which is taken from The Iron Trades of Great Britain, by Mr. J. Stephen Jeans :-

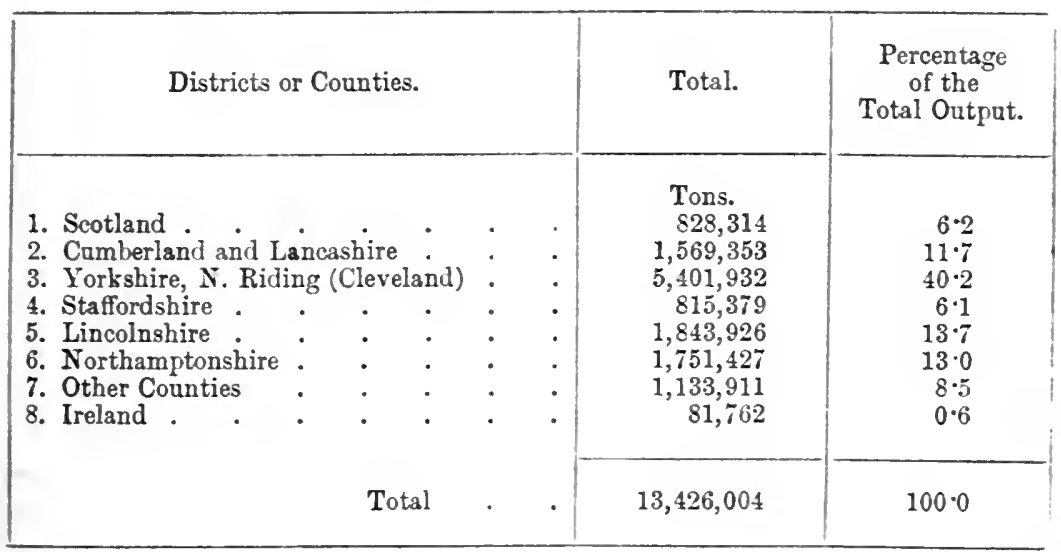

The next stage in the production of iron and steel is the manufacture of pig iron, but this can hardly be considered as a trade apart; for many large firms carry on all the processes of iron and steel manufacture, from the producing of the crude material to the turning out of the finished product.

The two principal kinds of pig iron made in Great Britain are(1) forge and foundry, and (2) Bessemer or hæmatite iron. . A third kind known as Spiegeleisen also deserves mention. The forge and foundry iron is by far the oldest kind of pig iron produced in this country. The other two kinds are of comparatively recent discovery. Mr. Jeans states that "in 1850 the total production of pig iron throughout the world was under five million tous. Ten sears later the output had advanced to $7,400,000$ tons, in 1870 it had risen to $11,900,000$ tons, and in 1880 to $18,484,000$ tons. Between 1880 and 1890 there was an increase of $9 \frac{1}{4}$ million tons, 
which compares with an increase of rather over $13 \frac{3}{4}$ million tons in the previous thirty years. But between 1890 and 1900 the world's increased make of iron was close on $13 \frac{1}{2}$ million tons, almost equalling the whole increase in the period 1850-1880." Mr. Jeans adds: "Up to the year 1870 Great Britain produced one-half or more of the total pig iron output of the world. . . . In the year 1903 Great Britain produced 20 per cent., the United States 42 per cent., and Germany $25 \frac{1}{2}$ per cent."

Hæmatite iron is only produced in six of the principal ironmaking districts of Great Britain, the more important being West Cumberland, South Wales, and Scotland. The following table shows the growth of pig iron production in this country since 1860 :-

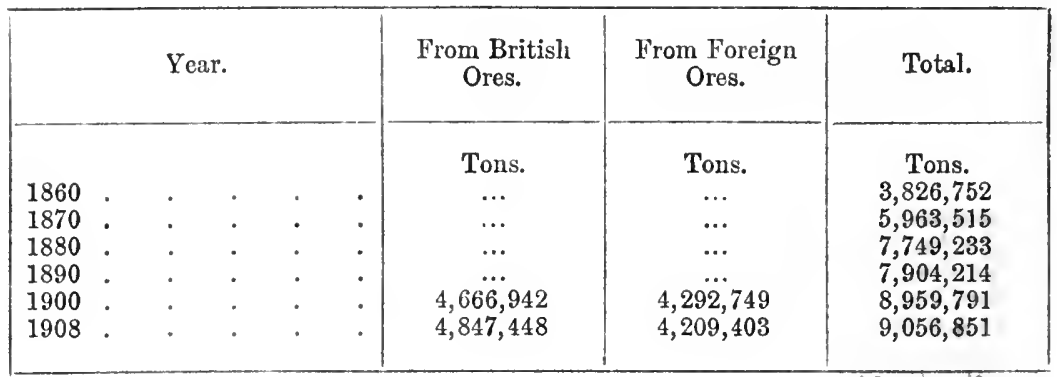

Sixty years ago the finished iron industry was the most important branch of the iron and steel trades; but since the development of modern methods of producing steel, it has diminished in importance. According to Mr. Jeans, "only about twenty-five years ago Great Britain produced well on to three million tons a year. At that time the principal centres of the trade in finished materials were South Staffordshire, the north-east coast of England, and South Wales, each of which produced from 750,000 tons to about a million tons of puddled iron annually." In 1902 and 1903 the total output of such iron had declined to under a million tons. The principal finished iron products of the present time are bar iron, sheets, rounds and squares, hoops, and wire rods. Bar iron represented about 40 per cent. of the total make of finished iron in 1904.

Of the priucipal clistricts that formerly produced finished iron, South Staffordshire is still of some importance; but the trade in South Wales has practically disappeared. Its place has been well filled, however, by the tin-plate industry.

The steel industry, though of course it existed in Porter's 
days, has undergone such revolutionary changes that it can almost be regarded as a new manufacture. Prior to 1850 there was only one process of making stcel, namely, the crucible process. Mr. Jeans says that "until thirty-five years ago the British steel industry was carried on almost entircly in sheffield and its neighbourhood. . . Until the year 1860 the quantity of steel yearly produced in Great Britain did not exceed 100,000 tons, and the output of the whole world was not twice that quantity annually. The steel then produced was almost wholly of the variety known as crucible, puddled, or cementation, and its cost was heavy, both because it was produced from expensive materialSwedish bar iron-and because the process of manufacture was long and costly. Up to about 1860 very little steel was produced at a less cost than $£ 20$ per ton, and much of the product went up to $£ 50$ and $\mathfrak{£} 60$."

The first great change in the conditions of steel-making came in 1856, when the Bessemer process was discovered. The Bessemer process consists of blowing a blast of air through molten iron so as to clear it of all carbon, and then adding sufficient carbon to convert it into steel.

The next great invention in the steel trade is known as the openhearth process. This was discovered by Siemens Brothers between 1864 and 1867 , but it was not until 1870 that the industry really began to develop; since then its progress has been very rapid. In Great Britain the annual output of open-hearth steel exceeds three and a half million tons. One great difference between the Bessemer and the open-hearth process is that while the former takes about fifteen minutes, the latter takes six to eight hours to consummate. The longer period is advantageous; seeing that it enables various degrees of hardness and temper to be introduced into the open-hearth steel which are not possible with the Bessemer method.

The third new process to be inaugurated was the basic process. This was discovered by Mr. Thomas and Mr. Gilchrist in or about the year 1879. The fundamental point in the basic process is that it eliminates phosphorus from impure ores. This had far-reaching results, as there were vast supplies of iron ore in the world, which had hitherto been useless, owing to their containing phosphorus. It affected about tro-thirds of the ores in the country, but it was of even more value to Germany and France, as the stores of phosphoric ores possessed by these countries wiss relatively greater than those possessed by England. In fact, it was the 
discovery of the basic process that made the modern German steel industry possible.

The following table, extracted from Mr. Jeans' valuable book, shows the iron and steel output of leading British districts in $1904:-$

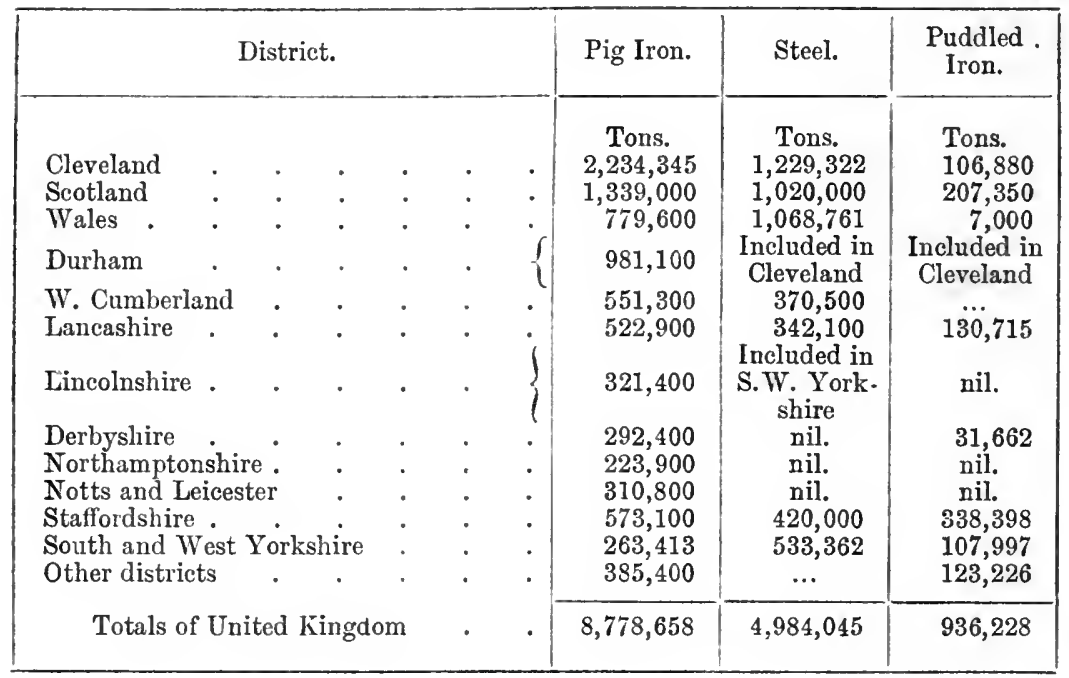

Our output of steel billets since 1850 is shown by the following figures, which are taken from statistics supplied by the Iron and Coal Trades Review for the use of the National Monetary Commission of the United States:-

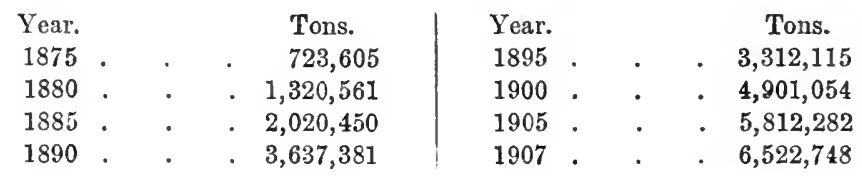

The average price of pig iron of the same quality in Glasgow in certain years from 1835 to 1849 was as follows:-

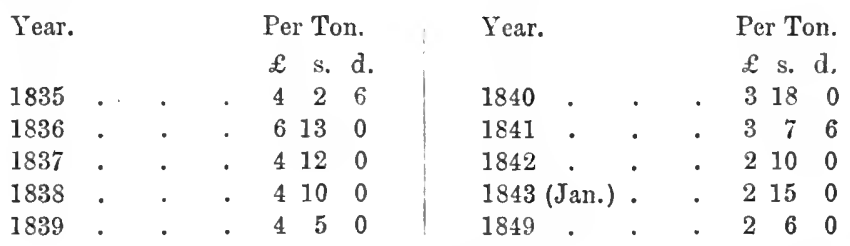

The selling price of English Merchant bar iron in Liverpool 
at the beginning of every ten years from 1806 to 1845 was as under:-

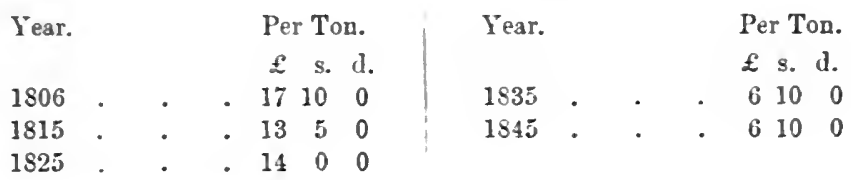

Mr. Jeans gives the following figures showing the average prices of leading descriptions of iron in Great Britain in 1880, 1890 , and $1900:-$

\begin{tabular}{|c|c|c|c|c|}
\hline & $\begin{array}{l}1880 . \\
£ \text { s. d. }\end{array}$ & $\begin{array}{l}1890 . \\
\stackrel{2}{2} \text { s. }\end{array}$ & & $\begin{array}{l}1900 . \\
\& \text { s. d. }\end{array}$ \\
\hline Scotch warrants & $\begin{array}{lll}2 & 4 & 4\end{array}$ & 23 & 4 & 2198 \\
\hline " bars . . . & 610 & 7 & 0 & 810 \\
\hline Merchant Bars, Liverpool & 515 & 6 & 0 & 910 \\
\hline S. Staffordshire List Iron & 7150 & 5 & 0 & 1015 \\
\hline
\end{tabular}

For 1907 the Census of Production gives the size of our iron and steel trades as:-

\begin{tabular}{|l|c|c|c|c|c|}
\hline & $\begin{array}{c}\text { Gross } \\
\text { Output. }\end{array}$ & $\begin{array}{c}\text { Cost of } \\
\text { Material } \\
\text { Used.* }\end{array}$ & $\begin{array}{c}\text { Net } \\
\text { Output. }\end{array}$ & $\begin{array}{c}\text { Number } \\
\text { Em- } \\
\text { ployed. }\end{array}$ & $\begin{array}{c}\text { Net } \\
\text { Output } \\
\text { per Person. }\end{array}$ \\
\hline $\begin{array}{c}\text { Iron and steel fac- } \\
\text { tories (smelting, } \\
\text { founding, and } \\
\text { rolling) }\end{array}$ & $£$ & $£$ & $£$ & $£$ \\
\hline
\end{tabular}

"Including payment for work given out to other firms.

The net output of iron and steel factories included in this table was valued at $£ 30,948,000$, this representing the amount by which the products as a whole exceeded the cost of the materials used and the work done on them by other firms for the principal firms. The actual cost of the raw materials used is not known, since the total of the sums returned as "materials" includes, like the total of the sums returned as "output," iron and steel made by one factory and sold to another. 


\section{CHAPTER XIV}

\section{MACHINERY, ENGINEERING, SHIPBUILDING, AND ELECTRICAL TRADES}

1800-1850.-Importance of perfect tools and implements-Progress of manu. facturing skill in their production-Foreign mechanical inventions perfected and adopted in England-Policy of allowing the exportation of machinery-Laws for restraining artisans from going abroad-Their repeal-Value of machinery exported.

1850-1909. - The engineering trades-Census of Production figures-Exports of machinery and mill-work, 1845-1910.

The Shipbuilding Industry.-The first iron-built vessels-Growth of industry, 1850-1910-Causes of growth-Steel-built vessels-Introduction of steam-The conspound engine-Early steam-vessels-Turbines-Changes in design and structureShipbuilding centres in the United Kingdom.

The Electrical Industry.-Age of industry-Early experiments-The discovery of the dynamo-Uses of electricity-Electric lighting and the arc lamp-The Edi-Swan lamp-Brush boom-Parliamentary legislation-Electric traction-The electric motor -Electric power-Effect on industry and manufactures-Towns-Some problems of the electrical industry-Foreign trade in electrical goods.

Locomotive and Wagon Building.-Our export trade in railway material, etc.

The Explosive Engine. - Early types of gas-engine-oil-engines-The motor tradeOur foreign trade in motors-Our foreign trade in cycles-Possibilities of the explosive engines-aeroplanes.

\section{$1800-1850$}

“

T no branch of manufacturing skill," writes Porter, "has more important and rapid progress been made of late years in this country than in the production of manufacturing implements and machinery. The great importance of this to a manufacturing people scarcely needs to be insisted on. Without superior tools and implements, how many valuable inventions now used, which minister extensively to the advantage and comfort of society, must have remained unapplied, if they had even at all suggested themselves to the minds of the ingenious men by whom they have been conceived?"

Some part of our cotton-spinning machinery was, during the first half of the nineteenth century, of foreign invention; but as the state of the mechanical arts was not sufficiently advanced for 
that purpose in their own countries, the inventors were obliged to resort to English workshops for the means of perfecting their conceptions, and as our factories offered at the same time the largest and most profitable field for the employment of these machines, our cotton manufacture fairly profited from the ingenuity which it mainly fostered. One of the most successful spinning frames used in the factories of Lancashire, in the middle of the nineteenth century, was the invention of a citizen of the United States of America.

The necessity for the employment of a-high degree of skill in the adjustment of machinery for manufacturing purposes, was illustrated by Dr. Ure in his work, The Philosophy of Manufactures, by the following anecdote:-

"A manufacturer of Stockport being, not long ago, about to mount 200 power-looms in his mill, fancied he might sare a pound sterling in the price of each by having them made by a neighbour machine-maker, instead of obtaining them from Mfessis. Sharp \& Roberts, in Manchester, the principal constructors of prower-looms. In order to give his fabricator every chance of success, the economist surreptitiously procured iron patterns cast from one of the looms of that Company, which, in its perfect state, costs no more than $£ 915 \mathrm{~s}$. His 200 looms were accordingly constructed at Stockport, supposed to be facsimiles of those regularly made in Manchester, and they were set to work. Hardly a day passed, however, without one part or another breaking down,-insomuch that the crank or tappet-wheels had to be replaced three times, in almost every loom, in the course of twelve months. The fabric of the cloth was also indifferent. The proprietor, perplexed beyond measure, inquired of a neighbour who worked similar power-looms nade br the Manchester machinicians, whether his wheels likewise went to piecez every other day, and learned, to his mortification, that not one of them had broken in the course of working, but that the four or five spare ones, originally sent from Janchester along with his 236 power-looms, were unused and quite at his serrice. The old proverb of 'Penny' wise and pound foolish' never had a better illustration. His weaving factory had been most irregular and unproductire, while that of his neighbour had been uniformly prosperous."

The circumstances that have just been mentioned seem naturally to lead to a consideration of the policy which so long prevailed, of prohibiting the exportation of machinery from this country. It may be conceded that, in cases where an individual or a nation is in the possession of superior manufacturing processes whereby greater profits can be realized, it is natural to use every fair means for keeping those advantages out of the hands of foreign competitors. It is clear that these competitors could have no just reason for complaining, if we preferred our own profit to theirs. Neither would the inventors of the machinery have much cause for 
complaint, if the Legislature should pass laws under which the manufacturers of this country would be secured in the monopoly of home inventions. Machine-makers have, so far, a contrary interest to the manufacturers, - - that they are benefited by the extension of the use of their machines, while the apparent advantage of the manufacturers consists in confining that use to themselves. To prohibit the exportation of his wares may therefore, at first sight, appear to be as great a hardship upon the machinist as it would be upon the weaver of cotton, if his productions were confined to the home market; but the cases are not in all respects parallel. By the restriction last supposed, the extension of the weaver's trade would be in a great measure limited to the slow natural increase of the people in the country of production; whereas the confining to that country of a machine, by means of which better or cheaper goods can be made, will be followed by nearly the same effect as if the exportation of the improved machines were allowed, siuce the greater quantity of goods produced by their means, and for which, in consequence of their superiority or cheapness, a foreign demand would be kept up, must cause a greater number of the machines to be used at home, and it can be of no moment to the maker of those machines, whether his customers reside in the United Kingdom, or in France or Germany.

The state of things which has been here supposed cannot, however, have any existence in reality. It has never been found practicable to adopt regulations whereby the exportation of machinery can be wholly prevented. Where the invention is the object of a patent, an accurate and complete drawing and description can be procured by any one without trouble; and by the transmission of these, any engineer of ordinary capacity can in most cases construct a machine which will at least answer as a very tolerable substitute for that made under the inspection of the inventor. In more complicated inventions, it mostly happens that the only part of the machine which is difficult of execution is of small dimensions, and it is consequently easy to convey it illicitly out of the kingdom. Uuder these circumstances, it appears to be the most prudent course to legalize the trade, and thereby to secure for a part of the community a profitable source of employment. Nor would the manufacturers in this kingdom have any right to complain of the facilities thus given to their foreign rivals. The inventions which they would seek to retain for their own advantage have cost them neither labour nor expense. In fact, they can in no case have any plea for such a restriction, except that of the 
general advantage of the community, and the cases can be but very few in which that plea can be successfully urged. The interest of the bulk of the people must, on the contrary, always be best promoted by that policy which gives the utmost freedom to industry, and tends to lower the prices of articles of consumption. Laws which prohibit the communication of facilities and improvements are liable to be imitated by other nations, either in a spirit of retaliation, or possibly from a belief in their wisdom, and both these reasons may be expected to operate most freely when the example has been set by a successful and powerful nation. Let us imagine that the American Congress, impressed with the wisdom of our old system of restrictions, or stung with a feeling of jealousy of our manufacturing superiority, had passed a law forbidding the communication to foreigners of the inventions of American citizens, so that the machines already spoken of as being derived from that country must have been brought into operation there and there only. It is far from being certain that while by the adoption of this course, England would have sustained a considerable injury, the American people would have derived any substantial benefit. In the fair and legitimate course of dealing between two people, it is so far from being true that what one of them gains the other must necessarily lose, that, on the contrary, few things are more certain than that both may be, and almost universally will be, gainers by their transactions. But neither does it follow, that in unprofitable dealings, what one loses must be gain to the other; both, on the contrary, may lose, and in the long run this is almost sure to be the result. In the case supposed, America would lose an excellent customer for a large amount of her raw produce, and her citizens would consequently be deprived of many articles of English manufacture, which they cannot procure at so good nor at so cheap a rate elsewhere. The capital required for carrying on the cotton manufacture upon a large scale would be withdrawn by them from other pursuits in which it is profitably embarked, and while a few might possibly be gainers, the many would be subjected to certain loss.

The laws prohibiting the exportation of machinery from this country were, however, gradually relaxed and at length repealed toward the close of the first half of the ninetcenth century. Previous to 1825 , the jealousy of our Legislature with regard to the progress of foreign manufactures was extended so far as to interfere with the natural right even of working artisans to trausfer their industry to countries where it could be most profitably exerted. 
Any man who had acquired a practical knowledge of manufacturing processes was thereby rendered a prisoner in his own country; and not only might the arm of the law be interposed to prevent his quitting his native shore, but heavy penalties were imposed upon all persons who should abet the expatriation of one of our artisans. This disgraceful law was happily expunged from our Statute Book after its futility had been exposed in the following

"Resolutions of Committee appointed to inquire into the state of the Law of the United Kingdom, and its consequences, respecting Artisans leaving the Kingdom and residing abroad, etc. Reported to the House of Commons, 21st May, 1824.

"1. That it appears by the evidence before this Committee, that notwithstanding the laws enacted to prevent the seduction of artisans to go abroad, many able and intelligent artisans have gone abroad to reside, and to exercise their respective arts in foreign countries; and that it is extremely difficult, if not impossible, in this country, by any mode of executing the present laws, or by any new law, to prevent artisans who may be so determined from going out of the country.

"2. That although the penalties which the laws inflict on artisans who disobey them are not distinctly understood by the workmen, yet an unfavourable opinion is generally entertained by them of the partial and oppressive operation of these laws, as preventing them from taking their labour and art to the best market; whilst all other classes of the community are permitted to go abroad, and to take their capital with them whenever they think proper.

" 3 . That it appears also by evidence, that many" British artisans residing abroad have been prevented from returning home, from an erroneous opinion that they have, by going abroad, violated the laws of their country, and cousequently incurred penalties under them.

"4. That, in the opinion of this Committee, it is both unjust and impolitic to continue these laws; they therefore recommend their entire repeal, and that artisans may be at liberty to go abroad and to return home whenever they may be so disposed, in the same manner as other classes of the community now go and return."

In and after 1825 permission might be had for the exportation of all the more common articles of machinery. A long list was given of various articles or classes of machinery the exportation of which was prohibited, but a discretionary power of relaxing the law was given to the Board of Trade, which decided upon each application, as it was made by the persons seeking to export, according to the merits of each particular case. Under this system, the practice was uniform in regard to so many articles, that but little difficulty was experienced by the merchants, who in general knew as to what machines or implements the indulgence would be extended, and from what it would be withbeld, with nearly as much certainty as 
they would have known if each object had been scherluled in an Act of Parliament. The principal advantage of this discretionary power vested in the Board of Trade consisted in its leaving to that Board the power of regulating the matter according to the changing interests of commerce.

The policy of restricting this, which might become an important branch of trade, was the subject of laborious investigation by Committees of the House of Commons which sat in 1824 and 1825 . The concluding paragraph of the report made by the Committee in 1825 explains the reasons why it was thought expedient to leave the list of prohibitions unrepealed, and shows that the result of their inquiry left no doubt on the minds of the members of the Committee as to the inexpediency of the existing system.

England is, beyond all other countries, interested in the most perfect freedom being given to this as well as to every other branch of commerce. Placed beyond all comparison at the head of civilization as regards manufacturing skill, with capital far more ample than that possessed by any other people, with cheap and inexhaustible supplies of iron and fuel, and with institutions every way favourable to the utmost development of the industry and ingenuity of her citizens, she must always be able at least to maintain her superiority of position where circumstances are in other respects equal; and be ready to turn to the utmost advantage every improvement which may reach her in common with less powerful rivals.

The first Act passed by the English Parliament for preventing the exportation of machinery is dated in 1696. This Act prohibited the exportation of Lee's stocking-frame, a machine which was invented in 1600 . The next restriction was passed in 1750 , after an interval of more than half a century. This Act was intended for the protection of the woollen and silk manufactures. The first of these branches of industry had previously flourished in England for more than 250 years without this protection. As to the silk manufacture, the tools and utensils employed in this industry were prohibited from being exported by this Act. The silk industry was then only in its infancy, and it never took firm root as one of the branches of the national industry, until the mounds and fences raised up by the Legislature for its protection had been removed, and it was left to work its way exposed to competition from the then more accomplished artisans of France. Another interval of twenty-four years passed before any further Act of the same nature was passed. The next law, passed in 1774, 
prohibited the exportation of certain tools used in the cotton and linen manufacture. From that time the system of prohibition appears to have been in great favour with the Legislature; the Acts which were passed forbidding the exportation of implements having followed each other with rapidity, and descending some of them to objects of a very tritling nature, such as "presses and dies for horn buttons," "engines for covering whips," "tools for pinching of glass" -in fact, anything for which it appears to have been thought worth while on the part of any class of manufacturers to seek what they considered protection at the hands of the Legislature through a monopoly of the implements required for the production of their goods.

Porter continues: "The subject having again been brought under the consideration of a Committee of the House of Commons, principally at the urgent instance of the members of our chief manufacturing towns, and a report having been made recommending the removal of all remaining restrictions, a clause to that effect was inserted in the Customs Duty Bill, 6 and 7 Victoria, c. 84, and machinery of all kinds may now be as freely exported as any other British manufacture. It is too early yet to judge correctly of the consequences of this measure, which took effect from August, 1843. It has, indeed, been followed by one result which could hardly have been anticipated. The French Government, which had offered as an excuse for augmenting the import duty upon linen yarn, our refusal to allow the exportation of flax-spinning machinery, and the consequent disadvantage at which French spinners were placed, have, now that the repeal is withdrawn, lent a favourable ear to the representations of their machine-makers, and have placed a heavy import duty upon the very article the withholding of which from them was represented as a grievance."

Considering the perfection to which the manufacture of textile machinery was brought in this country, the value of machinery exported under the system of restriction was quite insignificant, so far, at least, as undisguised trade is concerned. The following table shows the declared value of the shipments of machinery and millwork every ten years from 1822 to 1849 :-

\begin{tabular}{|c|c|c|c|c|}
\hline Year. & & $£$ & Year. & $\mathfrak{E}$ \\
\hline 1822 & . & 116,220 & 1840 & 593,064 \\
\hline 1830 & . & 207,767 & 1849 & 700,631 \\
\hline
\end{tabular}

The increase in the amount during the last years of the series was caused mainly by greater shipments to Europe. Before that 
time, at least one-half of the value of the shipments was made up by the demands of our own colonies and dependencies. How far this condition of things altered will be seen by the following figures, which show the value of machinery shipped to foreign countries in Europe :-

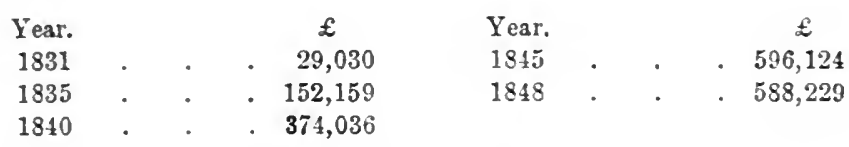

It would fill many large volumes, adds Porter, to describe the numerous inventions which during the present century have imparted facility to our manufacturing processes, and given perfection to the articles made. It will not be expected, therefore, that any enumeration of those inventions should be attempted in these pages. A description of all the improvements which have been made in steam-machinery alone, in the first half of the nineteenth century, would lead to investigations that could be profitably entered upon only in a treatise on mechanics.

\section{0-1910}

If it was difficult for Porter to give more than a very brief and general account of the progress of the machinery and engineering trades, it is far more difficult to continue the subject from 1850 to the present time. The various branches of the trades are so numerous and their ramifications so intricate, that to describe them with anything like detail would require many volumes. It is also well-nigh impossible to designate the various trades that come under the heading machinery and engineering. The amount of overlapping with other trades is enormous. For instance: are steel framework buildings and girder bridges to be classified as engineering trades, or as building trades? How far can toolmaking be separated from the cutlery trades, and so forth? There are, however, a few very important industries that are always classified as engineering trades. Such are the shipbuilding trades, the electrical industry, locomotive and railway wagon building, and the ercle and motor industrics. Upon these we may touch separately ; but, before going into any details, it may be interesting to examine a few general statistics relating to the engineering trades as a whole. The following statement has been compiled from the Preliminary Tables issued by the Census of Production and represents the size of these trades in 1907:- 


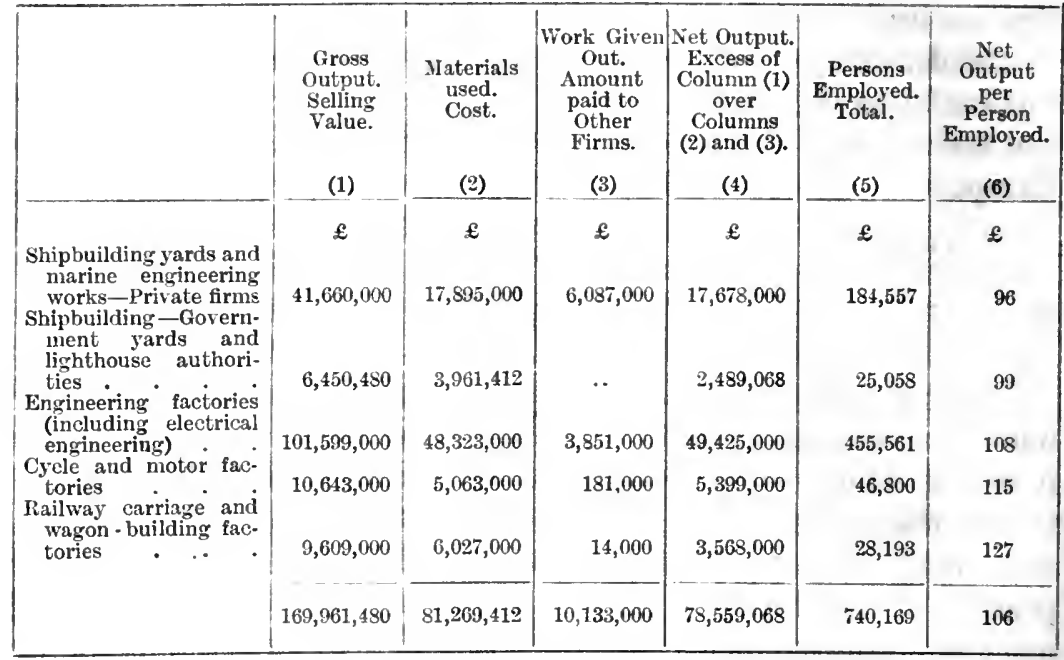

If we turn to our foreign trade statistics, we find that our exports of machinery and mill-work at intervals of ten years since 1845 have been :-

\begin{tabular}{|c|c|c|c|c|c|}
\hline Year. & & $\mathfrak{f}$ & Year. & & $£$ \\
\hline 1845 & - & 904,962 & 1885 & . & $11,086,869$ \\
\hline 1855 & . & $2,243,166$ & 1895 & . & $15,150,522$ \\
\hline 1865 & . & $5,222,633$ & 1905 & . & $23,260,326$ \\
\hline 1875 & . & . $\quad 9,058,647$ & 1910 & . & $29,271,380$ \\
\hline
\end{tabular}

\section{Simipbuilding. Early History}

The shipbuilding industry has been established in this country practically since the time of Alfred the Great. The Plantagenets did something to encourage shipbuilding, but the Tudor monarchs - Henry viI and still more Henry viI and Elizabeth-helped its development a great deal. The industry languished under the early Stuarts, but Cromwell made a notable attempt to develop it, and the famous Navigation Acts were the result of his efforts. It was not until well into the nineteenth century, when iron began to displace wood, that the supremacy of British shipbuilding over its foreign and American rivals became firmly established. Porter gives the following interesting account of the first developments of the use of iron as a material for shipbuilding :--

"Iron was first used about the year 1810 for the construction of vessels employed in canal and river navigation. In 1820 a steam-vessel called the Aaron Manby was constructed at the Horsley Ironworks, and made the voyage between 
the capitals of England and France without unlading any part of her cargo. This vessel was still in good condition in 18.45 although twenty-six years old, never having required any repairs to her hull. In 1825 a small iron stermboat was placed on the river Shannon, where sise is now employed, in good condition. In 1832, The Ellurkhah, an irou stean-vessel, built by Messrs. Macgregor Lairl \& Co., in Lirerpool, made the voyage from that port to the coast of Africa, and twice ascended the river Niger. This successful experiment led to the construction of many other iron steam-vessels. One builder, Jr. John Laird, of Birkenhead, near liverpool, has built 45 iron vessels of the aggregate burden of 12,600 tons. The total number lannched since 1830 is silu to exceed 150 . The largest iron vessel, with one exception, yet finished and in use is the Gundaloupe, a steam-frigate of 788 tons, carrying 68-pounders, and belonging to the Mexican government; but her dimensions are insignificant when compared with those of the Great Britain, since built at Bristol.

The length of this ressel, from her fignre-head to taffrail, was 320 feet
The breadth of beam
The depth of her hold -
Her draft of water, when loaded, was calculated to be

and her burden 3500 tons. The engines have a force equal to that of 1000 horses, and are used to keep in action, as the means of propulsion, an Archimedean screw. The draft of water will be seen not to exceed that of a first-class West Indiaman. At present this vessel can only be considered as an experiment; and should it fail, an abundance of ridicule will no doubt be cast upon the projectors by men whose genius would hardly have sufficed for the invention of a wherry.

"A great part of the steam navy of the East India Company consists of iron ressels, 25 of which are now in use in India, anong which are the Nemesis, the Phlegethon, the Ariadne, and the Medusa,-names well known to the British public from the conspicuous part which the vessels performed in the war with China.

"The advantages of iron orer timber, for naral architecture, are,- the absence of 'wear and tear' in the hull-no necessity for caulking and coppering-no possibility of injury from dry rot-greater lightness and increased capacityand, what is of even far more importance, greater safety. This last point has sometimes been questioned, but not by anyone haring knowledge on the subject. When a timber-built ship takes the ground with any violent shock, the whole frame-work of the ressel is strained, and in measure dislocated,-so that by the mere buffeting of the waves she will, in all probability, soon be made a complete wreck; but when an iron-built ressel strikes, however riolent the blow, it is only the part that is brought into collision with the rocks that will be injured. The plan of building these ships in water-tight compartments then proves its efficacy; for should the injury anount even to the tearing away of plates, the resulting mischief will only be to fill with water that particular compartment of the ressel to which the injury has occurred, so that the ship will be scarcely less bouyant than before; and experience has shown that damaze of this kind is easily repaired.

"The first cost of iron vessels is somerhat, but not much, less than that of timber-built vessels: their comparative cheapness results from their greater durability : after years of constant employment they are found to be as sound and as clean as when tirst built. Their weight, upon which depends the displacement of water, is - as a general rule-three-fifths the weight of wooden ressels of the same capacity. The weight of metal used in propertion to the burden of 
the ship varies, of course, with the size. A sea-going iron steam-vessel will take from nine to twelve ewt. of iron per ton register. Boats intended for river traffic, which do not require an equal degree of strength, of course take a less weight of metal.

"The building of iron ships is fast becoming an important branch of national industry; it is one in which our mineral riches and our great mechanical skill will secure to us a virtual monopoly." 1

$$
\text { 1850-1909 }
$$

The rapid growth of our shipbuilding trades since 1850 was one of the most striking features of our industrial development during the last part of the nineteenth century. The following figures will indicate this growth:-

\begin{tabular}{|c|c|c|c|c|c|c|c|c|}
\hline \multirow{2}{*}{\multicolumn{3}{|c|}{ Year. }} & \multicolumn{6}{|c|}{ Slips Built. } \\
\hline & & & \multicolumn{2}{|c|}{ Sailing. } & \multicolumn{2}{|c|}{ Steam. } & \multicolumn{2}{|c|}{ Total. } \\
\hline & & & No. & Tons. & No. & Tons. & No. & Tons. \\
\hline *1840 & . & . & 1,296 & 201,111 & 74 & 10,178 & 1,370 & 211,289 \\
\hline *1850 & . & . & 621 & 119,111 & 68 & 14,584 & 689 & 133,695 \\
\hline 1860 & . & . & & & & & & \\
\hline 1870 & . & . & 541 & 117,032 & 433 & 225,674 & 974 & 342,706 \\
\hline 1880 & . & . & 348 & 57,580 & 474 & 346,361 & 822 & 403,841 \\
\hline$\dagger 1890$ & . & . & 277 & 123,224 & 581 & 528,789 & 858 & 652,013 \\
\hline 1900 & . & . & 568 & 46,010 & 845 & 886,627 & 1,413 & 932,637 \\
\hline 1910 & . & . & 348 & 28,250 & 730 & 670,219 & 1,078 & 698,469 \\
\hline
\end{tabular}

* Figures for 1840-1850 relate to num ers of vessels built and first registered in the United Kingdom, but after that date to vessels built whether registered or not.

$\uparrow$ Exclusive of vessels built for foreign countries, and for the British Navy.

The above table shows very well the development of our shipbuilding industries since 1840. But we must not forget the wide variations, alternating from boom to crisis, to which the trade is subjected. Probably no industry feels a world-wide prosperity or adversity so keenly as the shipbuilding industry.

The main causes that have led to this remarkable growth may be summed up briefly under four heads: First, the introduction of iron, and later of steel, as a material for shipbuilding; secondly, the adaptation of the steam-engine to nautical purposes; thirdly, the fact that under our present Free Trade system British shipbuilders are always sure of obtaining cheap supplies of raw material; and fourthly, the marvellous growth of oversea trade during the last fifty years. With regard to the first of these causes, a previous extract from Porter recounted the first introduction of iron as a

${ }^{1}$ Porter's Progress of the Nation, 1845. 
shipbuilding material. It was in 1837 that the first iron vessel was registered in Lloyd's Register of British and Foreign Shipping, when the steamer Sirius of 180 tons was classified as having the 'A' character without a term of years and was noted as being built of iron. By 1844 the number of iron-built vessels was so large that it became necessary to lay down some definite rules for their classification.

Steel has been used as a shipbuilding material since 1875, and now at least 90 per cent. of the metal vessels built are constructed of steel. Its introduction was made necessary by the demand for larger and larger vessels. By 1875 the limit of the uses of iron had been reached, and shipbuilders found in steel a lighter and stronger material, which answered their purpose admirably. The earliest ocean-going steel steamer was the Rotomahana, built in 1879 by Messrs. William Denny Bros. of Dumbarton for the Union Steamship Company of New Zealand.

The displacement of sails by steam as a means of propulsion was quite as an important factor in the development of our shipbuilding trades as any change in structure or material. Sir David Pollack in his book on "The Shipbuilding Industry" states: "The earliest attempt to propel a vessel by steam is claimed by Spanish authorities to have been made by Blasco de Garay in the harbour of Barcelona in 1583. In 1690, Dionysius Papin proposed to use his piston engine to drive paddle wheels to propel vessels, and in 1707 he applied the steam-engine, which he had proposed as a pumping engine, to drive a model boat on the Fulda at Cassel, and was about to dispatch the same-" a vessel of singular construction," as record of the time put it-when the local boat or water men thinking they saw in the embryo steamship the ruin of their business attacked the vessel at night and utterly destroyed it."

Innumerable experiments have been made at various times with different types of steamships, and among the inventors, John Fitch, Robert Fulton, John Stevens of Hoboken, who was supposed the first to use serew propellors, and William Symington are perhaps the most famous. "The first really practically successful steamer on any serviceable scale," continues Sir David Pollack, "was the Charlotte Dundas, built at the eastern terminus of the Forth and Clyde Canal in 1801-1802." The best known of the early steamvessels was Bell's Comet, which was the first steam-ressel employed in Europe in regular passenger service. The new industry became firmly established in the 'twenties of the last century, and in 1836 the Great Western Steamship Company was formed under the direction of Isambard $\mathbf{K}$. Brunel, the famous engineer of the Great 
Western Railway. Their first vessel, the Great Western, has the honour of being one of the first steam-vessels to cross the Atlantic. She was dispatched on her voyage from Bristol on April 8, 1838. A rival vessel, the Sirius, had set out from Cork harbour three days previously, and the two ships arrived within five hours of each other-the Sivius in the forenoon with all her coal consumed, and the Great Western in the afternoon with nearly 200 of her origina' 800 tons of coal to spare. The lengths of the voyages were eighteen and fifteen days respectively.

The improvement in the marine steam-engine has been as remarkable as the improvement in the type of vessel built. The introduction of the compound in place of the single-acting engine marked one of the most important advances in marine engineering, and in 1854-56 John Elder fitted four cylinder-engines into the Brandon. The new principle enabled steam to be used at a much higher pressure than was practicable previously. "By these changes," states Sir David Pollack, "a reduction in the consumption of fuel was effected of nearly 60 per cent.; in other words, the consumption fell from 5 to $7 \mathrm{lb}$. per horse-power per hour to $3 \frac{1}{2}$ lb." Improvements were rapidly effected in the compound engine, and double, triple and quadruple types were evolved, all of which tended to reduce fuel consumption.

During the last twenty years the invention of the "Parsons" turbine has altered marine engineering considerably. The turbine which has a direct rotary action, economizes power, or gets more working power out of a given head of steam than a reciprocating engine. It is also better adapted for high speeds. It has been adopted both by the Admiralty and the more important shipping lines and has yielded wonderful results.

There has also been a wonderful advance in the structure of ships, apart from the materials of which they have been built. The introduction of the double-bottom is the most important of these. "Broadly and briefly described," writes Sir David Pollack, "the cellular system consists in the fitting in a thoroughly watertight manner, and sufficieutly high to be accessible for inspection and painting, of a double bottom or inner skin at the turn of the bilge, the space between being filled with a series of plates fixed both transversely and longitudinarily." The double bottom gives extreme rigidness to a ship and has an additional advantage in the fact that if a hole is made in the outer skin the ship does not necessarily fill and sink. The principle was derived from the girderwork used in iron bridges. Many other structural improvements 
were made during the nineteenth century, among which water-tight bulk-heads, water-ballast, alterations in ships' frames and stringers, as well as important modifications in the run or lines of ressels, may be mentioned. The shape and design of ships, more especially of cargo vessels, has been moulded largely by commereial considerations. Large eargo capacity with the light araft and a low net tonnage so as to pay lower harbour dues, have, roughly speaking, been the objects of shipbuilders, and many ingenious oxperiments have been tried, and many curious types of ships built in consequence.

The amount of information available about the details of shipbuilding is enormous, but with the limited space at our disposal we are unable to do anything but touch upon a few of the main points. Much might be written about the development of the internal combustion engine as a means of marine propulsion and much about the use of oil fuel. A brief reference should be made, however, to the chief shipbuilding districts of the United Kingdom. A good supply of ram materials and a good sheltered harbour are the first requisites for successful shipbuilding, and we find the main British shipbuilding distriets centred in such rivers as the Clyde, Tyne, Wear and Tees, where both conditions are met. Belfast, where Messrs. Harland \& Wolff's famous yards are situated, has also become a great shipbuilding centre. The shipbuilding ports and the tonnage turned out in the year 1910 are as follows. The figures are taken from the Annual Summary of Shipbuilding at Home and Abroad for the year 1910, issned by Lloyd's Register of British and Foreign Shipping:-

Table showing Vessels Launched in the Principal Shipbuilding Districts of the United Fingdom dwing 1910

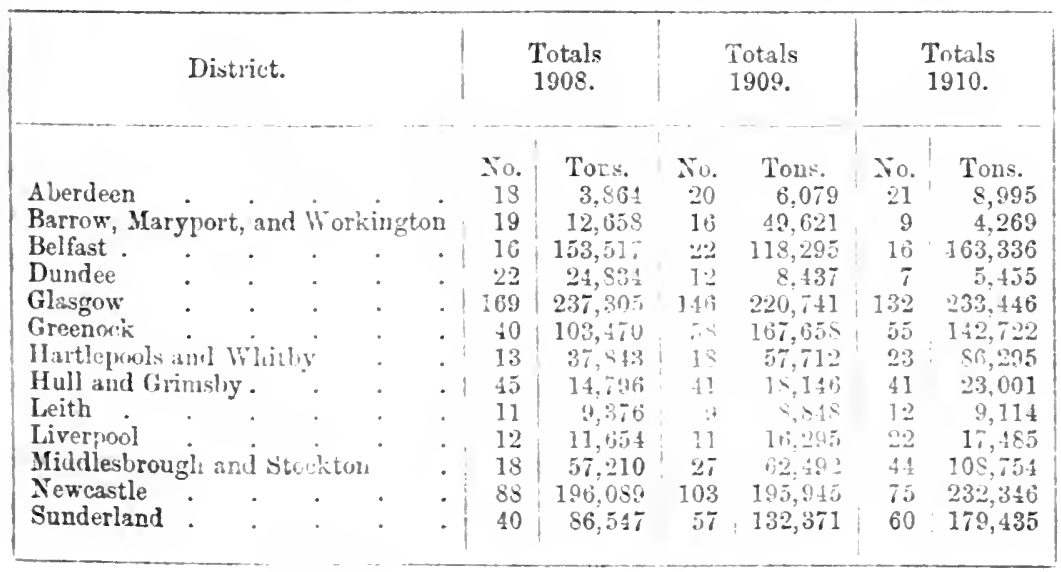




\section{The Electrical Industry}

The rapid growth of electricity as a huge branch of trade with infinite ramifications is perhaps the greatest economic miracle of the last half-century. It has supplied us with power, light, and the means of instantaneous communication. Of course the mysterious forces and possibilities of electricity had been guessed at long before. The ancients knew of electricity mainly as a result of friction, such as that obtained by the rubhing of a piece of amber. The discoveries of Galvani and later of Volta at the close of the eighteenth century opened up a new era in the history of science, and were the first experiments that led to such wonderful practical results. Volta's invention, the electric "pile" or "crown of cups," was the embryo of the modern electric battery. Another stage in the development of the science came early in the nineteenth century when Oersted, a Dane, established the connexion between electricity and magnetism. While Oersted was making his discoveries Sir Humphry Davy was carrying out experiments which laid the foundations of three branches of the modern electrical industry and established electro-chemistry and electro-metallurgy. He also made the first practical arc light. Michael Faraday, again, accomplished for electrical science much what George Stevenson did for steam locomotion. Faraday invented the dynamo and so at once converted electricity from a theoretical science into an art and an industry. He removed it, from the laboratory and placed it at the disposal of commerce. Hitherto the battery had been the only means of generating electricity, and the quantity so obtainable was naturally limited. Once mechanical means of generating electricity were discovered it was not long before the industry as we know it began to shape itself. Others, of course, contributed to the perfecting of the dynamo, and among these the names of Wheatstone and Siemens perhaps rank highest.

The uses to which electricity can be applied are apparently endless. It is possible to light, cook, heat, to run trains, to drive clocks, to transmit messages over fabulous distances, all by the means of this one force. All the uses to which electricity has been applied may for practical purposes be classified under the four heads, namely: Lighting, Traction, Communication, and Power.

The arc lamp, which was the earliest method of electric lighting, was, as we have stated, discovered by Sir Humphry Davy early in the nineteenth century. This lamp was, however, only 
a scientific toy, and the conditions of this branch of the industry can be judged by a remark made in 1879 by Sir William Preece before a Parliamentary Committee. "The electric light (i.e. the arc light)," he said, "is only economical when one machine is used to produce light." This, in a sentence, indicates the limitations of the arc light. It is a very brilliant light, which consumes a considerable amount of current. Consequently it is chiefly used to light large spaces, such as big halls, squares, and streets.

The British public-which is usually very conservative and sceptical about new inventions-was quickly captivated by the electric light, as soon as its commercial value was proved. Its advent created quite a panic among gas companies, and there was a violent fall in gas shares in consequence during the early 'eighties of the last century. The gas companies had hardly recovered from the shock of apprehension caused by the competition of the are lamp, when they were again menaced by the appearance of the Edi-Swan Incandescent Lamp. This lamp was the result of the simultaneous discoveries of Thomas Edison in America and Mr. J. W. Swan in England. In October 1883 the Edison and Swan United Electric Light Company was formed, and electric lighting was soon placed within reach of the average householder.

The electric lighting boom of the 'eighties has been long forgotten; but the industry is still suffering from the mistakes made at that time, and a rough idea of what happened may be obtained by extracting a few sentences from Mr. Cowans Whyte's book on "The Electrical Industry": "This speculation is still referred to as the 'Brush' boom owing to the part played in it by the companies formed to exploit the dynamo and arc lamp invented by Charles F. Brush, an American. . . . In 1882 the Brush boom began. The Anglo-American ${ }^{1}$ company became a prolific parent of subsidiary companies in London and various provincial districts. To these subsidiary companies was accorded the right, in exchange for large amounts in cash and shares, to deal in Brush dynamos and arc lights. That is to say, it created agents all over Great Britain, and made the agents pay handsomely for the privilege before they earned a single penny." The subsidiary cornpanies were nicknamed Brush babies, and they soon collapsed owing to the unsatisfactory nature of their composition. To continue our quotation:- “- Nemesis came swiftly. The Brush babies found themselves with expensive privileges which were of no money value until a demand for electric light had been created. Moreover, the

${ }^{1}$ The Anglo-American brush Electric Light Corporation, founded $15 S 0$. 
Brush companies were not alone in the field; there were others equally anxious to sell good dynamos and good lamps."

The pioneers of electric lighting were further hampered by parliamentary legislation. In 1882 an Electric Lighting Act was passed. The distribution of electricity from a central power station to a number of consumers involved the opening of streets to lay cables, and the opening of streets required parliamentary powers. There were various Acts passed during the 'eighties and 'nineties, all of which were complicated in the extreme. In some cases the electric lighting powers were granted to companies, while in others they were vested in municipalities. In every case, however, the local authority had the power of veto over any one company or neighbouring authority seeking powers to supply electricity in its area.

The innovation of electric traction came much later than that of electric lighting. In fact this branch of the industry is still in its infancy. The first system of electric traction was installed at Portrush (Giant's Causeway) in 1883, and various small schemes were inaugurated during the following twenty years. The system, however, essentially belongs to the twentieth century. The last ten years have seen the installation of electric tramways in most of our great cities, as well as the electrification of the London Underground Railway and the construction of the "Tubes." "The use of electric power to haul cars," writes Mr. Cowans Whyte, "was first demonstrated by Messrs. Siemens in 1879 ; but although an electric tramway on the overhead system was one of the features of the Paris Exhibition of 1881, public opinion was destined to take many years to get quite accustomed to 'live' electric conductors suspended overhead." Electric traction, like electric lighting, is partly in the hands of private companies and partly under municipal control. It was made possible by the discovery of the electric motor. An electric motor is, briefly explained, a dynamo reversed. That is to say, instead of generating current by a revolving armature between field magnates, as is the case with the dynamo, electric current is applied to the dynamo, which has the reverse effect and causes the armature to revolve. This discovery was made very shortly after the invention of the dynamo. The details necessary to applying it to practical purposes were rapidly worked out after the perfection of the dynamo. "The secret of the success of electric traction," according to Mr. Whyte, "lies in the economical way in which the power required for transport purposes is used. . . While a horse tramway has to spend $£ 80$ or more to 


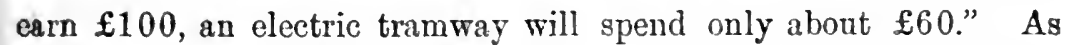
an offset to this, however, the original capital installation is much higher.

The remaining uses of electricity to supply "power" and to transmit messages are perhaps the most important of all. It is the nearness and quantity of the supply of industrial power that has been the most potent factor in the formation of modern industry. In the Middle Ages, when the supply was largely manual, or animal, industry was widely scattered over the whole of society. The individual worker was more or less an industrial unit to himself. Factories were unknown, production was in the hauds of craftsmen who at the outside employed but few apprentices. It is true that there were guilds in the Middle Ages, but these were associations to protect the individual worker rather than to co-operate in obtaining more economical working. The advent of steam power, however, revolutionized industrial production. The story of the Industrial Revolution is too well known to economic students to require repeating. Steam power had its limitations. A factory could be supplied with power from one steam-engine, but there, as a rule, the limit was reached. The result of this was the growth of manufacturing towns situated where coal and raw materials could be obtained most easily and cheapest. Electric power, however, can be supplied to numerous factories from one central "power station."

"The great excellence of electric power lies in the fact that it may be transmitted without serious loss over long distances," says Mr. Whyte: "if you use electric powel you are not compelled to place your factory at the point where coal is cheapest and may be most suitably used; you are at liberty to go further afield, planting your factory on an open site, and feeding it with power conveyed from a distant source."

The electrical industry is a curious one and has problems to solve peculiar to itself. At the outset it requires a large capital outlay, the generating machinery and the laying of mains through streets is very expensive. To be able to earn a profit on all the capital employed it is necessary to keen all the machinery constantly cunning. This is just what the average electric suplly company s unable to do. For instance, the denuand for electric light in the sity of London comes in the winter between the hrours of font Ind six. In any case, the demand for lighting purposes comes inly for a few hours out of the twenty-four. This means that a arge quantity of machinery has to be kept idle in readiness for the 
sudden call upon it. To meet this difficulty the companies try to arrange that their various customers should make their demands on the electrical supply at different times. To encourage this differential rates are charged. That is why electric light is so much more expensive than power. Every one wants the light at the same time, while the demand for power is much more constant. For instance, a company may have its machinery running at full pressure to meet the city light "lode," after which it will grant special rates to theatres if they will consume light, as they usually do, for the next three hours, after that power is supplied at cheap rates to newspaper offices for printing between stated times in the small hours of the morning, and then perhaps more cheap power will be given, say, to Smithfield Meat Market, in the later hours of the morning. In this way the machinery is kept running for a longer time.

A municipality stands in a more favoured position. As a rule, they dovetail their light and tramway "lodes," which come at different times of the day, and thus are able to keep the machinery more or less constantly running.

Statistics showing our foreign trade in electrical goods have only been compiled since the 'nineties, and at various periods were as follows:-

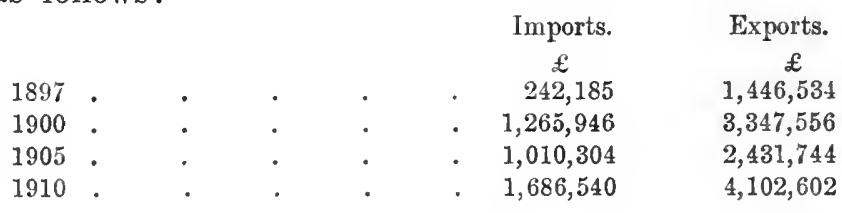

The development of telegraph and telephones will be dealt with in a later chapter on the Post Office. Of recent inventions in this branch the most wonderful perhaps is that of Marconi, whose wireless telegraphy is now installed on all the great ocean liners.

The manufacture of locomotives and railway material has been established in this country ever since the invention of railways, and English engines have won a special reputation for strength and durability. The export trade in locomotives and railway material is largely due to the fact that so inany railways abroad, in the colonies and in India, have been financed in England and are controlled mainly by English directorates. It is difficult to obtain separate figures showing these exports as they are classified under various headings in the Board of Trade returns; some under machinery, the figures for which we have previously given, some under iron and steel, and some under carriages. The changes in classification 
that have occurred from time to time in the statistical abstracts make a comparable series of figures impossible.

Another type of engine that came into prominence during the last half of the nineteenth century is the internal combustion or explosive engine. In the earlier forms of explosive engines the motive power was supplied by the explosion of ordinary coal gas and air mixed. Although the explosive engine was first made practicable during the last part of the nineteenth century, various attempts were made by Huyghens, Papin and others to utilize explosive agents, like gunpowder, in working machines; and a French artisan, Lebon, patented in 1799 an engine in which energy was obtained by exploding charges of coal gas mixed with air on each side of the piston alternately, the explosion being effected by an electric spark.

Gas is not the only explosive used in modern combustion engines. Oil is also used. The Diesel oil-engine is well known. The invention of the oil-engine made the modern motor car possible. It is difficult to realize that motor cars have been in general use for only about ten years. It is impossible to trace in a limited space the various stages of the development of the motor car. But the following figures of our imports and exports of motors will give some idea of the growth. The figures were not separately distinguished in the Board of Trade returns until $1904:$

\begin{tabular}{|c|c|c|c|c|c|c|c|c|}
\hline \multirow{2}{*}{\multicolumn{2}{|c|}{ Year. }} & & \multicolumn{2}{|c|}{ Imports. } & \multicolumn{2}{|c|}{ Re-exports. } & \multicolumn{2}{|c|}{ British Exports. } \\
\hline & & & Cars. & Parts. & Cars. & Parts. & Cars. & Parts. \\
\hline $\begin{array}{l}1904 . \\
1905 \\
1906 \\
1907 \\
1908 \\
1909 \\
1910\end{array}$ & : & : & $\begin{array}{c}\mathcal{E} \\
2,080,371 \\
2,438,002 \\
2,486,337 \\
2,080,266 \\
1,389,552 \\
1,223,053 \\
1,439,962\end{array}$ & $\begin{array}{c}£ \\
343,569 \\
929,121 \\
1,885,323 \\
2,472,520 \\
2,722,909 \\
3,093,556 \\
3,694,866\end{array}$ & $\begin{array}{c}\mathfrak{£} \\
169,313 \\
266,985 \\
312,303 \\
246,608 \\
161,561 \\
177,064 \\
234,45 \mathrm{~S}\end{array}$ & $\begin{array}{c}\mathcal{E} \\
27,523 \\
53,587 \\
109,991 \\
136,057 \\
197,760 \\
216,764 \\
287,714\end{array}$ & $\begin{array}{c}f \\
240,758 \\
376,230 \\
495,399 \\
857,647 \\
800,636 \\
952,431 \\
1,376,880\end{array}$ & $\begin{array}{c}\mathcal{E} \\
80,244 \\
125,572 \\
323,395 \\
467,311 \\
457,923 \\
611,174 \\
1,228,641\end{array}$ \\
\hline
\end{tabular}

The motor industry was tirst established in France, and French cars a few years ago were the best in the market. British manufacturers soon began to catch up, however, and now many makes of English cars are the best that can be obtained. The above figures indicate this; for while our imports have tended to decline, our exports have been growing. It should be mentioned 
that owing to changes in the Board of Trade classification, the figures for cars and for parts may not be strictly comparable, but they are near enough to indicate the general movement.

Another and older industry that is allied to the motor trade is the cycle industry. Our foreign trade in cycles since 1895 has been as follows:-

\section{Cycles and Parts (not Motor Cycles)}

\section{(In Thousands of £s)}

\begin{tabular}{cccc|cccc} 
& Imports. * & $\begin{array}{c}\text { Re. } \\
\text { exports.† }\end{array}$ & $\begin{array}{c}\text { British } \\
\text { Exports. }\end{array}$ & & $\begin{array}{c}\text { Re- } \\
\text { Imports.* }\end{array}$ & $\begin{array}{c}\text { British } \\
\text { exports.† } \\
\text { Exports. }\end{array}$ \\
1895 & $\ldots$ & $\ldots$ & 1,386 & 1904 & 83 & 10 & 740 \\
1897 & 527 & $\ldots$ & 1,430 & 1905 & 130 & 11 & 936 \\
1899 & 287 & $\ldots$ & 662 & 1906 & 158 & 16 & 1,140 \\
1900 & 195 & $\ldots$ & 531 & 1907 & 171 & 10 & 1,288 \\
1901 & 176 & $\ldots$ & 577 & 1908 & 156 & 13 & 1,420 \\
1902 & $145_{+}^{+}$ & $35_{+}^{+}$ & 718 & 1909 & 177 & 13 & 1,638 \\
1903 & 99 & 23 & 849 & 1910 & 210 & 21 & 1,957
\end{tabular}

* Not stated separately prior to 1897 .

+ Not stated separately prior to 1902.

\# Prior to 1902 the returns inelude motor cycles and parts.

In 1910 our imports included $£ 206,502$ worth, and our exports $£ 1,414,776$ worth of parts. For complete machines, Japan, India, and France are our best customer's. Our exports of cycles to foreign countries increased from $£ 95,000$ in 1905 to $£ 273,792$ in 1910; while in that period our exports to British Possessions remained stationary. The large influx of cycles in 1897 was due to the "invasion" of worthless American machines, which was of short duration. In 1907 we produced 590,300 cycles, valued at $£ 3,303,000$ (and 3600 motor cycles, valued at $£ 135,000$ ), besides $£ 1,719,000$ worth of parts, which shows that, great as our export trade is, our home trade is many times greater. The exported "parts" are, to a considerable extent, merely cycles taken to pieces for convenience in packing and to avoid tariff rates on complete machines, which are higher than on "parts."

The invention of the explosive engine has revolutionized many branches of industry. It has done more. Owing to its light weight, as compared with the power produced, it has rendered flight possible. The science of aviation is still in an experimental stage, and is only just approaching a commorcial status. Such strides have been made since the first clumsy attempts at flight with heavier than air machines were made less than four years ago that the art of aviation may before long be expected to have practical consequences alike in peace and in war. 


\section{THE MINOR MEIAL, TRADES-HARDWARE, GLASS, AND PO'I"TERY}

Populations of Sheffield and Birmingham, 1801-1851-Historical accounts of Birmingham industries-Metal trades no longer confined to Birmingham-Census of Production figures for 1907-Prices of hardware, 1812-1832-Imports and exports of hardware and cutlery, I805-1910-History of the cutlery trade-History of the tinplate trade-Exports of tin plates, 1860-1910-Exports of galranized plates, 18001910-Exports of wire, 1\$80-1910-Brass and copper manufactures exports, 1805-1910 -Plated goods and jerrellery trades-Exports of plated goods and jerrellery, 1830 1910-The glass trades in the first half of the nineteenth century-Exports and imports of glass since 1860-The modern glass industry-History of the pottery trades-Census of Production figures-Onr foreign trade in pottery

THERE are many branches of metal manufactures in this country which are of considerable importance from the number of hands to whom they give employment, but of whose progress and size, it was, until the middle of the nineteenth century, difficult to form an accurate judgment. Of these manufactures the chief are the hardware and cutlery trades, a host of minor metal industries, the plated goods, precious metals and jewellery trades, and the esrthenware and glass trades. The raw materials of these articles rere, during the first half of the nineteenth century, for the most part produced at home; and as most of the articles were not subjected to duty, there were no means of ascertaining the increase, or otherwise, of their quantity. But the expansion since Porter's time has been proved by the increasing import of their raw materials.

It was possible, before the metal trades had grown to their modern size, to obtain some idea of their development by tracing the increase of the population of Birmingham and Sheffield, in which in those days practically all the minor metal trades were concentrated. The census figures to 1851 were as follows:-

Sheffield.

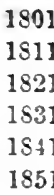

1801

1811

1821

1531

1841

1851
Birmingham. 
Birmingham has long been the seat of numerous metal industries. The following extract from Lewis' Topographical Dictionary of England (1842) gives a brief historical account of the trades of Birmingham from their origin in mediæval times:-

"It is not easy to trace with accuracy the origin of the numerous branches of trade and manufacture, which, in addition to those described by Leland, have been subsequently introduced into the town (Birmingham), and from their taste and variety, as well for the high degree of perfection to which they have attained, obtained for this place, from the celebrated Mr. Burke, the appropriate designation of the "Toy-shop of Europe." The toy trade was, it is believed, introduced in the reign of Charles II, the brass foundry in that of William III, and the buckle trade about the same period, the last of which, after exercising the ingenuity of the manufacturer in every variety of form, pattern and material, declined about the year 1812, and is now nearly extinct. The leather trade, which was carried on from a very remote period, has also experienced a very great diminution. It is uncertain at what time the button trade was first introduced, but it has continued to flourish from a very distant period, and though very much reduced is still a source of opulence to many, and employment to thousands. The manufacture of firearms commenced towards the close of the seventeenth century, and during the last war (Napoleonic wars) the Government contracts for muskets alone averaged 30,000 per month. Among the almost innumerable branches of trade and manufacture that were being carried on at 1850, are light and heavy steel goods (here called toys), brass and iron foundry, saddlery, military accoutrements, firearms, swords and cutlery of various kinds; jewellery ; gold, silver, plated and japanned goods ; buttons, medals ; gilt, silver, ivory, bone, and other toys ; glass, wood turnery, metal-rolling, tools and implements of all kinds, mills machinery of all sorts, and steam-engines on every known principle, and so forth."

Writing shortly after Lewis, Porter points out that of the articles most commonly manufactured at Birmingham few were produced in extensive factories in which large capitals must be employed for the erection of machinery. "Almost all the smallwares of the district are made by workmen who undertake, each one in his particular line, to execute orders received by the merchants and agents settled in the town. The profitable performance of their contracts, however, calls for the employment of a cheaper kind of power than is at the command of men who, like these workmen, have little or no capital." The usual plan was as follows:- "A building, containing a great number of rooms of various sizes, is furnished with a steam-engine, working shafts from which are placed in each apartment or workshop, which is likewise furnished with a lathe, benches, and such other conveniences as are suited to the various branches of manufacture for which the rooms are likely to be needed. When a workman has received an order for the supply of such a quantity of goods 
as will occupy him a week, or a month, or any other given time for their completion, he hires one or more of these rooms, of sizes and with conveniences suited to his particular wants, stipulating for the use of a certain amount of steam power. He thus realizes all the advantage that would accompany the possession of a steam-engine; and as the buildings thus fitted up are numerous, competition on the part of their owners has brought down the charge for the accommodation they offer to the lowest rate that will ensure to them the ordinary rate of profit on the capital employed."

"Before the introduction of this system," Porter adds, "the trade of Birmingham was for the most part carried on by men of large capital, who employed journeymen, and gave a considerable credit to the merchants who dealt with them. At present those merchants themselves employ the workmen, who can give no credit, but receive payment in ready money at the end of every week for such part of their goods as they can then deliver in a finished state."

This description is still partly applicable to the metal industries of Birmingham and the Midlands. The trades themselves are chiefly concerned with the manufacture of fittings and small articles, as the following quotation from the Board of Trade Inquiry on the Cost of Living of the Working Class ${ }^{1}$ will show :-

"Apart from the occupations in connexion with the manufacture of small arms, in which Birmingham from its earliest history has excelled, and apart from jewellery, another trade long associated with the city, there are numerous branches of iron and steel working, usually reierred to under the generic name of "the hardware industry," which give employment to a large proportion of the population, both male and female. The employment of female labour is a striking feature, as women form by far the major portion of the workers in the steel pen industry, in bolt, nut, and screw making, and in the leather goods trades, while they form a large percentage in bronze and brass working, white metal and electro-plate making, the goldsmith and jewellery trades, and other general industries of the town. In this matter of the employment of women it appears from the last census returns that nearly 40 per cent. of all women over ten years of age are "occuplied," and the percentage of married or widored women occupied is 19 , a relatively high figure. The employment of young children is not very considerable, $12 \cdot 6$ per cent. of boys and $8 \cdot 3$ per cent. of girls aged 10 and under 14 years being returned as "occupied."

Although there has been some tendency during recent rears to a concentration of small factories into larger establishments, on the assumption of securing certain economies and with a view to attracting financial support, the minor metal trades are still scattered among a number of more or less small firms. In some cases, such as chain-making, etc., the work is given out by the

$$
{ }^{1} \text { Cd. } 3864 \text { (1908). }
$$


piece. The report on the Census of Production (Part IV) states : 1805 outworkers are returned as borne on the books of the employing firms, namely, 1397 in the anchor, chain, nail, etc. trades, 278 in the lock and safe trades, and 130 in the scientific instrument, etc. trades.

Since 1850 the growth of these trades has been so rapid that they can no longer be said to be centred in Birmingham. They have spread practically all over the Midlands. Wolverhampton is now a great centre of the metal trades.

The latest Census of Production Report gives the following details with regard to these trades:-

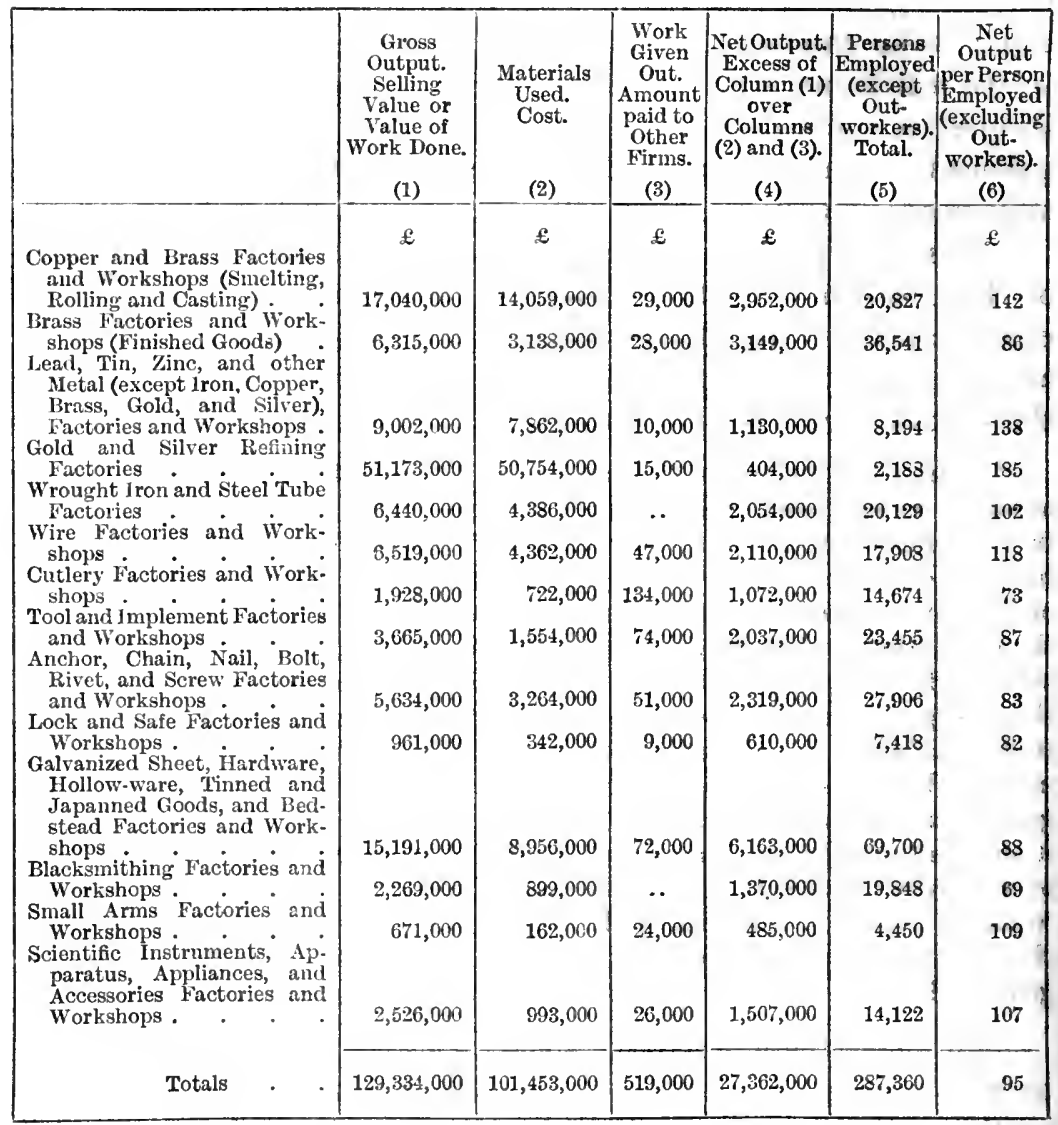

The following table, which gives some idea of the prices of iron goods early in the nineteenth century, is derived from a report by Mrr. Babbage, who "extracted it from the books of a highly respectable house at Birmingham":- 


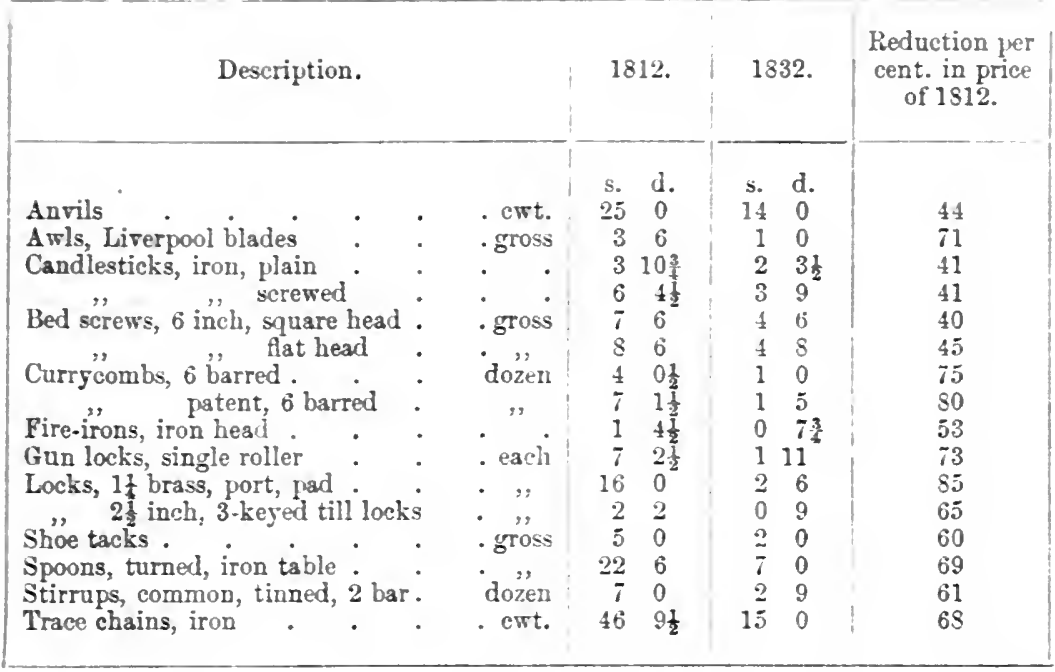

The interval that occurred between the dates here contrasted was twenty years, and it will be seen that during that time, in a pretty extensive list of articles, the price reduction in some cases came to 40 per cent., while on others it went to the almost incredible extent of 80 to 85 per cent. The cost of the material employed had, it is true, fallen very considerably in the interval; but this can have been but a minor influence in reducing prices, seeing that the first cost of the material forms only a minute portion of the value of the most finished article in the list.

It is unfortunately impossible to obtain figures showing the growth of our hardware trade separately. Until 1900 the returns of our foreign trade in hardware were included with those of cutlery. Our exports and imports of these goods were, so far as returns exist, as follow:-

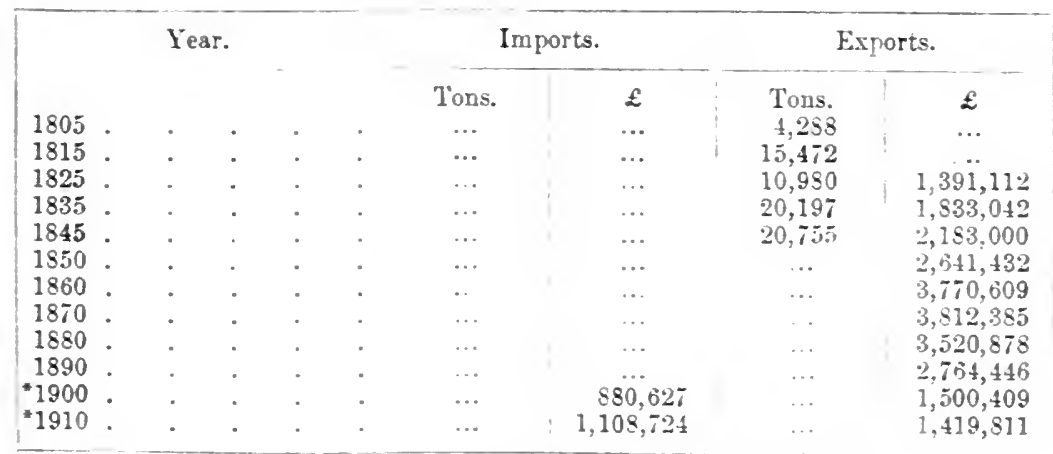

* The 1900 and 1910 figures are for Hardware only. 


\section{Cutlery}

We may now turn to another very important industry - the cutlery trade. This is one of our oldest industries, so old that the date of its establishment is unknown. It has been localized at Sheffield for centuries, where it was flourishing in the days of Queen Elizabeth. Mr. Frederick Callis ${ }^{1}$ in 1903 wrote: "The cutlers were then little better than serfs, working under the most repressive of restrictions and for the scantiest possible remuneration. The selection of Sheffield as the seat of this branch of trade was a very happy one, for it furnished advantages such as few, if any other, places possessed-advantages that meant much more in years gone by than they do even to-day. No fewer than five streams flow down the valleys into Sheffield from the hills and moors around, furnishing an abundance of water power. And coal, iron and stone are all within easy reach. Business began with the manufacture of the old "Sheffield thwytel or withel," as Chaucer called it, and passed on to the jack-knife, the spring knife, and other improvements alike in table and spring cutlery. The manufacture of scythes, sickles, shears, and other iustruments of husbandry was another important industry. Sheffield was also a great place for manufacturing arrow-heads, and after the invention of gunpowder it became equally celebrated for its firearms.

Although the cutlery tiade of Sheffield was of great importance during the Middle Ages and onwards to the nineteenth century, it was not until the last half of that century that it began to grow to its modern proportions. The causes that led to this growth are the same tlat led to the expansion of most of our industries during that period. First and foremost among these causes may be placed the rapid growth in wealth and numbers of the consuming population, next the discovery and application of steam power to industrial uses, and the improvement of machinery generally; the better education and improved health of the workers contributed to this progress.

In spite of this installation of machinery and improved methods of manufacture, it is interesting to note that the higher classes of cutlery are still made by the same methods of hand manufacture that obtained throughout the centuries. This is because this grade of cutlery is made of very hard steel, which breaks the cutting tools that are able to cut the softer steel employed in the

\footnotetext{
${ }^{1}$ British Indusiries under Frec Trude (Fisher Unwin).
} 
manufacture of inferior classes of knives. Sheffield has been liept up to date by German competition; but except in razors and certain specialities it has easily held its own and maintained its superiority in better class goods.

With regard to wages and the conditions of the workers generally in the cutlery trades, the following quotation from $\mathrm{Mr}$. Callis's paper is of interest. He states: "Mr. Howson compared it (i.e. the position of the worker) with what it was in 1847 , when his father commenced business, and stated that not only in money wages, but also in the conditions under which the workman does his work, and indeed in all directions, there has been distinct improvement. The introduction of the emery wheel has relieved the cutler of much exhausting labour." Mr. Ibbotson, a Sheffield cutler, who had been a workman himself, stated: "I used to work every day in the week, never taking a holiday or going on the drink, and my wages averaged a guinea a week! I used to make seven dozen Barlow knifes a day, and was paid sixpence a dozen. By the way from the material that is put into his hands, a cutler can now make eight dozen where I made six dozen."

During the last fifty years the "Little Mester," a very ancient institution, has been disappearing. A "Little Mester" was a manufacturer of cutlery in a small way. "He made cheap goods," says Mr. Callis, and " his people worked often amid most insanitary surroundings; he was dependent upon the sale of his output at the end of the week for the wherewithal to pay eren the poor wages he could aftord; and the income of both employer and employed was of a precarions character. The trade," he adds, "is now being concentrated more and more in the hands of men of capital, who own large, light, airy shops, who have the most efficient up-to-date machinery, and who have plenty of capital at command."

The various improvements in the manufacture of cutlery, introduced during the last century, principally during the last half, are briefly as follows:-The invention of what was known as the "Wharncliffe Knife" in 1820, which revolutionized pen and pocket cutlery. The manufacture of the hollow-ground razcr, a German invention which was too tardily adopted by English cutlers. The introduction of various machinery for the manufacture of cutlery, such as different sorts of hammers, cutting machinery, forging machinery, etc. These machines led to serious trouble with the workmen, and were the cause of the famous "rattening riots." 
Our foreign trade in cutlery is only shown as far back as 1900 , the first year for which figures were given separately, and is as follows :-

\begin{tabular}{|c|c|c|c|c|c|c|}
\hline 1900 & . & . & . & - & $\begin{array}{r}\text { Imports. } \\
\text {. } \quad £ 20,696\end{array}$ & $\begin{array}{l}\text { Exports. } \\
£ 639,269\end{array}$ \\
\hline 1905 & . & . & . & . & . $\quad 79,178$ & 667,099 \\
\hline 1909 & . & - & . & . & . 155,599 & 655,946 \\
\hline 1910 & . & . & . & . & . $\quad 171,687$ & 812,933 \\
\hline
\end{tabular}

\section{Tin Plates}

In striking contrast to the antiquity of the cutlery trade, we have a very modern industry - the tin-plate trade. This industry is so modern that Porter makes no mention of it in his book. It dates back, roughly, to the 'sixties, and is localized in South Wales and Monmouthshire. A tin plate, it should be observed, is not made wholly of tin, but consists of a plate of iron coated with a very small surface of tin. The trade developed very fast, principally owing to lack of foreign competition, and the strong demand for tin plates in the United States. The establishment of this industry was a godsend to South Wales, as it replaced the finished iron industry which was being killed by the growth of the steel trade. In the early stages of its development the tin-plate trade lived almost entirely on the American demand. In 1887-1890 the average yearly exports amounted to 399,329 tons of the value of $£ 5,682,641$. Of this quantity the United States took as much as 304,695 tons, of the value of $£ 4,278,667$. "Three out of four of the British manufacturers' eggs were in the American basket," writes Mr. Llewelyn Williams. ${ }^{1}$ "The whole of our exports to other countries only amounted to 94,634 tons, valued at $£ 1,403,974$. Seventy-six per cent. of this valuable trade was thus with the United States. The English home market, in the meantime, had been comparatively neglected. Enjoying a practical monopoly of the world's markets, our manufacturers could afford to pick and choose, and they naturally cultivated that market which ensured for them the largest margin of profit."

When this market was shut against them by the M'Kinley and Dingley Tariffs of 1800 and 1898 , our tin-plate manufacturers felt the blow seriously. So badly was the trade hit that many factories were closed down while others were transported, lock, stock, and barrel, to the United States. This state of affairs led

${ }^{1}$ British Industries under Free Trade (Fisher Unwin). 
to the most gloomy forebodings; prophets were loud in their predictions of the speedy disappearance of the industry. Never were appearances so completely falsified. Not only has the tinplate trade failed to disappear, but it has quickly risen to a more flourishing condition than ever.

Driven from one market our manufacturers turned their attention to others. The home market was developed, other markets were discovered abroad, and the trade generally was soon replaced in the position it had previously occupied. Then came the sequel. Inside the American tariff wall there had been going on a rapid formation of trusts. The tin-plate manufacturers, who had succeeded in shutting out British tin plates, were eclipsed by the Chicago packing interests and the Standard Oil Trust, which wanted to use those tin plates. The result was one of the most humorous situations in tariff legislation. In order to compete in the neutral markets of the world the packers were unable to pay the high price for tin plates that the American manufacturers demanded. And so to get cheap supplies from abroad, that is from Great Britain, they induced the Congress to allow them a rebate of 99 per cent. on all the tin used in the canned goods they exported. Thus the American tariff wall dwindled down to a mere 1 per cent., and the British trade was readmitted to its old market. We import practically no tin plates. Our export trade since 1860 is as follows:-

\begin{tabular}{|c|c|c|c|c|c|}
\hline Year. & Tons. & $£$ & Year. & Tons. & $£$ \\
\hline 1860 & $\cdots$ & $1,500,812$ & 1900 & $2 \pi 2,8 \pi i$ & $3,976,796$ \\
\hline 1870 & $\ldots$ & $2,362,872$ & 1905 & $354,86 t$ & $4,566,9 \$ 4$ \\
\hline 1880 & $21 i, 718$ & $4,457,887$ & 1910 & 482,981 & $6,545,024$ \\
\hline 1890 & 421,797 & 6,361,4 & & & \\
\hline
\end{tabular}

A trade somewhat similar to the tin-plate trade is the manufacture of galvanized sheets. We do a large foreign trade in these goods, both in the flat and corrugated form, which in conjunction with fencing wire, etc., are shipped in large quantities to our colonies. The figures for galvanized sheets since 1890 are-

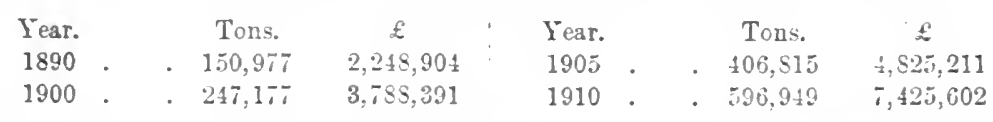

Our exports of iron and steel wire, except telegraph wire, since 1880 were-

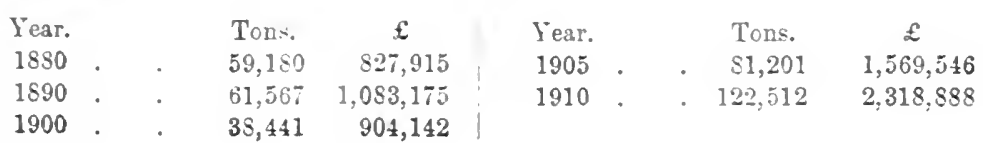


There is also a multitude of minor metal industries about whose progress it is impossible to give full detail. Such industries will be found enumerated in the table we have given previously, which has been extracted from the Census of Production report.

The quanity and value of brass and copper manufactures exported since 1805 , the earliest year of which we have any record, are as under. It is only in this branch that any estimate can be formed of the progress of these manufactures, but there is no reason to doubt that the home demand has at least kept pace with that from foreign countries.

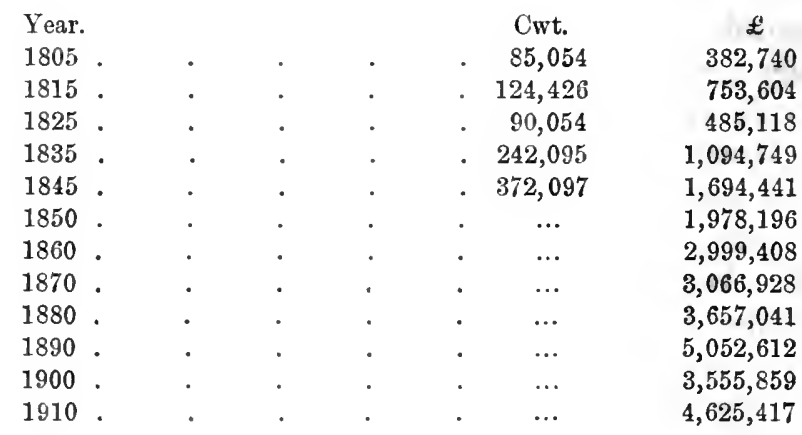

These figures include copper unwrought, copper ingot cakes, copper wrought or partly wrought, miscellaneous or yellow metal, other sorts, and brass of all sorts.

In the middle of the nineteenth century, according to Porter, " the largest shipments of these manufactures were made to India; the markets of Hindustan, in 1844, took from us 141,237 cwt., valued at $£ 611,109$, a quantity nearly double the amount of the shipments to all parts of the world in 1814. France is our next most considerable customer, having in 1844 , taken 103,214 cwt., valued at $£ 453,405$; to the whole of our colonies and dependencies, exclusive of India, we sent only 18,739 cwt., valued at $£ 80,232$. The United States took 43,811 cwt., valued at $£ 197,289$; leaving 81,881 cwt., valued at $£ 394,510$, for the supply of the rest of the world."

In 1910 , out of a total of $£ 1,285,385$, we sent $£ 78,768$ manufactures of brass to the Netherlands, $£ 82,413$ to France, $£ 86,334$ to the Argentine, $£ 70,268$ to Germany, and $£ 48,045$ to Belgium.

Copper rose much in industrial importance during the later years of the nineteenth century, owing to the rise of the electrical 
industry, which ereated a large demand for the metal. The growth of this industry is shown in the chapter dealing with machinery.

\section{Gold and Silver Manufactures}

The manufacture of plated goods, which is carried on in Sheffield, Birmingham, and the Midlands, is one of those branches of industry whose progress cannot be accurately measured. "The quantity exported forms no indication," states Porter, "and in fact there was not in foreign countries any reason equally eogent with that existing in England for the use of plated goods; for, so far at least as we know, there was not any country in which a duty was levied upon articles of use and luxury made of gold and silver." Touching the state of gold and silver manufactures during the first half of the nineteenth century, Porter writes:-

"It might be thought that the quantity of gold and silver plate manufactured for use at different periods would afford a good measure of the prosperity of the country; and we might have supposed that during the last quarter of a century there must have been a marked increase in this employment of the precious metals in this kingdom. Certainly during that interval the use of many utensils made of silver has been adopted by a much more numerous class of society than before, a remark which will be sufficiently corroborated by the fact that within that period it has first been customary to find silver forks at the tables of the generality of taverns. Before the termination of the war in 1815 , this article of dornestic convenience was uniformly made of steel, except among familics in decidedly easy circumstances, or in the first-rate taverns; whereas at present there is hardly a family to be found above the rank of artisans, whose table is not furnished with forks made of the more costly material. It will be matter for surprise, under these circumstanees, to find that the quantity of gold and silver plate made and retained for hone use within the kingdom was greater in weight during the eight years that preceded the peace, than it was during the like period from 1830 to 1837 inclusive. During the first period, namely, 1807 to 1814 , the quantities so retained for use were-of gold plate 50,750 ounces, and of silver plate $8,290,157$ ounces; and in the eight years, from 1830 to 1837 , the quantities were-of gold 48,432 ounces, and of silver $7,378,651$ ounces. This falling off is the more surprising because of the unprecedentedly high prices of bullion during a great part of the first of these two periods, whereby 
the difference in the money value was rendered much greater than the difference as here stated in the weight."

Some suggestions, he adds, have been offered in order to account for a circumstance seemingly so much at variance with every other indication of increased means and enjoyments on the part of the people: they are stated here only as suggestions, however, and are not relied on as affording a sufficient or satisfactory solution of the difficulty.

"First, it may be questioned whether the fact of the depreciation of paper, while it enhanced the money price of articles made of gold and silver, did not also occasion many persons, as a measure of prudent precaution, so to invest a part of their wealth, and thereby to secure the possession of a certain and tangible property of immediately convertible value. It may be objected that persons so acting were prudent overmuch, and, judging from the course which events have since taken, such an opinion appears well founded; but anyone who can recall to his recollection the dismal aspect then afforded by the political horizon-when every Power in Europe was leagued against us, and the necessary expenditure of the country was carried forward upon a scale which it would have been altogether impossible to have continued for even a few years longer-will hesitate before he pronounces such a precaution unwise. Even when the ambitious designs of Napoleon had detached from him and converted into enemies the allies who had pursued with him the object of destroying the power and resources of England, there came no intermission of efforts and sacrifices on our part, but, on the contrary, every ally that we gained in the field helped still further to exhaust our financial means. Let us suppose that the battle of Waterloo had been lost, or even that it had been less decisive in its results, could the public expenditure have been continued on anything like the scale of preceding years, while at the same time faith had been kept with the public creditors? Under such circumstances he would have been looked upon as a man of forethought and wisdom who should have provided himself with a species of convertible property that was independent of the stability of public credit; and as it is well known that many persons did at that time entertain very gloomy forebodings as to the future condition of this country, it is not unreasonable to suppose that some would be led to the precautionary course that has been here suggested."

"There was at the same time another circumstance in operation altogether opposite to, but not incompatible with, what has been stated, which probably led to the same desire of investing 
money in the purchase of gold and silver plate. The gains of persons engaged, either as owners or tenants, in the cultivation of the soil, had been out of all proportion great, and that for a length of time which gave an appearance of permanency to their prosperity. There are no classes of men so remarkable in this country as its nobility and country gentlemen for the importance which they attach to the possession and transmission of family plate; and with respect to the farmers, the alteration in their circumstances and character must have caused a great demand on their part for such luxuries. In those days it scarcely required the passing away of a generation in order to see in farmers' dwellings, on the same estates, spoons of rood or of horn give place to others of silver. It must further be considered that luxuries of this class are not of a perishable nature; that, except for the indulgence of ostentation, they are provided in the same family once for all, and we must not therefore expect that any sudden increase in their quantity will lead to further and equal additions when that immediate demand shall be satisfied. The improvement in the manufacture of plated wares has had a further infiuence in diminishing the sale of articles subject to the plate duty, although it may have led, and in all probability has led, to the increased consumption of the precious metals. Except in very wealthy families, it is now usual to see many articles, such as candlesticks, plated, where formerly they were of silver or brass."

"The combination of these various causes may probably be thought sufficient to account for the fact exhibited by the following table of the comparative decline experienced in this branch of consumption. The year 1825 is well remembered as a year of great commercial excitement and apparent prosperity, and it is curious to observe the clegree in which that excitement acted in promoting the desire of possessing gold and silver utensils."

"During the ten years from 1835 to 1845 the quantity retained for use, of both gold and silver articles, has increased. Those made of gold are now even greater in quantity than the average of the latter years of the war; but the increase is yet not nearly equal to the increase of population. The quantity of silver plate is still below the average of the years 1807 to 1814 . This fact of the greater comparative increase of gold as compared with silver plate, viewed in connexion with the increasing number of persons who keep a great number of carriages and servants, would seem to confirm the belief of the tendency of wealth to accumulate in large masses." 
Number of Ounces of Gold and Silver Plate upon which Duty was Paid and for which Drawback was Allowed, showing the Quantity retained for IIome Use, every Five Years, from 5th January 1801 to 5 th January 1850

\begin{tabular}{|c|c|c|c|c|c|c|c|c|c|}
\hline \multirow{2}{*}{\multicolumn{3}{|c|}{$\begin{array}{l}\text { Year ended } \\
\text { 5th January. }\end{array}$}} & & \multicolumn{2}{|c|}{ Duty Paid on } & \multicolumn{2}{|c|}{$\begin{array}{l}\text { Drawback } \\
\text { Allowed on }\end{array}$} & \multicolumn{2}{|c|}{$\begin{array}{l}\text { Retained for } \\
\text { Home Use. }\end{array}$} \\
\hline & & & & Gold. & Silver. & Gold. & Silver. & Gold. & Silver. \\
\hline $\begin{array}{l}1801 \\
1805 \\
1810 \\
1815 \\
1820 \\
1825 \\
1830 \\
1835 \\
1840 \\
1845 \\
1850\end{array}$ & . & $\begin{array}{l}\dot{5} \\
\dot{5} \\
\dot{5} \\
\dot{5}\end{array}$ & $\begin{array}{l}\text { : } \\
: \\
:\end{array}$ & $\begin{array}{l}\text { Oz. } \\
5,251 \\
4,854 \\
6,382 \\
6,779 \\
6,037 \\
7,662 \\
6,441 \\
6,116 \\
6,875 \\
7,242 \\
7 ; 373\end{array}$ & $\begin{array}{r}\text { oz. } \\
902,966 \\
902,788 \\
1,242,208 \\
974,245 \\
1,230,104 \\
1,258,658 \\
1,271,322 \\
1,050,232 \\
1,270,390 \\
1,025,412 \\
735,865\end{array}$ & $\begin{array}{r}\text { oz. } \\
77 \\
21 \\
53 \\
29 \\
1,607 \\
38 \\
12 \\
\cdots \\
7 \\
8 \\
3\end{array}$ & $\begin{array}{r}\text { oz. } \\
142,705 \\
114,829 \\
71,116 \\
55,948 \\
116,507 \\
70,482 \\
109,907 \\
102,251 \\
155,923 \\
170,987 \\
76,759\end{array}$ & $\begin{array}{c}\text { oz. } \\
5,174 \\
4,833 \\
6,329 \\
6,750 \\
4,430 \\
7,624 \\
6,429 \\
6,116 \\
6,868 \\
7,234 \\
7,370\end{array}$ & $\begin{array}{r}\text { Oz. } \\
760,261 \\
787,959 \\
1,171,092 \\
918,297 \\
1,113,597 \\
1,188,176 \\
1,161,415 \\
947,981 \\
1,114,467 \\
854,425 \\
659,106\end{array}$ \\
\hline
\end{tabular}

" The declared value of plated goods exported in the years 1831 , 1832 , and 1833 was no more than $£ 22,295, £ 20,727$, and $£ 24,209$ respectively; and about two-thirds of these amounts were sent to different colonies and dependencies of the British Empire, principally to India."

"Our makers of plated wares had, and still have to a certain extent, an advantage over all others, from the perfection of the machinery used in this country for rolling metals. The value of articles of this manufacture used in the United Kingdom was estimated in 1850 at $£ 1,200,000$ per annum; while in France the consumption did not excecd in value $£ 40,000$ sterling per annum, an equal value being also exported from that country, principally to Holland, Belgium, Spain and the Sardinian States, Germany, the United States of America, and Mexico."

The declared value of British-made plate, plated ware, jewellery, and watches exported from the United Kingdom (the whole of those articles being included together in the custom-house returns) has been as follows:-

\begin{tabular}{|c|c|c|c|c|c|c|c|}
\hline & & & $£$ & & & & $£$ \\
\hline 1830 & - & - & 190,515 & 1880 & . & - & 233,498 \\
\hline 1840 & . & . & . 208,614 & 1890 & . & . & 403,794 \\
\hline 1850 & . & . & - 296,078 & *1900 & . & . & . $\quad 458,781$ \\
\hline 1860 & - & . & - 564,160 & *1910 & . & . & . $1,019,326$ \\
\hline 1870 & . & . & 190,757 & & & & \\
\hline
\end{tabular}




\section{The Glass Trade}

The history of the glass trade in England illustrates among other things the tremendous effect upon home consumption which may be produced by taxing and so raising the price of any article, not of absolute necessity. In 1801, with a population of sixteen millions, the quantity of glass used was 325,529 cwt.; and in 1833 , with a population of twenty-five millions, the quantity was no more than $363,468 \mathrm{cwt}$. ; an increase of less than oneeighth, while the population had increased in the proportion of one-half.

The excise duty on glass, which may be compared in its effects with the window tax, was at its highest in 181:3 and was not finally repealed until 1845. The quantities of glass made and retained for consumption in Great Britain, between 1789 to 1844 , are shown in the following table:-

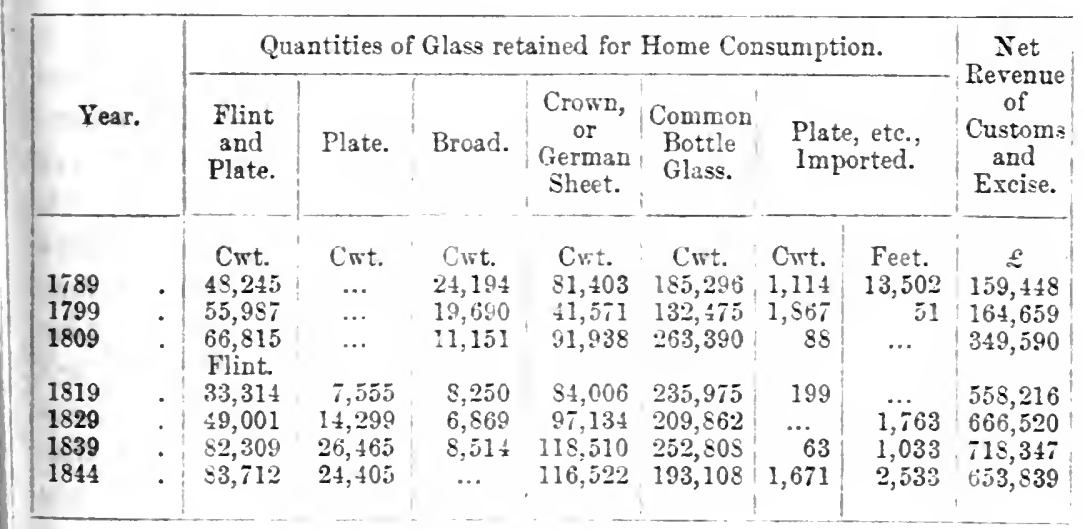

If the first and last years of the series from 1789 to 1844 are compared, it will indeed appear that there is an increase of rather less than 24 per cent. : but an average of the three years 1789 to 1791 and 1832 to 183.1 shows that the annul consumption in the former periol was 362,691 cwt. and in the latter period 342,172 cwt., exhibiting an actual falling ofi to the extent of $5 \frac{1}{2}$ per cent. In 1835 a reduction of two-thirds was made in the rate of the excise duty on flint glass, which was followed by a great immediate increase of consumption.

It is principally to the complicated regulations of the excise that this want of progress in our glass manufacture during the early part of the nineteenth century must be attributed. The 
business of glass-making is one the success of which depends in a peculiar degrce upon the right application of scientific principles; and when it is considered that a departure from any, the minutest, of the many arbitrary regulations then prescribed by Act of Parliament for conducting this manufacture, would subject the party so acting to heavy penalties, there is no cause for wonder that the industry stagnated.

The check on consumption was not wholly owing to the regulations whereby improvements were prevented, it was also occasioned, in part, by the excessive amount of the duty imposed, as was proved by the fluctuations in the demand which accompanied the various alterations in the rates of these duties. The pernicious effect of the glass duties was apparent from the contrast exhibited by this manufacture to others, not subjected to similar disadvantages; and it cannot be necessary, as Porter observes, to do more than point to this contrast as an argument in justification of the abandonment of the impost.

There were, however, other reasons, distinct from the above, which rendered the system under which the glass duties were levied peculiarly pernicious. The free progress of invention and improvement was by this means prevented, not only in the manufacture of glass, but also in many other arts and sciences to which glass is subsidiary. A manufacturer who by his skill had succeeded before 1845 in making great improvements in the quality of bottle glass, was stopped in his operations by the excise officers, on the plea that the articles which he produced were so good in quality as not to be readily distinguished from flint glass, to which description a higher rate of duty attached; the danger to the revenue being, that articles made of the less costly or less highly taxed ingredients would be used instead of flint glass.

Yet another reason is assigned by Porter for abandoning the duty upon home-rnade glass. "The ingredients of which glass is composed are exceedingly cheap, and the art is at the same time so simple, and calls for the use of so few accessaries, that it can be successfully followed by almost any person of ordinary aptitude for manual operations, working with simple and uncostly implements."

Up to 1845 the glass trade was subjected to serious restrictions, but in that year they were abolished. Thenceforward the manufacturers of glass, in all its forms, were relieved from the payment of duty and from the interference of revenue officers.

follows :-

Our foreign trade in glass since 1860 has been as 


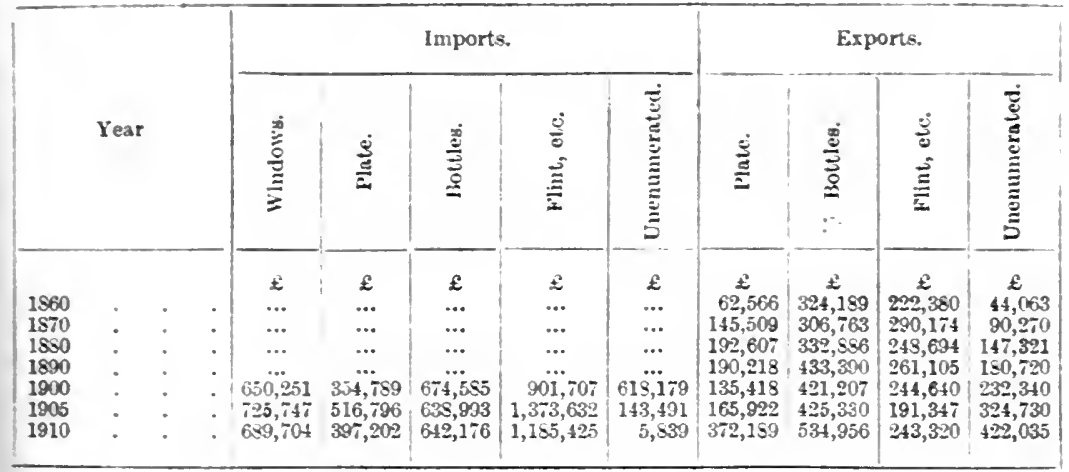

Prior to 1890 the Board of Trade returns did not specify separately the different sorts of glass we imported. Our total imports of glass from 1860 to that date amounted to-

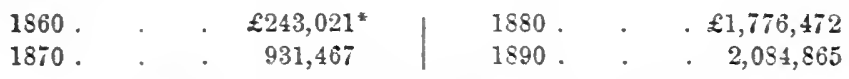

* Not including bottles of green or common glass.

The British plate-glass industry is centred at St. Helens, where the great firm of Pilkington Bros. carries on work upon an enormous scale. Their success is indicated by the continuous additions to the works, the plant of rival firms having been acquired in order to augment the capacity of these works.

Mr. Swinburne, the chief glass manufacturer at Newcastle-onTyne, in a report read to the British Association at its meeting in that town in 1863, said: "There has been no important improvement in the manufacture of glass bottles for the last trenty years. The relations of master and man in the blown, flint and bottle trade amount to a chronic strike .. and inflict upon the employer a burden which hopelessly fetters him in the race of competition and improvement." This seems to indicate that in 1863 the glass trade of Newcastle was in a dying condition, in consequence of resistance by the workers to improved methods of production.

According to the census returns, there were employed in glass manufacture in this country in 188112,630 men, which number had increased in 1901 to 30,081. A correspondent of The Economist wrote, on November 23, 1907 :-

"In the glass trade, as in other industries that might be named, economies in production have been introctuced of which we in this country have not taken proper advantage. One condition of successful glass manufacture is an abundant supply of cheap coal, and in this respect we ought to, and do, excel. But the 
metal from which glass is made must always be kept in a molten state, and to accomplish this the furmaces must be maintained from week-end to week-end at an even temperature, involving uninterrupted replenishment of fuel. Thus, if work does not proceed continuously there is waste, and this continental manufacturers have obviated by working the entire twenty-four hours, usually in three shifts of eight hours each. British manufacturers are not to blame for not having followed their example; they have done their utmost to induce their men to fall in with the arrangement, but in vain, and the full force of the trade unions have been behind the latter... As may be imagined, the worst sufferers are the manufacturers of cheap goods, bottles and inferior table and other domestic ware, in which cost of material and firing is in undue proportion to selling value. . . . Nearly all the small bottle makers have been crushed out of existence, and the trade-still very considerable, has become concentrated in the hands of the big firms. ... As far as window glass is concerned, Belgium has established an almost complete monopoly, and supplies not only the British Free-trade market, but most of the Protectionist ones of any consequence in the world, despite their efforts, by high duties, to keep it out."

\section{The PotTeries}

An important industry of which Porter strangely makes no mention is the manufacture of porcelain and pottery generally. There were large potteries in England in Roman times, and the art seems never to have been wholly lost. It was not until after 1760, however, when the celebrated Josiah Wedgwood began to improve the Staffordshire potteries, that English chinaware, earthenware, and porcelain obtained their world renown, and began to be exported abroad. The great centre of the china and earthenware manufacture is the district called the Potteries in North-west Staffordshire, which occupies some ten square miles and contained in 1840 some twenty thousand inhabitants. Two of the villages, Burslem and Hanley, were then growing into towns, thanks to the inventions of Wedgwood. The district supplied pottery to all parts of the kingulom, and among foreign countries the United States was their principal customer. The extent of the increase of these manufactures may be judged by the fact that Stoke-on-Trent, one of the pottery towns, which were amalgamated in 1909 into one municipality, had attained a population of 234,553 in 1911 .

The discoveries of Wedgwood gave to the English china and earthenware a reputation that it has never lost. It holds a high place in the world's markets for the beauty of its designs, the clearness of its body, and the delicacy of its finish. Art china is made at Worcester, Derby, and Coalport; there are potteries at Newton Abbot, Newcastle-on-Tyne, on the Clyde, and elsewhere, but the greatest quantity of English china is manufactured in 
the Pottery district, the progress of which we have just mentioned. It is difficult to estimate the annual production of the Potteries. In 1903 calculations varied between $£ 8,000,000$ and $£ 16,000,000$. The Census of Production gives the figures for 1907 as-

\begin{tabular}{|c|c|c|c|c|c|c|}
\hline & 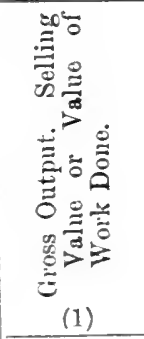 & 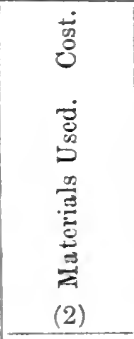 & 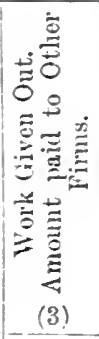 & 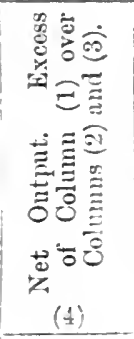 & 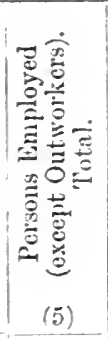 & 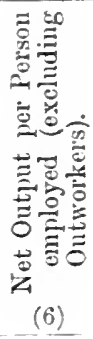 \\
\hline \multirow[t]{2}{*}{$\begin{array}{l}\text { China and earthenware } \\
\text { factories and work- } \\
\text { shops } \\
\text { Brick and fireclay fac- } \\
\text { tories }\end{array}$} & $\begin{array}{c}\stackrel{£}{ \pm} \\
7,531,000 \\
7,703,000\end{array}$ & $\begin{array}{c}\underset{f}{\mathfrak{2}, 85 \pm, 000} \\
2,643,000\end{array}$ & $\begin{array}{c}\stackrel{£}{£} \\
81,000 \\
\ldots\end{array}$ & $\begin{array}{c}\mathcal{E} \\
1,596,000 \\
5,060,000\end{array}$ & $\begin{array}{l}67,870 \\
63,287\end{array}$ & $\begin{array}{l}f \\
68 \\
80\end{array}$ \\
\hline & $15,23 \pi, 000$ & $5,497,000$ & 84,000 & $9,656,000$ & 131,157 & 73 \\
\hline
\end{tabular}

With regard to our foreign trade in pottery, in 1874 the export of all kinds of pottery amounted to $£ 1,861,760$. This, however, included bricks and other manufactures of clay. In 1883 we exported $£ 2,333,167$, but in 1885 only $£ 1,838,163$. For 1889 we are able to obtain statistics relating to earthenware, china, and porcelain separately, and the amount exported in that year was

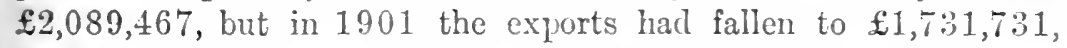
while in 1910 they rose once more to $\mathfrak{f}_{2}, 494,677$. England is peculiarly rich in supplies of raw material for the pottery trades, and foreign manufacturers especially are largely dependent on Cornwall and Devon for the supplies of ehina clay. 


\section{INTRODUCTION TO THE TEXTILE INDUSTRIES}

Early history of textile trades-Number of power-looms in use in 1835-Persons o different ages employed in textile trades, $1835-1839$ - Size of our textile trades in 1902 -Census of Production figures

TNGLAND has long stood pre-eminent for the skill of its inhabitants in manufactures of various kinds. But for that skill it is not possible to conceive that this country could have made the financial efforts which enabled us to carry on the long and unprecedentedly expensive war of the French Revolution. It has been a common assertion with a very powerful class in the community, so wrote Porter more that sixty years ago, that these efforts were principally, if not entirely, made at the expense of the proprietors of the soil. This position can only be rendered tenable by showing that the condition of those proprietors during the war was one of privation and sacrifice, whereas it is notorious that the direct contrary was the case; that through the enhanced prices of all kinds of agricultural produce, rents were more than doubled; and that the landlords were thence enabled to assume a scale of expensive living, to continue which, after the return of a more natural order of things, they had recourse to restrictions upon the importation of food, which were felt as an injury by all other classes. But the spinning-jenny and the steam-engine were the true moving powers of our fleets and armies. During the war, and throughout the first half of the nineteenth century, our manufacturing prosperity rested mainly on the textile trades. Before dealing with them separately it will be useful to take a panoramic view.

The following table of the number of power-looms used in the various manufactures of this country in 1835 was compiled from the returns of the Inspectors of Factories. 
Statement of the Number of Poxer-Looms used in Factories in the United Kingdom, at the end of the year 1835, distinguishing Counties, and the branch of Manufacture in which the same are used

\begin{tabular}{|c|c|c|c|c|c|c|c|c|c|}
\hline \multicolumn{4}{|c|}{ COUNTIES. } & Cotton. & Woollen. & Silk. & Flax. & $\begin{array}{l}\text { Mixed } \\
\text { Goods. }\end{array}$ & Total. \\
\hline \multicolumn{3}{|l|}{ Lancaster } & & 61,176 & 1,142 & 366 & $\ldots$ & $\ldots$ & 62,684 \\
\hline Westmoreland & & . & & $\ldots$ & & $\ldots$ & $\cdots$ & $\ldots$ & \\
\hline Chester . & . & . & & 22,491 & 8 & 414 & $\ldots$ & $\ldots$ & 22,913 \\
\hline Derby . & . & . & & 2,403 & & 166 & $\ldots$ & ... & 2,569 \\
\hline York . & - & . & - & 4,039 & 3,$7 ; 0$ & ... & $\cdots$ & $\ldots$ & 7,809 \\
\hline Stafford . & . & $\cdot$ & . & 336 & $\ldots$ & 119 & $\ldots$ & $\cdots$ & 455 \\
\hline Deron . & . & . & . & $\cdots$ & $\ldots$ & 80 & $\ldots$ & ... & 80 \\
\hline Essex . & . & . & - & $\ldots$ & $\ldots$ & 106 & $\ldots$ & $\cdots$ & 106 \\
\hline Kent . & . & $\cdot$ & . & ... & $\cdots$ & $\ldots$ & 12 & $\ldots$ & 12 \\
\hline Leicester & . & . & - & 40 & 89 & $\ldots$ & ... & $\ldots$ & 129 \\
\hline Middlesex & - & . & & 8 & $\ldots$ & ‥ & $\ldots$ & $\ldots$ & 8 \\
\hline Norfolk . & . & . & . & $\ldots$ & $\ldots$ & 300 & $\cdots$ & $\cdots$ & 300 \\
\hline Somerset & . & . & & $\ldots$ & 74 & 156 & $\ldots$ & $\ldots$ & 230 \\
\hline Warwiek & . & . & - & $\cdots$ & $\ldots$ & $\cdots$ & $\cdots$ & 25 & 25 \\
\hline Worcester & . & . & . & ... & $\ldots$ & 7 & $\cdots$ & $\cdots$ & 7 \\
\hline Gloncester & . & $\cdot$ & - & $\cdots$ & 4 & $\cdots$ & $\cdots$ & $\cdots$ & 4 \\
\hline Montgomery & - & . & . & $\ldots$ & 4 & $\cdots$ & .. & $\cdots$ & 4 \\
\hline Cumberland & . & . & - & 186 & $\cdots$ & $\cdots$ & $\ldots$ & $\cdots$ & 186 \\
\hline Durham & & $\cdot$ & & $\cdots$ & $\cdots_{6}$ & $\cdots$ & 29 & $\cdots$ & 29 \\
\hline Northumberla & & - & - & $\cdots$ & & & $\cdots$ & $\cdots$ & 0 \\
\hline \multicolumn{3}{|c|}{ Total in England } & - & 90,679 & 5,105 & 1,714 & 41 & 25 & 97,564 \\
\hline Lanark . & . & - & • & 14,069 & $\cdots$ & ... & $\cdots$ & ... & 14,069 \\
\hline Renfrew . & . & . & ${ }^{\circ}$ & 1,339 & $\ldots$ & $\ldots$ & 26 & $\ldots$ & 1,365 \\
\hline Dnmbarton & . & . & . & 534 & $\cdots$ & $\cdots$ & $\cdots$ & $\cdots$ & 534 \\
\hline Bute & . & . & & 94 & $\cdots$ & $\cdots$ & $\cdots$ & $\cdots$ & 94 \\
\hline Ayr $\quad \cdot$ & & . & . & 736 & $\ldots$ & $\ldots$ & $\ldots$ & $\ldots$ & 736 \\
\hline Kirkcudbright & & . & . & 90 & $\ldots$ & $\ldots$ & $\ldots$ & $\ldots$ & 90 \\
\hline Perth. . & & - & . & 421 & $\cdots$ & $\cdots$ & & $\cdots$ & 421 \\
\hline Aberdeen & . & . & . & 248 & $\ldots$ & $\cdots$ & 142 & $\ldots$ & 390 \\
\hline Roxburgh & - & $\cdot$ & - & $\cdots$ & 22 & $\cdots$ & $\cdots$ & $\cdots$ & 22 \\
\hline \multicolumn{3}{|c|}{ Total in Scotland } & - & 17,531 & 22 & $\ldots$ & 168 & $\cdots$ & $i 7,721$ \\
\hline Waterford & . & . & . & 339 & $\cdots$ & $\ldots$ & $\cdots$ & ... & 339 \\
\hline Wexford & . & . & . & 67 & $\ldots$ & $\ldots$ & $\ldots$ & $\ldots$ & 67 \\
\hline Kildare . & . & . & . & 52 & $\cdots$ & $\cdots$ & $\cdots$ & $\cdots$ & 52 \\
\hline Dablin . & . & . & . & 23 & $\cdots$ & $\cdots$ & $\cdots$ & $\ldots$ & 23 \\
\hline Antrim . & . & . & . & 340 & $\ldots$ & $\ldots$ & $\ldots$ & $\ldots$ & 340 \\
\hline Down . & . & . & . & 425 & $\cdots$ & $\ldots$ & & $\ldots$ & 425 \\
\hline Armagh . & - & . & . & 170 & $\cdots$ & $\cdots$ & 100 & $\cdots$ & 270 \\
\hline \multicolumn{3}{|c|}{ Total in Ireland } & . & 1,416 & $\cdots$ & $\cdots$ & 100 & $\cdots$ & 1,516 \\
\hline \multicolumn{10}{|c|}{ SUMMARY } \\
\hline \multirow{3}{*}{$\begin{array}{l}\text { Fingland. } \\
\text { Scotland. } \\
\text { Ireland . }\end{array}$} & - & - & . & 90,679 & 5,105 & 1,714 & 41 & 25 & 97,564 \\
\hline & $\cdot$ & . & • & 17,531 & 22 & ... & 168 & $\ldots$ & 17,721 \\
\hline & - & . & . & 1,416 & & & 100 & $\cdots$ & 1,516 \\
\hline \multicolumn{3}{|c|}{ United Kingdom } & . & 109,626 & 5,127 & 1,714 & 309 & $25^{*}$ & 116,801 \\
\hline
\end{tabular}

- The materials used are worsted, cotton, silk, and india-rubber thread; the articles manufactured are girths, belts, braces, garters, and the like. 
Passing from the factories equipped with power-looms to the hands employed, it was noted by the factory inspectors of that day that the proportion of children employed in the silk-mills was much greater than in the cotton, woollen, or linen mills.

The actual proportions in which persons of different ages were employed in each of these four branches of industry, in 1835 and 1839, were as follow :-

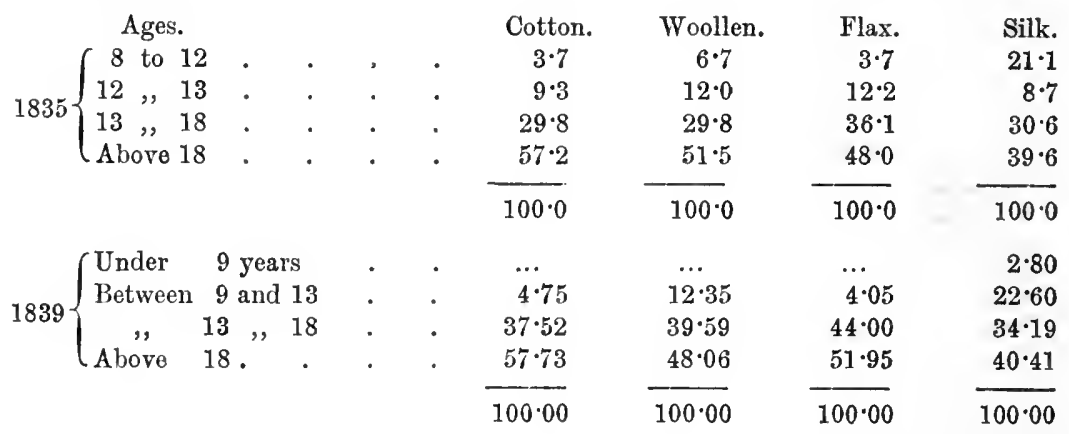

The proportions in which males and females were employed in 1835 and 1839 were :-

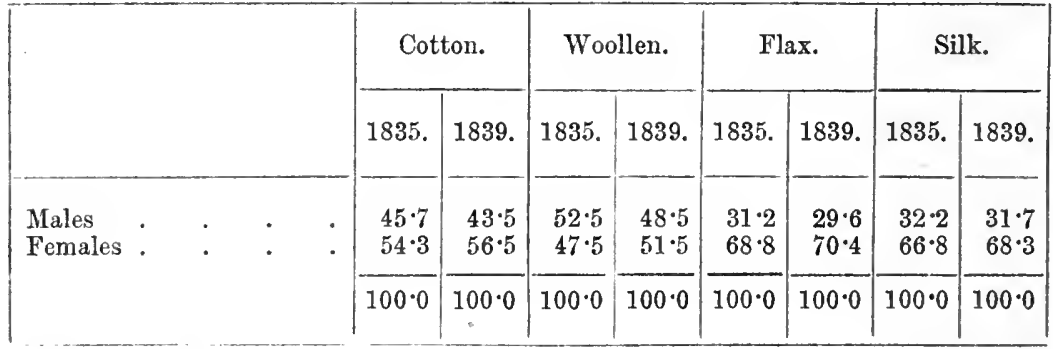

It may be noted also that at this time water and steam power were about equally used in the textile factories. The progress of our textile manufactures will be shown later in detail. But the present position may be summarized now in a very complete manner, thanks to an official census which has recently appeared.

In 1907 a census was taken under the Census of Production Act (1906), and the tables issued in the latter half of 1909 and the beginning of 1910 show clearly what contribution each industry makes to the national income. In the textile industries, the manufacture of cotton goods and the manufacture of woollen and worsted goods are pre-eminent in importance, and their respective positions are shown in the following table:- 


\begin{tabular}{|c|c|c|c|c|c|}
\hline & $\begin{array}{c}\text { Gross } \\
\text { Output. }\end{array}$ & $\begin{array}{c}\text { Cost of } \\
\text { Niaterial } \\
\text { Used." }\end{array}$ & Net Output. & $\begin{array}{c}\text { Number } \\
\text { Employed. }\end{array}$ & $\begin{array}{c}\text { Net Output } \\
\text { per Person. }\end{array}$ \\
\hline $\begin{array}{l}\text { Cotton factories } \\
\text { Wonllen } \\
\text { worstel } \\
\text { tories fac- }\end{array}$ & $176,940,000$ & $129,999,000$ & $46,941,000$ & 572,869 & 82 \\
\hline
\end{tabular}

* Including amount paid to other firms for work given out.

The lesser textile trades are summarized in our second table, which, taken in conjunction with the previous figures of cotton and woollen production, gives a complete statement of the textile production of the United Kingdom in the year 1907.

\begin{tabular}{|c|c|c|c|c|c|}
\hline & $\begin{array}{l}\text { Gross } \\
\text { Ouput. }\end{array}$ & $\begin{array}{l}\text { Cost of } \\
\text { Material } \\
\text { Used. }\end{array}$ & $\begin{array}{c}\text { Net } \\
\text { Output. }\end{array}$ & $\begin{array}{l}\text { Number } \\
\text { Employed. }\end{array}$ & 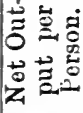 \\
\hline Jute, linen, and hemp (Great & $£$ & $\mathfrak{E}$ & $£$ & $£$ & $£$ \\
\hline Britain) & $18,667,000$ & $13,647,000$ & $5,020,000$ & 81,703 & 61 \\
\hline Do. inland spinning & $1,773,000$ & $3,152,000$ & $2,621,000$ & 38,195 & 69 \\
\hline Do. do. weaving & $6,093,000$ & $4,717,000$ & $1,376,000$ & 29,797 & 46 \\
\hline Do. do. making up & $1,265,000$ & 944,000 & 321,000 & 3,769 & 85 \\
\hline Silk $\cdot \cdot \cdot \cdot$ & $5,204,000$ & $3,454,000$ & $1,750,000$ & 32,036 & 55 \\
\hline Lace factories and ware- & & & & & \\
\hline$\underset{\text { Hosiery }}{\text { houses }}$ & $10,003,000$ & $6,621,000$ & $3,382,000$ & 34,583 & 98 \\
\hline & $\begin{array}{r}8,689,000 \\
848,000\end{array}$ & $\begin{array}{r}5,695,000 \\
565,000\end{array}$ & $\begin{array}{r}2,994,000 \\
283,000\end{array}$ & $\begin{array}{r}47,939 \\
4,292\end{array}$ & $\begin{array}{l}62 \\
66\end{array}$ \\
\hline $\begin{array}{l}\text { Cocoa-nut fibre, horsehair, } \\
\text { feather and sundry tex- } \\
\text { tiles, factories and work- }\end{array}$ & & & & & \\
\hline shops . . . & $1,162,000$ & 744,000 & 418,000 & 5,757 & 73 \\
\hline Rope, twine, and net. & $3,606,000$ & $2,650,000$ & 956,000 & 12,148 & 79 \\
\hline $\begin{array}{l}\text { Flock and rag } \\
\text { Bleaching, dyeing, printing, }\end{array}$ & 852,000 & 693,000 & 159,000 & 2,375 & 67 \\
\hline and finishing factories & & & & & \\
\hline and workshops & $17,782,000$ & $\tau, 413,000$ & 10,369 & 102,611 & 101 \\
\hline Flax scutching factories . & 91,000 & 23,000 & 68,000 & 3,760 & 18 \\
\hline Velvet and fustian factories & 117,000 & 5,000 & 112,000 & 3,443 & 33 \\
\hline Add_Totsl & $80,152,000$ & $50,323,000$ & $29,829,000$ & 402,408 & 74 \\
\hline $\begin{array}{l}\text { Cotton factories } \\
\text { Woollen and worsted fac- }\end{array}$ & $176,940,000$ & $129,999,000$ & $46,941,000$ & 572,869 & 82 \\
\hline tories & $70,331,000$ & $50,879,000$ & $19,452,000$ & 257,017 & 76 \\
\hline Total textile trades. & $327,423,000$ & $231,201,000$ & $96,222,000$ & $1,232,294$ & 78 \\
\hline
\end{tabular}

* Including amount paid to other firms for work given out.

These industries thus employ one-and-a-quarter million persons exclusive of outworkers, while the net product of the labour of this vast industrial army amounts to very nearly 100 millions sterling. 
This sum represents the additional value given by those engaged in the textile trades to the material on which they work, and is the fund from which wages, salaries, rents, royalties, rates, taxes, depreciation, advertisement and sale expenses, and all other similar charges as well as profits have to be defrayed. There is a very marked difference, however, between the various trades as regards the proportion which the cost of raw material bears to the total value of the output. For example, in the minor textile trades, as a whole, 400,000 persons operate on 50 million pounds' worth of material,

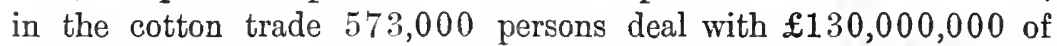
material. There is, of course, a certain amount of duplication in the figures, and this result is only approximate; but it does perhaps indicate the greater industrial advancement of the cotton trade compared with other textile trades. Lancashire's industry is a machine industry in which economy of labour has been carried to its utmost limit, each operative working on over $£ 200$ worth of material. In the silk industry, on the other hand, in spite of the greater cost of the material, each worker deals with barely $£ 100$ worth of material. The result is that whereas the gross output of the cotton trade is considerably more than half the total for the textile trades, the cotton figures in column three, which represent the expenses of the trade, are less than one-half of the totals for all textiles. One of the results of the investigation should be of general interest, namely, the attempt to discover the proportion which foreign trade bears to home trade in the respective occupations. Unfortunately, the differences of classification and the limitations of the census figures make this possible in very few cases only, of which the following are the most important:-

"About one-sixth of the quantity of jute yarn spun in the United Kingdom was exported, and between one-ninth and one-tenth of the linen yarn. About half of the quantity of jute piece goods woven was exported, about 62 per cent. of the plain linen piece goods, about 22 per cent. of the printed, checked, and other fancy linen piece goods, and about 18 per cent. of the sail cloth and canvas. The inports of jute yarn were trifling, but the imports of linen yarn were rather more than one-eighth of the quantity produced in the United Kingdom. The imports of piece goods cannot be compared with the quantities produced in the United Kingdom, as no particulars regarding the quantity imported are available."

And, again, with regard to the silk trade :-

"About three-quarters of the total quantity of the broadstuffs (wholly or partly made of silk) produced in the United Kingdom was exported, but the imports were nearly five times as great as the home production. The value of the ribbons manufactured in the United Kingdom is insignificant compared with the imports." 
The returns for bleaching, dyeing, etc. factories make it possible to complete an estimate for the respective branches of the cotton trade. The report now estimates the total value of cotton piece goods of all kinds when ready for consumption, exclusive of merchants' and warehousemen's profits, at $£ 95,000,000$ sterling. The value of exported piece goods in 1907 was $£ 81,000,000$. 


\section{CHAPTER XVI $(B)$}

\section{COTTON}

Early history of cotton trade.

The Cotton Industry, 1800-1850.-Imports of cotton in eighteenth century-Early textile machinery-Consumption of cotton and exports of cotton goods, 1801-1849The cotton trade early in the nineteenth century-Forcign trade in cotton goods in first half of nineteenth century-Tlie advantages of the power-loom-Effect of power manufacture on price of cloth-Prices in Stockport in 1812-The history of the powerloom-Labour conditions in textile trade early in the niveteenth century-Quantity of raw cotton consumed in first half of nineteenth century, and quantities of yarn manufactured-Persons employed in the early days of the textile trades-Wages in cotton trade, 1804-1833-Cotton printing-Restrictions on cotton printing-Value of cotton manufacture in first lalf of nineteenth century.

The Cotton Industry, 1850-1910.-Size and importance of modern cotton industryAmerican production and exports of cotton, 1790-1903-Lancashire's supplies and con. sumption of cotton-Our consumption of cotton, 1781-1908-The world's consumption of cotton in 1910-The Manchester cotton market-Wages in the cotton trade-The Scottish cotton trade-Textile machinery in last half of nineteenth century-Machinery in use, 1874-1903-Nunubers employed, 1881-1901-Our foreign trade in cotton goods.

\section{TTHE rise and progress of the cotton manufacture in Great Britain forms perhaps the most extraordinary chapter in the annals of British trade. The birthplace of cotton manufacturing was} India, where it probably flourished long before our earliest records. The mechanical inventions which have enabled the Western nations to compete with and greatly surpass the Hindoos had their origin in this country. England, therefore, may be called its second birthplace. The exact period when cotton manufacturing was introduced into this country is unknown; but it is pretty clear that it was well established in Manchester in 1641. Its growth in the next hundred years was by no means rapid. $U_{p}$ to the year 1760 the machines used were nearly as simple as those in India, though the handlooms were more strongly and perfectly constructed. About that time several inventions were made, notably the spinning-jenny. Small factories were erected, and the steam-engine was patented in 1769 . The whole industry was revolutionized. We soon began to export piece goods. In 1785 we shipped to the extent of $£ 864,710$, and

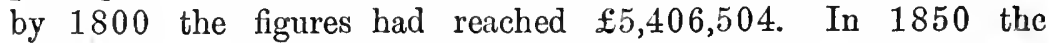
spindleage had reached 21 millions, and in 1911 there are about 
57 millions. To show the further growth of our exports of piece goods, it may be mentioned that in 1840 the figures for yarn and cloth were $£ 23,400,000$, and that for 1909 the yarn and cloth values were $\mathfrak{f} 80,100,000$. In 1885 the number of looms was 546,000 ; in $1911,742,000$.

\section{The Cotton Industry - $1800-1850$}

In the year 1800 , the quantity of cotton imported for use into the United Kingdom was 56,010,732 pounds, having been only $31,447,605$ pounds in 1790 , and $17,992,882$ pounds in 1785 . The total value of manufactured cotton goods exported in 1800

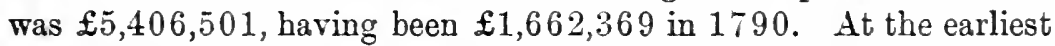
of these two dates, Sir Richard Arkwright's inventions bad very recently been thrown open to the public by the setting aside of his patent in the Court of King's Bench. The first steam-engine constructed for a cotton-mill was made by Watt in 1785 , and put to use at Papplewick in Nottinghamshire; some four years later the application of steam power to the same purpose was first made in Manchester. In the year 1800, the number of such engines in that town had increased to 32 , the aggregate power of which was estimated as equal to the labour of 430 horses. This increase shows that a great impulse had been given to the manufacture, which already was considered to be a thing of high national importance. At that time the application of the improved machinery was confined to the production of yarn; for although Dr. Cartwright's power-loom was invented as early as 1787 , the first practical use of his machine was in 1801, when a weaving factory was erected by Mr. Monteith, at Pollockshaws, near Ġlasgow, and furnished with 200 self-acting looms. The progress of the manufacture since that time is shown by the following table, in which are stated the quantity of cotton annually worked up in the kingdom, and the value of our exports of cotton goods:-

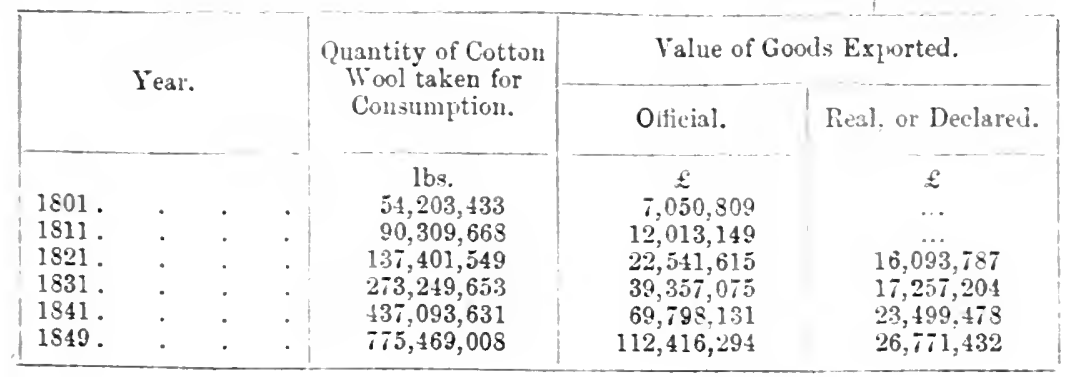


The quantity taken for consumption in 1801 and 1811 was found by deducting the quantity exported from the quantity imported in each year. In the later years, the quantities stated are those actually taken by the manufacturers in the course of each year.

The period from the beginning of the century to the return of peace is marked by a striking sluggishness of trade. The effect of the general adoption of Arkwright's invention for spinning had been to treble the manufacture in fifteen years. But there it may almost be said to have stopped, and in fact the quantity of raw material manufactured in each of the two last years of the war was smaller than that consumed in 1801. No sooner had peace returned, however, than new life was infused into the trade. In five years the quantity of cotton spun was trebled; in another five years it was four times what it had been in the last year of war; and at the expiration of another period of equal duration more than five times that quantity passed through the manufacturers' hands. The quantity used in 1835 was fully six and a half times greater than that used in 1813, while in the following nine years there was an increase of two-thirds, or 66 per cent., upon the figures of 1835 . The progress of the export trade in cotton goods was more regular throughout the period embraced in the table. Judging from the "official value," under which every yard or pound was estimated at an unvarying rate, it appears that the quantity of these goods exported was nearly three times as great at the close of the war as it had been at the beginning of the century - a fact which seems to prove that the capability of the population of this country to command the purchase of this the cheapest kind of clothing, must have diminished, the increased exports having left a much smaller quantity for the use of a population increased in the meanwhile by more than two millions.

Later accounts show the actual quantities of the different descriptions of cotton goods exported. In 1820 we exported $113,682,486$ yards of white or plain cottons, valued at $£ 5,451,024$, $134,688,144$ yards of printed or dyed cottons, valued at $\mathfrak{f} 7,742,505$, $£ 496,580$ of hosiery and smallwares, and $23,032,325$ pounds of twist and yarn, valued at $£ 2,826,639$, the total declared value amounting to $\mathfrak{f} 16,516,748$. Ten years later our exports were as follows: white or plain cottons $244,799,032$ yards (£6,562,397);

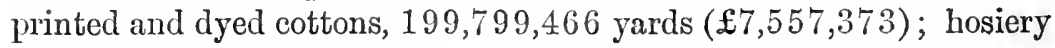

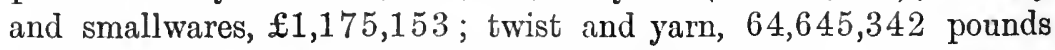
$(£ 4,133,741)$; total declared value, $£ 19,428,664$. Finally, in 1849 , we exported $795,112,525$ yards of white or plain cottons, 
valued at $£ 9,457,721 ; 542,423,591$ yards of printed or dyed

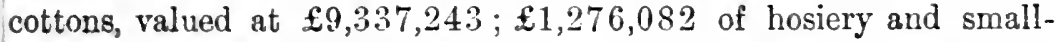
wares; and $149,502,281$ pounds of twist and yarn, valued at $\mathfrak{£} 6,704,089$ - in all amounting to $£ 26,775,135$. Thus, while the number of yards exported in 1849 is greater by 430 per cent. than the number exported in 1820 , the increase in the declared value is only 42 per cent.; the average price per yard, which in 1820 was $12 \frac{3}{4} \mathrm{~d}$., having fallen in 1844 to $3 \frac{2}{5} \mathrm{~d}$. If, in addition to these values, we take account of the reduction that occurred in the price of raw cotton, we may form some judgment as to the economy which had been introduced into the process of manufacture during the thirty years (1820-1850), and we may also be able to apportion the degrees of that economy which appertain to the spinning and to the weaving branches of the manufacture respectively. It is necessary, however, that for this purpose the average qualities of both cloths and twist should have been the same at both periods, which it is reasonable to suppose might be the case where the markets are so numerous, and the quantities shipped so large. The diminution of value in the twist appears to amount to 59 per cent., and in the cloth to 68 per cent.

The following is an interesting statement of the advantages gained by the employment of the power-loom by Mr. Baines, an historian of the cotton trade :-

"A very good hand-weaver, 25 or 30 years of age, will weave two pieces of $9-8$ ths shirting per week, each twenty-four yards long, containing 100 shoots of weft in an inch; the reed of the cloth being a forty-four Bolton count, and the warp and weft forty hanks to the pound.

"In 1823, a steam-loom weaver, about 15 years of age, attending two loons, could weave seven similar pieces in a week.

"In 1826, a steam-loom weaver, about 15 years of age, attending to four looms, could weave twelve similar pieces in a week; some could weave fifteen pieces.

"In 1833, a steam-loom wenver, from 15 to 20 years of age, assisted by a girl about 12 years of age, attending to four looms, could weave eighteen similar pieces in a week ; some can weave twenty pieces."

"In 1845 a steam-luom wearer about 15 years of age, attending to two looms, could weare 11 pieces of the same cloth; and a steam-loom weaver 16 to 20 years of age, assisted by a girl ahout 14 years of age, attending to four looms, could weave 22 similar piees in a week."

The following table shows the effect which these successive improvements had in diminishing the price of cotton cloths; the same article-a piece of calico known in the trade as $72 \frac{7}{8}-$ is given throughout:- 


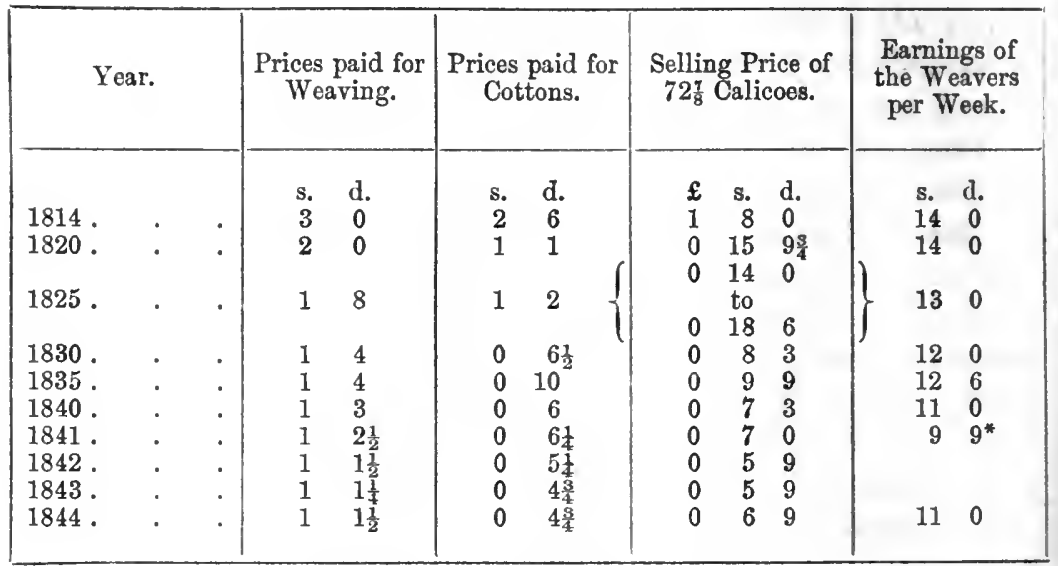

"Short time, and six weeks "turn out."

Wu Previous reductions are shown by the following list, which was g? inquir. 'y then made into the effects of the Orders in Council, issued in 1808 , in retaliation of the Berlin and Milan decrees of Napoleon:9.

Prices paide for Weaving Twenty-four Yards of Cambric at Stockport,

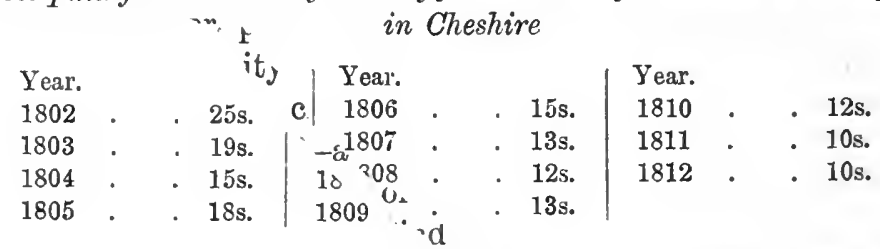

The low wages paid in the llater years, when every article of provisions was excessively high in $\mathrm{L}$ iprice, and when, even at these insufficient rates, but little employment was to be had, caused great and widespread misery among the manutaacturing population.

The following statement of the prc ?gress of the power-loom is taken from Mr. Baines's History of the Conston Manufacture, published in the year $18: 35$ :

"In 1813 there were not more than 2400 pow he er-looms in use; yet this was enough to alarm the hand-loom weavers, who, $\epsilon_{\text {attributing to machinery the }}$ distress caused by the Orders in Council and the American war, made riotous opposition to all new maclines, and broke the 3: power-looms set up at West Houghton, Middleton, and other places. Nevertls peless, the great value of the power-loom having now been proved, it was ador.rited by many manufacturers, both in England and Scotland: and it will, nog, doubt, in time supersede the hand-loom. The rapidity with which the pow'er-loom is coming into use is proved by the following table, the particulars $c$ hf which were stated by R. A. 
Slaney, Esq., M.P., in the House of Commons, on the 13th of May 1830, and which rest on the authority of Mr. Kennedy :-

"Number of Power-Looms in England and Scotland

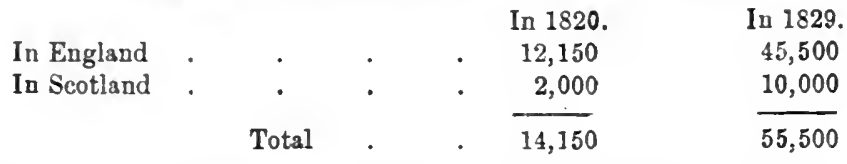

"This number would appear to have been somewhat underrated. Dr. Cleland states that, in 1828, the Glasgow manufacturers had in operation, in that city and elsewhere, 10,783 steam-looms, and 2060 more in preparation-total, 12,843. He supposes there was an increase of 10 per cent. between 1828 and 1832, which would make the number 14,127 in the latter year. This is independent of other parts of Scotland, unconnected with Glasgow. In 1833, evidence was given before the Commons' Committee on Manufactures, Commerce, etc., that, in the whole of Scotland, there were 14,970 steam-looms. We may therefore safely take the number of power-looms in Scotland at the present time (1835) at 15,000 .

"In England, the great increase took place during the years of speculation, 1824 and 1825 ; and comparatively few power-loom mills were built betwixt that time and 1832. But in 1832,1833 , and the former part of 1834 , the trade bas been rapidly extending; many mills have been built, and many spinners have added power-loom factories to their spinning-mills.

"Mr. W. R. Greg, an extensive spinner and manufacturer at Bury, gare evidence before the Select Conmittee of the House of Commons on Janufactures, etc, in August, 1833, that the number of power-looms had rery materially increased of late years in and about Bury, and also at Stockport, Bolton, Ashton, and in Cheshire. He stated that he did not know any person who was then building a spinning-mill without the addition of a power-loom mill.

“Mr. Kennedy's estimate for 1829 was probably too low for England, as well as for Scotland : at all events, there are good reasons for believing that there must now be 85,000 power-looms in England. This conclusion is deduced from a computation of the number of workmen employed in power-loom weaving, founded on actual returns, obtained by the Factory Commissioners from the cotton-mills in Lancashire and Cheshire. It is also supported by the calculations of Mr. Bannatyne, and Messrs. Samuel Greg \& Co., the spinners and manufacturers of Bury. At the present time (1835), the machine-makers of Lancashire are making power-looms with the greatest rapidity, and they cannot be made sufficiently fast to meet the demands of the manufacturers. The result we have arrived at is as follows :-

\section{"Estimated Number of Pourer-Looms in Grent Britain in 1833}

In England

85,000

In Scotland

Total

100,000

"AWhile the number of power-looms las been multiplying so fast, the handlooms employed in the cotton manufacture are believed not to have diminished between 1820 and 1834, but rather to have increased. In the former year they were estimated by Mr. Kennedy at 240,000. In 1833, Mr. Grimshaw, a spinner 
and manufacturer of Colne, gave his opinion before the Committee of the Commons on Manufactures, etc., that the number of hand-loom cotton weavers in the kingdom was about 250,000 ; whilst Mr. George Smith, manufacturer, of Manchester, estimated them at only 200,000. In the year 1834, several intelligent workmen and manufacturers from Glasgow gave evidence to the Commons' Committee 'On Hand-Loom Weavers,' that there were 45,000 or 50,000 handloom cotton-weavers in Scotland alone."

From the returus of the Inspectors of Factories, it appears that the total number of self-acting looms in the United Kingdom employed for weaving cotton at the end of 1835 was 109,626 .

Power-looms were not at first found generally applicable to the production of fine cloths, or what are called fancy goods. In the Report of the Select Committee of the House of Commons, appointed in the summer of 1834 , to examine the numerous petitions presented by the hand-loom weavers, we find a statement given in evidence by Mr. Makin, a manufacturer of Bolton, to the following effect:-

"I know that there is at present no surplus of weavers. I go nine miles from the seat of my manufacture on one side to get weavers, and I am putting out work nine miles across the country in another part to get weavers; and if I knew where I could get a certain description of weavers, by going nine miles another way, I should go. But it is a strange fact, that, whilst the demand for hand-loom cloth is greater than the production, yet the wages do not rise; and in about two months from this time (July, 1834), I know, from the experience of past years, that there will be demands for thousands of weavers more than can be obtained."

The fact stated by Mr. Makin, although seemingly at variance with the ordinary law of demand and supply, may admit of this solution; -that, when they could be furnished within a certain limited price, hand-loom cloths met with an extensive sale; but that, when that limit was passed, other goods of home production, or similar goods of foreign make, came into successful competition with them; so that the manufacturers were not enabled, by the most extensive demand, to increase the rate of wages paid to the weavers.

Much valuable and authentic information respecting the amount of labour employed in the spinning and weaving factories of the kingdom was embodied in the reports of the Commissioners appointed to collect information as to the employment of children in factories, and subsequently by the inspectors appointed under the Act of 1833 , for regulating the labour of children.

A calculation, made in 1833 and inserted in a Supplementary Report of the Factory Commissioners, was perhaps as near an approximation to the truth as the nature of the subject (the numbers continually fluctuating) allowed. Being founded upon 
actual and extensive returns, the statement may be received as substantially correct.

It did not include hand-loom weavers, printers, bleachers, dyers, cotton-thread lace-makers (an enormous and growing branch of the cotton manufacture), and many other branches of manufacture, either arising out of, or immediately dependent upon, the spinning of cotton by power. It comprehended those operatives alone who habitually worked in cotton factories. It showed them to number 212,800 persons, and to earn annually the enormous sum of

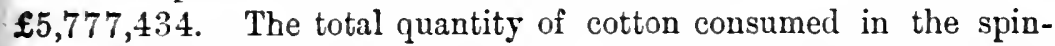
ning of yarn, in Great Britain, in 1832, as stated in Burn's Commercial Glance, was $277,260,490 \mathrm{lb}$.; and of this quantity, $27,327,120 \mathrm{lb}$. was consumed in Scotland, leaving for the cousumption of England 249,933,370 lb. The net loss of cotton in spinning is estimated variously by different individuals. In the calculations of Mr. Kennedy, made use of by him in a paper published in the Transactions of the Manchester Iiterary and Philosophical Society, it is taken at $1 \frac{1}{2}$ oz. per lb.; while Montgomery, in his Theory and Practice of Cotton-Spinning, put it at $1 \frac{5}{8}$ oz., and Burn at $1 \frac{3}{4}$ oz.; but as the amount taken by Mr. Kennedy is that which appears to be generally considered correct, it is adopted in these calculations:-

"If, then, from the quantity given abore, we deduct $1 \frac{1}{2}$ oz. per lb., or $23,431,253 \mathrm{lb}$., we shall have the total weight of yarn produced $226,502,11 \mathrm{lb}$. The average number of hanks in each pound of yarn spun was computed to be 40. Jontgomery took the average counts spun in Great Britain at 50, which, taking into account the finer average numbers spun in Scotland than in England, would fix the counts nearly as above stated. The returns made to the Lancashire forms of inquiry, as given in previous tables, show an arerage of finer counts than 40 , but, as the returns were better made from the fine mills, than from the coarse, and from Manchester, where the finer varn is spun, than from the country, it is evident that lower numbers ought to be taken than those shown in the returns; and, as the general opinion appears to be in favour of 40 , this arerage is adopted.

"Three mills, in different situations, and of average capabilities, made a return of the quantity produced by them in the month ending the 4th. May, 1833 ; and, as the average counts of the whole were $39-93$ hanks to the Ib., and as they also gave the number of hands enployed in spinning during that month, and the duration of their labour, they furnished data from which may be easily calculated the total number employed in factories in England in preparing and spinning cotton. In the mill of the first, 344 persons in the spinning department, working 276 hours, produced- 
"In the second mill, 245 liands, working 270 hours, produced-

$$
\begin{array}{r}
1,795 \mathrm{lb} \text {. of No. } 12, \\
4,285 \mathrm{lb} \text {. of No. } 22, \\
33,838 \mathrm{lb} \text {. of No. } 40 .
\end{array}
$$

"And in the third, 110 hands, working 286 houls, produced-.

$$
16,700 \mathrm{lb} \text {. of No. } 40 .
$$

"The average counts of the three being, as before stated, 39.98, and the produce $95,018 \mathrm{lb}$. The total number of hours worked will therefore be $\overline{344 \times 276}+\overline{245 \times 270}+\overline{110 \times 286}=192,554$; and the produce of each person per hour, $\frac{95,018}{192,544}=0 \cdot 49,346 \mathrm{lb}$. The usual estimate of 300 working days per annum of $11 \frac{1}{2}$ hours each, or 69 hours per week, would give $0.49,346 \times 11.5 \times 300=$ $1,702,437 \mathrm{lb}$. the produce of each person per annum, and $\frac{226,502,117}{1,702,437}=133,045$, the number of persons employed in the preparation and spinning of cotton in England. In the 67,819 persons of whom returns were made to the Commission, there were 42,401 engaged in preparing and spinning cotton, 23,920 in the weaving department, and 1,498 as engineers, mechanics, roller-coverers, etc. If, then, the same proportions are taken as existing in the total number of cottonworkers which are found in the returns made to the Lancashire forms of inquiry, the number of persons engaged in the manufacture of cotton-cloth in factories will be 75,055, and of those employed as engineers, etc., 4,700; making, with the 133,045 in the spinning department, a general total of 212,800 persons engaged in cotton-factories. Which total number of 212,800 persons may be divided and distributed, by adopting the proportions given in the returns made

\begin{tabular}{|c|c|c|c|c|c|c|c|c|}
\hline \multirow{3}{*}{ Employed in } & \multicolumn{2}{|c|}{ Adults. } & \multicolumn{6}{|c|}{ Children under 18 Years of Age. } \\
\hline & \multirow[b]{2}{*}{ Males. } & \multirow[b]{2}{*}{ Females. } & \multicolumn{3}{|c|}{ Males. } & \multicolumn{3}{|c|}{ Females. } \\
\hline & & & $\begin{array}{c}\text { In the } \\
\text { direct } \\
\text { Employ } \\
\text { of } \\
\text { Masters. }\end{array}$ & $\begin{array}{l}\text { In the } \\
\text { direct } \\
\text { Employ } \\
\text { of Oper- } \\
\text { atives. }\end{array}$ & 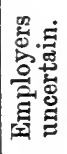 & $\begin{array}{l}\text { In the } \\
\text { direct } \\
\text { Employ } \\
\text { of } \\
\text { Masters. }\end{array}$ & $\begin{array}{l}\text { In the } \\
\text { direct } \\
\text { Employ } \\
\text { of Oper- } \\
\text { atives. }\end{array}$ & 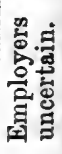 \\
\hline $\begin{array}{l}\text { Cleaning and } \\
\text { spreading cotton }\end{array}$ & 1330 & 2379 & 051 & 3 & 31 & 345 & & \\
\hline Carding . . & 10,361 & 15,062 & 4,983 & 461 & 78 & 8,099 & 458 & 163 \\
\hline Mule-spinning . & 22,727 & 5,196 & 3,038 & 23,634 & 257 & 1,255 & 8,663 & 82 \\
\hline Throstle-spinning & 793 & 3,000 & 1,409 & 25 & 100 & 2,203 & 19 & 160 \\
\hline Reeling & 722 & 11,208 & 182 & 25 & & 2,306 & 76 & 119 \\
\hline Wearing. & 20,440 & 28,566 & 4,581 & 2,582 & 204 & 12,109 & 4,261 & 119 \\
\hline Roller covering . & 261 & 389 & 19 & 3 & & 31 & 22 & $\ldots$ \\
\hline Engineers, etc. . & 3,759 & 34 & 151 & 9 & 19 & 3 & $\ldots$ & ... \\
\hline Total & 60,393 & 65,774 & 15,314 & 26,742 & 689 & 26,351 & 13,505 & 656 \\
\hline
\end{tabular}
to the Lancashire forms of inquiry, so as to show the probable number of persons employed in each of the eight branches or departments of cotton-working, and the aggregate amount of their net earnings per month." 


\begin{tabular}{|c|c|c|c|}
\hline Employed in & $\begin{array}{l}\text { Proportion } \\
\text { whose Age and } \\
\text { Sex are nncertain, } \\
\text { from a deficiency } \\
\text { in the Peturns. }\end{array}$ & $\begin{array}{c}\text { Total } \\
\text { Number } \\
\text { Employed. }\end{array}$ & $\begin{array}{c}\text { Aggregate Amount } \\
\text { of Monthly } \\
\text { Net Earnings. }\end{array}$ \\
\hline $\begin{array}{l}\text { Cleaning and spreading } \\
\text { cotton } \\
\text { Carding. } \\
\text { Mule-spinning : } \\
\text { Throstle-spinning : } \\
\text { Reeling. } \\
\text { Weaving : } \\
\text { Roller-covering : } \\
\text { Engineers, etc. }\end{array}$ & $\begin{array}{c}\ddot{819} \\
364 \\
\ldots \\
\ldots \\
2,193 \\
\ldots \\
\ldots\end{array}$ & $\begin{array}{r}4,998 \\
40,484 \\
65,216 \\
7,709 \\
14,638 \\
75,050 \\
725 \\
3,975\end{array}$ & $\begin{array}{rrr}\mathcal{L} & \text { s. } & \text { d. } \\
8,631 & 19 & 6 \\
75,276 & 10 & 0 \\
139,660 & 17 & 9 \\
11,615 & 10 & 1 \\
22,817 & 8 & 4 \\
168,663 & 16 & 3 \\
1,764 & 18 & 5 \\
15,987 & 0 & 9\end{array}$ \\
\hline Total & 3,376 & 212,795 & 444,418 \\
\hline
\end{tabular}

For spinning the quantities of cotton used in 1801 and subsequent periods, the following numbers of persons would be required :-

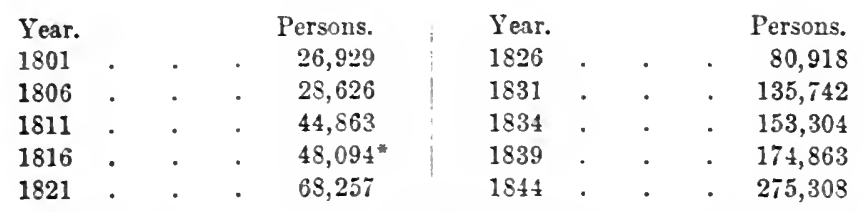

- Beginning of Peace. In 1814, the last year of war, the number would be 26,715 .

These numbers are exclusive of the persons who were employed in weaving in factories, who, it is estimated, amounted in 1832 to 75,055 . It would by no means furnish a correct view, however, if the amount of labour required for the conversion of the given quantities of cotton into yarn at the above-mentioned periods were taken at a uniform rate; for the vast improvements made in machinery must be considered. This fact is illustrated by the following statement, taken from the books of Thomas Houldsworth, an eminent cotton-spinner of Manchester, and laid before the Committee on Manufactures, Commerce, etc., which sat in 1833. It shows that, notwithstanding the great reduction in the rate of wages which accompanied the introduction of improved machinery, the actual money-earnings of the pperative spinner were greater in 1833 than at the beginning of the century, while his real wages gave him a still greater idvantage. 


\begin{tabular}{|c|c|c|c|c|c|c|c|c|c|c|}
\hline \multirow{2}{*}{ Year. } & \multicolumn{2}{|c|}{$\begin{array}{l}\text { Work turned off } \\
\text { by one Spinner } \\
\text { per Week. }\end{array}$} & \multicolumn{3}{|c|}{ Wages per Week. } & \multirow{2}{*}{$\begin{array}{l}\text { Hours } \\
\text { of } \\
\text { work } \\
\text { per } \\
\text { Week. }\end{array}$} & \multicolumn{2}{|c|}{$\begin{array}{l}\text { Prices from } \\
\text { Greenwich Hospital } \\
\text { Records. }\end{array}$} & \multicolumn{2}{|c|}{$\begin{array}{l}\text { Quantities which a } \\
\text { Week's Net Earnings } \\
\text { would purchase. }\end{array}$} \\
\hline & llss. & No. & Gross. & Piecers. & Net. & & $\begin{array}{c}\text { Flour } \\
\text { per Sack. }\end{array}$ & $\begin{array}{l}\text { Flesh } \\
\text { per lb. }\end{array}$ & $\begin{array}{l}\text { lbs. of } \\
\text { Flour. }\end{array}$ & $\begin{array}{l}\text { lbs. of } \\
\text { Flesh. }\end{array}$ \\
\hline & & & s. d. & s. d. & s. d. & & s. d. & d. d. & & \\
\hline 1804 & 12 & 180 & 600 & 276 & 326 & 74 & 830 & 6 to 7 & 117 & $62 \frac{1}{2}$ \\
\hline 1814 & 9 & 200 & $\begin{array}{lll}67 & 6\end{array}$ & 310 & 366 & 74 & 830 & 6 to 7 & 124 & $73^{\circ}$ \\
\hline 1814 & 18 & 180 & 720 & 276 & 446 & 74 & $70 \quad 6$ & 8 & 175 & 67 \\
\hline & $13 \frac{1}{2}$ & 200 & 900 & 300 & 600 & 74 & $70 \quad 6$ & 8 & 239 & 90 \\
\hline 1833 & $22 \frac{1}{2}$ & 180 & 548 & 210 & 338 & 69 & 450 & 6 & 210 & 67 \\
\hline ,, & $19^{\circ}$ & 200 & 653 & 226 & 429 & 69 & $\begin{array}{ll}45 & 0\end{array}$ & 6 & 267 & 85 \\
\hline
\end{tabular}

* The sack of flour is taken at $280 \mathrm{lb}$.

$N . B$. - The above is the result of an average of several men's work at the different periods.

It will be seen that, in 1833 , the number of hours employed during the week was 69 , instead of 74 , which it had been in the former years. But for this reduction in the time of working the net earnings would have been for No. 180, 36s. 1d., and for No. $200,45 \mathrm{~s} .10 \mathrm{~d}$; and the quantities of flour and meat would have been for No. 180, 224 lb. and 72 lb., and for No. 200, $285 \mathrm{lb}$. and $91 \mathrm{lb}$. respectively.

In the cotton-mill of Messrs. Houldsworths, in Glasgow, a spinner employed on a mule of 336 spindles and spinning cotton 120 hanks to the pound, produced, in 1823, working $74 \frac{1}{2}$ hours in the week, 46 pounds of yarn, his net weekly earnings for which amounted to $26 \mathrm{~s}$. $7 \mathrm{~d}$. In 1833 , the rate of wages having in the meanwhile been reduced $13 \frac{1}{3}$ per cent., and the time of working having been lessened to 69 hours, the spinner was enabled, by the greater perfection of the machinery, to produce, on a mule of the same number of spindles, $52 \frac{1}{2}$ pounds of yarn of the same fineness, and his net weekly earnings were advanced to $29 \mathrm{~s} .10 \mathrm{~d}$.

The art of printing on woven fabrics is of very ancient origin. Anderson, in his History of Commerce, states that it was first practised in London in 1676 . The first cotton printer in England is said to have been a Frenchman, whose print-ground was at Richmond, on the banks of the Thames. Owing to the interference of Parliament, first by the imposition of heavy duties, and afterwards by more direct restrictions, the trade was destroyed in 1720. The object of the Legislature in this proceeding appears to have been the encouragement of the silk and woollen manufactures. The restriction against wearing printed fabrics, of which cotton formed a part, was repealed in 1736 , and it was computed 
that, in 1750 , as many as 50,000 pieces of goods made of linenwarp and cotton-weft were printed in England. At that time no means had been devised for spinning cotton-yarn of a strength which fitted it for forming the warp. In about fifteen years thereafter, the printing business was introduced into Lancashire, and from that time appears to have grown in proportion to the increase of the cotton manufacture. But it was only during the nineteenth century that this branch of industry attained to any considerable importance. In consequence of the duty imposed upon printed cottons, we are acquainted with the quantity which has undergone the process at different periods up to the year 1831 , when the duty was wholly repealed.

\begin{tabular}{|c|c|c|c|}
\hline The quantity printed in 1796 was & & & $20,621,797$ \\
\hline In 1800 , it had increased to & & & $32,869,729$ \\
\hline In 1814 , it had further increased to & & . & $124,613,472$ \\
\hline And in 1830 , it had reached to. & & . & $347,450,299$ \\
\hline
\end{tabular}

being more than ten times the quantity printed at the beginning of the century, while on the other hand it is less by $55,971,101$ yards than the quantity exported in 1844 . The quantity printed in 1830 , after providing $199,799,466$ yards for exportation, left $147,650,833$ yards for use at home. This great increase is to be ascribed to numerous improvements, the chief of which was the substitution of metallic for wooden cylinders.

The policy of subjecting such an article as printed cottons to the burden and restrictions of the excise laws was always much questioned. To preserve our export trade, it was, of course, necessary, during the continuance of the duty, to grant a drawback upon shipment equal to the amount of the duty. The net revenue derived from the tax, on an average of the ten years preceding its repeal, was a little more than $\mathfrak{\$ 6 0 0 , 0 0 0}$ per annum; but in order to realize this sum to the Exchequer, the gross amount of duty levied during the same time averaged $£ 1,850,000$ per annum, more than two-thirds of the same being repaid as drawback upon quantities exported. This, in itself, was a great and acknowledged evil: it held out temptation, and opened the door to frauds, which, it is well known, were committed to a considerable extent; and besides this crying evil, the interference of revenue regulations placed many obstacles in the way of experiments and improvements, as we have since happily been able to ascertain. It is estimated that as a result of the removal of the duty and of the revenue officers from the printworks, the production of printed calico cloths was doubled. 
Various estimates were formed concerning the extent and value of the cotton manufacture in this kingdom in the earlier half of the nineteenth century. Mr. Dugald Bannatyne, in the Supplement to the Encyclopoedia Britannica, and Mr. M'Culloch, in the 1844 edition of his Dictionary of Commerce, both estimated the value of goods annually manufactured at the sum of thirty-four millions, and Mr. M'Culloch estimated the capital employed at the same sum, namely:-

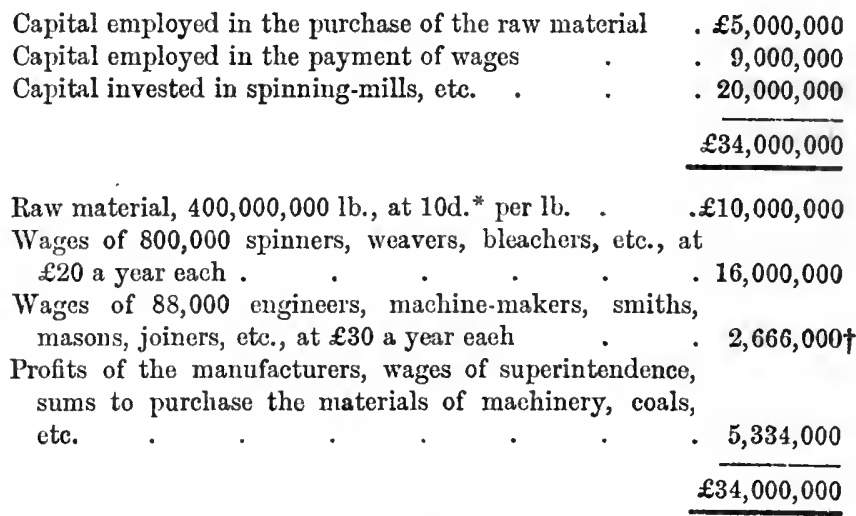

* So in original, the price should probably be $6 \mathrm{~d}$. per lb.

$\uparrow$ So in original.

Mr. Baines, by independent inquiries, arrived at substantially similar results.

\section{The Cotton Industry-1850-1910}

At the present time the manufacture of cotton goods is the second most important industry in Great Britain. With the exception of agriculture, it employs more people than any other section of our trade. Its operations are almost entirely confined to Lancashire; but some spinning factories and weaving sheds are to be found in Scotland and on the borders of Yorkshire and Cheshire. It is estimated that in the actual processes of spinning and weaving there are employed about 650,000 persons, and if we include the smaller auxiliary trades and the distribution of the manufactured goods, there are not far short of $3,000,000$ persons engaged in this enormous industry. The industry is entirely dependent upon foreign countries for its supply of raw material. The bulk of this comes from the United States, where the largest crop is grown. In 1821 only 370,000 bales were 
grown; in $1860,4,800,000$; in $1898,11,000,000$; in 1907 , $13,550,000$. In 1908 the crop fell to $11,500,000$ bales. Professor Chapman in The Cotton Industry and Trade gives the following table illustrating the enormous growth of the American production since the Revolution :-

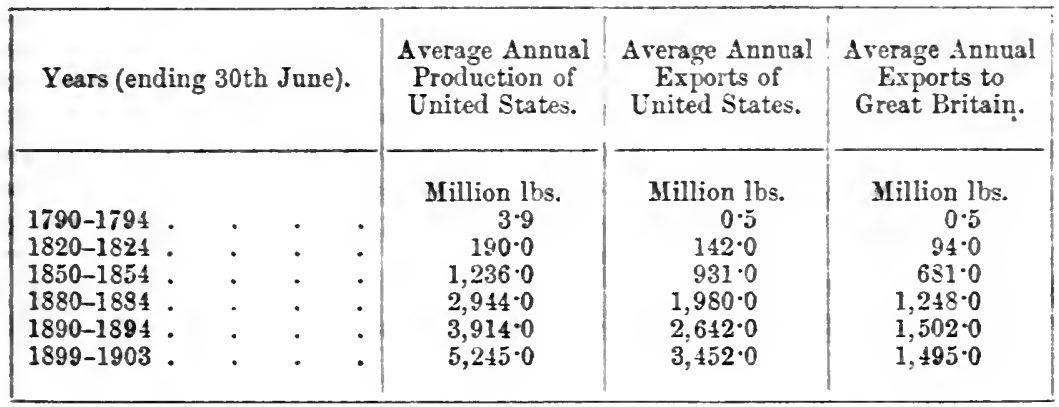

The American crop, however, has not kept pace with the need for cotton; thus, in the years 1870-71, 1880-81, 1898-91 and $1902-3$, the world's consumption of cotton in million bales advanced as follows : $4 \cdot 9,7 \cdot 2,10 \cdot 3,13 \cdot 7$; while the American crop, measured in the same way, moved from 4.4 in the first year to $6 \cdot 6,8 \cdot 7$, and 10.8 in the succeeding years. At the present time Great Britain absorbs 25 per cent. of the American crop. In recent years the percentage taken by Lancashire spiuners has decreased, chiefly owing to the tendency to produce finer counts of yarn, which, of course, require less raw material. An important source of supply is Egypt, and Lancashire takes quite 50 per cent. of the amount exported. Of late, the demand for this class of cotton has increased. The East Indian staple is now used very little in this country, but the supply is. important, as it eases the demand for American and Egyptian qualities, which are so extensively used in Lancashire. In 1910 two deputations of Indian and Lancashire Cotton Spinners waited upon the Secretary of State for India to express the anxiety of the trade as to the Indian supply. The speeches delivered on these occasions throw considerable light upon the question of cotton supplies. Sir C. W. (then Mr.) Macara, the distinguished President of the Master Cotton Spinners' Federation and perhaps the greatest living authority on the cotton industry, said :-

"It is of the utmost importance for the cottou industry of the world that cotton growing in India shall be developed to the full. We have had an immense extension of the Indian crop within the last few vears. Now it is very 
nearly half as large as the American crop, and the secretary of the International Cotton Federation, Mr. Arno Schmidt, who went to India to investigate what could be done, returned with the report that in a comparatively few years the Indian crop might be doubled. For a considerable number of years the idea has been prevalent that Indian cotton is of no value to Lancashire. That is not the case ; if the staple is improved Lancashire can use Indian cotton largely. Much attention has recently been drawn to the position England holds in the cotton industry to-day compared with the position say thirty-five years ago. I should like it to be borne in mind that thirty-five years ago, so far as we know, the annual cotton crop of the world was about $7,000,000$ bales. It is now about $20,000,000$ bales, and it would have been utterlyimpossible for a nation of $44,000,000$ people, although showing continued progression, to maintain the same relative position with that tremendous increase of raw material and the tremendous increase of the demand for cotton cloth, owing to the rapidly increasing population of the world. We in England are primarily indebted for our pre-eminent position to our great inventors, and to the intelligence, energy, enterprise, and skill of our machinists, spinners, manufacturers, merchants, and operatives."

And speaking on the same subject Lord Morley (then Secretary of State for India) said:-

"The three chief things in relation to cotton production in India are the areas under cultivation, the yield, and the quantity exported. Twelve or fourteen years ago the Indian cotton crop represented barely 3,000,000 bales, and the acreage was about $15,000,000$ acres. Within the last few years the acreage has increased to $20,000,000$ acres and upwards, and the yield in a fair average year is well over 4,000,000 bales. (The Indian bale, I believe, is one-fifth less than the American bale.) Last year's crop, instead of being 3,000,000 bales as it was twelve years ago, was returned at $4 \frac{1}{2}$ million bales; and as these returns are under-estimates, the probability is that the Indian cotton crop approached, even if it did not exceed, 5,000,000 bales. India, in fact, is the second largest producer of cotton in the world. The average export during the ten years ending 1900 was $1,300,000$ bales, but the average export of late years has been over 2,000,000 bales. In the year ending 31st of March 1910 it exceeded $2 \frac{1}{2}$ million bales. These are very remarkable figures, and they are encouraging."

Professor Chapman in his standard work on the cotton industry shows the striking changes which have taken place as regards the sources from which Great Britain draws her cotton, since the closing years of the eighteenth century. In 1786-1790 the British West Indies contributed 75 per cent. of the cotton received by Great Britain, the Mediterranean comtries 19 per cent., Brazil 8 per cent, the United States and India less than 1 per cent., and Egypt none at all. The following table shows the average quantities of raw cotton imported annually into the United Kingdom in the periods 1896-1900 and 1901-1904. 
1896-1900. 1901-1904.

Million lbs. Million lbs.

United States

Brazil.

Peru.

Chile (including the Pacific coast of Patagonia)

Venezuela and Colombia

British West Indian Islands and British Guiana

Turkey (European and Asiatic)

Egypt

British possessions in the East Indies

Austraiasia .

All other countries
$424 \cdot 0$

$31 \cdot 5$

$8 \cdot 6$

$2 \cdot 2$

0.5

$0 \cdot 6$

$1 \cdot 1$

$314 \cdot 4$

$61 \cdot 9$

$40 \cdot 7$

0.011

$3 \cdot 8$

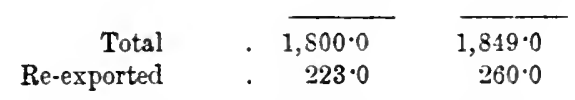

It would appear that the United States, India and Egypt now supply about four-fifths of all the cotton used in the world. They export to Great Britain something over nine-tenths of all the cotton she receives.

The following estimates of our total consumption of raw cotton are taken from Ellison's Handbook of the Cotton Trade, supplemented by the Board of Trade figures from 1854 onwards:-

\begin{tabular}{|c|c|c|c|c|c|c|c|}
\hline 1781 & . & . & . & • & . & . & $10,900,00011$ \\
\hline 1790 & . & . & . & . & . & . & $30,600,000$, \\
\hline 1800 & . & . & . & . & . & . & $51,600,000$ ： \\
\hline \multicolumn{4}{|c|}{ The arerage of 1800 to 1814} & . & - & - & $64,100,000$ \\
\hline \multirow{2}{*}{\multicolumn{4}{|c|}{$\begin{array}{l}\text { The average of } 1815 \text { to } 1829 \\
\text { The average of } 1830 \text { to } 1844\end{array}$}} & . & . & . & $144,000,000$ \\
\hline & & & & - & . & - & $373,400,000$ \\
\hline 1845 & . & . & . & . & . & . & $592,000,000$ \\
\hline 1856 & . & . & . & . & . & . & $920,000,000$ \\
\hline 1860 & • & . & . & . & . & - & $1,0 \$ 6,400,000$ \\
\hline 1870 & . & . & . & . & - & . & $1,075,200,000$ \\
\hline 1880 & . & . & . & . & . & . & $1,377,600,000$ \\
\hline 1890 & . & . & . & . & . & - & $1,657,600,000$ \\
\hline 1900 & . & . & . & . & . & . & $1,621,000,000$ \\
\hline 1908 & . & . & . & . & . & . & $1,721,800,000$ \\
\hline
\end{tabular}

Thus in the sixty-three years from 1845 to 1908 the total increase of cotton consumption was 1,132,800,000 lb., as compared with the increase of $587,200,000 \mathrm{lb}$. in the seventy years preceding.

During the latter period, it may be noted, there has also been a continuous tendency towards finer counts and finer eloths. The consumption of cotton for each working spindle has decreased. At the same time, the speed of the looms, the number of the looms per weaver, and the number of spindles per mule have increased. 
Finally, we may quote the statistics published in September 1910 by the International Federation of Master Cotton Spinners' and Manufacturers' Associations, which incidentally illustrate the highly organized character of the world's cotton industry. The table on opposite page shows the world's consumption of cotton for the year ending August 31, 1910.

The total stocks of cotton in spinners' hands throughout the world on August 31, 1910 were :-

\begin{tabular}{|c|c|c|c|c|c|c|c|}
\hline American & . & . & . & . & . & $1,123,826$ & bales \\
\hline East Indian & . & . & . & . & . & 995,892 & \\
\hline Egyptian & . & . & . & . & . & 111,718 & \\
\hline Sundries & . & . & . & . & . & 292,350 & \\
\hline
\end{tabular}

On the same date the estimated number of spindles at work throughout the world was $133,384,794$, as compared with $131,503,062$ in the previous year, $128,923,659$ in 1908 , and $114,096,168$ in 1907 .

Liverpool is the great raw cotton market through which spinners secure the bulk of their supplies, and the spot market there governs prices. Manchester, through the Ship Canal, is rapidly becoming a leading centre for the distribution of the raw material, especially in Egyptian descriptions. But probably not much further advance in this direction can be made until a spot market is established in Manchester. The spinning section of the industry is chiefly carried on in South and South-East Lancashire. The finer counts of yarn are spun in Bolton and district, but during the last few years several mills to spin fine yarns have been put up in the more southern part of the county, notably in Ashton-underLyne and Stalybridge. There are also several factories where extra fine numbers are produced in the Manchester district, most of the mills having a trade of a special character. The great spinning centre is Oldham, where coarse to medium counts are spun. The weaving sheds for the manufacture of cotton piece goods are spread over the whole of the county, but the bulk of the trade is carried on in the northern part of Lancashire. The finest fabrics are produced in Blackburn and district, and there are several firms who make special fancy cloths in Preston and Accrington. The heavier kinds of material are manufactured in Bury, Todmorden, the Rossendale Valley, and the Whitworth Valley. Burnley is an important weaving town, and here goods suitable for printing are extensively made, while in the neighbouring towns of Nelson and 


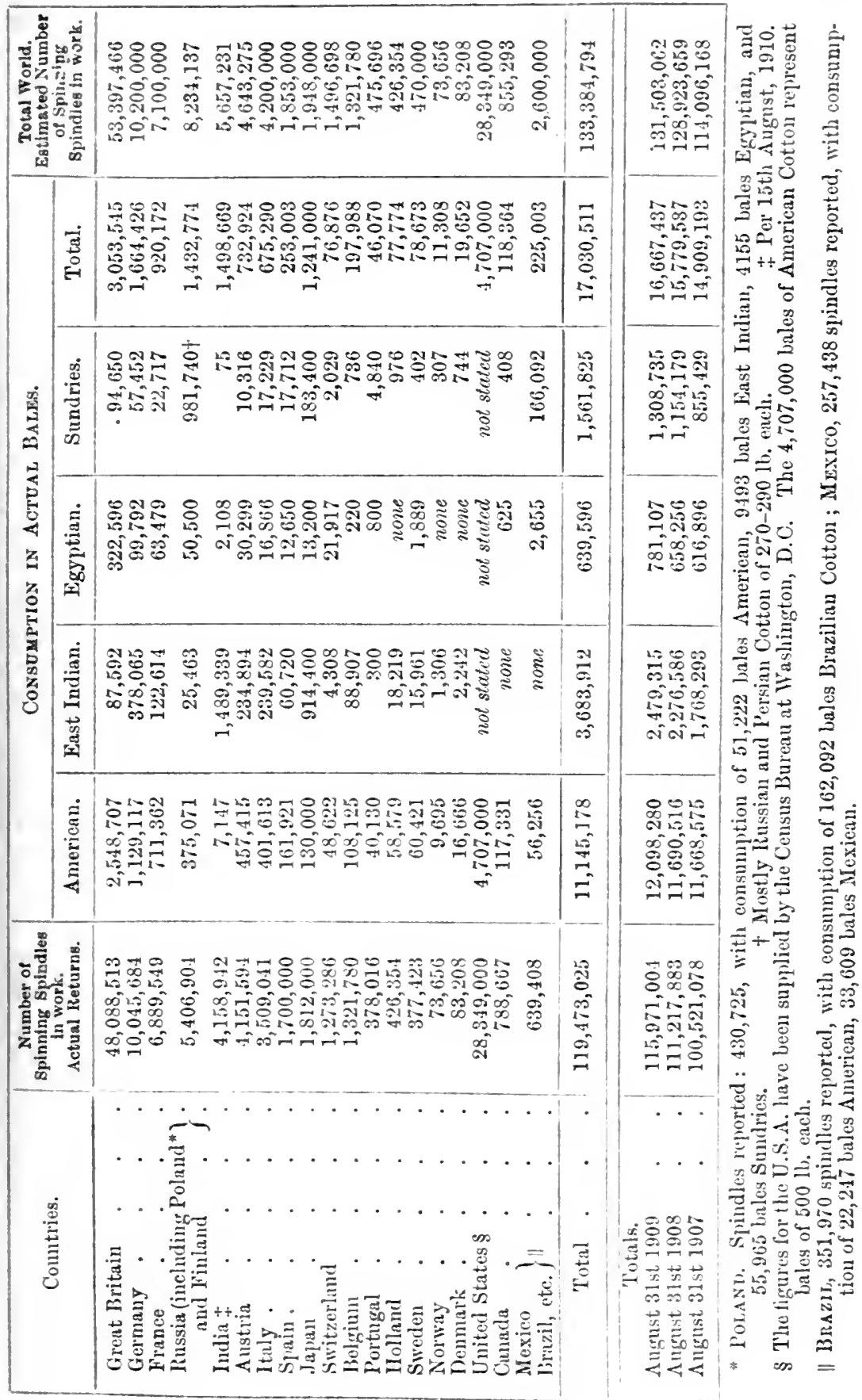


Colne coloured and dyed goods are produced on a large scale. The calico printing industry is not confined to any particular district, but there are several works in and around Manchester, and notably near Hayfield. Bleaching concerns are also spread over Lancashire, and in some instances works are attached to the weaving sheds.

In a manifesto addressed in 1909 to the President of the Board of Trade, Sir C. W. Macara wrote :-

"Lancashire, the centre of the cotton industry of England, has during the last fifty years doubled her population; she has also doubled her cotton machinery, considerably improved its efficiency, and increased the speed at which it is run, with the result that not only is there a proportionately greater output, but the output is of immensely increased valne. The importance of the cotton industry of England may be judged from the fact that its products, in addition to providing for our home requirements, represent about a third of our total exports of manufactures. This export trade is about three-quarters of the production of our $53 \frac{1}{2}$ million spindles and the dependent machinery. These exports go to the great nentral markets, as well as largely to the countries which have a cotton industry of their own, forming part of their exports. There are something like 78 million spindles in the other twenty-one cotton manufacturing countries. Next in importance to England comes the United States of America, with 28 million spindles; then on the continent of Europe, Germany leads with 10 million spindles; in the Far East there are in India $5 \frac{1}{2}$ million spindles, and about $1 \frac{1}{2}$ million spindles in Japan. In round figures, the cotton crop of the world now averages about 20 million bales, and a common fallacy is to gauge the value of the cotton industry by the weight of raw cotton consumed. England, with considerably over one-third of the spindles of the world, consumes annually 4 million bales of cotton, whereas the United States of America, with about half the number of spindles there are in England, consumes 5 million bales, and Germany, with considerably less than a fifth of the spindles in England, consumes $1 \frac{3}{4}$ million bales. The value of the cotton trade of the respective countries can really only be ganged by the extent oî the machinery, the labour employed, the fineness, variety, excellence, and value of the fabrics produced."

For some account of the movement of wages since 1850 we may turn to a valuable statistical work compiled by Mr. G. H. Wood entitled The History of Wages in the Cotton Trade during the Past Hundred Years, and published in 1910. The first district with which Mr. Wood deals is the Manchester district. Here the average wages of the card-room males have increased by not less than 120 per cent. from the lowest point in the middle of the century to 1906 .

"The wages of the card-and blowing-room females and throstle spinners rose progressively from 1850 to the middle of the 'seventies, falling away thereafter, but again advancing and reaching in 1906 a higher figure than ever before. The wages of the spinners rose from 21s. 8d. in 1841 to 41s. 5d. in 1906. Those of the piecers more than doubled. Wearers' wages advanced by nearly 100 per 
cent., winders-by about 70 per cent., reelers and overlookers by about 55 per cent. Including those working on short time and overtime, as well as those working the normal week, a fall of 13 per cent. in the whole district in the first half of the century was replaced by an increase of over 80 per cent. in the second half. Other districts have much the same tale to tell. In the Oldham centre, where the weaving of fustians and velveteens is the chief industry, spinners' wages rose from $24 \mathrm{~s}$. in the 'forties to $41 \mathrm{~s}$. $10 \mathrm{~d}$. in 1906 , and a state of affairs, in which wages were practically stationary during the first half of the century, was replaced in the second half by an increase of 91 per cent. In the Bolton district, which is a centre, not only for ordinary calicoes, but also for the weaving of quilts, etc., on broad looms, weavers' wages have increased continuously from 10s. 1d. in 1851 to $17 \mathrm{~s} .7 \mathrm{~d}$. in 1906 , and $18 \mathrm{~s}$. $4 \mathrm{~d}$. in 1909 . The average of all employés in the district shows an increase of 80 per cent. since the middle of last century. In the Ashton-under-Lyne district, the average wage of all occupied has risen from 10s. 7 d. in 1833 to $19 \mathrm{~s} .5 \mathrm{~d}$. in 1906, or an increase of 83 per cent. In Stockport and the neighbourhood, the rise has been from 10s. 11d. to 19s. $2 \mathrm{~d}$. or 75 per cent. In Clitheroe, a fall in wages down to 1850 has been replaced by an increase of no less than 157 per cent., or from $7 \mathrm{~s} .5 \mathrm{~d}$. to $19 \mathrm{~s}$. 3d., and $21 \mathrm{~s}$. in 1909. Preston shows an increase of 120 per cent., or from $8 s .3 \mathrm{~d}$. to $18 \mathrm{~s}$. $6 \mathrm{~d}$. Blackburn shows an increase of 127 per cent., or from $8 \mathrm{~s} .9 \mathrm{~d}$. to 20s. 8d. In Burnley, which is the centre for coloured goods, fast looms, and a high number of looms per weaver, the average wage for each operative was, in 1906, 23s. 10d., 2s. 10d. per week higher than in any other textile district in the United Kingdom, with the exception of the lace districts of Nottingham and Derby. In Burnley, 233. 10d. was the average of the women's wage also. In 1886, the arerage was 17. 10d., showing an increase of 33 per cent. in twenty years. In Rochdale, Bury, Bacup, and Todmorden, the average wage in 1833 was 9s. 2d., in 1906 19s. 6d.an increase of 112 per cent. For the Yorkshire district, mainly Halifax, Brighouse and Slaithwaite, the figures are very incomplete, but everything points to a considerable advance in the latter half of the century."

The history of the industry in the Scottish centres has been entirely unlike that in Lancashire. About a hundred years ago one-seventh of the cotton product of the United Kingdom was Scotch; at the present time the proportion is extremely small. Nevertheless, wages were reduced in this district before 1831 , and a fall of 7 per cent. in the 'thirties and 'forties has been replaced by an increase of 97 per cent. up to 1906 , the average wage having increased from $7 \mathrm{~s}$. $5 \mathrm{~d}$. to $14 \mathrm{~s}$. 9d. Mr. Wood combines all these varying averages for the different districts into one inclusive figure for the whole country, and finds that, on the average, the weekly wage of all cotton operatives has increased from $9 \mathrm{~s} .2 \mathrm{~d}$. in $1 S 50$ to $19 \mathrm{~s}$. $7 \mathrm{~d}$. in 1906 . "We are tolerably safe in saying," is his conclusion, "that the average wages of cotton factory operatives in the United Kingdom have advanced by more than 100 per cent. between 1832 to 1850 and 1906 ; that between 1810 and 1832 a fall of about 10 per cent. took place; that from 
the lowest point, which was reached in the great trade depression of 1847 to 1849 , to the maximum of the 'seventies, the advance was about 75 per cent.; that a series of reductions reduced the maximum earnings of the 'seventies by about 10 per cent., and that, by 1906 , the average was not only higher than was ever reached before, but was about 20 per cent. higher than the highest point reached in the 'seventies, and about 35 per cent. higher than the lowest point of the previous thirty years (i.e. 1879)." Down to 1840 there was a continuous fall in wages; in the 'forties there was little change, and 1850 saw the factory minimum. In the 'fifties and 'sixties wages were rising, in the 'seventies there was a further rise, and then a fall, and a recovery in 1881. In the 'nineties they were again slowly rising. From 1900 to 1906 there was a quick rise, and wages are now double what they were in the middle of the nineteenth century.

This enormous increase was not confined to any one class of operatives, but was experienced by all in different degrees. The least to benefit have been the weavers' helpers, but Mr. Wood points out that they have the satisfaction of in time becoming weavers themselves. The wages of frame-tenters, strippers, grinders, piecers, and ring spinners have advanced by more than 100 per cent., those of drawing-frame tenters by nearly 200 per cent.; winders, warpers and weavers by 90 per cent., and reelers by 50 per cent.

But the cotton operative has benefited, not only by having his wages doubled and by having his cost of living decreased by onequarter, but also by having his hours of labour decreased during the whole period under review. At the end of the eighteenth century it was customary to work eighty hours per week, a period which, during the first half of the last century, was gradually decreased to sixty hours about the year 1860 . Up to 1875 , sixty hours remained the working week; in the 'seventies, it was again reduced to fifty-nine; and from 1875 to $1902,56 \frac{1}{2}$ hours were worked; after 1902 , only $55 \frac{1}{2}$ hours a week were worked. The increase of 100 per cent. in wages was accompanied not only by a decrease of 24 per cent. in the cost of living, but also by a decrease of over 30 per cent. in the hours of labour. Further, Mr. Wood concludes that the reductions in the number of hours have in no case been followed by decreased earnings, and that they have not prevented wages from rising. Mr. Wood calculates that, from 1860, 13 per cent. of the increased wages, or $1 \mathrm{~s}$. $6 \mathrm{~d}$., has been due to the employment of relatively more adults and less children. The 
the past fifty years. The following passages from Mr. Wood's book explain the chief developments :-

"In 1833 the hand mule usually had 300 to 400 spindles, and the self-actors 360 to 480 . In the 'seventies the average might be put at from 720 to 960 ; to-day 1080 is a usual size. Speeds have increased very considerably. In 1830 Ure speaks of 3800 to 5000 revolutions of the spindles per minute. To-day the speed is from 8000 to 9000 . In 1876, when the Oldham spinning list was adopted, the standard number of draws, i.e. journeys in and out of the carriage which contains the spindles, was three in fifty seconds; to-day it is three in forty-two seconds.

"Turning to weaving we find an equally wonderful development of efficiency has taken place. The power-loom was invented in 1785 and patented in 1787 . For many years it came into use but slowly. Gradually improvements were made, and by 1813 it had assumed a form which has been little altered since. From that time to 1830 an enormous number were erected. Between 1833 and 1882 the improvements made trebled its producing power."

The following table shows the extent and growth of our machinery :-

\section{Machinery in the United Kingdom (in thousands)}

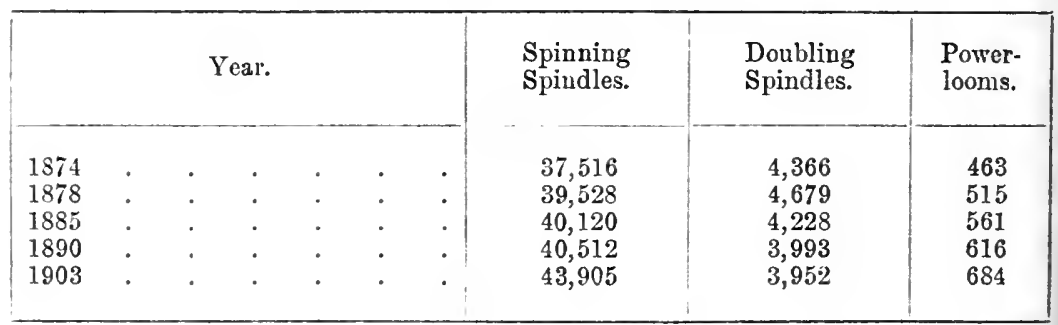

Turning to the census returns, we obtain a statement of the operatives employed in the cotton industry. The totals (in thousands) are:-

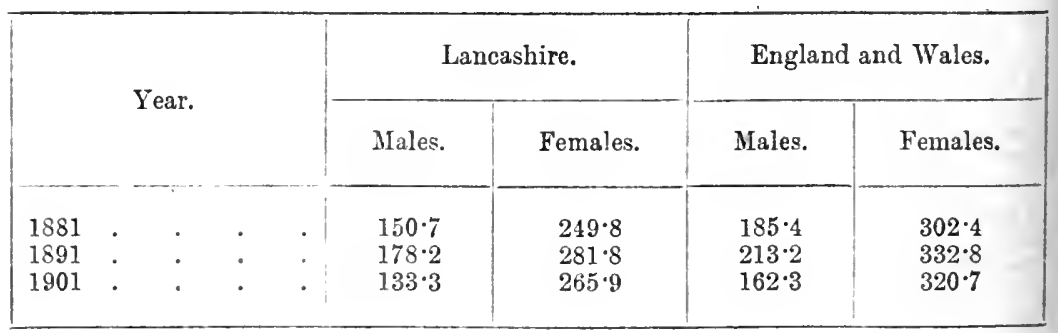

The 1901 statistics are further classified as follows (the figures in italics relate to married and widowed women):- 


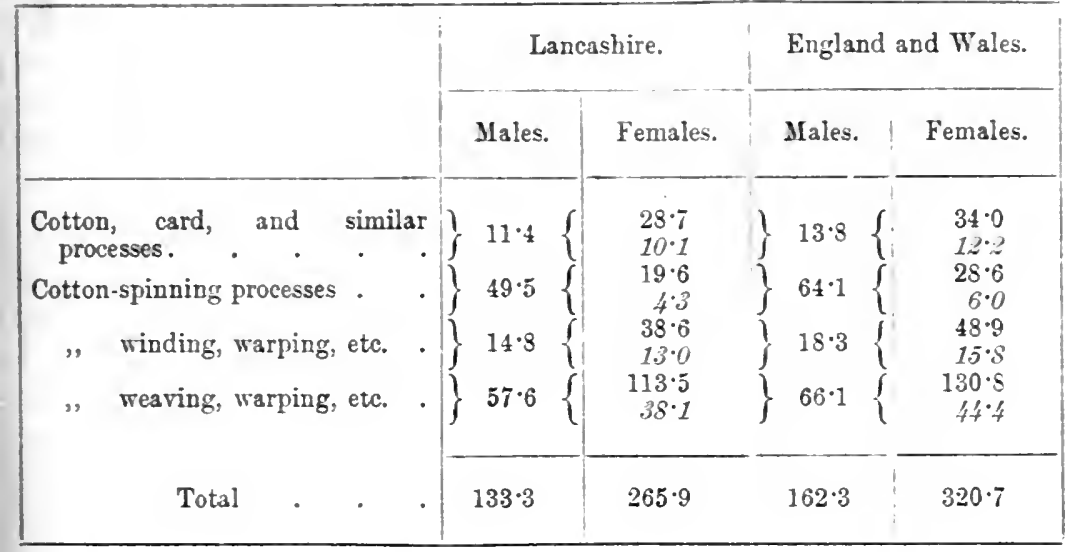

Our next table shows the number of operatives employed in cotton factories in the United Kingdom, and are further classified according to age. They are based on the returns of Factory Inspectors.

\section{Operatives Employed in Cotton Factories and Percentages of each Class}

\begin{tabular}{|c|c|c|c|c|c|c|c|}
\hline & 1835. & 1538. & 1817. & 1850. & 1856. & 1862. & 1867. \\
\hline $\begin{array}{l}\text { Males and females under } \\
13 \text {, or half-timers : } \\
\text { Males, } 13 \text { to } 18 \text {. } \\
\text { Males, over } 18 \\
\text { Females, over } 13\end{array}$ & $\begin{array}{l}13 \cdot 2 \\
12 \cdot 5 \\
26 \cdot 4 \\
47 \cdot 9\end{array}$ & $\begin{array}{l}45 \cdot 7 \\
16 \cdot 6 \\
24 \cdot 9 \\
53 \cdot 8\end{array}$ & $\begin{array}{r}5 \cdot 8 \\
11 \cdot 8 \\
27 \cdot 1 \\
55 \cdot 3\end{array}$ & $\begin{array}{r}4 \cdot 6 \\
11 \cdot 2 \\
28 \cdot 7 \\
55 \cdot 5\end{array}$ & $\begin{array}{r}6 \cdot 5 \\
10 \cdot 3 \\
27 \cdot 4 \\
55 \cdot 8\end{array}$ & $\begin{array}{r}8 \cdot 8 \\
9 \cdot 1 \\
26 \cdot 4 \\
55 \cdot 7\end{array}$ & $\begin{array}{r}10 \cdot 4 \\
8 \cdot 6 \\
26.0 \\
55.0\end{array}$ \\
\hline $\left.\begin{array}{l}\text { Total number of } \\
\text { cotton operatives }\end{array}\right\}$ & 218,000 & 259,500 & 316,400 & 331,000 & 379,300 & 451,600 & 401,100 \\
\hline & 1870. & 1874. & 1878. & 1885. & 1890 & 1895. & 1901. \\
\hline $\begin{array}{l}\text { Males and females under } \\
\text { 13, or half-timers } \\
\text { Males, } 13 \text { to } 18 \text {. } \\
\text { Males, over } 18 \\
\text { Females, over } 13\end{array}$ & $\begin{array}{r}9 \cdot 6 \\
8 \cdot 5 \\
26 \cdot 0 \\
55 \cdot 9\end{array}$ & $\begin{array}{r}14 \cdot 0 \\
8 \cdot 0 \\
24 \cdot 1 \\
53 \cdot 9\end{array}$ & $\begin{array}{r}12 \cdot 8 \\
7 \cdot 2 \\
25 \cdot 3 \\
54 \cdot 7\end{array}$ & $\begin{array}{r}9 \cdot 9 \\
7 \cdot 9 \\
26 \cdot 4 \\
55 \cdot 8\end{array}$ & $\begin{array}{r}9 \cdot 1 \\
8 \cdot 2 \\
26 \cdot 9 \\
55 \cdot 8\end{array}$ & $\begin{array}{r}5.8 \\
7.9 \\
27 \cdot 6 \\
58.7\end{array}$ & $\begin{array}{r}4 \cdot 1 \\
7 \cdot 0 \\
27 \cdot 8 \\
61 \cdot 1\end{array}$ \\
\hline $\begin{array}{l}\text { Total number of } \\
\text { cotton operatives }\end{array}$ & 450,100 & 479,600 & 483,000 & 504,100 & 528,800 & 538,900 & 513,000 \\
\hline
\end{tabular}

A further table (from the census returns) shows the number of ${ }^{\circ}$ operatives engaged in spinning, manufacturing and subsidiary 
processes (excluding lace-making but including the fustian manufacture) :-

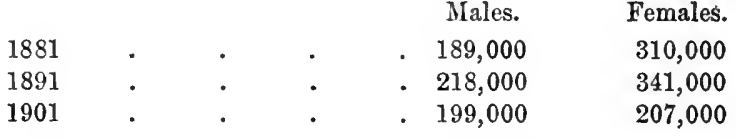

The following table (from special returns made by Factory Inspectors) shows the number of operatives engaged in the cotton industry, distinguishing the process, age, and sex :-

Spinning and Preparatory Purposes

\begin{tabular}{|c|c|c|c|c|c|c|c|}
\hline \multirow{2}{*}{ Years. } & \multicolumn{3}{|c|}{ Males in Thousands. } & \multicolumn{3}{|c|}{ Females in Thousands. } & \multirow{2}{*}{$\begin{array}{c}\text { Total } \\
\text { in } \\
\text { Thou- } \\
\text { sands. }\end{array}$} \\
\hline & $\begin{array}{l}\text { Half- } \\
\text { timers. }\end{array}$ & $\begin{array}{c}\text { Under } \\
18 .\end{array}$ & $\begin{array}{l}18 \text { and } \\
\text { over. }\end{array}$ & $\begin{array}{l}\text { Half- } \\
\text { timers. }\end{array}$ & $\begin{array}{c}\text { Under } \\
18 .\end{array}$ & $\begin{array}{l}18 \text { and } \\
\text { over. }\end{array}$ & \\
\hline $\begin{array}{l}1896 . \\
1898-1899^{*} \\
1901 .\end{array}$ & $\begin{array}{l}5 \cdot 58 \\
5 \cdot 42 \\
4 \cdot 98\end{array}$ & $\begin{array}{l}22 \cdot 24 \\
21 \cdot 57 \\
21 \cdot 10\end{array}$ & $\begin{array}{l}71 \cdot 44 \\
71 \cdot 37 \\
68 \cdot 98\end{array}$ & $\begin{array}{l}4 \cdot 40 \\
3 \cdot 86 \\
3 \cdot 10\end{array}$ & $\begin{array}{l}30 \cdot 12 \\
30 \cdot 44 \\
30 \cdot 98\end{array}$ & $\begin{array}{l}78 \cdot 69 \\
77 \cdot 64 \\
81 \cdot 68\end{array}$ & $\begin{array}{l}212 \\
210 \\
211\end{array}$ \\
\hline \multicolumn{8}{|c|}{ Weaving and Preparatory Purposes } \\
\hline $\begin{array}{l}1896 . \\
1898-1899^{*} \\
1901 .\end{array}$ & $\begin{array}{l}7 \cdot 54 \\
6 \cdot 21 \\
4 \cdot 72\end{array}$ & $\begin{array}{l}18 \cdot 79 \\
17 \cdot 29 \\
14 \cdot 86\end{array}$ & $\begin{array}{l}75 \cdot 81 \\
72 \cdot 74 \\
73 \cdot 81\end{array}$ & $\begin{array}{c}11 \cdot 87 \\
10 \cdot 38 \\
8 \cdot 0\end{array}$ & $\begin{array}{l}49 \cdot 19 \\
48 \cdot 38 \\
45 \cdot 66\end{array}$ & $\begin{array}{l}151 \cdot 34 \\
150 \cdot 99 \\
155 \cdot 03\end{array}$ & $\begin{array}{l}315 \\
306 \\
302\end{array}$ \\
\hline
\end{tabular}

* Average for 1898 and 1899 .

Professor Chapman, commenting upon the above table, writes: "The most noticeable features are the decrease in the proportion of children employed, and the steady increase in the number of operatives as a whole until recent years." In Scotland there are less than 15,000 cotton operatives distributed as follows:-

Card- and colouring-room processes

In Thousands.

Spinning-room processes

Winding, warping, etc.

Weaving, warping, etc.

Workers in other processes or undefined

Total

$$
\begin{array}{r}
.0 .4 \\
. \quad 2.1 \\
. \quad 2.7 \\
. \quad 6.8 \\
. \quad 2.8 \\
\hline 14.8
\end{array}
$$

The bulk of the cotton cloths produced in this country is shipped to foreign countries, especially the Eastern markets. India absorbs about 40 per cent. of the goods which are exported from 
Great Britain, and there is a tendency for her requirements to increase. China is an important market, and the shipments to the Near Eastern outlets, and also to the markets of South America, are of a substantial character. It is estimated that only about 20 per cent. of the goods produced in this country are iconsumed by the home population, but such fabrics are of a better quality than those shipped abroad. The export trade in manufactured cotton goods from this country is in money value the greatest export trade in manufactured goods of any kind from any country in the world. Our total exports of manufactured cotton goods during the five years $1905-1909$ raried from $£ 92,000,000$

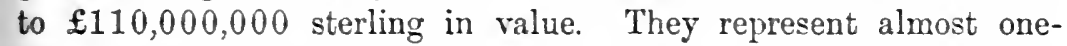
third of our total exports of manufactured goods. They equal almost half of the total value of manufactured goods exported from Germany, and come within $£ 20,000,000$ of the total of manufactured goods exported from France. The following table, compiled by Professor Chapman, offers a broad statistical survey of the course of British trade :-

\begin{tabular}{|c|c|c|c|c|c|c|c|c|c|}
\hline \multirow[b]{2}{*}{ Years. } & & \multirow{2}{*}{$\begin{array}{l}\text { Imports } \\
\text { of Raw } \\
\text { Cotton. }\end{array}$} & \multirow{2}{*}{$\begin{array}{c}\text { Raw } \\
\text { Cotton } \\
\text { Re-ex- } \\
\text { ported. }\end{array}$} & \multicolumn{3}{|c|}{$\begin{array}{c}\text { Exports of Cotton Yarns } \\
\text { and linufactures. }\end{array}$} & \multicolumn{3}{|c|}{$\begin{array}{c}\text { Imports of Cotton Yarns } \\
\text { and Manufactures. }\end{array}$} \\
\hline & & & & 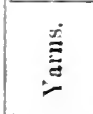 & 总莣 & $\stackrel{\vec{\pi}}{\frac{\pi}{0}}$ & $\stackrel{\dot{E}}{\stackrel{ \pm}{E}}$ & 主导 & 通 \\
\hline & & million lb. & million $\mathrm{ib}$ & million $t^{2}$ & million $£$ & million $\mathrm{E}$. & . million $\mathrm{E}$ & million $\mathcal{E}$ & million $\mathrm{f}$ \\
\hline $1700-1705$ & - & 1.17 & $\ldots$ & $\ldots$ & $\cdots$ & $\quad \ldots$ & ; $\quad \cdots$ & $1 \quad \ldots$ & $\ldots$ \\
\hline $1771-17.5$ & . & $4 \cdot 76$ & $\ldots$ & $\ldots$ & $\ldots$ & $\ldots$ & $\cdots$ & $\ldots$ & $\ldots$ \\
\hline $1785-1789$ & . & $\ldots$ & $\ldots$ & $\ldots$ & $\ldots$ & $1 \cdot 07$ & $\ldots$ & $\ldots$ & $\ldots$ \\
\hline $1791-1795$ & . & $2 b^{\circ} 00$ & $\ldots$ & $\ldots$ & $\ldots$ & 2.09 & $\ldots$ &.. & $\ldots$ \\
\hline $1816-1820$ & . & $139 \cdot 00$ & $10 \cdot 6$ & 2.5 & $13 \cdot 8$ & $16 \cdot 30$ & $\ldots$ & $\ldots$ & $\ldots$ \\
\hline $1831-1835$ & & $313 \cdot 00$ & $23 \cdot 0$ & 48 & $14 \cdot 2$ & $19 \cdot 00$ & $\ldots$ & $\ldots$ & $\ldots$ \\
\hline $1851-1855$ & . & 8.2 .00 & $124 \cdot 0$ & 6.8 & $24 \cdot 9$ & $31 \% 0$ & $\ldots$ & & \\
\hline $1876-18 s 0$ & . & 1456.00 & $180 \cdot 0$ & $12 \cdot \frac{1}{2}$ & $56 \cdot 1$ & $68 \cdot 30$ & $\ldots$ & $2 \cdot 29$ & $2 \cdot 29$ \\
\hline $1891-1895$ & . & 1716.00 & $21 \% \cdot 0$ & $9 \cdot 7$ & $5 b^{\circ} \cdot 6$ & $66 \cdot 30$ & $\cdot 42$ & $2 \cdot \%$ & $3 \cdot 20$ \\
\hline $1896-1900$ & . & 1795.00 & $223 \cdot 0$ & $8 \cdot 9$ & $58 \cdot 2$ & $67 \cdot 10$ & $\cdot 25$ & $4 \cdot 2 \tau$ & $4 \cdot 53$ \\
\hline $1901-1905$ & . & 1920.00 & 26500 & $8 \cdot 4$ & 70.7 & $79 \cdot 10$ & $\cdot 22$ & $5 \cdot 10$ & $5 \cdot 32$ \\
\hline
\end{tabular}

The average searly values of the exports of cotton, yarn and cloth from Great Britain for the decades 1881-1890 and 18911900 respectively are griven by Professor Chapman in his Cotton Industry and Trade (in million pounds):--

Cloth 1881-1890.

$1891-1200$.

Yarn. $£$ $\pm 57 \cdot 3$ 
The following is a comparison of our exports of cotton yarn and cotton manufactures in 1895 and 1909 :-

Exports of Cotton Yarn

\begin{tabular}{|c|c|c|c|c|c|}
\hline & & \multicolumn{2}{|c|}{1895.} & \multicolumn{2}{|c|}{1909.} \\
\hline $\begin{array}{l}\text { Yarn, grey } \\
\quad, \quad \text { bleached and dyed }\end{array}$ & $\dot{.}$ & $\begin{array}{c}\text { lbs. } \\
211,521,600 \\
40,467,400\end{array}$ & $\begin{array}{c}£ \\
7,455,996 \\
1,835,199\end{array}$ & $\begin{array}{c}\text { lbs. } \\
181,969,800 \\
33,253,600\end{array}$ & $\begin{array}{c}\mathfrak{E} \\
9,927,316 \\
1,894,829\end{array}$ \\
\hline Total & • & $251,989,000$ & $9,291,195$ & $215,223,400$ & $11,822,145$ \\
\hline
\end{tabular}

Exports of Cotton Manufactures (in thousands of yards)

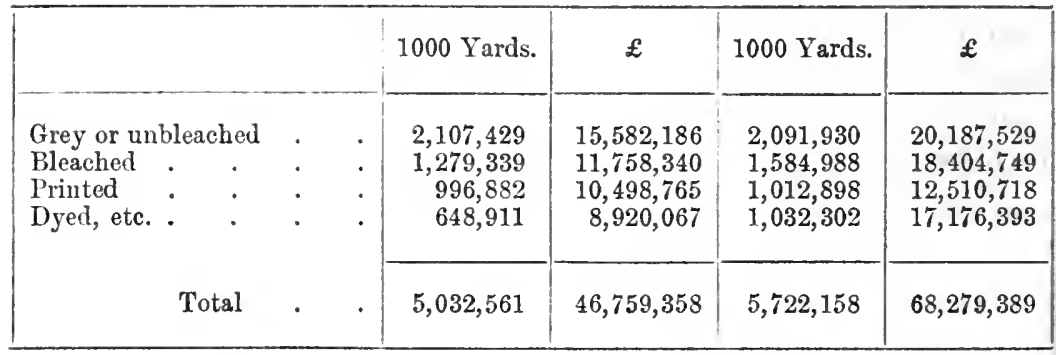

The following table is interesting, as showing the actual extent of the cotton trade (including yarns) between the United Kingdom and other countries. The figures are for the year 1909.

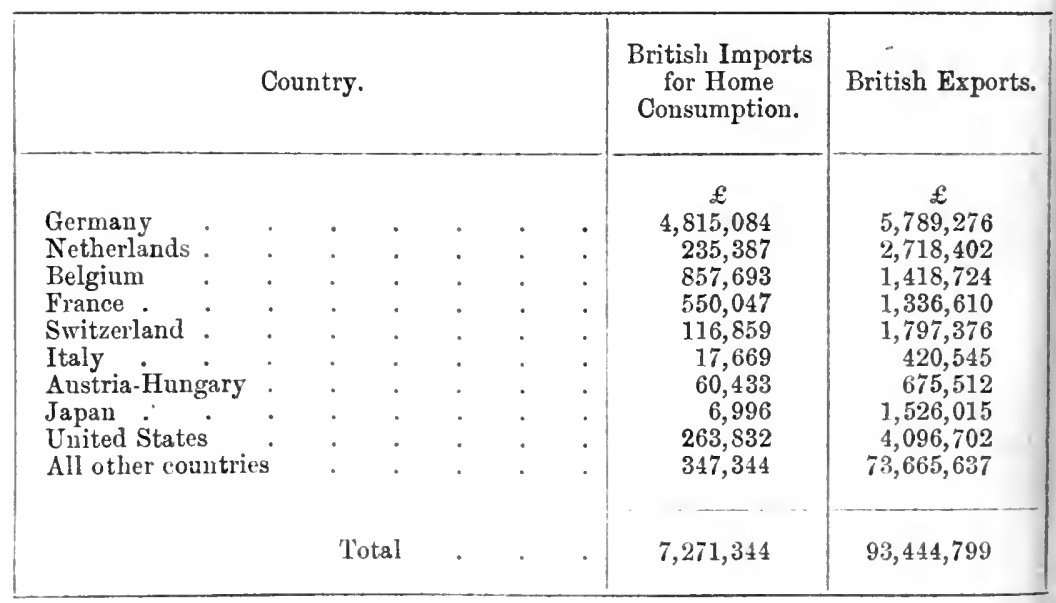

Of our total exports of $£ 93,500,000$ of cotton goods in 1909 , 
$£ 37,000,000$ worth was sent to British Possessions and some $£ 56,000,000$ to foreign countries. In the same year the value of our total exports was $£ 297,000,000$, so that our cotton exports formed practically one-third of our entire exports of manufactured goods, the second largest export being iron and steel.

Flannelette was introduced into the English market in 1885. The fabric, although it is nothing more than cotton with a raised surface, owes its popularity as a material for wearing apparel to the fact that it is warm, pleasant to the touch, and capable of being produced in colours so as to be hardly distinguishable from wool, to the fact that it wears well, and, above all, to the fact that it can be produced and sold at extraordinarily low prices. Owing to these qualities it has come to be used largely as a material for clothing among all classes of persons. Among the poor it may be said that women and children almost universally wear flannelette. There is a large manufacture of flannelette in Manchester, and it is imported in considerable quantities from Germany and Holland.

We may conclude our account of the cotton trade with the important statement of the Census of Production (1907). The value of the gross output of the factories-runs the Report-is, of course, far in excess of the value of the output of the trade as a whole, and owing to the fact that the sales of yarn to cotton manufacturers cannot be distinguished from sales to manufacturers in other trades or to foreign markets it is not possible to give any figures with regard to the quantity or value of cotton yarn sold outside the trade. As, however, factories engaged solely in dyeing, bleaching, and finishing are not included in this group, and the piece goods manufactured are not to any extent sold to other factories in the group, the following particulars of the piece goods manufactured for sale represent a practically complete statement of the output of the weaving branch of the cotton trade:-

\begin{tabular}{|c|c|c|c|c|}
\hline & & & Quantity. & Values. \\
\hline $\begin{array}{l}\text { Unbleached grey piece goods } \\
\text { Bleached white piece goods } \\
\text { Coloured cottons * }\end{array}$ & . & $\dot{:}:$ & $\begin{array}{r}\text { Yards. } \\
0,417,798,000 \\
5,265,000 \\
606,559,000\end{array}$ & $\begin{array}{c}£ \\
72,676,000 \\
79,000 \\
9,099,000\end{array}$ \\
\hline
\end{tabular}

* Including a small quantity of goods dyed in the piece.

The bleached piece goods above included are goods bleached by, or on commission for, weaving firms. No printed cottons are 
included in these returns. The great bulk of the bleaching and dyeing, and the whole of the printing of cotton goods is performed on goods purchased from the manufacturing firms. It will be seen that the total number of yards of cotton piece goods woven for sale was $7,029,622,000$ and the value $£ 81,854,000$. It should also be added that $16,881,000$ yards of unbleached piece goods and 44,982,000 yards of coloured cottons were woven on commission. Part of this is no doubt included in the figures given for piece goods woven for sale, being made for other manufacturers, but the great bulk would certainly be made for merchants. The selling value of these piece goods cannot be stated.

As regards cotton yarn the total quantity sold as such or manufactured for stock included in the returns was $1,507,381,000 \mathrm{lb}$. and the value of such yarn $\mathfrak{E} 79,371,000$. This figure involves some amount of duplication in respect of doubled yarn which is returned twice, once by the spinner and again by the doubler (in so far as the latter does not spin his own yarn), but the amount of such duplication is probably not considerable. It, however, excludes altogether yarn spun and used in the manufacture of other goods for aale by the same firm. In order, therefore, to obtain some measure of the total output of single cotton yarn, a voluntary question was addressed to all factories in this trade, and on the basis of the replies received to this question, which was answered by a large proportion of the more important firms, and of such other sources of information as are available, it is estimated that the total output of single yarn amounted to about $1,826,000,000 \mathrm{lb}$. From information voluntarily returned with regard to the number of spindles, it appears that the average production of cotton yarn per spindle was, per mule spindle, $29.5 \mathrm{lb}$. and per ring spindle, $60.5 \mathrm{lb}$. On the basis of the value of the yarn for sale as given in the returns, it would appear that the value of the whole of the yarn manufactured must have been about $£ 96,000,000$. The net output of cotton factories as a whole was $£ 46,941,000$, this sum representing the total amount by which the value of the products of the industry, taken as a whole, exceeded the cost of the raw cotton and other materials used in their manufacture and the work done on those materials by other firms for the principal firms. The actual cost of the raw materials used is of course not known, the total of the sums returned as "materials" including, like the total of the sums returned as "output," a quantity of cotton yarn manufactured by one factory and sold to another. 


\section{CHAPTER XVII}

\section{IVOOL}

Early history-Exports from 1815 to 1845 -Number of mills-Growth of imports in first half of century-Changes in manufacture-Later history-Colonial productionManufacturing centres-Effects of Free Trade-Number of factories and persons employed since 1870-Foreign trade since 1850-Minor industries

\section{The Woollex axd Worsted Trades, 1800-1850}

THE manufacture of woollen goods is said to have been introduced into this country by the Romans; but the tradition is not confirmed by any certain records. There is no doubt that broadcloths were made in England as early as the close of the twelfth or beginning of the thirteenth century; but the Flemings were at that time far more advanced in the art than our countrymen, and a considerable part of the cloths then, and for a long time afterwards, worn in this country, were made in Flanders from wool the produce of English flocks. From a very early period the woollen manufacture was an object of the especial protection of the English government. Originally, indeed, the freest exportation of British wool was allowed; but in 1660 it was strictly prohibited, and this law remained in force until 1825 . The prohibition was grounded upon a belief that the long-staple or combing-wool of England was superior for some manufacturing purposes to that of any other country, and that by keeping the raw material at home we should secure to ourselves the exclusive manufacture of certain fabrics. The mistaken policy of this selfish system has been rendered fully apparent since its abandonment. No sooner were the French manufacturers able to procure the combing-wool of England, than they set their ingenuity at work to profit fully from the concession, and produced new stuffs from English wool superior to any that we had ever produced in this country. Thus stimulated, our manufacturers also applied themselves to the discovery of superior processes, and in the course 
of a very few years produced merinos and other stuffs in every respect equal to the fabrics of France. By this means our stuff manufacture received an important impetus. In the five years from 1820 to 1824 , while the prohibition to export English wool was still in force, the average annual shipments of that description of woollen goods amounted to $1,064,441$ pieces. In the five years following, during which the removal of the restriction occurred, the average annual export of such goods amounted to $1,228,239$ pieces; and in the next quinquennial period, from 1830 to 1834 , the average rose to $1,505,993$ pieces; between 1835 and 1839 , the average export was $1,429,057$ pieces; and during the five years, 1840 to 1844 , it reached $2,128,212$ pieces, being exactly double the quantity exported during the last five years in which the prohibition existed: thus furnishing a satisfactory answer to those persons who predicted, as a necessary consequence of a departure from a restrictive policy, the absolute ruin of that branch of our export trade.

The value of woollen goods exported from England in 1700 was about $£ 3,000,000$. At the beginning of the nineteenth century, notwithstanding the great extent to which articles made of cotton had been substituted for woollen clothing, the value of our exports of woollen goods amounted to about double that sum. We have not any record of the quantity of goods exported at these periods, but as the price of wool at the end of the eighteenth century was more than clouble what it had been at the beginning, it is probable that the number of yards and pieces sent away was not much, if at all, greater at the later than it had been at the earlier period. It will be seen from the following table that the value of our exports of woollens did not increase in the first half of the nineteenth century; but owing to the diminished price of wool, and the great economy that was attained in various manufacturing processes, the quantities, on the whole, considerably increased. The largest export, in point of value, occurred in the year 1815, when, owing to the interruption of intercourse with the United States of America in the two preceding years, the quantities sent to that country were unusually great. The number of pieces exported to all parts in that year was $1,482,643$, the number of yards $12,173,515$, and the total value $£ 9,381,426$, of which $\mathfrak{£} 4,378,195$ was sent to the United States. 
An Account of the Quantities of British Manufactured Woollen Goods Exported every Fifth Year, from 1815 to 1845

\begin{tabular}{|c|c|c|c|c|c|c|}
\hline Years. & $\begin{array}{l}\text { Cloths of } \\
\text { all sorts. }\end{array}$ & $\begin{array}{c}\text { Napped } \\
\text { Coatings, } \\
\text { Duffels, } \\
\text { etc. }\end{array}$ & $\begin{array}{l}\text { Kersey- } \\
\text { meres. }\end{array}$ & $\begin{array}{l}\text { Baizes of } \\
\text { all sorts. }\end{array}$ & $\begin{array}{c}\text { Stuffs, } \\
\text { Woollen } \\
\text { or } \\
\text { Worsted. }\end{array}$ & Flannel. \\
\hline $\begin{array}{l}1815 . \\
1820 . \\
1825 . \\
1830 . \\
1835 . \\
1840 . \\
1845 .\end{array}$ & $\begin{array}{r}\text { Pieces. } \\
638,369 \\
288,700 \\
384,880 \\
388,269 \\
619,580 \\
215,746 \\
30 ;, 791\end{array}$ & $\begin{array}{r}\text { Pieces. } \\
88,588 \\
59,544 \\
45,268 \\
22,377 \\
20,083 \\
16,094 \\
4,773\end{array}$ & $\begin{array}{r}\text { Pieces. } \\
92,691 \\
78,944 \\
126,443 \\
34,714 \\
29,203 \\
27,122 \\
24,673\end{array}$ & $\begin{array}{l}\text { Pieces. } \\
69,687 \\
37,183 \\
47,100 \\
49,164 \\
47,854 \\
36,044 \\
23,583\end{array}$ & $\begin{array}{r}\text { Pieces. } \\
593,308 \\
828,901 \\
1,139,808 \\
1,252,512 \\
1,673,069 \\
1,718,617 \\
2,212,905\end{array}$ & $\begin{array}{c}\text { Yards. } \\
7,056,271 \\
2,569,105 \\
2,959,594 \\
1,613,099 \\
2,067,620 \\
1,613,477 \\
2,405,311\end{array}$ \\
\hline & $\begin{array}{c}\text { Blankets } \\
\text { and } \\
\text { Blunketing. }\end{array}$ & $\begin{array}{l}\text { Carpets } \\
\text { and } \\
\text { Carpeting. }\end{array}$ & $\begin{array}{l}\text { Woollens, } \\
\text { nixed } \\
\text { with } \\
\text { Cotton. }\end{array}$ & Hosiery. & $\begin{array}{l}\text { Sundries } \\
\text { unenume- } \\
\text { rated. }\end{array}$ & $\begin{array}{c}\text { Total } \\
\text { Declared } \\
\text { Value. }\end{array}$ \\
\hline $\begin{array}{l}1815 . \\
1820 \\
1825 \\
1830^{\circ} \\
1835 \\
1840 \\
1845 .\end{array}$ & $\begin{array}{c}\text { Yards. } \\
3,397,187 \\
1,288,409 \\
2,162,834 \\
2,176,391 \\
3,122,341 \\
2,162,653 \\
2,479,478\end{array}$ & $\begin{array}{c}\text { Yards. } \\
793,793 \\
526,124 \\
888,324 \\
672,800 \\
938,848 \\
758,639 \\
1,006,970\end{array}$ & $\begin{array}{r}\text { Yards. } \\
926,264 \\
407,716 \\
1,793,301 \\
1,099,518 \\
1,778,389 \\
3,628,874 \\
23,831,017\end{array}$ & $\begin{array}{r}\text { Dozens. } \\
202,900 \\
59,960 \\
106,498 \\
111,146 \\
207,014 \\
96,946 \\
174,061\end{array}$ & 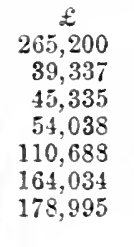 & $\begin{array}{c}\mathfrak{£} \\
9,381,426 \\
5,586,138 \\
6,185,648 \\
4,725,666 \\
6,840,511 \\
5,327,853 \\
7,693,118\end{array}$ \\
\hline
\end{tabular}

An Account of the Quantities of Sheep and Lambs' Wool, Foreign and Colonial, Imported into the United Kingdom in the Year 18.14, distinguishing the Countries from which they came

From -

Germany

New Sonth Wules.

Russia

Van Diemen's Land

Italy

East India Comprany's Territories .

Cape of Good Hole.

States of Rio de la l'lata

Denmark

Portugal

Turkey (inciuling Egespt and Syria)

Morocco

France

Spain

Peru
1..

$21,847,684$

$12,406,397$

$5,402,098$

$4,411,804$

$2,818,353$

$2,765,853$

$2,197,031$

$2,186,291$

$1,604,099$

$1,346,613$

1. $25 b^{\circ}, 90^{\circ} 3$

1,101, 824

$922,890^{\circ}$

918.553

821,032

Carry forward

$62,037,791$ 


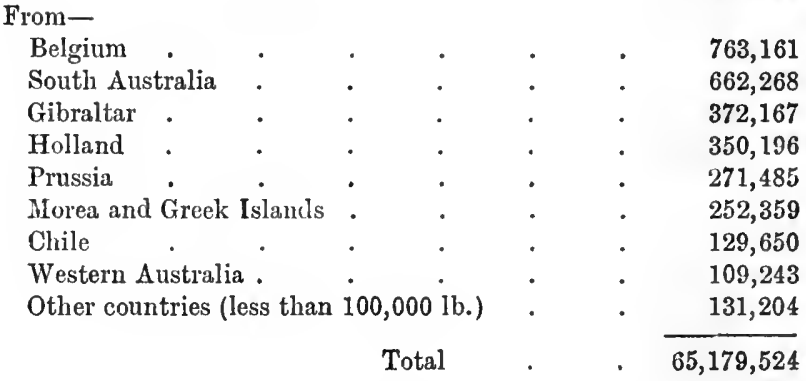

Of this total quantity imported, $1,924,826 \mathrm{lb}$. were reexported, 1,204,334 lb. going to Belgium alone, and 566,434 lb. to the United States.

The total value of British wonllen manufactures exported from the United Kingdom in the year 1844 amounted to

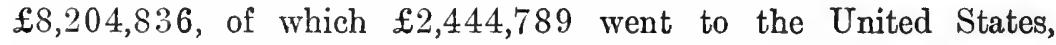
and $£ 1,031,573$ to Germany. China, the British North American Colonies, the East India Company's territories and Ceylon, Holland, Italy, Brazil, and Peru came next in order of importance as markets for British goods. Our exports of woollen manufactures exported in the same year were classified as follows:-

Cloths of all sorts, 317,073 pieces; trapped coatings, duffels, etc., 4616 pieces ; kerseymeres, 28,041 pieces; baizes of all sorts, 22,780 pieces; stuffs, woollen and worsted, $2,492,217$ pieces; woollens mixed with cotton, 20,661,259 yards; blankets and blanketing, 3,360,690 yards; flannel, 1,993,895 yards; carpets and carpeting, 924,326 yards; hosiery, namely, stockings, woollen and worsted, 284,390 yards; and sundries consisting of hosiery not otherwise described, etc., to the value of $£ 156,093$. To these statistics Porter added "an account of the quantities of British sheep and lambs' wool and woollen yarn exported from the United Kingdom in the year 1844," which shows that of the $8,947,619 \mathrm{lb}$. of British sheep and lambs' wool sent abroad in that year, 6,862,572 lb. went to Belgium and 1,685,890 lb. to France. The woollen and worsted yarn exported in the year 1844 amounted to 8,271,906 lb., and included 4,614,745 $\mathrm{lb}$. sent to Germany and $1,652,890 \mathrm{lb}$. sent to Holland. The quantity of mohair imported into the United Kingdom in 1844 was $1,290,771 \mathrm{lb}$., and $635,357 \mathrm{lb}$. of "wool of the alpaca and llama tribe" are also noted.

In the year 1839 there were 1322 woollen mills at work in 
the United Kingdom, 1029 in England, 150 in Wales, 112 in Scotland, and 31 in Ireland. There were besides 416 worsted mills in England. The persons employed in these mills numbered $\$ 6,411$ -in England 78,6 72, of whom rather more than half were females, in Wales 1433,956 of whom were males, in Scotland 5076, half men and half women, and in Ireland 1230, again half men and half women. A great number of children were employed in these mills, particularly in England. If we compare these statistics with those for 1835 , we find an increase of 132 factories or 10 per cent. in the four years, and an increase of 15,137 persons or more than 20 per cent.

It is not possible to measure, writes Porter, the progress of the woollen industry by means of the export trade, which is of far less magnitude than the home demand; nor can we arrive at any precise estimate from the quantities of the raw material which have been procured from abroad, since foreign wool has always formed an uncertain proportion of the material used for our cloth manufactures. Nor again does the growth of the population of particular towns and districts always furnish a certain criterion for forming a judgment upon the subject, because the manufacture, which was at first spread about in a great many different parts of the kingdom, has at different times diminished or ceased in some places, while it has increased in others, and in general the business has been carried on in districts where other branches of industry have been simultaneously prosecuted; so that it is not possible always to determine the degree in which the increase of manufacturing hands is occasioned by one particular branch or by another.

We have not any detail of the quantity of woollen goods exported earlier than 1815, and without such data the simple statement of value affords no precise knowledge of the extent of shipments of goods produced from a material, the qualities of which are so various, and the prices of which have so greatly fluctuated.

The following table shows the growth in our imports of foreign wool in the first half of the century:-

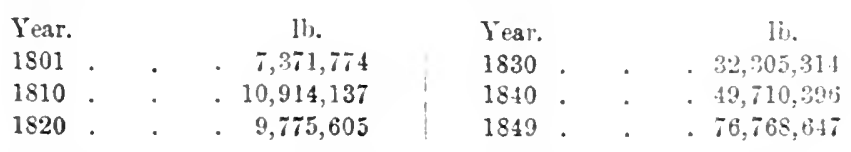

In consequence of a continual depression in the price of British wool, a Committes of the House of Commons was appointed, in 1828 , to inquire into the state of the woollen trade, and a con- 
siderable amount of evidence on the subject was collected on that occasion. The estimates offered to the Committee were indeed without the sanction of any certain authority; but as their general accuracy seems to have been acknowledged at the time by many persons practically experienced in this branch of trade, we are justified in availing ourselves of them, in the absence of more precise data. On that occasion a statement made by Mr. Luccock was produced, giving the estimated numbers of sheep kept in England and Wales in the year 1800, and distinguishing the longwoolled from the short-woolled flocks. According to this statement the number of sheep in that year amounted to 19,007,607, and of these the far greater proportion, namely, 14,854,299, were shortwoolled sheep. The quantity of wool yielded by these animals was estimated at 393,236 packs of $240 \mathrm{lb}$, or $94,376,640 \mathrm{lb}$. in all, being a very small fraction under $5 \mathrm{lb}$. for each fleece, taking one with another. Mr. Hubbard, a gentleman of great experience in the wool trade, by whom Mr. Luccock's table was brought forward in 1828 , then expressed his belief that the actual number of sheep in England and Wales had increased one-fifth since 1800 ; that the longwoolled sheep had become more numerous than the short-woolled; and that the weight of the fleece had so much increased, that, one with another, each sheep yielded more than $5 \frac{3}{4} \mathrm{lb}$. of wool.

Assuming these estimates to be correct, it appears that in 1800 the quantity of wool available for manufacturing purposes, exclusive of that produced in Scotland and Ireland, was-

Packs. $\quad 16$.

From flocks in England and Wales Foreign wool imported . .

- 393,236 , or $94,376,640$

Together • • • . $\overline{102,906,008}$

If between 1800 and 1828 the number of sheep had increased one-fifth, it is probable that by 1849 the increase had at least reached to one-third, and that the whole number in England and Wales then amounted to $25,343,476$. Assuming also, that the average weight of each fleece had further increased in the degree estimated by Mr. Hubbard, the whole quantity of wool applicable to manufacturing purposes must have been-

Packs. $\quad$ lb.

From flocks in England and Wales $\quad$. 607,18 7 or $145,724,880$

Foreign wool imported, $1849 \quad$. $\quad$. $\quad$ - $76,768,647$

Together . . . . . $\overline{222,493,527}$

showing an increase since 1800 of more than 115 per cent. 
During the first half of the nineteenth century the woollen and worsted industries increased rapidly in Yorkshire.

On the other hand, in the early part of the nineteenth century the manufacture of bombazeens, crapes, worsted stuffs and mixed fabrics called Norwich shawls at Norwich suffered a very great depression.

The population of the whole West Riding of Yorkshire rose between 1801 and 1841 from 563,953 to $1,154,101$, or 104 per cent.

During the first half of the nineteenth century the woollen manufacture underwent various changes. One of the greatest of these changes resulted from improvements in the breed of English sheep, in which it was more the object to obtain a greater weight of carcass than to improve or preserve the quality of the wool. The fleece, as we have seen, had become heavier, but, at the same time, the wool of the short-woolled sheep was coarser; and for the production of cloth of similar quality to that which thirty years before was produced wholly from British wool, it was necessary towards the end of this period to use an admixture of imported wool. This remark applies to South Down sheep, the wool of which was used for baizes, flannel, blanketing, druggets, and lowpriced cloths. The proportion of these sheep, however, had much diminished relatively to the number of sheep yielding long or combing-wool, which was employed for the manufacture of stuffs and worsted fabrics. The importation of foreign woollen rags into England for the purpose of re-manufacture had just begun. Mixed with English, or more commonly with Scotch wool of low quality, an inferior cloth was manufactured at a price sufficiently moderate to command a sale for export. By this means a market was obtained for wool of a very low quality, which might otherwise have been left on the hands of the growers. The blanket trade had also shown considerable development, the best blankets were made from unmixed British wool. The town and parish of Dewsbury, at which carpets were made, increased its population between 1801 and $18 \pm 1$ from 11,752 to 23,806 , or by 102 per cent.

The Woollex ANd Worsted Industri-From 1850 to the Presest Day

The later history of the woollen and worsted trades differs considerably from the earlier. Its conditions have almost entirely 
changed since Porter wrote. The multiplication of merino sheep in Australia and the consequent growth of our imports of fine wool from that country, as well as from South Africa and Argentina, are of first importance in surveying the past sixty years. The Australian fleeces began to appear in the English market before 1830 , but only in small quantities. By 1860 Australia, Tasmania, and Cape Colony had become the chief sources of English imports. At the same time South America began to develop its sheep-rearing industry, but from the first its trade was mainly Continental, as it is to-day. Between 1850 and 1870 New Zealand took her place as a great exporter of wool beside Australia and the Cape. Professor Clapham in his valuable book on the woollen industry describes how the New Zealand squatters, by systematic crossing with long-woolled English sheep, produced the cross-bred wool with most successful results. The cross-bred sheep is better suited for slaughtering than the merino, and, with the transport of frozen mutton and the demand for cross-bred wool, sheep rearing in New Zealand became most profitable. Breeding for mutton is now carried on in many parts of Victoria and South Australia; but the flocks of New South Wales, which produces more than half the Australian wool, are still mainly merino. In Argentina threequarters of the sheep are cross-bred, and this also is due to the growth of the frozen meat industry, which followed a drop in the price of merino twenty years ago. Taking the whole mass of Australasian, South African and River Plate wools, Professor Clapham estimates that almost exactly a half is now merino and a half cross-bred. Ten or twelve years ago the proportions were two-thirds merino to one-third cross-bred. The same authority has some interesting observations on the present state of the world's wool supplies. In most countries of Europe, though not in Great Britain, a remarkable fall in the stock of sheep took place during the last twenty years of the nineteenth century. Germany contained about twenty million head of sheep in 1880 , and less than ten million in 1900. Even in European Russia the fall was considerable; though in France, which with England and Russia, raises about two-thirds of the wool of Europe, it was not very marked. From 1895 to 1902 a fearful drought afflicted Australia, and swept away about half the flocks. There had been 106 million sheep in the country in 1891 ; there were but 53 million in 1902 . Since then the recovery has been rapid, and the latest return for 1910 gives the Australian total as 115 millions. The Boer War reduced the South African flocks, but the wool has 
since improved both in quality and quantity. The trade in sheep and mutton, and, above all, the trade in lamb, have limited the flocks of New Zealand and South America. In Argentina agriculture and also disease threaten the industry. The United States contains only about twice as many sheep and lambs as the United Kingdon-about sixty millions in fact. "There is thus a contraction of supplies all the world over," says Professor Clapham, but he consoles us for the threatened shortage by pointing to the large areas suitable for sheap rearing, of which as yet only partial use has been made.

To turn to the manufacture of the wool, we find that in East Anglia, which was the chief worsted district down to $1800-$ Worsted is the name of a Norfolk village-the industry has almost entirely disappeared. In Devon there are some half-dozen mills; and some of the finest cloths are still manufactured in Gloucestershire and Somerset. A recent writer on the West of England woollen industry describes how "with the nineteenth century came an age of industrial revolutions, and the cloth trade was the subject of mighty changes. The hand-loom disappeared from the weaver's cottage, replaced by the power-loom at the mill; in every direction machinery, power-driven, superseded hand labour; and, as the steam-engine took the place of the water-wheel, the cost of coal, proximity to coal fields, became for the first time an important consideration for manufacturers." Later came changes in the popular demand for cloth. "The old-fashioned broadcloths, the superfines for which the West of Frgland still remains unrivalled, declined from universal favour. The new demand was for a great and constantly changing variety of tweeds and of worsted suitings and serges. The situation of the West Riding of Yorkshire, within easy access of coal fields, gave an immense impetus to her industries from the very commencement of the industrial revolution; the subsequent changes in fashion gave her an opportunity of which she was not slow to avail herself, and she rapidly became preeminent, not for the production of the finest cloth of the highest value, but for her capacity to meet rapidly and cheaply the new demand." At the present time, certain districts in the West Piding are devoted to the production of worsted fabrics, and others to woollens. The market for raw wool centres in the city of Bradford. As a consumer of wool Bradford stands first in the world, no other city and district using so much raw material. Bradford is also the home of the mohair and alpaca trade. It is estimated that 75 per cont. of the mohair grown in Asia Minor 
and South Africa finds its way to the city of Bradford to be made into a great variety of materials. Heavy weights of mohair spun yarns are shipped to the Continent, besides being made locally into dress goods. Associated with Bradford in the worsted and mohair industries are Halifax, Cleckheaton, Bingley, Keighley, and all the intervening villages. In this part of Yorkshire worsted coatings and ladies' dress fabries are very extensively made, and are nearly all produced from worsted yarns. A large quantity of cotton yarns is also used in the production of ladies' dress goods, but Bradford and district is essentially the home of the worsted and mohair trades.

Leeds, Pudsey, Farsley, Calverley, Batley, Dewsbury, Ossett, Morley, Huddersfield, and the innumerable villages surrounding the larger towns, are all employed in the production of woollen fabrics of one grade or another. Leeds is essentially a woollen city, although worsted coatings and serges are largely made by certain firms. Most of the army goods required by the British Government are produced in the neighbourhood of Leeds. The custom among woollen manufacturers is to buy the raw material and turn out the finished product; this is seldom done by those producing worsted fabrics. Leeds is also a very large manufacturer of ready-made clothing. At Yeadon and Guiseley are some im: portant mills which are largely devoted to the production of ladies' clress goods, and fabries for men's caps.

What is known as the heavy woollen district includes Dewsbury, Batley, Birstall, Ossett, and Morley. Originally Dewsbury and Batley were the centres where heavy cloths, such beavers, presidents, meltons, and the like, were largely made. Cheap fancy tweeds, mantle cloths, ladies' costume cloths, overcoatings, cotton warp serges, meltons, vicunas, as well as khaki cloths, are all produced in this district. In Dewsbury there is a big blanket trade; in fact more blankets are turned out there than in any other centre in the world, a considerable proportion being for export. Large quantities of cross-bred wool are consumed by the blanket manufacturers. Dewsbury is also well known as the centre for handling huge quantities of rags, and rag auctions are held frequently in the town. These rags, with the addition of more or less wool and cotton, are manufactured at Dewsoury and Batley into cheap shoddy and mungo fabrics. There is no doubt that the competition of Yorkshire has been severely felt by woollen manufacturers in all parts of Great Britain and Ireland. Here, too, large quantities of carpets are made, all of which increase the consumption of wool. The Huddersfield district produces both woollen and 
worsted cloths. One can buy in Huddersfield almost any fabric, the range of prices varying from $1 \mathrm{~s}$. $3 \mathrm{~d}$. per yard broad width up to $15 \mathrm{~s}$.

It is impossible to review the commercial history of the past sixty years without recognizing that the realth and importance of our national industries is above all due to our Free Trade system. The impetus given to the woollen and worsted industries by the repeal of the Corn Laws and by the gradual removal of all fiscal restrictions poured wealth into the West Riding, substituted luxury for comfort, comfort for competence, and competence for starvation. What may seem to some people rather surprising is that, in face of the competition of foreign countries, armed with our machinery, supplied by our capital, and taught at first by English instructors, the condition of the workpeople has steadily improved, and the factories are now larger, better equipped, and more fully employed than ever. The following table gives a clear picture of the progress of the wool trade of the United Kingdom from 1850 to 1902, including the growth of our profitable re-export business :-

Consumption of Wool in the United Kingdom

\begin{tabular}{|r|c|cc|c|}
\hline Year. & $\begin{array}{c}\text { Estimated Yield of } \\
\text { Domestic Wool. }\end{array}$ & $\begin{array}{c}\text { Imports of Foreign } \\
\text { and Colonial Wool. }\end{array}$ & Exports. & Consumption. \\
\cline { 2 - 5 } & Million lbs. & Million lbs. & Million lbs. & $\begin{array}{c}\text { Million lbs. } \\
181\end{array}$ \\
1850 & 130 & 77 & 26 & 364 \\
1870 & 150 & 266 & 101 & 502 \\
1890 & 133 & 649 & 371 & 576 \\
1900 & 141 & 587 & 221 & 562 \\
1902 & 135 & 676 & 110 & \\
\hline
\end{tabular}

The wool trade, like every other trade, has its ups and downs; but the general movement has been from higher to higher levels. Its first stimulus came from the repeal of the Corn Laws; its second from the Cobden Treaty of 1860 , under which the duties on British woollens entering France were lowered, and the trade between the two countries was stimulated. Next came the Civil War in the United States, and the cotton famine from 1861 to 1865, which gave another impetus to the wool industry, with a corresponding inflation of prices, followed by a fall. And, fourthly, the Franco-German War in 1870- 7 , when, during the stagnation of production in the countries engaged in the war, there was the greatest boom ever known in the British wool industry, which, however, was to be surpassed in 190T, and again in 1909 and 1910. In many trades, the profits made in these good years were invested in new buildings and plant at a time when prices were 
at their highest, and, instead of the prosperous times continuing as was expected by many, there followed a severe shrinkage of values and of demand, both for home and export, intensified by a change of fashion against the bright goods of England and in favour of the soft all-wool goods of France. The loss of capital and employment towards the end of the 'seventies, resulting from over-expansion and the fall of prices, was the greatest ever experienced in the history of the trade, and seriously retarded for some time the prosperity of the wool industry.

Twenty years later the Boer War caused a severe depression, but if we compare our unprotected trade with the protected trade of our chief rival, France, we shall see not only our greater strength in surmounting tariffs, and finding neutral markets, but also our greater recuperative power after periods of depression. In 1882 British exports of wool manufactures were valued at $£ 22,200,000$,

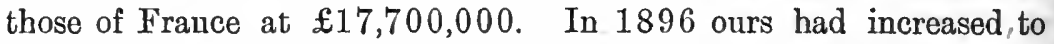
$£ 27,100,000$, while the French had fallen to $£ 12,900,000$. In 1898, under the Dingley Bill, ours had fallen to $£ 21,900,000$, and the French to $£ 10,100,000$. In 1907 , a record year of international trade, the exports of our wool manufactures had risen to the magnificent figure of $£ 34,200,000$, while those of France were valued at only $£ 12,100,000$. In 1882, Free Trade Britain led Protectionist France by only $\mathfrak{f} 4,500,000$; in 1907 she had increased this lead to 22 millions. The truth is that where our workpeople are skilled, and our millowners enterprising, the cheapness of food, clothing, and of all other things which enhance the efficiency of workers, and reduce the cost of production, make it difficult for foreigners to compete.

Moreover, an important development, consequent upon the extension of machinery in the German and other foreign woollen industries, is our increasing export of yarn. The development is thus explained by Sir Swire Smith, an eminent authority :-_"Our export trade has had to develop along the lines marked out by the fiscal systems of other countries, and, as a matter of business, manufacturers have had to take the only course open to them of selling what the tariffs would permit their customers to buy, goods to some, yarn and tops to others. Germany (one of our best customers in goods) has continued to be a good customer in every department, and especially in yarn, which she takes almost on a Free Trade basis." In 1909 Germany imported 52,848,000 lb. of British

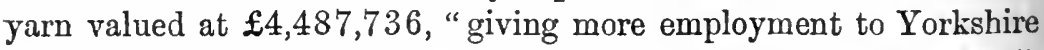
worsted spinning mills than all the rest of the world put together." 
The yarn contained in a piece of cloth worth, say, twenty shillings, may be fairly valued at fifteen shillings, and at this estimate more than half the value of the manufactured wool exports from Germany is represented by her imports of yarn from Britain. It is sometimes urged that the export of our yarn deprives British weavers and dyers-whose wages contribute a larger proportion to the value of the goods than the spinner-of their livelihood, and thus injures the weaving industry. To this Sir Swire Smith replies:

"As well complain that exports of cloth deprive tailors and dressmakers of their livelihood. It is admitted that there has been an increase in the value of our wool exports, but argued that they represent a much smaller amount of labour than formerly, that, for example, the wages paid in the production of a sovereign's worth of cloth are double the wages paid on a suvereign's worth of yarn. This contention, however, is dissipated by the actual facts, for, taking a series of years and adding to the exports of wool, tops, yarns and pieces, the export and wages of apparel, there was an increase of $£ 2,000,000$ in wages from 1889 to 1907 on the specified wool products exported."

The following table gives the number of factories in the United Kingdom at various dates between 1870 and 1890, with the number of spindles, power-looms, etc., in each case :-

\begin{tabular}{|c|c|c|c|c|c|c|c|c|}
\hline \multicolumn{9}{|c|}{ WoOLLES Factories } \\
\hline \multirow[b]{2}{*}{ Year. } & \multicolumn{5}{|c|}{ Number of Factories. } & \multicolumn{2}{|c|}{ Number of Spindles. } & \multirow{2}{*}{$\begin{array}{c}\text { Number } \\
\text { of } \\
\text { Power- } \\
\text { Looms. }\end{array}$} \\
\hline & Spinning & Wearing & $\begin{array}{l}\text { Spinning } \\
\text { and } \\
\text { Weaving }\end{array}$ & Other. & Total. & Spinning. & Doubling. & \\
\hline $\begin{array}{l}1870 \\
1878 \\
1885 \\
1890\end{array}$ & $\begin{array}{l}648 \\
547 \\
521 \\
494\end{array}$ & $\begin{array}{r}109 \\
96 \\
109 \\
124\end{array}$ & $\begin{array}{l}860 \\
927 \\
900 \\
895\end{array}$ & $\begin{array}{l}212 \\
162 \\
388 \\
250\end{array}$ & $\begin{array}{l}1,829 \\
1,732 \\
1,918 \\
1,793\end{array}$ & $\begin{array}{l}2,531,768 \\
3,337,607 \\
3,054,144 \\
3,107,209\end{array}$ & $\begin{array}{l}160,993 \\
318,154 \\
230,941 \\
299,793\end{array}$ & $\begin{array}{l}48,140 \\
56,944 \\
57,990 \\
61,831\end{array}$ \\
\hline \multicolumn{9}{|c|}{ Wopsted Factories } \\
\hline $\begin{array}{l}1870 \\
1878 \\
1885 \\
1890\end{array}$ & $\begin{array}{l}237 \\
226 \\
250 \\
276\end{array}$ & $\begin{array}{l}253 \\
298 \\
304 \\
295\end{array}$ & $\begin{array}{l}123 \\
127 \\
122 \\
126\end{array}$ & $\begin{array}{l}17 \\
42 \\
49 \\
56\end{array}$ & $\begin{array}{l}630 \\
693 \\
725 \\
753\end{array}$ & $\begin{array}{l}1,821,144 \\
2,096,820 \\
2,227,192 \\
2,402,922\end{array}$ & $\begin{array}{l}310,308 \\
456,114 \\
536,329 \\
669,328\end{array}$ & $\begin{array}{l}64,651 \\
87,393 \\
79,931 \\
67,391\end{array}$ \\
\hline \multicolumn{9}{|c|}{ SHODDY FACTORIES } \\
\hline $\begin{array}{l}1870 \\
1878 \\
1885 \\
1890\end{array}$ & $\begin{array}{r}19 \\
11 \\
11 \\
8\end{array}$ & $\begin{array}{r}\cdots \\
4 \\
1 \\
5\end{array}$ & $\begin{array}{l}39 \\
37 \\
46 \\
39\end{array}$ & $\begin{array}{l}62 \\
85 \\
50 \\
73\end{array}$ & $\begin{array}{l}120 \\
137 \\
108 \\
125\end{array}$ & $\begin{array}{r}133,211 \\
83,702 \\
93,766 \\
94,404\end{array}$ & $\begin{array}{r}582 \\
9,252 \\
2,222 \\
691\end{array}$ & $\begin{array}{l}2,690 \\
2,110 \\
1,981 \\
2,284\end{array}$ \\
\hline
\end{tabular}


In 1904 there were altogether 1377 factories, containing 329 rag-grinding machines for making shoddy, 6083 sets of carding machinery, 2,613,759 spinning spindles, 211,353 doubling spindles for twistiug yarns together, and 50,357 power-looms. The 161 shoddy mills had 566 rag-grinding machines, 319 carding sets, 77,815 spinning spindles, and 1432 looms. In the 841 worsted mills there were 2823 combing machines, 2,937,900 spinning spindles, 845,166 doubling spindles, and 52,725 power-looms. Nearly all the machinery is steam driven. A few mills use steam and water; fewer still use water alone. In some mills steam has been displaced by electricity. Since 1889 the number of worsted spindles has risen by 22 per cent.; the number of woollen spindles has fallen by nearly 16 per cent. The number of woollen looms has fallen from 61,831 to 50,357 . At the same time, as the figures of raw material consumption show, a steady increase in productive power accompanied this decline in the number of certain classes of machinery. In the last few years the Irish woollen industry has increased in importance. There were in 190199 mills employing 3523 hands. These, like the Welsh and North of Scotland mills, are almost entirely woollen mills. Scotland is renowned for the Tweed and Cheviot trades, which are situated in the three counties of Roxburgh, Selkirk, and Peebles. Lanark and Clackmannan have fairly large weaving industries.

The number of persons employed in woollen factories in the United Kingdom in 1870 was 125,130 , of whom 63,143 were male and 61,987 were female; at the same time 109,557 persons (43,094 males and 66,463 females) were employed in worsted factories, and 3816 persons (1906 males and 1910 females) in shoddy factories. In $1890,148,729$ persons were employed in woollen factories, 148,324 in worsted factories, and 4503 in shoddy factories, the proportion of male and female being about the same. In 1901 the number of persons in the United Kingdom employed in the whole of the woollen and worsted industries (including spinning and weaving and all allied processes, shoddy-making and carpet-making, but not hosiery-making) was 259,909 (106,598 males and 153,311 females), and of this total about 190,000 persons were employed in the West Riding. The latest statistics are to be found in the Census of Production (1907) and this gives the average number of persons employed as 257,017 , this total being made up as follows:- 
worsted tissues, $102,173,500$ yds. ; blankets, 857,900 pairs ; carpets and druggets, $8,739,900 \mathrm{yds}$; and flannels, $11,699,300 \mathrm{yds}$. The total value of these exports was $£ 23,796,009$. Finally, in 1908, the latest year available, our exports were valued at $£ 28,391,922$.

In any survey of the woollen and worsted industry the evidence provided in the Census of Production (1907) must find a place, and the following report is of considerable value :-The same considerations as those already alluded to in dealing with the cotton trade make it impossible to give any figures with regard to the value of the products of the woollen and worsted trades taken as a whole. As regards weaving, however, the following statement of the quantities and values of the principal woven goods made for sale may be regarded as practically complete and free from duplication. Goods made by commission weavers for merchants are, of course, not included, but the quantity is not large.

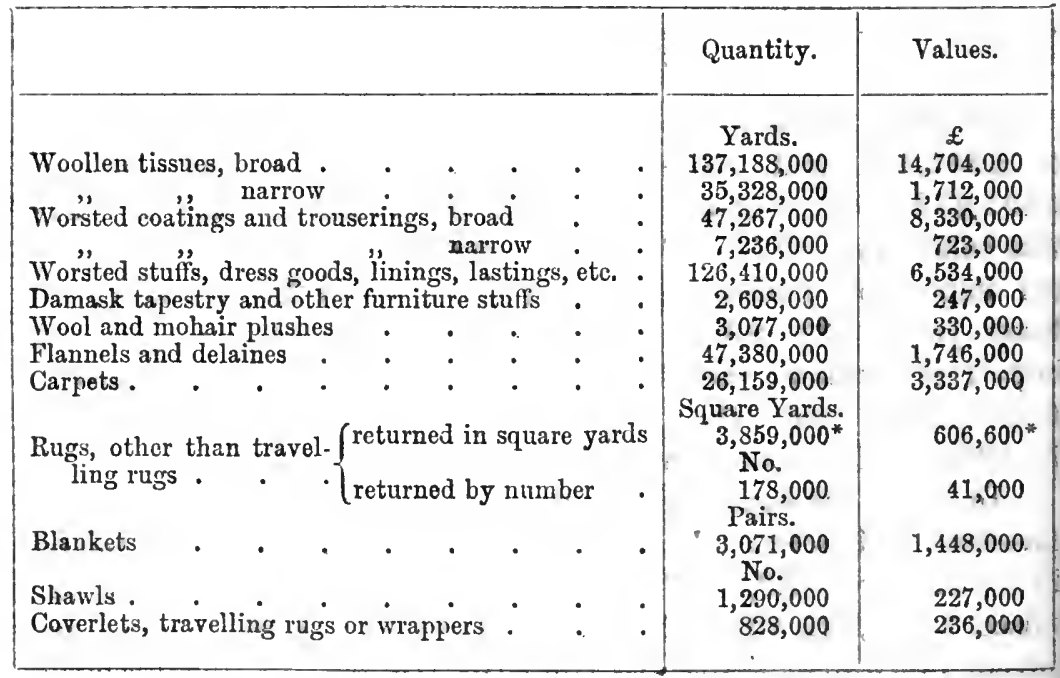

* Including a small amount of work done on commission.

It will be seen that the value of the goods included above amounted to about $£ 40,250,000$.

It is unfortunately not possible at present to afford any estimate of the total quantity of woollen or worsted yarn spun, the voluntary information furnished by manufacturers in this industry not having been sufficiently complete for the purpose. The returns show the following total quantities of yarn spun for sale or for stock, with their values :- 


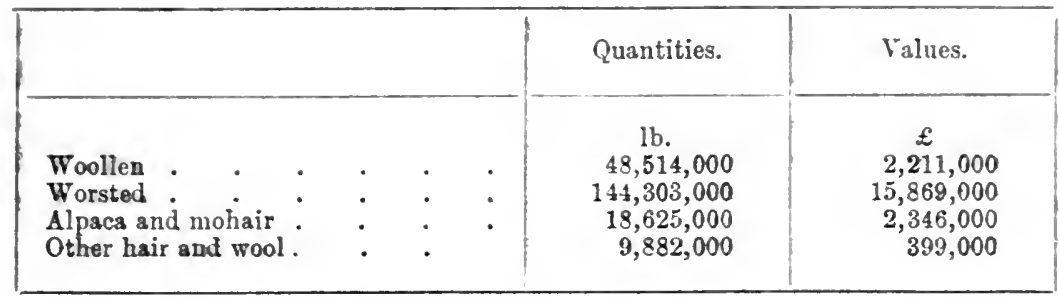

The total value of this yarn was returned as about $£ 21,000,000$. These figures are exclusive of the quantities of yarn spun and used in the manufacture of other goods for sale by the same firm.

The net output of woollen and worsted factories as a whole according to the census taken in 1907 was $£ 19,452,000$, this sum representing the total amount by which the value of the products of the industry taken as a whole exceeded the cost of the raw wool and hair and other materials used in their manufacture and the work done on those materials by other firms for the principal firms. The actual cost of these raw materials used is not known, since the total of the sums returned as "materials" includes, like the total of the sums returned as "output," yarn, etc., made by one factory and sold to another. Firms with an output of $£ 27,181,000$ in the censal year (or nearly 40 per cent. of the total) reported that their output in the previous twelve months was $£ 25,868,000$. The increase of value in 1907 compared with 1906 slightly exceeded 5 per cent.

The Census of Production also deals with two other minor industries, which may be included here, namely, flock and rag manufacture, and velvet and fustian cutting. The following statement shows the values of the chief products of the factories engaged in the sorting of rags and the preparation of flocks for bedding and upholstery:-

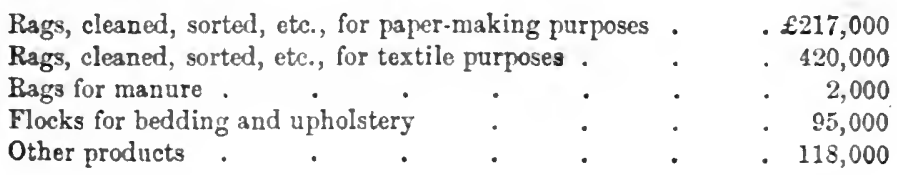

The "other products" are chiefly cotton and wool waste. The value of the goods included above is $\mathfrak{E} 852,000$ and represents the value of the total output of flock and rag factories as a whole, but does not include the output of workshops engaged in this trade. The net output of flock and rag factories included in this Report was $£ 159,000$, this sum representing the total amount by which 
the value of the products of such factories exceeded the cost of the rags purchased and sorted and other materials used. The actual cost of such rags and materials was $\mathfrak{E} 693,000$. The average number of persons employed in flock and rag factories is returned as 2375 , namely, 2208 wage-earners and 167 salaried persons, the total number being further classified according to age and sex :-

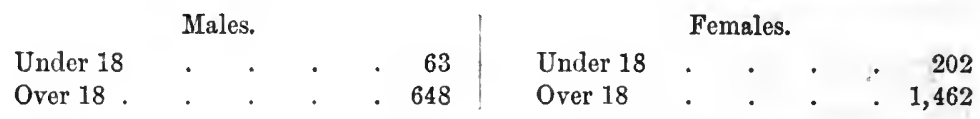

Velvet and fustian cutting is done almost exclusively on commission for firms which send out piece goods to be cut, and consequently the value of the "output" of the trade is the amount received for work done and not the selling value of the goods themselves. In the few cases where the firms buy goods, cut them, and then sell them, the returns have been compiled on the same basis as that adopted by persons or firms working on commission. The total amount received by the trade as a whole for work done was $£ 117,000$, this representing the additional value given to the goods by the process of cutting. The net output of establishments engaged in velvet and fustian cutting was $£ 112,000$, this sum representing the total amount by which the value of the work done by the trade as a whole exceeded the cost of the materials purchased and used in connexion with the work done and the amount paid to other firms for work done by them for the principal firms. The cost of the materials, mainly fuel and stiffening materials, was about $\mathfrak{£} 4000$, and the amount paid to other firms for work done by them for velvet and fustian cutting firms was less than $£ 1000$. The average number of persons employed in the velvet and fustian cutting trade is returned as 3443 , namely, 3377 wage-earners and 66 salaried persons; many principals of such establishments, however, who themselves work at the trade, have returned themselves as wage-earners. The total number is further distributed according to age and sex :-

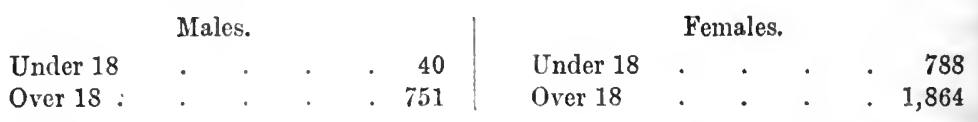

We may conclude our brief survey with some remarks from an interesting paper by Lord Eversley, who, revisiting Bradford in 1910 after a long absence, bore eloquent testimony to "the immense and unprecedented expansion of the woollen industry." It is not, he points out, one or two branches only which have prospered, as in 
past times, but every branch without exception shares in it. $\mathrm{He}$ found every mill working at full pressure, many of them overtime, some of them with double shifts. Every able-bodied man and woman willing to work was employed. In many districts there was said to be a shortage of labour. "At Bradford I am amazed at the increase of the town in fifteen years. Not many new mills, I believe, have been erected. But those which existed have been greatly enlarged. New machinery has been erected, and the output has been enormously increased." And he concludes: "What a marvel is this woollen industry of the West Piding! Wool comes to it from every part of the world, is worked up into manufactures of all kinds, and is then exported to every other country, finding its customers in spite of hostile tariffs imposed by its jealous rivals for the express purpose of excluding it, and with a result that the working men and women who constitute four-fifths of the whole population have better wages, cheaper food, and shorter hours than in any other part of Europe. What a striking testimony this is to the energy of Yorkshire manufacturers, to the skill of the labourers, and to the policy of Free Trade which is the life and breath of the whole trade!" 


\section{CHAPTER XVIII}

\section{O'IHER TEX'TILE 'TRADES-SIIK, LINEN, JUTE, AND HEMP}

Progress of silk manufacture during prohibition-Effect of repeal of duties-Exports of silk goods from 1820 to 1849 -Number of mills-Introduction of machinery-Effects of the Cobden Treaty - Foreign trade since 1850-Total ontput-Early linen production and trade-Imports of flax-Exports of linen from 1850 to 1910-Flax production in Ireland-Nnmbers employed in jute industry-Exports and imports of jute-History of hemp industry - Number of factories-Imports of raw hemp

\section{The Silk Trade-1800-1850}

$\mathrm{T}$ is only since about 1830 that the silk manufacture can be said to have been firmly established in this country. Silk goods have, indeed, been made in England since the time of Edward the Third, and at various times measures intended to act for the protection of the manufacturers have been passed by the legislature. With this view, the importation of silk goods manufactured in other countries was strictly prohibited in 1765 , and this system continued in force during a long series of years, such goods being expressly excluded from the benefit of the treaty of commerce concluded with France in 1786. By this prohibitory law, the English silk manufacturers were legally secured in the exclusive possession of the home market, from which, in the then imperfect condition of the manufacture, they would otherwise have been driven by the superior fabrics of foreign looms. Protected trades are, almost invariably, carried on without that regard to economy in the processes which is necessary, in order to provide for their extension, by bringing the protected article within the reach of a larger number of consumers. Hence silk goods came to be looked upon as mere luxuries, the use of which must be confined to the richer classes; and this state of things was aggravated by taxation. Heavy duties were imposed upon the importation of the raw and thrown silk; the manufactured goods made of a material, the cost of which was thus enhanced, continued beyond the reach of the multitude, and the manufacturers were consequently liable to considerable and violent vicissitudes 
from every change of fashion. On the other hand, those manufacturers feeling themselves secure in their legal monopoly of the home market, were without the necessary stimulus to improvement, and additional temptations were consequently held out to the smuggler to introduce the superior prohibited goods of France. - The slow progress made in this branch of manufacture in England, under this system of duties and restrictions, may be seen from the following table of the quantities of raw and thrown silk imported at various times into the kingdom, from the year 1765, when the prohibition of foreign silk goods was enacted, until the end of 1844.1

\section{Average Importation}

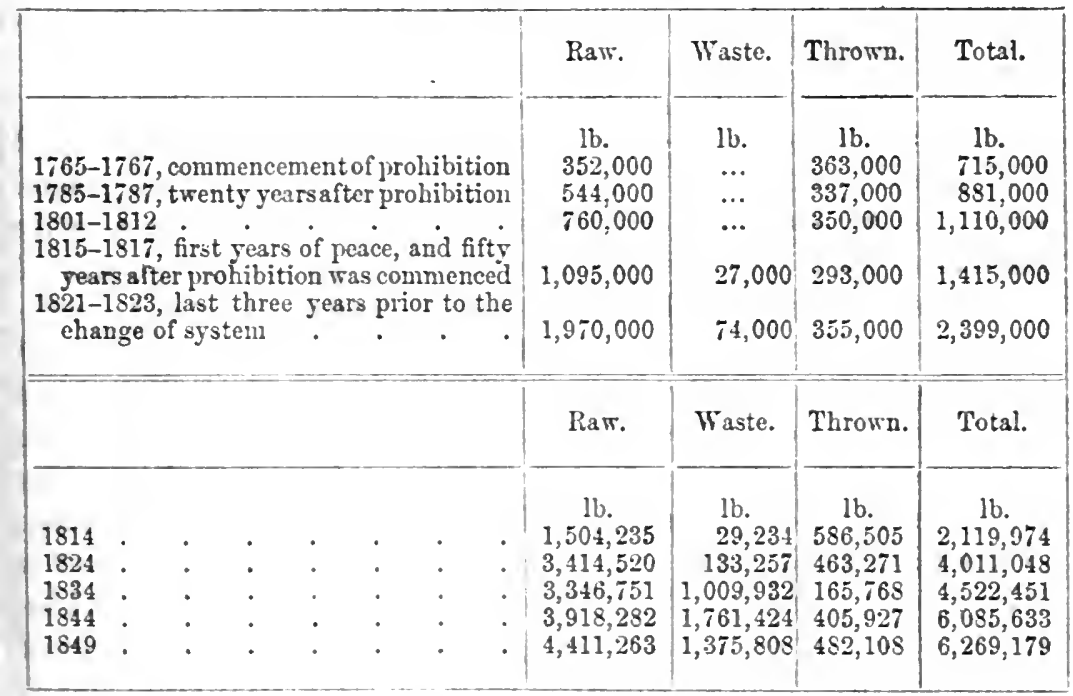

In 1824 the system was wholly changed. The high duties of 5s. 6 d. per lb. imposed upon raw silk, and of $14 \mathrm{~s}$. 8 d. per lb. upon thrown silk, were reduced; the former to $3 \mathrm{~d}$. and the latter to 7s. $6 \mathrm{~d}$. per $1 \mathrm{~b}$. These rates were afterwards further reduced; that on raw silk to $1 \mathrm{~d}$., and that on thrown silk to $3 \mathrm{~s}$. $6 \mathrm{~d}$. per $1 \mathrm{~b} .:$ a regulation of the custom-house permitting the latter duty to be drawn back upon the exportation of the goods into which foreign thrown silk is converted. In 1845 the duties on importation were wholly repealed. In 1824 the system of prohibition against the importation of foreign manufactured silk goods was prospectively repealed, and a scale of duties adopted, under which such goods might be imported; but in order to afford the silk manufacturers 
the opportunity of disposing of their stocks of goods already made, and of otherwise preparing for foreign competition, such importations were not allowed to take place until after the 5 th of July, 1826 . An immediate and great increase in the consumption of silk goods followed this reduction in the cost of the material. Every throwing mill and every loom was put in constant employment, and a great increase was made in the number of these establishments. The number of throwing-mills in different parts of the country was raised from 175 to 266 , and the number of spindles from 780,000 to $1,180,000$; yet, notwithstanding this additional productive power, it was not possible for the throwsters to keep pace with the demands of the weavers, who were frequently kept waiting during whole months for silk to enable them to complete the orders which they had in hand.

This full tide of prosperity was checked by the commercial panic which occurred at the close of 1825 ; and as the admission of foreign-made silk goods first took place during a time of general depression, a great clamour was raised on the part of the home manufacturers against the relaxation, which was said to be the chief, if not the only cause of the distress that had overtaken the trade. This distress, however, soon passed away, so that in the year 1827 a larger quantity of silk was manufactured in this country than had ever before passed in an equal time through our looms. In the ten years preceding 1824 , the quantity of raw and thrown silk used by our manufacturers amounted to $18,823,117 \mathrm{lb}$., being an average of $1,882,311 \mathrm{lb}$. per annum; in the ten years immediately following the change of system, the quantity used was $36,780,009 \mathrm{lb}$., or $3,678,001 \mathrm{lb}$. per annum, being an increase over the average of the former period of 95 per cent.; and in the eleven years ending with 1844 , the consumption was $43,588,386 \mathrm{lb}$, or $3,962,580 \mathrm{lb}$. per annum, being an increase of 110 per cent. upon the quantity used under the restrictive system.

It is further remarkable that, notwithstanding the great increase in the quantity of silk employed in our looms, the quantity of thrown silk imported was not at all augmented during this period, but, on the contrary, was sensibly diminished. The spur of competition drove forward the manufacture in both its branches. Improved machinery was introduced into our throwing-mills; and, by the adoption and improvement of the ingenious machinery of Jacquard, our weavers were enabled to produce fancy goods of high quality.

The charge made by English throwsters, previous to 1824 , for 
converting raw silk into organzine, was about $10 \mathrm{~s}$. per $\mathrm{lb}$. At that time the duty imposed upon foreign organzine was $14 \mathrm{~s}$. 8 d., or $9 \mathrm{~s}$. 2 d. beyond the duty upon raw silk, and yet a much larger proportion of the material used in our silk looms was then thrown abroad than was afterwards the case. In the ten years preceding 1824 the weight of thrown silk imported was equal to $23 \frac{3}{4}$ per cent. of the weight of raw silk, whereas the quantity imported in this state of preparation during the ten years ending with 1844 did not exceed $7 \frac{3}{4}$ per cent. of the weight of the silk thrown in the mills of this country; and later we were able to export British thrown silk to Germany, thus proving the ability of our throwsters to meet their Continental rivals in third markets. Our throwsters, after twenty years' competition with foreigners, succeeded in bringing down their charge from $10 \mathrm{~s}$. to from $3 \mathrm{~s}$. to $5 \mathrm{~s}$. per $1 \mathrm{~b}$., the rate depending upon the quality of the silk. The better the quality the lower the charge: a fact which arose chiefly from the throwster making good the waste which occurred in the process, which was greatest when the quality of the silk was worst.

When the prohibition on the importation of foreign silk goods was removed, a duty was imposed of 30 per cent. ad valorem, which was , soon after altered to specific rates per pound, so calculated upon different kinds of goods as to be equal, in most cases, to 30 per cent. upon the presumed value, this rate being assumed as the maximum of protection which in any case it was desirable to aflord to the English manufacturers. Apart from all considerations of a maximum as between the consumers and manufacturers in this country, however, it was found impossible to adopt any higher scale of protection, on account of the encouragement which would thereby be given to smugglers, and, in fact, while arranging the specific duties chargeable on the weight of the goods, it was on this account found necessary to fix the rate upon plain goods on a scale equal to no more than 25 per cent. on the value, while the higher percentage was retained upon other goods, the smuggler's charge on which was higher. The reason why this charge was less upon plain than upon fancy fabrics was that the latter, being made to answer the immediate demands of ever varying fashion, were required by the purchasers to be delivered to them without delay, while plain goods, which would be equally valuable at all times, could be kept back by the smuggler to a more favourable opportunity for eluding the government officers.

For some time before and after the opening of our markets to the fabrics of other countries, it was firmly believed, and loudly 
asserted, by many persons experienced in the trade, that such a measure would bring certain ruin upon the silk manufacturers of England, who, being accustomed to work for only the higher ranks of society, had constantly experienced the evils attendant upon a limited market, and had been kept in dread of competition from without; the successful adventures of contraband dealers having, under such circumstances, been frequently productive of temporary stagnations, which involved the manufacturers and their workmen in distress. The experience of twenty years served to show how groundless were these fears. By reducing the prices of their goods, which they were enabled to do through the reduction of the duty and the improvements in their machinery, the silk manufacturers extended their markets; and, stimulated by the rivalry of foreign manufacturers, they effected such improvements in the quality of their fabrics as fitted them for successful competition with the finest productions of foreign looms. With free permission to import upon even a high scale of duties, our silk manufacturers suffered less from foreign competition than in the days of prohibition, when the quantity of smuggled goods amounted to only a small fraction of what were afterwards legally imported. In 1810, when the smuggler's difficulties were increased by the war, the quantity of contraband silks brought into consumption in this country was felt to be so injurious to the manufacturers that they formed themselves into an association for the prevention of smuggling. Again, in 1818 and the following year, numerous petitions were presented to Parliament by the silk-weavers of Spitalfields and of Coventry, complaining of this illegal competition, and stating that, by means of it, "The demand for manufactured goods had for some time past so decreased as to afford serious ground of alarm to the manufacturers, and to threaten the existence of the silk manufacture of this country." In one of these petitions, it was stated that operative weavers who used to earn from $30 \mathrm{~s}$. to 40 s. per week were at that time able to earn no more than $10 \mathrm{~s}$. or $11 \mathrm{~s}$.

From the year 1824, when the shackles were partially removed from the trade, the silk manufacture in all its branches spread itself into various districts, and was conducted upon a scale, and according to principles which admitted of so great a degree of economy, as not only to place the products of our silk looms within the reach of the humbler classes of the community in this country, but to enable us successfully to compete in other markets with goods produced in foreign countries. The declared value of British manu- 
actured silk goods exported from the United Kingdom between 1820 and 1849 was as follows:-

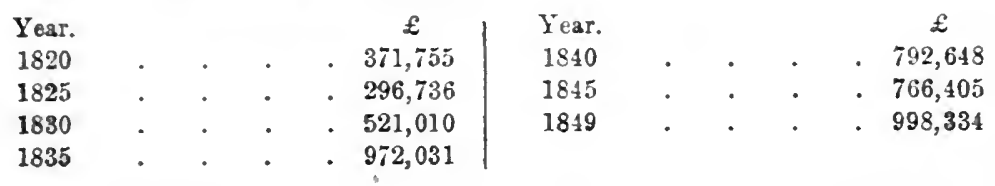

It is, perhaps, not the least surprising of the effects which ollowed the total alternation of our system in regard to this manufacture, that England regularly exported silk goods to a considerable value to France: these exports amounted in

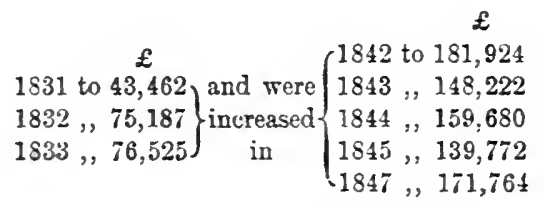

forming nearly three-fifths of the exports of those goods made to the whole of Europe. The most considerable part of our export of silks at this time was made to our North American Colonies, the West India Islands, and the United States of America.

The number of silk-mills in the townships of Manchester and Salford, which in 1820 was no more than five, had increased, in 1832, to sixteen. According to the statement of the Inspectors of Factories, the number of factories at work in the United Kingdom in 1835 was 238. Of the 238 factories at work, 231 were in England ( 88 in in Cheshire alone, 23 in Lancashire, the same number in Somerset, 15 in Derbyshire, and 11 in Staffordshire, the remainder being distributed throughout the country), 6 in Scotland, and 1 in Ireland. These altogether employed 30,682 persons, who are further classified according to age and sex :-

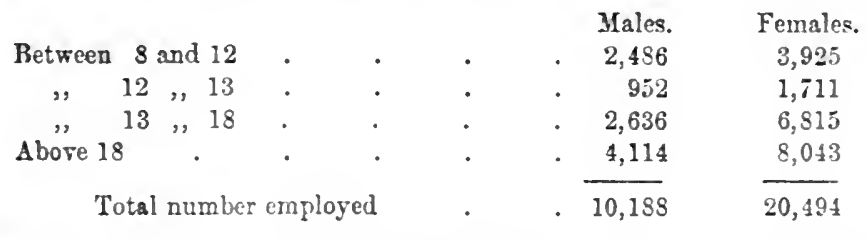

Except in the preliminary branch of the manufacturethrowing - it had not at this time been found practicable to apply machinery to any great extent for simplifying the processes of manufacturing the finer kinds of silk goods, or for economizing the cost of their production. For this reason, the improvements effected 
in the quality of silken fabrics was more the result of individual effort, than the improvements in those other branches of manufacture to which mechanical invention had been so successfully applied in this country. Among the causes to which the continued superiority of French silk weavers, in some articles, must be attributed, may be instanced the kind of education which they received, by means of which so many among those who were engaged in the labour of weaving were enabled to contribute to the perfecting of their art, by the invention of new patterns. As regards the texture only of silk fabrics, English-made goods became fully equal to the best produced by our neighbours. The greater cheapness of the necessaries of life in France at that time, as compared with England, gave an advantage, in point of price, to the French weaver over his English competitor; and this advantage was of course the greater in those descriptions of goods into the cost of which labour entered in the greatest proportion-such as gauzes, and other light and fancy fabrics. We have seen, however, that as regards other kinds of silk goods, our manufacturers were enabled to compete with their formidable rivals in markets which were equally open to both, and that we were, in fact, exporting continually the produce of our silk looms to France itself.

It will scarcely be affirmed that, in this respect, the manufacturers of England would have stood in so advantageous a position, had the old prohibitory system been maintained. Up to the very moment of the legal admission of foreign silk goods no improvement was perceptible in the quality or fashion of our own; by the most cursory glance, the difference between the fabrics could be distinguished, and yet, notwithstanding the facility thus afforded for the detection of contraband goods, the ingenuity of the smuggler was at all times successful to ensure their introduction; and this irregular competition was the more ruinous, as the foreign goods had not been subjected, in the country of manufacture, to the heavy impost then placed upon the raw material in England. It was a bold measure on the part of the Government of that day, in the face of so much prejudice, to remove the prohibition to import foreign silk goods, which prohibition had always been declared indispensable to the existence of the manufacture in England. The good effect of the change was made immediately apparent by the increased quantity of the material employed, and through the extension of the use of silks to nearly all classes the manufacture was rendered in a great measure safe from the ruin with which it was formerly threatened at every change of fashion. 
Even after the removal of prohibition under high protective uties a very large proportion of silk goods shipped from France for angland uniformly found their way into use without passing through he custom-house. A custom-house statement shows the extent 0 which this contraband trade was carried on. In the course of eventeen years (1827-1843) 50 per cent. of the silk goods hipped from France to England were smuggled. Thus in 1843 $84,438 \mathrm{lb}$. were exported from France to England, and as only 76,256 lb. (57.02 per cent.) were entered at custom-houses in Engand, $208,182 \mathrm{lb}$. (42.98 per cent.) more were actually shipped than rere entered. The duty received on $3,173,676 \mathrm{lb}$. of silk manuactures during these seventeen years (1827-1843) arnounted to $3,136,091$, which is at the rate of $19 \mathrm{~s} .9 \mathrm{~d}$. per lb. During the ame period the regular imports from France amounted to , 179,112 lb. weight, which is about equal to the whole quantity n which duty was paid. The sum received, if collected upon the rhole quantity shipped from France to England, would have been qual to a very small fraction less than $10 \mathrm{~s}$. per lb. The trade of he smuggler would, in all probability, hare been prevented, as egards silk goods, if the duty had been fixed at 10 s. per lb., which rould still have been a very high protecting duty, and the revenue rould have been as great at the lower as it has proved at the igher rate, while the gain to the consumers in England would have veen $9 \mathrm{~s} .9 \mathrm{~d}$. per $1 \mathrm{~b}$. in the price of the manufactures produced and mported. These amounted to $79,217,862 \mathrm{lb}$., including all qualities, rhich gives a sum of $£ 38,618,708$ lost to the great bulk of the comnunity in seventeen years, through the operation of excessive duties evied for the supposed benefit of one branch of our manufactures.

\section{The Silk Trade-1850-1910}

The later history of the British silk industry really begins with he year 1860 - the year of the Cobden Treaty, which removed the rotective duty of 15 per cent. on foreign silk manufactures. The mmediate effect was disastrous to a great number of firms. Mr. Iatthew Blair, a well-known authority, writes: "The silk firms in xistence in 1860 were numerous, and many of them not large. In the average they were little prepared for the storm. The eaker ones were quickly weeded out. The larger ones curtailed jeir production; and as the trade was not taking off the silk, many t the wealthy throwsters retired from the business. But those tanufacturers who were in a large way, with capital and modern 
ideas, although hard hit by the Cobden Treaty, were not destroyed, and many of them are still to the front. The trade, if not so large as formerly, is founded on a far more secure economic basis." It was the thrown silk branch of the trade which suffered. Spun silk, which was then in its infancy, is now a large and profitable industry. "Viewed as a whole," writes Mr. Blair, "the silk trade of the country has not decreased, but is larger to-day than ever it was, and we may also say that it is more lucrative." The introduction of the factory system, and the extension of power-loom weaving, which destroyed domestic weaving, are regarded by some as unfortunate developments. The principal silk manufacturing towns in England have been Coventry, Macclesfield, Congleton, Leek, Derby, London (Spitalfields), Manchester, Middleton, and Nottingham. At the best period some 150,000 looms found employment. In 1872 the number was reduced to 65,000 , of which 12,500 were power-looms. Spitalfields in its best days kept 24,000 hand-looms occupied; Manchester once had 20,000 looms weaving silk. The spun silk industry, to which we have referred, was developed in the Yorkshire and Lancashire textile centres-Bradford, Halifax, Rochdale, etc.

In 1870 there were 696 silk factories in the United Kingdom employing 48,124 persons (13,987 males and 34,137 females). In 1890 there were 623 factories employing 41,277 persons (13,470 males and 27,807 females). The number of persons employed in 1901 was 31,555 (8966 males and 22,589 females). In 1907 there were still less, according to the Statistical Abstract, 28,873 (8776 males and 20,097 females). The Census of Production, however, gives the average number of persons employed in that year as 32,036, namely, 30,541 wage-earners and 1495 salaried persons, and further classifies them according to age and sex :-

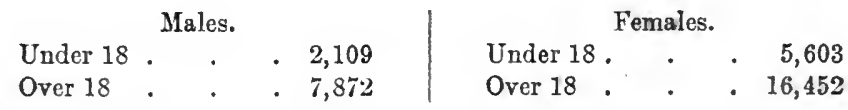

In considering our foreign trade it must be remembered that the opening of the Suez Canal in 1869 enormously affected our imports of raw silk. Before the Canal was opened, the bulk of the oriental silk used on the Continent came round by the Cape of Good Hope, and London was a convenient entrepôt; but with the Suez Canal open, these goods were naturally entered at Trieste, Genoa and Marseilles, and Lyons became the centre of the European industry. The effect of this is seen in the statistics of our imports of raw silk:- 


\begin{tabular}{|c|c|c|c|c|c|c|}
\hline $\begin{array}{l}\text { Year. } \\
1850\end{array}$ & . & . & . & . & $\begin{array}{c}\text { lb. } \\
4,912,407\end{array}$ & $\begin{array}{l}£ \\
\ldots\end{array}$ \\
\hline 1865 & . & . & . & . & $7,732,450$ & $10,184,85 \mathbf{a}$ \\
\hline 1875 & . & . & . & . & $4,457,837$ & $3,443,722$ \\
\hline 1890 & . & . & . & . & $1,961,281$ & $1,392,460$ \\
\hline 1910 & . & . & . & . & 996,565 & 589,572 \\
\hline
\end{tabular}

Our imports of silk manufactures have been as follow:-

\begin{tabular}{|c|c|c|c|c|c|}
\hline Year. & & $\stackrel{f}{f}$ & $\begin{array}{l}\text { Year. } \\
188^{5}\end{array}$ & & $\underset{10,268,690}{£}$ \\
\hline $\begin{array}{l}1854 \\
1860\end{array}$ & . & $\begin{array}{l}1,923,511 \\
2,799,137\end{array}$ & $\begin{array}{l}1885 \\
1890\end{array}$ & . & $\begin{array}{l}10,268,690 \\
11,318,883\end{array}$ \\
\hline 1865 & . & $7,325,709$ & 1895 & . & $15,237,238$ \\
\hline 1875 & . & $12,264,532$ & 1900 & - & $15,376,634$ \\
\hline 1850 & . & . $13,324,935$ & 1910 & . & $13,5: 1,021$ \\
\hline
\end{tabular}

The total value of our exports of silk manufactures every ten years since 1850 has been as follows:-

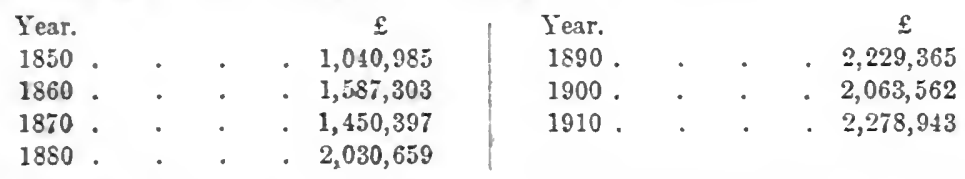

The returus for 1850 and 1860 give the total quantities of broad piece-goods, handkerchiefs, and shawls and ribbons cxported thus:-

$$
\begin{aligned}
& 1850 \text {. . . . . } 1,185,723 \mathrm{lb} \text {. } \\
& 1860 \text {. . . . 1,307,293,, }
\end{aligned}
$$

The later returns give the quantities of broad piece-goods alone. These are as follow:-

\section{Exports of Broad Piece-Goods}

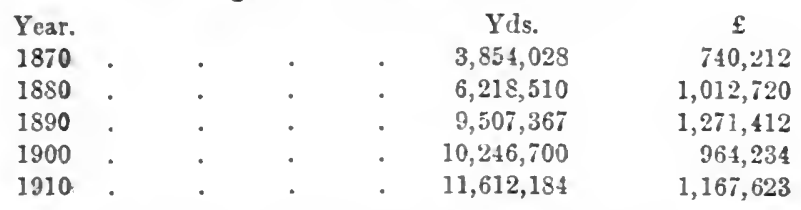

The following table shows our exports of thrown silk, twist, and

\begin{tabular}{|c|c|c|c|c|c|c|}
\hline Year. & & & & & lb. & $\mathfrak{E}$ \\
\hline 1850 & . & • & - & • & 544,342 & 196,380 \\
\hline 1860 & . & - & . & · & 897,402 & 826,107 \\
\hline 1870 & - & . & - & . & $\ldots$ & $1,154,364$ \\
\hline 1880 & . & . & . & . & $\ldots$ & 683,591 \\
\hline 1890 & . & . & . & . & 831,945 & 47,452 \\
\hline 1200 & . & . & . & • & $1,194,900$ & 425,647 \\
\hline 1910 & . & . & . & . & $1, \pm 6 \pi, 719$ & 511,909 \\
\hline
\end{tabular}
yarn from 1850 to 1909 :-

From 1868, when we exported thrown silk, twist, and yarn to

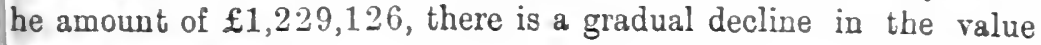
of our annual exports. 
The report on silk factories in the Census of Production (1907) is based on returns from factories engaged principally in the throwing, spinning and weaving of silk, as distinct from those engaged solely in the dyeing, bleaching and finishing of silk and other goods, or from those engaged in the manufacture of hosiery, silk net, and silk embroidery. The report points out that the value of the gross output of all factories is in excess of the value of the output of the trade considered as a unit, since net silk or spun silk yarn made at one factory is sold to another to be woven, and woven goods made at one factory are sold to others to be made up into neckties, handkerchiefs, etc. The quantities and values of net silk yarn (or thrown silk) and spun silk yarn spun for sale or for stock were as follow :-

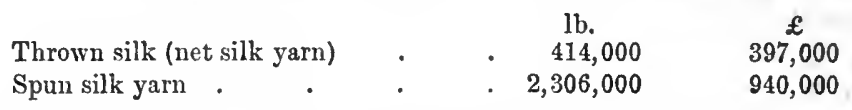

Exports of thrown silk in 1907 amounted to $34,000 \mathrm{lb}$, valued at $£ 37,000$, free on board, and of spun silk yarn, $1,036,000 \mathrm{lb}$., valued at $£ 364,000$. The remainder of the make of yarns above shown is partly included in the quantities and values of other goods made in silk factories, and partly represents yarns sold to hosiery, net, and other factories not included. The make of yarns indicated above is exclusive of the yarns made and used in the same factory in the manufacture of broadstuffs, ribbons, etc., and no estimate is given as to the total make of spun silk yarn. The total make of net silk yarn (or thrown silk) is roughly estimated at between 800,000 and $1,000,000 \mathrm{lb}$. The net imports of "knubs, noils, and waste" (the raw material for spun silk yarn) in 1907 were $6,865,000 \mathrm{lb}$.

The following statement shows the quantity and value of the output of broadstuffs and the values of ribbons, other silk manufactures, and other goods made in silk factories, exclusive of goods made by commission weavers and goods made into neckties, handkerchiefs, etc., by the weaving firms; it is free from duplication.

Broadstuffs-

Wholly of silk (net or spun)

Of silk mixed with other materials .

Ribbons-

Wholly of silk or of silk mixed with other materials Other manufactures of silk, mixed or not with other materials (iucluding smallwares).

Cotton and woollen manufactures

Other products

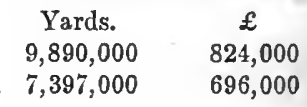

$\left\{\begin{array}{c}\text { Recorded } \\ \text { by } \\ \text { valne } \\ \text { only. }\end{array}\right\}$
121,000

$1,056,000$

328,000

33,000

The value of the goods included above amounted to $£ 3,058,000$. The following goods were also manufactured either from piecegoods woven by other firms and included in the foregoing statement 
(and consequently to that extent duplicated), or by firms who wove the silk out of which they were made:-

Made-up gools-

Neckties . . . . . . . $£ 279,000$

Handkerchiefs, scarves, mufflers, etc. (not in the fiece) . 291,000

Of these sums, neckties valued at $£ 92,000$ and handkerchiefs,

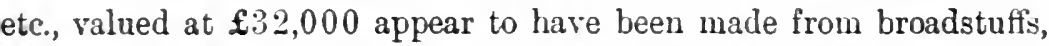
etc., returned as such by other firms making returns to the Census Office; while neckties valued at $£ 187,000$, and handkerchiefs, etc., valued at $\mathfrak{2 5 9 , 0 0 0}$ were made by weaving firms, and although it is not certain that they were in every such case made of tissues woven by the firm it appears probable that the great bulk of them was so made and that the tissues used in their manufacture are additional to those included in the previous statement. There are also included in the returns three further items:- Raw silk (wound),

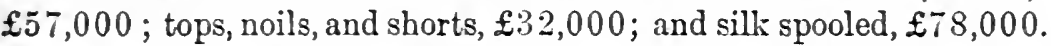
The whole or nearly the whole of these goods was no doubt sold to other firms in the trade and these sums are, therefore, almost entirely duplicated in other headings of output. The amount received for "work done on commission" was $\mathfrak{f}^{7}: 2,000$, made up as follows :-

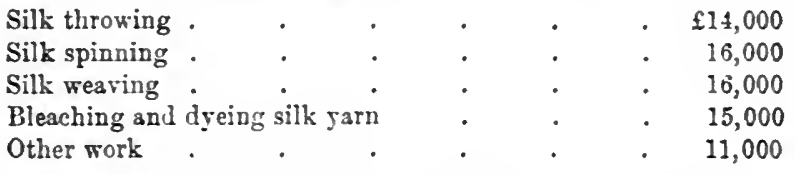

Allowing for the yarns sold to hosiery and other factories not included in this report, the value of the products of silk factories taken as a whole is estimated at between $3 \frac{3}{4}$ and $4 \frac{3}{4}$ millions sterling. The following statement compares as far as possible the production of broadstuffs, ribbons, etc., with the imports and exports in 1907 :-

\begin{tabular}{|c|c|c|c|}
\hline & Production. & $\begin{array}{l}\text { Exports } \\
\text { in } 1907 .\end{array}$ & $\begin{array}{l}\text { Net Imports* } \\
\text { in } 1907 .\end{array}$ \\
\hline $\begin{array}{l}\text { Broadstuffs- } \\
\text { Wholly of silk } \\
\text { Mixed with other materials } \\
\text { Ribbons, wholly of silk or of silk mixed } \\
\text { with other materials } \\
\text { Other manufactures of silk (mixed or not } \\
\text { with other materials) }\end{array}$ & $\begin{array}{l}\text { Yards. } \\
9,890,000 \\
7,397,000 \\
£ \\
121,000 \\
1,626,000\end{array}$ & $\begin{array}{c}\text { Yards. } \\
7,044,000 \\
5,974,000 \\
£ \\
42,000 \\
465,000\end{array}$ & $\begin{array}{c}\text { Yards. } \\
66,002,000 \\
16,469,000 \\
£ \\
2,409,000 \\
909,000\end{array}$ \\
\hline
\end{tabular}

* i.e. imports less re-exports.

About three-quarters of the total quantity of broadstuffs (wholly r partly made of silk) produced in the United Kingdom were ex- 
ported, but the imports were nearly five times as great as the home production. The value of the ribbons manufactured in the United Kingdom is insignificant compared with the imports. The net output of silk factories included in this report was $£ 1,750,000$, this sum representing the total amount by which the value of the products of those factories, taken as a whole, exceeded the cost of the materials used in their manufacture and the amount paid for work done on those materials by other firms for the principal firms. The actual cost of the materials is not known, since the total of the sums returned as "materials" includes, like the total of the sums returned as "output," yarn and broadstuffs made by one factory and used by another.

\section{The Linen Industry, $1800-1850$}

The linen manufacture has very long been prosecuted in England, and about the end of the seventeenth century was indirectly encouraged in Ireland by an act of legislative oppression, such as it would not be possible to enforce in this country at the present day. The woollen manufacturers of England, alarmed at the rapid progress then being made in Ireland in that brauch of industry, induced the Houses of Parliament to interfere with the king (William III) for its suppression. In his answer to their address, the king made the following promise:- "I shall do all that in me lies to discourage the woollen manufacture in Ireland, and encourage the linen manufacture, and to promote the trade of England." Nor was this an empty promise. Through the interference of the king with the Irish Houses of Parliament, an Act was passed prohibiting the exportation of all woollen goods from Ireland, except to England; an exception which could not operate to the relief of the Irish manufacturer, since prohibitory duties were already laid against their importation into this country. As some compensation for this act of injustice, various regulations were at different times made for the encouragement of the linen manufacture in Ireland; although it is doubtful whether those regulations, in reality, effected anything towards the establishment of the manufacture upon a healthy footing. Among other modes of encouragement, a bounty was paid upon the exportation of linen from Ireland. This was in force for more than a century, and only ceased in 1830 . It is not possible to trace, with any certainty, the growth of the linen manufacture in either part of the kingdom. Cotton and silk being productions of foreign growth, the quantities which pass through 
our custom-houses form, of course, a correct measure of the growth of those manufactures as far as quantity is concerned; but flax is a production of our own soil, as well as an article of foreign commerce, and the quantity imported from abroad gives therefore only an imperfect test of the quantity of linen produced in our looms. The following table shows the exports of linen goods from Ireland from 1800 to $1825:-$

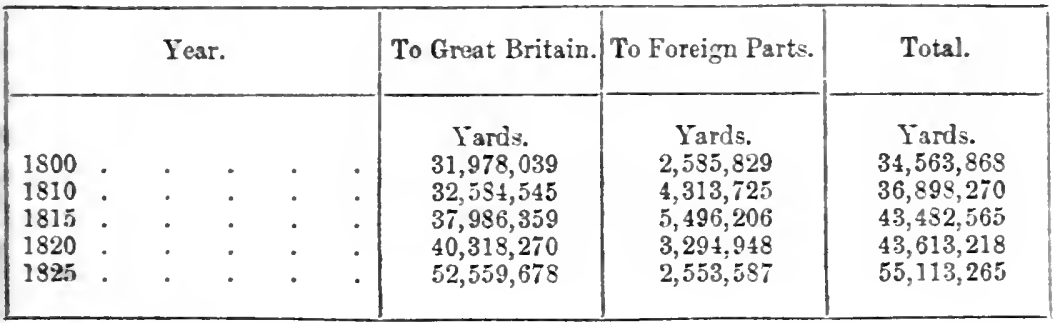

It will be seen from the next table that a large proportion of the linen exported from Ireland to Great Britain was re-exported to foreign countries:-

British and Irish Linen and Sailcloth Exported from the United K'ingdom, 1820-1833

\begin{tabular}{|c|c|c|c|c|c|c|}
\hline & Year. & & $\begin{array}{l}\text { British } \\
\text { Linen. }\end{array}$ & $\begin{array}{l}\text { Irish } \\
\text { Linen. }\end{array}$ & $\begin{array}{c}\text { British } \\
\text { Sailcloth. }\end{array}$ & $\begin{array}{c}\text { Irish } \\
\text { Sailcloth. }\end{array}$ \\
\hline $\begin{array}{l}1820 \\
1825 \\
1830 \\
1833\end{array}$ & $\begin{array}{l}\dot{*} \\
\dot{*} \\
\dot{ }\end{array}$ & $\dot{.}$ & $\begin{array}{c}\text { Yards. } \\
24,066,914 \\
33,643,655 \\
46,232,243 \\
51,393,420\end{array}$ & $\begin{array}{c}\text { Yards. } \\
12,455,419 \\
16,023,263 \\
13,244,269 \\
9,561,27 i\end{array}$ & $\begin{array}{c}\text { Ells. } \\
1,226,335 \\
1,879,506 \\
1,922,211 \\
2,229,777\end{array}$ & $\begin{array}{c}\text { Ells. } \\
18,117 \\
51,104 \\
32,550 \\
48,035\end{array}$ \\
\hline
\end{tabular}

The accounts subsequent to 1833 do not distinguish Irish from British linens. The exports from the United Kingdom of all kinds of linen goods and of flax yarn in 1834,1840 , and 1849 are shown in the following table:-

Linen Exported from the United Kingylom, 1834-1849

\begin{tabular}{|c|c|c|c|c|c|c|c|}
\hline \multirow{2}{*}{\multicolumn{2}{|c|}{ Year. }} & \multicolumn{2}{|c|}{ Entered by the Yard. } & \multirow{2}{*}{$\begin{array}{c}\text { Thread, } \\
\text { Tapes, and } \\
\text { Small- } \\
\text { wares. } \\
\text { Declared } \\
\text { Value. }\end{array}$} & \multicolumn{2}{|c|}{ Linen Yarn. } & \multirow{2}{*}{$\begin{array}{l}\text { Total } \\
\text { Declared } \\
\text { Value. }\end{array}$} \\
\hline & & Yards. & $\begin{array}{l}\text { Declared } \\
\text { Value. }\end{array}$ & & Pounds. & $\begin{array}{c}\text { Declared } \\
\text { Value. }\end{array}$ & \\
\hline $\begin{array}{l}1834 \\
1840 \\
1849\end{array}$ & $\dot{.}$ & $\begin{array}{r}6 \pi, 834,305 \\
89,373,431 \\
111,259,183\end{array}$ & $\begin{array}{c}£ \\
2,357,921 \\
3,194,827 \\
3,209,539\end{array}$ & $\begin{array}{c}\mathfrak{f} \\
85,355 \\
111,261 \\
281,291\end{array}$ & $\begin{array}{r}1,533,325 \\
17,733,575 \\
17,264,033\end{array}$ & $\begin{array}{c}£ \\
136,312 \\
822,876 \\
732,065\end{array}$ & $\begin{array}{c}£ \\
2,5 \% 9,658 \\
4,128,964 \\
4,225,895\end{array}$ \\
\hline
\end{tabular}


It was not until quite the end of the eighteenth century that flax spinning-mills were first erected in the north of England and in Scotland. Before that time the operation of spinning was altogether performed by women in their own dwellings. Up to 1814 the yarn spun in mills was sold to weavers, or to dealers, who acted as middlemen between spinners and weavers; but in that year some spinners became also manufacturers of linen. In Scotland this branch of manufacture was comparatively small before the peace of 1815. In 1814 the quantity of flax imported into Dundee for use in the manufactories did not exceed 3000 tons; but in the year ended May 31, 1831, the import was more than 15,000 tons, besides upwards of 3000 tons of hemp. Two years later the imports had further increased to 18,777 tons of flax and 3380 tons of hemp. The quantity of linen, sailcloth and bagging into which this material was made and which was shipped from Dundee in the same year amounted to sixty million yards, being probably equal to the entire shipments made from the whole of Ireland.

The length of a pound of yarn of average fineness was in 1813 and 1814 only 3330 yards, but in 1833 yarn of the average quality contained 11,170 yards. During that time the price of such average yarn had fallen from $29 \mathrm{~s}$. $5 \mathrm{~d}$. to $10 \mathrm{~s}$. $9 \mathrm{~d}$. per bundle; so that, taking the quantity into the account, the price of yarn has fallen in twenty years to one-ninth of the price which it bore at the close of the war, the price of the raw material having fallen in the same time about one-half. The improvements made in the operation of flax-spinning in England are evident from the fact that we became large exporters of linen-yarn to Ireland, and even to France. The earliest shipments to the latter country were made in 1833 , and amounted to only $76,512 \mathrm{lb}$., but the quantity rapidly increased until 1842 , when it reached $22,202,292 \mathrm{lb}$. In that year the French government, yielding to the representations of their flaxspinners, materially raised the rates of import duty, and our declared exports fell to $13,824,285 \mathrm{lb}$. in 1843 , and $13,546,758 \mathrm{lb}$. in 1844. It is said that the services of the smuggler were engaged to make good in part the difference in the quantity, and it is quite certain that the linen manufacture of France suffered very seriously from the increased price of their material, which diminished their export trade in linen goods, and limited their sales at bome. This country had previously been a constant importer of linen-yarn. In 1827 our weavers used very nearly four millions of pounds of foreign yarn, but in each subsequent year this quantity was diminished, until in 1834 it amounted only to about one million and a balf of pounds, 
and in 1844 hardly exceeded one million of pounds. Our principal foreign customer for linen fabrics was the United States of America : the exports to that country in 1844 amounting to $27,811,411$ yards, the declared value of which was $£ 872,414$.

The annual quantity of flax imported and consumed in the United Kingdom between 1820 and 1824 (when the duty payable was at the rate of $\mathfrak{£ 1 0} 14 \mathrm{~s}$. $6 \mathrm{~d}$. per cwt. on dressed flax and $5 \mathrm{~d}$. on undressed flax) varied from 376,170 ewt. to 739,651 cwt. In 1825 the duty was reduced to 4 d. per cwt. upon dressed and undressed flax, and the import immediately rose to $1,018,837 \mathrm{cwt}$. In the three following years the duty was reduced to $3 \mathrm{~d} ., 2 \mathrm{~d}$., and 1d. per cwt., and the import resumed its normal but accelerated growth. In 1830 it amounted to $955,112 \mathrm{cwt}$., in 1840 to $1,256,322$ cwt., and in 1845 , when flax was first admitted free, to $1,418,323$ cwt. In 1849 the import was $1,806,786 \mathrm{cwt}$.

In the year 1835 there were 347 flax factories in the United Kingdom-152 in England (64 of which were in the West Riding of Yorkshire, 21 in Dorset, 18 in Lancashire, and 13 in Somerset), 170 in Scotland, and 25 in Ireland. The English factories employed 16,193 persons (6015 males and 10,178 females), the Scotch 13,409 (3392 males and 10,017 females), and the Irish 3681 (988 males and 2693 females). After this time the Irish industry, whose chief seat is Belfast, began to forge ahead and soon beat its British rivals.

\section{The Linen Industry-1850-1910}

The outbreak of the Crimean War in 1853 was the first evil which befell the linen industry in this period. The supplies of Russian flax were necessarily interrupted during the war, but by 1860 the trade had recovered its normal conditions. In 1861 the American War broke out, and as the United States were our largest customers, its first effects on this trade were disastrous. The enormous rise in the price of cotton, however, created a great demand for linen, and under this stimulus the Irish linen inclustry expanded enormously. Between 1861 and 1868 the number of spindles in Ireland rose from 592,981 to 894,273 , an increase in seren years of 301,292 spindles or rather more than 50 per cent. The return to normal conditions was, not unnaturally, attended by a large number of failures. Again in 1870 the trade was for a short time affected by the Franco-German War, but the return to peace was followed by a period of great prosperity. A period of depression jegan in 1880 and the number of spindles declined. In 1850 
Ireland had 396,000 spindles, England had 265,000 spindles, and Scotland 303,000. ${ }^{1}$ In 1856 England attained its maximum with 441,000. Since that time its spindles have decreased, until now the English linen trade seems to be near vanishing point with less than 50,000 spindles. Scotland reached its maximum in 1871 with 317,000 spindles_now it has 160,000 ; while Ireland's share has increased by a larger number than the other two have lost. In 1874 Ireland had 906,000 spindles in operation; in 1888 it had 803,000. Sir William Crawford in a valuable paper entitled " "Irish Linen" (1910) estimates the present number of spindles in Ireland at 935,411 , belonging to some fifty different companies, of which seventeen are in Belfast. He also writes:-

"An average-sized flax-spinning mill may contain 20,000 spindles, and a mill of that size would give employment to about 750 persons. It would to-day cost $£ 6$ to $£ 8$ per spindle to erect it ; that means $£ 120,000$ to $£ 160,000$. The workers are employed in the proportion of two or three females to one male. A few children of both sexes, and of twelve to fourteen years of age, are employed as learners, who work and go to school on alternate days. About $£ 75$ are spent in turning $£ 100$ of flax into yarn, another $£ 75$ in turning that yarn into brown linen, and about $£ 50$ in turning that brown linen into white goods ready for market. Thus on $£ 100$ worth of flax about $£ 200$ is spent, chiefly in wages, and the finished product is worth $£ 300$. The flax used in Irish mills is the produce chiefly of four countries-Ireland, Belgium, Holland, and Russia."

In linen weaving also Ireland has far outstripped England and Scotland. At the present time she has 36,000 power-looms, owned by a hundred companies. Of these 21,000 are working in Belfast, 13,000 in other parts of Ulster, and 2000 scattered in small factories in Dublin, Cork, Dundalk, and Drogheda. Scotland has 17,000 power-looms, and England 4400 using linen yarn. Eight weaving factories in Belfast and eight in other parts of Ireland are attacbed to spinning-mills, but that system is not growing. In 1872,9000 looms were attached to mills; now the number is a few hundred less." The growth, or extension, has been in factories separate from mills; in 1872 they were 9000 ; now they are 27,000 looms. To quote Sir William Crawford again :-

"A power-loom factory for the weaving of light and narrow linens will cost $£ 40$ or $£ 50$. per loom. A factory for making wide damask or sheetings will cost $£ 100$ and up to $£ 200$ per loom. Generally speaking, one weaver attends to two looms, but for wide goods there is a weaver to each loom. Women attend to the looms weaving narrow and light cloth, and women also sometimes attend to looms making wide and heavy cloth, but many of such looms are attended to by men. Wages are paid by piece-work, and the same scale applies to men and women. The light end of the work is done by women, the heavy end by men,

${ }^{1}$ Parliamentary Paper No. 745 tor 1850. 
and between the two by either sex. The wages of tenters and other skilled men are comparatively high. The number of all persons employed in and about a weaving factory is somewhere about as many as the looms it contains."

For our foreign trade statisties we may turn to the "Statistical Abstract for the United Kingdom." The following table shows the movement of our foreign trade in linen manufactures in the last sixty years:-

Linen Exports from the United Kingdom

\begin{tabular}{|c|c|c|c|c|}
\hline & 1850. & 1870. & 1890. & 1910. \\
\hline Linen yarn, amount (lbs.) & $18,220,688$ & $37,239,314$ & $15,312,600$ & $18,548,900$ \\
\hline$", "$ value $(£ s)$ & 881,312 & $2,23 \tau, 492$ & $\begin{array}{r}10,010,390 \\
866,393\end{array}$ & $1,196,948$ \\
\hline Piece goods, amount (yds.) & $129,106,753$ & $226,470,696$ & $184,039,800$ & $220,568,000$ \\
\hline$, \quad, \quad$ value $(£ s)$. & $3,947,682$ & $7,248,345$ & $5,356,183$ & $6,115,414$ \\
\hline Thread for sewing, amount (lbs.) & $3,360,120$ & $2,378,631$ & $2,949,000$ & $2,738,900$ \\
\hline$,, \quad, \quad$ value (£s). & $\ldots$ & $\ldots$ & 353,985 & 342,208 \\
\hline
\end{tabular}

In the year 1860 we imported $£ 3,836,770$ of flax, dressed and undressed $(1,464,810 \mathrm{cwt}$.). In 1870 our import was only 50,985 ewt., valued at $£ 132,466$. In 1890 we imported $1,581,849$ ewt.

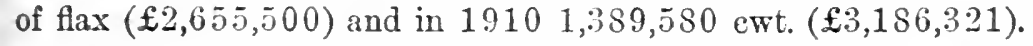

The Census of Production (1907) provides some additional statistics. The total make of linen and flax tow yarns in the United Kingdom in $190 T$ is estimated to have been between $15 t$ and 162 million pounds weight, and its value to have been nearly 8 millions sterling. The following is a statement showing the quantity and value of linen piece goods manufaetured in the United Kingdom :-

Linen piece goods (including union and other mixed fabrics)-

Yards.

Plain, unbleached or bleached

Checked, printed or dyed, and damask or diaper. . .

Sailcloth and canvas (including goots made therefrom, whether waterproofed or not)

$\begin{array}{cc}\text { Yards. } & \mathfrak{E} \\ 267,855,000 & 6,215,000 \\ 63,847,000 & 2,411,000 \\ 24,279,000 & \frac{1,213,000}{9,869,000}\end{array}$

Total value of linen piece goods . $\quad \overline{9,869,000}$

This statement includes the total make of linen piece goods with the exception of some linen eloth woven and male up into bousehold articles and articles of clothing by the same firms. The selling value of such articles made by weaving firms was $\mathfrak{f} 820,000$. It is probable that the bulk of these articles were made of eloth woven by the firm, and that this eloth is additional to that included in the above statement. Its value is estimated to have been between 
$£ 600,000$ and $£ 700,000$. The total output of articles of linen or union cloth made up in linen factories in the United Kingdom was as follows:-

\begin{tabular}{|c|c|c|c|c|}
\hline \multicolumn{5}{|l|}{ Handkerchiefs- } \\
\hline Plain & . & • & . & $£ 446,000$ \\
\hline Printed, embro & lered, etc. & . & . & 150,000 \\
\hline Household articles & . $\quad$. & . & . & $1,441,000$ \\
\hline Articles of clothing & . & . & . & 73,000 \\
\hline
\end{tabular}

The total value of these goods amounted to $£ 2,110,000$, but this sum does not represent the total value of all handkerchiefs, household articles, etc., made in the United Kingdom as it does not include the value of similar goods made in factories not connected with linen weaving mills. In addition, the value of work done for the trade and of goods not of linen made-up in making-up departments of linen factories was returned to the Census Office as $£ 27,000$. About 62 per cent. of the plain linen piece goods and 22 per cent. of the printed, checked and other fancy linen piece goods were exported. Finally, we have statistics of the bleaching, dyeing, etc. factories:-

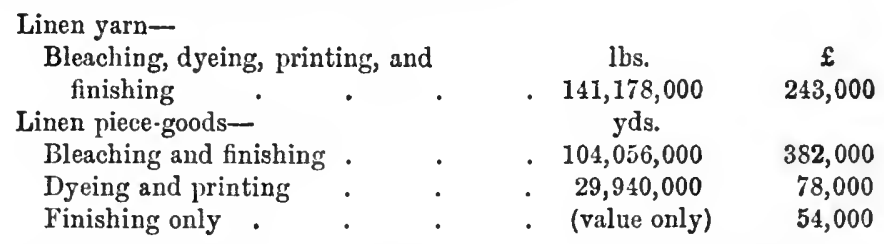

Returns were also obtained by the census authorities from flax scutching factories, which are with one exception confined to Ireland. The following table shows the quantity and value of the output included in the returns:-

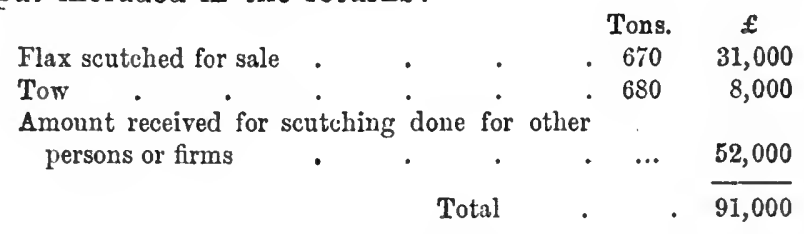

The usual practice of the trade is to scutch on commission, and the above figures consequently do not indicate the amount of flax scutched. As, however, the usual price received for scutching flax appears to have been one shilling per stone of fourteen pounds, the quantity of flax scutched on commission as shown by the returns would seem to have been about 6500 tons, and the total quantity scutched to have been about 7850 tons. These returns are admittedly unreliable. 
According to the Report of the Department of Agriculture and Technical Instruction for Ireland on the Agricultural Statistics of Ireland for 1908, the total quantity of flax produced in 1907 was 11,646 tons, and in 19087922 tons. The discrepancies between these figures and those returned to the Census Office are, no doubt, partly to be explained by the fact that the returns made to the Census Office cover parts of the years 1907 and 1908, but is also attributable to the imperfect nature of the returns themselves. It is not possible to make a comparison of production with imports, since "flax dressed or undressed" is included in one heading in the import list. The net output of flax scutching mills as a whole was shown by the returns to be $£ 68,000$, this sum representing the total amount by which the value of the flax and tow scutched for sale and the amount received for scutching done on commission exceeded the value of the materials used. The actual cost of materials was $£ 23,000$.

Flax scutching is carried on principally in the winter halfyear. Returns were received in respect of the persons employed on the last Wednesdays in January, April, July, and October; 408 persons were employed during one quarter only; 2488 during two quarters (recorded in January and October); 693 during three quarters; and 171 during four quarters. The total number of persons engaged in the flax scutching trade, as shown by the returns, was therefore 3760 , namely, 3721 wage-earners and 39 salaried persons. The small number of salaried persons is due to occupiers of mills who thenselves worked returning themselves as wage-earners, whilst farmers owning flax scutching mills appear in most cases to have excluded themselves from their returns. The total number of persons employed is distributed according to age and sex as follows:-

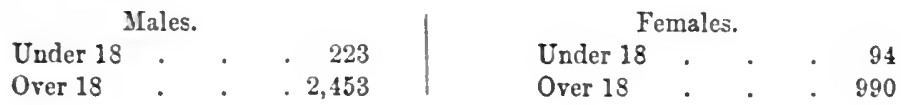

\section{The Jute Industry}

The jute industry is of modern growth, and neither jute nor hemp were noticel by Porter. Previous to the year 1930 recasional parcels of jute were sent to Europe by the Last India Jompany, and these were chiefly used for making door-mats. The nanufacturers of Abingdon in Berkshire first discovered its value n the manufacture of yarn and cloth; and in 1833 a quantity 
of dyed yarn was sent to Dundee, where it attracted much attention. Consignments of jute were then sent direct to Dundee and experiments were made, but with little or no immediate result. The Russian War in 1854-1856, which cut off the supplies of flax, and the cotton famine following upon the American Civil War assisted this industry, which has since grown steadily in importance. Dundee has remained the headquarters and centre of the trade. In the words of a recent report of the Board of Trade," "the character of the town, its industrial conditions, and its place in the commercial world are all determined by the fact that it is the principal seat of the jute trade."

"Its prosperity dates from the time of the American Civil War. The war had stopped the cotton supplies which America sent to the Lancashire mills, and the utility of jute, which could be cheaply produced, was recognized for many purposes for which cotton had litherto been used. Dundee took advantage of the favourable opportunity and began its world trade. The suecess which it then achieved has been maintained."

From this report we learn the following details relating to employment in the jute and hemp industries, etc., in Dundee :-

\section{Numbers Employed (1901)}

Hemp, jute, cocoa fibre manufacture

Carpet, Rug, felt manufacture

Bleaching, printing, dyeing, etc. .

Flax, linen manufacture

Males. Females.

9,201 23,976

$367 \quad 377$

1,397

$366 \quad 1,293$

Altogether jute and other textile trades in this city employed over 32,000 people. Of 37,567 females employed in Dundec, nearly 64 per cent. were engaged in the jute trade alone. The following particulars of wages relate to the jute manufacture:-

Occupations.

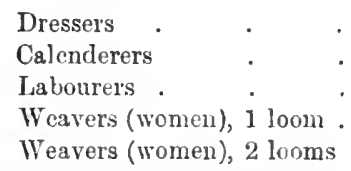

Weekly rates of wages.

s. d. s. d.

280 to $30 \quad 0$

$17 \quad 9,, \quad 220$

$\begin{array}{lllll}17 & 6 & , & 18 & 6\end{array}$

$120,, 16 \quad 0$

$14 \quad 0,2,18 \quad 0$

In 1870 the number of jute factories in the United Kingdom was 63 , employing 17,570 persons (4372 males and 13,198 females). By 1878 these had risen to 117 , employing 36,354 persons $(10,574$ males and 25,780 females). In 1890 there were only 116 jute factories, but the number of persons employed was

${ }^{1}$ Report of an Inquiry into the Cost of Living of the Working Classes (1908). 
4,810 (14,408 males and 30,402 females). Later returns group ute factories with hemp and other factories.

According to the censuses of 1881,1891 , and 1901 the umber of persons employed in jute, hemp and kindred industries n England and Wales were as follow:-

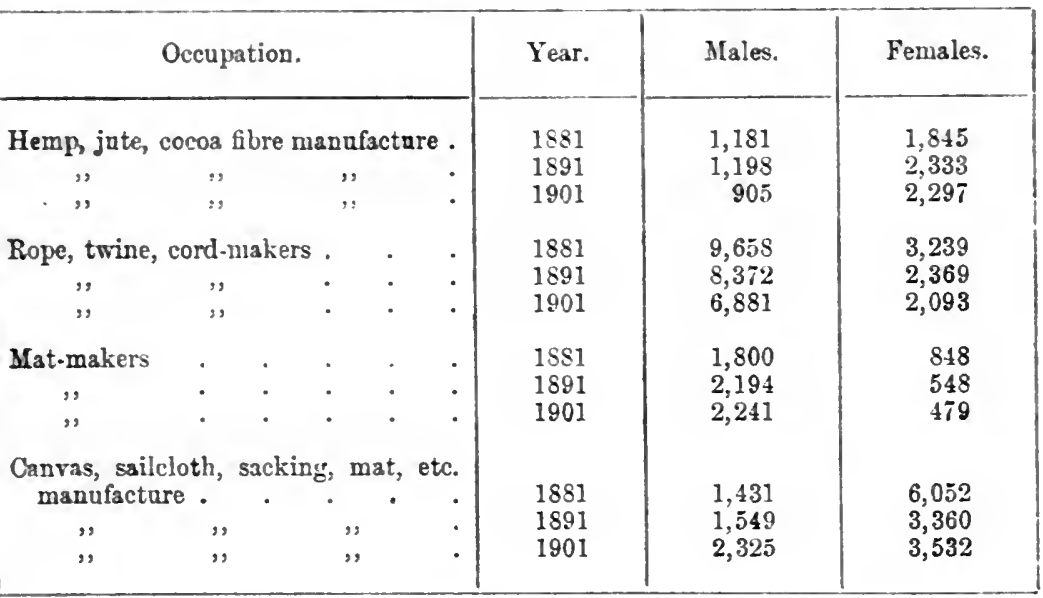

According to the Census of Production (1907) the total make of jute yarn and twist in the United Kingdom in that year was between 407 and 427 million pounds weight, the value of which is placed at about $5 \frac{1}{2}$ millions sterling. The following statement shows the quantities and values of jute piece-goods manufactured in the United Kingdom, as returned to the Census Office. In order to suit the convenience of manufacturers of jute piece-goods, weavers who made part of their piece goods into bags were allowed to return these bags in terms of the quantity and value of the piece goods used in their manufacture. Jute weavers were also permitted to state the quantity of their output either in fards or in hundredweights, according to the custom of their section of the trade, and, accordingly, it is not possible to state in terms of one unit the quantity of jute piece-goods made. Firms making up part of their output of canvas into more finished articles were similarly allowed to return such articles in terms of the canvas of which they were made.

Jute piece-goods (of jute or jute mixed
with other materials, including cloth
made into bags).
Total value of jute piece-goods


In a further statement of miscellaneous goods we find-

Cordage, cables, ropes, and twine (including hemp yarn spun in Ireland). .

Jute manufactures (other than cordage or piece goods)
Cwt.

690,000

(value only)
⿷

$1,514,000$

37,000

To these must be added jute goods (other than piece goods and cordage) to the value of $£ 11,000$, returned indirectly to the census authorities.

About one-sixth of the quantity of jute yarn spun in the United Kingdom was exported in 1907, as well as about half the quantity of jute piece-goods woven. The imports of jute yarn were trifling. Practically all jute is grown in India, and the size and destination of Indian exports for the last five years are given in the following table (which is taken from a circular issued by Messrs. Robinson, Fleming \& Co.) :-

Statistics of Jute and Jute Cuttings for Europe

\begin{tabular}{|c|c|c|c|c|c|}
\hline & 1906. & 1907. & 1908. & 1909. & 1910. \\
\hline \multirow{6}{*}{$\begin{array}{l}\text { Deliveries from London, including } \\
\text { transhipments for Liverpool, } \\
\text { Glasgow, Aberdeen, and Dundee } \\
\text { Direct imports at Dundee . } \\
\text { Direct imports at Hamburg and } \\
\text { Bremen . } \\
\text { Direct imports at other Conti- } \\
\text { nental ports . } .\end{array}$} & Bales. & Bales. & Bales. & Bales. & Bales. \\
\hline & $\begin{array}{r}934,776 \\
132,505\end{array}$ & $\begin{array}{r}973,526 \\
1\end{array}$ & $\begin{array}{r}807,736 \\
\end{array}$ & $\begin{array}{r}683,968 \\
6\end{array}$ & $\begin{array}{r}586,232 \\
1.080,287\end{array}$ \\
\hline & & & & & \\
\hline & 748,043 & 943,192 & 911,345 & 952,946 & 811,101 \\
\hline & 633,602 & 848,962 & 769,508 & $1,168,034$ & $1,027,952$ \\
\hline & $3,448,926$ & $3,804,301$ & $3,675,509$ & $3,773,295$ & $3,505,572$ \\
\hline
\end{tabular}

From this table it will be seen that the average size of the jute exports at the present time is a little over $3 \frac{1}{2}$ million bales, of which about 60 per cent. comes to the United Kingdom and the remainder goes to the Continent. The Director of Agriculture in Bengal issues annually an estimate of the coming jute crop. In 1908 and 1909 the official estimate was considerably too low; in each case the total crop turned out to be about $1,500,000$ bales over the estimate. The result was that there were large stocks of jute on the market, and the price dropped as low as $£ 137 \mathrm{~s}$. 6d. per ton. As an instance of fluctuations in price of the raw material, we will take the following analysis ${ }^{1}$ of the price of jute during the latter half of 1910 (that is, the first half of the 1910-1911 jute season). "The price of jute (first marks) at the end of July was $£ 14$ per ton; at the end of August it had risen to

${ }^{1}$ From The Economist of January 21, 1911. 
£15. Then suddenly in the middle of September it shot up to verer $£ 1810$ s., but fell again to about $£ 16 \quad 5$ s. at the end of that month, from whence it rose steadily through October, and reached its highest point of $£ 215 \mathrm{~s}$. in the middle of November, whence it declined to $£ 1915 \mathrm{~s}$. at the end of the year."

That these movements were somewhat exceptional, however, will be seen from the following extract from the Dundee Prices Current and Trade Report, which says:

"Though shipment jute had firmed up in value in the course of August month, lear prices were not entertained for a moment. September was begun with jute sradually tending dearer, and buyers declining to follow. A surprise, amounting to consternation, was sprung on the trade without the slightest warning, and on a day that few were likely to obtain the news. The irst of the district forecast returns came through disclosing a considerable hortage. When the significance of the intelligence was fully realized, ipeculators commenced buying, and in four days First Marks advanced from $£ 15$ 10s. to $£ 18$ 15s. Subsequently the Director of Agriculture stated that the inal forecast would not necessarily agree with the district returns, but this was oot until after the harm had been done."

In 1874 the world's crop of jute was a million and three-quarter bales. Its subsequent increase may be seen from the following table:-

\begin{tabular}{|c|c|c|c|}
\hline & Total $C$ & Crop & Jute \\
\hline 1874 & . & • & $1,750,000$ bales \\
\hline 88 & . & & $3,750,000 \quad$, \\
\hline & & & $5,250,000 \quad$, \\
\hline
\end{tabular}

The following jute statistics for the past ten years, compiled by Messrs. M'Nicoll, Pirie \& Co., of Dundee, affords a very complete history of the trade during that period. Between 1899 and 1909 the total out-turn of raw jute increased from 5,400,000 bales to $8,800,000$ bales. The consumption in various parts of the world meanwhile showed the following variations:-

\begin{tabular}{|c|c|c|c|c|c|c|}
\hline \multicolumn{4}{|c|}{ Season. } & $\begin{array}{l}\text { Exports to } \\
\text { Europe. }\end{array}$ & $\begin{array}{l}\text { Exports to } \\
\text { America. }\end{array}$ & $\begin{array}{c}\text { Indian Mill } \\
\text { Consumption. }\end{array}$ \\
\hline $\begin{array}{l}1899-1900 \\
1900-1901 \\
1901-1902 \\
1902-1903 \\
1903-1904 \\
1904-1905 \\
1905-1906 \\
1906-1907 \\
1907-1908 \\
1908-1909\end{array}$ & $\begin{array}{l}\dot{.} \\
\dot{.} \\
\dot{.} \\
\dot{.} \\
\dot{.}\end{array}$ & $\begin{array}{l}\dot{5} \\
\dot{5} \\
\dot{5} \\
\dot{5} \\
\dot{5}\end{array}$ & $\begin{array}{l}\dot{0} \\
\dot{ } \\
\dot{ }\end{array}$ & $\begin{array}{c}\text { Bales. } \\
2,149,875 \\
3,002,708 \\
3,596,926 \\
2,812,640 \\
3,221,353 \\
2,983,942 \\
3,530,841 \\
3,952,211 \\
3,655,228 \\
3,676,070\end{array}$ & $\begin{array}{c}\text { Bales. } \\
443,566 \\
521,015 \\
722,252 \\
438,414 \\
542,186 \\
534,736 \\
592,849 \\
586,637 \\
608,129 \\
951,386\end{array}$ & $\begin{array}{c}\text { Bales. } \\
2,300,000 \\
2,500,000 \\
2,600,000 \\
2,800,000 \\
3,000,000 \\
3,250,000 \\
3,400,000 \\
3,700,000 \\
3,905,000 \\
3,700,000\end{array}$ \\
\hline
\end{tabular}


The exports to Europe and America have fluctuated rather widely, while with the exception of a slight falling off in 1908-1909 the Indian mill consumption bas steadily increased throughout the period. The American demand, which contracted in 1907, expanded in the next twelve months to a record amount, having more than doubled within the ten years. The price of raw jute shows very striking variations, having been as low as $£ 11$ per ton at the beginning of 1902 , while in June 1906 it rose to $\mathfrak{f 2 8} 5 \mathrm{~s}$. The following table shows the average price at Dundee for the same ten years of jute, yarns, and cloth, and also the number of bales imported at Dundee after deducting the exports :-

\begin{tabular}{|c|c|c|c|c|c|c|c|}
\hline \multicolumn{4}{|c|}{ Season. } & $\begin{array}{l}\text { Net Receipts } \\
\text { at Dundee. }\end{array}$ & $\begin{array}{c}\text { Jute. } \\
\text { Per Ton. }\end{array}$ & Yarns. & Cloth. \\
\hline $\begin{array}{l}1899-1900 \\
1900-1901 \\
1901-1902 \\
1902-1903 \\
1903-1904 \\
1904-1905 \\
1905-1906 \\
1906-1907 \\
1907-1908 \\
1908-1909\end{array}$. & $\begin{array}{l}\dot{0} \\
\dot{5} \\
\dot{5} \\
\dot{5} \\
\dot{0}\end{array}$ & $\begin{array}{l}\dot{ } \\
\dot{5} \\
\dot{5} \\
\dot{5} \\
\dot{ }\end{array}$ & $\begin{array}{l}\dot{5} \\
\dot{5} \\
\dot{5} \\
\dot{5} \\
\dot{5}\end{array}$ & $\begin{array}{r}\text { Bales. } \\
849,632 \\
1,014,491 \\
1,266,088 \\
993,882 \\
1,122,090 \\
966,893 \\
1,278,334 \\
1,301,423 \\
1,239,881 \\
1,176,164\end{array}$ & $\begin{array}{rrr}\text { f } & \text { s. } & \text { d. } \\
14 & 14 & 7 \\
13 & 13 & 5 \\
12 & 0 & 0 \\
13 & 15 & 0 \\
13 & 10 & 2 \\
16 & 5 & 0 \\
19 & 14 & 7 \\
24 & 17 & 4 \\
16 & 12 & 11 \\
15 & 6 & 6\end{array}$ & $\begin{array}{cc}\text { s. } & \text { d. } \\
1 & 6 \frac{4}{16} \\
1 & 7 \\
1 & 3 \frac{9}{16} \\
1 & 4 \frac{8}{16} \\
1 & 4 \frac{8}{16} \\
1 & 7 \\
1 & 11 \frac{1}{16} \\
2 & 61 \frac{3}{6} \\
1 & 8 \frac{7}{16} \\
1 & 5 \frac{4}{16}\end{array}$ & $\begin{array}{l}\mathrm{d} . \\
2 \\
2 \frac{3}{48} \\
1 \frac{89}{8} \\
1 \frac{88}{48} \\
1 \frac{90}{48} \\
2 \\
2 \frac{19}{48} \\
3 \\
2 \frac{21}{48} \\
2\end{array}$ \\
\hline
\end{tabular}

The season of 1906-1907 was the year of greatest production, for the imports were larger than for any other year, and the average price of raw jute, of yarns, and of cloth was much higher than for any other year of the period.

The following table shows our imports of raw jute from 1854 to 1910 :-

\begin{tabular}{|c|c|c|c|c|c|c|c|}
\hline Year. & & & & & & Cwt. & $£$ \\
\hline 1854 & • & • & • & • & • & 481,733 & 553,993 \\
\hline 1860 & - & - & • & . & . & . $\quad 816,787$ & 660,913 \\
\hline 1870 & • & - & . & . & 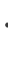 & $\begin{array}{c}2,376,690 \\
\text { Tons. }\end{array}$ & $2,326,910$ \\
\hline 1880 & - & • & . & & & . 231,945 & $4,018,800$ \\
\hline 1890 & . & . & . & & & 369,958 & $4,921,991$ \\
\hline $1900^{*}$ & . & . & . & & & 280,919 & $4,134,389$ \\
\hline $1910^{*}$ & . & . & . & . & & 296,720 & $4,670,265$ \\
\hline
\end{tabular}

* Not including " unenumerated vegetable substances (applicable to the same uses as hemp or flax)"- 
A parliamentary return of our jute exports in 1872 showed that our largest exports of jute manufactures were to-

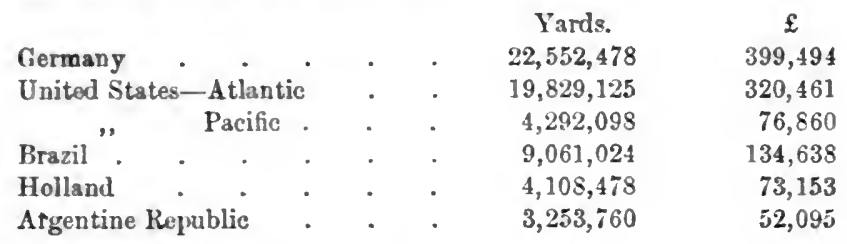

Our total exports of jute manufactures in that year was $84,452,457$

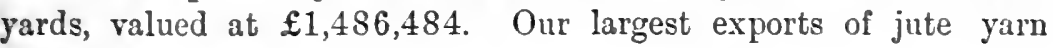
were to-

\begin{tabular}{|c|c|c|c|c|c|}
\hline Spain . & . & . & . & $\begin{array}{c}\text { lb. } \\
4,842,592\end{array}$ & $\begin{array}{c}\stackrel{f}{96,222} \\
9\end{array}$ \\
\hline Holland & . & . & . & $2,866,952$ & 54,448 \\
\hline Germany & .. & . & . & $1,684,272$ & 33,521 \\
\hline United S & es-Atlantic & . & . & $1,526,619$ & 28,189 \\
\hline , & Pacific & . & . & 14,429 & 278 \\
\hline
\end{tabular}

Our total exports of jute yarn amounted to $12,715,969 \mathrm{lb}$., valued at $£ 261,239$.

According to the Statistical Abstract, our total export of jute yarn and manufactures in 1910 were-

$$
\text { Jute Exports, } 1910
$$

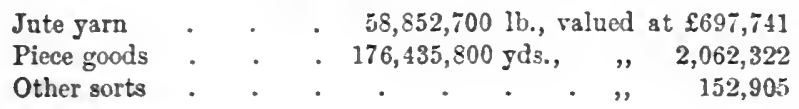

Some comparison with previous years is shown in the following table :-

Jute Exports, 1895-1910

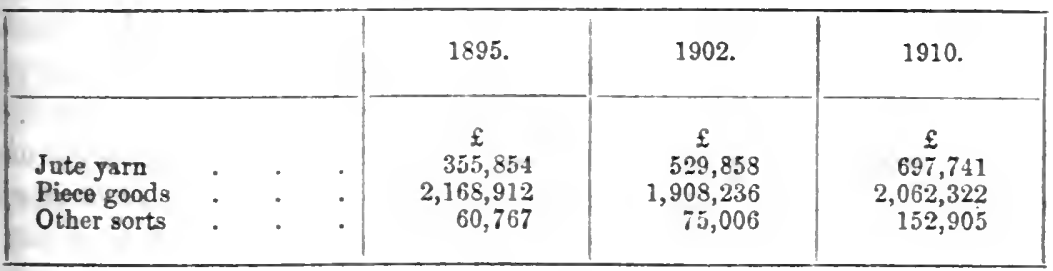

\section{The Hearp Industry}

The word hemp is derived from the Anglo-Saxon henep, called by the botanists Camabis sativa. The earliest mention of our subject would appear to be in the Biblical records when Haman prepared a gallows for the hanging of Mordecai. It is, however, 
more than probable that Haman's rope was not made of hemp at all, but of flax, for the former is not known to grow in Egypt or the neighbouring countries, whereas the latter is indigenous. It is an aunual plant, in appearance when growing very much like a nettle. The usual height of the Russian hemp is from six to eight feet; the stems look like the common and well-known "Jerusalem" artichoke. The inside of the stems consists of a hardish woodeny tube filled with pith, and the outside is a green integument or skin, which is the hemp itself. When the plant is full grown and the flower is forming the stalks are pulled up and dried on the fields. The canes are then retted, i.e. steeped in stagnant or running water for about two or three weeks, according to the temperature of the atmosphere. A less time is needed in stagnant than in running water, this process having the effect of rotting the inner part of the canes and permitting the refuse and outer part to be beaten off more readily. It at the same time renders the fibre more supple and mellow. The plants are next taken up in handfuls by workmen and beaten on wooden benches with mallets so as to break up the inner pith. Then they are taken up in handfuls at a time and beaten downwards with wooden bars like policemen's truncheons. In this way the adhering pith is knocked away and the fibre remains. It is then sorted into different lengths, baled, and made ready for export.

A century or so ago, when there were no steamboats or railways, and the climate in Russia was more severe than it generally is nowadays, the shipping ports being frozen from November till May, it was necessary for foreign countries to import enough hemp before the navigation closed to last the trade until it reopened in the spring. This necessitated imports into London. of large quantities of hemp, which were gradually distributed to the ropemakers; and so a system of finance grew up and became customary, which endures to this day in a modified form, although the conditions of supply are so vastly altered. It is said that the amount of hemp grown annually in Russia reaches 240,000 tons; of course, the greater part of this is consumed in Russia itself, which contains a very large number of spinning mills. There is an enormous traffic on the large rivers. There are said, for instance, to be at least a thousand tug steamers on the Volga alone, all engaged in towing barges with cargoes of the various grains and other products of the country to the shipping ports. Russia protects her own hemp against the import of other varieties of "hemp" by extremely onerous duties. In old days all the hemp had to come to 
Petersburg and Riga by water. When the barges arrived at the wharves where the hemp was to be stored, some one of the merchant's staff would be sent to sort the hemp into different grades, for up to this point it was all in bulk unselected. At that time the trade was mainly in the hands of English houses, and it was thought sufficient to grade the hemp into three kinds, called clean, outshot, and pass. ${ }^{1}$ There are two species of hemp, usually known as "Polish" and "Russian," the latter being grown mainly in the Eastern and the former in the Western provinces of Russia. The Polish is a much softer fibre than the "Russian," and is chiefly used for twine-making and weaving into sacks, sailcloth, etc., etc. The Russian is used for cordage. The same grading was originally used for Polish as for Russian qualities. That was sufficient formerly; to-day, space forbids our giving the titles of the thirty or forty different degrees into which the simple "clean, outshot, and pass" have been subdivided for market purposes.

Here we have, in short, the life-story of what is properly called hemp; but there is a fibre from Manila also called hemp for want of a better name, which from small beginnings of about 1000 bales in Mid-Victorian times, has increased till in 1908 there were over a million bales, of eight to the ton, exported from the Philippine Islands, a dependency of the United States. Of this amount America and Great Britain take about half each. The Continent also takes a certain quantity yearly, but that is chiefly re-exported from London. This Manila hemp is the product of a tree, the Musa textilis, a species of banana, which grows branchless to about 20 feet in height. The entire stem is a mass of straight fibre glued together by a natural gum. When wanted, the trees are cut down and divided into longitudinal sections. These are steeped in water for a certain period, dried and beaten so that the fibres become disintegrated, then bleached more or less by exposure to the sun, and finally graded and packed for export in bales of $2 \frac{1}{2} \mathrm{cwt}$. There are eight or ten grades, varying according to colour and fineness of fibre, and varying in value from about $\mathfrak{E 6 0}$ down to $\mathfrak{E} 15$ per ton. The finest of all these are called quilot, used if fashion bids for making hats in imitation of Panamis and such-like, and also for making trawl twine for fisherfolk.

I Outshot, from the German ausschuss-not good enough for clean, and the pass not good enough for outshot; chiefly a matter of length, incidentally the short was also soft. 
New Zealand also furnishes a considerable quantity of fibre (about 30,000 tons a year), divided between England and America. This is also called hemp. It is derived from an agave (bot. Phorimum tenax). Its long, fleshy, thick leaves are a mass of fibres. The outer skin being scraped off discloses these fibres in a solid mass, which is treated in the manner described above. The plant in appearance is very much like the yucca, but very much larger. The yucca is well known in all large gardens as an ornamental border plant. The New Zealand hemp is often called flax, because the first parcels sent here were made from the young short leaves of the plant, the fibre of which was very similar to flax, very strong and quite white. Apparently it was not profitable to produce it, for very little was sent over. Of this fine white flax the robes worn by the Maori natives are made. Italy also furnishes a large quantity of hemp, much superior to Russian growth, though originally sprung from Russian seed. There are many grades of this hemp. Its fineness and tenacity of fibre, as also its length, cause it to be favoured in twine and small rope-making, and for use on board ship as lead lines and halliards. India grows considerable quantities and varieties of hemp, and supplies Belgium and other countries as well as Great Britain with a large portion of their consumption. The United States grow some hemp in Kentucky, but not enough for their wants; they therefore take large imports of Russian, Italian, and Indian fibre. There are many other species of this universally necessary product. Central America, China, Java, Turkey, all pour their surplus stocks into this country. Nor must it be forgotten that nearly the whole of the Continent derives its supply of soft hemps from Russia. Most of the continental nations grow a certain quantity for their own use, but export practically nothing.

The manufacture of hempen rope has been carried on in various parts of the country from early times and particularly in shipping towns. Rope-making machinery was introduced at the end of the eighteenth century; previously rope was made, as it is still in some parts, by hand. Sir Honry Wood, in his work on Industrial England in the Middle of the Eightcenth Century, tells us that the manufacture of rope, cordage and fishing nets was the staple industry of Bridport in Dorsetshire from a very early date. The raw material was the hemp which was grown in large quantities in the county. The importation of hemp and hemp yarn from Holland and Russia caused the industry to decline, and the 
manufacture was also developed elsewhere. The making of twine and of nets has, however, continued to the present day, when it still offers one of the few surviving examples of a domestic industry. The making of sailcloth is by some said to have been introduced into England about 1681 by Bonhomme, a French emigrant; but it was an established industry in Ipswich a hundred years before that date. In the middle of the seventeenth century Suffolk sailcloth had a considerable reputation, and so had the cloth made in the West country at Bristol, Weymouth, and elsewhere. Both in Suffolk and the West country it was made from locally grown hemp, of which large quantities were raised. Canvas, as its name implies (cannabis, hemp) was at first made solely from hemp. Later flax was used. To a small extent hemp was used originally for table linen and sheets, and even for shirts.

The number of hemp factories in the United Kingdom in 1870 was 35 , employing in all 3150 persons (1442 males and 1708 females). In 1890 there were 105 factories, employing 10,572 persons (4644 males and $592 \mathrm{~S}$ females). The later returns giving the number employed (Statistical Abstract, 1910) group flax, jute, hemp and China grass iactories together thus:-

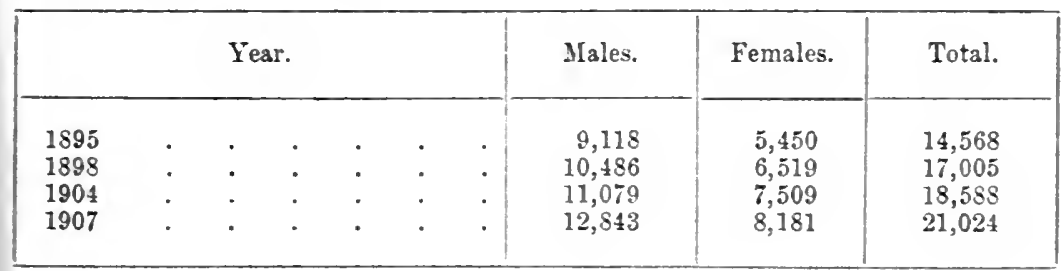

On the other hand the Census of Production (1907) gives the average number of persons (other than outworkers) employed in jute, hemp and linen factories in the United Kingdom on the last Wednesdays in January, April, July, and October of the year as 153,464 , namely, 149,845 wage-earners and 3619 salaried persons, and further classifies them as follows:-

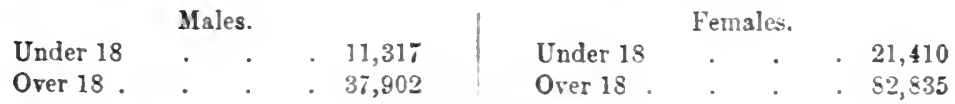

The total make of hemp and hemp tow yarns in the United Kingdom in 1907 is roughly estimated in the Census of Production $(1907)$ at 65 million pounds weight, and is valued at $1 \frac{1}{2}$ million sterling. 
The following table shows our imports of raw hemp from 1854 to $1910:-$

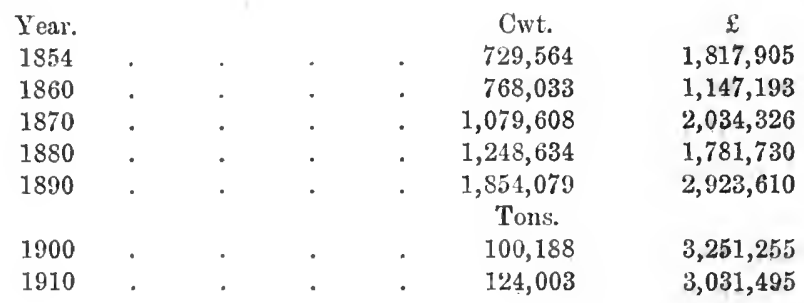




\section{CHAPTER XIX}

\section{LEATHER, BOOTS AND SHOES}

Leather.-Antiquity of leather-Tanning industry early in nineteenth century-. Growth of tanning industry-Imports of raw hides, 1876-1910-Conntries that send ns hides-Policy of American Beef Trust-Our foreign trade in leather.

Boot and Shoc Trades.-Present size, Census of Production figures-Difficulties of estimating the size of the boot and shoe trades-Growth of boot and shoe trades during the nineteenth century-Boot-making machinery-American competitionModern boots and shoes--Our foreign trade in boots and shoes.

T EATHER in some form or other has been used by mankind 1 from the remotest ages. In Ancient Egypt, in the Roman 1 from the remotest ages. In Ancient Egypt, in the Roman
Empire, and in the civilized states of the Middle Ages the tanned hides of animals were in general use. It follows therefore that the art of tanning was of very ancient origin, and like many ancient industries it remained almost unimproved and unchanged through the centuries. But it took on a fresh lease of life and progressed vigorously during the nineteenth century, more especially in the latter half. Mr. J. T. Day, the editor of the Shoe and Leather Record, in a published essay has pointed out that when the Corn Laws were repealed tanning was a scattered industry. "Every important town and many large villages, especially if they were near to oak timber and a stream, boasted a tanyard. These yards were in the hands of men who had been born in the business, as their fathers had been before them. Many of them ranked with the country gentry and they not infrequently had considerable landed interests. Tanning was an eminently respectable trade, as it implied the possession of either large capital or good credit on account of the long time taken to turn the hides into leather." Mr. Day points out another fact to be remembered in relation to the tanning trade. Its basis is the utilization of a by-product. "Hides and skins (except valuable furs) are not taken from the animal until the animal is wanted for food. The tanner is therefore in a position of comparative helplessness as to the supply of 
his chief raw material." The local tanner had to rely upon local hides, and when altered conditions diverted his natural supply he was nonplussed. In the old days tanning was a trade which descended from father to son; and Mr. Day adds: "Even under modern conditions the hereditary tanner has a strange advantage which I merely put on record without attempting to explain."

The English tanners were therefore highly conservative, and even after large importations of foreign leather began to take place under the new industrial conditions it was some time before they began to bring their business methods up to date. The demand for leather caused by the boot and shoe trades and the other industries that used it as a raw material, became so great in the second half of the nineteenth century that British tanners were unable to supply more than a part of the demand by leather manufactured from British hides. They were obliged to import foreign hides and these imports are shown below in five-yearly averages since 1876 :-

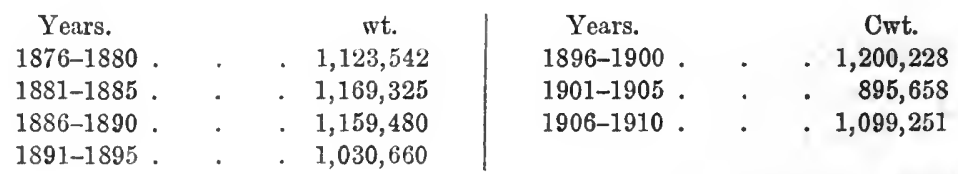

The most noticeable feature of the above figures is the fact that with the exception of the five years 1901-1905, there has been very little increase or decrease in our imports of raw hides (wet and dry). The exceptionally low figures for the quinquennium 1901-1905 are probably due to the extremely bad times our boot and shoe trades were expcriencing just then. The countries that send us the most raw hides one would naturally expect to be the greatmeat exporting countries, namely, Argentina, the United States, and Australia and New Zealand. We give below our imports of raw wet hides from the principal exporting countries for the last five years :-

\begin{tabular}{|c|c|c|c|c|c|c|c|c|}
\hline & & & & 1906. & 1907 & 1908. & 1909. & 1910. \\
\hline $\begin{array}{l}\text { Italy } \\
\text { Argentina } \\
\text { Germany } \\
\text { Australia }\end{array}$ & . & : & : & $\begin{array}{r}\text { Cwt. } \\
88,659 \\
117,706 \\
21,747 \\
22,082\end{array}$ & $\begin{array}{r}\text { Cwt. } \\
100,612 \\
118,381 \\
34,430 \\
30,117\end{array}$ & $\begin{array}{r}\text { Cwt. } \\
121,065 \\
99,150 \\
80,899 \\
44,567\end{array}$ & $\begin{array}{r}\text { Cwt. } \\
152,952 \\
45,698 \\
97,078 \\
57,927\end{array}$ & $\begin{array}{r}\text { Cwt. } \\
128,750 \\
121,144 \\
75,584 \\
81,743\end{array}$ \\
\hline
\end{tabular}

The figures of our imports from the United States for the 
same years are 2704 cwt., 3803 cwt., 11,202 cwt., $3507 \mathrm{cwt}$., and 15,134 cwt. respectively. These figures require interpretation. The smallest of our imports of hides from the United States would strike the casual observer as curious, but it should be remembered that a large quantity of hides come in on the backs of cattle. Thus while in 1910 our imports of hides from the United States amounted to $15,134 \mathrm{cwt}$. our re-exports to that country amounted to the enormous total of $101,691 \mathrm{cwt}$.

The explanation of this phenomenon is attributed by some to the fact that the Chicago Beef Trust only exports cattle on condition that their hides are returned to America. The growing power of this Trust in the Argentine, where it pursues the same policy, may perhaps account in part for the decline in our receipts of hides from that country. The deficiency has been made up by increased imports from Italy, Australia and Germany, and our tanners have not been seriously handicapped by lack of raw material.

Our foreign trade in leather (dressed and undressed) since 1876 is as under. The figures are five-yearly averages:-

\begin{tabular}{|c|c|c|c|c|c|c|}
\hline \multicolumn{4}{|c|}{ Years. } & Imports. & Re-exports. & British Exports. \\
\hline $\begin{array}{l}1876-1880 \\
1881-1885 \\
1886-1890 \\
1891-1895 \\
1896-1900 \\
1901-1905 \\
1906-1910\end{array}$ & : & : & : & $\begin{array}{c}\text { Cwt. } \\
491,000 \\
671,000 \\
821,000 \\
1,072,000 \\
1,301,000 \\
1,179,000 \\
1,172,000\end{array}$ & $\begin{array}{c}\text { Cwt. } \\
119,265 \\
121,055 \\
166,470 \\
204,790 \\
230,000 \\
148,652 \\
133,252\end{array}$ & $\begin{array}{c}\text { Cwt. } \\
164,443 \\
176,732 \\
152,556 \\
144,146 \\
149,839 \\
155,116 \\
214,281\end{array}$ \\
\hline
\end{tabular}

It will be seen that our imports of leather reached their highest point during the quinquennium 1896-1900, while they have remained practically stationary during the last ten years. Our exports on the other hand gradually declined until the five years 1891-1895, from whence they have risen to the record height of $214,281 \mathrm{cwt}$. in the last quinquennium.

The Census of Production (1907) gives the gross output of our leather factories (tanning and dressing) as $£ 17,551,000$, while the net output amounted to $£ 3,621,000$. The number of persons employed was 27,258 , and the net output per person employed came to $\mathfrak{f 1 3 3 .}$

Along with most of our industries the boot and shoe trades developed very rapidly during the latter part of the nineteenth 
century. Some idea of their present magnitude is given by the Census of Production tables which supply the following particulars:-

\begin{tabular}{|c|c|c|c|c|c|}
\hline $\begin{array}{c}\text { Gross } \\
\text { Outjut. } \\
\text { Selling Value } \\
\text { or Value of } \\
\text { Work done. } \\
\text { (1) }\end{array}$ & $\begin{array}{l}\text { Materials } \\
\text { used. } \\
\text { Cost. } \\
\text { (2) }\end{array}$ & $\begin{array}{l}\text { Work } \\
\text { riven out. } \\
\text { Amount } \\
\text { paid to other } \\
\text { Firms. } \\
\text { (3) }\end{array}$ & $\begin{array}{l}\text { Net Output. } \\
\text { Excess of } \\
\text { Col. } 1 \\
\text { over Cols. } \\
2 \text { and } 3 . \\
\text { (4) }\end{array}$ & $\begin{array}{c}\text { Persons } \\
\text { Employed } \\
\text { (except Out- } \\
\text { workers). } \\
\text { Total. } \\
(5)\end{array}$ & $\begin{array}{c}\text { Net Output } \\
\text { per Person } \\
\text { employed } \\
\text { (exeluding } \\
\text { Outworkers). } \\
(6)\end{array}$ \\
\hline$\stackrel{\mathfrak{f}}{22,959,000}$ & $\stackrel{£}{£}$ & $\stackrel{f}{\mathfrak{f}} 101,000$ & $\stackrel{f}{f}$ & $\underset{126,564}{\mathfrak{f}}$ & $\begin{array}{c}£ \\
71\end{array}$ \\
\hline
\end{tabular}

The estimation of the size of our boot and shoe trades was probably one of the most difficult tasks of the census authorities. Besides the large factories which manufacture boots and shoes on a wholesale scale, there are a host of small cobblers who live chiefly by repairing boots and shoes, but also make new ones for customers. In the report attached to the census tables further details with regard to the quantity of boots and shoes manufactured in 1907 are given. They are as follow:-

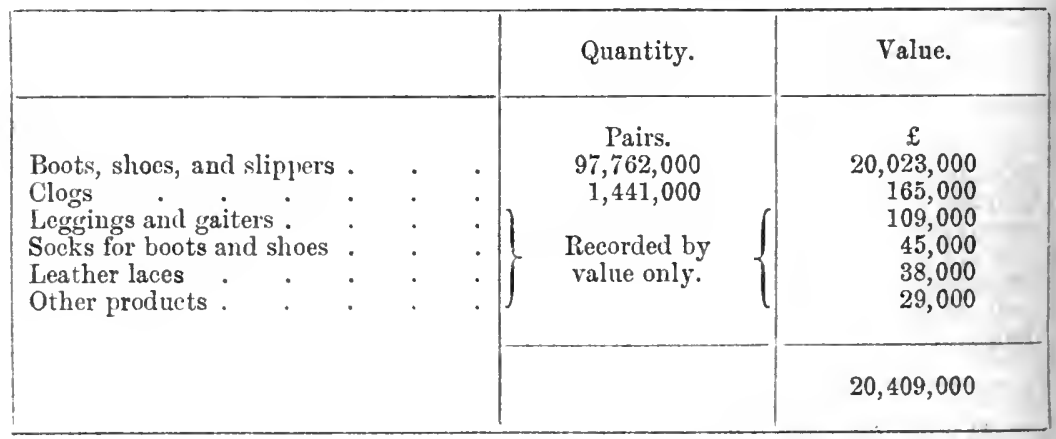

In addition to the total value given above $£ 1,908,000$ was included in the returns as received for repair work. The report states that "the returns are substantially complete as regards boot factories where power is employed," but the census had not power to compel a large number of workshops where men only are employed to make returns. "The figures given above," continues the report, "do not include the output of a large number of $(a)$ workshops where the occupier works alone (as is generally the case with the village shoemaker); (b) workshops attached to retail shops where a few men are engaged in repair work or a few special bespoke orders; and $(c)$ independent repairing shops where a few men work together. It is believed that these omissions have not 
seriously affected the validity of the figures relating to the prodnction of new boots, shoes and slippers, but there is little doubt that a considerable sum paid by customers for repairs has escaped record. There is no information at the disposal of the Census Office which would enable an estimate to be made of the total amount paid for the repairing of boots, shoes and clogs and slippers, and the fact that large numbers of the working classes do their own repairs makes even a rough calculation impossible."

Touching the growth of these trades during the last half of the nineteenth century, Mr. John T. Day, editor of the Shoe and Leather Record, wrote in the year 1903: "In 1846 the industry was in much the same position as the better class tailoring is today. People were measured for their boots, which were made by hand, by or under the direction of the bootmaker who took the measure. There were a few so-called factories in Stafford and Northampton, and a few more scattered about the country. But these were not factories in the modern sense of the term. They were shops whose leather was cut up by hand and given out to bootmakers working in their own homes, to make up by hand. The whole family was usually employed, the women and girls closing the uppers and the men performing the harder and more skilful work of joining the uppers to the soles and heels.... The introduction of the sewing-machine modified this system. The manufacturers bought sewing-machines and the women were taken into the factories to make the uppers, but the main work was still a home industry so far as the men were concerned. . . .

"In the carly 'sixties riveted boots were introduced. These were made on heavy cast-iron lasts, which could not be conveniently carried to and from the workmen's homes, so factory accommodation was enlarged, and with some difficulty sufficient men were induced to leave their home workshops and enter the factories. Almost at the same time a sewing-machine was invented which would sew on the soles of boots, and this was the beginning of the revolution of the industry. More men had to go into the factories, but a great deal of the labour was still performed at home. The work known as the 'finishing' of both machine sewn and riveted work remained a home industry, and the old hand-sewn system of bootmaking was also continued-and is also continued so far as it has survived-as a home employment."

The sole sewing-machine above mentioned was known in this country as the Blake machine and was of American invention. No machines were sold, as they were let out on the royalty system. 
Mr. Day adds: "The supply of machinery is a practical monopoly in America, where the United States Shoe Machinery Company of Boston levies royalties estimated to average five cents a pair on every pair of boots and shoes made in the United States, their royalty income amounting it is said to a million dollars a month."

The history of the invention of shoemaking machinery is romantic. It was indirectly caused by the American Civil War. So many skilled men were withdrawn from industry during the fight that shoes could no longer be made by hand in sufficient quantities. The pressure of necessity set the sharp minds of the Americans to work, and the sole-making machine was the result. The invention of boot-making machinery in America placed British manufacturers at a serious disadvantage when competing with their American rivals. But according to $\mathrm{Mr}$. Day, the American "was quite curiously unaware that in the course of about thirty years he had so improved his methods of manufacture that his productive labour was costing him (in some cases) less per dozen by 50 per cent. than it was costing the British shoe manufacturer for the same work."

A new method of making boots was introduced during the last few years of the nineteenth century. The modern boot is what is known as a welted boot. In 1893 the great middle-class trade was furnished with a boot sewn on the Blake machine. In 1903 the same class of trade was supplied with what is known as Goodyear or machine-welted boots at approximately the same price. "This welted boot is made precisely on the same principle as the old-fashioned hand-sewn boot of thirty years ago, which may still be obtained of a few fashionable West-end bootmakers by people who can afford to pay the price it commands. Its exact equivalent made by machinery is now within reach of all, and it has largely supplanted what is known as the ordinary machine-sewn boot."

As is usually the case, competition either kills out the weaker or stimulates them to new efforts. This is what happened to our boot and shoe trades. Threatened by the American the Britisher began to bethink him of new methods and new modes of manufacture. Perceiving the advantage his rival had in superior machinery, he proceeded to fight him with his own weapons and English boot and shoe manufacturers erected factories equipped with the latest types of American machinery. The result was highly satisfactory. The British manufacturer not only held his own but succeeded in developing his trade to an extent that would have been deemed impossible a few decades earlier.

A detailed analysis of our foreign trade in boots and shoes 
shows how the incidents mentioned above are reflected in the trade returns. The export trade in leather boots and shoes has for the past ten years shown a very satisfactory development. During 1910 our exports of these goods were by far the largest on record, both as regards quantities and values. In that year we sent out no fewer than 1,086,638 dozen pairs, which was 246,658 dozen pairs more than in the previous record year, 1909, and 322,431 dozen pairs better than in the good year, 1907.

The following table shows our foreign trade in leather boots and shoes for the past forty years. The net imports (imports less re-exports) can only be given for the last fifteen years.

Exports and Imports of Leather Boots and Shoes

\begin{tabular}{|c|c|c|c|c|}
\hline Five-Year & Averages. & Exports. & Imports. & Excess of \\
\hline $\begin{array}{l}1865-1869 \\
1870-1874 \\
1875-1879 \\
1880-1884 \\
1855-1889 \\
1890-1894 \\
1895-1899 \\
1900-1904 \\
1905-1909\end{array}$ & $\begin{array}{ll}\cdot & \cdot \\
: & : \\
: & : \\
: & : \\
. & : \\
. & :\end{array}$ & $\begin{array}{c}\text { Pairs. } \\
4,523,316 \\
5,751,516 \\
5,294,268 \\
6,356,460 \\
7,250,880 \\
8,217,216 \\
7,930,268 \\
8,513,160 \\
9,479,808\end{array}$ & $\begin{array}{c}\text { Pairs. } \\
\ldots \\
\ldots \\
\ldots \\
1,262,781 \text { gross } \\
1,385,868,, \\
1,338,552, " \\
1,883,148 \text { net } \\
2,686,920 \quad, \\
2,155,896 \quad,\end{array}$ & $\begin{array}{c}\text { Pairs. } \\
\ldots \\
\ldots \\
\ldots \\
\ldots \\
\ldots \\
6 \\
6,047,120 \\
5,826,2 \pm 0 \\
7,323,912\end{array}$ \\
\hline
\end{tabular}

After 1894 there was for some years a heavy increase in imports. In 1894 the net imports amounted to $1,263,672$ pairs, but in the next two years there were great jumps, and in 1901 the increase culminated in the net importation of $3,302,064$ pairs. This, of course, was largely due to the skill and enterprise of American boot manufacturers. The result of the stimulus given to British manufacturers was apparent in 1902, when the net imports fell away by 623,040 pairs from the high-water mark of 1901 . In the succeeding year, 1903, there was a further fall of 92,352 pairs, and in 1904 another drop of 300,408 pairs - a decreased importation in three years of 1,015,800 pairs. BF 1909 the net imports had shrunk to 2,057,964 pairs, or 1,244,100 pairs lower than they were in 1901. At the same time, the exports had grown largely, from 8,142,516 pairs in 1901 to $13,039,656$ pairs in 1910 .

The result is shown in the above table, where the two averages for the last ten years exhibit an increase of 966,018 pairs in the exports, a decrease of 531,024 in the net imports, and a consequent increase of $1,497,672$ pairs in the excess of exports over imports. 
The rate of progress during the past decade has, therefore, been highly satisfactory from the point of view of our boot manufacturers. As is well known, a great part of our exports of boots goes to British possessions, but a detailed examination of the records for the last few years discloses a remarkable and persistent change in the direction of our progress. The Annual Statement of Trade, which gives full particulars of the countries to which our goods go, showed for the four years ending with 1908 the following surprising record:-

Exports of Leather Boots and Shoes

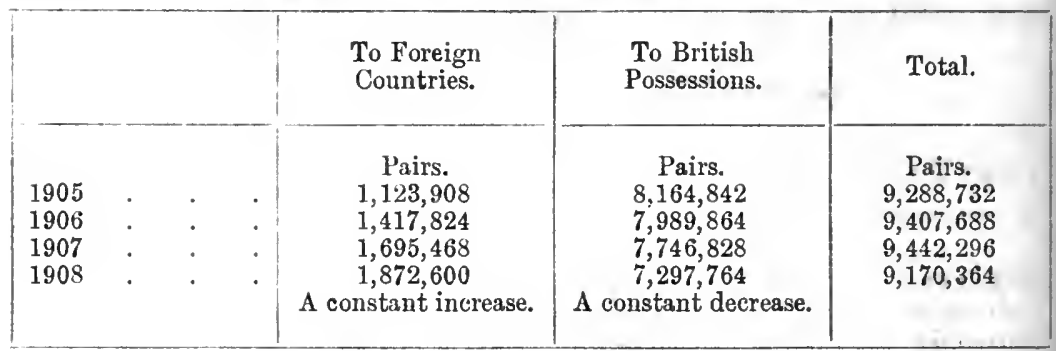

In these four years our trade with the British possessions fell by 867,060 pairs, while our trade with foreign countries rose by 748,692 pairs. It is plain that British boot manufacturers would have fared badly indeed had it not been for the very substantial growth of their sales to foreign countries-a growth which amounts to more than 66 per cent.

A substantial part of this new business has been done with European countries. Here are our sales to four European countries :-

\begin{tabular}{|c|c|c|c|c|c|c|c|}
\hline \multicolumn{3}{|c|}{ Year. } & Germany. & Holland. & Belgium. & France. & Total. \\
\hline $\begin{array}{l}1905 \\
1906 \\
1907 \\
1908\end{array}$ & $\dot{.}$ & : & \begin{tabular}{r}
\multicolumn{1}{c}{ Pairs. } \\
56,136 \\
82,104 \\
117,072 \\
124,812
\end{tabular} & $\begin{array}{c}\text { Pairs. } \\
264,984 \\
275,280 \\
314,808 \\
290,232\end{array}$ & \begin{tabular}{r}
\multicolumn{1}{c}{ Pairs. } \\
59,520 \\
82,848 \\
145,782 \\
155,068
\end{tabular} & $\begin{array}{c}\text { Pairs. } \\
174,156 \\
246,324 \\
313,008 \\
385,352\end{array}$ & $\begin{array}{c}\text { Pairs. } \\
554,796 \\
686,556 \\
810,670 \\
955,444\end{array}$ \\
\hline
\end{tabular}

In the four years our shipments to these European countries show an increase of 400,648 pairs. As we have seen above, the improvement in our business with all foreign countries during this period has amounted to 748,692 pairs, so that considerably more than half of this has been done with our four neighbours.

Since the reduction of the United States tariff on imported footwear British shoe manufacturers have succeeded in obtaining 
orders for shoes in America. Several large consignments are known to have been sent from Northampton and Leicester, and from the reports which have reached this country the goods are giving satisfaction, as there is no doubt British-made boots have a reputation for hard wear all the world over. Now our manufacturers have adopted all the best points in connexion with American shoemaking, there is no doubt that the open market for the world's best productions in leather has given them an advantage in the choice and quality of materials, which is telling even in "the cainp of the enemy."

So far, the trade returns do not separately schedule the shoes sent to the United States; however, as the value of exported footwear sent to "other countries" —outside those usually specially enumerated-has risen from $£ 145,430$ to $£ 197,475$ for the first quarters of 1909-1910 respectively, it is safe to assume that the advance is due to the unexpected American demand. It is more than likely that quite a fair proportion of these manufactured shoes actually contain American upper stock in the shape of box calf or glazed goat, so that British boot manufacturers have thus ample proof of the folly of any attempt to penalize foreign trade for the sake of a problematic benefit to colonial trade. The two great branches of our commerce are complementary. Our commercial history shows that at times-as in the 'seventies-an absolute decline of our total trade with foreigners has been partly neutralized by a rise in our trade with the Imperial Dominions. On the other hand, the ten year's ending with 1908 witnessed a profoundly important movement in the opposite direction.

It would be difficult to find a more complete reversal of the prophecies made by certain alarmists at the beginning of the twentieth century, than the above figures. It was freely stated by many public men that our boot and shoe trades were "going," and that the feet of the honest Briton would in a few years be shod in boots of alien manufacture. It is a remarkable tribute to the enterprise of the English manufacturer that, faced with the competition of the keen-witted American backed up with the most modern machinery, he was able, after a brief pause, not only to hold his own, but to increase his trade considerably, in spite of the tariff walls raised by the American and other foreign Governments. 


\section{CHAPTER XX}

\section{HOSIERY, LACE, HATS AND GLOVES}

The Hosiery Trade, 1800-1850.-Early seats of hosiery manufacture-Early estimates of stocking frames-Lee's stocking frame-Production of hosiery, numbers employed, wages, etc., in 1833-Bobbin-net trade-Improvements in machineryFancy productions-Warp lace.

1850-1910.-Mr. Thomas Henderson on development of hosiery trade-Amount of persons employed in hosiery trade in Leicester-Hosiery a female industry"Twist fever"-Effect of American Civil War-Lace trade-Numbers employed, and wages-Stocking making-Census figures of employment in hosiery trades-Census of Production figures-Our foreign trade in hosiery and lace.

Hats and Gloves. -Our foreign trade in hats and gloves, 1856-1910-Census of Production figures.

\section{The Hosiery and Lace Trades, 1800-1850}

$\mathrm{P}^{\mathrm{o}}$ ORTER found it impossible to make any very satisfactory estimate of the growth and progress of the manufacture of hosiery. The art of knitting is said by some to have been brought from Spain about the time of Henry vIII, but others ascribe the honour to Scotland about the year 1500 . Of course at that time all the knitting was done by hand on pins, and probably the only articles made would be hose, gloves, etc. The knowledge and practice of the art doubtless extended rapidly over the United Kingdom, and in 1589 the Rev. William Lee of Woodbridge, Nottinghamshire, invented the knitting (or stocking) frame, by which stockings and other articles were worked on a machine with a straight row of needles making several stitches by one movement. Lee not only made the first machine to produce unshaped web, but afterwards so improved it that he was able to turn out shaped work which would follow the curves of the foot and calf. Of course, his work required to be seamed before it was ready for the wearer, but the progress he made was nevertheless very great, and the ingenuity he displayed is thrown into strong relief when we remember that it was not till more than 200 years afterwards that succeeding inventors discovered how to make 
a stocking frame which would produce seamless work. Indeed, Lee's frame, which was invented in 1589 , was virtually unimproved by any other inventor until, 179 years later, the Derbyshire farmer, Jedediah Strutt, modified it so as to produce ribbed work. Strutt built up a fine business, and his grandson was made a peerLord Belper; but it is a sad thought that Lee, the father of the trade, received no adequate reward for the benefits he conferred on his countrymen.

Yet Lee founded an industry which has now an annual output of well over eight millions sterling, and gives employment to more than fifty thousand persons. It now produces not only the original " hose," or clothing for the legs, but all kinds of underwear for men, women, and children, as well as Cardigan jackets, fancy vests, jerseys, sweaters, shawls, ladies' and children's woollen goods, and other similar articles. All articles which are made by a knitting process come within the sphere of the industry, and it has been computed that no fewer than five thousand different descriptions of goods are now produced by firms in the hosiery trade. Naturally, however, stockings and socks constitute the most important section of the trade, forming, roughly, one-half of our total production and one-half of our exports of these goods. The greater part of our knowledge of the early history of the trade is due to Mr. Felkin, a merchant of Nottingham and a recognized authority. The chief seats of the hosiery manufacture in 1850 were (and the statement holds good to-day) the counties of Derby, Nottingham, and Leicester, in the last named of which nearly all the frames in which wool was employed were to be found, while Nottingham contained the largest number of frames for the production of cotton hosiery. The use of silk in this branch of manufacture was almost wholly confined to Derby and Nottingham. Blackner estimated that in 1812 there were 29,590 stocking frames at work in all the branches. Thirty years before that time the number had been estimated at 20,000 . If we are to judge from the localities assigned to the frames in 1812 , it would appear that rather more than one-third were employed in producing cotton hose, and that about one-half were used for woollen goods, but no very accurate estimate of the proportions can be formed from the locality of the machines. In 1833, a meeting was held of delegates from the frame-work knitters, when a resolution was formed for dividing the seat of the hosiery manufacture into districts, with the view of obtaining, among other things, exact details of the number and description of frames, the amount of labour employed in them, 
and such further particulars as might enable the workmen to co-operate for the more effectual protection and advancement of their interests. The resolution thus formed was not, indeed, carried into effect in the manner nor with the objects proposed; but it attracted the attention of Mr. Felkin to the subject, who drew up an estimate of the extent of the manufacture in its various branches, which was believed to present a sufficiently accurate approximation to the condition of the trade at that time to answer all practical purposes. Mr. Felkin's estimate for 1833 will be found on page 385 (Table A).

At the meeting of the British Association at York, in 1844, Mr. Felkin read a very elaborate report on the hosiery trade and the condition of the frame-work knitters. The survey and census upon which Mr. Felkin founded his report, were made in the spring and summer of 1844 , as far as respects the midland counties of England, by agents whom he employed for that purpose. The estimate for the remaining parts of the kingdom, which were adopted and considered correct by Mr. Felkin, will be found on page 386 (Table B). The quantity of cotton hosiery goods made in 1833 was estimated by $\mathrm{Mr}$. Felkin to have increased more than 50 per cent. in the preceding twenty years - an opinion which agrees with the fact that the use of cotton stockings had during that time been superseding those of woollen to a great extent among the women. It will also be seen from the statement of Mr. Felkin, that the number of frames employed for making cotton goods, which in 1812 was about one-third the whole number employed, formed about one-half in 1833 , or 16,300 out of 33,000 frames. The making of stockings at this date was altogether a domestic manufacture, being carried on in the dwellings of the workmen. Some of these persons possessed frames, which were their own property, but the greater part used frames which belonged to the master-manufacturers, by whom the workmen were employed, and who were paid by those workmen an annual rent, varying from forty shillings to five pounds, according to the size and capability of the frame. The bobbin-net manufacture grew up entirely in the nineteenth century, and in a comparatively small number of years became an object of national importance, finding employment for between 150,000 and 200,000 persons, whose wages amounted to $£ 2,500,000$ per annum, as stated in a memorial addressed in June, 1834, to the Lords of the Treasury by the principal merchants and manufacturers engaged in the bobbin-net trade.

The first successful attempt at producing, by means of 
‘

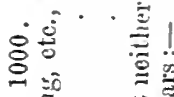

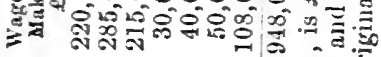

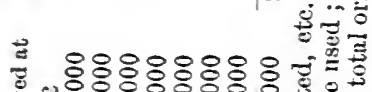

i.:. . .

$\equiv$

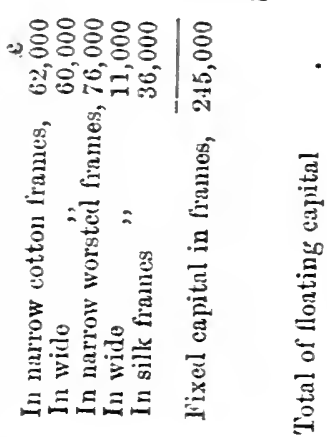

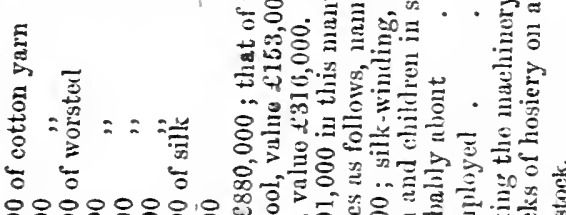

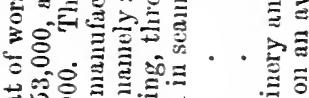

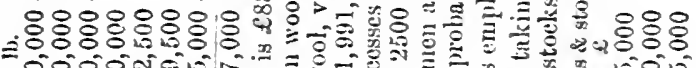

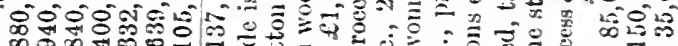
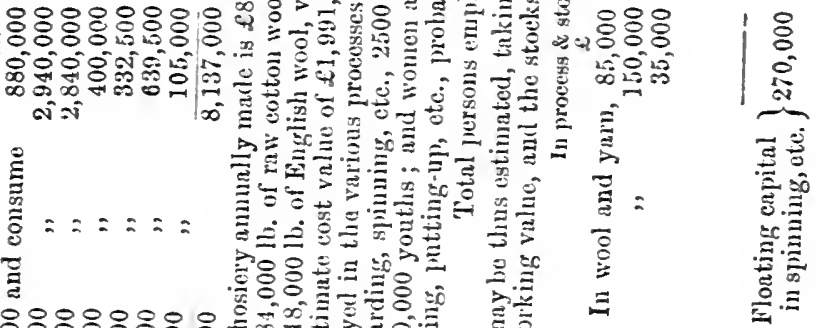

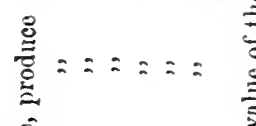

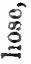

范

ट

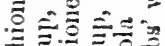

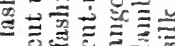
$\stackrel{x}{=}$ $\div 38$ ㅎㅇㅇㅇㅇ인

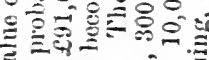
․ㅛㅇㅛ

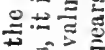

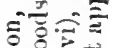

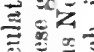

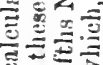

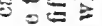

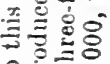
$\circ \stackrel{\circ=0}{\circ}$

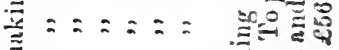

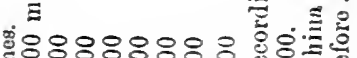

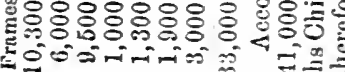
$\pm \equiv$

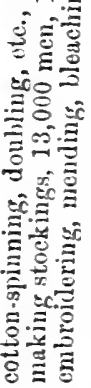

$\Xi$

.

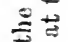
क्षे 总串 兽 冚㤩 롤

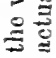
: 官 홍

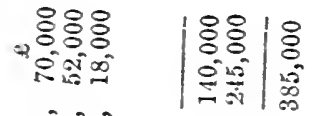

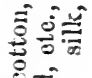

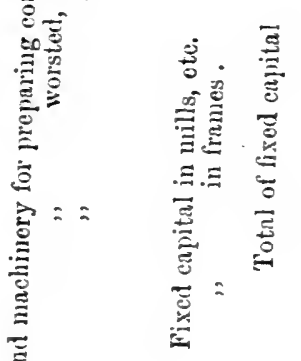
吾 E 


\begin{tabular}{|c|c|c|c|c|c|c|c|c|}
\hline 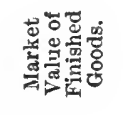 & CR & & 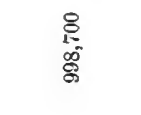 & & 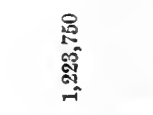 & & 惫 & 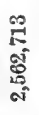 \\
\hline 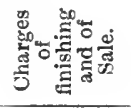 & Cx 鸽 & & 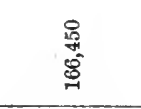 & & $\begin{array}{l}\text { 员 } \\
\text { 吾 }\end{array}$ & & 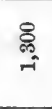 & 武 \\
\hline 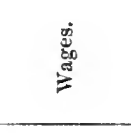 & 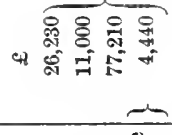 & $\begin{array}{l}0 \\
0 \\
\infty \\
\Rightarrow \\
7\end{array}$ & 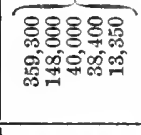 & 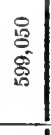 & 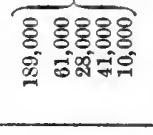 & $\begin{array}{l}\text { \& } \\
\text { of } \\
\text { क्ष }\end{array}$ & $\begin{array}{l}\text { \&్ష } \\
\text { â }\end{array}$ & 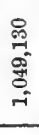 \\
\hline 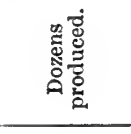 & 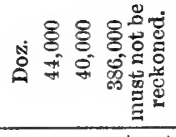 & 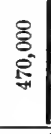 & 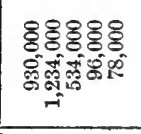 & 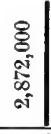 & 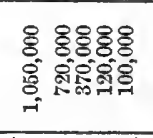 & 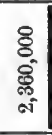 & 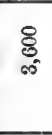 & 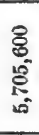 \\
\hline 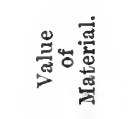 & 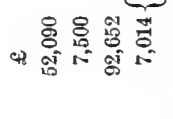 & 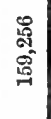 & 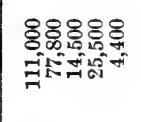 & 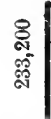 & : & 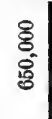 & $\mathbb{8}_{\infty}^{8}$ & 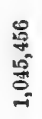 \\
\hline 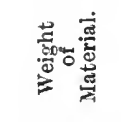 & 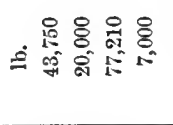 & $\begin{array}{l}\stackrel{8}{8} \\
\text { 焉 }\end{array}$ & 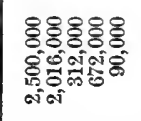 & 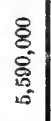 & $\begin{array}{l}\text { \&్ } \\
\text { षิ } \\
\infty \\
\infty\end{array}$ & $\begin{array}{l}8 \\
8 \\
\AA_{0}^{\circ} \\
\infty\end{array}$ & \& & : \\
\hline 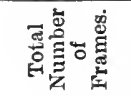 & 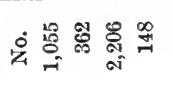 & $\underset{\infty}{\mathrm{E}}$ & 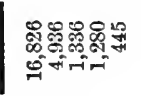 & \begin{tabular}{l}
$\dddot{\infty}$ \\
$\infty$ \\
\multirow{N}{*}{}
\end{tabular} & 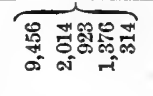 & $\begin{array}{l}\mathscr{g} \\
\stackrel{+}{=}\end{array}$ & 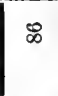 & 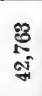 \\
\hline 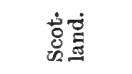 & $\dot{8}::::$ & $:$ & 品 : : : : & 잉 & 兽 & 递 & : & o \\
\hline 远节 & 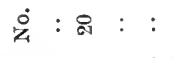 & 요 & \#吕: : : & $\mathbb{Z}$ & - & 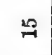 & 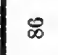 & : \\
\hline 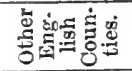 & 욱욤유: : & 8 & ్ㅜㅇㅛ : : : & $\notin$ & 禺 & $\stackrel{\mathscr{D}}{\sim}$ & : & $\%$ \\
\hline 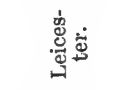 & $\dot{\delta}:{ }^{\infty} \vec{\Xi}:$ & 晜 & $\underset{0}{\mathbb{H}}$ : : & 骂 & 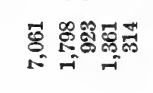 & 点 & : & 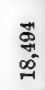 \\
\hline 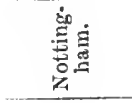 & 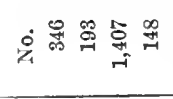 & 苦 & 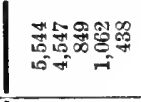 & 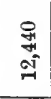 & 혀 : : : : & t) & : & 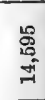 \\
\hline 苐 & 宠总怘吕: & 慕 & 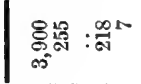 & $\begin{array}{l}\mathscr{D} \\
\text { 喿 }\end{array}$ & & a & : & 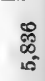 \\
\hline 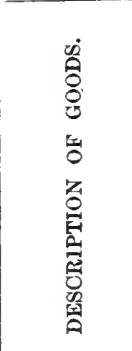 & 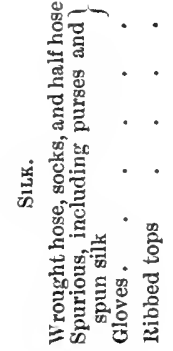 & & 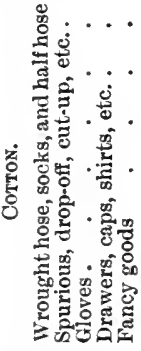 & & 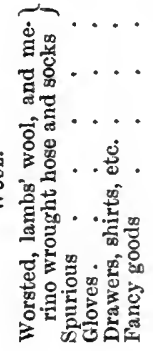 & & 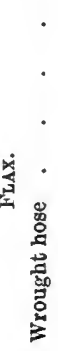 & 해요 \\
\hline
\end{tabular}


machinery, net-work bearing the characteristics of lace, was made in 1809: and this machine, rude in its construction, and comparatively slow and inefficient in its operation, was the subject of a patent, the possessors of which realized, during the continuance of their exclusive right, very large fortunes. After the expiration of this patent, the machinery of the frame was considerably simplified, and its efficiency increased; so that, by the application of an equal amount of labour, twelve times the quantity of net was produced which could have been previously made, and a quantity of the finished manufacture as then sold for $2 \mathrm{~s} .6 \mathrm{~d}$., which, during the continuance of the patent, was sold for $£ 5$. The extent to which the bobbin-net manufacture increased may be seen from the following statements drawn up in 1836 by $\mathrm{Mr}$. Felkin :-

\section{Statistics of the Bobbin-Net Trade}

Capital employed in spinning and doubling the yarn :-

Fixed capital in 35 spinning and 24 doubling factories $-724,000$ spinning, 296,700 doubling spindles.

$£ 715,000$

Floating capital in spinners' and doublers' stock, and necessary sundries

Deduct one-sixth, employed for foreign bobbing-net trade

Total capital employed in spinning and doubling for

English bobbin-net trade

Capitsl employed in bobbin-net making :-

Fixed capital in factories, principally for power-machines power-machines, averaging 11 quarters wide hand-machines, averaging 9 quarters wide

Floating capital in stock on hand, power-owners .

hand-owners

Capital in embroidering, preparing, and stock .

Total capital employed in the trade.

The value of the materials used was as follows :-

Net value of cotton yarn

Value of silk used

Wages, interest, wear and tear, etc.

Valne of rough goods 200,000 pieces, gassed, $3 \mathrm{~d}$.

300,000, bleached, $10 \mathrm{~d}$.

$300,000, \quad$ dressed, 1s. 9 d.

One-third figured, cost.

200,000 pieces, wide-nets, finished, 1s. 6d.

100,000 ," quillings, $3 \mathrm{~s}$.
200,000

915,000

155,000

$£ 760,000$

85,000

170,000

267,000

150,000

250,000

922,000

250,000

$£ 1,932,000$ 
The Number of Machines, exclusive of 165 not at work, was 3547 , of the following descriptions :-

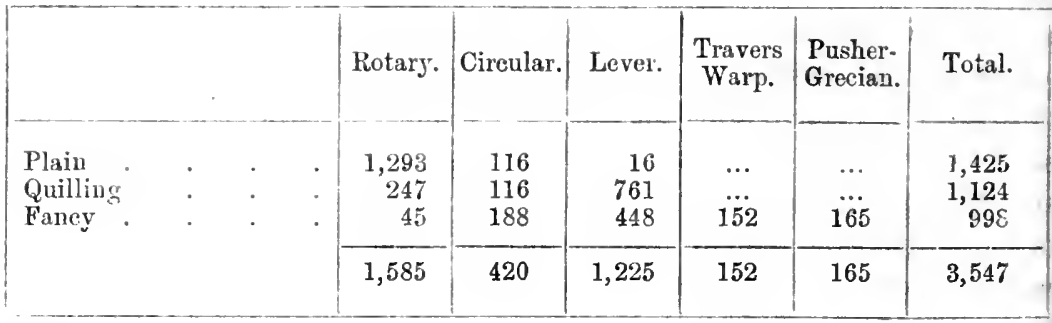

The parts of the Kingdom in which these machines were employed, were-

\begin{tabular}{|c|c|c|c|c|c|c|}
\hline & & Plain. & Quillings. & Fancy. & Total. & $\begin{array}{l}\text { Quantity of } \\
\text { Yarn used. }\end{array}$ \\
\hline \multirow[t]{2}{*}{$\begin{array}{l}\text { Nottinghamshire } \\
\text { Leicestershire } \\
\text { Derbyshire. } \\
\text { West of England }\end{array}$} & $\dot{5}: \dot{ } \cdot$ & $\begin{array}{l}372 \\
207 \\
192 \\
654\end{array}$ & $\begin{array}{r}1,006 \\
37 \\
49 \\
30\end{array}$ & $\begin{array}{r}782 \\
99 \\
14 \\
103\end{array}$ & $\begin{array}{r}2,160 \\
343 \\
255 \\
787\end{array}$ & $\begin{array}{c}\text { lb. } \\
640,000 \\
100,000 \\
100,000 \\
320,000\end{array}$ \\
\hline & & 1,425 & 1,122 & 998 & 3,545 & $1,160,000$ \\
\hline
\end{tabular}

The Quality and Value of the rough Goods produced by the different kinds of Machines was-

\begin{tabular}{|c|c|c|c|c|}
\hline Rotary & - & . & $\begin{array}{r}\text { Square Yards. } \\
. \quad 15,827,848\end{array}$ & $\begin{array}{c}\mathcal{\varepsilon} \\
662,255\end{array}$ \\
\hline Lever. & . & . & $8,327,240$ & 476,959 \\
\hline Circular . & . & . & $2,627,137$ & 141,864 \\
\hline Pusher-Grecian & . & . & 811,650 & 41,574 \\
\hline \multirow[t]{2}{*}{ Travers Warp } & . & . & 325,188 & 54,198 \\
\hline & & & $27,919,063$ & $1,376,850$ \\
\hline
\end{tabular}

The Number of Machine Owuers was 837, of whom 302 possessed only 1 machine.

The wages of persons employed in the different branches of the manufacture varied according to the kind of work produced. The net earnings of

$$
\begin{aligned}
& \text { Men were from 12s. to } 35 \mathrm{~s} \text {. per week, averaging about } 16 \mathrm{~s} \text {. } \\
& \text { Women , 3s. to 12s. , , } \\
& \text { Children ", 1s. 6d. to 5s. ", ", }
\end{aligned}
$$

Successive improvements in the arrangements of the machines had caused those first constructed-the Travers-warp machines-to go out of use, and a great number of them, which had cost $£ 300$ each, were sold and broken up for the value of the iron which they contained. It was afterwards found, that by a slight alteration these machines might be adapted to the production of fancy nets; such of them as remained were thus modified at a small expense, and employed for the production of fabrics of continually-increasing beauty and value. 
finished goods were of the value of $£ 350,000$, namely-cotton goods, $£ 200,000$; silk goods, $£ 150,000$.

\section{The Hosiery and Lace Trades-1850-1910}

The hosiery industry commenced a fresh course of development in the middle of the nineteenth century, when improved machinery and power were applied. The scope of the word hosiery was also expanded. Mr. Thomas Henderson, a Hawick manufacturer, recently pointed out in a valuable paper ${ }^{1}$ that the term " hosiery" properly applies to hose or stockings, and half-hose or socks, which up till about fifty years ago were almost the sole product. Now, however, it is applied to all knitted garments, the original name having stuck to the trade, although many firms do not make a single stocking from one year's end to the other. Until the middle of the last century men were accustomed to work nothing but stockings all the year round, and often from the same yarn and in the same size. The introduction of circular hose machines, the use of fine worsted yarns, and the taste for finer goods, brought a great change over this section of the trade, and it is now almost entirely carried on in England and Germany; although, in the west and north of Scotland especially, large quantities of ribbed socks and shooting hose are still manufactured. At the end of the nineteenth century a great development took place in the manufacture of knitted jackets, coats, mufflers, and other articles for outer wear; while another extension has been seen in the production by machinery on a large scale of knitted woollen gloves. The difference between a piece of hosiery fabric and a piece of cloth, as the same authority points out, is that "while the latter is woven with warp and waft, the former is knitted by a succession or chain of loops in exactly the same way as a lady knits a stocking."

Leicester is the principal seat of the hosiery manufacture in the United Kingdom, and a "Report of an Inquiry by the Board of Trade into the Cost of Living of the Working Classes," issued in 1908 , but dealing with the years 1905 and 1906 , gives the following amount of the distribution of the population of that city employed in this industry :-

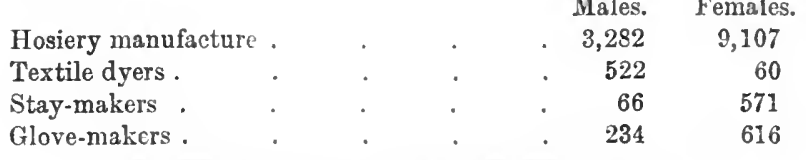

${ }^{1}$ Cp. The Scottish Banker's Magazinu, October 1910. 
Hosiery is largely a female industry, owing to the use in hosiery manufacture of machinery suitable to the capacity of women. The wages of female workers (sewing machinists, etc.) are given as $13 \mathrm{~s}$. to $19 \mathrm{~s}$. per week. These are the rates given for piece-work, and are quoted for September 1906. From the same report we obtain some account of the hosiery and lace industries of Nottingham. When hose-making machines were improved and applied to the manufacture of lace some years ago Nottingham rapidly took the lead in these trades. "Previous to 1851," says the report, "population and activity in the predominant industry advanced considerably. Thirty years before occurred the period of the 'twist fever,' when on the expiry of Heatheoate's patent for lace-making machines, there was a migration of people from all parts of the kingdom to Nottingham to become lace manufacturers. This period of prosperity extended to 1861 , when some depression was experienced, probably in consequence of the American Civil War. From 1873 to 1883 the lace trade was in an exceptionally prosperous state, and the number of machines in use at this time in the town is stated to have increased from 1050 2250 . The number of workpeople in all trades was augmented, both in the town itself and in the neighbouring villages. The reaction came in the period of depression which began in 1883 , and checked the expansion of the trade and the town. Since that date the population has increased, but in a more measured degree." The number of persons in Nottingham employed in hosiery manufacture is given as 6136 (2192 males and 3944 females). The manufacture of lace gave employment to 21,626 persons $(6925$ males and 14,701 females). The rates of wages paid in summer (when the hours worked are longer than in the winter) for a full week of $51 \frac{1}{2}$ hours were in 1906 -

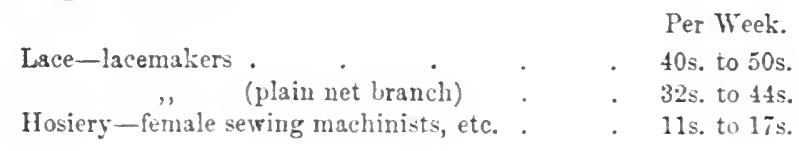

For some account of the Scottish hosiery trade, and incidentally of the trade generally, we may again turn to Mr. Henclerson's paper. After describing how Lee's machines and those of other makers with subsequent improvements found their way to Scotland, and how later centres, where there were "framework knitters" (as the operatives were called), are found in Aberdeen, Ayr, Dumfries, Glasgow, Hawick, Kilmarnock, Lanark, Langholm, Stirling, and other places, he writes: "In most of these towns the trade is still 
carried on, but the greatest settlement and advance of the industry may safely be claimed by Hawick and the south-east of Scotland." Until the modern improvements of Paget and Cotton about fifty years ago, steam-power was non-existent in Scotland. Its general use may be said to date from about forty years ago, and by far the greatest expansion has taken place during the last quarter-century.

Taking the Hawick trade as an example of the growth of the industry in Scotland, we find that in the first half of last century the number of stocking frames grew from 510 (in 1816), producing some 3500 pairs of woollen stockings and 600 pairs of cotton stockings, to 1209 (in 1838), producing considerably over a million pairs of stockings and some 12,500 articles of underclothing. In 1850 there were 1200 stocking frames producing 120,000 articles of underclothing. To-day the production will be twenty or thirty times that total. The production of articles other than stockings began about 1820-1830, and this soon changed the character of the trade. Mr. Henderson thus describes the development:-

"The adoption of steam-power gave a great stimulus to production and soon showed the possibilities of the industry; but in spite of this, up till twenty years ago, the number of handframe-workers was considerable. Indeed it was argued by some that the goods made by steam-power were inferior to those made by hand, and they for a time stood ont against the change. There was something to be said for the argument ; but the claims of cheapness and rapidity of productiou, not to mention other points such as uniformity, were too great, and the old stocking-makers soon began to see the beginning of the end. This, however, has not yet come, as about a hundred workers are still engaged in Hawick in more or less regular employment, making chiefly special garments ordered in small quantities.

"About forty or fifty years ago these stocking-makers were a large and highly organized body, and were distinguished for their independent spirit and great intelligence, and many of them who foresaw the changes of the trade turned their attention in time to the new machinery. They were able to direct and manage the new 'power-frame shops,' and sometimes to suggest improvements in the working and building of the frames.

"In the old days a "stocking shop' was the centre of all the local gossip, and for the discussion of the politics of the day. At one time only one newspaper was received in each shop, and all work was stopped while one of the workers read aloud the news of the day, after which the 'whizz' and 'click' of carrier and needles would begin again and free discussion took place during work-the arguments at times becoming very heated. This habit doubtless laid the foundation of the intelligence and deep interest displayed in both local and national politics which characterize the workers of the district to-day.

"To-day the vast majority of workers are women and girls, and a smarter class of workers it would be impossible to find. Owing to the nature of the work they are neat, tidy, clean, and of a far superior class to the generally imagined 'factory hand.' The workrooms are usually light, roomy, and clean, and the 'atmosphere' that of cheerfulness, industry, and content." 
At the present time both women and men are employed on the same work and are paid on the same scale of wages. In the process of "finishing," scouring, etc., men are employed; but the making-up or trimming is done by women only. Most of the work is paid by piece, and the wages range from about 1 is. up to $f 2$ weekly, according to class of work and skill. Apprentices are paid う̌s. per week, rising to $12 \mathrm{~s}$. $6 \mathrm{~d}$. or so during four or five years' apprenticeship. Altogether some 3000 workers are employed in the trade in Hawick, which is the largest centre in Scotland. The writer roughly estimates the amount of capital employed in the hosiery trade in Scotland at about a million sterling, or rather more.

According to the censuses of 1881,1891 , and 1901 the numbers of persons in England and Wales employed in the manufacture of hosiery, lace, etc., in those years were as follow:-

\begin{tabular}{|c|c|c|c|c|c|c|c|}
\hline \multicolumn{5}{|c|}{ Trade. } & Year. & Males. & Females. \\
\hline \multicolumn{2}{|c|}{ Hosiery manufacture } & . & . & . & $18 \diamond 1$ & 18,862 & 31,481 \\
\hline ", $\quad 1 "$ & - & . & • & • & 1891 & 18,200 & $30,88 i$ \\
\hline \multirow{2}{*}{ Lace manufacture } & - & . & - & . & 1901 & 13,893 & 21,510 \\
\hline & . & - & . & . & 1881 & 11,359 & 23,807 \\
\hline$" \quad$, & $\cdot$ & • & • & • & 1891 & 13,030 & 21,716 \\
\hline & & $\cdot$ & - & - & 1901 & 12,632 & 32,755 \\
\hline \multicolumn{3}{|c|}{ Carpet, rug, felt manufacture } & · & • & 1851 & 9,241 & 7,652 \\
\hline , & , & & . & . & 1891 & $9, \frac{135}{2}$ & 7,408 \\
\hline \multirow{2}{*}{ Fancy gools, ete. } & $\because "$ & & - & - & 1901 & $\tau, 150$ & 5,235 \\
\hline & · & - & • & - & $1 \leqslant 81$ & 4,339 & 17,115 \\
\hline$" \quad \quad "$ & - & - & . & . & 1891 & 5,315 & 18,968 \\
\hline ", & - & . & - & . & 1901 & 3,521 & 16,215 \\
\hline
\end{tabular}

In 1870 there were 129 hosiery factories in the United Kingdom, einploying 9692 persons ( $459+$ males and $509 \mathrm{~S}$ females). In 1890 there were as many as 257 and the persons employed numbered 24,838 (9208 males and 15,630 females). The number of persons employed in 1901 was 38,549 (9587 males and 28,962 females); and in 1907 the number was 39,971 (9609 males and 30,362 females). The Census of Production (1907) gives the average number of persons (other than outworkers) employed in hosiery factories in that year as 47,939 , namely, 44,724 wage-earners and 3215 salaried persons, and further classifies them thus:-

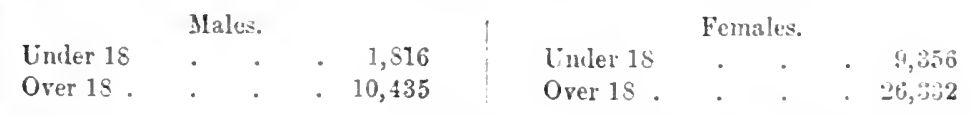

In addition the average number of outworkers was $4950(5+3)$ males and 4407 females).

In 1870 there were 224 lace factories in the United Kingdom employing 8370 persons (5998 males and 23.2 females). In 1890 
the number was 403 , and the persons employed numbered 16,930 (9820 males and 7110 females). The total number thus employed in 1901 was 17,902 (10,462 males and 7440 females), and in 1907 21,024 (12,843 males and 8181 females). The Census of Production (1907) gives the average number of persons employed (other than outworkers) in lace factories and warehouses as 34,583, namely, 31,839 wage-earners and 2744 salaried persons, and further classifies them according to age and sex :-

\begin{tabular}{|c|c|c|c|c|c|}
\hline \multicolumn{3}{|c|}{ Males. } & \multicolumn{3}{|c|}{ Females. } \\
\hline Unde & . $\quad$. & 2,520 & Under 18 & .. & \\
\hline Over 18 & . & 13,420 & Over 18. & . & 13,690 \\
\hline
\end{tabular}

In addition the number of outworkers is given as 4113 (91 males and 4022 females).

Before proceeding to examine our imports and exports of hosiery, it may be well to examine the return of the Census of Production for the year 1907, as given at page 45 of the Preliminary Tables, Part III. This is as follows :-

\section{British Production of Hosiery ${ }^{1}$ in 1907}

Underwear (including sliirts, pants, vests, bodices, spencers, combinations, etc.) $£ 2,672,000$ Fancy hosiery (including Cardigan jackets, fancy vests, jerseys, sweaters, Gloves .

shawls, ladies' and children's wool goods, etc.) .

Hose, half-hose, socks, and three-quarter hose

Yarns of wool, cotton, etc. . . . . . . . $\quad 244,000$

Women and girls' clothing and millinery . . . . . $\quad 128,000$

Elastic web and elastic hosiery . . . . . . . 78,000

Other products

Total value of goods made for sale .

. $£ 8,617,000$

From this it will be seen that the bulk of the production consists of stockings and socks and underwear, though fancy hosiery forms a not inconsiderable section. It is to be remembered that the return includes silk hosiery, though it appears probable that this is almost a negligible proportion of the total output. This output also includes $£ 244,000$ worth of yarns which were probably partly sold to other firms, and worked up into the finished goods appearing elsewhere in the table. Making allowance for this, the Director of the Census says (on page 13) that " the total value of the products of hosiery factories may be estimated at a sum lying between $\mathfrak{£} 8,400,000$ and $\mathfrak{£} 8,600,000$."

Taking, therefore, $8 \frac{1}{2}$ millions sterling as the gross production of the trade, we can now consider the import and export records without danger of losing our sense of proportion:-

$$
{ }^{1} \text { Of wool, cotton, and silk. }
$$


British Foreign Trade in Woollen and Cotton Hosiery, excluding Gloves (in thousands of pounds)

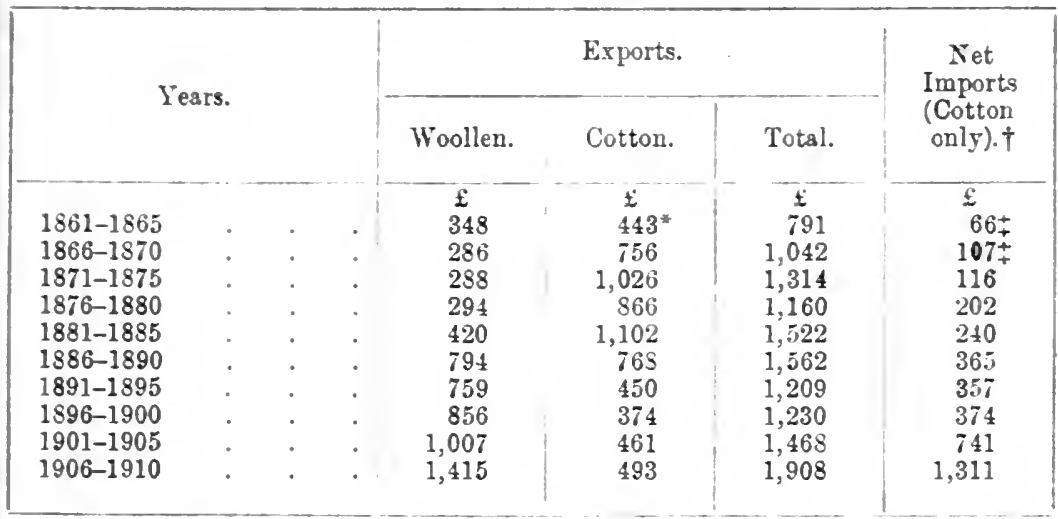

* Eour years 1862-1865, as the exports were separately entered only since 1862.

† Imports of woollen hosiery hare only been recorded during the last seven years.

$\mp$ Gross imports in these years; net imports would probably be $£ 10,000$ sterling less.

The table does not include gloves, since the import and export records of these have only been kept for two or three years, and are not complete at that. It will be seen that the progress of the woollen section of the industry has been eminently satisfactory, but that the same cannot be said of the cotton section. In the early 'sixties the woollen exports were considerably less than the cotton, and in the early 'seventies they were little more than one-fourth of the cotton exports. But after the early 'eighties woollen exports grew, and cotton exports fell so hearily that the woollen section is now three times as large as the cotton section of the export trade. Cotton hosiery exports have shown an improving tendency during the last fifteen years, but this goes against a very large increase in the net imports, and it is abundantly clear that our makers of cotton hosiery have to learn from the Germans the lesson which our boot manufacturers long ago learned from the Americans. They must find out the machinery and methods which have enabled the Germans to make such progress in cotton hosiery. At present no injury has been done to the home trade, for our exports of woolien and cotton hosiery are still considerably larger than our net imports, but the steady growth of the cotton imports during the past ten years indicates that our manufacturers must bestir themselves if they wish to retain their grip on this part of the trade. Our factory-owners may be reminded, too, that the world-trade in cotton hosiery is large enough to be well worth a struggle for an adequate share of it; for the imports of the United States alone have averaged $£ 1,598,000$ a 
year for the five years ending with 1910, and the supply of these is at present almost monopolized by the Germans.

In the foreign trade table given above no account is taken of the net imports of woollen hosiery, since these have only been recorded for the past seven years. It may, however, be instructive to see how they compare during this period with the exports:-

British Foreign Trade in Woollen Hosiery (in thousands of pounds)

\begin{tabular}{|c|c|c|c|c|c|c|c|}
\hline & 1904. & 1905. & 1906. & 1907. & 1908. & 1909. & 1910. \\
\hline $\begin{array}{l}\text { Exports } \\
\text { Net imports }\end{array}$ & $\begin{array}{c}£ \\
1,032 \\
207\end{array}$ & $\begin{array}{r}\mathfrak{f} \\
1,191 \\
402\end{array}$ & $\begin{array}{c}\mathcal{E} \\
1,269 \\
271\end{array}$ & $\begin{array}{c}£ \\
1,486 \\
267\end{array}$ & $\begin{array}{r}\stackrel{f}{5} \\
1,277 \\
300\end{array}$ & $\begin{array}{c}\mathfrak{£} \\
1,367 \\
352\end{array}$ & $\begin{array}{r}\stackrel{E}{1} \\
1,675 \\
465\end{array}$ \\
\hline Excess of exports & 825 & 789 & 998 & 1,219 & 977 & 1,015 & 1,210 \\
\hline
\end{tabular}

The woollen branch of the trade is, therefore, quite healthy, and in this we apparently have no cause for serious fear of any foreign competition; but in the cotton branch our imports largely exceed our exports-a state of affairs by no means creditable to British manufacturers. For there is no more reason why the Germans should be impregnable in the cotton than in the woollen branch, and the fact that they are far from being impregnable in woollen goods is proved by the following record for the last five years:-

Exports of Woollen Hosiery (in thousands of pounds)

\begin{tabular}{|c|c|c|c|c|c|c|c|c|c|}
\hline & & & & & 1906. & 1907. & 1908. & 1909. & 1910. \\
\hline $\begin{array}{l}\text { From Germany } \\
\text { From Britain . }\end{array}$ & . & . & : & . & $\begin{array}{c}£ \\
1,926 \\
1,269\end{array}$ & $\begin{array}{c}\mathfrak{E} \\
1,794 \\
1,486\end{array}$ & $\begin{array}{c}£ \\
1,509 \\
1,277\end{array}$ & $\begin{array}{c}\mathscr{E} \\
1,390 \\
1,367\end{array}$ & $\begin{array}{c}\mathcal{£} \\
1,567 \\
1,675\end{array}$ \\
\hline $\begin{array}{l}\text { German excess } \\
\text { British excess }\end{array}$ & . & . & : & : & $\begin{array}{l}657 \\
\ldots\end{array}$ & $\begin{array}{l}308 \\
\ldots\end{array}$ & $\begin{array}{l}232 \\
\ldots\end{array}$ & $\begin{array}{l}23 \\
\cdots\end{array}$ & $\dddot{108}$ \\
\hline
\end{tabular}

Here is a record of steady progress, a large German superiority being gradually pulled down and converted into a British superiority. And what our makers have done in woollen goods they might, with more energy and enterprise, repeat in cotton goods.

The lace trade developed very rapidly during the last half of the nineteenth century. During the last thirty years our gross imports from abroad have increased nearly five-fold; but in the same time our re-exports of this lace received from abroad have grown nearly forty-fold. A considerable proportion of the shipments received from abioad consists of English lace which has been scnt to Germany and Switzerland to be worked upon, improved 
in value, and retnrned to us in due course-part of it to be sold here, and part to be shipped again and sold to other foreign nations as re-exported foreign lace. Indeed, the large extent of the reexport trade is perhaps the most striking feature of the British commerce in lace, and our re-exports are. now much greater than our exports of British-male lace used to be twenty-five or thirty years ago. Coineidently with this increase we have witnessed an enormous growth in the shipments of lace produced in the United Kingdom, and during the past twenty years the two branehes of the trade have made progress which is in the highest degree satisfactory. The record for the past forty years is as follows:-

Britain's Foreign Trade in Lace (in thouscunds of pounts)

\begin{tabular}{|c|c|c|c|c|c|c|c|c|}
\hline \multirow[b]{2}{*}{$\begin{array}{l}\text { Five-Tear } \\
\text { Averages. }\end{array}$} & & \multicolumn{3}{|c|}{$\begin{array}{l}\text { Lace Imports, of Cotton, } \\
\text { Silk, and other Materials. }\end{array}$} & \multicolumn{3}{|c|}{ British Exports. } & \multirow{2}{*}{ 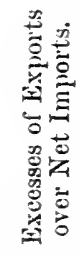 } \\
\hline & & 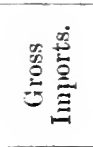 & 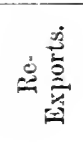 & 艺蓠 & 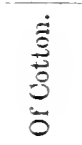 & 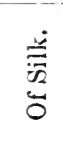 & हैं & \\
\hline & & $\mathfrak{E}$ & $£$ & $\mathfrak{E}$ & $\mathfrak{f}$ & $£$ & $£$ & $f$ \\
\hline $1871-1875$. & . & 643 & $\ldots$ & $\ldots$ & 1,074 & $\ldots$ & $\ldots$ & $\ldots$ \\
\hline $1876-1880$. & . & 468 & $\ldots$ & $\ldots$ & 1,332 & $\ldots$ & $\ldots$ & $\cdots$ \\
\hline $1881-1885$ & . & 757 & 53 & 704 & 2,528 & & & $\ldots$ \\
\hline $1886-1890$ & . & 1,016 & 99 & 917 & 2,102 & 204 & 2,306 & 1,389 \\
\hline 1891-1895 . & : & 1,077 & 145 & 932 & 1,964 & 225 & 2,189 & 1,257 \\
\hline 1896-1900. & . & 1,401 & 510 & 891 & 2,329 & 146 & 2,475 & 1,584 \\
\hline $1901-1905$ & . & 2,623 & 1,108 & 1,515 & 3,279 & 89 & 3,368 & 1,853 \\
\hline $1906-1910$. & . & 3,423 & 1,947 & 1,476 & 4,330 & 122 & 4,452 & 2,976 \\
\hline
\end{tabular}

* Imports for Home Consumption.

Most of our imports come from Germany and France, and though these arrivals from abroad have grown persistently since the late 'seventies, it will be noted how rapid and persistent the inerease in re-exports has been. Of the shipments received here we now re-ship and sell abroad more than half, so that less than half of the goods landed here are retained for home eonsumption. It should, however, be mentioned that imports have been steadily falling since 1906 ; and re-exports, too, though not in the same proportion. During these five years the tendency has been for us to retain a smaller and smaller amount for sale in the home market; and though this is satisfactory from the point of view of the home manufacturer, it is to be regretted that the valuable re-export trade shows a marked deeline.

Some curious features of the re-export trade are to be noted when we cousider the silk branch of the trade only, for during the 
past five years we have re-sold to oversea customers a greater quantity of foreign silk lace than has been landed on these shores during the same period. Thus, in 1907 we imported $£ 276,000$ worth, but re-exported $£ 446,000$ worth, and in 1908 the respective figures were $£ 286,000$ and $£ 577,000$. It is plain, therefore, that considerable quantities of foreign silk lace-which reach us almost entirely from France-must remain in English warehouses for several years and then be shipped and re-sold to oversea buyers. The movements will perhaps be made clearer by the following table:-

Imports and Re-Exports of Silk Lace (in thousands of pounds)

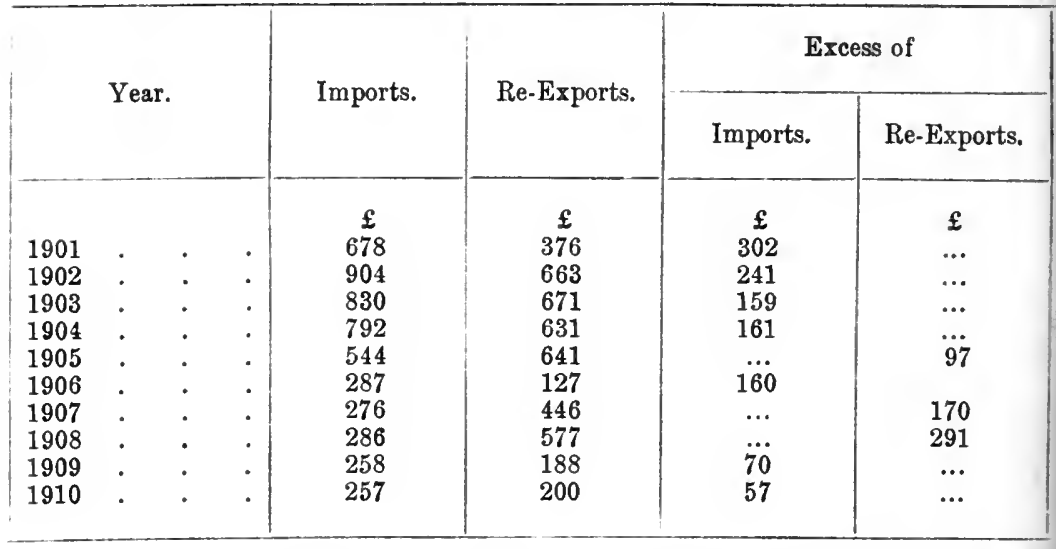

It will be noticed that up to 1904 a considerable, though diminishing, quantity was retained in this country, but during the succeeding six years the aggregate imports were $£ 1,908,000$, while the aggregate re-exports were $£ 2,179,000$. The conclusion seems unavoidable that in the earlier years of this century heavy stocks had been accumulated that could not be worked off in this country, and that these have been gradually disposed of to oversea buyers during the past six years.

In so remarkable a trade it is difficult to fix, even approximately, the extent of the home consumption of foreign silk lace, but anyone who considers the foregoing table attentively will probably conclude that it could not have been, during the past five years, anything like so large as the shipments of British-made silk lace, which have averaged $£ 122,000$ a year for that period. It will be observed, too, from the table (p. 397), that the exports of the British article have taken a most satisfactory jump upwards during the last decade. In this connexion it should be remembered that the census returns the home production of "silk net and lace and articles thereof" as 
Both the felt and straw hats produced by our manufacturers are world-famous for quality, and there is probably not a civilized country to which they do not go in greater or lesser quantities. Among Furopean nations the Norwegians, Swedes, Danes, Germans, Dutch, Belgians, French, and Spaniards all buy our wares in quantities sufficiently large to be separately specified in the Board of Trade records, and it is highly probable that the other European countries are customers also, though in a lesser degree. Among our extra-European foreign customers the United States, Argentina, and Japan figure prominently; while some of the British possessions (notably Canada) are handsome buyers.

An export trade which is thus widely and fairly evenly spread is not unduly dependent on the fiscal or other vagaries of any one country or even group of countries, and to this firmness of basis is probably due the absence of any violent fluctuations in the export records of the industry. That these records have, on the whole, been tolerably satisfactory is clear from the following statement:-

Average Exports and Net Imports of Hats

(of Felt, Straw, and Other Materials)

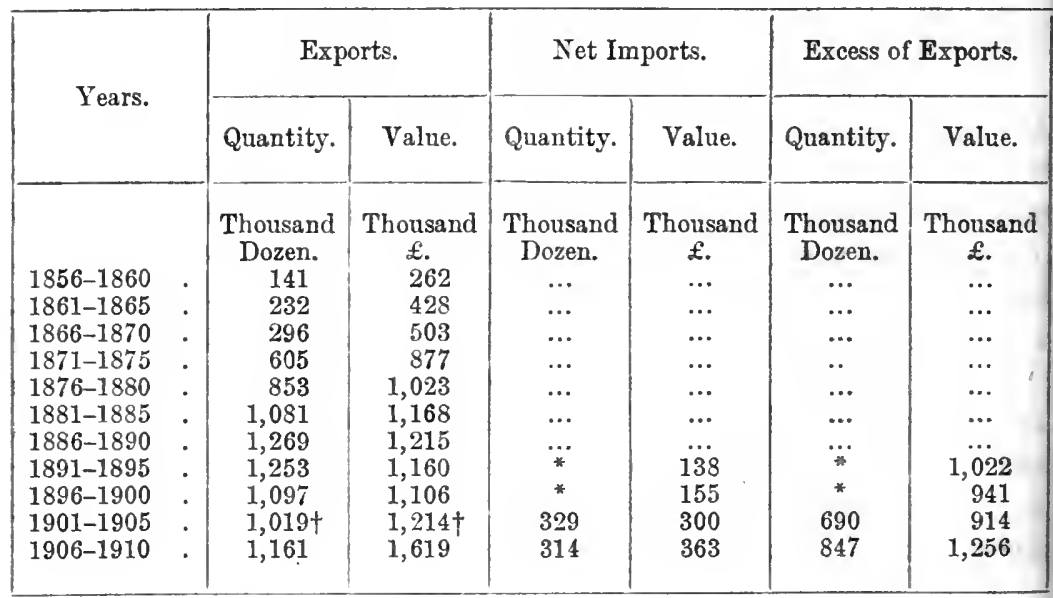

* Cannot be stated.

† Including trimmed hats in 1895 and after. All the import figures include trimmed hats.

In examining the records it will be noticed that down to the 'nineties the exports showed an unchecked growth both in quantity and in value. Afterwards, however, there was a decline in the number of dozens shipped, while in the five years just completed their value rose $£ 400,000$ higher than it had ever been before. 
The movement in values was partly caused by the general fall and rise of prices, but it was due much more to a change in the character of the goods. Thus in the late 'nineties only 443,000 dozens consisted of felt hats valued at more than 30 s. per dozen, the remainder being mostly straw hats at less than $13 \mathrm{~s}$. per dozen. But in the past five years there were 536,000 dozens of felt hats worth about $37 \mathrm{~s}$. per dozen, the remainder being mostly straw goods at less than $18 \mathrm{~s}$. per dozen. In other words, we have done better business in $30 \mathrm{~s}$. goods than in $13 \mathrm{~s}$. goods.

In comparing the imports with the exports, it has to be remembered that while we ship principally felt and straw hats, we import principally hats of "other sorts." It will be noted that during the last ten years imports have fallen in number and risen in value. This has mainly resulted from the progress of the "Panama," which reaches us mostly from Colombia, Peru, and Ecuador. These hats - which are classed by the Board of Trade among "other sorts"-are of relatively high value, and their popularity in recent years accounts for about three-fourths of the growth in the value of our net imports during the past decade. In spite of this, however, it will be seen that our excess of exports at $\mathfrak{£ 1 , 2 5 6 , 0 0 0}$ is now greater than it has ever been before.

Let us now see how our increased exports for the past decade have been distributed :-

Exports of Hats Analysed

\begin{tabular}{|c|c|c|c|c|c|c|}
\hline Five-Year Averages. & \multicolumn{2}{|c|}{$\begin{array}{l}\text { To Foreign } \\
\text { Countries. }\end{array}$} & \multicolumn{2}{|c|}{$\begin{array}{l}\text { To British } \\
\text { Possessions. }\end{array}$} & \multicolumn{2}{|c|}{$\begin{array}{l}\text { To All } \\
\text { Countries. }\end{array}$} \\
\hline Of Felt . $\quad\left\{\begin{array}{l}1900-1904 \\
1905-1909\end{array}\right.$ & $\begin{array}{c}\text { Thousand } \\
\text { Dozen. } \\
169 \\
230\end{array}$ & $\begin{array}{c}\text { Thousand } \\
\text { \&8. } \\
339 \\
479\end{array}$ & $\begin{array}{c}\text { Thousand } \\
\text { Dozen. } \\
281 \\
260\end{array}$ & $\begin{array}{c}\text { Thousand } \\
\text { £s. } \\
416 \\
416\end{array}$ & $\begin{array}{c}\text { Thousand } \\
\text { Dozen. } \\
450 \\
490\end{array}$ & $\begin{array}{c}\text { Thousand } \\
\text { Es. } \\
755 \\
895\end{array}$ \\
\hline Increase + or decrease - & +61 & +140 & -121 & $\ldots$ & +40 & +140 \\
\hline Of Straw $\cdot\left\{\begin{array}{l}1900-1904 \\
1905-1909\end{array}\right.$ & $\begin{array}{r}78 \\
106\end{array}$ & $\begin{array}{r}65 \\
101\end{array}$ & $\begin{array}{l}494 \\
417\end{array}$ & $\begin{array}{l}351 \\
349\end{array}$ & $\begin{array}{l}572 \\
523\end{array}$ & $\begin{array}{r}416 \\
-453\end{array}$ \\
\hline Increase + or decrease - & +28 & $+\quad 39$ & 77 & - & -49 & +37 \\
\hline Other Sorts $\cdot\left\{\begin{array}{l}1900-1904 \\
1905-1909\end{array}\right.$ & $\begin{array}{r}9 \\
28\end{array}$ & $\begin{array}{l}18 \\
50\end{array}$ & $\begin{array}{l}11 \\
37\end{array}$ & $\frac{10^{\circ}}{71}$ & $\frac{20}{65}$ & $\begin{array}{r}34 \\
121\end{array}$ \\
\hline Increase + or decresse - & $+\quad 19$ & $+\quad 32$ & +26 & +55 & $+4 \bar{j}$ & +87 \\
\hline Grand Totals $\cdot\left\{\begin{array}{l}1900-1904 \\
1905-1909\end{array}\right.$ & $\begin{array}{l}256 \\
364\end{array}$ & $\begin{array}{l}422 \\
633\end{array}$ & $\begin{array}{l}786 \\
714\end{array}$ & $\begin{array}{l}783 \\
\$ 36\end{array}$ & $\begin{array}{l}1,042 \\
1,078\end{array}$ & $\begin{array}{l}1,205 \\
1,469\end{array}$ \\
\hline Increase + or decrease - & +108 & +211 & 72 & +53 & 36 & +264 \\
\hline
\end{tabular}


In all three sections of the trade the sales to foreigners have made remarkable progress - and more especially in felt and straw goods, which together made up more than seven-eighths of the exports in the latter five years. Both felt and straw hatters have in this period been entirely dependent on foreign customers for all the improvements shown in the volume and value of their oversea business. The extremely poor showing made by the colonies in this comparison is very disappointing, though it must be admitted that imperial customers have provided a very welcome set-off by their much larger purchases of "other sorts" of hats. The rapid growth in exports of these "other sorts" is more especially satisfactory when viewed in conjunction with the following figures from the Census of Production report:-

\begin{tabular}{|c|c|c|c|c|c|c|}
\hline & & & & $\begin{array}{c}\text { Production, } \\
1907 .\end{array}$ & $\begin{array}{l}\text { Exports, } \\
1907 .\end{array}$ & $\begin{array}{c}\text { Net Imports, } \\
1907 .\end{array}$ \\
\hline $\begin{array}{l}\text { Felt } \\
\text { Straw : } \\
\text { Other Sorts }\end{array}$ & : & : & : & $\begin{array}{c}\text { Thousand } \\
\text { Dozen. } \\
1,363 \\
1,432 \\
198\end{array}$ & $\begin{array}{c}\text { Thousand } \\
\text { Dozen. } \\
\mathbf{5 3 4} \\
\mathbf{5 3 6} \\
\mathbf{5 5}\end{array}$ & $\begin{array}{c}\text { Thousand } \\
\text { Dozen. } \\
34 \\
28 \\
225\end{array}$ \\
\hline
\end{tabular}

The fact that the exports increased from 55,000 dozen in 1907 to 124,000 dozen in 1910 seems to indicate that the home production of "other sorts" of hats has grown largely since the census year.

If we now turn to the trade in leather gloves we find very different conditions, for our imports of these articles have always been extremely large while our export trade in them is of very recent growth. Indeed the exports have only been recorded by the Board of Trade since the year 1903, but we shall find that all the indications point to very substantial progress. During the eight years since 1903 the exports have grown as follows:-

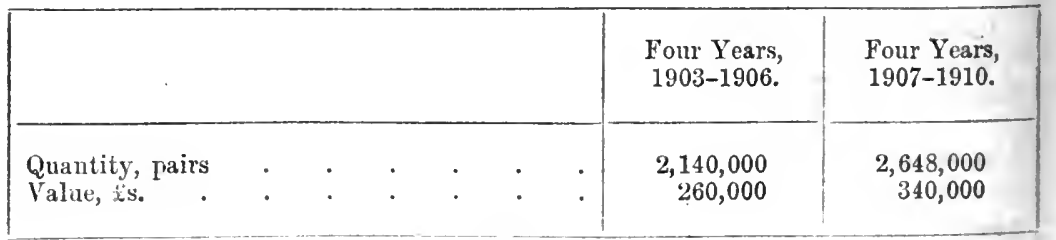

The goods exported are of high-class quality, the value having increased from $27 \mathrm{~s}$. $6 \mathrm{~d}$. per dozen pairs in 1903 to more than $30 \mathrm{~s}$. 
in 1910. But it is in the net imports that the strongest evidence of the progress of the home manufacturer is to be found. The following shows the imports retained for home consumption :-

Average Net Imports of Leather Gloves

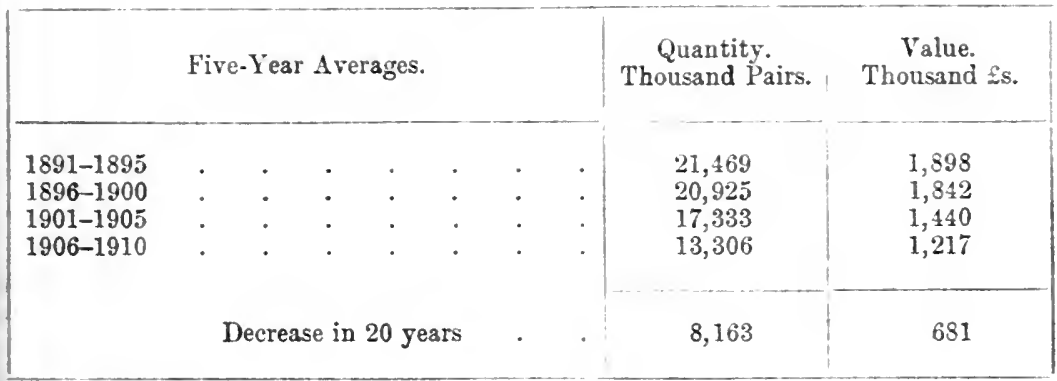

Allowing for the increase of population during the past twenty years, and for the much greater spending power of the upper artisan and lower middle classes, it is difficult to believe that the consumption of leather gloves has very seriously declined during the two decades. Some decline there has certainly been, but the Census of Production figures seem to indicate that a substantial proportion of these $8,163,000$ pairs formerly supplied by importers is now supplied by our own manufacturers. Here are the census returns, from page 20 of the Preliminary Tables, Part VI :-

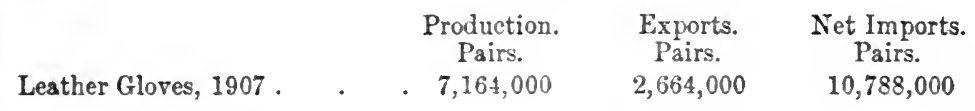

From this it is tolerably clear that highly satisfactory progress must have been made by our own manufacturers since the early 'nineties when the average net imports were $8,163,000$ pairs higher than they are now. 


\section{CHAPTER XXI}

\section{PAPER AND PRINTING TRADES}

Paper.-Introduction of machinery into paper-making-Excise duties on paper early in the nineteenth century-Progress of the trade since 1860-Esparto grassWood pulp-Our foreign trade in paper.

Printing. - The size of our printing trade-Census of Production figures-The introduction of machinery into the printing trades early in the nineteenth centuryThe evolution of the power press and of the linotype machine-The development of photography and the cheapening of illustrations-Our foreign trade in books and printed matter.

\section{The Paper Trade}

$\mathrm{P}^{\mathrm{A}}$

APER has been manufactured in this country for many centuries, although in the early and middle ages the favourite writing materials were either vellum or parchment. The invention of printing caused a great and growing demand for paper from the sixteenth century onwards. With the era of newspapers and popular education the demand expanded enormously. But invention fortunately kept pace, and in the second half of the nineteenth century improvements were made in every sort of machinery, while cheap paper is now manufactured on a huge scale from grass, wood, and other materials. The best paper is still made by hand. Various sorts of paper-making machinery were invented towards the end of the eighteenth century; and as steam power was applied generally to industry the paper trade was practically transformed. With the advent of the newspaper and the increased demand for paper that resulted, the trade began to develop rapidly. Its progress was seriously retarded, however, by the numerous excise duties that were imposed in this country on paper. The returns made in consequence of these excise duties were however of statistical value as showing to some extent the growth of the trade, and about them Porter writes:- "The manufacture of paper is carried on in certain localities, whence it is distributed over every part of the kingdom, so that English-made paper finds its way to Scotland and Ireland. 
The parliamentary volumes do not contain any statement of the quantity of paper brought to charge with the excise earlier than 1803 in the present century, which year is therefore inserted in the following comparison, instead of $1801 . "$

\begin{tabular}{|c|c|c|c|c|c|c|}
\hline & Year. & & $\begin{array}{l}\text { Pounds of Paper } \\
\text { Charged with } \\
\text { Duty. }\end{array}$ & $\begin{array}{l}\text { Amount of } \\
\text { Revenue. }\end{array}$ & $\begin{array}{l}\text { Revenue Paid } \\
\text { by each } \\
\text { Individual. }\end{array}$ & $\begin{array}{c}\text { Duty per lb. } \\
\text { on First- } \\
\text { class Paper. }\end{array}$ \\
\hline $\begin{array}{l}1803 \\
1811 \\
1821 \\
1831 \\
1841\end{array}$ & $\dot{.}$ & $\begin{array}{ll}\cdot & \cdot \\
\cdot & \bullet \\
\cdot & \bullet \\
\cdot & \text {. } \\
\cdot & \text {. }\end{array}$ & $\begin{array}{c}\text { lb. } \\
31,699,537 \\
38,225,167 \\
48,204,927 \\
62,738,000 \\
97,103,548\end{array}$ & $\begin{array}{c}£ \\
394,824 \\
477,414 \\
579,867 \\
728,860 \\
637,354\end{array}$ & $\begin{array}{l}\mathrm{d} . \\
5 \frac{3}{4} \\
6 \frac{7}{4} \\
6 \frac{1}{2} \\
7 \frac{1}{4} \\
5 \frac{3}{5}\end{array}$ & $\begin{array}{l}\mathrm{d} . \\
3 \\
3 \\
3 \\
3 \\
1 \frac{1}{2}\end{array}$ \\
\hline
\end{tabular}

The duty on paper was first imposed in 1711 by the Act 10 Anne, c. 19, which recites, as a reason for the tax, "the necessity of raising large supplies of money to carry on the war," and surely it required a case of strong necessity to justify the imposition of a tax which tended so directly to impede the progress of knowledge among the people. That it must have had this effect is evident from the statement here given. While the duty on first-class paper, which includes writing and printing paper, was continued at $3 \mathrm{~d}$. per $\mathrm{lb}$., the increased quantity used was, considering the increase of the population, very insignificant. The quantity used at the different periods, if equally divided among the population, would have been-

\begin{tabular}{|c|c|c|c|}
\hline $\begin{array}{l}\text { Year. } \\
1803\end{array}$ & $\begin{array}{l}\text { lb. } \\
1 \cdot 92 \text { for cach individual. }\end{array}$ & $\begin{array}{l}\text { Year. } \\
1831 .\end{array}$ & $\begin{array}{l}\text { lb. } \\
2 \cdot 54 \text { for each individual. }\end{array}$ \\
\hline 1811 & $2 \cdot 06 \quad \quad 1$ & 1838. & $3 \cdot 47 \quad, "$ \\
\hline 1821 & $2 \cdot 27$ & 1839. & 3.58 \\
\hline
\end{tabular}

The reduction of the duty took effect only in October, 1836 , and could not be expected to have produced its full effects for some years thereafter. The degree in which it has stimulated consumption may be seen from the quantities used every five years from 1835 to 1849 , namely:-

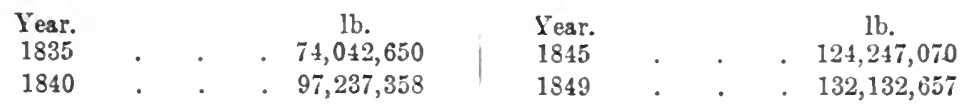

Previous to 1836 the paper duty was charged on two classes or qualities, of which the first class paid $3 \mathrm{~d}$. and the second class $1 \frac{1}{2} \mathrm{~d}$. per $\mathrm{lb}$. The higher rate was subsequently abolished and the duty charged on the lower only. 
The number of licences taken out by paper manufacturers was as follows:-

\begin{tabular}{|c|c|c|c|c|c|c|c|}
\hline Year. & & & & England. & Scotland. & Ireland. & Total. \\
\hline 1801. & . & . & . & . 413 & 33) $\mathrm{N}$ & Vo account kept & \\
\hline 1811. & . & . & . & 527 & $48\}$ & in Ireland. & \\
\hline 1821. & . & . & . & 564 & 55 & 47 & 666 \\
\hline 1831. & . & . & . & 507 & 54 & 59 & 620 \\
\hline 1841. & . & . & . & 370 & 49 & 48 & 466 \\
\hline 1845. & . & . & . & 381 & 45 & 47 & 473 \\
\hline 1849. & . & . & . & 349 & 48 & 40 & 437 \\
\hline
\end{tabular}

The price per ream of printing paper, of one particular description, was-

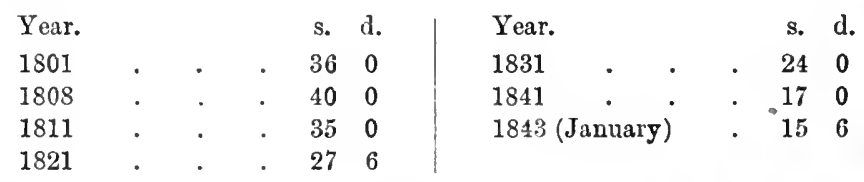

The effect of high duties in limiting the use of books may be inferred from the rapid extension caused to the sale of almanacs through the repeal of the stamp-duty of $1 \mathrm{~s}$. $3 \mathrm{~d}$. It was stated in the report of the Commissioners of Excise Inquiry, that two hundred new almanacs were started immediately upon the repeal, of some of which upwards of 250,000 copies were sold within a short period, although the old ones maintained their ground; and Moore's Almanack for the year 1835 is stated to have actually doubled its former sales. Some part of the increased manufacture of paper must be ascribed to the great reduction made, in 1836, in the stamp-duty on newspapers.

The year 1860 marks the birth of a new era in paper-making. In that year the paper-duties were finally removed by $\mathrm{Mr}$. Gladstone, and about the same time a substitute for rags as a raw material for the manufacture of paper was found. The supply of raw material (i.e. rags) had for several years previously been causing grave anxiety to paper manufacturers. The demand was increasing by leaps and bounds, and strenuous efforts were made to find a substitute for rags. At last one was found in esparto grass. Mr. A. Dykes Spicer, in his valuable book upon The Paper Trade, writes: "Nothing satisfactory was found to tide the paper-makers over the troublons years of 1860,1861 , and 1862 . It was the discovery of the uses of esparto grass which brought the crisis to an end. No sooner was it introduced into this country and put to practical purpose, than it was found to supply the impetus necessary to revive the English paper trade and enable it to face foreign competition on more equal terms." Esparto grass is found within the 
area known as the Esparto Zone $\left(32^{\circ}\right.$ and $41^{\circ}$ north latitude) including the southern part of Spain and the northern border of Africa.

The manufacture of paper from esparto grass is chiefly carried on in England. Mr. Spicer writes: "Since Mr. Routledge in 1861 patented his process for treating esparto, it has been the peculiar raw material used by England for her paper-making. Plant was erected and owing to eheap freights it was possible to introduce esparto at a low rate. But the real cause why this country alone has made use of esparto is the fact that England is the home of the chemical industries, and esparto requiring a very large amount of chemicals could easily be turned into pulp where this material was cheap."

In spite of the discovery and application of esparto grass to paper-making the demand for paper was so great that the new supplies were insufficient to satisfy it. A further source of raw material had to be found. "A new raw material," writes Mr. Spicer, "which had always appeared to possess great possibilities was wood. As early as 1800 , when Koops published his book on paper, the use of wood pulp was discussed; but at that period it could not be made to compete successfully against rags. . . . The first patent for beating wood by chemical methods and thus obtaining a more lasting and durable paper from wood pulp was taken out by B. G. Tilghman, a chemist of Philadelphia, in 1867." In 1879 large mills for manufacturing wood-pulp paper were erected at Ilford, near London, and still larger ones worked on the same principle were erected at Northfleet in 1884.

It was in the last decade of the nineteenth century that wood pulp began to be largely used. The cheap modern newspaper and the cheap editions of the "classics" were rendered possible by the introduction of this cheap paper. Mnch of the paper so made is very inferior and will probably crumble to dust in no great length of time.

Our foreign trade in paper for the last twenty-five years, in five-yearly averages, has been as under:-

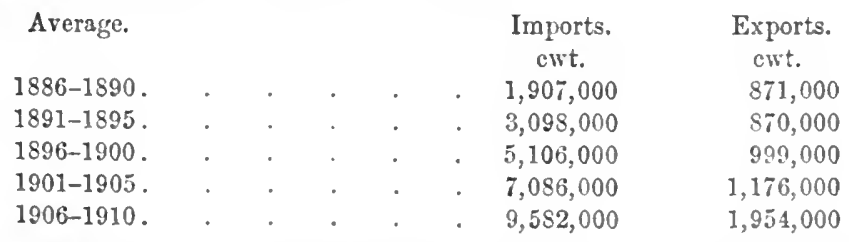

The figures for imports include paper, unprinted, printed or coated, strawboard, millboard, and wood-pulp board, while those for 
exports comprise writing or printing paper and envelopes, paperhangings, and all other sorts of paper. Prior to 1896 paperhangings were not included in these figures.

The rapid growth of our imports of paper during the last three decades has been largely due to the increased imports of wood-pulp board. In 1895, the first year in which wood-pulp board was specified separately, our imports amounted to 171,548 cwt.; by 1900 they had risen to 467,926 ; in 1905 they were $1,178,564$ cwt.; while in 1910 they amounted to $1,338,264$.

\section{The Printing Trades}

Few of our industries have undergone a more complete revolution during the last fifty years than the printing trades. In olden times printing was a costly art owing to the amount of care and labour required to produce even a few sheets of printed matter. Nowadays our printing trades are among the biggest of our industries. The Census of Production gives their size together with that of some subsidiary industries in 1907 as under:-

\begin{tabular}{|c|c|c|c|c|c|}
\hline & 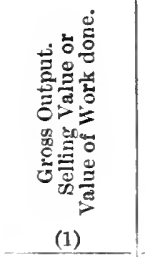 & 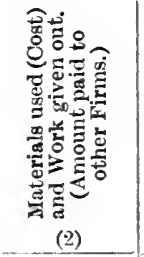 & 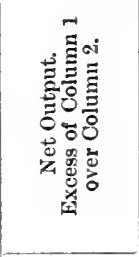 & 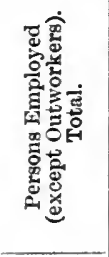 & 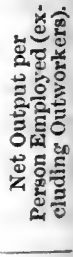 \\
\hline Printing and bookbinding fac- & $£$ & $\mathfrak{f}$ & $\mathfrak{E}$ & & $£$ \\
\hline $\begin{array}{l}\text { tories and workshops-Private } \\
\text { firms and companies }\end{array}$ & $24,597,000$ & $9,309,000$ & $15,288,000$ & 172,677 & 89 \\
\hline $\begin{array}{l}\text { Factories engaged in the print- } \\
\text { ing and publishing of news- } \\
\text { papers and other periodicals. }\end{array}$ & $13,237,000$ & $4,614,000$ & $8,623,000$ & 45,303 & 190 \\
\hline $\begin{array}{l}\text { Typefounding, stereotyping, eu- } \\
\text { graving, and die-sinking fac- } \\
\text { tories and workshops }\end{array}$ & 928,000 & 290,000 & 638,000 & 6,269 & 102 \\
\hline $\begin{array}{l}\text { Manufactured stationery, fac- } \\
\text { tories and workshops-Private }\end{array}$ & & 200,000 & 000,000 & 0,200 & \\
\hline firms and companies . & $4,186,000$ & $2,319,000$ & $1,86 \overline{7}, 000$ & 25,156 & 74 \\
\hline $\begin{array}{l}\text { Cardboard box factories and } \\
\text { workshops . }\end{array}$ & $2,011,000$ & 954,000 & $1,057,000$ & 20,379 & 52 \\
\hline \multirow{3}{*}{$\begin{array}{l}\text { Pen, pencil, and artists' materials } \\
\text { factories and workshops }\end{array}$} & & & & & \\
\hline & 729,000 & 242,000 & 487,000 & 6,307 & 77 \\
\hline & $45,688,000$ & $17,728,000$ & $27,960,000$ & 276,091 & \\
\hline
\end{tabular}

It will be seen that the largest group comprises printing and bookbinding factories. From these factories come the flood of cheap literature that caters for the popular reader, and it is curious 


\section{PAPER AND PRIN'TING TRADES}

that with such large scale production the net output per person should be as low as $£ 89$. In the newspaper factories it reaches $£ 190$, although here it should be remembered that the salaries of the editorial and publishing staffs, ete., are not deducted. The output of the typcfounding and stereotyping factories and workshops may seem unduly small, but it relates only to separate establishments, the stereotyping, etc., done by newspapers and other periodicals not being included in this total.

The great change that revolutionized methods of printing in this and other countries came fairly late in the nineteenth century when modern high-speed printing was introduced. A very interesting survey of the progress of the printing trades during the latter half of the nineteenth century is given by Mr. John Southward in his book The Progress of Printing and the Graphic Arts during the Victorian Era. Mr. Southward goes into many details; but to record briefly the history of the printing trades it will perhaps be simpler to take each of the various branches of the industry separately. By far the largest branch is that of "jobbing" printing, which is included in the first item given in the above table. The main cause of the development of this branch of the trade was the introduction into England of the small platen machine in 1866 . This machine was the invention of an American named Gordon, and it enabled much more rapid and effective printing to be done than was possible with the hand presses that were used previously. As regards the progress of newspaper printing, two inventions have done more than anything else to render the modern scale of production possible. One was the invention of the linotype machine, and the other the gradual application of the rotary principle of printing to the power press. The principal presses used during the first few decades of the nineteenth century were identical in principle with that used by Gutenberg in 1+50. One of the Earls of Stanhope (Charles Mahon) made considerable improvements in the printing press early in the nineteenth century, and an American, George Clymer, introduced an improved press called the "Columbia" in 1S17. The first power press was constructed by Frederick Koenig, a German printer of Leipzig, who emigrated to London in 1806 . Koenig's invention attracted the attention of Mr. James Walter of The Times, who ordered a machine, and in 1814 The Times had the honour of being the first newspaper to be printed by modern machinery. Improvements were made in Koenig's machine by Edward Cowper, an Englishman.

In 1857 the Hoe machine, an American press, and the proto- 
type of the modern high-speed newspaper machine, was invented by Col. Richard M. Hoe of New York. It was first used in this country to print Lloyd's News. The first printing done from a roll of paper instead of on flat sheets was done in 1862, and this method again was first used by Mr. James Walter of The Times. William Bullock, an engineer of Philadelphia, discovered the advantages of rotary printing in 1865 . The combination and perfection of the above discoveries has led to the modern newspaper printing press, which is capable of printing, cutting, folding and counting thousands of copies per hour. The linotype machine was the first practical form of composing machine, although earlier attempts had been made-notable among which was that of Young and Delcambre in 1840 , and that of Mackie in 1858. It would be difficult to exaggerate the important effect this discovery had upon the printing trades, more especially as regards newspaper printing. The old method of composing by hand was both tedious and expensive, but with the linotype not only was much time saved, but the final appearance of the printed matter is becoming equal if not superior to that obtained from hand-set type.

A branch of the printing trades that sprang into great prominence during the last decade or so of the nineteenth century was the reproduction of cheap illustrations. Of course the beautiful art of engraving on wood, steel, and copper had been long practised, and few moderns can match the older masters. 'But modern art for the million is another matter. It was the discovery of photography, however, that at last has made the daily and rapid reproduction of persons, scenes, and occurrences possible in the daily newspapers. The first attempts at photography were made as early as 1727, when one Schultze published the results of his experiments proving the darkening by light of a silver salt. No real advances were made, however, until 1727, when one of the sons of the famous Josiah Wedgwood, the great chemist and potter, first printed on paper or leather impregnated with chloride of silver under silhouettes. Mr. A. J. Newton, in a valuable series of articles which appeared in the Lithographic Artists' and Process Workers' Quarterly, gave in considerable detail the various stages in the evolution of photo-mechanical illustration. One of the main advances was made by Daguerre in 1839 , who originated and gave his name to the daguerrotypes that were so popular in the 'forties of the last century. In the same years Fox Talbot invented the calotype. In 1862 dry plates were first used and were placed on the market, and in 1873 H. W. Vogel found the means of rendering plates sensitive to 
coloured rays. In the year 1864 , J. W. Swan improved very greatly the carbon process and patented methods of producing engravings which anticipated to some extent the very latest methods of photogravure. An important adjunct to the satisfactory reproduction of photographs was the "screen." The process of reproduction is complicated ; but, roughly stated, the "screen" is placed between the plate in the camera and the object to be photographed. When the photograph is taken this has the effect of dividing the negative into a number of fine points, and from this a plate or block can be constructed. Mr. Newton states " that Fox Talbot first mentioned the screen in his patent of 1852 , and described its use for zinc and stone as well as steel." Numerous improved screens were made at later dates in the nineteenth century. "The introduction into commerce of the perfect cross line screen," continues Mr. Newton, "and the gradual dissemination of the correct principles that underly its use, has probably done more for the spread of "process' than anything else."

One very recent discovery in the reproduction of illustrations deserves mention, namely, the invention of the three-colour process. "The first suggestion of the possibility of the modern three-colour photography," says Mr. Newton, "was made by Clerk Maxwell, who, in 1861, working Young's hypothesis that there are three fundamental colour sensations, produced photographs of coloured ribbons, which were only imperfect because there were no plates at that time sensitive to green and red light."

The rapid and cheap production of illustrations has done much to alter the appearance of books and newspapers, and the twentieth century has witnessed an innovation known as illustrative journalism which bids fair to last.

Our foreign trade in books during the past forty years has been as under:-

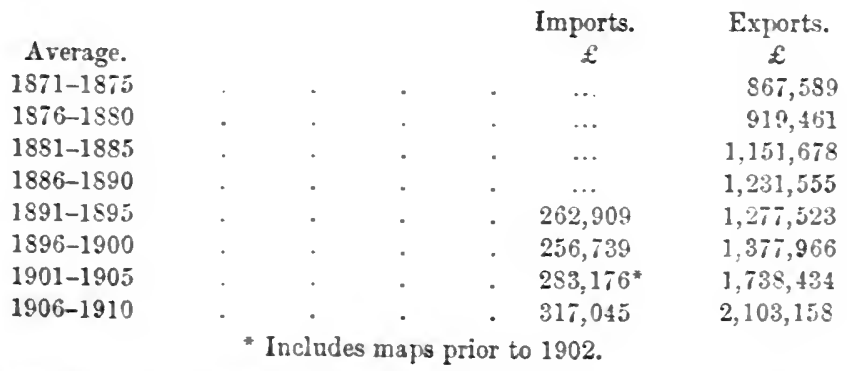

These figures show that, like most branches of manufacture, our book trade thrives in the open air of free competition. 


\section{CHAPTER XXII}

\section{THE CHEMICAL AND SOAP TRADES}

The Chemical Trades.-Some founders of the chemical trades-The alkali industry and the manufacture of bleaching powder-Census of Production figures-Our foreign trade in chemicals-Situation of the chemical industries-Difficulties of early chemical manufacturers-The Alkali Act-Chemical manures-Combinations among chemical manufacturers-The United Alkali Co.-Various other combines.

The Soap Trades.-The soap trades early in the nineteenth century and their modern growth-Exports of soap, 1853-1910-Consumption of soap-Imports of soapQuantity manufactured in the United Kingdom.

$\mathrm{T}$

IHE chemical trades of this country are now so large and occupy so important a place in our industries, that it is difficult to recall the time, only a century ago, when practically no chemicals were manufactured on a commercial scale. The historic discoveries of Priestly, Lavoisier and others in the eighteenth century were merely first steps that afterwards lead to the growth of our present vast industries. Science and discovery come first, then the practical inventor and the enterprizing capitalist. The history of the foundation of the chemical trades may be considered romantic even for a period when so many giant industries were growing up under tremendous difficulties.

Perhaps the most famous among the pioneers of the chemical trades are William Gossage, J. C. Gamble, James Muspratt, Andreas Kurtz, and James Shanks. Gossage did much to develop the alkali trade. "On the 24th December 1836," writes Mr. Fenwick Allen in his book on Some Founders of the Chemical Industry, "he specified his condensing towers, and wherever the Leblanc process has been established a Gossage condensing tower has been one of the features of the plant." Gossage was also one of the first to turn the science of metallurgy to practical uses, and did much to improve the methods of copper smelting. Gamble was a chemical manufacturer at St. Helens and was one of the early manufacturers of sulphuric acid, bleaching powder, alum, and Glauber's salts.

The Napoleonic Wars, although they caused such acute suffering in England at the time, had in one way a stimulating effect on the early history of our chemical trades. Foreign chemists of great ability found the turmoil of war on the Continent too disturbing for 
the safe establishment of a trade, and as a result they came over to England to perfect their inventions. Notable among these desirable aliens was Andreas Kurtz, a native of Reutlingen, who had studied in Paris under Lavoisier. Kurtz set up a small factory at Thames Bank in 1816, and devoted his attention mainly to soapboiling. In 1820 he removed to Manchester where he remained for ten years, and made many inportant discoveries about colours. Afterwards he removed to St. Helens and became an alkali manufacturer. The alkali industry has now risen to great importance; and Sir Alfred Mond, a partner of the famous firm of Brunner, Mond \& Co., has given a short account of its growth in British Industries under Free Trade. He writes:-

"The manufacture of alkalis and bleaching powder, the former of which includes the production of soda ash, soda crystals, caustic soda, and bicurbonate of soda, has long been one of the staple industries of England; in fact, although the first manufacturing process on a large scale was invented by the Frenchman Le Blanc, the industry was taken up and developed in England in advance of all other European countries. In this industry, as in the case of many others, England had an early predominance of manufacture, which was largely due to the favourable conditions obtaining as regards raw materials (which conditions still prevail, although not to the same extent as formerly); also to her greater freedom from disturbance due to war or political upheavals, and to the fact that she possessed larger resources both in the way of capital, skilled workmen and energetic manufacturers than those of any other European country."

It is not altogether easy to collect statistics on the development of the English alkali trade of an absolutely reliable nature, and although Sir Alfred Mond's figures were carefully compiled they must (he warns us), particularly as regards the earlicr and historic portion, be considered rather as estimates.

"For the production of alkalis in England, commencing with the year 1850 , the following table gives the percentage increase or decrease of production up to the year 1902 :-

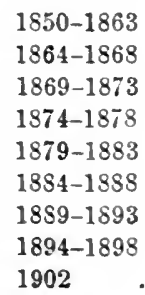

- Increase 90.5 per cent.

$\begin{array}{crrr}. & , & 10 \cdot 0 & , \\ . & , & 13 \cdot 6 & , \\ . & , & 20 \cdot 0 & , \\ . & , & 43 \cdot 3 & , \\ . & , & 4 \cdot 6 & , \\ . & , & 10 \cdot 3 & , \\ . & \text { Decrease } & 6 \cdot 1 & , \\ . & , & 7.6 & ,\end{array}$


"These figures show a very large increase indeed in the period 1850 to 1863 , the kind of increase which one would naturally expect in the earlier stages of an industry, but which from the very nature of things could not be expected to continue on the same scale as the consumption became more normal. Still, there is a steady increase up to the period 1894 to 1898 . The period of 1898 to 1902 shows a slight decrease in production, though not to any alarming extent; in fact, on comparing the figures of 1850 with the figures of 1902 , one finds that the total production has quadrupled during that period."

"The explanation of the decrease before mentioned is recognized by any one connected with the trade as due to the very large diminution of exports of English alkalis to America. This result was due partly to the increased duties on alkalis imposed in 1897, but mainly to the rapid development of the manufacture of alkalis in America, and undoubtedly contributed one of the severest blows the English alkali trade received during the many years of its existence. There can be no doubt that the increase of the then existing duty of 1894 to a higher figure in 1897 diminished the exportation of English alkalis to the United States; but long before then alkalis were being manufactured in America by the ammonia-soda process in increasing quantity, and the development of this industry, in a country which is in every respect favourably situated for the production of alkalis, was bound in time to affect our exports to America. The same result is seen to some extent in European countries such as France, Belgium, Germany, Austria and Russia, and merely illustrates the fact that, given suitable conditions, industrial countries of modern times naturally develop their own resources and supply themselves with products which they had before imported mainly from Great Britain."

The manufacture of bleaching powder is another very large branch of the chemical trades, and Sir Alfred Mond writes :-

"With regard to the production of bleaching powder, this product which is always classed with alkalis, and is manufactured in conjunction with them as far as the Leblanc process and electrolysis is concerned, is of relatively much smaller importance, as the total tonnage produced is much less than that of the alkalis we have already dealt with. The bleaching industry has been very seriously affected by the revolution caused in the paper trade by the introduction of wood pulp, and more especially wood pulp bleached with sulphurous acid, which has very largely diminished the consumption of bleaching powder in its most important outlet, namely, 
paper-making. As a consequence of this change in the requirements of the paper industry, the consumption of bleaching powder has remained practically constant since $1881 . "$

The size of our chemical and soap trades in 1907 as given in the Census of Production tables is as follows:-

\begin{tabular}{|c|c|c|c|c|c|}
\hline & $\begin{array}{c}\text { Gross } \\
\text { Output. }\end{array}$ & $\begin{array}{l}\text { Cost of } \\
\text { Materia! } \\
\text { used. * }\end{array}$ & $\begin{array}{c}N \in t \\
\text { Output. }\end{array}$ & $\begin{array}{c}\text { Number } \\
\text { Enl. } \\
\text { ployed. }\end{array}$ & $\begin{array}{l}\text { Net } \\
\text { Output } \\
\text { per } \\
\text { Person. }\end{array}$ \\
\hline \multirow{11}{*}{$\begin{array}{l}\text { Chemicals, coal-tar products, } \\
\text { drugs and perfumery fac- } \\
\text { tories and workshops. } \\
\text { Paint, colour, and varnish } \\
\text { factories. } \\
\text { Soap and candle factories } \\
\text { Soed-crushing factories . } \\
\text { Oil factories (other than seed. } \\
\text { crushing) } \\
\text { Fertilizer, glue, sheep-dip, } \\
\text { and disinfectant factories, } \\
\text { and workshops. } \\
\text { Jatch and frelighter factories } \\
\text { and workshops . } \\
\text { Ink, gum, and saling-wax } \\
\text { factories . }\end{array}$} & $£$ & $f$ & $£$ & & $£$ \\
\hline & $23,447,000$ & & $9,464,000$ & 51,088 & 185 \\
\hline & & & & & \\
\hline & $8,380,000$ & $5,711,000$ & $2,669,000$ & 13,476 & 198 \\
\hline & $11,723,000$ & $8,925,000$ & $2,798,000$ & 17,889 & 156 \\
\hline & $12,838,000$ & $11,5 \$ 8,000$ & $1,330,000$ & 7,629 & 174 \\
\hline & $6,072,000$ & $5,060,000$ & $1,012,000$ & $5,2 j 6$ & 192 \\
\hline & $5,690,000$ & $3,756,000$ & $1,934,000$ & 12,028 & 161 \\
\hline & 851,000 & 413,000 & 408,000 & 4,229 & 96 \\
\hline & & & & & \\
\hline & 799,000 & 382,000 & 416,000 & 1,310 & 315 \\
\hline Tota! & $69,890,000$ & $49,858,000$ & $20,032,000$ & 112,925 & 177 \\
\hline
\end{tabular}

* Including amount paid to other firms for work given out.

Many proprietary articles are included above, and the expense of many soap and other advertisements with which we are all too familiar is met out of the twenty millions quoted in column three. The proportion of the cost of material used to the gross output also varies considerably. In the chemical trades proper it is fairly lowabout 60 per cent.-but in seed-crushing factories, oil factories, and paint, colour, and varnish factories it is much largel, and in some cases amounts to about 90 per cent. of the gross output. With regard to the chemical trades, an interesting table, which compares the production and exports of certain sorts of chemicals, is given in the report. From it we learn that in 1907 (ireat Britain produced $1,437,000$ cwt. of aluminous sulphates (including alum), of which $192,000 \mathrm{cwt}$. were exported. In the same year we produced 2,181,000 cwt. of bleaching powder, of which 1,078,000 cwt. were exported, while our net imports amounted only to $176,000 \mathrm{cwt}$. In the case of coal-tar dyes, on the other hand, we exported 51,000 cwt. out of a total production of $139,000 \mathrm{cwt}$., but imported $322,000 \mathrm{cwt}$, which is considerably more than double 
our home production. It is possible that in the course of a few years the patent law of 1907 will cause a very different result in this industry, which has hitherto been almost a German monopoly. Exports of soda compounds (except chromates, cyanides, borax, and soda), leading products of the competing alkali manufacturers Brunner, Mond, \& Co. and the United Alkali Company, are also quoted. In 1907 we produced $13,631,000 \mathrm{cwt}$., of which 5,704,000 cwt. were exported, while our imports amounted to the insignificant total of $340,000 \mathrm{cwt}$.

If we turn to the records of our foreign trade in chemicals, we find that the various statistical abstracts of the United Kingdom enable us, so far as the export records are concerned, to give tables covering a period of forty years. In doing so, we shall divide into seven sections the products at present classed by the Board of Trade under the head of manufactured "chemicals, drugs, dyes, and colours." Of these seven, two have shown so serious a decline that the exports are now much smaller than they were forty years ago, and another has shown no material progress for the past twenty years.

These three sections may be considered first, and they are as follows :-

Average Exports of Manufactured Chemicals

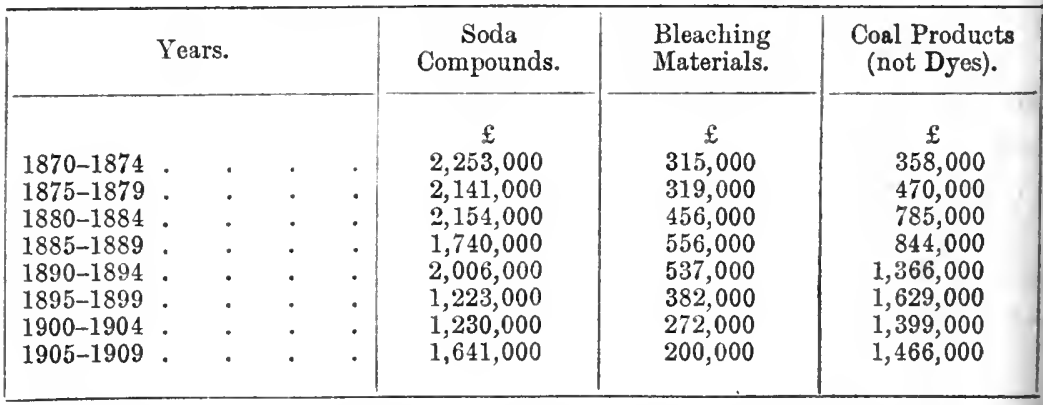

As regards soda compounds (which were formerly entered as "alkali"), the comparison might have been carried back another fifteen years. The average exports for $1855-59$ were $£ 720,000$; for $1860-64, £ 848,000$; for $1865-69, £ 1,448,000$; and for $1870-74$,

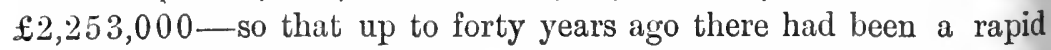
and highly satisfactory growth. The value then began to decline, and though there have been temporary revivals, the value of the exports has never since reached the level achieved in 1870-74. This, of course, is partly, and even largely, due to the fall in prices; for the average quantity exported in $1875-79$ was $1,179,000$ cwt. 
in excess of the average quantity for $1870-74$, and the succeeding five years (1880-84) showed a continued rise amounting to a further $1,159,000 \mathrm{cwt}$. In other words, we exported in $1870-74,4,450,000$ cwt. of soda compounds for $£ 2,253,000$, and in 1880-84 we exported $6,788,000$ cwt. for $£ 2,154,000$.

But it is to be noted that since $1880-84$, when the exports were $6,788,000 \mathrm{cwt}$., there was a fall in every quinquennium down to $1900-4$, when the average exports were only $4,137,000$ cwt. In the last period, 1905-9, there was a substantial increase to $5,178,000$ cwt., but even this is about a million cwt. lower than the average quantity for the fifteen years 1880-1894.

Much the same may be said about the next column-bleaching materials. Here the average exports of $544,000 \mathrm{cwt}$. in $1870-74$ brought about the same price as the average exports of $1,003,000$ cwt. in 1875-79. There was a further rise in the next five years to $1,572,000$ cwt., but since that time there has been a steady decline in every quinquennium, so that the exports for 1905-9 averaged ouly $943,000 \mathrm{cwt}$.-or $629,000 \mathrm{cwt}$. below the high-water mark of 1880-84. As regards the third column ("coal products, not dyes "), it is not possible to give any indication as to quantities, but the table shows that, so far as values are concerned, there has been no material improvement in the past twenty years.

The next sections to be dealt with give the following results:Average Exports of Manufactured Chemicals

\begin{tabular}{|c|c|c|c|c|c|c|}
\hline \multicolumn{4}{|c|}{ Years. } & $\begin{array}{c}\text { Fertilizers. } \\
\frac{£}{586,000}\end{array}$ & $\frac{\text { Medicines. }}{\mathfrak{f}}$ & $\begin{array}{l}\begin{array}{c}\text { Painters' Colours } \\
\text { and Materials. }\end{array} \\
\frac{£}{1,036,000}\end{array}$ \\
\hline $\begin{array}{l}1870-1874 \\
1875-1879 \\
1880-1884 \\
1885-1889 \\
1890-1894 \\
1895-1899 \\
1900-1904 \\
1905-1909\end{array}$ & $\begin{array}{l}\text { : } \\
\text { : } \\
\text { : } \\
\text { : }\end{array}$ & $\begin{array}{l}\dot{ } \\
: \\
\text { : } \\
\text {. }\end{array}$ & $\begin{array}{l}\dot{5} \\
\dot{5} \\
\dot{5}\end{array}$ & $\begin{array}{r}£ \\
586,000 \\
891,000 \\
1,851,000 \\
1,776,000 \\
2,192,000 \\
2,065,000 \\
2,681,000 \\
3,885,000\end{array}$ & $\begin{array}{r}\mathcal{f} \\
681,000 \\
719,000 \\
901,000 \\
886,000 \\
1,009000 \\
1,113,000 \\
1,353,000 \\
1,602,000\end{array}$ & $\begin{array}{c}£ \\
1,036,000 \\
1,130,000 \\
1,256,000 \\
1,369,000 \\
1,505,000 \\
1,667,000 \\
2,021,000 \\
2,373,000\end{array}$ \\
\hline
\end{tabular}

Here is a much more satisfactory record, especially in the case of fertilizers. In this section the best progress during the last fifteen years has been shown in the export of sulphate of ammonia. In 1895-99 the exports of $£ 2,065,000$ were made up of $£ 1,263,000$

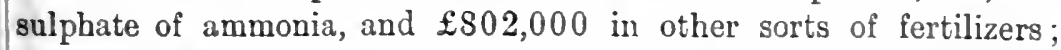

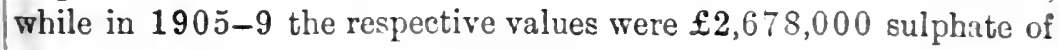
ammonia and $£ 1,207,000$ other sorts of fertilizers. During this period 
the growth in exports was more than a 100 per cent. for sulphate and about 50 per cent. for other sorts of fertilizers. Part of the improvement in sulphate of ammonia is due to a rise in price, but nevertheless the quantity shipped went up from 134,271 tons in 1895-99 to 224,058 tons in $1905-9$; and in the same period shipments of other sorts of fertilizers grew from 260,676 tons to 410,880 tons.

The export of medicines shows a moderate but very steady improvement over the forty years. In this case there are no records of quantities.

In painters' colours and materials the growth has also been very steady, an increase being shown in every one of the quinquennial periods. Records of the quantities of these goods have only been kept for the past seven years, but during this period an increase has been shown in nearly every year. The quantity exported was $1,707,000$ cwt. in $1903,1,677,000$ cwt. in $1904,1,787,000$ cwt. in $1905,1,949,000$ cwt. in $1906,1,994,000 \mathrm{cwt}$. in 1907 , $1,991,000 \mathrm{cwt}$. in 1908 , and $2,142,000 \mathrm{cwt}$. in 1909. The slight drop in 1908 (when our general trade suffered so heavily) and the substantial increase shown in 1909 over 1908 and 1907 must both be regarded as highly satisfactory to this branch of the trade.

There now remains only one section, that of miscellaneous chemical exports, and to this we add a column giving the total exports of all chemical manufactures:-

Average Exports of Manufactured Chemicals

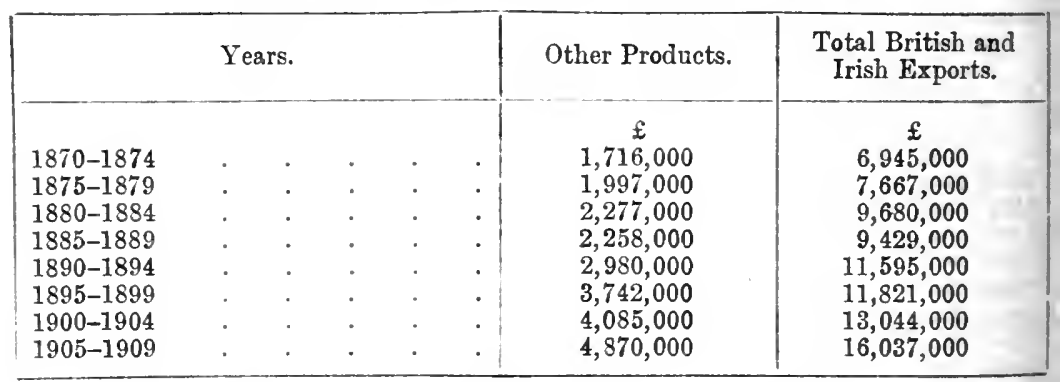

The column of "other products" includes dye stuffs, sulphate of copper, and saltpetre. The exports of dye stuffs, products of coal

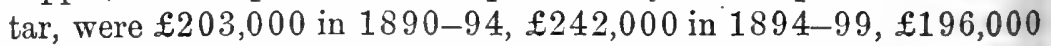
in 1900-4, and $£ 176,000$ in $1905-9$; while exports of dye stuffs of other sorts were $£ 270,000$ in $1890-94, £ 218,000$ in 1905-9, $£ 136,000$ in $1900-4$, and $£ 161,000$ in $1905-9$. It is impossible to say how the quantities of these exports have fluctuated. In sulphate of copper the exports have increased in value from 


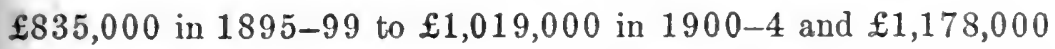
in $1905-9$; the respective quantities being 48,793 tons, 49,187 tons, and 52,060 tons. Saltpetre (British prepared) exports were 28,432

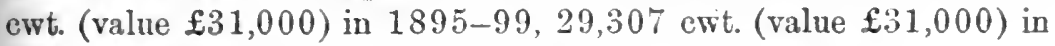

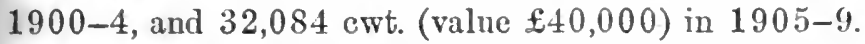

From the second column in the last table it will be seen that British progress in the exportation of chemicals, drugs, dyes, and colours, taken as a whole, has not been altogether unsatisfactory. During the past forty years we have increased these exports from $\mathfrak{£ , 9 4 5 , 0 0 0}$ per annum to $£ 16,037,000$ per annum. In that period the mean population has risen from about thirty-two to fortyfour millions, so that the growth of exports has done much more than keep pace with the growth of population. To be exact, the exports in 1870-74 were 4s. 4d. per capita, and in 1905-9 $7 \mathrm{~s} .4 \mathrm{~d}$. per capita. This, of course, is much less than the progress shown in some of our other industries, but there are indications justifying a more hopeful outlook for the near future. It should not be forgotten that after the boom of 1907 , when our exports of steel and iron goods fell by $£ 9,000,000$, other metals by nearly $\mathfrak{£} 3,000,000$, cotton manufactures by nearly $£ 14,000,000$, and woollen by nearly $\mathfrak{£} 6,000,000$, chemical exports fell off less than $\mathfrak{£ 1 , 0 0 0 , 0 0 0}$, and in 1909 they had again risen to within $\mathfrak{£ 2 4 6 , 0 0 0}$ of the high level reached in 1907.

It may be interesting to compare the exports with the net imports for the past fifteen years-it is not possible to do so accurately over a more extended period:-

Exports and Net Imports of Manufactured Chemicals, etc.

\begin{tabular}{|c|c|c|c|}
\hline 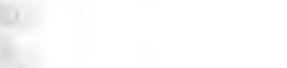 & $1895-1899$. & $1900-1904$. & $1905-1909$. \\
\hline $\begin{array}{l}\text { Exports } \\
\text { Net imports* : }\end{array}$ & $\begin{array}{r}\stackrel{f}{1} \\
11,821,000 \\
6,260,000\end{array}$ & $\begin{array}{r}f \\
13,044,000 \\
7,211,000\end{array}$ & $\begin{array}{r}£ \\
16,037,000 \\
8,796,000\end{array}$ \\
\hline Excess of exports & $5,561,000$ & $5,833,000$ & $7,241,000$ \\
\hline
\end{tabular}

- Imports less re-exports.

In this connexion it may be remarked that last year, when our exports were only $£ 246,000$ lower than in $190 \%$, the net imports

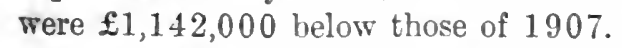

Unquestionably the chemical industry presents indications that it has recently entered upon a period of renewed vigour.

The chemical trades are chiefly situated in Lancashire and 
Cheshire. Chester, St. Helens, Northwich and Widnes are all concerned largely in chemical manufacture. Widnes in 1849 contained only from three to four thousand inhabitants, yet in 1861 the population had risen to 6905 and in 1881 to 24,905 . Some idea of the earlier growth of the alkali trade in Lancashire is given by the following table, which has been extracted from $\mathrm{Mr}$. Feuwick Allen's book referred to previously :-

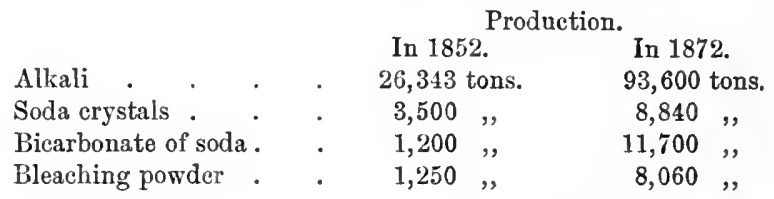

At first chemical manufacturers, when their plants were in a crude state, met with strong and very natural opposition from persons resident near their works. According to Mr. Allen, "the works at Widnes increased so rapidly, the amount of uncondensed vapour was so large, and the volume of smoke so dense, that notwithstanding the long stretch of river over which the vapours were carried by the westerly winds, which are the winds during which the principal damage is done, the plantations, and even the farm lands on the Runcorn side toward Norton Priory, received very great injury. Sir Richard Brooke moved in the matter, and in the other manufacturing districts found many who sympathized with his complaints. A Royal Commission was appointed, and the Alkali Act of 1863 was the result."

The manufacture of chemical manure is an important branch of the chemical trades. The famous Liebig was largely instrumental in the foundation of this branch of the industry. Mr. Allen writes: "When Liebig was making his researches and working out his theories in agricultural chemistry, and when he thought he had discovered the secret of the refertilization of the soil, the principal thing being to restore to the soil, as manure, the inorganic constituents which it was found by the analysis of the ashes of the vegetation had been taken out of the soil by the plant, he got James Muspratt to carry out his ideas by manufacturing certain manures. This manufacture was carried on at Newton, about the years 1843-1844."

The nature of chemical production lends itself to combination among producers, and the history of the chemical trades during the last twenty-five years of the nineteenth century is largely one of the formation of combines. In the alkali trade the great combine is the United Alkali Company. Mr. H. W. Macrosty in his book 
on The Trust Movement in British Industry ascribes the origin of this company to over-competition and unsuccessful attempts to reconcile conflicting interests. "In the autumn of 1890 ," he writes, "the company was registered and orders for chemicals were placed in abundance for 1891 at the uuion prices, which were on the basis of the average of the preceding six years, that is, the old combination prices. Forty-eight firms were included, of which three were salt makers-fourteen were situated at Widnes, nine at St. Helens, niue on Tyneside, four in Scotland, three in Ireland, three at Runcorn, two in Flint, and one at Bristol; the salt works were two at Port Clarence and one at Flectwood." Another great and continuously prosperous alkali manufacturing firm, outside the United Alkali Company, is Messrs. Brunner, Mond \& Co., of Winnington and Northwich, which manufactures alkali by the ammonia process and not by the Leblanc.

Other branches of the chemical trades have had their combines. In the borcx trade the Borax Consnlidated is the largest. Mr. Macrosty writes: "Borax Consolidated was formed in January 1899 to put an end to competition which had reduced prices 50 per cent." In the dye trades the principal combines are The British Dyewoods \& Chemical Co., The United Indigo Co. (of Manchester), and The Yorkshire Dyeware and Chemical Co. In the manufacture of explosives the Nobel Dynamite Trust, Messrs. Curtis \& Harvey, and Messrs. Kynoch are perhaps the biggest. It should be added that British combines have often been floated for financial purposes and frequently to the detriment both of consumers and investors.

\section{SOAP}

Another great industry which is closely allied to, if not a part of, the chemical trades is the manufacture of soap. Although, of course, it was not made in anything like the scale it is nowadays, soap was manufactured largely during the first half of the nineteenth century. Porter gives the following interesting account of the manufacture of soap in those days:-

"The consumption of soap is in some deyree dependent on the growth of manufactures, since it is extensively employed in many processes, and in this country is increasingly so employed; the actual consumption for personal and household purposes cannot therefore be accurately known witlout first ascertaining the quantity otherwise disposed of, no particular statement of which has been given in any parliamentary papers. An allowance is made for the duty on soap used in the silk, woollen, cotton and linen manufactures; but these do not comprise the whole of the manufacturing processes into which soap enters. It is, besides, impossible to make any true estimate of the quantity used generally, 
because of the intervention of the contraband maker. It is known that frauds upon the revenue are thus committed to a great extent, not so much perhaps as was done before the reduction of the duty in 1833; but the degree in which that reduction was calculated to affect the fraudulent maker by reducing his profits, has been since in part countervailed by simplifications in the process, which have lessened at once the expenses of the manufacture and the chances of detection. That frauds to a great extent are committed by the surreptitious production of soap, may be believed from the fact, that there are fifty persons in England who each take out an annual licence, the charge for which is \&4, and who do not pay duty to the excise on a greater quantity than one ton in the course of the year, leaving room for suspicion that the licence is used as a cover for fraudulent processes. There are besides great numbers of persons who make soap secretly, and without taking out any licence, and who consequently pay no duty whatever. The manufacture can be successfully carried on in any cellar or small room, with very inartificial apparatus; and, so long as the rate of the duty offers any temptation, it is much to be feared that there will always be persons in whom the desire of gain will be strong enough to lead them to engage in such secret manufacture. ${ }^{1}$

". . . The excise regulations, which it may be presumed are necessary for the protection of the revenue, so entirely prevent improvement in the processes, that the quality of soap made in foreign countries, where no such regulations are imposed, is invariably superior to that of English soap, and, unless to our own colonies and dependencies, we cannot be said to have any export demand for British-made soap. We pay an import duty on the chief ingredient used in the manufacture, which is not returned on that part which is exported, and our duties are so regulated that our manufacturers are in a great degree restricted to the employment of a material which is not calculated to produce soap of the finest quality. The manufacturers of Marseilles use almost exclusively vegetable oil, while ours are chiefly restricted to the use of tallow, which produces an article so inferor in quality that the preference is given in foreign countries to almost any soap over that made in this kingdom; and this is especially the case where the article is used in manufacturing processes.

"After these remarks it will be understood that the following statement regarding the use of soap is not to be taken as correct, although it is as much so as public documents will admit.

\begin{tabular}{|c|c|c|c|c|c|}
\hline Year. & $\begin{array}{l}\text { Number of } \\
\text { Pounds of Soap } \\
\text { Consumed. }\end{array}$ & Rate of Duty. & Quantity. & $\begin{array}{l}\text { Amount of } \\
\text { Duty } \\
\text { Contributed } \\
\text { per Head. }\end{array}$ & $\begin{array}{l}\text { Number of } \\
\text { Licensed } \\
\text { Makers. }\end{array}$ \\
\hline 1801 & $52,947,037$ & $\begin{cases}21 \mathrm{~d} . & \text { per lb. hard } \\
13 \mathrm{~d} d . & \text { soft }\end{cases}$ & $\begin{array}{l}\text { lb. } \\
4 \cdot 84\end{array}$ & $\begin{array}{l}\text { s. d. } \\
0 \text { 11 }\end{array}$ & 624 \\
\hline 1811 & $73,527,760$ & Ditto." & $5 \cdot 83$ & $11 \frac{1}{4}$ & 522 \\
\hline 1821 & $92,941,326$ & $\left\{\begin{array}{l}3 d . \text { per lb. hard } \\
13 \text { d. }\end{array}\right.$ & $6 \cdot 43$ & $1 \quad 7 \frac{1}{4}$ & 363 \\
\hline 1831 & $103,121,577$ & Ditto." & $6 \cdot 23$ & $16 \frac{3}{4}$ & 532 \\
\hline 1841 & $170,280,641$ & $\left\{\begin{array}{l}1 \frac{1}{\mathrm{~d}} \mathrm{~d} . \text { per lb. hard } \\
1 \mathrm{~d} .\end{array}\right.$ & $9 \cdot 20$ & $11 \frac{3}{5}$ & 344 \\
\hline 1845 & $190,187,163$ & Ditto." . & $9 \cdot 65$ & $12 \frac{3}{4}$ & 356 \\
\hline
\end{tabular}

${ }^{1}$ The excise duty on soap was not levied in Ireland. 
"The progressive decrease in the number of licensed makers, until they are now little more than one-half as many as in 1801 , is a very remarkable circumstance, and one for which it is difficult to assign a sufficient reason."

The excise duty, to which Porter refers, was removed in 1853. According to Mr. A. H. Scott, an authority on the soap industry, the quantities of soap manufactured and the amounts collected during the three years preceding the abolition of the duty were as follows :-

Soap Charged with Excise Duty, 1850-1852

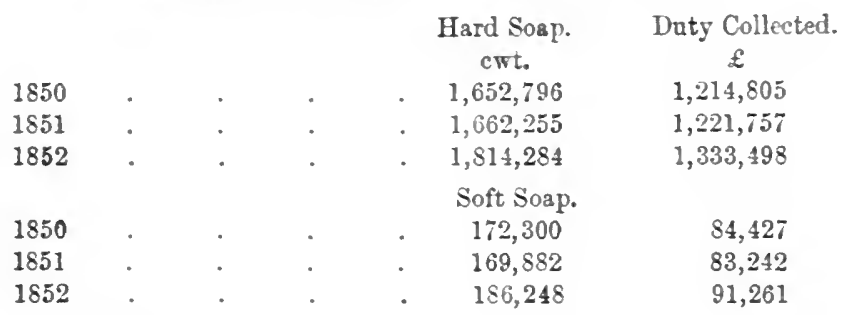

Mr. Scott adds: "The Board of Trade returns during the same period do not show the export of soap separately, but include candles as well. It is safe to assume that at least two-fifths of the quantities exported consisted of candles at that time. From the date of the abolition of the excise duty the returns are given for soap only, whilst up to the end of 1852 soap and candles are recorded together. The following set of figures represent the Board of Trade returns compiled in periods of ten years each, and show quantities and values exported from 1833 to 1902 inclusive, the figures up to 1852 being for soap and candles combined:-

\section{Exports of Soap and Candles, 1833-1852}

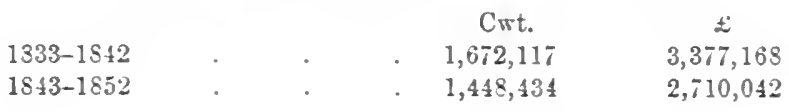

Exports of Soap Only, 1853-1910

$1853-1862$

$1863-1572$

$1873-185 \%$

$1883-1892$

1893-1902

1903-1910

\section{Cwt.}

$1,874,467$

$1,831,157$

$3,052,265$

$4,704,554$

7,977,595

$9,527,977$
$£^{2}$

$2,482,349$

$2,435,770$

$3,044,36 \bar{i}$

$5,040,1 \times 6$

$8,366,259$

$11,024,500$

"On the face of them these figures appear as if the weights and the cash value were disproportionate. But it must be remembered

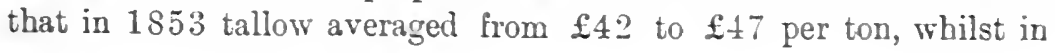


recent years the value came down to average from $£ 20$ to $£ 30$ per ton, and in 1897 touched the lowest price, namely, below $£ 20$ per ton. Other raw materials used in the manufacture of soap also became cheaper in proportion, and as a consequence the sale price of soap fell."

Taking the Board of Trade returns for the year 1852, we find that $1,814,284 \mathrm{cwt}$. of hard soap was manufactured in the United Kingdom, out of which 65,000 cwt. was exported, leaving for home consumption 1,750,284 cwt. which was consumed by an aggregate population of, roughly speaking, $28,000,000$ people.

Assuming for the sake of comparison that no greater consumption per capita has since taken place, the manufacture of soap for home consumption for the last three census years should stand as follows:-

\begin{tabular}{|c|c|c|c|c|c|}
\hline 1888 & . & . & . & $\begin{array}{r}\text { Population. } \\
36,000,000\end{array}$ & $\begin{array}{c}\text { Quantity. } \\
2,257,560 \mathrm{cwt} \text {. }\end{array}$ \\
\hline 1890 & - & . & . & $38,000,000$ & $2,413,380$, \\
\hline 1902 & . & . & . & $42,000,000$ & $2,643,820$ \\
\hline
\end{tabular}

Or taking the year 1902 , the soap manufactured for home consumption and export in this onc year only shows:-

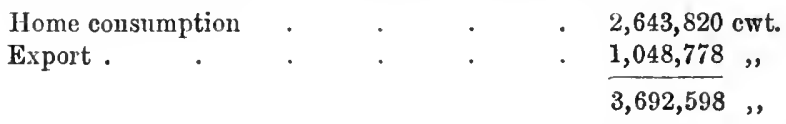

which is equal to the exports of soap from 1833 to 1855 , including candles, namely, for a period of twenty years.

The amount of soap and soap-stock imported into the United Kingdom is only a small percentage of the total amount consumed. Our imports for the last few years were as follow:-1905, $£ 500,430$; 1906 , £522,169; 1907, £632,720; 1908, £536,449; 1909,

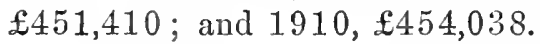

In 1902 the soap manufactured for home consumption in the United Kingdom was estimated at about 2,600,000 cwt., and the Board of Trade returns for the same year show exports of 874,214 cwt., making a total of $3,474,214$ cwt.

Hence the imports during 1900 of $191,233 \mathrm{cwt}$. are only equal to $7 \frac{1}{3}$ per cent. of the soap manufactured in the United Kingdom or to 22 per cent. of the soap exported from the United Kingdom. The size of our soap trades, according to the Census of Production, will be found in a previous table on page 415 . 


\section{CHAPTER XXIII}

\section{TIMBER, AND THE BUILDING TRADE}

Imported timber-Amounts in difierent years-Sources of supply-Census of Production figures-The building trade-Its importance-Peculiar conditions determining it-Unemployment in-The supl'y of labour-Ferro-concrete-By-laws

A MONG raw materials other than food, timber and coal are perhaps the most indispensable. As Porter remarks: "The use, at different epochs, of timber, an article of such general application, exhibits forcibly the comparative progress and industry of a people. The quantity of 'timber eight inches square and upwards,' of colonial and foreign growth, used in the United Kingdom between 1801 and 1845 , was-

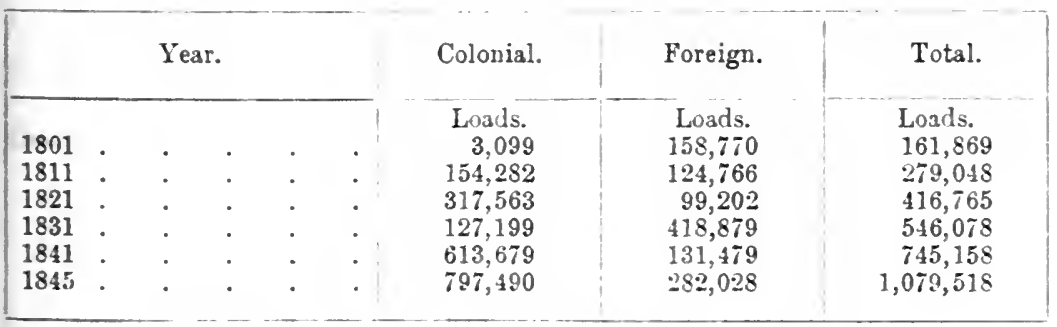

These quantities are exclusive of all kinds except square timber: It would be useless to bring forward the like statements with regard to all the forms under which wood is imported, such as deals, battens, and staves, the quantities of which will most probably vary nearly in the same proportions as timber.

"It results from these figures that the increase has been-

Between 1801 and 1811, i2 \{ $\left.\begin{array}{l}\text { per cent., the increase of } \\ \text { population having been }\end{array}\right\} 13 \frac{1}{2}$ per cent.

\begin{tabular}{|c|c|c|c|}
\hline 1811 and $18: 21,49$ & :" & , & $11+$ \\
\hline 1821 and 1831,31 & & " & $1: 3$ \\
\hline 1831 and 1541,36 & ,, & , & $13 \frac{1}{2}$ \\
\hline
\end{tabular}

Comparing 1801 with 1841 , it will be seen, that while the increase of the population is $64 \frac{1}{2}$ per cent., the use of imported timber has increased 360 per cent. The great increase, beyond that 
of all former years, in the consumption of 1845 , is evidently the result of diminished duties in concurrence with a period of great and general prosperity."

Since the year 1845 , as Table II shows, the importation of

TABLE II.-Imports (in quantities)

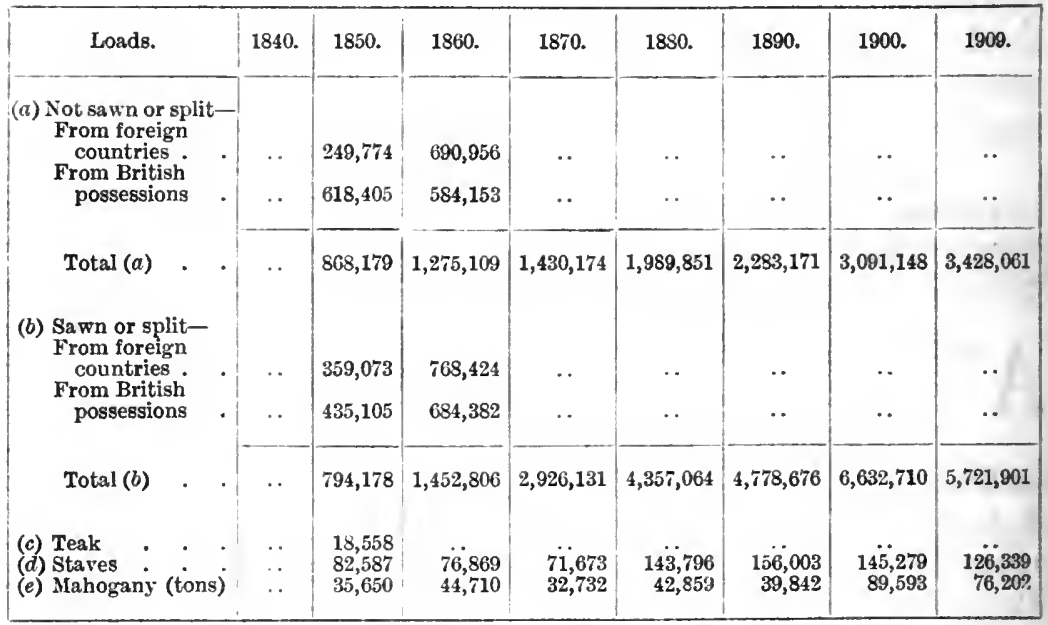

timber has gone on steadily increasing. Table III shows the different classes into which imported woods, and other raw materials

TABLE III.-Quantity and Value of Imported Timber and other Materials employed in the Building Trade

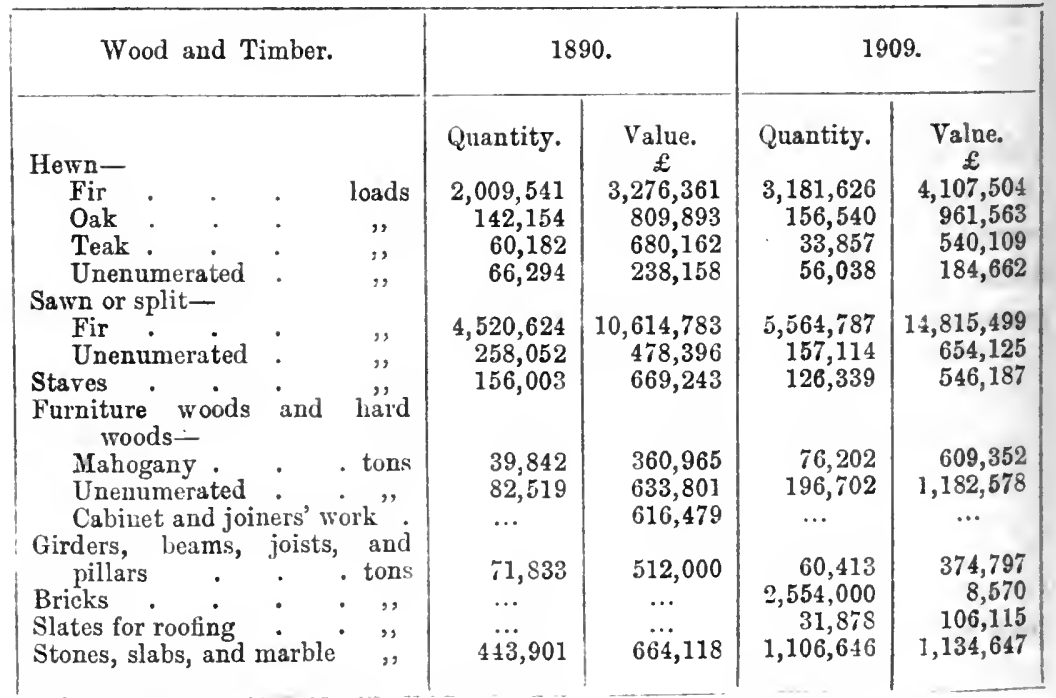


employed in construction, fall, and also indicates the rise in the value of wood which is naturally to be looked for with the steady increase in the world demand. Scientific forestry has cnly recently been applied in any country with the exception of France: in many there has been a reckless destruction of supplies of which the effect is likely to be reflected in steadily rising prices.

Sources of Supply.-Table IV shows the different sources of our supply in each decade from 1870-1900. In 1902 no less than on $\theta$-sixth of our total importation came from Canada, which sent us 78,000 loads (hewn) and 1,639,000 loads (sawn). The decline in our imports from the States, on the other hand, is noticeable. Sweden, Russia, and Canada now send us most.

TaBLE IV.-(1) Heion Fir Timber (in loads)

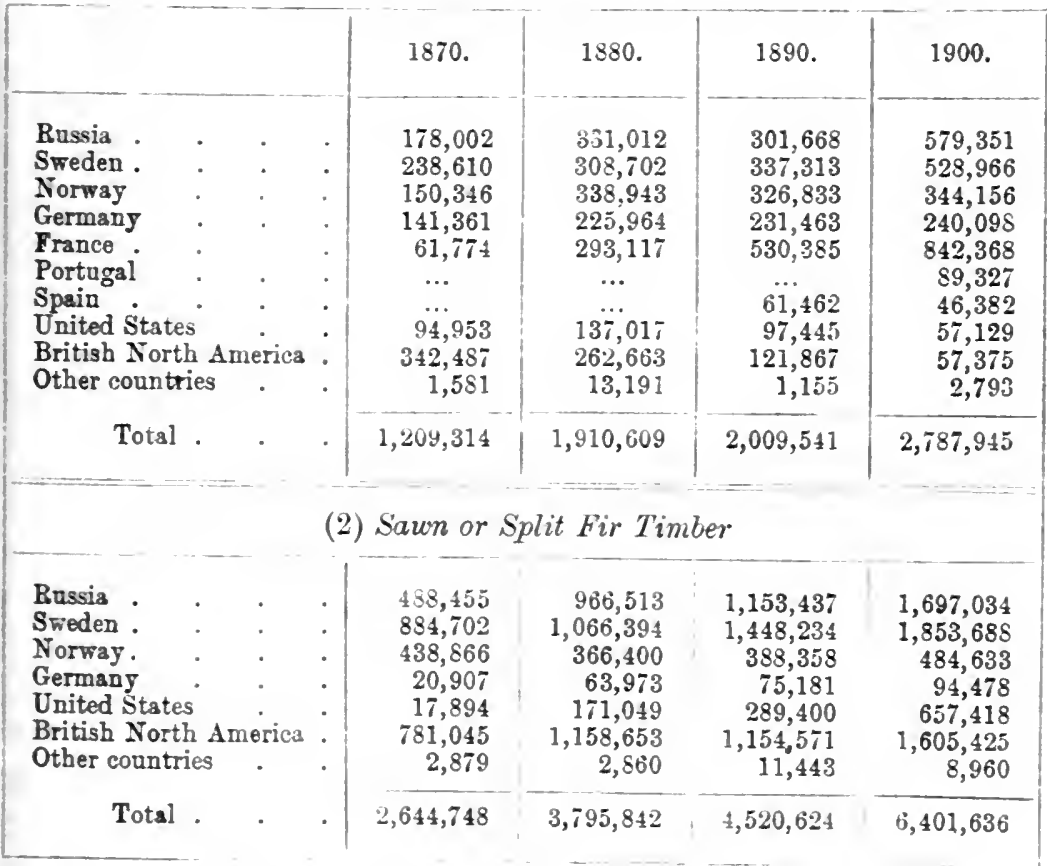

At any time we have in this country a supply of soft wood that varies between a maximum sufficient for six month' needs, and a minimum sufficient for one month and three-quarters.

Soft and Hurd Woods. - Timber, it should be pointed out, falls into two elasses-soft and hard wood. Soft wood (which is far the more important in point of quantity) is employed for all constructive and building purposes: hard wood for cabinet-making, 
the fittings of ships, etc. It was also formerly used in shipbuilding, but has now of course been superseded. Supplies of soft wood come in between May and November-when the export ports are not frozen, that is to say. Hard wood, which comes from British Honduras (mahogany), Mexico, West Africa, and Burma and Siam (teak), is imported all the year round. In the case of the heavy woods, as long as two years may elapse between their felling in the forest and arrival at the sawmills.

As an illustration of the rise in price, it was given in evidence before the Commission on Wood Supplies that Swedish standard deals which cost $£ 9$ ten years before, cost $£ 1210$ s. in 1902 .

The Census of Production gives the following information about the timber trade and some similar industries:-

TABLE V

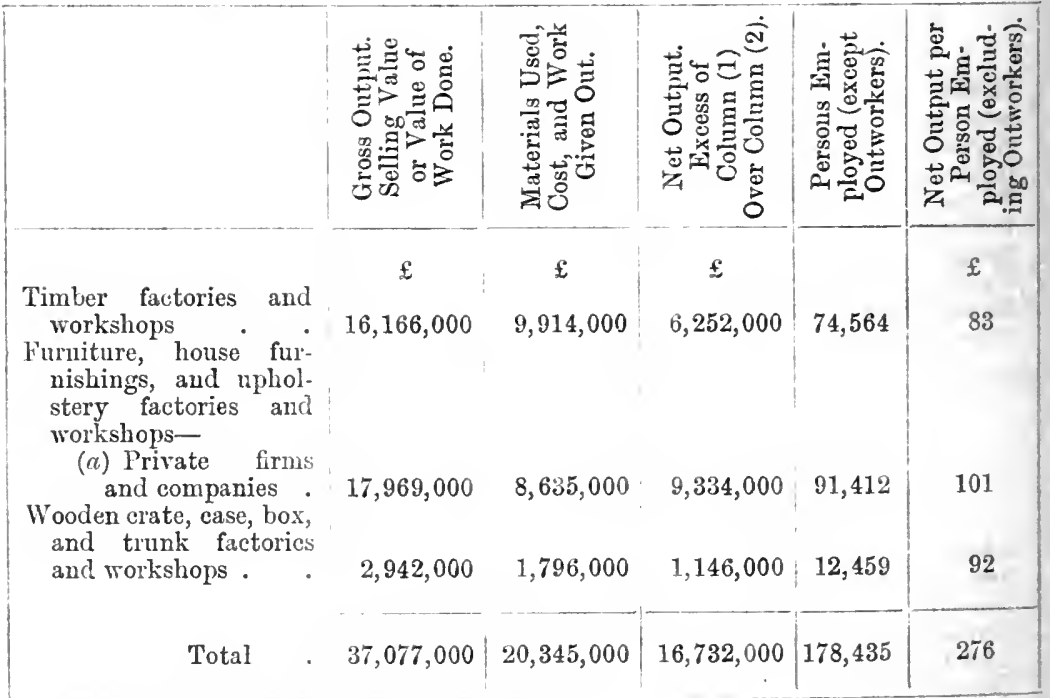

It appear's that 91,412 men were employed in furniture, house furnishing, and upholstering factories and workshops as against 74,564 in the timber trade. The total net output was $£ 9,334,000$ in the former branch as against $£ 6,252,000$ in: the latter, and the output per head was $£ 101$ compared with $\mathfrak{£} 83$ in timber factories and workshops.

The Building Trade.-Timber is chiefly important as raw material for the building trade; but in arguing from statistics referring to either as to the level of prosperity it must be remembered that, as was put in evidence before the Labour Commission by a 
representative of the building trade: "We are the last to feel the effects of a depression, and the last to feel the effects of revival: always the last." In fact, "the trade is dependent on general prosperity : it will therefore be found that an increase or decrease of employment in this trade follows rather than coincides with a similar movement in the general average." (Public Health and Social Conditions, Cd. 4671.)

Statistics of the Trade.-Adequate material for comparing the conditions of the trade now with those prevailing half a century ago, do not exist: but the following table (Table VI) shows (1) the number of inhabited houses at each census year and the rate of increase since 1851 ; (2) the numbers employed in the trade in the same periods.

\section{TABLE VI.-The Building Traile}

\begin{tabular}{|c|c|c|c|c|c|}
\hline $\begin{array}{l}\text { Census } \\
\text { Year. }\end{array}$ & $\begin{array}{c}\text { Number of } \\
\text { Males } \\
\text { Employed } \\
\text { in } \\
\text { Building } \\
\text { Trade. }\end{array}$ & $\begin{array}{l}\text { Number of } \\
\text { Inhabited } \\
\text { Houses. }\end{array}$ & $\begin{array}{l}\text { Number of } \\
\text { Houses } \\
\text { Building. }\end{array}$ & $\begin{array}{l}\text { Number of } \\
\text { Uninbabited } \\
\text { Houses. }\end{array}$ & $\begin{array}{l}\text { Increase } \\
\text { per cent. in } \\
\text { Number of } \\
\text { Buildings } \\
\text { Constructed } \\
\text { or under } \\
\text { Construction }\end{array}$ \\
\hline $\begin{array}{l}1801 \\
1811 \\
1821 \\
1831 \\
1841 \\
1851 \\
1861 \\
1871 \\
1881 \\
1891 \\
1901\end{array}$ & $\begin{array}{c}\ldots \\
\ldots \\
\ldots \\
\ldots \\
463,491 \\
472,103 \\
581,903 \\
685,112 \\
698,839 \\
952,093\end{array}$ & $\begin{array}{l}1,575,923 \\
1,797,504 \\
2,088,156 \\
2,481,544 \\
2,943,945 \\
3,278,039 \\
3,739,505 \\
4,259,117 \\
4,831,519 \\
5,451,497 \\
6,260,852\end{array}$ & $\begin{array}{l}16,207 \\
19,274 \\
24,759 \\
27,444 \\
26,571 \\
27,305 \\
37,803 \\
46,414 \\
38,387 \\
61,909\end{array}$ & $\begin{array}{r}57,476 \\
51,020 \\
69,707 \\
119,915 \\
173,247 \\
153,494 \\
184,694 \\
261,345 \\
386,676 \\
372,184 \\
448,982\end{array}$ & $\begin{array}{c}\ldots \\
\ldots \\
\ldots \\
\ldots \\
10 \cdot 0 \\
14 \cdot 3 \\
15 \cdot 4 \\
15 \cdot 5 \\
11 \cdot 3 \\
15 \cdot 5\end{array}$ \\
\hline
\end{tabular}

The building trade and works of construction, together with the allied trades grouped under the general term, is numerically among the largest occupations. In 1901 it employed 1,042,864 males, i.e. $8 \cdot 6$ per cent. of the male population of England and Wales above the age of ten.

Conditions of the Trade.-It is at once the most widespread and the least localized of occupations. Generally speaking it is true, as Mr. Charles Booth has observed, that the building trade is "the most conspicuous example of a great industry carried on in almost complete dependence on a local demand." Owing to the increased cost of raw materials and of labour in London, a large amount of London work is now sent up from the provinces: 
stone-work, for example, and joinery is largely done in the provinces at provincial rates. At the same time, no less than one-fourth of the whole population engaged in the trade is returned as belonging to Greater London. While the building trade contributed a fifth of all the cases of unemployment investigated by Distress Committees, between 50 and 75 per cent. of the unemployed who applied between 1905-1908 in Greater London registered themselves as builders.

Unemployment in the Trade.-The building trade is not only the most widespread of occupations; it is the one which expands most rapidly in good times, when it attracts great numbers of general and casual labourers. Here, no doubt, lies part of the explanation of the high rate of unemployment from which the trade suffers. Apart from the effect of cyclical fluctuations affecting all trades, and which, as has been seen, reach the building trade late and hold it long, it is at all times highly seasonal in its character. In June and July it is slack; in November, December, January and February there is little doing. In the winter, weather prevents outdoor work, and then, as in the height of the summer season, there is little renovating, painting, etc., to be done. Spring and autumn, on the other hand, see great activity. At these busy times the contractors employ a very much larger number of men, casually engaged, than can be maintained throughout the year; and a considerable proportion of these men are not in any sense skilled builders, painters, plumbers, or whatever the branch may be.

The Supply of Labour.-They are merely labourers: and the supply of such men is in excess of the demand except at times of rush. Again, "the artisan in the building trade is faced by the fact that the old apprenticeship system" (by which a supply of skilled men was ensured) "is disappearing, and nothing has arisen to replace it." Moreover, the whole conditions of the trade are in process of transformation by the increasing substitution of ferro-concrete for stone-work.

Ferro-concrete.- "Fifty years ago flitched plates, and not long afterwards pollard iron joists, began to be used, replacing the old timber edifices. Then about twenty years since, Bessemer steel, in the form both of stanchions and girders, began to come in, followed not long afterwards by the use of coke-brize and other forms of concrete. The danger of the use of iron by itself in building construction, owing to its liability to warp in great heat, is not experienced where the steel, as in the new process, is encased in concrete, and the two together are considered to have 
greater resisting power than even brick or stone".... (see Dearle. Problems of Unemployment: The London Building Trade). The power of resistance is, of course, extremely important in the case of large buildings; and it is to them that the new process, which is making rapid strides, has mainly been applied. Ferroconcrete is fire-proof: it is still a question whether it is permanently damp-proof.

By-laws.-At present a special licence is needed before it can be applied to walls in London: and in general, in London and districts where the model by-laws (based upon the London Building Act of 1907) are in force, regulations as to materials, thickness of walls, etc., at present much impede the use of the new forms. Building in England generally is regulated solely by local enactment: and none of these regulations go so far in the positive direction as those which regulate sanitary fittings in New York or provision for protection against fire in France. 


\section{FOOD SUPPLIES AND CONSUMPTION}

Statistics of consumption-Changes in 50 years : $(a)$ Conditions governing our food supply; (b) Variety; (c) Standard of consumption-Working-class budgets-Certain staple foods-Wheat--Other cereals-Meat-Fish-Poultry-Dairy Produce-Groceries -Tea-Coffee-Sugar-Cocoa-Confectionery, etc. - Fruit and vegetables

WRITING about 1850 Porter had to point out: "There are no means provided by which the consumption of the prime necessaries of life in this country can be traced at different periods. It is only with respect to those few articles of native production which have been subjected to the payment of duties that any provision has ever been made for ascertaining their quantity; and as the chief articles of food and clothing, when of native production, have never been directly taxed in England, we have always been ignorant in this respect regarding the quantities produced."

Indeed, with regard to consumption in general, there was a complete lack of any statistical material. The compilation of any such returns was opposed by the same irrational prejudice which had been roused, at the close of the preceding century, by proposals for an enumeration of the people. Any estimate of national consumption was impossible, except in the case of dutiable articles; and Porter had, beyond that, to content himself with giving family budgets for certain establishments that had come under his own notice. As he says, and as is clear, "the want of this information has been found greatly inconvenient, both by statesmen and by writers on subjects of social economy, the latter of whom have frequently had recourse to the expedient of computations founded on insufficient data, which have therefore given an unsatisfactory character to their writings."

The issue of the Statistical Abstract in each year since 1840 renders available accurate information as to the food-stuffs imported into this country; and a table can be given showing the amount of that imported food consumed per head of the population (Table I). It is, however, still the case that "there are no 
official statistics dealing with home production." Certain information can be drawn from the report of the Census of Production now being issued; but it is as yet far from complete either as to matter or method. Moreover, in spite of several inquiries recently undertaken, we do not yet possess the budgets for different classes of the population which are needful from the point of view of the social student. But in seeking to estimate the progress of the nation it is possible to formulate certain broad general conclusions with regard to our food.

TABLE I.-Consumption of Imported Food per Head of Population

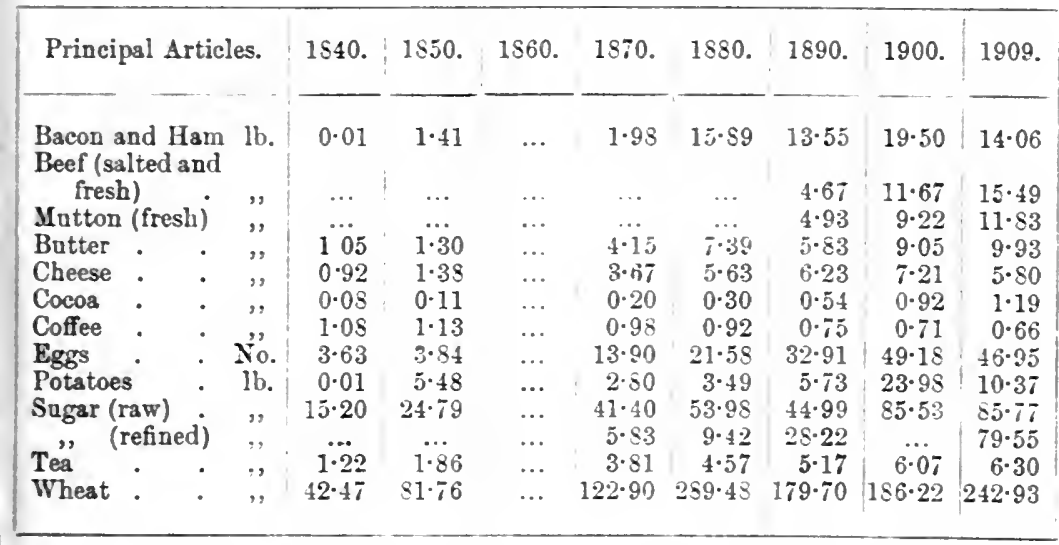

1. Conditions of Food Supply-Porter's survey appeared at a time when the conditions governing our food supply were in process of transformation. England was rapidly establishing her export trade and tending more and more to divert her energies from the production of her own food, for which she was but moderately adapted, to the production of manufactured articles, for which she possessed great differential advantages. This is not the place for any consideration of the effects, whether immediate or remote, of the adoption of a Free Trade policy: but it must be noted as the factor determining the conditions on which the food supply of a small island with a rapidly-growing industrial population depends. A glance at the table of food imports shows that there is hardly a single article of common consumption for which we are not mainly dependent for supplies from abroad (Table II), supplies which now come from every portion of the habitable globe.

2. Variety-Connected with this is another notable fact, the inmense increase in variety in our food. This is again testified by even the most condensed list of our various food imports. 


\begin{tabular}{|c|c|c|c|c|c|c|}
\hline$\stackrel{8}{\stackrel{8}{S}}$ & 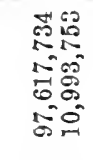 & 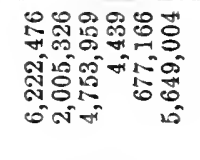 & 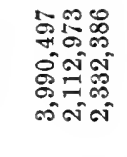 & 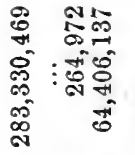 & 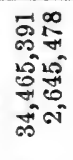 & 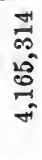 \\
\hline ஓं & 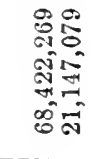 & 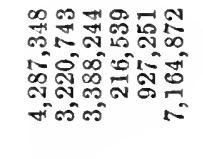 & 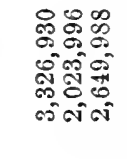 & 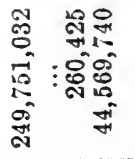 & 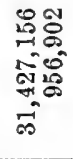 & 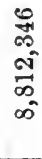 \\
\hline$\underset{\stackrel{\infty}{\sim}}{\stackrel{\dot{D}}{\sim}}$ & 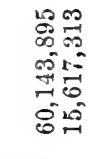 & 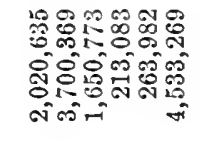 & 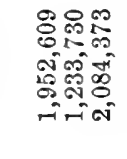 & 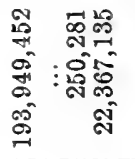 & 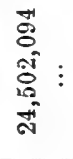 & 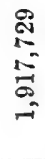 \\
\hline $\begin{array}{l}\dot{8} \\
\text { 心 } \\
\text { - }\end{array}$ & $\vdots \vdots$ & $\vdots \vdots \vdots \vdots \vdots \vdots$ & $\vdots \vdots \vdots$ & $\vdots \vdots \vdots \vdots$ & $\vdots \vdots$ & $\vdots$ \\
\hline$\underset{\substack{\infty \\
\rightarrow}}{\stackrel{0}{\infty}}$ & $\vdots \vdots$ & $\vdots \vdots \vdots \vdots \vdots \vdots$ & $\vdots \vdots \vdots$ & 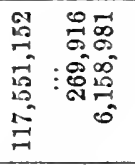 & $\vdots \vdots$ & \\
\hline $\begin{array}{l}\dot{8} \\
\stackrel{D}{2}\end{array}$ & 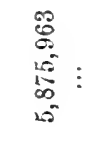 & $\vdots \vdots \vdots \vdots \vdots \vdots$ & $\vdots \vdots \vdots$ & 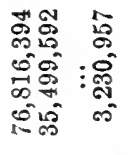 & 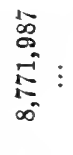 & $\vdots$ \\
\hline $\begin{array}{l}0 \\
10 \\
\infty \\
\infty\end{array}$ & 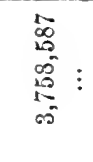 & $\vdots \vdots \vdots \vdots \vdots \vdots$ & $\vdots \vdots \vdots$ & 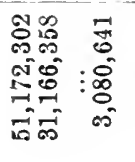 & 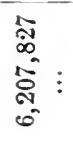 & $\vdots$ \\
\hline 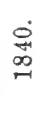 & $\vdots \vdots$ & $\vdots \vdots \vdots \vdots \vdots \vdots$ & $\vdots \vdots \vdots$ & $\vdots \vdots \vdots \vdots$ & $\vdots$ & $\vdots$ \\
\hline & 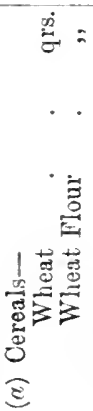 & 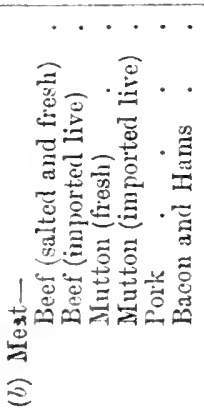 & 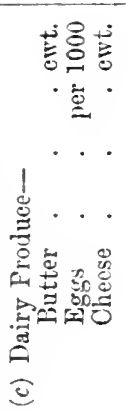 & 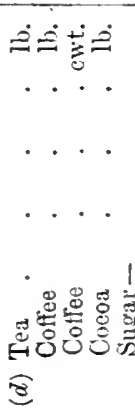 & 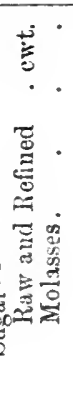 & 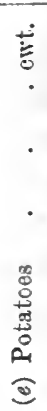 \\
\hline
\end{tabular}


3. Rise in the standard of Consumption.-Moreover, this increase in variety is not confined to any one class. Just as bananas, unknown save at banquets in the 'forties, are to-day' sold from street barrows at a penny or less, so we find the family budget of the ordinary well-to-do artisan in the towns now containing a range of items which only the rich could command in Porter's day. Meat, for example, is now eaten by all classes; even by the poorest at least once a week. Tea, which was rapidly gaining in favour fifty years ago, is now universal; and fruit, confectionery, tinned goods, and a variety of relishes, are used everywhere. Only in the remote agricultural districts does the bread and bacon still survive, which, like oatmeal porridge in Scotland, once formed the staple diet of the poor. Although there yet remains a considerable margin of people who are insufficiently and wrongly fed, the standard of consumption has certainly risen in the last half-century. There is a much wider range of choice in food. Unsuitable food of all kinds does, doubtless, tempt to unwise expenditure; the accessibility of timned salmon and cheap sweets may not be a desirable thing: but good food is cheaper. The importance of this is obvious. The proportion of income that has to be spent on food is larger in the case of the very poor. For incomes below $30 \mathrm{~s}$, a week, two-thirds of the

TABLE III

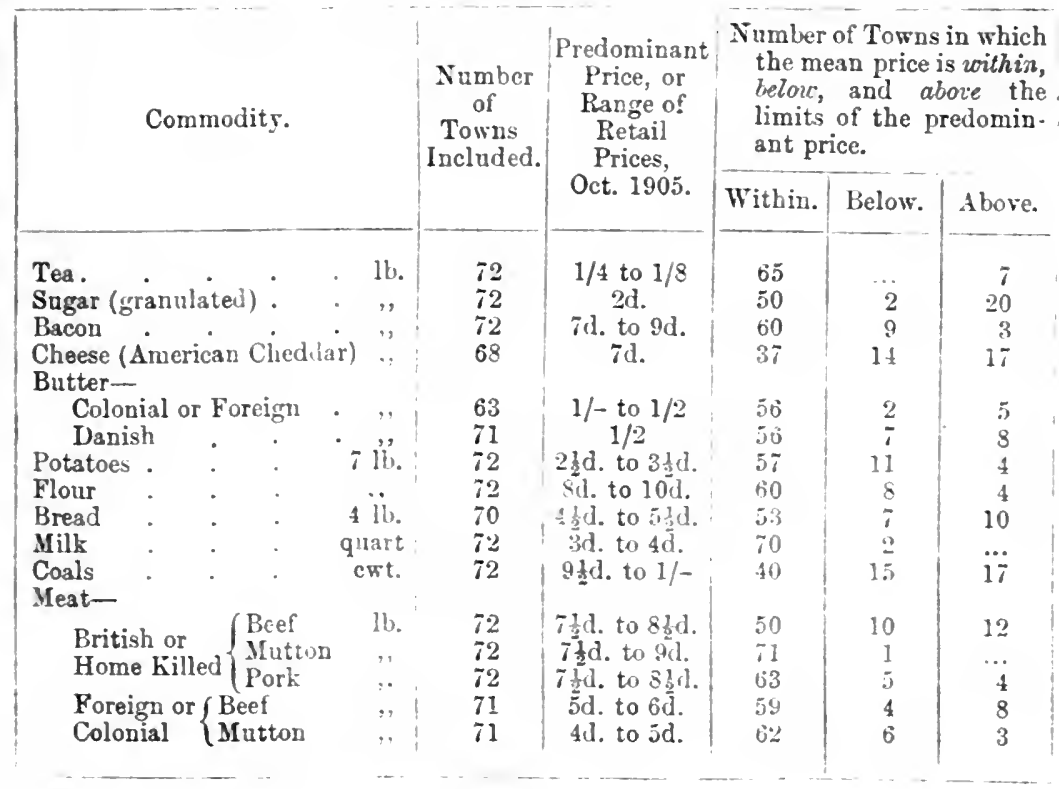


total, it is found, goes on food; 21 per cent. of incomes below $25 \mathrm{~s}$. goes on bread and flour, 18 per cent. on meat, bacon, and fish.

Table III gives the result of an inquiry recently undertaken into the cost of living of the working classes in towns: it shows the predominant price paid for the staple commodities forming the budget of the working-class family whose income ranges between $25 \mathrm{~s}$. and $40 \mathrm{~s}$. The weekly consumption of that family, assuming it to contain three to four children, is as follows :-

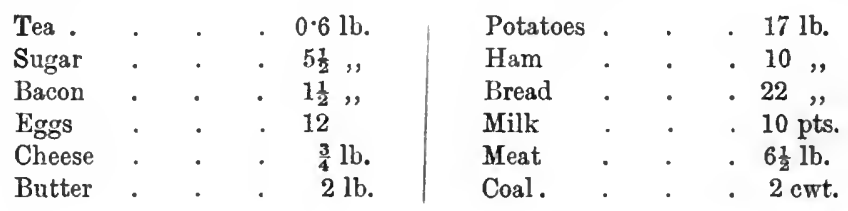

We may now pass to consider our supply of certain of these staple commodities more in detail.

Wheat.-In spite of the great increase in the variety of our food supply resulting from the immense acceleration and extension of transport, which has, in the course of the last half-century, brought the products of every quarter of the globe to our doors at all seasons, bread still remains the great staple food of all sections of our people. Although the consumption of every other article of food has increased enormously in the course of the century (Table IV), the consumption of wheat per head, which was 42.47 in 1840 , and 122.90 in 1870 , was in $1909242.93 \mathrm{lb}$. per head of the population.

\section{TABLE IV.-Source of Wheat Supply}

\begin{tabular}{|c|c|c|c|c|c|}
\hline & & \multicolumn{2}{|c|}{1899.} & \multicolumn{2}{|c|}{1909.} \\
\hline & & Cwt. & $\begin{array}{c}\text { Percentage } \\
\text { of } \\
\text { Total. }\end{array}$ & Cwt. & $\begin{array}{c}\text { Percentage } \\
\text { of } \\
\text { Total. }\end{array}$ \\
\hline \multicolumn{6}{|l|}{ Foreigu Countries- } \\
\hline United States & . & $60,210,000$ & 61 & $24,830,000$ & 22 \\
\hline Argentina . & . & $11,520,000$ & 12 & $20,160,000$ & 18 \\
\hline Russia . . & . & $2,520,000$ & $2 \cdot 5$ & $17,840,000$ & 16 \\
\hline Austria-Hungary & . & $1,430,000$ & $1 \cdot 5$ & 150,000 & $\cdots$ \\
\hline \multicolumn{2}{|l|}{ British Empire- } & $8,730,000$ & 9 & $19,550,000$ & 17 \\
\hline India. . & . & $8,190,000$ & 8 & $14,630,000$ & 13 \\
\hline Australasia & . & $\therefore, 730,000$ & 4 & $11,150,000$ & $9 \cdot 5$ \\
\hline \multicolumn{6}{|c|}{ Other countries and posses- } \\
\hline sions & - & $2,180,000$ & 2 & $5,330,000$ & $4 \cdot 5$ \\
\hline & & $98,510,000$ & 100 & $113,640,000$ & 100 \\
\hline
\end{tabular}


The conditions governing our wheat supply are thus of the very greatest importance. Before 1846 England was dependent upon what her own harvests produced. A high tariff was employed, in the strictly protective seuse, to keep out foreign imports. The supply was thus strictly limited, and in years of scarcity millions of people all over Great Britain and Ireland were unable to afford an adequate supply of bread. To-day, only 16 per cent. of our wheat is home grown; 84 per cent. being imported. In 1909 the total amount of wheat grown in the United Kingdom was $63,196,696$ bushels; of this $2,641,225$ quarters represented the whole amount placed upon the market-an insignificant proportion of the total wheat consumed. In the same year, no less than $97,854,425 \mathrm{cwt}$. were imported; 40,685,245 coming from British possessions and the rest from abroad.

Up to the last decade of the nineteenth century the main source of supply was the United States. For more than half a century, in fact, this country benefited almost exclusively by the opening up of new sources of supply which had been largely due to the expenditure of British capital.

\begin{tabular}{|c|c|c|c|c|}
\hline Table & V.-Wheat & and & Flour Imports from & United State \\
\hline 1840 & • & . & $\begin{array}{l}\text { Wheat. } \\
319,605 \text { cwt. }\end{array}$ & $\begin{array}{l}\text { Wheat Flour. } \\
984,467 \text { cwt. }\end{array}$ \\
\hline 1850 & . & . & $6,497,335,$, & $2,254,232$, \\
\hline 1870 & . & . & $12,371,922$, & $2,254,232$, \\
\hline 1880 & . & . & $29,634,820$ & $6,873,829$ \\
\hline 1909 & . & . & $16,469,300$, & $6,849,811$ \\
\hline
\end{tabular}

In the 'nineties a change began. The world's clemand for wheat had been steadily growing with the industrial development of a quarter' of a century of peace. Germany found herself unable to supply the growing needs of her population; the home demand in the States claimed an increasing share of the supply. Indeed, it is now clear that importation from Canada may soon be necessary there.

This increased demand, however, did not merely send up the world price of wheat. In so far as it did so, it called forth new supplies. The world's wheat-growing area extended in response to the demand. Thus, our supplies, instead of coming exclusively or even mainly from America, are, as Table IV indicates, drawn from many different sources. The advantage of this enlargement of the area of supply is clear. We are no longer dependent on the climatic conditions which may affect crops in one country or even in one hemisphere. For example, in 1903 our imports from Australia, which had been $1,383,100$ cwt. in 1901 , fell to 26 ; 
those from America (Atlantic ports), which had been 31,824,400 in 1901 , fell to $18,419,326$; but those from Russia, which had been only $2,541,500$ cwt. in 1901 , rose to $17,176,300$; and those from India, which had been $3,341,500$ cwt. in 1901 , to $17,057,857$.

It is clear that, as the world's demand goes on increasing, even a small shrinkage in production must mean a rise in price; but our open market, which enables us to draw supplies from the world, preserves us from the dangers of those excessive fluctuations in price which would inflict disaster were we dependent on any single source -we stand to gain by a cheap and free market more than any other country since we still import more than twice as much as any other country. In 1909 Great Britain imported over 27 million quarters; Germany, which came next, imported 11,700,000 quarters.

Thus, before 1850 the price of wheat, varying directly with the home crop, showed the most rapid and violent fluctuations at a high level. In 1810 , at the crisis of the war, it was as high as $127 \mathrm{~s}$. a quarter. In 1840 it was $66 \mathrm{~s} .4 \mathrm{~d}$; in $1845,53 \mathrm{~s}$; in $1850,53 \mathrm{~s}$. $3 d$. Between 1895 and 1905 , on the other hand, the price varied between $23 \mathrm{~s}$. and $29 \mathrm{~s}$. a quarter.

Other Cereals. - In 1907 England had 1,537,208 acres under wheat, producing 33.96 bushels per acre; 1,411,163 under barley, producing 35.67 bushels per acre, or $6,292,461$ quarters in all; $1,967,682$ acres under oats, producing 46.61 bushels per acre, or $11,464,406$ quarters in all. In the same year our imports were-

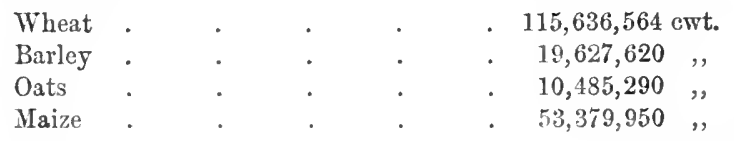

The annexed table shows the relative proportions of imports and home production over the five years 1898-1902.

Table VI

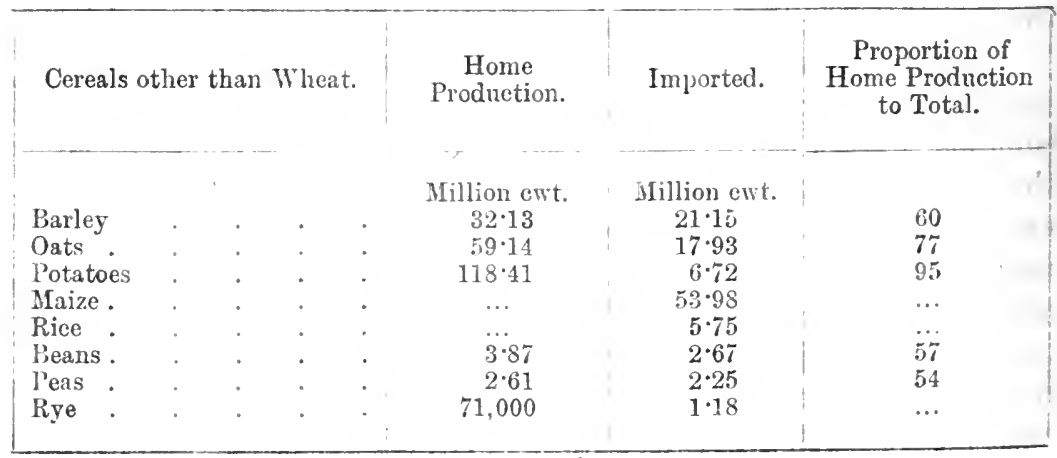




\section{TABLE VII}

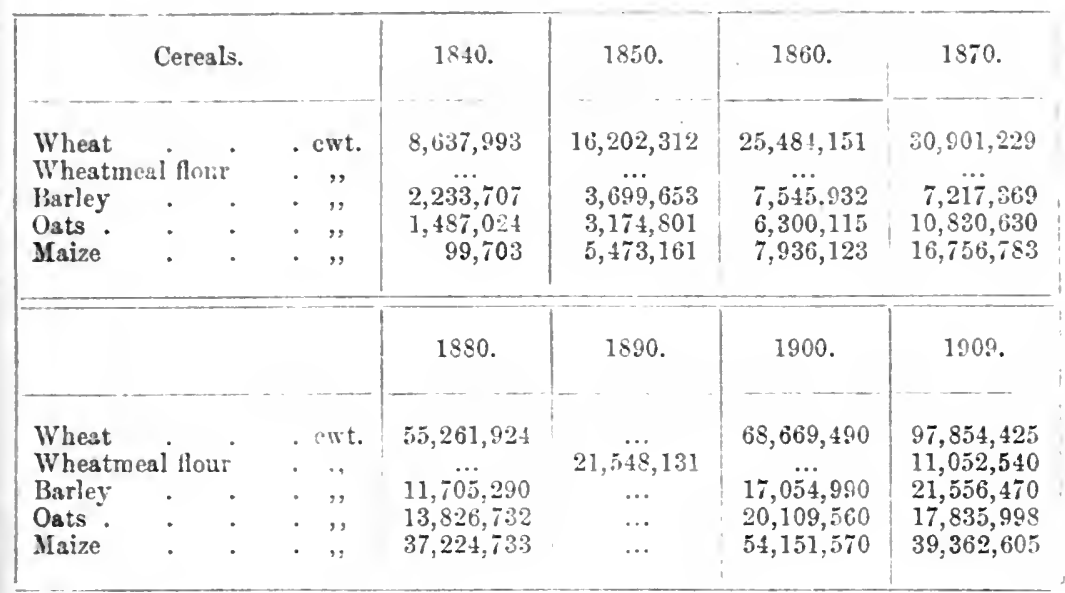

Meat.-In Porter's day meat occupied but a small place in the daily food budget of the great majority of the people. The remarkable degree to which its consumption has been extended among all classes shows as clearly as any single set of facts can do, the rise in the standard of comfort that has taken place in the last fifty years. At the same time, the price of meat has fallen to a remarkable extent. In 1850 we relied for our meat supply mainly on the home production. To-day, 45 per cont. of our supply comes from abroad, as Table VIII shows:-

TABLE VIII.-Period 1898-1902

\begin{tabular}{|c|c|c|c|c|c|}
\hline & & $\begin{array}{c}\text { Hone } \\
\text { Production. }\end{array}$ & Inported. & Total. & $\begin{array}{l}\text { Perzentage } \\
\text { of Improrts } \\
\text { to Total. }\end{array}$ \\
\hline $\begin{array}{l}\text { Beef and veal } \\
\text { Mutton and lami } \\
\text { Bacon and ham }\end{array}$ & $\begin{array}{l}\cdot \\
\dot{5} \\
.\end{array}$ & $\begin{array}{l}\text { Tons. } \\
662,520 \\
313,822 \\
269,578\end{array}$ & $\begin{array}{c}\text { Tous. } \\
336, \pm 00 \\
193,150 \\
410,391\end{array}$ & $\begin{array}{l}\text { Tons. } \\
1,048,920 \\
506,972 \\
679,972\end{array}$ & $\begin{array}{l}37 \cdot 0 \\
35 \cdot 0 \\
80 \cdot 0\end{array}$ \\
\hline Tota! & . & $1,245,920$ & 989,944 & $2,235,864$ & 41.5 \\
\hline
\end{tabular}

In the case of Iondon, indeed, two-thirds of the supply is i mported. 
Home-grown meat, however, is still considered the best. It is also proportionately dearer. Beef from Aberdeen fetches the best price in the London market; while Welsh and Highland mutton are highly esteemed. In the same way, we export pedigree stock to other countries for breeding purposes.

Importation on a large scale dates from the 'eighties (Tables $\mathrm{X}$ and XII). Here, indeed, England's isolated Free-trade position gives her a double advantage. Not only are her ports open to the meat supplies of the world, but the effect of the foreign tariffs on meat is to force those supplies to come here. Practically all the New Zealand frozen mutton comes to this country, as well as the greater part of the Argentine supply. The means of preserving meat during a long voyage began to be perfected some thirty years ago, and since that time continual improvements in methods of transport have brought fresh areas within reach of the English market. The history of our import trade is shown in the following table, which includes imports of cattle (for food), fresh and frozen beef, and fresh and frozen mutton:-

\section{TABLE IX}

\begin{tabular}{|c|c|c|c|c|c|c|c|c|c|}
\hline \multirow[b]{2}{*}{ 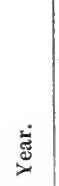 } & \multicolumn{3}{|c|}{ Cattle. } & \multicolumn{3}{|c|}{ Beef, Fresh and Frozen. } & \multicolumn{3}{|c|}{ Mutton, Fresh and Frozen. } \\
\hline & $\begin{array}{l}\text { 峁 } \\
\text { 范 }\end{array}$ & $\stackrel{\Xi}{\Xi}$ & 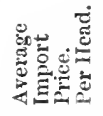 & $\begin{array}{l}\text { 营 } \\
\text { 范 } \\
\text { 。 }\end{array}$ & 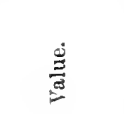 & 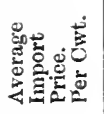 & 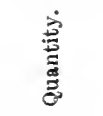 & 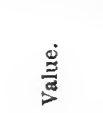 & 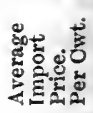 \\
\hline $\begin{array}{l}1880 \\
1890 \\
1900 \\
1905 \\
1909\end{array}$ & $\begin{array}{l}390 \\
643 \\
496 \\
565 \\
321\end{array}$ & $\begin{array}{c}\mathcal{E} \\
7,793,000 \\
10,506,000 \\
9,012,000 \\
9,664,000 \\
5,566,000\end{array}$ & $\begin{array}{ccc}\mathcal{E} & \text { s. } & \text { d. } \\
19 & 19 & 11 \\
16 & 6 & 7 \\
18 & 3 & 5 \\
17 & 2 & 1 \\
17 & 6 & 9\end{array}$ & $\begin{array}{c}\text { Cwt. } \\
1,018,000 \\
1,855,000 \\
4,128,000 \\
5,038,000 \\
6,141,000\end{array}$ & $\begin{array}{c}\mathfrak{£} \\
2,425,000 \\
3,923,000 \\
8,163,000 \\
8,932,000 \\
10,293,000\end{array}$ & $\begin{array}{l}\text { s. } \\
47 \cdot 6 \\
42 \cdot 3 \\
39 \cdot 5 \\
35 \cdot 4 \\
33 \cdot 5\end{array}$ & $\begin{array}{c}\text { Cwt. } \\
\ldots \ddot{1} \\
1,656,000 \\
3,392,000 \\
3,811,000 \\
4,762,000\end{array}$ & $\begin{array}{c}£ \\
\ddot{1} \\
3,448,000 \\
5,842,000 \\
7,336,000 \\
7,839,000\end{array}$ & $\begin{array}{c}\text { s. } \\
41 \cdot 63 \\
34 \cdot 43 \\
38 \cdot 50 \\
32 \cdot 93\end{array}$ \\
\hline
\end{tabular}

Practically all the cattle come from the United States, the only other country which sends live cattle being Canada. It is a significant feature of this table that the import of cattle has been very largely superseded by the import of fresh and frozen beef, which comes from Argentina, the change being a sign of the growing home demand in the United States itself. While prices of frozen meat have steadily fallen, the price of American cattle touched bottom five years ago, and has since been on the up-grade. It is highly satisfactory that the decline has occurred in those kinds of meat which are consumed by the poorer classes of the country. 


\section{TABLE $\mathrm{X}$}

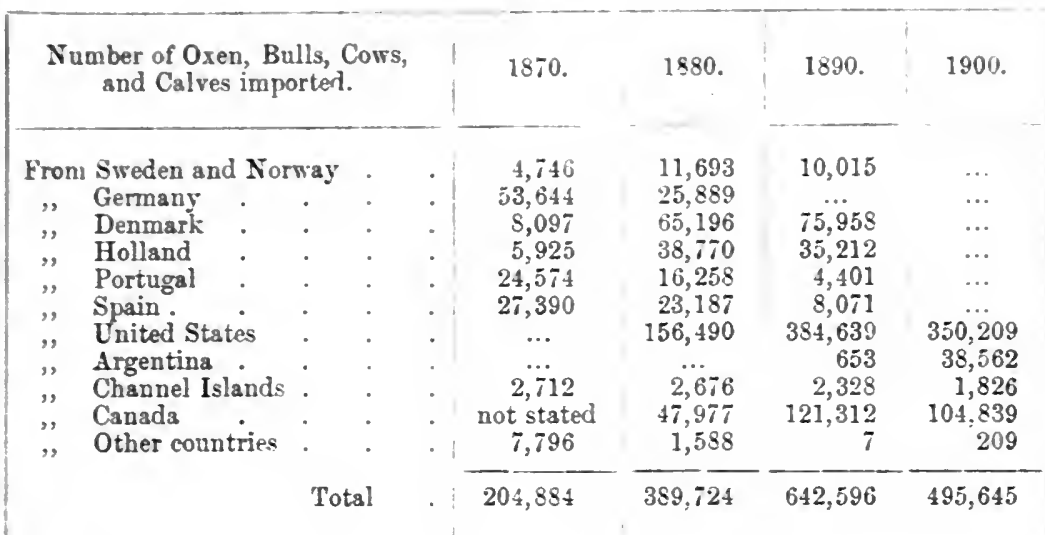

Table XI

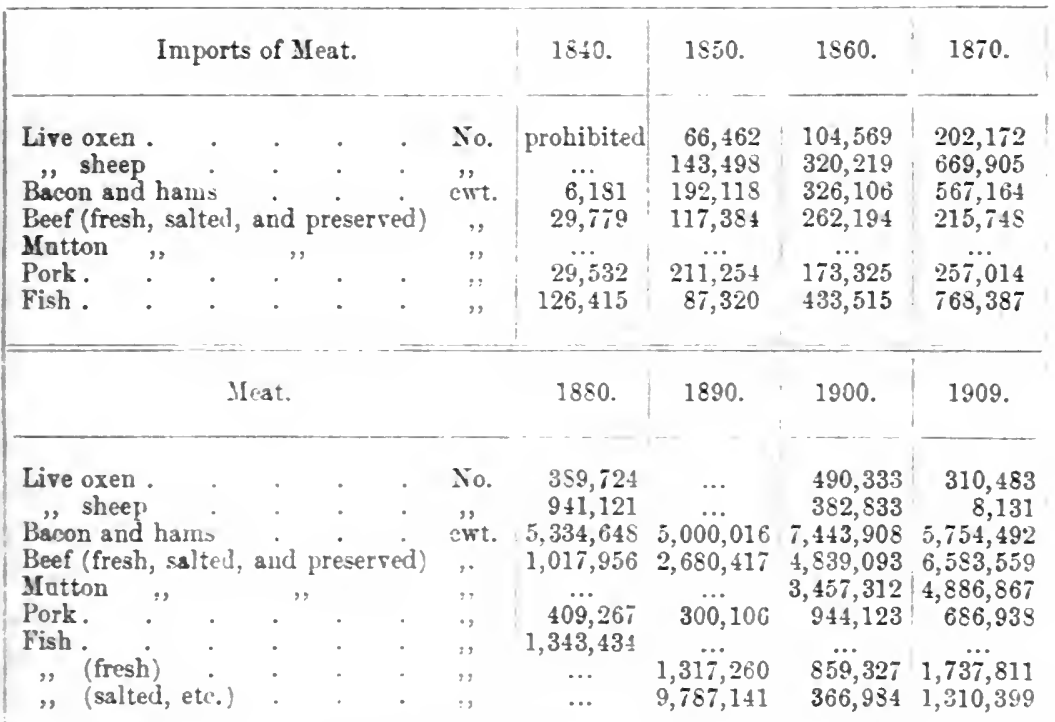

If we turn to the figures showing our imports of salted and preserved meats we get another story (Table XII).

In all these cases prices have risen very rapidly since 1905 . Our imports of bacon come in about equal quantities from Denmark and the United States, while our imports of hams and preserved and salted meat come almost entirely from the United States. Thus the influence of rising prices in America can be traced in every one of those classes of meat which we get from that country. 


\section{TABLE XII}

\begin{tabular}{|c|c|c|c|c|c|c|c|c|c|}
\hline \multirow[b]{2}{*}{ Year. } & \multicolumn{3}{|c|}{ Bacon. } & \multicolumn{3}{|c|}{ IIams. } & \multicolumn{3}{|c|}{ Beef, Preserved and Salted } \\
\hline & 莣 & 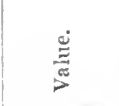 & 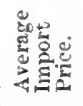 & 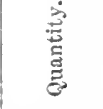 & $\frac{\mathscr{\Xi}}{\tilde{E}}$ & 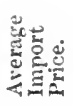 & 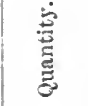 & 巳̈ & 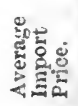 \\
\hline $\begin{array}{l}1880 \\
1890 \\
1900 \\
1905 \\
1909\end{array}$ & $\begin{array}{c}\text { Cwt. } \\
5,335,000^{*} \\
5,000,000^{*} \\
5,641,000 \\
5,499,000 \\
4,625,000\end{array}$ & $\begin{array}{c}\mathfrak{E} \\
10,986,000 \\
9.847,000 \\
11,774,000 \\
12,775,000 \\
13,802,000\end{array}$ & $\begin{array}{c}\text { s. } \\
41 \cdot 2 \\
39 \cdot 5 \\
41 \cdot 74 \\
46 \cdot 46 \\
59 \cdot 68\end{array}$ & $\begin{array}{c}\text { Cwt. } \\
\because . \\
1,800000 \\
1,318,000 \\
1,129,000\end{array}$ & $\begin{array}{c}f \\
\ddot{0} \\
4,222,000 \\
3,118,00: \\
3,113,000\end{array}$ & $\begin{array}{c}\text { s. } \\
\ddot{.} \\
46 \cdot 84 \\
47 \cdot 31 \\
55 \cdot 14\end{array}$ & $\begin{array}{l}\text { Cwt. } \\
275,000 \\
711,000 \\
741,000 \\
443,000\end{array}$ & $\begin{array}{c}\mathcal{E} \\
38 \ddot{2}, 000 \\
1,714,000 \\
1,992,000 \\
1,548,000\end{array}$ & $\begin{array}{l}\text { s. } \\
27 \cdot 9 \\
48 \cdot 25 \\
53 \cdot 6 \\
69 \cdot 8\end{array}$ \\
\hline
\end{tabular}

* Includes hams.

Under these circumstances, it is, however, surprising that imports of preserved meat-which include the tinned products of the notorious beef trust-have not diminished more rapidly. But tinned meats are a speciality, and apparently high prices have less influence than a scare such as that created in 1906 by the publication of Mr. Upton Sinclair's book, which gave a very gruesome picture of the methods of the Chicago packers. The effect of The Jungle on public opinion and taste may perhaps be seen in the following table of imports of preserved beef :-

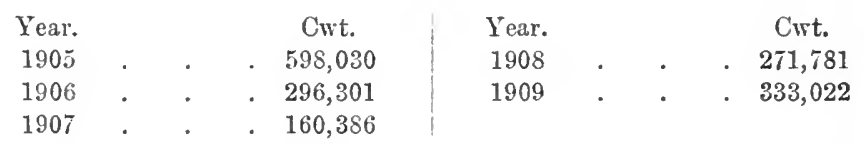

There are only four countries in the world which export beef and mutton on a large scale, namely, the United States, Argentina, New Zealand, and Australia. In each case at least 90 per cent. of their exports come to this country. The United States exported in 1908 $1,796,018$ cwt. of fresh and frozen beef, of which 1,446,121 cwt. came to this country, while the Argentine Republic exported about three and a half million cwt. of chilled beef, and about one and a half million cwt. of frozen mutton, practically all of which came to England. New Zealand exported 2,120,303 cwt. of chilled meat, chiefly mutton, in 1908 , and Australia 818,818 cwt. of frozen mutton and lamb, of which about two million cwt. and six hundred thousand cwt. respectively came to this country. So long as England continues to hold a virtual monopoly of the world's surplus meat supply, and so long as other agricultural products, such as wheat, etc., do not dispute possession with cattle and sheep for the vast acres of Argentina and Australasia, so long will prices favour the British consumer. 
TABLE XIV.-Dairy Produce

\begin{tabular}{|c|c|c|c|c|c|c|}
\hline \multicolumn{3}{|c|}{ Period 1898-1902. } & $\begin{array}{c}\text { Home } \\
\text { Production. }\end{array}$ & Imported. & Total. & Percentage \\
\hline $\begin{array}{l}\text { Milk . } \\
\text { Cheese } \\
\text { Butter. }\end{array}$ & $: \quad:$ & . & $\begin{array}{c}620,000 \text { gals. } \\
1,366 \text { cwt. } \\
3,211 \text {, }\end{array}$ & $\begin{array}{l}201 \text { gals. } \\
2,520 \text { cwt. } \\
3,638,,\end{array}$ & $\begin{array}{c}620,201 \text { gals. } \\
3,886 \mathrm{cwt} . \\
6,849 \text { ", }\end{array}$ & $\begin{array}{l}\cdot 03 \\
64 \cdot 8 \\
53 \cdot 1\end{array}$ \\
\hline
\end{tabular}

(From Royal Commission on Food Supplies, Cd. 2643.)

With regard to poultry, it is estimated that there were, in $1865,21,963,027$ fowls on farms, etc., in the United Kingdom; in $1902,29,136,312$-or an increase of $7,173,285$.

Groceries.-The consumption of all kinds of groceries has increased: and practically all the supply comes in from abroad. Nor are any very large stocks retained at any time. As a witness before the Commission on Food Supplies pointed out, "London is fed weekly."

\section{The Tea Trade}

Although tea may not be a necessary of life in the strict economic sense, it is so widely consumed that it can at any rate be considered one of the prime comforts of life for all classes in this country. Tea first made its appearance in England in the middle of the seventeenth century, but, of course, the price at that time was so high as to prohibit its consumption by any but the very wealthy.

As Porter points out: "The history of the tea trade affords abundant proof of the effect produced on consumption by alterations in the rate of duties. In 1784 the duty was $1 \mathrm{~s}$. per pound, and 67 per cent. on the value, and the quantity consumed was no more than $4,948,983 \mathrm{lb}$. In the following year the rate was reduced to $12 \frac{1}{2}$ per cent. on the value, and the consumption rose in that and the two following years as under:-

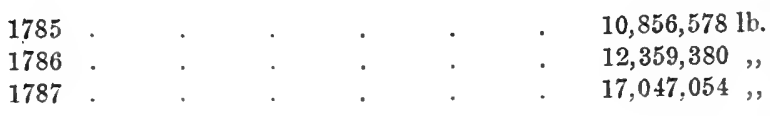

Similar effects had followed reductions in the duty at former periods. In 1746 a reduction equal to about $2 \mathrm{~s}$. per pound caused an increase in the quantity to more than three times that on which duty had been paid in 1745 . In 1768 an abatement of $1 \mathrm{~s}$. per 
This steady increase in consumption is not confined to this country, though the Anglo-Saxons consume more than any other race for which statistics are available. We stand second in the list with an average consumption of 6.03 lo. per head; Australasia coming first with $7 \cdot 1$ and Canada third with $4.0 \mathrm{lb}$.

China tea-the first tea to be introduced into England-has been grown and drunk from time immemorial in China. The Japanese variety is also of ancient date. The Indian and Ceylon teas are of comparatively recent origin, and were first cultivated in the 'forties of the last century. Although the tea plant is believed to be indigenous to Assam and the Shan States, and can be found growing wild in some of the Indian jungles, no attempt was made to cultivate it, and the early pioneers of the Indian and Ceylon tea estates actually imported tea plants from China. These alien plants did not flourish at first, and it was not until they had crossed themselves with the wild tea plants growing in the jungles near by that satisfactory results were obtained. The Indian tea plant, as we know it, is a hybrid-i.e. a cross between the cultivated China and the wild Indian variety.

The new Indian and Ceylon teas have been steadily supplanting the old China teas in the public taste, as the following figures, which have been very kindly supplied by Messrs. Appleton, Machin, \& Smiles, indicate:-

TABLE XVII

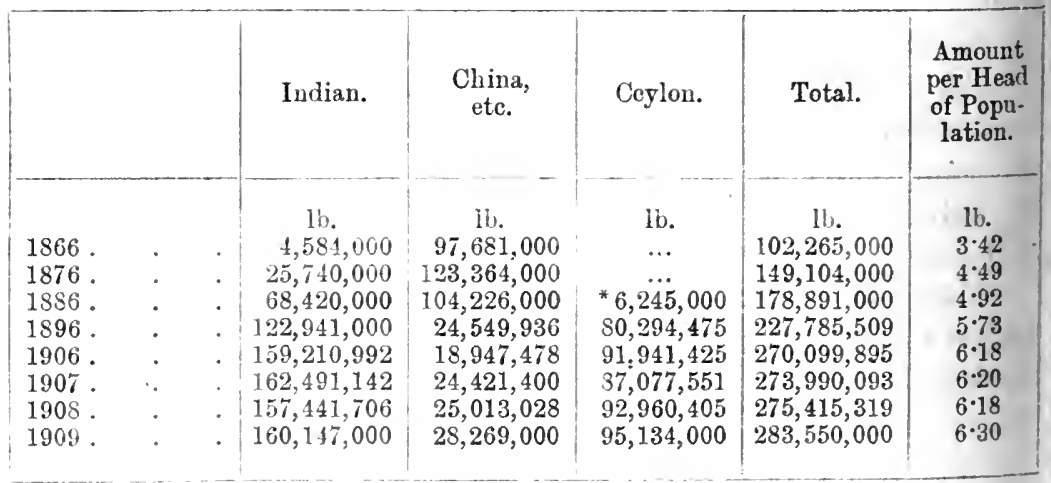

* Ceylon tea is included with the Indian tea prior to 1886.

A rise in the price of tea seems not improbable, iu view of the fact that the very high prices to be obtained for rubber 
are likely to cause rubber to be a more profitable product than tea in Ceylon.

\section{COFFEe}

Although coffec-houses flourished in London long before tearooms, yet aiter tea really got hold of the public taste it rapidly outstripped coffee as a popular drink. Coffee, unlike tea, is not a native of the Far East; it is supposed to have come originally from Kaffa, in Abyssinia. Although it was introduced into Arabia at the beginning of the fifteenth century, it did not find its way across Europe to England until a century later. The first coffee-house in London was opened in the days of Cromwell, in 1652.

These establishments rapidly grew in the public farour, and in Charles In's time as many as three thousand were supposed to exist in London alone. It was in one of these coffee-houses, situated in Lombard Street, and owned by one Edward Lloyd, that the present Corporation of Lloyd's had its origin. The London shipping merchants used to meet there to discuss business matters, and out of their informal discussions the vast marine insurance organization grew up.

The Dutch sent coffee plants to Java in 1650 , and in 1723 coffee was first planted in Martinique, from whence it gradually spread to the mainland of South America. South America, and Brazil in particular, now produces by far the greater part of the world's coffee supply, and true Mocha coffee is very hard to obtain.

Coffee has probably been subject to more adulteration than either tea or cocoa. In George I's time an Act was passed to prevent "divers evil disposed persons who at the time of, or soon after, the roasting of coffee made use of water, grease, butter, or such-like materials whereby the same is rendered unwholesome." Since that time there have been a whole series of Acts dealing with the adulteration of coffee. Among the various substances used for the purpose, chicory is the best known and the most respectable, but cereals, sawdust, bark, cacao husks, acorns, figs, lupine, peas, etc., have all played their part, and even the lately discovered soya bean has been adapted. In England, coffee is comparatively little drunk; less now than at the beginning of the century. Thus in 1831 the average consumption per head was 11 b. 549 oz.; in 1909 it was only 71 lb. Compare this with the arerage consumption in Holland- $18.42 \mathrm{lb}$. per head; or the United States, 11.07 lb. It does not enter into the English working-man's 
budget at all. As Porter points out, no commodity of geueral use has been subjected to such varying duties as coffee. For instance, as the table shows, in 1801 there was a duty of 1s. $6 \mathrm{~d}$. per lb.; in 1841 that had been reduced to $6 \mathrm{~d}$.; and at the present time coffee is taxed at $14 \mathrm{~s}$. per cwt.

\section{TABLE XVIII}

\begin{tabular}{|c|c|c|c|c|c|c|c|}
\hline \multicolumn{2}{|c|}{ Year. } & $\begin{array}{l}\text { Number of } \\
\text { Pounds } \\
\text { Consumed. }\end{array}$ & $\begin{array}{c}\text { Rate of Duty } \\
\text { per Pound } \\
\text { on British } \\
\text { Plantation } \\
\text { Coffee. }\end{array}$ & $\begin{array}{c}\text { Population } \\
\text { of Great } \\
\text { Britain. }\end{array}$ & $\begin{array}{r}\text { Av } \\
\text { Cons? }\end{array}$ & $\begin{array}{l}\text { erage } \\
\text { mption. }\end{array}$ & $\begin{array}{c}\text { Sum } \\
\text { Contributed } \\
\text { per Head } \\
\text { to the } \\
\text { Revenue. }\end{array}$ \\
\hline $\begin{array}{l}1801 \\
1811 \\
1821 \\
1831 \\
1841\end{array}$ & $\dot{.}$ & $\begin{array}{c}\text { lb. } \\
750,861 \\
6,390,122 \\
7,327,283 \\
21,842,264 \\
27,298,322\end{array}$ & $\begin{array}{ll}\text { s. } & \text { d. } \\
1 & 6 \\
0 & 7 \\
1 & 0 \\
0 & 6 \\
0 & 6\end{array}$ & $\begin{array}{l}10,942,646 \\
12,596,803 \\
14,391,631 \\
16,262,301 \\
18,532,335\end{array}$ & $\begin{array}{c}\text { lb. } \\
0 \\
0 \\
0 \\
1 \\
1\end{array}$ & $\begin{array}{c}\text { oz. } \\
1 \cdot 09 \\
8 \cdot 12 \\
8 \cdot 01 \\
5 \cdot 49 \\
7 \cdot 55\end{array}$ & $\begin{array}{c}\mathrm{d} . \\
1 \frac{1}{4} \\
4 \\
6 \\
8 \\
10 \frac{1}{2}\end{array}$ \\
\hline
\end{tabular}

It appears from the above statement, that when the duty amounted to $1 \mathrm{~s} .6 \mathrm{~d}$. per $1 \mathrm{~b}$., the use of coffee was confined altogether to the rich. The quantity used throughout the kingdom scarcely exceeded, on the average, $1 \mathrm{oz}$. for each inhabitant in the year, and the revenue derived was altogether insignificant. In the interval between 1801 and 1811 the rate of duty was reduced from 1s. $6 \mathrm{~d}$. to $7 \mathrm{~d}$. per lb., whereupon the consumption rose 750 per cent., and the revenue derived was increased more than three-fold. During the next deceunary period the duty was again advanced to $1 \mathrm{~s}$. per lb., by which means the progressive increase was checked so as to render the consumption actually less in 1821, taking the increased population into account, than it was in 1811 . In 1825 the duty was again reduced to one-half the previous rate, and we see that in 1831 the consumption was consequently increased $14 \frac{1}{2}$ millions of lbs., or nearly 200 per cent., the average consumption of each individual being raised from 8 to $21 \mathrm{oz}$. per annum, while the revenue was increased by $£ 100,000$.

The yield to the customs, which was $£ 921,551$ in 1840 , was in 1870 only $£ 347,755$; in $1909-1910$ it was $£ 530,457$.

Although $819,558 \mathrm{cwt}$. were imported in 1909 , only 264,972 cwt. were retained for home consumption. And this figure represents the average consumption of the past ten years.

The principal sources of our supply are as follow:- 


\section{FOOD SUPPLIES AND CONSUMPTION}

TABLE XIX.-Home Consumption of Coffee

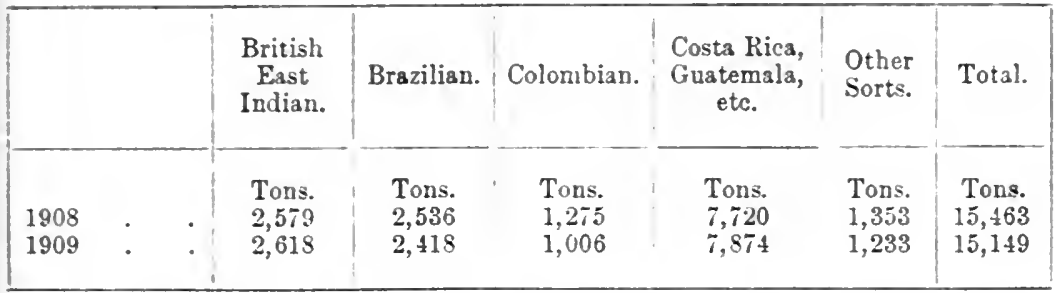

From these figures it will be seen that the countries which send the most coffee here are Costa Rica and Guatemala. Of the 7874 tons that came from Costa Rica and Guatemala in 1909, 5525 tons came from the first and 2349 from the second. Costa Rican coffee is of a very fine quality, and correspondingly expensive. England is Costa Rica's best customer with regard to coffee-in fact, over half the Costa Rican coffee crop comes to this country. That is to say, such coffee as is drunk in England is of very good quality.

\section{StGar:}

Anything like a full treatment of the many political and other controversies that have, at various times, raged over the commodity sugar would occupy a whole chapter. The customs policy of the country with regard to it has been subject to marked fluctuations. In 1801 there was a duty of 20s. per cwt.; in 1811 this was raised to $27 \mathrm{~s}$. ; in 1874 all duty was repealed. A war duty was imposed in 1900; in 1908-1909 this was reduced to a rate of $10 \mathrm{~d}$. per cwt. or over, according to the degree of polarization; the same being imposed on molasses and glucose in its liquid form. On solid glucose the duty was 1s. 2d. per ewt.

Porter held that "while it is necessary to raise any considerable revenue, and so long as it shall be thought advisable to do so by means of indirect taxation, it would be difficult to point out any article better fitted for the purpose than sugar. Without being one of the absolute necessaries of life, long habit has in this country led almost every class to the daily use of it, so that there is no people in Europe by whom it is consumed to anything like the same extent. It is besides, from its bulk, in proportion to its value, not likely to be clandestinely imported. If it were attempted to subject it to such a rate of duty as would convert it into an object of temptation to the smuggler, the legitimate consumption would fall off to such a degree as would render the attempt on the part of the government altogether abortive. The action of the smuggler, 
which, with regard to many articles-such as tobacco and spiritsmay be considered to form the natural limit to taxation, affords therefore no criterion in the case of sugar, but we may find in the foregoing computations a sufficiently significant indication that the rate of duty, although now somewhat lower than it was during the war, is still too high; and that by making a great reduction in that rate we may, under ordinary circumstances, so increase the consumption as not merely to give an impulse to trade, but also to increase the revenue. Confining the inquiry to Great Britain, it appears that if we take population as an element in the computation, the revenue did not, gain by the increased rates imposed in $1805 "$ :

TABLE XX

\begin{tabular}{|c|c|c|c|c|c|c|}
\hline & Year. & & Population. & $\begin{array}{c}\text { Net } \\
\text { Rerenue. }\end{array}$ & Rate of Duty. & $\begin{array}{l}\text { Tax per } \\
\text { Head. }\end{array}$ \\
\hline $\begin{array}{l}1801 \\
1811 \\
1821 \\
1831 \\
1841\end{array}$ & $\dot{\dot{r}}$ & 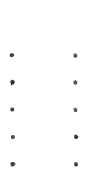 & $\begin{array}{l}10,942,646 \\
12,596,803 \\
14,391,631 \\
16,539,318 \\
18,532,335\end{array}$ & $\begin{array}{c}£ \\
2,782,232 \\
3,339,218 \\
3,660,567 \\
4,219,049 \\
4,686,241\end{array}$ & $\begin{array}{l}20 \mathrm{~s} . \text { per cwt. } \\
27 \mathrm{~s} . ", \\
27 \mathrm{~s} . \quad " \\
24 \mathrm{~s} . \\
24 \mathrm{~s} . \text { and" } 5 \text { per cent. }\end{array}$ & $\begin{array}{ll}\text { s. } & \text { d. } \\
5 & 1 \\
5 & 3 \frac{1}{2} \\
5 & 1 \frac{1}{2} \\
5 & 1 \frac{1}{4} \\
5 & 0 \frac{9}{4}\end{array}$ \\
\hline
\end{tabular}

In 1909 the yield to the customs from a 10d. duty was

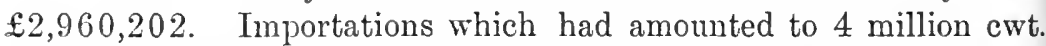
of raw sugar in 1840, reached in that year a total of over 16 millions raw, 3 millions molasses, and nearly 19 millions refined sugar.

TABLE XXI.-Food Imports: Groceries

\begin{tabular}{|c|c|c|c|c|c|}
\hline & & 1840. & 1850. & 1860. & 1870. \\
\hline \multirow{4}{*}{\multicolumn{2}{|c|}{ 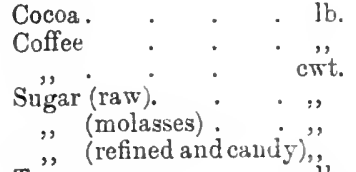 }} & $3,499,746$ & $4,478,252$ & $9,009,860$ & $14,793,950$ \\
\hline & & $\begin{array}{c}70,250,766 \\
\ldots\end{array}$ & $50,803,152$ & $82,767,746$ & \\
\hline & & $\begin{array}{r}4,035,845 \\
457,657\end{array}$ & $\begin{array}{r}6,291,535 \\
904,950\end{array}$ & $\begin{array}{r}8,817,277 \\
345,011\end{array}$ & $\begin{array}{r}12,798,631 \\
795,111\end{array}$ \\
\hline & & & & & $1,710,176$ \\
\hline \multirow{3}{*}{ Confectionery } & - $\quad$ lb. & $28,021,882$ & $50,512,384$ & $88,946,532$ & $141,020,767$ \\
\hline & . ewt. & $\cdots$ & $\cdots$ & $\cdots$ & $\cdots$ \\
\hline & & 1880. & 1890. & 1900. & 1909. \\
\hline Cocoa. & - Ih. & $23,511,101$ & $30,585,633$ & $60,508,284$ & $88,704,898$ \\
\hline Coffee & . cwt. & $1,546,451$ & 864,454 & 759,656 & 829,558 \\
\hline Sugar (raw). & . , , & $17,001,613$ & $15,717,476$ & $13,234,934$ & $16,302,696$ \\
\hline ," (molasses) & & 211,541 & $1,563,687$ & $1,347,931$ & $3,089,244$ \\
\hline,$\quad$ (refined an & d candy), & $3,036,074$ & $9,976,665$ & $19,248,187$ & $18,887,438$ \\
\hline Tea . . & . $\quad$ lh. & $206,971,570$ & $223,494,511$ & $300,230,857$ & $341,658,157$ \\
\hline Confectionery & . cwt. & 206,590 & 99,427 & 172,294 & 671,424 \\
\hline
\end{tabular}




\begin{tabular}{|c|c|}
\hline 宮 & 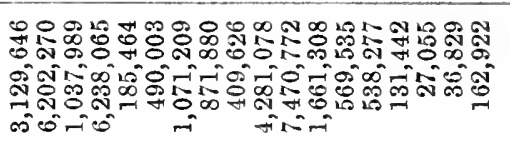 \\
\hline ஓ் & 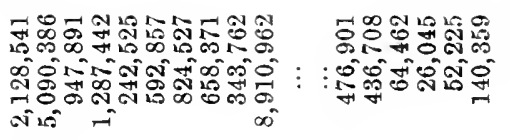 \\
\hline 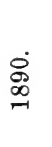 & 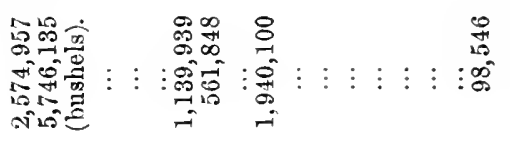 \\
\hline $\begin{array}{l}\dot{\infty} \\
\text { 市 } \\
\stackrel{2}{\sim}\end{array}$ & 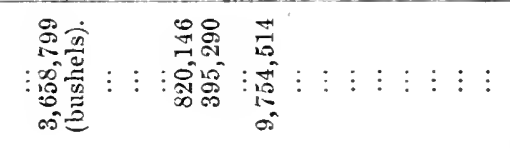 \\
\hline$\underset{\substack{\infty \\
\text { 足 }}}{0}$ & 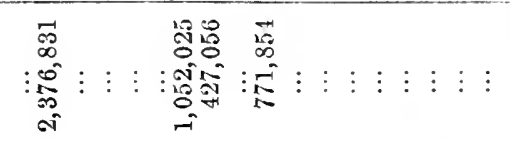 \\
\hline 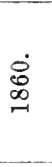 & 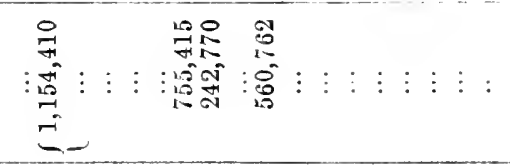 \\
\hline $\begin{array}{c}\dot{0} \\
\substack{\infty \\
\infty}\end{array}$ & 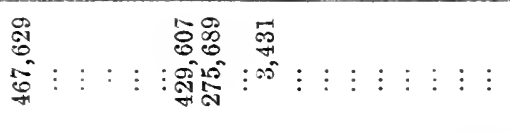 \\
\hline 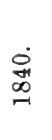 & 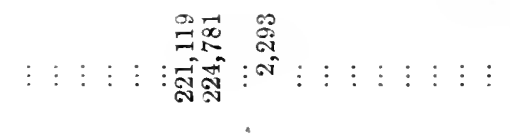 \\
\hline 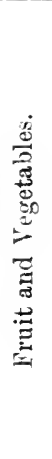 & 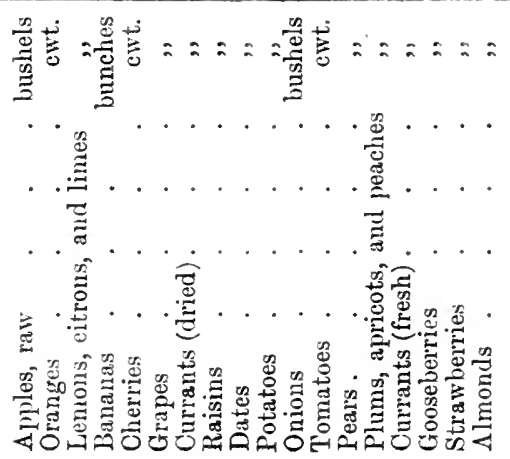 \\
\hline
\end{tabular}


that good refined sugar came into general use. The West Indian sugar previously imported had to be refined in this country, and the finished article was inferior in quality. This, taken in connexion with the very high price due to heavy costs of production plus duty, prevented the development of the subsidiary-industries which have sugar as their raw material, e.g. jam, confectionery, etc.

Between 1855 and 1874 , when the sugar duty was abolished, one enterprising British merchant enjoyed a practical monopoly of the export jam trade. This was Alexander Keiller of Dundee, who bad, with singular business acumen, established great factories in the free market of the Channel Islands.

With the removal of the duty and the rapid introduction of improved machinery, great strides were made in the production of jam, chocolate, confectionery, and tinned goods of all kinds.

Fruit and Vegetables.-Table XXIV gives some idea of the immense increase in the variety and anount of fruit and vegetables consumed. There has been an extraordinary expansion in the imports from distant countries of all kinds of fruits. Bananas, which a generation ago were a rare luxury of the rich, are now a favourite fruit of the working classes. The use of cold storage, of improvements in packing, and the acceleration of steam transit. have all helped to bring distant fruit-growing countries like the West Indies, British Columbia, Tasmania, and Cape Colony into touch with the great London market. 


\section{CHAPTER XXV}

\section{BEER, WINE, SPIRITS, AND TOBACCO}

Beer.-Origin of beer-Early London beers-The beginning of the brewery-Duties on beer-Quantities of beer consumed in England and Wales, and duties thereon, 1801-1829-Quantity of beer made, exported, and retained for home consumption, 1881-1909-Changes in public taste during the last fifty years-Licensing dutiesYields from virious beer taxes, 1882-1910-Number of licences taken out, 1899-1903 -The brewing trade during the past thirty years-Our exports of beer.

Malt.-Consumption of malt in the United Kingdom, 1801-1841-Rates of duty and average consumption per head of population, 1740-1790-Quantity of malt, sugar, and other important ingredients used in brewing, 1880-1910.

Wine, 1500-1850.-Quantity and descriptions of wine used in Great Britain and Ireland-Average consumption and amount of duty contributed, 1801-1841-Rates of duty, 1801-1841-Consumption during the eighteenth century-Quantity of wine unade in France in first half of nineteenth century-Quantities of French wine sold for consumption in the United Kingdom, 1815-1845.

1850-1910.-Our imports of wine, 1850-1910-Decrease in consumption during second half of mineteenth century-Our re-export trade in wine, 1860-1910-Countries that send us wines--Sorts of wine imported in 1909-Yield froin customs duties on wine, $1850-1910$.

Spirits, 1800-1850. - Consumption of spirits during first half of nineteenth century-Spirit drinking in Ireland-Spirit drinking in Scotland-Rerenue derived from foreign spirits, 1841 - Imports of $\mathrm{rum}$ and foreign spirits into the United Kingdom, 1802-1841.

1850-1910.--Quantities of spirits made, exported, retained for home consumption and retained in bond, 1880-1910-Imports of rum, brandy and other spirits, 18601910-Exports and re-exports of British spirits, 1860-1910-Yields from spirit dnties, 1860-1910.

Tobacco.-The introduction of tobacco into England-Tobacco duties in first half of nineteenth century-Consumption of tobacco per head in modern nations-Tobacco prices, 1842-1908.

A MONG alcoholic beverages beer still takes the first place in working-men, just as whisky is the national drink of Scotland and porter of Ireland.

The early English monasteries were noted for the strength of their ales, and at the time of the Reformation many of the monks from the dispossessed monasteries took to brewing. The early beers 
were brewed without hops, and were not, it is believed, made bitter by that herb until the fifteenth century. "In early times," writes Mr. Julian L. Baker in his book on The Brewing Industry, "a great deal of the brewing was carried on by women. Up to the eighteenth century the making of ale in country houses was a recognized duty of the housewife. Frequent references are made by writers of Elizabethan times to ale-wives." Brewing remained an important home industry in the rural districts until the middle of the last century, though already in the reign of Henry iv the brewers of London formed themselves into a mutual society, and in 1445 the first charter was given to the Brewers' Company.

In the early part of the eighteenth century London became famous for its "porter," which originated in a curious way. The popular malt liquors then were ale, beer, and "two-penny"; and it was quite common for a customer to ask for "three threads," that is, a mixture of the three drinks. This involved a drawing from three separate casks, and an ingenious gentleman of the name of Harwood concocted a liquid called "porter" composed of the three ingredients, which rapidly became extremely popular. The greatest manufacture of porter is now that of Guinness in Dublin.

Beer and ale have long received the attention of Chancellors of the Exchequer, and they have been able to defend their imposts by moral considerations, though they have been more successful in raising revenue than in diminishing consumption. The first beer duty was imposed by Charles II in 1660, and amounted to 2s. 6 d. per barrel on strong, and 6d. a barrel on table beer. The duty was increased by successive stages until about 1830 , when the beer duty and malt tax together amounted to about 1.3. $8 \mathrm{~d}$. per barrel. In 1830 the beer duty was repealed, and the retail sale was thrown open with disastrous results. As Srdney Smith wrote: "The new Beer Bill has begun its operations. Everyody is drunk. Those who are not singing are sprawling. The sovereign people are in a beastly state."

From 1830 to 1880 the duties on beer and ale were levied by means of the malt tax. Hops were also subject to a tax until 1860, when Mr. Gladstone substituted a new scale of brewers' licences in its place. In $1880 \mathrm{Mr}$. Gladstone abolished the malt duty. The loss to the revenue was made up by the imposition of a penny in the pound on the income-tax, and by a duty of $6 \mathrm{~s} .3 \mathrm{~d}$. per barrel upon beer. In 1894 this duty was raised to 6 s. $9 \mathrm{~d}$. a barrel, and in 1900, to help meet the expenses of the South African War, it was increased to $7 \mathrm{~s}$. $9 \mathrm{~d}$. a barrel, at which rate it 
still remains. Up to the date of the repeal of the beer duty, when statistics ceased, the course of consumption in England and Wales was as follows:-

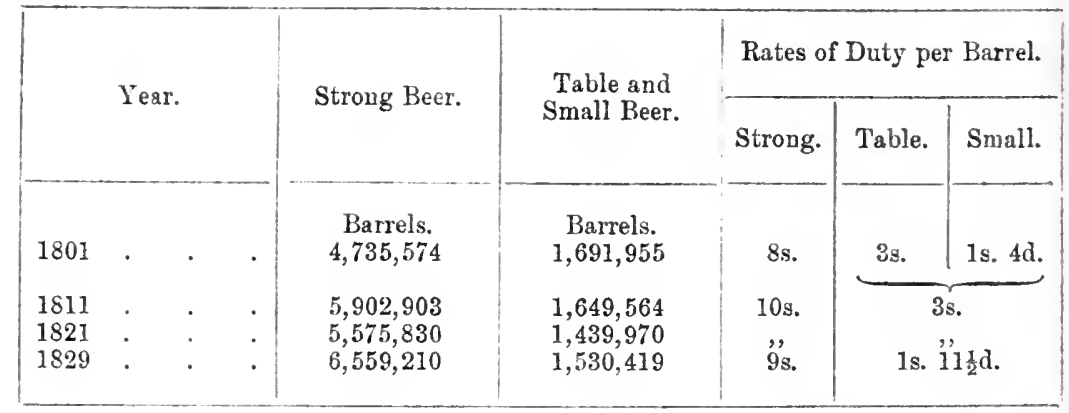

The produce of the duty on the above quantities and the average consumption and amount of duty paid per head in England and Wales were:-

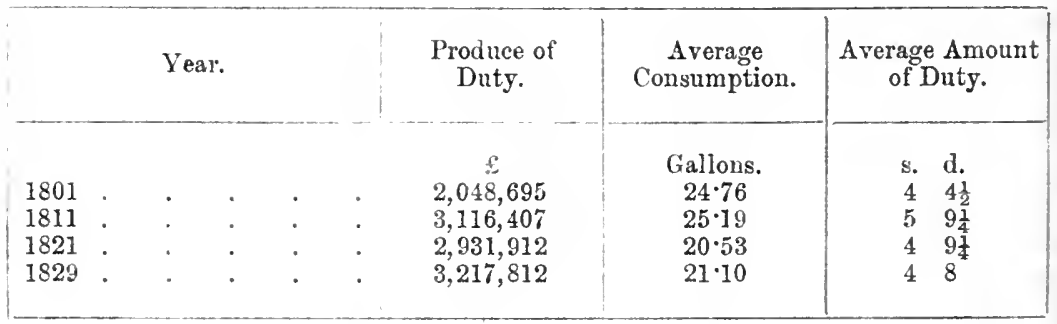

Porter writes: "These figures do not afford a true statement of the consumption of beer by the people, because the duty was paid, and cousequently the account was taken, only with reference to that which was brewed for sale, no duty having ever been charged on beer brewed in private families. It was proposed, in the budget brought forward by Lord Henry Petty in 1807, to subject private families equally to payment of the duty; but such was the amount of selfish clamour raised against this proposal that it was necessarily abandoned. It would no doubt have been an exceedingly vexatious thing for private families to be subject to the visitation of excise officers, and without such surveillance it would not have been possible to prevent a very general evasion of the tax; but this objection leaves untouched all considerations arising from the glaring injustice of the tax, which was necessarily paid by every poor man in the country who consumed beer, while all other classes had the means of relieving themselves from the burden." 
Since 1880 the statistics of consumption are again available, and the following figures, taken from the Board of Trade returns, show the quantity of beer (British) made, consumed and exported every ten years since 1881

\begin{tabular}{|c|c|c|c|c|c|}
\hline \multicolumn{3}{|c|}{ Year ended 31st December. } & $\begin{array}{c}\text { Quantity } \\
\text { made. } \\
\text { Barrels. } \\
2 \pi, 469,26 \pi\end{array}$ & $\begin{array}{l}\text { Quantity } \\
\text { exported. } \\
\begin{array}{c}\text { Barrels.* } \\
502,918\end{array}\end{array}$ & $\begin{array}{c}\text { Quantity } \\
\text { retained for } \\
\text { Home } \\
\text { Consumption. } \\
\text { Barrels. }\end{array}$ \\
\hline $\begin{array}{l}1881 \\
1890 \\
1900 \\
1910\end{array}$ & $\dot{\dot{ }} \cdot \dot{ }$ & $\dot{.}$ & $\begin{array}{c}\text { Barrels. } \\
2 \pi, 469,267 \\
31,835,594 \\
36,668,555 \\
33,470,875\end{array}$ & $\begin{array}{l}\text { Barrels.* } \\
502,918 \\
598,776 \\
591,714 \\
640,802\end{array}$ & $\begin{array}{c}\text { Barrels. } \\
29,966,349 \\
31,236,818 \\
36,076,841 \\
32,834,244\end{array}$ \\
\hline
\end{tabular}

* Includes the quantities shipped to foreign countries as merchandise as well as those taken for ships' stores, etc.

There is a noticeable decrease both in the quantity of beer made and the quantity retained for home consumption during the last ten years. Part of this decrease can be attributed to the increase in the price caused by the increased duties on beer, and to the sugar tax imposed at the time of the South African War. Most of it, however, can be fairly ascribed to more temperate habits, which have been largely brought about by the warnings of the medical profession. The hard drinking traditions of the first fer generations of the nineteenth century seem to be gradually breaking down. The change of taste from heavy to light beer was the first symptom. "For many years past," writes Mr. Baker, "a steady change has been arising in the taste of the beer-drinking public. The old-fashioned, heavily-hopped ales have been practically displaced by highly-hopped, fresh, and bright ales." The German Munich and Pilsner beers have produced popular imitations during the past few years. Another great change in the brewing trade during the last half of the nineteenth century bas been the growing popularity of bottled beers. This is partly owing to the fact that a cask of beer seldom maintains its quality if it is kept on draught for any length of time, as it has to be in a private household, and partly to the fact that the lighter beers are especially suitable for bottling. "The varieties of beer brewed at the present day" are classified by Mr. Baker into strong, medium, and light. "In the strong, we may include stock or old ales and the heavier stouts. The medium comprises the lighter stouts, superior bitter beers, mild or four ale, which latter is still the beverage of the working classes, and porter." 
The retail trade in alcoholic liquors is licensed. The licence to sell liquor for consumption on or off the premises is given for one year by the justices of the peace in return for an annual payment, or licence duty, which is based on the rateable value of the premises. The system is based on the Act of 1828," which provided that justices of the peace should hold special sessions for granting licences for the sale of beer, wines, and spirits." In 1830 , as we have seen, free trade in beer was introduced, and any person was enabled to open his house as $a^{\circ}$ beer-shop on payment of an excise fee of two guineas. Some restrictions were gradually made, and at last in 1869 the Wine and Beer-House Act transferred the granting of new beer-house licences from the excise to the licensing justices. When this Act was passed there were over 9000 fully licensed public-houses and about 49,000 beer-houses, of which over 31,000 remained in 1894 . The proceedings of the licensing justices of to-day are chiefly regulated by the Licensing (Consolidation) Act, 1910, which provides inter alia for the reduction of licensed houses by compensation provided out of the trade. The licence duties on large houses were greatly increased in the Budget of 1909-1910. The revenue from beer since 1882 has been as under:-

\begin{tabular}{|c|c|c|c|c|c|}
\hline & Year. & & Customs. * & Excise. & Total. \\
\hline $\begin{array}{l}1882 \\
1891 \\
1901 \\
1911\end{array}$ & $\dot{.}$ & 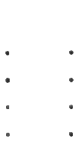 & $\begin{array}{c}£ \\
\ldots \\
\ldots \\
23,190 \\
23,088\end{array}$ & $\begin{array}{c}£ \\
8,530,819 \\
9,390,141 \dagger \\
13,718,438 \\
12,767,217\end{array}$ & $\begin{array}{r}\mathfrak{1} \\
8,530,819 \\
9,390,141 \\
13,741,628 \\
12,790,305\end{array}$ \\
\hline
\end{tabular}

* Not specified separately earlier than 1901.

† Exclusive of additional duties collected for local authorities, which, however, were very small in amount.

The following figures, which are extracted from Mr. Baker's book, show the number of licences taken out by brewers in the United Kingdom between 1899 and 1903 :-

\begin{tabular}{|c|c|c|c|c|c|}
\hline & Year. & & $\begin{array}{c}\text { Prewers' for } \\
\text { sale. }\end{array}$ & $\begin{array}{l}\text { Brewers' not } \\
\text { for sale. }\end{array}$ & Total. \\
\hline $\begin{array}{l}1899 \\
1900 \\
1901 \\
1902 \\
1903\end{array}$ & $\dot{.}$ & $\dot{.}$ & $\begin{array}{l}6,888 \\
6,447 \\
6,110 \\
5,898 \\
5,692\end{array}$ & $\begin{array}{l}14,009 \\
12,734 \\
12,410 \\
11,872 \\
11,752\end{array}$ & $\begin{array}{l}20,897 \\
19,181 \\
18,520 \\
17,770 \\
17,444\end{array}$ \\
\hline
\end{tabular}


The brewing trade has met with varying fortune during the last thirty years. The height of its prosperity was during the years 1898-99, when the price of some brewery securities touched fabulous heights. The boom, however, was largely fictitious, being based on absurd over-valuations of the monopoly given by the State in the form of licences. This monopoly enabled the "tied house" system to be developed. Many large breweries were converted into Joint Stock Companies whose stock proved to have been heavily "watered," and when the lean years came and the English drink bill began to decline in consequence of war taxation, the brewing trade fell upon evil days. The ordiuary and preference shares of nearly all the breweries which had speculated in tied houses collapsed, and thonsauds were ruined. Many even of the debenture holders suffered heavily. Nevertheless the quality of British beer and stout has been maintained by Bass, Guinness, and other leadiug firms. The extent of our export trade in beer and ale during the last fifty years is shown in the following table:-

\begin{tabular}{|c|c|c|c|c|c|c|}
\hline & & & & & Barrels. & $\stackrel{£}{£}$ \\
\hline 1860 & - & - & - & - & 534,827 & $1,868,144$ \\
\hline 1870 & . & - & . & - & 521,199 & $1,881,673$ \\
\hline 1880 & . & . & . & . & 412,192 & $1,733,505$ \\
\hline 1890 & - & . & . & . & 503,221 & $1,874,886^{\circ}$ \\
\hline 1900 & . & . & . & . & 510,843 & $1,760,552$ \\
\hline 1910 & . & . & . & . & 590,346 & $1,793,185$ \\
\hline
\end{tabular}

It will be seen that the quantity exported has remained fairly coustant.

A large and important trade that is subsidiary to brewing is the malt trade. The maltster supplies the brewer with one of the most important of his raw materials. Malt, which is made from barley, has long been used for brewing in this country, but the consumption fell off inaterially during the end of the eighteenth and the beginning of the nineteenth centuries, when compared with the numbers of the people: but it would not be correct to attribute this circumstance wholly to the effect of taxation, although there can be no doubt that the consumption was materially checked by the duty imposed. The introduction of tea and coffee into extensive use throughout the kingdom must necessarily have interfered with the consumption of beer, and the same effect must have followed the increased use of spirits, only a small proportion of which is distilled from malted grain.

The consumption of malt at various periods during the first half of the nineteenth century in the United Kingdom was as follows:- 


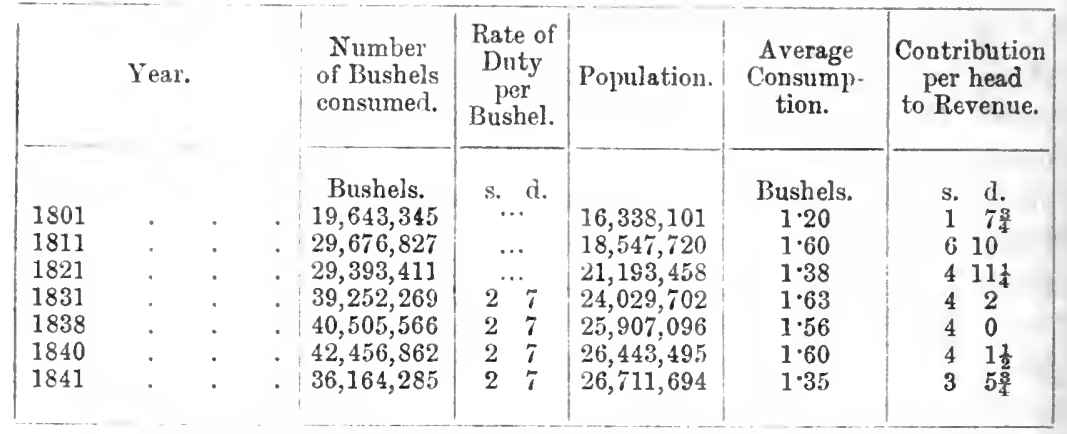

In the eighteenth century the consumption of malt in England was greater, in proportion to the population, than at any subsequent time. The average consumption of each individual in each decennary year, from 1740 to 1790 , was as follows:-

Bushels. Rate of Duty.

\begin{tabular}{|c|c|c|c|c|c|c|}
\hline 1740 & . & . & . & $3 \cdot 78$ & $\begin{array}{ll}\text { s. } & \text { d. } \\
0 & 6 \frac{1}{2} \frac{5}{7}\end{array}$ & per bushel. \\
\hline 1750 & . & . & . & $4 \cdot 85$ & $-2-21$ & 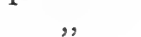 \\
\hline 1760 & . & . & . & $4 \cdot 29$ & $0 \quad 9 \frac{1}{4} \frac{2}{2}^{2}$ & , \\
\hline 1770 & . & . & . & $3 \cdot 38$ & $91 \div$ & , \\
\hline 1780 & . & . & . & $3 \cdot 94$ & $4 \frac{1}{4}$ & , \\
\hline 1790 & . & . & & $25 \%$ &, & ," \\
\hline
\end{tabular}

A great increase of consumption during the fifteen years from 1835 to 1850 was occasioned by the repeal of the duty on beer, which, while it existed, was, in fact, an additional duty on malt. The number of bushels used, and the proportion when compared with the population from 1830 to 1845 , were as follow:-

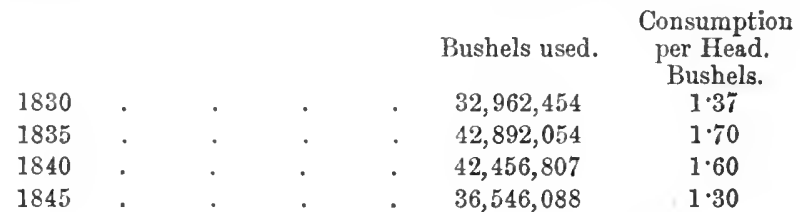

The quantity of malt, sugar, and other important ingredients used in brewing since 1880 has been as under:-

\begin{tabular}{|c|c|c|c|c|c|}
\hline Years. & $\begin{array}{l}\text { Malt and } \\
\text { Corn. }\end{array}$ & $\begin{array}{l}\text { Sugar (including } \\
\text { equivalents of } \\
\text { Syrups, Glucose, } \\
\text { and Saccharine). }\end{array}$ & $\begin{array}{c}\text { Rice, Rice Grits, } \\
\text { Flaked Rice, } \\
\text { Maize Grits, } \\
\text { Flaked Maize, etc. }\end{array}$ & Hops. & $\begin{array}{l}\text { Hop Sub- } \\
\text { stitutes. }\end{array}$ \\
\hline $\begin{array}{l}1880-1881 . \\
1890-1891 . \\
1900-1901 . \\
1909-1910 .\end{array}$ & $\begin{array}{c}\text { Bushels. } \\
\ldots \ddot{ } \\
55,698,523 \\
56,792,028 \\
50,068,856\end{array}$ & $\begin{array}{c}\text { cwt. } \\
1,125,342 \\
2,025,659 \\
2,859,091 \\
2,910,076\end{array}$ & $\begin{array}{c}\text { cwt. } \\
\cdots \\
\ldots \\
1,325,754 \\
1,293,738\end{array}$ & $\begin{array}{c}\mathrm{lb} . \\
\cdots \\
\cdots \\
\cdots \\
61,739,796\end{array}$ & $\begin{array}{c}l \mathrm{lb} . \\
\cdots \\
\cdots \\
\ldots \\
4,053\end{array}$ \\
\hline
\end{tabular}




\section{WINE}

Wine, owing chietly to its costliness in this country caused by the heavy duties imposed, has never been consumed by the working classes. The nobility and gentry drank very heavily in the eighteenth and the early part of the nineteenth century, port and claret being their favourite wines. But after the first few decades of the nineteenth century the quantity of wine drunk began to decrease steadily.

The quantity of all descriptions of wine used in the United Kingdom at different periods from 1801 to 1841 was as follows, distinguishing Great Britain from Ireland:-

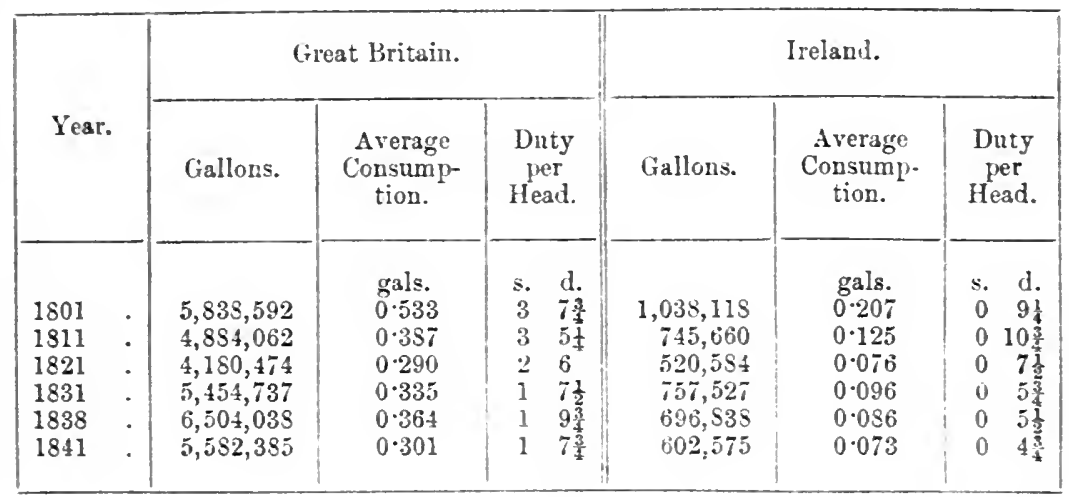

The average consumption, and the amount of duty contributed per head, in the whole kingdom, in the same years, were-

\begin{tabular}{|c|c|c|c|c|c|c|c|}
\hline \multicolumn{2}{|r|}{ Year. } & $\begin{array}{l}\text { Average } \\
\text { Consump- } \\
\text { tion. }\end{array}$ & $\begin{array}{l}\text { Duty } \\
\text { per } \\
\text { Head. }\end{array}$ & \multicolumn{2}{|c|}{ Year. } & $\begin{array}{c}\text { Averagse } \\
\text { Consump- } \\
\text { tion. }\end{array}$ & $\begin{array}{l}\text { Duty } \\
\text { yer } \\
\text { Head. }\end{array}$ \\
\hline $\begin{array}{l}1801 \\
1811 \\
1821\end{array}$ & : & $\begin{array}{l}\text { gals. } \\
0 \cdot 431 \\
0 \cdot 304 \\
0 \cdot 221\end{array}$ & $\begin{array}{cc}\text { s. } & d . \\
2 & 8 \\
2 & 7 \\
1 & 10 \frac{3}{3}\end{array}$ & $\begin{array}{l}1831 . \\
1541 .\end{array}$ & . & $\begin{array}{l}\text { gals. } \\
0 \cdot 255 \\
0.267\end{array}$ & $\begin{array}{ll}s . & d \\
i & 31 \\
1 & 4\end{array}$ \\
\hline
\end{tabular}

A table on the next page shows the rates of duty per imperial gallon between 1801 and 1841 .

As stated before, the consumption of wine in the eighteenth century was much greater in proportion to the population than in the nineteenth. In 1700 the arerage annual consumption of each individual in England and Wales amounted to a very small îraction 


\begin{tabular}{|c|c|c|c|c|c|c|}
\hline & \multirow{2}{*}{ Year. } & & \multicolumn{2}{|c|}{ Great Britain. } & \multicolumn{2}{|c|}{ Ireland. } \\
\hline & & & French. & Other Kinds. & French. & Other Kinds. \\
\hline $\begin{array}{l}1801 \\
1811 \\
1821 \\
1831 \\
1841\end{array}$ & $\dot{.}$ & : & $\begin{array}{rl}\text { s. } & \text { d. } \\
10 & 2 \frac{1}{2} \\
13 & 8 \frac{1}{2} \\
13 & 9 \\
5 & 6 \\
5 & 6\end{array}$ & $\begin{array}{ll}\text { s. } & \text { d. } \\
6 & 9 \frac{3}{4} \\
9 & 1+\frac{1}{4} \\
9 & 1 \frac{1}{4} \\
5 & 6 \\
5 & 6\end{array}$ & $\begin{array}{rc}\text { s. } & \text { d. } \\
6 & 11 \\
10 & 6 \\
13 & 9 \\
5 & 6 \\
5 & 6\end{array}$ & $\begin{array}{cc}\text { s. } & \text { d. } \\
3 & 11 \\
7 & 0 \frac{1}{2} \\
9 & 1 \frac{1}{4} \\
5 & 6 \\
5 & 6\end{array}$ \\
\hline
\end{tabular}

below an imperial gallon, while in the middle of the nineteenth century it scarcely exceeded one-fourth of that quantity.

It appears from official accounts printed by the French government in the early part of the nineteenth century, that the quantity of wine made in France in years of ordinary or average production amounted to $924,000,000$ imperial gallons. Of this quantity $24,530,000$ gallons were exported to foreign countries, only a very small proportion of which was consumed in this kingdom. In former times the taste of Englishmen led them to a far greater proportionate use of French wine, but by the ill-judged Methuen Treaty, concluded in 1703, whereby we bound ourselves to impose 50 per cent. higher duties on the wine of France than on that of Portugal, a great change in this respect was gradually brought about, so that the consumption of French wine was in time reduced to a quantity altogether insignificant. The Methuen Treaty ceased to operate in 1831, and thenceforward the duty charged upon wines the growth of all foreign countries was equalized, and the proportionate consumption of French wine increased in consequence; and further encouragement was given by the Cobden Treaty of 1860 , which reduced the duties on light wines. From that time cheap claret, Moselle and hock came more and more into fashion, port and sherry declining in favour.

The quantity of French wine of all qualities sold for consumption in the United Kingdom from 1815 to 1845 , and the rates of duty chargeable, were as follow :-

\begin{tabular}{|c|c|c|c|c|c|c|}
\hline Year. & & Gallons. & Per Gallon. & Year. & Gallons. & Per Gallon. \\
\hline $\begin{array}{l}1815 \\
1825\end{array}$ & : & $\begin{array}{l}200,918 \\
525,579\end{array}$ & $\begin{array}{rl}\text { s. } & \text { d. } \\
13 & 8 \frac{1}{2} \\
7 & 2 \frac{1}{2}\end{array}$ & $\begin{array}{l}1835 \\
1845\end{array}$ & $\begin{array}{l}271,661 \\
469,001\end{array}$ & $\begin{array}{ll}\text { s. } & \text { d. } \\
5 & 6 \\
5 & 6\end{array}$ \\
\hline
\end{tabular}


The increased rate of consumption in the later years of the series amounted to no more than one gallon per annum among sixty people.

The following figures show the imports of wine into the United Kingdom every ten years from 1850 to 1910 :-

Wine

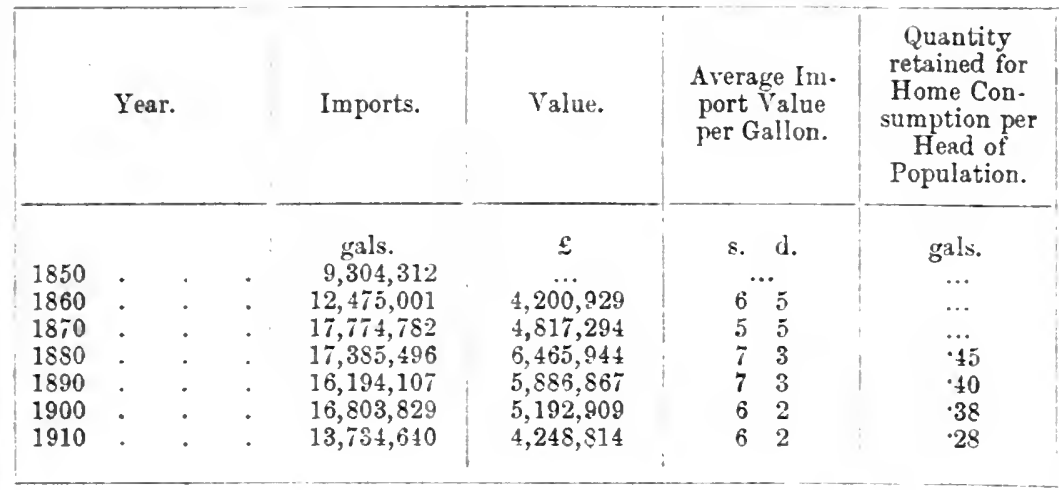

It will be seen that our imports of wine since 1870 have declined actually, as well as relatively. The decrease in consumption that was noticeable for the first half of the nineteenth century was continued during the secoud, after the temporary stimulus given by the French Treaty. England has also a fairly large re-export trade in wine. The figures are as under. The quantity of wine retained for home consumption is shown as well:-

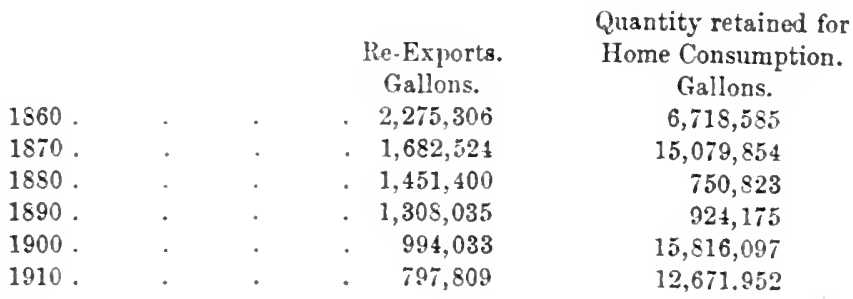

In 1909 , out of a total import of $12,334,473$ gallons, $11,333,742$ gallons came from foreign countries, while the remaining $1,000,731$ gallons came from the British Empire. Our imports of wine from France were highest and amounted to $3,647,037$ gallons; but the Spanish imports came very close and amounted to $3,252,222$ gallons. Portugal sent us 2,978,28t gallons; Germany, 818,608 gallons; South Australia, 490,848 gallons; and Victoria, 363,766 gallons. In $1909,1,251,715$ gallons of sparkling wines in bottles were im- 
ported, and of this total 1,037,025 gallons were champagne, the remainder being made up of 98,769 gallons of Saumur, 11,676 gallons Burgundy, 24,385 gallons of hock, 66,617 gallons of Moselle, and 13,243 gallons of other sorts. The customs duty on wine produces less revenue now than in 1850 , despite an enormous increase in wealth and population.

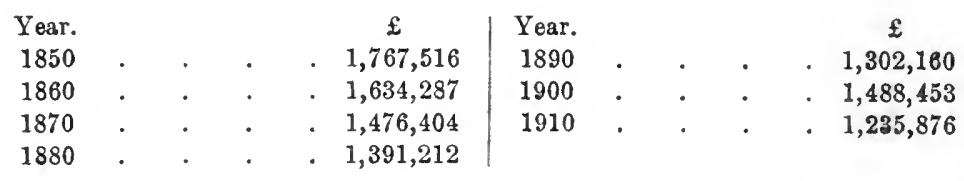

\section{SPIRITS}

The worst evils and the worst consequences of intemperance -lunacy, crime, and pauperism-spring mainly from spirit drinking, and indeed the "free trade legislation" of 1830 favouring beer was partly designed in order to counteract the growth of spirit drinking. The growing taste for Irish and still more for Scotch whisky is partly responsible, no doubt, for the decline which we have noticed in the consumption of wine and beer. But the extra tax on spirits imposed by the 1909 Budget had a counteracting effect. Gin is less popular than formerly, when the gin palaces of East London were so notorious. The best brandy and rum have always been imported into this country, the former from France and the latter from the British West Indies and British Guiana.

The following table from Porter's Progress of the Nation shows the consumption of spirits at various years in the first half of the nineteenth century :-

\begin{tabular}{|c|c|c|c|c|c|c|}
\hline & Year. & $\begin{array}{l}\text { Number of } \\
\text { Gallons. }\end{array}$ & $\begin{array}{l}\text { Rate of } \\
\text { Duty per } \\
\text { Gallon. }\end{array}$ & Population. & $\begin{array}{c}\text { Average } \\
\text { Con- } \\
\text { sumption. }\end{array}$ & $\begin{array}{l}\text { Coutribution } \\
\text { per Head } \\
\text { to Revenue. }\end{array}$ \\
\hline $\begin{array}{c}\text { United } \\
\text { Kingdom }\end{array}$ & $\begin{array}{l}1802 \\
1812 \\
1821 \\
1831 \\
1838 \\
1840 \\
1841\end{array}$ & $\begin{array}{r}\text { gals. } \\
9,338,036 \\
9,213,795 \\
9,822,573 \\
21,845,408 \\
26,486,543 \\
21,859,337 \\
20,642,333\end{array}$ & $\begin{array}{c}\text { s. d. } \\
\ldots \\
\ldots \\
\ldots \\
\ldots \\
\ldots \\
\ldots \\
\ldots\end{array}$ & $\begin{array}{l}16,560,864 \\
18,812,294 \\
21,193,458 \\
24,029,702 \\
25,907,096 \\
26,443,495 \\
26,711,694\end{array}$ & $\begin{array}{l}\text { gals. } \\
0.56 \\
0.49 \\
0.46 \\
0.90 \\
1.02 \\
0.82 \\
0.77\end{array}$ & $\begin{array}{lr}\text { s. } & \text { d. } \\
2 & 3 \\
3 & 94 \\
2 & 11 \frac{1}{4} \\
4 & 3 \frac{1}{4} \\
4 & 2 \frac{1}{2} \\
3 & 11 \frac{1}{4} \\
3 & 10 \frac{1}{4}\end{array}$ \\
\hline
\end{tabular}

Porter, writing on the consumption of spirits in Ireland early in the nineteenth century, refers the falling off in the con- 
sumption of spirits in Ireland in the years 1840 and 1841 to one of the most remarkable events of his day. "It resulted entirely from the efforts of one man," the Rev. Theobald Mathew, a Catholic clergyman, who availed himself of his power of influencing his fellow-men to produce a sudden change in the habits of vast numbers, reclaiming them for a time from the vice of drunkenness and its accompanying evils to an extent which only the clearest evidence could have induced us to think possible. "Father Mathew, to use the name by which he is generally known, aware of the command over themselves which many of his countrymen have occasionally exhibited in keeping their vows to abstain for some limited time from the use of intoxicating liquors, led vast numbers of them to pledge themselves so to abstain, not indeed for all future time, but until they should formally signify to him their intention of recurring to the use of whisky." The extent of his influence was shown by the following figures, giving the quantity of spirits distilled in Ireland, and the revenue collected thereon, in each of the five years from 1837 to 1841 :-

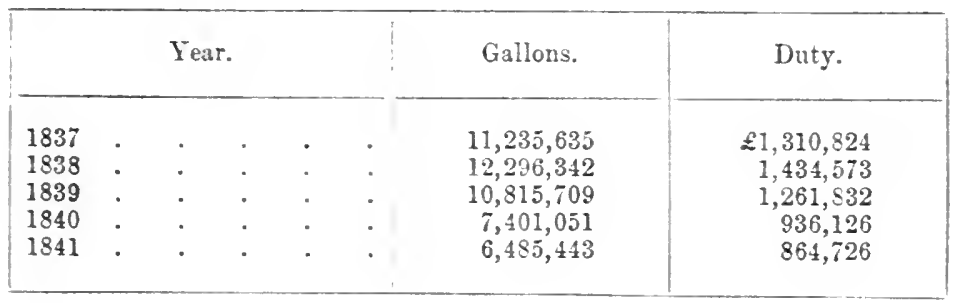

"The consumption of colonial and foreign spirits in Scotland and Ireland," continues Porter, "has at all times been small in comparison with the use of those articles in England." By 1845 home-made spirits had almost wholly taken the place of rum and brandy in Scotland and Ireland. Of 2,277,970 gallons of rum and $1,186,104$ gallons of foreign spirits on which consumption duty was paid in 1841 , there were $2,217,073$ gallons of rum and 1,127,849 gallons of brandy and Geneva used in England.

The diminished consumption of foreign spirits observable in 1812 was occasioned by the war at that time carried on with all the countries of Europe, which for some time wholly shut out from our ports the produce of France and Holland. When trade was resumed, it was kept down by heavy duties protecting homemade spirits. In 1802 , with a duty of $11 \mathrm{~s} .4 \frac{3}{4} \mathrm{~d}$. per imperial gallon, the arerage consumption of each person in England some- 
what exceeded one-fifth of a gallon; while in 1841, with a duty of $22 \mathrm{~s} .10 \mathrm{~d}$, per gallon, the average consumption was scarcely more than one-third of that quantity. The evil, said Porter, was "partially counteracted through the agency of contraband traders," but this temptation to smuggling was diminished in 1846 , when the duty on foreign spirits was reduced from $22 \mathrm{~s}$. $10 \mathrm{~d}$. to $15 \mathrm{~s}$. per gallon.

The revenue derived from the consumption of foreign spirits amounted in 1800 to $£ 1,382,718$, when the rate of duty was 11s. 1d. per imperial gallon. In 1841, with that rate advanced to $22 \mathrm{~s}$. $10 \mathrm{~d}$. per gallon, the revenue amounted to no more than $£ 1,354,079$; the sum which it should have yielded, according to the increased rate and the additional population, was $£ 3,840,279$, being $£ 2,465,767$ or 179 per cent. beyond the amount really collected. The effect of the reduction in 1846 was quickly felt. From 1,073,778 gallons of foreign spirits in 1845 the consumption rose to $2,214,275$ in 1849 ; and the revenue grew from

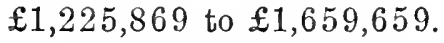

The quantities of rum and foreign spirits imported in ten-yearly periods between 1802 and 1841 was as under:-

Rum

\begin{tabular}{|c|c|c|c|c|c|c|}
\hline & Year. & Gallons. & $\begin{array}{l}\text { Rate of } \\
\text { Duty per } \\
\text { Gallon. }\end{array}$ & Population. & $\begin{array}{c}\text { Avelage } \\
\text { Con- } \\
\text { sumption. }\end{array}$ & $\begin{array}{l}\text { Contribution } \\
\text { per Head to } \\
\text { the Revenue. }\end{array}$ \\
\hline $\begin{array}{l}\text { United } \\
\text { Kingdom }\end{array}$ & $\begin{array}{l}1802 \\
1812 \\
1821 \\
1831 \\
1841\end{array}$ & $\begin{array}{l}3,310,065 \\
3,775,169 \\
2,324,315 \\
3,624,597 \\
2,277,970\end{array}$ & $\begin{array}{c}\text { s. d. } \\
\ldots \\
\ldots \\
\ldots \\
\ldots \\
\ldots\end{array}$ & $\begin{array}{l}16,560,864 \\
18,812,294 \\
21,193,458 \\
24,029,702 \\
26,711,694\end{array}$ & $\begin{array}{l}\text { gals. } \\
0 \cdot 20 \\
0 \cdot 20 \\
0 \cdot 11 \\
0 \cdot 15 \\
0 \cdot 09\end{array}$ & $\begin{array}{ll}\text { s. } & \text { d. } \\
1 & 84 \\
2 & 8 \\
1 & 6 \\
1 & 4 \\
0 & 9 \frac{1}{2}\end{array}$ \\
\hline
\end{tabular}

Foreign Spirits

\begin{tabular}{|c|c|c|c|c|c|}
\hline & Year. & Gallons. & $\begin{array}{l}\text { Rate of } \\
\text { Duty per } \\
\text { Gallon. }\end{array}$ & $\begin{array}{c}\text { Average } \\
\text { Consumption } \\
\text { per Head. }\end{array}$ & $\begin{array}{c}\text { Contribution } \\
\text { per Head to } \\
\text { the Revenue. }\end{array}$ \\
\hline $\begin{array}{l}\text { United } \\
\text { Kingdom }\end{array}$ & $\begin{array}{l}1802 \\
1812 \\
1821 \\
1831 \\
1841\end{array}$ & $\begin{array}{r}2,431,577 \\
195,693 \\
1,013,400 \\
1,268,198 \\
1,186,104\end{array}$ & $\begin{array}{cc}\text { s. } & \text { d. } \\
\ldots & \\
\ldots & \\
\ldots & \\
22 & 6 \\
22 & 10\end{array}$ & $\begin{array}{l}\text { gals. } \\
0.150 \\
0.010 \\
0.049 \\
0.050 \\
0.044\end{array}$ & $\begin{array}{cr}\text { s. } & \text { d. } \\
1 & 8 \frac{1}{4} \\
0 & 3 \frac{1}{4} \\
0 & 11 \frac{3}{4} \\
1 & 1 \frac{1}{2} \\
1 & 0\end{array}$ \\
\hline
\end{tabular}


The records of the quantity of spirits manufactured in this country have only been kept since 1880 . The figures are as under :

\section{Spirits (British)}

\begin{tabular}{|c|c|c|c|c|c|}
\hline \multirow{2}{*}{$\begin{array}{c}\text { Year } \\
\text { ended 31st } \\
\text { December. }\end{array}$} & \multirow{2}{*}{$\begin{array}{l}\text { Quantity } \\
\text { Made. }\end{array}$} & \multirow{2}{*}{$\begin{array}{l}\text { Quantity } \\
\text { Exported. }\end{array}$} & \multicolumn{2}{|c|}{$\begin{array}{l}\text { Quantity retained for } \\
\text { Home Consumption. }\end{array}$} & \multirow{2}{*}{$\begin{array}{l}\text { Quantity of } \\
\text { British Spirits } \\
\text { retained in } \\
\text { Bond at the } \\
\text { end of the } \\
\text { Year. }\end{array}$} \\
\hline & & & Potable.* & Methylated. & \\
\hline 1880 & $\begin{array}{c}\text { Proof gals. } \\
\ldots\end{array}$ & $\begin{array}{r}\text { Proof gals. } \\
2,718,638\end{array}$ & $\begin{array}{l}\text { Proof gals. } \\
\qquad 29,0\end{array}$ & $\begin{array}{l}\text { Proof gals. } \\
7,303\end{array}$ & $\begin{array}{c}\text { Proof gals. } \\
\ldots\end{array}$ \\
\hline $\begin{array}{l}1890 \\
1900 \\
1910\end{array}$ & $\begin{array}{l}43,508,130 \\
57,228,031 \\
40,974,601\end{array}$ & $\begin{array}{r}3,922,628 \\
6,219,782 \\
10,323,638\end{array}$ & $\begin{array}{l}29,410,431 \\
3 \pi, 125,241 \\
24,02 \tau, 032\end{array}$ & $\begin{array}{l}2,118,703 \\
5,028,738 \\
6,594,307\end{array}$ & $\begin{array}{r}86,313,357 \\
158, \$ 58,410 \\
149,524,683\end{array}$ \\
\hline
\end{tabular}

* Includes the quantities shipped to foreign countries as merchandise as well as those taken for ships' stores.

As in the case of beer the quantity of spirits made during the last ten years has decreased. The reason for this decrease is the same in both cases, namely, the more temperate habits of the English nation during the present century which have been encouraged by the increased duties, medical advice, and the improvement of other beverages. The same phenomenon is observable in the quantity of imported spirits retained for consumption in this country, as the following figures indicate:-

Spirits (Potable). Imported and Retained for Home Consumption

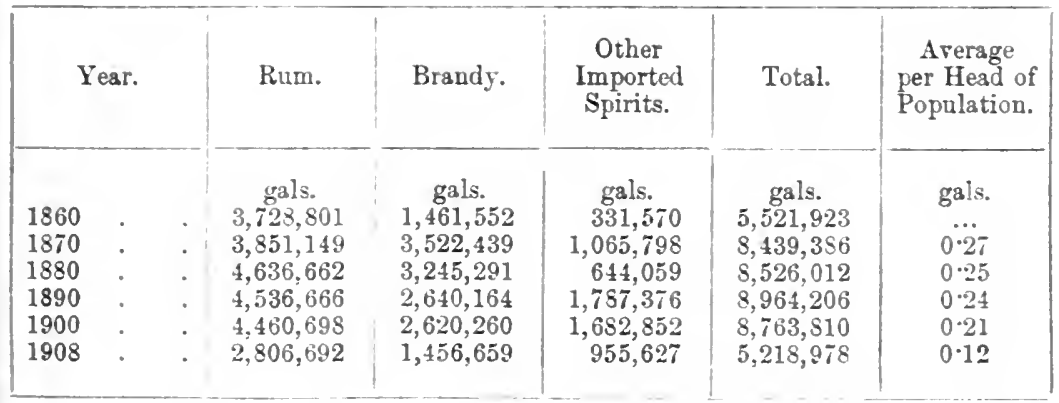

There is a large export and re-export trade in spirits from this country. The principal article exported being whisky. 
Our exports in ten-yearly periods from 1860 to 1910 were as under:-

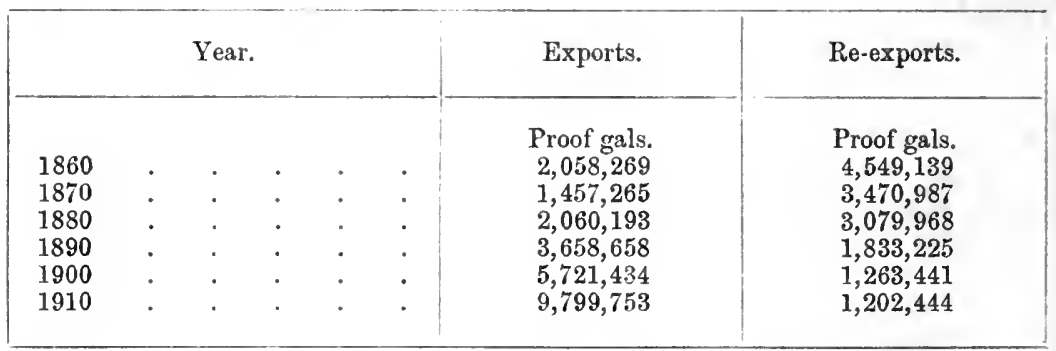

While our export trade in spirits has increased, it is noticeable that our re-export trade has diminished rapidly.

The amount of revenue derived from the spirit duty during the past fifty years has been as under:-

\begin{tabular}{|c|c|c|c|c|c|c|}
\hline & Year. & & & Customs. & Excise. & Total. \\
\hline $\begin{array}{l}1860 \\
1870 \\
1880 \\
1890 \\
1900 \\
1910\end{array}$ & $\begin{array}{l}: \\
: \\
:\end{array}$ & : & $\dot{5}$ & $\begin{array}{c}\mathfrak{E} \\
2,523,654 \\
4,191,400 \\
4,682,927 \\
4,681,225 \\
4,987,787 \\
4,298,484\end{array}$ & $\begin{array}{r}\mathfrak{E} \\
9,778,960 \\
10,969,189 \\
13,631,785 \\
13,860,002 \\
20,124,003 \\
18,751,206\end{array}$ & $\begin{array}{c}\mathfrak{E} \\
12,302,614 \\
15,160,589 \\
18,314,612 \\
18,541,227 \\
25,111,790 \\
23,049,690\end{array}$ \\
\hline
\end{tabular}

The rapid increase in the yield of the excise revenue, while the customs revenue has decreased slightly, speaks well for the efficiency of the British spirit industry.

\section{ToBACco}

Tobacco is now so generally consumed, and the habit of smoking so firmly ingrained, that it is difficult to imagine that only about three and a half centuries ago Europeans were ignorant of its existence. As is well known, tobacco is an American plant, and tradition links the name of Sir Walter Raleigh with its discovery. As is often the case, tradition is not strictly accurate. To Sir Francis Drake, and not Sir Walter Raleigh, probably, belongs the honour of its introduction in 1585 from Virginia into England. Hernandez de Toledo had brought it to Spain and Portugal a quarter of a century earlier, and it was not long before the new habit of smoking spread over most of Europe and into parts of Asia as well. 
In spite of royal and other attempts to discourage smokingnotable among which is James I's famous "counterblast against tobacco" - the English rapidly acquired the habit, and now, although not such great smokers as many other nations, consume some 90 million lb. annually.

Although tobacco is American in its origin, and the United States is still by far the largest tobacco grower, the plant is successfully cultivated in other countries-but not in the United Kingdom, though some experiments have been made in Ireland. The following figures, which are averages for the years 1900 to 1903 , indicate the quantities and value of the tobacco produced by the chief tobacco-growing countries:-

\section{Production of Tobacco}

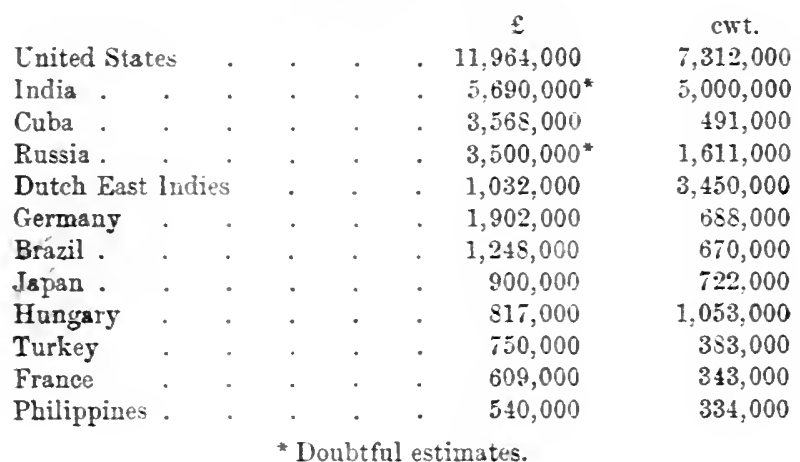

These figures show very clearly from which countries the higher grades of tobacco come. For instance, the 7 million odd cwt. grown in the United States were worth about 12 million pounds, while the five hundred thousand cwt. grown in Cuba were worth three and a half milliou pounds; for it is Cuba, of course, that supplies the rich men of the world with their cigars.

It is not until the nineteenth century, however, that any statistics are available as to the consumption of tobacco. The quantity of tobacco upon which consumption duty was paid at the middle of the nineteenth century was considerably less, taking the kingdom throughout, and making allowance for the increased population, than at the beginning of that century. This was clearly attributable to the increase made in the rate of duty. The falling off in the consumption was principally experienced in Ireland, where the smoking of tobacco had long been a chief luxury among the working classes, and where, considering the few 
comforts that usually fall to their lot, its diminution betokened a great degree of privation. In Great Britain, where the condition of the people generally was more satisfactory than in Ireland, the consumption per head remained about what it was at the beginning of the century, and the contribution to the revenue was consequently more in agreement with the increased rate of the duty.

The following figures show the consumption of, and duty on, tobacco from 1801 to 1841 in ten-yearly periods:-

\begin{tabular}{|c|c|c|c|c|c|c|}
\hline & Year. & $\begin{array}{c}\text { Pounds } \\
\text { Weight } \\
\text { cousumed. }\end{array}$ & $\begin{array}{c}\text { Duty } \\
\text { per } \\
\text { Pound. }\end{array}$ & $\begin{array}{c}\text { Amount } \\
\text { of } \\
\text { Duty. }\end{array}$ & $\begin{array}{l}\text { Average } \\
\text { Yearly } \\
\text { Con- } \\
\text { sumption. }\end{array}$ & $\begin{array}{c}\text { Average } \\
\text { Contribution } \\
\text { to the } \\
\text { Revenue. }\end{array}$ \\
\hline $\begin{array}{l}\text { Great } \\
\text { Britain }\end{array}$ & $\begin{array}{l}1801 \\
1811 \\
1821 \\
1831 \\
1841\end{array}$ & $\begin{array}{c}\text { lb. } \\
10,514,998 \\
14,923,243 \\
12,983,198 \\
15,350,018 \\
16,830,593\end{array}$ & $\begin{array}{ll}\text { s. } & \text { d. } \\
1 & 7 \frac{6}{20} \\
2 & 2 \frac{3}{20} \\
4 & 0 \\
3 & 0 \\
& 0\end{array}$ & $\begin{array}{c}£ \\
923,855 \\
1,710,848 \\
2,600,415 \\
2,338,107 \\
2,716,217\end{array}$ & $\begin{array}{c}\text { oz. } \\
15 \cdot 37 \\
18 \cdot 95 \\
14 \cdot 43 \\
14 \cdot 84 \\
14 \cdot 52\end{array}$ & $\begin{array}{rr}\text { s. } & \text { d. } \\
1 & 8 \frac{1}{4} \\
2 & 8 \frac{1}{2} \\
3 & 7 \frac{3}{8} \\
2 & 9 \frac{7}{8} \\
2 & 11 \frac{7}{8}\end{array}$ \\
\hline
\end{tabular}

It is made evident by these figures that the duty of $4 \mathrm{~s}$. per $1 \mathrm{~b}$. was excessive. The advance to that rate from $2 \mathrm{~s}$. $2 \mathrm{~d}$. caused a diminished comsumption to the extent of one-fourth, and the revenue per head which, had the consumption not been lessened, would have been $4 \mathrm{~s} .10 \frac{1}{2} \mathrm{~d}$, , amounted to only $3 \mathrm{~s}$. $7 \frac{3}{8} \mathrm{~d}$.

We next give similar figures for Ireland and the United Kingdom :-

\begin{tabular}{|c|c|c|c|c|c|c|}
\hline & Year. & $\begin{array}{c}\text { Pounds } \\
\text { Weight } \\
\text { consumed. }\end{array}$ & $\begin{array}{c}\text { Duty } \\
\text { per } \\
\text { Pound. }\end{array}$ & $\begin{array}{c}\text { Amount } \\
\text { of } \\
\text { Duty. }\end{array}$ & $\begin{array}{l}\text { Average } \\
\text { Yearly } \\
\text { Con- } \\
\text { sumption. }\end{array}$ & $\begin{array}{c}\text { Average } \\
\text { Contribution } \\
\text { to the } \\
\text { Revenue. }\end{array}$ \\
\hline $\begin{array}{c}\text { United } \\
\text { Kingdom }\end{array}$ & $\begin{array}{l}1801 \\
1811 \\
1821 \\
1831 \\
1841 \\
1801 \\
1811 \\
1821 \\
1831 \\
1841\end{array}$ & $\begin{array}{r}\text { lb. } \\
6,389,754 \\
6,453,024 \\
2,614,954 \\
4,183,823 \\
5,478,767 \\
16,904,752 \\
21,376,267 \\
15,598,152 \\
19,533,841 \\
22,309,360\end{array}$ & $\begin{array}{ll}\text { s. } & \text { d. } \\
1 & 0^{*} \\
1 & 7 \\
3 & 0 \\
3 & 0 \\
3 & 0 \\
3 & 0 \\
\ldots & \\
\ldots & \\
\ldots & \\
\ldots & \\
\ldots & \end{array}$ & $\begin{array}{c}\mathfrak{£} \\
285,482 \\
552,082 \\
528,168 \\
626,485 \\
863,946 \\
1,209,337 \\
2,262,930 \\
3,122,583 \\
2,964,930 \\
3,580,164\end{array}$ & $\begin{array}{r}\text { oz. } \\
18 \cdot 95 \\
17 \cdot 35 \\
6 \cdot 15 \\
8 \cdot 61 \\
10 \cdot 71 \\
16 \cdot 05 \\
18 \cdot 44 \\
11 \cdot 77 \\
12 \cdot 85 \\
13 \cdot 36\end{array}$ & $\begin{array}{cc}\text { s. } & d . \\
1 & 0 \frac{3}{4} \\
1 & 10 \frac{1}{4} \\
1 & 6 \frac{1}{2} \\
1 & 7 \frac{1}{4} \\
2 & 0 \\
1 & 5 \frac{3}{4} \\
2 & 5 \frac{1}{4} \\
2 & 11 \frac{4}{4} \\
2 & 5 \frac{1}{4} \\
2 & 8\end{array}$ \\
\hline
\end{tabular}

Owing to the enormous duties on tobaceo (which have recently been increased, and are by weight not by value), tobacco has always been a favourite article of contraband, and smuggling still goes on. 
According to a French statistician, the amount of tobacco consumed per head of the population of the principal countries of the world in 1910 is as under:-

\begin{tabular}{|c|c|c|c|c|c|c|c|}
\hline Holland . & . & $\begin{array}{c}\text { lb. } \\
\tau \cdot 48\end{array}$ & Austria & - & . & . & $\begin{array}{l}\text { lb. } \\
2 \cdot 97\end{array}$ \\
\hline United States & . & . $4 \cdot 62$ & Canada & . & . & . & $2 \cdot 31$ \\
\hline Argentina . & . & . $3 \cdot 80$ & France & . & . & . & $2 \cdot 07$ \\
\hline Belginm . & . & . $3 \cdot 03$ & Russia & & . & . & - $2 \cdot 00$ \\
\hline Germany & . & . $3 \cdot 27$ & United & ngdom & & . & . $2 \cdot 02$ \\
\hline Australia . & . & . 3.08 & & & & & \\
\hline
\end{tabular}

If these French estimates can be relied upon-and the British figure comes from the Board of Trade-the United Kingdom stands very low on the list of the nations that are large smokers. This may be ascribed partly to the duties on tobacco and partly to the popularity of the pipe, partly to the fact that English women hardly smoke at all. The pipe is not only healthier than cigars, it is also far more economical; for the same weight of tobacco lasts the pipe smoker far longer than the man who puffs away cigars and cigarettes. All our tobacco is imported, and 90 per cent. of it still comes from the United States, the most popular kinds being Kentucky and Virginia tobaccos. Holland supplies about 5 per cent., Turkey and Germany about 1 per cent. each. The best cigars come from Cuba, and as the duty is by weight it is a negligible part of the price.

The price of tobacco in England, apart from duties, has, on the whole, risen during the last sixty years, more especially at the beginning and end of the period, as the following figures of nincyearly average prices will show. They are taken from tables published by Messrs. W. O. Muller \& Co.:-

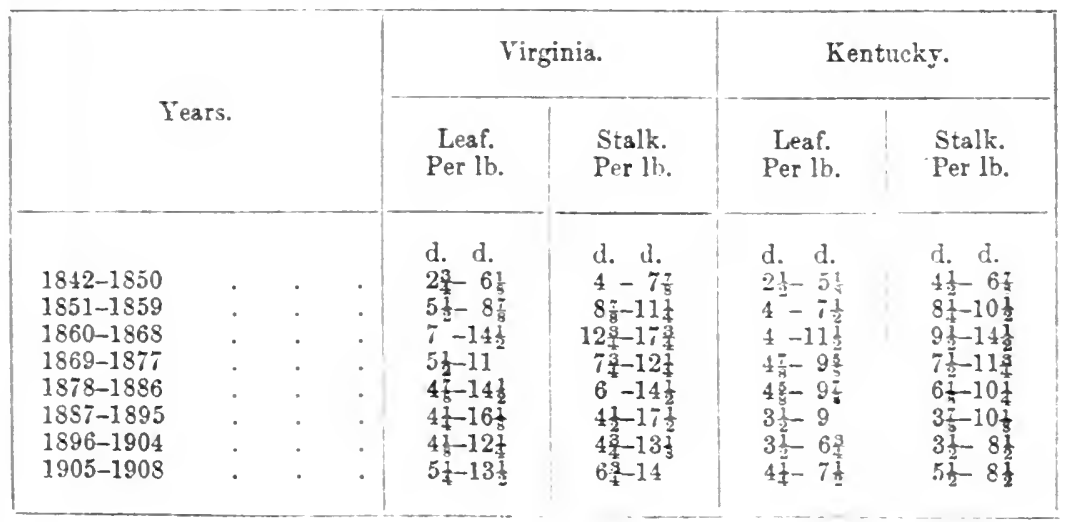


The later rise may be partly due to the Imperial Tobacco Company, which was formed in 1902. The history of the formation of this company is one of the most romantic in the annals of modern commerce. About 1900 the American Tobacco Trust, which had completely subjugated the American market, began to invade the English market. They commenced operations by buying the business of Messrs. Ogden. This invasion of their preserves seriously alarmed British tobacco manufacturers, and about fifteen of the largest-amongst whom W. D. \& H. O. Wills, Limited, John Player \& Sons, Limited, F. \& J. Smith were conspicuous-formed the Imperial Tobacco Company (of Great Britain and Ireland), with

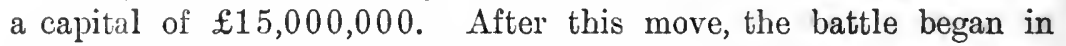
earnest, and both sides tried to outbid one another by the cutting of prices and distribution of bonuses among retailers. Ultimately an agreement was come to, the main features of which were that the Imperial Tobacco Company was to remain unmolested in the English market, while the American Combine was freed from their competition in foreign markets. 


\section{CHAPTER XXVI}

\section{A VIEW OF OUR FOREIGN COMMERCE AND NAVIGA- IION IN THE FIRST HALF OF THE NINETEENTH CENTURY 1}

Dependence of various countries upon each other for comforts and conveniencesPeculiar adrantages of England for prosecuting foreign commerce-Effect of wars and commercial systems upon foreign trade-Growing importance of its commerce to England-Influence of extended markets in preventing ruinous fluctuations-The corn laws-Progress of foreign and colonial trade, from 1801 to 1549 -Conrse of trade with rarious countries-Opeuing of East India and China trades-Discriminating duties on sugar-on coffee-on timber-Continental srstem-Return of peaceFree Trade petition of London merchants--Relaxation of Navition Acts-Reciprocity tresties-Registered tonnage-Shil's built-Ships entered and cleared, 1501-1849.

THERE are but few countries so circumstanced with regard to their natural capabilities of soil and climate as to be independent of all other countries for the supply of many of those productions which have become necessary to the comfort, if indeed they be not indispensable requisites to the well-being, of their inhabitants. England is assuredly not one of those countries, and foreign commerce is to its inhabitants a thing of social, if not of physical, necessity. But for our traffic in foreign productions, even the home trade of England would lack a great part of its activity, because, as regards what is yielded by our own soil, each part of the kingdom is nearly independent of every other part. The south has no need to draw its supplies of grain from the north, nor does the west require to receive the cattle bred in the east. With respect to our minerals, a great part even of these are found in different and distant parts of the island; so that in almost every case that part of the produce of our industry which exceeds in each particular branch the wants of the population engaged for its supply must seek a market in other countries, and he there exchanged for edition.

'Reprinted with some abbreriations from Porter's Progress of the Nation, 1851 
such articles of convenience as Nature refuses to yield to us in sufficient cheapness or abundance from our own soil.

The geographical position and capabilities of England furnish her with advantages for the prosecution of this foreign commerce far greater than are possessed by any other country of equal extent. To these advantages we have added a spirit of industry, fostered by our free institutions, and a degree of commercial enterprise, beyond those of any other people either ancient or modern, with, perhaps, the recent exception of the United States of America. But although the amount of our foreign trade is greater than that of any other country, it by no means follows that it is as great as it should be, or that the home market should furnish a more important array of customers than all other civilized communities, even when we include with the latter the inhabitants of our many colonies and populous dependencies, whose direct trade we so long reserved to ourselves.

The argument in favour of the greater comparative value to a country of its home than of its foreign trade, which has been founded upon the greater economy and celerity with which the operations of the former are conducted, is far from being always correct when applied to England. The trading communication between the south and east coasts of Great Britain and the north and west shores of many European countries, is kept up with greater facility and economy than the traffic between some of our distant counties. The time and money expended in conveying a bale of goods from Manchester to London, by canal or by the ordinary road, are greater than are required for its conveyance from London to Rotterdam; and the charge made for the cartage of a puncheon of rum from the West India Docks to Westminster exceeds the charge that would be made for conveying the same puncheon of rum from those docks to Hamburg. Even in those branches of foreign commerce where from the length of the voyage a considerable time must elapse between the shipment of goods, their reception and sale abroad, and the transmission of returns to the hands of the shipper, a remedy for the evil of delay has been found in the operation of commercial bankers, whose dealings consist in the purchase and sale of bills of exchange, and are founded upon the varying necessities of different individual traders.

In this country, limited as it is in geographical extent, with a population to all appearance fast overtaking the capability of the soil to yield the necessary amount of food, we have a motive which every year becomes more and more cogent for giving the greatest 
possible facilities to our commercial intercourse with other countries. We have seen that, in the twenty years that elapsed between 1811 and 1831 , the increase in the total number of families in Great Britain was 869,960 , or at the rate of 34 per cent. upon the numbers of 1811 , while the increase in the number of families employed in agriculture was only 65,136 , or but little more than $2 \frac{1}{2}$ per cent.; the remainder, amounting to 804,824 families, having betaken themselves to trading and manufacturing employments. The census returns for 1841 were still more decisive, as they showed a positive diminution in the number of persons employed in agriculture in that year as compared with 1831 from 1,243,057 to $1,207,989$.

We cannot reasonably expect that the soil can always be made to yield increasing harvests to meet the constant augmentation of the population, nor that the labours of our artisans, whose additional numbers must be reckoned yearly by bundreds of thousands, can continue to find profitable employment in a sphere thus made narrower from year to year. The onward progress of our population cannot be checked without reverses which would plunge the greater part of the nation into a state of misery painful to contemplate, and on the other hand such a check can only be averted by a great, a rapid, and a permanent extension of commercial relations with countries whose inhabitants, being in different circumstances, may be willing to exchange the products of their soil for the results of our manufacturing industry.

We have happily now (1844 to 1850) entered upon such a course of commercial legislation as, when fully carried out, must realize advantages in this direction which are more and more becoming matters of necessity to this country. That the system of free trade, by which expression is meant unrestricted intercourse with foreign countries, in which no one country shall be placed, by regulations or differential duties, at a disadvantage with any other, and no customs duty shall be levied for any purpose whatever save the necessary onc of revenue-a system in which the fallacy of protection shall be utterly disowned and abolished-that this system must be progressively carried out by us to its utmost limit, is now seen to be among the most settled of certainties. To persons who have observed the effects of such relaxations in our tariff as have already been carried into effect, the result of such a perfecting of the system as is here described cannot be at all doubtful. That the capital, skill, and energy possessed and exercised by the inhabitants of these islands will, when unfettered, carry us forward 
to a degree of commercial and manufacturing prosperity of which the world has hitherto seen no example, it required little boldness to foretell; and that this prosperity will be attained to a very high degree, although the example of England should fail to convince the governments of other countries, and to be followed by them, does not admit of any doubt. But it is not conceivable that our example, which, on all other occasions has furnished motives of action, shall cease to do so; and it cannot but add greatly to the feeling of gratification called forth by the changes now in progress, to believe that the sum of our prosperity shall be increased through the advancement of the general happiness. Shall we, then, too greatly flatter ourselves if we hope that the nations of the world, too long divided by hatred in war, and jealousy in peace, shall be brought to see and act upon the conviction that the happiness and prosperity of each must tend to increase the happiness and prosperity of each and all other nations?

In seasons of general prosperity, when the productive classes are fully and profitably employed, it is always found that a stimulus is given to consumption, and it very frequently has happened that the effective demand for manufactured goods thus created has excited increased production to a degree beyond what has been immediately required. When circumstances change, and a check is given to consumption, those persons who have been led thus to apply an additional amount of capital and labour, are exposed to considerable losses, and it must be obvious that the danger of encountering the evil is greater in proportion as the market which they supply is circumscribed. If limited to one country, which is suffering under circumstances of depression, the distress of the producers must be highly aggravated, but if they are accustomed to carry on commercial dealings with many foreign lands, it is not probable that all will be at the same time under depression; the evil, as far as the producers are concerned, will be easily remedied, and a small reduction in the price of their goods will then cause such an increased demand in foreign countries as will greatly palliate, if it do not remedy, the mischief arising from fluctuations in the home demand.

The amount and progress of the foreign and colonial trade of the United Kingdom in each year from 1801 to 1849 , with the exception of 1813 , the records of which year were burned with the custom-house, are given in the following abstract :- - 
Statenent of the Amount of the Foreign and Colonial Trade of the Uniled, Kingdom, specifying the Official Value of Foreign and Colonial Mcrihandise imported and, re-exportin, and the Official and Real or Declared Value of British and, Irish Produce and Manufactures exported in each Year from 1801 to $18: 9$

\begin{tabular}{|c|c|c|c|c|c|c|c|}
\hline & \multirow{2}{*}{\multicolumn{3}{|c|}{ Year }} & \multicolumn{3}{|c|}{ OEFICLAL VALLE. } & \multirow{2}{*}{$\begin{array}{c}\text { Real or Declared } \\
\text { Value of } \\
\text { Eritish and Irish } \\
\text { Produce } \\
\text { and Janufactures } \\
\text { Exported. }\end{array}$} \\
\hline & & & & $\begin{array}{l}\text { Imports of } \\
\text { Foreign and } \\
\text { Colonial } \\
\text { Yerchandise. }\end{array}$ & $\begin{array}{l}\text { Exports of } \\
\text { Foreign and } \\
\text { Colonial } \\
\text { Jerchandise. }\end{array}$ & $\begin{array}{l}\text { Exports of } \\
\text { British and Irish } \\
\text { Produce and } \\
\text { Manufactures. }\end{array}$ & \\
\hline & & & & $31-86260$ & $\frac{1^{2}}{330} a 6 f^{2}$ & $\stackrel{ \pm}{ \pm}$ & \\
\hline 1801 & $\cdot$ & $\cdot$ & $\cdot$ & $31,786,262$ & $10,336,966$ & $24,927,684$ & $39,730,659 *$ \\
\hline 1802 & . & . & - & $29,826,210$ & $12,677,431$ & $25,632,549$ & $45,102,330^{*}$ \\
\hline 1803 & - & . & . & $26,622,096$ & $8,032,643$ & $20,467,531$ & $36,127,78 \tau^{*}$ \\
\hline 1804 & . & . & . & $27,819,552$ & $8,938,741$ & $22,687,309$ & $37,135,746^{\circ}$ \\
\hline 1805 & . & . & . & $28,561,270$ & $7,643,120$ & $23,376,941$ & $38,077,144$ \\
\hline $1806^{\circ}$ & . & . & . & $26,899,658$ & $7,717,555$ & $25,861,879$ & $40,874,953$ \\
\hline 1807 & . & . & . & $26,734,425$ & $7,624,312$ & $23,391,214$ & $37,245,877$ \\
\hline 1808 & . & . & . & $26,795,510$ & $5,776,775$ & $24,611,215$ & $37,275,102$ \\
\hline 1809 & . & . & . & $31,750,557$ & $12,750,355$ & $33,542,274$ & $47,371,393$ \\
\hline 1810 & . & . & . & $39,301,612$ & $9,357,435$ & $34,061,901$ & $48,438,680$ \\
\hline 1811 & . & . & . & $26,510,186$ & $6,117,720$ & $22,631,400$ & $32,890,712$ \\
\hline 1812 & . & . & . & $26,163,431$ & $9,533,065$ & $29,508,508$ & $41,716,964$ \\
\hline 1813 & - & . & - & Records des & trored by fire. & … & $\ldots$ \\
\hline 1814 & . & . & . & $33,755,264$ & $19,365,951$ & $34,207,253$ & $45,494,219$ \\
\hline 1815 & . & . & . & $32,987,396$ & $15,748,554$ & $42,875,996$ & $51,603,025$ \\
\hline 1816 & - & - & . & $2 \vec{\imath}, 431.601$ & $13,480,780$ & $35,717,070$ & $41,657,873$ \\
\hline $181 \%$ & . & . & . & $30,834,299$ & $10,292,684$ & $40,111,427$ & $41,-61,132$ \\
\hline 1818 & . & . & . & $36,885,182$ & $10,859,817$ & $42,700,521$ & $46,603,249$ \\
\hline 1819 & - & - & . & $30,776,810$ & $9,904,813$ & $33,534,176$ & $35,208,321$ \\
\hline 1820 & . & . & . & $32,438,650$ & $10,555,912$ & $38,395,625$ & $36,424,652$ \\
\hline 1821 & - & - & - & $30,792,750$ & $10.629,689$ & $40,831,744$ & $36,659,630$ \\
\hline 1822 & . & . & . & $30,500,094$ & $9,227,5 \leqslant 9$ & $44,236,533$ & $36,968,964$ \\
\hline 1823 & . & . & . & $35,798,707$ & $\$, 603,904$ & $43,504,372$ & $35, \pm 58,048$ \\
\hline 1824 & . & . & - & $37,552,935$ & $10,204,785$ & $48,-735,551$ & $38,396,300$ \\
\hline 1825 & . & . & . & $41,13 \bar{i}, 4 \$ 2$ & $9,169,494$ & $47,166,020$ & $38,87 i, 388$ \\
\hline 1826 & . & . & . & $37,686,113$ & $10,076,2 \varepsilon 6$ & $40.965,735$ & $31,5 \$ 6,723$ \\
\hline 1827 & - & . & . & $44,857,774$ & $9,830,723$ & $52,219.280$ & $37,181,335$ \\
\hline 1823 & . & . & . & $45,028,805$ & $9.946,545$ & $52,797,455$ & $36,812,756$ \\
\hline 1829 & . & - & . & $43,981,317$ & $10,622,402$ & $56,213,0 \leq 1$ & $35,812,623$ \\
\hline 1830 & - & . & . & $46,245,241$ & $8,550,437$ & $61,140,864$ & $38,271,597$ \\
\hline 1831 & . & . & . & $49,713,880$ & $10,745,071$ & $0,653,933$ & $37,164,372$ \\
\hline 1832 & . & . & . & $44,586,741$ & $11,044,869$ & $65,026,702$ & $36.450,594$ \\
\hline 1833 & . & . & . & $45,952,551$ & $9,833,753$ & $69,989,339$ & $39,667,347$ \\
\hline 1834 & . & . & . & $49,362,811$ & $11,562,036^{\circ}$ & $73,831,550$ & $41,649,191$ \\
\hline 1835 & . & . & . & $48,911,542$ & $12,797,724$ & $73,376,731$ & $47,372,270$ \\
\hline 1836 & . & . & . & $57,023,867$ & $12,391,711$ & $85,229,837$ & $53,368,571$ \\
\hline $183 i$ & . & . & . & $54,737,301$ & $13,233,622$ & $72,518,047$ & $42,069,245$ \\
\hline 1838 & . & . & . & $61,265,320$ & $12,711,318$ & 92.459 .231 & $50,060,970$ \\
\hline 1839 & . & . & . & $62,001,000$ & $12,-95,990$ & $97,102,725$ & $53,233,5 \leq 0$ \\
\hline 1810 & . & . & . & $67,432,961$ & $13,774,306$ & $102,705,3,2$ & $51,406,430$ \\
\hline 1841 & . & . & . & $64,37 \div, 962$ & $14,723,151$ & $102,180,517$ & $51,634,6 \geq 3$ \\
\hline 1812 & - & - & . & $65,204,729$ & $13,584,15 \mathrm{~s}$ & $100,260,101$ & $47,351,023$ \\
\hline 1843 & . & . & . & $70,093,353$ & $13,956,113$ & $117,877,278$ & $52,2,8,449$ \\
\hline 1844 & . & . & . & $85,411,555$ & $14,397,246$ & $131,564,503$ & $53,584,292$ \\
\hline 1845 & . & - & . & $\$ 5,2 S 1,958$ & $16,280,870$ & $134,599,116$ & $69,111,081$ \\
\hline 1846 & . & - & . & $75,953.575$ & $16,296,162$ & $132,288,345$ & $57,7 \leqslant 6,575$ \\
\hline 1817 & - & . & . & $90,921,86 t^{\circ}$ & $20,036,160$ & $126,130,986$ & $58,812,377$ \\
\hline $1 \$ 48$ & - & - & . & $93,547.134$ & $18,368,113$ & 132.617 .681 & $52,849,445$ \\
\hline 1849 & . & . & . & $105,874,607$ & $25,561,890$ & $164,539.504$ & $63,596,025$ \\
\hline
\end{tabular}

* The declared ralue of British and Irish produce, etc., exporter in the 5ears 1801 to 1804, applies to Great Britain only, the real ralne of exports from Ireland not having been recorded earlier than 1805 . The exports from Ireland are, however, inconsiderable. 
The rates of valuation employed for computing the amounts given under the head of official value were fixed in the year 1694, and have not since been altered, so that the sums thus stated must not be supposed to give any accurate exhibition of the value of goods imported and exported. This system of valuation has been preserved in the public accounts, because it has been supposed to afford a correct measure of the comparative quantity of merchandise which has made up the sum of our annual commercial dealings with other countries. It is, perhaps, impossible to ascertain with absolute correctness the value of all the foreign and colonial merchandise imported, because of the great range of qualities and consequently of value as regards many of the principal articles of commerce, which value cannot be accurately estimated before the goods are landed and submitted to inspection; it would, however, be not only possible but easy of accomplishment, to arrive at a satisfactory approximation to the truth, if some competent persons in various lines of business were employed every year to affix an average value to the different descriptions of goods that had been imported in the course of the preceding year, which average value should be used by the computers at the custom-house for ascertaining the amount of the year's commercial dealings. The fallacy of the present system will be at once apparent if the amounts given as the official value of imports and exports in any one year are brought into comparison. On the supposition of the correctness of the custom-house valuations, our foreign and colonial trade must long since have proved the ruin of our merchants, since the value assigned to the exports is enormously greater than that given to the imports. To instance the first and last years of the series in the following table, the loss of the country in 1801 must have amounted to $\mathfrak{E} 3,478,388$, and in 1849 to $\mathfrak{f} 84,226,787$. The adoption of a second method for recording the value of the exports of British and Irish produce and manufactures, according to the declaration of the exporters, affords better means for judging as to the actual progress of our foreign trade, since it is certain that, taking one year with another, the amount of the shipments so made must be brought back to us together with the ordinary rate of profit. If the foregoing table be taken in this way as the test of the progress of our foreign trade, during the present century, it will be seen that, from 1819 to the year 1835 , little or none was made-that, in fact, the amount of our foreign trade had not then been equal to that which was carried on during some of the years when we were at war with nearly all Europe, nor to that of the 
:

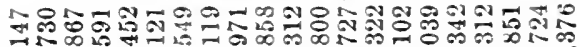

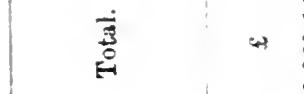

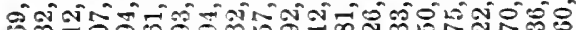

에 คे

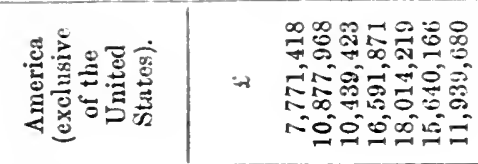

\begin{tabular}{|c|c|c|c|}
\hline 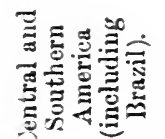 & $\Rightarrow$ & $\vdots \vdots \vdots \vdots \vdots$ & 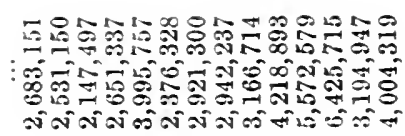 \\
\hline
\end{tabular}

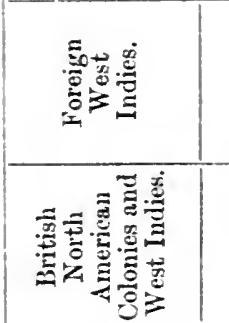

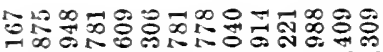

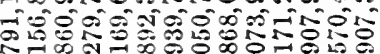

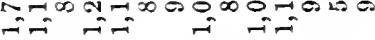

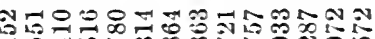

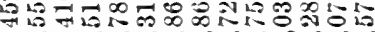

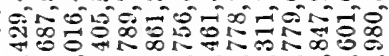

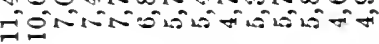

\begin{tabular}{|c|c|}
\hline 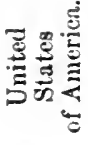 & $\Rightarrow 1$ \\
\hline$\frac{\dot{B}}{3}$ & $A$ \\
\hline 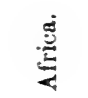 & $=$ \\
\hline 䒿它 & \\
\hline
\end{tabular}

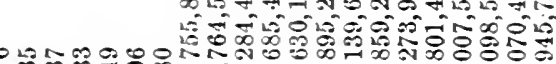

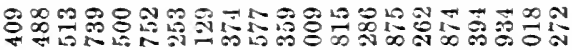

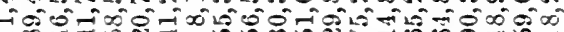

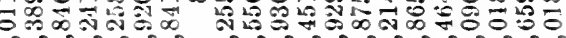

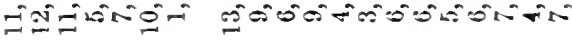

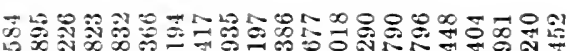

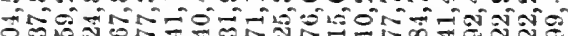
잉

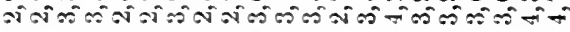

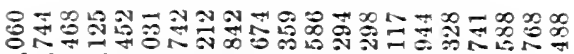
- 50 -

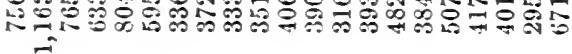

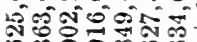
0 两 00000 吾离

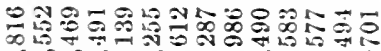

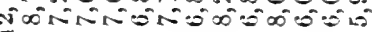

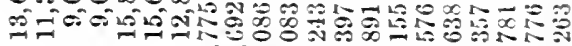

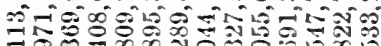
चब

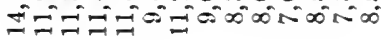




\section{Е}

|

哬

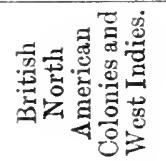

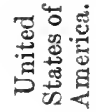
$\frac{\sqrt[m]{3}}{4}$ $\stackrel{8}{4}$

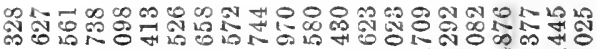

(4) लीN

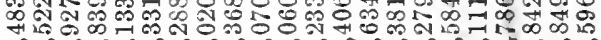

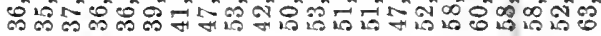

\begin{tabular}{|c|c|}
\hline 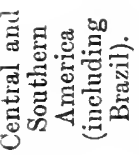 & 4] \\
\hline 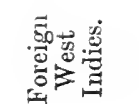 & 4) \\
\hline
\end{tabular}

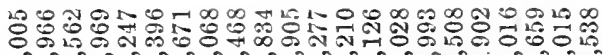

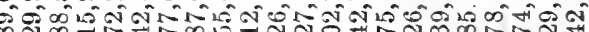
舟

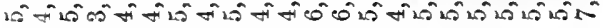

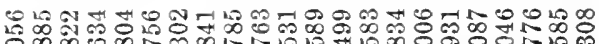

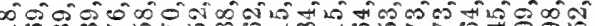
D.

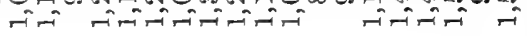

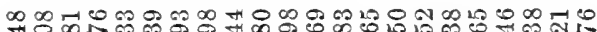
स인

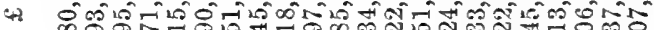

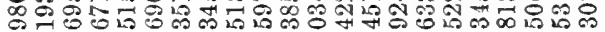

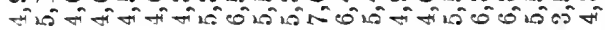

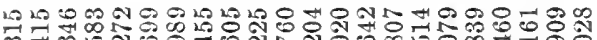

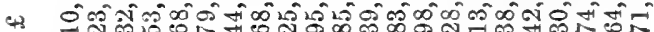

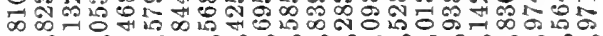
मी ने की

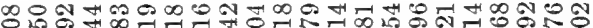
H

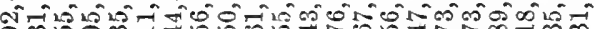

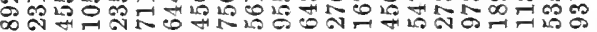

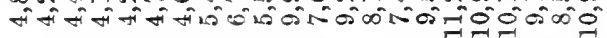

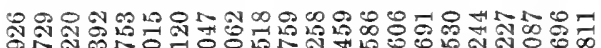
को 150 की

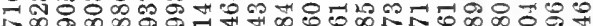

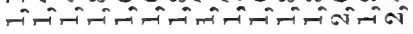

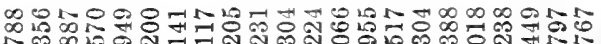

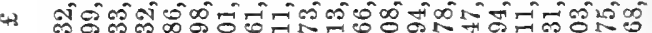

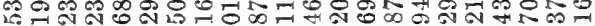

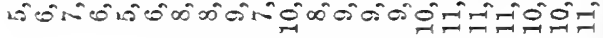

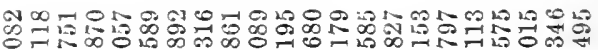
考宫

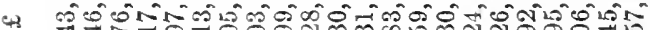

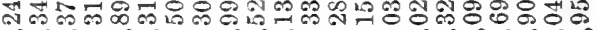

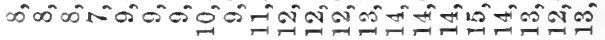

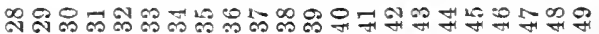

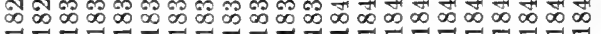


first five years of peace that followed. The average annual exports of British produce and manufactures in the decennary

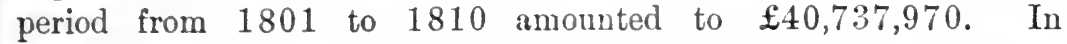
the next ten years, from 1811 to 1820 , the annual average

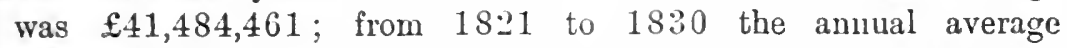

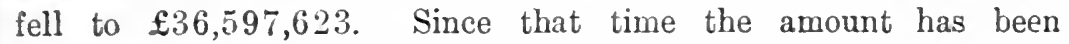
progressively advancing, and in the next decennary period (1831

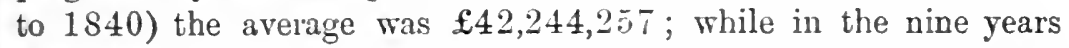
that close the series, the average value of our exports reached $£ 55,896,021$.

With 1831 were begun, under the auspices of the late Lord Sydenham, a series of fiscal reforms far too numerous to be particularized here. In the eight years during which, excepting one short interval in 1834-1835, he officiated as Vice-President and then as President of the Board of Trade, that minister carried through the House of Commons reductions and modifications of duties affecting more than 700 articles of importation. The individual effect of these reforms may not have been great, but in their aggregate they were followed by the happiest results. Among the measures here alluded to were several which affected our commerce with France, and especially the equalizing of the duties upon wine, the produce of that country, with the rates charged upon other foreign wines. During subsequent years, and until this time, the legislatures of France have done little or nothing in liberalizing its tariff; but, on the contrary, duties materially affecting the industry of England have been increased by them with the declared intention of discouraging certain branches of our trade; and yet (so true is it that a nation cannot sell without buying), their augmented sales to us of French produce have been accompanied by continually augmented purchases from us in return. The value of our exports to France, which in 1830 amounted to only $\mathfrak{f} \pm 75,884$, rose in the 'forties to more than sixfold that sum.

The imperfect manner in which the custom-house accounts were formerly called for by Parliament, and the subsequent destruction of the custom-house by fire, do not allow of any analysis being made of the foregoing statement for all the earlier rears of the series. The abstract given on pages 479 and 480, exhibiting the course of our export trade from 1805 to 1811 , and from 1814 to 1849 , will show in how great a degree it has been owing of late years to the enterprise of our merchants in seeking new and distant fields for commercial 
operations that the money value has been maintained of the produce and manufactures of the kingdom which have been exported, and that we have been able to command and to consume to a greater extent than formerly the productions of other countries.

That part of our commerce which, being carried on with the rich and civilized peoples of Europe, should present the greatest field for extension, had fallen off in a remarkable degree. Our average annual exports to Europe were less in value by nearly 20 per cent., in the five years from 1832 to 1836 , than they were in the five years that followed the close of the war; and it affords strong evidence of the unsatisfactory footing upon which our trading regulations with Europe were established, that our exports to the United States of America, which with a population of only twelve millions, and removed to a distance from us of three thousand miles across the Atlantic, then amounted to more than one-half of the value of our shipments to the whole of Europe, with a population fifteen times as great as that of the United States of America, and with an abundance of productions suited to our wants, which they are naturally desirous of exchanging for the products of our mines and looms.

The value of all the British and Irish produce and manufactures that were exported in each of the twenty-two years from 1827 to 1849 , and the proportions in which those shipments were made to different countries, are shown in the following tables (pp. 483-486), which thus exhibit the most accurate view, that can be given by any custom-house document, of the actual and relative importance of each branch of our foreign commerce.

Some few remarks appear to be necessary here, in order to prevent our falling into mistakes as regards our foreign trade with some of the countries particularized in the annexed tables (pp. 483456). Under the head of Prussia, we see a value assigned to the exports which is quite inconsiderable, and which, if left unexplained, might lead to a very wrong conclusion. A very small part of the British goods which find their way to Prussia for consumption are exported direct to any Prussian port: some of those goods pass through the Netherlands to the Phenish provinces, and still more are shipped to Hamburg and other ports in the North of Germany, whence they are forwarded by land-carriage to the interior. In an official statement compiled at Berlin, to show the amount of importations into the Prussian States, as to which this kingdom 
An Aceount of the Declared Value of British and Irish Producc and Manufactures Ex ported from the United Kingdom, etc.-continued

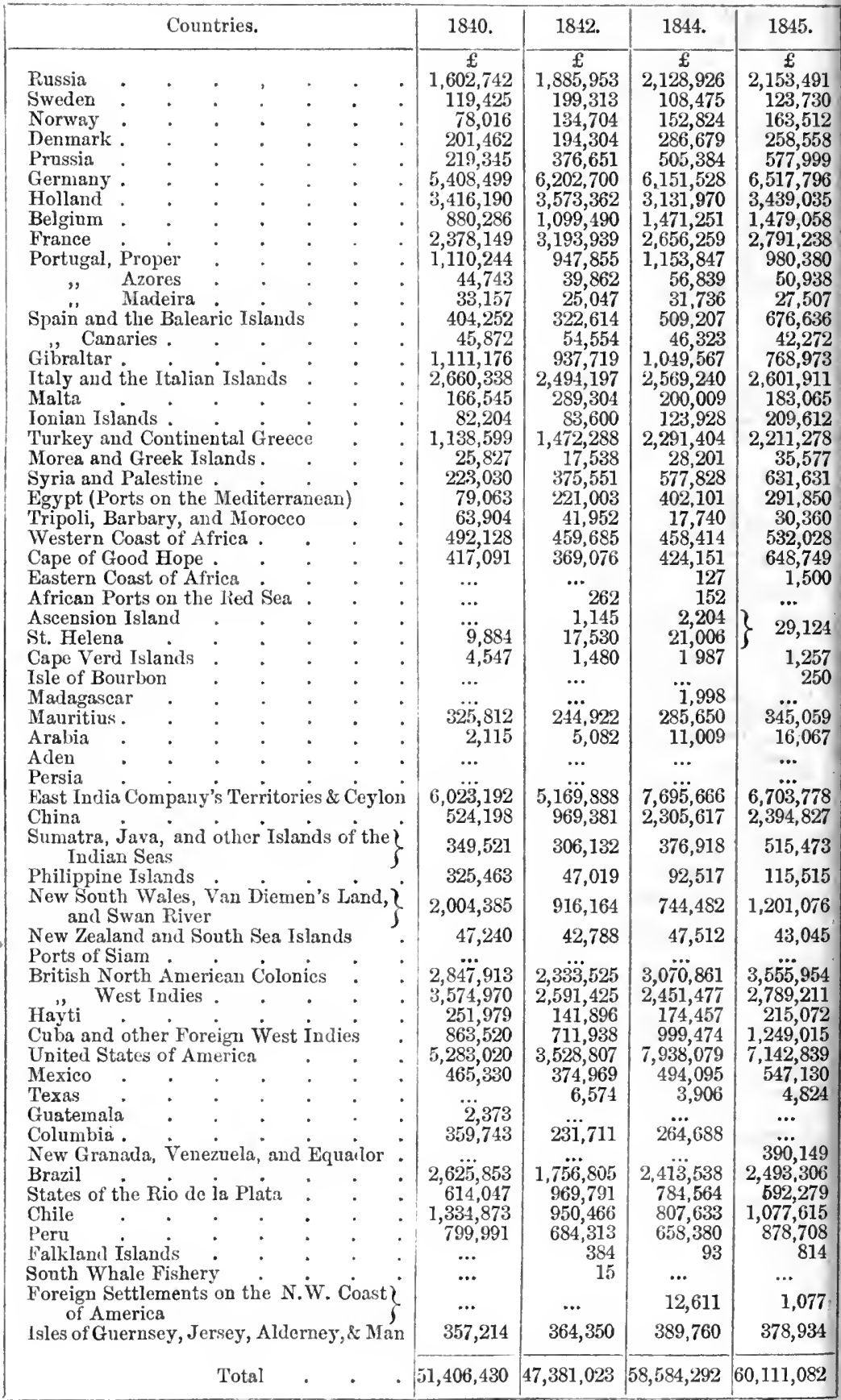


An Account of the Declared Value of British and Irish Produce and Manufactures Exported from the United Kingdom, specifying the various Countries to uhich Exported, in the Years 1847, and 1849

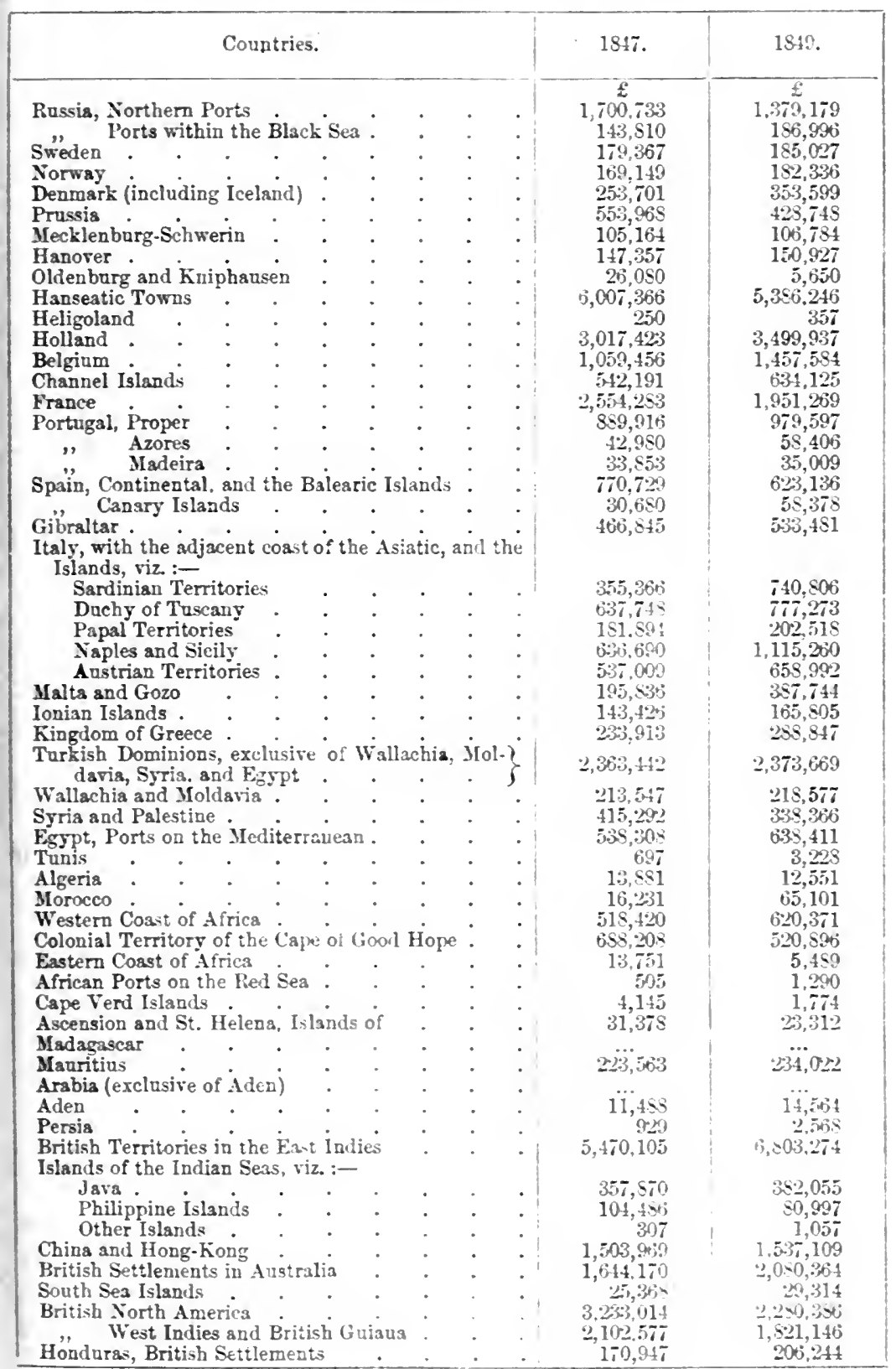


An Account of the Declared Value of British and Irish Produce and Manufactures Exported from the United Kingdom, etc.-continued

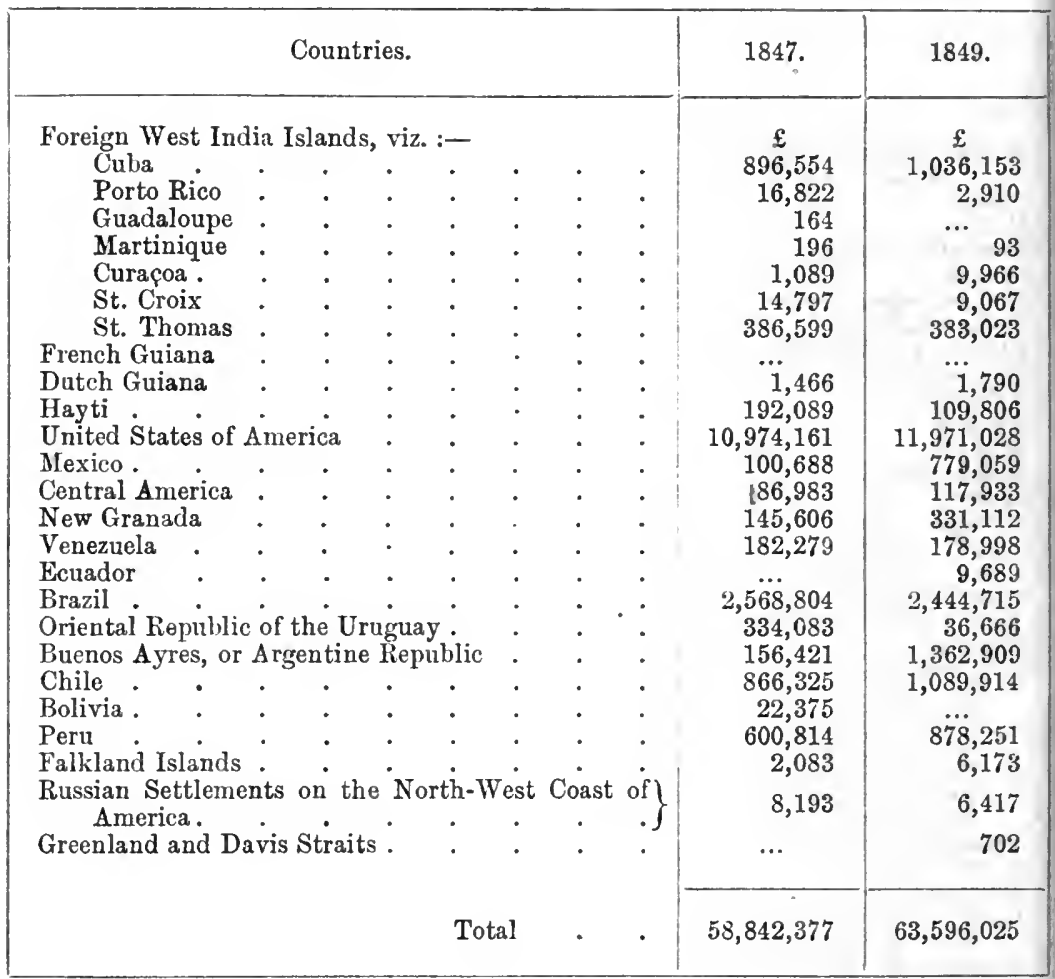

was interested in the years 1832,1833 , and 1834 , the valuc is thus given :-

\begin{tabular}{|c|c|c|c|c|}
\hline & & 1832. & 1833. & 1834. \\
\hline \multirow{2}{*}{$\begin{array}{l}\text { British produce and manufactures } \\
\text { Other goods (colonial produce, etc.) }\end{array}$} & & 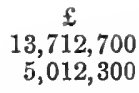 & $\begin{array}{r}f \\
12,826,380 \\
4,655,050\end{array}$ & $\begin{array}{c}\stackrel{f}{1} \\
10,531,010 \\
5,583,760\end{array}$ \\
\hline & & $18,725,000$ & $17,481,430$ & $16,114,770$ \\
\hline
\end{tabular}

The rates of valuation applied in the computation of these amounts are very greatly exaggerated; but when the necessary allowance shall be made for this fact, it will still be found that the Prussians are far better customer's to our manufacturers than would appear upon the face of our public documents. 
Spain appears, from the same table, to take from us goods to a very inconsiderable amount; and there can be no doubt that, if the political troubles of that country were at an end, and if a more rational system of commercial policy than has hitherto been pursued were adopted by the Spanish government, our trade with Spain must increase in a most important degree. Still that trade is at present much greater in reality than it is in appearance; a large part of the goods exported from this country to Gibraltar and to Portugal being afterwards introduced clandestinely into the Spanish provinces. The extent of the contraband trade carried on at Gibraltar is strikingly exhibited by the fact, that the annual importation of tobacco into that colony amounts to from six to eight millions of pounds; nearly the whole of which is purchased by smugglers, and introduced by them clandestinely into Spain.

The value of our exports to the whole of the West Coast of Africa averaged, during the five years ending with $184 t$, the sum of $£ 482,326$ per annum. More than one-half of this amount was taken by the British settlements on the Gambia, Sierra Leone, Cape Coast Castle, and Accrah, leaving little more than $£ 200,000$ for the remaining parts of the country, embracing, between the river Gambia and Angola, nearly four thousand miles of coast, and containing upon a moderate estimate $30,000,000$ of inhabitants. These people must not be considered, as regards commercial objects, in the same light as those who enjoy a greater degree of civilization; but the experience of the last forty years affords sufficient proof of the value which the trade with the negro population might be made to assume. In 1808 the whole quantity of palm oil imported did not exceed 200 tons; in 1836 it amounted to 13,850 tons; in 1844 to 20,732 tons; and in 1849 to 44,666 tons. Thirty years ago African timber was unknown to us, and our annual importations have since amounted to more than 20,000 loads. This increase has taken place, too, under the most unfavourable circumstances, The whole country is disorganized, and, except in the immediate vicinity of the towns, the land lies waste and uncultivated, the wretched natives living under constant dread of being carried off into slavery. The legitimate trade of our vessels when on the African coast is continually impeded by the appearance of slave-traders, on the arrival of which, the natives quit all other occupations and proceed on marauding expeditions, to seize the members of some neighbouring tribe, and sell them as slaves. Until a sufficient number of these poor creatures is collected to crowd the vessel of the slave- 
trader all other occupations are stopped; and it is not merely the loss of time and consequent expenses thus occasioned that are to be deplored, but the great waste of life among the crews of the English traders while uselessly detained upon an unhealthy coast. Everywhere are to be seen the baleful effects of this traffic, producing desolation where Nature has been prodigal of her gifts. According to Mr. Laird, one of the most intelligent travellers to that region, "The Delta of the Niger alone, if cleared and cultivated, would support a population in proportion to its area far exceeding anything known in Europe. Its square surface is equal to the whole of Ireland; it is intersected in all directions by navigable branches of the parent stream, forming so many natural channels for communication: it is altogether composed of the richest alluvial soil, which now teems with a rank luxurious vegetation, comprising all the varieties of the palm-tree, besides teak-wood, cedar, ebony, mahogany, and dye-woods: the sugar-cane grows wild in the bush, and the palm-nut rots upon the ground unheeded and neglected. The population of this Delta I should consider does not exceed half a million."

If the population of this region-and there are many others to which the same description might be applied-were weaned from their present habits of violence, and if advantage were taken of their desire for obtaining some kinds of European manufactures, to engage them in the cultivation of the soil, can it be believed that our commercial dealings with them would continue, as it is at present, scarcely greater in amount than the value of the eggs brought annually from Ireland to the single port of Liverpool? Among the objects to which the industry of Africans could be profitably applied, perhaps the most important is the article of cotton. Its cultivation does not call for any great amount of labour; the returns are speedily obtained; the market for it is continually being extended; and, as regards this country, it is a matter of very high importance that the million of persons who are dependent for their daily subsistence upon the regular supply of that material, should have the chances of disappointment lessened, as far as possible, by extending the number of the producers, and multiplying the regions in which they are found.

There is reason to believe that the goods exported from the United Kingdom to our North American colonies do not all remain for the consumption of the colonists, but that a portion is conveyed across the St. Lawrence into the territory of the United States. On the other hand, some shipments made apparently to the United 
States, accompany English settlers, who proceed through the States to their ultimate destination in Upper Canada; but the value in both these cases must be comparatively unimportant. Of the exports to the British West Indies, some part is shipped in transitu, and goes for consumption to Cuba, and to ports on the Mosquito coast. The whole amount assigned to Turkey does not properly belong to our trade with that country, some part being sent forward to Asia Minor and Persia. With regard to the exports to our West Indian colonies, it may further be observed, that the value of late years has materially fallen off, which fact is probably owing, in part, to the peculiar nature of the population, for the supply of which given quantities of stores and clothing were formerly required, without reference to their cost in this country; so that the reduction in price of the generality of articles which make up the sum of our exports has not been followed by much, if any, increased consumption. Besides this, goods were in former years sent to Jamaica, intended for the supply of the neighbouring continent, to which shipments are now made direct from this country.

It will be seeu that the value of our exports to India and China did not experience any increase until after the partial opeuing of the trade in 1814 . Since that time, and particularly since 1826 , a considerable improvement has taken place in the amount of our commerce with India; so that, contrasting its amount in 1849 with that in 1814 , there is found an increase of more than 190 per cent. The recent opening of the trade with China is calculated to add still more importantly to the value of our commerce with that quarter of the world. Aithough this trade at first might be accompanied by losses to those who engaged in it without possessing the requisite degree of knowledge, it could not be doubted that a few years' experience on the part of our merchants would euable them to draw very great advantages from commercial intercourse with a people so enterprising and so keenly alive to the benefits resulting from foreign trade as the Chinese are now allowed to be. Already the consumers in this country have benefited by the opening of the trade with China, in the greatly diminished price of an article of general and daily consumption; and there is every reason to hope that the individual skill and enterprise now directed to this trade will succeed in making continual additions to its amount, until it bears a more reasonable proportion than it has hitherto done to the trading capabilities of the inhabitants of that thickly-populated country. This trade was thrown open on the expiration of the East India 
Company's Charter in April, 1834. Since that time the declared value of English manufactures exported to China has been-

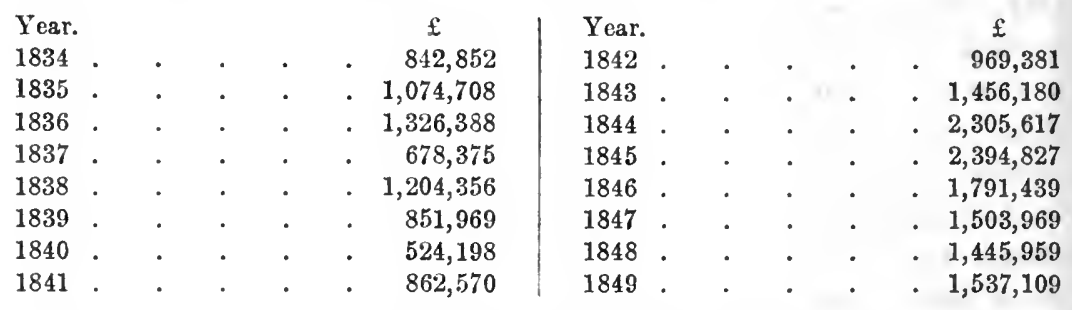

Previously to 1834 , no distinction had been made in the customhouse records between the exports to India and those made to China, nor will this deficiency of information be supplied by the statement of the amount of shipping employed in the trade, because a great part of the trading intercourse of British subjects with China is carried on through the intermediate ports of India; and this was the case to a greater degree formerly than it is at present.

The discriminating duties which, until lately, have been charged upon certain articles of East India produce, naturally tended to prevent increase in that branch of our trade. A wiser policy is now recognized and followed, and will no doubt be productive of solid advantages to the people of this country, as well as to the natives of Hindustan. The capabilities of that vast region are hitherto but very imperfectly known in Europe; and, indeed, until the Act of 1833, which prohibited the East India Company from trading, and gave to British-born subjects the right to settle for commercial and agricultural purposes in British India, there was but little inducement to cultivate that field of inquiry. There is, perhaps, no one circumstance that would tend so much to increase the commerce of India as the opening of good roads. The course of the great rivers is at present available, at least during part of the year, for the conveyance of Indian products towards the coast; but this means of transport is of but little avail for the return trade; and even the partial facility of water conveyance is confined to only a small part of the peninsula. Good roads would be practicable at all periods of the year, and in every part of the country; and would be equally available for the transmission of English goods to the inner and upper provinces of India, as for the conveyance of their products to the coast. This improvement is especially needed in some of the cotton-yielding districts, where the present expensive mode of conveyance upon the backs of oxen acts most injuriously, 
by enhancing the cost of an article which it is of the utmost importance to our Lancashire manufacturers to receive as abundantly and at as cheap a rate as possible. As a political measure, the construction of roads in India would prove highly advantageous. Their cost would be quickly and amply repaid by the improving revenues of the country, and by the grateful feelings that would be raised on the part of the native population. The inhabitant of Western Europe, who has always been accustomed to have brought to his door every article that he can desire, and that his means can purchase, can have but a faint idea of the various privations experienced by great multitudes of the inhabitants of Hindustan, and it may be confidently added that a Government which should place within the reach of the poor cultivators an ample supply of saltan article, the obtaining of which never costs us a thought-would be sure to receive the blessings of millions.

A discriminating duty at the rate of $28 \mathrm{~s}$. per ewt., or 50 per cent., was, until lately, imposed upon coffee, the growth of the British possessions in India, for the presumed benefit of the planters in our Western colonies. Until 18.5, this discriminating duty amounted to $56 \mathrm{~s}$. per cwt., but was at that time comparatively but little felt, because, orving to the excessive duty levied upon all descriptions of coffee, the consumption of the kingdom was below the supply obtained from our West India colonies, and as the surplus had to seek a market in foreign countries, the prices of every description of coffee were necessarily governed by the demands of the world in general. In the year just mentioned the duties previously levied upon all kinds of coffee were reduced to one-half. The produce of the British plantations in America, thenceforward until 1842 , was admitted to consumption at the rate of 6 d. per $1 b$., or 56s. per cwt. East India coffee from British possessions was charged 9 d. per 1 b., or 84 s. per cwt., and all other kinds were charged $1 \mathrm{~s} .3 \mathrm{~d}$., or $140 \mathrm{~s}$. per cwt., amoumting to a prohibition against their consumption. In 1842 , the duty on coffee from all British possessions was reduced to 4 d. per $1 b$, and all other coffee was admitted at $8 \mathrm{~d}$. per 1 b. until 1844 , when the duty on foreign coffee was lowered to $6 \mathrm{~d}$. per $1 \mathrm{~b}$. The consequence of the reduction in 1825 was to increase the annual consumption of cotfee from about $8,000,000 \mathrm{lb}$. in 1824 to $22,000,000 \mathrm{lb}$. in 1830 , which increase, as might be expected, occurred almost entirely with the produce of our West India colonies, and as the power of production in these colonies is limited, and by this increased demand cousumption had overtaken that limit, the price of West India coffee was driven up 
to a rate so high that the difference of $28 \mathrm{~s}$. per cwt. did not prevent the use of an increased quantity of the produce of our Indian possessions. The price of fine Jamaica coffee, which at the time the duty was reduced about $90 \mathrm{~s}$. per ewt., advanced, through the demands of the consumers, to $125 \mathrm{~s}$. per cwt., but without producing any increased production. The quantily annually imported of British plantation coffee, in the five years that preceded the reduction of the duty in 1825 , averaged $30,280,360 \mathrm{lb}$., and the average quantity imported in the five years from 1832 to 1836 reached only $19,812,160 \mathrm{lb}$., being a reduction of 34 per cent. in the supply, notwithstanding an advance of 39 per cent. in price, thus proving beyond all cavil the inability of the West India planters to keep pace with the wants of the English consumers. In September 1835 our tariff was so far modified, that coffee imported from the British possessions in India, if accompanied by a certificate of its being the actual produce of those possessions, was admitted to consumption, on payment of the same rate of duty as British plantation coffee. The quantity of East India coffee taken for consumption while the duty remained at $9 \mathrm{~d}$. per $\mathrm{lb}$, advanced, because of the increasing price of West India coffee, as already noticed, from about $300,000 \mathrm{lb}$. per annum to about $1,500,000 \mathrm{lb}$. The assimilation of the rates of duty did not take effect until two-thirds of 1835 had elapsed, but in that year the consumption of East India coffee advanced to 5,596,791 lb., and in 1837 reached 9,114,793 lb. A few years must necessarily elapse before the production of coffee can be increased in any particular place; but experience has proved that there was good reason to expect that the stimulus thus afforded would not be checked in our Eastern, as it has been in our Western possessions, through natural causes, and that continually growing supplies might be furnished, until the English public should no longer be forced to pay a monopoly price for this agreeable beverage. That time has now arrived. The importations of coffee from our own possessions has gone beyond the wants of the consumers, and the protecting duty still offered by the tariff has ceased to operate in favour of the colonial grower. The quantities received from Ceylon, which in 1835 were under 2,000,000 lb., exceeded $35,000,000 \mathrm{lb}$. in 1849 .

If the sound principles, that no duties should be levied except for purposes of revenue, and that it is both unjust and unwise to tax the whole community for the supposed benefit of a part, were recognized and fully acted upon, there can be no doubt of the advautages that would result to the country at large, through all its 
various interests, by the increased activity that would be imparted to its foreign commerce.

Much has been done during the last few years, beyoud what has been already particularly noticed, to simplify our tariff and to reduce or abolish duties charged upon the raw materials of manufacture, and there is every reason for believing that the subsequent extension of our foreign trade has been mainly owing to that cause. There is still something to be done in this way. The two great monopolies of corn and timber, the first maintained for the assumed benefit of the possessors of land, the second conceded to the clamour of a certain class of ship-owners, were, when the third edition of this work appeared in 1846, the chief remaining obstacles to the growth of our commercial relations with European nations. The most grievous of those two monopolies, that which condemned the people to pay more for their food than was paid by the inhabitants of other countries, has at length been swept away, and there are strong grounds for believing that the duty on timber, which is essentially a raw material of the greatest importance to every branch of manufacture, must shortly be wholly abolished also.

It is a mistake to suppose, as generally is done, that the high discriminating duty upon timber was originally imposed for the benefit either of the North American colonists, or of the English ship-owners; neither the one nor the other of those parties was thought of in the business any further than as they might be made the means of relieving the consumers of timber in this country from the evil consequences resulting to them through our exclusion from ports in the Baltic. The discriminating duty was not intended to have been continued after the necessity out of which it arose should have passed away with the return of peace. The duty upon a load (fifty cubic feet) of European timber, which at the beginning of the war had been $6 \mathrm{~s}$. $8 d$., was raised by inconsiderable steps to $27 \mathrm{~s}$. 2.d., in 1806 ; this rate was doubled in 1811 , and in 181: the duty was further advanced to $65 \mathrm{~s}$. Colonial timber was admitted free of duty up to 1798 , when it was subjected to 3 per cent. ad ralorem; from 1803 to 1806 the ad valorem rate was changed to a specific duty of abont 2s. per load, and in the latter year was again alto. gether removed. In 1821, in consequence of the recommendations of Committees of the Houses of Parliament, the system was so far altered that the rate upon European timber was reduced to 55s., while upon colonial timber a duty was imposed of $10 \mathrm{~s}$. per load, and those rates were continued to the year 1840 , when $1 \mathrm{~s} .6 \mathrm{~d}$. per load was added to them respectively. In October 1843 the 
duties were reduced to $25 \mathrm{~s}$. per load on foreign timber, and $32 \mathrm{~s}$. per load on foreign deals, and to 1 s. per load on timber, and 2 s. per load on deals the produce of British possessions. Further modifications of the duties upon foreign timber were adopted in the session of 1846, so that on the 5th of April 1847 unsawn wood was adnitted at 20 s., and deals and battens at $26 \mathrm{~s}$. per load; which rates were further reduced on the 5th of April 1848 to $15 \mathrm{~s}$. and $20 \mathrm{~s}$. respectively.

The colonial timber trade cannot be said to have existed before 1803. In the fifteen years that occurred from 1788 to 1802 , while our inportations of European fir timber amounted to nearly $3,000,000$ loads, we imported from the American colonies only 19,429 loads. In 1803 the quantity so imported was 10,113 loads, but from that time it increased rapidly; first from the stimulus of high prices occasioned by the events of the war, and afterwards in cousequence of the greater preference given to colonial timber by our tariff. The price of Memel timber, which in 1802 had been $78 \mathrm{~s}$. per load, with a duty of $16 \mathrm{~s}$. 10d., advanced in 1807 to 150 s., and in 1809 to 320 s., the duty having in the meantime been raised to $27 \mathrm{~s}$. 2d., as above stated. Under these circumstances, it might perhaps be wise to stimulate the importation of colonial timber; but so soon as the return of peace again opened to us our old channels of supply, there could be no good reason for burthening the people with a heavy tax, only a small part of which found its way to the Exchequer, and all that could with propriety have been asked by the parties who had embarked their capitals in the new trade was a reasonable term during which they might withdraw from its prosecution.

That the clianges here noticed in our duties for protection have not been productive of evil to the colonial wood trade is made evident by the quantities since imported from our.American possessions, and from foreign countries :-

\begin{tabular}{|c|c|c|c|c|c|c|}
\hline & Year. & & & Colonial. & Foreign. & Imported. \\
\hline $\begin{array}{l}1843 \\
1844 \\
1845 \\
1846 \\
1847 \\
1848\end{array}$ & $\dot{i}$. & : & : & $\begin{array}{r}\text { Loads. } \\
922,087 \\
941,221 \\
1,281,974 \\
1,214,442 \\
1,086,070 \\
1,102,254 \\
1,047,320\end{array}$ & $\begin{array}{c}\text { Loads. } \\
395,558 \\
544,136 \\
675,840 \\
810,497 \\
809,752 \\
701,080 \\
580,372\end{array}$ & $\begin{array}{c}\text { Loads. } \\
1,317,645 \\
1,485,357 \\
1,957,814 \\
2,024,939 \\
1,895,822 \\
1,803,334 \\
1,627,692\end{array}$ \\
\hline
\end{tabular}


In every civilized country timber is an article of consumption of the very first necessity, and where, as in this country, our forests do not supply it in the necessary abundance, its importation should be rendered as free as possible. If, through the necessities of the Government, it should be found necessary to tax this, which may be called one of the chief raw materials of maunfacture, without which, in fact, scarcely any other manufacture could be carried on, it would be some consolation to know that the tax answered its legitimate purpose, and perhaps stood in the place of some other equally objectionable impost. Owing, however, to the discriminating duties in favour of the timber of our Northern colonies, a sum at least equal to the amount that now funds its way under this head to the Exchequer is lost to the public, its only use being to afford employment to a number of old aud worn-out ships, which it would be more advantageous to the country to buy, and then break them up and sell their materials for fuel, than it would be to continue the present modified system.

Owing to the mode employed up to 1833 for calculating the duties upon planks, deals, and battens, which were taxed by the great hundred in classes, according to certain specified limits of dimension, it was not easy to estimate the actual quantity of wood brought for consumption into the country. Such an estimate was carefully made at the custom-house with reference to the importations of 1833 , and from this it appears that the quantity imported that year, expressed in loads, amounted to $1,163,518$, and the duty collected to $£ 1,285,379$, being at the average rate of $22 \mathrm{~s} .1 \frac{1}{4} \mathrm{~d}$. per load. If the duty upon the whole of this quantity had been charged at the rate imposed upon European timber, the proportion brought from the colonies would no doubt have been reduced, and the supplies from the Baltic must have been proportionally increased, by which means the price in the countries of production would have been raised, and this circumstance would so far have acted in diminution of the advantage accruing to the country through the greater receipts at the Exchequer; but when an ample allowance has been made on this account, it will be found that the loss to the public at large, through adherence to the present system, amounted to nearly or quite one million and a half of money in that one year. The importations in the years that have since elapsed have been much greater than those of 1833 , and the loss was consequently for some years still more than the sum here mentioned. It is the opinion of well-informed men, who were examined before the Select Committee of the House of Commons which sat in 1835 to consider 
this subject, that by a return to a more wholesome state of the trade, the price in the countries of production in Europe would be raised only temporarily, the supply of growing timber in those countries being equal to any demand that could possibly arise by that means.

But if these gentlemen should have taken too sanguine a view of the capabilities of the various countries to which we have hitherto and formerly resorted for a supply of timber, there are other districts to be explored into which the woodman's axe has never yet penetrated, with a view to the supply of Western Europe, whence we may draw supplies for ages to come of a quality equal to everything that can be wished, and adapted to purposes which it is now difficult to satisfy. From the forests of Albania, as well as those of Circassia, and all the coasts of the Black Sea and the banks of the Danube, we may - if political, and still more, if fiscal obstacles are removed-draw inexhaustible supplies of the finest wood, including oak of the largest size, and at prices more advantageous than any other countries have offered, at least in modern times.

Under these circumstances, we are, without any adequate or legitimate motive, shutting against onr manufacturers markets which were formerly, and would be again, of considerable importance to them, and are at the same time giving advantages to our manufacturing rivals, of which they are by no means slow to avail themselves. ${ }^{1}$

The official value of goods imported has a nearer agreement with the actual value than has been maintained between the official and the actual values of British manufactured goods exported. The greater part of our importations consists of produce in its raw or unmanufactured state, or of products in a state of preparation which has not called for any great amount of labour, and as to which there is, consequently, but little room for economizing the cost. Our exports, on the contrary, consist in great part of goods upon the preparation or manufacture of which a great amount of labour has been expended; and as the mechanical inventions of the last fifty years have introduced the most important degrees of economy into nearly every process of manufacture, the prices of such goods fixed 180 years ago have become exceedingly wide of their true value. The error which might thus have been exhibited by the custom-house returns,

${ }^{1}$ The full merits of this very important question may be learned by consulting the evidence given before the Committee of 1835, referred to in the text, and also from an article in the fourth number of the British and Foreign Quarterly Review, which was written by one of the most intelligent witnesses examined on that occasion--the late Mr. J. D. Hume. 
has been rectified by the plan of obliging the merchants at the time of shipment to declare the real value of British goods exported. The only course effectual for correcting the error in valuation in the case of foreign goods imported, would be to contrast the quantities so brought into the country at various periods. Such an account it is impossible to present; if even it were procurable, its bulk would prevent its insertion in these pages, and to render it a faithful record it would be necessary to accompany it by many voluminous explanatory statements.

The opening of the present century found this country involved in war, but at the end of 1801 the Peace of Amiens was signed, and its effect was immediately seen; for the value of British goods exported in 1802 exceeded by more than $£ 5,000,000$, or 13 per cent., the value exported in 1801 . The recurrence of war in 1803 put an end to this improvement, and brought our exports below the amount of 1801 . We have not the means of analysing our foreign commerce in any year earlier than 1805 , but in that and the two following years it will be remarked that very nearly one-third of our foreign export trade was carried on with the United States of America. Under the then existing circumstances of the country, with the ports of the Continent shut against us as completely as the power of Napoleon enabled him to accomplish that object, this trade was of peculiar importance to us, not only because it gave employment to our manufacturing population, but also because it provided us with the means of meeting the foreign expenditure of the Government occasioned by the operations of the war. The merchants of the United States were at that time accustomed to sell their produce in the continental markets to a much greater amount than their purchases in those markets; while, in their dealing with this country, the practice was directly the reverse, and they had every year a large balance to pay to this country. The means of liquidating this balance were furnished by the excess of their continental sales, the amount of which was paid to the agents of the English government for bills upon the Treasury, which came as a remittance to our exporting merchants, and thus were funds placed at the disposal of our armies, and the payment of subsidies was accomplished which must otherwise have drained this country of every guinea which it possessed. At the end of 1806, Napoleon aimed an additional and severe blow at this country by means of his famous Berlin decree, whereby he declared all the ports of Great Britain in a state of blockade, and forbade all trading with us or in the articles of our produce and manufactures, declaring such to be subject to seizure and condemnation wherever 
they were found, and forbidding the importation into the countries under his control, which then included nearly, all continental Europe, of any goods of such kinds as were included among the home or colonial productions of this country, unless they should be accompanied by certificates showing their origin to have been other than British. The consequent measures of retaliation adopted by the English government were so far from averting the evil consequences of this Berlin decree, that they proved directly and immediately injurious to our trade, in a greater degree than all the efforts of the enemy would probably have succeeded in accomplishing. Our Orders in Council, issued in the course of 1807 , served indeed only to give efficacy to the paper blockade of Napoleon, against which the whole trading community of the world would have been arrayed but for the notable expedient of the English government. By these Orders in Council it was declared, as the only condition upon which neutrals might trade with countries not at peace with Great Britain, that the vessels in which that trade was carried on should touch at some port in this country, there to pay such amount of customs duties as should be imposed by the British government, and any vessel found to bave on board the certificate of origin required by the French government was declared lawful prize. In answer to these Orders in Council, Napoleon issued his decree from Milan, dated 27th September 1807, in which it was declared that any ship that should have paid any tax to the British government, or that had submitted to be searched by any British authorities, was thereby denationalized, and became good and lawful prize; and in order to give full effect to this decree, it was provided that any person on board a foreign vessel arriving at a port in France, who should notify to the authorities the fact of sucb vessel having visited' an English port, or of its having submitted to be searched, should be entitled to receive one-third of the net value realized from the sale of the vessel and cargo. Further to circumvent the designs of the French government, a system of providing neutral vessels with forged papers, by means of which they might elude the vigilance of the French authorities, was encouraged by the English government; and thus in spite of all the hazard attending this course of very questionable morality, a considerable amount of trade was carried on in vessels bearing the flag of Pappenburg, Oldenburg, and other petty continental powers. Such an expedient was clearly not one which the government of the United States of America could adopt for the prosecution of trade with Europe; and finding that the American flag was thus effectually exeluded from the ports of the Continent, that government interdicted altogether the trade of its 
subjects with either of the belligerents, first, by blockading her own ports, and next, by a law forbidding intercourse with the belligerents, while it allowed of trade with other parts of the world, and which provided for the renewal of trading relations with either of the interdicted nations which should rescind its obnoxions reguiations. The return to wisdom, in this respect, was first evinced by France, and war was declared against this country by the United States.

It will be clear, from the preceding recital, that the great advantages which we had derived from our trade with America, as already described, must have ceased when the blockade of their ports was enforced; and accordingly we find that the amount of our exports became altogether inadequate to meet our public expenditure abroad, the foreign exchanges turned ruinously against this country, and the drain of the precious metals was such that the price of gold rose from $80 \mathrm{~s}$. per oz., at which price it had been stationary during the six preceding years, to $91 \mathrm{~s}$. per oz. in 1809 , to $97 \mathrm{~s}$. $6 \mathrm{~d}$. in 1811 , to $105 \mathrm{~s}$. in 1812 , and $110 \mathrm{~s}$. in 1813 ; these prices being respectively $14,20,25$, and 29 per cent. above the Mint price of $77 \mathrm{~s}, 10 \frac{1}{2} \mathrm{~d}$. per oz. During this period the evil consequences of this state of things was aggravated by the great quantities of foreign goods, beyond the wants of the consumers, that were accumulated in our warehouses, and for which no market could be found. These goods were either actually the property of English merchants, having been received in return for manufactures exported, or were virtually so through advances made to the owners, in addition to the freight, insurance, and other charges which had been incurred upon them. Such of our manufacturers as had the means of doing so, had accumulated large stocks of goods in their stores, but one after another their weans of employing workmen fell off, so that in the beginning of 1811 the state of distress anong all the trading classes had arisen to a most alarming height; meetings were held in the city of London to consider as to the course to be pursued to mitigate the evil, and a Select Committee of the House of Commons was appointed with the same view. The distress was partially alleviated by the issue of Exchequer bills on loan to the merchants, but effectual relief was not obtained until the tide of prosperity began to turn away from the ruler of France, and the continental nations casting off the shackles in which he had bound them, leagned together in alliance with England, for the recovery of their independence: their ports were then of course open to our commerce, and the grools which had been accunulating in our docks and warehouses were distributed to willing purchasers.

The desire of obtaining British manufactured goods and colonial 
produce was exhibited on the part of the inhabitants of the Continent in a remarkable manner during the years which immediately followed the promulgation of the Berlin decree. The scheme for the destruction of our trade was not confined to France, but was adopted likewise by the governments of Austria, Prussia, the States of the Germanic Confederation, Russia, Holland, and the Italian States, then leagued with France against this country; and neither trouble nor precaution was spared in order to ensure its complete adoption. So great, however, was the desire of obtaining the prohibited articles, that all the efforts of the French Commissioners were of little avail, and the export trade of the country was maintained during the years in which the continental system was enforced, at a level nearly as high as it had previously acquired. The well-informed author $^{1}$ of a pamphlet, published in 1835, entitled England, Ireland, and America, says, when speaking on this subject: "It would be amusing, and full of romantic interest, to detail some of the ten thousand justifiable arts invented to thwart this unnatural coalition, which, of necessity, converted almost every citizen of Europe into a smuggler. Bourienne, who was himself one of the Commissioners appointed to enforce these prohibitions at Hamburg, gives some interesting anecdotes in his Memoirs under this head. The writer is acquainted with a merchant who was interested in a house that employed 500 horses in transporting British goods, many of which were landed in Sclavonia, and thence conveyed overland to France, at a charge of about $£ 28$ per cwt., more than fifty times the present freight of merchandise to Calcutta!" In the plenitude of his power, Napoleon was unable to prevent the clandestine introduction and sale of English goods in the very capital of his empire; he was, besides, led occasionally to relax the system so far as to grant licences for the introduction of British and colonial goods. Those licences, which were given to some favoured individuals among his staff and court, were sold to the merchants; and it has been stated that as much as a million of francs- $£ 40,000$ - has been realized from the sale of one of these commercial indulgences.

It has been often brought as matter for reproach against the ministry of that day, that in the negotiations at Vienna, which followed the downfall of Napoleon, the commercial interests of this country were heedlessly abandoned. It can hardly be denied that the minister by whom England was represented at the Congress of Vienna, knew but little, and cared as little, about commercial matters; and that certain of the better-informed 
diplomatists of other countries were not backward to take advantage of his ignorance and supineness. Conquests, which offered wide and improving fields for commercial and manufacturing enterprise, were given up as it were through complaisance; and the whole subject of trade was abandoned, apparently lest the pursuit of what might be called our selfish interest should tarnish the laurels we had gathered in the fields of slaughter. The amount of the sacrifices thus made it would be impossible to estimate; but at however high an amount they may be reckoned, it is probable that we have since suffered far more through our long persistence in a system of restriction and prohibition. This, although it might have been comparatively inoperative during the period of war, could not fail to be viewed with jealousy and anger so soon as peace enabled other nations to turn their attention to foreign commerce. The pertinacity with which we so long adhered to our navigation laws, and the numerous anti-social vices that were suffered to deform our tariff, were calculated to foster this spirit of jealousy on the part of others, and to provoke them to acts of retaliation, from which we, as the most commercial nation, were sure to be the greatest sufferers. The ministry of that time was supported in this adherence to a system of restriction by many merchants who dreaded lest its relaxation might be followed by personal loss to themselves; and it was their endeavour, in which they too well succeeded, to persuade the Government and the legislature that any change of system must tend to destroy the foreign commerce of the country. It has been, unfortunately, the common practice in this country, when legislating upon conmercial matters, to consider the interests of the merchants actually engaged in its prosecution, and not the advantage of the trade itself, which is always best promoted by attention to the interests of the consumers, rather than by assisting the merchants to obtain, by means of what is called protection, an unnatural rate of profit.

The narrow views which have been explained were not universally held by mercantile men. In the year 1820 a considerable number of the most wealthy and enterprising houses in London joined in a petition to the House of Commons, embodying principles, the justice and liberality of which will assure to them the assent at all times of enlightened nen, and reference will long be made to this petition as to the deliberate opinions of practical and experienced merchants upon points which they are peculiarly fitted to understand. 


\section{This petition was in the following terms:-}

"To the Honourable the House of Commons of the United Kingdom of Great Britain and Ireland-

"The humble Petition of the undersigned Merchants of the city of London,

"Sheweth,-That foreign commerce is eminently conducive to the wealth and prosperity of a country by enabling it to import the commodities for the production of which the soil, climate, capital, and industry of other countries are best calculated, and to export in payment those articles for which its own situation is better adapted.

"That freedom from restraint is calculated to give the utmost extension to foreign trade, and the best direction to the capital and industry of the country.

"That the maxim of buying in the cheapest nuarket, and selling in the dearest, which regulates every merchant in his individual dealings, is strictly applicable as the best rule for the trade of the whole nation.

"That a policy founded on those principles would render the commerce of the world an interchange of mutual advantages, and diffuse an increase of wealth and enjoyments among the inhabitants of each state.

"That, unfortunately, a policy the very reverse of this has been, and is, more or less, adopted and acted upon by the Government of this and of every other country, each trying to exclude the productions of other countries, with the specious and well-meant design of encouraging its own productions; thus inflicting on the bulk of its subjects, who are consumers, the necessity of submitting to privations in the quantity or quality of commodities; and thus rendering what ought to be the source of mutual benefit and of harmony aniong states, a constantly-recurring occasion of jealonsy and hostility.

"That the prevailing prejudices in favour of the protective or restrictive system may be traced to the erroneous supposition that every importation of foreign commodities occasions a diminution or discouragement of our awn production to the same extent; whereas it may be clearly shown, that although the particular description of production which could not stand against unrestrained foreign competition would be discouraged; yet as no importation could be continued for any length of time without a corresponding exportation, direct or indirect, there would be an encouragement, for the purpose of that exportation, of some other production to which our situation might be better suited; thus affording at least an equal, and probably a greater, and certainly a more beneficial employment to our own oapital and labour.

"That of the numerous protective and prolibitory duties of our commercial code, it may be proved, that while all operate as a heavy tax on the community at large, very few are of any ultimate benefit to the classes in whose favour they were originally instituted, and none to the extent of the loss occasioned by them to other classes.

"That amiong the other evils of the restrictive or protective system, not the least is, that the artificial protection of one branch of industry or source of production against foreign competition, is set up as a ground of claim by other branches for similar protection; so that if the reasoning upon which restrictive or prohibitory regulations are founded were followed out consistently, it would not stop slort of excluding us from all foreign commerce whatsoever. And the same train of argument, whicl, with corresponding prohibitions and protective duties, should exclude us from foreign trade, might be brought forward to justify the re-enactment of restrictions upon the interchange of 
productions (unconnected with public revenue) among the kingdoms composing the union, or among the counties of the same lingdom.

"That an investigation of the effects of the restrictive system, at this time, is peculiarly called for, as it may, in the opinion of the Petitioners, lead to a strong presumption that the distress which now so generally prevails is considerably aggravated by that system; and that some relief may be obtained by the earliest practicable removal of such of the restraints as may be shown to be most injurious to the capital and industry of the community, and to be attended with no compensating benefit to the public revenue.

"That a declaration against the anti-commercial principles of our restrictive system is of the more importance at the present juncture, inasmuch as in several instances of recent occurrence, the merchants and manufacturers in foreign states have assailed their respective governments with applications for further protection or prohibitory duties and regulations, urging the authority and example of this country, against which they are almost exclusively directed, as a sanction for the policy of such measures. And certainly, if the reasoning upon which our restrictions have been defended is worth anything, it will apply in behalf of the regulations of foreign states against us. They insist upon our superiority in capital and machinery, as we do upon their comparative exemption from taxation, and with equal foundation.

"That nothing would more tend to counteract the commercial hostility of foreign states than the adoption of a more enlightened and more conciliatory policy on the part of this country.

"That although, as a matter of mere diplomacy, it may sometimes answer to hold out the removal of particular prohibitions, or high duties, as depending upon corresponding concessions by other states in our favour, it does not follow that we should maintain our restrictions in cases where the desired concessions on their part cannot be obtained. Our restrictions would not be the less prejudicial to our ovon capital and industry, because other governments persisted in preserving impolitic regulations.

"That, upon the whole, the most liberal wonld prove to be the most politic course on such occasions.

"That, independent of the direct benefit to be derived by this country on every occasion of such concession or relaxation, a great incidental object would be gained by the recognition of a sound principle or standard to which all subsequent arrangements might be referred, and by the salutary influence which a promulgation of such just views by the legislature, and by the nation at large, could not fail to have on the policy of other states.

"That in thus declaring, as your ${ }_{3}$ Petitionel's do, their conviction of the impolicy and injustice of the restrictive system, and in desiring every practicable relaxation of it, they have in view only such parts of it as are not connected, or are only subordinately so, with the public revenue. As long as the necessity for the present amount of revenue subsists, your Petitioners cannot expect so important a branch of it as the customs to be given up, nor to be materially diminished, unless some substitute, less objectionable, be suggested. But it is against every restrictive regulation of trade not essential to the revenue-against all duties merely protective from foreign competition-and against the excess of such duties as are partly for the purpose of revenue, and partly for that of protection, - that the prayer of the present Petition is respectfully submitted to the wisdom of Parliament.

"Your Petitioners therefore humbly pray, that your honourable House will 
be pleased to take the subject into consideration, and to adopt such measures as may be calculated to give greater freedom to foreign commerce, and thereby to increase the resources of the State."

With the single exception of the passage printed in italics, the foregoing petition is highly honourable to the accomplished economist ${ }^{1}$ by whom it is understood to have been drawn up, and to the many eminent merchants by whom it was subscribed. It may be fairly admitted that the light which it has thrown on, and the attention which it has been the means of drawing towards, the subject, have tended in a powerful manner to bring about the successive relaxations which, since its presentation to Parliament, have been made in our commercial code. The degree of success by which it has thus been followed, must make it a matter of great regret that it should contain anything capable of being perverted to an opposite end. The author of the petition would be among the first to disclaim the advocacy of any disingenuous diplomacy, fortifying himself in this disclaimer by the whole tenor of the document, and especially by the qualifying clause that follows the objectionable paragraph. It is unfortunate, however, that the course of proceeding which it suggests has in many instances been since adopted by the English government. It has been seen on these occasions that, by the relaxation of some restriction, or the abolition of some protective duty, a positive good would arise to the trade of this country; but it has been seen, at the same time, that this reform would be also beneficial to the commerce of some other country; and it has been thought desirable to render the relaxation doubly profitable to ourselves, by making it the equivalent for some corresponding relaxation in favour of English commerce on the part of the country that would participate in the improvement. From some cause or other--probably the misconception of our motives, or the fear of being overreached-it has generally happened that it has been thought unwise to grant the price we have demanded for the alteration, and we, having made our relaxation dependent upon the payment of that price, no longer feel ourselves at liberty to persevere to our own profit in a course which we should otherwise be glad to adopt. When communities in general are become more enlightened to the principles that should regulate commerce, such negotiations as that above described can never occur. Commercial treaties will then be unknown, because each country will be led to adopt plans that will be of advantage to itself, unchecked by

1 Thomas Tooke. 
the cousideration that some part of that adrantage may be shared by others; and not only so, but will be induced the more readily to pursue those plans for the very reason that others will participate in the benefit, assured that the prosperity of its neighbours must always have a beneficial influence upon its own condition.

The part of our restrictive system which was viewed with the greatest favour among all classes, was embodied in the measure generally known under the name of the Navigation Act. The foundation of this Act was laid during the Protectorate, and the system was perfected by the 12 Charles II, chap. 18. This Act provided, that no merchandise of either Asia, Africa, or America should be imported into Great Britain in any but English-built ships, narigated by an English commander, and having at least three-fourths of their crew English. Besides this exclusive right imparted to British shipping, discriminating duties were imposed, so that goods which might still be imported in foreign ships from Europe were in that case more highly taxed than if imported under the English flag. The system here described continued to be steadily and pertinaciously maintained during more than 160 years, and was looked upon as a monument of wisdom and prudence, to which was mainly attributable the degree of commercial greatness to which we had attained. May we not hope that, with the present amount of our knowledge, it would be difficult to arrive at any such conclusion, or to believe that the trade of any country could possibly be promoted by compelling the merchants to employ dear instead of cheap ships? The carliest deviation from the Navigation Act that was sanctioned by Parliament, arose out of the treaty with the United States of America, in 1815. The States, soon after the establishment of their independence, had passed a navigation law in favour of their shipping, similar in all its main provisions to the English law; and it affords an instructive lesson, that the practical carrying out of this restrictive system to its fullest extent by the two nations was found to be so unproductive of all good effect, as to call for its mutual abandonment. By this treaty, the ships of the two countries were placed reciprocally upon the same footing in the ports of England and the United States, and all discriminating duties chargeable upon the goods which they conveyed were mutually repealed. It adds greatly to the value of this concession, that it was made by no disciple of free-trade doctrines, but was forced by the very consequences of the system itself, from a Government strenuously opposed to all change in the direction of relaxation. From that moment it became easy to 
foretell the abandonment of our long-cherished system of protection, since every country that desired to remove the disadvantage under which we had placed its trade or shipping, had it thenceforward in its power, by adopting our plans in the spirit of retaliation, to compel us to a relaxation of our code. It is worthy of remark that, amidst all the complaints that have been made by British shipowners, of the abandonment of their interests by their Government, it has never been attempted to question the propriety of the American treaty, nor to complain of its results.

With the exception here noticed, the restrictive system was continued in full force until 1822, when Mr. Wallace, then President of the Board of Trade, introduced five Bills which effected a very important alteration. Of these Bills (3 Geo. IV, cc. 41, 42, 43,44 , and 46 ) the object of the first was to repeal various obsolete statutes that were enacted in relation to foreign commerce before the passing of the Navigation Act. The second Bill repealed various laws dating from the Navigation Act downwards, including those parts of the Navigation Act itself which enacted that goods of the growth, produce, or manufacture of Asia, Africa, or America, should not be imported into this country, except in British ships navigated as already described, and that no goods of foreign growth, production, or manufacture, shall be brought into England from Europe in any foreign ship, except from the place of their production, or from the ports whence they are usually brought, and in ships belonging to the countries of production or accustomed shipment. The third Bill was intituled "An Act for the encouragement of navigation and commerce, by regulating the importation of goods and merchandise, so far as relates to the countries or places from whence, and the ships in which, such importation shall be made." By this Act, certain enumerated goods were allowed to be brought to this country from any port in Europe, in ships belonging to the port of shipment. Ships belonging to Holland, which, by the Navigation Act, had been forbidden to enter English ports with cargo, were placed upon the same footing as the ships of other countries. South American produce, which, before the passing of this Act, could be brought only from certain ports of Spain and Portugal, were now permitted to be imported direct from the places of growth in ships of the country, the only exception to this concession being against places to which British ships were not admitted for the purposes of trade. The regulation of the trade between our possessions in America and the West Indies, and other places in the same quarters, was the object of the fourth Bill. 
It permitted the importation, subject to specified duties, into certain ports, of various articles from any foreign country in America, or port in the West Indies, either in British vessels, or in vessels belonging to the country or place of shipment, and the goods so imported might be again exported to any colony, or to the United Kingdom. The fifth Bill also applied to the regulation of the trade of our Western colonies. By its principal provision it was made lawful to export, in British ships, from any colony to any foreign port in Europe or Africa, any goods that have been legally imported into the colony, or which were of its own growth or manufacture; and it was further made lawful to export certain enumerated articles, in British ships, to any such colony from any foreign port in Europe or Africa. By means of these relaxations, the colonists were enabled to draw their supplies from any country in Europe, Africa, or America, and to send their prodnce in return to such markets as should hold ont the greatest indueements.

In the year following that in which these Acts were yassed, a notification was made to our Gorernment by Prussia, that mnless and until some relaxation of our system was made in favom of the ships of that country, heavy retaliatory duties would be imposed upon English shipping that should enter any Prussian port. It is surprising, considering the snccessful stand made eight years before by the United States, that so long a time should have been allowed to elapse before the continental nations proceeded to force us into the adoption of a more liberal course, by making us in turn the vietims of our anti-social system. The adoption of this natural policy on the part of Prussia would assuredly have been soon followed by a similar movement in other comtries, and our merchants and shipowners became immediately clamorous for the interference of the Govermment to obtain the removal of the duties imposed by Prussia. It was under these circumstances that what in are called the Reciprocity Aets $(4 \mathrm{Geo}$. IF, c. 77 , and 5 Geo. IF, c. 1) were passed. These Acts authorized His Majesty, by Order in Couneil, to permit the importation and exportation of goods in foreign vessels, on payment of the same duties as were chargeable when imported in British vessels, in favour of all such cuuntries as should not levy discriminating duties upon goods imported into those countries in British vessels; and further to levy upon the vessels of such countries, when frequenting British lorts, the same tonnage duties as are chargeable on British vessels. A power was, on the other hand, given to the Crown by these Acts of Parliament, to impose additional duties upon goods and shipping against any 
countries which should levy higher duties in the case of the employment of British vessels in the trade with those countries. The concessions thus made met with only a feeble opposition, the principal Act having passed the Commons by a majority of 5 to 1 .

Under the authority of these Acts of Parliament reciprocity treaties were concluded with most foreign countries.

A great depreciation has undoubtedly taken place in the value of ships in this country. If, while the prices of all other kinds of property had undergone reduction, the price of ships had been exempted from alteration, it would have been extraordinary, and a circumstance by no means favourable to commerce. It is not possible to estimate proportionally the degree in which this general abatement of prices has affected shipping. One ship differs from another in those qualities which determine its marketable value; and not only so, but each ship is continually undergoing a change in those qualities. It may be fairly presumed, however, that the general fall of prices has not borne harder upon the owners of ships than upon the holders of other kinds of property, since we find from public documents, as shown in this volume, that the number and tonnage of vessels built since that fall became matter of complaint, have been greater than they were during years which are now pointed out as periods of prosperity by the shipping interest. The materials of which ships are built all participated in the fall-wood, hemp, iron, copper, sail-cloth,--every article that can be mentioned as portions of a ship or of her stores, had become cheaper, and as new ships could be profitably employed upon lower terms than those built in dearer times, the owners of the latter were of course compelled to accept less remunerative rates of freight. Their value in the market was, of course, affected by the same circumstance, and as no man likes to see his property made less valuable, their owners became discontented. Overlooking the obvious cause of depression, and seeing that not only were they underbid by the owners of British ships built with cheaper materials, but also by the foreign shipowner, whose vessel was built still more cheaply, they forgot the circumstances which had in a manner compelled the Government to relax our navigation laws, and attributed their losses and disappointments to the reciprocity treaties. With this feeling a deputation of shipowners waited upon Mr. Huskisson, when President of the Board of Trade, to remonstrate against the injustice of the new system, which obliged them to enter unprotected into competition with foreign shipping built and navigated so much more cheaply than their own. To meet this 
complaint in the manner that appeared most obviously fair to all parties, Mr. Huskisson proposed to grant to the builders of ships in this country a drawback equal to the full amount of any duty that had been paid upon the materials used in their construction and equipment. For very obvious reasons, this proposal was not favourably received by the complainants, who dreaded lest the Government, by acting upon Mr. Huskisson's suggestion, should give a fresh stimulus to shipbuilding at home, and raise up new competitors, who would be able to rival them successfully in every branch of commerce.

There is not any class of persons in this country, with the exception perhaps of the landowners, which has made such loud and continued complaints of distress as the shipowners have done since the peace in 1815. These gentlemen form a numerous, wealthy, and influential body, and acting as they do, in concert, with an organized committee to watch over their interests, they have always been able to command attention to their representations, and occasionally to defeat such measures of Government as were seemingly opposed to their interests. It is not intended to question here the importance, in a political point of view, of our mercantile marine; that importance has always been considered so great that if a sacrifice were needed on the part of the nation, in order to keep up the number and efficiency of our trading-vessels, there would be little question as to the propriety of such a course. In admitting this, it is by no means intended to allow that any such sacrifice is necessary, or that the activity of our merchants would not furnish an adequate amount of employment in those branches of commerce, where British vessels can be advantageously employed, withont the necessity for inciting them by discriminating duties to embark in any course of trade which may tend to injure other classes of the community. If this position be correct, it would be difficult to show why ships, the tools merely with which merchants work, should be more considered than the traffic itself for the conveyance of which they are constructed, why they should be looked upon, as they generally have been in this country, not as the means of commerce, but as its end.

If it were not for political considerations, no one could have questioned that the true interests of commerce would require that we should employ the ships of any country which would best and cheapest perform the office of conveying merchandise to and from our shores. It is, indeed, no longer doubtful whether, all restrictions imposed on our foreign commerce in favour of our own flag being abolished through the repeal in 1849 of our navigation laws, 
English vessels are able successfully-nay, triumphantly-to compete with the ships of every other country. It is a fact, that in our trade with the United States of America, a continuallyincreasing proportion of British tonnage has of late years been employed. In 1821, the proportion of British vessels which entered the ports of the United States was $7 \frac{1}{5}$ per cent., compared with the American tonnage employed in the foreign trade of the States; while, in 1835 , that proportion was increased to 39 per cent., which proportion was maintained in 1844 , and increased in 1849 , to $55 \frac{3}{4}$ per cent.: the actual numbers in each of the twenty-eight years, from 1821 to 1849 , have been as follow :-

\begin{tabular}{|c|c|c|c|c|c|c|c|}
\hline Year. & & $\begin{array}{l}\text { British } \\
\text { Tons. }\end{array}$ & $\begin{array}{c}\text { American } \\
\text { Tons. }\end{array}$ & Year. & & $\begin{array}{c}\text { British } \\
\text { Tons. }\end{array}$ & $\begin{array}{c}\text { American } \\
\text { Tons. }\end{array}$ \\
\hline 1821 & . & 55,188 & 765,098 & 1836 & & 544,774 & $1,255,384$ \\
\hline 1822 & 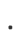 & 70,669 & 787,961 & 1837 & & 543,020 & $1,299,720$ \\
\hline 1823 & . & 89,553 & 775,271 & 1838 & & 484,702 & $1,302,974$ \\
\hline 1824 & & 67,351 & 850,033 & 1839 & & 495,353 & $1,491,279$ \\
\hline 1825 & . & 63,036 & 880,754 & 1840 & & 582,424 & $1,576,946$ \\
\hline 1826 & . & 69,295 & 942,206 & 1841 & & 615,623 & $1,631,909$ \\
\hline 1827 & . & 99,114 & 918,361 & 1842 & & 599,502 & $1,510,111$ \\
\hline 1828 & . & 104,167 & 868,381 & 1843 & . & 453,894 & $1,443,523$ \\
\hline 1829 & . & 86,377 & 872,949 & 1844 & . & 766,747 & $1,977,438$ \\
\hline 1830 & . & 87,231 & 967,227 & 1845 & & 753,882 & $2,035,486$ \\
\hline 1831 & . & 215,887 & 922,952 & 1846 & & 813,287 & $2,151,114$ \\
\hline 1832 & . & 288,841 & 949,622 & 1847 & . & . 993,210 & $2,101,359$ \\
\hline 1833 & . & 383,487 & $1,111,441$ & 1848 & & . $1,177,104$ & $2,393,482$ \\
\hline 1834 & . & 453,495 & $1,074,670$ & 1849 & & . $1,482,707$ & $2,658,321$ \\
\hline 1835 & & 529,922 & $1,352,653$ & & & & \\
\hline
\end{tabular}

The incrcase in British shipping between the first and the last years of the series is 2584 per cent.; but the increase in American shipping during the same time has been nearly 248 per cent.; and in the face of this positive increase of employment we have not heard any complaints from American shipowners against the system of reciprocity under which the far greater proportionate increase of British shipping has occurred. If all the foreign tonnage that entered the ports of the United States in each of the years 1821, 1835, and 1849 were compared with the American tonnage in those years respectively, it would be found that, in 1821 , the proportion was 10.65 ; whilst, in 1835 , it was 47.42 of foreign to 100 American, and in 1849 , it was 64.36 . If, then, we compare in the same way the British and foreign tonnage that entered the ports of the United Kingdom in the same years, it will be found, that in the former year the proportion was 27 per cent.; while, in 1835 , it was $35 \frac{1}{2}$ per cent., and in $1849,41.67$ per cent. If we then turn to the halcyon days of British ship- 
owners-the days to which they are accustomed to refer as the period of theil greatest prosperity-we shall find that this prosperity was certainly not occasioned by the absence of competition on the part of foreign vessels; for in each of the years as to which the records have been preserved, which occurred between the beginning of the century and the termination of the war, the proportion of foreign to British shipping which entered our jorts was far greater than it is at present:-

In 1801 for 100 tons British, there were 84.56 tons foreign.

\begin{tabular}{|c|c|c|c|c|}
\hline 1802 & , & , & $36 \cdot 02$ & ," \\
\hline 1803 & , & ,, & $57 \cdot 19$ & , \\
\hline 1804 & , & , & $67 \cdot 11$ & , \\
\hline 1805 & , & , & 72.58 & ", \\
\hline 1806 & ," & ," & $67 \cdot 77$ & ", \\
\hline 1809 & , & , & 80.88 & , \\
\hline 1810 & , & , & $131 \cdot 27$ & , , \\
\hline
\end{tabular}

In whichever way we estimate the amount of our foreign and colonial commerce, whether by the "official value" of the customhouse, or the declared value of the exporters, we shall acquire a very imperfect test of its importance. It is not according to the money value of the goods, but according to the amount of industry which bas been set in motion for their production, that we should estimate our exports; while, on the other hand, it is the quantity and not the money value of the foreign productions that we receive in return, that forms the true measure of the sum of enjoyment which they occasion to the country. The amount of tonnage employed for the conveyance of these products from and to our shores forms, perhaps, a much better ineasure of the progress of our foreign trade than any computations of their cost in money. If, then, we contrast the amount of shipping that entered and left our ports in the two years 1802 and 1836 , we find that in the former year it amounted to rather less than half the tonnage employed in 1836 ; the numbers being $3,448,060$ and $r, 061,069$ respectively. In 1814 , the first year of peace, the tonnage employed amounted to no more than $3,764,428$; but since that time the quantity has progressively increased, somewhat slowly at first, but more rapidly of late years. The average of the five years, 1814 to 1818 , was $4,147,257$ tons. The averages during subsequent periods have been as follow:-

$$
\begin{aligned}
& 5 \text { sears, } 1819 \text { to } 18234,200,332 \text { tons. } \\
& 5 \quad, 1824,, 1828 \quad 5,332,122 \text {,, } \\
& 5 \text {,, } 1929,1833 \quad 5,916,311 \text {, } \\
& 5 \quad \text {, } 1834,1838 \quad \tau, 056,097 \quad . \\
& 6 \text { ", } 1839,, 1844 \quad 9,514,123 \text {,, } \\
& 5 \text {, } 1845,184913,216,620 \text {, }
\end{aligned}
$$


The actual numbers in each of the last five years of the series were:

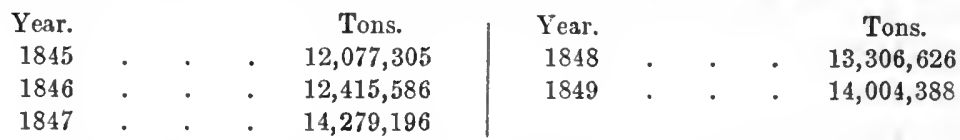

The number and tonnage of registered ships belonging to the United Kingdom and its dependencies in various years from 1803 (the earliest year to which the record extends) down to 1849 show expansion mainly in the last decade. In comparing the amount of tonnage that existed during the war with the amount since on the registry, it must be borne in mind, that in the former period a considerable part of our mercantile marine was employed in the public service, for the conveyance of troops and warlike stores, and that during a time of peace a smaller number of ships will suffice for carrying on a given amount of traffic than are required during war, when they are liable to detention for convoy. In addition to these circumstances, we must bear in mind the fact already mentioned, that where steam-vessels are employed, the celerity of their movements occasions a great saving in the tonnage required.

Vessels belonging to the United Kingdom and its Dependencies

\begin{tabular}{|c|c|c|c|c|c|c|c|c|c|}
\hline & \multicolumn{3}{|c|}{ Year. } & \multicolumn{2}{|c|}{$\begin{array}{l}\text { United Kingdom } \\
\text { and Possessions } \\
\text { in Europe. }\end{array}$} & \multicolumn{2}{|c|}{ Colonies. } & \multicolumn{2}{|c|}{ Total. } \\
\hline & & & & Ships. & Tons. & Ships. & Tons. & Ships. & Tons. \\
\hline 1803 & - & . & . & 18,068 & $1,986,076$ & 2,825 & 181,787 & 20,893 & $2,167,863$ \\
\hline 1810 & . & . & . & 20,253 & $2,210,661$ & 3,450 & 215,383 & 23,703 & $2,426,044$ \\
\hline${ }^{*} 1814$ & . & . & . & 21,550 & $2,414,170$ & 2,868 & 202,795 & 24,418 & $2,616,965$ \\
\hline 1815 & . & . & . & 21,869 & $2,447,831$ & 2,991 & 203,445 & 24,860 & $2,681,276$ \\
\hline 1816 & . & & . & 22,026 & $2,504,290$ & 3,775 & 279,643 & 25,801 & $2,783,933$ \\
\hline 1820 & ? & 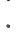 & . & 21,969 & $2,439,029$ & 3,405 & 209,564 & 25,374 & $2,648,593$ \\
\hline 1825 & . & & & 20,701 & $2,328,807$ & 3,579 & 214,875 & 24,280 & $2,553,682$ \\
\hline 1826 & . & & & 20,968 & $2,411,461$ & 3,657 & 224,183 & 24,625 & $2,635,644$ \\
\hline+1827 & . & & . & 19,524 & $2,181,138$ & 3,675 & 279,362 & 23,199 & $2,460,500$ \\
\hline 1828 & . & 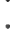 & . & 19,646 & $2,193,300$ & 4,449 & 324,891 & 24,095 & $2,518,191$ \\
\hline 1830 & . & & . & 19,174 & $2,201,592$ & 4,547 & 330,227 & 23,721 & $2,531,819$ \\
\hline 1835 & 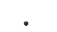 & & & 20,300 & $2,360,303$ & 5,211 & 423,458 & 25,511 & $2,783,761$ \\
\hline 1840 & . & & . & 20,685 & $2,584,408$ & 6,308 & 543,276 & 26,993 & $3,127,684$ \\
\hline 1845 & . & 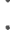 & . & 24,388 & $3,123,180$ & 7,429 & 590,881 & 31,817 & $3,714,061$ \\
\hline 1849 & & & . & 25,902 & $3,485,958$ & 8,188 & 658,157 & 34,090 & $4,144,115$ \\
\hline
\end{tabular}

* The records of 1812 and 1813 were destroyed at the burning of the custom-house.

† The new Registry Act (6 Geo. IV, c. 110) came into operation this year; previously to that time many ressels which had been lost from time to time were continued in the registry, no evidence of their loss having been produced.

The number and tonnage of merchant vessels built and registered in the British dominions in various years, from 1801 to 1849 , are given in a table on the following page. 
It will be seen that the amount of new vessels was very much greater during the years 1825 to 1849 than it was during the former part of the century. The casualties to which ships are liable are evidently greater luring war than in peace; and we should assuredly have required, on that account, to build a larger number between 1801 and 1813 than subsequently, but for the number of foreign trading ressels captured between those years and admitted to the privileges of a British register. There is not any

Statement of the Number and Tonnage of Vessels Built and Registered in the United Kingdom and its Depentencies in various Years since 1801

\begin{tabular}{|c|c|c|c|c|c|c|c|c|}
\hline \multicolumn{3}{|c|}{ Year. } & \multicolumn{2}{|c|}{$\begin{array}{l}\text { United Kingdom, } \\
\text { and Possessions } \\
\text { in Europe. }\end{array}$} & \multicolumn{2}{|c|}{ Colonies. } & \multicolumn{2}{|c|}{ British Empire. } \\
\hline & & & Ships. & Tons. & Ships. & Tons. & Ships. & Tons. \\
\hline 1801 & . & . & $\ldots$ & $\ldots$ & $\ldots$ & $\ldots$ & 1,065 & 122,593 \\
\hline 1810 & - & . & & & & & 685 & 84,891 \\
\hline 1814 & . & . & 706 & 86,075 & 158 & 11,874 & 864 & 97,949 \\
\hline 1815 & . & . & 912 & 102,903 & $2 \pi 1$ & 25,637 & 1,183 & 128,540 \\
\hline 1816 & . & . & 852 & 84,676 & 422 & 32,725 & 1,274 & 117,401 \\
\hline 1820 & • & . & 635 & 68,142 & 248 & 16,440 & 883 & 84,582 \\
\hline 1825 & - & . & 1,003 & $12 ;, 029$ & 536 & so, 995 & 1,539 & 204,924 \\
\hline 1830 & . & . & 750 & 77,411 & 367 & 32,719 & 1,117 & 110,130 \\
\hline 1835 & . & . & 916 & 121,722 & 455 & 63,230 & $1,3 \pi 1$ & 184,952 \\
\hline 1840 & . & . & 1,406 & 216,949 & 771 & 143,258 & 2,177 & 360,237 \\
\hline 1845 & . & . & $\$ 90$ & 124,919 & 638 & 90,696 & 1,528 & 215,615 \\
\hline 1849 & . & . & 771 & 121,266 & *60s & 109,518 & 1,379 & 230,784 \\
\hline
\end{tabular}

* The returns for the colonies not having been all received when this account was made up, the uumbers for 1849 cannot be accurately giren, and are below the truth.

existing account of the actual number so admitted in each of the years, but a parliamentary return gives the number and tonnage of foreign-built vessels thus privileged, which continued in existence on the 30th September of each year, from 1792 to 1812: these ressels form part of the tonnage included in the statement already given.

Statement of the Number and Tonnage of Prize Ships admitted to British Registry, which continued in existence on the 30th of September of each Year from 1801 to 1812

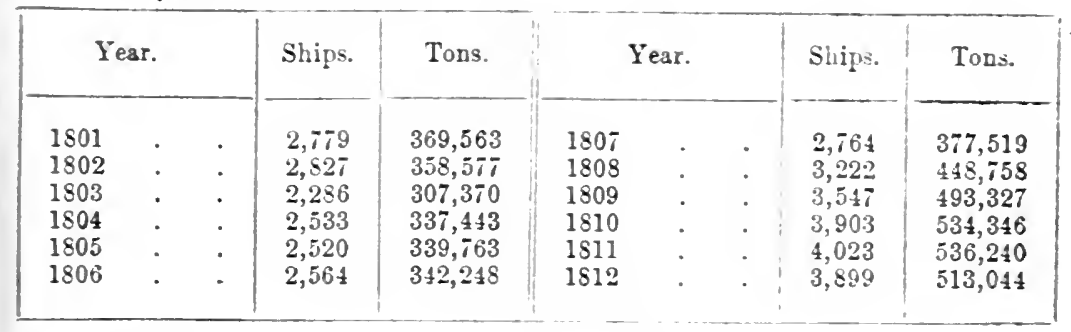


It is a singular fact, that notwithstanding the importance which has always been assigned to the subject of the employment of shipping in this country, there are not any public documents in existence from which a perfect account can be compiled of the number of vessels and their tonnage that entered the ports of the United Kingdom, and cleared from the same in the years that occurred between 1801 and 1814 . In this latter year the customhouse of London was destroyed by fire, and for all information

Statement of the Number and Tonnage of Vessels, British and Foreign, that entered the Ports of the United Kingdom, exclusive of the intercourse between Great Britain and Ireland, and of the Coasting Trade, in various Years from 1801 to 1849 , so far as the same can be made up from records at the Custom-house

\begin{tabular}{|c|c|c|c|c|c|c|c|c|}
\hline \multicolumn{9}{|c|}{ INWARDS. } \\
\hline \multicolumn{3}{|c|}{ Year. } & \multicolumn{2}{|c|}{ British. } & \multicolumn{2}{|c|}{ Foreign. } & \multicolumn{2}{|c|}{ Total. } \\
\hline & & & Ships. & Tons. & Ships. & Tons. & Ships. & Tons. \\
\hline 1801 & . & . & 4,987 & 922,594 & 5,497 & 780,155 & 10,484 & $1,702,749$ \\
\hline 1810 & . & . & 5,154 & 896,001 & 6,876 & $1,176,243$ & 12,030 & $2,072,244$ \\
\hline 1815 & . & . & 8,880 & $1,372,108$ & 5,314 & 746,985 & 14,194 & $2,119,093$ \\
\hline 1820 & . & . & 11,285 & $1,668,060$ & 3,472 & 447,611 & 14,757 & $2,115,671$ \\
\hline 1830 & . & . & 13,548 & $2,180,042$ & 5,359 & 758,828 & 18,907 & $2,938,870$ \\
\hline 1835 & . & . & 14,295 & $2,442,734$ & 6,005 & 866,990 & 20,300 & $3,309,724$ \\
\hline 1840 & : & . & 17,883 & $3,197,501$ & 10,198 & $1,460,294$ & 28,081 & $4,657,795$ \\
\hline 1845 & . & . & 21,001 & $4,310,639$ & 11,651 & $1,735,079$ & 32,652 & $6,045,718$ \\
\hline 1849 & . & . & 23,646 & $4,884,210$ & 13,426 & $2,035,690$ & 37,072 & $6,919,900$ \\
\hline
\end{tabular}

Statement of the Number and Tonnage of Vessels, British and Foreign, that cleared from the Ports of the United Kingdom, exclusive of the intercourse between Great Britain and Ireland, and of the Coasting Trade, at various Years from 1802 to 1849 , so far as the same can be made up from records at the Custom-house

\begin{tabular}{|c|c|c|c|c|c|c|c|c|}
\hline \multicolumn{9}{|c|}{ OUTWARDS. } \\
\hline \multicolumn{3}{|c|}{ Year. } & \multicolumn{2}{|c|}{ British. } & \multicolumn{2}{|c|}{ Foreign. } & \multicolumn{2}{|c|}{ Total. } \\
\hline & & & Ships. & Tons. & Ships. & Tons. & Ships. & Tons. \\
\hline 1802 & . & . & 7,471 & $1,177,224$ & 3,332 & 457,580 & 10,803 & $1,634,804$ \\
\hline 1810 & . & . & 3,969 & 860,632 & 6,641 & $1,138,527$ & 10,610 & $1,999,159$ \\
\hline 1815 & . & & 8,892 & $1,398,688$ & 4,701 & 751,377 & 13,593 & $1,150,065$ \\
\hline 1820 & . & . & 10,102 & $1,549,508$ & 2,969 & 433,328 & 13,071 & $1,982,836$ \\
\hline 1830 & . & . & 12,747 & $2,102,147$ & 5,158 & 758,368 & 17,905 & $2,860,515$ \\
\hline 1835 & : & . & 13,948 & $2,419,941$ & 6,047 & 905,270 & 19,995 & $3,325,211$ \\
\hline 1840 & $\dot{.}$ & . & 17,633 & $3,292,984$ & 10,440 & $1,488,888$ & 28,073 & $4,781,872$ \\
\hline 1845 & . & . & 20,231 & $4,235,451$ & 12,296 & $1,796,136$ & 32,527 & $6,031,587$ \\
\hline 1849 & . & : & 22,328 & $4,785,428$ & 15,275 & $2,299,060$ & 37,603 & $7,084,488$ \\
\hline
\end{tabular}


connected with that branch of the public service, which refers to years preceding that event, we are obliged to depend upon returns that had already been made to Parliament. Since 1814, however, the documents are complete.

These tables prove, to demonstration, that the gloomy forebodings of Euglish shipowners, as already explained, have altogether failed of realization. It is a well-known fact, that the mercantile navy of Prussia, a country to which they looked with the greatest degree of apprehension, has been most markedly diminished in amount since the commencement of our reciprocity agreement with that country. Our shipping, on the contrary, is far from having been diminished by admitting this amount of foreign rivalry. Having amounted, on the average of the three years 1824 to 1826 , to $2,582,971$ tons, it was increased on the average of the three years ending with 1836 , to $2,761,169$ tons, and in the three years ending with 1849 , to $4,049,600$ tons. If we compare the average amount of British and foreign tonnage that entered the ports of the United Kingdom at the earliest and latest of these triennial periods, we shall find that, while that under the British flag has increased from $1,964,183$ to $4,797,279$ tons, or $2,833,096$ tons, the average amount of foreign tonnage so entering has increased only from 803,896 to $2,083,347$, or $1,279,451$ tons.

A table on the following page, with which this chapter may fitly conclude, shows the course of the import and export trade of the United Kingdom with the principal divisions of the world in each of the years $1802,1814,1835$, and 1849 :- 


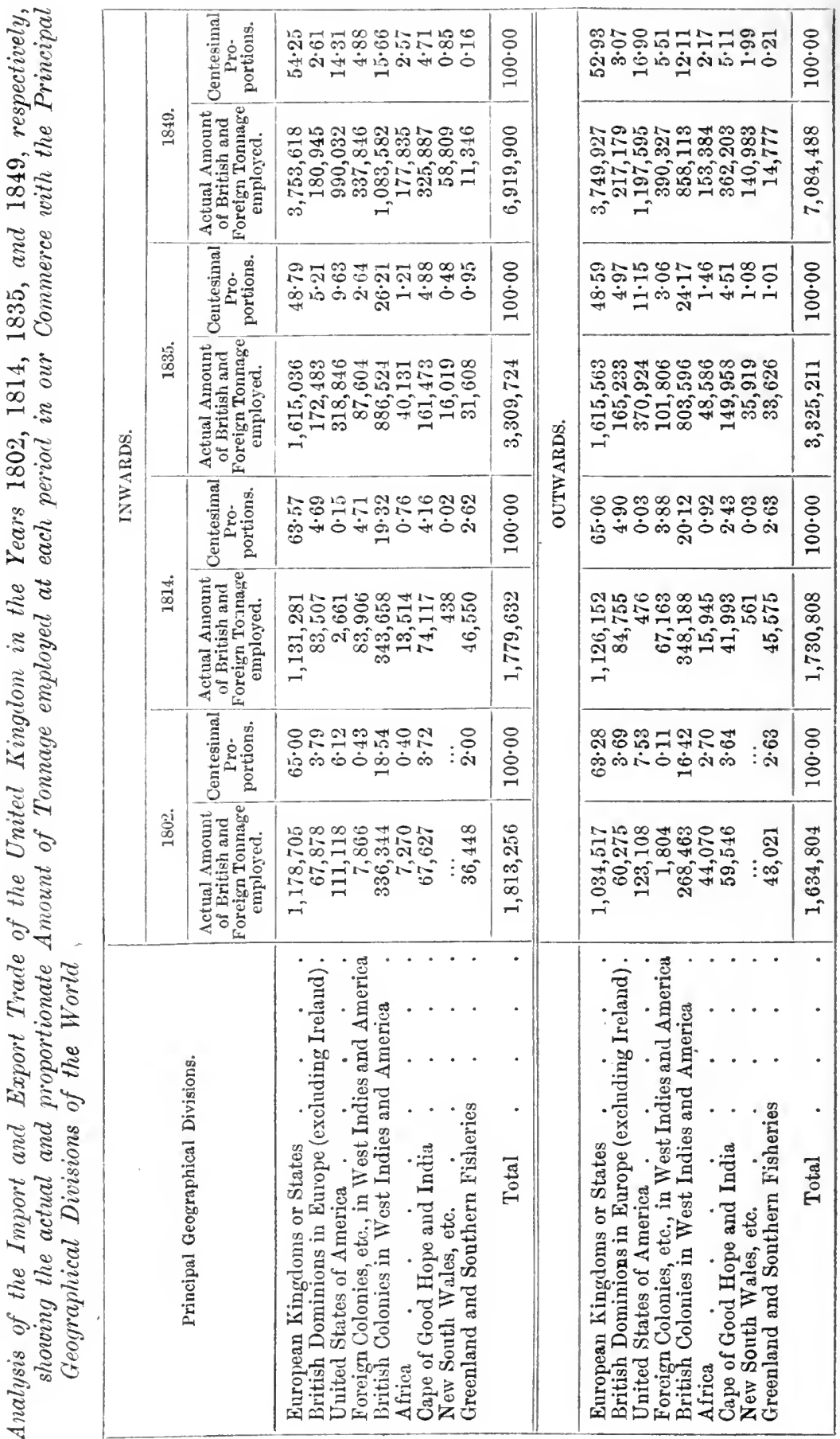




\section{CHAP'TER IXVII}

\section{BRITISH FOREIGN TRADE (IMPOR'TS AND EXPOR'TS), 1850-1910}

Imports and exports, 1850-1870--Second period, 1870-1890-Third perior, 15901910-Mr. Chamberlain's Protectionist campaign with its statistical basis-Exports of coal and machinery-The excess of imports-Food and raw material-Our chief foreign and colonial customers-Our chief imports and exiorts, 1860-1910

ПHE preceding chapter, written by Porter and republished (with a certain number of abbreviations) as it appeared in the edition of 1851 , gives a retrospect of the foreign trade of Great Britain for the first half of the nineteenth century. At the Board of Trade Porter had seen the movements he described, had helped to collect and reform the statistics which he set forth, and had developed his opinions and theories in the course of his administrative work. Shortly after his death the Statistical Abstract for the United Kingdom began to be published, and this invaluable annual publication gives the "declared real value" of our imports and exports (as well as the quantities of some principal articles), from the year 1850 for exports and from the year $155 \pm$ for imports onwards to the present time. The first two decades of Free Trade, 1850 to $18 \% 0$, beginning with the repeal of the Corn Iaws and Navigation Acts and marked by the two great Free Trade budgets of 1853 and 1860 , exhibit an extraordinary expansion and elasticity. Thanks to inporoved machinery and a lowering of prices, in which other nations did not share, production was rapidly cheapened in all directions: the etficiency of labour increased even more rapidly than wages, and the profits of manufacturers and merchants kept pace with the rapidly improving conditions of labourers and artisans. In fact, trade and revenue were advancing by leaps and hounds, while the public economy which had been learned in hard times was maintained.with such rigour and consistency, that (except during the Crimean War") constant surpluses of revenue were available for reducing taxes and relieving the 
consumer of many burdensome duties. Taking these first twenty years, we find that the total exports of British produce rose from a value of 71 millions sterling in 1850 to 97 millions in 1854, 135 millions in 1860, and 199 millions in 1870. Meanwhile the re-cxports (i.e. the exports of foreign and colonial produce which indicate the volume of our highly-profitable emporium trade) were valued at 18 millions in 1854,28 millions in 1860 , and 44 millions in 1870. Our total imports from abroad (representing the payment for these exports as well as for shipping services and interest on capital invested abroad) were valued at 152 millions in 1854,210 millions in 1860 , and 303 millions in 1870 . The greater our surplus wealth, the greater is the overflow in the shape of investments abroad and in the colonies. As these capital investments have increased, and as British shipping has increased, during the last half-century the greater must be the gap between imports and exports. In other words, the amount by which British imports exceed British exports measures the interest on our investments and the payments received by British shippers for performing more than half the sea transportation of the world.

The next period of twenty years-from 1870 to 1890 -commences with the war between France and Germany by which prices were at first unnaturally stimulated and British manufacturers reaped a golden harvest. The natural depression followed this inflation of values. In 1875 many commercial failures occurred. In 1878 the City of Glasgow Bank came to grief, and the depression in Germany led to a protectionist agitation and a higher tariff. At the same time Victoria and Canada adopted protectionist tariffs. In the early 'eighties the Russian, Austrian, and German tariffs were further increased, while that of the United States was reduced. The Transvaal gold discoveries of 1885 did not prevent a severe depression of trade with much unemployment (accompanied by a "fair trade" movement) in the following year. In these years no great changes or improvements took place in taxation. Some further reductions in the tariff were effected, but in the late 'seventies the income-tax began to rise in consequence of severai small wars. In 1875 our imports stood at 374 millions, our exports of British produce at 223 millions, and our re-exports at 58 millions. In 1880 the corresponding figures were 411, 223, and 63 millions respectively. In 1890 our total imports were valued at 421 millions sterling, exports of British produce were 263 millions, and re-exports 64 millions. These twenty years showed a steady increase of prosperity, but there was no such sensational expansion 
in foreign trade as that which marked the first twenty years of Free Trade.

The record of the last of our three periods, from 1890 to 1910 , is cxtraordinarily interesting as a study alike in commercial policy and in commercial statistics. It began with the M'Kinley Tariff, saw further progress in the demonitization of silver and four great wars -between Japan and China, between the United States and Spain, between Great Britain and the Boer Republics, between Russia and Japan. In 1894 the high Republican Tariff of M'Kinley was lowered by the Wilson (Demoeratic) Tariff. But the Republicans, returning to office in 1897 , carried the Dingley Tarifi, which was the high-water mark of Protection in the United States. In the following year Sir Wilfrid Laurier's Liberal Govermment in Canada retorted by according a preferential tariff with lower duties to Great Britain. About this time Mr. Chamberlain was mooting the idea of an imperial zollverein on a more or less Free Trade basis, but his schemes were interrupted by the Boer War, which broke out in the autumn of 1899 , lasting for two years and eight months. The war cost us 250 millions of money. It becran at a moment of splendid trade and high credit. It was followed by several years of trade depression and unemployment. The eapital lost conld not easily be replaced, and Goremment securities fell 20 per cent., railwars and most other stocks following suit. A swall protective duty on corn (imposed during the war), which was thought to be unpopular, was removed immediately afterwards. Mr. Chamberlain, who had hoped to use this tax for the purpose of bargaining with the Colonies, left the Cabinet and began to preach throughout the country a policy of colonial preference, which he gradually associated with the more popular doctrine of protection for home manufactures. He founded his proposals upon a statistical comparison of the years 1872 and 1902 -the first being a year of great expansion and high prices, the second a year of depression and low prices. He also made a survey of British trades with a view to showing that many had already been ruined, that many were being ruined, and that many even of the most prosperous showed symptoms of decline. The remedy, he said, was to shut out the foreigner from the home market and to cultivate trade with the Colonies. Unluckily for Mr. Chamberlain, exports of British manufactures, which he treated as the best index of industrial prosperity, began to increase soon after the commencement of his campaign, and the working classes of the north refused to be convinced. The food taxes were especially unpopular, and the general elections of 1906 gave an overwhelming 
majority to the Liberal and Free Trade party. The Tariff Reform League continued its operations, but was again defeated in the two general elections of 1910. Meanwhile at the end of 1907 the great trade boom was terminated by a crisis in the United States. It was followed by a severe depression, and the same causes that helped Mr. Chamberlain in 1902 to start a protectionist crusade produced a great anti-protectionist movement in the United States, which culminated in the Democratic victories of 1909 and the conversion of Mr. Taft to the advocacy of reciprocity with Canada and of a lower tariff with a view to reduce the cost of living.

The following table from the Fiscal Blue Book, compiled by the Board of Trade for Mr. Balfour's Government in 1903, shows the statistical basis upon which $\mathrm{Mr}$. Chamberlain conducted his campaign, and at the same time supplies the total imports and the total exports of British produce for the first twelve years of our period. We have added a fifth column to show our emporium trade:-

Imports and Exports (in million pounds)

\begin{tabular}{|c|c|c|c|c|c|c|}
\hline Years. & & $\begin{array}{c}\text { Total } \\
\text { Iniports. }\end{array}$ & $\begin{array}{l}\text { Imports of } \\
\text { Mianufactured } \\
\text { and partly } \\
\text { Manufactured } \\
\text { Goods. }\end{array}$ & $\begin{array}{c}\text { Total Exports } \\
\text { of Britisl } \\
\text { Produce. }\end{array}$ & $\begin{array}{c}\text { Exports of } \\
\text { British Manu- } \\
\text { factured and } \\
\text { partly Manu- } \\
\text { factured Goods. }\end{array}$ & $\begin{array}{l}\text { Exports of } \\
\text { Foreign } \\
\text { and } \\
\text { Colonial } \\
\text { Produce. }\end{array}$ \\
\hline & & $£$ & $£$ & $\stackrel{£}{2}$ & $£$ & $£$ \\
\hline 1872. & . & 355 & 63 & 256 & 233 & 58 \\
\hline 1890 & . & 421 & 98 & 263 & 228 & 64 \\
\hline 1891 . & . & 435 & 97 & 247 & 213 & 61 \\
\hline 1892 . & . & 424 & 98 & 227 & 195 & 64 \\
\hline 1893. & . & 405 & 98 & 218 & 188 & 58 \\
\hline 1894 . & . & 408 & 101 & 216 & 183 & 57 \\
\hline 1895 . & . & 417 & 107 & 226 & 195 & 59 \\
\hline 1896 . & . & 442 & 117 & 240 & 208 & 56 \\
\hline 1897. & . & 451 & 123 & 234 & 199 & 59 \\
\hline 1898 . & . & 471 & 125 & 233 & 198 & 60 \\
\hline 1899 . & . & 485 & 135 & $255^{*}$ & $213^{*}$ & 65 \\
\hline 1900 . & . & 523 & 145 & 283 * & 224 * & 63 \\
\hline 1901 . & . & 522 & 142 & 271 * & $221 *$ & 67 \\
\hline 1902 . & . & 528 & 148 & $278^{*}$ & $227^{*}$ & 65 \\
\hline
\end{tabular}

* These figures exclude the value of ships and new boats exported with their machinery, which were recorded for the first time in 1899. These exports fluctuated widely from four millions in 1903 and 1904 to ten millions in 1907 and 1908.

At the commencement of the so-called Tariff Reform movement in 1902, the opponents of Cobdenism (though generally anxious to encourage exports and discourage imports) professed to look with disfavour upon two branches of the export trade-coal and machinery-because these exports supplied our rural manufacturers 
abroad with the means of competition. Very little opposition was, however, made to the removal of the export duty on coal, which had been very unpopular in the coal-mining districts, and the idea of reimposing the old export duty on machinery was never pressed, as it would have antagonized a very important section of manufacturers who, in fact, desired import duties on machinery in order to enable them to raise their prices in the home market. Nevertheless, in the first Fiscal Blue Book coal and machinery were treated

British Exports (in thousand pounds sterling) of Coal, Machinery, and other Articles, 1870-1902

\begin{tabular}{|c|c|c|c|c|c|c|}
\hline \multicolumn{2}{|c|}{ Year. } & & $\begin{array}{l}\text { Coal, Coke, } \\
\text { etc. }\end{array}$ & $\begin{array}{l}\text { Machinery } \\
\text { and }\end{array}$ & $\begin{array}{l}\text { All other } \\
\text { Articles }\end{array}$ & $\begin{array}{l}\text { Total Value of } \\
\text { all British Exports, } \\
\text { Texclusive of Shins? }\end{array}$ \\
\hline & & & $£$ & $f$ & $£$ & $£$ \\
\hline 1870 & . & . & 5,638 & 5,293 & $188,650^{\circ}$ & $199,5 \leq \gamma$ \\
\hline $18 \pi 1$ & . & . & 6,246 & $5,90^{\circ}$ & 210,854 & $223,066^{3}$ \\
\hline 1872 & . & . & 10,442 & 8,201 & 237,614 & 256,257 \\
\hline 1873 & . & . & 13,189 & 10,020 & 231,956 & 255,165 \\
\hline 1874 & . & . & 11,984 & 9,791 & 217,753 & 239,558 \\
\hline 1875 & . & . & 9,658 & 9,059 & 204,749 & $223, \pm 66$ \\
\hline 1876 & . & . & 8,905 & 7,210 & 181,524 & 200,639 \\
\hline 187 & . & . & 7,844 & 6,723 & 184,326 & 195.893 \\
\hline 1878 & . & . & 7,330 & 7,498 & 178,021 & 192,849 \\
\hline 1879 & . & . & 7,207 & 7,279 & 177,046 & 191,532 \\
\hline 1880 & . & . & 8,373 & 9,264 & 205,423 & 223,060 \\
\hline 1881 & . & & $8,780^{\circ}$ & 9,960 & 215,277 & 234,023 \\
\hline 1882 & . & . & 9,564 & $11,4 \pm 6$ & $220, \pm 57$ & $241,46 \pi$ \\
\hline $18 \varepsilon 3$ & . & . & 10,645 & 13,022 & 216,121 & 239,792 \\
\hline 1884 & . & & 10,851 & 12,717 & 209,457 & 233,025 \\
\hline 1885 & . & . & 10,633 & 10,715 & 191,767 & 213.115 \\
\hline $18 \varepsilon 6$ & . & . & $8,83 i$ & 9,702 & $193,1 \& 6$ & 212.725 \\
\hline 1887 & . & . & 10,170 & 10,623 & 201,121 & 221,914 \\
\hline 1888 & . & . & 11,345 & 12,494 & $210,690^{\circ}$ & 234,535 \\
\hline 1889 & . & . & $14,7 \leqslant 2$ & 14,672 & 219,481 & 248,935 \\
\hline 1890 & . & . & 19,020 & 16,411 & $22 \S, 100$ & 263,531 \\
\hline 1891 & . & . & 18,895 & 15,070 & 213,270 & 247,235 \\
\hline 1892 & . & . & 10,811 & 13,069 & 197,336 & 227,216 \\
\hline 1893 & . & . & 14,375 & 13,200 & 130,684 & 218.260 \\
\hline 1894 & . & . & 17,372 & 13,435 & 185,183 & 216,006 \\
\hline 1895 & . & . & 15,134 & 14,235 & 126.458 & $226,12 s$ \\
\hline 1896 & . & . & 15,155 & 16,059 & 208,931 & 240,146 \\
\hline 1897 & . & . & 16,655 & 15,181 & $202,3=1$ & 234,220 \\
\hline 1898 & . & . & 18,136 & $1 \pi, 306$ & $19 \pi, 917$ & 233,359 \\
\hline 1899 & . & . & 23,094 & 18,372 & $213, \S 30$ & 255,296 \\
\hline 1900 & . & . & $-38,620$ & 19,620 & 224,354 & 282.001 \\
\hline 1901 & . & . & 30,335 & 17,812 & $2 \geq 2,726^{\circ}$ & 270,873 \\
\hline 1902 & . & . & $=7,591$ & 18,755 & 231,216 & $27 \pi, 552$ \\
\hline
\end{tabular}


separately, and it was shown that the exports of both had increased enormously since 1850 . From 1850 to 1871 they grew simultaneously at approximately the same rate. In 1850 coal exports were valued at $£ 1,284,000$, and exports of machinery at $£ 1,042,000$. By 1857 they had risen to over three millions, and by 1864 to over four millions apiece. From 1870 to 1902 we may give the full table (p. 521) as it appears in the first Fiscal Blue Book (Cd. 1761 of 1903 ).

It may here be observed that coal exports are especially desirable for the following reasons:-

1. Our coal fields have been shown by royal commissions to be practically inexhaustible.

2. But invention, by harnessing the tides or in other ways, may supersede coal or greatly reduce its use and saleable value.

3. A much greater part of the value of coal is due to the wages of British labour than is the case with most of our manufactured articles.

4. The export trade in coal supplies our ships with the one bulky article which we have to give in return for the many bulky articles which we buy. To discourage coal exports is to discourage British shipping and raise freights.

In 1902 various uninstructed writers and speakers expressed the greatest alarm about the annual excess of imports over exports, although, had their reading of the figures been correct, it would have meant that the people of the United Kingdom were receiving far more for their exports than they were really worth. A careful examination of the facts by Sir Robert Giffen in 1882 and 1898, and again by the Board of Trade in 1902, has, however, made the matter clear. The excess value of British imports over British exports mounted from 132 millions sterling in 1893 to 184 millions sterling in 1902 , and the average for the ten years was 161 millions. In most of these years we imported more gold than we exported, and the average annual excess of gold imports over gold exports was 6 millions sterling. Taking the excess at 160 millions, about 90 millions is on account of the earnings of our carrying tradeboth shipowners and underwriters. This great sum of course does not enter into the returns of foreign trade. Another 90 millions, according to the estimate of Sir Robert Giffen in 1898, was represented by interest on investments abroad, against which, however, was to be set our new capital invested abroad every year. For just as the interest on investment comes in commodity imports (chiefly of food and raw materials), so our new capital exported 
abroad goes in the form of commodity exports (chiefly of railway material, machinery, and other mannfactured articles), so that the excess of imports over exports is swollen by the interest on our investments and reduced by our now investments. Supposing the shipping and investment imports to remain stationary, it is eertain that an increase of imports will involve an increase of exports and vice versa. It follows, therefore, that a tariff poliey which checks imports is bound to reduce exports also, sinee the one pays for the other.

We must now examine the records of our foreign trade from 1902 to 1910 , adding Mr. Chamberlain's index year of 1872 and the corresponding figures of the suceeeding years, in order to show how his principle of going thirty years back works out in the light of eight additional years' experience. As his purpose in so doing was to show the failure of British exports to expand, it is w only fair to continue his table in order to see how far the event has verified his prediction. If his views and forecasts were eorrect, we ought to see the steady decay and ruin of our chief industries in a steady decline of exports. Let us now look at the figures:-

1. Total Imports into the United Kingdom (in millions sterling)

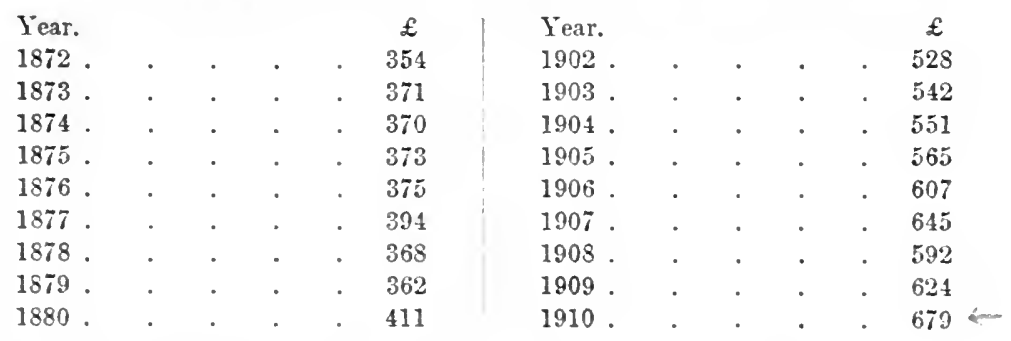

2. Total Exports of British moduce from the Unital Kingdom (in millions sterling)

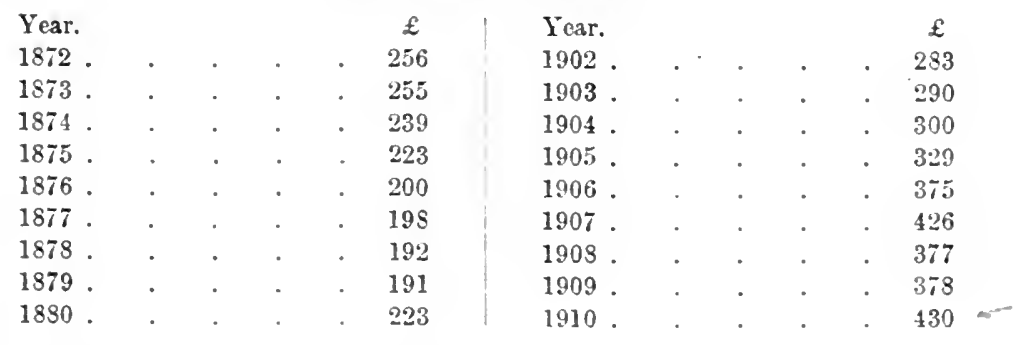

The general effeet will not be in the least altered by breaking up the figures or by subtracting particular items. It will be seen 
that from 1906 to 1910 the exports from the United Kingdom averaged in pounds sterling just about double the exports in the corresponding period 1876 to 1880 , although in the selected year, 1902, for special reasons the increase measured by gold values was quite trifling. If the system of ten-yearly averages be adopted, and the growth of population as well as changes in the value of gold be allowed for, it will be found that the years 1900 to 1910 compared with the years 1870 to 1880 show a highly satisfactory and very remarkable expansion. And this comparison is a fair one, as each of the decennial periods included years of severe depression and of great prosperity in trade. Further, if our re-export trade in foreign and colonial produce were included, our progress would appear still more remarkable.

The leading exports and their fluctuations have been dealt with under separate chapters dealing with particular industries; but it will be useful here to reproduce from the Fiscal Blue Book the data collected in 1903 in regard to the principal external sources of supply on which we depend for our food and raw material.

The table on page 525 shows the principal countries from which the food supplies of the United Kingdom (other than those produced at home) were drawn in the year 1902.

$>$ With the variations of the harvests throughout the world there are, of course, immense variations in the exportable surpluses of corn, so that the positions of the United States, Russia, India, Argentina, etc., change from year to year. In connexion with this subject, the Fiscal Blue Book gave some elaborate tables and memoranda on the subject of import duties and their effects upon price in countries which import food-stuffs. As to consumption, it was shown that between 1883 and 1902 the imports of wheat and flour into the United Kingdom varied between $207 \mathrm{lb}$. per head of the population in 1886 , and $306 \mathrm{lb}$. in 1895 , the general tendency being to increase gradually. In France the imports fluctuated from $10 \mathrm{lb}$. to $120 \mathrm{lb}$. per head, the tendency being for the imports to decline. In Germany the imports rose with fluctuations, the lowest figure being $14 \mathrm{lb}$. per head in 1887, and the highest $86 \mathrm{lb}$. per head in 1901. From 1898 to 1901, when the German import duty on wheat was $7 \mathrm{~s} .7 \frac{1}{2} \mathrm{~d}$. per qr., the average price of wheat in Germany was higher by 6s. 6d. in $1898,8 \mathrm{~s} .1 \mathrm{~d}$. in $1899,5 \mathrm{~s} .9 \mathrm{~d}$. in 1900 , and $8 \mathrm{~s} .6 \mathrm{~d}$. in 1901. In the case of France in years of small importations when the home crop was almost sufficient for home consumption, the average price in France exceeded the average 
Imports of Food-stuffs into the United Kingdom in the Year 1902

[Value in Thousands of Pounds]

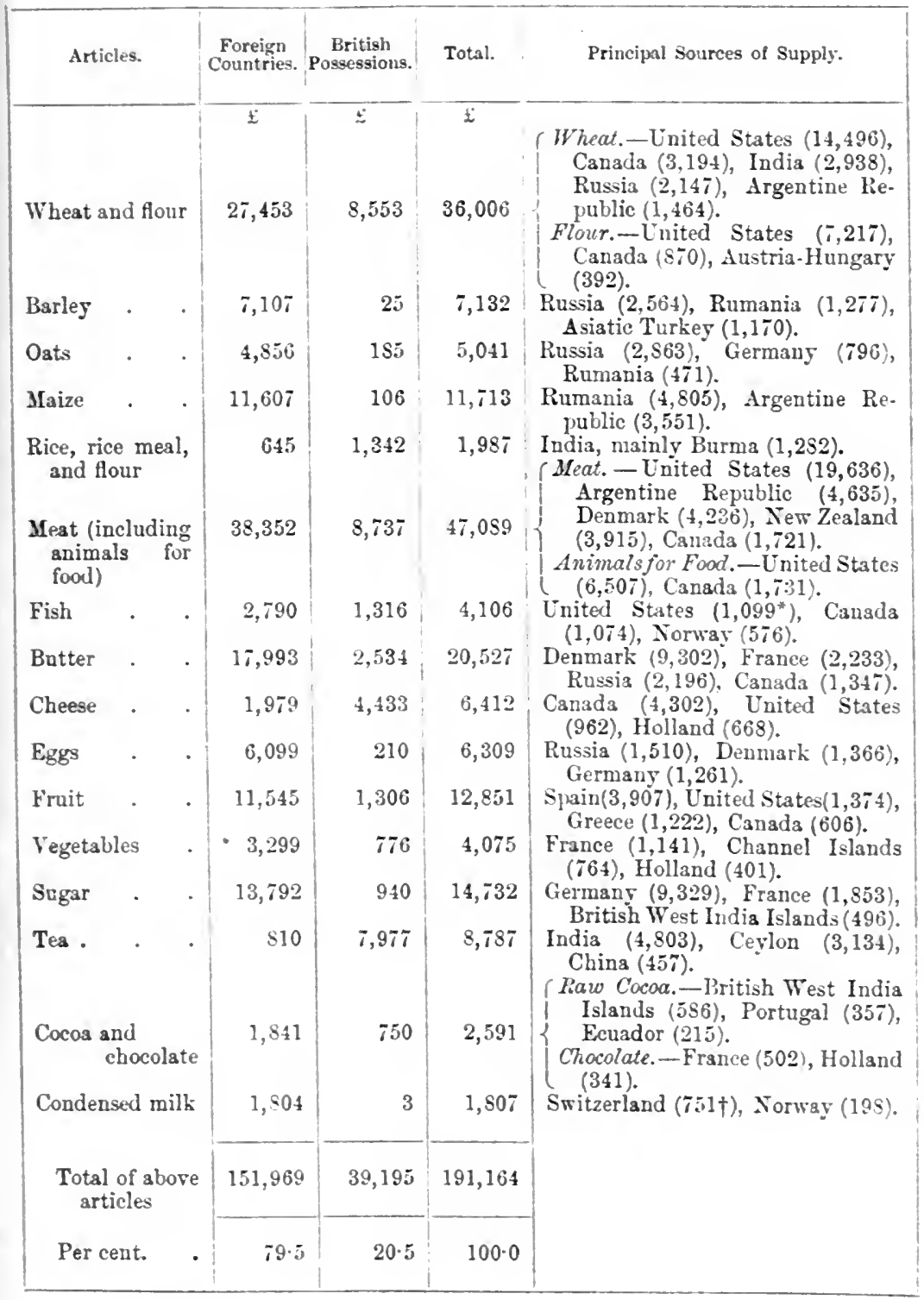

* Mainly tinned salmon.

† Valne of condensed milk exported from Switzerland to the Lnited Kingdom in the sear 1901. The figures for 1902 are not srailable. 
Countries from which our Principal Raw Materials were Imported into the United Kingdom in the Year 1902

[Value in Thousands of Pounds]

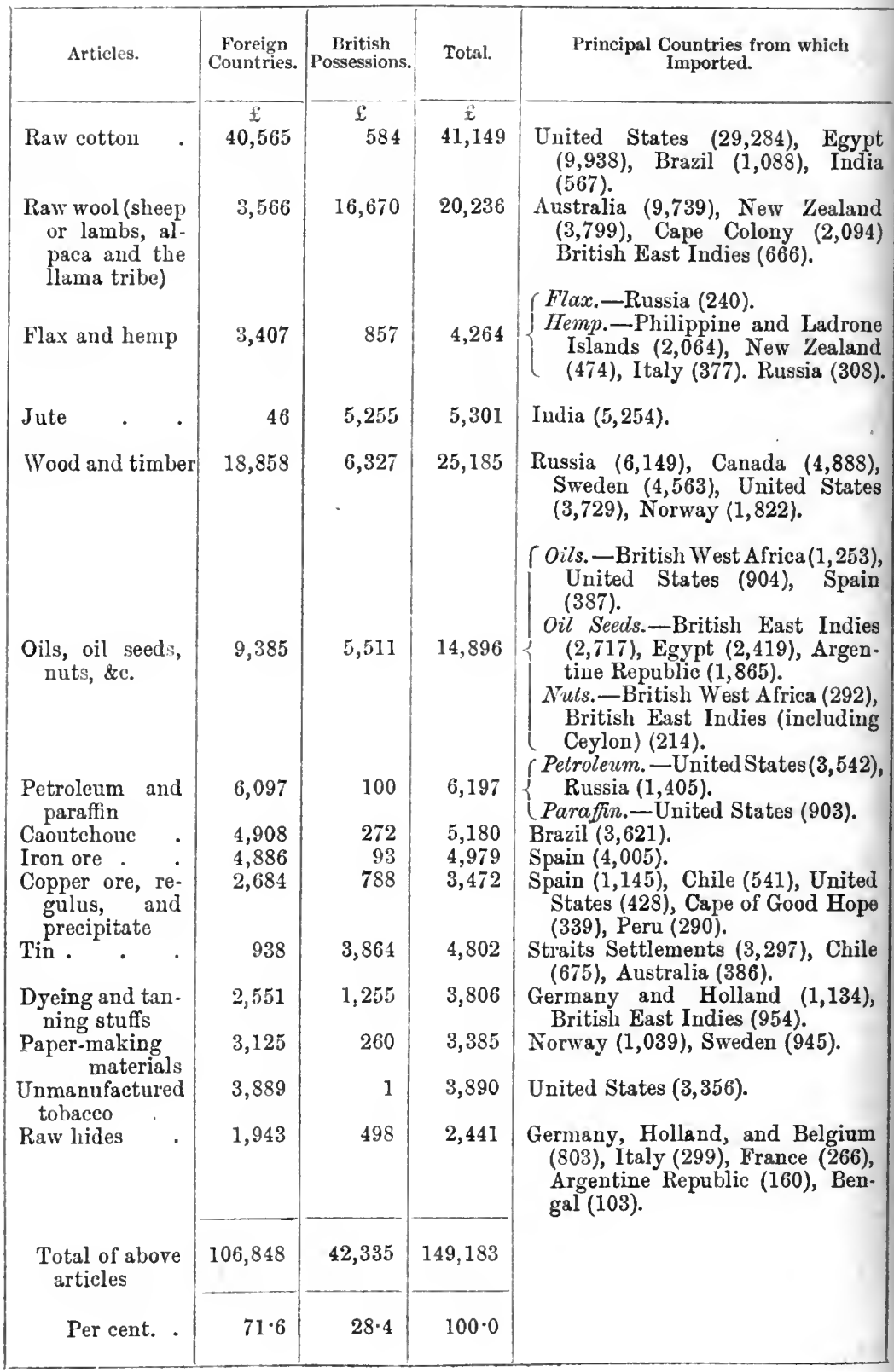


price in England by considerably less than the duty. But in every year but one when French imports of wheat and flour exceeded $30 \mathrm{lb}$. per head the difference in price exceeded the duty.

There is much less variation from year to year as regards our supplies of raw materials, than as regards our supplies of food. The table on page 526 gives our chief sources of supply in 1902 .

Nearly all our principal industries, it will be seen, depend largely or entirely for their raw materials upon foreign and colonial supplies.

We may conclude this chapter with some observations and statistics upon the destination of our exports, and the course of our foreign trade in the second half of the nineteenth century. Nearly all the customers of the United Kingdom have improved, but they have not improved steadily or equally. In 1854 our total exports were valued at 116 millions, of which 79 millions' worth went to foreign countries, and 37 millions' worth to British possessions. In 1872 , out of 315 millions, foreign countries took 249 millions and British possessions 66. In 1892, out of 291 millions, foreign countries took 210 and British possessions 81 . In 1902 , out of 34 ? millions (excluding ships), foreign countries took 227 millions and British possessions 116 millions. Taking annual averages for quinquenuial periods, we find that the foreign share of our export trade (excluding re-exports) rose to $i \pm$ in the early 'seventies, whereas from 1880 to 1900 it averaged from 65 to 66 per cent. At first the United States was our largest customer, but it was superseded by India, and later also by Germany. The following is a list of our leading customers in 1910, with their respective imports from the United Kingdom :-

\begin{tabular}{|c|c|c|c|}
\hline India . & . $£ 45,000,000$ & Australia & $£ 27,000,000$ \\
\hline Germany & $3 \pi, 000,000$ & France & $22,000,000$ \\
\hline United States & $31,000,000$ & Canada & $19,000,000$ \\
\hline
\end{tabular}

Finally, it will be instructive to show the comparative importance of our leading imports and exports with the changes that have occurred since 1860 . For this purpose the Board of Trade returns for $1860,1880,1900$ and 1910 have been examined with the following results:- 


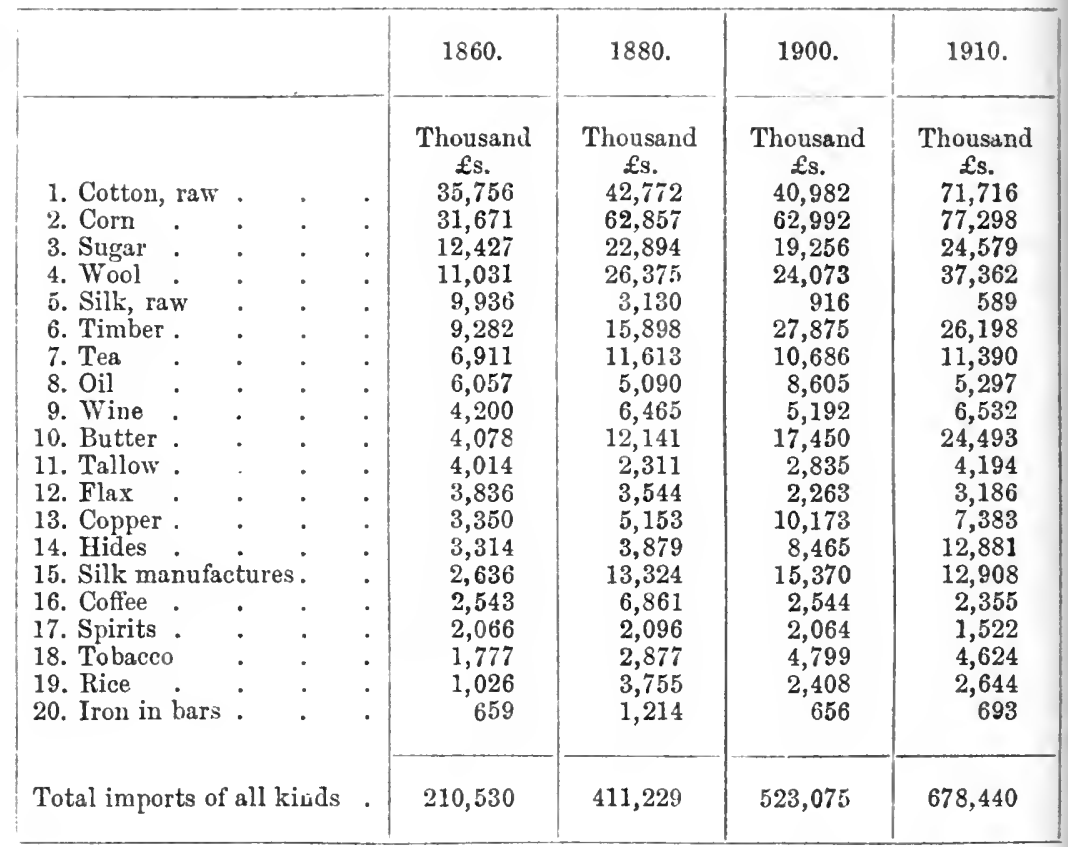

Appended is a list showing in their order of importance the first twenty articles imported in 1910 :-

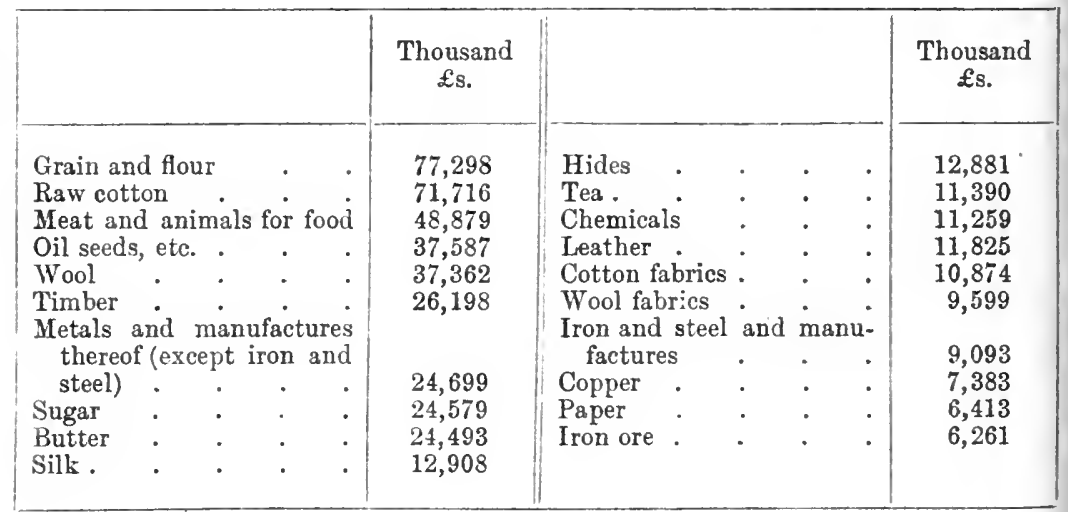

It will be observed that the majority of these articles are either food or raw materials, and that there have been many interesting changes since 1860 in the nature of our imports. But, it should be noted, some of the variations shown above are due to ehanges in price. A clear idea of these price changes is afforded by The Economist Index Number, the basic number of which (2200) 
is calculated on the average of the prices for 1845-1850 of twentytwo representative commodities. In January 1860 the Index Number stood at 2713, in 1880 at $257 \%$, and in 1900 at 2145 , while in 1910 the figure was 2417. From these figures it may be inferred that the import values between 1880 and 1900 were depressed by a general fall in prices, while the figures of 1860 and of 1910 are subject to a discount.

The most noticeable thing about the above tables is that since 1860 , wine, tallow, flax, coffee, spirits, tobacco, rice, and iron bars have disappeared from the list of our twenty largest imports, while meat (and animals for food), chemicals, leather, cotton fabrics, iron and steel manufactures, woollen fabrics, jajer, and iron ore have taken their place. The growing importance of our imports of food is also very striking. Our payments for corn (chiefly wheat) have gone up by leaps and bounds since 1860 , in spite of the fall in prices. Our imports of butter in 1910 were more than six times as large as in 1860 , if values only are considered. Meat first began to figure in our import returns in the 'eighties when refrigerators and cold storage began to be developed. Since then it has grown in importance until it ranks third among our imports. Our imports of sugar have, as shown by the above figures, almost exactly doubled in the fifty years, but when it is added that the sugar Index Number, which stood at $11 \pm$ in 1860 , fell to 70 in 1880 , and to 31 in 1900 , but rose to 35 in 1910 , it will be seen that the quantity of sugar imported rose much faster than the values. Wine and spirits show a slight increase orer the period, which is more than accounted for by the rise in price-the actual quantity imported having slightly decreased. Our imports of tea have gone up by leaps and bounds owing to the heary fall in price during the past fifty years. This is chiefly due to the reduction of the tea duty from about 5 s. to $5 \mathrm{~d}$.

The most important group of our imports, after food, is composed of the raw textile materials, cotton, wool, silk, and flax. Raw cotton, which headed the list in 1860 , gave place to wheat, and fell to the second position in 1880 , where it has remained ever since. The Index Number for raw cotton lose from 86 in 1860 to 110 in 1880 , but fell to 69 in 1900 , and rose again to 154 in 1910 - an abnormal figure owing to the American cotton shortage. Wool shows a very big increase between 1860 and 1880 , and as the Index Number decreased from 130 to 116 in the same years, the increased quantity imported must have been greater still. Our imports of raw wool decreased slightly in value between 1880 
and 1900 , but there has been a big increase during the present century. The value of our imports of flax has remained fairly stationary, though the quantity has increased considerably, as the Index Number fell from 121 in 1860 to 78 in 1880 , and 97 in 1910.

We now present a similar list of the twenty largest exports. The details are as under :-

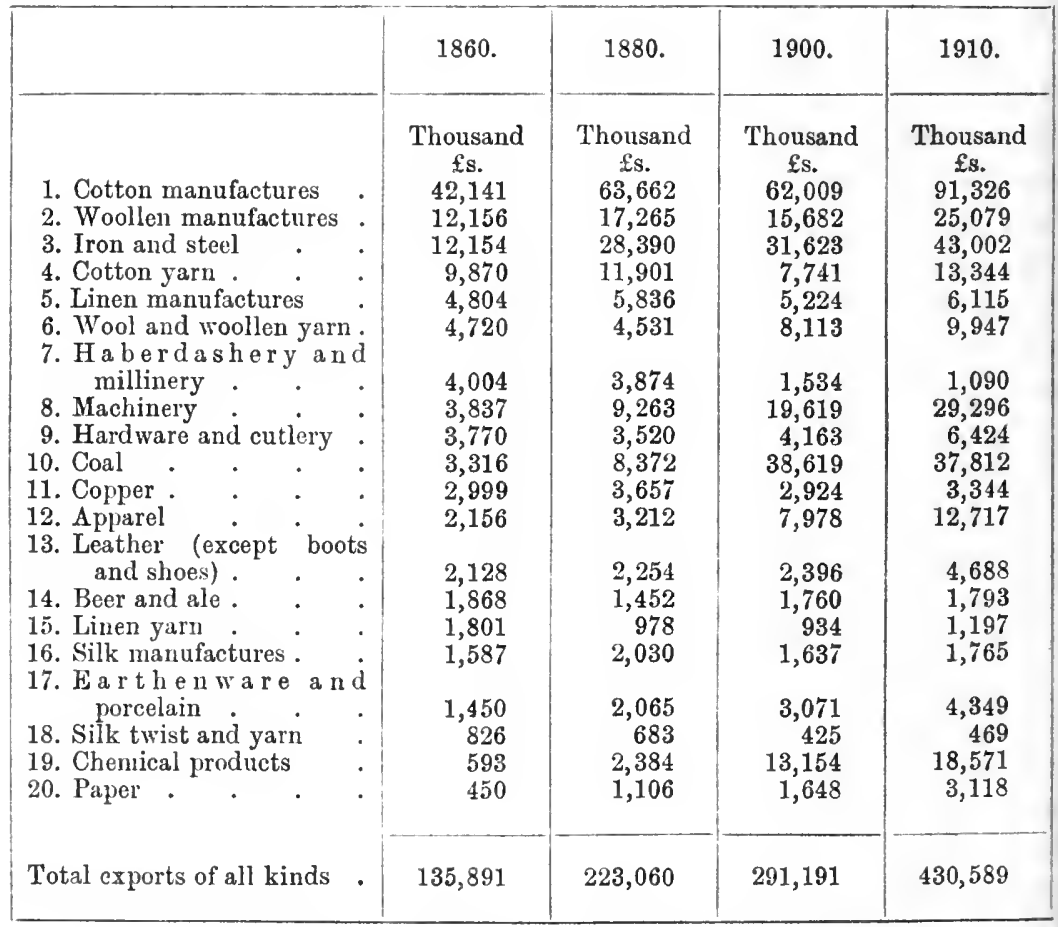

The following were the twenty chief articles exported from this country in $1910:-$

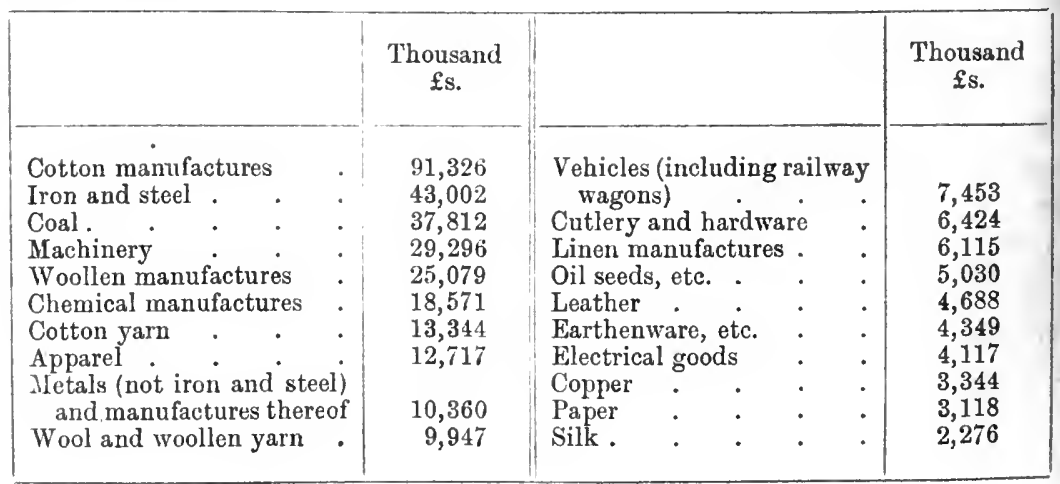


While our imports are mainly food and raw materials, our exports are mostly manufactured goods. Since 1860 haberdashery and millinery, beer and ale, linen yarn and silk twist and yarn have disappeared from the list of our twenty largest exports. Their place has been taken by vehicles (including railway wagons, motor cars, etc.), oils, seeds, etc., and electrical goods, while a new section has been introduced into the Board of Trade classification showing the manufactures of various metais. Our exports of textiles form the largest group. Cotton manufactures, woollen manufactures, cotton yarn, linen manufactures, wool and woollen goods, haberdashery and millinery, apparel, linen yarn and silk manufactures are contained in this section. Cotton manufactures maintain their place easily at the head of the list, their apparent stagnation between 1880 and 1900 being due to a fall in price-the Index Number for cotton cloth having fallen from 95 to 83 in that period. Our exports of coal have increased enormously during the past halfcentury, having risen from the tenth place on our list to the third. This may be ascribed to the growth of our "tramp" mercantile marine, which finds coal an extremely useful outward cargo. In fact, it is largely owing to the bulk of coal-which makes it especially useful as a cargo for a merchant vessel that would otherwise have to proceed in ballast or not go at all-that our shipping trade has been able to expand so marvellously. Iron and steel goods have risen from the third to the second place on our list over the fifty years, while chemical goods have come into much greater prominence. Two comparatively new trades-the motor and clectrical industries-secured the eleventh and sixteenth places in the British export list for 1910 . 


\section{CHAPTER XXVIII}

\section{PROGRESS OF BRITISH SHIPPING}

1800-1850. - Early days of steam navigation-Steam-vessels built and registered in the United Kingdom and British colonies, 1814-1844 - Steam-vessels belonging to British Empire, 1814-1844-Early days of steam navigation on the Thames-Steamvessels entered and cleared in coasting and foreign trade, 1820-1844.

1S50-1910. - Tonnage of vessels registered as belonging to United Kingdom, 1850-1910-Tonnage of British vessels entered and eleared in foreign trade, 1851-1910 - Where British tonnage is employed-Development of Far Eastern and Indian tradeThe Suez Canal-Australian trade-The Atlantie traffic-European and Mediterranean trade-South Afriean trade-Sonth American trade-The development of our coasting trade-Numbers employed on British ships, distinguishing British subjects and foreigners.

TYHE history of England's maritime greatness goes back to the Middle Ages; but it was not until the beginning of last century or thereabouts that any adequate statistics were available to exhibit the size of our mercantile marine. Porter was at great pains to collect a large amount of information showing the growth of our shipping industry during the first half of the nineteenth century. He also gathered some interesting facts to illustrate the first stages of the history of steam navigation. Our account of this early progress is drawn largely from his pages.

The application of steam power to navigation, although proposed in the middle of the eighteenth century by Jonathan Hulls, and attempted in France, in the United States of America, and on the Forth and Clyde Canal between the years 1781 and 1790 , was not successfully accomplished until after the beginning of the present century. The first practical application of this important improvement was made by Fulton, who, putting in execution the instruction he had gained from Mr. Miller, of Dalswinton, by witnessing his experiments in the Forth and Clyde Canal, established a steamboat in 1806 or 1807 which plied successfully on the river Hudson, between New York and Albany - a distance of 160 miles. The first steamboat that was worked for hire in this kingdom was the Comet, a small vessel of 40 feet keel and $10 \frac{1}{2}$ feet beam, with an engine of three horse-power, which plied with passengers on the Clyde in 1811; two years later the Elizabeth, of eight horse-power, 
and the Clyde, of fourteen horse-power, were placed on the same river. Since that time the progress of this invention has been very rapid.

From a return made by the Registrar-General of Shipping, it appears that in the year 1844 there were employed at different ports in the United Kingdom, and her colonies, 9SS steam-vessels, the aggregate burden of which was $125,6 j 5$ tons, namely :-

$\begin{array}{rrrrrr}\text { In the Ports of England } & \cdot & \cdot & \cdot & 679 & 75,047 \\ ", \quad \text { Scotland } & \cdot & \cdot & \cdot & 137 & 20,666 \\ \text { Ireland } & \cdot & \cdot & \cdot & 81 & 17,519 \\ \text { In Guernsey, Jersey, ete. } & \cdot & \cdot & \cdot & 3 & 445 \\ \text { In the Colonies } & \cdot & \cdot & \cdot & 88 & 11,998 \\ & & & & 988 & 125,675\end{array}$

These were exclusive of ressels belonging to Government.

The number and tonnage of steam-vessels built and registered in the United Kingdom and the British colonies, every ten years from 1814 to $1 S 44$, have been as follow:-

Steam-ressels built and registered in the United Kingdom and the British Colonies

\begin{tabular}{|c|c|c|c|c|c|c|c|c|c|c|c|c|}
\hline \multirow{2}{*}{ Year. } & \multicolumn{2}{|c|}{ England. } & \multicolumn{2}{|c|}{ Scotland. } & \multicolumn{2}{|c|}{ Ireland. } & \multicolumn{2}{|c|}{$\begin{array}{l}\text { Enited } \\
\text { Kingdom. }\end{array}$} & \multicolumn{2}{|c|}{ Plantations. } & \multicolumn{2}{|c|}{ Total. } \\
\hline & 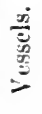 & $\stackrel{\dot{D}}{\Xi}$ & 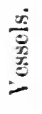 & $\stackrel{5}{\overrightarrow{0}}$ & 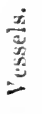 & 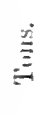 & $\begin{array}{l}\frac{x}{2} \\
2 \\
2\end{array}$ & $\stackrel{\dot{D}}{E}$ & 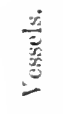 & 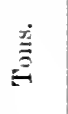 & 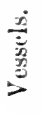 & $\stackrel{\stackrel{2}{:}}{=}$ \\
\hline 1814 & & & 5 & 285 & $\ldots$ & $\ldots$ & 5 & 285 & 1 & $3 \leqslant \pi$ & 6 & 672 \\
\hline 1824 & 12 & $1,6 \leq 7$ & 5 & 547 & $\ldots$ & $\ldots$ & 17 & 2,234 & & & 17 & 2,234 \\
\hline 1834 & 26 & 3,453 & 10 & $1,67:$ & 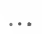 & & 36 & 5,128 & 3 & 628 & 39 & $5,75 t$ \\
\hline 1844 & 50 & 3,350 & 13 & 2,450 & 2 & 307 & 65 & 6,113 & 8 & 817 & 73 & 8,930 \\
\hline
\end{tabular}

The progress every ten years from the first introcluction of steamships was as under:-

Steam-ressels belonging to the British Empire, every Ten Years, from 1814 to 1844

\begin{tabular}{|c|c|c|c|c|c|c|c|c|c|c|c|c|c|c|}
\hline \multirow{2}{*}{ Year. } & \multicolumn{2}{|c|}{ England. } & \multicolumn{2}{|c|}{ Scotland. } & \multicolumn{2}{|c|}{ 1reland. } & \multicolumn{2}{|c|}{$\begin{array}{c}\text { Cnited } \\
\text { Kingdom. }\end{array}$} & \multicolumn{2}{|c|}{$\begin{array}{l}\text { Guernsey, } \\
\text { ete. }\end{array}$} & \multicolumn{2}{|c|}{$\begin{array}{c}\text { British } \\
\text { Plantations. }\end{array}$} & \multicolumn{2}{|c|}{ Totai. } \\
\hline & 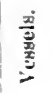 & 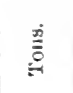 & 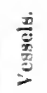 & $\stackrel{\underline{E}}{E}$ & $\begin{array}{l}\frac{j}{0} \\
\frac{1}{2} \\
\frac{3}{2}\end{array}$ & 这 & 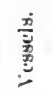 & $\stackrel{\text { t. }}{\underline{0}}$ & 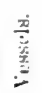 & 竞 & 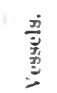 & : & $\begin{array}{l}\frac{i}{3} \\
\frac{3}{3} \\
\frac{1}{2}\end{array}$ & 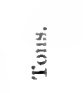 \\
\hline $\begin{array}{l}1814 \\
1824 \\
1834 \\
1844\end{array}$ & $\begin{array}{l}\text { so } \\
301 \\
6.9\end{array}$ & $\begin{array}{r}8,042 \\
27,009 \\
75,047\end{array}$ & $\begin{array}{r}1 \\
29 \\
77 \\
13 i\end{array}$ & $\begin{array}{r}69 \\
2.602 \\
8,107 \\
20,006\end{array}$ & $\begin{array}{r}3 \\
48 \\
81\end{array}$ & $\begin{array}{r}400 \\
8,183 \\
16,519\end{array}$ & $\begin{array}{r}1 \\
114 \\
124 \\
597\end{array}$ & $\begin{array}{r}69 \\
11,733 \\
43,409 \\
113,232\end{array}$ & $\begin{array}{l}\dddot{3} \\
6 \\
3\end{array}$ & $\begin{array}{l}214 \\
711 \\
445\end{array}$ & $\begin{array}{c}1 \\
10 \\
3 \geq \\
50\end{array}$ & $\begin{array}{r}397 \\
3.792 \\
6,595 \\
11,995\end{array}$ & $\begin{array}{l}12 \frac{2}{3} \\
462 \\
908\end{array}$ & $\begin{array}{r}456 \\
15,739 \\
50,735 \\
125,675\end{array}$ \\
\hline & & & & & & & & & & & & & & \\
\hline
\end{tabular}


Porter adds the following interesting account of the early days of steam navigation on the Thames:-

"It is scarcely half a century ago since tilt-boats for the conveyance of passengers to and from London to Gravesend were, in shape and speed, just what the Trinity-house ballast-lighters are at present, and taking four tides and more for the completion of the voyage. They were succeeded by the Dundee boats, which were, as fast sailers, both the wonder and admiration of all who witnessed the improvement. They, however, were of the most inconvenient nature, as the passengers were frequently not only called upon to embark in the middle of the night, in order to have the first of the flood, and after tacking and beating about, together with sometimes too much wind, sometimes too little wind, or none at all, besides being huddled in a low inconvenient cabin, were frequently, after being six or eight hours on the water, compelled to land at Woolwich, Blackwall, or Greenwich, and then have to find their way in the best manner they could to the metropolis. At length the progress of science introduced steam for the ferry, which, however, at first, generally took from five to seven hours to arrive in London, a length of time it was considered a desideratum to lessen. On Sunday last the Diamond started from the Gravesend pier at 4 p.m., landed her passengers in London and returned, and at 9 minutes before 8 o'clock was again at her moorings off the town pier: thus performing the two voyages, a distance of 64 miles, in 3 hours and 40 minutes, including stoppages. It should have been stated that the vessel had the advantage of a favourable tide, both in ascending and descending the river."

The number of passengers conveyed between London and Gravesend by steam-packets in 1835 was ascertained by the collector of the pier-dues at the latter town to have been 670,452 , not one in a hundred of whom would have been induced to make use of the Dundee hoats just described. It was stated in evidence before a Committee of the House of Commons in 1836, that at least 1,057,000 passengers, including those to and from Gravesend, pass Blackwall in steam-vessels every year. The number of passengers conveyed by the Hull and Selby steam-packets in the twelve months which preceded the opening of the Leeds and Selby Railway was 33,882 , whereas in the twelve months that followed that event the number eonveyed was 62,105 .

The table next given is interesting, because it exhibits a statistical history of steam navigation, as applied to commercial purposes in this country, from its first adoption to the end of 1844 .

The figures do not include vessels arriving and departing in ballast, or with passengers, which are not required to enter at the custom-house. Steam-vessels were not employed in this kingdom for conveying goods coastwise previous to 1820 , and, except for carrying passengers, such vessels were not engaged in foreign trade earlier than 1822 . 
An Account of the Number and Tonnage of Steam-vessels, including their repeated Voyages, which entered the Ports of the United Kingdom and cleared from the same in every Ten Years from 1820 to 1844; distinguishing the Vessels employed in the Coasting Trade from those engaged in Foreign Voyages, and separating Foreign from British Vessels

\begin{tabular}{|c|c|c|c|c|c|c|c|c|c|c|}
\hline \multirow{4}{*}{\multicolumn{2}{|c|}{ Year. }} & & \multicolumn{8}{|c|}{ INWARDS. } \\
\hline & & & \multirow{2}{*}{\multicolumn{2}{|c|}{$\frac{\text { Coasting Trade. }}{\text { British. }}$}} & \multicolumn{6}{|c|}{ Foreign Trade. } \\
\hline & & & & & \multicolumn{2}{|c|}{ British. } & \multicolumn{2}{|c|}{ Foreign. } & \multicolumn{2}{|c|}{ Total. } \\
\hline & & & Vessels. & Tons. & Vessels. & Tons. & Vessels. & Tons. & Vessels. & Tons. \\
\hline $\begin{array}{l}1820 \\
1824 \\
1834 \\
1844\end{array}$ & $\dot{\dot{.}}$ & $\dot{.}$ & $\begin{array}{r}9 \\
888 \\
10,07 \% \\
15,553\end{array}$ & $\begin{array}{r}505 \\
124,073 \\
1,761,752 \\
3,383,160\end{array}$ & $\begin{array}{r}139 \\
988 \\
3,124\end{array}$ & $\begin{array}{r}10,893 \\
146,720 \\
507,549\end{array}$ & $\begin{array}{r}\cdots \\
6 \\
12 \\
558\end{array}$ & $\begin{array}{r}312 \\
3,164 \\
85,91 \%\end{array}$ & $\begin{array}{r}\ddot{145} \\
1,000 \\
3,682\end{array}$ & $\begin{array}{r}11,205 \\
149,884 \\
593,466\end{array}$ \\
\hline \multicolumn{11}{|c|}{ OUTWARDS. } \\
\hline $\begin{array}{r}1820 \\
i 1824 \\
1834 \\
1844\end{array}$ & $\dot{\dot{.}}$ & $\begin{array}{l}\dot{\bullet} \\
\dot{.}\end{array}$ & $\begin{array}{r}1,197 \\
9,972 \\
15,500\end{array}$ & $\begin{array}{r}1 \ddot{4}, 5,523 \\
1,749,698 \\
\mathbf{3 , 2 7 0 , 4 9 9}\end{array}$ & $\begin{array}{r}\ddot{208} \\
896 \\
3,053\end{array}$ & $\begin{array}{r}15,796 \\
137,607 \\
491,115\end{array}$ & $\begin{array}{r}\ddot{8} \\
5 \% \\
569\end{array}$ & $\begin{array}{r}416 \\
12,015 \\
85,176\end{array}$ & $\begin{array}{r}\ddot{216} \\
953 \\
3,632\end{array}$ & $\begin{array}{r}16,212 \\
149.625 \\
5 ; 6,291\end{array}$ \\
\hline
\end{tabular}

In 1850 the net tonnage of vessels registered by Lloyd's as belonging to the United Kingdom was 3,565,133 net tons, in 1910 it was 11,555,663 net tons. These figures by themselves show how greatly our shipping developed during the last half of the nineteenth century - a development that counts as remarkable even during that period of rapidly-growing inclustries. The growth of our mercantile marine between 1850 and 1910 is indicated by the following figures, which show the total number and net tomnage of vessels registered as belonging to the United Kingdom (with Jersey, Guernsey, and the Isle of Man) every ten years from 1850 to 1909 :-

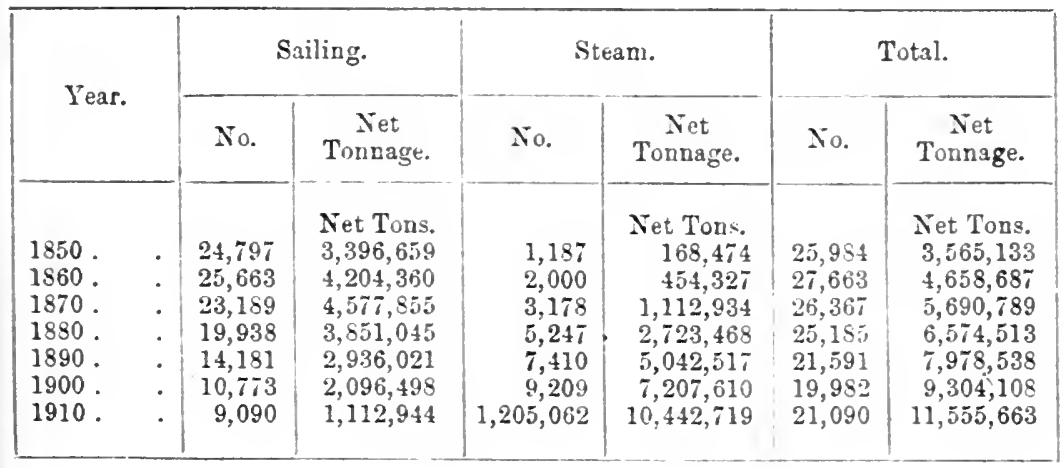


As might be expected ,the noticeable feature about the above table is the decrease in the number of sailing ships on the Register and the increase in the number of steamers. The figures also indicate very clearly the increase in the size of ships, for in 1860 there were 27,663 vessels of $4,658,687$ tons on the Register, while in 1910 the number of vessels had decrcased to 21,090 but the net tonnage had increased to $11,555,663$ tons. The developinent of the large ship is dealt with at greater length in a section on shipbuilding in the chapter on the machinery and engineering trades. Coming next to the proportion of British ships employed in our oversea trade, we find that numbers entered and cleared at British ports give some idea of the growth of our shipping. The following are the figures:-

Net Tonnage of British Vessels entered and cleared (with cargoes and in ballast) at Ports in the United Kingdom for Ports in Foreign Countries and British Possessions

\begin{tabular}{|c|c|c|c|c|c|c|}
\hline \multirow{2}{*}{ Average. } & \multicolumn{3}{|c|}{ Entered. } & \multicolumn{3}{|c|}{ Cleared. } \\
\hline & Sailing. & Steam. & Total. & Sailing. & Steam. & Total. \\
\hline $\begin{array}{l}1851-1860 \\
1861-1870 \\
1871-1880 \\
1881-1890 \\
1891-1900 \\
1901-1910\end{array}$ & $\begin{array}{c}\ldots \\
\ldots \\
\cdots \\
\cdots \\
1,731,691 \\
675,818\end{array}$ & $\begin{array}{c}\ldots \\
\ldots \\
\cdots \\
28,072,810 \\
35,716,988\end{array}$ & $\begin{array}{r}5,873,168 \\
9,987,752 \\
16,272,467 \\
23,527,108 \\
29,804,501 \\
36,392,806\end{array}$ & $\begin{array}{c}\cdots \\
\cdots \\
\cdots \\
1,816,749 \\
646,807\end{array}$ & $\begin{array}{c}\ldots \\
\cdots \\
\cdots \\
28,270,734 \\
36,022,652\end{array}$ & $\begin{array}{r}5,976,612 \\
10,121,746 \\
16,699,528 \\
24,090,862 \\
30,087,482 \\
36,668,459\end{array}$ \\
\hline
\end{tabular}

It will be observed that the period of greatest growth was during the 'seventies and 'eighties of the last century, and, of course, there has been a large decrease in the number of sailing vessels entered and cleared with a corresponding increase in the number of steamers. The number of vessels entered and cleared at British ports, however, only gives a partial idea of where British tonnage is employed. Much oi it is employed entirely abroad. The following figures have been extracted from the Board of Trade tables to illustrate the progress of merchant shipping in the United Kingdom and the principal maritime countries of the world. They show the total entrances and clearances for the years 1890 and 1908 of all the merchant shipping of the great maritime powers, distinguishing that of the United Kingdom, the British Empire, and foreign countries. 
Tonnage of Sailing and Steam Vessels of different Nationalities entered and cleared in the Foreign T'rade of the Principal Maritime Countries (in net tons)

1890

\begin{tabular}{|c|c|c|c|c|c|}
\hline & & Yational. & British.* & $\begin{array}{c}\text { Other } \\
\text { Nationalities. }\end{array}$ & Total. \\
\hline $\begin{array}{l}\text { United Kingdom . } \\
\text { British Empire } \\
\text { Foreign countries }\end{array}$ & . & $\begin{array}{c}\cdots \\
\cdots \\
\left\{\begin{array}{c}30 \cdot 6 \\
62,858,718\end{array}\right.\end{array}$ & $\left\{\begin{array}{c}72 \cdot 6 \\
53,973,112 \\
78 \cdot 7 \\
28,541,144 \\
42 \cdot 3 \\
88,565,984\end{array}\right.$ & $\begin{array}{c}27 \cdot 4 \\
20,310,757 \\
21 \cdot 3 \\
7,721,151 \\
27 \cdot 1 \\
57,621,011\end{array}$ & $\begin{array}{c}100 \cdot 0 \\
74,283,869 \\
100 \cdot 0 \\
36,262,295 \\
100 \cdot 0 \\
209,045,713\end{array}$ \\
\hline Total & . & $\left\{\begin{array}{c}19 \cdot 7 \\
62,858,718\end{array}\right.$ & $\begin{array}{c}53 \cdot 9 \\
171,080,240\end{array}$ & $\begin{array}{c}26 \cdot 4 \\
85,652,919\end{array}$ & $\begin{array}{c}100 \cdot 0 \\
319,591,877\end{array}$ \\
\hline
\end{tabular}

1908

\begin{tabular}{|c|c|c|c|c|c|}
\hline $\begin{array}{l}\text { United Kingdom . } \\
\text { British Empire } \\
\text { Foreign countries }\end{array}$ & . & $\begin{array}{c}\ldots \\
\ldots \\
28 \cdot 1 \\
133,574,006\end{array}$ & 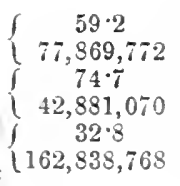 & $\begin{array}{c}40 \cdot 8 \\
53,576,424 \\
25 \cdot 3 \\
14,383,378 \\
39 \cdot 1 \\
177,692,489\end{array}$ & $\begin{array}{c}100 \cdot 0 \\
131,446,196 \\
100 \cdot 0 \\
37,264,448 \\
100 \cdot 0 \\
474,105,263\end{array}$ \\
\hline Total & . & $\left\{\begin{array}{c}20 \cdot 2 \\
133,574,006\end{array}\right.$ & $\begin{array}{c}42 \cdot 8 \\
253,5 \$ 9,610\end{array}$ & $\begin{array}{c}3 \hat{j} \cdot 0 \\
245,652,291\end{array}$ & $\begin{array}{c}100 \cdot 0 \\
652,815,90 \pi\end{array}$ \\
\hline
\end{tabular}

* Including Colonial.

It will be seen that the total entrances and elearances of shipping at all the great maritime countries increased from $319,591,877$ net tons in 1890 to $662,815,907$ net tons in 1908 - that is more than doubled. The entrances and clearanees of British vessels increased from $171,080,240$ net tons in 1890 to $283,589,610$ in 1908 -an increase of about 65 per cent.

A rough idea of the British tonnage trading between the United Kingdom and foreign countries, and the tonnage trading entirely between foreign countries, can be obtained by doubling the amount of British tonnage entered and eleared in the United Kingdom and subtracting this total from the total anount of British tonnage entered and cleared of all the great maritime powers. It is, of conrse, necessary to double the figures for the United Kingdom, as, wher statistics of entrances and clearances are taken for 
one country, one end of the voyage only is recorded. This method is, however, very rough, as on a long voyage a vessel may be entered and cleared at as many as half a dozen countries. If we do this for 1890 figures we find that out of a total of $171,080,240$ net tons of British ships entered and cleared there were $107,946,224$ net tons of entrances and clearances of vessels trading between foreign countries and British ports, while the entrances and clearances of British vessels trading mainly abroad amounted to $63,134,016$ net tons. In 1908 we find that the entrances and clearances of British vessels trading between home ports and foreign countries amounted to $155,739,544$ net tons, while the entrances and clearances of British vessels trading chiefly between foreign countries, amounted to $127,850,066$ net tons. If we work out the proportion of our tonnage that was trading chiefly between foreign countries we find that in 1890 about 37 per cent. traded mainly abroad while in 1908 the proportion had risen to about 45 per cent. These figures are extremely satisfactory as they show that British ships are gaining a larger and larger share of the world's commerce. But, on the other hand, it should be noted that the proportion of foreign vessels entered and cleared at British ports increased from 27.4 per cent. in 1890 to 40.8 per cent. in 1908. This increase can partly be explained by the growth of the big foreign shipping lines-notably the Germau lines that use English ports as ports of call. The increase in the number of British entrances and clearances indicated by the above figures is stupendous, though in some cases the relative increase is of course less than in the case of foreign vessels.

Much light is thrown on the expansion of our maritime commerce by the history of the great shipping lines that trade in various parts of the world, and a brief survey of the growth of some of our bigger lines may be of interest. Let us first take our trade to the Mediterranean, India, and the Far East. Ever since the formation of the East India Company and our conquest of India our trade with India had been growing in importance, and with the advent of the steamship it is not surprising that attempts were made to establish steam communication with that country. "Soon after steam navigation began to attract attention in Great Britain," says Mr. Fenwick Allen in his book The History of Steam Navigation, " a public meeting was held in London (1822) for the purpose of forming a steamship company to trade between England and India." The first route selected was that via the Cape of Good Hope, the old trade route to India. The first steamboat to make 
this voyage was the Enterprise, owned by the East India Company, and about this early experiment Porter writes: "The voyage made in 1826 by the Enterprise to Calcutta was considered a failure and doubtless had for a time considerable influence in deterring our merchants from undertaking distant steam voyages." Other experiments of the same kind were, however, made and with perfect success.

A Conmittee of the House of Commons was appointed in June 1837 to inquire into the best means of establishing a communication by steam with India by way of the Red Sea. The inquiry thus begun was cut short by the sudden termination of the session, but the evidence collected by the committee contained information of great interest, tending to show the advantages to commerce that must result from so great an acceleration of correspondence.

It was stated to this committee by Sir John Hobhouse, then President of the Board of Control, that in August 1834 the Directors of the East India Company, acting in furtherance of a recommendation made by a Committee of the House of Commons, which sat in that year, sent directions to the Governor-General of India to dispatch a steamship at stated periods from Bombay to Suez. In order still further to expedite the transmission of mails between India and England, the Governor of Bombay, and subsequently the home authorities in England, established a dromedars post from Bagdad to Damascus, and thence to Beyrout, on the coast of the Mediterranean, to which port the voyage of the steamvessel that before plied to Alexandria was extended. In 1836, as a result of this improvement, the overland mails began to bring dispatches from London to Bombay in from seven to nine weeks, and in 1837 a regular monthly steam communication was established via the Red Sea by arrangement between the Government and the East India Company, the route being London to Marseilles, Marseilles to Malta and Suez, Suez to Mocha, and Mocha to Bombay.

The mail communications betreen this kingdom and its eastern empire continued on the above footing until 1S41, when the Government entered into a contract for the conveyance of the mails between England and Egypt, with the Peniusular and Oriental Steam Navigation Company, which undertook further to employ porrerful steam-vessels for the carrying of letters and passengers between Suez, Cerlon, Madras, and Calcutta, torrards the expenses of which the East India Company undertook to contribute $£ 20,000$ 
per annum for five years. When this arrangement had been for some time in operation, a further extension of the plan was found necessary, and an agreement was made to the effect that the Government should contribute $£ 50,000$ per annum towards the expense of the line of steam-packets between Bombay and Suez, $£ 115,000$ per annum for the service between Calcutta and Suez, and $£ 45,000$ for the service betwen Ceylon and Hong-Kong, making in all $£ 210,000$, of which sum one-third, or $£ 70,000$, was repaid by the East India Company.

"There is reason for believing," continues Porter, "that the passage by the Mediterranean route to India may be further facilitated by the construction of a railroad between Cairo and Suez, which would open a more direct communication than the dromedary post already mentioned. The isthmus has been surveyed for this object by an English engineer, and a considerable part of the materials for the railway has been collected by the Pacha of Egypt. When finished, the distance between Cairo and Suez ( 80 miles) might be traversed in four hours. The traffic between these places is at present considerable in the articles of coffee, drugs, and grain. If the time consumed in passing across the desert were reduced, as it might then be, to four hours, and the charge for conveyance were moderate, the trade would assuredly be much increased, and other goods would find their way from India to Europe by the same means. Silk, spices, gums, shawls, and various other articles which are valuable in proportion to their bulk, would be sent by this route rather than round by the Cape of Good Hope, because the saving of time would more than compensate for the difference in the expense. Another project, the cutting of a ship-canal between the Mediterranean and the Arabian Gulf, has been seriously proposed, and surveys have been made which seem to show the reasonableness of the proposal. Such a shortening of the route between Europe and Asia must be followed by consequences the importance of which to this commercial country it would not be easy to estimate."

The Suez Canal, opened in 1869, was, as Porter predicted, one of the most potent factors in stimulating our trade with the Far East. The British India Steam Navigation Company had the honour of sending the first steamer through the canal, and their vessel, the India, was the first steamer to arrive in England via Suez carrying British produce. The record of vessels that passed through the Suez Canal every ten years since 1870 is as follows :- 


\begin{tabular}{|c|c|c|c|c|c|c|}
\hline & & & $\begin{array}{l}\text { No. of } \\
\text { Yessels. }\end{array}$ & $\begin{array}{c}\text { Gross } \\
\text { Tonnage. }\end{array}$ & $\begin{array}{c}\text { Net Tonnage } \\
\text { (Suez Canal } \\
\text { measurement). }\end{array}$ & $\begin{array}{c}\text { Mean Net } \\
\text { Tonnage per } \\
\text { Vessel. }\end{array}$ \\
\hline $\begin{array}{l}1870 \\
1850 \\
1890 \\
1900 \\
1910\end{array}$ & : & : & $\begin{array}{r}456 \\
2,026 \\
3,339 \\
3,441 \\
4,533\end{array}$ & $\begin{array}{r}654,915 \\
4,344,520 \\
9,749,129 \\
13,699,237 \\
23,054,901\end{array}$ & $\begin{array}{r}436,609 \\
3,057,422 \\
6,890,094 \\
9,738,152 \\
16,581,898\end{array}$ & $\begin{array}{r}898 \\
1,509 \\
2,033 \\
2,830 \\
3,658\end{array}$ \\
\hline
\end{tabular}

The figures showing the mean net tonnage per vessel are exceptionally interesting, as they afford a very good indication of the growth in the size of the world's shipping. The nationalities of vessels passing through the eanal have been distinguished in the returns since 1882 , and the British tonnage that passed through at various years since is as under:-

\begin{tabular}{|c|c|c|c|c|c|c|}
\hline 1882 & . & . & . & - & . & . \\
\hline 1890 & . & . & . & . & . & . \\
\hline 1900 & . & . & - & . & . & . \\
\hline 1908 & . & . & . & . & . & . \\
\hline
\end{tabular}

The growth of the Peninsular and Oriental Steam Navigation Company affords some idea of the development of steam navigation to India and the East. The company was started in 1834 and established a service with India via the Mediterranean and Red Sea. But, of course, before the cutting of the Suez Canal, passengers and merehandise had to journey over some 100 miles of desert. This was known as the overland route. In 1852 the P.\& $O$. started its Australian services, and since that date its growth has been constant. Other important shipping companies trading with India and the Far East are the British India Steam Navigation Company, the Orient Company, Messrs. Shaw, Savill, and Albion, the White Star Line (Ismay, Imrie, \& Co.), Messrs. Bibby Bros., and Messrs. T. and J. Brocklebank. The following figures, showing the entrances and clearances of British and Colonial vessels with India and the other important countries in the Far East, indicate the growth of our shipping industry in the Orient:-

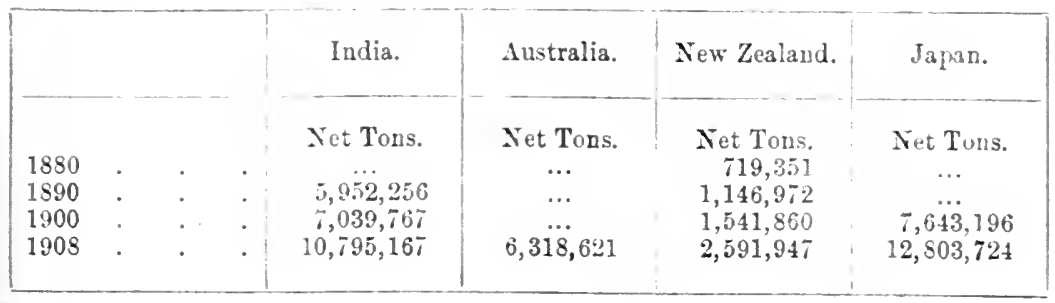


The first attempt to establish a steamship service across the Atlantic was in 1832, when an Act of Parliament was passed incorporating the Valentia Transatlantic Steam Navigation Company. The proposal was to establish a service from Valentia on the west coast of Ireland to New York; the ships to coal if necessary at the Canaries. This early scheme fell through, however, from lack of public support. The early steamship voyages across the Atlantic are described in the section on shipbuilding. The City of Dublin Steam Packet Company was among the pioneers of early Atlantic Steam Navigation, and in 1838 their steamer the Royal William completed the passage from Liverpool to New York in nineteen days and the homeward passage in fourteen and a half days. The Cunard Company has been connected with the transatlantic steam navigation almost from the first, for it was in 1840 that the company's first steamer the Britannia made her maiden voyage across the Atlantic. Since then the Cunard Company has maintained a regular service of boats and has gained a high reputation for efficiency and speed. Their early struggles with their great American rivals, the Collins Line, are extremely interesting but too lengthy to be detailed here. The other leading transatlantic line, the White Star, which is now partly under American control, was founded in the middle of last century, and was first concerned with Australian trade during the "gold rush" of the 'fifties. It was not until 1867, when Mr. Thomas Ismay became managing owner, that the company began to compete for the North Atlantic traffic. In 1902 Mr. J. Pierpoint Morgan formed his great shipping combine, and the White Star Line was one of the companies that he purchased. His attempt, however, proved a financial failure. The White Star maintains the British flag. Another important Atlantic shipping company is the Allan Line. Its service commenced in 1859, and its vessels run chiefly to Canada. Two other big North Atlantic shipping companies are the Canadian Pacific Railway and the Dominion Line.

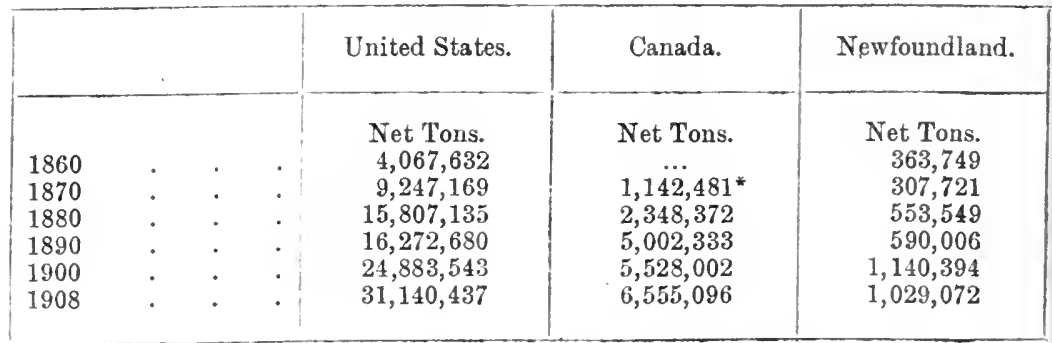

* Figures for Ontario, Quebec, New Brunswick, and Nova Scotia only. 
The entrances and clearances of British shipping in the United States of America, Canada and Newfoundland since 1860 have been as shown in the foregoing table, and indicate the growth of British shipping in the North Atlantic.

British boats have, of course, long traded with Europe and the Mediterranean. With the advent of the steamship this ancient trade naturally grew very rapidly, as the following figures of entrances and clearances of British shipping at the principal European maritime countries show:-

\begin{tabular}{|c|c|c|c|c|c|c|c|c|c|}
\hline & & $\begin{array}{c}\text { Russia in } \\
\text { Europe. }\end{array}$ & Norwa & & Swe & den. & & nmark. & Germany. \\
\hline $\begin{array}{l}1880 \\
1890 \\
1900 \\
1908\end{array}$ & : & $\begin{array}{c}\text { Net Tons. } \\
\ldots \\
6,423,570 \\
6,296,974 \\
7,220,167\end{array}$ & $\begin{array}{r}\text { Net To } \\
471,97 \\
781,61 \\
672,64 \\
928,67\end{array}$ & & $\begin{array}{r}\text { Net } \\
92 \\
2,20 \\
1,69 \\
1,34\end{array}$ & $\begin{array}{l}\text { Tons. } \\
8,553 \\
7,114 \\
4,15 \% \\
9,850\end{array}$ & & $\begin{array}{l}t \text { Tous. } \\
17,426 \\
32,918 \\
19,509 \\
36,620\end{array}$ & $\begin{array}{r}\text { Net Tons. } \\
4,984,473 \\
7,466,231 \\
7,854,999 \\
11,286,750\end{array}$ \\
\hline & & Holland. & Belgium. & & & Port & & Spain. & Italy. \\
\hline $\begin{array}{l}1880 \\
1890 \\
1900 \\
1908\end{array}$ & $\dot{\text {. }}$ & $\begin{array}{l}\text { Net Tons. } \\
3,409,791 \\
5,665,953 \\
7,881,065 \\
8,601,213\end{array}$ & $\begin{array}{r}\text { Net Tons. } \\
4,223,704 \\
6,167,174 \\
7,564,392 \\
12,403,161\end{array}$ & $\begin{array}{l}\text { Ne } \\
10, \\
12, \\
15, \\
20,\end{array}$ & $\begin{array}{l}\text { ons. } \\
, 902 \\
, 319 \\
595 \\
, 395\end{array}$ & $\begin{array}{r}\text { Net } \\
3,62 \\
5,65 \\
11,34 \\
13,79\end{array}$ & $\begin{array}{l}15 . \\
76 \\
03 \\
73 \\
19 \dagger\end{array}$ & $\begin{array}{r}\text { Net Tons. } \\
\quad \ldots \\
8,039,759 \\
7,851,981 \\
10,796,417\end{array}$ & $\begin{array}{r}\text { Net Tons. } \\
3,377,513 \\
7,036,278 \\
7,768,865 \\
13,896,867\end{array}$ \\
\hline
\end{tabular}

* 1907 figures.

$\uparrow 1905$ tigures.

The Cape of Good Hope and South Afriea generally have long supplied a valuable trade route to British shipping. The UnionCastle (Donald Currie \& Co.) and Messrs. J. T. Rennie \& Sons are both well-known lines running to the Cape. The West African trade is chietly in the hands of the Elder Dempster Line (African Steamship Company). The growth of this trade is shown by the entrances and clearances of British shipping at the Cape of Good Hope and Natal which are as under:-

\begin{tabular}{|c|c|c|c|c|c|}
\hline 1880 & . & . & . & $\begin{array}{c}\text { Cape of Good Hope. } \\
\text {. } \quad 1,376,305\end{array}$ & $\begin{array}{l}\text { Natal. } \\
355,529\end{array}$ \\
\hline 1890 & . & . & . & $2,599,127$ & 926,831 \\
\hline 1900 & . & . & . & $8,538,713^{*}$ & $2,546,485$ \\
\hline 1908 & . & . & . & $5,006,827 \dagger$ & $4,203,261$ \\
\hline
\end{tabular}

* Inclusive of the tonage of transports carrying stores, but exclusive of the tonnage of those conveying troops.

t The figures in $1900^{\circ}$ and subsequent years were compiled by the South African Customs Statistical Bureau, and exclude vessels trading with Natal previously included. These particulars are therefore not strictly comparable with those for earlier years. 
Our trade with South and Central America, Mexico and the West Indies has of late been expanding rapidly. For many years past not only has a large amount of British capital been profitably sunk in Argentina, Brazil, Chile, etc., but a large portion of the foreign commerce of the whole South American continent is carricd in British ships. To mention a few of the lines that trade with South America only, we have the Booth Line, the Elder Dempster Line, the Royal Mail Steam Packet Co., Nelson Line, and a host of other important companies. The following are the entrances and clearances of British ships with Chile and Argentina, and they afford some idea of the growth of our trade with South America :-

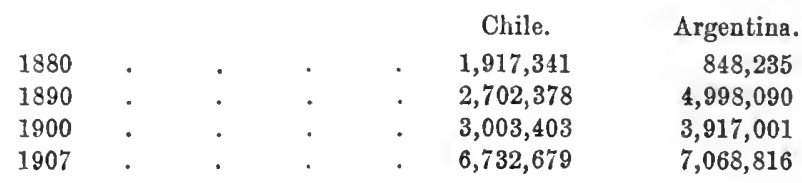

One of the most important branches of British shipping is, of course, the coasting trade. Unfortunately, as Porter observes, the custom-house does not contain any records from which the amount of our coasting trade in general can be ascertained for any period earlier than 1824. From 1825 to 1845 the tonnage of coasting vessels that entered inwards at ports in Great Britain from other ports in Great Britain every ten years, including their repeated voyages, has been as follows:-

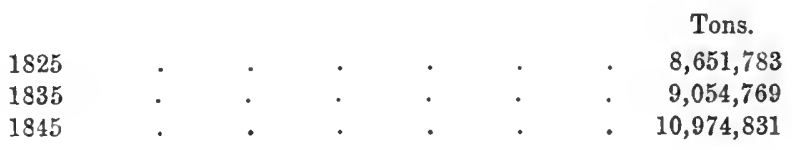

A large amount of this tonnage was engaged in the conveyance of coals coastwise between different parts of the kingdom. The arrivals in the port of London alone in 1834 and 1844 were-

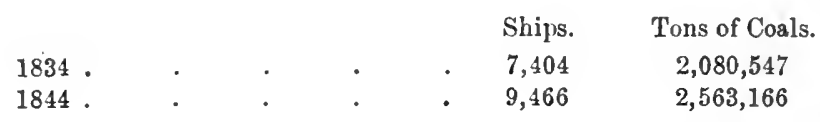

During the second half of the nineteenth century our coasting trade, of course, developed very greatly. The following figures show the total net tomnage of British vessels entered and cleared coastwise at ports in the United Kingdom. The figures are ten-yearly averages. 


\begin{tabular}{|c|c|c|c|c|c|c|}
\hline \multirow{2}{*}{ Average. } & \multicolumn{3}{|c|}{ Entered. } & \multicolumn{3}{c|}{ Cleared. } \\
\cline { 2 - 8 } & Sailing. & Steam. & Total. & Sailing. & Steam. & Total. \\
& & & & & & \\
\hline & Net Tons. & Net Tons. & Net Tons. & Net Tons. & Net Tons. & Net Tons. \\
$1851-1860$ & $\ldots$ & $\ldots$ & $14,255,242$ & $\ldots$ & $\ldots$ & $\ldots$ \\
$1861-1870$ & $\ldots$ & $\ldots$ & $17,616,800$ & $\ldots$ & $\ldots$ & $\ldots$ \\
$1871-1880$ & $\ldots$ & $\ldots$ & $22,687,800$ & $\ldots$ & $\ldots$ & $21,791,970$ \\
$1881-1890$ & $\ldots$ & $\ldots$ & $27,260,142$ & $\ldots$ & $\ldots, 120,143$ \\
\hline $1891-1900$ & $7,982,637$ & $44,017,869$ & $52,000,506$ & $7,082,903$ & $40,413,420$ & $47,496,323$ \\
$1901-1910$ & $4,731,338$ & $50,928,954$ & $55,660,292$ & $4,686,028$ & $50,130,180$ & $51,816,208$ \\
\hline
\end{tabular}

N.B.-Tonnage entered and cleared at Irish ports was included in the returns for the first time in 1856.

* Since 1891 the returns are for vessels entered and cleared in cargoes and in ballast, but prior to tliat date with cargoes only.

The following information showing the number and nationality of persons employed on British vessels may be of interest:-

Number of British and Foreign persons employed in British vessels, exclusive of vessels employed in rivers and for inland navigation

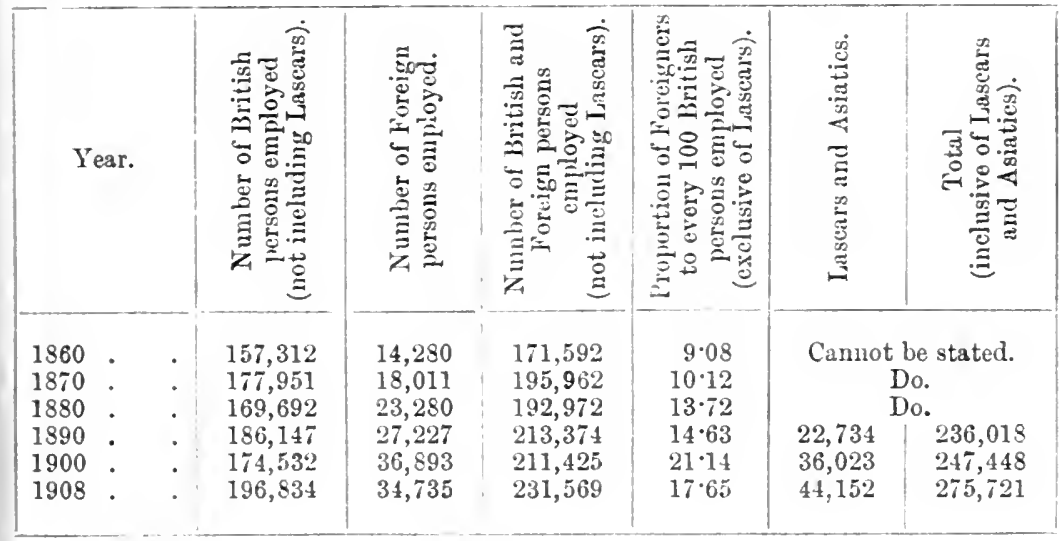

The proportion of foreigners to British subjects employed on British ships increased very rapidly from 1860 until it reached its maximum of 22.88 in 1903 , since which date it has steadily declined. 


\section{CHAPTER XXIX}

\section{INTERNAL COMMUNICATION}

Introductory-Roads-Canals-Railways : railway statistics-The gauge-SpeedCompetition-Receipts-Expenditure

\section{INTRODUCTORY}

THERE is probably no department of public affairs which shows more remarkable and rapid progress than that of internal communication. This is true whether our standard be 1800 or 1850. When we review the facilities for travel and transport of all kinds existing in Great Britain at the present day, and compare them with the conditions prevailing in 1850 , it is amazing to find Porter writing:-

"There is not any circumstance connected with the internal condition of England which more strongly excites the admiration and envy of foreigners than the degree of perfection to which we have brought our means of internal communication. The skill and labour that have been applied to this object are among the chief exciting causes of that high degree of activity which characterizes and pervades the productive classes in every part of the country. The perfection to which we have carried the means of transporting persons and property from one part of the kingdom to another has indeed become one of our national characteristics." And our industrious predecessor could add, with just pride, "We have done more than any other nation of Europe for facilitating communications from and to every nook and corner of the land," at a time when travelling was still for the most part accomplished by stage-coach, and goods conveyed either by pack-horse or canal-boat: when the performance of the journey from High Wycombe to London by an express train in an hour and three-quarters was regarded as a feat, and it was held to be a matter for congratulation that "there is not any spot south of the county of Durham at a greater distance than fifteen miles from water conveyance." 
Such satisfaction may help us to realize the vast strides made in the last half-century. At the same time, a generation that is witnessing the conquest of the air may feel that what has been accomplished will prove less sensational to what is to come.

\section{ROADS}

Ruskin said that "all social progress resolves itself into the making of roads."

When Porter wrote, the main roads of England had recently been reconstructed on scientific principles due to John Loudon M'Adam. New roads were being created and their surface improved. This was, of course, of great importance at a time when most persons moved about the country by coach or carriage, for the improvement in the roads rendered a more rapid rate of progression feasible. Porter notes, "On all the principal roads communicating with London, the rate of travelling by the turnpike roads is now nearly or quite ten miles an hour, nor is it in celerity alone that improvement has been made. It might have been supposed that, to attain so high a degree of speed, the personal safety of passengers would be further endangered, but the very contrary is the fact, so that, notwithstanding the rapidity with which we are whirled along, the number of accidents is actually lessened, a result produced by the better construction of the carriages, the greater perfection of the harness, ... and, more than all, by the superior character of the drivers-a steady, wellconducted, and sober class of persons having taken the place of men with habits and characters the very reverse."

These main or tumpike roads were controlled by Turnpike Trusts and Highway Boards, constituted in different districts by Act of Parliament, and maintained by means of tolls levied for that purpose, in accordance with ancient usage, upon those travelling over them. Toll-gates or toll-bars were placed at intervals to collect these dues. The unpopularity of the tolls was testified by the disturbances which broke out in Wales in 1843 under the name of the "Rebecca Riots." Bands of people, often amounting to as many as five hundred, and frequently disguised as women, broke down the turnpikes at night. A strong military force was required to put the riots down. Popular feeling was on the side of the rioters, and the Commission appointed to inquire dealt lightly with the offenders.

Tolls were first abolished in Ireland, the last disappearing 
there in 1857. In England 27 toll-bars near London and 81 on the north side were abolished in 1864 : in the next year 61 on

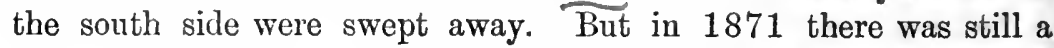
toll-house every six or eight miles in most parts of the country, and about five thousand men were employed as collectors. Every toll-bar had its board showing the rates for carts, horses, cows, etc. The Roads and Bridges Act of 1878 abolished tolls in Scotland, the last disappearing from that country in 1883 ; but it was not until 1889 that the system of tolls in Great Britain was finally superseded by the present mode of arrangement. The only survival of the old method is seen in the bridge-tolls (abolished in London in 1878-1879) and pier-tolls levied in many parts of the country.

The Highways Act of 1870 assigned one-half of the cost of maintenance of main roads, which then ceased to be turnpike roads, to the county, to be met by a county rate. The Local Government Act of 1888 levied the whole burden of their upkeep upon the county. To-day the administration of roads, maintenance, paving, drainage, cleansing, repair, etc., belongs to the sanitary authorities, that is, to the councils of municipal boroughs acting under the Public Health Acts of 1872 and the Highways Act, and generally to the councils of urban districts other than boroughs, to the metropolitan sanitary authorities, and to the sanitary, highway, and other authorities in rural areas. These said sanitary authorities are responsible for a larger share of local rates than any other group of local authorities and for an increasing proportion of those rates. In 1905-1906 the cost of the upkeep of roads in rural districts (exclusive of main roads), made up more than a half of the total expenditure of rural district councils. In 1905-1906 the sanitary authorities generally spent $£ 7,500,000$ on the upkeep of highways outside London.

Recently the question of roads and their upkeep has acquired a new importance from the advent of the motor-car. As the Chancellor of the Exchequer declared, in introducing the Budget in 1908 , "It is quite clear that our present system of road-making is inadequate for the demands which are increasingly made upon it by the new form of traction." In 1909 the number of private motors was estimated at 55,000, and this total, as well as that of public omnibuses and taximeter cabs, is increasing daily. In some districts the destruction wrought by pleasure cars has doubled the cost of road maintenance, and the motor licence duties have not compensated ratepayers for their losses. 


\section{Canals}

Perhaps the most important means of transport, especially coal transport, existing in the beginning and middle of the last century, was provided by canals.

The great period of canal construction in England dates from the undertakings of the Duke of Bridgewater and his engineer, James Brindley, who, "to the last illiterate, hardly able to write, and quite unable to spell," nevertheless became "the father of inland navigation." In spite of strong opposition from the turnpike trustees canal construction spread. The Duke expended $£ 220,000$ on works from which he soon derived an annual income of $\mathfrak{£} 80,000$; and the superior facilities for goods traffic afforded by canals, as well as the high dividends to be made from them, caused what almost amounted to a canal mania in the last decades of the century. In 1792 eighteen canals were promoted, and 45 Acts of Parliament for the construction of canals were presented between 1792 and 1794. Shares went up to a very high price. Canals paid by dividends and charged heary rates. For half a century indeed canals had everything their own way. Between 1800 and 1850 more than thirty separate canals were cut, covering over 600 miles in length; and the total mileage of the navigable canals used for the transport of goods and produce was estimated at over 1800 miles.

In 1906, when the Royal Commission on Canals was appointed, though there were 3900 miles of canals the greater part of the system was of very little use for traffic, and part of it actually in disuse. Manj canals are now being run at a loss.

The reason of this changed aspect of things is partly that railway development offered a better, quicker, and more advantageous means of transport. For long the canals resisted the railways; but, instead of attempting to undersell them, as they might hare done at a stage when the railways were burdened with the heary capital charges, they ruined themselves by exorbitant rates. When they did lower their rates it was too late.

In the period 1840-1860 many canals found themselves unable to pay expenses and practically forced the railway companies to buy them up. In 1845 the control of canals by the railway companies was expressly sanctioned by Parliament, and in the two following years a great deal of canal mileage came into their possession. In many cases the investment prover far from profitable-many companieș are maintaining canals at a loss. An 
example may be given of the canals owned by the Great Western Railway for the half-year ending December 31, 1904, indicating loss of over three thousand pounds for the half-year. In 1883 there were no less than 1717 miles of canal under railway control.

\section{TABLE I.-Canals}

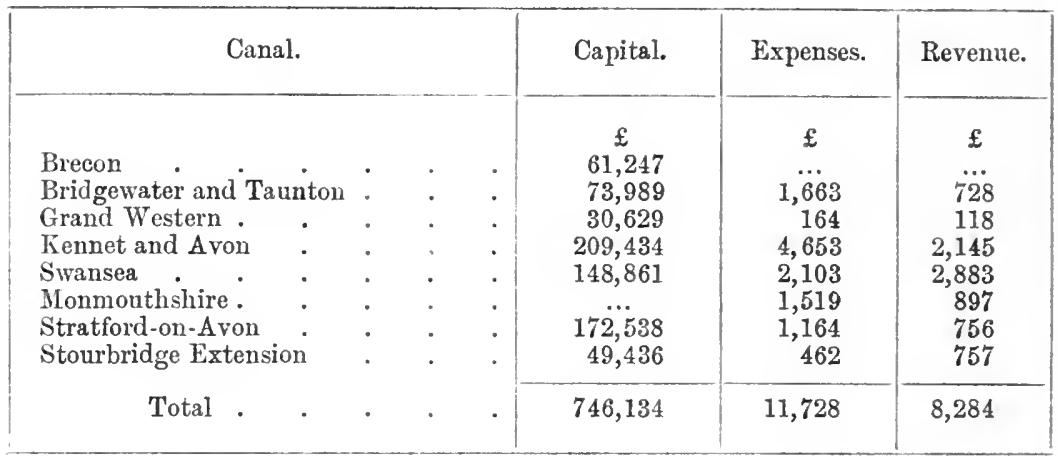

That the canals have been unable to maintain themselves against the competition of the railways is true. Even the Leeds and Liverpool, a comparatively flourishing one, paid only 1 per cent. in 1907. The reason for their failure to maintain themselves is found in the superiority of railroad trausport. England possesses few navigable rivers, while the inequalities of the land and its extremely hilly character place great natural difficulties in the way of an efficient canal system. Other real causes for the decline of canals are the number of locks and the time occupied in getting through them. On the waterways of England and Wales there are no fewer than 2377 locks, or one lock for every mile and a quarter. The Rochdale Canal, $34 \frac{1}{2}$ miles long, has 92 locks between Manchester and Sowerby Bridge. The average capitalized cost of each lock is $£ 1360$, and it takes a boat four minutes to get through. On the system there are, moreover, 45 canal tumnels over 100 yards long; at any time the rate of progress on a canal is slow. For a journey of 190 miles each way, one way with load and the return journey without, the canal boat will take 15 days. Each boat has two men and a horse, and will carry between 20 and 40 tons. A train will do the distance in 5 hours.

As Mr. Pratt observes:- " The spreading of the total volume of trade over a larger area; the introduction of men of smaller capital, who cau do with a few hundredweights or a few tons of raw material to serve immediate wants, but could not afford or find room for a boat-load; the absolute necessity that small stocks 
thus kept on hand should be replenished promptly, so that they may not get too low; and the increased facilities in the way both of quick conveyance and of direct delivery alike to manufacturers (with their private sidings) and to general traders, have all had a most powerful effect in diverting the stream of traffic from the waterways to the railways."

Nevertheless, the majority of the Royal Commission recommended (1909), that, in view of the great canal system in existence, covering the whole country, and capable of being utilized to great advantage for certain kinds of traffic, means should be employed to stimulate the employment of canals. As to their proposals there is much difference of opinion. Parliament has not yet dealt with the question.

\section{Railways}

"The public railways of England," said Porter, "are strictly creations of the present century. It was in 1801 that the first Act of Parliament for the construction of a work of this kind received the sanction of the Legislature."

In 1835 there was but one passenger line in England and another, 7 miles long, in Scotland. In the course of the next twenty years, however, all this was changed, and even in 1834 the Poor Law Commissioners could, with some reason, anticipate, from this source alone, the entire absorption of all the surplus labour of the country at no distant date. In 1836 eight thousand labourers were engaged in the construction of the London and Birmingham line, and new lines were being planned in every dircetion. 1845 saw an outburst of extraordinary speculation in railways, seven hundred millions was in that year forthcoming for railway schemes alone. The columns of Punch at this period give some idea of the lengths to which people were carried by the railway mania. In 1847 over-speculation was followed by a disastrous crisis; but real progress had already been made and steadily continued.

The total number of miles of railway completed and in use in the United Kingdom, to July $1 S 45$, was 2264, of which there were on the wide grange of 7 feet, 274 miles, the remainder, with the exception of 57 miles in Ireland and 32 miles in Scotland, of an intermediate width, were all on the gauge of 4 feet $S \frac{1}{2}$ inches. The total receipts for passengers, goods, and cattle upon the lines which made returns to the Board of Trade were $£ 3.976,341$ passengers

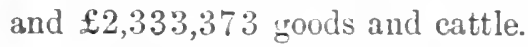

These figures may be usefully contrasted with recent returns. 


\begin{tabular}{|c|c|c|c|c|}
\hline 莺 & 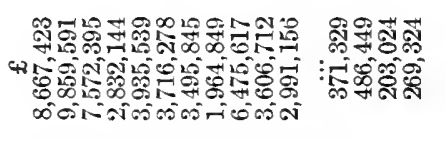 & 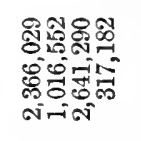 & 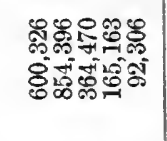 & 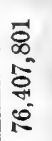 \\
\hline 㤩: & 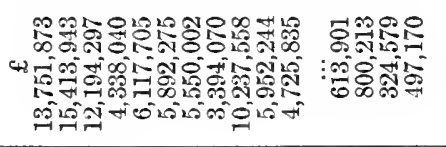 & 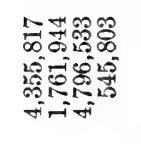 & 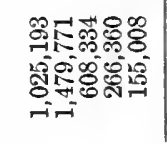 & 商 \\
\hline 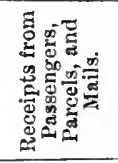 & 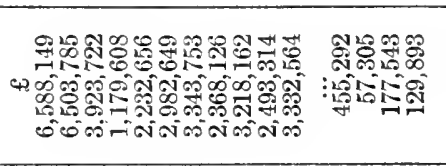 & 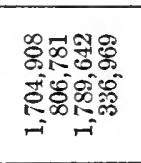 & 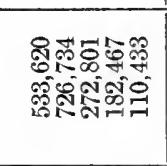 & $\vdots$ \\
\hline 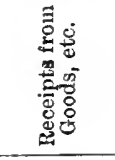 & 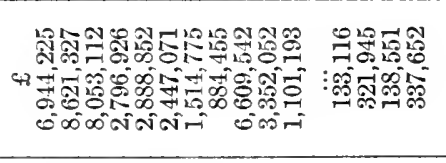 & 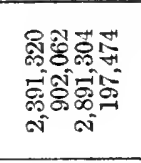 & 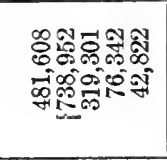 & $\vdots$ \\
\hline 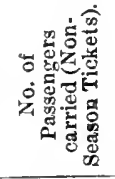 & 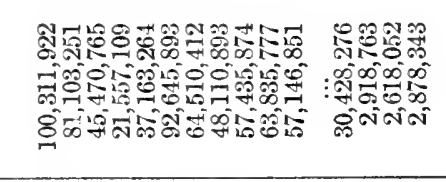 & 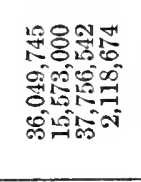 & 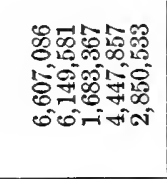 & 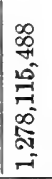 \\
\hline 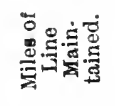 & 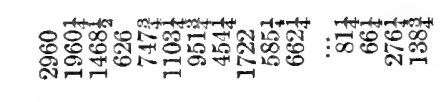 & 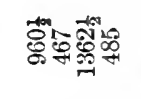 & 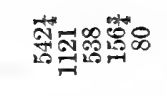 & 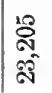 \\
\hline 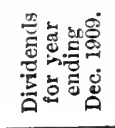 & 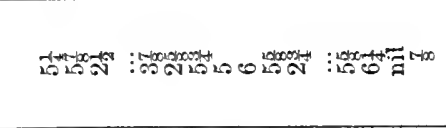 & 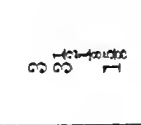 & 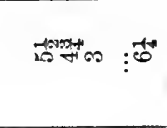 & $\vdots$ \\
\hline 至方 & 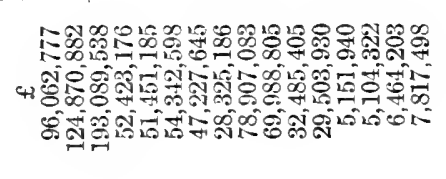 & 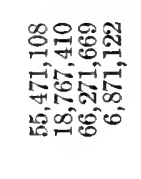 & 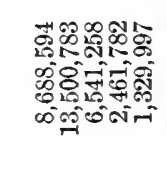 & 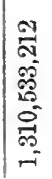 \\
\hline 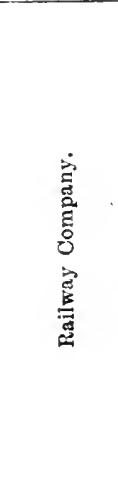 & 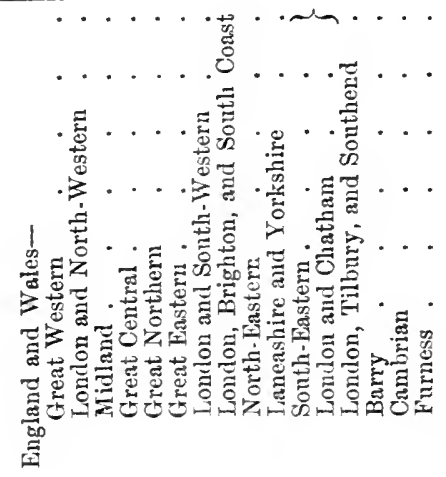 & 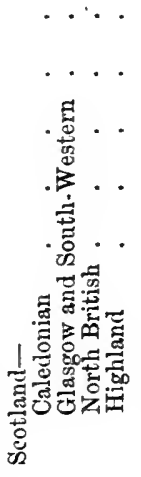 & 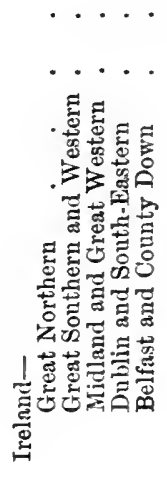 & 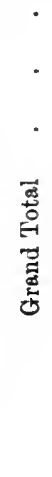 \\
\hline
\end{tabular}


TABLE III.-Comparative Railway Statistics for the United KingdomFrom 1850 to 1908

\begin{tabular}{|c|c|c|c|c|c|c|}
\hline \multicolumn{3}{|c|}{ Year. } & $\begin{array}{l}\text { Length of } \\
\text { Line open } \\
\text { for Traffic. }\end{array}$ & $\begin{array}{l}\text { Total Number } \\
\text { of Passengers } \\
\text { carried } \\
\text { (exclusive of } \\
\text { Season Ticket } \\
\text { Holders). }\end{array}$ & $\begin{array}{l}\text { Weight of } \\
\text { Goods and } \\
\text { Minerals. } \\
\text { Conveyed. }\end{array}$ & $\begin{array}{l}\text { Total Capital } \\
\text { Paid Up. }\end{array}$ \\
\hline $\begin{array}{l}1850 \\
1860 \\
1870 \\
1880 \\
1890 \\
1900 \\
1908\end{array}$ & : & $\dot{5} \cdot$ & $\begin{array}{r}\text { Miles. } \\
6,621 \\
10,433 \\
15,537 \\
17,933 \\
20,073 \\
21,855 \\
23,205\end{array}$ & $\begin{array}{r}\text { No. } \\
72,854,422 \\
163,435,678 \\
336,545,397 \\
603,895,025 \\
817,744,046 \\
1,142,275,686 \\
1,278,115,488\end{array}$ & 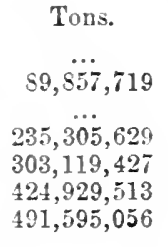 & $\begin{array}{c}£ \\
240,270,745 \\
348,130,127 \\
529,908,673 \\
728,316,848 \\
897,472,026 \\
1,176,001,890 \\
1,310,533,212\end{array}$ \\
\hline \multicolumn{3}{|c|}{ Year. } & $\begin{array}{c}\text { Gross } \\
\text { Receipts. }\end{array}$ & $\begin{array}{l}\text { Working } \\
\text { Expenses. }\end{array}$ & $\begin{array}{c}\text { Net } \\
\text { Receipts. }\end{array}$ & 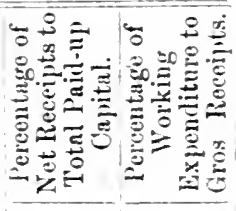 \\
\hline $\begin{array}{l}1850 \\
1860 \\
1870 \\
1880 \\
1890 \\
1900 \\
1908\end{array}$ & $\dot{.}$ & $\begin{array}{l}\dot{.} \\
\dot{.} \\
\dot{.} \\
\dot{.} \\
\dot{.}\end{array}$ & $\begin{array}{c}£ \\
13,204,669 \\
27,756,622 \\
45,078,143 \\
65,491,625 \\
79,948,702 \\
104,801,858 \\
119,894,327\end{array}$ & $\begin{array}{c}\mathcal{\Phi} \\
\ldots \ddot{1} \\
13,18 \overline{7}, 368 \\
21,715,525 \\
33,601,124 \\
43,188,556 \\
64,743,520 \\
76,407,801\end{array}$ & $\begin{array}{c}£ \\
14,579,254 \\
23,362,618 \\
31,890,501 \\
36,760,146 \\
40,058,338 \\
43,486,526\end{array}$ & $\begin{array}{l}4 \cdot 19 \\
4 \cdot 41 \\
4 \cdot 38 \\
4 \cdot 10 \\
3 \cdot 41 \\
3 \cdot 32\end{array}$ \\
\hline
\end{tabular}

Table III gives certain comparative statistics for 1850,1860 , $1870,1880,1890,1900$, and 1908, and shows clearly the remarkable progress made.

The standard gauge of England, Wales, and Scotland is now 4 feet $8 \frac{1}{2}$ inches. Stephenson built the Liverpool and Manchester railway on this gauge as that employed for normal coal earts in the Tyneside district, where the earliest form of railway started. Until 1838 all lines conformed to this gauge. Then, however, the Great Western Railway was built with a gauge of 7 feet, from the designs of Brunel. After long discussion and trial of the different gauges, a Parliamentary Commission was appointed in 1846. The Gauge Regulation Bill of the same year provides that (1) no new line was to be constructed on the broad gauge; (2) in certain places mixed gauges should be laid down. The report of the Commission had been distinctly favourable to the broad gauge, hut the Bill of 1846 marked its doom. It was not, however, until May 1892 that 
the broad gauge lines were finally converted to the statutory gauge of 4 feet $8 \frac{1}{2}$ inches. It is now almost unanimously agreed that the broad gange was better adapted for high speed, and more stable at high speed. Its defect was a higher cost of construction. But the main reason of its conversion was that in England, at the time of the Gauge Commission, there were 274 miles of broad gauge line, and 1901 miles of narrow gauge line. It was obvious that all must in time be of one gauge, hence the broad, being very much in a minority, must be converted. However, if 7 feet was too broad, 4 feet $8 \frac{1}{2}$ inches is certainly too narrow. Many have suggested 6 feet as about the best, and this occurs in parts of the U.S.A. The gauge of Irish railways is 5 feet 3 inches, not 4 feet $8 \frac{1}{2}$ inches.

Speed of Trains.-For the best express trains an average start-to-stop speed of 50-57 miles an hour is maintained on the main lines. Some rise to 59 , and two trains per day are timed at over 60 miles per hour. At the same time it should be noted that the weight of trains has increased enormously since 1850 , owing to increased comfort of travel, institution of corridor trains, dining and sleeping-cars, etc. The fares, however, have not gone up; they remain at about 1 d. per mile third class.

It is noteworthy in this connexion that while the railways are doing far more work than they did even ten years ago, net profits have declined when looked at in proportion to capital expenditure. (See Table IV.) This change is due to the increase of working expenses, the main items being the increased price of materialespecially of coal-and the increase of wages.

The 23,000 miles of railway working in the United Kingdom in 1907 were constructed at a cost of about 1294 millions-an average cost of $£ 50,000$ per mile. This cost is higher than that of any other system in the world, but it must be remembered that British railways have a higher average of double track than those of any other country. On December 31, 1907, the number of persons employed by the railway companies of the United Kingdom was 621,341 .

Competition.-The railways compete with each other from London to almost every important town in the country, and between very many of the provincial towns. In fact there is hardly a large town with only one railway company. This system of competing lines is most extensive in Scotland, and least so in Ireland, where it is almost non-existent. It should be noticed that while previous to 1907 or so, competition was the rule, now the companies are working more and more together, and it was a 


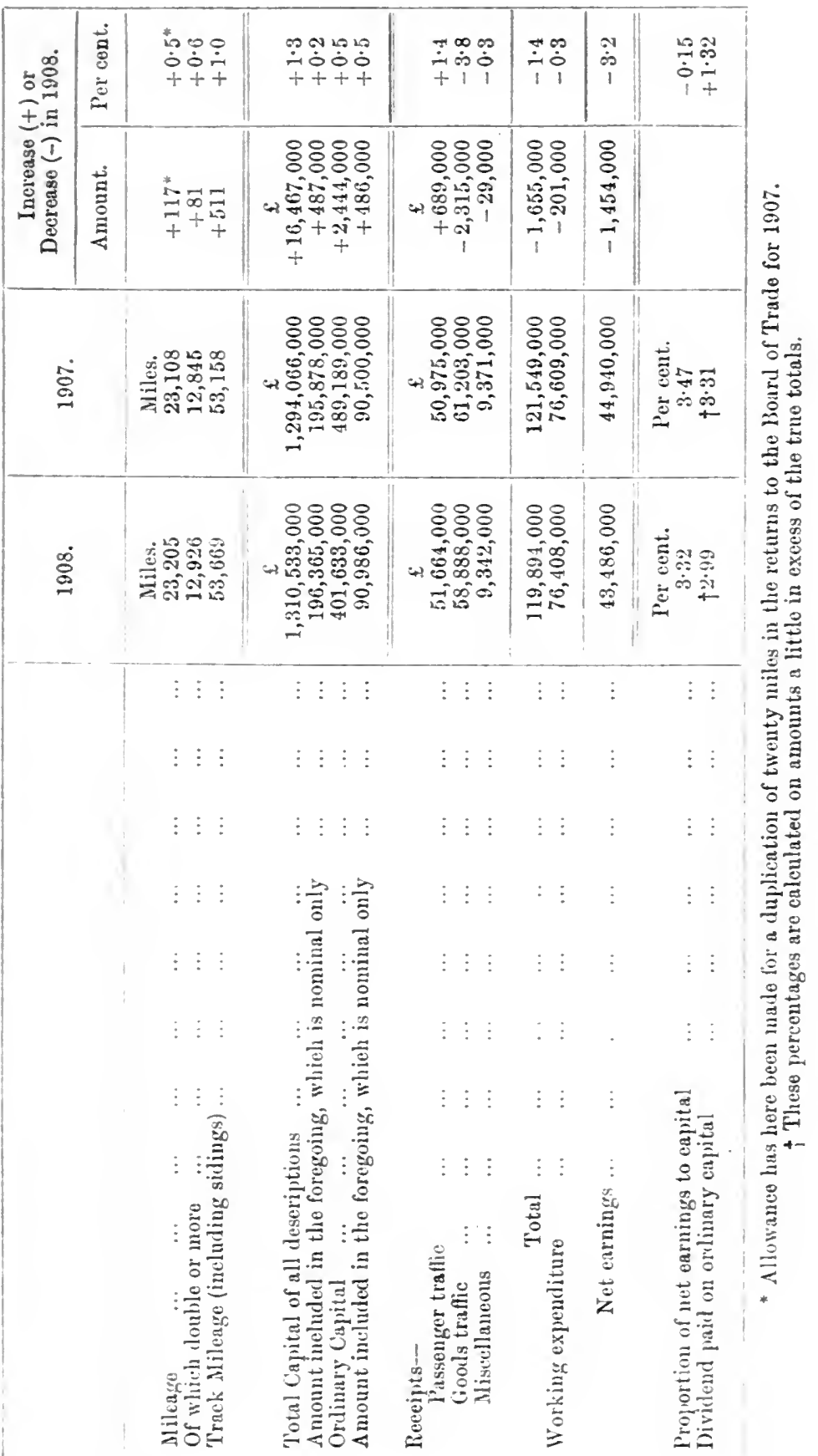




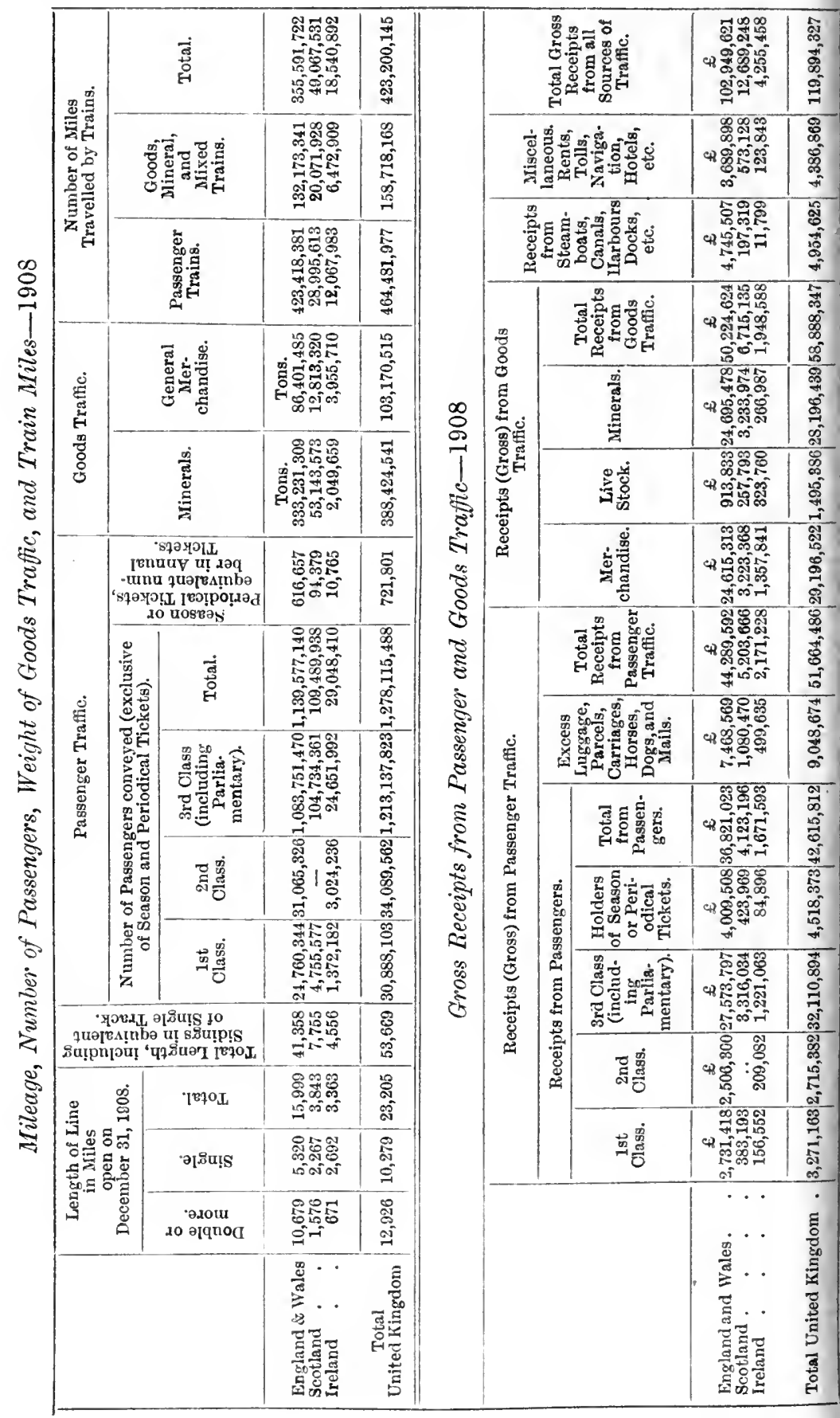


significant fact that, in 1908, the Great Northern Railway, Great Eastern Pailway, aud Great Central Railway sought to amalgamate, although Parliament would not allow the formation of a company having a monopoly in such a large district as would have thus been formed.

In the same way the amalgamation of the Glasgow and SouthWestern and the (English) Midland was strongly opposed. In England, as in America, there has never been any strong movement in favour of railway nationalization. On the contrary, Parliament and the courts while fixing rates have endeavoured to encourage competition and discourage amalgamation. As before pointed out, a large number of canals are owned by the railway companies. Many companies also own steamship lines and docks. Thus the South-Eastern and Chatham Railway, the London and South-Western, the London, Brighton, and South Coast, and the Great Eastern own fleets plying to and from continental ports and the docks from which they depart. The Great Western Railway has steamers for Ireland and the Channel Islands; the London and North-Western and Midland have steamers for Ireland and the Isle of Man; these three lines respectively own the harbours of Fishguard, Holyhead, and Heysham.

The Lancashire and Yorkshire Railway has boats plying to the Isle of Man. The North-Eastern, Lancashire and Yorkshire, and Great Central Railways have Heets that ply from Hull, Grimsby and Goole to Holland and Belgium. In fact, almost all the steamship lines between Britain and the European continent and Ireland are railway owned. The railways have almost invariably erected hotels at all important stations. No account of the available means of internal communication would be complete which neglected to mark the immense growth of tramways, electric and other light railways, especially in recent years. Table $\mathrm{V}$, showing the comparative number of passengers conveyed by different railways in 1909 , shows the immense traffic for which some of these city lines are responsible, notably in London. The Metropolitan Railway, indeed, is fourth on the list, with $76,667,797$ passengers in the course of the yoar.

In 1895 the total length of tramways and light railways in the United Kingdom was 982 miles. In 1909 it was 2526 miles. In 1895 the net receipts were $£ 855,200$, and the total number of passengers $661,760,461$. In 1909 the net receipts were $\mathfrak{f 4 , 5 9 5 , 7 7 9}$, and the total number of passengers $2,659,981,136$. 


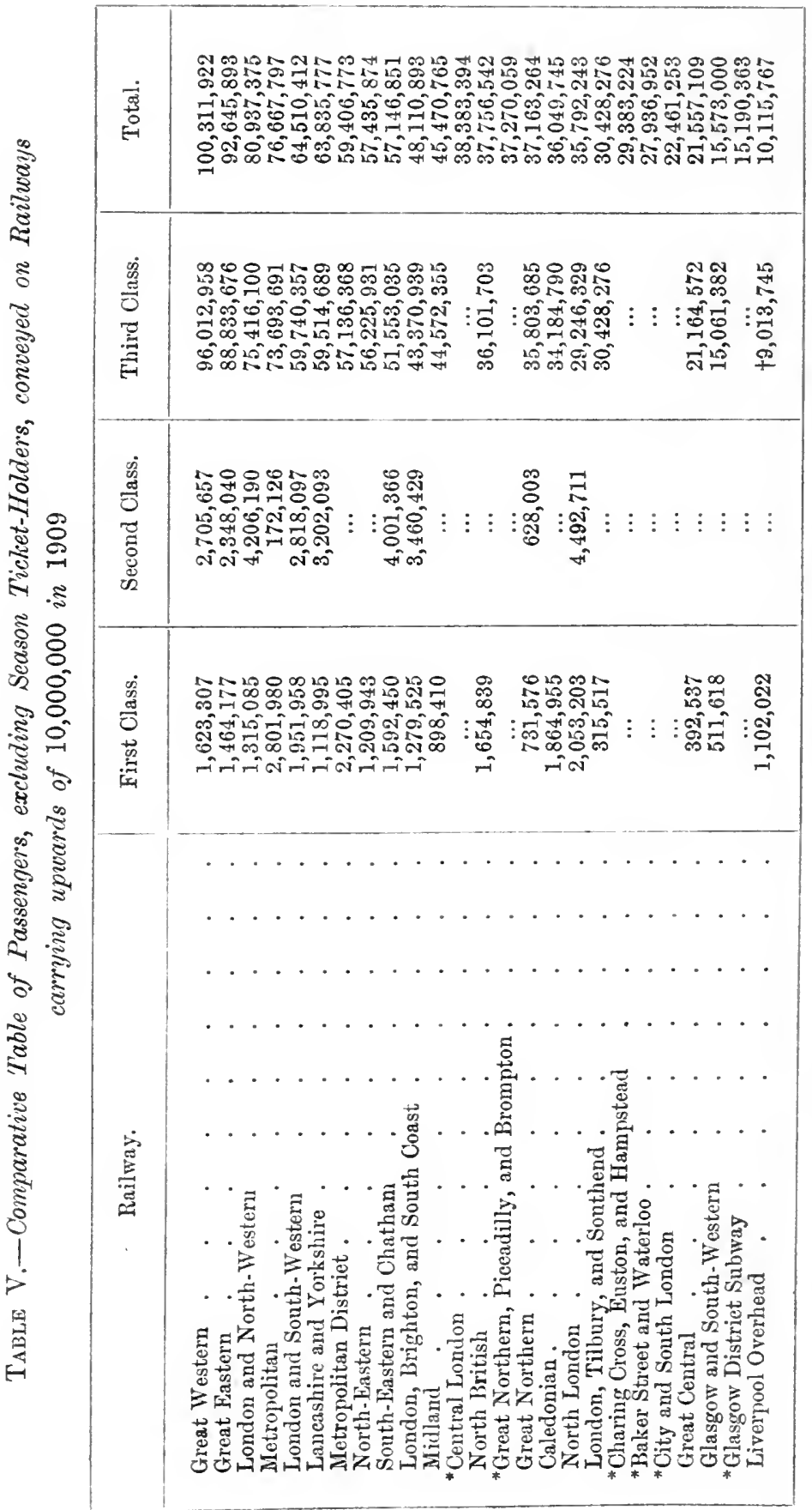

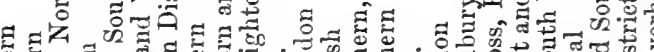

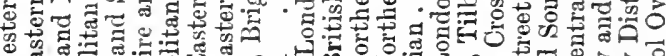

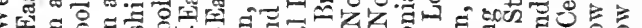

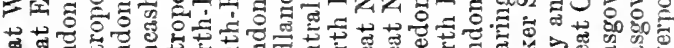

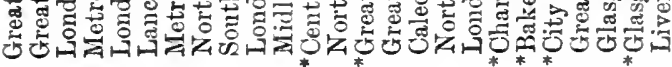


TABLE VI.-Comparative Statement of Receipts and Expenditure of Railuays earning uprards of $\$ 100,000$ per annum

ENGLAND AND WALES.

YeAR ENDING December 31, 1909.

London and North-Western

Great Western

Midland

North-Eastern

Great Northern

Lancashire and Yorkshire

Great Eastern

London and South-Western.

South.Eastern and Chatham

Great Central

London, Brighton, and Soutl Coast

* Cheshire Lines

Taff Vale

North Staffordshire

Barry .

Metropolitan

Hull and Barnsley

London, Tilbury, and Southend

Metropolitan District

Cardiff.

Furness

North Loudon

Rhymney

Cambrian

Great Northern, Piccadilly, and Brompton

Central London

Alexandra (Newport and Soutl Wules) Docks and Railway.

Charing Cross, Euston, and Hampstead

Baker Street and Waterloo

City and South London

Brecon and Merthyr Tydfil Junction

Maryport and Carlisle .

\begin{tabular}{|c|c|c|}
\hline Receipts. & Expenditure. & $\begin{array}{c}\text { Net } \\
\text { Receipts. }\end{array}$ \\
\hline$\stackrel{£}{2}$ & t & $£$ \\
\hline $15,413,943$ & $9,859,591$ & $5,554,352$ \\
\hline $13,751,873$ & $8,667,423$ & $5,084,450$ \\
\hline $12,194,29 i$ & $7,572,395$ & $4,621,902$ \\
\hline $10,237,558$ & $6,475,617$ & $3,761,941$ \\
\hline $6,117,705$ & $3,935,539$ & $2,182,166$ \\
\hline $5,952,244$ & $3,606,712$ & $2,345,532$ \\
\hline $5,892,275$ & $3,716,278$ & $2,175,997$ \\
\hline $5,550,002$ & $3,495,845$ & $1,754,157$ \\
\hline $4,725,835$ & $2,991,156$ & $1,734,679$ \\
\hline $4,338,040$ & $2,832,144$ & $1,505,896$ \\
\hline $3,394,070$ & $1,964,849$ & $1,433,221$ \\
\hline $1,077,939$ & 859,250 & 218,689 \\
\hline $1,006,536$ & 572,235 & 434,301 \\
\hline 977,901 & 598,310 & 379,591 \\
\hline 800,213 & 486,449 & 313,764 \\
\hline 770,213 & 308,147 & 462,096 \\
\hline 656,250 & 384,302 & 271,978 \\
\hline 613,901 & 371,329 & 242,572 \\
\hline 552,929 & 300,768 & 252.161 \\
\hline 516,557 & 328,3 & 188,210 \\
\hline 497,170 & 269,324 & 227,816 \\
\hline 458,899 & 279,303 & 180,596 \\
\hline 363,279 & 213,165 & 150,114 \\
\hline 324,579 & 203,024 & 121,555 \\
\hline 310,33 & 143,5 & 166,788 \\
\hline 305,421 & 178,925 & 126,499 \\
\hline 276,697 & 160,501 & $116,190^{\circ}$ \\
\hline 210,321 & 116,084 & 94,237 \\
\hline 180,088 & 84,868 & 95,220 \\
\hline 179,448 & 81,250 & 98,198 \\
\hline 124,529 & 78,164 & 46,365 \\
\hline 114,494 & 63,185 & 51,309 \\
\hline
\end{tabular}

SCOTLAND.

YeAR ENDIN; JeLY 31, 1909.

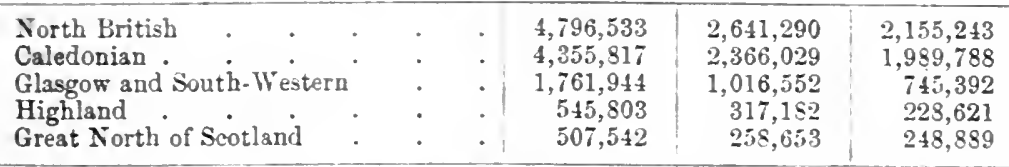

IRELAND.

Yeap exisg December 31, 1909.

Great Southern and Western

Great Northern

Midland Great Western

Dublin and South-Eastern

Belfast and County Down

$1,479,771$
$1,025,193$
608,331
266,360
155,008

$854,390^{\circ}$

600,320

364,470

165,163

$92,300^{\circ}$
625,375

424,867

243,864

$101,19 \%$

63,302

* The Cheshire lines' figures refer to the year ending December 31, 1908. 


\section{CHAPTER XXX}

\section{'THE POS'T OFFICE}

Historical - The penny post-Post-office revenue and expenditure-Post-office savings banks--Telegraphs and telephones

THE remarkable development of the means of transit and communication, which the century has witnessed in connexion with railways, tramways, steamships, etc., is equally striking in respect of the conveyance of letters, messages, and news. Porter wrote after Sir Rowland Hill had, as the result of strenuous agitation, induced a somewhat unwilling government and Postmaster-General to accept his views, but before the great results that followed from the introduction of the penny post could be fully estimated. On November 12, 1839, he tells us, a Treasury Order was issued, under an Act passed in the previous August, which directed that all letters should be charged by weight instead of according to the number of sheets or enclosures, and that, on and after the 5 th of December in that year, the single postage rates between places in the United Kingdom which exceeded fourpence should be reduced to that uniform rate; on the 10 th of January 1840 the uniform rate of one penny per half-ounce came into general operation, and on 6th May following prepayment by the use of stamps was begun.

Before the introduction of stamps, the postage was not prepaid. The postman had to collect the postage on each letter as he delivered it -an extremely expensive and cumbersome plan. The rates were very heavy. Between London and Birmingham a single sheet was $9 \mathrm{~d}$.; a sheet with an enclosure, 1s. 6d. A letter to Edinburgh cost 1s. 1d. Within the London area letters took fifteen hours in transmission. There is an instance, from the year

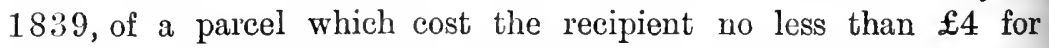
delivery. Although the post office had a legal monopoly, the revenue had made no progress between 1816 and 1839 , and a great proportion of letters were smuggled for lower rates. The right of franking, abolished by Rowland Hill's efforts, possessed by all members of the Upper and Lower House, accounted for no 
less than five million letters a year, to say nothing of packages of the most miscellaneous description, varying from a hat to a piano. Mr. Sydney Buxton (Finance and Politics, vol. i. p. 1404) gives an interesting quotation from the Life of Lord Campbell. The noble lord wrote that "the loss of consequence from ceasing to be able to frank a letter for a lady or, in travelling, for the waiter at an inn, gave great disgust to many members of both Houses, and made some of them openly declare that there was no longer any use in being in Parliament!"

Hill's reforms were opposed at the time on the ground that the revenue must suffer by the reduction in the exorbitant rates then charged; and he himself did not urge in favour of the penny post that it would primarily be of advantage to the Exchequer. His view was that any loss thus sustained-which he estimated as inconsiderable-would be counterbalanced by the stoppage in the illicit conveyance of letters and the stimulus to trade that must result from the cheap rate.

His prophecy was soon proved correct. The post office acquired a real monopoly, and its business increased rapidly and continuously. In 1839 the number of letters delivered in the United Kingdom was 99 millions odd; in 1843 it had risen to 265 millions. In forty years it nearly quadrupled itself, for in 1873 the number of letters delivered had risen to 907 millions or 28 per head of population; and in 1909-1910 it reached the enormous total of $2,517,100,000$ or 70 letters per head of population (cf. Table I).

TABle I.-Post Office

\begin{tabular}{|c|c|c|c|c|c|c|c|c|c|c|c|c|}
\hline \multirow{2}{*}{ Year. } & \multicolumn{4}{|c|}{$\begin{array}{l}\text { Number of Letters delivered } \\
\text { (in nillions). }\end{array}$} & \multicolumn{4}{|c|}{$\begin{array}{l}\text { Number of } \\
\text { Letters delivered } \\
\text { per Head of } \\
\text { Population. }\end{array}$} & \multicolumn{4}{|c|}{$\begin{array}{c}\text { Number of Post Cards } \\
\text { delivered } \\
\text { (in millions). }\end{array}$} \\
\hline & 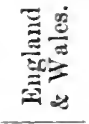 & 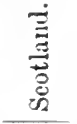 & 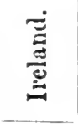 & 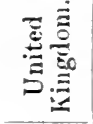 & $\begin{array}{l}= \\
2 \\
\dot{z}\end{array}$ & 焉 & 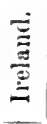 & 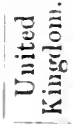 & 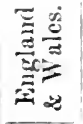 & 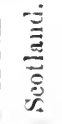 & 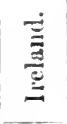 & 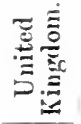 \\
\hline 1839. & 79 & 9 & $10 \frac{1}{2}$ & 99 & ... & $\ldots$ & $\ldots$ & 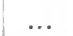 & $\ldots$ & $\ldots$ & $\cdots$ & $\ldots$ \\
\hline 1843. & $218 \frac{1}{2}$ & 231 & 23 & 265 & & & $\ldots$ & & $\ldots$ & $\ldots$ & . & $\ldots$ \\
\hline 1863. & $529^{\circ}$ & 61 & 52 & 642 & 25 & 19 & 9 & $21 \cdot 8$ & $\ldots$ & $\ldots$ & $\ldots$ & \\
\hline *1871. & 721 & 80 & 66 & 867 & 31 & 23 & 12 & $27 \cdot 0$ & $\ldots$ & $\ldots$ & $\ldots$ & \\
\hline 1873. & 756 & 84 & 67 & 907 & 32 & 24 & 12 & 28.0 & & & $\ldots$ & 72 \\
\hline 1881. & 981 & 105 & 79 & 1165 & 38 & $2 S$ & 15 & 34 & 104 & 13 & 6 & 123 \\
\hline 1891-1892. & 1516 & $146 \frac{1}{2}$ & 105 & $1767 \frac{1}{2}$ & 52 & 36 & 22 & $47 \cdot 0$ & 2051 & $25 \frac{1}{2}$ & 11 & $241 \frac{3}{4}$ \\
\hline 1901-1902. & $20844^{8}$ & $218 \frac{3}{10}$ & $1488^{6}$ & $2451_{10}^{\frac{5}{10}}$ & 64 & 49 & 33 & $59 \cdot 0$ & $3 s 0_{\frac{3}{10}}^{3}$ & $45 \mathrm{~s}^{7} \mathrm{c}$ & $188_{Y 0}^{9}$ & $444^{3}$ \\
\hline 1908. & $2443 \frac{3}{10}$ & $255 \frac{7}{10}$ & $164 \frac{7}{10}$ & $2 S 63 \%$ & 70 & 54 & 38 & & $729^{2} \frac{2}{5}$ & $923^{2} 0$ & $36 \%$ & $858_{\frac{1}{16}}$ \\
\hline & & & & $2947 \frac{1}{10}$ & 70 & 53 & 40 & & & 84 & & \\
\hline
\end{tabular}

* Halfuenuy post introduced 1871. 
There was, as a matter of fact, a decline in gross revenue in the years immediately following the reforms in the postal system, but time has more than justified them. Between 1816 and 1839 the revenue derived from the post office was practically stationary. In 1816 the net revenue was $£ 1,537,505$, in 1826 it was $£ 1,589,762$, in $1836 £ 1,645,835$, in $1839 £ 1,649,088$. In 1840 it fell to $£ 495,514$. From that figure, however, it steadily though slowly rose. Table II gives a general review of post-office receipts and expenditure; in 1909-1910 the net receipts amounted to $£ 4,337,000$.

\section{Table II}

Revenue

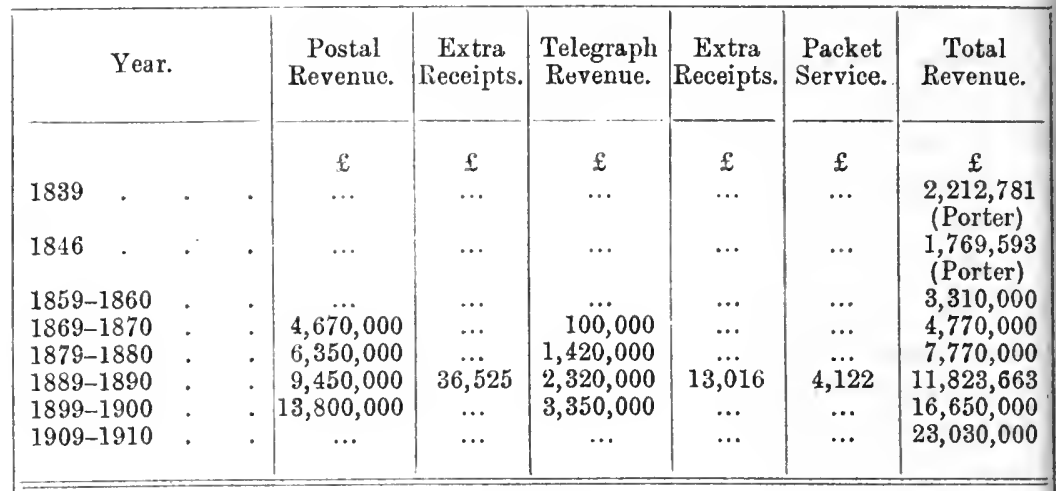

Expenditule

\begin{tabular}{|c|c|c|c|c|c|c|c|}
\hline \multicolumn{4}{|c|}{ Year. } & $\begin{array}{c}\begin{array}{c}\text { Post } \\
\text { Office. }\end{array} \\
\ldots\end{array}$ & $\begin{array}{c}\text { Packet } \\
\text { Service. } \\
\ldots\end{array}$ & $\frac{\text { Telegraphs. }}{\ldots}$ & $\begin{array}{c}\begin{array}{c}\text { Total } \\
\text { Expenditare. }\end{array} \\
2,116,798\end{array}$ \\
\hline $\begin{array}{l}1839 . \\
1846 . \\
1859-1860 \\
1869-1870 \\
1879-1880 \\
18,99-1890 \\
189: 9-1900 \\
1909-1910\end{array}$ & $\begin{array}{l}\dot{5} \\
\dot{.} \\
\dot{5} \\
\text {. }\end{array}$ & $\begin{array}{l}\dot{5} \\
\dot{5} \\
\dot{5} \\
\dot{5} \\
\text { : }\end{array}$ & : & $\begin{array}{c}\ldots \\
\ldots \\
1,947,058 \\
2,316,000 \\
3,333,000 \\
5,463,205 \\
8,480,000 \\
\ldots\end{array}$ & $\begin{array}{r}989,486 \\
1,221,553 \\
772,820 \\
664,000 \\
760,000 \\
\ldots\end{array}$ & $\begin{array}{c}\ldots \\
\ldots \\
\ldots \\
60,000 \\
1,107,000 \\
2,172,455 \\
3,504,837 \\
\ldots\end{array}$ & $\begin{array}{r}2,116,798 \\
1,035,221 \\
2,936,544 \\
3,597,553 \\
5,212,820 \\
8,299,660 \\
12,744,837 \\
18,693,000\end{array}$ \\
\hline
\end{tabular}

In 1871 the halfpenny postage was introduced, and post cards, at first inly sold with the printed stamp, first issued. Table I shows the - immense development of this department; while its volume is ${ }^{3}$ surpassed by the numbers of newspapers, book-packets, circulars $a^{\text {jl }}$ d samples also sent under a halfpenny stamp. In 1909-191(a) they amounted to no less than 1,173,800,000.

Anothe! ${ }^{\mathrm{b}} \mathrm{r}$ important and increasing branch of post-office business 
is the issue of money and postal orders. The money order office was instituted in 1792. In 1909-1910 money orders to the value of $£ 39,738,631$ and postal orders to the value of $£ \notin 5,557,000$ were issued in the United Kingdom, exclusive of money orders issued for payment abroad and in the Colonies.

Post-Office Savings Banks.-In 1861 the post-office savings banks were instituted, which, as Mr. Buxton says, "have not only done very much to increase thrift and saving but have given to successive governments a means they did not previously possess of creating large amounts of terminable annuities, and thus greatly facilitating the redemption of debt." Interest on deposits was fixed at $2 \frac{1}{2}$ per cent., from which rate it has never varied. The minimum limit of deposit has remained at 1 s., but the maximum was raised from $£ 150$ to $£ 200$ in 1891 . The amount of deposits

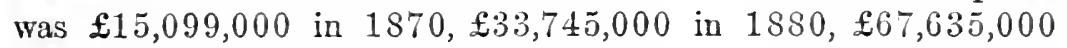
in $1890, £ 13 \tilde{5}, 500,000$ in 1900 .

Telegraphic Service.-The first telegraph was worked so early as 1837 ; but telegraphic installation proceeded very slowly in the next decade. In 1847, however, the Queen's Speech was, for the first time, transmitted to the provinces by electric telegraph; and the news of the coup d'état in 1851 reached London only two hours after its occurrence, for by that time there was a submarine cable working between England and France. The first Atlantic cable, laid in $185 \mathrm{~s}$, proved a failure; and eight years passed before telegraphic communication was suecessfully established between England and America. By 1868 telegraphs extended all over the country, and the principal towns were served by them. Since the lines were owned by various companies the quality, extent and rate of the service varied very mueh from one locality to another; in the less accessible parts of the country the delivery was slow, expensive, and unreliable. In large towns, for example, local telegrams were delivered at a charge of $6 \mathrm{~d}$. per 20 words; messages of the same length within a radius of 100 miles cost 1s., up to 200 miles 2s. Between Great Britain and Irelaud the charge for a message was $4 \mathrm{~s}$. In rural districts the cost of porterage, uncertain in amount and often extortionate, had to be added.

By this time the success of the post office as a business concern was established. Over 800 million letters were delivered annually and the business showed a net profit of over $\mathfrak{E} 1,000,000$. The unifortnity, certainty and cheapness of the postal service were strong arguments, from the consumer's point of view, in favour of post-office telegraphs. A Select Committee of the House reported 
favourably. The cost of acquiring the existing telegraphic plant, etc., which had been estimated at four millions, had risen to seven millious by the time the purchase was completed, and a large additional capital outlay was required in order to make the service efficient and complete. In the course of the years succeeding the transfer the annual expenditure continued to expand, and in 1888 Mr. Buxton wrote that "the business is now carried on at a considerable annual loss." In 1870 the government supplied a telegraph office to every 6000 of population, whereas the companies had only served every 13,000. In 1884 there was a loss of $£ 36,000$ which together with $£ 326,000$ of interest made a deficit of $£ 362,000$, and this had risen to $£ 472,000$ in 1885 , after the introduction in the previous year of sixpenny telegrams. In 18991900 the expenditure on the telegraph service was $£ 3,504,837$; the reccipts $£ 3,350,000$, - but the real annual loss on the service is estimated at close on a million.

In 1907-1908 eight stations for the transmission of messages by wireless telegraphy on Marconi's system were acquired by the post office. In that year 3266 radio-telegrams were sent out to ships, and 27,727 inward messages received.

Another direction in which great progress has recently been made is the laying of underground wires for telegraphic communication. The cable stations on the west coast are now connected with London underground; there are two lines to Birmingham, and the underground line to the north is complete as far as Edinburgh.

Telephone.-An important feature in recent commercial progress is the development of the telephone. So far as Great Britain is concerned the telephone service has been largely used only in the last ten or fifteen years; and at the present date it is tolerably certain that this country is not keeping pace in the rate of telephone development with many others. At the same time, to quote from a recent publication, "so important a part is the telephone playing, and so increasingly vital a part is it destined to play, in commercial progress, that the proper development or otherwise of the industry must infallibly leave its mark in each country (in the shape of increased vigour or decline) on that progress in so far as it relies upon this most efficient and rapid of all means of communication."

In 1889 the three principal telephone companies then existing amalgamated to form the National Telephone Company. The number of lines was about 28,000. In 1910 the National system had 503,643 lines out of the total 601,269 in Great Britain and Ireland; 5000 belonging to two municipal services and 92,626 to 
the service which had in 1892 been set up by the General Post Office. Since 1896 the trunk service all over the country has been under its control, and in spite of the real difficulties which had to be faced in its extension, it is rapidly progressing. In 1897 there were $5 \frac{3}{4}$ million messages per annum on the long-distance lines; in 1910 there were over 26 millions; in the same period the revenue per mile of circuit has risen from $\mathfrak{f} 48 \mathrm{~s}$. to $\mathfrak{f} 612 \mathrm{~s}$. The service, purchased in 1896 for less than half a million, now represents a capital of over 5 millions. Against any defects in the speed, etc., of the service as compared with that of America, must be set its comparative cheapness to the consumer. A 200-mile call for which the fee in England is about 2s., costs 5 s. in the States.

At the close of 1911 the whole telephone service of the country passed under post-office management. The effect of nationalization on the service and upon subscriber's rates, remains to be seen. It may be noted, however, that while the capital expenditure of the National Telephone Company is $£ 31$ per station, that of the post office is $£ 52$, and that, under present arrangeinents, the inclusive rates granted to the National subscribers involve a loss to the company.

Table III.-Post-Office Telephones and Telegraphs

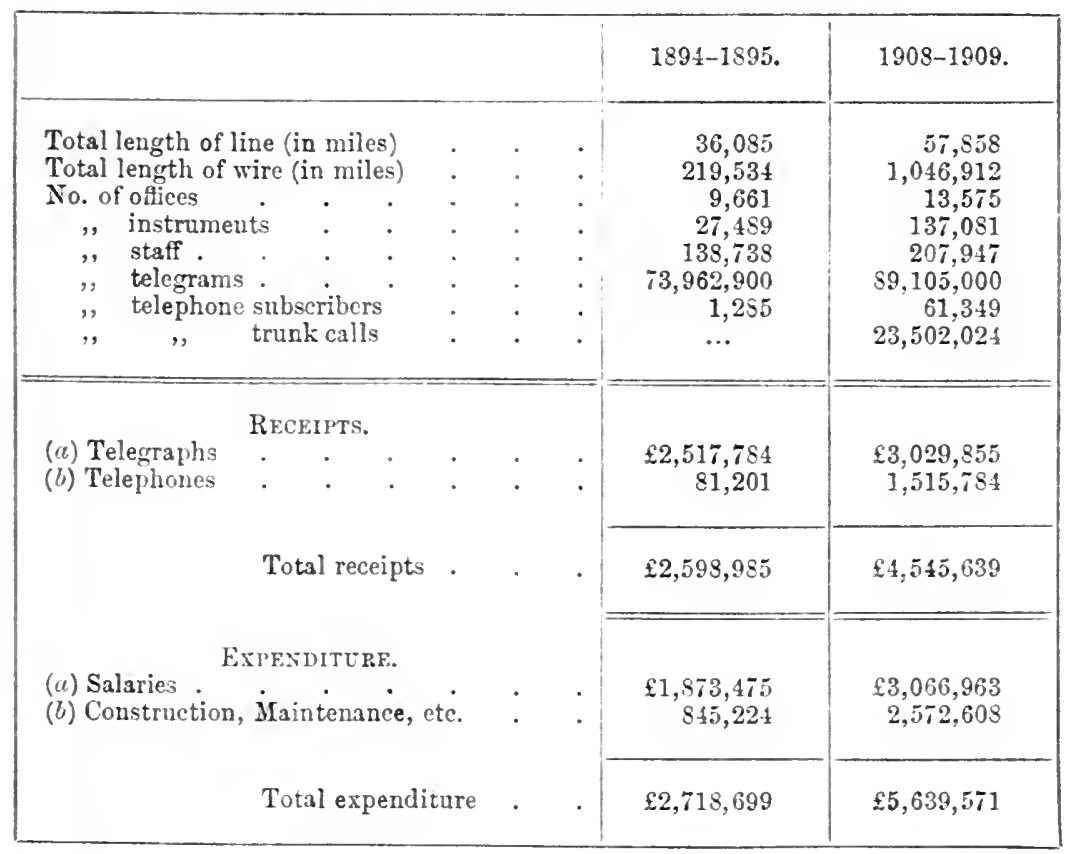


Table III, showing the receipts and expenditure of the two post-office services of telegraphs and telephones (which have been amalgamated), indicates that the department is at present being managed at a loss. In 1908-1909 the receipts were $£ 4,545,639$, the expenditure $£ 5,639,571$, i.e. there was an annual loss of over a million.

In 1910 the number of inhabitants per telephone in Great Britain and Ireland was 68 . In Germany the proportion was 65, in Sweden and in Denmark 30, in Norway 39, in France 186, in Russia 1022, United States 11 . The proportion is of course much higher in many towns. The following are the principal urban systems :-

TABLE IV

\begin{tabular}{|c|c|c|c|c|}
\hline & & \multicolumn{2}{|c|}{ Number of Telephones. } & \multirow{2}{*}{$\begin{array}{l}\text { Population per } \\
\text { Telephone. }\end{array}$} \\
\hline & & 1910. & 1911. & \\
\hline London & . & 104,208 & 181,011 & 36 \\
\hline Glasgow : : & : & 43,928 & 42,855 & 24 \\
\hline Liverpool, Birkenhead & . & 26,849 & 27,783 & 37 \\
\hline Manchester, Salford. & . & 21,209 & 23,462 & 47 \\
\hline Birmingham & . & 13,479 & 14,336 & 64 \\
\hline Edinburgh, Leith & . & 10,889 & 11,791 & 44 \\
\hline Hull • . . & . & 10,800 & 11,060 & 24 \\
\hline Leeds . . . & . & 9,072 & 9,365 & 55 \\
\hline
\end{tabular}

Looking at the rate of increase, Great Britain stands last among the larger states. In Japan, Austria and Russia telephone development is in its infancy, so that "any noticeable progress sends up the average in a way that would be impossible in a welltelephoned country." 


\section{CHAPTER XXXI}

\section{THE COINAGE SYSTEM OF GREAT BRITAIN AND THE EMPIRE}

Bad state of the coinage at the beginning of the nineteenth century-Disappear. ance of coin-Bank tokens-Moneys coined, 1801 to 1910-Diminished weight of silver coins-Prcposal of double standard-Copper coinage, 1821 to 1910-History of coinage after 1850-India and the Colonies

THE condition of our coined money during the early years of the nineteenth century was most unsatisfactory. Of silver coin issued from the Mint there was scarcely any. The shillings and sixpences that passed from hand to hand by common consent were almost all of them blank pieces of silver, intrinsically worth less than half the sums at which they were current. Guineas, half-guineas, and gold pieces of the value of seven shillings, were occasionally seen; but the rapid advance in the market-price of gold, after the suspension of specie payments in 1797 , at length effectually drove all coins of that metal from circulation. The place of guineas was supplied by bank-notes, of the denominations of one and two pounds; and to provide the community with the means for carrying on the smaller transactions of daily traffic, different expedients were successively adopted. At first, Spanish dollars stamped with a diminutive impress of the King's head were issued by Government, at the rate of $4 \mathrm{~s}$. $6 \mathrm{~d}$. each; but these soon disappeared, and the Bank of England was authorized to issue "tokens," and put into circulation pieces of the respective nominal values of $1 \mathrm{~s}$. $6 \mathrm{~d}$., of $3 \mathrm{~s}$, and of $5 \mathrm{~s}$. The last of those tokens consisted of Spanish dollars, the original impress upon which was removed, and a different one given by means of a powerful press. The smaller tokens-those of $3 \mathrm{~s}$. and $1 \mathrm{~s} .6 \mathrm{~d}$. - were intrinsically so far below their nominal value, that they remained in circulation until called in; but the dollars, or five shillings tokens, were so much nearer in value to their nominal rate, that on a further advance in the market price of silver 
bullion, it became necessary to raise their nominal value 10 per cent., causing them to pass for 5s. 6d. each. From 1831 to 1856

Gold and Silver Money coined at the Mint from 1801 to 1910

\begin{tabular}{|c|c|c|c|c|c|c|c|}
\hline Year. & $\begin{array}{c}\text { Gold. } \\
£\end{array}$ & $\begin{array}{l}\text { Silver. } \\
\qquad\end{array}$ & $\begin{array}{c}\text { Total. } \\
£\end{array}$ & Year. & $\begin{array}{c}\text { Gold. } \\
£\end{array}$ & $\begin{array}{l}\text { Silver. } \\
\quad £\end{array}$ & $\begin{array}{c}\text { Total. } \\
\mathbf{f}\end{array}$ \\
\hline 1801 & & 5 & & 856 & $6,002,114$ & 62,528 & $6,464,642$ \\
\hline & & 62 & & & & & \\
\hline 1803 & 4 & 72 & 596,516 & 1858 & & & \\
\hline 1804 & 8,397 & 77 & 718,474 & & & & \\
\hline 1805 & & 183 & 54,851 & 1860 & & & $3,340,112$ \\
\hline 1806 & 405,105 & nil. & 405,105 & 1861 & $8,190,170$ & 209,484 & $8,399,654$ \\
\hline 1807 & nil. & 108 & 108 & 1862 & $7,836,4$ & 148,518 & $7,984,931$ \\
\hline 1808 & 371,744 & nil. & 371,744 & 1863 & $6,997,2$ & 161,172 & $7,158,384$ \\
\hline 1809 & 298,946 & 115 & 299,061 & 1864 & $9,535,5$ & 535,194 & $10,070,791$ \\
\hline 1810 & 316,935 & 121 & 317,056 & 1865 & $2,367,6$ & 501,7 & $2,869,346$ \\
\hline 1811 & 312,263 & nil. & 312,263 & 1866 & $5,076,676$ & 493,416 & $5,570,092$ \\
\hline 1812 & nil. & 52 & 52 & 1867 & & 193,8 & 690,239 \\
\hline 1813 & 519,722 & 90 & 519,812 & $186 \mathrm{~s}$ & $1,653,3$ & 301 & $1,954,740$ \\
\hline 1814 & nil. & 161 & 161 & 1869 & & & 48,632 \\
\hline 1815 & $\ldots$ & nil. & nil. & 1870 & 2,3 & 336,7 & $2,650,182$ \\
\hline 1816 & 然 & 805,251 & $1,805,251$ & 1871 & 9,919 & 701, & $10,621,170$ \\
\hline 1817 & $4,275,337$ & $, 436,298$ & $6,7$. & 1872 & $15,261,4$ & $1,243,8$ & $16,505,278$ \\
\hline 1818 & $2,862,373$ & 576,279 & 3,4 & 1873 & & 1,08 & \\
\hline 1819 & 3,574 & $, 267,273$ & 1,2 & 1874 & 1,46 & & 2,35 \\
\hline 1820 & 949,516 & 847,717 & & 187 & & & ,264 \\
\hline 1821 & $9,520,758$ & 3,686 & 9,9 & 187 & 4,69 & & \\
\hline 1822 & $5,356,787$ & 31,430 & & 18 & & & \\
\hline 1823 & 759,748 & 285,272 & & & 1,15 & &, 778 \\
\hline 1824 & 4,06 & 282,070 & & 187 & 35 & & 104 \\
\hline 1825 & 4,58 & 417,535 & 4,9 & 188 & $4,150,052$ & & 4,911, \\
\hline 1826 & 5,8 & 608,60 & 6,5 & 1881 & & & \\
\hline 1827 & 2,51 & 3,020 & & & & 209 &, 880 \\
\hline 1828 & 1,00 & 16,288 & & & $1,403,713$ & 1,274 & $2,678,041$ \\
\hline 1829 & 2,44 & 108,260 & & & & & \\
\hline 1830 & 2,38 & 151 & & & $2,973,4$ & & $3,694,405$ \\
\hline 1831 & & 3,696 & & 1886 & & & 417,304 \\
\hline 1832 & 3,7 & & & & & & \\
\hline 1833 & $1,225,269$ & 14 & & & & & 478 \\
\hline 1834 & & 432,775 & & & & & 588 \\
\hline 1835 & 1,10 & & & & & & \\
\hline 1836 & & 7,719 & & 1891 & 6.723, & 1,00 & 7,7 \\
\hline 1837 & & & & & 13,90 & & 32 \\
\hline 1838 & $2,855,364$ & & & & & 1,00 & $10,275,271$ \\
\hline 1839 & 504,310 & & & & 5,6 & & $6,620,956$ \\
\hline 1840 & & & & & & & \\
\hline 1841 & & & & & & & \\
\hline 1842 & & 2. 6 & 6,169 & & & & \\
\hline 1843 & & & & & & & \\
\hline & & & & & & & \\
\hline 1845 & 4,2 & & & 19 & $13,103,793$ & $2,013,3$ & 15,11 \\
\hline 1846 & & & & & & & \\
\hline & & & & & & & \\
\hline 1848 & & $44-2$ & & & 10,144 & 558,247 & $10,702,247$ \\
\hline 1849 & & & $\therefore 207547$ & & & & $11,647,801$ \\
\hline & & & & & & & $7,010,491$ \\
\hline 1851 & $4,400,411$ & & $4,488,2$ & & $12,165,0$ & $1,705,070$ & $13,870,070$ \\
\hline 1852 & $8,742,270$ & & & & & $2,019,8$ & \\
\hline & & & & & & 815,7 & $15,415,751$ \\
\hline 1854 & & & & 1909 & $13,800,000$ & $1,389,599$ & $15,189,599$ \\
\hline 1855 & $9,008,663$ & 195,510 & $9,204,173$ & 1910 & $25,300,000$ & $2,520,591$ & $27,820,591$ \\
\hline
\end{tabular}


(at the suggestion of Joseph Hume) fourpenny pieces or groats were struck; but the threepenny bit was eventually preferred. It is too small, however, to be a favourite, just as the old copper twopenny pieces were inconveniently large.

With the exception of an insignificant amount of small coins struck for the purpose of distribution as alms by the King, and known as Maundy Money-from the circumstance of its being given away on Maundy Monday - there was not any silver coinage by the State until 1816 . Previous to that year, $12 \mathrm{oz}$. of standard silver, containing 11 oz. 2 dwts. of pure silver, and 18 dwts. alloy, were by law to be coined into 62 shillings; but in that year an Act was passed, making gold coin only legal tender in all payments of more than $40 \mathrm{~s}$, and providing that the pound, or twelve ounces troy of standard silver, should be coined into 66 shillings, giving to the State, as seignorage, the difference between the market price of silver of the Mint standard and $5 \mathrm{~s}$. $6 \mathrm{~d}$. per ounce. Before the passing of this Act $(56 \mathrm{Geo}$. III, c. 68), silver coin of standard weight and fineness was a legal tender to the amount of $£ 25$. "The market price of silver has not been such since the year 1816 as to afford any temptation for melting or exporting silver coins issued at this rate of depreciation." 1

It has been proposed at various times that we should adopt a double standard, and make silver as well as gold a legal tender to any amount. Under such a state of the law, wrote Porter, it would be necessary again to coin silver money of standard fineness at the Mint rate of $5 \mathrm{~s}$. 2d. per ounce; and if, owing to any sudden mercantile demand, or such a commercial derangement as we have too often witnessed, it should ever become profitable to export silver, we might then be subjected to very great inconvenience. On the other hand, it must be allowed that, if such an option as that supposed were given-namely, that of paying in whichever coin might best suit the debtor,-the Bank of England, in meeting a foreign demand, might occasionally realize large profits, from which it is at present shut out; but this is the only advantage that can be anticipated from the establishment of a double standard, and it would surely be unwise to incur the risk of the general inconvenience for the sake of a profit that might possibly result to a private body.

Copper coin is issued from the Mint at the rate of $£ 224$ per ton, or more than 100 per cent. above its market value; there can hardly be expected, therefore, to arise any temptation for its 
conversion to any other purpose. The copper coinage (twopennies, pennies, halfpennies, and farthings) which was issued in 1797 , in place of the old defaced Tower halfpence, was of the intrinsic value of $£ 1496 \mathrm{~s}$. 8d. per ton; but as the market value of the metal rose in 1806 to $£ 200$ per ton, it was afterwards thought advisable to adopt the rate above mentioned. The value of copper coin issued after the peace up to 1849 was as follows:--

\begin{tabular}{|c|c|c|c|c|c|c|c|}
\hline Year. & Copper. & Year. & Copper. & Year. & Copper. & Year. & Copper. \\
\hline $\begin{array}{r}1815 \text { to } 1820 \\
1821 \\
1822 \\
1823 \\
1824 \\
1825 \\
1826 \\
1827 \\
1828 \\
1829 \\
1830 \\
1831 \\
1832 \\
1833 \\
1834 \\
1835 \\
1836 \\
1837 \\
1838 \\
1839 \\
1840 \\
1841 \\
1842\end{array}$ & $\begin{array}{r}\text { nil. } \\
2,800 \\
43,355 \\
32,480 \\
\text { nil. } \\
9,408 \\
50,400 \\
19,712 \\
2,464 \\
1,568 \\
2,464 \\
7,392 \\
448 \\
\text { nil. } \\
3,136 \\
2,688 \\
1,792 \\
4,592 \\
1,568 \\
5,040 \\
3,136 \\
3,808 \\
\text { nil. }\end{array}$ & $\begin{array}{l}1843 \\
1844 \\
1845 \\
1846 \\
1847 \\
1848 \\
1849 \\
1850 \\
1851 \\
1852 \\
1853 \\
1854 \\
1855 \\
1856 \\
1857 \\
1858 \\
1859 \\
1860 \\
1861 \\
1862 \\
1863 \\
1864 \\
1865\end{array}$ & $\begin{array}{r}10,080 \\
6,944 \\
6,944 \\
6,496 \\
8,960 \\
2,688 \\
1,792 \\
448 \\
3,584 \\
4,312 \\
10,190 \\
61,538 \\
41,091 \\
11,418 \\
6,720 \\
13,440 \\
8,512 \\
37,990 \\
273,578 \\
352,800 \\
151,648 \\
18,069 \\
57,493\end{array}$ & $\begin{array}{l}1866 \\
1867 \\
1868 \\
1869 \\
1870 \\
1871 \\
1872 \\
1873 \\
1874 \\
1875 \\
1876 \\
1877 \\
1878 \\
1879 \\
1880 \\
1881 \\
1882 \\
1883 \\
1884 \\
1885 \\
1886 \\
1887 \\
1888\end{array}$ & $\begin{array}{r}50,624 \\
33,301 \\
16,328 \\
20,832 \\
32,704 \\
7,616 \\
47,413 \\
46,218 \\
65,632 \\
69,813 \\
61,450 \\
51,146 \\
17,024 \\
44,651 \\
19,264 \\
39,349 \\
42,560 \\
33,450 \\
69,290 \\
57,568 \\
51,669 \\
45,173 \\
39,499\end{array}$ & $\begin{array}{l}1889 \\
1890 \\
1891 \\
1892 \\
1893 \\
1894 \\
1895 \\
1896 \\
1897 \\
1898 \\
1899 \\
1900 \\
1901 \\
1902 \\
1903 \\
1904 \\
1905 \\
1906 \\
1907 \\
1908 \\
1909 \\
1910 \\
\end{array}$ & $\begin{array}{r}66,950 \\
90,285 \\
89,535 \\
58,556 \\
46,664 \\
33,485 \\
40,995 \\
122,860 \\
107,230 \\
84,555 \\
139,065 \\
168,295 \\
120,280 \\
148,499 \\
113,895 \\
77,895 \\
100,325 \\
184,520 \\
227,550 \\
155,580 \\
121,811 \\
151,452\end{array}$ \\
\hline
\end{tabular}

Previous to the copper coinage made in 1797 the country was inundated from one end to the other by coins put into circulation as halfpence, struck by tradesmen or other private adventurers. The encouragement to this course was found in the then existing state of the small coinage. The halfpence put into circulation by private parties were some of them creditable specimens of the art of coining; and all of them, although intrinsically below their nominal value, were yet considerably nearer to it than the halfpence otherwise circulating. When the State undertook, in 1797, to issue new copper coins, the circulation of these private tokens was prohibited. But they were revived in many towns and again prohibited by Statute in 1812. In 1860 bronze was substituted for copper, and the weight was reduced. The pound avoirdupois of bronze was divided into 48 pennies, which are legal tender up to one shilling. Otherwise there bas been no change 


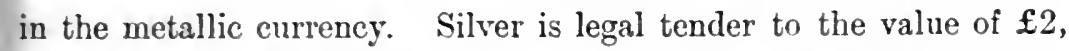
and gold to any amount. In 1870 an Act was passed "to consolidate and amend the law relating to the coinage and to Her Majesty's Mint." But as regards coinage and the standard of quality or fineness, weight and legal tender, this Act practically maintained the previously existing law. The provisions as to light coin were amended by an Act of 1889 , providing that light gold coin issued before 1837 , which had been reduced in weight by fair wear and tear, might be exchanged at the Mint for good weight coin. Under the Act of 1870 the Crown is authorized to determine the size of coins and their denominations, to determine the minimum weight at which a coin may remain legal tender, etc. It was also authorized to establish a branch of the Mint in, and extend the provisions of the Act to, any British possession. The regulation of the Mint was placed under the Treasury, and the office of the Master of the Mint (established in the reign of Henry I) was amalgamated with that of Chancellor of the Exchequer, the DeputyMaster and other offices being appointed by the Treasury. The custody of the standard trial plates of gold and silver as well as of the standard weights and measures, was rested in the Board of Trade.

\section{The Indian Currency}

Besides the British currency, which circulates at home and in the colonies, we are also responsible for the currency of India. A standard rupee weighing 180 grs. (of which 165 grs. were of fine silver and 15 of alloy) was adopted by the East India Company in 1835 , and for a long time its value stood at about two shillings. From 1841 a gold mohur, equivalent to 15 rupees, was put into circulation and was coined in small quantities till 1891. But this and other attempts to introduce a gold coinage in India failed. By the Indian Coinage Act of 1870 the Indian mints were opened to the free coinage of silver. Unfortunately, soon after this silver began to depreciate and the rupee began to fall in terms of gold. In 1876 the rupee which had been the equivalent of 2 shillings when the mints were opened to free coinage dropped to $1 \mathrm{~s}$. $6 \frac{1}{2} \mathrm{~d}$., and in 1892 it fell below $1 \mathrm{~s} .3 \mathrm{~d}$. The effect of the rapid fluctuations and of the depreciation were disastrous. The exchanges were deranged, and merchants engaged in trade with India were seriously hampered. The worst sufferers were, of course, the people of India, who underwent all the evils of a debased currency. The Indian government lost heavily in revenue, and its officers being paid in 
rupees found themselves in a bad plight. A Commission was appointed and in 1893 an Act was passed closing the mints to the free coinage of silver, and fixing the value of the rupee at 1s. $4 \mathrm{~d}$. In 1894, when the market price of silver fell below 2 shillings per oz. the gold value of the rupee dipped to $1 \mathrm{~s} .0 \frac{1}{2} \mathrm{~d}$.; but after the Act began to operate, and in spite of the low price of silver, the value of the rupee gradually rose, and since 1898 it has been wonderfully stable at $1 \mathrm{~s} .4 \mathrm{~d}$. The profits of coinage, which are very large, have been used partly to supply capital for new railroads, etc., and partly to build up a gold reserve by which the exchange value of the rupee can be maintained when the influences are unfavourable. The rupee, though universally used, is now really token money and has been compared to an inconvertible note printed on silver. In 1899 the sovereign was made legal tender in India, and in 1906 the copper coinage was superseded by bronze. Sovereigns are little used. For large sums rupee paper notes are in circulation and are legal tender. The note circulation is governed by the Acts of 1861 and 1905. The stability of the exchange with India is greatly assisted by the sales of India Council Bills in London. India, it should be added, buys gold almost every week from London for jewellery, the arts, and hoarding, although the annual yield of the Indiau gold mines is considerable.

\section{Colonial Currencies}

At the beginning of the nineteenth century the state of the metallic and paper currencies was very bad in our colonies and possessions. In 1825 an attempt was made to universalize British money and especially to make the ordinary English silver coins circulate in all our colonies. But where the dollar was established this attempt, generally speaking, failed, and in 1838 the home government wisely recognized in its colonial administration the principle of currency areas under which a colony should adopt the currency best suited to its position and customers. Thus Mauritius and Ceylon followed India and took the rupee as their standard coin, Canada kept the American dollar, and in 1887 British Honduras was permitted to take the silver dollar of the neighbouring Spanish republics. On the other hand, Australia, New Zealand, South Africa, the Fiji Islands and St. Helena all have the British gold and silver currency. Some have their own mints. The Sydney mint was established as early as 1855 in consequence of the gold discoveries. In Canada the English sovereign is legal tender 
as well as the American eagle. Malta has the English currency;

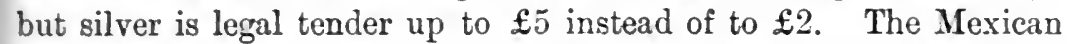
dollar is the standard coin in Hong-Kong and the rupee in East Africa, Uganda, and the Seychelles. The English currency runs in the West Indies, British Guiana, the Falkland Islands, and British West Africa-but with this difference, that silver is legal tender to any amount. Besides the Sydney mint there have been established at various times branches of the Royal Mint in Melbourne, Ottawa, and other colonial cities. When Cape Colony became a British possession in 1806 the standard coin was the silver ducat. A depreciated paper currency followed with a frequent dearth of silver and copper coins. In 1881 the Coinage Act of 1870 was applied to British South Africa. French Canada had a paper currency based on the French écu, and attempts to establish a British failed. After the Federation of Canada the Dominion parliament adopted a gold standard with a paper dollar and cent currency. The English sovereign is $4 \cdot 86 \frac{2}{3}$ dollars and the American eagle is 10 dollars. In Newfoundland the chief coin is a twodollar piece. There has been a gold standard since 1863, but curiously enough the Spanish doubloon was legal tender in Newfoundland until 1887 . 


\section{CHAPTER XXXII}

\section{PAPER CURRENCY AND BANKING, 1800-1850 ${ }^{1}$}

Bullion Committee of 1810-The controversy on the currency-High prices of gold, 1809-1815-Issues of paper money-Peel's Act-Panic of 1825-Formation of branches by Bank of England-Establishment of joint-stock banks-Number established, 18261836-Advantages of having only one bank of issuc-National Bank-Influence of currency on prices-Plan for estimating rise and fall of prices-Effects of abundant or deficient harvests upon currency and prices - Table of notes in circulation and bullion held by the Bank

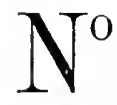

subject of public and general interest, wrote Porter in 1850 , has been more frequently or earnestly debated and examined in this country, than that which relates to our system, or rather our practice-for it can hardly be said that we have pursued any steady system - as regards currency and the operations of banking. Since the appointment, in 1810 , of the committee of the House of Commons, which has been so celebrated as The Bullion Committee, this subject has repeatedly forced itself upon the attention of the mercantile part of the public and of the government, and at each recurring period when the distress attendant upon the derangement of money operations has been experienced, the whole subject has been submitted to so much examination, and has occasioned such keen controversy between public economists on the one hand, and what are called practical men on the other hand, that it is surprising we have not long since arrived at conclusions which can be recognized as correct by all parties, and would lead to the adoption of principles and practice by means of which the ruinous alternations now constantly recurring would be rendered impossible. The subject is certainly involved in difficulty, but not, assuredly, to such a degree as should render its solution impossible. Why then, it will be asked, is the public to this moment in so much doubt and perplexity concerning it, and why are our commercial men so ill-informed upon the subject as to be continually liable to mistake appearances which, if understood aright, should guide them as to

${ }^{1}$ Reprinted, with some abbreviations and additions, from Porter's Progress of the Nation. 
the propriety of extending or contracting their undertakings ? Where so many and such high authorities are found to disagree, it might perhaps be considered bold to offer an opinion as to which of the parties in the controversy is right. It may be thought still more presumptuous to hazard the suggestion that both may be in some degree wrong, and to remark that our "practical men" have erred because they reasoned from partial and insufficient premises, and sought for the solution of a general question in the particular circumstances that passed under their own limited obscrvation; while the theorists, or, as it has become the fashion to call them, the "bullionists," have erred because they have made little or no allowance for disturbing influences, the operation of which has been palpable to every man actually engaged in commercial pursuits. By this means the "practical men" have been confirmed in their total disbelief of the doctrines put forth by the "bullionists," and these, on the other hand, seeing that what they hold to be the most incontrovertible truths are set at naught by their opponents, may have been rendered unwilling to enter anew upon their inquiries, with the view of determining the modes and degrees in which their abstract principles are liable to disturbance through the circumstances insisted on-perhaps too urgently-by their opponents. It would be out of place in this work, if even the author were competent to the task, to attempt to settle this inuch controverted question; the foregoing remarks seem necessary, however, in order to account in some degree for the fact, that on a point which involves such important consequences, and where, for want of its being settled, commercial communities have been periodically visited with wide-spreading ruin, so little advance has hitherto been made towards reducing the subject of currency to scientific rules and principles. On each occasion, when the money market has been subjected to one of these paroxysms, clever men have put thenselves forward to explain the causes, and to point out how the evil may in future be avoided; and to those who will be at the pains to examine the arguments and assertions used on both sides of the controversy, it must be curious to observe how complete an identity of opinion and almost of expression there is between the writers who have advocated the same side of the question at different periods, so that the pamphlets put forth in 1811 or in 1826 would be found to embody all the principal arguments, and to have reference to the same set of circumstances, as formed the staple of the pamphlets written in 1837.

The measure adopted in 1797 of restricting the Bank of 
England from paying its notes in specie, while it continued in operation, placed the currency of this country under circumstances wholly dissimilar to those that have attended it either before or since. The peculiar operation of these circumstances was besides considerably exaggerated by the events of the war, and by the peculiar character given to that war during the seven years that preceded the peace of Paris. For these reasons, it is difficult to make the condition of the currency, as marked by the priee of gold and the rate of the foreign exchanges at that time, the sole test of the soundness of the practice pursued by those who managed and controlled the issue of our paper currency. During the greater part of the period alluded to, more obstacles were opposed to the prosecution of our foreign trade than were ever at any other time put in action. Our goods were excluded from almost every port on the continent of Europe, and the difficulties that attended the importation of goods abroad were such as materially to enhance the cost of nearly every article brought here for consumption. At the same time, the demand for some kinds of foreign productions was inereased by the purchases of warlike stores on the part of Government, which purchases were necessarily made without reference to prices. As an instance of this, hemp may be mentioned. In 1793, just before the breaking out of the war, the price had been $£ 22$ per ton; it advanced progressively between that time and the Peace of Amiens to $£ 86$ per ton, but in 1802 fell to $£ 32$ per ton. On the renewal of hostilities the price again advanced, and in 1808 and 1809 reached $£ 118$ per ton. In 1815 , after the second overthrow of Napoleon, the price fell to $£ 34$, and afterwards went considerably lower. On the other hand, all those descriptions of goods which were produced by us, or which necessarily came here from our colonies or elsewhere, in quantities beyond our own wants, were greatly depressed in price. At the same time, the prices on the Continent of the goods so abundant, and so depressed in our markets, were exorbitantly high. Gold and silver were the only articles of merchandise which could safely be taken in exchange for the goods of which we were purchasers from the Continent, and the vessels in which those were brought returned from our ports in ballast, while the prices of colonial produce and British manufactured goods were such as would have rendered their introduction into continental ports profitable to a most exaggerated degree. These circumstances, acting in conjunction with the Bank Pestriction Act, under which the directors of that establishment were relieved from the dangers that would otherwise have attended any departure from prudence 
in the management of its issues, caused such an enhancement in the price of the precious metals, when measured by the paper currency, as forced all our metallic money out of eirculation. In times of war, when armies are to be kept in motion, gold especially is greatly in requisition. The difference in value of Bank of England notes and gold, estimated at the Mint price during the years from 1803 to 1808 , was no more than $£ 213 \mathrm{~s}$. 2 d. per cent. In the seven following years, that excess in value of gold was raised in the following degrees:-

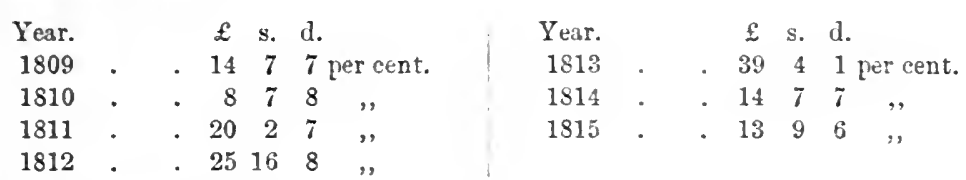

The fall in the price of gold which occurred in 1814 was brought about by a reversal of the circumstances that have been explained above. Trade again flowed through its natural channels; we found anxious customers for goods with which our warehouses had been overloaded; prices which for those goods had been ruinously depressed, rose greatly and rapidly; our exports became suddenly so much greater than our imports, that gold flowed back into this country with greater rapidity than it had previously left us; and if at this time the currency had been managed with the smallest approach to prudence and ability, the prices of gold and bank-notes might have been brought into agreement without producing any of those commercial disasters which have usually attended such an adjustment. The calculations just given are founded upon the prices of gold in the month of August in each year. In December 1814 the influx of gold had brought down its price to $£ 46 \mathrm{~s}$. $6 \mathrm{~d}$. per ounce, or $\mathfrak{£} 919 \mathrm{~s}$. $5 \mathrm{~d}$. per cent. above the Mint price, although the issues of the Bank of England had been

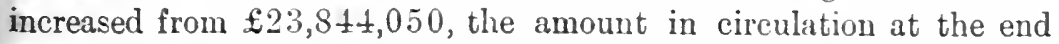
of 1813 , when goll was $£ 510$ s. per ounce, or $£ 294$ s. 1 d. per cent.

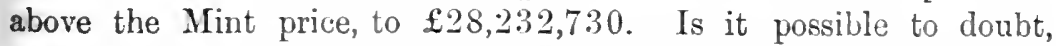
with these figures before us, that if the directors of the Bank had contented themselves with maintaining their circulation eren at the high level of December 181:3 the price of the precious metals would have fallen to the level of our Mint price, and that the gold and silver that flowed into our coffers would have remained in circulation without our being called upon to undergo the difficulties and losses which accompanied the resumpion of specie payments when that measure could no longer be deferred? 
A different course was followed. The government, having large financial operations to make in winding up the accounts of the war, thought it most profitable to effect those operations in a redundant paper currency; the Bank Restriction Act was renewed from time to time to the great profit of that establishment, but to the manifest disadvantage of all other classes; an opportunity, the best that could possibly have been hoped for whereby to extricate ourselves from a false and dangerous position, was allowed to escape unimproved, and the gold which had sought our shores was again driven away by a redundant inconvertible paper currency. The conduct of the Bank of England in those days exhibited a most lamentable want of intelligence. Being aware of the approach of the time at which the restriction which had been so profitable must cease, the directors of that establishment made a large provision of bullion, which, as it could not be demanded in payment for their notes, remained in their coffers uninfluenced by the rate of foreign exchanges, or the market price of gold. Had this provision been accompanied by a corresponding diminution of their issues, the directors might safely have pursued the course which they afterwards unsuccessfully adopted in anticipation of the termination of their Restriction Act; but no such prudence was allowed to influence their conduct, and when in April and September, 1817, notices were given to pay off in specie, first the notes in circulation dated prior to 1816 , and afterwards those issued before 1817 , the amount of the circulation was unusually large, and the price of gold fully 3 per cent. above that of bank-notes. Under these circumstances, the gold was withdrawn from the bank coffers, so that in August, 1819 , they were nearly exhausted, and it was necessary to hurry through Parliament an Act restricting the directors from acting any further in conformity with the notices they had given.

In the same year (1819), the Act, commonly known as Peel's Act, was passed, which provided for the gradual resumption of specie payments. Under the provisions of this law, the Bank restriction was continued until February 1820 , from which time till October in the same year, the public was entitled to demand payment of notes in bullion at the rate of $\mathfrak{E} 4 \mathrm{1s}$. per ounce. From October 1820 to May 1821 payment might be demanded in bullion at the rate of $£ 319 \mathrm{~s}$. 6d. per ounce; from May 1821 to May 1823, bullion might be demanded at the Mint price of £3 $17 \mathrm{~s}$. $10 \frac{1}{2}$ d. per ounce; and from the last-mentioned date, the current gold coin of the realm might be demanded. The provisions of this Act, as regarded the periods named, were anticipated, 
and on the 1st of May 1821 the bank had placed itself in a position to meet all of its outstanding engagements that should be demanded in specie.

Perhaps there never was in the whole history of legislature in this country any measure of internal policy which occasioned such warm and long-continued controversy as this Act for the resumption of specie payments. After a quarter of a century the measure was still assailed with virulence by many, who attributed to it every cloud which during all that time had obscured the commercial horizon, and scarcely a session was suffered to pass without some attempt being made to induce the legislature to consent to its repeal. But Peel's Bill in reality did nothing more than establish certain steps or gradations through which we should pass in order to arrive at that which had always been contemplated and declared to be the settled purpose of the legislature, and at what in fact would have become law by the simple efflux of the time fixed in the Bank Restriction Acts.

The question of a return to cash payments was really only a question of time. And yet the advocates of an inconvertible currency frequently asserted that, if the statesmen and economists, by whom the return to cash payments was advocated in 1819 , could have forcseen the consequences of that measure, they would have forborne to give to it the sanction of their approval. In particular, David Ricardo was repeatedly held up as having recanted the opinion expressed by him, that the fall in prices to be brought about by returning to a metallic standard would be no more than the difference between the market and the Mint prices of gold, which at the passing of Peel's Bill did not exceed 4 per cent. There is, in truth, no warrant whatever for this assertion, which, like many other figments, was repeated until it acquired the authority of truth. Ricardo never did assert, and never could have asserted, that when we should return to specie payments, prices would never fall more than $t$ per cent. below their level at the time the Bill was under discussion. It would have been as reasonable to affirm that if, instead of returning to the old standard price of gold, $\mathfrak{f} 317 \mathrm{~s} .10 \frac{1}{2} \mathrm{~d}$. per ounce, the legislature had fixed the standard at the actual market price of the time, no fluctuation in prices would ever have occurred in future. Between June 1833 and August 1836 there was a progressive rise in the market value of goods, amounting, in the whole, to 35 per cent., and during all that time we were acting with a currency based upon gold at the same standard. Will it be contended that if during the same period our 
currency had consisted of inconvertible paper promises, a like fluctuation in prices would have been impossible? Is it not, on the contrary, probable that the fluctuation would have been much more violent? It is precisely when prices are low that the advocates of extended issues of paper money are the most clamorous, their single object being to enhance the nominal value of their goods. They do not, or will not see, that it is only during the period in which the advance is going forward they can experience the advantages which they anticipate. When the rise shall have fully taken place, and prices shall have adjusted themselves, there will no longer be any benefit; but, on the other hand, there will be considerable and constant danger of a fall, which may be occasioned by various circumstances that would be inoperative under a different condition of things. In truth there is no safety from commercial disasters; in other words, there can be no permanent prosperity for the trading and producing classes, but in low and moderate, and therefore, steady prices.

It is generally held that the commercial crisis or "panic," as it is usually called, which occurred towards the end of 1825 , was brought on by the conjoint operations of the Government and the Bank of England. It was the object of the Government, when peace was fully established, to make money abundant, and consequently cheap, in order to carry through various arrangements whereby the permanent charge upon the public income might be lessened. By the means adopted to this end, the market rate of interest was so far reduced at the beginning of 1822 , that the 5 per cent. annuities were raised to 6 or 8 per cent. above par, under which circumstances more than $£ 140,000,000$ of that stock was converted into an annuity at 4 per cent., on terms by which the annual charge to the public was reduced by $£ 1,122,000$. In 1824 the Chancellor of the Exchequer was enabled to effect a further saving of $£ 380,000$ per annum, by the conversion of $£ 76,000,000$ of 4 per cent. into $3 \frac{1}{2}$ per cent. annuities.

If the fall in the rate of interest by which the Minister was enabled to. effect those operations had occurred through natural causes, there could be no question as to the propriety of the step, but brought about as they were by means of the unnatural and forced extension of bank issues, it is hardly to be doubted that the mischief resulting from that extension has been productive of more loss to various classes of the community than can have been compensated to the nation at large by the saving. With a reckless disregard of consequences to a degree which can be attributed only 
to want of knowledge, the directors of the Bank of England forced their paper into circulation, by proffering facilities to all classes of the community. Money was lent upon the mortgage of land and upon the deposit of stock, in addition to liberal advances to commercial men, through the more legitimate channels of issue; and the directors, at the same time, permanently crippled their ineans of controlling the currency by investing a large proportion of their issues in the purchase of an annuity for a term of years, known as the Dead Weight Annuity, an investment which must always be least marketable at those periods when it would be most desirable that the Bank should have all its resources at command. By these means speculation was excited, the business transactions of the country were multiplied unnaturally, and by the general rise of prices thus occasioned, our markets became overstocked with foreign produce, while the export trade was checked; the quantity of mercantile paper thrown into circulation aggravated the evil.

Between the beginning of 1822 and the month of April 1825 the Bank had increased its circulation to the extent of four millions. At the latter date it was possessed of bullion and coin to the value of ten millions, but, from that period to the following November, the drain upon its coffers was so rapid that no more than

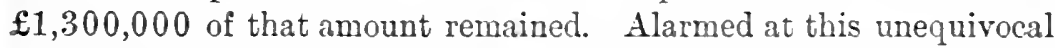
indication, the directors suddenly diminished the circulation to the extent of $£ 3,500,000$ : a general feeling of distrust then took place of the undue confidence, which had previously pervaded the whole country; the notes of country bankers were returned upon them to such a degree that great numbers failed; a run upon several London bankers was followed by the stoppage of some of those establishments; commercial distress of the most frightful description ensued; and such was the want of confidence, that the wealthiest merchants were driven to make heavy sacrifices of property in order to provide for their immediate engagements. To use the memorable expression of Mr. Huskisson, "the country was within twenty-four hours of a state of barter." In this state of things there was no longer any evil to be apprehended from increasing the paper circulation, and the bank directors came forward with promptitude and liberality to the assistance of the trading classes, by lending money upon almost every description of property that could be offered, and by discounting bills without adhering to those rules by which they have ordinarily been gricled in conducting this part of their business. Between the 3rd of Yorember and the 29 th of December, the amount of mercantile bills under discount at 
the Bank of England was increased from four millions to fifteen millions; the number of bills discounted on one particular day having been four thousand two hundred. The efforts thus made were assisted by a circumstance purely accidental. A box containing one-pound notes which had been overlooked at the time when the Bank called in all its notes under five pounds, was discovered at the lucky moment, and in the opinion of Mr. Harman, one of the directors, the timely issue of these notes "worked wonders-it saved the credit of the country." On the 3rd of December 1825, the amount of Bank of England notes in circulation had been only $£ 17,477,000$; but on the 31 st of that month was increased, by the means here mentioned, to $£ 25,700,000$. This great increase was rendered necessary in order to replace the notes of country bankers that had been suddenly withdrawn from circulation, and to counteract the tendency to hoarding always indulged by the timid in periods of embarrassment; it was consequently not followed by any undue rise of prices, which had been suddenly thrown down in the previous convulsion; the foreign exchanges again turned in our favour, and the gold which, by the previous mismanagement had been forced abroad, again came back. The value of coin and bullion in the Bank in the last weeks of February, May, August, and November, 1825 , respectively, was $£ 2,300,000$, $\mathfrak{f} 4,300,000, \mathfrak{f} 6,600,000$, and $\mathfrak{f} 8,900,000$; in the February following it amounted to $£ 10,000,000$. The notes of the Bank in circulation in the same weeks fell gradually from $£ 24,900,000$ in February 1826 to $£ 19,900,000$ in November. At the close of 1826 the currency was therefore once more restored to an appearance of soundness.

At the time of its occurrence, this commercial crisis was attributed by many persons to the increase of paper money, put into circulation by the country banks; and in the parliamentary inquiries that followed, the principal object aimed at was the regulation of private banks of issue. The establishment by the Bank of England of branches in different parts of England, was suggested and'recommended to that establishment by Lord Liverpool, then at the head of the Government, as a means of controlling the issues of private bankers, and in part also of substituting a more secure description of paper for that which circulated throughout the country. The principal aim of Parliament and the Government, on that occasion, was not so much the regulation of the currency, by means which would prevent the recurrence of the evils resulting from over issues, as it was to provide for the ultimate security of 
the holders of notes. They committed the mistake too commonly made of confounding currency with solvency, and of imagining that if the issuers of notes had sufficient capital to meet, at some time or other, the whole of their engagements, no other evil was to be apprehended.

At the same time, provision was made by Parliament for the establishing of joint-stock banks, which should be banks of issue; but this being considered an invasion of the privileges of the Bank of England-in favour of which establishment no other bank having more than six partners was thought to be entitled legally to issue notes - a compromise was made with that establishment, and jointstock banks of issue were not permitted to carry on their business nearer to London than sixty-five miles.

At the time when encouragement was given to the formation of joint-stock banks, Parliament took measures for withdrawing from circulation all notes of a lower denomination than $£ 5$; the granting of stamps for smaller notes was immediately stopped, and from the 5th of April 1829 it was declared illegal for any banker to issue such. The prlicy of this measure met at the time with general concurrence.

The establishing of joint-stock banks as substitutes for other banks of issue, which could offer less satisfactory security for the amount of their engagements, has yielded great advantages to the public. But it may well be doubted, whether those advantages are in all respects such as were in contemplation at the time of their formation. Some of the numerous joint-stock banks, established since 1826, are not new establishments, but extensions of private banks previously in operation; others of them do not issue their own notes, but circulate the notes of the Bank of England, under an agreement with that corporation, which gives to them certain facilities in the way of discounts. This fact is well known, having been stated in evidence before parliamentary committees; but it is not so well known that, in making these arrangements, the Bank of England not only gave permission to the other parties to send bills for discount up to a certain sum, but stipulated that the sum so required should always reach at least to that amount: providing thus for the extension of the issue of its omn paper, whatever the wants of the commercial world or the rates of the foreign exchanges. It is not with a very gool grace that the Bank directors, while thus acting, complain of the excessive issues of other joint-stock associations, their rivals in the country districts. There is no doubt that a competition of this kind might have an injurious effect, and that 
the spirit of competition renders all parties less prudent than they might otherwise be in acting upon those indications which should govern the amount of the circulation. In the event of that circulation proving redundant, the adoption of a prudent course by one or more establishments, in contracting their issues, might only offer inducements to others to endeavour to turn that course to their own peculiar advantage, by filling up the void. The advantage to the country of confining to one establishment the power of issuing paper-money has of late years been very strongly insisted on by a principal advocate and apologist of the Bank of England. In his zeal for the interests of the establishment with which he is connected, that gentleman has not allowed himself to express a doubt as to the body which shall be entrusted with so important a function. The one bank of issue in his estimation is, without doubt, to be the joint-stock association with which he is connected. There is, however, a third alteruative, which has been ably advocated by the late Mr. Ricardo, ${ }^{1}$ and more recently by Mr. Clay, ${ }^{2}$ Colonel Torrens, ${ }^{3}$ and Mr. S. Ricardo, ${ }^{4}$ - that of the establishment of a national bank, "under the management of competent functionaries, qualified by the possession, not of bank stock, but of economical science; appointed, not by the holders of bank stock, but by the Government; responsible, not to their coproprietors, but to Parliament; and having for their first object and primary duty the protection, not of their own corporate property, but of the general interest of the nation." 5

The shock given to mercantile credit, and the losses encountered by commercial men, in 1825 , were of a nature and to an extent not likely to be immediately forgotten. The lesson of prudence which they taught was enforced by the withdrawal of small notes from circulation, and for a considerable time speculation -at least in any extensive degree-was unseen. But it is the common effect of long-continued security to beget imprudence. The years which followed the panic of 1825 were marked, as we have seen, by a progressive extension of our chief branches of industry; the operations of trade and manufactures were, with some fluctua-

I Plan for the Establishment of a National Bank, by David Ricardo, M.P., 1824.

"Speech, on moving for' a Committee on Joint-Stock Banks, with Reflections, etc., by W. Clay, M.P., 1836.

${ }^{3}$ Letter to Lord Melbomme, on the recent Derangement in the Money Market, and on Bank Reform, by R. Torrens, 1837.

${ }^{4}$ A National Bank the Remedy for the Evils attendant upon our present system of Paper Currency, by Samson Ricardo, 1838.

${ }^{5}$ Torrens' Lelter, 2nd edition, p. 64. 
tions, accompanied by a degree of general prosperity which naturally engendered the desire for increasing them, and this desire being met, in the middle of 1833 , by some relaxation in the currency, prices began to rise. The circulation of the Bank of Eugland, which throughout 1832 had been, on the average, $£ 18,139,000$, was increased to $£ 19,060,000$ in the first half of 1833 , and to $£ 19,201,000$ in the second half of that year; and this increase, taken in conjunction with the presumed extension of issues on the part of joint-stock and private bankers-an extension which was rendered practicable only through the greater circulation of Bank of England notes-was quite sufficient to give a new stimulus to commercial dealings

It is a point that has given rise to much controversy, whether under the regime of a circulating medium, convertible at pleasure into gold, any issues of paper can be made and kept out to an excess that will tend to raise the general prices of goods. Nor is the point at all settled among writers of the greatest authority upon the subject. By those who deny the possibility of such a result it is urged, that at times when the currency has been full to redundancy the prices of many important articles of consumption have fallen, and that, on the other hand, while the circulation has been undergoing a process of contraction the prices of some goods have risen. The reasoning upon the subject, in the Report of the Bullion Committee of 1810, having been offered when the notes of the Bank of England were inconvertible, cannot be held applicable to au altered condition of things. In the words of that Report-" An increase in the quantity of the local currency of a particular country will raise prices in that country exactly in the same manner as an increase in the general supply of precious metals raises prices all over the world." Many circumstances may arise to occasion the rise or fall in the prices of some kind of goods, but a general alteration of prices can only be occasioned by a permanent alteration in the amount of circulating money. An increase in the quantity of specie, arising from the greater productiveness of the mines, would raise prices in all countries alike, and would therefore occasion no serious derangement, nor be followed by any revulsion; whereas, a rise occasioned by the undue extension of a local and inconvertible currency, will be confined to the country in which it is issued, and must derange its commercial relations with foreign markets. It must be, therefore, at all times au interesting and a valuable question to determine, under such circumstances, whether prices are actually rising or falling, or stationary; and to ascertain 
the degree of such rise or fall, as an indication of the state of the currency. A rise or fall thus caused will generally-perhaps always-precede a variation in the foreign exchanges; and if ascertained, and a timely remedy were applied, the evil might be corrected before it could reach a point that would be indicated by any such disturbance of foreign trade as would affect the rates of exchange. ${ }^{1}$

From a table of index numbers taking for its basis or index the prices of 50 articles of commerce for the first week of January 1833, it appears that during the first six months of that year prices remained steady. But in the month of July there occurred a sudden rise of $3 \frac{3}{5}$ per cent., which was increased to 7 per cent. in August, and to 10 per cent. in September; from which time prices were again remarkably steady at that higher level until the middle of the following year. Another rapid advance was then experienced, which continued until February 1835, when prices had reached to 16 per cent. above the index price of January 1833. At this further advance there was again considerable steadiness for six months, when a fresh impulse was given, which carried the average price rapidly upward, with an unvaried progression, until August 1836. It will be seen that the average was then very nearly 35 per cent. higher than in the beginning of 1833 . The measures adopted by the Bank of England in July and September 1836, of. raising the rate of their discounts from 4 to $4 \frac{1}{2}$ and then to 5 per cent., and further, of throwing discredit upon a class of mercantile bills which at that time represented a very large part of the floated commercial engagements of the country, acted instantaneously upon the prices of goods, and a fall began which was more rapid than the rise which has been described.

Thomas Tooke, the author of the History of Prices held that the abundance or scarcity of circulating money has little or no influence upon prices, but that these are regulated by the wants and capabilities of the great body of the consumers, who cannot at any time be expected to use more of any articles because they may have a greater facility in raising money for commercial purposes. In support of this position it is urged that, while prices generally were advancing, grain which, in respect of the amount of money involved in buying and selling it, is perhaps of more importance than all the other articles that together form the sum of our commercial

\footnotetext{
${ }^{1}$ Porter here introduced a digression on the theory of index numbers, which is omitted, along with some elaborate tables showing prices and rates of exchange between 1833 and 1837.
} 
dealings, was as constantly and regularly falling in price. There can be no doubt of the fact; but there cannot, on the other hand, be any doubt that this fall in the price of the principal article of food was the effect of natural causes, which causes could not fail to have produced their natural effect in driving down the price, unless checked by such an issue of paper money as could only have been kept in eirculation under a system of restriction from specie payments. The objection raised by the accomplished author of the History of Prices is no doubt true in the long run, where no bank restriction is allowed to interfere. It is no doubt true that, in the end, the prices of all commodities are governed by the wants and capabilities of the consumers taken in conjunction with the cost of production. But this is not the question at issue. That question is whether, as a consequenee-a natural and almost a necessary consequence-of any excessive amount of currency, a speculative demand for goods is not created, one of the evils attendant upon which is, that it cannot be sustained, but when the immediate cause through which it was produced is withdrawn, gives place to a revulsion? Owing to the stimulus given to production, and the check offered to consumption-both of which are necessary consequences of high prices - that revulsion, when it arrives, finds us with glutted markets, and with a mass of commercial engagements greater than the ordinary wants of trade should occasion: the consequences of which state of things it cannot be necessary to describe. The fact adduced that, while the prices of imported articles rose, grain became eheaper in a greater ratio, may be considered, under a restrictive system of corn-laws, as one cause of that general enhancement of prices. Owing to the custom which prevailed in our grain markets of making sales at a short period of credit, a smaller sum of currency was needed for carrying on the trade in corn than would have been required for the purchase and sale of an equal value of foreign goods, where longer credits were usually given. The amount of money engaged in the corn trade was, however, so great, that any material fall in the price of corn must have had an effect upon the eurrency equivalent to an increased emission of bank-notes. With our foreign corn trade free, this consequence will not happen, because we shall be preserved from those violent fluctuations in the prices of farming produce which have attended upon the vicissitudes of seasons. Under protection, a deficiency in the harvest always produces a more than equivalent rise in the price of farming produce: so that, on the supposition of 1000 quarters of wheat being required for the ordinary wants of the people, if the supply proved deficient to the extent of 
100 quarters, the remaining 900 would sell for a greater amount of money than that which would be received for 1000 quarters under the case first supposed; while the consequence of an increased production to the same degree would be so to depress prices that 1100 quarters would not produce so great an amount as the 900 quarters in the one case, or the 1000 quarters in the other.

Mr. Gregory King, in his computation of the land product of England, given by Dr. Davenant, states that a defect in the harvest may raise the price of corn in the following proportions :-

Defect of 1 -tenth, raises the price 3-tenths.

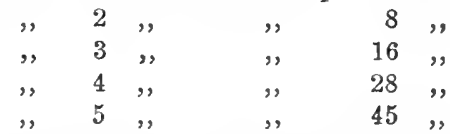

If we adopt these proportions as the basis for our calculations, it will be found that 1000 quarters, when the supply is just equal to the wants of the consumers, will sell-the price being 50 s. per quarterfor

$£$

If the harvest sliould prove deficient one-tenth, the remaining ninetenths, represented by 900 quarters, would sell, at $65 \mathrm{~s}$., for .

A deficiency of one-fifth would leave 800 quarters, which, at $90 \mathrm{~s}$., would produce

A deficiency of three-tenths would leave 700 quarters, which, the price being advanced to 130 s., would produce

$\Lambda$ deficiency of four-tenths, leaving 600 quarters for sale at 190s., would

A deficiency of one-half would raise the price to $275 \mathrm{~s}$., at which rate 500 quarters wonld sell for

No means have hitherto been devised for ascertaining the actual produce of corn in the country, and it is superfluous to say that the above computation can be at the best only a reasonable estimate. Mr. Tooke is of opinion that it is not very wide of the truth, "from observations of the repeated occurrence of the fact, that the price of corn in this country has risen from 100 to 200 per cent. and upwards, when the utmost computed deficiency of the crops has not been more than between one-sixth and one-third of an average." On the other hand we have seen, through the consecutive occurrence of three favourable harvests in 1833,1834 , and 1835 , that the price of wheat has fallen from $55 \mathrm{~s}$. $5 \mathrm{~d}$. to $36 \mathrm{~s}$. 0d. per quarter, although, during the whole of those years, every branch of industry throughout the country was in full activity, and all classes of the people were in full enjoyment of the means of living. It is to the circumstances that affect the labourers and artisans of the country that we must look for the causes that influence the greater or less consumption of corn. The classes who 
are more at ease in their circumstances subsist in a far greater degree upon more costly kinds of food, and do not consume more bread than ordinary in years of abundance. This may not be the case with those who are in less comfortable circumstances; but with regard to them even it is certain that, when bread is cheap, they do not increase their use of it so as to absorb a proportion of their earnings equal to that which they so expend in scarce or ordinary seasons, but employ a greater part of their wages in the purchase of comforts; and this consideration renders it clear why, as above stated, so large an amount of money is not paid for an increased as is paid for a diminished supply of this first necessary of life; and also why, in a time of scarcity, the mass of the town population being driven towards the more exclusive use of breadwhich will still be the cheapest food upon which they will subsist - the demand for other articles of consumption and convenience will be lessened, and their prices consequently diminished.

Wherever the system of virtually excluding the farming produce of other countries is suffered to exist, the occurrence of a harvest of more than average productiveness should act as the signal to those who have the control of the currency to be more particularly on their guard against the consequences of redundancy, which should be prevented by a timely lessening of the sum in circulation. This doctrine may not be very palatable to those who, depending upon the produce of the soil, may see as its practical effect only a further depression in the price of grain. On every occasion that has arisen since the return of the Bank to specie payments, when an abundant harvest has caused great depression in the prices of corn, it has been the fashion to attribute the consequent "agricultural distress" to a deficiency of circulating money, and a clamour has been raised against the law which prevents the issue in England of notes under $\mathfrak{f 5}$. If, on such occasions, the wish of these advocates for a greater abundance of paper money had been gratified, there is but little ground for believing that they would have really been benefited as they desired to be, at the expense of the remaining classes of the community, because the same system which tended to raise the price of what they had to sell would equally have raised the prices of all they required to buy; and as the enhancement of prices would in all cases be principally the effect of speculative demand, there is reason for believing that speculators would not choose, as an object for purchase, an article which was known to be held in undue abundance, while other articles were to be found against which so strong an objection 


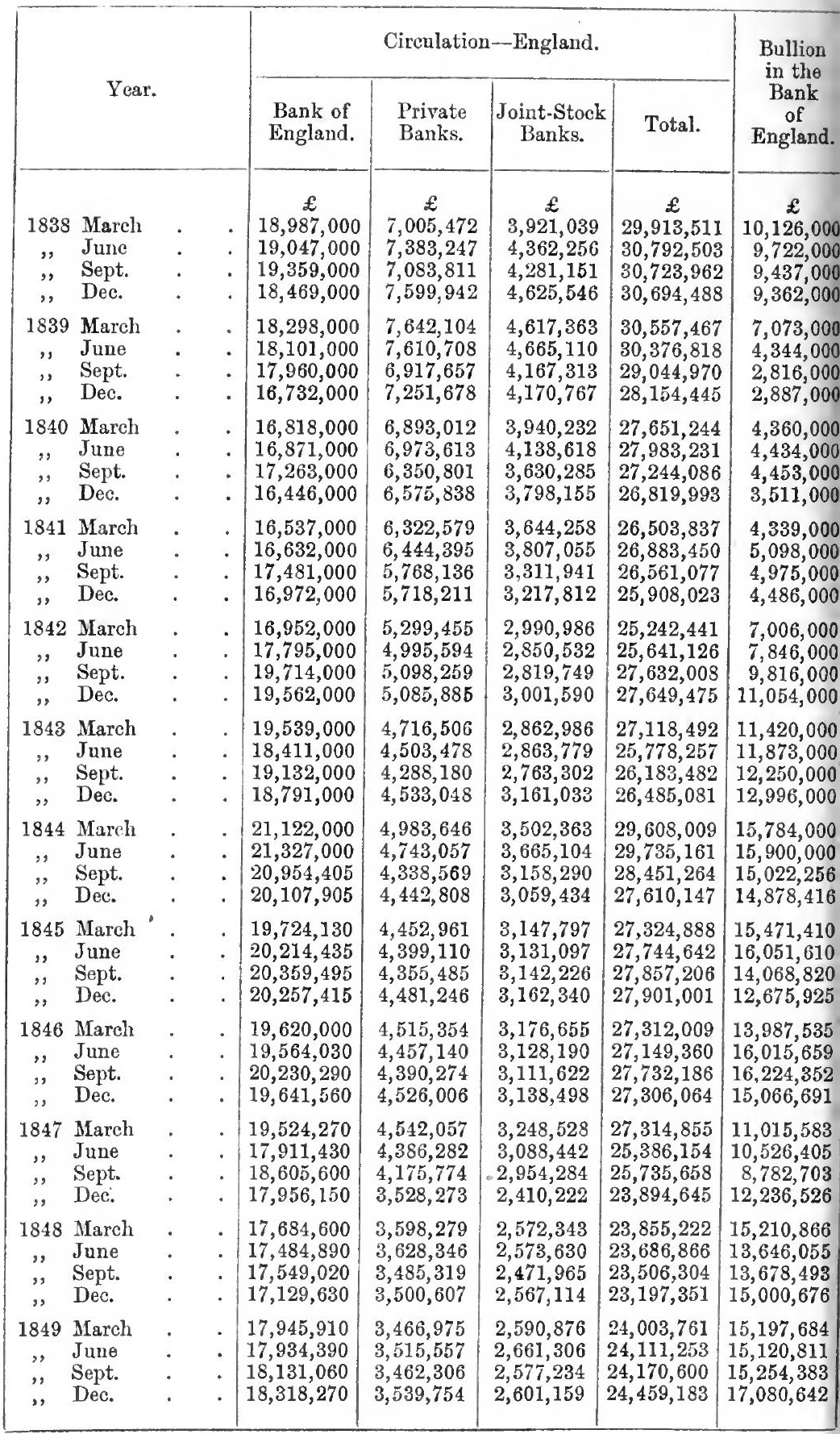


would not apply; and for this reason the rise in the prices of agricultural produce, if experienced at all, would be so in a less degree than the prices of other commodities, a result which would be highly detrimental to agriculturists.

If the suggestion that has been here thrown out is entitled to any consideration, it is clear that, to enable us to judge with correctness whether the currency be at any time redundant or otherwise, we require to ascertain other facts than that of the amount of bank-notes in circulation. There is, perhaps, no single circumstance more pregnant with instruction on this subject than a general rise or fall of prices when viewed and adjusted in combination with local or temporary causes of disturbances. With this end in view it would be highly iustructive if tables of prices were made and recorded, at short intervals, accompanied by remarks explanatory of any peculiarities which may be thought to offer disturbance to the correctness of their result. By this is meant not a mere record of the prices of goods, such as would be afforded by a collection of prices-current, bnt a calculation which would afford, on inspection, a correct comparative view of the average fluctuations that should occur.

The circulation of notes payable to bearer in England, and the amount of bullion in the Bank of England, at the end of each quarter, during the years 1838 to 1849 , is shown in the foregoing table (p. 590).

In 1849 , the last year of this series, the circulation of notes in Scotland and Ireland in each quarter was as follows:-

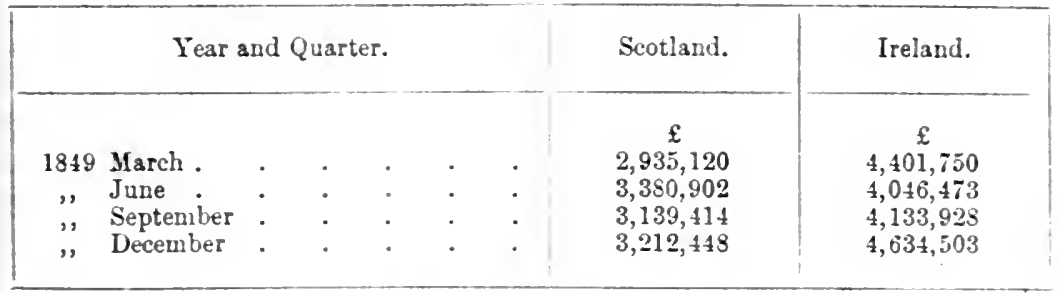

The Scotch banking system differs from, and is independent of, the English. The Bank of Scotland was founded in 1695. Its monopoly expired in 1716, nine years after the Act of Union. Shortly afterwards, in 1727, the Royal Bank of Scotland received a charter. This corporation originated the system of cash credits, which is a characteristic feature of Scotch banking. A cash credit is a drawing account on which a customer may operate, paying interest on the daily balance at his debit instead of receiving interest 
on the daily balance at his credit. Other banks started up and issued notes in unlimited quantities of all denominations until a restrictive Act was passed in 1765. In 1797 the Scotch banks followed the example of the Bank of England and suspended specie payments. After the crisis of 1825 when one-pound notes were prohibited in England they were retained in Scotland, where they are still preferred to sovereigns. In 1845 Scotch bank-note issues were restricted and regulated on the model of the English Act of 1844 ; but neither their notes nor the notes of the Bank of England were made legal tender in Scotland. Besides the Bank of Scotland and the Royal Bank of Scotland, six other Scotch banks have the right of issue, namely, the British Linen, the Commercial, the National, the Union, the Clydesdale, and the North of Scotland.

The Bank of Ireland was established in 1782 on the model of the Bank of England. In 1825, when the English and Irish exchequers were united, the Irish currency was made identical with the English. The Bank Act of 1845 was applied to Ireland and Scotland simultaneously with very slight differences. The Bank of Ireland is the Government's bank, and performs for Ireland functions similar to that which the Bank of England performs for England and Wales.

An Act was passed in 1844 renewing for ten years the charter of the Bank of England. By this Act, which was represented by Sir Robert Peel as "the complement of the Act of 1819," great changes were introduced into the system by which it had previously been attempted to regulate the currency of the country.

The privilege of issuing paper money within a circle of sixty miles' radius round London was continued exclusively to the Bank of England, but with the following restrictions: The establishment was divided into two departments wholly distinct from each other, placed under separate officers, and keeping separate accounts. One of these departments was continued for the ordinary purposes of banking, while the other was created for the single purpose of regulating the issue of notes, the amount of which was in no case ever to exceed fourteen millions of pounds in addition to the actual amount of gold and silver bullion lodged by the banking department in the department of issue. The sum of $£ 14,000,000$ which the bank is thus authorized to issue beyond the value of bullion in its coffers is made up of $£ 11,000,000$, the amount of its capital which has been lent permanently to Government, at 3 per cent. interest, and $£ 3,000,000$ of public securities, bearing interest, which the bank of issue is empowered to hold for that purpose. Under 
this system the Bank must always keep in its vaults gold or silver ${ }^{1}$ bullion equivalent to all its notes in excess of $\mathfrak{£} 14,000,000$, for which uncovered sum the public holds, through the Government, the best possible security - that of the property of the Bank. No question as to the solvency of the establishment can therefore ever arise, while it is hardly possible to conceive that a drain upon the treasure of the Bank should ever be carried so far as to reduce its

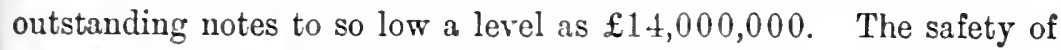
the Bank, as well as that of the public, may be considered as secured, so far as the question of credit is at stake. It remains, however, to be proved whether, under all circumstances that may arise, the security of the public is thus equally well attained as respects the management of the currency; and there are not wanting men of great practical experience in such questions, who have expressed strong doubts upon this subject. It would be out of place to enter upon the controversy here. Those who desire to know the opinions to which reference has been made, will uaturally consult the writings of the accomplished men who have published their reasonings upon the subject, particularly those of Mr. Tooke and Mr. Lloyd, who take opposite views regarding it, and the series of articles on "Currency and Banking," published in the Economist weekly paper, between March and May 1845 .

It must be evident that any attempt to regulate the currency by controlling the issues of the Bank of England, must fail of its object unless an equal control were exercised over the issues of private and joint-stock banks. It was accordingly provided by the Act of 1844 that "no person other than a banker, who on the 6th of May 1844 was lawfully issuing his own notes, shall make or issue bank-notes in any part of the United Kingdom." The privilege of such issue was thus continued to the banks which then possessed it; but the amount of notes that might be issued was restricted to the amount which constituted their actual issues upon the average of the two preceding years.

Further, the most perfect publicity was provided as regards the amount of issues by weekly publications in the London Gazette.

${ }^{1}$ Under the Act the holding of silver must not exceed one-fourth of the gold. But in practice for many years the Bank has kept all its bullion in grold. 


\section{CHAPTER XXXIII}

\section{PROGRESS OF BANKING, 1850-1900}

Working of the Bank Charter Act and of the bank rate during crises-Development of joint-stock banks-Amalgamations and combinations-The crises of 1847, $1857,1866,1890$, and 1907-Paid-up capital and deposits

$\mathrm{P}^{\mathrm{F}}$

EEL'S, great Bank Charter Act of 1844 has proved a wonderful success, though on three occasions (the railway crisis of 1847 , the American crisis of 1857 , and the Overend-Gurney crisis of 1866) it was found necessary to suspend cash payments in order to relieve the monetary pressure. In 1857 the Bank reserves being reduced to $£ 581,000$, and the minimum rate of discount 10 per cent., the Government authorized suspension. Two millions of uncovered notes were issued, and the panic ceased. On Black Friday, May 11, 1866, following the Overend-Gurney failure, there was such a run on the banks that suspension was again resorted to, and the Bank of England was authorized to issue five millions of uncovered notes. In the Baring crisis of 1890 the bank rate was raised to 6 per cent., and proved effective. In the American crisis of OctoberNovember 1907 the rate was raised to $5 \frac{1}{2}$ per cent. on October 31, to 6 per cent. on November 4 , to 7 per cent. on November 7, on which date the total bullion in the Bank was $£ 28,700,000$, and the proportion 35.2 per cent. Thenceforth gold flowed in steadily from twenty-four different countries, and by the end of January the rate had been reduced to 4 per cent.; the total bullion was $£ 38,500,000$, and the proportion $56 \cdot 6$. Considering the strain and drain, this achievement was a splendid demonstration of the soundness of our system, which makes London the gold centre of the world. It is a system whose special merit is free trade in gold with an economical concentration of gold reserves in a central institution.

Since Porter wrote, British banking has developed in a marvellous way, and the organization of credit in London is admittedly the most complex and perfect system the world has ever seen. Bank of England notes now play a very subordinate part in the mechanism of credit. They are merely a section of the 
ordinary currency, chietly useful in the operations of the Bank of England and as bank reserves and till money. The cheque is the almost universal means of payment for sums in excess of one pound. It is cheap, safe, and convenient, but is not legal money, because it is subject to dishonour if the drawer is insolvent. Otherwise it is superior to bank-notes, for it can be made in any amount by a stroke of the pen, and is in itself a receipt and record of payment. The London Clearing-house, founded in 1775 , is a voluntary association of the great London banks by which the balances between banks are adjusted day by day, and an enormous expenditure of labour saved by the mutual exchange and crossing off of liabilities. In 1854 .Joint-Stock Banks were admitted to the clearing-house. The Bank of England is a member, but "on one side only." It presents through the clearing-house all drafts on clearing bankers paid into it by its customers; but the clearing bankers do not present through the clearing-house drafts on the Banh of England paid into them by their customers. Such drafts are paid direct to the credit of their accounts at the Bank of England. In another way the Bank of England is complementary to the Clearing House, because the settlements of the London Clearing-house are made in account with the Bank of England.

Our present banking system has for the most part grown up in the latter balf of the twentieth century. In 1551 , when the last edition of Porter's Progress appeared, the great joint-stock banks were in their infancy; for only seven years had elapsed since the passing of the "Bank Charter Act" of 1844 , which enlarged and defined the rights of joint-stock banks, while it restricted the privileges of the Bank of England. The Act was really a currency Act, having for its object the securing of the note issue of the Bank of England. The general circulation of bank-notes was restrained; but in other respects a greater measure of freedom was conferred upon joint-stock banks. In this country banks have been remarkably free from legislative interference and public control, except as regards the issue of paper currency; and it is largely because they were saved from this fatal rock by the 1844 Act, and so were led to develop the cheque, that their progress has easily kept pace with the growth in our trale and commerce. The secret of success undoubtedly lies in the cheque system, which combines perfect elasticity with an extraordinary degree of convenience and security. In almost all cases in which large sums are transferred, cheques have superseded bank-notes. Notes are 
only employed where the eredit of the individual is unknown, or where by custom or by law cheques may not be employed. But the note circulation of the Bank of England has not decreased, for the bank-note is now treated as a bullion certificate, and the joint-stock banks hold a large proportion of their reserves in the form of Bank of England notes. On the other hand, the notes of the country banks which have the right of issue under the Act of 1844 have sunk to a small figure much below the amount authorized-a fact which clearly proves that bank-notes are not now required by the public to even so great an extent as in 1844 . The outstanding note issues of all the English banks other than the Bank of England, which are entitled to issue notes, are now under $£ 250,000$, although the number of banks having the right of note issue has not decreased to the extent anticipated by the framers of the 1844 Act. Indeed, it was anticipated that all country banks' note issues would have lapsed long before this. True, the circulation of the Bank of England has increased, but the actual amount in the hands of the public is very much smaller, the excess being held by the joint-stock banks.

Until 1833 the only banks allowed to operate within sixty-five miles of London were the private banks. The "Bank Charter Act " of that year, however, did not exclude joint-stock banks within this area, though it prohibited them from issuing notes. But it was not until some time had elapsed that the general right of banking in London was realized, and even then the right was controverted. The Bank of England attempted to have this flaw in their Charter, as they considered it, removed, but without success; and to make the position clear, the 1844 Act expressly permitted the formation of joint-stock banks within the sixty-five mile limit, provided they did not issue notes. Several of the great London banks were formed as soon as it was realized that the 1833 Act did not exclude jointstock banks from operating in the metropolis. The London City and Midland, London County and Westminster, and London JointStock Banks were all established in 1836. At first the jointstock banks were not very popular, but they soon won their way to public favour. For some time they confined themselves entirely to London, where business activity allowed them full scope; but gradually they found it profitable to extend into the provinces, both by opening branches and by amalgamation with existing provincial banks. The old private bankers naturally resented the intrusion of the joint-stock banks, but successful opposition was out of the question. Most of the private banks which remain 
depend almost entirely upon family custom. In some cases private banks have been absorbed by the joint-stock banks. In others a new stock bank has been created by an amalgamation of several private banks. Barclay's, for instance, was formed as recently as 1896 by a combination of several important London and provincial private banks. In 18.32 there were sixty-two private banks in the metropolis and of these only four or five remain. The extension into the provinces of the great London banks has not altogether pleased the customers of the old provincial banks, who say that their facilities have been reduced and that the money of the district is drawn away for employment in financial transactions in London. The customer, it is said, does not get as much consideration from the branch of a big London bank as he was wont to receive from the country banker. So strong is this feeling in certain districts that quite recently a wealthy Lancashire bank, which had agreed to amalgamation with a large London establishment, cancelled the agreement (by mutual consent) on account of the rery strong disapproval manifested by its customers. On the other hand, the opening of numerous branches, though a doubtful policy as far as the bank's profits are concerned, has extended banking facilities to the small trader and the general public; and on the whole there has been a gain in facilities as well as in security to the community at large. The strength of the present banking system is the result of long experience. In the old days before that experience was gained, the fabric of credit was at times severely shaken. In times of depression small banks constantly came to grief. There were crises in $1836,1847,1857,1866^{\circ}$ which brought serious disaster. More recently, in 1890 and 1907 , English banking successfully withstood severe tests. The earlier panics, as we have seen, were the result of over-trading and speculation either at home or abroad, and in all of them some of the weaker members of the banking community went down under the strain.

The crisis of 1847 was really a railway crisis, resulting from wild speculation in the shares of railway companies. The popular demand was met by fraudulent prospectuses, and when the inevitable crash came the money market fell into confusion. The position was aggravated by the bad harvests of 1846 , in consequence of which unusually heary imports of foreign wheat were required. This led to large exports of gold at a most inopportune moment. Unluckily at the same time the Government was negotiating for a loan, but the Bank of England, rather than raise its rate to the disadvantage of its most important customer, allowed 
its reserves to fall very low. Owing to the scarcity, wheat had been forced up to famine prices; but in September the market broke suddenly and a large number of failures followed, with a consequent loss of confidence in business circles. The Bank then raised its rate and restricted loan accommodation, thus precipitating a panic. Several banks failed, and the situation became so strained that the Bank, in order to prevent suspension of all business, found that money must be lent. Thereupon the reserve fell rapidly until its amount was only 15 per cent. of the deposits. A deputation of city merchants then asked that the Bank Act might be suspended, and though the Chancellor of the Exchequer at first refused, the permission was shortly afterwards granted, and the bank was authorized to issue notes against securities in excess of the legal amount. The panic was over at once, for as soon as it was known that money was obtainable there was no longer a disposition to hoard gold.

The 1857 panic originated in America, where 150 bank failures followed the downfall of the Ohio Land and Trust Company. Sensational panics, slumps, and bear operations occurred in American stock and share markets; and, as eighty millions of American railroad shares were owned in this country, there is no wonder that the 1857 panic spread to Great Britain. Large credit failures occurred, and a severe strain was imposed on the Bank of England by the necessity of heavy gold exports. On this occasion the Bank Act was again suspended, and $£ 6,776,000$ of notes were issued in excess of the statutory limit. ${ }^{1}$ From 6 per cent. in October 8, 1857, the directors of the Bank had actually raised their rate to 10 per cent. on November 9 . Yet two days later-just before the suspension of the Bank Charter Act-the reserve stood at only $£ 1,462,000$.

The 1866 panic is attributed partly to the cessation of the American cotton supplies-the Lancashire cotton famine-owing to the Civil War in the United States. But the losses and dislocations so caused would not alone have brought about such a downfall of credit. As usual, bad banking and wild speculation, preceded the crash which culminated in the stoppage of Overend, Gurney \& Co. The Companies Act of 1862 had been followed by the flotation of hundreds of companies, including new banks and discount houses. Many of these companies were not financially sound, and failed under the pressure of the high bank rates which began in the autumn of 1865 . The official rate was raised to

1 Then $£ 14,475,000$. 
8 per cent. in January, and February saw severe liquidation on the Stock Exchange. The Joint-Stock Discount Company and Barned's Bank in Liverpool failed in April 1866, and panic conditions followed. The Bank rate rose to 9 per cent. on May 9, and on the following day, Overend, Gurney \& Co.a firm of world-wide reputation-failed for $\mathfrak{1} 10,000,000$. The effect of this unexpected calamity was terrible, and the panic in the city was declared by the Chancellor of the Exchequer to be without a parallel. Business was at a standstill, and the banks were besieged by mobs of panic-stricken depositors. But the Bank of England had learnt from experience, and advances were freely made. The Bank Act was suspended by a letter from the Premier and the Chancellor of the Exchequer to the Governor on the day following the failure of Overend, Gurney \& Co., but though the reserve as shown by the weekly return of June 1, had fallen to less than $£ \$ 60,000$, the provisions of the Act were not broken. This is the last occasion on which the Bank Act of 1844 has been suspended. Since that time the national wealth and resources have increased prodigiously, the Bank's reserve has been gradually enlarged, and panics have not been allowed to develop.

The crisis of 1890 was brought about through the failure of the great city house of Baring to meet its maturing liabilities. The trouble was due to excessive speculation and over-investment in Argentiua, a rich but ill-governed country, which disappointed and ruined many of those interested in its premature development. Happily this serious crisis never developed into a panic; for, finding that a collapse was inevitable, Baring's laid the position before the Court of the Bank of England, who were then able to prepare for a gradual liquidation and to announce a scheme of arrangement as soon as the failure was known.

In October 1907 the failure of the Knickerbocker Trust in New York led to a suspension of cash payments by all the American Banks, resulting in a wholesale breakdown of credit in the United States. Gold shipments were made from Europe at an alarming pace, and, owing to its free market for gold, London had to provide the bulk of the specie. The strain was terrific, but it was met with splendid success by the Bank of England, whose power of attracting gold from all parts of the world by means of a high bank rate proved more effective than ever. Although in the month of November 1907 more than fifteen million sterling left England, the Bank, by raising its bank rate to 7 per cent., was able to replemish its reserve from 
continental and other foreign centres. The strain, of course, fell entirely on the Bank of England, but the smallness of the effect on the general monetary conditions in England is a striking testimony to the strength of the English banking system. Trade, however, throughout the world was thrown into a severe depression, from which the recovery was very slow.

Paid-up Capital

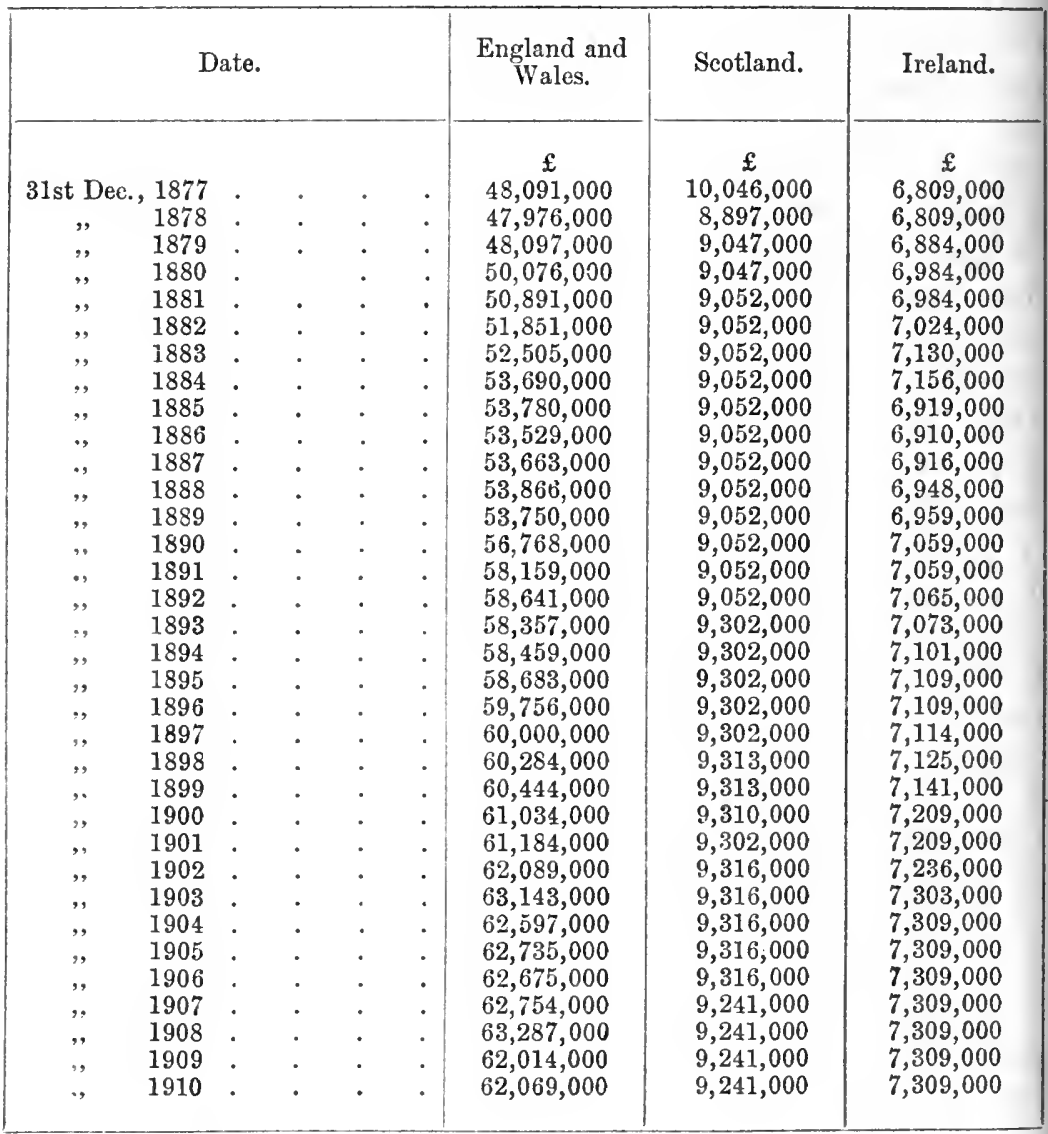

It is difficult to obtain any consolidated figures relating to English joint-stock banking in the early days; but since 1877 a continuous record of the position is provided by The Economist Banking Supplements. In the first tabular summary showing the figures as at the end of December 1.877, the paid-up capital of the banks is given as $£ 48,000,000$, the reserves $£ 16,500,000$, and the amount of deposits just under $£ 240,000,000$. Since then 
These statistics are necessarily somewhat incomplete for the earlier years, as the publication of joint-stock balance-sheets was then very unsatisfactory. In 1877 only 50 banks out of about 120 were included, in the second year 71, and in the third 73 . The statements then became more complete, and owing to greater uniformity in the balance-sheets the figures were more consistent. By 1886 only 5 banks out of the total were omitted, and by 1888 the figures were complete for all the banks of England and Wales. The Scottish bank returns were complete in 1878 , but in the following year the figures were affected by the failure of the City of Glasgow Bank. The Irish bank figures in the early years represented only about 45 per cent. of the real total, but they gradually improved and were complete after 1886 , when the returns of the Bank of Ireland were obtained for the first time.

In the tables on pages 600-601 the figures of England and Wales include those of the Bank of England, but not those of private banks. None of these published any balance-sheets until 1892 when 37 were available. After this the number decreased very rapidly as the banks were absorbed by various large joint-stock banks. Thus the rapid increase in the deposits of the joint-stock banks in the last few years is very largely due to the addition of the deposits of the private banks. 


\section{CHAPTER XXXIV}

\section{INSURANCE}

Growth of insurance business - Marine insurance - Lloyd's - Fire insuranceEmployers' liability-Life insurance-Scientific exactitude-The enormous rolume of business

$\mathrm{I}^{\mathrm{F}}$

great changes have occurred in banking since the middle of the nineteenth century, the development of insurance has been still more remarkable. It represents, in fact, a veritable revolution in business and finance. Porter had very little to say on the subject; but it is impossible now to pass it over in a survey of material progress. Great insurance companies like the Alliance have become immensely powerful as underwriters and investors in new issues of capital. A good insurance manager pays as much attention to the investment of his funds as to the enlargement of his business. The theory of insurance has developed with the practice. Broadly, it may be described as a scientific development of mutual assistance by which risks are provided against and the great losses of a few met out of small contributions by the many. The theory of chance and probabilities has been worked out to a nicety in the life insurance branch. In the other two great branches of provision against fire and shipwreck, the risks are less easily measured. Besides these three older branches of the business, modern insurance has many ramifications. Personal accidents, disease, invalidity, burglary and many other risks can be covered by paying an annual premium. The adoption of legislation making employers liable for the consequence of accidents to their workmen opened another wide field, and in many cases this new burden conla hardly have been borne by industry without the aid of insurance. Within the last few years employers' liability provisions have been extended to clerks, domestic servants, and many other occupations, and in every case the immediate application of insurance has followed. Fire, marine, accident and most other insurance contracts are entered into for a period of one year only, so that either party may terminate the 
agreement at the end of that time. Marine contracts, of course, differ in this respect, as the voyage of the vessel generally constitutes the period of risk. With life insurance, however, the case is different. Here the term is the duration of a human life, and consequently the risk can only be undertaken by a corporate body which cannot die. It is in life insurance that the most scientific development is seen, for it has been found that the mortality of human lives varies so little over a long period in a particular community that the experience of the past can be applied to gauge the future with wonderful accuracy.

Marine insurance seems to be the oldest of all forms of insurance; but its principles and even the wording of its contracts have probably changed least, and the joint-stock principle has been applied less to it than to the other common forms of insurance. The most famous organization in the world for marine insurance is Lloyd's (originally a committee meeting in Lloyd's coffee-house), which also governs the relations between ship-owners and marine underwriters, and superintends the registry of ships. But Lloyd's policies do not cover marine risks alone. In recent years there has been a vast expansion in the business of the "room," and Lloyd's brokers and underwriters are now prepared to deal with risks of fire, earthquakes, strikes, wars, general elections, or any imaginable calamity involving pecuniary loss which is capable of being insured against.

Fire insurance, although perhaps the simplest branch of the business, was hardly practised at all until after the great fire of 1666, when underwriting was undertaken by individuals on a small scale. The first mention of any fire insurance office occurs in 1681 when a small partnership apparently conducted this business at the back of the Royal Exchange. Soon after this, one or two fire offices were formed; and one, "The Hand in Hand," founded in 1696, survives to this day. Several date from the early part of the eighteenth century, and many were formed in the South Sea Bubble. The collapse of the "Bubble" swept away most, and also checked the formation of new companies. The Royal Exchange and London Insurance Company, however, were both established in 1720 and survived the crisis. Fire insurance received little encouragement from the Government in its early years. Fire policies were subject to heavy stamp duties (raised in 1816 to $3 \mathrm{~s}$. per cent.), and not finally repealed until 1869 , when the tax was reduced to the nominal amount of $1 \mathrm{~d}$. per policy.

The growth of the amount insured against fire was used by 
Porter as a means of measuring the growth in the amount of real and personal property, the figures being obtained from the stampduty payments on the sums insured. The principle of the stamp duty was rightly condemned by Porter, but its removal makes it impossible to form any idea of the amount now insured against fire in England and Wales. The tax was repealed in 1869 and we have extended the comparison as far as possible in the following figures :-

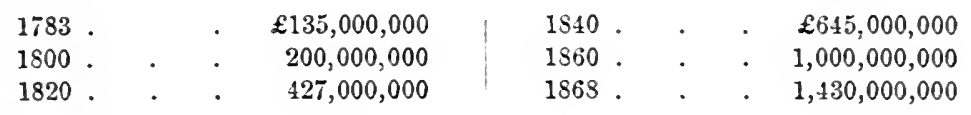

Some property was exempt from the duty, and the returns are therefore rather below than above the correct amount.

Since 1868 no estimate of the total property insured has been made, but as fire insurance companies have to contribute towards the expenses of the London Fire Brigade in respect of the amount insured by them in the administrative county of London, we may show the growth of the sums assured in this area as follows:-

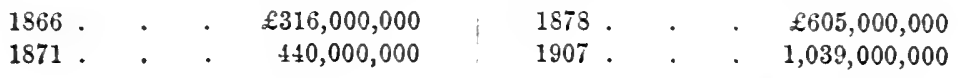

This is a striking rate of progress, but it is now, of course, no guide whatever to the rate of growth in the value of property. Insurance against fire is now universal, and the severe competition among insurance offices together with the increased securities against fire has led to continual improvements in the position of the insured. Lower rates, better terms and more liberal settlements are the results. Early in the history of fire insurance, the usual rate for private houses was $\mathfrak{f} f$ or $\mathfrak{E} 5$ per cent., and it may well seem incredible that the present-day rate of $1 \mathrm{~s}$. $6 \mathrm{~d}$. per cent. can meet the risk, provide commission, pay all expenses, and yet leave a profit for the fire oftice. The explanation lies, of course, in the enormous number of insurances which are effected and the almost entire prevention of serious fires. British fire offices, as a whole, have undoubtedly been well managed. Few bad failures have occurred; their business has extended all over the world, and the reputation they have built up has enabled them to more than hold their own against the native offices of practically any nation. In other branches of insurance, some even of our best conpanies have had to take up new risks of iusurance without the knowledge and experience acquired in regard to fires, and throngh a too keen competition premiums have often been too low. These errors correct 
themselves in time, but meanwhile the insured obtains the benefit of the insurance at less than its proper cost, and the shareholder suffers.

The employers' liability business, for instance, is at present returning no profits in the aggregate; many of the individual offices are working at a loss, and must continue to do so until their books have been cleared of unremunerative risks. In the Post Magazine of November 5, 1910, a summary of the results of all the British offices transacting employers' liability business appeared. The figures were given of thirty-four tariff companies and twenty non-tariff companies, and showed that in the case of the

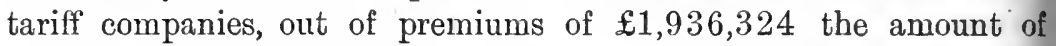
claims was $£ 1,250,845$, or $64 \cdot 6$ per cent. Commission absorbed

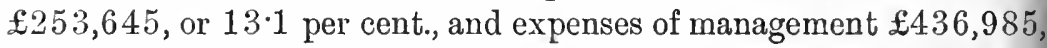
representing 22.62 per cent., leaving a total deficit on balance of $£ 6151$. In the figures of the individual companies, the results varied, ranging from a profit margin of 40 per cent. of the premium income on an extremely small business to a deficit of 21.7 per cent. of the premium income on quite a large business. The non-tariff companies' results were in the aggregate even less satisfactory. The total premiums were $£ 472,678$, out of which claims absorbed $\mathfrak{£} 350,816$, no less that $74 \cdot 2$ per cent. Commission took $£ 70,009$, or 14.8 per cent., expenses $£ 106,042$, or 22.4 per cent., so that on balance there was a deficit of $£ 54,189$, or 11.4 per cent. of the premiums. These companies were on the average very much smaller and their results were even more diverse. One of the companies showed a profit margin of 56 per cent. of the premiums on a small business, while another showed a loss of 91 per cent. of the premiums. These unsatisfactory results are partly explained by the fact that the losses under employers' liability contracts are not necessarily liquidated, as fire losses are, in the year in which they are incurred; for in cases of total disablement the employe receives an annuity for the rest of life. A portion of the premiums of each year must therefore be reserved to cover the outstanding claims, but at present many companies are reserving too little. The position, however, is less serious than might appear, as most of the companies endeavour wherever possible to settle claims by means of an immediate payment.

Attempts are already being made to apply actuarial principles to this class of insurance. Just as in life insurance, so here past experience should form the most reliable guide to the future, and when more experience has been gained the premiums may be calculated on more scientific bases and adequate reserves accumu- 
lated against future liabilities. A step in this direction was taken in the Employers' Liability Companies Aet of 1907, which laid down the principles on which employers' liability companies might estimate their unpaid claims. This Act also prescribed the form on which these companies were to render their accounts, and made it obligatory on them to deposit their accounts with the Board of Trade in the manner which had worked so successfully with regard to life insurance under the Acts of 1871 and 1872 .

When we turn to the consideration of life insurance we find that the companies are working in the sphere of an exact science. So much experience is available that the application of mathematics provides a means of estimating the probable results of the future with the closest accuracy. The contrast with the past is truly remarkable.

The principle of life assurance as we now know it enters so intimately into ordinary business life, and the majority of the companies conducting it are so firmly established, that few realize the vicissitudes with which the earlier companies had to contend. Life assurance is based upon credit and trust as much as, if not more than, banking, though the depositor in a bank has a right to demand his money at any time, while the policy-holder in a life office must continue to pay his premium throughout the whole or the greater part of his life, trusting that after many years the office will carry out its contract. That he is able to rely on such fulfilment is because life assurance has been raised to an exact science, and protective legislation ensures that the position of every life company shall be open to the examination of all.

In the early days, however, the pioneers worked entirely in the dark. Some honest societies failed because their principles were unsound, others failed because their founders hardly expected otherwise. The business lent itself readily to fraud, for after collecting a considerable sum in premiums the promoters could assist the spreading of unfarourable rumours and frighten the majority of policy-holders into allowing their policies to lapse. In those days there was no surrender value or return of premiums, and the rogues would pocket the proceeds. The first socicty which rose to fame was the Amicable Society for a Perpetual Assurance, founded in 1706. It was the fourth company to be formed on the mutual contribution principle. Though very defective in its working, its basis was sound, and at the beginning of 1721 , after the bursting of the South Sea Bubble, it was the only life office in Great Britain; but the London Assurance Corporation and the Royal Exchange Assurance Corporation, both established in the excitement of 1720 , 
began to accept life risks early in 1721. The premiums at this time were not dependent on the age, the usual rate for a year being 5 per cent. for a year, this then being the customary charge for marine risks.

At this period more attention began to be paid to the question of rates, and the eighteenth century saw great progress in mortality investigation and research. But it was not until 1762, when the Equitable was finally established, that the knowledge gained was put into practice, and the old, inefficient methods swept away by the competition of the new society. In 1760 , before the foundation of the Equitable, the amount of life assurance in force was very small. Mr. Cornelius Walford in his comprehensive essay on the History of Life Assurance in the United Kingdom, has computed the total sums then insured at $£ 350,000$, including assurances by private persons estimated at $£ 30,000$. The rates quoted by the Equitable were based upon tables formed upon the bills of mortality for London and Breslau, and were much lower than those of the other oflices, though two years later it was deemed advisable to raise them. This society's deed of settlement contained a clause providing for a periodical investigation of the liabilities, and the first of these took place in 1776 . This is remarkable in that it was the first life office valuation ever made. Bonuses first arose out of the fact that the premiums charged were too high, and, therefore, the surplus rightly belonged to the policy-holders. The method of distribution was for a long time very unequal, but the expansion of the business was not interrupted, because the bonuses were rather like lottery prizes. The Equitable continued to expand, reaching its maximum size about 1840 , when it had over $£ 14,000,000$ of insurances in force. After this, owing to the competition of younger offices and the result of a change in its method of distribution, its business fell away. Towards the end of the eighteenth century many new societies were formed, and several works upon mortality statistics appeared. One of the most famous of these was Dr. Price's Observations on Reversionary Payments, which ran to several editions, and contained the Northampton table of mortality, which was adopted by the Equitable, and followed by many other offices. But for this fact the table would probably not have been so famous. It remained the standard until it was proved to have been founded on fallacious principles, and displaced by Milne's Carlisle table in 1815. The great multiplication of new life offices in the early part of the nineteenth century brought them more and more before the public eye, and various Acts were passed control- 
recent years, for the figures are summarized in the Blue Books. As the valuation figures are furnished only at the periodical investigations, the foregoing table does'not give the amount of sums assured at the end of the particular year, for the table includes some returns made up at an earlier date. For the purpose of showing the rate of progress, however, the figures are useful. In the first two columns are the amounts of insurance in force, less reassurances, and though the increase is not quite even, for the reasons given above, it is quite evident that life insurance has progressed at a very rapid rate during the last twenty years.

For some time life offices have been enjoying a period of cheap investments, and their funds are earning a rate of interest considerably in excess of that assumed in arriving at their liabilities. Consequently, they may look forward to increasing surpluses from interest earnings. The position of the leading British life offices cannot be questioned, and though in larger countries there may be companies which boast greater sums assured and higher accumulated funds, no country in the world has insurance companies which can compare with ours in stability, resources, and the excellence of their management. As the big companies are more and more inclined to absorb smaller companies, and to combine different branches of insurance, their power in the investment market is continually growing, and they now take a leading part in the underwriting and purchase of new issues. 


\section{CHAPTER XXXVi}

\section{PUBLIC REVENUE AND EXPENDITURE, 1800-1850}

Financial condition at the close of the eighteenth century-Triple assessmentIncome-tax imposed-Repealed-Enormous Government expenditure-Fallacious show of prosperity-Misery of the working elasses-Their diminished command of the necessaries of life-Effect of mechanical inventions in supporting the country under difficulties-Gigantic expenditure during the French War-Consequent exhaustionGloomy forebodings of political writers in former times-Amount of debt, 1793-1816 - Fearly income and expenditure, 1792-1849-Debts contracted, 1801-1521-Sinking fund-Dead-weight annuity-Conversion of perpetual into terminable annuitiesExpenditure beyond income during the war-Income beyond expenditure sincePlans of finance budgets-Civil List from 1701-1819-Crown revenues-PensionsMiscellaneous services-Salaries in Public Departments-Reductions between 1815 and 1835

$\mathrm{I}^{\mathrm{N}}$

$\mathrm{N}$ order to give an intelligible account of the financial state of the kingdom at the beginning of the nineteenth century, it is necessary to explain briefly the system which had been brought into operation by Mr. Pitt during the preceding three years.

In November, 1797 , that minister had recourse to what he was pleased to call "a perfectly new and solid system of finance." The public expenditure of that year amounted to $25 \frac{1}{2}$ millions, of which sum only $6 \frac{1}{2}$ millions were provided for by existing unmortgaged taxes, leaving 19 millions to be raised by extraordinary means. In the then condition of the money market it was felt to be impossible to borrow such an amount in the ordinary manner, that is, providing by new taxes for the payment of only the permanent annual burthen occasioned by the increased debt; and a new impost, calculated to produce 7 millions, was sanctioned by Parliament, which impost was to be continued until it should, in conjunction with the produce of the sinking fund, repay the 12 millions that wonld be still deficient. This new system of finance might have been entitled to the character given of it by Mr. Pitt, if it had not been probable-nay, certain-that in the following years an equal

\footnotetext{
${ }^{1}$ Reprinted, with some abbreriations, corrections, and additions, from Porter's Progress of the Nation, Section IV.
} 
expenditure must be met by similar means, until the 7 millions would prove inadequate even for the payment of the annual interest of the sums for which the tax was imposed, when it would become part of the permanent burthens of the country. This new impost, to which the name of "triple assessment" was given, was in fact an addition made to the assessed taxes, "in a triplicate proportion to their previous amount-limited, however, to the tenth of each person's income."

The adoption of this, or some similar plan of financial arrangement, was hardly a matter of choice with the minister, by whom the funding system, as ordinarily practised, could not have been any further pursued at that time. Unfortunately for the success of the principle which it was thus sought to establish, the mode in which it was proposed to raise the 7 millions of additional revenue was highly unpopular, and indeed it has always excited dissatisfaction on the part of the public to be called on for the payment of any tax from which they have not the power to protect themselves, by abstaining from the use of the taxed commodity. This consideration has always made our finance ministers prefer indirect to direct taxation, and led, during the progress of a long and expensive war, to the imposition of duties that weighed with destructive force upon the springs of industry. The financial difficulties by which the Government was then embarrassed may be known from the fact that a loan of 3 millions was raised in April 1798 at the rate of $£ 2003$ per cent. stock, and 5s. long annuity for each $£ 100$ borrowed, being at the rate of $6 \frac{1}{4}$ per cent., and that the "triple assessment," which was calculated to produce 7 millions, yielded no more than $4 \frac{1}{2}$ millions. In the following December the triple assessment was repealed, and in lieu of it an income-tax was imposed at the rate of 10 per cent. upon all incomes amounting to $£ 200$ and upwards, with diminishing rates upon smaller incomes, down to $£ 60$ per annum, below which rate the tax was not to apply. This tax was estimated to produce 10 millions: it was called a war tax; but, when the minister proceeded to mortgage its produce to defray the interests of loans to a large amount, such a name appeared to be little better than a delusion. Like the triple assessment, the produce of the income-tax fell greatly short of its estimated amount, and yielded no more than 7 millions, a large part of which was quickly absorbed to defray the interest of loans for which it was successively pledged. In 1801, after deducting the sums thus chargeable on it, this tax produced only 4 millions towards the national expenditure. In proposing a loan of $25 \frac{1}{2}$ 


\section{PUBLIC REVENUE AND EXPENDITURE, 1800-1850 613}

millions for the service of that year, it was considered inexpedient to mortgage the income-tax any further, and new taxes were imposed, estimated to yield $£ 1,800,000$ per annum. In Mareh 1802 peace was made with France, and in the same month notice was given by the Chancellor of the Exchequer, Mr. Addington, of his intention to repeal the income-tax, which was felt to be highly oppressive, and had become more and more odious to the people. In effecting this repeal, and at the same time to keep faith with the public creditors, to whom its produce had been mortgaged to the extent of $56 \frac{1}{2}$ millions of 3 per cent. stock, additional taxes were imposed upon beer, malt, and hops, and a considerable increase was made to the assessed taxes, besides which an addition, under the name of a modifieation, was made to the tax on imports and exports, previously known under the name of the convoy duty.

At this time the aggregate amount of permanent taxes was $38 \frac{1}{2}$ millions, exactly double what it had been at the breaking out of the war in 1793. During those nine years, taxes to the amount of $£ 280,000,000$, exclusive of the cost of collection, had been levied from the people; yet notwithstanding this ruinous rate of expenditure, many of the great interests throughout the country wore the outward appearance of prosperity. A nation engaged in an expensive war, which calls for the systematic expenditure of large sums beyond its income, may be likened to an individual spendthrift during his career of riot and extravagance; all about him wears the aspeet of plenty and prosperity, and this appearance will continue until his means begin to fail, and those who have fattened upon his profusion are at length sent away empty. The enormous expenditure of the Government, joined to the state of the currency (as already explained), necessarily caused a general and great rise of prices: as regarded agricultural produce, this effect was exaggerated by the ungenial nature of the seasons. Rents had risen throughout the country in a far greater degree than the necessary expenditure of the land-owners, who thence found their situations improred, notwithstanding the additional load of taxation. The great number of contractors and other persons dealing with the Government had derived a positive benefit from the public expenditure, and, being chiefly resident at the seat of government, they were enabled greatly to influence the tore of public opinion. The greater command of money thus given to considerable classes occasioned an increased demand for luxuries of foreigu and domestic production, from which the merchants and dealers derived advantage. There were, besides, other classes of persons who profited from the 
wal expenditure. These were the producers of certain manufactured goods, and those who dealt in them, who found their dealings greatly increased by means of the foreign expenditure of the Government in subsidies and expeditions, the means for which were furnished through those dealings: the manufacturers were at the same time beginning to reap the advantages that have since been experienced in a more considerable degree from the series of inventions begun by Hargreaves and Arkwright, which acted in some degree as palliatives to the evil effects of the Government profusion.

As in the case of the spendthrift, while all these causes were in operation, there was an appearance of prosperity, and those who were profiting from this state of things were anxious to keep up the delusion. That it was no more than delusion will be at once apparent to all who examine below the surface, and who inquire as to the condition of poverty and wretchedness into which the great mass of the people were then plunged. In some few cases there had been an advance of wages, but this occurred only to skilled artisans, and even with them the rise was wholly incommensurate with the increased cost of all the necessaries of life. The mere labourer-he who had nothing to bring to market but his limbs and sinews-did not participate in this partial compensation for high prices, but was, in most cases, an eager competitor for employment, at the same or nearly the same wages as had been given before the war. Nor could it well be otherwise, since the demand for labour can only increase with the increase of the capital destined for the payment of wages; and we have seen that capital was so far from being suffered to accumulate, that it was dissipated by the Goverument expenditure more rapidly than it could be accumulated by individuals. In London and its vicinity the rates of wages are necessarily higher, because of the greater expense of living, than in country districts; and it is asserted, from personal knowledge of the fact, that at the time in question there was a superabundant supply of labourers constantly competing for employment at the large Government establishments, where the weekly wages did not exceed $15 \mathrm{~s}$. , while the price of the quartern loaf was $1 \mathrm{~s} .10 \mathrm{~d}$., and the other necessary outgoings of a labourer's family were nearly as high in proportion. If we contrast the weekly wages at the two periods of 1790 and 1800 , of husbandry labourers and of skilled artisans, measuring them both by the quantity of wheat which they could command, it will be seen that the former could, in 1790, purchase 82 pints of wheat, and in 1800 could procure no more than 53 pints, while the skilled artisan, who in 1790 could buy 
196 pints, could procure in 1800 only $\$ 3$ pints. To talk of the prosperous state of the country under such a condition of things involves a palpable contradiction. It would be more correct to liken the situation of the community to that of the inhabitants of a town subjected to a general conflagration, in which some became suddenly enriched by carrying off the valuables, while the mass were involved in ruin and destitution.

It may be objected to the view here taken, founded upon facts that hardly admit of controversy, that, had such been the condition of the country, we must have sunk under the greater efforts we were so soon after called on to sustain; and there is every reason to believe that, but for the invention of the spinningjenny, and the improvements in the steam-engine, which produced almost magical effects upon the productive energies of this kingdom, it would have been impossible to have withstood the combiuation with which, single-handed, we were called upon to contend.

The public expenditure of England during the war which was begun in 1793, and continued (with short intermissions in 1801 and 1814) until the final overthrow of Napoleon in 1815, was conducted throughout upon a truly gigantic scale. In 1792 , the last year of peace, the entire public expenditure of the kingdom was $£ 19,859,123$, which sum included $£ 9,767,333$ interest upon the public debt. In 1814 the current expenditure amounted to $\mathfrak{£} 76,780,895$, and the interest upon the debt to $£ 30,051,365$, making an aggregate sum of $£ 106,832,260$ paid out of the public exchequer for the disbursements of that one year.

The financial efforts of the Government had been made for several preceding years with a degree of lavish profusion that was continually augmented until it reached the height above mentioned; the expeuditure, including interest upon the debt, during the ten years from 1806 to 1815 inclusive, averaged $£ \$ 4,067,761$ per annum, sums which, until the years in which they werc actually expended, it would have been considered wholly chimerical to expect to raise. The experience of that period has shown how impossible a thing it is to judge correctly from the past as to the growing resources of our country. Without that experience for their guidance, our ancestors, in former but not very remote times, gave way to gloomy forebodings as to their future prospects, at which we cannot but smile, when thinking of the comparatively pigmy efforts which called them forth. Some of those forebodings have been recorded by Sir John Sinclair, in his work on the public revenue of this kingdom. A few passages upon the subject, taken from that work, 
and with the dates at which they wore written, may not be without interest.

"1736. The vast load of debt under which the nation still groans is the true source of all those calamities and gloomy prospects of which we have so much reason to complain. To this has been owing that multiplicity of burthensome taxes which have more than donbled the price of the common necessaries of life within a few years past, and thereby distressed the poor labourer and manufacturer, disabled the farmer to pay his rent, and put even gentlemen of plentiful estates under the greatest difficulties to make a tolerable provision for their families.-The Craftsman, No. 502, 14th February, 1736."

At the time this gloomy picture was drawn the public debt did

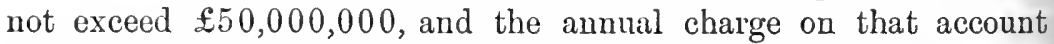
was somewhat under $£ 2,000,000$, being considerably below the sums added to the public burthens in the single year 1814 .

"1749. Our parliamentary aids, from the year 1740 exclusively, to the year 1748 inclusively, amount to $£ 55,522,159$ 16s. 3d., a sum that will appear incredible to future generations, and is so almost to the present. Till we have paid a good part of our debt, and restored our country in some measure to her former wealth and power, it will be difficult to maintain the dignity of Great Britain, to make her respected abroad, and secure from injuries or even affronts on the part of her neighbours.-Some Reflections on the present State of the Nation,' by Henry St. John, Lord Bolingbroke."

The debt, to the effects of which so much evil is here attributed, was still under $\mathfrak{2} 80,000,000$, and the annual interest scarcely more than $£ 3,000,000$.

"1756. It has been a generally received notion among political arithmeticians, that we may increase our debt to $£ 100,000,000$, but they acknowledge that it must then cease, by the debtor becoming bankrupt.-Letters by Samnel Hannay, Esq."

In the few years that preceded the publication of Mr. Hannay's letters the debt had been somewhat diminished, so that it amounted to about $£ 75,000,000$, and the aunual charge on the country

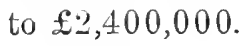

"1761, The first instance of a debt contracted upon parliamentary security, occurs in the reign of Henry vi. The commencenent of this pernicious practice deserves to be noted; a practice the more likely to become pernicious the more a nation advances in opulence and credit. The ruinous effects of it are now become apparent, and threaten the rery existence of the nation.-Hume's History of England, 8vo edition, 1778, vol. iii. p. 215."

The public burthens had by this time so far exceeded the possible limit assigued by Mr. Hannay, that the debt amounted to

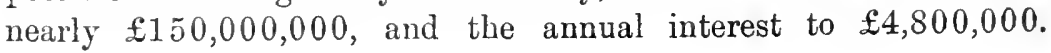


The amount was somewhat reduced between that period and the breaking out of the American War, when a succession of loans again became necessary. On winding up the accounts of that coutest,

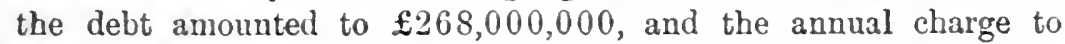

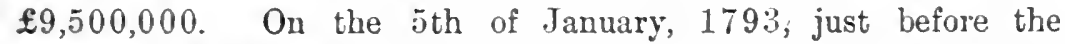
beginning of the war of the French Revolution, the debt continued nearly the same as at the beginning of the peace (the exact amount of funded and unfunded debt, including the value of terminable annuities, was $£ 261,735,059$, and the annual charge was $\mathfrak{f} 9,471,675)$. From that time to the Peace of Amiens hardly a year passed without witnessing some increase to the national burthens, so that at Midsummer, 1802 , the capital of the funded

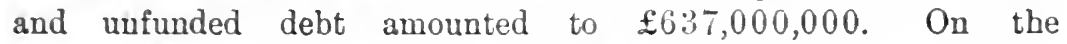
5 th of January, 1816, the capital was $£ \$ 85,186,323$, and the annual charge was $£ 32,457,141$. The following abstract exhibits the movements of public income and expenditure, at intervals from 1792 to 1849 , including the annual charge for the public debt, and the amounts raised by loans and the funding of Exchequer Bills.

Abstract of Public Income and Expenditure in the United Kingdom, in various Years from 1792 to 1849

\begin{tabular}{|c|c|c|c|c|c|c|}
\hline \multirow[b]{2}{*}{ Year. } & \multicolumn{3}{|c|}{ Income. } & \multicolumn{3}{|c|}{ Expenditure. } \\
\hline & $\begin{array}{l}\text { Amount of } \\
\text { Revenue pasd; } \\
\text { into the } \\
\text { Exchequer, } \\
\text { the produce } \\
\text { of Taxation. }\end{array}$ & $\begin{array}{l}\text { Amount } \\
\text { received on } \\
\text { account of } \\
\text { Loans and } \\
\text { Exchequer } \\
\text { Bills, beyond } \\
\text { the allount } \\
\text { redeemed in } \\
\text { the Year. }\end{array}$ & $\begin{array}{l}\text { Tutal Amount } \\
\text { raised for } \\
\text { Public C'ses. }\end{array}$ & $\begin{array}{l}\text { Interest paid } \\
\text { on Public } \\
\text { Debt, Funded } \\
\text { and } \\
\text { Cnfunded. }\end{array}$ & $\begin{array}{l}\text { Sums applied } \\
\text { to redemption } \\
\text { of Public Debt } \\
\text { beyond the } \\
\text { amount of } \\
\text { Losns, etc., i: } \\
\text { the Year. }\end{array}$ & $\begin{array}{l}\text { Total Amount } \\
\text { Paid and } \\
\text { Expended i } \\
\text { the Yes. }\end{array}$ \\
\hline & $100 . \mathfrak{f}$ & $£$ & & & $\mathfrak{E}$ & \\
\hline 1800 . & $\begin{array}{l}19,255,514 \\
34,145,584\end{array}$ & $23,030,523$ & $\begin{array}{l}19,258,814 \\
5 ;, 166,113\end{array}$ & $\begin{array}{r}9,767,333 \\
17,351,561\end{array}$ & $\begin{array}{c}2, \pm 21, \operatorname{es} 1 \\
\ldots\end{array}$ & $\begin{array}{l}19,559,123 \\
56,821,267\end{array}$ \\
\hline 1810. & $67,144,542$ & $7,792,444$ & $74,936,28 \mathrm{C}$ & $24,246,946$ & $\ldots$ & $78,865,543$ \\
\hline 1815. & $72,210,512$ & $30,241,507$ & $92,452,319$ & $31,5=6,074$ & $\begin{array}{l}\cdots \\
\cdots\end{array}$ & $9=2 \times 0,1 \leqslant 1)$ \\
\hline 1816. & $62,264,546$ & 514,059 & $60,778,605$ & $32,938,751$ & $\ldots$ & $65,169,761$ \\
\hline 1817. & $52,055,913$ & & $52,055,913$ & $31,436,245$ & $1, \approx 206,814$ & $55,2 \times 1,230$ \\
\hline 1820 . & $54,982,953$ & ... & $54,252,958$ & $31,157, \$ 46$ & $1,913,019$ & $54,45 i, 247$ \\
\hline $1830^{\circ}$ & $50,056,616$ & $\ldots$ & $30,056,616$ & $29,118,35 s$ & $1,935,465$ & $49,075,106$ \\
\hline 1840. & $47,567,565$ & $\ldots$ & $47,567,565$ & $29,381,718$ & 8,016 & $\begin{array}{r}49,169,532 \\
\end{array}$ \\
\hline 1845. & $53,060,354$ & $\ldots$ & $53,060,354$ & $28,253, \mathrm{siz}$ & $4,143, \$ 91$ & $53,33,3,603$ \\
\hline 1849. & $52,951, \pi+9$ & $344,56 \mathrm{~S}$ & $53,326,317$ & $23,323,961$ & 21,074 & $50,5 i 4,690$ \\
\hline
\end{tabular}

An extraordinary degree of delusion is observable in the proceedings of the different finance ministers by whom the support of the sinking fund was advocated during the war. It has been pretended that the purchases made by means of that fund had the effect of keeping up the market value of the public debt, and 
thereby enabled the minister to contract loans upon more advantageous terms than, without this machinery, would have been possible. It may well be doubted, however, whether the re-purchase in this manner, from time to time, of parts only of that surplus portion of the public debt which was created for the express purpose of such operations, had any real effect in raising the price of the remaining portion of the public securities - in other words, whether the price, thus factitiously acted upon, of the larger amount of debt, was at any time greater than the price would have been of the smaller amount of debt that would have existed if the sinking fund had not been created, the purchases of the Commissioners never having in fact accomplished more than the repurchase of the soneedlessly-created part of the debt. It has been further urged in defence of the sinking fund, that the prospect which it enabled the minister to hold out of the speedy redemption of the whole debt had the effect of reconciling the people to the payment of a larger amount of taxes than they would otherwise have been willing to pay. Allowing that the effect here stated was produced, we may still doubt the wisdom of that Government which is obliged to resort to a juggle in order to reconcile the people to its measures, and especially when, as in the case under examination, the delusion was so expensive and likely to prove so permanently injurious in its nature.

The average rate at which 3 per cent. stock was created between 1793 and 1801 was $£ 577 \mathrm{~s} .6 \mathrm{~d}$. of money for $£ 100$ stock, and the average market price during that period was $\mathfrak{f} 6117 \mathrm{~s} .6 \mathrm{~d}$. for $£ 100$ stock. The loss to the public upon the additional sum borrowed in order that it might be redeemed during that period, which was $£ 49,655,531$, amounted to $4 \frac{1}{2}$ per cent., or $£ 2,234,500$. Between 1803 and the termination of the war, the average price at which loans were contracted was $£ 60$ 7s. 6 d. per $£ 100$ stock, and the average market price during that time was $£ 6217 \mathrm{~s}$. 6 d. per $£ 100$. The loss was, therefore, $2 \frac{1}{2}$ per cent. upon the sum redeemed during that time, $£ 176,173,250$, or $£ 4,404,331$, making together an amount of $£ 6,638,831$ absolutely lost to the public by these operations. This amount, reckoned at the average price of the various loans, is equivalent to a capital of more than eleven millions of 3 per cent. stock, with which the country is now additionally burthened through the measure of borrowing in a depressed market more money than was wanted in order to its being repaid when the market for public securities was certain to be higher. The fallacy atteuding this system is now so fully recognized that it is not likely 
any minister will in future make a show of redeeming debt at the moment when circumstances compel him actually to increase its amount for that purpose.

Another error of a still more important nature, involved in this system, remains to be noticed. The absurdity of borrowing money in order to extinguish debt could never have been seriously adopted but with the anticipation of the good effects that might be drawn from such a course after the necessity for further borrowing should cease, when it might be beneficial to apply towards the redemption of the debt the high scale of taxation which that system rendered practicable. There never could have existed any doubt of the fact, that whenever the necessity for borrowing should cease, the market value of the public funds would advance greatly, and would therefore in an equal degree limit the redeeming power of the surplus income, however arising. The knowledge of this fact should have led the ministers, by whom successive additions were made to the public debt, to the adoption of a course which would have enabled them to turn this rise of prices to the advantage of the public, instead of its being, as it has proved, productive of loss, and this end would certainly have been accomplished, if at the expense of a small present sacrifice the loans had been contracted at a high rate of interest, instead of their having been contracted, as for the most part they were, in 3 per cent. anuuities. It is presumable that, if the borrowing had been restricted to the sums actually wanted from time to time, without thought of a sinking fund, the public might possibly have had to pay at the outside a quarter per cent. more of annual interest than they actually paid. At this rate the deficiency of income compared with expenditure, between 1793 and 1815 , which

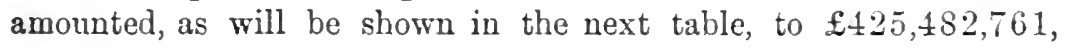
would have occasioned an addition to the capital of the debt to the amount of $£ 455,266,554$ of 5 per cent. stock, the annual interest of which would have been $£ 22,763,327$, instead of a nominal capital of $£ 547,292,764$, with the annual additional charge

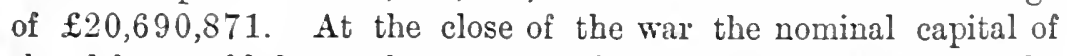
the debt would have then amounted to $\mathfrak{E} 724,285,729$, and the

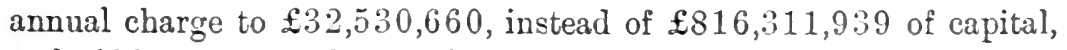

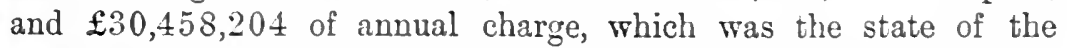
unredeemed public debt on the 5th of January, 1816. The Government would then have been in the most farourable position for taking advantage of the lowering of the rate of interest which was certain to follow, and many years before the present time the whole of the 5 per cent. annuities might have been converted, without 
any addition to the capital, into annuities of the same amount, bearing interest at the rate of $3 \frac{1}{2}$ per cent., or perhaps lower. Assuming, however, that the reduction would not have gone lower than $3 \frac{1}{2}$ per cent., and taking into consideration the surplus revenue which has been actually applied to the redemption of debt between 5th January 1816 and 5th January 1837, which, as will be seen, amounted to $\mathfrak{f} 46,086,321$, the funded debt existing on 5th January 1837 would have amounted to $\mathfrak{f} 678,199,408$, and the annual charge to $\mathfrak{f} 23,736,979$, instead of its actual amount, $\mathfrak{£} 761,422,570$, and its actual annual charge, $£ 29,234,873$; showing that the loss entailed on the country by the plan pursued, of funding the debt in stock bearing a nominal low rate of interest, was $\mathfrak{£} 83,223,162$ of capital, and $£ 5,497,894$ of annual charge.

The charge of inconsistency on the part of our finance ministers is fully deserved by their adoption of two measures having for their objects results exactly opposed to each other. These measures are, first, the creation of what is called the dead-weight annuity, and secondly, the conversion of perpetual annuities into anmuities for lives or for terms of years; the effect of the first being to bring present relief at the expense of future years, while the second increases the present burthen with the view of relieving posterity. It is unnecessary here to inquire which of these two modes of proceeding is preferable. Under different circumstances either of them might be wise or prudent, but it is quite impossible that at the same time, and consequently under the same circumstances, both could be either wise or prudent, and the minister and legislators by whom the plans were proposed and sanctioned must be allowed to have stultified themselves by the operations. Of the two courses that is assuredly the most generous under which the parties by whom it is adopted subject themselves to additional burthen in order to lighten the load for their successors, and indeed it would seem no more than an act of justice on the part of those by whom the debt was contracted to adopt every means fairly within their power for its extinction.

It is singular that, with so much experience and so much of scientific acquirement that might have been brought to the correct elucidation of this subject, the tables first adopted for the creation of terminable annuities were incorrect, to a degree which entailed a heavy loss upon the public. The system was established in 1808, and during the first year of its operation annuities were granted to the amount of $£ 58,50610 \mathrm{~s}$. per annum. Of that amount there continued payable $£ 23,251$ per annum at the beginning of 1827 , 
when, to adopt the calculation of the actuary of the national debt, as given in a report to the Chancellor of the Exchequer, the public had already sustained a loss of more than $£ 10,000$ by the transactions, besides having the above annual sum of $£ 23,251$ still to pay for an indefinite term. In this report of Mr. Finlaison, he states that the loss to the public through miscalculation in these tables was then (April, 1827) proceeding at the rate of $£ 8000$ per week, and during the three preeeding months had exceeded $£ 95,000$. The discovery of this blunder had been made and pressed upon the attention of the finance minister as early as 1819 , but no active steps were taken to remedy it until 1828 , and even then the rates at which annuities were granted upon the lives of aged persons were, after a time, found to be so unduly profitable to the purchasers, that the Government was again obliged to interfere, and to limit the ages upon which life annuities could be obtained.

It is quite impossible that any similar series of blunders could have been committed by any private persons or assoeiation of individuals, whose vigilance would have been sufficiently preserved by their private interest; and it is disgraceful that the Government, which could at all times command the assistance of the most aecomplished actuaries, should have fallen into them. It is yet more disgraceful that, after the evil had been discovered and pressed upon its notice, so many years were suffered to elapse before any step was taken to put a stop to the waste of public money.

It would require a voluminous account to explain all the financial operations of the Government during the period embraced in the foregoing statements. In the earlier years of that time, while on the one hand the minister was annually borrowing immense sums for the public service, an expensive machinery was, as we have seen, employed to keep up a show of diminishing the debt, and by this means the people were brought to view with some degree of complacency the most ruinous addition to their burthens, under the expectation of the relief which, through the magical effect of the sinking fund, was to be experienced by them in future years. The establishment and support of the sinking fund was long considered as a masterstroke of human wisdom. Having since had sufficient opportunity for considering its effects, we have arrived at a different conclusion, and can no longer see any wisdom in the plan of borrowing larger sums than were wanted, and paying in consequence more dearly for the loan of what was actually required, in order to lay out the surplus to accumulate into a fund for buying up the debt at a higher price than that at which it was contracted. 
In the fourth report of the Select Committee on Public Income and Expenditure, which was printed by order of the House of Commons in 1828, there are three statements showing the difference between the public receipts and disbursements in the ten years ended 5th January 1802, the fourteen years ended 5 th January 1816, and the twelve years ended 5th January 1828.

It appears from this statement, that during the ten years from 1792 to 1802

The public Expenditure exceeded the Income

$£$

Between 1802 and 1816, the excess of Expenditure was

Excess of Expenditure during 24 years of war was

During 34 years of peace, between 1816 and 1850 , the excess of Income over Expenditure was.

- $189,153,451$

$236,329,310$

$425,482,761$

$45,779,046$

At this rate it would require 316 years of peace to cancel the debt incurred during 24 years of war, or 13 years for 1 ; but the comparison is even more unfavourable than this, because at the time of borrowing the rate of interest is high, and the value of public securities low, whereas at the time of liquidation the reverse of these circumstances is experienced, so that on the most favourable supposition it requires 15 years of saving in peace to repair the evil consequences of one year of war expenditure; at which rate, our successors who may be living about the close of the $22 \mathrm{nd}$ century might, if during all that time the nation should remain at peace, find themselves relieved from that portion of the public debt which has been contracted since 1792 .

During the period here under review the accounts accompanying the budgets were in many ways defective. They omitted interest on debt and other permanent charges, and nothing was stated regarding the produce of the permanent taxes, forming what is called the consolidated fund, except the amount of its surplus or deficiency, as the case may be, after providing for the permanent charge upon it. The Budget, as it is the practice to call this annual exposition, explains on the one hand the sums required for the public service during the year, under the different heads of Navy, Army, Ordnance, and Miscellaneous Services, together with any incidental charges which may apply to the year; and on the other hand are given the ways and means for meeting the same. These ways and means consist of the surplus (if any) of the consolidated fund, the annual duties, and such incidental receipts as come in aid of the national resources. 
It was long before the country could be relieved from the crushing burthen of taxation imposed during the war in the form of customs and excise duties upon commodities; for in the year 1816, the first year of the peace, Parliament insisted upon repealing the whole of the two shilling income-tax. However, between 1821 and 1831 the taxes repealed exceeded those imposed by more than 17 millions. In the next ten years the net relief amounted to about 4 millions, and between 1841 and 1849 , with the aid of an income-tax calculated at first to yield 5 millions, taxes on consumption were repealed or reduced to the extent of $8 \frac{1}{2}$ millions. The successive reductions of customs and excise produced such great increases of consumption that the small and reduced customs and excise tariff' of 1849 produced $£ 34,622,284$ against a total of only $\mathfrak{1} 19,330,867$ for the much larger and oppressive list of 1801. It is calculated that after allowing for an increase of 77 per cent. in the number of consumers, the increase of consumption accounted for 9 millions sterling of the customs and excise revenue in 1849 .

The following table shows the yield of the principal branches of the public revenue in $1801,1811,1821,1831,1841$, and 1849 :-

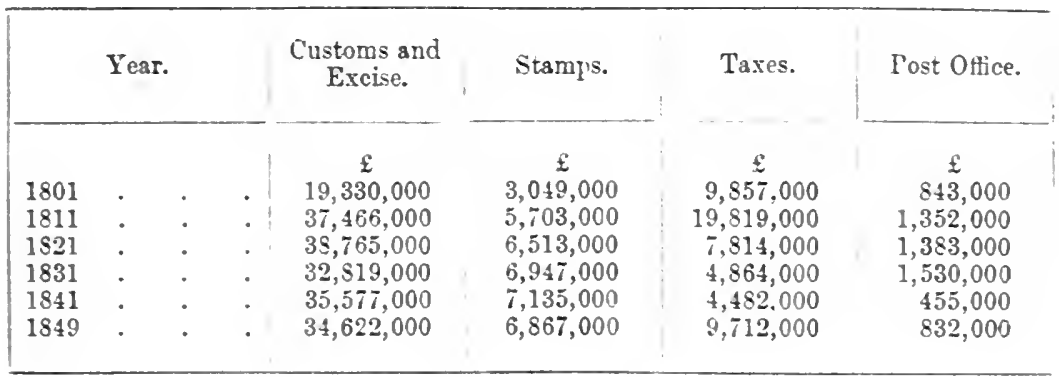

Under the head of stamps were included the probate and legacy duties. In 1801 the total capital subject to legacy duty (which then ranged from 1 to 6 per cent.) was only $£ 3,5 \pm 1,000$. In 1805 the graduation was raised to 10 per cent. In 1816, the first year of peace, the capital subject to duty was 24 millions, and in 1848 it was 44 millions. Upon these duties Porter made the following remarks and criticisms :-

"It is in the nature of these duties to be-more than almost any othersunaroidable. If a heavy tax is laid upon wine, or upon male servants, or any similar object, every one has it in his power to avoid the payment, by foregoing 
the use of the taxed article; but as every one must die, and must leave his property behind him, and as few persons, comparatively, like to quit the world without making such a disposition of their possessions as is dictated by a sense of justice, or by feelings of friendship and affection, the cases will be few in number wherein property of even moderate amount, which devolves by succession, is not brought within the operation of these duties. The motire of saving to their families the amount of the legacy duty, which might otherwise influence some persons to omit making any testamentary disposition of their property, is removed by the regulation which subjects property in such cases to a much higher rate of probate duty (generally 50 per cent.) than is chargeable when a will is proved. If we except those duties which operate in the nature of moral restraints-such, for instance, as the duty upon spirituous liquors, when not sufficiently high to excite smuggling-there are not any taxes to the effects of which some social evil may not be ascribed. It has been objected to the probate and legacy duties, that, falling inevitably upon capital, they impair the funds applicable to the maintenance of labour, and thereby diminish the future production of the country. 'If,' says Mr. Ricardo, 'a legacy of $£ 1000$ be subject to a tax of $£ 100$, the legatee considers his legacy as only $£ 900$, and feels no particular motive to save the $£ 100$ duty from his expenditure, and thus the capital of the country is diminished; but if he had really received $£ 1000$, and had been required to pay $£ 100$ as a tax on income, on wine, on horses, or on servants, he would probably have diminished, or rather not increased, his expenditure by that sum, and the capital of the country would have been unimpaired." 1

"It might, on the other hand, be suggested, that, while these duties are accompanied by the advantage which generally attends direct taxation, namely, that a much larger part of their produce than of the produce of taxes indirectly collected finds its way into the public treasury, they are likewise free from the evil effect commonly ascribed to direct taxation, that it engenders irritation, and is regarded as a greater burthen by the public than the payment of duties to a greater amount upon consumable commodities. The legacy and probate duties are in truth not felt as a tax, and it is this circumstance which has exposed them to the objection urged by Mr. Ricardo. Another and apparently a much better-founded objection to them, as levied in this country, might be brought forward, namely, the partiality shown in excluding from their operation that description of property which, from its greater comparative value and security, is called real property. This partiality has always been felt as a grievance, and the sense of injustice which it is calculated to awaken is of more moment than any temporary irritation that may accompany the demand for money taxes, which soon passes away, and will be felt only by those persons who have given little or no consideration to the subject."

The partiality complained of here was redressed by $\mathbf{M r}$. Gladstone shortly after Porter's death.

Among the reductions effected from 1831 inclusive, several are of duties which were partial and unjust in their operation, while others were highly impolitic in their tendency, and prevented the extension of certain branches of industry. Among the former may

${ }^{1}$ Principles of Political Economy and Taxation, p. 166, third edition. 
be mentioned the duty upon coals carried coastwise, which acted in aggravation of the natural disadvantage experienced by the inhabitants of those parts of the country to which fuel was conveyed at a great expense, while the districts in which coal abounds, and where, consequently, its cost is small, were exempt from the tax. Among the duties to which the charge of impolicy is applied was that upon printed cottons, the evil effects of which have been sufficiently explaiued in a former section. The discriminating duties upon sugar and coffee, the produce of British possessions in India, have also been removed, a measure which could not fail to have the best effects upon our commerce with that part of the world, and a long list of articles, the revenue derived from which was insignificant in amount, but hurtful in its effects upon various branches of the national industry, have either been removed from the tariff or the duties upon them reduced to rates that are merely nominal.

The custom-house accounts exlibited in 1842 a list of 190 articles upon which duties were levied, independent of such as were not considered worth euumerating, but were described as "all other" articles," and the duties upon which, in that year, amounted to

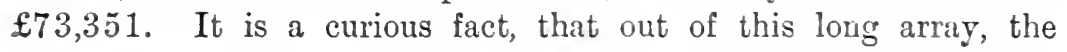
net produce of the duties upon which amounted, in 1840 , to $\mathfrak{f} 23,341,813$, the large proportion of $93 \frac{1}{5}$ per cent., or $\mathfrak{E} 21,872,508$, was collected upon eighteen articles, as shown in the following list. By extending the list so as to comprise all articles which yield annually $\mathfrak{1 0 , 0 0 0}$ and upwards, it will be found to comprehend, altogether, only forty-five articles, yielding $£ 22,742,601$, or $97 \frac{1}{2}$ per cent. of the whole. There are left 145 articles together with all

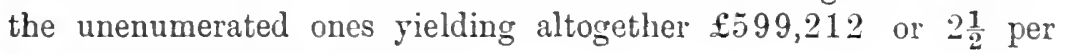
cent. of the customs revenue.

\begin{tabular}{|c|c|c|c|}
\hline Tea & & & $£ 3,472,864$ \\
\hline Sugar and Mo & & . & $4,650,016$ \\
\hline Tobacco & & . $\quad$. & $3,588,192$ \\
\hline $\begin{array}{l}\text { British Planta } \\
\text { Spirits }\end{array}$ & & Foreign & $2,440,9$ \\
\hline Wine . & . & . & $1,791,646$ \\
\hline Timber . & & . & $1,731,549$ \\
\hline Coffee . & • & . & 921,550 \\
\hline Cotton Wool. & - & . & 648,937 \\
\hline Butter. . & . & . & 257,576 \\
\hline
\end{tabular}

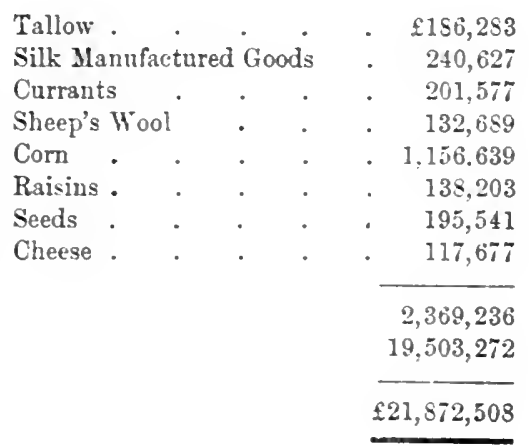

Tallow . . . . . $£ 1 \$ 6,283$ Currants . . 201,57\% Sheep's Hool . . . 132,689 Corn . . . . . 1,156.639 Raisins . . . . 138,203 Seeds . . . . . 195,541 Cheese. . . . 117,677 


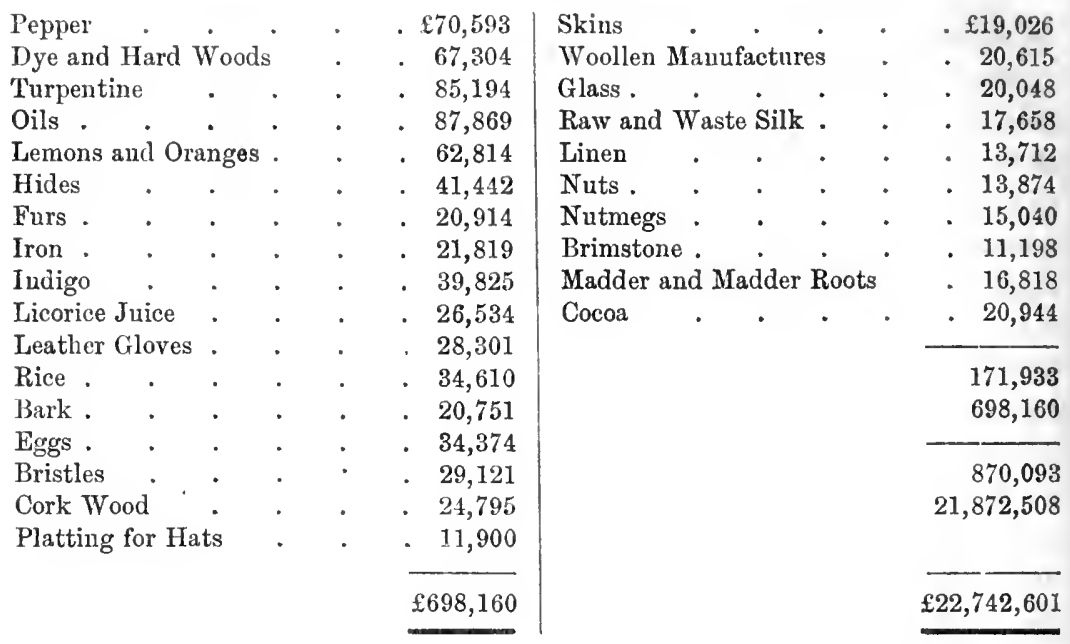

Is it possible to conceive any better use that could have been made of a surplus of revenue to the extent of $\mathfrak{f} 600,000$, than in repealing all this long array of comparatively unproductive duties, which could but exercise a prejudicial effect upon comnerce ? ${ }^{1}$ Some part of those unproductive duties were imposed for what is called the protection of our manufactures, and some others because of the excise duties charged upon the like articles of English manufacture. It must surely be bad policy for this country to set the example of charging duties for the protection of domestic industry. Such duties must long ago have become wholly inoperative, through the perfection and economy which have been attained in our manufactories; and if perchance this should not be the case with every minute branch of skilful employment, we ought to have learned, from the experience of former relaxations,

1 In the last edition of 1851, Porter adds: "Since 1842 the customs duties have been repealed on cotton wool, sheep's wool, various seeds, turpentine, oils, hides, furs, iron, indigo, bark, bristles, cork wood, skins, woollen manufactures, raw and waste silk, linen, brimstone, madder and madder roots; and the then existing rates have been reduced on sugar and molasses, foreign spirits, timber, butter, tallow, silk manufactures, currants, corn, raisins, and cheese, all included in the above list."

A similar examination of the custom-house accounts for 1849 shows the following result of these inportant ehanges, namely, that upon 12 articles, yielding each more than $£ 100,000$, the revenue has amounted to $95 \frac{1}{2}$ per cent. of the whole; that upon 14 articles, yielding each between $£ 10,000$ and $£ 100,000$, the proportion was beyond $2 \frac{1}{2}$ per cent., while all other articles, the revenue from each of which was less than $£ 10,000$, yielded less than 2 per cent. of the yearly amount, which, notwithstanding the abolition and reduction of duties since 1840 , to the extent of $£ 7,479,685$, or 32.88 per cent., yielded in 1849 within $£ 473,738$, or about 2 per cent. $(2 \cdot 08)$ of the revenue of 1840 . 
that the true and certain way to ensure improvement is to throw down the mounds of protection. If even, against all probability and all experience, some few sickly and exotic branches of employment should leave the country, the sacrifice would be small indeed in comparison with the good to be attained through the practical carrying out of a principle from the universal adoption of which we have so much to gain, but which never will be generally adopted by other countries, so long as their prohibitory or protective duties are countenanced by the provisions-however inoperative-of our tariff.

Where excise duties are charged upon articles of English production, it is assuredly only justice to the home manufacturer to levy equivalent duties upon the admission of the like articles from foreign countries; but in such cases it were well to inquire whether the sums received afford a sufficient compensation for the evils always attendant upon duties levied in manufactories. The excise duty on vinegar made in the United Kingdom amounted to

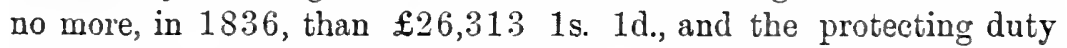
on foreign vinegar to $£ 13511 \mathrm{ss}$. $10 \mathrm{~d}$. The duties being now removed, the manufacturers are allowed to carry on their processes freed from the restrictive rules of revenue officers, and it cannot be doubted that they must always produce vinegar at a price which will ensure to them the supply of the home market, while our trade with France has been increased in a manner which tends to secure for us the good wishes and co-operation of one of the largest and most influential classes of proprietors in that country. The imposition of an excise duty on vinegar was long justified on the plea of care for the health of the public, which was to be protected by means of the revenue officers, who would prevent the use of any deleterious ingredients in our vinegar-yards, a plea which will scarcely meet with supporters at the present day, since it is known that no surveillance will suffice to prevent illegal mixtures, where it is to the interest of manufacturers to make them.

The Government has, since 1840, acted upon the suggestion here thrown out, of repealing many of the comparatively unproductive customs duties which then swelled the tariff, and we see that the money collected upon the remaining more important articles amply compensates for the amount given up.

It would have been a favourable circumstance for commerce, and consequently for the progress of social improvement, if govern- 
ments had never imposed any duties upon foreign productions, except with the single object of obtaining revenue. Duties of regulation, whatever may have been the motives for their adoption, have always in their ultimate effects been productive of more evil than good, a fact which has been kept out of view principally because the good, which is frequently very doubtful at best, is enjoyed by individuals through whom it is rendered apparent, while the evil has partly consisted in the absence or rather the prevention of good, and has operated silently but most injuriously upon the welfare of the community at large.

Duties have too frequently been imposed in the spirit of retaliation,- -an unwise and unworthy spirit, whether adopted by individuals or by nations, and which has long ago been thus ably exposed by Dr. Franklin :-

"Suppose a country, X, with three manufactures, as cloth, silk, iron, supplying three other countries, A, B, C, but is desirous of increasing the vent and raising the price of cloth in favour of her own clothiers.

In order to do this, she forbids the importation of foreign cloths from A.

$A$, in return, forbids silk from $\mathrm{X}$.

Then the silk-workers complain of a decay of trade.

And $\mathrm{X}$, to content them, forbids silks from $\mathrm{B}$.

$\mathrm{B}$, in return, forbids iron-ware from $\mathrm{X}$.

Then the iron-workers complain of decay.

And $\mathrm{X}$ forbids the importation of iron from $\mathrm{C}$.

$\mathrm{C}$, in return, forbids cloth from $\mathrm{X}$.

What is got by all these prohibitions?

Answer.-All four find their common stock of the enjoyments and conveniences of life diminished."

In levying duties of regulation, governments legislate for the benefit of the producers only of the country, leaving out of sight the interests of the consumers-the universal class-all of whom are thus placed at a disadvantage for the supposed profit of a few among their number. The minister acts, without doubt, in accordance with the feeling of the majority, when, in return for the imposition by a foreign government of any duty which tends to limit the trade of some of the producers in his own country, he attempts to punish the offending nation by aiming a similar blow at some branch of its industry. The doctrine of "an eye for an eye and a tooth for a tooth" is never more fully nor more fatally acted upon than in commercial legislation, although in the present day, and in our own country, the evil tendency of this anti-social spirit has been demonstrated until it has become hardly possible 
for any one to hazard an argument in its favour. ${ }^{1}$ We may not, in every case, have imposed retaliatory duties precisely in the manner supposed by Dr. Franklin, but our adherence to the principle involved in them is still but too apparent, and especially appears whenever it is proposed to remove or relax any duty upon importation. In these cases, without considering whether such a relaxation will be beneficial to ourselves, and then adopting it accordingly, we have, until the last four years (1846-1850), sought to render the measure subservient to another object, that of producing a corresponding relaxation on the part of the foreign country of production in favour of some branch of our national industry. In this endeavour we but seldom proved successful. The feeling of commercial rivalry too generally disposes governments to imagine that any proposals to such an effect must have some covert and selfish aim; and, having once rendered our proposed relaxation contingent upon some corresponding proceeding on the part of another country, the refusal of our offers was allowed to bind us to the continuance of a course known and felt to be prejudicial to ourselves. Would it not have shown greater wisdom and magnanimity in us to take our measures independently of the conduct of others, in the full assurance that the course of events must soon have led to the willing adoption of principles from which foreign governments might have been deterred solely through misapprehension of our motives? The commercial greatness of this country was achieved under the prevalence of a system of restriction and monopoly favoured by circumstances altogether different from those in which the States of Europe are placed at this time. We have become convinced that a rigid perseverance in that system of exclusiveness, if even it were practicable, would now be no longer profitable, and have been at much pains to produce this conviction in the minds of other people, both by means of the Press and by negotiations, but we too long left comparatively untried the strongest argument that could be used in favour of our altered views - that afforded by our unreserved adoption of a more liberal policy. The success that accompanied our restrictive regulations has been, not unreasonably perhaps, mistaken for their effect, and it was required from us that we should give to the world a practical illustration of our conversion before we could expect to produce a conviction of our sincerity. The necessity for our adopting such a course was shown very forcibly during the Nation.

${ }^{1}$ This passage appears in both the two last editions of Porter's Progress of the 
discussions in the American Congress which preceded its adoption of the tariff in 1824, and which are thus described in the dispatch of our minister at Washington to Canning, dated 30th May in that year:-

“' The example of Great Britain,' says Mr. Addington, 'has been adduced as the main support of the arguments used on either side, both parties admitting with equal zeal and admiration the fact of her unrivalled prosperity, but each ascribing it to those grounds which best suited their own line of reasoning. The recent measures adopted by her for the liberalization of her external commercial system, and her emancipation from her ancient system of restriction, are pretty generally ascribed by the advocates of the tariff to a desire to inveigle other nations into an imitation of her example, with the intention, as soon as they shall have embarked sufficiently deeply in her schemes, of turning short round upon them, and resuming to their detriment her old systein of protection and prohibition. This scheme, they affirm, Great Britain will, by her superior means, be enabled to execute without hazard to herself.'"

The following passage taken from Addington's letter on the same occasion will show how practically mischievous to ourselves are the restrictions which we lay upon the importation of foreign produce:- "I have only to add, that had no restrictions on the importation of foreign grain existed in Europe generally, and especially in Great Britain, I have little doubt that the tariff would never have passed through either House of Congress, since the great agricultural States, and Pennsylvania especially, the main mover of the question, would have been indifferent if not opposed to its enactment."

In examining the details of the public expenditure, we cannot fail to be struck with the exceedingly great proportion that is absorbed by the expense attending the naval and military force which circumstances have made it necessary for us to maintain. In the last year of the war (1814) the sums expended for the army, navy, and ordnance service, amounted to $£ 71,686,707$, and if to this sum is added the interest of the debt, all of which had been incurred in the prosecution of wars, it will be seen that these branches of expenditure amounted, in that one year, to $£ 101,738,072$, a large part of which was expended in foreign countries, and consequently was abstracted from the capital of the nation. The drain upon our resources which had been thus in operation for a continuous series of years affords alone quite sufficient explanation of the state of exhaustion in which the country was placed during the first few years that followed the restoration of peace, without our being required to ascribe any part 
of the evil to the cause so vaguely assigned at the time, namclythe transition from war to peace. In an opposite state of circumstances, where the transition should be from peace to war, it is easy to conceive that such a destruction of property might be encountered as would bring on a considerable derangement of the commercial dealings of the country, but that the return of peace, accompanied as it is by a remission of taxes, and by the opening of various channels that had before been closed against our trade, should produce evils of the nature alluded to, appears little better than a practical contradiction. The country did, indeed, at that time exhibit all the signs of exhaustion, and the single fact of that exhaustion appearing after the restoration of peace was received as sufficient proof that it was caused by the cessation of war. The ceasing of a war demand for various articles consumed by the army, or which were exported to provide payment of our loans and subsidies to foreign countries, may have occasioned loss to the comparatively small number of individuals who had supplied the Government, or had conducted certain branches of the export. trade; but those persons, and those departments of business must have been insignificant when compared with the great mass of our commercial dealers, who must have benefited by the change. Had we not been placed by the lavish expenditure of the latter years of the war in a state unfavourable for taking advantage of the beneficial alteration in the years immediately following the find overthrow of Napoleon, they must have been to us years of the highest prosperity. The prices of those articles generally, of which we were buyers, fell, while on the contrary the goods which we had to offer in exchange rose in value. During the ten years between 1805 and 1814 the Government expenditure exceeded $£ 800,000,000$; and although some considerable part of this amount doubtless came back to individuals, and prevented that expenditure from being altogether a loss of capital to the country, the part which found its way to foreign lands, without producing any immediate return, was greater than we could bear without suffering, and was, in all reasonable probability, the cause of the difficulties which bore so hard upon our merchants in the few following years, and before the benign influence of peace had adequately remedied the evil.

The following statement shows the amount expended in each year from 1801 to 1849 , under the heads of nary, army, and ordnance expenses :- - 
Amount Expended from 1801 to 1849

\begin{tabular}{|c|c|c|c|c|c|c|c|}
\hline & Year. & & & Navy. & Army. & Ordnance. & Total. \\
\hline & & & & $\stackrel{£}{£}$ & $\stackrel{\mathfrak{E}}{\mathrm{E}}$ & $\stackrel{£}{£}$ & $\stackrel{£}{£}$ \\
\hline 1801 . & - & - & • & $17,266,135$ & $17,752,947$ & $2,197,186$ & $37,216,268$ \\
\hline 1802 . & . & - & $\cdot$ & $\begin{array}{r}12,037,162 \\
80728 \%\end{array}$ & $11,836,407$ & $1,142,839$ & $25,016,408$ \\
\hline 1803 . & . & . & . & $8,072,878$ & $13,488,080$ & $2,029,799$ & $23,590,757$ \\
\hline 1804 . & . & . & . & $11,921,551$ & $17,927,422$ & $4,046,054$ & $33,895,027$ \\
\hline 1805. & . & . & . & $14,493,843$ & $19,790,181$ & $5,105,426$ & $39,389,450$ \\
\hline 1806 . & . & - & . & $16,143,628$ & $19,294,982$ & $5,250,376$ & $40,688,986$ \\
\hline 1807 . & . & . & . & $16,896,661$ & $19,373,101$ & $4,260,079$ & $40,529,841$ \\
\hline 1808 . & . & . & . & $17,685,390$ & $21,916,198$ & $5,148,852$ & $44,750,440$ \\
\hline 1809 . & . & . & . & $19,372,061$ & $23,910,222$ & $4,928,674$ & $48,210,957$ \\
\hline 1810 . & . & • & . & $20,021,512$ & $23,038,479$ & $4,808,745$ & $47,868,736$ \\
\hline 1811 . & . & 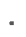 & . & $19,202,679$ & $29,160,530$ & $1,495,816$ & $52,859,025$ \\
\hline 1812 . & . & . & . & $20,370,339$ & $31,004,701$ & $5,240,537$ & $56,615,577$ \\
\hline 1813 . & . & . & . & $21,833,522$ & $44,241,285$ & $5,241,628$ & $71,316,435$ \\
\hline 1814 . & . & 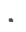 & . & $22,124,437$ & $45,259,377$ & $4,302,893$ & $71,686,707$ \\
\hline 1815 . & . & . & . & $16,073,870$ & $35,321,544$ & $3,248,759$ & $54,644,173$ \\
\hline 1816. & . & . & . & $9,516,325$ & $15,027,898$ & $2,748,841$ & $27,293,064$ \\
\hline 1817. & . & . & . & $6,473,063$ & $9,718,066$ & $1,417,648$ & $17,608,777$ \\
\hline 1818. & . & . & . & $6,521,714$ & $7,785,979$ & $1,247,197$ & $15,554,890$ \\
\hline 1819 . & . & . & . & $6,395,553$ & $8,998,037$ & $1,243,639$ & $16,637,229$ \\
\hline 1820 . & . & & . & $6,38 \pi, 799$ & $8,944,814$ & $1,092,292$ & $16,424,905$ \\
\hline 1821 . & . & & . & $6,107,280$ & $9,138,845$ & $1,183,727$ & $16,429,852$ \\
\hline 1822 . & . & 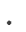 & . & $5,042,642$ & $7,698,974$ & $1,007,821$ & $13,749,437$ \\
\hline 1823. & . & & . & $5,613,151$ & $7,351,992$ & $1,364,328$ & $14,329,471$ \\
\hline 1824 . & . & & . & $6,161,818$ & $7,573,026$ & $1,407,308$ & $15,142,152$ \\
\hline 1825 . & . & & . & $5,849,119$ & $7,579,631$ & $1,567,087$ & $14,995,837$ \\
\hline 1826 . & . & & . & $6,540,634$ & $8,297,361$ & $1,869,606$ & $16,707,601$ \\
\hline 1827 . & . & & & $6,444,727$ & $7,876,682$ & $1,914,403$ & $16,205,812$ \\
\hline 1828 . & . & & & $5,667,970$ & $8,084,043$ & $1,446,972$ & $15,198,985$ \\
\hline 1829 . & . & & . & $5,902,339$ & $7,709,372$ & $1,569,150$ & $15,180,861$ \\
\hline 1830 . & . & & . & $5,309,606$ & $6,991,163$ & $1,613,908$ & $13,914,677$ \\
\hline 1831. & . & & . & $5,689,859$ & $7,216,293$ & $1,472,944$ & $14,379,096$ \\
\hline 1832 . & . & & . & $4,882,835$ & $7,129,874$ & $1,792,317$ & $13,805,026$ \\
\hline 1833. & . & & 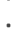 & $4,360,235$ & $6,590,062$ & $1,314,806$ & $12,265,103$ \\
\hline 1834 . & . & & & $4,503,909$ & $6,493,925$ & $1,068,223$ & $12,066,057$ \\
\hline 1835 . & . & & . & $4,099,430$ & $6,406,143$ & $4,151,914$ & $11,657,487$ \\
\hline 1836. & . & & & $4,205,726$ & $6,473,183$ & $1,434,059$ & $12,112,968$ \\
\hline 1837 . & . & & & $4,750,658$ & $6,521,716$ & $1,444,523$ & $12,716,897$ \\
\hline 1838 . & . & & • & $4,520,428$ & $6,815,641$ & $1,384,681$ & $12,720,750$ \\
\hline 1839 . & . & & & $5,490,204$ & $6,542,662$ & $1,951,210$ & $13,984,076$ \\
\hline 1840 . & . & & & $5,597,511$ & $6,890,267$ & $1,631,640$ & $14,119,418$ \\
\hline 1841. & . & & & $6,489,074$ & $6,418,422$ & $1,815,132$ & $14,722,628$ \\
\hline 1842 , & . & & & $6,640,163$ & $5,987,921$ & $2,174,673$ & $14,802,757$ \\
\hline 1843 . & . & & & $6,606,057$ & $5,997,156$ & $1,910,704$ & $14,513,917$ \\
\hline 1844. & . & & & $5,858,219$ & $6,178,714$ & $1,924,311$ & $13,961,244$ \\
\hline 1845. & . & & & $6,809,872$ & $6,744,589$ & $2,109,707$ & $15,664,168$ \\
\hline 1846 . & . & & & $7,803,464$ & $6,699,699$ & $2,361,534$ & $16,864,697$ \\
\hline 4847 . & . & & . & $8,013,873$ & $7,540,405$ & $2,947,869$ & $18,502,147$ \\
\hline 1848. & . & & & $7,922,287$ & $6,647,284$ & $3,076,124$ & $17,645,695$ \\
\hline 1849 . & . & . & . & $6,942,397$ & $6,549,109$ & $2,332,031$ & $15,823,537$ \\
\hline
\end{tabular}

According to this table, the total cost of armaments and war up to the middle of the nineteenth century exceeded 1200 millions of money; $52 \frac{1}{2}$ per cent. of which was expended in the fourteen 
years of war, while the remaining $47 \frac{1}{2}$ per cent. has been incurred in the thirty-five years of peace, namely:-

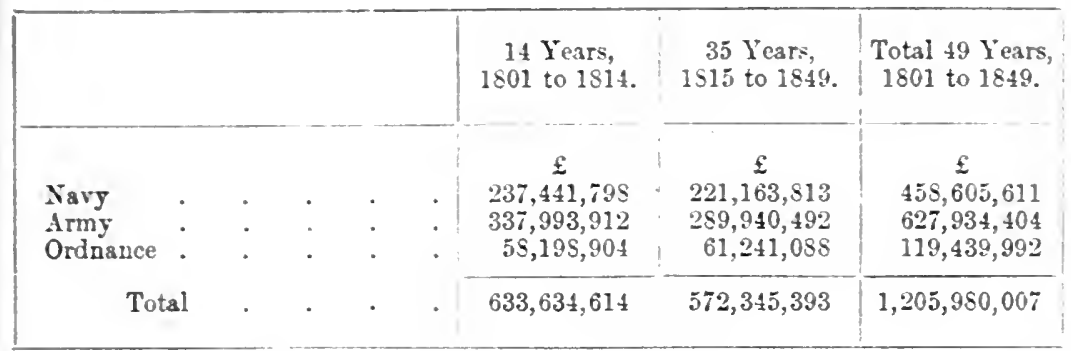

The average annual expenditure under these three heads was, in the fourteen years ending with $1814, \mathfrak{f} 45,259,615$ : in the thirty-five years ending with $18 \pm 9$ it declined to $£ 16,352,725$. If we confine the comparison of the expenditure for national defence to the six years ending with 1836 , it will be found that the average amount in this latter period was $£ 12,714,289$, or less by 72 per cent. than it was previous to 1814. In the sixteen years between 1815 and 1830 the average annual expenditure for naval and military purposes was $£ 18,751,108$, compared with which the cost in the six years ending with 1836 exhibits a saving of 32 per cent. In the six years from 1809 to 1814 the expenditure for army, navy, and ordnance services was $£ 348,557,538$, being an annual average of $£ 58,092,906.1$

One source of public expenditure which bore very hard upon our national resources during the war consisted of the amount of loans and subsidies paid to foreign countries. The aggregate sum thus abstracted from the national resources in the twenty-two years

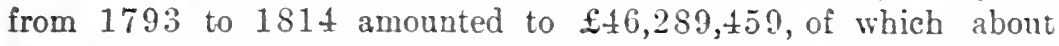

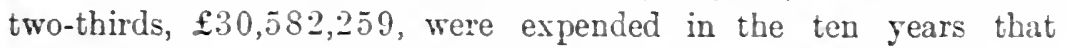
preceded 1814. Almost every country and principality in Europe received one or more of these loans and subsidies, besides arms, munitions, clothing, and stores from the British Government.

The remaining branches of public expenditure that call for notice are the Ciril List, or the provision made by Parliament for the support and dignity of the Crown, including the salaries and

1 The armaments of 1910 , during the greatest and most desperate of all our wars, cost, it will be observed, mach less than the armaments of 1910, a year of profound peace. 
expenses of the various great officers of state, and the annual votes made for miscellaneous services.

The sums disbursed under these two heads in every tenth year from 1805 to 1845 , and in 1849 , were as follow :-

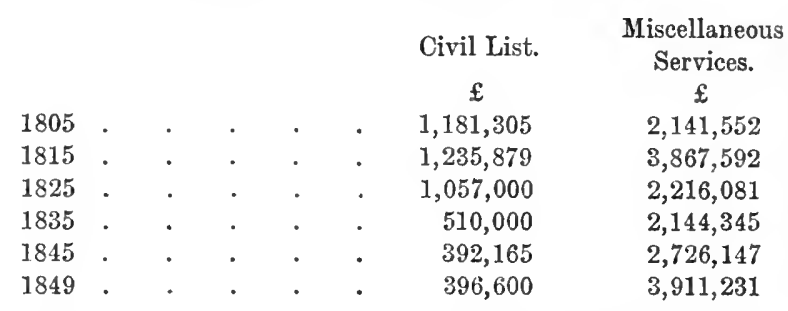

The history of the Civil List first dates from the accession of Queen Anne in 1701, when, in consideration of an annuity of

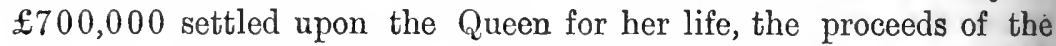
Crown lands and of certain excise duties, which had been granted by Parliament to Charles II and his successors, were surrended to the public. The sum here mentioned was applied to defray the expenses of the Queen and her household, to pay the salaries of her ambassadors and other representatives in foreign countries, and to provide for the administration of justice at home, as well as some other minor charges which had previously been defrayed by the Crown out of the revenues that were relinquished. This arrangement ceased at the death of the Queen, when the hereditary revenues reverted to the Crown; but the precedent made by Queen Anne, as here described, has since been followed at the accession of each succeeding monarch. At the beginning of the reign of George III the Civil List was fixed at $£ 800,000$ per annum, to which sum additions were made from time to time, partly on the ground of the general enhancement of prices caused by the depreciation of the currency: the sums paid on this account from the consolidated fund in each year from 1801 to the accession of George IV, in 1820 , may be known from the foregoing table. By the arrangement made between George IV and the Parliament in 1820, some part of the charge upon the Civil List was transferred to the consolidated fund, and the payments on the former account were fixed at $£ 850,000$ per annum. On the accession of William IV a fresh distribution of these charges was made, expenses which had no immediate connexion with the royal dignity were transferred to the consolidated fund, and the Civil List was voted under five different classes, amounting in the aggregate to $£ 510,000$ per annum, as follows:- 


\section{PUBLIC REVENUL AND EXPENDITURE, 1800-1850 635}

1st Class. -For the King's Privy Purse, $£ 60,000$; for the Queen, $£ 50,000$

$£ 110,000$

130,000

171,500

23,200

75,000

$£ 510,000$

On the accession of Queen Victoria, a Committee of the House of Commons was appointed to inquire into the subject of this branch of the public expenditure; and in compliance with the report and recommendation of that committee, an Act was passed in which the principle adopted in 1830 bas been preserved, and the Civil List was fixed at $£ 3 \$ 5 \tilde{0}, 000$ per annum, with a power to the Crown to grant pensions to an amount not exceeding £1200 in any one year. The heads of the arrangement were-

\begin{tabular}{|c|c|c|c|}
\hline 1 st $\mathrm{C}$ & lass & -For the Queen's Privy Purse . & $\{60,000$ \\
\hline 2nd &, & Salaries of Queen's Household and Retired & \\
\hline & & Allowances . & 131,260 \\
\hline 3rd & ", & Expenses of the Royal Household . & 172,500 \\
\hline 4 th & , & Royal Bounty, Alms, and Special Services & 13,200 \\
\hline 5 th & $"$ & Pensions to the extent of $£ 1200$ per & \\
\hline & & annum & \\
\hline & ", & Unappropriated MIoneys . & $8,0 \pm 0$ \\
\hline & & & \\
\hline
\end{tabular}

It would appear from a return that was laid upon the table of the Honse of Lords in December 1837, that during the three reigns of George the Third, George the Fourth, and William the Fourth, the public gained considerably by the arrangements that have been here described. In the first of these reigns, which embraced a period of 591 years, the sum paid to the Civil List, including $£ 3,395,062$ granted at various times for the discharge of debts contracted on that account, amounted to $\mathfrak{f} 56,975,451$, while the amount of the King's lereditary and temporary revenues given up to the public realized $£ 75,138,695$, showing a gain to the public of $£ 18,16:, 244$. In the reign of George $w$, which occupied about $10 \frac{1}{2}$ years, the payments to the Crown were $£ 8,847,987$, and the receipts by the public $£ 19,732,732$, showing a saving of $£ 10,884,745$; and in the seven years which comprised the reign of William iv the payments were $£:, 561,59: 3$, while the receipts were $f 21,913,388$, so that the public appears to have gained, by the arrangement with the late king, $£ 18,351,745$. The saving effected during the reign of the three kings amounted, 
according to this return, to $£ 37,399,784$. The increasing receipts from the ceded revenues have of late years made the bargain more favourable to the public than formerly, but it must be kept in mind that many charges once borne by the Crown and now defrayed by the public are not included in this statement.

The Crown is entitled to certain revenues as Duke of Lancaster and (while there is no heir apparent) as Duke of Cornwall also; which revenues have not hitherto been relinquished to the public.

The difference observable between the amount of the Civil List granted at the beginning of his reign to William $\mathrm{IV}$, and that established in 1837, was occasioned, first, by the absence at that time of a consort, and next, by economies made regarding pensions.

The sums included in the foregoing table under the head of Miscellaneous Services comprise a great variety of objects, and necessarily differ materially from year to year. The nature of these services will be sufficientiy indicated by the following abstract, which is taken from the Finance Accounts for 1845 :-

Civil Contingencies . $£ 78,38014 \quad 5$

Public Works and Buildings, including New Houses of Parliament 372,928156

Salaries and Expenses of Public Departments . . . 754,304 182

Law and Justice . $\quad . \quad$. $\quad . \quad 0 \quad 653,144132$

Education, Science, and Art $\quad$. $\quad . \quad$. $\quad . \quad$. $\quad$. 288,176158

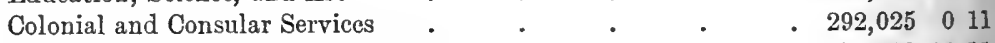

Superannuations and Retired Allowances . . . 170,4891411

Special and Temporary Objects . . . . 116,6961010

$£ 2,726,147 \quad 3 \quad 7$

No statement has been made public of the amount paid for salaries in the various departments of the public service during the years that elapsed prior to 1815 . During the war that branch of expenditure had gone on at a constantly increasing rate of progression, and in the year just mentioned had reached the sum of $£ 3,763,100$. It will be seen from the following statement that in the twenty years that followed, reductions to the amoun of 26 per cent. were made. These reductions would have been greater, but for the annual allowances it was considered just to make to persons whose offices were abolished, and who enterec the public service upon the faith of such a provision being made.

The charge for salaries in the various public departments of 
the kingdom in each year, from 1815 to 1835 , was as follows :-

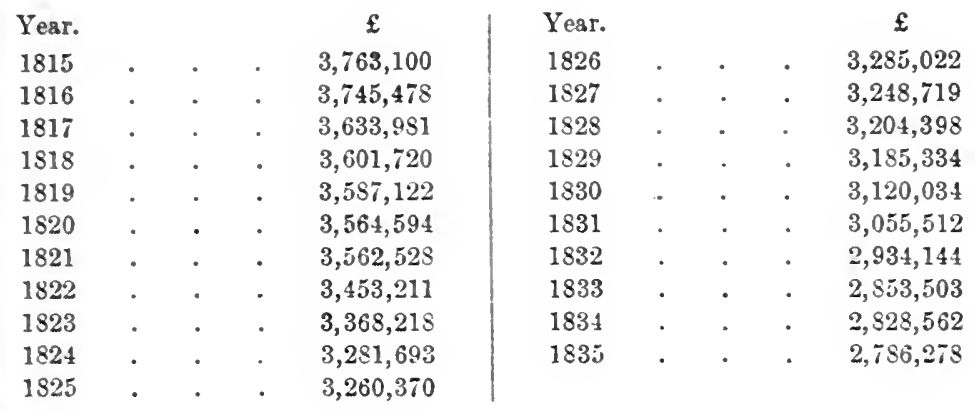

The number of persons employed in the various departments (exclusive of army, navy, etc.), and the amount of salaries paid in each department in the years 1815 and 1835 , are shown in the following table, from which it appears that the reduction since the war came to 3787 persons and $£ 976,822$, being about $1 \pm$ per cent. in the number and 26 per cent. in the amount. It appears from a statement presented to Parliament in 1828 , but which exhibits several omissions and cannot be received with much confidence, that the reduction in the twelve years from 1815 to 1827 embraced 1686 persons and $£+13,532$, or 6 per cent. in number and 11 per cent. in amount: according to which statement there were reductions made in the eight years from 1827 to 1835 amounting to 2101 persons and $£ 563,290$ of annual charge, or 8 per cent. in number and nearly 17 per cent. in amount. The reductions between 1815 and 1835 would have appeared much more considerable, but for the addition of 3913 persons forming the preventive coastguard under the Commissioners of the Cnstoms, whose salaries, amounting to $£ 259,916$ per annum, had before been paid out of the Navy Estimates. 


\begin{tabular}{|c|c|c|c|}
\hline \multirow{2}{*}{\multicolumn{2}{|c|}{ 突 }} & 崖要 & 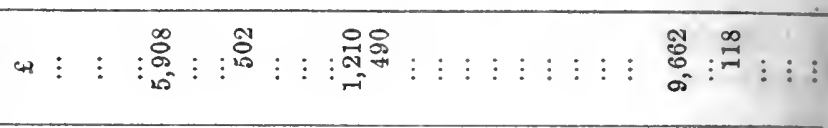 \\
\hline & & 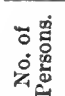 & 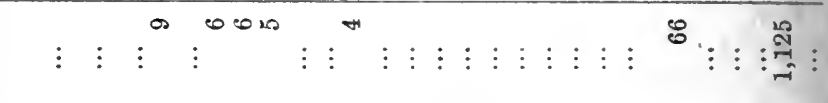 \\
\hline \multirow{2}{*}{\multicolumn{2}{|c|}{ 害 }} & 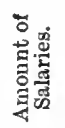 & 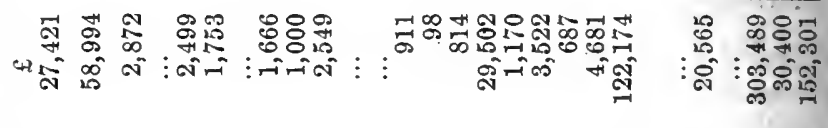 \\
\hline & & 密 & : \\
\hline \multirow{4}{*}{ 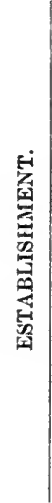 } & \multirow{2}{*}{ 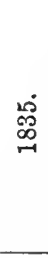 } & 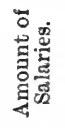 & 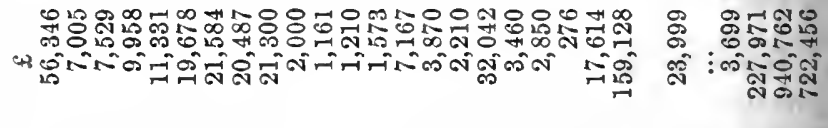 \\
\hline & & 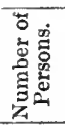 & 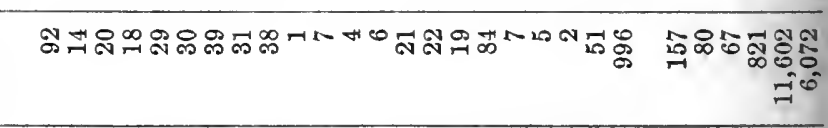 \\
\hline & \multirow{2}{*}{$\underset{\substack{\infty \\
\infty \\
\rightarrow \infty}}{\rightarrow-1}$} & 要 & 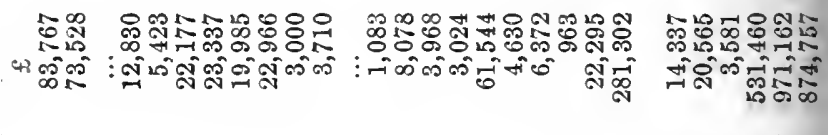 \\
\hline & & 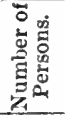 & 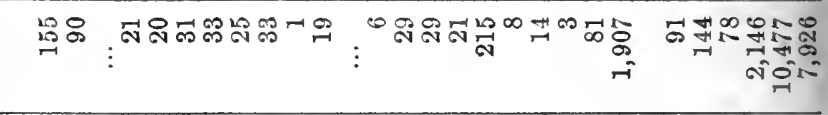 \\
\hline & 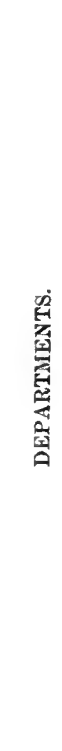 & & 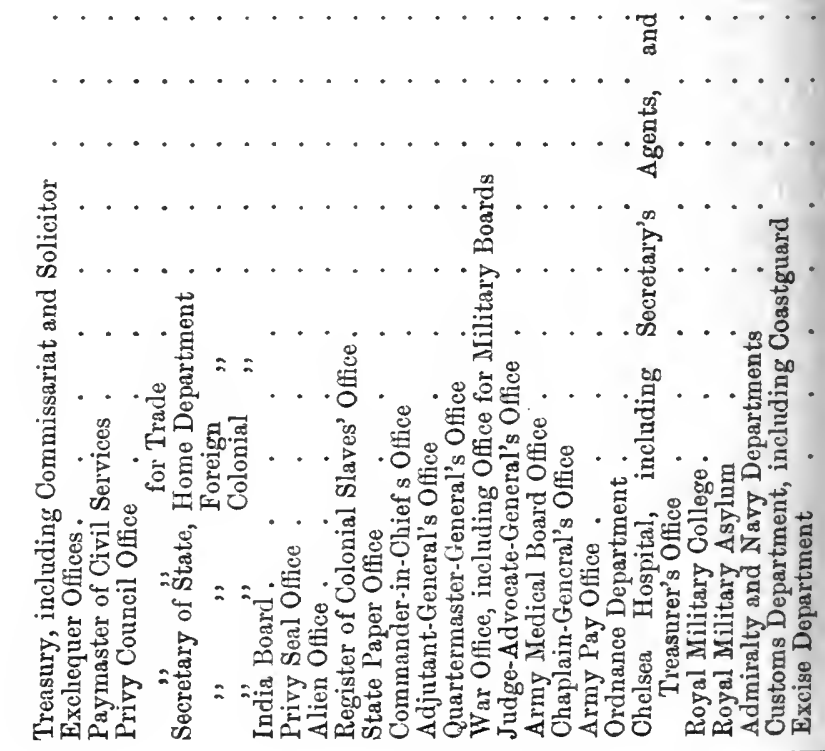 \\
\hline
\end{tabular}




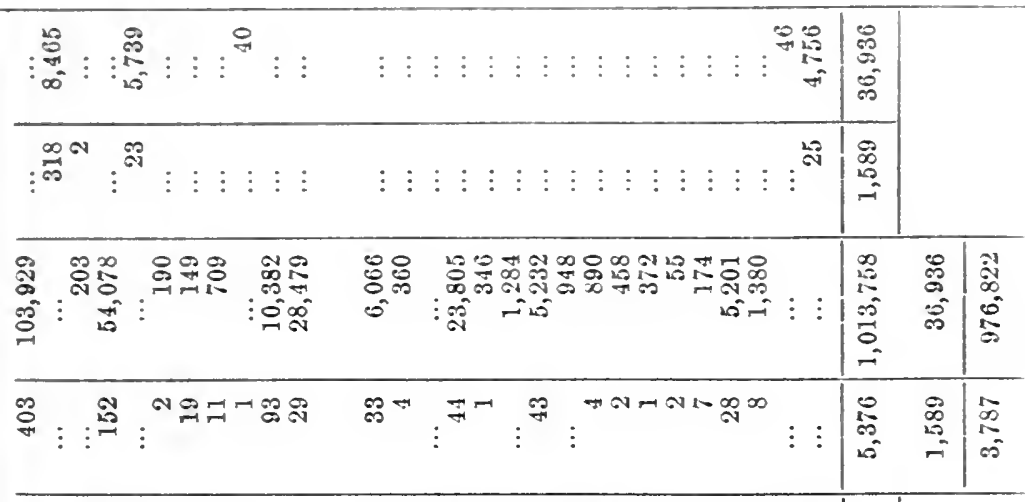

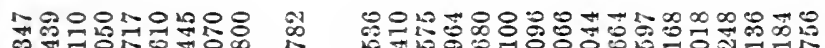

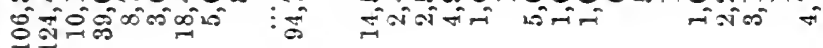

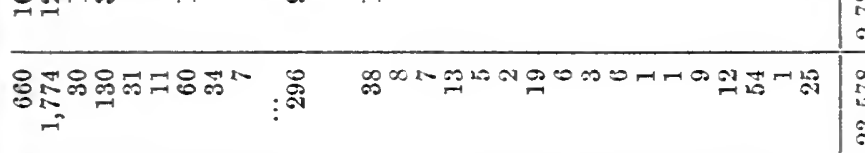

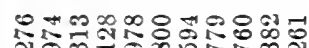

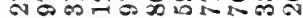

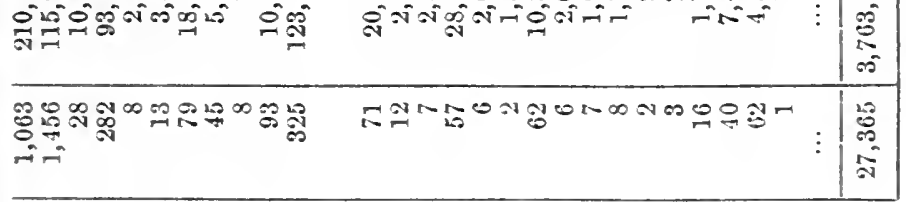

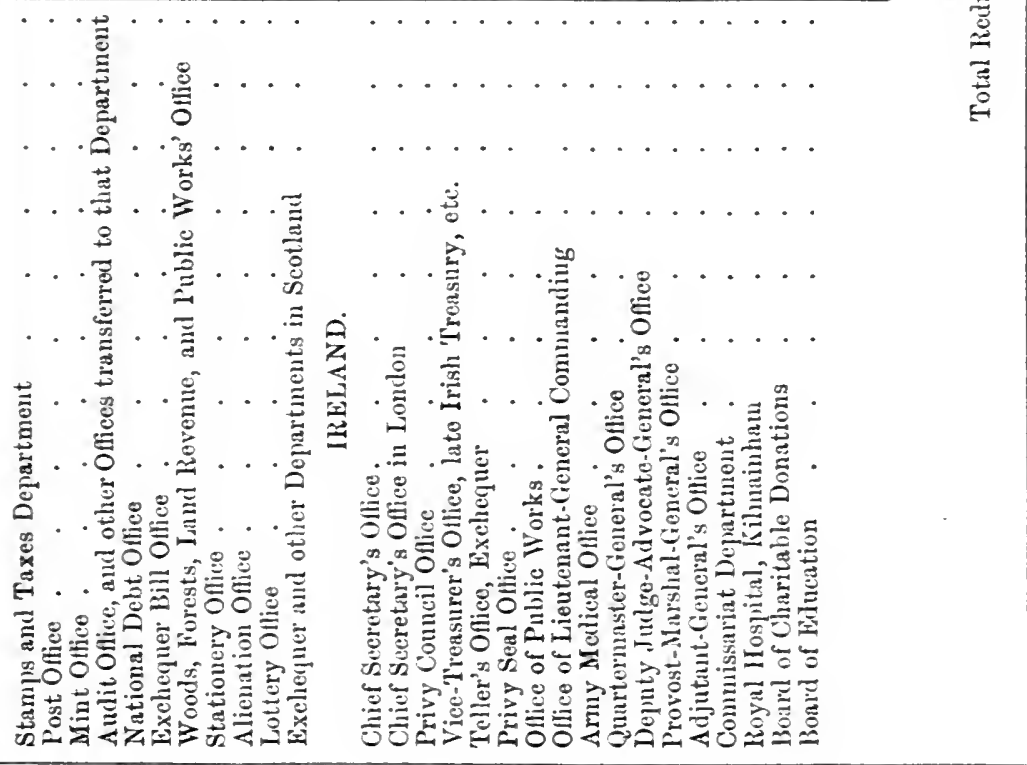




\section{CHAPTER XXXVI}

\section{NATIONAL EXPENDITURE AND DEBT, 1850-1910}

National expenditure in 1851-Movements of revenue and debt from 1867-General survey of expenditure-The national debt-The army expenditure-Naval expenditureCivil services

TN 1851, the year when Porter's last edition was published, the total national expenditure (including $£ 4,237,577$ for collecting

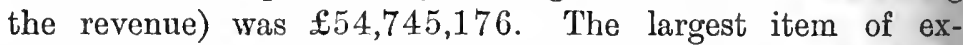
penditure then was the charge for interest and management of the national debt, $£ 28,117,584$. Then came the Army and Ordnance, $£ 8,955,061$; the Civil List and Civil Charges, $£ 6,997,071$; and finally the Navy, $£ 6,437,883$. At that time the taxpayer was in a fortunate position; for, while on the one hand, as a consequence of the Reform Bill of 1832 and the purification of the tariff, the old system of robbery and corruption was being rapidly swept away; on the other hand, the poorer classes were not yet organized or powerful, nor had the great contractors yet fastened a policy of constant expansion upon the Admiralty and the War Office. Leading statesmen on both sides were always for economy in opposition, and were not easily induced to adopt extravagant schemes when in office. But for this spirit it would bave been impossible to remove such enormous burdens of taxation from the people without imposing very heavy direct imposts. In 1874, when Mr. Gladstone offered to repeal the income-tax, the taxes on cousumption were probably no heavier than now, while the taxes on property were very much lighter.

In the succeeding chapter we shall survey the commercial policy and the movements of taxation from 1840 to 1910 . The two outstanding events in the history of expenditure are the Crimean 'War and the South African War. The first added to the debt and for a time raised the expenditure. But the opposition to extravagance was at that time very strong, and ultimately prevailed. When the South African War broke out, public and 640 
private waste were already enormous, and thenceforward the floodgates of expenditure were opened wide.

If we turn to details we find that, starting in 1857, after the Crimean War, the army estimates were much enlarged during the first decade, but thereafter remained at much about the same figure for forty years. They began to grow just before the South African War, and when that was over an alarming increase in both the size and the cost of the establishment was demanded and sanctioned, despite the protests of the Liberal party then in opposition. The cost of the Civil Services has risen as the natural consequence of multiplied and enlarged activities in all directions, and the advance has been especially heavy during the last twenty years. But the civil estimates include large grants for education, poor law, the improvement of roads and health, and many other services which conduce to national well-being. It stands on a very different economic level from armaments, which represent the workings of international discord and jealousy. In the last thirty-two years the cost of the navy has almost trebled, and no less than 12 millions were added between 1909 and 1911. With a falling birth-rate and a slowly increasing population, the increase of unproductive expenditure is becoming an intolerable burden.

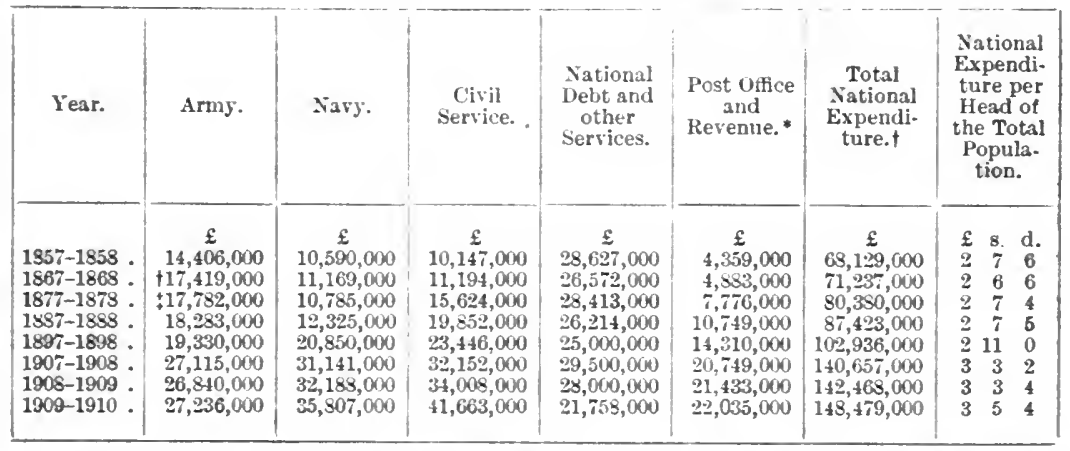

* Including the total expenditure of the Post Office, Customs, and Inland Revenue Departments. t Includes $£ 2,000,000$ tor Abyssinian War.

I Includes $\mathfrak{E} 3,500,000$ vote of credit for Russo-Turkish War.

The total figures, it is true, are swollen by post-office expenditure, which is more than covered by revenue from stamps, etc.

Owing to the inmensely increased vote for the Civil Services and the Navy, the estimated expenditure of 1910-1911 showed an enormous jump of nearly fourteen millions beyond the actual expenditure of the financial year ending March 31, 1910, and the budget of 1911 showed another upward bound of nine millions to the 
gigantic total of $\mathfrak{1} 180,984,000$. The remarkable thing is that Mr. Lloyd George's budget of 1909 has proved such a tremendous engine that the revenue has expanded as rapidly as the expenditure. But the taxation of wealth is already leading to evasion of incometax, as well as to steady sales of consols, under which Government securities have been falling for several years, in spite of peace, prosperity, and an active sinking fund. A clear idea of the changes in the levels of national expenditure will be obtained by comparing the figures of 1897-1898, before the Boer War, with those of 19091910 - twelve years later.

We take, first of all, the Consolidated Fund Services, which fall into two divisions, the first being set apart for the National Debt. This service again subdivides under four heads :-

IA.—National Debt Services

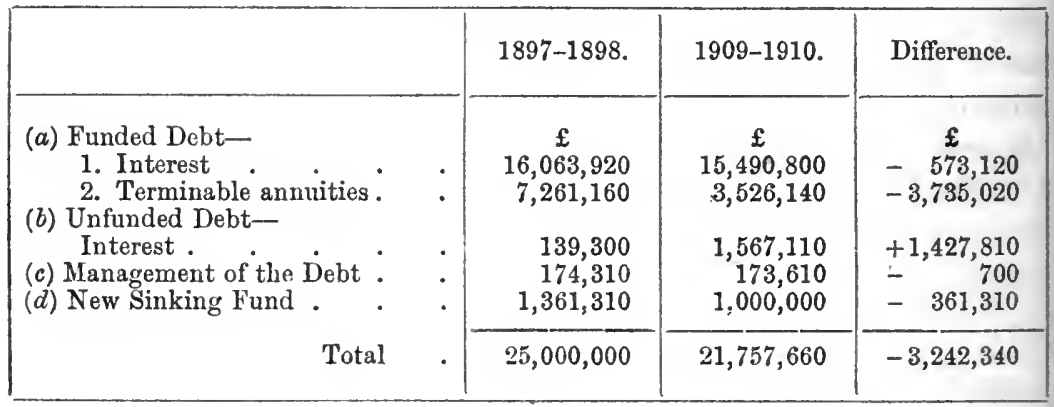

It may be mentioned that, in spite of the reduction of interest from $2 \frac{3}{4}$ to $2 \frac{1}{2}$ per cent., which occurred in the interval, taxpayers were paying in 1907 a debt charge $4 \frac{1}{2}$ millions greater than ten years previously. And if the interest on Works Debt had been added, the showing would have been much worse. But the Liberal Government has made large reductions of debt, and even in 1910 with a reduced charge there was still a substantial and operative sinking fund provided for in Mr. Lloyd George's Budget. The new sinking fund was interfered with in 1909-1910 by the rejection of the Budget in the House of Lords; in the following year it amounted to $£ 4,112,961$.

The second division of the Consolidated Fund Service comprises the items given in a table on the following page.

King George's Civil List (which covers about half the charge on taxpayers for supporting the King and the royal household) exceeds by more than $\mathfrak{E} 60,000$ that of Queen Victoria, and is practically a reproduction of that of King Edward. A curious feature of the 
IB.-Other Consolidated Fund Services

\begin{tabular}{|c|c|c|c|}
\hline & $1897-1898$ & 1909-1910. & Difference. \\
\hline $\begin{array}{l}\text { (a) Civil list. } \\
\text { (b) Annuities and pensions } \\
\text { (c) Salaries and allowances } \\
\text { (d) Courts of Justice } \\
\text { (c) Miscellaneous services } \\
\text { (f) Expenses under Coinage } \\
1891 \text { and } 1893 \\
\text {. }\end{array}$ & $\begin{array}{r}\stackrel{£}{£} \\
408,289 \\
291,109 \\
79,560 \\
512,483 \\
344,553 \\
250,000\end{array}$ & \begin{aligned} \multicolumn{1}{|}{} \\
470,000 \\
265,270 \\
72,330 \\
518,560 \\
327,390 \\
$\ldots\end{aligned}$ & $\begin{array}{l}£ \\
+\quad 61,711 \\
-\quad 25,839 \\
-\quad 7,230 \\
+\quad 6,077 \\
-\quad 17,163 \\
-250,000\end{array}$ \\
\hline Total & $1,885,994$ & $1,653,550$ & $-232,444$ \\
\hline
\end{tabular}

new settlement was the release of the King from income-tax, which had been paid by Queen Victoria and King Edward ever since its introduction by Sir Robert Peel. An addition to the Consolidated Fund Services appears for the first time in 1910-1911 under the head of Development and Road Improvement Funds, which are administered by the Development Commissioners (to assist agricultural education and experiments, horse-breeding, etc.) and by the Road Board. The total sum applied to these purposes in the year was $£ 1,362,641$.

The -second branch of expenditure is classified under the head of Supply Services, and here the outlay is entirely under the control and purview of Parliament and of the Government. The first three items, of course, command special attention, for it is on their movement that the increase of taxation mainly depends.

II.-Supply Services

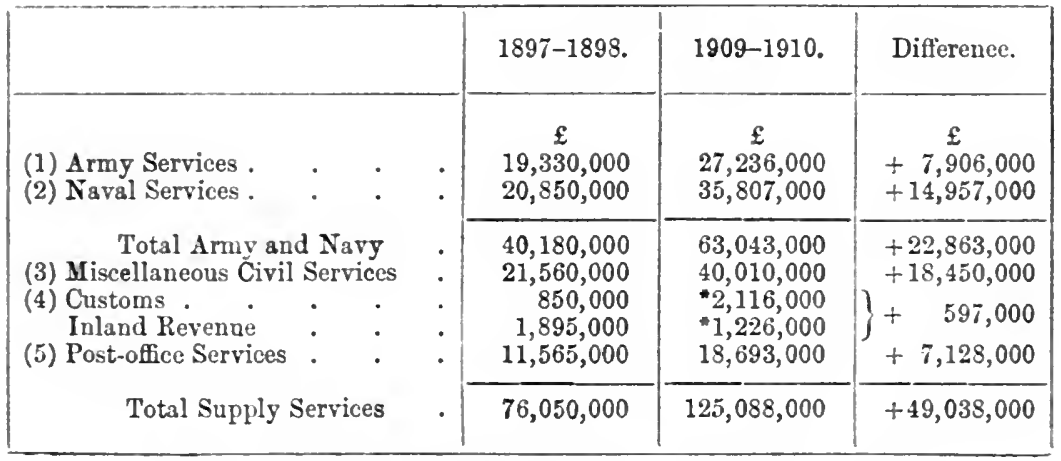

* Excise transferred from Inland Revenue to Customs, 1909-1910.

The post office, it should be observed, stands in a separate category ; for it does not impose a burden on the taxpayer, but appears 
to relieve him, as the revenue still largely exceeds the expenditure. The movement of postal revenue will be seen from the following:-

\section{Gross Revenue}

$\begin{array}{lccr} & & 1897-1898 . & 1909-1910 . \\ \text { Revenue from Post Office } & & £ 12,170,000 & £ 18,220,000 \\ \text { Revenue from Telegraphs } & \text {. } & 3,010,000 & 3,090,000 \\ \text { Revenue from Telephones } & \text {. } & \ldots & 1,720,000\end{array}$

The net revenue is obtained by deducting the cost of the Post Office Services from the above figures. The major part of the huge addition to Miscellaneous Service is due to Old-age Pensions.

There is one other important item on the expenditure side, which illustrates better than anything else the financial profligacy of the war period. In 1897 the vicious system of borrowing for works had already been introduced, but the taste for loan money had not yet been fully acquired by the great spending departments. It ended in 1904 (after the war) by swallowing up the sinking fund (which was nominally established after the war), thus giving the finishing touch to that heavy depreciation of public credit which the Boer War, with its enormous additions to the Funded and Unfunded Debt, had begun. Mr. Asquith's policy, begun in 1906, produced a marked improvement; for in 1907-1908 public borrowing had sunk below three millions, having exceeded eight in 1904-1905 and six millions in 1905-1906. In 1910 the borrowing was only a million-a substantial improvement even upon 1897-1898. The present Chancellor of the Exchequer and his predecessor in office deserve immense credit for cutting down these mischievous loans for unproductive works. But for this policy they could not have reduced the National Debt from 796 millions in 1905 to 733 millions in 1911. The following table illustrates these so-called capital issues:-

III.-Issues to meet other Expenditure

\begin{tabular}{|c|c|c|c|}
\hline & $1897-1898$ & 1909-1910. & Difference. \\
\hline $\begin{array}{l}\text { (1) Under Barracks Act, } 1890 \text { - } \\
\text { (2) Under Telegraph Acts, } 1892-1907 \\
\text { (3) Under Uganda Railway Act, } 1896 \\
\text { (4) Under Public Offices and Build- } \\
\text { ings Acts } \\
\text { (5) Under Naval Works Acts, } 1895- \\
1905 \\
\text { (6) Under Military Works Acts, } 1897- \\
1901\end{array}$ & $\begin{array}{c}£ \\
300,000 \\
160,000 \\
595,000 \\
350,000 \\
596,000 \\
750,000\end{array}$ & $\begin{array}{c}£ \\
\ldots \\
950,000 \\
\cdots \\
230,000 \\
\ldots \\
100,000\end{array}$ & $\begin{aligned} & £ \\
- & 300,000 \\
+ & 790,000 \\
- & 595,000 \\
- & 120,000 \\
- & 596,000 \\
- & 650,000\end{aligned}$ \\
\hline Total borrowings . & $2,751,000$ & $1,280,000$ & $-1,471,000$ \\
\hline
\end{tabular}


The remaining issues from the Exchequer, comprising " advances for bullion," issues for the redemption of debt, and Treasury bills paid off subject to renewal, raise technical difficulties, and we shall leave them on one side, as they do not really belong to our subject.

\section{Local Expenditure}

The accounts of local authorities necessarily take a longer time to consolidate than the national accounts, and the latest figures given are taken from the Statistical Abstract for 1911. The expenditure of the local authorities is defrayed partly out of revenues (rates, taxes, and profits) and partly out of loans. The revenues of the local authorities of the United Kingdom rose from 36 millions in $1867-1868$ to 101 millions in $1897-1898$, and to 163 millions in $1905-1906$, and to 168 millions in 1908-1909; while the local debt of England and Wales rose from 136 millions (£5 6s. 6d. per head) in 1S $79-1880$ to 482 millions ( $£ 1319 \mathrm{~s} .4 \mathrm{~d}$. per head) in 1905-1906, and 512 millions in 1908-1909.

\section{Course of the National Debt}

The course of the National Debt since 1836 is shown by an elaborate annual official return, ${ }^{1}$ from which the following facts are taken. The "aggregate gross liabilities" of the state were 846 millions sterling in 1836 , and were still 828 millions in 1850 . At the beginning of April 1854 the debt had been reduced to 802 millions, but was raised to 836 millions in 1857 by the Crimean War. Thence it fell to 800 millions in 1867 , and to 767 millions in 1875. In 1876 it amounted to 771 millions, but fell to $7: 39$ millions in 1885 . In 1886 the figure was 742 millions. Then another period of debt reductions commenced which lasted till 1899. On March 31 of that year the National Debt was only 635 millions. The following table gives the growth of Works Debt and of National Debt from 1893-1894 to 1904-1905. It has been extracted from Table VII on page 14 of the Statistical Abstract for the United Kingdom. The first column shows how the sinking fund was destroyed. The second shows the real growth of the National Debt.

${ }^{1}$ Return showing the aggregate gross liabilities of the State, etc., 1910 (Cd. 5206). 


\begin{tabular}{|c|c|c|c|c|}
\hline 1893-1894 & - & • & - & • \\
\hline 1894-1895 & . & . & . & . \\
\hline 1895-1896 & . & . & - & . \\
\hline $1896-1897$ & - & . & • & • \\
\hline 1897-1898 & - & . & . & . \\
\hline 1898-1899 & - & . & • & . \\
\hline 1899-1900 & - & . & • & - \\
\hline $1900-1901$ & - & - & • & - \\
\hline 1901-1902 & - & - & - & - \\
\hline $1902-1903$ & . & . & • & • \\
\hline $1903-1904$ & • & . & . & • \\
\hline 1904-1905 & - & - & . & . \\
\hline
\end{tabular}

Capital Liabilities Aggregate Gross Liaowing to borrowing bilities of the State, under various Acts. including Works Debt.

* The lowest point since the Napoleonic wars.

+ The highest point since 1870 .

The heavy borrowings for the Boer War, together with capital issues for military, naval, and other works, wiped out the savings of thirty-five years, raising the debt to 798 millions in 1903 .

The following table gives (1) the gross liabilities, and (2) the net increase or reduction in each financial year from 1892 to 1898 (before the Boer War), and from 1903 to 1911 (after the Boer War)

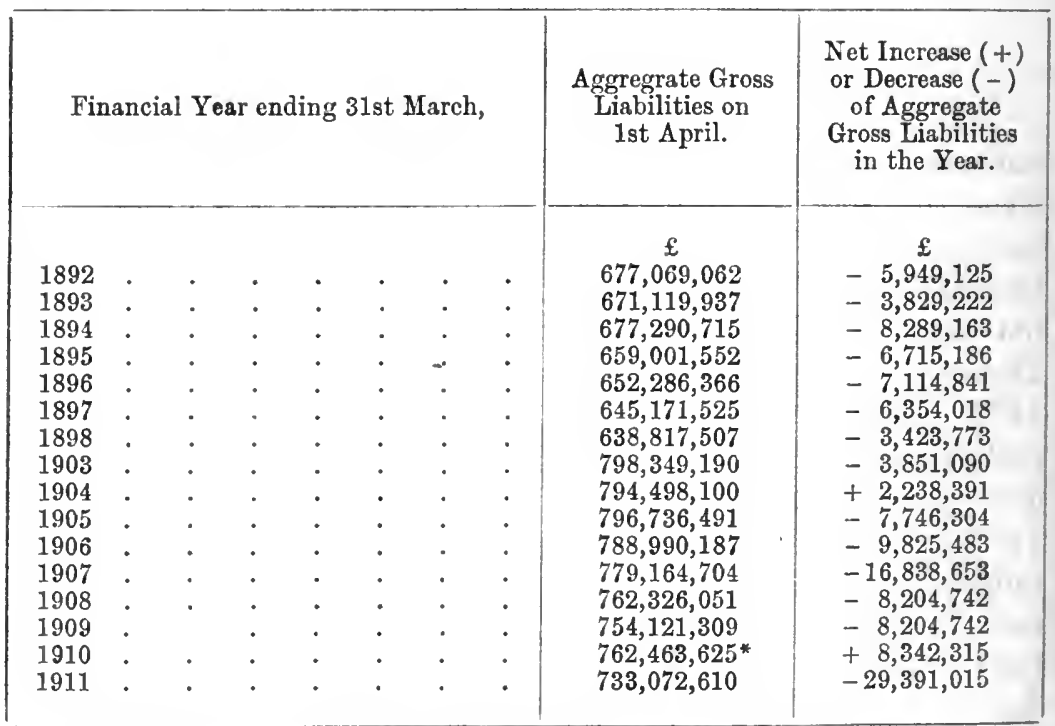

* Increase caused by financial dislocation following rejection of budget by House of Lords.

It will be seen that, thanks to the vigorous policy of $\mathrm{Mr}$. Asquith in cutting down capital expenditure and so increasing the 
real surplus for the reduction of debt (which policy was assisted by large surpluses of revenue), over sixty-three millions of National Debt were cancelled-nearly one-third of the total added during the Boer War. This is far the most striking achievement in the history of the National Debt, under the beneficent double operation of the old and new sinking funds.

\section{The National Expenditure or the Army}

From 1841 until the Crimean War the expenditure upon the army (including ordnance) remained almost stationary at about nine millions a year; but the revenue grew rapidly with the expansion of commerce and wealth under the influence of Free Trade, the taxes becoming at once fewer in number, less burdensome, and more productive. The Crimean War of course changed all this, doubling the income-tax and leaving forty millions of debt behind it; yet it is remarkable how much more easily we bore our share of the cost than our French allies or our Russian foes. In 1857 , however, the inevitable reaction after war brought commercial failures and severe unemployment as the winter came on. But what happened as the immediate result of peace is particularly instructive. The original estimates for 1856 were-Army, $£ 34,998,000$; Navy, $£ 19,876,000$; but as pence was concluded in May, the actual sums spent were $£ 20,811,000$ and $£ 13,459,000$. Next year, when Parliament met, Lord Palmerston and his colleagues were believed to be in favour of retaining the war taxes, so that they might keep military and naval expenditure at a high level. Neither Europe nor Asia appeared inclined for peace, and it might have been thought that the moment was ill-suited for any movement in the direction of reduced armaments. But there were strong men in the House of Commons, and the three leading statesmen outside the Government-Lord John Russell, Mr. Disraeli, and Mr. Gladstone-joined hands in the struggle for economy, and, undismayed by the threatening aspect of affairs in other countries, pressed their opinions with a determination and a courage which more modern statesmen seldom display.

Mr. Disraeli began the campaign by announcing that he would move resolutions against the continuance of war taxation. "By so doing," he said, "I think we shall give a great impetus to salutary economy, and shall in a most significant manner express our opinion that it is not advisable that England should become what is called 'a great military nation.'” Mr. Gladstone proposed 
to "grapple with" the estimates, "not by nibbling at them here and there, but by a general motion taking the sense of the House upon the expediency of saddling the country with such a charge." Lord John Russell quoted the precedent of 1816, when the estimates were withdrawn and reduced, and insisted on the need for "low establishments in time of peace." The three statesmen carried the House with them, and their policy was practically accepted by the Government; for the army and navy estimates of 1857 only totalled £20,699,000. Then came the Indian Mutiny and the China War, followed by the rising of Italy against Austria, and once more economy was banished. An invasion scare, artfully worked up, and supported by Palmerston, also helped to bring up the army estimates to $£ 14,970,000$ in 1860 and to $£ 600,000$ more next year. Even Mr. Gladstone's vehement opposition within the Cabinet, backed by Cobden and Bright outside, could not prevent the commencement of a costly and utterly futile fortification scheme financed by a loan. But this panic, like others, died down, and Mr. Gladstone's influence then prevailed, with the striking effect shown in the following figures, giving the total cost of the army in the years 1862-1865:

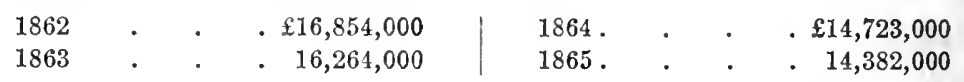

The great Chancellor of the Exchequer was then at his best, and successive budgets showed huge surpluses and generous remissions of taxation. As a natural consequence trade flourished, wages rose, and pauperism declined. Thenceforward until the early 'nineties the policy of low establishments in time of peace, as expounded by Cobden, Disraeli and Gladstone, was more or less maintained with the consent of both political parties.

Lord Cardwell's reorganization of the army in 1870 gave increased efficiency at a lower cost. Moreover, his reforms inspired confidence, so that even the Franco-German War created no panic. A small addition to the army was naturally made, but our military expenditure went down again to $£ 14,729,000$ in 1873 , and in 1874 to $£ 14,426,000$, or a figure lower than the sum spent on the much inferior force of 1863 . These figures are surely enough to disprove the contention, now so often accepted as an axiom, that a high level of expenditure, when once established, cannot be reduced. For it was done thirty-five years ago, leaving the army in a better and stronger condition than before, and it could be done again. 
After Mr. Gladstone came Mr. Disraeli, and as his name is associated with a "spirited foreign policy," historians might expect to find a heavy increase in the cost of military establishments. But the inventor of the word Imperialism, though he had a weakness for display, took care to provide himself with a frugalminded Chancellor of the Exchequer, and for the first years of his Premiership kept the cost of the army between $13 \frac{1}{2}$ and $14 \frac{1}{2}$ millions-in fact, the two services together cost much less than either does now. Foreign complications, it is true, beset his administration towards the close of its existence, and produced their usual results in swollen estimates. Nevertheless, in 1881 Mr. Gladstone's second administration brought the cost of the army

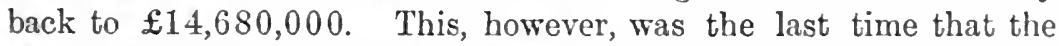
War Office contented itself with fourteen millions; the gradual rise in cost during twelve years may be traced in the following table:-

\begin{tabular}{|c|c|c|c|c|c|c|c|c|}
\hline \multicolumn{7}{|c|}{ Year. } & Army Expenditure. & $\begin{array}{l}\text { Secretary for War. } \\
\text { Mr. Gathorne Hardy }\end{array}$ \\
\hline $\begin{array}{l}1874 \\
1875 \\
1876 \\
1877 \\
1878 \\
1879 \\
1880 \\
1881 \\
1882 \\
1883 \\
1884 \\
1885\end{array}$ & $\begin{array}{l}\dot{.} \\
\dot{5} \\
\dot{5} \\
\dot{5} \\
\dot{5} \\
\dot{.} \\
\dot{.}\end{array}$ & : & $\begin{array}{l}\dot{.} \\
\dot{5} \\
\dot{5} \\
\dot{5} \\
\dot{5} \\
\dot{5}\end{array}$ & $\begin{array}{l}\cdot \\
\cdot \\
\cdot\end{array}$ & $\begin{array}{l} \\
\\
\\
\\
\\
\\
\end{array}$ & : & $\begin{array}{c}£ \\
13,495,000 \\
13,991,000 \\
14,200,000 \\
14,479,000 \\
14,281,000 \\
16,945,000 \\
15,025,000 \\
14,680,000 \\
15,738,000 \\
15,133,000 \\
16,095,000 \\
18,600,000\end{array}$ & $\begin{array}{c}\text { Mr. Gathorne Hardy } \\
,, ", \\
\text { Colonel 'Stanley ", } \\
\text { ", 'Shilers } \\
\text { Mr. Che ,' } \\
\text { Lord Hartington } \\
\text { ", } \\
\text { Mr. W. H.'Smith }\end{array}$ \\
\hline
\end{tabular}

In more ways than one the year 1884 constitutes a turningpoint in national finance. It marked the close of the old regime, instituted by Sir Robert Peel, and continued by Mr. Gladstone, of frugality and financial reforms. The tariff had been reformed, but in a sense very different from that in which those words are now used; hundreds of duties had been swept away, and the yicld of the few which survived had increased enormously. England had become the freest and cheapest market in the world, and London the commercial and banking centre of the world. The year 1884 also saw the first naval scare of modern times, ingeniously organized by Mr. W. T. Stead and Mr. Arnold Forster in the Pall Mall Gazette.

As a consequence, the income-tax, which had been as low as $2 \mathrm{~d}$. in 1875 , was gradually raised to $8 \mathrm{~d}$, and the reduction of indirect 
taxation upon the comforts of the poor ceased. But the mania for war expenditure in time of peace had not yet seized the War Office in any violent form. The beginnings were modest. The Egyptian policy required a garrison of $6000 \mathrm{men}$, and the military burden of India was aggravated for no particular reason by a large increase of the garrison. Many wise Anglo-Indians shook their heads at the time, and declared that India would have been happier, stronger, and more contented if the money had been used to diminish taxes, or to improve education, sanitation, and police. The number of men provided for in our own army estimates gradually rose from about 140,000 to 156,000 , at which figure they stood when Sir H. Campbell-Bannerman was War Secretary-i.e. from 1892 to 1895. The army estimates for 1886 were also introduced by Sir H. Campbell-Bannerman; but Mr. Gladstone's third Administration only lasted till August, and Mr. W. H. Smith became War Secretary. In the autumn of 1887 a sharp contention arose between the spending departments and Lord Randolph Churchill, who as Chancellor of the Exchequer endeavoured to enforce a scheme of retrenchment in the hope of being able to provide in his budget for a free breakfast-table. His resignation was not followed by any expansion in the army expenditure, which, indeed, after being above 18 millions in 1887 and 1888, dropped below 16 millions in 1889 , and then settled down at 17 millions odd in the six following years. Here are the official figures of army expenditure from 1886 to 1895 :-

\begin{tabular}{|c|c|c|c|c|c|c|}
\hline 1886 & . & . $£ 17,027,000$ & 1891. & . & - & . $£ 17,550,000$ \\
\hline 1887 & . & . $18,429,000$ & 1892 . & . & . & $17,258,000$ \\
\hline 1888 & . & $18,167,000$ & 1893. & . & . & $17,541,000$ \\
\hline 1889 & . & $15,919,000$ & 1894. & . & . & $17,939,000$ \\
\hline 1890 & . & $17,345,000$ & 1895. & . & . & $17,899,000$ \\
\hline
\end{tabular}

The end of this period saw the beginning of " borrowing for works." The Admiralty at first was the principal offender, but in 1893 the War Office chimed in and began to borrow about half a million a year under the Barracks Act of 1890 .

We are now reaching the epoch of disaster in the history of our military peace establishment. The present dilemma of the Chancellor of the Exchequer in his search for a social service fund, the disgust of income-tax payers, the complaints of the numerous interests hit by the sugar duties or land taxes, or by increased duties on beer, tobacco, etc., or the low state of national credit, are all traceable, in whole or in part, to the failure (or refusal) of the War Office and Admiralty to return after the war to anything 
like the scale of expenditure which preceded the war. If Mr. Haldane's estimates, for example, had been the same as those of Sir H. Campbell-Bannerman in the spring of $1895, \mathrm{Mr}_{1}$. Iloyd George could have repealed the sugar duties and have provided for old-age pensions without recourse to the land taxes or death duties. If Mr. M'Kenna had only asked for the sum that satisfied Lord Speneer thirteen years ago the income-tax might stand at eightpence, and there would be plenty to spare for other purposes. Millions of capital that are being vainly consumed in piling up armaments would be restored to the channels of industry, wages and profits would rise, pauperism would diminish, ample funds would be set free for improving the health and intelligence of the nation. And uniess Peel and Gladstone and Disraeli were extravagantly and ridiculously wrong, the real military strength of the nation and its real preparedness for war would be increased instead of being diminished by a reduction of our overgrown establishments and a return to a normal level of peace expenditure. As Sir William Harcourt once observed, it is positively unsafe, from the standpoint of a possible great war, to keep the instrument of taxation "at concert pitch" in ordinary times; the strength of the nation, in war as well as in peace, depends upon the soundness of its finances.

The estimates for $1895-1896$ were $£ 17,983,000$, an addition of $£ 97,000$ for barracks and so forth being more than counterbalanced by reductions on forage and provisions. But the profligate system of supplementary estimates had come into action. A supplementary estimate for $£$ 0,000 was taken by Lord Lansdowne, the new War Seeretary, in August, and another for $£ 601,000$ was required in the following February. The actual expenditure on the army for the year ending March 31, 1896, the first year of Lord Salisbury's Administration, was $£ 18, \pm 59,000$, compared with $£ 17,899,000$ in the last complete year of the Liberal Government. In the original estimates of Sir H. CampbellBannerman, issued early in 1895 , the total number of men on the establishment of the regular army, exclusive of India, was $1 \pm 6,2 \pm 9$, and the total regular force, including the staff of the auxiliary forces, the medical service instructors, and so on, was 155,403, showing practically no change on the previous year. In the following year (1896-1897) the total number of mell on the home and colonial establishments, exclusive of those serving in India, was $156,17 \pm$, and the pay rote amounted to $£ 5,862,000$. The total net estimate was $\mathfrak{f} 18,056,000$, showing a slight increase on 
that of Sir H. Campbell-Bannerman, but a large reduction on the actual expenditure of 1895-1896. Supplementary estimates, however, again raised the actual above the estimated expenditure. The estimates of 1897-1898 may be taken as a fair indication of the peace level of expenditure before the South African War, after a Unionist Administration with a surplus revenue had added a little to the establishment maintained by the Administrations of $\mathrm{Mr}$. Gladstone and Lord Rosebery. A new West Indies regiment was raised for a war in West Africa, and extra pay was provided for officers. The total force which the Government proposed to add to the army in order to provide for warlike expeditions was 7385 , of which number, however, only 2590 were to be recruited during the year. The addition to regimental pay was estimated for the year at $£ 77,000$; but under Vote 7, "Provisions, forage, and other supplies," came an increase of $£ 33,500$, and under Vote 8, "Clothing," an increase of $£ 35,400$, the first sum being partially and the second wholly ascribed in the official explanations that accompanied the estimates to the increasing numbers of the army. The following table is taken from the abstract of army estimates issued by Lord Lansdowne from the War Office on January 29, $1897:-$

I. Numbers. - Number of men on the home and colonial establishments of the Army (1897-1898), exclusive of those serving in India:-Gross estimate, 163,569; net estimate, 158,774 .

II. EFFeCTIVE Services 1897-1898 Estimates:-

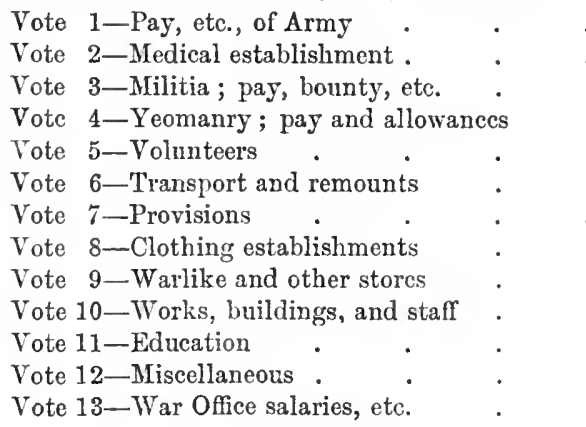

Total effective services

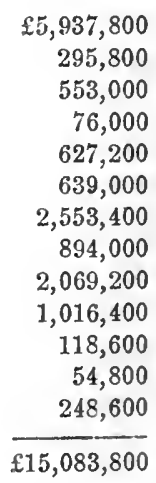


This, however, was not the whole estimated expenditure on the army, for there had to be added various items in the civil service estimates, which brought up the total to $£ 18, \pm 57,691$. And, further (outside the estimates, except as regards the interest and sinking fund), there was the loan expenditure for military works, which then amounted to about a million, and was already making heavy inroads on the sinking fund for the redemption of the National Debt. The estimates for 1897-1898 have been given in detail in order to show the last estimates for a peace establishment before the South African War compared with Mr. Haldane's post bellum peace establishment. As a matter of fact, the warlike disposition of the Government in 1897 and 1898 (which showed itself in Ashanti, Eggpt, and the North-West frontier of India) led to large supplementary estimates; and the actual expenditure for the year amounted to $£ 19,528,390$, if we take the figures of the War Office, or $£ 19,329,900$ if we take those of the Statistical Abstract. In the following year there was more war and more expansion, so that the army expenditure for the five years preceding the South African War reads as follows:-

\begin{tabular}{|c|c|c|c|c|}
\hline 1894-1895 & & . $£ 17,899,800$ & $189 \pi-1898$ & . $£ 19,329,900$ \\
\hline $1895-1$ & & . $18,459,800$ & $1898-1899$ & . $19,999,700$ \\
\hline $1896-1897$ & & $18,269,800$ & & \\
\hline
\end{tabular}

The official note on the expenditure of 1897-1898 explains that the net increases are due "partly to the general increase of the army, and partly to special expenditure in connexion with Egypt, South Africa, and Crete," while the note for 1898-1899 states: "Transport again increased on account of the Soudan expedition and manœuvres; and there was additional expenditure on medical services, supplies and stores, due to the increase of the army." It is easy to understand the costliness of the small wars of 1897 , 1898 , and 1899 ; but the expansion of our military expenditure in those years was clearly the consequence of an expansionist policy at the Colonial and Foreign Offices, as well as of a gradual weakening in Treasury control. The high scale of War Office expenditure now is deliberate, and contrasts sharply with the pacific policy of the Foreign Office.

To find, therefore, how our present peace establishment for the army compares with that which preceded the war in South Africa, we must take an average of the six years from 1893 to 1899 , or the expenditure of 1896-1897, or the estimates of 1896-1898. The swollen army expenditure of the two years preceding the war 
$(£ 19,329,000$ and $£ 19,999,000)$ represented the beginnings of a new militarist and imperialist expansion which culminated in the South African policy of Mr. Chamberlain. A perfectly fair comparison of the scale which Lord Salisbury's Administration adopted before the war, and of that which Mr. Balfour's Administration adopted after it, is afforded by contrasting the $£ 18,260,000$ spent on the army by Lord Landsdowne in the year ending March 31, 1897 , and the $£ 28,849,000$ which Mr. Arnold Forster (succeeded in December 1.905 by Mr. Haldane) spent on the same service in 1905-1906. The difference it will be seen exceeds $10 \frac{1}{2}$ millions. If the comparison be made with the average expenditure of Sir H. Campbell-Bannerman from 1892 to 1895 , the addition is about eleven millions sterling to the annual cost of the army alone on a peace footing, equivalent to the interest on from three to four hundred millions of debt!

"War suspends ispo facto every rule of public thrift," wrote Mr. Gladstone once out of the bitterness of experience, and "tends to sap honesty itself in the use of public treasure, for which it makes such unbounded calls." The South African war scandals still live painfully in the memory of the nation, but although the public purse was undoubtedly robbed of many millions by swindling contracts, and lost many more through the laxity, or worse, of those who superintended supplies in South Africa, ${ }^{1}$ by far the greatest of the financial misfortunes suffered by the inhabitants of the United Kingdom is the permanent addition to unproductive expenditure. The additional charge for interest on the debt fixed and floating (from four to five millions) has been rapidly reduced in the last five years by large cancellations of debt. The addition made to the burden of armaments was over four times greater. Between 1895-1896 and 1905-1906 (when so-called "normal" estimates were restored) the ordinary expenditure on the army rose by nearly $10 \frac{1}{2}$ millions and on the navy by over $13 \frac{1}{2}$ millions-i.e. 24 millions in all, representing a capital withdrawn from trade and industry of some 800 millions sterling! - probably three times the total capital invested in all branches of our great cotton industry in Lancashire. A large addition has also been made to the military expenditure in India. Yet from a British standpoint

1 Sir William Butler in his reminiscences considers that 100 millions were lost through thieving and bad management. "Four million pounds were thrown away in the (Zulu) war of 1879 ; at least one hundred millions were flung to the winds in that of 1899 and the two following years."-Sir William Butler's Autobiography (London, 1911), chap. xiii. p. 211. 


\section{NATIONAL EXPENDITURE AND DEB'T, 1850-1910 655}

international politics are admittedly more favourable than they were during the war. The naval estimates have been inflated for years far beyond the old standards of security, and there is nothing in the movement of military expenditure in France, Germany, Austria, and Italy during this period to suggest the necessity for more than a very slight addition to our own in the decade under review.

It is the opinion of eminent authorities, some with long experience of Treasury finance and others with long experience of Cabinet Government, who have been consulted by the witer, that the only remedy for this fatal growth-the only means by which the newly imposed burden can be removed-is to break with the new method and return to the old tradition. The new method is for the First Lord of the Admiralty and the Secretary for War to find out from their subordinate admirals and generals and eagerly co-operating contractors how much public money they can possibly get rid of within the year. This fixes the maximum demand, which is always ahead of the year before. Then the First Lord and the War Secretary consider the political horizon, the attitude of the Press, the economists, and the Labour members. Then their financial assistants are asked to cut off a few thousands here and a few there. The estimates are brought down to "an irreducible minimum." A letter is sent to the Treasury explaining what extraordinary economy has been observed in framing the estimates. In November and December the Treasury is allowed to prune down the irreducible minimum. Then perhaps, if the Chanceller of the Exchequer finds that the revenue is not coming in very well, and that some small sop is needed to propitiate the taxpayer, or the social reformers, he begs for another half-million. If the Prime Minister supports him, this concession is reluctantly made after the Cabinet has been almost frightened out of its wits by dire threats from generals, admirals, and other warlike officials, and by inspired sensations in the Opposition newspapers. The old tradition was totally different. Sir Robert Peel, Lord Palmerston, Lord Beaconsfield, and Mr. Gladstone would never have dreamt of allowing the balance of the national budget to be upset by the head of the Admiralty or War Office, much less by the naval and military officials attached to those departments. The amount that could be allotted to the army and navy was arrived at by the Prime Minister and the Chancellor of the Exchequer in consultation with their leading colleagues. When that amount had been decided, its allocation was entrusted to the First Lord and the Secretary for War, who endeavoured, according to their capacity and industry, with the assistance 
of their expert advisers, to see that it was laid out to the best advantage. The old function of the paid expert was to assist in securing efficiency and economy in the administration of the sums allocated by the Government and the House of Commons. It was for them, as trustees of the nation and representatives of the taxpayers, to decide what should be the scale of taxation and expenditure. But now the expert claims to be the master instead of the servant of the public. He "runs" the First Lord and Secretary for War, bullies the Cabinet, and if his views are not fully adopted fills columns of the Press with plaints against economy. The burden of armaments is virtuously deplored and persistently increased.

The first need of the army and of the War Office is the abolition of the system of social patronage and jobbery by which favoured persons too often receive posts for which they are wholly unsuited, while mere merit and efficiency are left out in the cold. If Parliament had the will and ministers the courage there would be no difficulty in effecting important retrenchments in the army. A military establishment can be reduced far more readily than a civil one, because of the short service system. The annual number of recruits is very large indeed compared with the total force, and an immense waste of money and energy is involved in taking so large a number every year; for the percentage of those who have to be dismissed on physical grounds is much larger than it would be if the numbers of the army had not been so much enlarged. The rise and fall of the army estimates depend mainly upon the numbers of men voted, though in order to return to the pay vote of 18971898 it would be necessary to vote a somewhat smaller force, owing to the fact that the common soldier is rather better paid now than then.

The following table of the numbers of regulars voted, the pay vote, and the total is extracted from War Office statements:-

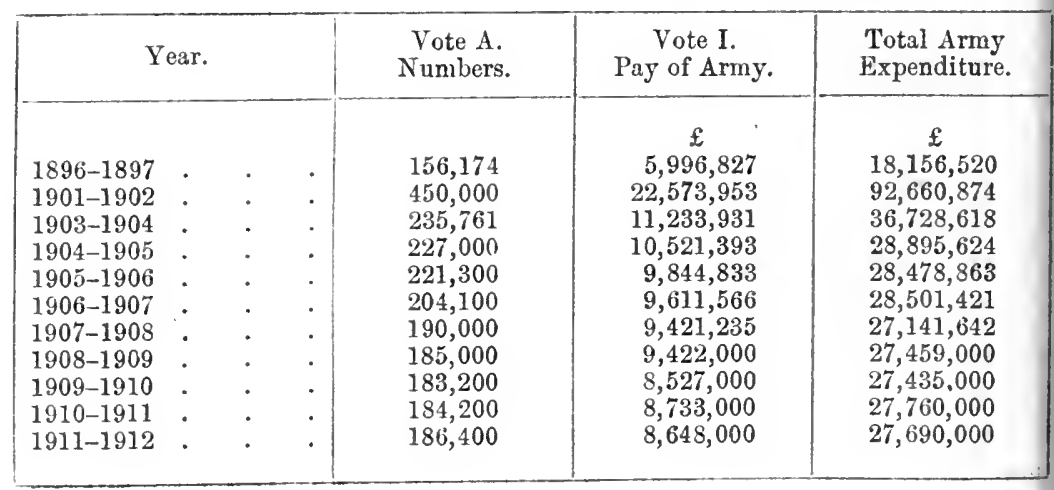


The above table brings out very plainly how it is that the army cost 50 per cent. more after the war than it did before the war. Instead of reducing the war establishment by 300,000 men the Government reduced it by 260,000 , leaving the hard-pressed taxpayer to provide for more soldiers than before. These additional men cost seven or eight millions sterling a year, so that there is no longer any mystery about the necessity of keeping on war taxes. If Parliament allows war establishments in time of peace, it must, of course, acquiesce in war taxation. Unfortunately, another criticism that is forced upon one by an examination of these figures is that the taxpayers have been deprived by Mr. Haldane of the greater part of the benefits which they should have received, in spite of the fact that the new Territorial Force is much better trained and far more efficient than the old Volunteers. As several of the votes have been rearranged, the army expenditure of ten years ago cannot be compared in every detail with the present. However, some of the main items can be set out:-

\begin{tabular}{|c|c|c|c|}
\hline & $\begin{array}{l}\text { Lord Lansdowne's } \\
\text { Army Expenditure } \\
\text { in } 1896-1897 \text {. }\end{array}$ & $\begin{array}{l}\text { Mr. Haidane's } \\
\text { Army Expenditure } \\
\text { in } 1907-1908 .\end{array}$ & $\begin{array}{l}\text { 1910-1911 } \\
\text { Estimates. }\end{array}$ \\
\hline $\begin{array}{l}\text { 1. Total } \\
\text { 2. Numbers of regular } \\
\text { army } \\
\text { 3. Pay rote. } \\
\text { 4. Mrilitia : } \\
\text { 5. Imperial Yeomanry. } \\
\text { 6. Volunteer corps } \\
\text { 7. Supplies and clothing } \\
\text { 8. Works } \\
\text { 9. War Office : }\end{array}$ & $\begin{array}{r}£ 18,156,520 \\
156,174 \\
£ \\
5,996,827 \\
533,902 \\
74,273 \\
885,952 \\
3,377,709 \\
980,748 \\
243,037\end{array}$ & $\begin{array}{c}£ 27,141,642 \\
190,000 \\
£ \\
9,421,235 \\
727,943 \\
407,108\} \\
1,487,051 j \\
4,463,710 \\
2,351,775 \\
563,959\end{array}$ & $\begin{array}{r}£ 2 \tau, 760,000 \\
184,200 \\
£ \\
8,733,000 \\
\$ 33,000 \\
+2,660,000 \\
4,930,000 \\
2,598,000 \\
429,000\end{array}$ \\
\hline
\end{tabular}

- Territorial Forces.

The increase in the Works Vote is due to a curtailment of the loan system, under which money was frittered away on barracks and fortifications, many of which have since been abandoned.

The army estimates now are eight or nine millions higher than before the Boer War. The addition represents interest on some three hundred millions sterling of National Debt. "Looking to the future," wrote Mr. Haldane, "it is, I am convinced, impossible to make further diminutions in army expenditure on a considerable scale unless we first of all reduce the number of troops serving abroad." Reductions in the South African garrison have saved something, but there are still some ten thousand men there main- 
tained at the expense of British taxpayers in a large self-governing colony, which ought to be contributing to the cost of imperial defence. The normal cost of a battalion at home is $£ 60,000$, and 20 per cent. should be allowed for the extra cost of maintenance in South Africa, where living is very expensive.

We may conclude our account of army finance with a table, which gives the army estimates for 1911-1912 by votes:-

\begin{tabular}{|c|c|c|c|c|c|c|}
\hline Year. & $\begin{array}{l}\text { Vote A. } \\
\text { Numbers. }\end{array}$ & $\begin{array}{l}\text { Vore I. } \\
\text { Pay, etc., } \\
\text { of the } \\
\text { Army. }\end{array}$ & $\begin{array}{l}\text { Vote II. } \\
\text { Medical } \\
\text { Services. }\end{array}$ & $\begin{array}{l}\text { Votв III. } \\
\text { Special } \\
\text { Reserves. }\end{array}$ & $\begin{array}{l}\text { VoTE IV. } \\
\text { Territorial } \\
\text { Forces. }\end{array}$ & $\begin{array}{l}\text { VoTE VI. } \\
\text { Quartering, } \\
\text { Transport, } \\
\text { and } \\
\text { Remounts. }\end{array}$ \\
\hline 1911-1912 (estimate) & 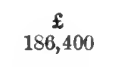 & $\underset{8,648,000}{\mathfrak{E}}$ & $\stackrel{\mathfrak{E}}{437,000}$ & $\begin{array}{c}\mathfrak{E} \\
742,000\end{array}$ & $\underset{2,766,000}{£}$ & 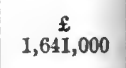 \\
\hline Year. & $\begin{array}{l}\text { Vore VII. } \\
\text { Supplies } \\
\text { and } \\
\text { Clothing. }\end{array}$ & $\begin{array}{l}\text { VoTs VIII. } \\
\text { Ordnance } \\
\text { Establish- } \\
\text { ments and } \\
\text { General } \\
\text { Stores. }\end{array}$ & $\begin{array}{c}\text { Vore IX. } \\
\text { Armaments } \\
\text { and } \\
\text { Engineer } \\
\text { Stores. }\end{array}$ & $\begin{array}{l}\text { Vote } \mathrm{X} \text {. } \\
\text { Works. }\end{array}$ & $\begin{array}{l}\text { Votв V. } \\
\text { Educa- } \\
\text { tional } \\
\text { Establish- } \\
\text { nients. }\end{array}$ & $\begin{array}{l}\text { VoTE XI. } \\
\text { Miscella- } \\
\text { neous. }\end{array}$ \\
\hline 1911-1912 (estimate) & $\stackrel{f}{4,295,000}$ & $\underset{581,000}{£}$ & $\stackrel{\mathfrak{f}}{1,472,000}$ & $\stackrel{£}{\stackrel{f}{2,591,000}}$ & $\stackrel{\mathfrak{E}}{147,000}$ & $\stackrel{\mathfrak{f}}{73,000}$ \\
\hline Year. & $\begin{array}{l}\text { VoTe XII. } \\
\text { War Office } \\
\text { and Army } \\
\text { Accounts } \\
\text { Depart- } \\
\text { ments. }\end{array}$ & $\begin{array}{l}\text { Vote XIII. } \\
\text { Non- } \\
\text { Effective } \\
\text { Charges-- } \\
\text { Officers. }\end{array}$ & $\begin{array}{l}\text { Vors XIV. } \\
\text { Non. } \\
\text { Effective } \\
\text { Charges- } \\
\text { N.C.O.'s } \\
\text { and Men. }\end{array}$ & $\begin{array}{c}\text { Yore XV. } \\
\text { Superan. } \\
\text { nuation, } \\
\text { etc., } \\
\text { Allowances. }\end{array}$ & $\begin{array}{l}\text { Losses } \\
\text { Irrecover- } \\
\text { able. }\end{array}$ & Total. \\
\hline 1911-1912 (estimate) & $\stackrel{\mathfrak{E}}{436,000}$ & $\stackrel{\mathfrak{f}}{1,808,000}$ & $\underset{1,900,000}{\mathfrak{E}}$ & $\begin{array}{c}£ \\
153,000\end{array}$ & $£$ & $\underset{27,690,000}{\varepsilon}$ \\
\hline
\end{tabular}

\section{Expenditure on the Navy}

From 1857 to 1887 naval expenditure was almost stationary, and at the last-named date the British navy cost only two-thirds as much as the army. In the next decade it overhauled the army. Between 1897 and 1907 (the disastrous decade which included the Boer War) naval expenditure rose from 22 to 31 millions, while military expenditure rose from 18 to 28 millions. Yet common prudence would suggest that expansion in one department should be offset by economy in the other. The cost of our army depends, or is supposed to depend, on the work it has to do-in India, Africa, etc.-and its size bears no relation to the conscript armies of continental nations. But the size and cost of the navy are regulated professedly by the size or estimated fighting strength 
of the navies belonging to other nations. In the earlier part of the nineteenth century, it was practically an accepted maxim on both sides of the Channel that the British fleet should stand to the French fleet in the proportion of three to two. As Cobden once showed, by a series of statistical proofs covering the period from 1816 to 1860 , "in comparing the expenditure of the two countries, it will be observed that they almost invariably rise and fall together." Thus, if we added to our fleet, France added to hers, in the belief that her diplomatic position would be weakened if she submitted to a smaller proportion than two or three. Under a restless and unconstitutional emperor like Napoleon the Third, France played a rather aggressive and domineering rôle in Europe. She drove Austria out of Italy, invaded Mexico, and finally declared war on Prussia. It was only natural, therefore, that British statesmen should take care to maintain an ample margin of naval supremacy, and this margin all parties held to be a superiority of about 50 per cent. on paper. Occasional outbursts of panic and excitement made very little impression upon our Governments. Statesmen kept their heads. The leading newspapers were conducted with prudence and moderation, and up to 1885 the naval votes seldom exceeded $10 \frac{1}{2}$ millions. In fact, at that time, the navy cost less than the army, and about one-third of what it costs now. Twenty-five years ago, however, an agitation was fomented by Mr. Stead and others, who protested that our naval expenditure was not large enough. It was declared that a readjustment of the naval balance had become necessary, and eventually the formula of the two-Power standard was invented in order to give a plausible excuse for naval expansion. So our expenditure began to rise. The 13 millions point was passed in 1885 , and in 1889 , with a million transferred from the army vote, the figure nearly reached 17 millions. This increase, of course, invited France to fresh efforts, and the French vote rose from 8 to 10 millions in 1892 , while Russia was spending a little over 5 millions. Great Britain, however, went on forcing the pace, and our estimates went forward by leaps and bounds, passing 20 millions in 1897 , and 25 millions in 1899 . In that year the French vote reached 12 millions, at which figure it remained practically stationary. Russia now joined in the race, increasing her naval votes from 6 millions in 1897 to 11 in 1901. We may now sec what was our own expenditure just before the South African War, with the numbers of men and shipbuilding contracts, as given in the navy estimates, which did not 
include appropriations in aid or expenditure out of borrowed money.

Navy Expenditure Before the War

\begin{tabular}{|c|c|c|c|c|c|}
\hline Yea & & & Numbers. & $\begin{array}{l}\text { Shipbuilding } \\
\text { Contracts. }\end{array}$ & $\begin{array}{c}\text { Total } \\
\text { Expenditure. }\end{array}$ \\
\hline $\begin{array}{l}1896-1897 \\
1897-1898 \\
1898-1899\end{array}$ & & : & $\begin{array}{r}91,507 \\
96,925 \\
103,330\end{array}$ & $\begin{array}{c}\mathfrak{f} \\
5,292,911 \\
3,553,649 \\
4,864,295\end{array}$ & $\begin{array}{c}\stackrel{£}{22} \\
22,271,902 \\
20,848,863 \\
23,880,875\end{array}$ \\
\hline
\end{tabular}

The South African War broke out in October, 1899. The illfecling aroused by that war on the Continent, and the fear of intervention by the European Powers while our troops were in Africa, led to further sensational additions to the navy. Including the amounts borrowed for new works, the expenditure reached the unparalleled figure of 31 millions in 1900 , or three times as much as had been demanded when Lord Goschen, the First Lord, served his apprenticeship at the Admiralty as Mr. Goschen in 1871. Immense sums, borrowed with fatal facility, were sunk in docks, basins, dredging, and other works, in all parts of the world, many of which have been abandoned as useless, or admitted to be unnecessary. This, we may add, is the usual result of spending money which is borrowed and not raised immediately by taxation. The Admiralty and the War Office are only the biggest examples of the relation between waste and borrowing. Town councils have often frittered away the money which they have obtained from loans in the same way, though not to the same extent, as the Admiralty and the War Office.

In the four years of war our naval expenditure, excluding loans for works, was as follows :-

\begin{tabular}{|c|c|c|c|c|}
\hline Year & & Numbers. & $\begin{array}{l}\text { Shipbuilding } \\
\text { Contraets. }\end{array}$ & $\begin{array}{c}\text { Naval } \\
\text { Expenditure. }\end{array}$ \\
\hline $\begin{array}{l}1899-1900 \\
1900-1901 \\
1901-1902 \\
1902-1903\end{array}$ & $\begin{array}{l}. \\
\dot{.} \\
\dot{0}\end{array}$ & $\begin{array}{l}108,595 \\
112,429 \\
117,116 \\
121,870\end{array}$ & $\begin{array}{c}£ \\
5,111,279 \\
6,931,654 \\
6,794,326 \\
7,601,950\end{array}$ & $\begin{array}{c}\mathcal{\complement} \\
25,731,220 \\
29,999,529 \\
30,981,315 \\
31,003,977\end{array}$ \\
\hline
\end{tabular}

With the establishment of peace in South Africa, with the return of the army to Great Britain, and with the dying down 
of the anti-English sentiment on the Continent, it might have been supposed that our naval outlay would decline, as foreign perils disappeared. Important and favourable changes also occurred in the international situation. In 1904 the war between Russia and Japan resulted in the extinction of the Russian navy, and so made the two-Power standard a meaningless formula. An entente cordiale was next effected with France, and two long-standing differences were finally settled by the French recognition of our position in Egypt, and by ours of the French position in Morocco. In the Far East an alliance with Japan brought another strong fleet into partnership with our own, and relieved us of all possible anxiety in the Pacific Ocean. Our natural friendship with the United States was improved by diplomacy. On the continent of Asia all possibilities of difference with Russia were removed by an agreement with the Russian Government, and although many people in England disliked the idea of association with a despotic Power, no one could deny that the agreement made for peace, and might have been used in the interests of economy.

These four events, all reassuring, had paved the way for a reduction in naval armaments. Economy in armaments was earnestly preached by the Liberal leaders right down to the general election of 1906 . And indeed to a slight, a very slight extent this policy was put into execution by the Admiralty in the last year of Mr. Balfour and again under Sir Henry Campbell-Bannerman; for it deeided to reduce both the Mediterranean and China Squadrons, recalling eight out of the fourteen battleships in the Mediterranean and all the four battleships from the Far East. Thus the fighting strength of the home fleet was immensely augmented. A second change in the policy of the Admiralty stopped a considerable source of expense, even if it did not actually add to our fighting strength in home waters. This change was the decision to give up the practice of maintaining great numbers of cruisers in every part of the world. Many of these "protected cruisers" were recalled and "scrapped." A further change of policy withdrew one of our naval squadrons from the other side of the Atlantic, its place being taken by a squadron of armoured cruisers with its base in Great Britain, which now and then crosses the ocean. As a result of this, the West Indian dockyards have been abaudoned, and a considerable saving effected.

These economies, however, have been far more than swallowed up in new expenditure on construction. What prodigious and un- 
paralleled sums have been expended on new ships will appear from the naval estimates of the last nine years:-

Navy Expenditure after the War

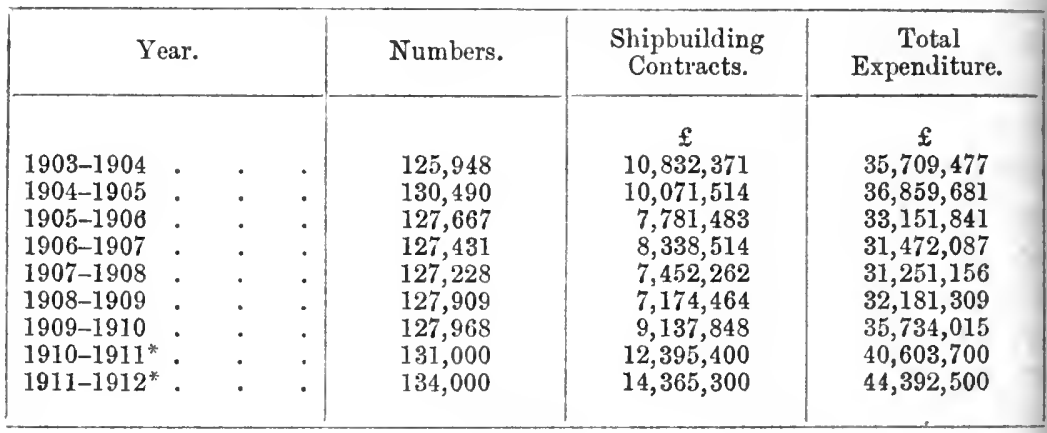

* Estimate.

Why is it, then, with these facts before us, that our navy has not been put upon a peace footing, maintained, of course, in full efficiency, but yet not continually in a state of provocative expansion and restless increase? The official answer is found in the rise of a new naval Power. Until a few years ago the German Government contented itself with the possession of the most powerful and best organized army in the world; but more recently, alarmed, perhaps, by the close alliance between the two great military nations on the Eastern and Western frontiers, and also by the "isolation" which is supposed to be the result of a malign British diplomacy, it has turned its thoughts to sea power. One cause, no doubt, is the unfortunate seizure of the Bundesrath during the Boer War, and another our frequently declared policy of maintaining the right to capture or destroy private property at sea during war. But the German Emperor is mainly responsible for the Big Navy policy, for it does not appear to be popular either with the military caste or with the masses of the people, and all sections of the German people seem to be united in a determination not to contribute the new taxation which the augmentation of the navy requires. Under the Naval Act, German naval construction has been paid for mainly out of borrowed money; but even so, the total expenditure of Germany in 1911 is only about twenty-two millions, and her navy can hardly be considered to have attained more than one-third the strength of the British navy. Since that time the cost of our navy has been augmented far more than the cost of hers. How far the panic which raged in a section of the London Press during 1908 and 
1909 was organized for political purposes, and how far it was assisted by parties interested in the lucrative contracts which are put out every year by the Admiralty, cannot be examined here. The curious thing to note is that the whole basis of alarmism and of the vast additions to expenditure made during the last three years was the Dreadnought theory. The Dreadnoughts are merely enlarged battleships bigger than the King Edward type but not essentially different. Naval experts disagree as to whether three King Edwards (costing the same) would be more likely to vanquish or to be vanquished by two Dreadnoughts. But the idea that the Dreadnoughts have superseded the King Edwards, or that the super-Dreadnoughts have superseded the Dreadnoughts, has obviously been started for the purpose of inducing Parliament to approve of estimates which go far beyond reason. Dreadnoughts were intended to supersede other ships, but the Board of Admiralty, which started them, deserved the severest censure $;^{1}$ for by so doing it would have enabled any Power which chose to spend as much as we did on construction to overtake us in a few years. In the summer of 1911, according to official figures, the British navy was four times as strong as the German in cruisers and double as strong in battleships. In comprarison with France our predominance was still more marked.

To return to the policy of monster battleships. In view of the development of submarines, mines, and torpedoes, numbers, apart from pattern and size, count more and more; for submarines and mines and torpedo boats are no respecters of size or pattern, and "every serviceable ship that carries a good gun may fire a decisive shot." Again, it must be reckoned on our side that we can still build faster than the Germans, and that we have more slips available for the largest vessels; so that we can continue our policy of building from year to year, making alterations and improvements in the design of each successive ship.

One of the foremost admirals in the fleet wrote to The Economist during the German panic, deprecating the increased expenditure and ridiculing the mania for Dreadnoughts. It is a natural tendency of the human mind to admire mere size in buildings, ships, and everything else. Then the more costly the job in ironmongery the better pleased are the armament firms whose

"As a matter of fact, the "inventors" of the Dreadnought were adrertised as heroes by the same journalists, who declared that the Dreadnoughts had superseded the rest of the fleet! 
designers are constantly employed on new devices. A portion of the Admiral's letter may usefully be quoted :-

"When the Dreadnought was declared by writers in the newspapers to have made all existing ships obsolete or prematurely obsolescent, it was pointed out that she in her turn might soon be exposed to a similar fate. A few figures will show how this could be. The Dreadnought had an official displacement of 17,900 tons. She was soon followed by the Bellerophon class, with 18,600 tons displacement. Next came the St. Vincent class of 19,250 tons. Later we have the Neptune, with a displacement of 20,000 tons or more. As two ships, said to be of 26,000 tons, are being built for the United States navy, we ought-if we still accept the doctrine to which we owe the introduction of the Dreadnought-to assume that the not yet completed Neptune has already been made obsolete or prematurely obsolescent by the American ships. We are likely to be committed to what Sir William White calls the "perpetuation on an increasing scale of size and cost of so-called Dreadnoughts.' 'There is reason for apprehending that a couple of millions of pounds sterling will be deliberately expended on the construction of each of several ships, which-in accordance with our own widely propagated creed-can be, and will be, rendered almost obsolete before they take the water. This, moreover, does not allow for the increase in expenditure caused by the necessity of making new docks big enough to admit the new ships, enlarging old docks and basin entrances, or deepening channels.

"It has lately been stated, on good authority, that 'many naval officers consider the King Edwards to be superior to the Dreadnought in offensive and defensive power.' 'The King Edwards are earlier, smaller, and less costly. It may be taken as certain that a still larger number of naval officers believe that the sum of money expended in producing the Dreadnought and her successors, if utilized in a different way, would increase the effective strength of our battleship force much more. It is not necessary to assume that the Dreadnoughts are not powerful ships, but it may be maintained that we could have a more powerful group of ships for the sum that they are costing us or an equally powerful group for a smaller sum. In naval affairs it is specially desirable that means should be proportionate to ends. The substance of a nation may be expended, and largely wasted, in providing not that which is necessary for the work to be done, but that which cannot be utilised to its full capacity. We ought not, of course, to delay the completion of ships already begun or designed, as it would be absurd to say that they are useless. It is, nevertheless, very desirable that a searching investigation into the real utility of the Dreadnought type should be made. At present this at least may be said with confidencethere is no proof that the group of which the type is composed is at all more capable of defeating the battleships of a hostile fleet than a group of far less costly individuals."

As the Dreadnought theory, in connexion with a dangerously exaggerated standard of naval supremacy, is responsible for the continuous and increasing strain upon our finances, shown by the high rates of income-tax and death duties, the importance of the above criticism needs no emphasis. But the financial burden of 
naval competition is already so oppressive that international action for the proportional limitation of armaments camnot long be delayed.

\section{The Civil Service and Revexue Departmexts, from 1850}

As we have pointed out before, there was an enornous increase in the cost of government during the second half of the nineteenth century and in the new century the movement has been accelerated. Generally speaking, the people get a quid pro quo in the shape of comfort or increased efficiency for that portion of the taxes which is paid to the Local Government Board, the Boards of Education, Agriculture, and Trade. Every penny spent on the army and navy is economic waste, and if war could be abolished the abandonment of these services would be sheer gain. But most, if not all, of the services we are now considering are essential to civilization; and many of them (such as the provision of education and roads, a postal service, telegraphs and telephones) are absolutely necessary if the nation is to prosper in its agriculture, manufactures, and commerce. If the whole world lived together in brotherly affection, and all disputes between nations were settled in courts of law, the expenditure on local and civil government would be more likely to increase than to diminish. At the same time there is undoubtedly a tendency to be too lavish with public money, and there is inuch avoidable waste in our civil departments as well as in our local expenditure. Administrators of public money hold the most solemn and responsible of all trusteeships. If an expenditure is not absolutely necessary its utility and productive character must be proved to demonstration, and it must also be shown that the scheme can be carried out without imposing an undue strain upon the public credit and resources. Great Britain may be the richest country in the world, but no state is rich except by comparison with the greater poverty of its neighbours. Nine families out of ten are poor. Most of them, but not all, have just enough to live on. But their savings are very small, and they have very little to fall back upon. The tenth family is very comfortably off, on the average, and if this "emerged" tenth were able and willing to provide the whole revenue, a government might almost be pardoned if it extended the scope of its functions and enlarged its grants liberally. But apurt from the political evils which would flourish in a state supported only by a small well-to-do fraction of its citizens, a modern state, with an elaborate system of education, an enormously costly arrangement for the incarceration of criminals, 
lunatics, and paupers, immense forces of police in addition to a mighty machinery designed and maintained regardless of expense for the purpose of menacing the security of other nations and safeguarding its own, cannot possibly rely upon the rich alone.

As we have already seen, the cost of the civil service has increased even more rapidly than that of the army or the navy, the figures for the fifty years from 1857-1907 being as follows:-

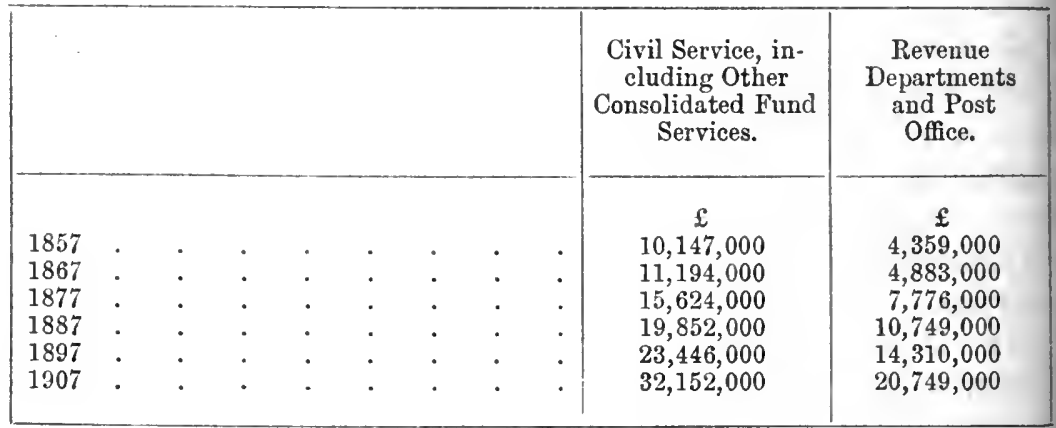

There has thus been a steady increase in the burden of the Civil Service from 1857 to 1897 , and in the last ten years of the table an increase of nearly nine millions, or, including the revenue departments, which are grouped with the Civil Service estimates,

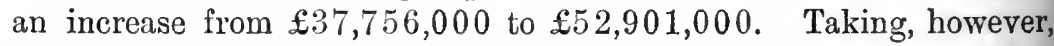
the Miscellaneous Civil Services alone, the charge has risen from just over 20 millions in $1897-1898$ to $\mathfrak{£ 3 0 , 1 8 0 , 0 0 0}$ in 19071908 , and to no less than $£ 43,098,000$ for $1910-1911$.

But in addition to the sums provided amnually, very considerable sums are spent under the authority of various permanent Acts of Parliament. These are the "Other Consolidated Fund Charges." They include provision for the Sovereign's Civil List, for the salaries and pensions of the judges, and various other charges. Apart from two or three pensions for distinguished military or naval services, the whole of this expenditure is civil in character. The figures are as follows :-

\section{Other Consolidated Fund Charges}

1897-1898

$1907-1908$

* This figure is swollen by a charge of $£ 250,000$ for expenses under the Coinage Acts 1891 and 1893.

It is unfortunate that these charges are not discussed with the Civil Service estimates, but at present no estimate of the Consolidated Fund Charges is laid before Parliament, except in the 
budget statement of the Chancellor of the Exchequer. This is one of the weak points in the financial control exercised by the House of Commons. Several of these charges would certainly be criticized if members generally were aware of their existence, and though none of them can be repudiated, many of them lapse in the ordinary course of nature, and their renewal might be prevented.

We have not, however, yet reached the limit of civil expenditure. Another large item consists of the revenue derived from certain taxes set aside for the benefit of the local authorities. These taxes are imposed by the authority of Parliament; they are collected by officials under the control of Parliament, and the revenue so obtained is then distributed among the local authorities in the manner prescribed by Act of Parliament. In effect, these taxes are a portion of the imperial revenue, and their distribution should properly be treated as imperial expenditure. This course is now being followed as a consequence of the reform instituted by Mr. Asquith. These assigned taxes do not, however, constitute the whole of the imperial subsidy to local needs. In addition, direct grants amounting to over a million sterling are paid out of the Consolidated Fund. Taking the two elements together, we obtain the following figures as the total contribution from the imperial taxes to local finance:-

1897-1898

$1907-1908$

$£ 9,402,000$

$11,155,000$

We have now collected all the items of civil expenditure, but before bringing them together it is necessary to make certain deductions. Under the peculiar system of account-keeping maintained by the Government, certain military and naval charges are borne upon civil votes. Whenever the First Commissioner of Works is called upon to do any building for the Admiralty or the War Office, it is charged upon the vote for the Board of Works, and appears as civil expenditure. The same confusion occurs with the stationery supplied to the army and navy by the Stationery Department, and with the services rendered by the Post Office. The sums to be deducted on the head of naval and military expenditure

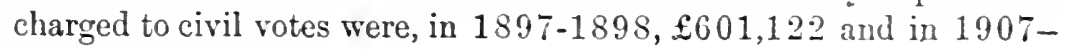
$1908, £ 822,000$.

Deducting these sums from the various items of civil expenditure enumerated above, we have the following result:-

Total Civil Expenditure of the Uniter Kingdom 
This result shows that in a period of ten years our civil expenditure increased by nearly 40 per cent., and the actual addition made came to $£ 17,000,000$ a year.

\section{Comparative Analysis of Expenditure in 1897 and 1907}

In order to see where the increase occurred in these figures it is proposed to analyse the sums which have been quoted. The analysis follows the classification of the Appropriation Accounts as far as possible, for though the form in which these accounts are drawn up makes it difficult to separate the cost of the various departments-for many appear under more than one head-it would be impossible to rearrange the details of the two large volumes. The account is further confused by the appropriations in aid which accrue to many of the departments. These are in the nature of county court fees, proceeds of sale of stores, etc., the money sometimes being paid by the public and sometimes by other Government departments.

The appropriation accounts quote the gross expenditure and also the appropriations in aid received under each head. The difference between these represents the sum to be provided by Parliament, and is to some extent comparable with the estimates for the coming year, though the latter are too often added to later in the session by the supplementary estimates.

\section{Summary}

\begin{tabular}{|c|c|c|c|}
\hline & $1897-1898$. & $1907-1908$. & $\begin{array}{c}\text { Estimates, } \\
1910-1911 .\end{array}$ \\
\hline I. Public Works and Buildings . & $\stackrel{£}{£}$ & $\stackrel{\mathfrak{E}}{2,716,400}$ & $\stackrel{\mathcal{E}}{\stackrel{\mathcal{L}}{3}, 452,294}$ \\
\hline $\begin{array}{l}\text { II. Salaries and Expenses of Civil Depart- } \\
\text { ments }\end{array}$ & & 2886564 & 3455,545 \\
\hline 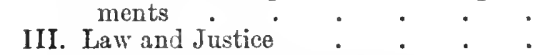 & $\begin{array}{l}2,097,932 \\
3,628,681\end{array}$ & $\begin{array}{l}2,886,564 \\
3,854,402\end{array}$ & $\begin{array}{l}3,450,545 \\
4,442,611\end{array}$ \\
\hline IV. Education, Science, and Art & $11,525,818$ & $17,163,278$ & $18,651,483$ \\
\hline V. Foreign and Colonial Services . & $1,160,212$ & $2,042,364$ & $1,862,190$ \\
\hline VI. Non-Effective and Charitable Services & 747,639 & 810,377 & $* 10,073,049$ \\
\hline VII. Miscellaneous.$\quad \cdot \quad \cdot \quad \cdot$. & 355,859 & 512,707 & 748,274 \\
\hline VIII. Revenue Departments & $14,265,009$ & $20,843,581$ & $23,382,656$ \\
\hline Total & $35,669,830$ & $50,829,673$ & $66,068,102$ \\
\hline
\end{tabular}

* Includes Old-age Pensions, $9 \frac{1}{4}$ millions.

Apart altogether from Old-age Pensions, which is a steadily increasing item, there are some considerable advances. As between 
1897 and 1907 , the largest increases are in education and the revenue departments, which between them account for 12 millions of the 16 millions increase. Other items to which attention should be given are those in respect of public buildings, which show an increase of nearly 50 per cent., the expenses proper of the civil departments, which have risen 47 per cent., the cost of the colonial and foreign services, and miscellaneous expenses.

\section{Public Works and Bulldixgs}

The first class is that of public works and buildings. Many of these items are for departments, like the post office, which figure in the returns elsewhere. Apart, however, from the confusion, there seems to be great and growing extravagance in public buildings.

Class I.-Public Works and Buildings

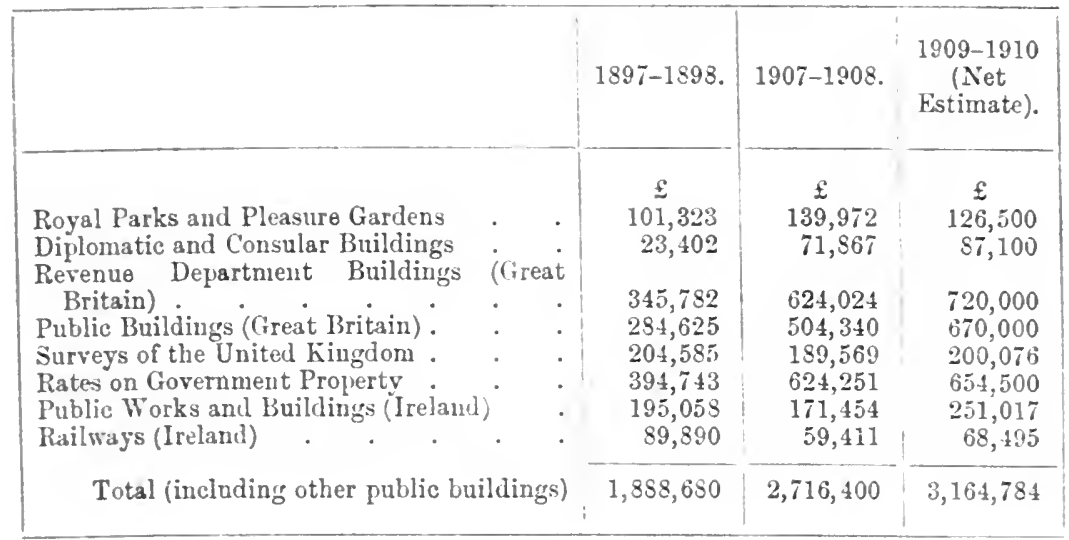

The entry for rates on Government property shows an inerease out of proportion to the sum spent on buildings, but it has to be remembered that Government property has increased in every one of the intermediate years. The expenditure on public buildings shows the largest proportionate increase. It may be pleaded that Great Britain is not lavish in its public buildings compared with some other countries, and in the case of the Govermment departments efficiency may have suffered from inadequate housing and the scattered location of independent offices, and sometimes even of branches of the sane department. Nevertheless, the idea that every civil or municipal officer must live in a palace has been sadly overdone. 


\section{Class II.-Salaries and Expenses of Civil Departments}

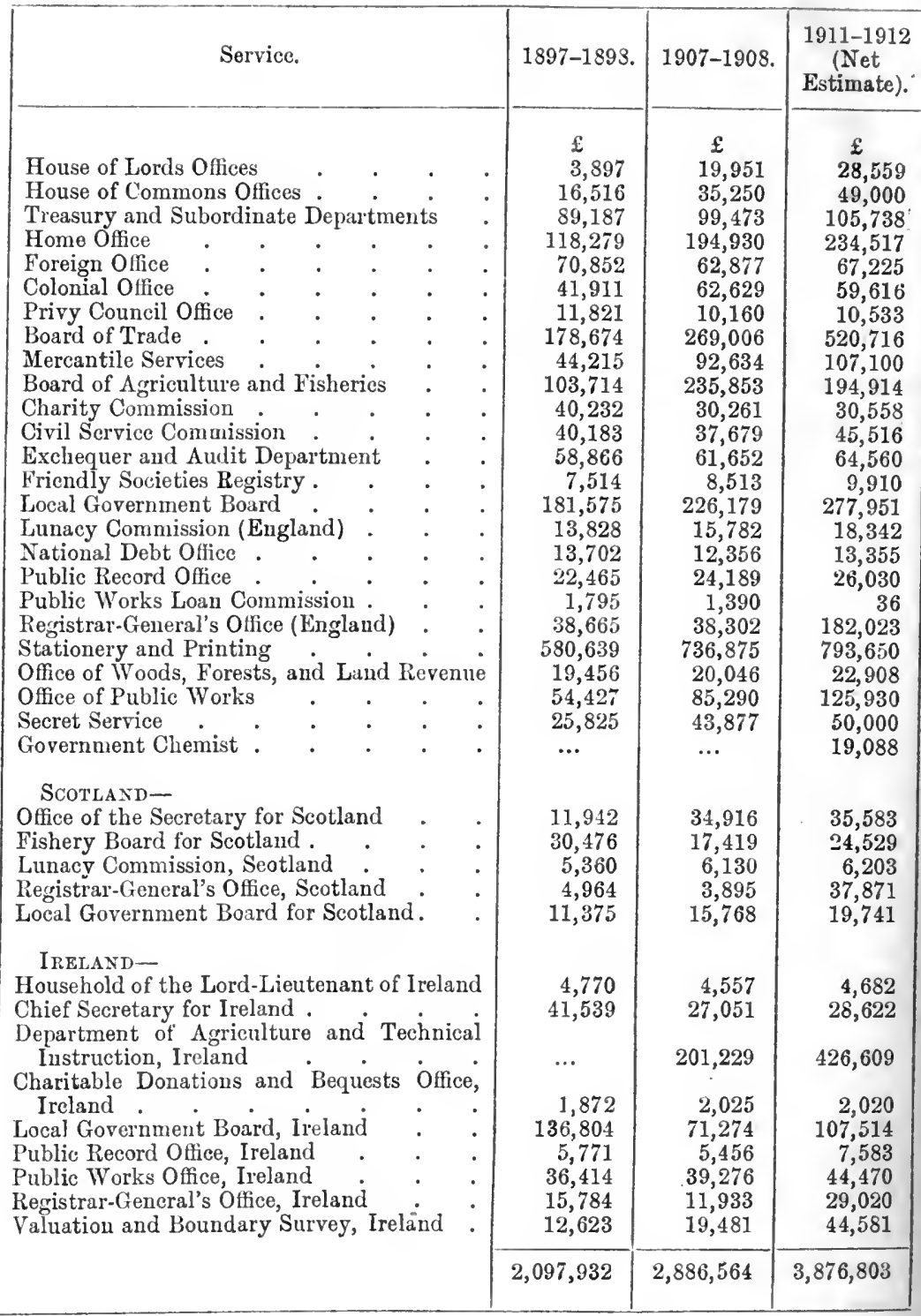

\section{Salaries and Expenses of Civil Departments}

The second group contains the expenditure of the administrative departments. The three millions to be voted under this head are, in fact, the cost of running the permanent civil service, and those 
who hold with the dictum that the best Government is that which spends most lavishly would probably find an outlet for their spendthrift propensities in a great addition to this sum. Every fresh form of Government activity, every new department created means an addition to the cost of these civil departments, and, as will be seen from the table on the previous page, the total expenditure has nearly doubled in the fourteen years covered by the figures.

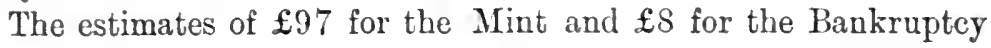
Department of the Board of Trade are omitted from the table, as the receipts and fees of these departments exceed the cost; in fact, they contribute no balance to the Exchequer. The votes are included so as to bring the departments before the House of Commons. As regards England, it will be seen that large increases are recorded in the case of the Home Office, the Board of Agriculture, the Local Government Board, the Stationery Office, and, in particular, in the Board of Trade, which has been compelled to undertake an enormous number of new or additional duties in connexion with labour.

The Home Office has had to add greatly to its staff on account of the work put upon it by recent Factory and Workshop Acts and other industrial legislation. A comparison of 1897 with 1907 in regard to factory inspection yields the following result:-

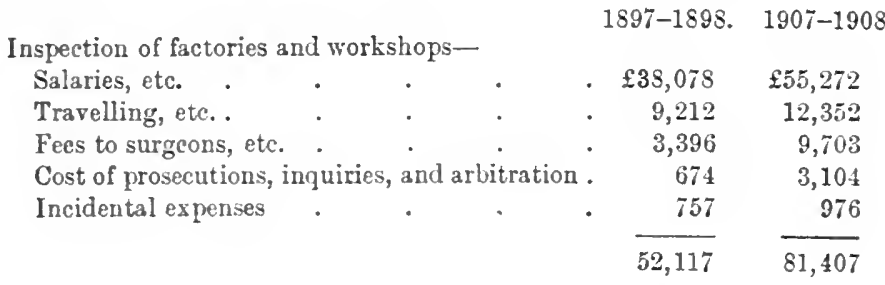

The remainder of the increase is due to contributions towards the maintenance of certified inebriates' reformatories under the Act of 1898 (absorbing a sum of $£ 26,000$ ) and a sum of $£ 11,000$ the cost of the Aliens Act of $1905-£ 9206$ being the salaries, fees, and allowances to officers. In view of the admitted failure of the Aliens Act as a real safeguard against the admission of undesirable persons, it would scem that $\mathfrak{£ 1 1 , 0 0 0}$ is a large sum to pay to keep out a few poor refugees. The increase in the Local Government Board Vote is incurred in respect of the general staff and of the district auditors. The increase in the salaries of the latter is well spent if it improves their supervision over the expenditure of local authorities. In the Board of Trade, which shows the largest in- 
crease of all the departments, the additional expenditure is mainly incurred in two departments-namely, the Commercial, Labour, and Statistical Department, and the Patent Office. Since the first fiscal inquiry, initiated by Mr. Balfour, the Board of Trade has engaged in a series of important investigations, and has enlarged its statistical functions to meet the demand for more information on the leading social and economic questions of the day. The cost of this development increased the sum spent by the Labour Department from $£ 19,000$ to $£ 47,500$. The Patent Office has shown a similar increase, owing to the greater trouble taken in the investigation and recording of patents. Salaries and wages in this department have risen from $£ 57,000$ to $£ 110,000$. The increase of $£ 50,000$ in the Board of Trade estimate includes the cost of the Census of Production Office, whose reports have been freely used in this book. Whether the census was worth undertaking is however arguable, for there are limits to expenditure of this kind.

The Civil Service Departments of Ireland and Scotland naturally show smaller advances. The most important of the sums is that for the Agricultural Board of Ireland; but the "work which has been done in arresting Ireland's agricultural decline and developing its resources is a more productive undertaking than many which could show a credit balance in their account.

\section{Law, Justice, and Police}

The third class includes expenditure on law and justice, so far as this comes within the province of the central administration. It is of some interest to note how the increase in this section between 1897 and 1907 , which amounts to about $£ 550,000$, is distributed among the three kingdoms:-

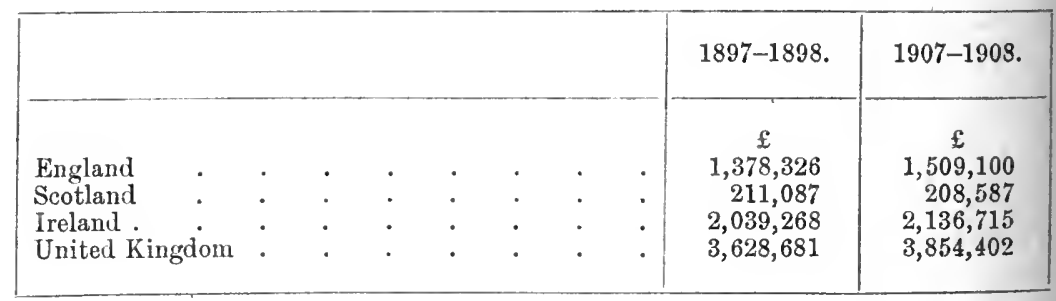

Thus England's expenditure has increased by 20.8 per cent., Scotland's by 7.6 per cent., and Treland's by 12.3 per cent. Ireland's immense share is due to the fact that the Royal Irish Constabulary 
is a charge on the United Kingdom, and also to the Irish Land Commission.

The detailed items which comprise these totals are as follows:-

Class III.-Law and Justice

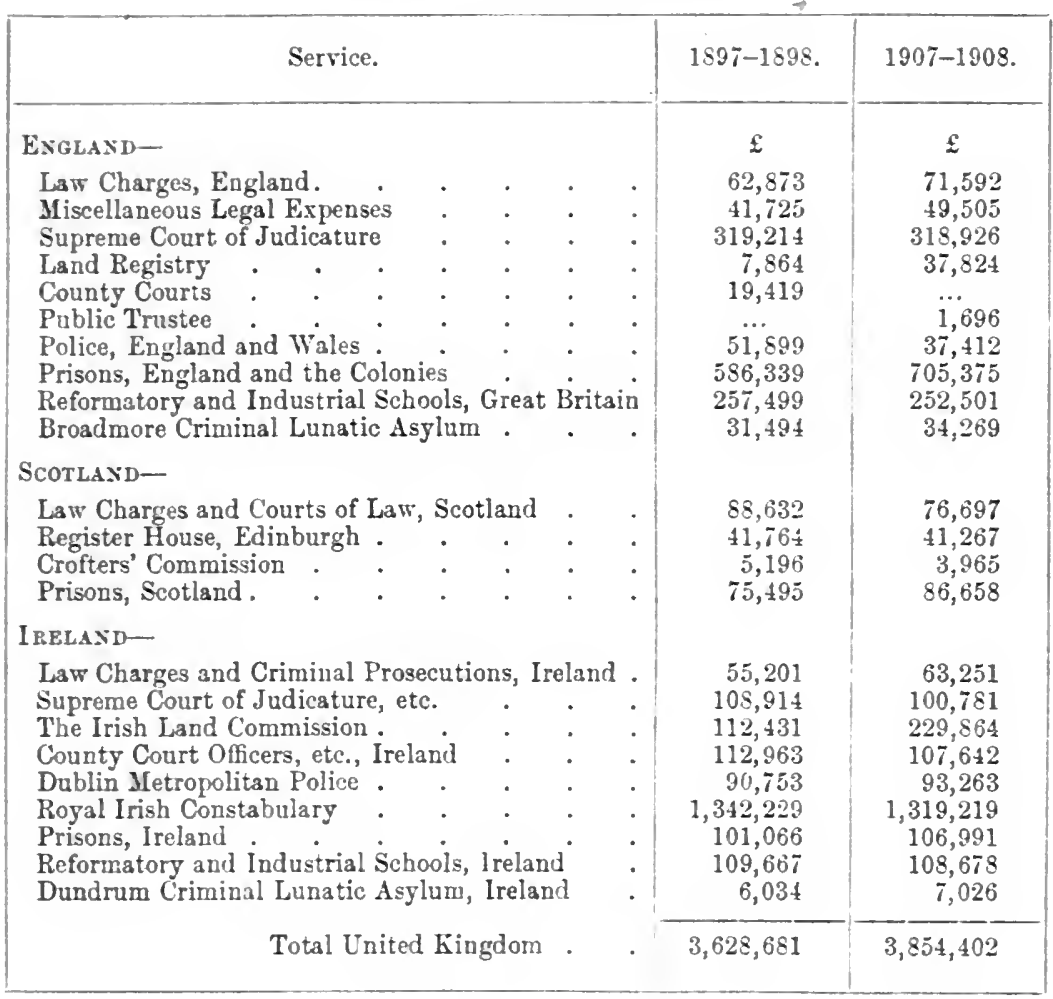

In examining these figures, it should be borne in mind that they do not represent the gross cost of the various bodies included, for nearly all of them have large receipts or appropriations in aid, which they receive from fines, etc. The London police courts, for example, are not included, as they are entirely self-supporting, and, in fact, make a lucrative business out of those unheroic persons who prefer a fine to imprisonment. Similarly the county courts in recent years have made no call on the public purse. The upkeep of prisous is chiefly responsible for the increase in the English figures, the sums for 19071908 being $£ 120,000$ in excess of that for $1897-1898$.

The Irish statistics testify to the extravagance of the rule of Dublin Castle. The increased cost of the Irish Laud Commission represents the expense of working the Wyndham Act of 1903. 
On the whole, the expense of administering justice and keeping order in the United Kingdom has shown only slight changes. It is a branch of the estimates which we may hope to see reduced with the diminution in crime. Any tendency that there might be in this direction has, however, hitherto been checked by the increased administrative expenses of the prisons themselves, and, in particular, by the very lavish scale of pay in proportion to the work done in the numerous law offices and departments of the country.

\section{The Board of Education and Other Votes}

In the Civil Service the most important spending department is the Board of Education, which now requires annually about $13 \frac{1}{2}$ millions of the imperial revenue. It is, of course, impossible to obtain either from the estimates or from the appropriation accounts a complete statement of the amount spent on public education in this country, because much of the money is raised in the form of rates and expended by local authorities under the supervision of Whitehall. This naturally complicates the accounts, and it is a standing subject of disagreement among educational experts whether the Treasury is at present supplying a larger or a smaller percentage than formerly of the total cost. It has, for example, been said that " in 1871 the percentage contributed by the Treasury was 90 per cent., and now it is less than 50 per cent.," but these figures are arrived at by neglecting all the voluntary contributions, the fees, and the income from endowments, which formerly met the greater part of the expenditure of elementary schools; these sources of income must obviously be taken into account if we are to form a proper estimate of the Treasury's importance in educational finance, and it is probably correct to say that in 1871 the Treasury contributed not 90 per cent., but 14 per cent. of the total. In any case, the actual cost to the Treasury has enormously increased in the past few years, and, taking together elementary education and the expense of the Science and Art Departments maintained out of the Imperial Exchequer, we find that the estimate for $1908-1909$ is roughly $\mathfrak{L} 13,600,000$ against an expenditure of $£ 8,800,000$ in $1897-1898$. The accounts themselves are complex and difficult; much of the money is not disbursed under any statutory direction, but in accordance with an everchanging and bewildering mass of codes and regulations which are too technical, and are no doubt meant to be too technical, for discussion in the House of Commons. It follows that over a long period, which, like 1897-1908, covers many changes in legisla- 
tion and the administrative system, it is extremely difficult to trace movements exactly, and discover just how the increase has come about; and a fortiori it is still more difficult to decide whether the taxpayer has had value for his money. In the following analysis questions of policy must be left on one side, and attention fixed on the difference in the various items between the present estimates and those of ten years ago.

The estimates for the Board of Education come under Class IV, which now covers fourteen separate heads, all of which are connected more or less closely with education, though only one of them has to do with English elementary education, the department in which expenditure has risen most rapidly. The other heads deal with the British Museum, picture galleries, research, and university education, and the financial burden of these institutions falling on the Treasury has altered comparatively little during the ten years. The following table shows the cost borne by the Exchequer under a number of different headings, all of which fall in Class IV of the estimates:-

Class IV.-Education, etc.

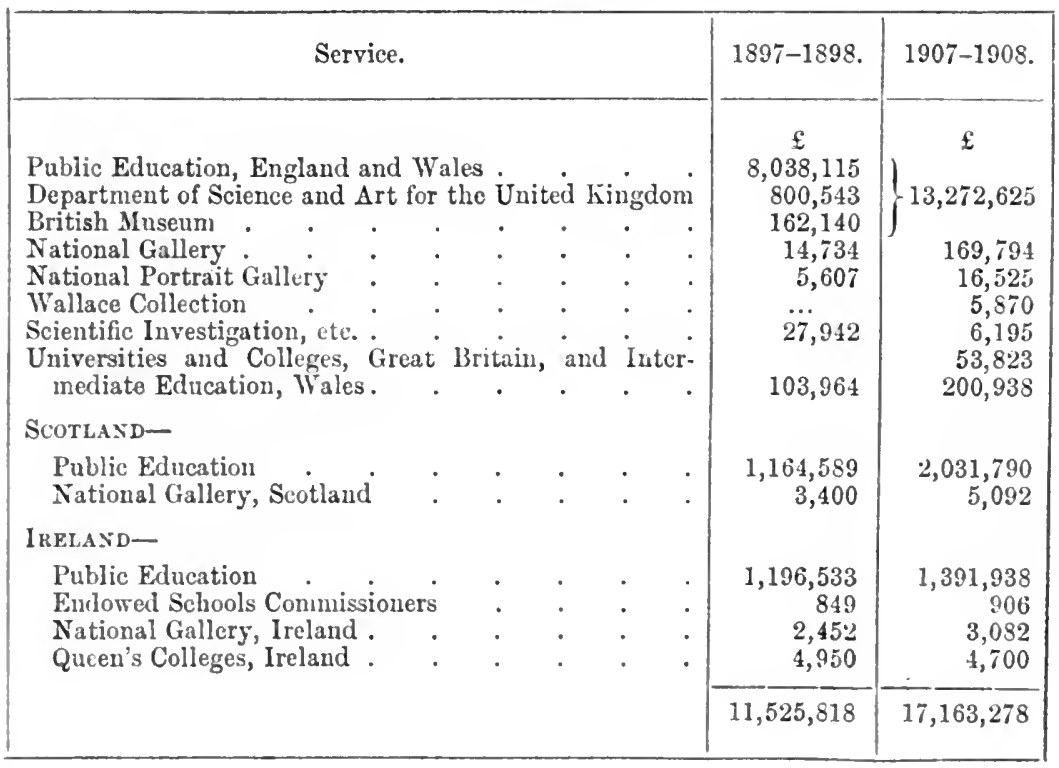

Taking first the expenditure in England, we find that the relation between public education, etc., and minor institutions works out in the following way :- 


\begin{tabular}{|c|c|c|c|c|}
\hline & & $1897-1898$ & $1907-1908$. & Increase. \\
\hline \multirow[t]{2}{*}{$\begin{array}{l}\text { Public Education and } \\
\text { Art } \cdot \text {. } \\
\text { Other departments }\end{array}$} & \multirow[t]{2}{*}{$\begin{array}{c}\text { Science and } \\
\cdot \quad \cdot \\
\cdot \quad \cdot\end{array}$} & $\begin{aligned} \mathfrak{f} \\
8,845,065 \\
339,918\end{aligned}$ & 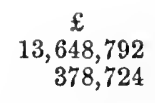 & $\begin{array}{c}£ \\
+4,803,727 \\
+\quad 38,806\end{array}$ \\
\hline & & $9,184,983$ & $14,027,516$ & $+4,842,533$ \\
\hline
\end{tabular}

So far, then, as England is concerned, the expenditure on the other departments in Class IV is small, and the increase in ten years moderate.

But when we come to the cost of elementary education in Great Britain we get a very different story. Here the Treasury is cxpending very nearly $£ 5,000,000$ more than it spent in 18971898 , the percentage of increase being well over 50 per cent. The chief items of expenditure are, of course, the grants made for different purposes to different sorts of elementary schools. The various administrative charges evolved since 1897 have carried with them corresponding changes in the form of the accounts, and the phraseology of the department has altered so much that an exact and detailed comparison is very difficult. But in the following figures we show the difference between the total sum put down to grants in the appropriation accounts of $1897-1898$ and the appropriation accounts of 1907-1908:-

\section{Grants to Elementary Schools}

$\begin{array}{rrr}1897-1898 . & 1907-1908 . & \text { Increase. } \\ \mathfrak{1} 6,981,000 & £ 11,129,000 & £ 4,148,000\end{array}$

Thus practically the whole of the increase in the Board of Education accounts arises out of the grants made to elementary schools, and it may be well to set out the various heads under which this expenditure was incurred in 1907-1908:-

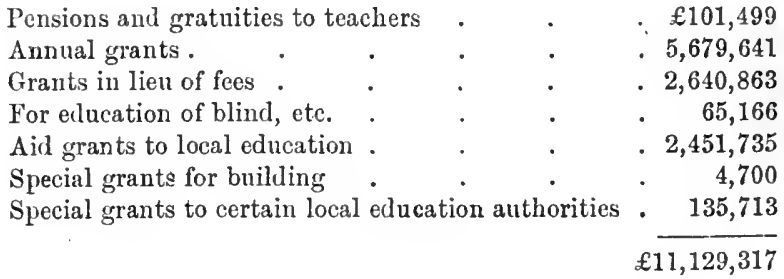

The appropriation accounts for 1897-1898 gave the following results :- 
Pensions and gratuities

Aunual grants .

Frce grants for day scholars

Grants for blind, etc. .

Grants to school boards under special $A$ cts
$£ 34,095$

- $4,546,835$

. $2,240,772$

17,723

141,997

$£ 6,981,422$

Broadly, it may be said that all legislation of the last few years has tended to increase the burden laid upon the Treasury. Whatever the object of the particular Bill, whether to appease the Church or satisfy the Nonconformists, whether to "co-ordinate education" or "strengthen popular control," the financial effect has always been the same, and the sums demanded from the taxpayer have constautly risen. Unfortunately, expert knowledge of education and expert knowledge of finance are not often found in combination, and the greatest enthusiasm for educating the young is often accompanied by an utter carelessness of the money of the taxpayer.

The figures that have been given in the above tables show that the cost of public edueation is enormously greater now than it was ten years ago, and that, unless the growing generation is mentally far better equipped now than then, there has been a serious waste of public funds. Whether we are really getting our money's worth out of the local authorities and the elaborate system that has been built up since 1897 is a question that cannot be decided by figures; but there are certain considerations that ought to be taken into account, and it may be suggested that much may undoubtedly be done to ensure greater efficiency and prevent leakage. The Treasury should secure that grants are more strictly earmarked for the benefit of the child. At present there is a vast amount of waste in unnecessary luxuries, in the building of ornamental palaces, in the multiplication of clerks, inspectors, and so forth. The regulations of the Board of Education offer a rational method of economizing grants and increasing the efficiency of the schools; the grant for any school may be diminished wherever there is inefficiency; this power might be freely used; it should, in fact, be a rule of the Board to penalize in this way a considerable percentage of the schools; such pressure on the worst 25 per cent. would quickly improve them, and would, at the same time, set free a very substantial sum of money; but these powers are not used. Many of the old safeguards for efficiency and economy have been swept away, and the Board of Education pays less regard to those which it has inserted in its voluminous codes. The taxpayer pays, and no questions are asked.

A departmental committee was appointed by 
the Treasury a few years ago to inquire into the proper relations to be established between the taxpayer and the ratepayer; but it was quietly suppressed and made no recommendations. The recent Education Bills of the Government were supposed, incidentally, to secure certain grants and to regulate the conditions on which grants should be given. But in the process of incubation at Whitehall they became Bills to abolish all statutory grants and to abolish nearly all statutory conditions, leaving the whole sum voted by Parliament to be dispensed at the discretion of the Board of Education. The first principle would be to secure by statute a fixed and certain contribution towards the education of every child; and secondly, a substantial supplementary contribution towards the additional cost thrown on any district by its poverty, its superabundance of children, its low rateable value, or its high cost of living; and thus secure to each locality that minimum income which is essential. After that the locality which desired to spend its own money in improving local education should be free to do so.

\section{Foreign AND COLONIAL}

The next class shows an alarming increase in expenditure in the ten years. The chief items are as follows:-

Class V.-Foreign and Colonial.

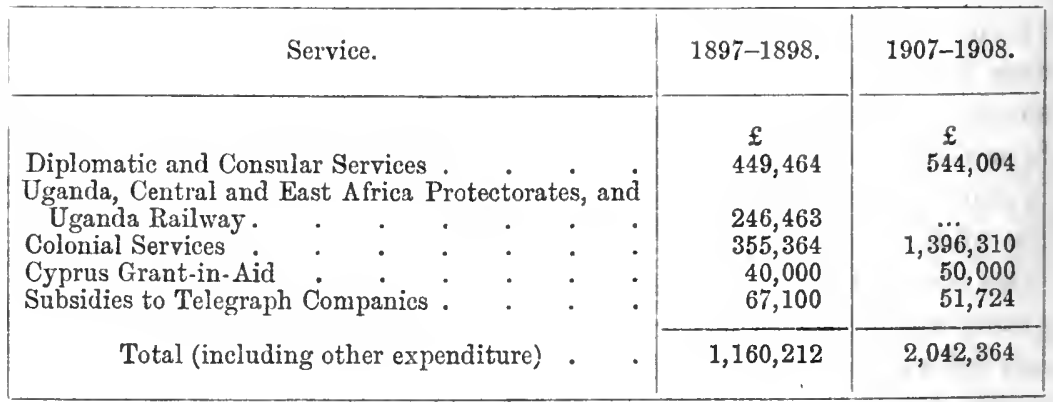

The larger part of the expenditure under this head arises from the practice of subsidies. The leading colonies became selfsupporting, and consequently a source of strength to the mother country. But even colonies so long established as Jamaica and the other West India Islands constantly receive assistance from the Imperial Exchequer', while the newer colonies in East and West Africa are a cause of a very heavy expenditure. The defence usually put forward for this expenditure, at any rate in the case of 
Nigeria and East Africa, is that the present outlay must be regarded as a capital investment, but no attempt is made to keep a capital account or debit the colonies with the money expended upon their development. For example, in the case of the Uganda Railway, which is now beginning to yield a revenue in excess of working expenses, the whole of the excess is handed over to the East African Protectorate, while the British taxpayer still continues to provide the whole of the interest and sinking fund upon the capital he has invested.

\section{Superanyuation and Non-Effective Services}

The first item in this class reflects a serious growth in the personnel of the Civil Service. Every person added to the Government service, whether civil or military, is a person withdrawn from the productive and revenue-producing classes, and added to the great army of those who live upon and swell the taxes. The item of Savings Bank and Friendly Society deficiencies is swollen by the sum paid on account of the Post-office Savings Bank, which pays a higher rate of interest on deposits than is justified by the low return obtained from its investments. This deficiency, which was $\mathfrak{1 1 , 6 0 0}$ in 1897 , amounted to $£ 120,000$ in 1907 .

\section{Class VI.-Non-Effective and Charitable Services}

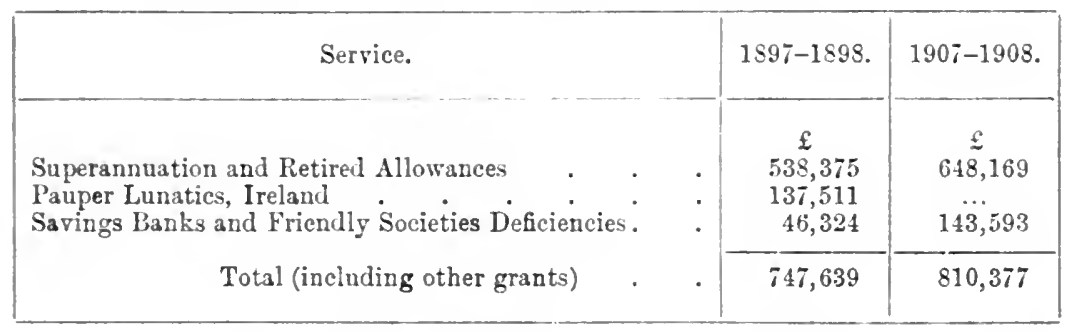

Old-age Pensions are now included in this estimate. They have grown for 1911-1912 to the enormous total of $£ 12,415,000$, owing to the removal of pauper disqualification.

\section{Miscellaneous}

The payments under this heading have increased considerably during the last ten years, but it will be seen that a great part of the addition is under the two heads-Irish Development Grant and the Unemployed Workmen's Act, 1905. 
Class VII.-Miscellaneous

\begin{tabular}{|c|c|c|}
\hline Service. & $1897-1898$ & $1907-1908$. \\
\hline 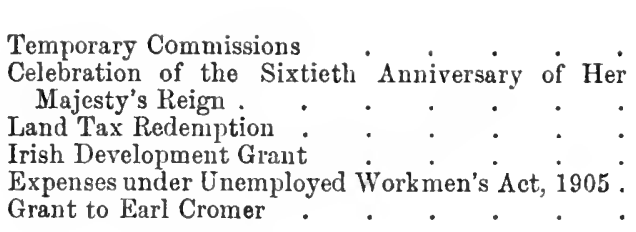 & $\begin{array}{c}£ \\
31,624 \\
76,408 \\
100,446 \\
\cdots \\
\cdots \\
\cdots\end{array}$ & 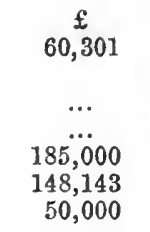 \\
\hline Total (including other grants) & 355,859 & 512,707 \\
\hline
\end{tabular}

The sum for Temporary Commissions (almost the only permanent item in this list) shows a very large proportionate increase, namely, $£ 60,300$ in 1907-1908, compared with $£ 31,624$ in 1897-1898. This item is one of those small leakages which, because the sum involved does not run into millions, often escape notice. There is very little control over the expenditure of these twenty-eight temporary commissions, for they are usually left to determine more or less the extent and scope of their own inquiry, as the terms of reference are so often vague. The recent Poor Law Commission, for example, is a case in which, though the members were unpaid, money was spent very lavishly.

No one would wish to deny that these temporary commissions often do good service to the nation. The mere possibility that the Tuberculosis Commission may do something to check the ravages of that disease is perhaps worth the $£ 57,000$ which has been spent by the commissioners, while the evidence collected by the Poor Law Commission will have much value for future workers on social matters. The point to which attention should be drawn is the absence of any real control, and there is much to be said for the policy of not giving the commissions a free hand, but of assigning a given sum to be spent in the investigation of a particular subject. But perhaps those in authority find a Royal Commission the easiest, if not the cheapest, means of keeping busybodies quiet and sending inconvenient enthusiasm to sleep.

\section{Revenue-Earning Departments}

Of the three items included under this head, the post office shows the largest increase. 
Class VIII._Revenue Departments

\begin{tabular}{|c|c|c|c|c|c|c|c|c|c|}
\hline & & & & & & & & $1897-1898$. & $1907-1908$. \\
\hline $\begin{array}{l}\text { Customs } \\
\text { Inland revenue } \\
\text { Post office } \\
\text { Post packet service } \\
\text { Post telegraphs }\end{array}$ & . & . & $\dot{ }$. & . & : & $\dot{.}$ & $\begin{array}{l}\cdot \\
\cdot \\
\cdot \\
\cdot\end{array}$ & $\left.\begin{array}{c}f \\
84 \bar{j}, 191 \\
1,818,642 \\
7,602,564 \\
746,757 \\
3,251,855\end{array}\right\}$ & $\begin{array}{c}\mathfrak{£} \\
949,387 \\
2,275,184\end{array}$ \\
\hline & & & & & & & & $14,265,009$ & $20,843,581$ \\
\hline
\end{tabular}

As regards the post office, the accounts must be taken on both sides. The figures of revenue for the years 1897 and 1907 compare with the expenditure as follows:-

\begin{tabular}{|c|c|c|c|c|}
\hline & . & . & $\begin{array}{c}\text { Rerenue. } \\
. \quad £ 15,180,000\end{array}$ & $\begin{array}{l}\text { Expenditure. } \\
£ 11,601,000\end{array}$ \\
\hline 30 & . & . & . $22,300,000$ & $17,619,000$ \\
\hline
\end{tabular}

It will be seen that the profit earned by the department for the relief of the taxpayer increased from $£ 3,579,000$ in $1897-1898$ to $\mathfrak{E} 4,681,000$ in $1907-1908$, and if this growing profit were earued in the ordinary way of business it would be magnificent. But it is necessary to remember that the post office is endowed with a monopoly, and that the profit earned arises exclusively from the collection, conveyance, and distribution of penny letters. That service costs considerably less than a balfpenny per letter, and the extra halfpenuy ought, therefore, to be regarded as a tax. It is a very good tax, as taxes go, but its yield should be judged like the yield of other taxes, and no Chancellor of the Exchequer ought ever for a moment to admit that because this tax yields a considerable revenue, therefore the post office is justified in indulging in needless or unprofitable expenditure. This, however, is what is in practice done. The administration of the telegraphs by the post office involves the nation in a heavy loss of not less than $£ 1,000,000$ a year, apparently because the Postmaster-General undercharges consumers, especially newspapers, for telegrams. 


\section{CHAPTER XXXVII}

\section{TAXATION AND COMMERCIAL POLICY, 1840-1910}

Gradual removal of our old Protective and Preferential Tariff-Mr. Gladstone's budgets-South African War finance-Mr. Lloyd George's budget of 1909

T $\mathrm{T}$ was mainly under the auspices of Huskisson, Peel and Gladstone that the system of Protection and Colonial Preference, built up during the commercial wars of the eighteenth century and increased during the Napoleonic wars, was relaxed and finally swept away. Porter, one of the severest critics of the system which he had to administer at the Board of Trade, assisted in the introduction of Free Trade, though he did not live to see its practical completion in the budgets of 1853 and 1860 . Huskisson had popularized the idea of a more liberal commercial policy at the Board of Trade and as Colonial Secretary; but when Peel came into power in 1841 he found a multitude of vexatious burdens still impeding our foreign and colonial trade. "Probably," wrote Sir Stafford Northcote, "no budget was ever awaited with more interest, anxiety, or curiosity, than that of 1842 . Serious financial difficulties had been accumulating for several years. Five times in succession the revenue had fallen short of the expenditure by amounts averaging about a million and a half per annum." In the year 1840-1841 the income had fallen short of the estimate by more than a million sterling, and this was the more alarming, adds Northcote, "since the failure had occurred in the portion of our revenue upon which we mainly depended, and which then constituted about four-fifths of the whole, namely, the revenue from the customs and the excise." Such was the testimony of a strong Conservative, a close student of public finance, who afterwards became Chancellor of the Exchequer under Disraeli, and leader of the House of Commons. This failnre of our old fiscal system, combining protection, retaliation and preference, appeared in his view "to inply an exhaustion of the resources of the people, more serious 
than any deficit in the Exchequer, which was unhappily but too much in accordance with other disheartening signs of the times." For there was at this period, as he reminds us, "a great deal of suffering among the lower orders, and especially among those engaged in mannfactures; there was a scarcity of employment, and provisions were at a high price." The policy of Sir Robert Peel and his Cabinet was influenced indirectly by Adam Smith's Wealth of Nations, which had been cleverly applied to the fiscal problems of the day by Sir Henry Parnell in his work on Financial Reform. The Import Duties Committee of 1840 had also spread distrust of Protection among men of intelligence, while the strenuous efforts of the Anti-Corn Law League, led by such persuasive orators as Cobden, Bright, and Fox, were rapidly converting the industrial districts of England and Scotland to an out and out advocacy of Free Trade. On the existing basis of taxation, Sir Robert Peel, in laying his great new plan of finance before the House of Commons on March 11, 1842, made the following estimate of income and expenditure, showing, as will be seen, an anticipated deficieney of $£ 2,469,000$.

\begin{tabular}{|c|c|c|c|c|c|c|c|}
\hline \multicolumn{8}{|c|}{ Revenue } \\
\hline Customs & . & . & . & . & & . & $£ 22,500,000$ \\
\hline Excise & . & . & . & . & . & . & $13,450,000$ \\
\hline Stamps & . & . & . & . & . & . & $\tau, 100,000$ \\
\hline Taxes & . & . & . & . & . & . & $4,400,000$ \\
\hline Post oflice & & . & . & . & . & . & 500,000 \\
\hline Crown lands & & . & . & . & . & . & 150,000 \\
\hline Miscellaneor & ous & . & . & . & $\bullet$ & . & 250,000 \\
\hline \multicolumn{5}{|c|}{ Total income } & . & . & $£ 48,350,000$ \\
\hline \multicolumn{8}{|c|}{ Expenditure } \\
\hline \multirow{2}{*}{\multicolumn{4}{|c|}{$\begin{array}{l}\text { Debt (Funded and Unfunded) } \\
\text { Charges on Consolidated Fund }\end{array}$}} & . & . & . & $£ 29,427,000$ \\
\hline & & & & . & . & . & $2,368,000$ \\
\hline Army & . & . & . & . & . & . & $6,617,000$ \\
\hline Nary & . & . & . & . & • & • & $6,739,000$ \\
\hline Ordnance & . & . & . & . & . & $\cdot$ & $2,084,000$ \\
\hline Miscellaneot & & 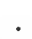 & . & . & . & . & $2,800,000$ \\
\hline \multicolumn{4}{|c|}{ Canada, clothing and volunteers } & . & . & . & 108,000 \\
\hline \multicolumn{3}{|c|}{ Expedition to China } & . & . & . & . & $6 \pi 5,000$ \\
\hline \multicolumn{5}{|c|}{ Total expenditure } & & & $\mathcal{E} 50,819,000$ \\
\hline
\end{tabular}

The above statement gives a very good view of public finanee as Peel found it. As far as expenditure goes, the only ordinary item which is larger than at present is the charge for debt. The army and ordnance together, it will be seen, cost less than nine millions and the navy less than seven. Sir Robert Peel refused to 
meet the deficit by increasing the charges on articles of consumption, because in this direction, he said, we had "arrived at the limits of taxation," and he was unwilling to add to the burdens of the labouring classes. He rejected the idea of reimposing old duties on salt and leather, or laying new taxes on railways and gas, nor would he resort to further loans which would depreciate national credit. He therefore proposed as his remedy that the income of the country should bear a charge of $7 \mathrm{~d}$. in the pound, or $£ 218 \mathrm{~s} .4 \mathrm{~d}$. per cent. "for the purpose of not only supplying the deficiency in the revenue, but of enabling me with confidence and satisfaction to propose great commercial reforms, which will afford a hope of reviving commerce, and such an improvement in the manufacturing interests as will react on every other interest in the country, and by diminishing the prices of the articles of consumption and the cost of living will in a pecuniary point of view compensate you for your present sacrifices." From the income-tax and an additional tax on spirits in Ireland in lieu of income-tax, with minor measures, he anticipated $£ 4,380,000$, and looked for a probable surplus of $£ 1,800,000$, which he applied to sweeping reforms and reductions of the commercial tariff. The tariff at that time was laid upon 1200 articles, and 950 of them were reduced or abolished in this budget of Sir Robert Peel's. He removed prohibitions. He reduced duties on law materials to a 5 per cent. maximum. He reduced duties on semi-manufactured articles to a $12 \frac{1}{2}$ per cent. maximum. He reduced duties on fully manufactured goods to a 20 per cent. maximum. The relief to the consumer was much greater than the loss to the revenue; in fact it was calculated to be nearly double. In the two following years, various but unsuccessful attempts were made to conclude commercial treaties with foreign countries on the basis of retaliatory bargaining.

Peel's budget whetted the appetite of manufacturers and workmen for more reductions. In 1843 the tax on machinery was abolished, and in 1844 the success of Sir Robert Peel's policy from the standpoint of revenue appeared in a surplus of over four millions sterling. Goulburn, who had been made Chancellor of the Exchequer by Sir Robert Peel, thereupon reduced, or abolished, a large number of import duties, and in the next year the incometax was renewed, this time "not for the purpose of providing the supplies of the year," to quote Sir Robert Peel's own words, "but distinctly for the purpose of enabling us to make the experiment of reducing other taxes." Upon this all-important question of Sir Robert Peel's commercial policy it may be well to quote the very 
cautious and moderate language of Sir Stafford Northcote: "The experience, however, of the last three years had led both the nation and the ministry to look with a different eye upon our system of indirect taxation. The seeming paradox that a larger revenue might be obtained from smaller duties had turned out to be the simple expression of an economical law which appeared capable of more extensive application than it had yet received. Duties had been largely reduced and even in some cases repealed, yet the revenue was as large as before, and was evidently growing. Perhaps this fact did not conclusively prove that the increase of revenue was caused by the remission of the duties; but it undoubtedly afforded a fair presumption that there was some connexion between them."

On this occasion remissions and reductions of taxation were made to the extent of $£ 3,338,000$. The coal and other export duties were removed, and about 4.30 articles, yielding small revenues, were swept from the tariff at an expense of only $\mathfrak{f} 320,000$. Uuder Excise the auction duty and the duty on glass were abolished. This budget again was very satisfactory, for at the end of the financial year there was a surplus of $£ 2,380,000$. The remission of $£: 3,300,000$ in customs and excise duties caused a loss of only $\mathfrak{f 2}, \pm 36,000$ to the revenue. The events leading to the repeal of the Corn Laws in 1846 , which struck a final blow at the protective system in England, cannot be detailed here, but it should be observed that in the same year many large reductions were made in various duties upon raw and manufactured materials, including tallow, timber, cottons, woollens and linens, soap, candles, boots and shoes. In the next two or three years of Whig government, while the corn duties were being reduced to a registration duty of one shilling per quarter, no very large alterations were made in fiscal policy. In 1848 Lord John Russell sought to raise the income-tax from sevenpence to a shilling in the pound in order to increase the military and naval expenditure, but this proposal was abandoned, and the military and naval estimates were reduced.

In 1849 , as a corollary to the practical abandonment of the protectionist system, the old navigation laws were repealed, and in the following year the excise duty on bricks was abolished. In 1851 the window duties were abolished, the coffee duties reduccd, and the duties on foreign timber were halved. In the following year the Tories returned to office for a short time, but after the dissolution of Parliament they- were defeated and the Peelite 
government of Lord Aberdeen was formed in December, 1852, with Mr. Gladstone as Chancellor of the Exchequer. This brings us to Mr. Gladstone's great budget of 1853, which was founded on a renewal of the income-tax, and upon an important extension of the legacy duties, and a further increase of the spirit duties. As a set-off against the extension of the income-tax to Ireland, $\mathrm{Mr}$. Gladstone remitted the whole debt of $£ 4,500,000$ due from Ireland to England for advances made during the Irish famine.

Revenue, $1853-1854$

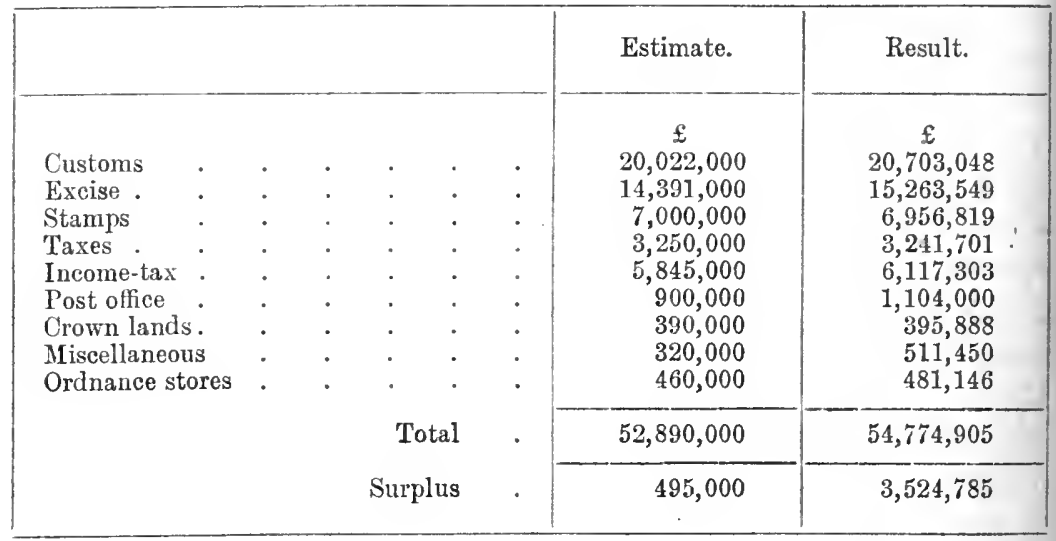

Expenditure, 1853-1854

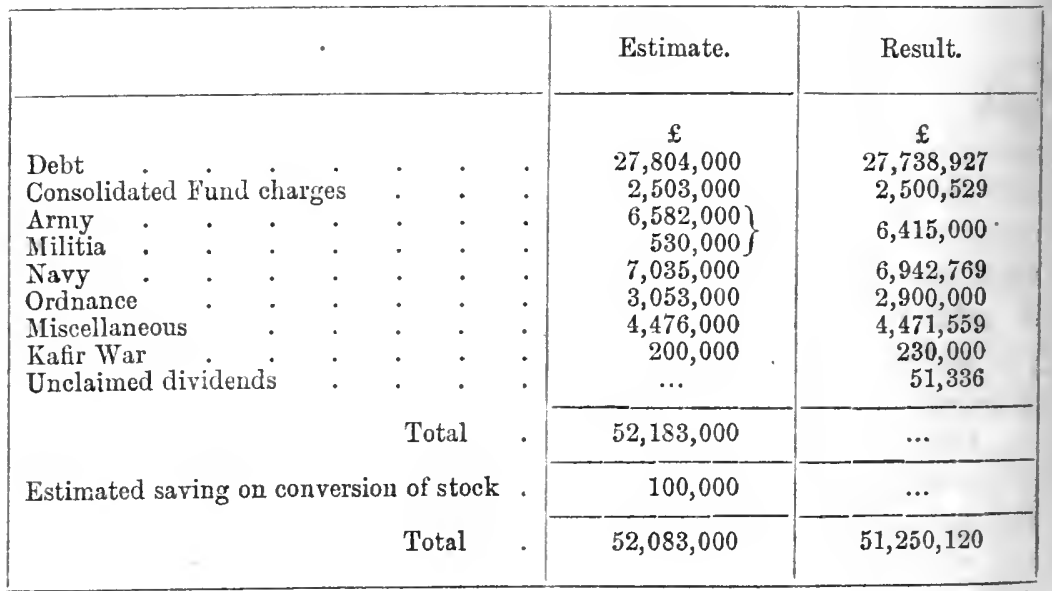

He repealed the soap duty, introduced a uniform penny stamp on receipts, reduced the advertisement duty, the newspaper stamp 
duty, and the hackney carriage duties. Under the head of Customs he abolished duties on 123 articles, and reduced them on 133 . Most of the remaining preferential and protective duties were abandoned, and the budget, as well as the budget speech, may fairly be regarded as one of the boldest and most brilliant in the history of British finance. The foregoing statement of the revenue and expenditure for 1853-1854 will show elearly some of the general changes that had occurred since Sir Robert Peel took our finances in hand.

Mr. Gladstone's budget of 1853 , with its famons defence and criticism of the income-tax, was accompanied by a plan for the gradual reduction of that tax and for its final extinction in 1860 . This object he hoped to facilitate by an extension of the legacy duty, which was to apply henceforth to real as well as to personal property and to successions as well as to bequests by will. $\mathrm{He}$ expected this change to realize nltimately a new revenue of $£ 2,000,000$.

But these fair financial prospects were destroyed by the Crimean War, into which Lord Aberdeen's Government drifted in the following year. To meet the cost of the war out of taxation as far as possible, Mr. Gladstone promptly doubled the incometax, raising it from $T$ d. to $1 \mathrm{~s}$. $2 \mathrm{~d}$. in the pound. $\mathrm{He}$ also raised the duties on Scotch and Irish spirits, revised and raised the sugar duties, and made a great increase on the malt duty. He defended these strenuous measures as a salutary and wholesome check which would compel the nation to keep its eye well fixed both upon the necessity of the war and upon the desirability of concluding as soon as possible an honourable peace. The expenses of a war, he said, "are the moral check which it has pleased the Almighty to impose upon the ambition and the lust of conquest that are inherent in so many nations." The Aberdeen Administration fell, and Sir George Cornewall Lewis succeeded Mr. Gladstone as Chancellor of the Exchequer. He raised a loan for $£ 16,000,000$ at $\mathfrak{f} 3 \mathrm{~s} .6 \mathrm{~d}$. per cent; he also raised the duties on sugar, coffee, tea, spirits and stamps, and added a further twopence to the income-tax. In this way the burden of the war was borne withont harassing commerce, and the policy of privateering and of commerce destruction at sea was practically abandoned by mutual arrangement with Russia.

The Chancellor of the Exchequer pointed out that the foreign trade of the country and its wealth had grown enormously since the French war. In 1815, he said, imports were valued at thirty- 
two and exports at fifty-eight millions. In 1853 imports had risen to 153 and exports to 242 millions sterling. These, of course, were official values and were very different from real values, but they formed a very fair standard of comparison. When the budget of 1856 was introduced on May 19th the war had come to an end. It appeared that the whole cost of the war was over seventyseven millions sterling, of which about forty-two millions had been added to the funded and unfunded debt. In this and in the following year, Disraeli, Gladstone, Cobden and various independent members of the House of Commons laid great stress upon the necessity for economy. The high taxation was very unpopular, and meetings were held in various parts of the country to get rid of the "war ninepence." A general attack was made upon the large and expensive establishments both for the army and navy which threatened to grow out of the war.

In 1857 the income-tax was lowered to sevenpence, the war duty on sugar was reduced, and the duty on tea was fixed at $1 \mathrm{~s} .3 \mathrm{~d}$. per pound. The Goverument, defeated on Mr. Cobden's motion condemning its Chinese policy, dissolved and was returned to office. In the autumn of this year, 1857, a serious panic occurred, and the Bank Act was suspended. With a change of government, Disraeli, who became Chancellor of the Exchequer, was compelled to make some small additions to taxation, and in the following year $\mathrm{Mr}$. Gladstone, who had joined the new administration of Lord Palmerston, was compelled to add to the income-tax in order to meet the growth of expenditure.

The budget of 1860 depended on the commercial treaty with France, negotiated by Cobden, and involving large remissions of duty on French produce and manufactures, which Mr. Gladstone estimated would involve a loss to the revenue of $£ 1,190,000$. Altogether, allowing for a heavy increase in the burden of armaments, including Lord Palmerston's fortification scheme, which Mr. Gladstone resisted with only partial success, there was an apparent deficit of $£ 9,400,000$ to face. The new budget scheme was based on a reimposition of the income-tax at tenpence in the pound on incomes of over $£ 150$ per year, leaving it at sevenpence on the lower incomes. In pursuance of the commercial treaty with France, the duties on silk, linen and woollen manufactures, gloves and leather, watches, artificial flowers, china, glass, etc. etc., were repealed, and the duties on wine and brandy were reduced. But apart from the commercial treaty Mr. Gladstone also proposed to repeal the duties on paper, tallow, butter, cheese, eggs, oranges and 
lemons, nuts, etc. etc., reducing also the duties on timber and various other articles. He also proposed to repeal the excise duty on paper, and to reduce the duty on hops.

$\mathrm{By}$ this extraordinary budget the articles subject to custom duties, which since 1842 had been gradually reduced from 1052 to 419 , were brought down at a stroke to 48 . The whole of the budget passed excepting the paper duties. The paper duty Bill was very unpopular with a powerful section of society, including many members of the Government. It was only carried by a small majority in the House of Commons, and was thrown out by the House of Lords.

In the following year, however, the repeal of the paper duties was wrapped up in the budget and successfully passed. At the same time (1861-1S62) the income-tax was reduced from tenpence to ninepence, in 1863-1864 from ninepence to sevenpence, in 1864-1865 from sevenpence to sixpence, and in 1865-1866 from sixpence to fourpence. These remarkable results were achieved in consequence of the severe economies which Gladstone imposed upon all the spending departments, and also of course by the extraordinary elasticity and expansion of the national trade and revenue. Mr. Gladstone in 1861 dwelt upon the growth of expenditure from $\mathfrak{f 5 1 , 0 0 0 , 0 0 0}$ in 1853 to $\mathfrak{£ 7 2 , 0 0 0 , 0 0 0}$ in 1860 . The local expenditure at the same time bad only risen from sixteen to eighteen millions. The reduction of taxation did not end with the incometax, for in 1865 the tea duty was halved-from one shilling to sixpence per pound. No wonder that the comfort of the working classes and the wealth of the whole nation were advancing at a prodigious rate.

From this time forward until the commencement of the Boer War in the autumn of 1899 , the fiscal and commercial policy of the nation proceeded more or less on the lines laid down by Peel and Gladstone. Perhaps the most interesting incident was the rejection by the country at the elections of 1874 of Mr. Gladstone's offer to repeal the income-tax, which has since become under the increasing pressure of military, naval and civil expenditure the mainstay of our financial system. as it had previously been the great engine for the removal of protection and the simplification of the tariff. The framework of the income-tax has undergone considerable changes. Under Peel the limit of exemption was $£ 150$ : this was subsequently lowered to $£ 100$, but afterwards raised again, and it

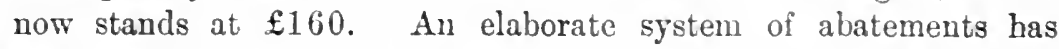
also been introduced for small incomes. After 1875 , when the 
income-tax was actually reduced to twopence, it was gradually increased to eightpence, which in the early 'nineties was thought to be a very high rate in times of peace.

When Sir William Harcourt, as Chancellor of the Exchequer, in 1892-1895 found himself hard pressed by the demand for naval expansion, he fell back, as Mr. Gladstone had done in 1853 , on the plan for taxing property at death, which has by some theorists been regarded as the best form of taxation. Sir Williarn Harcourt's death duties provided for the expansion of the military and naval estimates from 1895 to 1899 , and left a margin for the reduction of debt and for some small remissions of taxation.

The finance of the Boer War under Sir Michael Hicks-Beach was much less courageous than that of the Crimean War, though the country was infinitely more rich and prosperous, and therefore far more capable of paying its way. Altogether in the three years of the war $£ 76,000,000$ was raised by new and additional duties,

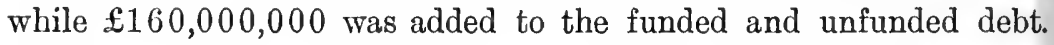
Of war revenue $£ 27,000,000$ was raised out of customs by increasing the old duties on tea, tobacco and spirits, by imposing a new duty of $4 \mathrm{~s}$. $2 \mathrm{~d}$. per hundredweight upon sugar, a duty of $2 \mathrm{~s}$. a quarter upon corn, and an export duty of $1 \mathrm{~s}$. per ton on coal. Nearly $£ 8,000,000$ was raised by additional excises on beer and

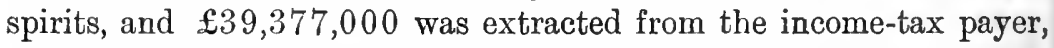
by additions of $4 \mathrm{~d}$. in $1900,2 \mathrm{~d}$. in 1901 , and a penny in 1902 . If the income-tax which stood at $8 \mathrm{~d}$. had been immediately doubled, and the death duties had been screwed up to the point which they have since reached, a much larger proportion of the cost of the war might have been paid out of current taxation.

The new duties on corn and flour, which stood at $3 \mathrm{~d}$. and $5 \mathrm{~d}$. per cwt. respectively, were repealed by Mr. Ritchie after the war, and this action led to the resignation of Mr. Joseph Chamberlain from Mr. Balfour's Cabinet, and to the Birmingham campaign in favour of preference and protection which has so changed the course of English politics, and has done so much to break up the Unionist party. The return of the Liberals to power with an unprecedented majority in 1906 was accompanied by good trade and an overflowing revenue. During the three years of Mr. Asquith's chancellorship the natural increase of the revenue, coupled with a severe curtailment of loans for works, enabled prodigious reductions of debt to be effected and also some reductions of taxation. The income-tax on earned incomes up to $£ 2000$ a year was eased off to $9 \mathrm{~d}$; t the export duty on coal was removed; the war duty on sugar was 
halved, and a penny was taken off the tea duty. But before the cleath of Sir Henry Campbell-Bannerman and Mr. Asquith's succession to the Premiership, the Government announced a scheme of old-age pensions involving an addition to the expenditure estimated at eight or nine millions, but soon found to exceed that sum. Hence when Mr. Lloyd-George came to the Exchequer he found himself faced by a very big deficit, enlarged by the demands of the navy and other services, and accompanied by a loud call from his Radical supporters for a democratic system of finance (in which a graduated income-tax and land taxation figured most prominently), while temperance reformers, indignant at the rejection of the Licensing Bill by the House of Lords, put forward urgent requests for a revision and scaling-up of the licensing duties on public-houses and ginpalaces. This situation led to the production of Mr. Lloyd-George's famous budget of 1909, which not only marks a turning point in the financial and constitutional history of the United Kingdom, but has also had widespread effects in other countries.

The main features of this budget may be set out as follows:-

New and
Increased Taxes.
Income-tax and snper-tax
Estate dnties
Stamp duties
Land taxes .
Liquor licences
Motor car licences .
Tobacco duties
Spirit duties
Petrol duties

Total estimated rerenue

\section{Estimated Revenue} in First Year.

$£ 3,500,000$

$2,850,000$

650,000

500,000

$2,600,000$

260,000

$1,900,000$

$1,600,000$

340,000

$£ 14,200,000$

At the same time, as he estimated for a deficit of $£ 16,712,000, \mathrm{Mr}$. Lloyd-George took three millions out of the sinking fund, which gave him an estimated surplus of $£ \notin 88,000$. "The People's Budget" fell heavily upon smokers and spirit drinkers, but it was recognized by the Unionist party as a double challenge to property and to their policy of tariff reform. Accordingly, when, after six months of debate, the budget (amended in various directions) passed the Commons, the House of Lords was induced (largely through the special dislike of its members for the land taxes) to take the unprecedented course of refusing its assent. The Government was therefore driven to the country in January 1910. Returning with a coalition majority of over a hundred, it eventually passed the budget, but the financial accounts of the country were thrown into great confusion, from 
which they only fully recovered at the beginning of the financial year 1911-1912.

As a revenue producer this Free Trade budget proved eminently successful. Its effect, both in raising revenue and in redistributing the burden of taxation, may be seen by comparing the revenue of 1908-1909, i.e. of the year preceding Mr. Lloyd-George's budget, with the estimated revenue for 1911-1912.

\section{Revenue (Exchequer Receipts), 1908-1909}

\begin{abstract}
Customs .
Excise

Estate duties

Stamps .

Old land tax

House duty

Income-tax
\end{abstract}

$$
\begin{aligned}
& £ 29,200,000 \\
& 33,650,000 \\
& 18,370,000 \\
& 7,770,000 \\
& 730,000 \\
& 1,900,000 \\
& 33,930,000 \\
& \text { Total . . } £ 125,550,000
\end{aligned}
$$

Adding to this the produce of the postal service, Crown lands and other non-tax revenue (in all $£ 26,028,000$ ), we get a grand total revenue for the year 1908-1909 of $£ 151,578,000$.

Let us now take the estimated revenue for the year 1911$1912:-$

\section{Estimated Revenue Receipts}

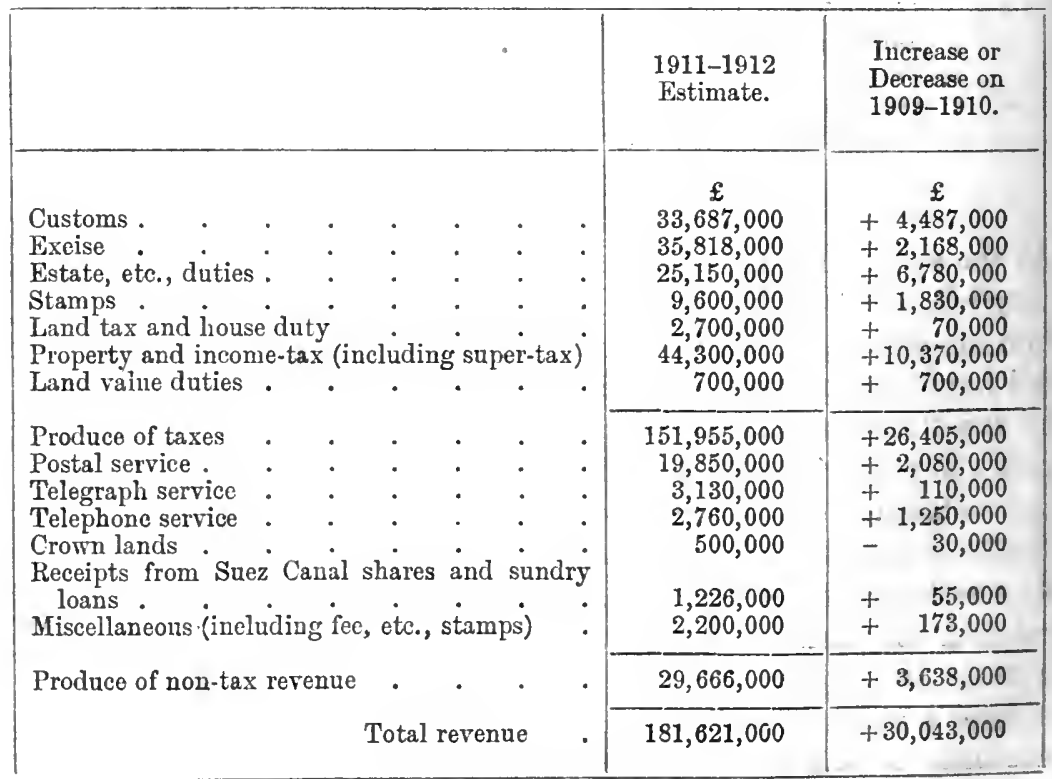


A comparison of these two years shows unmistakably the source from which has come the revenue for the navy and old-age pensions. Though the expansion of trade has brought in a big return from customs and excise, the new estate duties, and, above all, the graduated income-tax, have been the chief contributors to the Treasury. The expanded income-tax just pays for the expanded navy, but the estate duties do not cover the cost of the army. 


\section{CHAPTER XXXVIII}

\section{THE GROWTH OF WEALTH AND CAPITAL}

The increase of capital and its measurement-Estimated growth of British capital from 1600 to 1800 , from 1800 to 1885 , and from 1885 to 1910

" THE principal way in which capital increases in England now 1 is by abstinence from enjoyment." So wrote Bagehot in one of his economic essays, and what was then true is still true, although abstinence should have become pleasanter as the average income of the people has increased. While it is comparatively easy to see why capital grows, it is anything but easy to measure the rate of accumulation in any given country during any given period. For savings take innumerable forms. One man may buy land; another may build a house; another may pull down an old mill and construct a new one ; another may scrap his machinery and invest in new machinery, which will enlarge his profits and greatly increase his future accumulations, though it may absorb a substantial fraction of his past savings. Possibly it may be said that the ordinary man who saves 'puts his money into the Post-office Savings Bank or buys Stock Exchange securities for himself But this leaves out of account insurance, and there are probably tens of thousands of cases in which the annual premium accounts for the whole difference between income and expenditure. The records of capital issues, i.e. new loans and new companies of all kinds, which are floated in London, and for the most part subscribed in London and the provinces, form a very useful indication of the rate at which wealth accumulates. But as private forms of capital investment do not remain stationary, it would be unsafe to conclude that because capital issues are higher in one year than in another, therefore the savings and accumulated wealth of the nation as a whole have been increasing in the same proportion.

Economists and statisticians have recognized the interest and utility of ascertaining the capital wealth of the country at different dates, in order that they may see whether the country is growing more prosperous, and if so at what pace; whether the increase of 
taxes or rates has caused a visible decline in our aggregate income and savings; whether the increase of the national debt in a given year has made a large hole in the savings of the country, and so on. Porter was alive to the importance of the matter, and his whole book might be regarded as an attempt to measure the growth of national wealth. But the measurement of the nation's capital he failed to achieve. Nor did he even realize what good work had already been done in this direction. However, the late Sir Robert Giffen took up the subject systematically and reduced it almost to a science, yet even he recognized that only approximate results are obtrinable. "Imagination," he wrote, "shrinks from the task of framing a catalogue or inventory of a nation's property as a valuator would make it; the idea of a valuation of the whole property of a country, as if a country could really be valued as a going concern, is itself a violent hypothesis." But in the absence of complete inventories, Sir Robert Giffen held, and held rightly, that approximate inventories or valuations could be arrived at by valuing the leading items of national property upon a definite and scientific plan, and that by these approximate valuations the growth of capital and accumulated wealth could be roughly measured, and the capital of one country could be compared with itself at another time or with the capital of another country. Sir Robert Giffen's principal book on the subject was published in 1889 . He there explained his own method, compared it with previous valuations by earlier authorities, and, after making careful corrections, arrived at a sort of rough history of the growth of national wealth, commencing so far back as the year 1600 . The estimate of 1600 by a British merchant is perhaps of no great value, but it may be interesting to mention here the main features of the valuation. The total rental of England at that time was put at six millions, giving a capital of seventy-two millions at twelve years' purchase. The stock of moveable capital would be about one-third, so that "the total valuation of England at the beginning of the seventeenth century could not be more than 100 millions sterling, or about $£ 20$ per head," taking the population to be $4 \frac{1}{2}$ millions. Towards the end of the century the population had risen to $5 \frac{1}{2}$ millions, and according to more accurate estimates the property per head had nearly trebled in pounds sterling. But the purchasing power of gold had fallen heavily, so that a large part of the advance was nominal. The following table gives four valuations of England from 1690 to 1800 , corrected in each case by Sir Robert Giffen, so that the comparisons are at least approximately accurate:- 
Growth of Capital and Population in England from 1690 to 1800

\begin{tabular}{|c|c|c|c|c|c|}
\hline & Year. & & Population. & Property. & $\begin{array}{l}\text { Property } \\
\text { per Head. }\end{array}$ \\
\hline $\begin{array}{l}1690 \\
1720 \\
1750 \\
1800\end{array}$ & $:$ & $:$ & $\begin{array}{l}\text { Millions. } \\
5 \frac{1}{2} \\
6 \frac{1}{2} \\
7 \\
9\end{array}$ & $\begin{array}{c}\text { Millions Sterling. } \\
320 \\
370 \\
500 \\
1,500\end{array}$ & $\begin{array}{r}\mathfrak{\varepsilon} \\
58 \\
57 \\
71 \\
167\end{array}$ \\
\hline
\end{tabular}

In the estimate of 1690 English land was valued at 100 millions and houses at 45 millions sterling. In 1800 the proportion of land to the total property had fallen from 60 to 40 per cent., though its value had risen to 600 millions. Houses were entered at 180 millions or 15 per cent. of the total-the same proportion as in 1690 .

The following is a summary of the estimates of income and capital made by the Rev. H. Beeke, B.D., apropos of Pitt's incometax proposals in 1800 :-

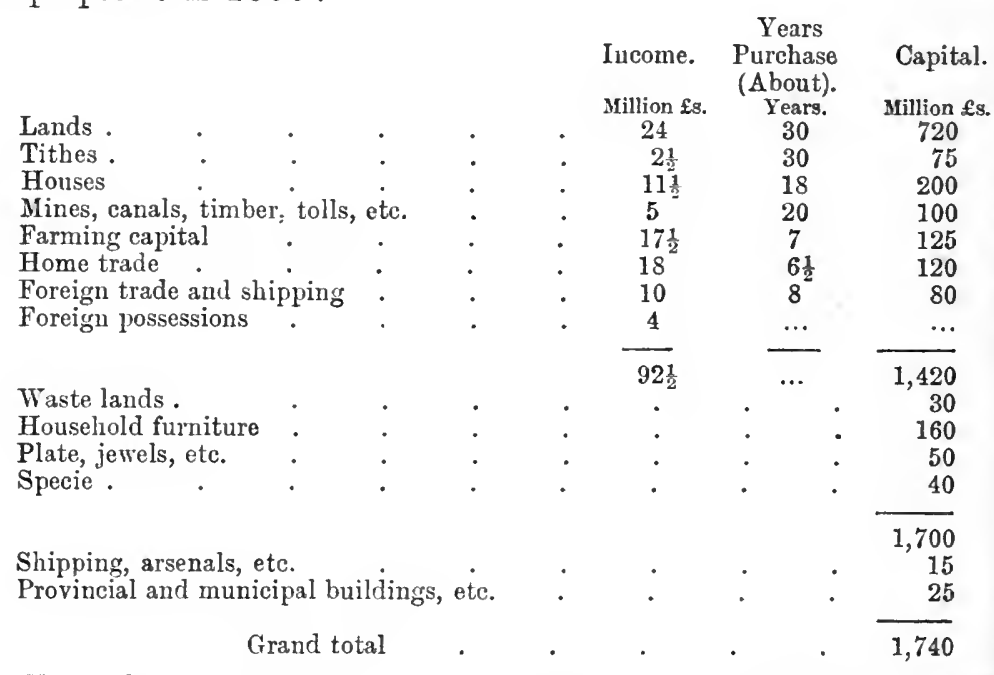

The above estimates are corrected by Sir Robert Giffen, so that they are the more valuable for comparative and scientific purposes. It should be added that Beeke made important classifications in his book, ${ }^{1}$ distinguishing, first of all, private property from public property, and, secondly, subdividing private property into property productive of income and property unproductive of income. Out of a total of 1120 millions of private property productive of income, 600 millions, in Beeke's estimate, represented

${ }^{1}$ Observations on the Produce of the Income-Tax. By the Rev. H. Beeke, B.D. London, 1800. 
cultivated lands in England and Wales, and 120 millions cultivated lands in Scotland; 200 millions represented houses not included in the above rent; 100 millions represented mines, canals, tinber, etc.; 125 millions represented farming capital; 120 millions home trade; and 80 millions foreign trade and shipping. Curiously enough, Beeke added 300 millions for the capital value of income from the public debt. With this item deducted the private property productive of income amounted in 1800 to 1420 millions, whilst the unproductive private property consisted of 280 millions -namely, 160 millions for household furniture, 50 millions for plate, jewels, etc., 40 millions for specie, and 30 millions for waste land. Beeke's figures were confirmed by the income-tax schedules of

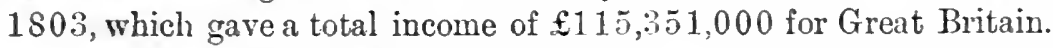

In 1812 another valuation was made by Colquhoun, and included Ireland. In that year the income-tax of Great Britain was 130 millions. An addition of one-quarter for Ireland (probably an excessive figure) would give a total of 165 millions, and the incomes of the poor not subject to income-tax might bring the total up to about 400 millions as the national income of 1812 , of which 320 millions were attributed to Great Britain and the remainder to Ireland. Colquhoun's valuation of property in the United Kingdom was 2736 millions, of which 900 millions represented lands in Great Britain, and 300 millions lands in Ireland. The following details are given for trade. (1) Home manufactures: -England, 100 millions; Scotland, 16 ; Ireland, 24. (2) Foreign trade:- England, 33 millions; Scotland, 4; Ireland, 3. Shipping:-England, 20 millions; Scotland, 4 ; Ireland, 3. Fisheries:-England, 3 millions; Scotland, $3 \frac{1}{2} ;$ Ireland, $3 \frac{1}{2}$. It is not necessary to assume that there was any improvenent between 1800 and 1812, even if Colquhoun's estimates are not excessive, as both population and prices were rising rapidly. In 1822 another valuation was made by Joseph Lowe, ${ }^{1}$ of which the following is a synopsis :-

\begin{tabular}{|c|c|c|c|}
\hline & & & Million $£$ \\
\hline Land under cultivation & - & • & . 1,200 \\
\hline Farming capital & . & . & 200 \\
\hline Dwelling houses, warehouse & s, and manufacto & ories (houses) & 400 \\
\hline Manufactured goods . & . $\quad$. &.$\quad$. & 140 \\
\hline British shipping & . & . & 20 \\
\hline Other mercantile and manu & acturing capital & . & 130 \\
\hline Mines and minerals &.$\quad 0$ & . & 65 \\
\hline Canals, tolls, and timber & . & . & 45 \\
\hline
\end{tabular}

1 The Present Siat of England. By Joserh Lowe. London, 1823. 
Lowe held that there had been some progress between 1812 and 1822 , and it is possible that the actual value and amount of fixed and moveable property had increased, though the condition of the people may have been stationary or retrogressive. In 1833 an alien resident named Pablo de Pedro made another valuation based upon that of Colquhoun. His general plan was to add onethird to Colquhoun's valuation, though the population had increased by more-in fact, by 41 per cent. His total works out at 2471 millions for England, 2843 millions for Great Britain, and 3690 millions for the United Kingdom. Sir Robert Giffen, in his anxiety to make out that things were improving even at that time, failed to note how Pablo de Pedro's estimate made the increase of wealth less than the increase of population, which means that people were getting worse off. There is no doubt, however, that about this time the wealth of Great Britain began to increase, especially among the mercantile and manufacturing classes; for in 1843 the assessments for income-tax (which were 130 millions in 1812) amounted to 240 millions. Working on these figures, Sir Robert Giffen thinks that a total valuation for the whole of the United Kingdom in 1845 would probably be 4000 millions. Even this, however, does not show much advance in the amount of property per head, as compared with the valuation of 1800 ; but Sir Robert Giffen argues that it indicates a real advance in wealth, if allowance is made for the fall in prices from 1812 onwards. But "the hungry 'forties" were not happy years for England or Scotland, and Ireland was certainly going downhill, though its population had risen very rapidly.

We now come to the three valuations, all based on income-tax returns, and all made on the same system by Sir Robert Giffen in 1865,1875 , and 1885. These valuations were collected by Sir Robert Giffen in a convenient but rather scarce work, entitled The Growth of Capital, in which, as he says, he resumed and continued the notes on the accumulation of capital in the United Kingdom which he had read to the Statistical Society in 1878, and had reprinted in his Essays on Finance. His special object, of course, was to measure the rate of accumulation or the growth of capital and wealth; but he recognized that only approximate results are obtainable. No method of valuation could be perfect, but periodic stocktaking is useful for a nation, as it is for an individual business. The method adopted by Sir Robert Giffen was " to take the income returned for assessment to the income-tax, capitalize the different portions of the income derived from capital-land, houses, and so 
on-at so many years' purchase, and then make an estimate for other property in the country where the income was not got within the sweep of the income-tax net." The plan was not quite original; for a similar method had been employed (by Mr. Newmarch) in The Economist in 1873. The chief difficulty, of course, is to decide how many years' purchase should be assigned to each description of income, and whether valuations made at different dates should vary the number of years' purchase or not. Thus, between 1875 and 1885 the capital value of many sorts of income, i.e. the number of years' purchase at which they would sell, undoubtedly rose, while in regard to land the number of year's' purchase at which the same nominal rental would sell undoubtedly diminished. Another important item is, of course, the variations of price. If the value of gold falls, an increased valuation in pounds sterling may obviously be compatible with an actual diminution in the national wealth. In regard to these considerations, it should be mentioned that for the valuation of $1875 \mathrm{Sir}$ Robert Giffen took thirty years' purchase in the valuation of lands, and in the valuation of $1 S S 5$ he took twenty-six years' purchase. For Ireland, however, he only took fifteen years' purchase. For houses he took fifteen years' purchase. For Schedule B, farmers' profits, he took eight years' purchase. For quarries, mines, and ironworks, four years' purchase was taken in both 1875 and 1885 . For gasworks, trenty years' purchase was assigned in 1875 , but in 1885 , when the fear of electric light diminished, twenty-five years' purchase was adopted. For other public companies and for foreign and colonial securities the number of years' purchase was raised from fifteen in 1875 to twenty in 1885 , and in the case of home railways the figure was raised from twenty-five to twenty-eight, on the supposition that the average yield to investors had fallen from $£ \pm$ to $£: 311 \mathrm{~s} .6 \mathrm{~d}$. per cent. The income from foreign investments was capitalized at ten years' purchase. The raluations for 1875 and 1885 were made in more detail than the earlier one, and are strictly comparable in all respects. But all three appear in the following table, classified according to their main items.

The following table is described by Sir Robert Giffen as a comparison of the "approximate amount of capital or property in the United Kingdom in 1865 , in 1875 , and in $1885 . "$ It will be seen that between 1865 and 1875 , a period mainly of rising prices, the in-

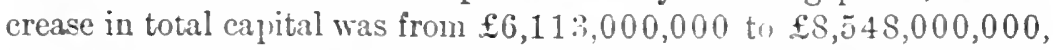
an extraordinary increase of 40 per cent. Between 1875 and 1885 the rate of increase was less than hali, being only $17 \frac{1}{2}$ per cent., in consequence, no doubt, of the iall in prices, and despite an increase 


\section{Approximate Amount of Capital or Property in United Kingdom in 1865, 1875 , and 1885 compared}

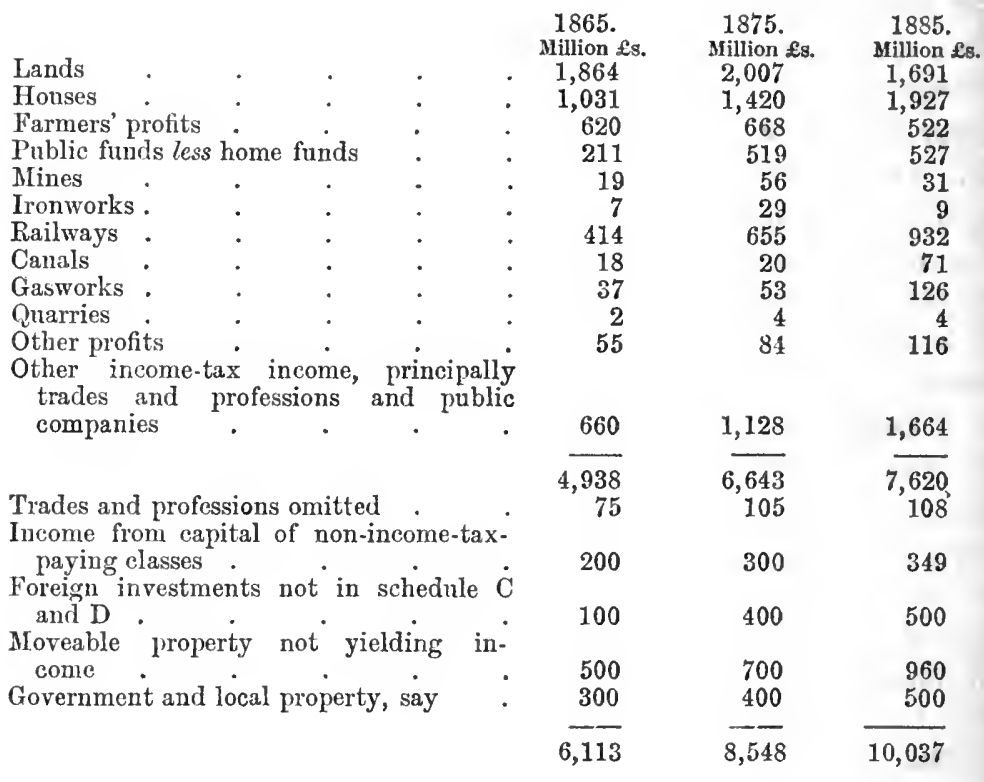

in the number of years' purchase applied, as we have seen, in capitalizing certain branches of income. Sir Robert Giffen put the fall in prices from 1875 to 1885 at about 15 per cent., after a comparison of The Economist Index Numbers with those of Mr. Sauerbeck and Mr. Soetbeer.

There is some reason for thinking that Giffen's method tended to over-estimate the nation's capital, but the same method applied to-day will at least give a fair idea of the rate of increase. The Economist in 1911 published a valuation or estimate of national wealth and capital for the year 1909, made out on Giffen's principle of capitalizing the profits revealed by the income-tax returns. The following table shows the result of this calculation, estimates on the same plan, with certain modifications, being added for the years 1895 and 1905 .

In arriving at these results the number of years' purchase at which profits have been capitalized was altered in several cases. For it is generally recognized that the return to capital has, on the whole, risen considerably since 1885 . This has caused a shrinkage in the value of many fixed-interest securities, such as consols, railway debentures, etc., and even in the case of ordinary stocks of 
In Million $\mathfrak{E s}$

\begin{tabular}{|c|c|c|c|c|}
\hline & 1885 & 1895. & 1905. & 1909. \\
\hline Land $\cdot \quad \cdot \quad \cdot \quad \cdot \quad \cdot \quad \cdot$ & 1,691 & 1,385 & 1,306 & 1,300 \\
\hline Houses . . . . . . & 1,927 & 2,318 & 3,024 & 3,284 \\
\hline Farmers' capital . . . & 520 & 368 & 340 & 348 \\
\hline Railways in United Kingdom . & 932 & 960 & $1,0 \Xi 0$ & 1,075 \\
\hline $\begin{array}{l}\text { Mines, quarries, ironworks, gasworks, } \\
\text { waterworks, canals, and other in- } \\
\text { dustries separately distinguished }\end{array}$ & 330 & $42 \pi$ & 568 & 550 \\
\hline Other trade capital,public companies, & & 82 & 000 & 0.00 \\
\hline firms, etc. & 1,414 & 1,500 & 2,458 & 2,727 \\
\hline British capital invested abroad $\cdot$ & 1,302 & 1,600 & 2,025 & 2,332 \\
\hline $\begin{array}{l}\text { Capitalized value of local loans guar- } \\
\text { anteed by the rates }\end{array}$ & 126 & 175 & 240 & 290 \\
\hline Cavital of non-income-tax payers. & 335 & 380 & 420 & 450 \\
\hline Furniture, etc. & 960 & 1,000 & 1,000 & 1,000 \\
\hline Government and local property & 500 & 550 & 605 & 630 \\
\hline Total & 10,037 & 10,663 & 13,036 & 13,986 \\
\hline
\end{tabular}

British railways-the return to which has for various reasons not increased during the period-the market value has fallen; for investors have demanded, and have been able to secure, a better return than the $2 \frac{3}{4}$ per cent. which was common in the early 'nineties. Hence, Giffen's twenty-eight years' purchase was reduced to twenty-five years. Similarly, Giffen's fifteen years' purchase of the profits from firms, public companies, and private traders in miscellaneous concerns was reduced to twelve years' purchase, and other minor modifications were introduced. Giffen's surprising assumption of four years' purchase in the case of quarries, mines, and ironworks was increased to eight years' purchase. For though it is true that mines and quarries are ultimately exhausted, while a very heavy depreciation needs to be made in the case of ironworks, a review of the reports of such companies shows that the market estimate of their capital value is far greater than four year's' purchase of the profits. As a matter of fact, the total market value of ironworks and mining companies included in the list published by the Investors' Monthly Manual shows that the Stock Exchange valued 85 millions' worth of nominal capital in iron and coal companies at $£ 108,000,000$. This figure is some 20 millions sterling greater than the total value of British mines and ironworks, estimated on Sir Robert Giffen's assumption of four years' purchase, and as the number of such concerns, which are in private hands or owned by companies whose shares are not quoted on the London Stock Exchange, is very large, it is evident that eight years' pur- 
chase of the profits would not give too high a figure for the country as a whole.

Important features of the calculation are the changes in the first three categories. The total capital value of land shows a steady decline since 1885, and even in that year Sir Robert Giffen's figure was more than 300 millions lower than in 1875. The capital value of houses, on the other hand, has increased rapidly, a result which is certainly not unexpected in view of the growth of the town population of the United Kingdom. The figure as to farmers' capital is put forward with all reserve. Farmers' profits are calculated for income-tax purposes at one-third of the annual value of the property, the estimate having been one-half of the annual value at the time when Giffen made his estimate. This is a purely arbitrary figure, affording little indication of the amount of farmers' capital. The alternative method of estimating it by assuming an average amount of capital per acre is scarcely more definite, for statisticians are not agreed as to the average amount per acre, taking the country as a whole. In view, however, of modern methods of high farming and the increasing stock carried on our pasture lands, Giffen's eight years' purchase was raised in The Economist's valuation to sixteen years. The figure given for foreign investments of British capital is also possibly too low, and though some allowance has been made for profits escaping the net of the Income-tax Commissioners, the sum given in the table is considerably less than Mr. Paish's estimate in the Statistical Journal for 1909. But there are many uncertain factors in the calculation of foreign investments, and in particular it is possible that, taking successful and unsuccessful ventures together, the present market value is substantially less than the nominal value of the capital originally subscribed. In this class of investment there is, in fact, a certain amount of wastage; but when everything has been taken into account, the figure given in the above table is a minimum rather than a maximum.

Giffen's estimate for furniture, etc., is left practically unchanged; it was almost certainly an overstatement in 1885 , and even now, after a great increase in population and wealth, the figure is still probably too high. The capital of non-income-tax payers is also a guess without any real statistical basis. The sum, however, is small, and does not seriously affect the result. The capitalized value of local loans is included, as it represents property, such as tramways, etc., though gas and waterworks owned by municipalities are included in the previous group with privately-owned concerns 
of this description. There is, in addition, a considerable sum of local property included with Government property in the last item of the above table, representing parks, roads, sewage works, and other property of the community against which no mortgage is held on the rates. Such property has been paid for directly out of revenue or has become free of mortgage charged by the operation of local sinking funds, etc. The item "Government and local property" includes many costly buildings and works which cannot be regarded as capital, and many of which, such as barracks and battleships, and buildings of all kinds, involve enormous annual charges upon taxpayers and ratepayers. It would be absurd, therefore, because these unproductire expenditures have trebled in the period, for that reason to treble the item as if the wealth of the nation had increased through the building of palaces, etc., by public authorities. Hence The Economist only added at the rate of 1 per cent. a year to this item, assuming that publicly-owned capital has increased at about the same rate as the population.

These estimates, compared with Giffen's previous valuation, yield the following result, showing the increasing accumulation of wealth since 1865 :-

\begin{tabular}{|c|c|c|c|c|c|c|c|}
\hline & & & & & & & $£$ \\
\hline 1865 & - & - & - & . & . & . & $6,113,000,000$ \\
\hline 1875 & . & . & . & . & . & . & $8,548,000,000$ \\
\hline 1885 & . & . & . & . & . & . & $10,037,000,000$ \\
\hline 1895 & . & . & . & . & . & . & $10,663,000,000$ \\
\hline 1905 & . & . & . & . & . & . & $13,036,000,000$ \\
\hline 1909 & . & . & . & . & . & . & $13,986,000,000$ \\
\hline
\end{tabular}

In this comparison the changes are, of course, affected by price variations, the period 1875 to 1895 being one of falling prices, and that from 1895 to the present day one of rising prices. This consideration affects certain categories more than others; for while rising prices tend to swell profits and increase the value of capital in general trade, they have no such effect on, say, railway capital, where the income earned is restricted by a legal maximum for freights and fares. Hence, while the estimate of railway capital in the United Kingdom shows an increase during the last fifteen years of some 12 per cent., general trade capital has increased $\$ 2$ per cent. Price changes, therefore, are responsible for part of the change shown in this table.

Estimates of the national income in 1901 give a total of about $£ 1,900,000,000$, and considering the improvement in trade, the figure for 1911 cannot be far short of $£ 2,000,000,000$. On the whole, the valuation of the national income is inuch more certain 
than the estimate of capital, for it is clear from what has been said above that everything turns on the number of years' purchase at which the various classes of income are capitalized-every modification in the ratios assumed having a considerable effect on the total estimate. In this connexion it has been urged that the basis of capitalization is too high, and that this is proved by the valuation of estates for death duty purposes. If we could tell precisely the number of estates in the hands of living persons compared to the number that pass by death in any one year, it would be possible to arrive at the value of existing wealth by multiplying the estate duty figures by this ratio. Thus, if there were thirty estates in the hands of living persons for each estate that passed by death in 1910, we should get an approximate figure by multiplying the estate duty figures by thirty. The question of the correct "multiplier" is, however, a most difficult one, though Mr. Bernard Mallet has given strong reasons for supposing that it should be twenty-six in the case of the United Kingdom. In 1910-11 the property reviewed by the Inland Revenue Department was $£ 300,000,000$, and on Mr. Mallet's assumption we should arrive at $£ 7,800,000,000$ as the value of private capital in that year-a figure much below that which we have given above. But the discrepancy may be explained in large measure by gifts before death and by various other methods of evading death duty; and this supposition is strengthened by a more detailed examination of the estate duty figures. The most recent returns are as follow:-

\section{Property of which the Inland Revenue Department had Notice as Passing} at Death in 1910-11

Stocks, funds, shares, and other securities Cash in house and bank

Money lent on mortgages, bonds, bills, etc.

Trade assets-stock, goodwill, etc.

Insurance policies

Household goods, apparel, etc.

Agricultural land

House property, business premises, etc. .

Ground rents and similar charges

Other property

\begin{tabular}{|c|c|c|}
\hline & & Million $f$ \\
\hline - & - & . $\quad 121$ \\
\hline - & . & . 18 \\
\hline . & . & $20 \frac{1}{2}$ \\
\hline - & . & $17^{4}$ \\
\hline . & . & $10 \frac{1}{2}$ \\
\hline . & . & 8 \\
\hline - & . & 17 \\
\hline . & . & 42 \\
\hline - & . & 4 \\
\hline - & . & 42 \\
\hline • & - & . 300 \\
\hline
\end{tabular}

Total

To take only the first item in this list, the value of securities held in this country must be far greater than even thirty times $£ 120,000,000$, for it is quite certain that the stocks of British and foreign railways, British and foreign Government securities, and British local loans would exceed $£ 4,000,000,000$, to say nothing 


\section{THE GROWTH OF WEALTH AND CAPITAL 705}

of stocks and shares in trading and other concerns. Thus an examination of death duty figures shows that either the evasion of duty is greater than is generally supposed, or that estimates of wealth obtained by capitalizing income are too large-the truth probably lying somewhere between these two estimates.

It will be clear from what has been said that the valuations given should be used with caution, and it must not be assumed that a very accurate result can be obtained by Giffen's method. But the series of valuations has the merit of continuity, and from the historical point of view gives the only comprehensive and available test of national growth in respect of accumulated wealth and capital. Let us hope that fifty years hence a similar comparison will provide posterity with as good grounds for satisfaction as our retrospect in this chapter and in many preceding pages happily affords. 


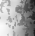




\section{ANALYTICAL INDEX}

A berdeen, shipbuilding industry in, 261

Accidents, industrisl, 1897 and 1901, 44, 45

Accrington, cotton industry in, 310

Africs : British trade with, in $1850,48 \pi$

exports of British produce and manufac. tures to, 1805-1849, 479,480,483-486

imports of hard wood from, 428

Age, classification of, in census, 2. See Population

Agricultural Holdings Act, 1875, 198

Agricultural Rates Act, 1896, 205

Agriculture: bounty system, the, 182

breeding, encouragement of, by Agricultural Societies, 198

capital, agricnltural, amount of, 1800$1909,696,702$

co-operative movement, the, 206

draining, 187, 198

farms, size of, 181, 189, 200, 208, 209

grazing, total area of pasture laud, 1850 , $189 ; 1874-1881,202: 1909,209$

Highland Agricultural Society, the, 195

intensive cultivation, 198

labour: children, employment of, in agriculture, $2 \bar{\imath}, 200$

employers and employed, relative proportion of, 1831, 189

Nations! Agricultursl Labourers' Union, the, 202

numbers eraployed, 1841, 38 ; 1851-1901, 196,$200 ; 1901,43$

percentage of population employed in agriculture, 1811-1811, 35, 36 ; 18811901, 39

prosperity of agricultural labourer, increase in, during last quarter of nineteenth century, "202, 208

women, numbers employed in agricul. ture, 1811,38 ; 1851-1901, 200 ; proportion of, to total number employed, 1831-1901, 40

land: arsble land, total ares of, 1874-1851, 202,$204 ; 1909,209$

capital ralue of agricultural land, 18751894,203

cultivated land, total area of, $182 \pi, 188$

decrease in value of sgricultural land, 37 pasture land, total ares of. See Agriculture, grazing

uncultivated land, estimated area of, $1827,188,189$

machinery : dearth of labour overcome by increased ase of machinery, 200

respers, introduction of, $19 \pi$

steam plough, introduction of, 197

steam power, use of, 187, 197, 198

msnure: import of bone and guano, $1800-1850,179$
Agriculture, continued-

improvement in systems of manuring in latter half of nineteenth century, 197, 198

mortality, rate of, in Agriculture, 44

pasture. See Agriculture, grazing.

prices : average price of whest, 1800-1850,

181 ; of agricultural products, 1876 -

$1895,203,204 ; 1895-1908,20 \bar{T}$

production, incresse in amount of agri. cultural products, $1800-1850,175-$ 178

productivity of the soil : increase in, during niveteenth century, $179,185,197$; average yield per acre, 1850 and 1868,198 prosperity, fluctuations in : decline of agri. culture during nineteenth century, 23, $35,36,37-40,48$; especially in latter balf of century, 196, 200-206

economic improvements in latter balf of century, 198

increased prosperity, 1800-1850, 185, $186 ; 1850-1875,196,19 \pi, 199$

prosperity of sgriculture during Napoleonic War, 280

protection, effect of, ou agriculture, 178 , 183,184

summary, 1850-1910, 208

protection, effect of, on Agriculture, 178, 183,184 ; bounty system, the, 182 . See Corn Laws

railwass, effect of, on derelopment of agriculture, 188, 189

rates, agricultural, reduced by one-half by the Agricultural Rates Act, 1896, 205

reclamation of land for Agricultural pur. poses, Gorernment grants for, 198

rent, agricultural, $1800-1850,186 ; 1850$ $18 \% 0,199,200 ; 1880-1896,204,205$; $1896-1900,207,208$

rotation of crops, 180,185

Royal Agricultural Society, the, 198

Royal Agricultural Society, the (Ireland), 198

science, agricultural: progress of, 1800 1850,180 ; after 1850,197

contributions of Liebig, Davy, and Sinclair to, 180

improsement in method after 1850,197 , 198

small holdings, 205, 206, 209

statistics, lack of, in first half of century, 80 ; for 1909,208

wages, increase of, in latter half of rine. teenth century, 199, 200, 315; table of, 1851-1908, 195

See Barley, Wheat, etc.

See Cattle, Sheep, etc. 
Alcohol : consumption, 1880-1910, 457, 467 ; 1909,122 ; decrease in, 1900-1910, 123, 457,467 ; canses of this, 123

crime, alcohol as a cause of, 120,124

drunkenness : average number of charges, $1857-1907,123$

among women, 123,124

increasc of among working classes, 172,173 inebriates' homes, under Habitual Drunkards Acts, 1879 and 1898, 124, 125

duties, effect of, on consumption, 122, 123 expenditure on, $172 ; 1837-1860,121$; 1909,122

insanity, alcohol as a cause of, $125,130,131$ licensing system, the, 458

mortality, rate of, increased by the consumption of alcohol, 121, 123, 124

pauperism, alcolol as a cause of, 120

public-houses, number of, 1869 and 1894 , 458

See Beer, Spirits, Wine

Aliens Act, 1905 , cost of, 671

Aliens: immigration, Commission on (1902), 7

numbers resident in United Kingdom, 1841-1901, 7, 16

distribution of, 7

pauperism among, 8

Alkali Act, 1863, 420

Alkali industry : ammonia-soda process, the, 412,413

exports, 1907,416

imports, 1907,416

Leblane process, the, 412, 413

output, 1850-1902, 413, 414; 1907,416

See Chemicals

Allan Line, The, 542

Allen, Fenwick, authority on the alkali trade, 420 ; author of The History of Steam Navigation, 538.

Allen, William, joint founder of The British and Foreign Scliools Society, 33

Alliance Assurance Company, The, 603

Allotments, 38, 39

Alum, imports and exports, 1907, 415 ; output, 1907, 415

America, communication with, 542. See United States, Canada, Argentina, etc.

American Tobacco Trust, The, 472

Ammonia-soda process, The, 414

Ammoniacal manures, 197

Anderson, Doctor, pioneer of free higher education, 139

Anthrax, number of cases, 1900 and 1901, 44

Anti-Corn Law League, 'The, 683

Appleton, Machin, and Siniles Ltd., Messrs., statistics as to the tea trade, 446

Arable land. See Agriculture, land.

Arch, Joseph, founder of the National Agricultural Labourers' Union, 202

Argentina : exports to the United Kingdombeef, 1908, 442 ; hides, 1902 , 526 ; 1908 $1910,374,375$; meat, 440,525 ; oil seeds, 1902 , 526 ; wheat, 1899-1909, 436 ; 1902, 525 ; wool, since 1850,330

imports from the United Kingdom-brass manufactures, 1910, 278; coal, 1908, 223 ; hats, 400 ; jute manufactures, 1872 , 367 ; lace, 399

sheep, number of, 331

ships, British, tonnage of, entering and leaving Argentine ports, 544
Argentina, continued-

tobacco, cousumption of, per head of population, 1910, 471

Army : cost of, 1801-1849, 630-633 ; 1857 $1910,641,643 ; 1891-1912,647-658$; detailed account, 1897-1898, 652

percentage of population employed in, 38

Arnold, Matthew, on Schools Inquiry Commission, 138

Arsenic poisoning, 44

Artisans and Labourers Dwellings Act, 100

Artisans Dwelling Company, The, 99

Artists' materials, output, 1907, 408

Ashton-under-Lyne, cotton industry in, 310

Asia, exports of British produce and manufactures to, 1805-1849, 479, 480

Asylums, number of inmates, 22

Alistralasia : exports to United Kingdomcotton, 1896-1904, 309 ; flax, 1902, 526 ; hides, 1906-1910, 374, 375; tin, 1902, 525 ; wheat, 1899-1909, 436, 437 ; wine, 1909,463 ; wool, $1844,325,326$; since 1850,$330 ; 1902,526$

frozen meat industry, growth of, 330 gold, discovery of, 54

imports from United Kingdom-British produce and manufactures, 1827-1845, $483-486$; lace, 399 ; value of total imports from United Kingdom, 1910, 527

sheep, number of, 330, 331

ships, British, tonnage of, entering and clearing from Australasian ports, 18801910,541

tobacco, consumption of, per head of population, 1910, 471

transportation to, 107

Australia. See Australasia

Austria-Hungary : alkali industry in, 414 ; imports of alkalis from United Kingdom, 414

cotton industry in, 311 ; exports of cotton to United Kingdom, 320 ; imports of cotton from United Kingdom, 320

tobacco, consumption of, per head of population, 1910,471

wheat and flour, export to United King. dom, 1899-1909, 436; 1902, 525

Aviation, 268, 547

Bacon : consumption, 1840-1909, 170, 433,434

imports, $1840-1909,433,434,439,442$

price, 1880-1909, $442 ; 1905,435$

production in United Kingdom, 18981902, 439

Baker, Julian L., author of The Breving Industry, 455, 457, 458

Baker Street and Waterloo Railway, statistics, 1909, 558, 559

Bananas, increased consumption of, 435,453

Bank Charter Act, 1833, 583, 596

Bank Charter Act, 1844, 592, 594, 595; suspension of, $594,598,599$

Bank of England : account of operations of, $1800-1826,575-582$

notes, amount in circulation as against bullion retained, $1838-1849$, 590 ; issue of notes restricted to $£ 14,000,000$ in excess of bullion retained, 592 ; issue of uncovered notes since 1814, 594, 598, 599 ; suspension of cash payments since 1814,591 
Bank of Ireland, The, 592

Banking : American crisis of 1847, 594, 597 , 598

American crisis of 1907, 594, 598

Bank Charter Act, 1833, 583, 596

Bank Charter Act, 1844, 592, 594, 595

Baring crisis, 1890, 594, 599

capital, $1877-1910,600$

cheques, increased use of, 595

country, extension of London banks to, 597

deposits, 1877-1909, 601 ; security for, 601

development since $1850,594 \mathrm{ff}$.

joint-stock banks, encouragement given by

Parliament to establishment of, 583 growth of, since $1844,596,597$ notes, amount issued by joint-stock banks, 1838-1819, 590 ; 1910, 596 ; restriction on issue of notes by, 593

London Clearing House, the, 595

national bank, proposal for establishment of, 584

notes. See Bank of England, Paper Currency. See also Banking, joint-stock banks, prirate banks

Orerend-Gurney crisis, the, 1866, 594, 598,599

private banks, absorption of, by joint-stock banks, 597

notes, smount issued, 582,$583 ; 1835$ 1849,590 ; restriction on issue of notes by prirate banks, 593

rail way crisis of $1847,594,597,598$

reserves, smonnt of, since $1877,600,601$

system, strength of, 597,600 .

See Paper Carrency

Barclay's Bank, establishment of, 597

Baring Crisis, The, 1890, 594, 599

Bsrley: acreage under, 1907, 435: 1909 209,210

imports, 1898-1902, 438; 1850-1908, 194, 5:5

prices, 1850-1870, 197; 1876-1894, 203; 1895,207

production of, in United Kingdom, 159S1902,438

sources of supply, 525

Barrow, shipbuilding industry in. 261

Barry Railway, statistics, 1909, 552, 5,59

Bass, Messrs, brewers, 159

Baxter, Dudley, estinate of tlie national income in 1867,167

Beale, Miss, principal of Cheltenham College, 139

Beans : screage under, 1909,210

imports, 1898-1902, 438

production of, in Uniterl Kingdom, 15981902,438

Betforrl, Bishop of, on riport of Housing Commission, 1885, 101

bedford College, establishment of, 139

Pedlam, condition of, until widdle of the nineteenth century, 126,127

Beef: consumption of imported beef per hearl of popnlation. 1840-1909, 433

imports, 1840-1909, 191, 410, 411 : $1898-$ 1902,439

price, 1870-1870, $197 ; 1330-1909,207,435$, 440,442

preservel aud saltcd, imports, 1\$\$0-1909, 442

production in Linited Kin odom, la3s-1902. 439
Beer: loottled, increased consumption of, 457 brewing industry, early history, 454

imports of ingredients, 1880-1910, 454

licences, number taken out by brewers, 1899-1903, 458

prosperity, Huctuations in, during last thirty years, 459

"tied house" system, the, 459

consumption, 1801-1829, 456; 1881-1910,

457 ; per heal of population, 1907, 170 ; decrease in, 1900-1910, 123, 457

duty, fluctuations in, 455,456 ; temporary abolition of, in 1830, effects of this, 455 ; revenue derived from, 1852-1911, 458

exports, 1860-1910, 457, 459, 530, 531

licensing svistem, 458

output, 1881-1910, 457

"porter," origin of, 455

Belfast, shipbuilding industry in, 261

Belfast and County Down Railway, statistics, 1909,552

Beigium : alkali industry in, 414

cotton industry in, 311

exports to the Linited Kingdom-cotton, 1909,320 ; hides, 1902,526 ; wool $1844,326^{\circ}$ glass trade in, 286

imports from United Kingdom-British produce and manufactures, $1827-1845$, 183-1\$6; alkalis, 414; boots and shoes, 1905-1908, 380; brass manufactures, 1910, 278; coal, 1908, 223; cotton, 1909, 320: hats, 400 ; lace, 399 ; raw wool and woollen yarns, 1844, 326

ships, British, tonnage entering and clear. ing at Belgian ports, 1880-1908, 543

tobacco, consumption per head of popula. tion, 1910,471

Bell, Dr. Anilrew, founder of Church Schools, $13^{5} 3$

Bentham, Jeremy, 64 ; his view of the scope of criminal legislation, 111; triumph of Benthanuite ideas in the Poor Law Amendment Act. 1834,154

Berlin Decree, 1806, effect of, 497,498

Bessemer process of making steel. See Steel

Betting, increase of expenditure on, 17:2

Bibby Bros., Mlesss., shipowners, 541

Bicarbonate of soda. Nee Alkali

Birkbeck, Dr., founder of the Birkleck Institute, ]:39

Birkenheal, telephone service in, 566

Birmingham : housing, af

female and child labour in, $2 \pi 1$

industries, 270,271

population, increase of, 1800-1550,63

telephone service, 5,66

Birth-rate, decrease in, 'auses of, 11 : econ. omical aspects of this, 11, 1:': drcrease ill illegitinate births, 11

Births and Death., Registration ofi, instituted in 1337.8

Biscuits, output, 1908, 451

Blsckburn: cottou industro in, 310

labour-chilu?ren, 28: women. 24

Plachismithing. output and number of persons employed, $190 \%, 2 \%$

Bleaching industry : exports, 18;0-1900, 415 416,417

number of persons employed, $190 \overline{7}, 291$

output. 190\%. 291, 415

prices, $1570-1850,417$ 
Blind : education of, 141 ; public expenditure on education of, 1907-1908, 676, 677

number of, 1851-1901, 20, 21

Block dwellings. See Overcrowding, Housing

Board of Agriculture, control over local administration, 164

Board of Trade: control over local ad. ministration, 164

Public Health jurisdiction of, 157

salaries and expenses, 1897 and 1907, 670, 671

statistical department of, 672

Board of Trade Wages Inquiry, 52

Boarding-ont system for Poor Law children, 79,80

Boer War : cost of: 519,690

effect of, on national credit, 519

Bolt-making, output and number of persons employed, 1907, 272

Bolton, child labour in, 28 ; cotton industry in, 310

Bone mannre, effect of introduction of, 179

Bookbinding: child labour in early part of the century, 24

output, 1907,408

proportion of males to females employed in, 1901, 30, 31

Book trade: child labour in, 1891 and 1901, 27

imports and exports, 1871-1910, 411

percentage of population employed in, 1881-1901, 39

Boot and shoe trade: American conipetition, 378,381

factory system, growth of, 377

home work in, 33

inıports and exports, 1865-1909, 379

labour, number of persons employed, 1907,376 ; proportion of males to females employed, 1861-1901, 31

machinery, introduction of, 377,378 output, 1907, 376, 377

protection, effect of, on the trade, 381

welted boots, introduction of, 378

Booth, Charles, 94, 123, 429

Borax Consolidated, 421

Borstal System, The, 117, 118

Botany Bay, transportation to, $10 \tau$

Boumeville, experiments in town-planning at, 102

Bradford : child labour in, 28

housing, 96

wool industry in, 331, 332

Brandy, imports, 1811,465 ; 1860-1908, 467

Brass manufacture: exports, $1805-1910$. 278

output and number of persons employed, 1907,272

Brazil : cotton industry in, 311

exports to United Kingdoin-caoutchouc, 1902, 526; coffee, 1909, 449 ; cotton. 1896-1904, 309 ; 1902, $526^{\circ}$

imports from United Kingdom-British produce and manufactures, $1827-1845$, 483-486; coal, 1908, 223 ; jute manufactures, 1872 . 367 ; woollen manufactures, 1844, 326

tobacco, production of, 1900-1903, 469

Bread : output, 1908, 451

inean nrice, 1905,435

Brewing. Sec Beer
Brickmaking : child labour in, 24

number of persons employed, 1907, 287

percentage of population employed in, 1881-1901, 39

output, 1907, 287

Brindley, James, "the father of inland navigation," 549

British and Foreign Schools Society, 133

British Columbia, import of fruit from, 453

British Dyewoods and Chemical Co., 421

British East India Steam Navigation Co., 540,541

British Honduras, import of hard woods from, 428

British Museum, annual expenditure, 1897 and 1907,675

Broadhurst, Mr., on report of Housing Commission, 1885, 104

Brocklebank, T. and J., Messrs., shipowners, 541

Bronchitis, decline of, since 1870, 10

Brunner, Mond \& Co., alkali manufacturers, $413,416,420$

Brush, C. F., electrical discoveries of, 263

Brush-making, home work in, 33

proportion of male to fermale labour employed, 31

Bryce, Mr., chairman of Elucation Commission, 1897, 140, 142

Building and bnilding trade : by-laws, 421

concrete, introduction of, 430

conditions of the trade, 429,430

ferro-concrete, introduction of, 430,431

labour: casual labour in, 431 ; numbers employed, 1801-1901, 429 ; percentage of population employed in, 1881-1910, 39 ; unemployment, frequency of, 73,430 public works, cost of, 1897 and 1907,669 statistics, 1881-1901, 429

steel, introduction of, 430 wages, 53, 315

Bullion Committee, The, 1810, 574, 585

Burgundy, imports, 1909, 464

Burms, imports of hard wood from, 428

Burnley, child labour in, 28; femsle labour in, 34

Burns, John, 58

Bury, child labour in, 28 ; cotton industry in, 310

Buss, Miss, founder of the Girls' Public Day School Company, 139

Butler, Mrs. Josephine, pioneer of the University Kxtension Movement, 149

Butter : consumption of imported butter, 1840-1909, 170, 433, 434

duty on, revenue derived from, 625

imports, 1840-1910, 194, 443, 528, 529

price, 1895-1908, 20\%, 435

production of, in United Kingdom, 1898-1902, 443, 444

Buxton, Mr., prison reformer, 109

Caird, Mr., estimate of average yield of wheat per acre, 1850 and 1868, 198; of losses caused by agricultural depression, 201

Caledonian Railway, statistics, 190?, 552, 558,559

Calico-printing, child labour in, 24

California, discovery of gold in, effect of on prices, 54 
Cambrian Railway, statistics, 1909, 552, 559

Cambridge University, and women's elacation, 139

Canada : cotton industry in, 311

exports to United Kingdom-cattle, 1870$1900,410,441$; food-stuffs (classified), 1902, 5:5; timber, 1870-1900, 427 ; 1902 , 526 ; whest, $1871-1875$ and $1896-1900$, $195 ; 1899-1909,436 ; 1902,525$

imports from United Kingdom-British prodince and mannfactures, $182 \bar{i}-1845$, 483-486; bats, 400 ; lace, 399 ; silk manufactures, $1830-1850,347,348$; woollen manufactures, 1844,326 ; ralne of total imports from United Kingdom, 1910,527

reciprocity with United States, proposals for, 520

ships, British, tonnage of, entering and clearing from Canadian ports, 18601908,542

tariff, protective, adopted, 518

tobacco, consumption per head of population, 1910,471

Canadian Pacific Railway, 542

Canals : cspital, 1904, 550

control of, by railway companies, 549,550

effect of coustruction of railways on, 549

unable to compete with railways; reasons for this, 550,551

revenue, 1904,550

mileage, 1850 and 1910, 549

manis for construction of, in last years of eighteenth century, 519

Royal Commission op, $1906,549,551$

Candles, manufacture of : output, $190 \bar{\gamma}, 415$

number of persons employed, 1907, $\$ 15$

Canvas-making, numbers employed, 18811901,363

Caoutchouc, sources of supply, 520\%. See Rabbe

Cape Colony : exports to United Kingdomwool, 1902, 526 ;

imports of British produce and manufac. tures, $182 i-1845,483-4 \$ 6$

refuses to receive transported convicts, 108

Capital, national, mersnrement of, 694, 695; growth of, $1690-1910,690^{\circ}-705$

Capital Punishment. Nee Death Penalty

Cardboard box making, ontput, $1907,40 \mathrm{~s}$

Cardif, housing in, $90^{\circ}$

Cardwell, Lord, reorganisation of the armp by, 1870,643

Care of Poor Law Children, Committec on, 1896,79

(urpet-making, proportion of wales to females employed, 31 See Wool

Carrington, Lord, on report of Housing Commission, 1585,104

C'sttle: export of pedigree stock from United Kingdom, $\$ 10$

arerage price, 1880-1909, 440

imports, $1850-1880,197 ; 1880-1909,440$, 441

numbers in United Kinglom, 1875-1880, 200,$202 ; 1909,212$

sources of supply, 441. 525

Caustic soda. See Alkali
Celtic movement, the, 152

Cement, manufacture of, percentage of populstion employed in, 1881-1901, 39

Census : first proposals for, 1 ; early opposition to, 1; first Bill passed, 1800, 1; machinery, scope, and classification of 1801 census, and of subsequent censuses, 2 ; imperfection of first four censuses, 2

classification as to age, 2 ; as to place of birth, 2 ; as to occupstion, $2,35-37,38$, 39 ; importance of classification as to occupation, 23

Central London Railway, statistics, 1909 , 558,559

Central Poor Law Board, The, 65

Chadwick, Edwin, 64, 67, 68, 156

Chain-naking, home work in, 38 ; ontput and number of persons employed, $\mathbf{2 7 2}$

Chamberlain, Joseph, 519, 520, 523, ỏ90

Champagne, imports, 1909,464

Chance, Sir William, 78

Channel Islands: exports to United King. dom-cattle, $1870-1900,441$; regetsbles, 1902,525

imports of British produce and mannfactures, $1827-1845,483-486$

populstion, 1821-1911, 4

Cliapman, Professor, authority on the cotton industry, $308,318,319,330$

Charing Cross, Enston, and Hampstead Railway, statistics, $1909,558,559$

Charity, growth of charitable effort in the assistance of the poor, 73,74 ; need for co-ordination among charitable societies, 74

Charity Commission, The, 138

Charterhouse School, 138

Chartist Movement, The, 58

Cheese: consumption of imported cheese per head of population, 1840-1909, 170, 433,434

daty on, revenne derived from, 1842,625

imports, $1840-1909,443$

mean price, 1905,435

production of, in United Kingdom, 1898$1902,443,444$

sources of supply, 525

Chemical industries: Alkali Act, 1863, provisions of, 120

combines in, 420,421

levelopment of, 412,413

distribution of, 419,420

exports, 1860-1910,415-119, 530,531

imports, 1s95-1909, 415, 416, 419 ; 1910, 528

number of persons employed, 1907, 415 ; 1881-1901, 39

output, $1907,41 \%$

Cheshire: chemical trales is, $419,4: 0$

child labour in, $2 S$

average rent, 97

Chicago Beef Trust, The, 37;

Children: criminsl, numbers committed the prison in first half of the nineteenth century, 115 ; 1861-1903, 117 ; reformatory trestment of, 116,117

hcalth of, in public elementary schools, $145-147$; effects of overcrowding on, 95 ,

Isbour: occnpational statistics, 23-28; restrictions on child labour, 23, 24, 20: decline in child labour, 1851-1201, 26 ; 
Children, continued-

legislation, opposition to, 24 ; half-time system, the, 24-28; effect of child labour on unemployment, 56 ; child labour in various industries-agriculture, 200 ; cotton, 302,315 , 318; silk, 347 ; wool, 327

pauper children : apprenticeship, compulsory, system of, 79; boarding out system, the, 79, 80 ; Committee on the Care of Poor Law Children, the, 1896, 79 ; decrease in child pauperism since 1870, 78; education of pauper children, 78,79

Chile: exports to United Kingdom-copper, 1902 , 526 ; cotton, 1896-1904, 309; tin, 1902,526

imports of British produce and manu. factures to, $1827-1845,483-486$

ships, British, tonnage entering and clearing at Chilian ports, 1880-1907, 544

China : British trade with, to 1850,489

imports from United Kingdom-British produce and manufactures, 1827-1850, 483-486; cotton manufactures, 319 ; woollen manufactures, 1844,326

China. See Pottery

Chocolate, sources of supply, 525

Cholera : decline of, since 1870, 10; epidemic of 1848,156 ; of 1866,9

City and South London Railway, statistics, $1909,558-559$

Civil Service: percentage of population employed in, 1841, 38 ; 1881-1901, 39 ; salaries and expenses (analysed), 1897$1912,668,670,671$

Civil Services: expenditure, 1815-1835, $636 ; 1857-1910,641,643,665-681$; comparative analysis of expenditure in 1897 and 1907,668

Clapham, Professor, authority on the wool industry, 330,331

Clergymen, rate of mortality, 44

Clerks: number of children employed as, 1891-1901, 27

proportion of males to females employed as, 1861-1901, 31, 34

unemployment among, 57

wages, no statistics as yet available, 52

Climate, effect of, on growth of population, 5

Clothing industries: exports, 1860-1910: 530,531

child labour in, 27

home work in, 33

proportion of males to females employed, 1861-1901, 30, 34

Clough, Miss, pioneer of University Extension Movement, 149

Clover, acreage under, 1909, 211

Coal: coastwise trade in coal, 1819-1848, 217

consumption, 1850-1909, 222 ; amount consumed in the production of iron, 1850,218

exports, 1801-1849, 215, 220, $221 ; 1850$ $1909,222-224,521,522,530,531$; duty on exported coal, 1902, 520, 521 ; policy of such a duty, 223, 625; effect of export of coal on the expansion of the shipping trade, $224,522,531$
Coal, continued-

freights, 1801-1845, 216;1900, 224, 225

inland trade, 1816, 217

labour: number of children employed, 1891 and 1901, 27 ; numbers employed, $1851-1901,39,41 ; 1907,221$

"limitation of the vend," methods and effects of, 218-221

prices, 1801-1845, 216; 1850-1900, 224, 225 ; 1905,435 ; artificial raising of by "limitation of the vend," 218-221

production in United Kingdom, 18501909,222 ; value of total amount produced, 1907, 221

safety lamp, invention of, 215

supply, inexhaustible, $223,225,522$

wages, 1850-1906, 315

working, method of, in early part of the nineteenth century, 214, 215

Coal tar products, exports, 1870-1909, 416,418

output, 1907,415

number of persons employed, 1907, 415

Cobden, Richard, 500

Cocoa : consumption per head of population, $1840-1909,170,433$

duty on, revenue derived from, 1842, 626

import, 1840-1909, 450

output of British factories, 1908, 451

sources of supply, 525

Cocoa-nut fibre : output, 1907, 291

number of persons employed, 1907, 291

Coffee : adulteration of, 447

consumption per bead of population, 1840 $1909,170,433$; decline of, since beginning of century, 447 ; effect of, on consumption of beer, 459

duty on, fluctuations in, 448; revenue derived from, 448,625

foreign trade in, 1800-1850, 493-496

inports, 1840-1910, 449, 450, 528, 529

protection, effect of, 491,492

sources of supply, 449

Coffee-houses, first establishment and growth of, 447

Coffee plant, distribution of, 447

Cohn, Hermann, investigations into the health of school child ren, 145

Coinage: bad state of, at the beginning of the nineteenth century, 567-569; amount of gold and silver money coined at the Mint, 1801-1910, 568; silver coinage, 569 ; double standard proposed, 569; gold only legal tender for sums exceeding 40s., 569; copper coinage, 569,570 ; standards, custody of, 571 ; Indian currency, 571, 572; colonial currencies, 572,573

Colombia: exports to United Kingdomcoffee, 1909, 449; cotton, 1896-1904, 309

imports of British produce and manufactures, 1827-1845, 483-486

Colonial service, cost of, 1897 and 1907, 678

Colonies : currencies of, 572,573

export of timber to United Kingdom, $1801-1845,425$

imports from United Kingdom-brass and copper manufactures, 1844, 278; coal, 1908, 224 ; cotton goods, 1909, 321

persons born in, numbers living in United Kingdom, 1841-1901, 16 
Combines: in the chenical trades, 420, 421 ; in the tobacco trade, 472

Commerce, percentage of population employed in, 1851-1901, 38, 39

Commissions : cost of, 1597 and 1907,650

Alien Immigration, 1902,7 ; Canals, 1906 , 549, 551 : Coal Supply, 225 ; Education, 1S61, 79; Employment, 1840, 24; Feeble-minded, 1908, 128; Food Snpplies in Time of War, 428, 443; Licensing Laws, 121 ; Poor Law, 1832, 63, 64: $1909,30,35,69,72,680$; Sanitary, 1866, 9: Schools Inquiry, 186̈1, 138; Tuberculosis, 680

Committees: Edncation, 1897, 140 : Import Duties, 1840, 683; Physical Deterioration, 123

Communication: improvement in, in the bineteenth century, 171

with America, 542; India, 533-541; South Africa, 543; South America, 544 ; West Indies, 544

internal, in 1850,546

Confectionery : increase in consumption of, 435

imports, 1840-1909, 450

out tput, 1908, 451

Congress of Vienna, neglect of interests of British comnerce at, 500, 501

Conveyance, number of persons emploved in occupations grouped under this head, 1851-1901, 42, 43, See Railways, Transport

Copper : history of British copper-mining. 229 effect of the growth of the electrical iudustry on the copper market, 278,279 exports of manufactured copper, 18051910,$278 ; 1860-1910,530,531$

imports of copper ore and regulus, 18511809,$228 ; 1910,528$

mortality in copper-mines, rate of, 44

numbers employed in copper-mines, 1851-1901, 41 ; in factories, 1907,272

output of manufactured copper, 1907,272

production of copper in Lnited Kingdom, $1771-1908,228,230$

sources of supply, 526

Corn: duties on, luring Boer War, 690; revenue derived from duties on, 1842,625 imports, 1860-1910, 528, 529

Se Barley, Oats, Wheat

Corn Laws: effect of, on wagcs, 47 repeal of, $1846,54,55,55,51 \%, 655$

Cornwall. export of china clay from, $28 i$

Costa Rica, export of coffee to Lnited Kingdom, 1909, 449

Costermongers, rate of mortality among, 44

Cottage llomes for pauper children, 80

Cotton: capital employed in the industry. 1840,306

consumption of, 1832, 301; 1781-1908, $309 ; 1910,311$

distribution of the industry. 310, 312

duty on, 304. 305; evils of duty on cotton, 625: revenue derived fron duty on cotton, 1842,625

exports, 1800-1910, 291-297, 305, 319-321, $530 ; 1907,233 ; 1909,312$

thannelette, introduction of, 321

imports: raw cotton, 1800-1910, 225, 307$311,319,320,528,523$
Cotton, continued-

manufactured cotton, 1876-1905, 319 ; 1910,528

labour: numbers employed and sex distribution of, $1800-1850,300-303$; $1861-1901,42,316-318$; 1907, 291 ; 1911,306

child labour, 41 ; 1835-1901, 290, 317

hours of labour, $302,304,314$

inproved conditious of labour, in latter part of nineteenth century, 314

women, increased $\in$ mployment of, 31

See also under numbers employed

machinery: effect of introduction of machinery, 49

improvement in machinery, 1850-1910, 315,316

power-10om, numbers in use, 1820-1835, 297,$298 ; 1835,288,299$; 1874-1903, $310^{\circ}$

effect of introduction of, 299,316

esrly unpopularity of, 298,299

spindles: number at work, 1871-1903

$310^{\circ} ; 1910,310,311$

increase in speed of, 316

spinuing-jenny, invention of, 294

stean-power, introduction of, 295-297

output of manufactured cotton goods and

yarn, 1833, 301, 302, 304; I 840,306 :

$1907,291-293,315,321,322$; prints,

$1800-1850,305$

price, $1860-1910,529$

printing: introduction of. 304, 305

restrictive legislation, 304

progress of the industry: view of the cotton industry in 1909,312 ; foreign competition, 311, 312; increasing prosperity in spite of rise in wages, $1850-1900,49,50$

early history of the industry, 294, 295 , progress of, at the close of the Napoleonic War, 296

See Cotton, machinery

sources of supply, 526

wages, 49-53, 60. 298, 303, 304, 312-315

Couling, Mr., estimate of amonnt of uncultivated land in 1827, IS5, 189

County Council. Sec under Lacal Government

County Councils Act, 1888,158

Coventry, silk industry in, 350

Comper-Temple Clause, The (undenominational teaching in ratc-aided schools). 135

Crawford, Sir William, authority on the linen industry, 358

Credit, national, recent decline of, 642,650

See Debt, national

Crime: age rlistribation of criminals, $1512-1901,116$

alcohol as a cause of crime. 120, 121

code, crimiual, severity of in the eariy nineteenth century, I06

commitments, annual number of, 1841$1207,105,110$

discharger! prisoners. treatmeut of, 117

illiteracy and erine. 100, 119, 130

insanity and crime, 152, 130

movernents of crime, causes of, 112 ; decrease, 1550-1900, 111; increase, $1900-1910,111.120$

offences, iucreasc in number of, 111-113 
Crime, continued-

proportion per 1000 of the population committed to prison, 1909,120

recidivism, $115,118,119$

statistics, 109-113

summary of crime in the nineteenth century, 105, 106

unemployment as a cause of crime, 120

Crimean War, cost of, 687,688

Criminal Justice Act, 1855, 110

Criminal Law Amendment Act, 1855, 111

Cuba : export of tobacco to United Kingdom, 471

imports of British produce and manufactures, $1827-1845,483-486$

production of tobacco in, 1900-1903, 469

Cumberland: iron and steel, output, 1904, 246 ; iron ore, output, 1904, 243

bousing, 96

Cunard Shipping Co., The, 542

Currants: consumption per head of popula. tion, 170

revenue derived from duty on, 1842,625

Currency. See Coinage, Paper Currency

Curtis \& Harvey, Messrs., manufacturers of explosives, 421

Customs : expenditure, 1897-1910, 643, 681

effect of the reduction of duties after the Napoleonic War on revenue and on consumption, 623

revenue derived from, 1801-1849, 623

Customs Duty Act, 1843, 254

Cutlery, 272, 274-276, 530, 531

Cycle Trade, The, 256, 268

Dairy produce : imports, 1840-1909, 443 prices, 1876-1891, 204

production in United Kingdom, 1898-1902, 204

Davy, Sir Humphrey, 180, 215, 262

Day, J. T., editor of The Shoe and Leather Record, 373, 377

Dead Weight Annuity, The, 581

Deaf and dumb, numbers of, 20,21 ; education of, 141

Death penalty : number of persons sentenced, $106,107,109$

number of persons executed, 109

number of capital offences, 106

Deaths, Registration of institnted in 1837, 8

Death-rate, decline in, 43,44 ; causes of this, 9 ; mortality of rural as compared with urban districts, 10

Debt, number of commitments for, 120

Debt, municipal, 1897-1909, 645

lebt, national : amount of, $1736-1802,615-$ $617 ; 1836-1899,645 ; 1893-1905,646$ annual cost of, 1857-1910, 611-643

"borrowing for works," evils of, 644, 650 reduction in, 1905-1911, 642, 644

sinking fund, 1793-1837, 617-620, 621 ; $1905-1911,642,644$

total borrowings, $1897-1910,644$

De Morgan, Professor, authority on insurance, 609

Denmark : agriculture in, 201, 206

cotton industry in, 311

exports to United Kingdom-bacon, 441 ; butter and eggs, 1902,525 ; cattle, 1870 1900,411 ; nleat, 1902,525 ; wool, 1844 , 325
Denmark, continued-

imports from United Kingdom-British produce and manufactures, 1827-1845, $483-486$; coal, 1908, 223 ; hats, 400

ships, British, tonnage of, entering and clearing at Danish ports, 1880-1908, 543 telephone system in, 566

Density of population, 20

Derby, silk industry in, 350

Derbyshire, production of iron in, 238, 239 , 246

Devon port, housing in, 92

Devonshire : export of china clay from, 287 wool industry in, 331

Dewsbury, wool industry in, 329, 332.

Diarrhca, decline of, since 1880, 10

Die-sinking, output, 1907, 408

Diplomatic service, cost of, 1897 and 1907, 678

Discharged Prisoners Aid Societies, 118

Disestablishment of the Irish Church, 164, 165

Disinfectants, output, 1907, 415

number of persons employed, 1907, 415

Disraeli, Benjamin, opposition to military expenditure, 647,648

Distress Committees, number of applications for relief to, 1905-1909, 58, 73

Domestic service: number of children em. ployed, 27

number of domestic servants per 100 of population, 32

proportion of males to females employed in, 30

number of married women employed, 34

percentage of population employed in, 38 , 39

increase of numbers employed in, 57

effect on sex distribution of population, 12

increase of wages during the latter half of the nineteenth century, 52

Dominion Line, The, 542

Donald Currie \& Co., shipowners, 543

Drapery trade: proportion of males to females employed in, 31

percentage of popnlation employed in, 39

Dressmaking: home work in, 33 ; number of married women employed in, 34

Drink industries : child labour in, 27 ; female labour in, 34 ; percentage of population eluployed in, 39

Drink. See Alcohol

Drugs : output, 1907,415 ; uumber of persons employed, 1907,415

Drunkenuess. See Alcohol

Dublin, housing in , 91, 98

Dublin and South-Eastern Railway, statis. tics, 1909,552

Dundee: jute industry in, 363,364 shipbuilding in, 261

Durliam: housing in, 96 ; iron and steel industry in, 246; shipbuilding in, 43

Dutch East Indies, production of tobaceo in, $1900-1903,469$

Dyes and dyeing industry: duty, revenue derived from, $1842,626^{\circ}$

exports, $1890-1909,415,418$

imports, 1907, 415

number of persons employed, 1907, 291

output, 1907, 291, 415

raw material, sources of supply, 526

Dysentery, decline of, since 1870, 10 
Earthenware industry : exports, 1860-1910, 530,531

proportion of males to females employed, 31 See also Pottery

Ecclesiastical Commissioners, method of collecting rents, 100

Economist, The: articles on "Currency and Banking," 1845, 593

Banking Supplements, 600

estimate of the national wealth and capita] for the year 1909, 700-703

Edinburgh : housing in, 91 ; telephone service in, 566

Edison, Thomas, 263

Education: administration of, under the Act of 1902,142 ; subject to the control of the Board of Education, 164

age of leaving school, 136

Board of Fducation, control of, over locs] administration, 164

Charity Commissioners, the, 138

Cockerton case, the, 140

compulsory education, first institnted in 1876,135 ; exemptions, 135,137

continuation schools, institution of, 140 ; numbers attending, 140, 144; cost of, 140,144

Cowper-Temple Clause, the, 135

Endowed Schools Act, 1869, 138

expenditure, 1833-1901, 111, 149: 1905, $160 ; 1897$ and 1907 (analysed and compared), $668,674-678$

future prospects, 147,148

grants, development of, from 1833, 13: $\mathrm{fl}$. ; conditions under which grants are given, 133,137

health, feeding, etc., of children attending public elementary schools. See under Children

illiteracy, lecrease of, 1839-1907, 147 ; and crime, $106,119,120$

numbers attending primary schools, 18601908, 131-136, 141-143 ; continuation schools, 144 ; secondary schools, 115

psuper children, education of, 78-80

primary education: history of, in the nineteenth century, 132-13i: advantages of co-ordination of primary and secondary education, 143 ; cost of, 160,676

public schools, 137, 138

Public Schools Act, 156\$, 138

religious teaching: sunday schools, institution of, 132; Chureh of Eugland schools, institution of, 182; numbers educated in, 190S, 14:' : Nonconformist schools, numbers culucated in, 1908, $11^{33}$; controversies as to religions teaching canse the failure of the Bill of 1829,133 : uudenominational teach. ing in rate-aided schools under the Act of 1870 (Cowper-Tenuple Clause), 135 ; under the Act of 1902,142

School Boards, secondary education supplied by (the Cockerton case), 140: merged in the County and Borough Councils, 159

secondary education, definition of, 142 ; history of, in the nineteenth century, $13 \pi-145$ : revival of, as a result of the Schoola Inquiry Commission. 1861, 138; supplied by the old School Boards (the

\section{Edication, continued-}

Cockerton case), 140 ; numbers attend. ing secondary schools, 1907, 145; advantages of co-ordination of primary and secondary education, 143

teachers: appointment of, under the Act of 1902,142 ; training of, 133, 137, 142, 143,144 ; salaries of, $137,143,144$; Headmasters' Conference, the, 143: National Union of Teachers, the, 143: Teachers'Superannuation Act, 1898, 144 teclunical education : cost of, 110 ; detinitiou of, 140 ; foundation of first grant-sided teclinical schools, 139 ; People's College, the, Sheffield, 139 ; polytechnics, 110 ; Science and Art Department, the, 139 ; "whisky money," 140; Working MIen's College, the, 139

Universities. See Universities

women, education of, Charity Commissioners' Report on, 135; growth of higher education of women, 139

Elucation Act, $1870,26,135,157,200$

cducation Act, 1902,26 ; a compromise between educational and religious difficulties, 142

Education (Administrative Provisions) Act, 1907: imposes oll local education authorities the duty of medically inspecting childreu attending school, 145 ; administration of, 146,147

Elucation, Board of, $140,142,164$

Elucation, Royal Commission on, 1861, 79

Elucatiou, Committee on, 1897, 140 :

Elucation (Provision of Meals) Act, 1907, 145 ; cost of, 146

Eggs : consumption per head of population, $1810-1907,170$

duty on, revenne derived from, 1842, 626

imports, 1840-1909, 433, 434, 443

production in Cnited Kingdom, 1898-1202. 443,444

sources of supply, 525

Egypt: exports to the Cnited Kingdomcotton, 307-311; 1902, 520; ; oil-seeds, 1902,526

fertility of, 458

imports from United Kingdom-British produce and manufactures, $1827-1846$, 483-486; cos1, 1908, 223

Elastic webbing : output, 1907,291 ; number of persons enployed in manufacture of, 1907.291

Elder Dempster Linc, The, $\mathbf{5} 43$

Eldon, Lord. opposes the abolition of the death peualty for theft, 106

Electrical industries: dyiano, inrention of. 202

effect of the detelopment of the electrical industry on the comper uarket. 278.279 exports, $1897-1910.206: 1910,530,531$

lighting: invention of the first practical arc light, "202, 20.3 : invention of the Hliswan incandescent lamp, 203 ; tle "Brush" hroom, 263, "264; cost of, as conipared witli the cost of electric jower, 266: municipal control of, ad. vantayes of this, 264,266

notor, elcctric, invention of, 251 numbers emplovei:, 33

power, clectric, adrantages of, as comparct. 
Elcctrical industries, continuedwith steam, 265 ; cost of, as compared with cost of electric light, 266 price-differential rates, system of, 266 problems of the industry, 265, 266 traction, beginnings of, 264 ; economic advantages of, 264, 265

Electric Ligliting Act, 1882, 264

Ellenborough, Lord, opposes abolition of the death penalty for theft, 106

Ellison, Mr., 49, 50

Emigration : effect of, on growth of population, 5; of agricultural labonrers, 202 ; from 1reland, 164 ; statistics, 5, 6

Employers' Liability Companies Act,1907,607

Employers' Liability Insurance. See Insurance

Employnent, Commission on, 1840, 24

Endowed Schools Act, 1869, 138

Engels, Frederick, 58, 59

Engineering: explosive engine, effect of invention of, 268

internal combustion engines, introduction of, 267

marine: compound engine, introrlnction of, 260

internal combustion engine, introduction of, 260

oil fuel, use of, 261

steam-power, first application of, to ships, 259

turbines, introduction of, 260

numbers employed in, 1851-1901, 170; 1891-1901, 43

oil engines, 267

wages, 1850-1906, 315

See Machinery

Engraving, output, 1907, 408

Enteric fever, decline of, since 1869, 10

Equitable Assurance Company, The, 608

Eton College, 137, 138

Europe, Northern, export of British produce and manufactures to, $1805-1849,479,480$

Europe, Sonthern, export of British produce and mantufactures to, 1805-1849, 479, 480

Eversley, Lord, view of the wool industry in $1910,310,341$

Excise duties, effect of, on consumption of alcohol, 122, 123

Executions, took place in public until 1868,107

See Death Penalty

Explosives, manufacture of, 421

Exports from the United Kingdom: British produce and manufactures, 1801-1849, 477 ; 1872-1910, 520, 521, 523, 527

classification of, $1860-1910$, 530

distribution of, $1800-1849,479,480$; $1872-$ 1910,527

tonnage employed in the export trade, $1802-1849,516$

value of total exports, $1850-1890,518$; 1872-1910, 520, 521, 523

alkalis, 1907, 416; alum, 1907,415 ; ammonia sulphate, 1895-1909, 417, 418 ; beer, 1860-1910, 457, 459, 530, 531; bleaching inaterials, 1870-1909, 415, 416; books, 1871-1910, 411; boots and shoes, 1876-1909, 379; brass manufactures, 1805-1910, 278: chemical products and manufactures, $1860-1910,415,416,530$,
Exports from United Kingdom, continued531 ; clothing, $1860-1910,530,531$; coal, 1800-1850, 215, 217, 220, 221; 1850-1910, 222-224, 521, 522, 530, 531 ; coal tar products, 1870-1909, 416; copper, 1805-1910, 278, 530, 531; copper sulphate, 1895-1909, 418, 419 ; cotton manufactures, $1800-1850,295-$ 297,319 ; 1850-1910, 293, 319-321, 530, 531 ; cutlery, 1860-1910, 276, 530, 531; cycles, 268; dyes, 1890-1909, 415, 418; electrical goods, 1897-1910, 266, 531 ; fertilizers, $1870-1909,417,418$; foreign and colonial merchandise, 1801-1849, 477 ; galvanized sheets, 1890-1910, 277 ; glass, 1870-1910, 285; gloves, leather, 1903-1910, 402, 403; haberdashery, $1860-1910,530,531$; hardware, 1805$1910,273,530,531$; hats, 1856-1910, 400,401 ; hosiery, 1861-1910, 395 ; iron, $1800-1850,240$, 242; 1860-1910, 530, 531 ; iron wire, 1880-1910, 277; jute manufactures, 1895-1910, 292, 364, 367 ; lace, 1871-1910, 397, 398; lead ore, 1900-1909, 231 : leather, 1860-1910, 530, 531 ; linen, 1850-1910, 292, 359, 530, 531 ; machinery, 1822-1849, 254, 255; 1860-1910, 521, 522, 530, 531 ; medicines, $1870-1909,417,418$; millinery, $1860-$ 1910,531 ; motor cars, 67 ; paint, $1860-$ $1909,417,418$; paper, 1860-1910, 407 , $408,528,530,531$; plate, gold and silver, 1830-1910, 282 ; pottery, 1860-1910, 287. 530,531 ; railway materials, 266 ; ribbons, 1907,292 ; saltpetre, 1895-1909,419; silk inanufactures, $1820-1850,347 ; 1850-$ $1910,292,351,353,530,531$; soap, $185.3-1910,423,444$; soda compounds, $1855-1909,416$; spirits, 1802-1841, 467; 1860-1910, 468; steel, 1800-1850, 241; $1860-1910,530,531$; steel wire, 1880 1910,277 ; sulphates, aluminous, 1907 . 415 ; tin, $1820-1819$, 226 ; tin plates, 1860-1910, 276, 277 ; varnish, 1870-1909, 417, 418; wire, iron and steel, 18801910,277 ; wheat, 182, 183 ; wool, 1815$1845,324-326 ; 1850-1910,333-338,530$, 531 ; woollen hosiery, 1904-1910, 396

Factories, accidents in, 44,45

Factory Acts, The, 24, 26; effects of, on production, 24

Factory and Workshops Act, The, 45 ; cost of, 1897 and 1907,671

Fancy goods industry, home work in, 33

Faraday, electrical discoreries of, 262

Farmers, rate of mortality among, 44

Farr, Dr., improvements in statistical nethods introduced by, 2

Feeble-minded. See Insanity

Feeble-minded, Cornmission on, 1908, 128

Felt industries, home work in, 33

See Hat trade

Fens, draining of, $185,186,187$

Fertilizers : exports, 1870-1909, 417, 418; output, 1907,415 ; number of persons employed in manufacture, 1907, 415

Finance, national, debt. See Debt, national expenditure: analysis, 1742-1849, 617 ; 1857-1910, 641

army, 1801-1849, 630-633; 1857-1910 
Finauce, continued-

641,$643 ; 1897-1912,647-658$; detailed sccount, 1897-1898, 652

civil list, 1805-1849, 634, 636; 189i1910,644

Civil Services, 1815-1835, 636; 1857$1910,641,643,665-681$; comparative analysis of expenditure iu 1597 and 1907,668

consolidated fund service, 1857-1910, $641-643$

customs, 1897-1910, 643

Inland Revenue, 1897-1910, 643

miscellaneous services, 1515,$636 ; 189 \bar{i}-$ 1910,644

nะเy, 1801-1549,630-633; 185i-1910, $641,643,658-665$

Post Office, 185i-1910, 641, 643, 644

during Napoleonic War, 280, 613, 615

Pitt's "perfectly new and solid system of fuance," 1797, 611

rerenue, $1800-1850,617,623,683 ; 1853$, 686 ; 1908-1910, 692

sinking fund. See Debt, national

Fines, average number of persons fined yer annum, 113; average number of persons committed to prison in default of payment of fines, 113

Fireclay, production of, in United Kingdom, 236

See Brickmaking

Fire Insurance. Siee Insurance

First offenders, treatment of, 115

Fish: amount landed on British coasts, 1902, 413

curing industry, output, 1908, 443

numbers employed in fishing industry, 39 sources of supply, 525

Fitzwilliam, Earl, on the Corn Laws, $1 \$ 5$

Flannelette. See under Cotton

Flax: decline of flax industry since 1861, 41, 42

imports, 1860-1910, 528, 529

child labour in flax industry, 290 ; proportion of males to females employed, 220 prices, $1860-1910,529,530$

sources of supply, 526

See Linen

Flock inlustry, 339, 340 ; ontput, 1907, 291 ; number of persons employed, 1907, 291

Florists. See Market Gardening

Flour, mean price, 1905,435

See Wheat

Flower-msking (artificial), home work in, 33

Food: consumption, increase in, 1\%0; amount of imported food consumed per heal of population, 1840 and 1909,433

imports, 1840-1909, 433, 434, 525, 529

industry, labour in: child labour, 27; femsle labour, 34 ; percentage of population emplosed, 39

supply, 36 ; adequacy of, 1800-1850, 175$17 \%, 189$; growing deficiency of after 1850, 193 ff., 475 ; chsnge of conditions governing food-supply since 1550, 194, 433 ; sources of supply, 524, 525; statistics, lack of, as to production of food in United Kingdom, 432, 433; variety of, 433,434

Foreign trade: home trade dependent on foreign trade, 473
Foreign trale, continued-

foreign trade not necessarily of less value than home trade, 474

British ships gaining an increasingly large share of the world's commerce, 538

excess of imports over exports necessary, 522,523 ; and is the measure of inrest. ments abroad and of shipping profits, 518

growtl of, 1801-1849, 47\%; 1850-1870, $518 ; 1872-1902,520$

sources of supply, 525, 520

tonnage (total) employed in foreign trade, 180'2-1849, 516; of British ships em. ployed in as compred with that of other nations, 1890 and 1908,537

Forster, Mr., 135

Foster, Joseph, joint founler of British and Foreign Schools Society, 133

Fox, Joseph, joint fonder of British and Foreign Schools Society, 135

Fox, Wilson, 48, 49

France, agriculture in, $198,200^{\circ}$

alkali industry in, 414

cotton industry in, 311

exports to United Kingdom-butter, 1902. 525 ; chocolate, 1902 , 525 ; cotton, 320 ; bides, 1902, 526 ; lace, 397 ; silk, 349 ; sugar, 1902, 525; timber, 1870-1900, 427 ; vegetables, 1902,525 ; wheat, 194 ; wine, 462 , 463 ; wool, 1814, 325

imports from United Kingdom-British produce and manufactures, $1827-1845$, $483-4 \$ 6$; alkalis, 414 ; boots and shoes, 1905-1908, 350; brass and copper mant. factures, 278; coal, 223; cotton, 320 ; hats, 400 ; lace, 399 ; silk manufactures, $1830-1850,347,345$; wool, raw and Yarn, 1814,326 ; value of total inports from Unitel Kingdom, 1910, 527.

infant mortality in, 11

motor car industry in, 267

sheep, number of, in, 330

ships, British, tonnage of, entering and clearing at French ports, 1890-1908, 543 sill: industry in, 348

telephone service in, 566

tobacco, consumption per head of population, 1910, 4i1

wheat, imported, consumption per heal of population, 1853-1902, 524; price of wheat in, compared with United Kingdom and German y, 1883-1902, 524, $520^{\circ}$ wool industry in, 334

Franchise, effect of extension of, 17t

Franchise, municipal. Ste under Local Gorernment

Franco-German War, effect of, on prices, 518

Franklin, Dr., on Protection, 628

Free Trade. Ste Protection

Friendly Societies, evidence of, is to the prosperity of the working classes, 168, 169

Fruit: acreage under, 1909,211 ; incressed cultiration of, $206,20 \overline{7}, 211$

bottled, ontput, 1905,451

consumption of, increase in, 169, 171, 435,453

imports (classified), 1840-1909, 152

sources of supply, 525

Frys, The, and prison reform, 109

Furness Railway, statistics, 1009, 552, 559 
Furniture trade: output, 107,428 ; number of persons employed, 39,428

Furs: duty on, revenue lerived from, 1842, 626

percentage of the population engaged in the fur trade, 39

Fustian industry, 339, 340; ontput, 1907, 291 ; number of persons employed, 1907, 291

Galvani, his electrical discoveries, 262

Galvanized sheets, exports, 1890-1910, 277

Gamble, J. G., pioneer of the chemical trade, 412

Gamekeepers, rate of mortality, 44

Garden Cities, 102

Gardeners, rate of mortality, 44

Garrett, Miss, applies in 1872 for a nichical diploma at Loudon University, 139

Gas : effect of invention of electric light on the gas industry, 263

percentage of population employed in the production of, 39

average wages in the industry, 53

Gateshead, housing in, 92,96

Gauge Pegulation Act, 1846, 553

General Labour: number of children employed, 27 ; mortality, rate of, 44 ; percentage of population employed in, 38,39 ; average wages, 53

Germany : agriculture in, 206

alkali industry in, 414

cotton industry in, 311,312

hosiery industry in, 395, 396

exports to United Kingdom-cattle, 18701900, 411 ; cotton, 1909, 320 ; dyeing and tanning stutis, 1902, 526; hides, 1902,526 ; 1906-1910, 374, 375 ; lace, 397 ; sugar, 1902, 525 ; timber, 18701900,427 ; tobacco, 471 ; wheat, 1819 , 194; wine, 1909, 163 ; wool, 1844, 325, 326

iron industry in : production of pig-iron, 244 ; effect of discovery of basic process, 246

inports from United Kingdom-British produce and inanufactures, 1827-1845, $483-486$; alkalis, 414 ; boots and shoes, 1905-1908, 380 ; brass manufactures, 1910,278 ; coal, 1908, 223 ; cotton, 1909,320 ; hats, 400 ; jute manufactures, 1872, 367 ; lace, 399 ; wool, raw and manufactured, 1844, 326 ; value of total imports from United Kingdom, 1910,527

navy, growth of, 662

sheep, number of, in, 330

ships, British, tonnage of, entering and clearing at German ports, 1880-1908, 543 telephone service in, 566

tobacco, production of tobacco in, 19001903, 469; consumption per head of population, 1910,471

wheat, imported, consumption per head of population, 524; total imports of wheat, 1909, 438; price of wheat in, as compared with United Kingdom and France, 524, 526

Gibraltar: imports of British produce and manufactures, $1827-1845$, 483-486 ; export of wool to United Kingdom, 1844, 326
Giffen, Sir Robert, 167, 169, 171, 522, 691

Gilchrist, Mr., discoverer of open heartl process of steel-making, 245

Girls' Public Day School Company, The, 13!

Girton College, 139

Gladstone, Mr., financial policy of, 647 . $649,686,689$

Glasgow : housing in, 94,95 ; shipbuildin industry in, 261 ; telephone service in 566

Glasgow and South - Western Railway statistics, 1909, 552, 558, 559

proposed amalgamation of, with Midlan Railway, 557

Glass-making industry : Belgian competition 286 ; consumption, 1789-1844, 283 duty on, effects of, on the industry 283-284; revenue derived from, 1842 626 ; exports, $1860-1909$, 285 ; imports $1800-1910$, 283, 285; labour trouble in, 285, 286; numbers employed, 285 percentage of population employed, 39 Gloucestershire, wool industry in, 331

Glove-making : proportion of males t females employed in, 31

leather gloves: imports, 1891-1910, 400 401 ; exports, 1903-1910, 402, 403 output, 1907, 403

Glucose, duty on, 449

Glue factories: output, 1907,415 ; numbe: of persons employed, 1907,415

Gold: effect of changes in the production and consumption of gold on prices, 54 55 , 59 ; price of, $1803-1813,499$; pro duction of, in United Kingdom, 236

Gold plate: consumption of, $1800-1850$ 281, 282 ; exports, 282

Goschen, Mr., 74

Gossagc, Williain, pioneer of the chemica trade, 412

Grass, acreage under, 1909, 209, 210, 211

Grazing. See nnder Agriculture

Great Central Railway: statistics, 1909 $552,558,559$

proposed amalgamation with Grea Eastern Railway and Great Northerr Railway, 557

Great Eastern Railway: statistics, 1909 $552,558,559$; proposed amalgamatior with Great Central Railway and Greal Northern Railway, 557

Great Northern Railway: statistics, 1909 $552,558,559$; proposed amalgama tion with Great Central Railway anc Great Eastern Railway, 557

Great Northern Railway (Ireland), statistics, 1909, 552

Great Northern, Piccadilly, and Brompton Railway, statistics, $1909,558,559$

Great Southern and Western Railway (Ireland), statistics, 1909, 552

Great Western Railway, statistics, 1909 , $552,558,559$

Greece : exports of wool to United Kingdom, 1844,326

imports of British produce and manufactures, $1827-1845,483-486$

Greenock, shipbuilding industry in, 261

Grimsby, fish trade in, 443

Guano, imports of, to United Kingdom, 179,197 
arlians, Boarl of. See Local Government istemala: exports of coffee to United Kingdow, 1909, 449

mports of British produce anil manu. factures, $1827-1845,483-186$

inness, Messrs., brewers, 455, 459

inness Trast, The, 99

m, output, 1907, 415 ; number of persons employed in manufacture of, 1907, 415

rneys, The, and prison reform, 109

berdashery, exports, 1860-1910, 530, 531 bitual Drunkards Act, 1879 , failure of, $124 ; 1598,125$

ir industries, percentage of population employed in, 39

lifax: child labour in, $2 S$; wool industry in, 332

m. See Bacon

ad-in-Hand Fire and Life Insurance Company, 604

rcourt, Sir William, 690

rdware : exports, 1805-1910, 273, 530, 531 ; imports, 1805-1910, 273

rland \& Wolff, shipbuilders, 261

rrison, Frederic, teaches at the Working Men's College, 139

rrow School, 138

rtlepool, shipbuilding industry in, 261

$t$ trade : exports and imports, 1856-1910, 400,401 ; output, $1907,40^{\prime}$; home work in, 33 ; proportion of male: to females employed in, 31

$y$, total area nnder, $1909,211,212$

alth. See Public Health

mp : 369-372; imports, 1854-1910, 372 : ontput, $1907,291,371$; number of persons employed, 1870-190\%, 41, 291, 391 ; proportion of males to females employed, 31 ; price, 1793-1815, 576; process of preparation, $368-370$; sonrces of supply, 526

iks-Besch, Sir Michael, 690

les: duty on, revenue derivel from, 1842,626 ; imports, $1860-1910,529,529$ : sources of supply, 526

hland Agricultaral Society, 'The, 198

hland Railway, statistics, $1909,152,559$

hway Act, 1870 , provisions of, as to the upkeep of roads, 518

huay Boards, The, $5 ! 7$

1, Octaria, 100

'g, Quintin, 140

idays, increased demand for, 73

land : cotton industry in, 311

sports to United Kingdom-cattle, 1870 1900, 441 ; cheese, 1902, 525; chocolate, 1902,525 ; cotton, 1909,320 ; dyeing and tanning stuffs, 1902, 520'; hides, 1902,526 ; tobacco, 471 ; wool, 1844, $320^{\circ}$ uports from the United Kingdon: Britisl produce and manufactures, $1827-1845$, 483-486; boots and shoes, 1905-1908, 380 ; brass manufactures, 1910,278 ; cosl, 1908, 223; cotton, 1909, 320; hsts, 400; jute manufactures, 1872 , 367 ; wool, raw and manufactured, 1844,326

fant mortality in, 11

ips, British, tonnage of, entering and clearing st Dutch ports, 1980-1908, 543
Holland, continued-

tobscco, cousumption of, per heal of population, 1910, 471

Home Office: police, control over, 164 ; public health jurisdiction of, 157 ; salaries and expenses, 1897 and 1907, 670,671

Home work, 32-31

Hops: acreagc under, 1309,210 ; imports, 1910,201

Horsehair industry: output, 1907, 291; uumber of persons employed, $190 \mathrm{j}, 291$

Horses, number of, 190-192, 202,212

Hosiery: cotton hosiery, proportion of cotton to wool employed, 395 ; German competition in cotton hosiery, 395; growth of cotton hosiery industry in early part of the nineteenth century, 384 distribution of the industry, 383

early history of the industry, 382,383

exports, 1861-1910, 395, 396

imports, 1861-1910, 395

labour: child labour, 24 ; female labonr. $31,390,391$; home work, 33 ; numbers employed, 1870-1910, 291, 383, 393

mortality, rate of, 44

output, 1907, 291, 394

steam-power, introduction of, 392

stocking frames, invention of, $38 \%, 38$ ?

wages, $1906,391,393$

woollen hosiery, proportion of cotton in woul amployed, 395 ; imports and exports, 1901-1910, 396

See Cotton, Wool

Hospitals: number of inmatcs, 22 ; $\cos t$ of. 160

Hours of Labour. See Working Day

Housing : block dwellings, 92, 100

expenditure of London County Council on working-class dwellings, 161

louses, number of, inhabited, uninbabiter, and building, 1801-1901, 91, 429

legislation, 100,102

local authorities, accommodstion provider by, 101

molel dwellings, 100,101

number of inhabitants per bouse, 1801$1301,91,92,94$

rural districts, present lack of accon. modation in, ?1, 103, 104

sanitation, 93,102

typical working-class dwellings in varion: parts of the country, 97, 95

Sie Crarden Cities

Housing Act, 1820, practically a dead letter, 103

Housing and Town Planning Act, 1909, 102

Honsing Commission, 1585, 104

Housing, Committee on. 1900, 102, 103

Housing of the Working C'lasses Acts, 1890 , $1900,1903,100$

Howard, Mr., prison reformer, 100, 108

Huddersfeld, wool industry in, 261

Hull: shipbuilding industry in, 261 ; tele. phone service in, 566

Hull and Barnsley Railway, statistics, 1909. 559

Huggary, production of tobacco in, 1900 1903,469

Hutchins and Harrison, Messrs, authors of The History of Faclory Legislation, $5 \%$ 
Illegitimate births, decrease in, 11

Immigration. See Alien

Immigration, Alien, Commission on, 1902, 7

Imperial Tobacco Company, The, 472

Import Duties Committee, 1840, 683

Imports into the United Kingdom: value and classification of total imports, 18501870,518 ; 1870-1910, 520-529; sources of supply, 525, 526 ; tonnage employed in the import trade, $1800-1850,516$; foreign and colonial merchanclise, imports of, 1801-1849, 477; alkalis, 1907 416 ; alum, 1907, 415; bacon, 1840$1910,433,434,439,442$; barley, 1850 1910, 194, 438, 525 ; beans, 1898-1904, 438; beef, 1849-1910, 194, 439, 441; books, 1871-1910, 411 ; boots and shoes, 1876-1909, 379; brandy, 1800-1910, 465-467; butter, 1860-1910, 194, 525, 528; cattle, 1840-1910, 197, 440, 441 ; cheese, 1902, 525; chemicals, 1907, 415, 416 ; 1910 , 528; chocolate, 1902,525 ; cocoa, 1840-1909, 450, 525 ; coffee, 1860 $1910,450,528$; confectionery, 18401909, 450; copper, 1850-1910, 228, 229, 526, 528; corn, 1860-1910, 528, 529; cotton, raw, 1800-1910, 295,307-311, 319, 320, 525, 528, 529; manufactured, 1910, 528; cutlery, 1900-1910, 276 ; cycles, 268 ; dyes, 415, 526; eggs, 1902, 525 ; fish, 1840-1910, 441, 525; flax, 1814$1850,356,357$; $1850-1910,359,526$, 528 ; fruit, $1840-1910$, 452 , 525 ; glass, 1800-1910, 283, 285; gloves, leather, 1891-1910, 403; hardware, 1805-1910, 273 ; hemp, raw, 1814-1833, 356 ; 1854$1910,372,526$; hides, $1860-1910,374$, 528 ; hops, 1910,460 ; hosiery, 18611910, 395 ; hosiery, woollen, 1904-1910, 396 ; iron, $1860-1910,526,528$; jute, raw, 1854-1910, 292, 366, 526 ; lace, 1871-1910, 397, 398; leather, 1910, 528; linen, 1827-1844, 356, 357; 1907, 292; maize, 1898-1909, 438, 525 ; meat, 1840$1910,440,441,525,528$; milk, condensed, 1902, 525; motor cars, 267 ; mutton, 1840-1910, 439, 441; oats, 1850-1910, 194, 438, 525; oil, 1860-1910, 526, 528; paper, 1886-1910, 407, 408, 526, 528; peas, 1898-1904, 438; pork, 1840-1909, 441 ; potatoes, 18981909,438 ; ribbons, 1907,292 ; rice, $1860-1910,438,525,528$; rum, $1800-$ $1910,465-167$; rye, 1898-1904, 438 ; sheep, 1840-1909, 441 : silk, raw, 1850$1910,292,351,352,528$, 529; manufactured, $1850-1910,351,353,528$; soap, 1905-1910, 424; soda compounds, 1907,415 ; spirits, $1802-1841,186,467$; 1910 , 528; steel, 1910 , 528; sugar, 1850-1910, 450, 528, 529 ; sulphates, aluminous, 1907,415 ; tallow, $1860-$ 1910 , 528; tea, $1840-1910,450,528$, 529 ; timber, 1800-1910, 526, 528, 529 ; tin, $226,227,228,526$; tobacco, 18601908, 526, 528: vegetables, 1902, 525 ; wheat, $1800-1850,176,182,183 ; 1860$ $1910,194,436,437,438,525,528,529$; wine, 1850-1910, 463, 528; wool, 1800$1850,327,329$; 1850-1910, 333, 337, 338, $526,528,529$
Imprisonment. See Prisons

Inclosure of common land: area inclosed, $1760-1850,187,188$

effect of inclosure on production of wheat 181,184

Inclosure Acts, number passed, 1800-1850, 181,183

Income tax. See Taxation

India: British trade with, to $1850,490-492$ commnnication with, 538-541

Suez Canal, opening of, 540

cotton industry in, 311,312

currency of, 571,572 ; Huctuations in the value of the rupee, 571

exports to United Kingdom-coffee, 1909 , 449 ; cotton, 307-311, 526; dyeing. stuffs, 1902, 526; hides, 1902, 526 ; jute, $364,365,526$; rice, 1902, 525 : wheat, 1899-1909, 436, 438, 525; wool, 1844,$325 ; 1902,526$

garrison of, 650

hemp, production of, 369

imports from United Kingdom-British produce and manufactures, 1827-1845, 483-486; brass and copper manufactures, 1844 and 1910,278 ; cotton, 318 ; wool, 326 ; value of total imports from United Kingdom, 1910, 527

jute industry in, 365

roads, lack of, in first half of nineteenth century, 490,491

ships, British, tonnage of, entering and elearing at Indian ports, 1880-1910, 541

tobacco, production of, 1900-1903, 469

Indiarubber industries, proportion of male to female labour employed in, 31

Indigo, duty on, revenue derived from, 1842,626

Industrial Revolution, The, in the nineteenth century, 23, 47, 105, 231

Industrial Schools: cost of, 1897 and 1907, 673

proportion of feeble-minded inmates, 130 number of children iu, 143

institution of, 116

Inebriates. See Alcohol

Inebriates' reformatories, cost of, 671

Infant mortality : statistics, 10, 11

decline of, since 1870,11

in England as compared with foreign countries, 11

gravity of the problem, 11

overcrowding as a cause of, 94, 95

Ink, manufacture of: output, 1907,415 . number of persons employed, 1907, 415

Inland Revenue, expenditure, 1897 and 1907, 643, 681

Insanity: alcohol as a cause of, 125, 130, 131

Asylums, numbers confined in, 127

education of feeble-minded children, 141 crime and insanity, 129

expenditure of local authorities on Asylums, etc., 1905, 160, 163

feeble-minded, Committee on, 1908, 128

grants from Exchequer towards mainten. ance of pauper lunatics in County Borough Asylums, 128

legislation, summary of, 125, 126 need of extension to cover all mentslly defective persons, 129 
Insanity, continued -

licensed houses, numbers confined in, 127

Lunscy Coumissioners, appointment of, 126

Metropolitan Commission in Lunacy, 1844, 126

numbers of inssue, 22, 126-i29

trestment of inssue in early part of nineteenth century, 125, 126

workhouses, numbers consined in, 127

Insurance: Bosird of Trade, returns to be made to, 609

development of, since 1850,603

employers' liability insurance : unremner. ative at present, 605 ; figures, 1910,606 ; Employers' Liability Companies Act, 1907,607

fre insurance : history of, 604-606 ; stamp duty on policies, 604 ; smonnt insurer, 1783-1868, 605; improvements in position of insured, 605 ; rstes, decrease in, 605

investment by Insurance Companies, 610

life insurance: history of, $607-609$ : an exsct science, 607 : English Life Table No. 1, 609; "Seventeen Offices Table," 609; Northampton Table of Mortality, 605; Milne's Carlisle Table of Mortality, 608 ; legislation, 608, 609 ; bonus system, institution of, 608

scope of insurance, 603

security of British Companies, 609, 610

theory of insurance, 603

Irelsnd : agrarian discontent, 198, 199

agriculture in, 165,206

alcohol, consumption of, 1800-1841, 451 . $465 ; 1909,122$

census, institution of. 2

education in, $64,65,141,147,151,152$

emigration from, $5,6,89,90,161,199$

famine of $1848,89,164,177,199$

feeble-minded, trestment of, 131

fever epidemic of $1 \$ 16,89$

bousing, 91, 98

iron ore, output of, 1904, 21.

land tenure, system of, ins, 199

linen industry in, $354-358$

local government, 164,165

pauperism in, $88-91$

population of, $3,5,39$

railways, statistics, 1200,552

rent, 98

tobscco, consumption of, $16 ?, 170$

wool industry in, $3330^{\circ}, 354$

Iron iadustry : blasting, hot air nethor], 23\%, 242

coal, amount consumed in the production of iron. 218, 239

coke-smelting, 237

consuroption, 1800-1850, 242

derelopment since $1850,212 \mathrm{fr}$.

duts, revenue derived from, 1812, 626

exports, 1800-1550, 210, 242; 1-60-1910. $530,5.31$

finished iron industry, 244

brmatite iron, 243,214

imports, 1860-1910, 526.528

Iabour, numbers emplored, 41

ore, production in the United Kinglon, 243 ; imports, $1850-1310,243$ : sources of supply, 526
Iron industry, continued -

pig. varions kinds of, 243 ; production of, 1850,244

price, $1806-1845,246,247,273$

output, 218, 238-241, 243, 246, 247

pyrites, production in Únited Kingdom, 236

tube-making, output. and number of persons employed, 272

wages, $1850-1906,53,315$

Ironstone, production in Unitel Kingdom. 326

Ismay, Imrie, \& Co., shipowners, 541, 512

Italy : cotton industry in, 311

emigration of Italisns to United Kingdom, 6

exports to United Kingdom-cotton, 1909 , 320 ; hides, 1906-1910, 374. 375; rool, 1541,325

hemp, production of, 369

imports from United Kingdom-British produce and manufactures, $182 ;-1845$. 483-486; coal. 1905, 223; cotton, 1903 . 320 ; woollen manufactures, 1844,326

ships, British, tonnage of, entering and clearing at Italian ports, $1880-1008,543$

Jacquard, silk manufacturing machinery of, 344

Jam, output, 1905. 451

Japsn : cotton industry in, 311,312 ; exports and imports of cotton to and from United Kingdom, 1909, 320: import of hats from United Kingdom, 400 ; ton. nage of British ships entering and clearing at Japanese ports, 18\$0-1810, 511 ; production of tobacco, 1900-1903. 469

Japanned goods, ontput. and number of persons emplored, 1907,272

Joini-stock banks. See Banking

Juries, diminution in number of cases tried bv, 110

Justice, public expenditure, 1897 and $190 \bar{i}$, $608,672-674$

Jute industry : consumption, 1900-1210, 365

derelopment of, $361-363$

exports, 1S95-1910, 292, 364, 367

imports, 1854-1910, 292, 366, 525

number of persons employed, 1881-1301. $363 ; 1907,291$; proportion of males to fermales employed, 31

ontput of Inanufactured jute, 1907. 201. 363,364

price of raw jute, 1900-1910, 364-366

production, total. of raw jute, 187t-182. 365

sources of supply, $520^{\circ}$

wsyes, 1850-1900, $50,313,30 \%$

Keiller, Alexander. d C'o., jum manufacturers. $4: 3$

Kingaler, Cliarles, teaches ai Working Jen's College, 139

Knickerbocker Trust. The, failure of, 599

hrirtz, Andreas, pioneer of the chemical trade, 412, 413

Kynoch, Messrs., manufacturers of explo. sives, 42I 
Labour, casual : unemployment in, 57, 58 general, rate of mortality, 44

hours of. See Working Day mobility of, effect on unemployment, 56 organization of, effect on stability of real wages, 60

Labourers Acts (Ireland), 91, 98, 165

Labourers Dwellings Improvement Act, 100

Labouring Classes Lodging-Houses Act, 100

Lace industry: general survey of, to 1850 , $384,387-380$

imports and exports, 1871-1910, 397-399

output, 1907, 291, 398, 399

number of persons employed, 1870-1907. $41,291,393,394$

proportion of males to females cmployed, 31

Lancashire : clenical trades in, 419,420

child labour in, 28

cotton industry in, $306,30 \%, 310,312$

iron and steel, output, 1904, 246; iron ore, ont put, 1904, 243

average rent, 97

Lancaster, Joseph, pioneer of free education, 132

Land, agricultural, decrease in value of, 37 capital value of, $1800-1909,696-701$

tenure of, 198

reclamation of, 198

See under Agriculture

Land Acts (Ireland), 1878 and 1881. 165, 199

Land Purchase Acts (Ireland), 1885-1909, 165

Land Registry, expenditure, 1897 and 1907, 673

Laundries: child labour in, $2 \pi$; female labour in, 33 ; home work in, 33 ; proportion of males to females employed, 31 ; percentage of population enployed in, 39

Law, public expenditure on, 1897 and 1907 , $668,672-674$

Lead : imports and exports, 1900-1909, 231, 232

number of persons employed in lead industries, 41,272

output, 1907, 272

price, 1800-1909, 232

production of, in United Kingdon, 1850$1908,231,232$

Lead poisoning, 44

Leather: duty on, revenue derived from, 1842,626

exports, 1860-1910, 375, 530, 531

imports of hides, 1876-1910, 374, 375, 528

number of persons employed, 39,375 output, 1907, 375

Leeds : alien population of, 7

telephone service in, 566

wool industry in, 332

Leicester, hosiery industry in, 390

Leicestershire, iron and steel, output, 1904 246

Leith, shipbuilding industry in, 261

Lemons, duty on, revenue deriver from, 1842,626

Letchworth, garden city at, 102

Levi, Professor Leone, 121

Libraries. See under Local Government

Licensed Victuallers, rate of mortality, 44

Licensing. See under Local Government
Licensing (Consolidation) Act, 1910, 458

Licensing Duties, effect of, on consumption of alcohol, 122, 123

Licensing Laws, Royal Commission on, 121

Liebig, Dr., 180, 420

Life insurance. See Insurance

Limestone, production of, in United Kingdom, 236

Lincolnshire: iron and steel, output, 1904, 246 ; iron ore, output, 1904, 243

Linen industry : $41,42,354-361$

distribution of the industry, 358

duty on, revenue derived from, 1842, 626

exports, 1850-1910, 292, 359, 530, 531

imports, $1827-1844,356,357 ; 1907,292$

labour, number of persons employed, 291 , 357,361 ; proportion of males to females employed, 355

outpüt, 1907, 359,360

wages, 53

Literature, increased demand for, 174

Liverpool: alien population of, 7

cotton industry in, 310

lousing in, 96,101

shipbuilding industry in, 261

telephone service in, 566

Lloyd-George, Mr., budget of 1909, 642, 691

Lloyds, 447, 604

Local Government: activity of, increase in as result of Municipal Corporations Act, 1835,158

areas of administration, 157-159

authorities, local, summary of functions of, 159,160

Boroughs, County, 155, 156; Municipal, condition of, prior to passing of Municipal Corporations Act, 1835, 154 ; reorganization of, by Act of 1835, 154-156 by-laws, 431

central and local government, balance of, $153,154,156$

Counties, reorganization of, by County Councils Act, 1888, 158

County Boroughs. See Local Government, Boroughs

County Councils, creation of, 158

debt. See Local Government, finance

democratization of local government, 154, $157,158,159$

development and history of local government, $153-159$

education, 155

elections, 155

electricity, 159-164, 264, 266

expenditure. See Local Government, finance finance : debt, $160,161,163,645$; expenditure, $160,162,645$; loans, conditions under which they may be raised, 155 , 161 ; rates, assessment and amount of, 162,163 ; revenue, total amount of, 162 , 163; amount derived from imperial sources, 667 ; taxes, proceeds of certain taxes payable to local revenne, 161

franchise, municipal, qualifications for, $156,157,158$

gas, $159,160,163,164$

Guardians, Board of, substituted for Jus. tices of the Peace as administrators of relief, 154; responsible under the Poor Law Act of 1834 for local administration of Poor Law, 66 
Local Goveroment, continued-

harbours and docks, 160

housing. See under Housing

judicial and ministerial functions, separation of, 158

justice, local administration of, 155,156

libraries, 160

licensing, 158, 458

loans. Nee Local Gorernment, tinance magistracy, 155

markets, 160

ministerial and judicial functions, separa. tion of, 158

Municipal Boroughs. Se Local Govern. ment, Boroughs

manicipal trading, 159-161, 16:3

Parish Councils, creation of, 158

Parish Councils Act, 1894, provisions of, 159

parks and open spaces, 160

police, $155,160,161,164$

Poor Law Amendment Act, 1834, effect of. 154

Public Health, alministration of. Sie Public Health

Quarter Sessions, functions of, prior to passing of County Conncils Act, 1888, 158

rates. See Local Government, finsuce revenue. See Local Gorernment, finance roads, 160,548

Raral Districts, creation of, 15s, 159

sanitation, 155

Town Councils, constitution and functions of, $150^{\circ}$

tramways, 159-161, 163, 161

Urban Districts, creation of, 158, 159

water, 159-161, 163, 164.

Local Government Act, 1858, 150

Loial Government Act, 1894, 6ib

Local Government (Scotland) Act, 1894, 10\%)

Local Government Bosrd, creation of, $15 \%$; financial administration of, 161,164 ; general control over local government, 164 ; Poor Law department of, $60^{\circ}$ : undertakes general direction of local administration of public liealth, 9: salaries and expenses, 1897 and $100 \tau$, 670,671

irocal Goternment Bosnd for lreland, $16 \%$

Local Gorernment Boand for Sicntland, 165

Local Taxation (Excise) Act, 1889 : effect of, nn technical education, 140

Iock-making: home work in, 33 : output, and number of persons employed, $190 \%$, $\because 2 \cdot 2$

London: alien population of, 7,8

death-rate of, 10

dronkennessin-areragenumber of charges, 123

housing, 92, 93, 95, 96, 101

lousl goverament of. made s single ad. ininistrative county. 15s

pauperism in, 63, $72,73,70$

population of, 12, 18, 19

rates, $16:$

rent, srerage, $97,98,93$

shipbuilding in, 43

telephone service in, $56 t^{\circ}$

London and North. Western Rsilway, statis. tics, $1909,552,555,559$
London aul South. Western Railway, statis. tics, $1909,552,558,559$

London, Brighton, and South Coast Railway statistics, $1909,552,558,559$

Inudon Building Act, 1907, 431

Loudon City and Midlaud Bank, establish. ment of, $590^{\circ}$

Lonilon Clearing Honse. The, 595

London County and Westminster Bank. establishnient of, 596

London Insurance Company, 604, 607

London Joint Stock Bark, establishment of, 596

London, Tilbury, and Soutbend Failway, statistics, $1909,552,558,559$

Iondon Tniversity, and women's education, 139

Lunacy Commission, The, 126

Lunacy, Lunatics. See Insauity.

M'Adan, Joln Loudon. inventor of mac. arlanized roads, 547

Macara, Sir C. W., anthority on the cotton industry, 307.312

Macclesfield, silk industry in, $3 \% 0$

Machinery: development of use of, in the nineteenth century, 23, 41

export duty on, jil ; policy of such a duty, 249-254

exports, 1820-1910, 2\%t, 255, 256, 521, $522,530,531$

number of persons enuployel in the manu. facture of $41,43,256$

frotection, effect of, on the indastry, 242 251

Macintosh, Mr., prison reformer, 106, 109

M. Nicoll. Pirie. \& Co., statistics as to the jute industry, $30^{\circ}$,

Macrosty, H. W., author of The Trust Move. inent in British Industm, 420,421

Madagascar, export of British produce snd manufactures to, $1827-1845,483-186$

Maize: production of, in United Kingdom, 1895-1902, 438: imports, 1898-1902. 438 ; sources of supply, 525

Malt : duty on, Huctuations in, 455,460 : con sunption, 1s01-1841, 460

Malts export of British produce and mannfactures to, $182 \pi-1845,483-486$

Malthus, Essay on Population, 1

Man, Isle of, population of, 4

Mauchester: alien polulaion. $i$ : hnusing. 3. 101: cotton industry, 310; silk industry, 347,350

Manchester Riots, The, 48

Mangold, acreage under, 1009, 210

Ianila, proruction of hemp in, 369

Mauning, Cardinal, on report of Honsing Commission, 1895, 104

Manure, chemical, manufacture of, 420

Marconi system, uumber of radio-telegrams sent and receirerl, 1908, 564

dlargarine: imports, I840-1909. 443 : output in United bingdom, 1898-1902, 443, 444

Larket gardening: numbers employed in, 202 ; total srea wader market gardens, 20 ?'

Markets. Se unfler Local Goverament

Marmalade, output, 1208, 45I 
Marriagc-rate, decrease in, a sign of bad times, 53; cffect of good harvest on, 53, 54; statistics, 13-15

Matches: output, 1907,415 ; number of persons employed in the manufacture, 415

Mathew, Father, temperance reformer, 465

Maunday Money, 569

Maurice, F. D., pioneer of higher education for women, and founder of the Working Men's College, 139

Mauritius, export of British produce and manufactures to, $1827-1845,483-486$

Meat : consumption of, increase in, 169, 171, 435

frozen meat industry, 440

imports, 1880-1910, 439, 440, 528

prices, $197,203,204,435,439,440$

production in United Kinglom, 1898-1902, 439

sources of supply, 440,525

Medical Office, The, 157

Medicines, exports, 1870-1909, 417, 418

Merchant Taylors' School, 138

Merthyr Tydvil, housing in, 92

Metal trades: child labour in, 27

conditions of employment, 272

development of, 1800-1850, 269; since 1850,272

imports, 1910, 528

number of persons employed, 39, 41, 43, 272

output, 1907,272

strikes, 51,52

wages, 51, 52, 53

Methylated spirits, consumption, 1880-1910, 467

Metropolitan District Railway, statistics, $1909,558,559$

Metropolitan Poor Act, 1867, 75

Metropolitan Irailway, statistics, 1909, 557 , 558,559

Mexico: cotton industry in, 311

exports of hard wood to United Kinglom, 428

imports of British produce and manufactures, $1827-1845,483-486$

Middlesbrough, shipbuilding industry in, 261

Middlesex, housing, 91

Midland and Great Western Railway (Ireland), statistics, 1909, 552

Midland Railway: statistics, 1909, 552, 558,559

proposed amalgamation with Glasgow and Sonth-Western Railway, 557

Milk: mean price, 1905,435

condensed, sources of supply, 525

Millinery : exports, 1860-1910, 530, 531

home work in, 33

Minerals, amount conveyed by railways in United Kingdoun, 1908, 550

Mines and mining: accidents in, 44, 45

capital value of British mines, 1865-1909, 700,701

child labour in mines, 24, 27

numbers employer in mining, $39,40,41$. 170

strikes, 51, 52

wages, 51,52

Mint, The, amount of goll and silver coined at, 1801-1910, 568
Mond, Sir Alfred, account of the growth of the alkali industry, 413

Morgan, J. Pierpont, fonnder of the American Shipping Combine, 542

Morley, Mr., on report of Housing Commis. sion, 1885, 104

Morocco: exports of wool to United Kingdom, 1844, 325

imports of British produce and mannfactures, 1827-1845, 483-486

Mortality. See Death - Rate, Infant Mortality

Moselle, imports, 1909, 464

Motor cars : number of private motors, 1909, 548

destruction of roads by, 548

imports and exports, 1904-1910, 267

growth of the industry in United Kingdom, 267, 531

output, 1907,256

number of persons employed in the manufacture of motor cars, 256

Muller, Messrs. W. O. \& Co., statistics as to the tobacco trade, 471

Municipal Boroughs. See under Local Government

Municipal Corporations Act, 1835, 155

Municipal Corporations Act, 1882, 155

I unicipal service, numbers employed in, 38, 39,57

MInnicipal Trading. See under Local Government

Music Halls, improvement in, 173

Muspratt, James, pioneer of the chemical trades, 412,420

Mutton: imports, 1840-1909, 433, 434, 439, 440,441 ; price, $197,207,435,440$; production in United' Kingdom, 1899' 1902,439

Nailmaking, output and number of persons employed, 1907,272

Nantwich, female labour in, 35

Napoleonic war: cost of, 622,631 ; effect of, on British foreign trade, $497-500,576$; and on prices, 576 ; false appearance of prosperity during the Napoleonic war, 613,614

National Gallery, cost of, 1897 and 1907, 675

National Gallery (Ireland), cost of, $189 \bar{\tau}$ and 1907,675

National Gallery (Scotland), cost of, 1897 and 1907,675

National Portrait Gallery, cost of, 1897 and 1907,675

Navigation Acts, The, 505-508, 517, 685

Navy : cost of, 1801-1849, 630-633 ; 1857$1910,641,643,658-665$

size of, must be regulated by that of forcign navies, 658,659

"Dreadnought theory," the, 663, 664

"two-power standard,", the, 659

recent change in policy by reduction of the oversea fleets, 661

construction, great increase in, 1903-1912, 662

percentage of population employed in, 38

Netherlands. See Holland

Netmaking, 370, 371 
Newcastle-on.1yne : amount of coal shipped from, $1801-1849,215,216$

housing in, 92,96

shipbuilding industry in, 43, 261

Newfonndland, tonusge of Britislı ships entering and clearing at Newfoundland ports, 1880-1908, 542

Newgate prison, condition of, in early part of nineteenth century, 103

Newaham College, 139

New South Wales, transportation to, 107

Newspader trade, ontput, 1907,408

Newton, A. J., survey of the development of photo-mechanical illustration, 110 , 411

New Zesland : export of beef from, 440 production of hemp in, 369

tonnage of British ships entering and clearing at Few Zealaud ports, 18501910,541

Nicholls, George, 89

Nitrate of soda, as manure, $19 \vec{\imath}$

Nobel Dynamite Trust, The, $\$ 21$

Vorfolk, shipbuilding in, $4: 3$

wool industry in, 3.31

Norfolk Island, transportation to, $10 \mathrm{~S}$

Sorthamptonshire: iron and steel iudustry in, 246 ; output of iron ore, 1904, 24.3

North British Railway, statistics, 1909 , $552,558,559$

Northcote, Sir Stafford, 682,685

North London Railway, statistics, 1909 , 558,559

Northumberland: production of irou in, 239 housing in, $96^{\circ}$

Northwich, chemical trades in, 420

Norway: cotton industry in, 311

exports to Cinited Kingdom-cattle, 1870 1900 , 411; fish, 1902, 525; milk, condensed, 190:' 525; timber, 15701900,$427 ; 1902,525$

imports from United Kingdom-British produce and manufactures, $1827-1815$, $483-456$; coal, 1908,223 ; hats, 400

ships, British, tonnage of, entering and clearing at Norwegian ports, 1S50-1908, 513

telephone service in, 566

Norwich, wool industry in, 329

Notes. See Paper Currency

Nottingham : silk industry in, 350

hosiery and lace industry in, 391

Iottinghamshire, iron and steel, output of, 1904,246

Nursing: female labour in, 34; proportion of males to females employed, 30

Oats: acreage under oats, $1000,209,435$; increase in cultivation, $200^{\circ}$

imports, 1850-1908, 194, 438

price, 1850-1570, 197; 1876-1894, 203; since 1595,207

production in Cuited Kiuglom, 1 899-1902, 433

sources of supply, 52:5

Occupation: clasification of, in census, 2, $35-37,33,39$ : inportance of statistics relatiug to, 23 ; movement of, in the uineteenth century, 23; in arhan and rural districts respectively, 3i. See under Women, Children
Occupational mortality, 43, 41

O'Connell, Daniel, 88

Grsted, electrical discoveries of, 262

Offences, increase in number of, 111

Ogilen, Messrs., tobacco manufactnrers, 472

Ogle, Dr.. improvements in statistical methods introduced by, 2

Oil: duty on, revente derived from, 1842, 626

imports, 1560-1910, 528, 529: imports of paln oil from Africa, 180S-1849,487

number of persons enıployed in preparation of, 1907,415

ortput, $1907,41:$

sources of supply, 526

Oil shale, production of, in United Kingdon, 236

Old Age Pensions Act: effect of, on panperisin, if

cost of, 641, 668, 679,691

Oluham, cotton industry in, 310

Open spaces, provision of, secured by Housing and Town Plauning Act, 102

Oranges, duty on, revenue derived from, 1842. 626

Orders in Council, 1807, effect of, 498

Ontdoor Labour Test Orders, 67, 70

Ontiloor Relief Prohibitory Order, The, 1844,67

Ontdoor Relief Regulation Order, The, 1852,67

Overcrowding: gravity of the problem, 91, $93,94,102,103$

Physical Deterioration Comnittee on evils of, 94

effect of, on infant mortality, 94, 9;

decrease of, in 1901 ceusus, 9 ;

definition of, accorling to number of occupiers per room, 95

voluntary efforts for alleviation of, 99 ; inunicipal efforts, 99

destruction of bad houses not sufficient. 101,102

to be estimated not by average number of persons per house, but per room or per so much cubic space, 92

solved in Ireland by Labonrers Acts, 91

in urban as compared with rural districts, 103

legislation, 100, 102

Se Housing

Overend-Gnrmey Crisis, The, 150́6, :34, 598, 599

Overseers of the Poor, abolished by the Poor Law Act of $1831,66^{\circ}$

Owen, Rohert, prowoter of the Factory Act of $18 \% 2,24$

Oxford University, and women's elucation, 139

Paint : exports, $1570-1909,417,418$ : output, 1907,415 ; number of persons employel, 1907,415

Palmerston, Lord, 647, 645

Psper, duty ou, repeal of, 639

Paper-making, child lalour, 27 female labour, $30,31,34$ early history of, $404-406$ effect of imposition of duty, 40:-434 consumptiou, 1803-1550, 405 prices, 1801-1843, 406 
Paper-making, continued-

esparto grass, introduction of, 406, 407 wood-pulp, introduction of, 407 imports and exports, 1886-1910, 407, 408, $528,530,531$

Paper currency: amount in circulation as compared with bullion retained at Bank of England, 1838-1819, 590; effect of increase in circulation on prices, 585

Bank Charter Act, 1844, 592, 594, 595

Bank Restriction Act, 1797, 576,577

bills, mercantile, number under discount at the Bauk of England, 1825, 581, 582

cheques, developnent of use of, 595

controversies on the subject of papes currency, 1800-1850, 574, 575

depreciation of paper currency, 1809-1815, 577

fluctnations in price of gold, effect of, on paper currency, 576, 577

inconvertible paper currency, arguments against, 579,580

interest, fall in, occasioned by extensive increase in circulation of paper currency, 580

issue of Bank of England notes restricted to $£ 14,000,000$ in excess of bullion retained, 592

notes, decrease in use of, 595, 596: issue of, by joint-stock and prirate banks, $582,583,584,593$

Peel's Act, 1819, providing for the gradual resumption of specie payuients by the Bank of England, 578-580

redundant paper currency, evils of, 578

specie payments, cessation of, by Bank of England, 1797, 576, 577; resumption of, 1819,578

uncovered notes, issue of, by Bank of England since Bank Charter Act, 1844, $594,598,599$

Paraftin, sources of supply, 526

Parisl Councils Act, 1894, 158

Parkhurst, first reformatory at, 116

Parks, public expenditure ou, 189- and $190 \%, 669$

See under Local Goverument

Parsons, Hon. Sir C. A., inventor of the steam turbine, 260

Pauperism: able-bodied paupers, increase of, in urban centres in receut years, 70 , $72,73,78$

alcohol as a cause of pauperism, 120

child pauperism, decrease of, since 1870 , 78

created by bad administration of outcloor relief, 69

daily pauperism, average, 1906-1908, 71

female pauperism, rate of female pauperism higher than male, 78

insane paupers, numbers of, 81,82

movement of pauperism in the latter half of the niueteenth century, 70-74

Old Age Pensions Act, effect of, on pauperism, 77

permanent paupers, number of, 19061908, 71

urban as compared with rural pauperism, $7 \overline{4}, 78$

See Vagrancy, Relief
Peabody Trust, The, 99

Peus: acreage under, 1909, 210 ; production of, in United Kingdom, 1898-1902, 438 ; imports, 1898-1902, 438

Peel, Sir Robert, finaucial policy of, $682-684$

Pen-making: home work in, 33 ; output, 1907,408

Penal servitude: took the place of transportation in 1853, 108

average number of persons sentenced to penal servitude, 109

remission, grant of, 109

Pencil-making, output, 1907, 408

Peninsular and Oriental Steam Navigation Company, 539-541

People's College. 'The, at Sheffield, 139

Pepper, revenue derived from duty on, $184^{4}, 626$

Perfumery: output, 1907, 415; number of persons employed in manufacture of, 1907,415

Peru : exports to United Kingdom-cotton, 309 ; wool, 1844, 326

imports frow United Kingdom-British produce and manufactures, 1827-1845, 483-486; woollen manufactures, 1844, 326

Peterloc Massacre, The, 48

Petroleum, sources of supply, 526

Philippines, production of tobacco in, 19001903, 469

Phosphatic manures, 197

Photography: development of, 410, 411 ; proportion of male to female labour employed in, 31

Phthisis, decline of, since 1870,10

Physical Deterioration, Committee on, 94, 123, 145

Physical infirmity, statistics as to, 20-22

Pickles, ontput, 1908, 451

Pigs, nunber of, in Uuited Kingdom, 202, 212

Pilkington Bros., plate-glass manufacturers, 285

"Pinch-Pauper Triumvirate," The, 64

Pitt, his "perfectly new and solid system of finance," 1797,611

Place, Francis, 65

Place of birth, classification of, in census, 2

Player, John, \& Sons, Ltd., tobaceo manu. facturers, 472

Plumbers, lead-poisoning among, 44

Plymouth, housing in, 101

Police : local administration of, $155,160,161$, 164 ; grants subject to approval of Home Oftice, 164. See under Local Gorern. ment

Political offences, transportation for, 108

Poor Law, allowance system, the, 62, 63

Central Poor Law Board, the, 65

early legislation, 61,62

Royal Commission of 1832 ; effect of recommendations of, $63-65$.

See also Pauperism, Relief

Poor Law Act, 1834, 2, 154

Poor Law Board, The, 157

Poor Law Commission, 1909, 30, 35, 69, 72, 680

Poor Law Inquiry Commission (Scotland), 1813,84 
Poor Law Union, made the unit of the census alministration, 2

Population, census. See Census

constitution of, age, tirst attempts at classificstion of population according to age, 12 ; value of this classitication, 12 , 13 ; age distribution of rural as compared with urban districts, 15 ; statistics, 13, 14, 15

birthplace, statistics as to, 15,16

marriage, decline of marriage-rate since 1850,13 ; rise in marriage-rate since 1891,13 ; statistics, 14,15

sex, excess of femsle over male popnlation, 12 ; excess of male births over female, 12 ; proportion of sexes varies according to industrial and social conditions, 12 ; reasons for variation, 12

density of population, 20

growth of population, traceable after 1838 by comparison of birth and death rates, 2 ; rate of increase during nineteenth centnry, 3, 4,175 ; causes of increase, 5,6

movement of population, 16, 17-20; causes of, 5

physical infirmity, statistics as to, 20-22

rent, and population, 98,100

statistics, first attempt to obtain, 1, 2

Pork: imports, 1840-1909, 434; price, $1850-1894,197,203 ; 1905,435$

Port Sunlight, experiment in town-plsnning at, $10^{\circ} 2$

Portugal : cotton industry in, 311

exports to United Kingdom-cattle, 18701900,411 ; timber, 1870-1900, 42. wine, $1909,466^{\circ}$; wool, 1844, 3.25

imports from United Kingdoln-British produce and msaufactures, $1827-1845$, $483-486$

ships, British, tonnage of entering and clearing at Portuguese ports, 1880-1908, 513

Post Office: expenditure, 1839-1910, 502 , $641,643,614: 1897$ and 1907 compared, 681

frank system, the, 560,561

halfpenny rate, introrluction of. 561,562 ; revenue derived from, 561,502

letters, number delivered, 1859-1910, ‘ money orders, amount issued 1910, $56 \%$ penny postage, iutroluction of, 500 rates prior to $1810, \vdots 60$

postal orders, anount issued 1910,

revenue prior to $1840.560,623 ; 1810-1910$, 562,$644 ; 1897$ and 1907 compared, 681

savings bank : institution of, 563 ; amourat of deposits, $1570-1.400$, $560 ;$; evicience as to the prosperity of the working clasies leducible from, 168

telegraphs: revenue derived iron, 15601910 , 562 ; expenditure, $1869-1910,562$; monopoly acquirel by Post Oflice, 563 , 504 . See Telegrapli

telephones. See Telephone

Potatoes: acreage under, 1900, 210; consumption yer heal of population, 170 ; imports, 1840-1902, 430, 434, 433: price since $1895,20 \%$, 435 ; production in United Kingulom, 1893-1902, 438

Potteries, The, 287 ; lead-poisoning in, 4
Pottery, manufacture of : exports, 237 ; production, 1907, 287 ; number of persons employed, $190 \%, 2 S \%$; proportion of males to females employed, 31

Poultry, number of, in United Kinglon, 1865 atd 1902,444

Precious metals, number of persons em. ployed in manufacture, 39

l'reston: cotton industry in, 34; fernale labour in, 310

Preston-Thomas, Mr., 69

Prevention of Crimes Act, 1908, 117, 118

Price, Dr., author of Observutions on Recersionary Payments, 603

Prices: Franco-German war, effect of, on prices, 518

gold, effect of changes in the production and consumption of gold on prices, 54 , 55,59

harvest. effect of good harvest on prices, 587,588

movement of prices during nineteenth century, 54, 55, 109, 170, 529

paper currency, effect of incresse in circulation of, on prices, 585

prices of various articles-bacon, 1880$1909,435,442$; barley, 1850-1970, 197 ; 1876-1894, 203: 1895, 207 ; beer, 18501870,$197 ; 1880-1909,207,435,44 \hat{\jmath}$, 442 ; bread, 1905 , 435 ; butter, 18451908, 207, 435; cattle, 1850-1909, 440 ; cheese, 1905, 435; coal, 1801-1345, 216 ; $1950-1900,224,225$; 1905, 435; cotton, 1S60-1910, 529; Hour, 1905, 435 ; Hax, 1S60-1910, 529 ; rueat, 18501880,197 ; $1880-1909,435,440$; milk, 1905,435 ; mutton, $1850-1909,435,440$; oats, $1850-1870,197$; $1870^{\circ}-1894,203$; since 1895, 207; pork, 1850-1894, 197, 20.3 ; 1905, 435; potatoes, since 1895 , 207 , 435; sugar, $1860-1910,435,529$; tea, 1905,135 ; tobacco, $184^{\circ}-1908,471$; wheat, 1800-1550, 181, 183; 1850-1908, $195-197.203$, 438; wool, 1800-1350, $324 ; 1860-1910,204,529$

Printing: Columbia press, invention of, 409 development of the industrs, 408-411

illustrating, 410,411

linotype machine, invention of, 409 numbers employed, 39

output, 1907, 405

steam.power, introduction of, 409

wages, $1850-1910,51,315$

Printing, textiles: intraluction of, 304.305 : numbers employed, 1907 , 291 ; ontpat, 1907,291

Prisons : administration of, 113, 11:

condition of, in the early part of the uineteeutl century. 108

cost of, 1897 and $190 \%, 073$

discharged prisoners, treatment of, 118

discrimination between classes of prisoners, 114,115

employment for prisoners. 114

feeble-minded prisoners, numbers of, 130

first offenders, treatment of, 115

liard labour, in practice almost obsolete, 114

legislation, 105, 109

numbers of prisoners, 22, 113

preferred to casual wards by ragrants. 114 
Prisons, continued-

preventive detention, 118

reformation rather than punishment to be aimed at, 108

star class system, the, 115

Prison Commissioners, first appointed in $1877,113,114$

Prison Discipline, Society for the Improve. ment of, 109

Privy Council, public health jurisdiction of, 157

Probation of Offenders Act, 1907, working of, 59

Productivity of the soil, increase in, 179 , 185

Professions, percentage of the population engaged in, 38,39

Progress: to be measured by the change in the ordinary daily life of the average person, 166 ; general progress since 1850 , 166 ; standard of life, improvement in, $160,167,171,173$

Protection : abandonment of, $682-68 j$; effects of this, 517

arguments against protection, 475,476 , $501-505,626-630$

movements in farour of protection, 1878 and 1885,518

smuggling encouraged by protection, 345 , 346,358

working classes, effect of protection on the prosperity of, 47

effects of protection on various industriesagriculture, 77,78 ; boot and shoe trade, 381 ; coffee, 491, 492; cotton, 254; linen, 254; machinery, 249-254; silk, 342-348, 353; shipping, 505-508; timber, 493-496; tin, 226, 276, 277; wool, 253, 323, 324, 333, 334

See Corn Laws

Public Health: administration, local, controlled by the Local Government Board, $9,156,157,164$; sanitary administra. tion prior to 1875,157

areas, local, 157

Board of Health, 156

centralization of control, 156, 157

Chadwick, Edwin, 156

Committee appointed to examine into the sanitary condition of the country, 1868, 157

health districts and boards, creation of, 156

legislation, peruissive until the Act of 1875,157

Local Government Board, central control of Public Health, 9, 156, 157, 164

rural sanitary authorities inerged in rural district councils, 159

urban sanitary authorities merged in urbau district councils, 159

Public Health Clauses Act, 1845, 156

Public Health and Social Conditions in the Last Half-Century, by John Burns, 58

Public Schools, abuses in early part of nineteenth century, 137. See under Education.

Public Schools Act, 1868, 138

Public Trustee, expenditure, 673

Public Works. See Works

Publicans, rate of mortality, 44, 123
Punishment : savagery of, in early nineteenth century, 106 ; theories of, 108

See Crime, Death Penalty, Fines, Penal Servitude, Transportation

Quarries, accidents in, 44, 45

Quarter Sessions, 155

Rag trade, 291, 332, 339, 340

Raikes, Robert, founder of Sunday Schools, 132

Railways : accidents, 44,54

agriculture, effect of construction of rail. ways on, 188,189

amalgamation of competing lines, 554, 557

canals owned by railway companies, 549 , 550,557

capital, 1850-1909, 552, 553, 555, 700, 701

carriage and wagon building, output and numbers employed, 1907, 256

construction during the first half of the nineteenth century, 551 ; cost of con. struction, 554

development of the English railway system, 1850-1908, 553

dividends paid, 1909,552

expenditure, 1850-1909, 552, 553, 554, 559

export of railway material, 266

fares, 554

gauge, change of, 551, 553, 554

goods, amount carried and receipts from goods traffic, 551, 552, 553, 556

hotels owned by railway companies, 557

labour, numbers employed, $43,57,554$

light railways, 557

mileage, 1845,$551 ; 1850-1908,553 ; 1909$. $552,555,556$

minerals, amount carried, 1908, 556

nationalization of railways, 557

passengers, numbers carried and receipts from passenger traffic, 1845,551 ; 1850 1908,$553 ; 1909,552,556,558$

receipts, $551,552,553,555,556,559$

speed of trains, 554

statistics, 1860--1908, 553; 1909, 552, 555, $556,558,559$

steamship lines owned by railway com. panies, 557

wages, $52,53,554$

weight of trains, 554

Raisins, duty on, revenue derived from, 1842,625

Rates, equalization of, 162

See under Local Government, Relief

Rathbone, Mr., description of English system of Local Government, 157

Rebecca Riots, The, 1843, 547

Reciprocity Acts, The, 1823 and 1824,507

Redditch, female labour in, 35

Re-exports from United Kingdom, value of, 1850-1902, 518, 520

Reformatory Schools : institution of, 116 ; number of children in, 143 ; proportion of feeble-minded inmates, 130 ; expenditure, 1897 and 1907,673

Registration of Births and Deaths, instituted in 1837,8

Registratiou Act, 1836, 2

Reid, Mrs., pioneer of higher education for women, 139 
Relief: sble-bodied, out-relief of, evils of, $63,64,65,67$; conditions under which it may be given, 70

sdministration, bad administration of relief creates psuperism, 69. See Relief, authorities

age distribution of recipients of relief, 76 aged paupers only recently treated sepsrately, 76 ; value of out-relief as compared with in-relief of aged paupers, 75

authorities, constitution of, under the Act of 1834, 65; Central Poor Law Board, the, 64: Local Government Board, Poor Law Department of, 66. See also Union, Guardians

children, relief of. See under Children

co-ordination between various relieving bodies desirable, 74

cost of relief, $160,162,163$; cost per head during nineteenth century, 63 ; increased cost of during the last thirty years, 74 ; cost of indoor as compared with outdoor relief, 69

medical relief, before and after the Act of 1834,75 ; administration of, 75,76 ; no longer a civil disqualification, 75

ontdoor relief, figures, $187 \pm-1910,67,68$

unemployment and relief, 68

voluntary relieving agencies, $\pi 3$

workhouses, improvement in, 69,74 ; act as a deterrent to decent but not to the work-shy, 69

See Panperism, Poor Law

Religion, decreasing influence of, 174

Rennie, J. T., \& Sons, shipowners, 543

Rent: agricultural, 1880-1896, 201, 205

geographical distribution and rent, 97

higher in London than for the country as a whole, 97

movement of rent during the nineteenth century, 169, 171 ; increase from 1880$1900,98,99$

overcrowding and rent. $93,96,99$

transport, effect of development of, on rent, 55

Ribbons, imports and exports, 1904 and 1907,292

Picardo, David, 579

Pice: consumption per head of population. $1810-1907,170$

imports, 1860-1910, 438, 528, 529

sources of supply, 525

Rich : expenditure of, 172 ; proportion of national wealth owned lyy, 163

Rickman, John, supervisor of the tirst four censuses, 2

Pivet-making, output and number of persons emplored, 1907,272

Poads: in 1850, 547 ; destruction of, by motors, 548; macadarnization of, 547 ; tolls, abolition of, 54\%, 549; turapike, total length of, in 1829, 189: upkeep of, provisions as to, 548

Robinson, Fleming, \& Co., statintics as to tle jute industry, 364

Rogers, Professor Thorold, $4 \pi$

Romilly, MIr., prison reformer, 106

rope-ruaking, 370,371 ; numbers ent. ployel, 1881-1901, 363 ; output, 1907. 361
Routledge, Mr., patentee of process of manu. facturing paper from esparto grass, 407

Royal Agricultural Society, The, 198

Royal Bank of Scotland, The, 591, 592

Royal Exchange Insurance Company, The, 604,607

Royal Sanitary Commission, The, 1866, 9

Rugby School, $1: 38$

Rum, imports, 1841, 465 ; 1860-1908, 467

Rural depopulation, $16,17,3 \pi, 38,39,98$, 103

Rural District Council. See under Local Government

Rushin, John, teaches at Working Men's College, 139

Russell, Lord John : restricts death penalty, 107 ; opposes nilitary expenditure, 647

Russia : alkali industry in, 414

cotton judustry in, 311

emigration of Russians to United Kingdom. 6

exports to United Kingdom-butter and eggs, 1902, 525: flax and hemp, 1902, 526; petroleum, 1902, 526 ; timber, $1870-1900,427 ; 1902,525$; wheat, $1899-1909,436,435,525$; wool, 1814, 325

henip industry in, 368,369

imports from United hingdom-Britislı produce and manufactures, 1827-1815, $483-486$; alkalis, 414; coal, 1908, 223

infant mortality in, 11

sheep, number of, in, 330

ships, British, tonnage of, entering and clesring at Russisn ports, 1880-1908, ¿43

tobacco, consumption of, per head of population, 1910, 471 ; production of: $1900-1903,469$

telephone service in, $560^{\circ}$

Rye: production of, in Cinited Kingdom. 1S?9-1902, 438

imports, $1898-1902,438$

Sailcloth-making, 363,371

Sainfoin, acreage under, 211

St. Helens : chemical trades in, 420 ; plateglass industry in, "285

St. Paul's School, 138

Salford: housing in, 101 ; silk industry in, 347 ; telephone service in, $566^{\circ}$

Salt: consumption of, 235 ; iuties on, 234 ; production of, 234, 235; exports of. 231,235

Saltpetre, exports, 189:-1909, 419

Sandstone, proluction of, in United King. dom, 236

Sanitary Commission, The, $186^{\circ}, 9$

Sanitation. Se orercrowding, publio Health

Saumur, imports, 1909, 464

Sarings Bank. See Post Office

Scarlet ferer, decline of, since 1870.10

School Attendance Acta, 1593 and 1899, 20

Schools. See Education

Schools' Inquiry Commission, 1861, 135

Scjentific instruments, output snd number of persons employed in the manufacture of, 27:2 
Scotland: agriculture in, 1800-1850, 180, 181

alcohol, consumption of, 122; expenditure ou, 122 ; number of committals for drunkenness, 120

banking, system of, 591, 592

cotton industry in, $306,313,318$

crime, proportion per 1000 of population committed to prison, 120

education, 141, 147, 149-151,164, 165

hosiery and lace industry in, 391,392

housing in, 91, 95, 98

insanity, Lunacy Board, constitution of, 126 ; feeble-minded, treatment of, 131

iron industry in, output of iron and steel, $238,239,246$

output of iron ore, 243

linen industry in, 356

local government, 164,165

pauperism in, $83-88$

population of, 3,4

railways in, statistics, 1909,552

rent, average working class, 98

wool industry in, 336

Scott, A. H., authority on the soap industry, 423

Screw-making, output and number of persons employed, 272

Sea, percentage of the population employed at sea, 38,39

Seed-crushing factories : output, 1907, 415 ; number of persons employed, 1907, 415

Seedsmen. See Market Gardening

Senior, Nassau William, 64

Sex. See Population, constitution of

Shale, production in United Kingdom, 236

Shanks, James, pioneer of the chemical trade, 412

Shaw, Savill, \& Albion, Messrs., shipowners, 541

Sheep : number of, 200, 202, 212, 328, 330, 331 ; imports of, 1840-1909, 441; improvements in breeding of, 329 ; average produce of wool per sheep, 328

Sheffield : cutlery trade in, 273 ; housing in, 101 ; population of, $1800-1850$, 269; steel industry in, 240,245

Shipbuilding : design, 261

distribution of the industry, 261

double bottom, introduction of, 260

early history of the industry, 256-258

iron, first use of, 256-258, 259

labour, numbers employed, 43, 256

number and tonnage of ships built in

United Kingdom and Colonies, 1801-

$1819,513,533 ; 1840-1910,258,261$

steam-power, introduction of, 259,260

steel, use of, 259

wages, 53,315

Shipping : coal, use of, for ballast, 224, 522, 531

coasting trade, tonuage employed, 18251910,525

freights, decrease in value of, in early part of the rineteenth century, 508

number and tonnage of ships entering and clearing from British ports, 511514,536

proportion of British to foreign tonuage entering British ports, 510, 511
Shipping, continued-

proportion of British to American tonnage entering United States ports, 510

number and tonnage of ships registered in United Kingdom and Colonies, 513, 535

number and tonnage of ships built in United Kingdom and Colonies, 258, 261, 513, 533

number and tonnage of steamships em. ployed in United Kingdom and Colonies, 533!

increase in size of ships since 1850,536 , 511

number and nationality of persons em. ployerl in shipping, 545

steam-power, introduction of, 532

Navigation Ácts, the, system of, $505-508$

decrease in value of ships in the early part of the nineteenth century, 508

Shirt-making, home work in, 33

Shopkeeping: female labour in, 31 ; rate of mortality in, 44

Shrewsbury School, 138

Shropshire, production of iron in, 238, 239

Shuttleworth, Sir J. Kay, efforts for popular education, 134

Siam: export of hard wood to United Kingdom, 423

import of British produce and manufac. tures, $1827-1845,483-486$

Siemens, electrical discoveries of, 262, 264

Siemens Brothers, introducers of open liearth process of manufacturing steel, 215

Silk : consumption, 1814-1844, 344

development of the industry, number of factories, 1835,$347 ; 1870-1907,350$; effect of protective duties on the industry, 342-348; decline of the industry since $1861,41,42$; spun silk industry, development of, 350

distribution of the industry, 350

duty on silk, revenue derived from, 1842 . 625,626 ; abolition of, $343,345,349,350$ exports, 1820-1850, 437; 1850-1910, $292,351,353,530,531$

imports, 1765-1850, 313; 1860-1910, 292, $351,353,528,529$

labour: number of persons employed, $291,292,347,350$; child labour, 24, 290,317 ; proportion of males to females employed, $31,290,347$

machinery: employment of, 347,348 ; Jacquard loom, invention of, 344 ; number of power-loons in use, 1835 , 288,289

output, 1907, 291, 292, 352-354

Suez Canal, effect of opening of, on the silk industry, 350

wages, 53

Silver industry, output and number of persons employed, 272

Silver, production of, in United Kingdom, 236

Silver-plate : increase in use of, during the nineteenth century, 279; consumption of, 1800-1850, 280-282

exports, 282

Simon, John, "the creator of sanitary science in all its modern aspects," 9 
Simpson, H. B., Mr., 112

Sinclair, Sir John, cormpiler of the Statistical A ccount of scotland, 180

Sinclair, Upton, wathor of The Jungle, 442 ; effect of The Jungle on the preserved meat trade, 442

Six Acts, The, 48

Skins, proportion of the population em. ployed in the preparation of, 39

Slave trade in Africa, The, 457,488

Small arms, ontpnt and number of persous exployed, 272

Small holdings, 3S, 39

Small Holdings Act, 1892: provisions of, 205 ; failure of, 205 , $200 ;$

Sunsll Holdings Act, $1907,200^{\circ}$

smallpox, decrease in number of Weaths from, 9,10

Sruitb, F.' \& J., Messrs., tobacco mauu. facturers, $47 \%$

Smith, Sydney : opposes prison reform, 109 his opinion of English jutlic schools. 1.35

Sruuggling, encouragement of, by protection, $345,346,345$

Soap: consumption of, in the first half of the nineteentb century, 421,$422 ; 1902$, 424

duty on, until 1853, 422, 423

exports, 1833-1910, 423, 424

number of persons employed in the natus. facture of, 415

output, 1550-190\%, 415, 423,424

Solls compounds: exports, $1555-1209,415$. 417

imports, $190 \overline{\bar{\tau}}, 416$

output, 1907,416

prices, $1870-188 \%, 416,41 j$

Soda. See Alkali

Somerset, wool industry in, 331

Sonth Africa : communication with, "4."

exports of wool to United Kingdon, 1544. 325 ; since $1550,3: 30$

etrigration to, 5

garrisou of, 6 is

sheep, number of, 330,331

ships, British, tonnage of, entering and clearing at South African ports, 18501909,543

South African War. See Boer War

suuth America: export of wool to United Kingdom, 1814, 325 ; since 1850, 330

imports from United Kingdom, British produce and manufactures, $1505-1849$, 479,450 ; cotton, 315

sleep, number of, 331

South- Eastern and Chathan liailway, sististics, 1909, 502, 5is, 5ive

Southampton, housing in, 42,101

southward, John, survey of the progress of the priuting trades during the latier balf of the nineteenth ceutury, 403

Spsin : cotton industry in, 311

exports to ['nited Kinglom-cattle, 141: fruit, 1902 , 525 : irols ore, $1902,520^{\circ}$; copper ore, 1902, 5.to; timber, 1870 1900,427 ; wine, 19008,403 ; wool, 1541 , 325

imports from Utnited Kinglom-British produce and wanufactures, $1 \leqslant 2 \bar{i}-1345$, 453-486; cosl, 1908, "223; hat. 400" jute manufactures, $18 \% 2,367$
Spsin, continued-

ships, British, tonnage of, entering and clearing at Spanisb ports, 1850-1908, 543

Spicer, A. Dykes, authority on the paper trade, $400^{\circ}, 407$

Spinning industry. See Cotton

Spirits : consumption, $1800-1850,464-166$; $1850-1907,170$

luty, rerenue derived from, 1550-1910, $46-1,465,468$

exports, 1802-1811, 467; 1S60-1910, 468

inports, 1502-1541, 186, 467; 1910, 528

ontput, 1880-1910, 467

Spitaltields, silk industry in, 350

Staffordshire, iron industry in, 238, 239, $244,246^{\circ}$; production of iron ore, 1904 , 243

Stationery, manufacture and trade, proportion of males to fenales eraployed in, 30, 31 : output, 1907, 408

Statistical Abstract for the L'nited Kingdom, The, 517

Statistical Department, The, established by Edwin Chadwick, $156^{\circ}$

Statistical Jummal, The, 51, 52

Statistical methods, improvements in, introduced by Drs. Farr and Ogle, 2

Stead, W. T., advocates increased expenditure on the navy, 619,659

Steel: basic process of manufacture, discovery of. 245

Bessemer process, liscovery of, 245

development of the indust ry since 1850,242 exports, 1800-1850, 241; 1560-1910, 50, 5,31

fuel used in process of manufacture, cost of, 241

imports, 1910, 523

number of persons employed, 1907,272

open hesrth process, discovery of, $24 j$

output, to $1860,241,245 ; 1875-190 \%$, 246,217

Sitereotyping. output. 1907,408

Stocking frame, invented in $1600,25 \%$

Stocktou, coal industry in, 215

Stoke-on-Trent, pottery industry in, 256

Strawberries, acreage nuder, 1909, 211

Straw-plsiting: child labour in, 24: hone work in, 33 ; proportion of msles to ferales employed, 31

see Hat trade

Strikes, rarying effect of, sccorling to the industry affected, 51

Stuart, Jarues, founder of Lniversity Exteusion Morement, 148

Siuez Canal: opening of, 5. 10 ; number snil tonzuge of ships pissing through, 1s,0 1910 , 41

Sugar : consumption per heal of popalstion, $1840-1909,170,43: 3$

duty on, evilis of $44.450,625$; revelue derived from. 1442, 025

leet sugar, proportion of, to cane sugar imported, 451

iruports, 1s40-1910, 4:0. 525, 329

output, 1908, 451

prices, $1800-1910,435,5: 3$

sources of supply, 525

Sulphate of animonia: exports, 1585-1909, 417,418 ; of copper, exports. 1995-1909, 413,419 
Sulphates, aluminous, imports and exports, 1907,415

Summary Jurisdiction Acts, 110

Sunday, increasingly a day of recreation, 173

Sunday Schools, founded by Rohert Raikes in 1781,132

Sunderland, coal industry in, 215; shipbuilding industry in, $26^{\circ}$

Sussex, housing in, 96

Swan, W. J., electrical discoveries of, 263

Sweating, 32

Sweden: cotton industry in, 311

exports to United Kingdom-cattle, 441 ; timber, 1870-1900, 427

imports of British produce and manufactures, 1827-1845, 483-486; coal, 1908,223 ; hats, 400

ships, British, tonnage of, entering and clearing at Swedish ports, 1850-1908, 543

telephone service in, 566

Swedes, acreage under, 1909, 210

Switzerland: cotton industry in, 311 ; exports of cotton manufactures to United Kingdom, 320 ; imports of cotton manufactures from United Kinglom, 320

exports of condensed milk to United Kingdom, 1902, 525

Sydenham, Lord, reduction in duties effected by, 1830-1840, 481

Taff Vale Railway, statistics, 1909, 559

Tailoring, home work in, 33 ; proportion of males to females enuployed, 31

Tallow: duty on, revenue derived from, 1842,625 ; imports, 1860-1910, 528, 529 ; price, 1853-1907, 423,421

Tanning industry, raw material, sources of supply, 526

See Hides, Leather

Tariff Reform League, The, 520

Tariffs. See Protection

Tasmania, exports of fruit to Uniter Kingdom, 453

Taxation: amount imposed during Napoleonic War, 613

direct, unpopularity of, 612

income tax, first imposition of, 1798,612 ; repeal of, 1816,623 ; reimposition of, in 1842,623 ; movement since $1860,650,689$, 690 ; Gladstone's defence and criticism of, 687 ; evidence as to national wealth deducible from, 168

legacy duties, 623, 624, 686, 657, 690

revenue derived from taxation, 1801-1849, 623

Tea: consuuption of, $170,433,434,435$, 445,446 ; effect of alteration of duty on consumption, 444,445 ; effect on consumption of beer, 459

luty, 1840-1910, 444, 445, 625

imports, 1840-1910, 450, 528, 52?

price, 1905,435

sources of supply, 525

'Teachers' Superannuation Act, 1898, 144

'Teaching. See under Education

Telegraphs: cable between England and France, 563 ; first Atlantic cable, 563

loss, annual, on telegraphs, 1854-1900, 564,681
Telegraphs, continued-

monopoly acquired by Post Office, 563, 564 progress to 1868,563

proportion of males to females employed in, 31

radio-telegrams, 564

revenue derivel from, 1869-1910, 562

Telephone : expenditure, 1894 and 1909,565 line, length of, 1894 and 1909,565

lines, number of, 1889 and 1910, 564, 565 monopoly acquired by Post Oflice, 565 municipal services, 564

National Telephone Company, formation of, 561

numbers employed, 31 ; 1894 and 1909, 565 number of inhabitants per telephone in United Kingdom compared with other countries, 566

receipts, 1894 and 1909,565

statistics, 1894 and 1909, 565

subscribers, number of, 1894 and 1909,565

trunk service, acquired by Post Office,

565; number of messages, 1897 and 1910, 565 ; rates, 565

Tenement: the unit for housing statistics, 92

one-roomed temements, decrease in number of, 92 ; rate of mortality in, 94,95

five-rocmed tenements, increase in number of, 92,94

average number of rooms per tenement in 1901 census, 92, 93 .

Sce Housing, Overcrowding

Territorial Forces, The, 657, 658

Textile industries: development of, fluctuations in prosperity since $1861,41,42$; decrease in since 1895,41

home work in, 33

labour, numbers employed, 39, 291 ; child labour in, 24, 25, 27, 28; female labour in, $29,30,34$; statistics of employment, 42

output, 1907,291

power-looms, number in use, 1835, 288, 289

water-power, use of, 290.

See Cotton, Linen, Wool

Thames, steam navigation on, in early part of nineteenth century, 534

Thomas, D. A., authority on coal-mining, 221,222

Thomas, S. G., inventor of open hearth process of making steel, 245

Thompson, R. J., estimate of average rent per acre of agricultural land, 1850-1877, 199

Three Colour Process, The, 411

Timber: duty, protective, on, 493-496; revenue derived from, 1842,625

foreign trade in, to $1850,493-496$

imports, 1800-1910, 526, 528, 529

numbers employed in the industry, $190 \%$, 428

prices, 1892-1902, 428

sources of supply, 1870-1900, 427, 496, 526

Tin: exports, 226

imports, 226, 227, 228, 526

mortality, rate of, in tin-mining, 44

numbers enployed in mining and nanufacture, 41,272

output, 1850-1909, 227, 272

price, 1801-1834, 230 
Tin, continued-

production in United Kingdom, 1750-1530, 225 ; 1850-1908, 220

sources of supply, 526

wages, 53

Tin-plate trade: derelopment of, 276

effect of American tariffs on, 276,27 exports, 276,27

Tinned foods, increased consumption of, 435

Tobacco: consumption, 1801-1840, 470; $1840-1910,170,469,471$

duty on, 469,470 ; revenue derived from, 1842,625

imports, $1860-1908,526,523$

labour, child labour in, 27 ; percentage of population employed in the tobseco industry, 39 ; proportion of males to females employed. 31

prices, 1842-1908, 4il

sources of supply, $520^{\circ}$

trusts in the industry, $47: 2$

Tooke, Thomas, drafter of the petition of London merchants to Parliament in farour of free trade. 504: author of Mistory of Prices, 586

Tool-msking, ontput and number of persons employed, $2 \tau^{i}$

Town planning: Housing and Town Planning Act, 1909,102

Garden Cities, 102

Towns, growth of population in, $14,17,37$, $98,200,202$

Trade: female labour enplnyed in. 34 ; percentage of population emploted in, 35,30

Trade Unions: standard rate of wages, $46^{\circ}, 4 \pi$ effect of the concession of the right to form Unions on the prosperity of the working classes, 47

evidence of, as to the prosperity of the working classes, 168,169

returns of. as to unemplorment bezetit. $56,57,58$

l'raining-ships for Poor Law boys, ig

'Tramways: development, 4:)

mileage, 1895 and $1909,5 \%$

number of passengers carried, 1895 anu 1909,557

receipts, 1895 and 190?, 557

See under Local Government

Transport: development of, in the nineteenth century, 23, 39 ; effect on the movenent of rent, 50

we Railways, Shipping

Transport industries: labour tinrest in, in the first decade of the twentieth century carses of this, 60

child labour in, 27

percentage of populstion employed in. 39

Transportation: instituted in 1783, 107 : abolished in 1553, 108; average number of persons trasported per annum. $10 i$

'Travel, effect of cheap trarel on staniturd of life, 171

see Communication

Treadmill, sbolished in 1895,114

Trimmer, Mrs., founder of ('hurch Schools. 133

Trusis. See Combines

Tuberculosis, decline of, since 1870. 10: in creased by overcrowding. 94

Tuberculosis Commission, cos: of, 680
Turkey: exports to linited Kinglomcotton, 1896-1904, 309 ; tobacco, 471 : wool, 1844, 325

imports of British produce and manu. factures, $1827-1845,483-486$

production of to bacco in, 1900-1903, 463

Turnips, acreage under, 1909,210

'Turnpike Trusts, The, 547

Tynemouth, housing in, 92

Typefounding, output, 1907,408

Typhus, decline of, since 1869,10

Umbrella.making, hotne work in, 33

Unemployed Workmen's Act, 1905,680

Unemployed Workmen's Act, 1908, 73

Untmployment: especially noticeable in the niueteenth century; reasons for this. 56 ; stability of statistics concerning, 57 ; effect of poor relief on, 63,69 ; effect of rapil change of fashion on, 172 ; unemployment is a cause of crime, 120

Union, The, unit of Poor Law administration under the Act of 1831,66

Union Castle Line, The, 543

Unions. Sie Trade Unions

United Alkali Company, The, 416, 420

United Indigo Company, The, 421

[nited States, alkali intustry in, 414

cotton industry in, 311. 312

emigration from United Kingdom to, 5, 6 exports to United Kingdom-bscon, 411 : beef, 1908, 142 : catile, 1870-1900, 410 , 441 ; 1902 , 525; cheese, 1907. 525 ; copper, 1902, 526: cotton, 1800-1910, $30 \%-311,320,526$; fish, 1902, 525; fruit, 1902,525 ; hides, $1900-1910,374$, 375 ; meat, 441, 525 : oil, 1902, 526 ; timber, $1870-1900,427 ; 1902,526$; tobacco, 471, 526: whest, 1840-1909. $194,195,436,437,525$

lemp, production of, in Lnited States, 309

imports from Lnited Kingdom-British produce and manufactures, $1827-1845$, $479,480,483-486$ : alkalis, 414 ; boots and shoes, 100;-1909. 380, 381; brass anil copper manufactures, 278; hats, 400 ; cotton manufactures, 320,395 jute manufactures, $1872,36 \%$; lace, 399: linen fabrics, 1844, 357; silk gools, 1830-1850, 347, 348; stcel, 211 tin-ulate, 276 ; woollen manufactures. $1841.320^{\circ}:$ value of totsl imports from United Kingdom, 1910, 527

iron, production of. in United States. 244

jute, consumption of, in United States. 365,366

sheep, number of, 331

ships, British, tonnage of, entering and learing at United States ports, 1860 1908,542

tarifts in. 519.520 : anti.protectionis: morement in. 5io proposals for reciprocity with (anada, $5: 20$

telephone service in, 50 6

tobaces. proluction of. 1900-1903, 469 : consumption per heal of population, 1910, 471

Lniversities: growth of Universities in the nineteentli centnry, 148

Cniversity Extension movement, 148, 119 
Universities, continueddiffusion of University education in Scotland, 148

University education of women, 139

Urban District Council. See under Local Government

Vaccination, effect of, on death-rate, 9

Vagrancy : increase of, 81, 83, 120

distribution of, 83

discharged soldiers as vagrants, 83 vagrants in prisons, 83,114

Van Diemen's Land, transportation to, 108

Varnish : exports, 1870-1909, 417, 418 output, 1907, 415

number of persons employed in the manufacture of, 1907,415

Veal. See Beef

Vegetables, sources of supply, 525

Velvet, manufacture of, 339,340 ; output, 1907,291 ; number of persons employerl, 1907, 291

Venezuela, export of cotton to United Kingdom, 309

Vestries, as unit of Poor Law administration, abolished by Act of 1834, 66

Victoria, adopts protectionist tariff, 518

Volta, electrical discoreries of, 262

Wages : importance of study of real wages as a test of national prosperity, 46

statistical material for study of, 46,47

allowances in kind, 49 ; grants in aid, 47 , 63

fluctuations in industrial wages caused by changes in the methods of production, 49

movement of wages in the nineteenth century, 47, 48, 51-53,169, 170, 315

See under the various industries

Wales, iron and steel industries in, 238, 239, 244,246 ; rent in, 97

Walford, Cornelius, author of A History of Life Assurance in the United Hingdom, 608

Wallace Collection, cost of, 1907,675

Water supply, percentage of population employed, 39 ; average wages, 53

See under Local Government

Wealth: increase of national wealth during nineteenth century, 58, 167, 703; estimate of national income, $16 \tau, 703$, 704: amount of property passing at death, 1910, 704; general diffusion of wealth, 167; growth of small incomes, 167,168 ; measurement of increase of national capital, 694,695

Wedgwood, Josiah, 286

West Indies : exports to United Kingdomcotton, 309 ; cocon, 1902, 525 ; fruit, 453

imports from United Kingdom-British produce and manufactures, $1827-1850$, $479,480,483,486$; silk manufactures, $1830-1850,347,348$

Westminster School; 138

Wheat: acreage under wheat, 202, 204, 209, 210,438 ; decrease in cultivation of wheat in favour of oats and fruit, 206

consumption per head of population, 1800-1850, 177, 178; 1850-1907, 170, $433,436,529$
Wheat, continued-

duties on, revenue derived from, 1842 , 625 ; during the Boer War, 690

imports, 1800-1850, 176, 182, 183:18601910, 194, 436, 437, 438, 525, 528, 529

prices, $1800-1850,181,183 ; 1850-1908$, 195-197, 203, 438

production in United Kingdom, 1800-1850, $175-178 ; 1874-1879,201 ; 1909,437$

solurces of supply, 436,525 ; extension of area of supply, 437,438

Wheatstone, electrical discoveries of, 262

White, Miss, applies in 1856 for a medical diploma at London University, 139

White Star Line, The, 541, 542

Widnes, chemical trades in, 420

Wilberforce, Mr., prison reformer, 109

Wills, W. D. \& H. O. Ltd., tobacco manufacturers, 472

Winchester College, 138

Wine : consumption, $1801-1840,461 ; 1860$ $1910,170,463$

duties on, 1801-1841, 462 ; revenue derived from, 1842,625

duties, 1850-1910, 464

imports, 1850-1910, 463, 528

Wine and Beerhouse Act, 1869, 458

Wire, manufactnre of, output and number of persons employed, $2 \% 2$

exports, $1890-1910,277$

Women: alcohol, consumption of, by women, 123, 124, 173

labour, 28-35; occnpations in which the number of females employed exceeds that of males, 30 ; restrictions on labour of women, 24; effect of female labonr on unemployment, 56 ; does not compete with male labour, 29,30 ; employment of married women, 34,35 .

See also under the various industries

Wood. See Timber

Wood, G. H., author of History of Wages in the Cotton Trade during the Past Hundred Years, 312, 314

Wool: Boer War, effect of, on wool industry, 334

Civil War in America, effect of, 333

consumption, $1800-1828$, 328 ; 1850-1902, 333

cross-bred wool, production of, 330

distribution of the industry, 331, 332

duty on, revenue derived from, 1842, 625, 626 ; effect of the repeal of the Corn Laws on the industry, 323,333

exports of wool mannfactures, 1815-1845, $324-326$; 1850-1910, 333-338, 530, 531 ; woollen hosiery, 1904-1910, 396

Franco-German War: effect of, on the industry, 333

imports, 1800-1850, 327, 329 ; 1850-1910, $33 \%, 337,338,526,528,529$

labour, numbers employed, 1839, 327; 1870-1907, 291, 336, 337 ; child labour, 290,327 ; female labour, $31,290,327$, $336,33 \pi$; improvement in conditions of labour since 1850, 333 ; statistics, 42

merino wool, production of, 330

ontput of manufactured woollen goors, $1907,290,338,339$

prices, $1800-1850,324 ; 1860-1910,204$, 529 
Nool, continued -

production in United Kingdom, 1800-1828, $325 ; 1850-1902,333$; sverage produce per fleece, 325 ; merino and cross-bred wool, production of, 330

progress of the industry, esrly history, 323: number of power-looms in use, 1835, 288, 289; 1870-1904, 335, 336; number of mills at work, 1839, 327; 1870-1904, 335, 336; steam-power, introduction of, 331 ; change in conditions after 1850, 334; fluctuations in the prosperity of the industry during the nineteenth century, 334

sources of sapply, 526

wages, $51,53,315$

water-power, use of, 336

Workhouses: number of inmates, 22 ; schools, 79

See also Panperism, Relief

Working classes: alcohol, expenditure on, 173

anusements of, 172,173

conditions of, during the Napoleonic War, 614,615

condition of (historical summary), 47

discontent among, in first decade of twentieth century; economic causes of this, 59,60

expenditure of, 170, 171

food, weekly consumption of various commodities, 436 ; rise in standard of
Working classes, continued-

consumption in latter half of nineteenth century, 435 ; expenditure on food, 435 , 436

harvest, effect of a good harvest on the prosperity of the working classes, 53, 54 housing, improvement in, 55

prosperity of, summary of fluctuations in, $55,56,168$

See also Housing, Orercrowding

Working day, shortening of, $56^{\circ}$; in cotton trade, $302,301,314$

Works, public: expenditure, 1897 and 1907, 668,669

Workshops, inspection and regulation of, 26

Worsted. See Wool

Wyndham Act (Ireland), 1903, 199

Yarn. See Wool

Yorkshire: child labour in, 228; housing in, 96; iron industry in, 233, 239,243 , 246 ; average rent in, 97 ; shipbnilding in, 43 ; wool industry in, $322,331,332$, 336

Yorkshire Dyeware and Chemical Company, The. 421

Young, Arthar, 47

Zinc: production of, in United Kingdom, 233 ; exports, 233 ; imports, 233 ; price, 233 ; output and number of persons employed, 272 
Printed b"

Morrisos \& Gire LIMTED

Eidinburgh 



$$
2^{6}+2^{1,3^{3}}
$$


M.K.H.H.4.4.46
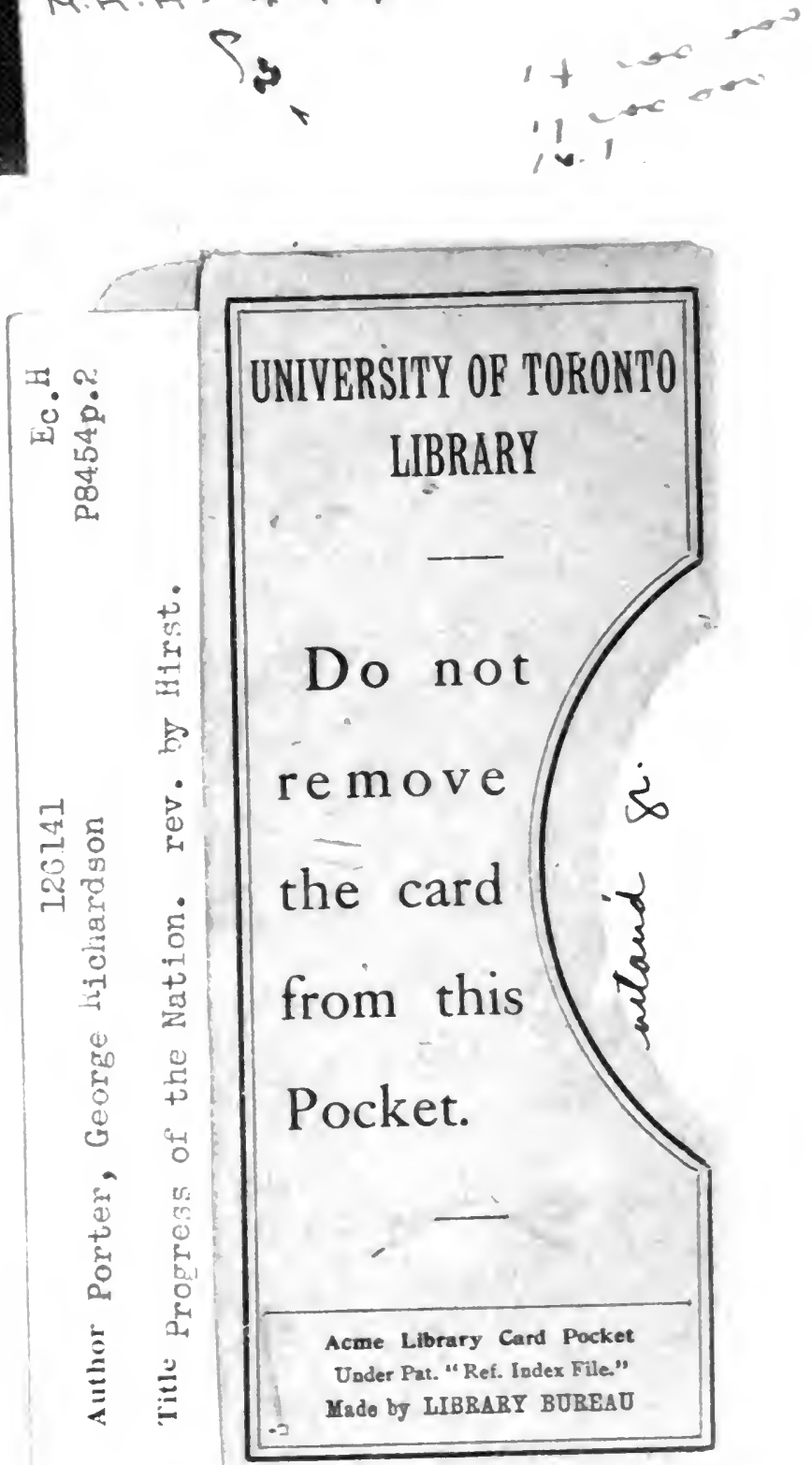
4.450 .

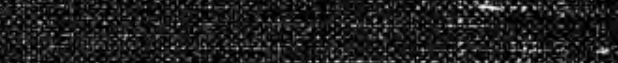

$$
\begin{aligned}
& \text { H. }
\end{aligned}
$$

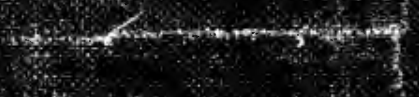

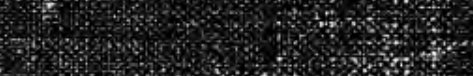

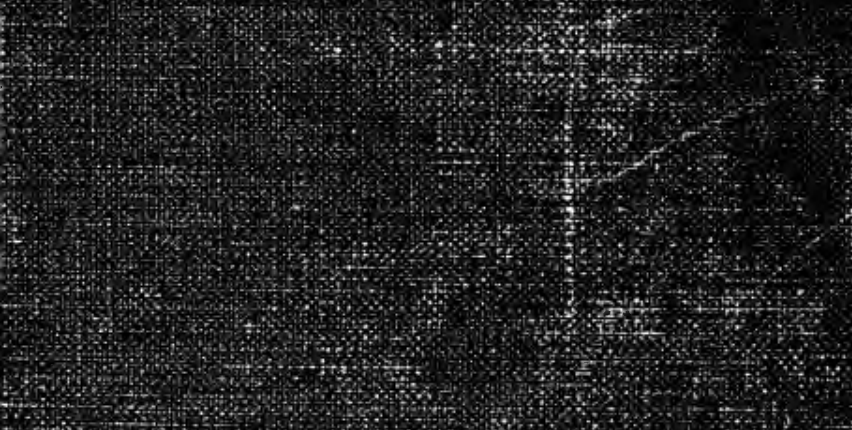

\section{8}

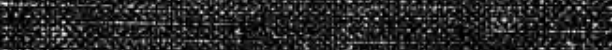

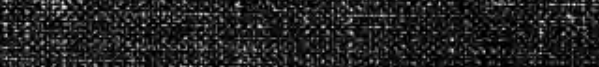

W

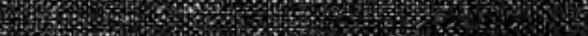

\begin{tabular}{|c|c|c|}
\hline & & \\
\hline
\end{tabular}

\begin{tabular}{lll}
\hline & & \\
\hline
\end{tabular}

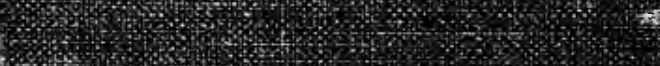

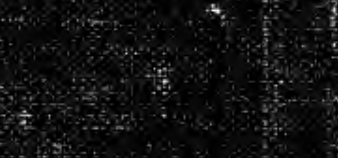

